



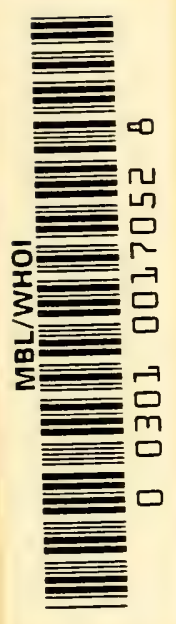








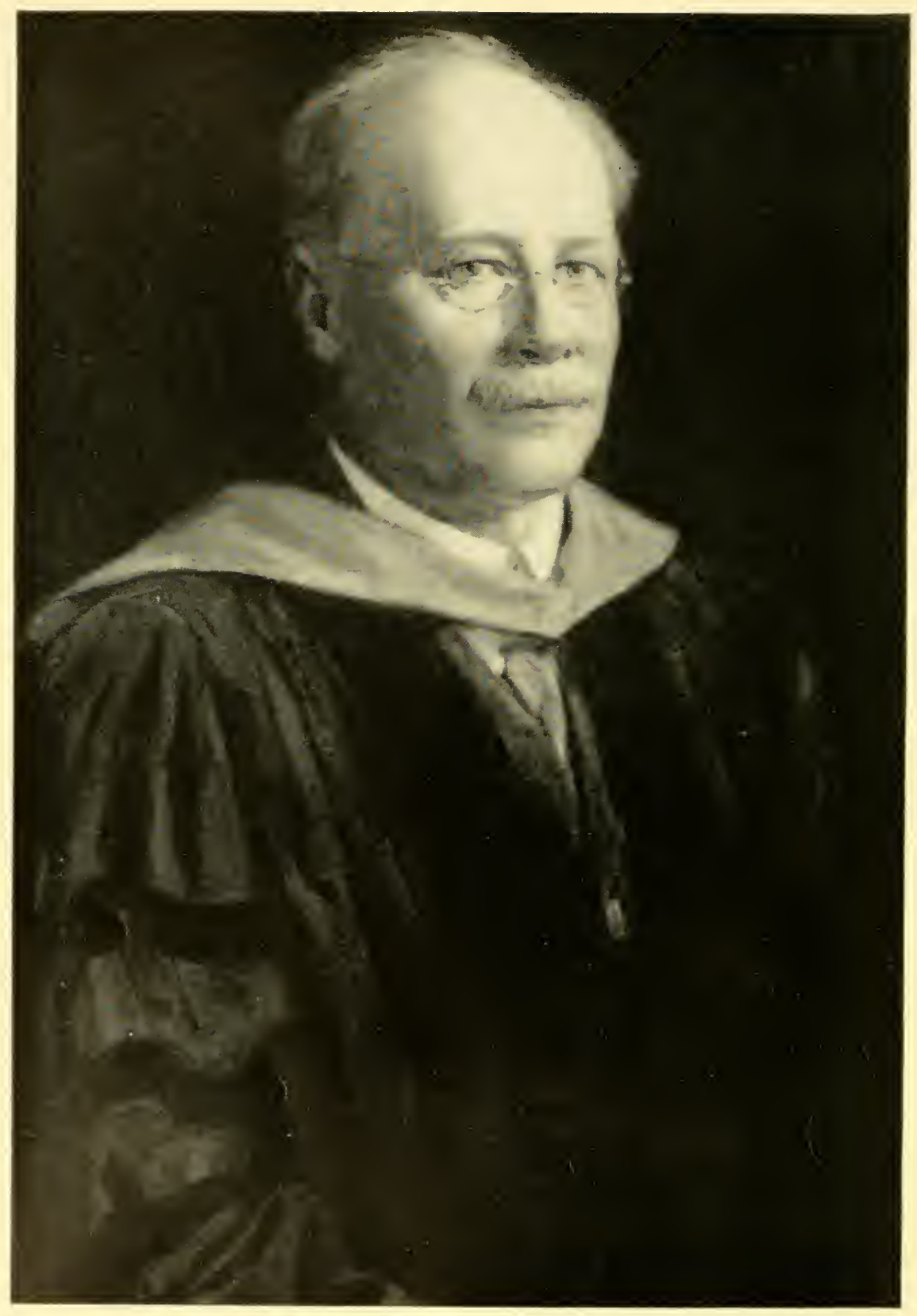




\title{
The Families and Genera of
} North American Diptera

\author{
By C. H. CLRR.AN, D. Sce, \\ American Museum of Natural History, \\ New York, N. I.
}

C. H. CURRAN 
Copyright, 1934.

by C. H. Currax.

Printed in the United States of America by The Ballou Press,

New York, N. Y. 1934. 


\section{CONTENTS}

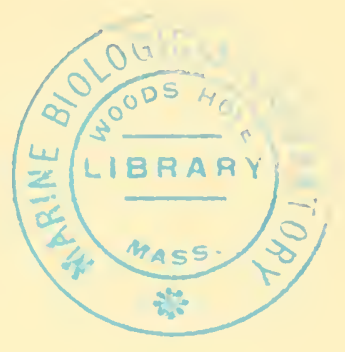

Frontispiece. Portrait of Dr. S. W. Williston.

PAGE

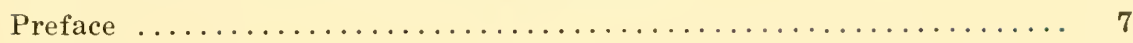

Acknowledgements $\ldots \ldots \ldots \ldots \ldots \ldots \ldots \ldots \ldots \ldots \ldots \ldots \ldots \ldots \ldots \ldots \ldots$

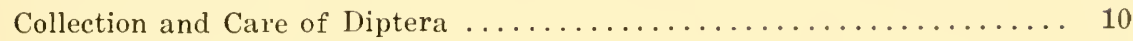

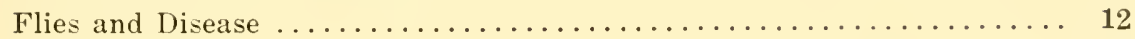

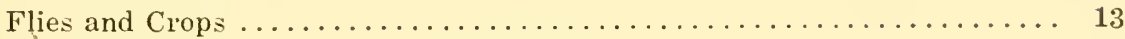

Beneficial Flies .................................. 14

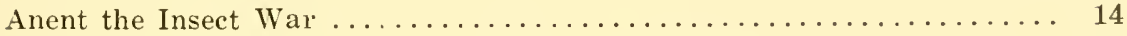

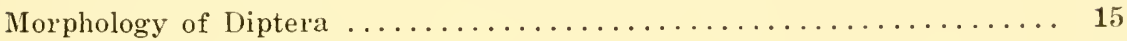

Classification of Diptera .......................... 16

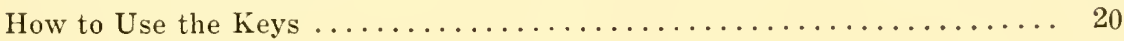

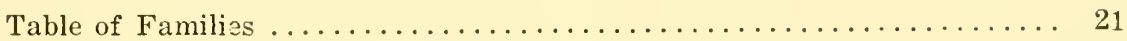

Characteristics of Families and Keys to Genera ..............28 to 479

Glossary of Terms Used in Dipterology .................. 480

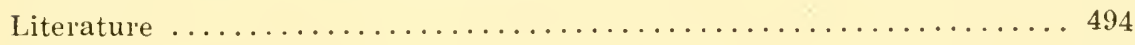

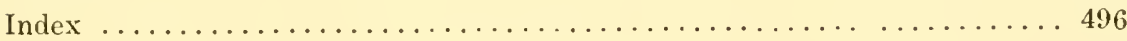

\section{Erratı}

1. 2.2. add the following line:

Wings rounded at the apex, almost always with crossveins......31.

p. 76. Isoccusta Garrett $=$ Alluandomyia, and not Dasyhelea.

p. 82. third line, for Amopheles read Anopheles and for Algypti read a!ypti.

p. 274. for " 29 " in middle of page read 24 .

pp. 286, 288, 290, 292, 294 and 295. for Trypaneida read Trupaneidæ.

p. 405. second line, for Sacrophaga read Sarcophaga.

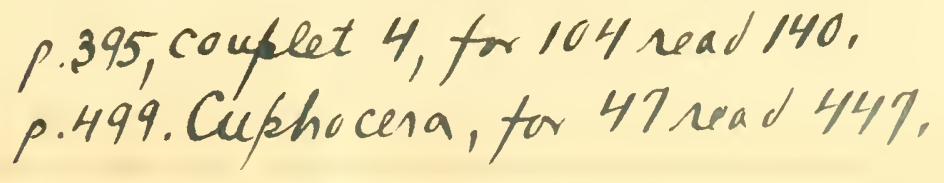





\section{Preface}

Twenty-five years ago Williston 's Manual of North Ameriean Diptera (third edition), was offered to the publie and in the interim it has held the esteem of students of Dipterology in every quarter of the globe. Williston's first syruopses of families and genera appeared in 1884 and following years in the Bulletin of the Brooklyn EntomoIogieal Society and in $1 S S S$ the first edition of the "Manual" appeared. This "pamphlet", as it was modestly termed by its anthor, contained SS pages, excluding as it did, the Nematocera and Muscoidea. The second edition appeared in 1896, and included the Nematoeera but omitted the Tachinidx and Dexiida. The third edition contained all the families, fifty-eight in number.

The present attempt at a classification of the genera of Nortl Ameriean Diptera is the result of many years of study but it is inconceivable that this work should be minflueneed by such a masterpiece as that of Williston. That a new synopsis is urgently needed becomes obrious when one considers the enormons number of new genera de. seribed sinee the appearance of Williston's Manual, the realignment of genera, the application of newly discovered characters and the inereased importance of the study of flies in relation to human welfare.

Innowing, as I do, the excellent quality of Dr. Williston's work it is with temerity that I offer this contribution to a eritical public. Even though great pains have been taken in its preparation and every effort has been made to make the keys as complete and simple as possible I fear that some few errors have erept in. That is inevitable. Where they oceur I do not know, nor do I offer exenses for them other than to admit an utter ignorance in regard to the characters of thonsands upon thonsands of Diptera, even though I have had available for study the excellent eollections of the Smithsonian Institution, Canadian National Collection and the Ameriean Musenm of Natural History and the gen. erous assistanee of various specialists. If mention is not made of those who have contributed to this work, either wittingly or unwittingly (through their synoptie revisions), it is only beeause the body of the paper has increased to such proportions that a complete acknowledgment must be omitted.

A few innovations will be found. Where reasonably complete specific keys oceur these are referred to in footnotes and the same is true in the case of family revisions. The synonymy has increased so greatly that some indication of it must be given, especially where old familiar names have been changed; this is indicated in the index and while it is far from complete it is hoped that some help may be derived from sueh an arrangement. 
It is my hope that those who may discover errors or omissions may be kind enough to eall them to my attention, indicating the manner in which the corrections may be made. Owing to the numerous footnotes it has not been possible to indicate the genera which have been ineluder? from deseription only. Such genera naturally weaken a key as it is . impossible to use eharacters which may be available for a more suitable arrangement. Any speeimens representing genera improperly placed, or not common, would be most greatly valued by the author.

Finally I wish to express my unbounded admiration for the late Samuel Wendell Williston. To him I owe, as do very many others, an everlasting gratitude for his kindly eneomagement, while he lived, anc! real inspiration from his printed works. I know of no Dipterologist who has so clearly set forth the facts or who has been so great an inspiration to others. And as a slight token of my appreciation I respectfully dedieate this book to his memory.

C. H. Curran.

Ameriean MLseum of Natural History, New York City, 1933. 


\section{Introduction}

\section{Acknowledgments}

It is impossible to express fully my appreciation of the generous cooperation of all those who have assisted in the preparation of this work. It is most fitting that I should mention first the generosity of Mrs. S. W. Williston for not only permitting me to use the illustrations from Williston's "Manual of North Ameriean Diptera", but for her offer to furnish the euts themselves. Needless to say this offer was ae. cepted and many of the illustrations are reproduced from cuts used in the Manual. Unfortunately, due to a rearrangement of many genera and their transfer to different families, it has not been possible to use all of the euts. Further, in this connection, I owe much to Mrs. Cieorge Shor, a daughter of Dr. and Mrs. Williston, for her assistance in this matter, and for her sympathy in the work. It might not be out of place to mention here that, aceording to Mrs. Shor, her father, upon the completion of the manuseript of the third edition of his Manual, dropped it upon his desk and remarked: "Well, that's finished. When it is rerised again, it will be by someone else."

Every request for the loan of specimens and for the review of keys met with a wholehearted response and as a result the value of this book has been greatly enhanced. Dr. C. P. Alexander is deserving of especial thanks for the preparation of the manuseript dealing with the Tipuloidea and the preparation of the illustrations for that superfamily. Drs. Jos. Bequaert, C. T. Brues, O. A. Johannsen, Robert Matheson, F. M. Root and Mr. Marston Bates have assisted very materially in checking over keys and suggesting changes. Dr. E. P. Felt suggested the use of illustrations from lis papers published in the Bulletins of the New York State Museum on the Cecidomyidx (Itonididx) and Dr. C. C. Adams very generously funished the cuts. Drs. J. M. Aldrich, F. H. Benjamin and Mr. Marston Bates, and others have loaned specimens not found in the American Museum collection and Dr. Matheson has given permission to use illustrations from his " Handbook of the Mosquitoes". I wish also to express my appreciation to all those Inipterologists of the past and present whose works have been so freely drawn upon.

The preparation of a work of this kind entails a large amount of stenographic and routine work and for the eareful typing of the manuseript I am indebted to Miss Ethel Olsen. Mr. Adolph Klein has contributed the excellent colored plate of several typical forms, while my wife has assisted with the illustrations and in many other ways. 
For the encouragement he has given during the preparation of the manuscript I shall always feel a deep sense of gratitude to Dr. Frank E. Lutz. The Ameriean Insenm of Natural History is deserving of particular mention, since the work has been done in this institution without any limitations as to time devoted to it.

If the book should be found useful and helpful, full eredit should be given to the Mnseum as well as to all those who have so generously given of their time and knowledge.

\section{Collection and Care of Diptera}

So mueh has been written about the ease with which eollections of insects may be eared for that I feel a word of warning to be not amiss. It is true the Lepidoptera and Odonata may be "papered", Hymenoptera, Hemiptera and Coleoptera may be packed between layers of cotton and Coleoptera may be collected in alcohol but most of the other Orders recquire more care. With the exception of Coleoptera and the small insects normally collected in alcohol and intended for study in this liquid, or for slide preparation, all insects are much better pinned while fresh. Packing Diptera between layers of eotton may result in recognizable specimens and a small pereentage of really good specimens may be secured lout the majority enn never be made to look attractive.

With small flies pinning should take place within four or five hours of the time of capture and all specimens should be mounted within eight hours. In cold or damp weather a greater time may be allowed to elapse and the time should be shortened in hot, dry weather.

Mounting Diptera should not be a slip-shod process and care should be taken to have the flies an even height on the pins. An excellent practiee is to have the mesonotum about one-third the distance from the top of the pin. This permits of eareful handling of the specimen and reduees danger of damage to a minimum. Many Entomologists pin Diptera less than a fourth the distance from the head of the pin with the result that the specimens are cuickly damaged and ultimately eease to have value. Double mounts should never be used for Diptera. If a specim"n is too small to be pinned through the thorax it should be fastened to the side of the pin by first eireling it (the pin) with a narrow ring of white shellae and touching it to the side of the inseet. In this way the specimen may be handled in the usual manner and all parts may be readily seen. If possible, the wings should be arranged so that they extend over the back of the insect in an upright position. Pins of suit- 
able size should be used and it will be found that good, steel No. 00 pins may be used for quite small inseets for pinning through the thorax. some collectors seem to have a craze for double mounts, not realizing that the value of their collection is greatly lessened due to the increased risk during shipping and many of them place the aceessory mount much too high on the pin. Another practice, that of placing specimens (nicely spread, it is true) on a circular or oval mount of cardboard by use of minute pins, is to be condemmed as the characters available on the under side of the specimen are concealed.

Labelling is an important detail and insufficiently labelled specimens are of little more value than none at all. The fact that a proud collector knows exactly when and where he eaptured a certain prize is of no value to the student who must needs study the specimen in the absence of the eollector. Every specimen should be labelled with the locality, date and name of the collector. labels should be small and neat and shonld be placed on the pin along the long axis of the insect, the locality on the right hand side. Labels should never be placed crosswise as they are liable to damage adjacent specimens when the insect is being removed for examination. One guide to labelling all insects is to remember that the label should afford protection to the specimen and not be so large that the collection looks like a collection of locality labels rather than one of insects. The labels should be printed, either by machine or by hand and the month should always be in Roman numerals.

In various places in the following pages will be found instructions for the eare of those flies which require special attention. No doubt there are many people who will neglect to read the instructions here but to those who do I offer a few pertinent hints. Never place l)iptera in rials or bottles with other insects. Never cram a vial full of flies. Shake them loose occasionally so that the wings will not become folded. Nerer place small flies in a vial with large ones and be eareful not to place more than a few speeinens of flies which rub easily in a vial. Always lecp mating pairs together: a goot plan is to have a vial for this purpose and to put only different species in it.

Collecting ontfits need not be claborate. I usually carry six to eight lest tubes and a bottle about an inch across and four inches long. If the rollecting is to be aeneral a bottle two inches across may he carried. Such an outfit will suffice for a half day of very good collecting and if the trip) be an all-day one the eateh may be transferred to a box and stored in a cool place. Emptr mateh boxes are convenient leceptaces for the transference of fragile specimens and pairs.

'The making of the bottle is a simple affair. Get some fine sawdust. place in the vial or bottle a small amount of sodium or potassium eranide 
and add about half an inch of sawdust; wedge this in with a ball of cotton, place in the sun for half an hour and the bottle is ready for use. The eyanide should be broken into small lumps but need not be partienlarly fine. It must be remembered that cyanide is a deadly poison and extreme care is necessary in handling it. Do not use it unless you are properly instrueted, and if you do, be sure to destroy by burning or burying all paper, pieces of wood, ete., which the eyanide might have touched and wash thoroughly in rumning tap water hammers, ete. used in erushing the material, as well as your hands. Never handle cyanide if there is an open sore upon the hands. A little extra eare may be worth a lot. It might not be amiss to note here that the most efficient antidote for cyanide poison is the intra-renous injection of methelyne blue, one of the best known aniline dres.

\section{Flies and Disease}

As agents in the spread of diseases of mammals the Diptera undoubtedly rank first in importance among the insects. The chief carricrs of diseases are, of course, the biting flies belonging to the families Psychodidx, Simuliidx, Culicidx, Tabanidæ, Glossinidx, Ceratopogonidæ and Muscidx. Species of Flebotomus carry papataci fever, verruga or oroya fever, kala-azar and oriental sore. Other names are applied to these diseases. The mosquitoes carry blackwater fever, yellow fever, dengue, filariasis and malaria. Onchocerelasis is earricd by speeies of Eusimulium. A form of filariasis is believed to be carried by a species of Culicoides and species of Chrysops are known to transmit the disease. Tularæmia, anthrax and trypanosomiasis are other diseases transmitted by Tabanids. The stable-fly, Stomoxys calcitrans, is known to earry a number of species of trypanosomes and may also be responsible for the spread of poliomyelitis (infantile paralysis), although no definite proof has been obtained. Sleeping siekness is earried by the Tse-tse flies.

In addition to carrying diseases the biting flies themselves eanse a great deal of irritation by their bites, especially in the vicinity of water. Life is often made miserable in northern regions by the hordes of mosquitoes and black flies while the sportsman is plagued by almost all the biting forms while in the woods and bathers eome in for much undesired attention from no-see-nms, mosquitoes and Tabanids, partieularly the so-called "green-heads", along the coastal regions.

The house fly carries on its body the germs causing typhoid fever, dysentery, eholera, anthrax and conjunctivitis, while a few other flies earry other diseases. Considerable has been written about myiasis caused by the larræ of flies living in the human body. If we except the 
bot-flies. I think that we may regard the ocemrence of fly larva in the body of man as entirely aceidental and clismiss the matter as being a subject of academic interest rather than one calling for serions consideration. There are, of comse, the bot-flies, belonging to tinree distinct families and they are serious pests. In the tropies one species commonly attacks man, but the gueatest damage is done to domestic animals. Hides are frequently so greatly ridelled with "warble" holes as to be almost valueless.

The birel and bat parasites, as well as the so-ealled bec-louse (Braula caeca), ale probably not serions pests althongh the shecp tick, belonging to the Hippoboseidae, is often suffieiently numerous to cause serious damage and some species of II ippoboscu bite humans in addition to their attacks on holses, camels, ete.

In many places the so-called blow-flies cause serious loss to sheep owners by "blowing" the wool.

I have given just a rery brief summary of some of the injury eansed by flies to animal life, as it affects human weltare, and a very meat deal that is of interest has been omitted. One frequently receives inquiries as to the diseases carried by flies, and these few paragraphs may serve to answer the questions. In the following pages, under the families mentioned, additional information is given, particularly concerning diseases earried by flies in North America. If the student desires further information on this important subject he should secure a eopy of one of the better books on Medical Entomology.

\section{Flies and Crops}

It is impossible to enumerate all the flies attacking field, horticultural and garden erops, but mention might be mate of the various root maggots, the leaf miner's, gall makers, fruit flies, wrass stem flies and the Hessian fly. The amount of damage done by the groups of insects mentioned must be enormous but it must be rememberer that there cam be no aetual measure of erop damage from a financial point of view. A large crop invariably means lower proces and a small erops higher prices. It is only when individuals or limited rommunities suffer serious loss in the volume of their produce that there is any real loss, and then it is of a loeal nature and not national for the produeers of the crop affected. It so happens in surh eases that one man's loss proves to be another man 's gain. While flies undoubtedly do a great deal of damage to our erops and flowers, they are of less importanee in this respect than some of the other order's of insects and the Diptera are, in actual fact, much more beneficial than injurious. 


\section{Beneficial Flies}

No group of insects, except, perhaps, the Hymenoptera, are so important to mankind as are the flies. In these two groups are man's best friends among the insects. It would be useless to argue abont the relative merits of the two orders because we know so little about them that no one is in a position to make any authoritative statement. It is suffieient to say that flies play an extremely important part in the pollination of flowers, but they undoubtedly occupy second position to the bees. It is in the field of predaceous and parasitic members that these two groups render the greatest service to mankind. If the world should suddenly find itself without flies and bees it would quickly revert to a sphere lacking animal and plant life, so important are these insects in maintaining the "balance of nature".

I believe that the majority of flies, in relation to the number of known species, are either predaceous or parasitic on other insects. Such large families as the Asilidæ, Empidæ and Dolichopidæ are all predaceous in the adult and probably in the larval stage, white the Bombyliidæ, Nemestrinidæ, Conopidæ and Tachinidæ are insect parasites. Other families or groups ean be added to the list and we might also include forms which are predaceous in the larval stage. More about the habits of flies will be found in the following pages.

Flies are also beneficial as seavengers and examples of their effectiveness may be found everywhere. They dispose of eareasses, decaying vegetation and waste animal products and in this way do much to keep the air pure and wholesome.

\section{Anent the Insect War}

I am aware that there has been some sensational propaganda about "the war against insects" and I cannot forego a few remarks. Insects are our hest friends and we owe a great deal to them. They are also our worst enemies but this fact should not be proclaimed from the housetops without at the same time erying much louder of the benefits they give us-flowers, fruits, vegetable, clothes, food, pure air, beauty. The stressing of the danger of the "insect menace" may do entomology a great deal of harm and I think it has already done some. It has taught people to dislike all insects and the fact that the "menace" has not developed pereeptably has resulted in some loss of faith in entomologists.

The Diptera contain some of our worst enemies. The public shonld be made aware of this and steps taken to eliminate the pests in so far as possible. Every effort must be made to keep people suffering from 
insect-carried diseases ont of the comntry, if such diseases do not oceur here and if there are any known carriers of the disease among our insect population. Yellow ferer is an excellent example. We have the yellow ferer mosquito and if persons suffering from this disease should cnter any part of the comntry where the mosquito occurs the disease might well become established. Every effort should be made to reduce the numbers of the house-fly, stable-fly, and other pests. On the other hand the introduction of parasites, particularly of imported pests, should be encouraged and people should learn to differentiate at least the more beneficial of their insect friends.

\section{Morphology of Diptera}

It is not my intention to go into detail concerning the structure or morphology of flies since I have appended a glossary of terms used in this and other works. However, a few remarks on the subject may not be amiss. In Williston 's manual a simple system of nomenclature is used and I follow the same system. During recent years attempts have been made to homologize the parts of the various orders of insects and as a result many long and unfamiliar terms have been proposed. To my mind the homologies of the parts are much less important to the systematist than a simple, easily followed and long used termin. ology. Nevertheless it is important to know the origin of the various parts, especially so to a zoologist, if he deigns to study that group which comprises three-fourths of the animal kingdom. In each order of insects a simple terminology has long been in use and such terms should be employed because the average student can understand them without diffieulty. After" all, some one has said that "Nature is an open book, and rou have but to study nature to mderstand." Perhaps those are not the exact words, hut they will do.

The determination of genera is based upon structure and it is therefore necessary to be acquainted with these parts. The average student will find no difficulty on this score if he will follow the simple expedient of using the keys and consulting the glossary. In this way the terms used will soon be mastered and the student will find little difficulty in tracing out specimens.

The student who desires to delve into the anatomy of I)ipter: should obtain a bibliography of the works on this subject, particularly those by Crampton and Snodgrass. Many references will be found in Imms' "Recent Arlvances in Entomology" and "Biologieal ibstracts"

It will be found that authorities differ as to the origin and homology of different orgaus. A comparison of the Comstock-Needham system as used by Dr. Alexander in this work and that of Comstock will 
show eertain differences while others disagree in the terminology as applied to the reins in other families of Diptera as well as in other orders of Insects. It must be pointed out that the Comstock-Needham terminology of wing renation is very widely used, probably by more students of Diptera than any other system, and if Ameriean students desire to study exotic flies they must familiarize themselres with this system as well as the system used by many Europeans. Explanations of these systems will be found in the glossary.

\section{Classification of Diptera}

The classification of any group of animals is a complex problem having its basis in the morphology, histology, embryology and general biology of the phylum, and without a knowledge of these "ologies" no satisfactory classification can be obtained. In addition we must also turn our attention to palaontology, although it must be confessed that very little is known concerning the Diptera of the past ages. In the present work we deal almost entirely with morphology of the adult flies, not from any desire to ignore the other pliases of study, nor from any lack of interest in them, but because our space is so limited and each field is so vast that a lifetime of study would leave any field almost untouched. The truth is that we know practically nothing about the hiology of flies although we may say, in a general way, that we are aequainted with their mass biology and that we ean usually place a species biologically by associating it with some related form.

The taxonomist, howerer, is foreed to deal with adult structures, to classify the ereatures by characters he may select and to leave to some one else the pleasure of working out the biology of the insects studied. If you are at heart a taxonomist and are informed that you know nothing of biology unless you study life histories, do not be dis couraged. Instead, feel rather strongly inclined to turn a deaf ear to your adviser, taking solace in the fact that even though you may spend all your available time at the systematic study of the adult inseets, and gleaning what you may from the writings of others on biology and life history studies, you will never be able to fully master the field you have chosen. There are so many flies that no one ean ever truly profess to know them all and their rely numbers preclude a thorough survey of the order tending to a romplete elassification.

It is well, and necessary, to warn against too great specialization, and at the same time it is realized that many students with limited time are mable to study more than one or two families. The great trouble with the intensive specialist is that he loses his sense of proportion and relatively minor details are liable to assume the greatest importance in 
his mind. In order to overeome this intra-specialization the student should enlarge his outlook by collecting in other families and also in other orders, even though no time be available for a study of his complete catch. The collector who studies a single family may produce a monumental work providing he is painstaking and aceurate while the general worker is less liable to accomplish lasting results.

I hope I may be exeused if I wander a little aside from a technical discussion of elassification to disenss lighter but equally important matters. The real object of this work is not the elassification of the Diptera but the presentation of keys to enable the student to place his specimen in the proper genus-or, in short, the generic identification of flies. Nevertheless, we must glanee below the generic classification and find out something ahout species, and it is about the description of species of which I wish to say a few words here.

There is nothing more pleasing than a good description and nothing more aggravating than a poor one. All of us, in our ignorance, may offer poor deseriptions at times but we should always strive to make them clear and concise. We should try to step beyond ourselves and look at the deseription from the riewpoint of another student. If two animals are different, in our estimation. we should elearly express the differences, laying special stress mon the outstanding characters. A deseription shonld not be too long, nor should it be brief and stilted. I can do no better than recommend that every Dipterist read the descriptions eontained in Williston's "Synopsis of North Ameriean Syrphide" and pattern descriptions after those. The elimination of words and the excessive nse of abbreviations is seareely to be condoned, even on the glound that it is "scientific". If "scienee" is to be measured by a stilted language and a lack of consideration for others. it deserves little consideration from humanity as a whole and we should divoree "science" and study insects just for the fun of the thing.

Today the student need not worry a gueat deal about some one "stealing his thunder". Most eminent entomologists are only too glad to be of assistance to the young student and to leave to him the deseription of new species. This does not mean that the specialist is willing to name large collections and return all the material. If he were he would be so swamped with work that he would have no time for his other duties. Most specialists name material on the understanding that they may retain what they wish, and as a rule they desire very little. The beginner should be only too glan to assist the specialist by filling in gaps in his collection, hecause every species added makes his work that much easier in future. It must also be remembered that many speeialists are employed by institutions having large collections of unworked. 
material and that erery collection named means less time for institutional work and, to make a blunt statement, it is only fair to expect the institution to look for some return from the labor of its employees. Howerer, I do not know of anyone who is not happy to rerify a student's findings and to give opinions and suggestions concerning the distinctness of specimens, and, of course, in such cases ther are letumed if desired.

I cannot condemn too strongly the professor who permits a student to work on a systematic or biological paper and to allow or eren mrece that the results be published mless the material has been examined by a specialist, or the species of which the biology is beine studied has been identified by one in authority. Each year many students are ciren such problems and the results are frequently rery unsatisfactory. Too much eare can not be exercised in the preparation of scientifie descriptions of either genera or species and it should be realized that a good collection must be available befole any work can be faithfully undertaken.

The preparation of keys is a very important matter and their incorporation in a contribution adds greatly to its value. Some authors attempt, in their keys, to portray what they ter'm a "natural classificition", but it should be borne in mind that this is impossible. We know too little about the inseets with which we are dealing to produce any such result. In preparing keys we arbitrarily aceept one or more characters for the separation of groups and, if the key is to be useful, the charaeters used for each separation must be clean-eut. In any large group it will be found to be very difficult to find clean-eut eharacters in every case, some forms apparently going into either group although the character used may serve for the vast majority. In cases of this kind the doubtful forms should be rum through both categories. In the so-ealled "natural" groupino it is very frequently necessary to employ characters which are not conspicuous and such keys are liable to prove very difficult to use. Characters expressing a degree of variation should be avoided wherever possible, i. e. front produced rs. front less produced. These characters may be obvious to the maker of a key but are ecrtainly not recognizable to other students whose collections may be limited. It is msually easy to use a key if you know most of the forms but often difficult or impossible otherwise.

All keys should be dichotomous and the use of more than two altematives should always be aroided. In a short key one may use the "a" and "aa" strstem but it is not to be recommended in any ease. Keys so constructed are more time consuming than such as are used in the present rork. In the present ease an attempt has been made to 
produce simple keys, amply illustrated. It must be remembered, however, that the illustrations will not serve for all speeies in a genus but represent, as a rule, typical forms.

No use has been made, in general, of subfamilies or subgenera. The use of such almost always ealls for many exceptions and also unnecessarily eneumbers the literature. A sub-family is supposedly a distinct entity within a family, a group separable upon certain eharacter's, but that such classification is mmecessary is evidenced by the execptions. As an example-the Tachinidx have been divided into many sub-families, or eren families, upon such characters as the absence of abdominal bristles, shape of head, ete., ete., but there is not a single character, nor for that matter group of characters, upon which any of these groupings may be retained. Many of the eharacters in this family are excellent up to a certain point, but every character falls down, not once, but in many instances throughout the family. It is entirely impossible to separate the Tachinide and Dexiidae, just as it is to separate the Muscidx, Anthomride and Scatophagidx.

Subgenera are superfluous. They are moposed as a mule because the author hopes that some day some character may be found upon which a distinet genus may be based. It is well to remember that in nature there is no such thing as a subgenus, genus or family. Their use is a human creation made possible because links connecting the groups have either entirely disappeared or have not been diseovered by man. Genera are therefore artifieial and the answer to the question of "what is a genus?" is that it is something limited in some way by some one. This may sound facetious but it is not meant to be so. The truth is that eertain arbitrary character's have been set 11 , all the species falling within the limits set forth constituting a genus (or a species or family). It is presumed, but by no means certain that comnecting links do not exist.

Many people deseribe sub-species, rarieties, raees, forms, ete., espe(rally in the Lepidoptera, but, fortumately, the fad las not become extensive in Dipterology and it is to be hoped that it may never do so. In actual fact there is no difference in a sub-species, race or variety. A variety is something which differs from the typical or first deseribed form in some definite way. Ther are explained as potential species, ignoring the fact that no two speeimens are exactly alike and that if two extremes of similar type shomld mate a new race would be formed. Tn each bateh of egas there are produced forms possessing eharacters somewhat different from the parents. But the species does not ehange because the average is maintained by the resultant mating. It is only when forms become more or less isolated that a definite trend ocenrs and 
so-called races (supposedly geographic forms) are developed. In such cases connecting or transition forms usually occur and it is almost always true that the races, say northern and southern, are connected in the intervening region by a perfect transition of the characters of the two races. Races are interesting but it is not necessary to give them names. Horeover, "variety" was used in the same sense long before people thought of "races" for biological classification and 1 think we may extend the law of priority and use it in this sense, thus eliminating "race" and "sub-species".

The naming of aberrations, transition forms and such things shonld be beyond the pale in true seience and such a practice must eventually result in ridicule of the science as a whole. It is, of course, very necessary to eall attention to these forms but to name them is utterly needless. Knowledge of them is essential in tracing out the relationship and development of species, and of great interest, too, but we should not lose our perspective and attach exaggerated importance to names.

\section{How to Use the Keys}

The use of keys is not a diffieult matter but there may be some who have not had experience with them. Some keys may not be altogether simple and may not rum as smoothly as others. To find the gemus to which your specimen belongs tmin to the table of families (on the following page) and read over couplet 1 . Two alternatives are given: the insect must go in either section. If it has large wings you go to couplet 2 and you repeat the process until it is found that your specimen comes to a section where it agrees with the diagnosis ending in a family name. You have now found the "family", but to be sure rearl over the other alternative so that the characters in both may be checked. Now turn to the family indieated and continue in the same way until the genus is reached.

It should be remembered that keys are merely guides and the fact that a species traces ont to a certain place in a key is no guarantee that it actually belongs there. If one is familiar with the genera of a family he may be reasonably certain either that the insect belongs where it traces or that it is quite different; in either ease he should eheek with descriptions of genera not included in the key or with the gemus included, either by means of determined speeimens or with the generic deseription. If a specimen does not seem to agree with the genus to which it traces check back and try one of the other alternatives since there may have been an error in interpretation of the eharacters used or the speeimen may be one that is somewhat aberrant. 

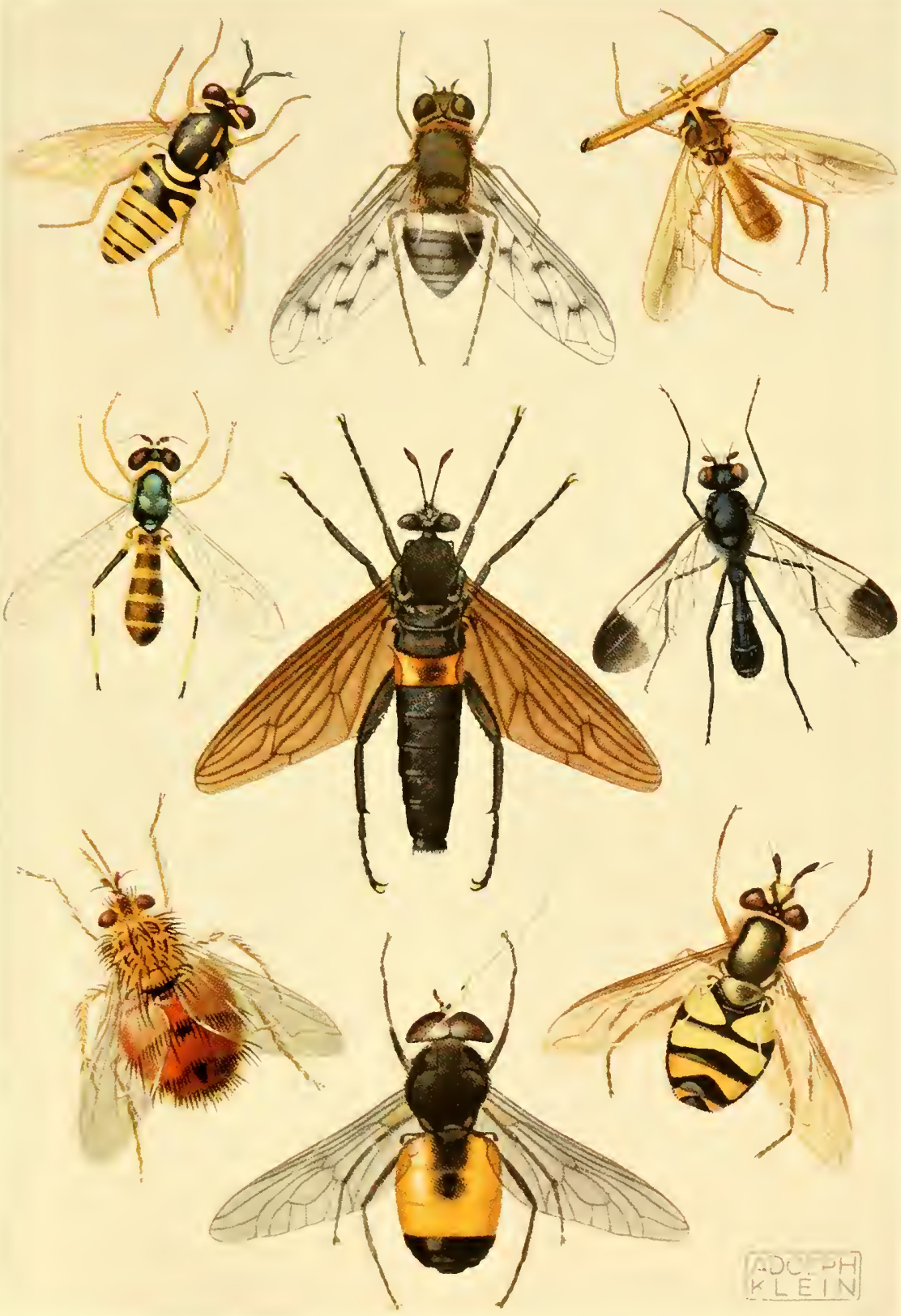

sphecomyin rittatr Wied.

(Syrphidac)

Aloipha cingulat: Schtner (stratiomyide)

Dejeania rexatrix (). S. (Tachinidie)
Hyperalonia hela Eriehs. (Bombylidide)

Mydas claratus Fabr. (.1ydadie) (Ttib):Hidie)
Lichardia telescopica Gerst. (c)itidit) Michogaster niner sichm. bided fuscipes Mraeq. 



\section{TABLE OF FAIILIES}

1. Wings absent or greatly reduced.............................

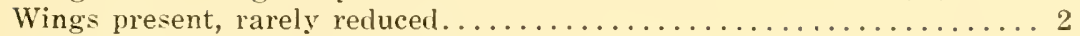

2. Antennæ composed of six or more freely articulated segments........ 3

Antennæ composed of not more than five freely articulated segments, the third segment sometimes complex, usually bearing a style or

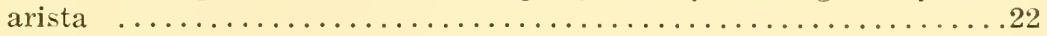

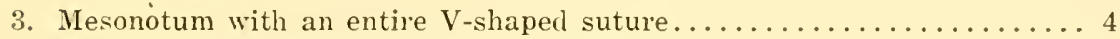

Mesonotal suture transverse, not $\mathrm{V}$-shaped $\ldots \ldots \ldots \ldots \ldots \ldots \ldots \ldots$

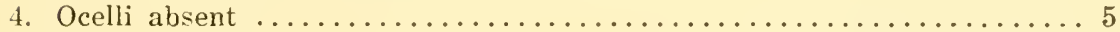

Ocelli present .................. 31) TRICHOCERIDA.

5. Only one anal vein reaches the wing margin...............6 Two anal veins reach the wing margin........... (p. 33) TIPULIDE

6. Second and third veins each with two branches (radius 5-branched) (Tipulidæ plate II, fig. 11) ................. (p. 29) TANYDERIDE Second and third veins with only three branches reaching the wing margin (radius 4-branched) (Tipulidæ plate II, fig. 12) (p. 30).

PTYCHOPTERIDA

7. Wings without a network of folds or creases.............. 8 Wings with a network of fine folds or creases (p. 61) BLEPHARICERIDAE

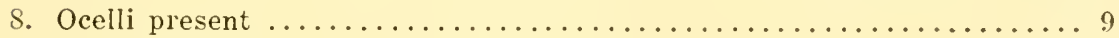

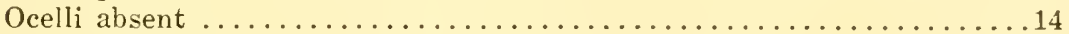

9. Costa continuing around the wing, although weakened behind.

(p. 101) CECIDOMYIDAE

Costa ending at or near the wing-tip ....................

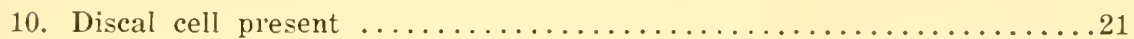

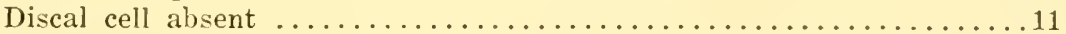

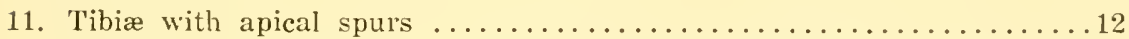

Tibiæ without apical spurs, though produced spur-like.

(p. 131) SCATOPSIDAE

12. Eyes more or less connected by a projection above the base of the

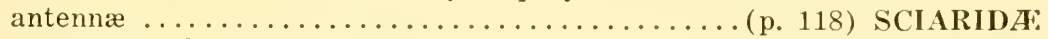

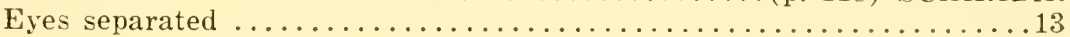

13. Antennæ placed below the compound eyes, usually close to the oral

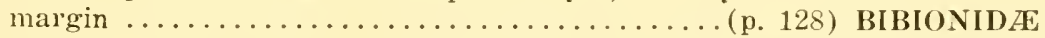

Antennæ situated at most slightly below the middle of the compound eyes ....................... (p. 120) MYCETOPHILIDA.

14. Costa continued around the margin of the wings, though weaker behind

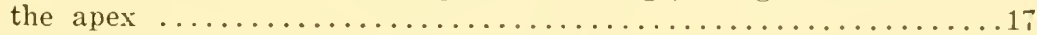

Costa ending at or near the apex of the wing ...............

15. Wings very broad, the posterior veins weak and poorly developed.

(p. 63) SIMULIIDA:

Wings narrow and long, the posterior veins stronger ............ 16 
16. Wings lying flat over the back when at rest; metanotum short and without a longitudinal groove; femora sometimes swollen.

(p. 74) CERATOPOGONIDA

Wings lying roof-like over the back when at rest; metanotum long and with a median longitudinal groove; legs long and slender.

(p. 69) CHIRONOMIDE

17. Wings short and broad, folded roof-like over the body when at rest, usually pointed ................... 78 ) PSYCHODIDE:

Wings long, or if broad, the apex very broadly rounded, always lying

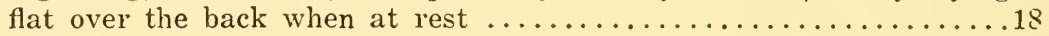

18. Venation very much reduced, several of the veins lacking.

(p. 101) CECIDOMYIDEE

Venation not reduced, the veins strong .................... 19

19. Basal cells long, extending to or beyond the middle of the wing.....20

Basal cells, especially the second, short, not extending nearly to the middle of the wings ................ (p. 67) THAUMALEIDA

20. Apical veins strongly arched $\ldots \ldots \ldots \ldots \ldots \ldots \ldots \ldots$ (p. 80) DIXID $A$ E Veins straight or nearly so............... (p. 83) CULICIDA

21. Fourth posterior cell widely open............ (p. 59) ANISOPODIDAE Fourth posterior cell closed ............... (p. 133) RACHICERIDA:

22. Emporlium cleveloped pulvilliform, the three pads nearly equal......23

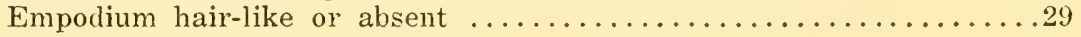

23. Third antennal segment compound, composed of annuli ..........24

Third antennal segment simple, usually bearing an elongated style or

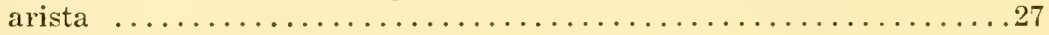

24. Squamæ large and conspicuous .............. 148) TABANIDAF:

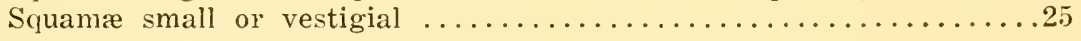

25. At least the middle tibiæ with spurs ..........(p. 146) CCENOMYIDE

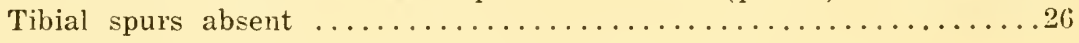

26. Posterior branch of the third vein ending before the wing-tip.

(p. 134) STRATIOMYIDA: Posterior branch of the third vein ending well behind the wing-tip.

(p. 155) PANTOPHTHALMIDEE

27. Squamæ very large; head very small, placed low down, composed almost entirely of the eyes, the face and front very narrow or obliterated.

(p. 203) CYRTIDIE

Squamæ small; head larger, the face or front broad............28

28. Middle tibiæ with spurs; venation not complex... (p. 157) RHAGIONIDA

Tibiæ without spurs; venation intricate, many veins ending before the wing-tip .................... 201) NEMESTRINIDA

29. Wings rounded apically, with strong veins anteriorly and very weak, oblique ones; coxæ not widlely separated by the sternum.

(p. 234) PHORIDE

Wings with normal venation or pointed at the apex, or the coxæ broadly

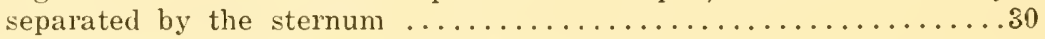

30. Wings pointed at the apex, without crossveins.

(p. 232) LONCHOPTERIDAE

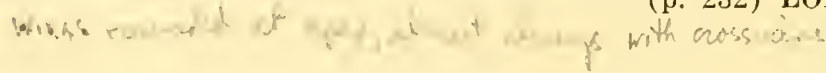


31. Two or more submarginal cells, the third vein furcate............. 32 Only one submarginal cell, the third vein simple................ 38

32. Front hollowerl between the eyes, strongly concave from anterior view. . 3:3 Front scarcely or not at all concave from anterior view...........

33. At most one ocellus; at most two veins reach the wing margin behinr

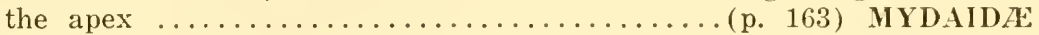
Three ocelli; at least four veins reach the wing margin, or extend toward it, behind the apex ................ 167) ASILIDF,

34. Costa continuing around the wing; fourth vein ending beyond the wing-

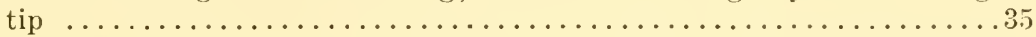
Costa not continued beyond the apex of the wing; fourth vein ending before the wing-tip ................. (p. 161) SCENOPINIDAE

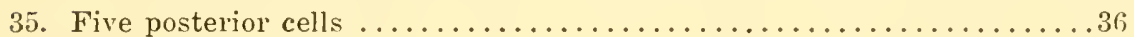

At most four posterior cells ............................

36. Fourth vein ending before the apex of the wing..(p. 189) APIOCERIDAE Fourth vein ending behind the apex of the wing...(p. 185) THEREVIDEE

37. Anal cell open or closed near the wing margin, the anal vein reaching the margin ....................... 191) BOMBYLIIDAE Anal cell closed far from the wing margin, the anal vein never extending to the margin, sometimes absent............ (p. 205) EUIPIDAE

38. Anal cell elongate, tapering and acute apically, closed near the border of the wing; basal cells usually elongate..................

Anal cell short, transverse, oblique, or convex apically, if somewhat pointed the apex partly transverse, partly drawn out into a triangular

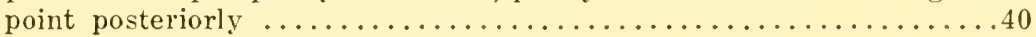

39. Anal cell closed very close to the wing margin; a spurious vein running obliquely between the third and fourth longitudinal veins.

(p. 247) SYRPHIDE

Anal cell usually shorter; no spurious vein................. 40

40. Head extremely large, hemispherical, the front and face very narrow; arista dorsal .................... (p. 245) PIPUNCULIDE

Head not unusually large; face or front usually wide............41

41. Frontal lunule entirely absent, the parafacials not differentiated by a

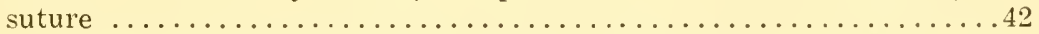

Frontal lunule present; parafacials differentiated by a suture which extends above the antennæ and is indistinct only in some Conopiræ...44

42. Anterior crossvein situated at or before the basal fourth of the wing; second basal and discal cells always united...(p. 215) DOLICHOPIDA: Anterior crossvein situated far beyond the basal fourth of the wing or the second basal cell complete ...........................

43. Anal cell pointed posteriorly; proboscis never rigid and adapted for piercing ....................... 242) PLATYPEZIDAE

Anal cell not pointed posteriorly; proboscis usually rigid; never a single row of acrostical hairs .................. (p. 205) EMPIDEE

44. Coxæ close together at the base, the legs attached ventrally.........45 Coxæ widely separated at the base, the legs attached toward the sides of the thorax; usually leathery or coriaceous flies; ectoparasites

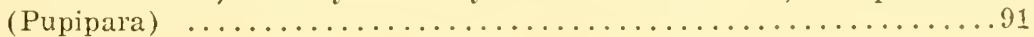


45. Second antennal segment with a longitudinal seam along the upper outer edge extending almost the whole length; posterior calli definitely formed by a depression extending from behind the base of the wings to above the base of the scutellum (Calypteratæ; Muscoidea)..85

Second antennal segment rarely with a well developed dorsal seam, the posterior calli not differentiated (except in Gasterophilus); squamæ

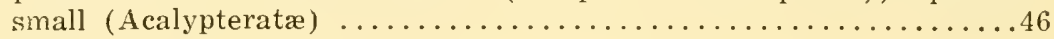

46. Mouth parts vestigial, sunken in a very small oral pit.

(p. 400) GASTEROPHILIDA

Mouth parts well developed, the oral opening large..............

47. Posterior spiracle with several hairs on the border in addition to the pubescence, (visible only with high magnification) ........... 50

Posterior spiracle with pubescence only .................... 48

48. Subcosta complete, free from the first vein and ending in the costa

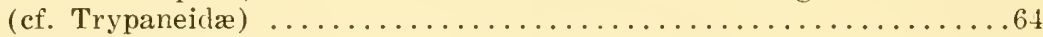

Subcosta incomplete, or not ending in the costa or the apex curved forward beyond the bend ............................ 49

49. Subcosta curved forward at nearly a right angle and weakened beyond the bend, the costa fractured at the apex of the subcosta; wings almost always pictured................. 285) TRUPANEIDAE

Subcosta not angularly curved and weakened................. 51

50. Head broad, flattened above; scutellum and thorax flattened, the former elongate; large flies................. (p. 299) ROPALOMERIDA

Head rather spherical; scutellum usually convex, not elongate; small, cylindrical flies ...................... (p13) SEPSIDA

51. First segment of the posterior tarsi shortened and incrassate.

(p. 360) BORBORIDFE

First segment of the posterior tarsi normal, usually longer than the

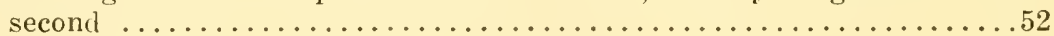

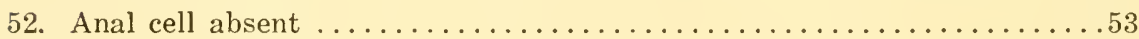

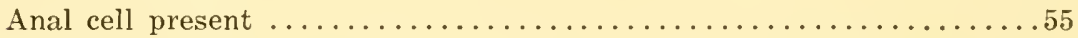

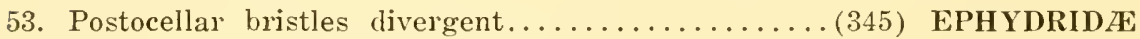

Postocellars convergent or absent........................

54. Ocellar triangle large; fifth vein with a distinct curvature near the middle of the discal cell................ (p. 339) CHLOROPIDAE Ocellar triangle small; fifth vein straight or without a sharp curvature.

(p. 325) DROSOPHILIDE

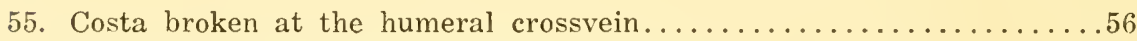

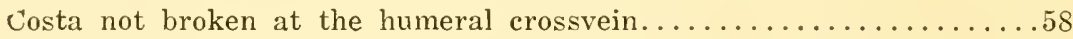

56. Postocellars divergent, if absent the arista absent.

(p. 332) AGROMYZIDAE

Postocellars convergent, parallel or absent, arista present.........57

57. A pair of convergent frontal bristles anteriorly; interfrontals often present .................... (p. 334) PHYLLOMYZIDAE Anterior frontals not convergent........... (p. 325) DROSOPHILIDA

58. Postocellar bristles convergent............... (p. 329) OPOMYZIDZE Postocellar bristles divergent or absent...................59 
59. Ocellar triangle large and shining, reaching the anterior edge of the

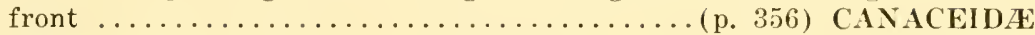

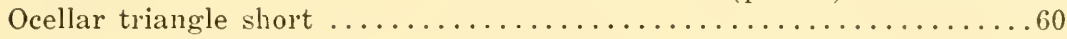

60. Second vein joining the costa just beyond the apex of the first.

(p. 328) ASTEIIDA Second vein joining the costa far beyond the apex of the first......61

61. Custa fractured or weakened at the apex of the auxiliary vein......62 Costa not at all weakened............... p. 323) PERISCELLID $F$

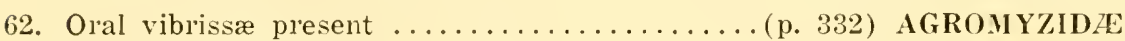

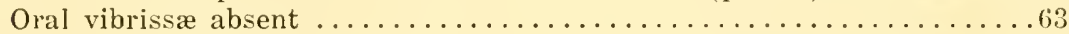

63. Sternopleural bristle present.............. (p. 329) OPOMYZIDE Sternopleural bristle absent................ (p. 374) PSILIDE

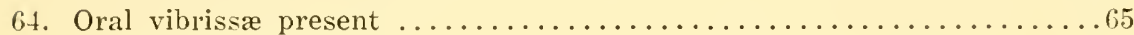

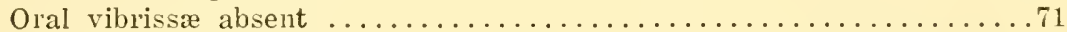

65. Mesonotum and scutellum convex, if rather flattened the abdomen and

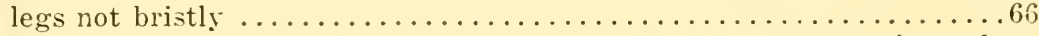

Mesonotum and scutellum flattened; legs and abdomen conspicuously

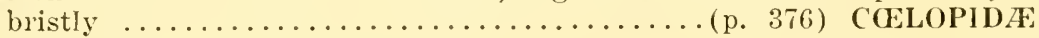

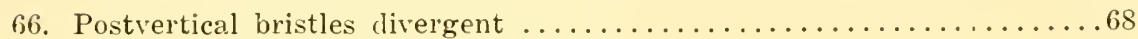

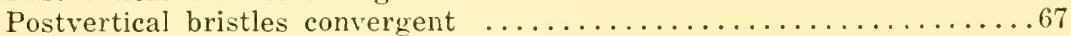

67. Orbital plates bearing the frontal bristles short and oblique.

(p. 378) HELOMYZIDAE

Orbital plates long, extending to the anterior margin of the front or almost so ......................... 371) CHYROMYID.F

68. Second basal and discal cells separated .................... 69

Second basal and discal cells confluent...... (p. 325) DROSOPHILIDE

69. Anterior half of the front with strong bristles, two to four pairs present on the front; third antennal segment short and rather orbicular, the arista subapical ....................... (p. 362) CLUSIIDAE

At most two pairs of rather weak frontal bristles situated on the pos-

terior half; arista sub-basal ............................

70. Eyes round; occiput convex and prominent.......(p. 310) PIOPHILIDAE Eyes, vertical, elongate; occiput concave; antennæ long.

(p. 298) LONCHAIDAE

71. Legs long and slender, stilt-like; apical cell narrowed............72

Legs shorter and more robust, if rather long the apical cell not strongly

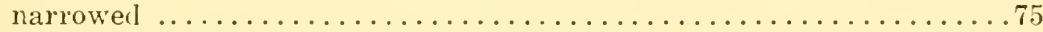

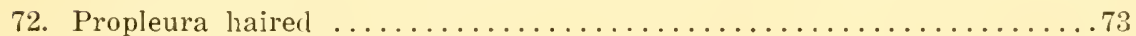

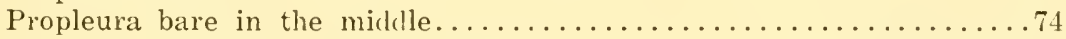

73. Pteropleura haired on whole surface..........(p. 301) TANYPEZIDAE

Pteropleura bare on anterior half; second basal cell confluent witl the discal ......................... (p06) HICROPEZIDAE

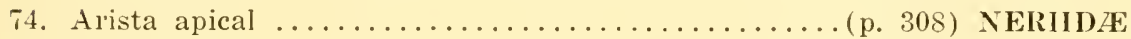
Arista dorsal ....................... (p. 303) CALOBATIDEE

75. Apical cell closed or almost so in the wing margin; abdomen cylindrical, the genitalia usually large................ (p. 265) CONOPIDEE

Apical cell not strongly narrowed or the abdomen short and broad.....76 
76. Some or all of the tibiæ with preapical dorsal bristle............ 77 Tibiæ without preapical bristle......................... 80

77. Postocellar bristles parallel, divergent or absent.............. 78 Postocellar bristles convergent............. (p. 315) LAUXANIIDE

78. Clypeus never prominent; femora with bristles................ 79 Clypeus very prominent; femora without bristles. (p. 382) DRYOMYZIDA

79. Ovipositor flat and wide; front long and moderately narrow; head short, hemispherical, the antennæ never porrect; shining blackish flies.

(p. 298) LONCHAIDA

Ovipositor not prominent; front wide; head more or less orbicular or the front produced; antennæ usually porrect; very rarely shining black ....................... (p. 367) TETANOCERIDAE

S0. Antennæ situated on the eye-stalks or at their base.(p. 358) DIOPSIDF Antennæ situated on the front, though widely separated, regardless of

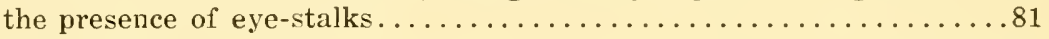

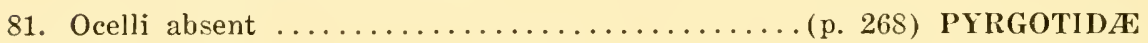

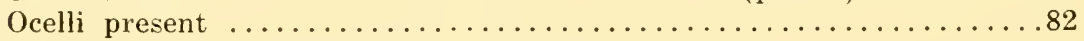

82. Postocellar bristles convergent or absent $\ldots \ldots \ldots \ldots \ldots \ldots \ldots \ldots$ \&3

Postocellar bristles divergent or parallel ................. 84

83. Posterior femora swollen and spinose beneath; abrlomen clavate; small, slender flies .................. (p. 373) MEGAMERINIDA Posterior femora not swollen and spinose; abdomen short and rather broad, never clavate ................ (p. 365) CHAMFMYIDE

84. Presutural dorsocentrals absent or the subcostal and first veins end

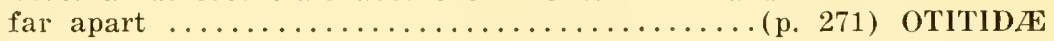

Presutural dorsocentrals present or the thorax bearing very long, fine pile .................... 296) PALLOPTERIDA

85. Metascutellum developed, appearing as a strong convexity below the scutellum; hypopleura with strong bristles.....(p. 415) TACHINIDA

Metascutellum weak or absent, or if developed there is only hair on the

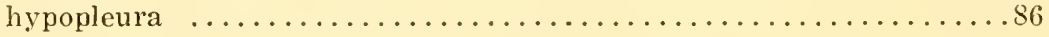

86. Oral opening and mouth parts very small; hypopleura with abundant

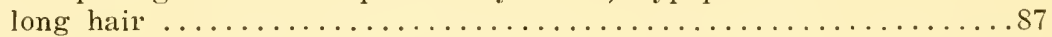

Oral opening normal; hypopleura with a row of bristles or only short,

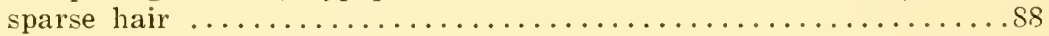

87. Scutellum extending far beyond the base of the metanotum; metascutellum never developed................ (p. 411) CUTEREBRIDA

Scutellum very short; metascutellum usually strongly developed; palpi usually large ........................... (p. 413) EESTRIDA

88. Hypopleura with a row of bristles....................... 89

Hypopleura with fine, short hair or bare ................... 90

89. A pical cell strongly narrowed apically......... (p. 402) METOPIID $\mathbb{E}$ Apical cell not at all narrowed apically........... (p. 384) MUSCIDA

90. Oral vibrissæ absent; mesonotum without bristles except above the

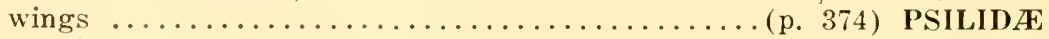
Oral vibrissæ present; mesonotum with bristles.....(p. 384) MUSCIDA 


\section{PUPIPARA AND FLIES WITHOUT OR WITH ABORTED WINGS}

91. Coxæ widely separated by the sternum; usually parasitic on warm

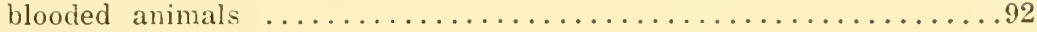

Coxæ approximate basally; not parasitic on warm blooded animals (ex-

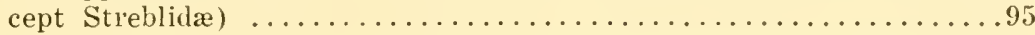

92. Mesonotum short, resembling the abdominal segments; antennæ inserted in lateral grooves.................. (p. 472) BRAULIDAE

Mesonotum and abdomen differentiated ................ 93

93. Head small and narrow, folding back into a groove on the mesonotum; prosternum produced ..................... (476) NYCTERIBIIDAE

Head not folding back in a special groove; prosternum not produced....94

94. Palpi broader than long; wings uniformly veined..(p. 477) STREBLIDA Palpi elongate, forming a sheath for the proboscis; wing veins crowded anteriorly, weak or absent posteriorly.......(p. 473) HIPPOBOSCIDE

95. Antemæe and mouth parts present ......................... 96 Antennæ and mouth parts absent............ p. 477) STREBLIDAE

96. Antennæ consisting of six or more freely articulated segments ......97 Antennæ consisting of at most three freely articulated segments.....103

97. Mesonotum without a complete, V-shaped suture $\ldots \ldots \ldots \ldots \ldots \ldots . \ldots 9$ Mesonotum with a complete V-shaped suture.......(p. 33) TIPULIDE

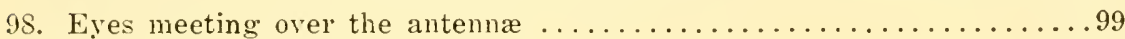
Eyes widely separated above the antennæ................... 101

99. Abclomen enormously swollen, the apical four segments slender; termite

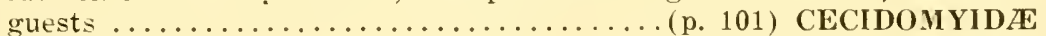

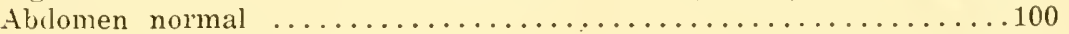

100. Scutellum and halteres present................ (p. 131) SCATOPSIDA: Scutellum and halteres absent................ (p. 118) SCIARIDA:

101. Termite guests; ocelli absent; wings with several veins.

(p. 78) PSYCHODIDA

Not termite guests . . . . . . . . . . . . . . . . . . 102

102. Halteres present ................... (p. 69) CHIRONOMIDA Halteres absent .................. (p. 120) MYCETOPHILIDA

103. Antennæ apparently consisting of one more or less globular segment; posterior femora robust and laterally compressed..(p. 234) PHORIDE Antennæ with two or three quite evident segments; posterior femora not laterally compressed ...................................

104. Frontal lunule present ................................

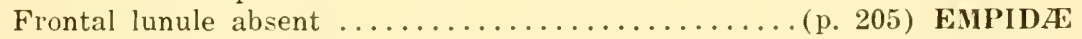

105. First segment of the posterior tarsi short and swollen. (p. 360) BORBORIDA

First segment of the posterior tarsi longer than the second segment

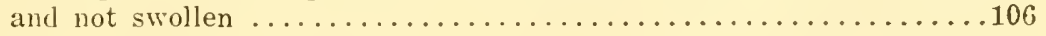

106. Arista with long, sparse rays............ (p. 325) DROSOPHILIDA Arista pubescent or bare; third antennal segment orbicular; wings mutilated by the fly..................... 378) HELOMYZIDE 


\section{Superfamily Tipuloidea}

These are the "Crane Flies" and inelude the families Tanyderidæ, Ptychopteridæ, Trichoceridæ, Tipulidie and Anisopodidæ. The first four mentioned families are characterized by the presence of a $\mathrm{V}$-shaped suture on the mesonotum, and have, until recent years constituted the family Tipulide. In the Ptychopterida this suture is more or less obsolete posteriorly where it extends into the preseutellar depression but its form is always very well marked. The inclusion of the Anisopodidie with the Crane-Flies may be questioned by some students of the Order. I think the question is a debatable one: at any rate, the family seems to form more or less of a connecting link between the Tipulids and Mycetophilids.

The manuseript for the Tipuloidea has been prepared by Dr. C. P. Alexander and this fact assures the student of thorough and accurate keys together with the latest views on generie limits and classification. The study of this group might almost be said to be a "world apart" in the study of Diptera and I cannot fully express my gratitude to Dr. Alexander for the service he has rendered in preparing this part of the work. 


\section{Family Tanyderidæ-The Primitive Crane Flies}

Generalized flies of medium size, usually with a handsomely banded wing-pattern. Houthparts often produced. Antennæ with from 15 to 25 segments; flagellar segments simple, cylindrical. Eyes with erect setæ between ommatidia; ocelli lacking. Latero-cervieal sclerites sometimes greatly elongated, short in the local species. Wings with five branches of Radius reaching the margin ("Fig. 11); most genera with one or two supernumerary erossveins in the outer radial or medial ficlds, these never exceeding two in any one genus, usually with a single such element. Male hypopygium with a single dististyle, usually simple, weakly bifid in the two regional genera. Aedeagus trifid.

The immature stages oceur in sandy soil at margins of major streams, the larva being aquatic or nearly so.

There are 23 recent species of Tanyderidx, distributed in 10 genera, chiefly Australasian in distribution. Two genera with three species occur in North America.

\section{KEY TO GENERA}

1. A supernumerary crossvein in cell $\mathrm{M}_{3}$ of the wing (*Fig. 11).

Protoplasa Osten Sacken

Wings without supernumerary crossveins.......Protanyderus Handlirsch

The most important recent literature is as follows:

Alexander, C. P.

1919. The crane-fies of New York. Part I. Distribution and taxonomy of the arlult flies. Cornell Univ. Agr. Expt. Sta., Mem. 25: p. 883,1 fig.

1927. Diptera. Fam. Tanyderidæ. Genera Insectorum, Fasc. 189.

1930. Observations on the Dipterous family Tanyderidæ. Proc. Linn. Soc. New South Wales, lv, pp. 221-230, 2 pls., 1 fig. (larva and pupa).

Crampton, G. C.

1925. A phylogenetic study of the thoracic sclerites of the non-Tipuloid Nematocerous Diptera. Ann. Ent. Soc. America, xviii, pp. $49-74,5$ pls.

1926. The external anatomy of the primitive Tanyderid Dipteran Macrochile spectrum Low, preserved in Baltic Amber. Bull. Brooklyn Ent. Soc., xxi, pp. 1-14, 2 pls.

1930a. Some anatomical details of the pupa of the archaic Tanyderid Dipteron Protoplasa fitchii O. S. Proc. Ent. Soc. Washington, xxxii, pp. 83-98, 3 pls.

1930b. A comparison of the more important structural details of the larva of the archaic Tanylerid Dipteron Protoplasa fitchii, with other Holometabola, from the standpoint of phylogeny. Buli. Brooklyn Ent. Soc., xxv, pp. 239-258, 4 pls.

Williams, Inez

1933. The external morphology of the primitive Tanylerid Dipteron Protoplasa fitchii O. S., with notes on the other Tanyderidx. Journ. N. Y. Ent. Soc., xli, pp. 1-36, 7 pls. (anatomy of adult; comparative wing-figures of all genera of Tanyderidæ).

* Plate II, Tipuloidea. 


\section{Family Ptychopteridæ-The False Crane Flies}

Antennæ elongate, with 16 (Ptychopterinæ) to 20 segments (Bittacomorphinæ); flagellar segments eylindrieal. Suture between praeseutum and scutum obsolete-posteriorly. Wings with $R_{2}$ preserved as a distinet element, lying far distad, subequal in length to $\mathbf{R}_{\mathbf{1}+2}$; three branches of Radius reach margin; two or three branches of Hedia; a single Anal vein ("Fig. 12).

The immature stages oecur in saturated organie earth, the larva with an elongate eandal breathing-tube, the pupe with a single greatly elongated pronotal breathing-horn.

There are two subfamilies, with 3 genera, Ptychopter with $2 t$ speeies, Bittacomorphella with 3 speeies, Bittacomorpha with 2 speeies. In the New World, the family is found only in the Nearetie region, all gencra being found on the eastern and western coasts but rare or lacking in the plains region.

\section{IEY TO GENERA}

1. Antennæ 16-segmented; wings with cell $M_{1}$, present - (*Fig. 12);

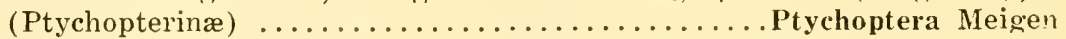
Antennæ 20-segmented; wings with cell $\mathrm{M}_{1}$ lacking; (Bittacomorphinæ).. 2

2. Wings with macrotrichia in distal ends of radial and medial cells; basitar'si of legs not dilated .................. Bittacomorphella Alexander Wings without macrotrichia in cells; basitarsi of legs conspicuously

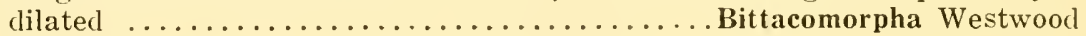

The latest literature on the family:

Alexander, C. P.

1919. The crane-flies of New York. Part I. Distribution and taxonomy of the adult flies. Cornell Univ. Agr. Expt. Sta., Mem. 25, pp. 884-886, figs. 2-4.

1920. The same, Part II. Biology and Phylogeny. Ibid., Mem. 38, pp. 772-787, pls. 14-18, incl. (larva and pupa).

1927. Diptera. Fam. Ptychoptericlæ. Genera Insectorum, Fasc. 188, pp. 1-12, 1 pl.

* Plate II, Tipuloidea. 


\section{Family Trichoceridæ-The Winter Crane Flies}

Small or medium-sized flies of slender build, the antenna elongate, setaceous. Three oeelli. Wings with m-eu lying far distad; two complete Anal veins, 2nd A very short, ineurved to anal angle, slightly longer and more extended in Diazosma. Male hypopygium with a single dististyle, this cylindrieal or with a varionsly dereloped lobe on basal portion of mesal face. Ovipositor with eerci upeurved, the eonvexity being on the ventral surface.

The so-ealled "winter erane flies" are most numerous in Spring and Fall, though sometimes abundant during mild days of Winter. They are usually found in large to small swarms in the open, but may be found in cellars, mines and similar places. The immature stages occur in deearing vegetable matter.

There are 4 valid genera with about 45 deseribed species. Trichocera is essentially a genus of the northern Hemisphere; Diazosma is represented only by 2 species, with a wide distribution in the Holaretic region. Paracladura has sereral species in New Zealand and Chile, with a few others in eastern Asia; a single species (trichoptera O.S.) is found on our Pacifie coast.

\section{KEY TO GENERA}

1. Wings. with vein 2 nd $A$ subsinuate, not short and curved abruptly into the anal angle; north temperate............. Diazosma Bergroth Wings with vein 2 nd $A$ short, curved abruptly into the anal angle..... 2

2. Tibial spurs present; tarsi with basitarsus longer than segments 2 and 3 taken together; (* fig. 13); north temperate to arctic.

Trichocera Meigen

Tibial spurs lacking; basitarsus very short, only two or three times as long as wide, shorter than the third tarsal segment; western.

The most important recent literature:

Paracladura Brunetti

Alexander, C. P.

1919. The crane-flies of New York. Part I. Distribution and taxonomy of the arlult flies. Cornell Univ. Agr. Expt. Sta., Mem. 25, pp. 887-888, figs. $165,166$.

1920. The same. Part II. Biology and Phylogeny. Ibid. Mem. 38, pp. 789-791, pl. 19 (larva and pupa).

1926. The Trichoceridæ of Australia (Diptera). Proc. Linnean Soc. New South Wales, 51, pp. 299-304, 11 figs. (key to genera).

* Plate II, Tipuloidea. 
Edwards, F. W.

1928. Diptera. Fam. Protorhyphidæ, Anisopodidæ, Pachyneuridæ, Trichoceridæ. Genera Insectorum, Fasc. 190, pp. 1-41, 2 pls.

Rhynehart, J. G.

1925. The larva and pupa of Trichocera regelationis L. Proc. Belfast Nat. Hist. and Phil. Soc., sess. 1922-1923, pp. 3-14, pls. 1-3. 
Family Tipulidæ-The Crane Flies

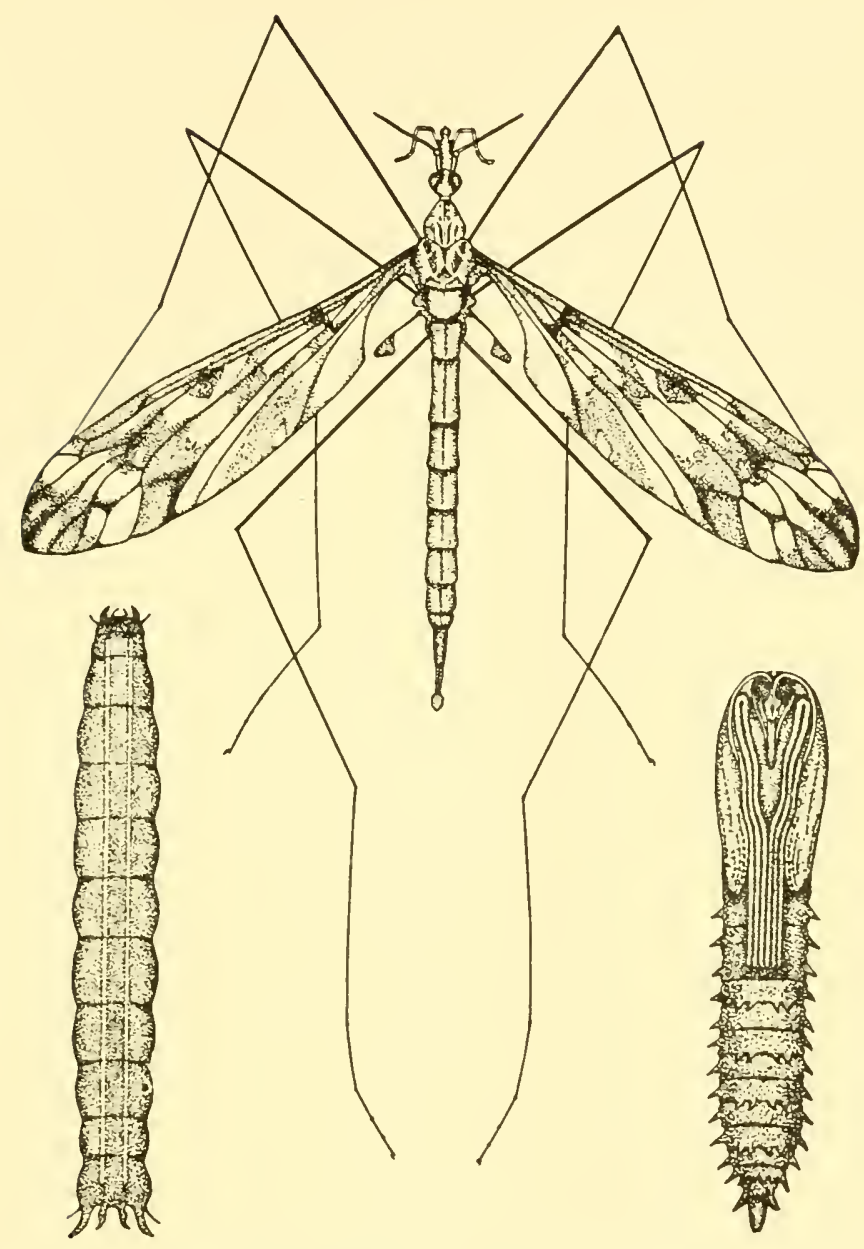

Tipula trivittata-adult, larva, pupa.

The present family, commonly called "erane flies", includes slen. der-bodied flies, having long to very long, musually brittle legs that break readily between the trochanter and femur. From allied families of Nematocera, they are readily told by the lack of oeclli. two Anal reins, and the presence of the so-ealled I-shaped suture between the mesonotal prescutum and seutum. In many species there is a closed diseal (1st $\mathrm{MI}_{2}$ ) cell. In size, the various species show a range almost as great as that foumd in the entire order, from tiny flies with a wing- 
length of about 2 millimeter's (as Dasymolophilus) to gigantie forms with a wing-length in excess of 45 millimeters (Ctenacroscelis).

Rostrum sometimes greatly elongated, in some (Elephantomyia: Troxorhina) produeed by a great lengthening of the front, the reduced mouthparts being at the extreme tip; in others (Limonia: Gcranomyia) the similarly greatly lengthened mouthparts consist ehiefly of the labial palpi. In most Tipulidxe the rostrum is short to rery short. In many Tipulinæ it is further tipped by a small nose-like point, the nusus. Maxillary palpi ranging in number of segments from 1 (some Limonia and Hexatoma: Conosiu) to the normal number of 4 . Antenne ranging in number of segments from 6 (Hexutoma) to 39 (Gynoplistia: Cerozodia): sometimes very greatly lengthened in males, being one or more times the length of the entire body (Megistocera: Hacromustix; Hexatoma: Eriocera; Rhabdomastix); sometimes with branched flagellar segments (many Tipulinx; some Crlindrotomina; a few Limoniinæ, as Limonia: Rhipidia and Gynoplistia); pedicel shorter than seape (except in some Eriopterine (laduraria): sometimes the basal flagellar segments united into a fusion-segment (Claduraria, Toxorhinaria). Eyes with ommatidia variable in size and coarseness; sometimes holoptic ( $\mathrm{Li}$ monia), usually broadly dichoptic. Pedicini with short ereet seta between ommatidia.

Pronotum sometimes lengthened (some Limonia. Toxorthina). Praseutum sometimes produced cephalad over pronotum (Conosia, Trentepohlia). Paired double dots, the tuberculute pits, often present, one on either side of midtine on eephalic half of præsentum. Pseudosutural foreae often present as shiny depressions on humeral portion of preseutum. Postnotal pleurotergite sometimes produced into a tubercle (some Tipulinx). Halteres long to very long. Legs with troehanters short, rarely lengthened (Atarba, Rhabdomastix); tibiæ with or without terminal spurs; claws simple or rarionsly toothed (Limonia, Tipula). Wings of various shapes, sometimes long and marrow, the anal angle eorrespondingly reduced (some Limonia), sometimes with the region squarely developed (Antocha). In eases, a pale longitudinal fold in cell ('u of wings (Dicrenoptycha). The details of venation are not discussed here, having been thoroughty considered by the present writer in recent papers that are cited in the morphological bibliography at end of paper and which may be consulted for details. The chief prenise of the interpretation of the radial field is that the so-ealled radial crossrein, $r$, of the Comstock-Needham sistem, has never been developed in the Diptera, the rein that has been so interpreted in the fow families where it is found being the transverse free portion of $R_{2}$. The anterior branch of the radial ficld is labelled $R_{1+2}$, exeept in the subtribe Limoni- 
aria, where the free tip of vein $\mathrm{Sc}_{2}$ has migrated along vein $\mathrm{R}_{1}$ to ocempy the extreme tip of the vein. A series of diagrams (Figs. 3 to 10) indicates this tendener, which involves many hundreds of speeies in the rast genus Limoniu. The medial and eubital fields are interpreted according to the Tillyard modification of the Comstock-Needham system.

Male hypopygium usually simple, the basistyles (coxites) bearing the dististyles (styles) at or near apex. Aedeagus and its subtending gonapophyses furnishing characters of paramount importance for specifie determination. A dorsal lobe of the basistyle, the interbase, sometimes present. Ovipositor with the teroal valves (cerci) lengthened, heavily selerotized, usually gently to strongly upeurved, exeecling the short, straight sternal valves (hyporalva); in a few cases (as some Tipulina; Cylindrotomina: Styringomyia and others), the valves of the ovipositor are short and fleshy.

'Tipulide are great lovers of moist conditions, being chicfly restrieted by humidity. Species have been taken within 600 miles of the North Pole, while others ocem at altitudes of over 17,000 feet in Thibet. The majority of the species occupy the intermediate zone, the family being very numerous in species in all temperate parts of the World and similarly numerous in the subtropieal and temperate portions of the mountainous regions of the Tropics. Lowland tropical species are fewer in number and are apt to have a very wide distribution. The lesser oceanic islands are practically devoid of the larger crane flies (Tipulina) while having numbers of species of the small fragile Limoniins (as Limonia, s.l.; Styringomyia: Gonomyia: Lipophleps; Trentepohlia). Ender rigorous eonditions, as the aretie, wind-swept coasts, high mountains and the like, species with redueed wings are frequently found, being most numerous in the female sex. The areatest reduetion of wings is found in Chionea, which is virtnally apterous in both sexes.

The Tipulida of the World now include more than 6000 species, arranged in 283 genera and subgenera (Tipulinx, 76, Cylindrotominse, 9; Limoninx, 198, the latter further distributed in the following tribes: Lechrini. 4; Limonimi, 37; Pedieini, 12: Hexatomini, 70, and Eriop1erini, 75). Representatives of all three subfamilies and of all tribes with the exception of the Lechriini ocem in the area moler consideration.

Keys avalable for the identifieation of the adult flies are very few in number. The writer's preliminary stuty on the "Crane flies of New Tork", is now seriously out-of-date due to the great additions made in intervening years. The forthoming volume on Diptera in the "Tnsects of Connecticut" series will largely supereede the earlier work. Both of these reports are restricted to the area embraced in northeastern 
North America. No keys are available for most of the groups in other regions of the continent, with the exception of the papers listed in the bibliography on certain groups of Tipulidæ, which are lessened in value due to the great additions that have been made in later years.

\section{KEYS TO SUBFAMILIES AND TRIBES, GENERA, ETC.}

1. Terminal segment of maxillary palpus elongate, whiplash-like; nasus usually distinct; antennæ usually with 13 segments; wings with Sc usually atrophied; vein $\mathrm{Cu}_{1}$ constricted at m-cu, the latter usually at or close to fork of $\mathrm{M}_{3+4}(1,17$ to 20$)$; body-size usually large.

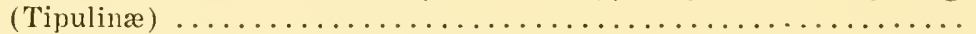

Terminal segment of maxillary palpus short; no distinct nasus; antemnæ usually with 14 or 16 segments; wings with $\mathrm{Sc}_{1}$ present, its extreme tip atrophied in some Cylindrotominæ; vein $\mathrm{Cu}_{1}$ straight, not constricted at $\mathrm{m}$-cu, the latter placed far before the fork of $M_{3+4}$, usually at or close to fork of $M(21$ to 44$)$; body-size

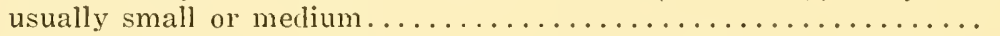

2. Legs unusually long and filiform; wings with vein $\mathrm{R}_{1+2}$ atrophied and with $\mathrm{Sc}_{3}$ ending in Sc close to origin of $\mathrm{Rs}$ (Dolichopeza, 19), when $R_{1+2}$ is preserved (Brachypremna, 18; Tanypremna; Megistocera, 17), vein $\mathrm{Sc}$ is very long, $\mathrm{Sc}_{1}$ reaching $\mathrm{C}$ as a distinct element some distance beyond fork of $\mathrm{Rs}$ and with cell 2nd A usually

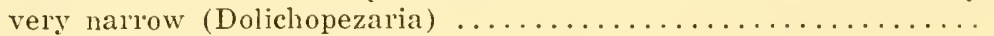

Legs of normal stoutness for the family; wing's with vein $R_{1+2}$ preserved (20); when. atrophied (a few species of Tipula) with Sc of moderate length, $\mathrm{Sc}_{1}$ atrophied before fork of $\mathrm{Rs}$ and $\mathrm{Sc}_{2}$ ending at or near millength of Rs (exception, some species of Longurio);

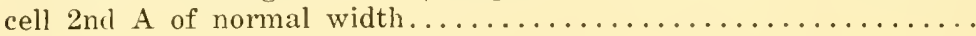

3. Wings with origin of vein $\mathbf{M}_{4}$ basad of that of $\mathbf{M}_{1+2} ; \mathbf{R}_{2+3}$ angularly bent at near midlength (17); tropical, subtropical.

Megistocera Wielemann

Wings with origin of vein $M_{4}$ distad of that of $M_{1+2}$, usually far be-

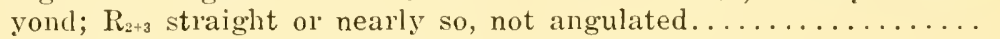

4. Wings with $R_{1+2}$ pale, perpendicular to $R_{2+3}$; Rs strongly arcuated at

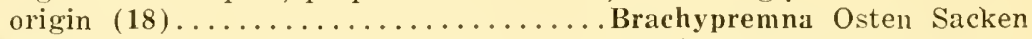

Wings with $\mathrm{R}_{1+2}$, when present, oblique; Rs straight or gently arcuated throughout length, sometimes very short and transverse..........

5. Rs of moderate length, subequal to m-cu; Sc long, $\mathrm{Sc}_{1}$ preserved, ending beyond fork of $\mathrm{Rs}$; $\mathrm{R}_{1+2}$ pale but preserved; tropical.

Tany premna Osten Sacken

Rs short. transverse, simulating a crossvein, about equal in length to one-half m-cu; Sc unusually short, $\mathrm{Sc}_{1}$ atrophied, $\mathrm{Sc}_{2}$ entering Sc before to just beyond origin of $\mathrm{Rs}_{\mathrm{s}}$; $\mathrm{R}_{1+2}$ atrophied. (Dolichopeza)

6. Wings with cell 1 st $\mathbf{M}_{2}$ open by atrophy of basal section of $\mathrm{M}_{3}$, the outer medial field thus appearing pectinately branched (19);

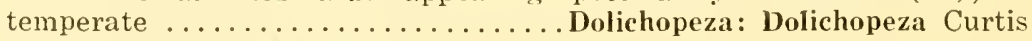

Wings with cell 1 st $M_{2}$ closed ..................... 7

7. Cells beyond cord with abumlant macrotrichia; tropical.

Dolichopeza: Megistomastix Alexander Cells beyond cord glabrous; temperate... Dolichopeza: Oropeza Needham 
8. Antennal flagellum of male branched, of female branched or serrate; legs relatively short and stout. (Ctenophoraria)................ Antennal flagellum simple (serrate in Prionocera, readily told by lack of antennal verticils); legs usually more slender. (Tipularia)...... 1

9. Antennæ of both sexes with two short branches at extreme base of flagellar segments two to seven inclusive; tropical.

Ozodicera: Dihexaclonus Enderlein

Antennæ of male with three or four branches on each of flagellar segments two to nine, of female merely serrate; north temperate. .

10. Antennæ of male with three pectinations on flagellar segments two to rine, each segment with a single branch on apical half, in addition to the usual basal pair; ovipositor greatly elongated,

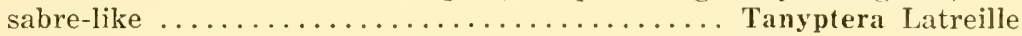

Antennæ of male with two pairs of pectinations on flagellar segments two to nine, one pair being subbasal, the other subapical; ovipositor short and of normal Tipuline structure....... Ctenophora Meigen

11. Wings with vein $R_{3}$ bent strongly caudad before encl, thence angularly deflected cephalad, cell $R_{3}$ thus being much constricted at near midlength; western and tropical................... Wings with vein $\mathrm{R}_{3}$ straight or only gently arcuated throughout its

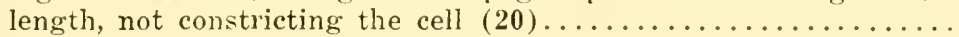

12. Flagellar segments without verticils, the lower face of individual segments produced to give the organ a serrate appearance; terminal flagellar segment abruptly more slender, north temperate to arctic.

Prionocera Lœw

Flagellar segments verticillate, simple or nearly so........... 13

13. Abdomen in both sexes greatly elongated, somewhat resembling that of a lragon-fly; verticils of outer flagellar segments very long and conspicuous; valves (cerci) of ovipositor with smooth margins;

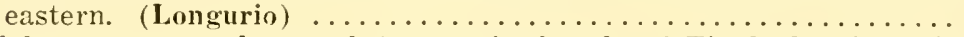

Abdomen not so elongated (except in female of Tipula longiventris Lw., which has the cerci of ovipositor serrate on margins); anten-

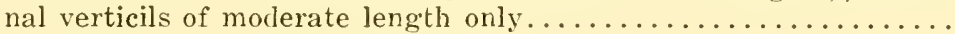
11 

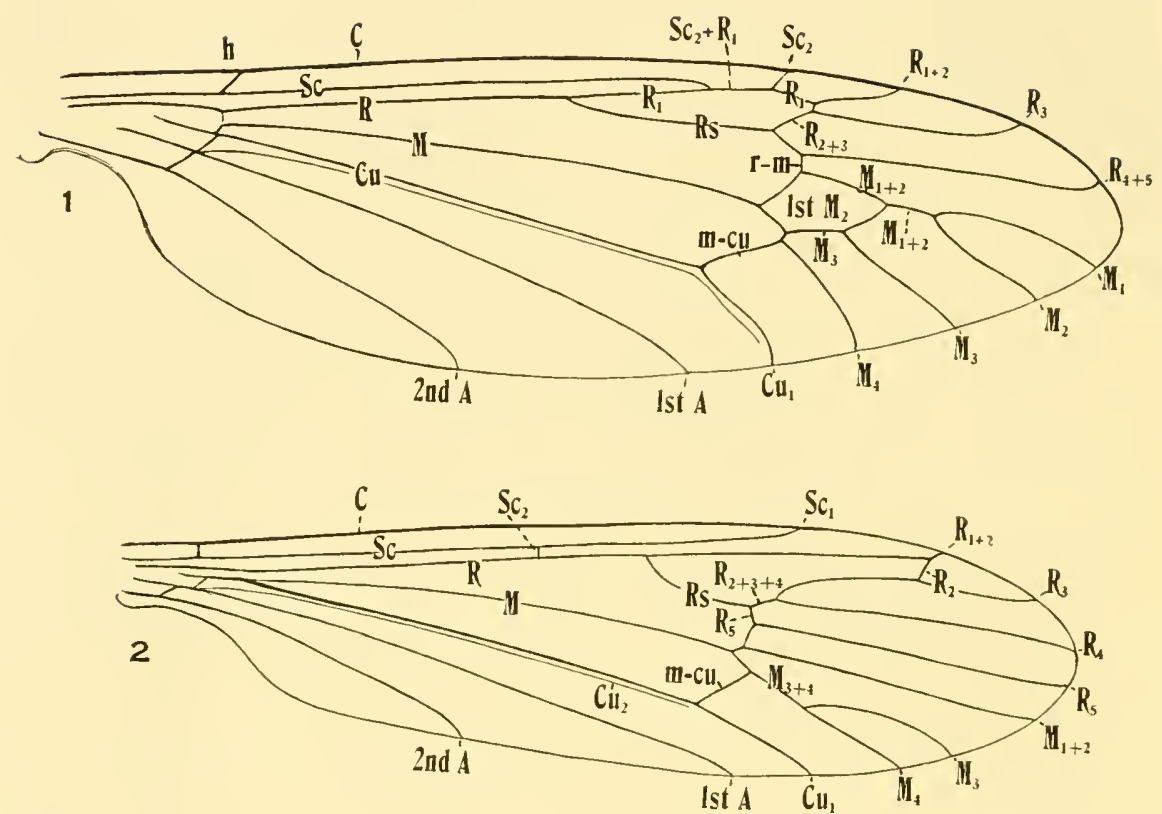

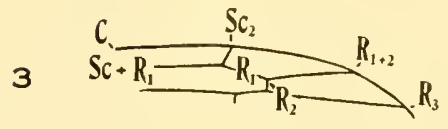

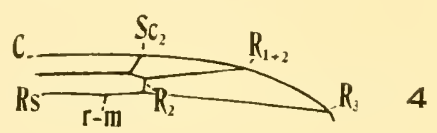

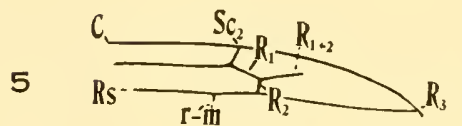

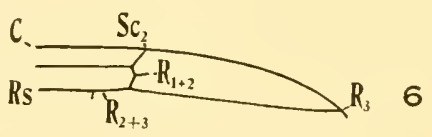

$7 \stackrel{S C+R_{1}-\frac{S C_{2}}{R_{2+3}-R_{1}+R_{2}}}{R_{3}}$

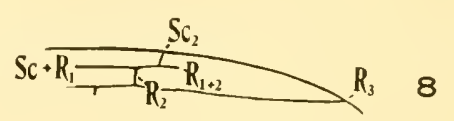

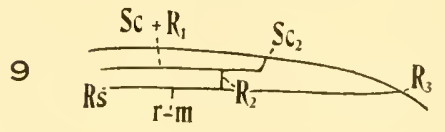

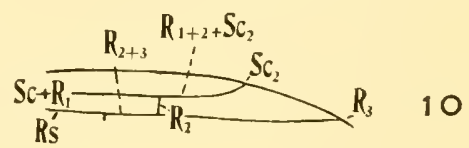

Tipuloidea, Plate I. 


\section{EXPLANATION OH PLATE}

1. Tanyptera fumipemis, venation.

2. Dicranota (Plcctromyia) modesta, venation.

3-10. A series of diagrams to illustrate the modification of the outer subcostal and radial fields of the wing, as found in the Tipulinæ, Cylindrotominæ, Lechriini and Limoniini.

3. The type found in the Orimargaria: $S_{2}$ preserved, $R_{1+2}$ complete, attaining the wing-margin.

4. A further development of 3 . S Sc has moved distad, shortening $R_{1} ; R_{1+2}$ still entire.

5. Condition as in 4 but with tip of $R_{1+2}$ atrophied. Found in several Orimargaria, Limoniaria.

6. An accentuation of 5 . The atrophy of $R_{1+2}$ is still greater, $R_{1}$ more shortened and more or less in transverse alignment with the free tip of $\mathrm{Sc}_{2}$. Condition found in numerous Limoniaria.

7. A still further modification of 5 . The atrophy of $R_{1+2}$ is now complete and $R_{1}$ is in direct transverse alignment with $R_{2}$, both in turn being in transverse alignment with the free tip of $\mathrm{Sc}_{2}$. This is the commonest type in the Limoniaria, being found in most members of the following subgenera of Limonia,-Dicranomyia, Geranomyia and Rhipidia, as well as in some Limonia, s.s.

8. A type that reverts back to condition 5 , with a long spur of $R_{1+2}$ persisting, with the free tip of $\mathbf{S c}_{2}$ migrated distad along this spur to lie beyond the level of $\mathrm{R}_{2}$. A condition found in several subgenera of Limonia, as Peripheroptera, Limonia and Libnotes.

9. A further modification of 8 , where $\mathrm{Sc}_{2}$ has migrated to the extreme tip of the spur of $R_{1+2}$ but still forms a rectangular bend. Limonia: Libnotes.

10. The culmination of the series, where the free tip of $\mathrm{Sc}_{2}$ has migrated to the extreme tip of the spur of $R_{1+2}$ and then bends to the costal margin at a gently oblique angle. This condition is common in many Limonia of the subgenera Limonia and Discobola.

\section{EXPLANATION OF SYMBOLS}

\section{Comstock-Needham system, as modified by Alexander and Tillyard}

$\mathrm{C}=$ Costa $\mathrm{Cu}=$ Cubitus; 1 st $\mathrm{M}_{2}=$ cell 1 st $\mathrm{M}_{2} ; \mathrm{M}=$ Media; $\mathrm{m}-\mathrm{cu}=\mathrm{me}-$ dial-cubital crossvein; $\mathrm{R}=$ Radius; $\mathrm{r}-\mathrm{m}=$ radial-medial crossvein; $\mathrm{Rs}=$ Radial sector; $\mathrm{s}=$ supernumerary crossvein; $\mathrm{Sc}=$ Subcosta; $\mathrm{A}=$ Anal veins. 
40

NORTH AMERICAN DIPTERA
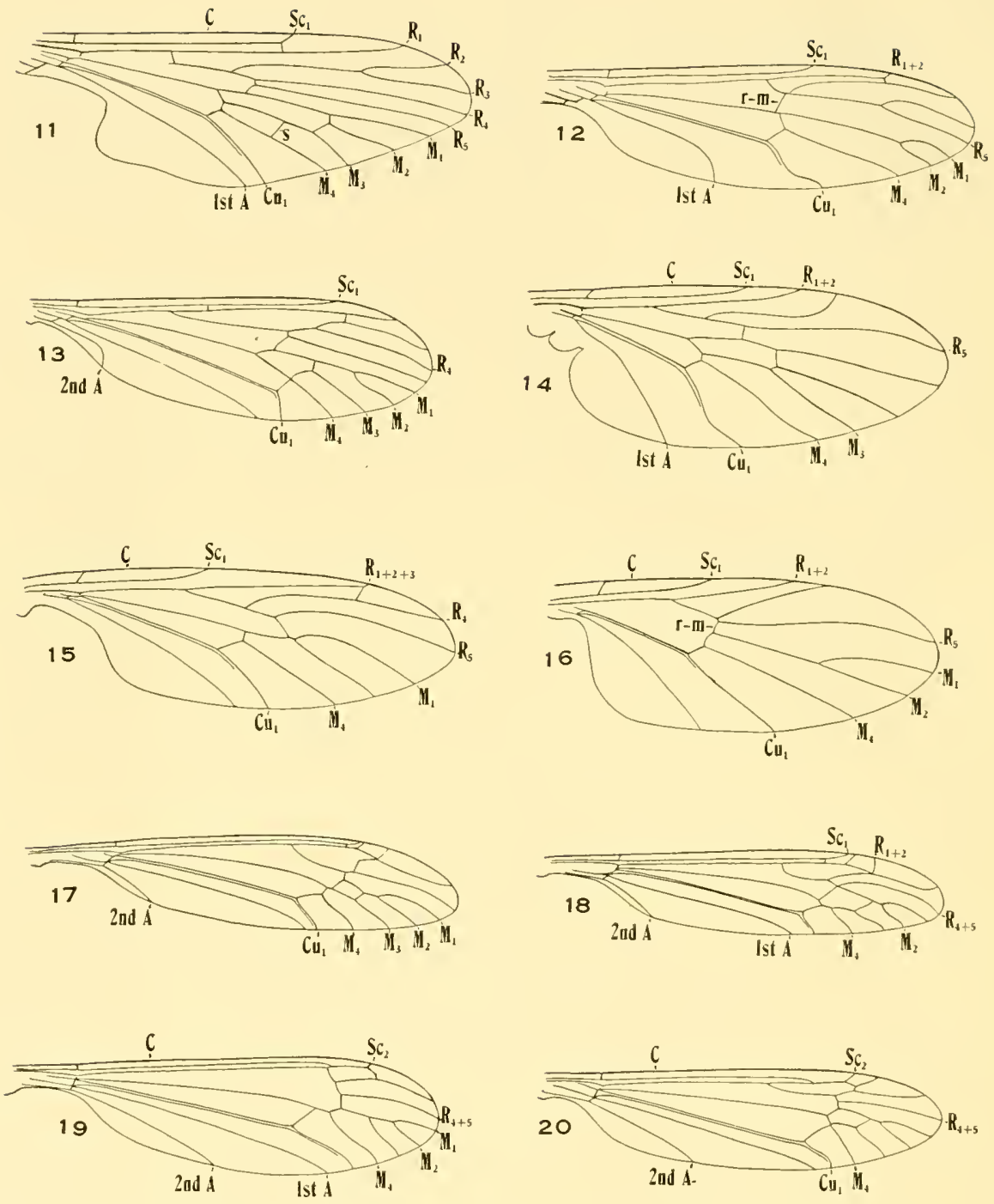

Tipuloidea, Plate II.-11. Protoplasa fitchii, venation; 12. Ptychoptera rufocincta, venation; 13. Trichocera colei, venation; 14. Anisopus alternatus, venation; 15. Axymyia furcata, venation; 16. Mycteboia divergens, venation: 17. Megistocera longipennis, venation; 13. Brachypremna dispellens, venation; 19. Dolichopeza (Dolichopeza) americana, venation; 20. Tipula (Tipula) dorsomacula, venation. 
18. Wings with macrotrichia in apical cells...Tipula: Trichotipula Alexander Wings with cells glabrous............... Tipula: Tipula Linnæus

19. Wings with tip of $R_{1+2}$ atrophied, griving the appearance of a long fusion back from margin of veins $R_{1}$ and anterior branch of $R s$; free tip of $\mathrm{Sc}_{\text {. }}$ preserved $(21,22,23)$ (Cylindrotominæ) ........ 20

Wings sometimes with tip of $R_{1+2}$ atrophied (some Limoniini) but not giving the appearance of a long fusion backward from margin of veins $R_{2}$ and anterior branch of $R s$; free tip of $S_{2}$ preserved in many species of tribe Limoniini, lacking in other tribes in this

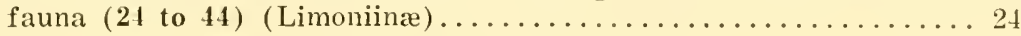

\section{CYLINDRO'TOMINAE: GENERA}

20. Hearl and intervals of mesonotal præscutum with rumerous deep punctures; a deep median groove on præscutum.... Triogma Schiner

Head and intervals of mesonotal præscutum smooth; no median

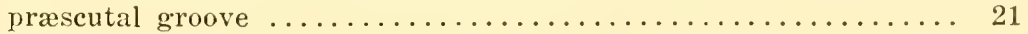

21. Three branches of Radius reach the margin, $R_{1+2}$ being preserved as a distinct element ................... Phalacrocera Schiner

Two branches of Radius reach the margin, $R_{1+2}$ being entirely atrophied, giving the appearance of a long backward fusion of veins $R_{1}$ and anterior branch of $R s(21-23) \ldots \ldots \ldots \ldots \ldots \ldots \ldots 22$

22. Four branches of Media reach the margin (21). Cylindrotoma Macquart Three branches of Media reach the margin................ 23

23. Wings with crossvein $r$-m present; outer end of cell 1 st $M_{2}$ almost always closed by a single transverse vein, cell $M_{1}$ being present, sessile to short-petiolate; cells 2 nd $\mathrm{M}_{2}$ and $\mathrm{M}_{3}$ confluent by atrophy or partial atrophy of distal section of vein $\mathrm{M}_{3}$; antennæ nearly simple, the lower face of individual segments not produced (22.

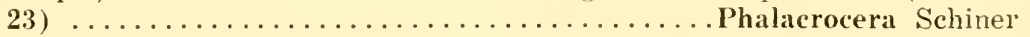

Wings with crossvein $\mathrm{r}-\mathrm{m}$ usually shortened to quite obliterated by the approximation or fusion of veins $R_{i+5}$ and $\mathrm{M}_{1+;}$; outer end of cell 1 st $M_{2}$ closed by two transverse veins, these being $M$ and the basal section of $M_{3}$; cell $M_{1}$ lacking, cells 2nd $\mathrm{M}_{2}$ and $\mathrm{M}_{3}$ distinct; antennæ strongly nodulose, especially in male, the individual flagellar segments nearly cordate...............Liogma Osten Sacken

\section{TRIBES OF LIMONIINAE}

24. Eyes hairy; wings with vein $\mathrm{Sc}_{1}$ very long, $\mathrm{Sc}_{2}$ lying basad of origin

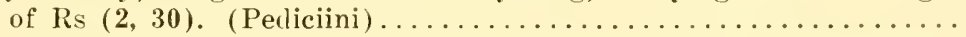
Eyes glabrous; wings with $\mathrm{Sc}_{1}$ short or of morlerate length, when long (some Eriopterini), $\mathrm{Sc}_{2}$ lying distad of origin of Rs; where $\mathrm{Sc}_{2}$ lies basad of origin of Rs (some Limoniini, Eriopterini), the

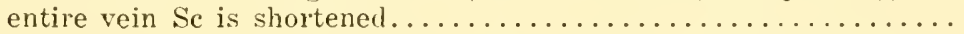

25. Wings with free tip of $S c_{2}$ often present; veins $R_{4}$ and $R_{5}$ fused to margin, only two branches of Rs being present; antennæ usually with 14 (Limoniaria) or 16 segments; (1-10, 21-29) (Limoniini)..

Wings with free tip of Sc: atrophied; veins $R_{4}$ and $R_{5}$ separate, the former usually transferred to the upper branch, $R_{2+3}$, to form a distinct element $R_{2+3+4}$; usually with three branches of $R s$ present (except in Atarba, Elephantomyia, Styringomyia, Teucholabis, Gonomyia and Toxorhina, where $R_{4}$ is captured by $R_{2 r 3}$, as above); antennæ usually with 16 segments; $(31-41) \ldots \ldots \ldots \ldots \ldots \ldots$ 

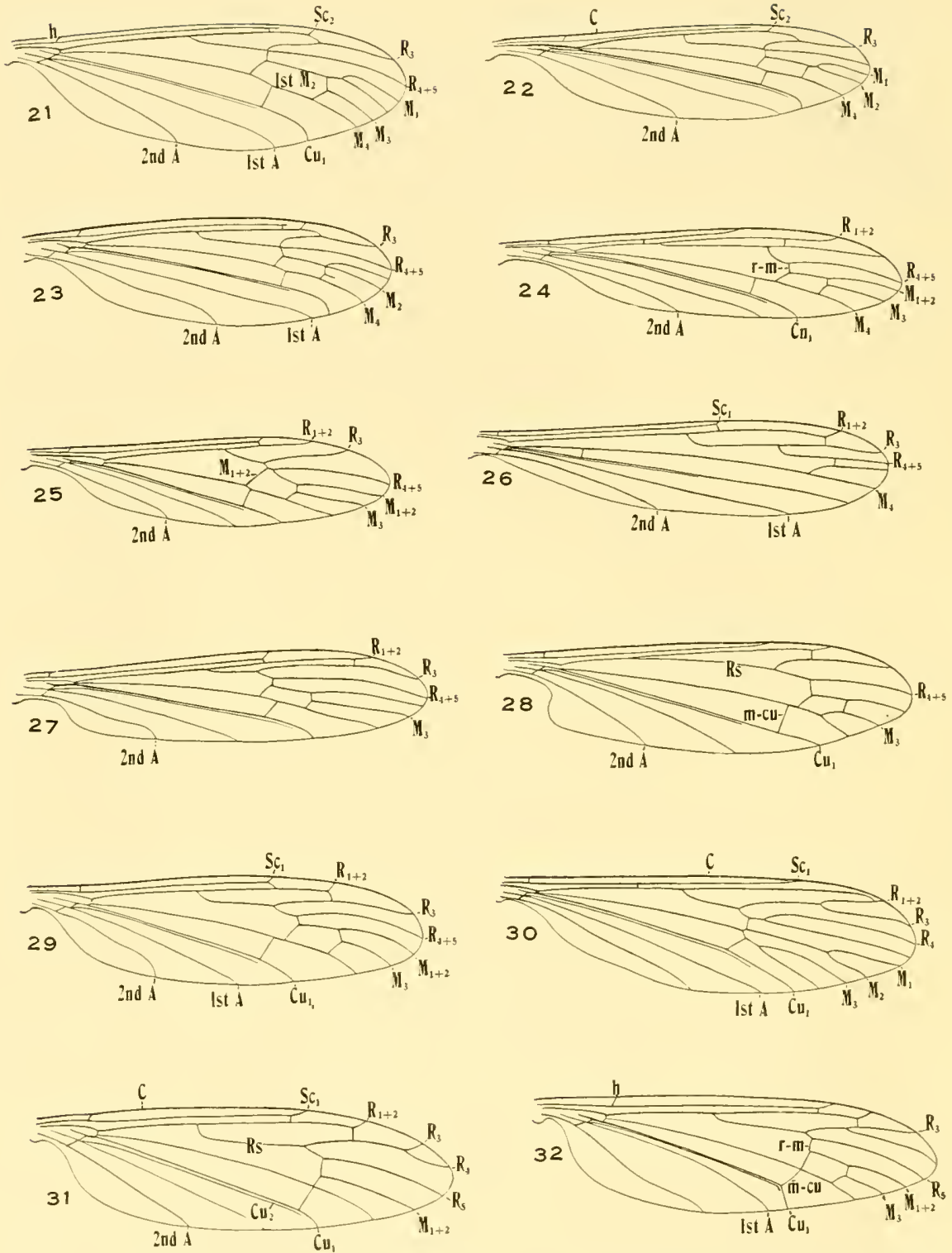

Tipuloidea Plate III-21. Cylindrotoma tarsalis, venation; 22. Phalacrocera tipulina, venation: 23. Phalacrocera occidentalis, venation: 24. Elliptera tennessa, venat. Dicranoptycha (Helius) flavipes, venation; 26. Orimarga (Diotrepha) mirabilis, (Limonia) immatura, venation tigrina, venation; 28. Antocha saxicola, venation; 29. Limonia (Hexatoma) megacera, venation:

30. Pedicia (Tricyphona) protea, venation, 


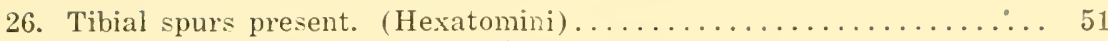

Tibial spurs lacking. (Eriopterini) .................. $7 \delta$

\section{LIIONIINI：SUBTRIBES, GENERA, SUBGENERA}

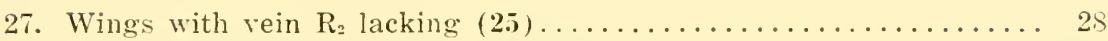

Wings with vein $R_{2}$ present $(21,26,29) \ldots \ldots \ldots \ldots \ldots \ldots \ldots \ldots .29$

28. Rostrum short and inconspicuous; Rs long and straight, running close to $R_{1}$ and in alignment with $R_{s+3} ; r-m$ distinct. (Ellipteraria).

Elliptera Schiner

Rostrum of moderate length, about equal in length to 'remainder of head; Rs short, gently arcuater, not in alignmert with $R_{:-3} ; r-m$ often shortened or obliterated by approximation of arljoining veins

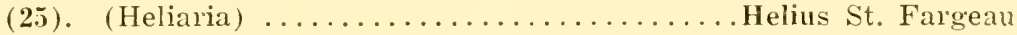

29. Wings with m-cu more than three, (and usually much more), times its own length before the fork of M (26). (Orimargaria, Orimarga)

Wings with $\mathrm{m}$-cu close to or beyond the fork of $\mathrm{M}$, if before, the distance not or scarcely exceerling the length of the vein itself

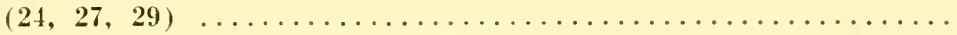

30. Wings with three branches of Media reaching margin, cell $\mathrm{M}_{3}$ being present; $m-c u$ beneath Rs......... Orimarga: Orimarga Osten Sacken

Wings with two branches of Media reaching margin, cell $\mathrm{M}_{3}$ lacking; m-cu far before origin of $\mathrm{Rs}(26)$. Orimarga: Diotrepha Osten Sacken

31. Wings with vein $R_{2}$ lying far distad, beyond level of outer end of cell 1 st $\mathrm{MI}_{2} ; \mathrm{m}$-cu beyond fork of $\mathrm{M}(27)$ (Dicranoptycharia).

Dicranoptycha Osten Sacken

Wings with vein $R_{2}$ in almost transverse alignment with $r-m$ and basal half of cell 1 st $M_{n}$ : $m-c u$ at or slightly before fork of $M(24$,

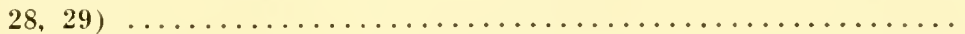

32. Wings with $\mathrm{Rs}_{\mathrm{S}}$ long and straight $(24,28)$; antennæ 16 -segmented... Wings with Rs shorter and more arcuated (21); antennæ 14-

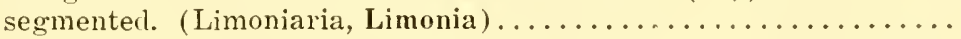

33. Anal angle of wing very prominent, almost square; Rs long, diverging at an acute angle from $R_{1}$, ending approxinately between the branches of $R_{s}$ or in alignment with $R_{t+5}$ (28) (Antocharia).

Antocha Osten Sacken

Anal angle of wing normally rounded; Rs long, lying very close to $R_{1}$ and nearly parallel to it, its end in alignment with $R_{2+3}$; basal section of $R_{++3}$ short and arcuated, diverging from the end of $R s$ at nearly a right angle (24) (Ellipteraria)........... Elliptera Schiner

34. Wings with $\mathrm{M}$ and both sections of $\mathrm{M}_{3}$ lacking, cell $\mathrm{M}_{3}$ thus entirely

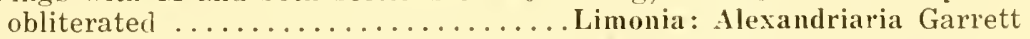

Wings with at least the distal section of $\mathrm{M}_{3}$ preserved and usually with both sections, together with $m$, cell $\mathrm{MI}_{3}$ thus usually present (29)

35. Supernumerary crossveins present in certain cells of wing....... 36 No supernumerary crossveins in cells of wing (excepting a weak element sometimes evident in cell Sc) $(29) \ldots \ldots \ldots \ldots \ldots \ldots \ldots . \ldots \ldots 77$ 

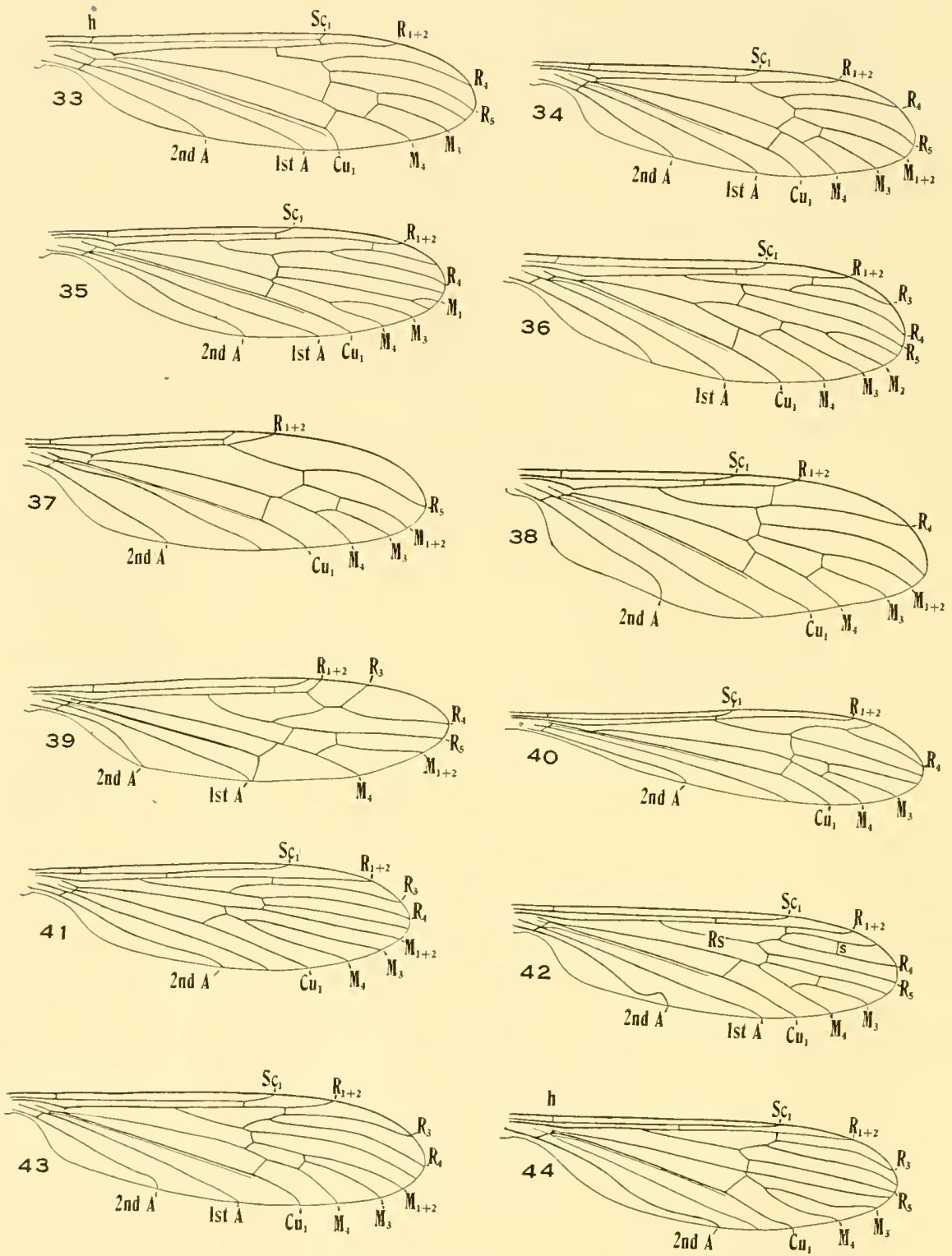

Timuloidea, Plate IV.-33. Elephantomyia westwoodi, venation; 34. Atarba (Atarba) picticornis, venation; 35. Polymera (Polymera) rogersiana, venation; 36. Prolimnophila areolata, venation: 37 . Toxorhina (Toxorhina) muliebris, venation; 38. Teucholabis (Teucholabis) complexa, venation; 39. Trentepohlia (Paramongoma) bromeliadicola, venation; 40. Gonomyia (Gonomyia) subcinerea, venation: 41. Molophilus nitidus, venation; 42. Helobia hybrida, venation; 43. Gnophonvia tristissima, venation; 44. Erioptera (Erioptera) septeintrionis, venation. 
36. Wings with $\mathrm{Sc}$ short, $\mathrm{Sc}_{1}$ ending opposite or before origin of Rs; a supernumerary crossvein in cell $R_{3}$. . Limonia: Neolimnobia Alexander Wings with Sc long, ending about opposite fork of Rs; a supernumerary crossvein in cell 1 st $\mathrm{A}$, connecting the Anal veins.

Limonia: Discobola Osten Sacken

37. Mouthparts, and especially the labial palpi, lengthened, the rostrum much longer than remainder of head, and usually about as long as the combined head and thorax........... Limonia: Geranomyia Haliday

Mouthparts, with the labial palpi, not notably lengthened, shorter

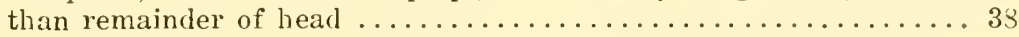

38. Antennæ of male more or less branched (bipectinate, unipectinate or subpectinate), of female simply serrate, sometimes very weakly so.

Limonia: Rhipidia Meigen

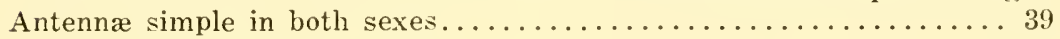

39. Wings of male with the prearcular region greatly developed, of female less markedly so; wing-apex very obtuse; Sc; ending approximately opposite origin of Rs; tropical.

Limonia: Peripheroptera Schiner

Wings of both sexes with prearcular cells small and inconspicuous; wing-tip not so obtusely rounded (except in some Limonia, s.s., where Sc is elongate, ending beyond midlength of $\mathrm{Rs}) \ldots . \ldots 40$

40. Wings with Sc short, $\mathrm{Sc}_{1}$ ending opposite or before origin of Rs.

Limonia: Dicranomyia Stephens Wings with Sc long, $\mathrm{Sc}_{1}$ ending beyond midlength of Rs (29).

Limonia: Limonia Meigen

\section{PEDICIINI: SUB'TRIBES, GENERA, SUBGENERA}

41. Wings with numerous macrotrichia on membrane (Ularia). Ula Haliday

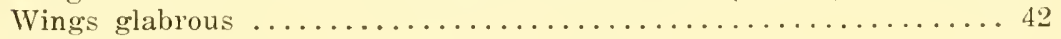

42. Rostrum produced into a beak that is subequal in length to remainder

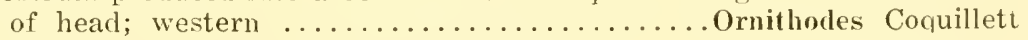

Rostrum only inconspicuously developed ............... 43

43. Antennæ with usually 16 segments; size large, wing usually over

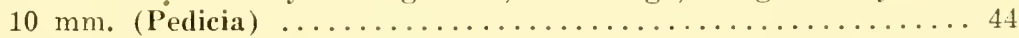

Antennæ with usually 13 or 15 segments; size small, wing usually

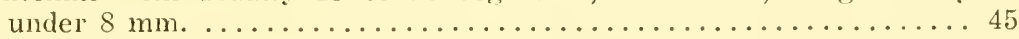

44. Size very large (wing, $20 \mathrm{~mm}$. or more); wings with a dark pattern that is arranged as a triangle, including broad costal and cubital seams that are connected across the very oblique cord; maxillary palpus with terminal segment elongate.....Pedicia: Pedicia Latreille

Size smaller (wing, under $18 \mathrm{~mm}$.); wings without a dark pattern arranged as a triangle, as above described; cord of wing transverse or nearly so (30); maxillary palpus with terminal segment short .............................. Tricy phona Zetterstedt

45. Wings with four supernumerary crossveins, located in cells $R_{1}, R_{3}, R_{4}$

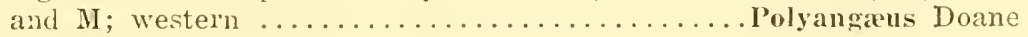

Wings with at most a single supernumerary crossvein, this in cell $R_{1}$, basad of vein $R_{2}$ (Dicranota) ................... 46

46. A supernumerary crossvein in cell $R_{1}$ about opposite end of vein $S_{1}$. 47 No supernumerary crossveins in cells of wing............... 49 
47. Cell 1st $M_{2}$ closed; eastern........... Dicranota: Eudicranota subg. n. Cell 1st $\mathrm{M}_{2}$ open by atrophy of $\mathrm{m} \ldots \ldots \ldots \ldots \ldots \ldots \ldots \ldots \ldots$

48. Cell $\mathrm{M}_{1}$ lacking Dicranota: Paradicranota subg. n.

Cell $M_{1}$ present Dicranota: Dicranota Zetter'stedt

49. Cell 1st $\mathrm{M}_{2}$ closed; eastern ..........Dicranota: Amalopina Brunetti

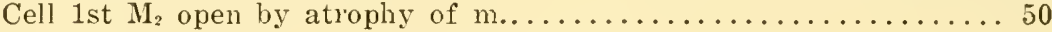

50. Cell $M_{1}$ lacking (2)...........Dicranota: Plectromyia Osten Sacken Cell $\mathrm{M}_{1}$ present ............Dicranota: Rhaphidoiabis Osten Sacken

\section{HEXATOMINI：SUBTRIBES, GENERA, SUBGENERA}

51. Antennæ with not more than 12 segments (Hexatomaria, Hexatoma). 52 Antennæ with more than 14 segments ........................ 54

52. Cell 1st $\mathrm{M}_{2}$ open; two branches of $\mathbf{M}$ reach the wing-margin (31);

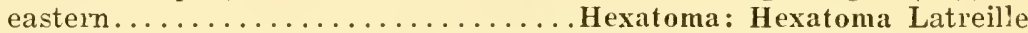
Cell 1st $M_{2}$ closed; three or four branches of $M$ reach the wing-

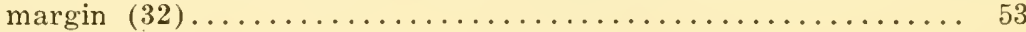

53. Feet snowy-white; eastern and tropical.. Hexatoma: Penthoptera Schiner

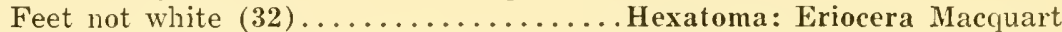

54. Wings with only two branches of $R$ s present; vein $R_{2}$ lacking...... 55 Wings with three branches of $R$ s present; vein $R_{2}$ preserved (except

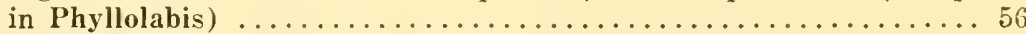

55. Rostrum elongate, exceeding one-half the length of the entire body (33); (Elephantomyaria).............Elephantomyia Osten Sacken Rostrum short and inconspicuous, not exceeding the remainder of head (34); eastern and tropical (Atarbaria).

Atarba: Atarba Osten Sacken

56. Apical cells of wing with macrotrichia ................... 57 Cells of wing without macrotrichia (excepting in stigmal area).....61

57. A supernumerary crossvein in cell $\mathrm{M}$; eastern (Limnophilaria).

58. Cell $R_{3}$ of wings sessile, subsessile or short-petiolate; $R_{2+3+4}$ lacking or much shorter than m-cu. (Limnophilaria) . .............. 59

Cell $R_{3}$ of wings long-petiolate, $R_{2+3+4}$ being as long as or longer than

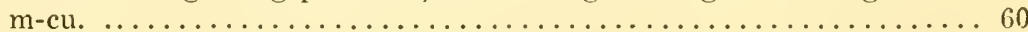

59. Wings with macrotrichia abundant, involving the cells basad of cord.

Ulomorpha Osten Sacken

Wings with sparse macrotrichia in cells beyond cord only.

Limnophila: Lasiomastix Osten Sacken

60. Small species (wing, $0^{*}$, less than $5 \mathrm{~mm}$.); cell $\mathrm{M}_{1}$ usually present; antennæ short in both sexes (Adelphomyaria).....Adelphomyia Bergroth

Larger flies (wing, $0^{\star}$, over $6 \mathrm{~mm}$.); cell $\mathrm{M}_{1}$ lacking; antennæ of male very long; tropical (Limnophilaria) ........ Shannonomyia Alexander

61. A supernumerary crossvein in cell C (Epiphragmaria).

Epiphragma Osten Sacken

No supernumerary crossvein in cell $\mathrm{C}(35) \ldots \ldots \ldots \ldots \ldots \ldots \ldots . \ldots 62$ 
62. Wings with vein $\mathrm{R}_{2}$ lacking; m-cu at outer end of cell 1 st $\mathrm{M}_{2}$; western.

Phyllolabis Osten Sacken

Wings with vein $\mathrm{R}_{2}$ present; $\mathrm{n}-\mathrm{cu}$ at or before two-thirds the length of cell 1 st $M_{2}$, when the latter is present $(35,36) \ldots \ldots \ldots \ldots 63$

63. Wings with cell 1 st $\mathbf{M}_{2}$ open by atrophy of $\mathrm{m}$ (35); male with elongate nodulose antennæ; tropical and subtropical.

Polymera: Polymera Wiedemann

Wings with cell 1st $M_{2}$ closed; antennæ of male not norlulose......6 64

64. Wings with $\mathrm{Sc}$ very long, $\mathrm{Sc}_{1}, \mathrm{R}_{1+2}$ and $\mathrm{R}_{3}$ all ending close together at costal margin; tropical ...................... Esaronius Enderlein

Wings with Sc short, wiclely separated from either $R_{1+2}$ or $R_{3}(36) \ldots 65$

65. Wings with $\mathrm{m}$-cu at or close to fork of $\mathrm{M}$; anterior arculus lacking.

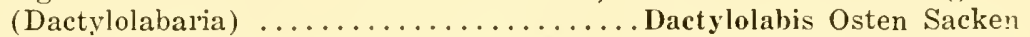

Wings with $\mathrm{m}-\mathrm{cu}$ beyond the fork of M, at from one-third to about one-half the length of cell 1 st $\mathbf{M}_{2}$; where close to fork of $\mathbf{M}$ (some Pseudolimnophila) the arculus complete...............66

66. Wings with the anterior arculus lacking (36) (Pseudolimnophilaria,

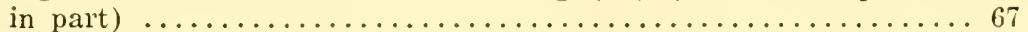

Wings with the anterior arculus present $\ldots \ldots \ldots \ldots \ldots \ldots \ldots \ldots 68$

67. Cell 1st $\mathrm{M}_{2}$ of wings very large, its inner end lying far proximad of the other elements of the cord $(36) \ldots . .$. . Prolimnophila Alexander

Cell 1st $\mathrm{M}_{2}$ of wings of normal size, its inner end straight and in approximate alignnent with the elements of the anterior cord.

Archilimnophila, g. n.

68. Wings with Sc relatively short, $\mathrm{Sc}_{1}$ ending before the level of the fork of Rs; where slightly longer (Limnophila albipes Leonard) the posterior tarsi snowy-white. (Limnophilaria, in part)...........6. 69

Wings with Sc longer, $\mathrm{Sc}_{1}$ ending opposite or beyond the fork of $\mathrm{Rs}$; (compare some species of Pilaria, distinguished by having the an-

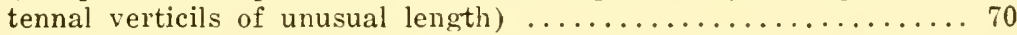

69. Antennæ with long conspicuous verticils; tuberculate pits present, small, placed at extreme cephalic end of præscutum; Rs elongate, exceeding vein $R_{3}$; cell $M_{1}$ present or lacking.........Pilaria Sintenis

Antennæ with short verticils; tuberculate pits lacking; Rs short and strongly arcuated or angulated at origin; cell $\mathbf{M}_{1}$ lacking.

Shamnonomyia Alexander

70. Head strongly narrowed and prolonged behind; radial and medial veins beyond cord long and sinuous; vein $R_{3}$ extending generally parallel to vein $R_{t}$, not diverging markedly at tips; vein 2 nd $A$ strongly curved to margin (Pseudolinmnophilaria, in part).

Pseudolimnophila Alexander

Head broad, not conspicuously narrowed behind; radial and medial veins beyond cord more nearly straight; vein $R_{3}$ diverging strongly from vein $R_{4}$, cell $R_{3}$ conspicuously widened at margin; vein 2nd $A$ not curved strongly into margin (Limnophilaria, in part, Limnophila).

71. Supernumerary crossveins in either cell $R_{3}$ or cell $M$ of wing..... 72 No supernumerary crossveins in cells of wing ............ 74 
72. A supernumerary crossvein in cell $\mathrm{R}_{3}$; eastern.

Limnophila: Dicranophragma Osten Sacken

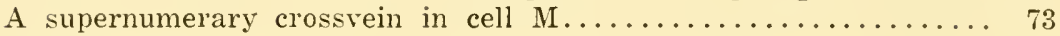

73. Rs long-spurred at origin; antennæ of male elongate.

Limnophila: Idioptera Macquart Rs slightly if at all spurred at origin; antennæ short in both sexes.

Limnophila: Elrophila Rondani

74. Cell $R_{3}$ sessile; cell $M_{1}$ lacking...... Limnophila: Idiolimnophila, subg. ㄱ. Cell $R_{3}$ petiolate; cell $M_{1}$ present....................... 75

75. Very large species (wing over $16 \mathrm{~mm}$.); wings with the branches of M leaving the main stem at a strong angle, cell 1st $\mathrm{M}_{2}$ thus being strongly hexagonal; eastern........ Limnophila: Eutonia Van der Wulp

Smaller species (wing uncler $14 \mathrm{~mm}$.); wings with the branches of $M$ not strongly divergent, especially $M_{3+4}$, cell 1 st $M_{2}$ being more

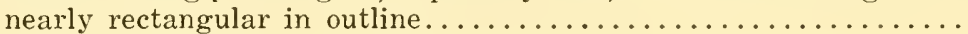

76. Wings with vein $R_{2+3+4}$ short, subequal to the basal deflection of $R_{5}$; $\mathrm{Rs}$ elongate, exceeding four times $\mathrm{R}_{2+3+4}$; coloration polished black or gray, the latter group having the male hypopygium with a series of teeth on margin of outer dististyle, producing a comb-like appearance ................. Limnophila: Prionolabis Osten Sacken

Wings with $R_{2+3+4}$ longer, usually exceeding the basal deflection of $R_{5}$; Rs shorter, not exceeding three times $R_{2+3+4}$; where the above character's are doubtful, the species have a closely irrorate brown wing-pattern; bocly coloration never polished black; when gray, male hypopygium without a comb of spines on outer dististyle....

77. Rs short, weakly to more strongly angulated at origin, more rarely merely arcuated; $R_{2+3+4}$ subequal to or shorter than $\mathrm{m}$-cu; antennæ short in both sexes............. Limnophila: Phylidorea Bigot

Rs longer, more gently arcuated; in species with shorter Rs, antennæ of male elongate and usually with $\mathrm{R}_{2+3+4}$ long, considerably exceed-

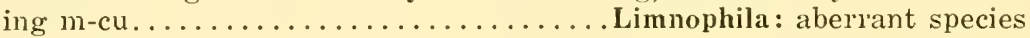

\section{ERIOPTERINI : SUBTRIBES, GENERA, SUBGENERA}

78. Nearly apterous, the wings reduced to microscopic structures that are smaller than the halteres; northern. (Clarluraria). Chionea Dalman

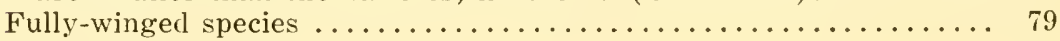

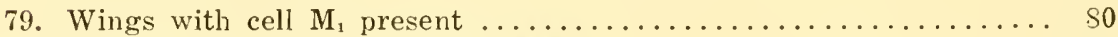

Wings with cell $M_{1}$ lacking $(37-44) \ldots \ldots \ldots \ldots \ldots \ldots \ldots \ldots \ldots \ldots \ldots \ldots \ldots$

80. Antennæ with the basal two to four segments united into a fusionsegment; wings with $\mathrm{R}_{2+3+4}$ much longer than the short basal section of $R_{5}$; veins $S_{c_{1}}$ and $R_{1+2}$ widely separated at margin, the distance on Costa between them approximately three times $r-m$; legs plainly

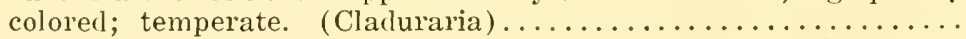

Antennæ with all flagellar segments distinct; wings with basal section of $R_{5}$ elongate, much exceeding $R_{2+3++}$; veins $S c_{1}$ and $R_{1+2}$ closely approximated at margin, the distance on costa between them subequal to or shorter than $\mathrm{r}^{\prime}-\mathrm{m}$; legs conspicuously hairy, banded with black, rufous and white; tropical. (Lecteriaria).

Lecteria Osten Sacken 
81. Wings with $R_{2+3+4}$ subequal to or longer than vein $R_{3}$, cell $R_{3}$ thus being subequal to its petiole; vein $R_{2}$ at or before the fork of $R_{3+4}$.

Neolimnophila Alexander

Wings with $R_{2+3+4}$ shorter than vein $R_{3}$, cell $R_{3}$ being much longer than its petiole; $R_{2}$ far beyond fork of $R_{2+3+4} \ldots \ldots \ldots \ldots \ldots$

82. Wings with cell $M_{1}$ very small, about one-third its petiole; fusionsegment of antenna very long, about equal to the succeeding four segments combined; western.............. Pterochionea Alexancler

Wings with cell $M_{1}$ subequal to or longer than its petiole; fusionsegment of antennæ shorter, about as long as the succeeding two or three segments combined. (Cladura)..................

83. Wings with $R_{1+2}$ elongate, exceeding $R_{2+3+4} ; R_{2+3}$ subequal to $m-c u$; male hypopygium with two dististyles..Cladura: Neocladura Alexancler

Wings with $R_{1+2}$ shorter than $R_{2+3+4} ; R_{2+3}$ approximately twice $\mathrm{m}$-cu; male hypopygium with a single powerful dististyle.

Cladura: Cladura Osten Sacken

84. Rostrum very long and slender, approximately one-half the entire body or longer; setæ of legs profoundly bifid (Toxorhinaria,

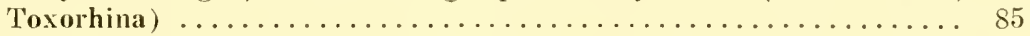
Rostrum short, not exceeding remainder of head; setre of legs simple. 86

85. Wings with Rs having a single branch (37); eastern and tropical.

Toxorhina: Toxorhina Osten Sacken Wings with Rs having two branches; tropical.

Toxorhina: Ceratocheilus Wesché

86. Two branches of $R$ s reach the wing-margin $(38) \ldots \ldots \ldots \ldots \ldots \ldots$ ? Three branches of Rs reach the wing-margin $(39-44) \ldots \ldots \ldots \ldots .89$

87. Wings with $R_{1}$ ending before midlength; anterior branch of $\mathrm{Rs}$ diverging strongly from posterior branch, arising at or close to $\mathrm{r}-\mathrm{m}$, straight and oblique; tropical. (Styringomyaria)...Styringomyia Lœw

Wings with $R_{1}$ ending about opposite two-thirds their length; branches of Rs subparallel on basal half. (Gonomyaria)............ 88

88. Wings with $R_{2}$ present, close to fork of $\mathrm{Rs}$; Sc usually long, $\mathrm{Sc}_{1}$ ending beyond origin of Rs (38); some eastern, but chiefly

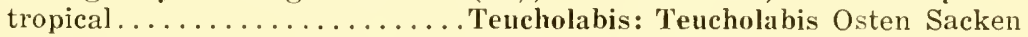

Wings with $\mathrm{R}_{2}$ lacking; Sc short, $\mathrm{Sc}_{1}$ ending opposite or before origin of Rs; chiefly tropical (Gonomyaria)...Gonomyia: Lipophleps Bergroth

89. Wings with $R_{5}$ fused with $M_{1+2}$ to form the entire cephalic face of cell 1 st $M_{2}, 1-m$ thus obliterated; only two branches of $M$ reach the margin; vein 2nd A very short (39); tropical. (Trentepohliaria).

Trentepohlia: Paramongoma Brunetti

Wings with $R_{5}$ entirely distinct from $M_{1+2}$, being separated by the $r-m$ crossvein (the veins fused only in a few species of Paratropesa, where the alternative characters hold); three branches of $M$ reach the margin; vein 2 nd $A$ of normal length $(40-11) \ldots \ldots \ldots$.

90. Wings with cell $R_{3}$ short, vein $R_{3}$ shorter than the petiole of cell $R_{3}$

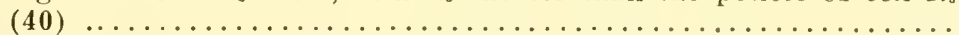

Wings with cell $R_{3}$ deep, vein $R_{3}$ longer than the petiole of cell $R_{3}$ $(42-44)$; shortest in Progonomyia and Empedomorpha......... 


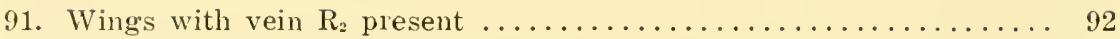

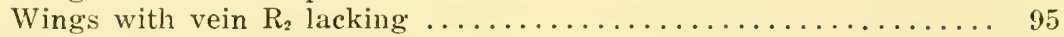

92. $R_{2}$ at end of $\mathrm{Rs}$, in alignment with the other elements of the cord; $r-m$ obliterated by the long fusion of veins $R_{t+5}$ and $M_{1+2}$; tropical.

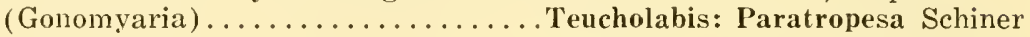

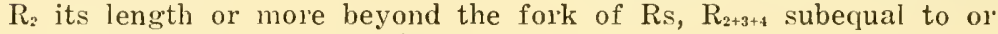

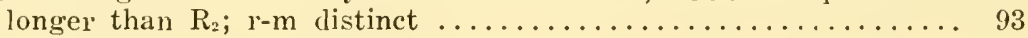

93. Wings with Rs long and straight, exceeding the distal section of $\mathbf{M}_{1+2}$; tuberculate pits on cephalic portion of præscutum; trochanters elongate; arctic and subarctic. (Rhabdomastix).

Rhabdomastix: Sacandaga Alexander

Wings with Rs shorter, less than the distal section of $M_{1+2}$; tuberculate pits removed from cephalic margin of præscutum; trochanters

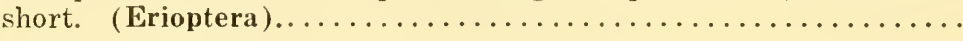

94. Wings with veins $R_{3}$ and $R_{4}$ strongly diverging, cell $R_{3}$ having a Gonomyia-like shape.............Erioptera: Gonempeda Alexander Wings with veins $R_{3}$ and $R_{\ddagger}$ more generally parallel, cell $R_{3}$ having the more normal Erioptera-shape, but shorter.

Erioptera: Empeda Osten Sacken

95. Wings with $\mathrm{Sc}$ long, $\mathrm{Sc}_{1}$ extending to near opposite or beyond midles.gth of $\mathrm{Rs} ; \mathrm{m}-\mathrm{cu}$ at or beyond fork of M. (Eriopieraria, Rhab-

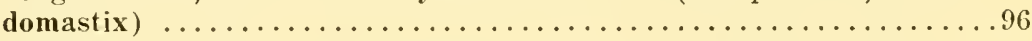

Wings with Sc short, not extending to beyond midlength of Rs; if $\mathrm{Sc}$ is relatively long (Ptilostena), m-cu lies more than its own length before the fork of M. (Gonomyaria, Gonomyia)........ 97

96. Antennæ of male longer than body; chiefiy tropical

Rhabdomastix: Rhabdomastix Skuse Antenne of male scarcely attaining wing-root; chiefly temperate.

Rhabdomastix: Sacandaga Alexander

97. Wings with m-cu more than its own length before form of M.

Gonomyia: Ptilostena Bergroth

Wings with m-cu at or very close to fork of M (40) ......... 98

98. Wings with cell $R_{3}$ very small, at margin subequal in extent to cell $R_{2}$; antennal verticils long and conspicuous.

Gonomyia: Lipophleps Bergroth

Wings with cell $R_{3}$ larger, at margin considerably exceeding in extent cell $R_{2}$; antennal verticils not conspicuously elongated.

Gonomyia: Gonomyia Meigen

99. Wings with distinct macrotrichia in outer cells...............

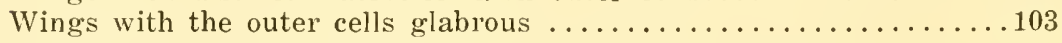

100. Wings with $\mathrm{Rs}$ shortenerl, its union with $\mathrm{R}_{2+3+4}$ forming an angle, so cell $R_{1}$ is nearly equilateral in outline; chiefly tropical. (Eriop-

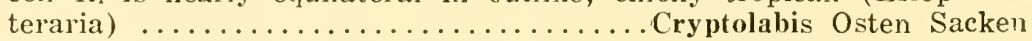

Wings with $\mathrm{Rs}$ long, normal in position, cell $\mathrm{R}_{1}$ elongate........101

101. Size very small (wing, $3 \mathrm{~mm}$. or less); Rs encling in cell $\mathrm{R}_{3}$, this cell thus being sessile, without element $R_{2+3++}$; temperate. (Eriopteraria $\ldots \ldots \ldots \ldots \ldots \ldots \ldots \ldots \ldots \ldots$ Dasymolophilus Gœtghebuer

Size larger (wing over $4 \mathrm{~mm}$.); $R$ s ending in cell $R_{4}$, cell $R_{3}$ being petiolate by the presence of a distinct element $R_{2+3+4} \ldots \ldots \ldots \ldots 2$ 
102. Wings with $\mathrm{Sc}_{2}$ close to tip of $\mathrm{Sc}_{1}$, the two veins thus being subequal in length or nearly so. (Gonomyaria)...... Gnophomyia Osten Sacken Wings with $\mathrm{Sc}_{2}$ far removed from tip of $\mathrm{Sc}_{1}$, the latter vein long, subequal in length to Rs; temperate. (Eriopteraria)....Ormosia Rondani

103. Wings with $R_{s}$ ending in cell $R_{3}$, there being no element $R_{2+3+4}$ (11)

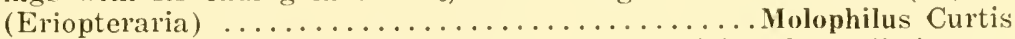

Wings with $R$ s ending in cell $R_{4}$, cell $R_{3}$ being petiolate by a distinct

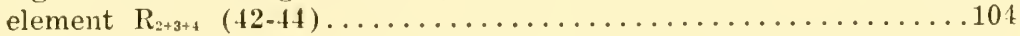

104. Wings with a supernumerary crossvein in cell $R_{3}$; vein 2 nd $A$ strongly

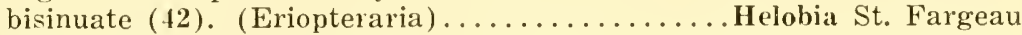

Wings without a supernumerary crossvein in cell $R_{3}$; vein 2 nd $A$

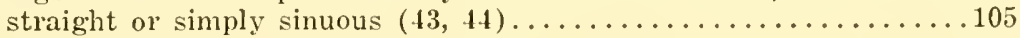

105. Wings with veins $R_{3}$ and $R_{4}$ divergent, unequal in length, $R_{3}$ being less than two-thirds $R_{4}$, cell $R_{3}$ at margin much more extensive than

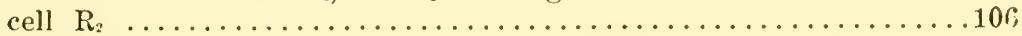

Wings with veins $R_{3}$ and $R_{4}$ nearly equal in length, or with $R_{3}$ exceeding three-fourths of the length of $R_{4}$, the veins extending generally parallel to one another to the margin; cell $R_{2}$ at margin wider

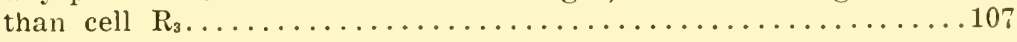

106. Wings with veins $R_{3}$ and $R_{4}$ very unequal in length, widely divergent or sprawly, $R_{3}$ being only about one-fourth $R_{4}$ and encling in costa close to vein $R_{1+2}$; cell $R_{3}$ at margin some eight times as wide as

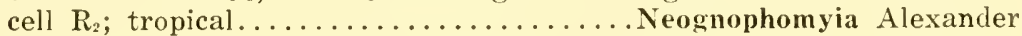

Wings with veins $R_{3}$ and $R_{4}$ less conspicuously unequal, $R_{3}$ being about one-half $R_{1}$; cell $R_{3}$ at margin some three or four times as wide as cell $R_{2}$; tropical and subtropical. (Gonomyia).

Gonomyia: Progonomyia Alexander

107. Antennæ of both sexes with the flagellar segments more or less kidney-shaped to give a norlulose appearance to the organ; large species (wing, $15 \mathrm{~mm}$. or more); tropical. (Sigmatomeraria).

Sigmatomera Osten Sacken

Antennæ of both sexes simple or nearly so, not nodulose; smaller (wing less than $12 \mathrm{~mm}$., usually less than $10 \mathrm{~mm}$.)............... 108

108. Coxæ of midlle and hind legs only slightly separated by the small meral region; wings with $\mathrm{Sc}_{1}$ relatively short, not exceeding one-

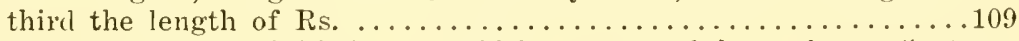

Coxæ of middle and hind legs widely separated by a large "potbellied" meral region; wings with $\mathrm{Sc}_{1}$ very long, exceeding one-half the length of Rs. (Eriopteraria).........................

109. Wings with $\mathrm{Rs}$ in alignment with $\mathrm{R}_{2+3+4}$; $\mathrm{Sc}$ short, $\mathrm{Sc}_{1}$ ending opposite the fork of $\mathrm{RS}$ and far before $\mathrm{R}_{2}$; $\mathrm{Sc}_{1}$ and $\mathrm{Sc}_{2}$ subequal; male hypopygium with interbasal structures conspicuously developed as

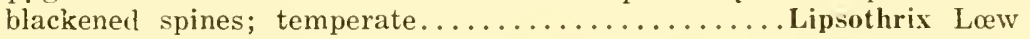

Wings with $\mathrm{Rs}$ in approximate alignment with $\mathrm{R}_{5}$; Sc long, $\mathrm{Sc}_{1}$ encling opposite or shortly before $R_{2}$, at or beyond midlength of $R_{2+3+4}$; $\mathrm{Sc}_{1}$ much longer than $\mathrm{Sc}_{2}$ (43); male hypopygium without evident

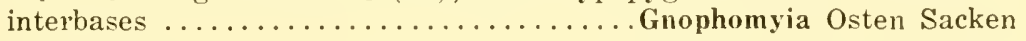

110. Wings with $R_{2}$ far before fork of $R_{2+3+4}$, at or just beyond the fork of Rs; male with a very large hairy stigmal region that more or less distorts the adjoining veins; western plains..Empedomorpha Alexander Wings with $R_{2}$ beyond the fork of $R_{2+3+4}$; stigma normal.........111 
111. Wings with vein $\mathrm{Cu}_{1}$ nearly straight, its distal section not swinging cephalad toward wing-tip; cell 1st $M_{2}$ small, less than one-half the distal section of $\mathbf{M}_{1+2}$; terminal three segments of antennæ smaller than the remainder of flagellum............. Trimicra Osten Sacken

Wings with vein $\mathrm{Cu}_{1}$ having its distal section slightly deflected at apex toward wing-tip; cell 1 st $M_{2}$, when present, elongate, subequal to or longer than the distal section of $\mathrm{M}_{1+2}$; flagellar segments becoming progressively smaller to outer end (44) (Erioptera)....112

112. Wings with vein 2nd $A$ arcuated so cell 1st $A$ at midlength is as broad as, or broader than it is at margin; cell 1 st $\mathbf{M}_{2}$ opening into cell 2nd $\mathrm{M}_{2}$ by atrophy of $\mathrm{m}$; (14); chiefly temperate.

Erioptera: Erioptera Meigen

Wings with anal veins divergent, cell 1 st A being widest at margin; cell 1 st $M_{2}$ generally closed...........................

113. Wings with cell 1 st $M_{2}$ open........................

Wings with cell 1 st $M_{2}$ closerl, the basal section of $M_{3}$ greatly ex-

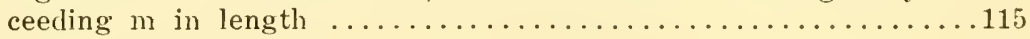

114. Wings with cell 1 st $\mathrm{M}_{2}$ opening into cell $\mathrm{M}_{3}$ by atrophy of basal section of $\mathrm{M}_{3}$; where closed, the elements closing outer end not greatly disproportionate in length, $m$ being one-half or mole of $\mathrm{M}_{3}$; chiefly

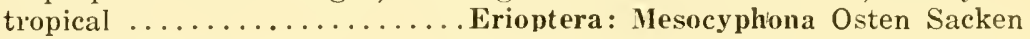

Wings with cell 1st $\mathrm{M}_{2}$ opening into cell 2nd $\mathrm{M}_{2}$ by atrophy of $\mathrm{m}$; northern and western ..........Erioptera: Psiloconopa Zettersterlt

115. Wings with a spur from the basal section of vein $\mathrm{M}_{3}$, jutting basad into cell 1st $M_{2} \ldots \ldots \ldots \ldots \ldots \ldots$ Erioptera: Hoplolabis Osten Sacken Wings with no such spur as described.........Erioptera: Ilisia Rondani

\section{SUPPLEMENTARY KEY TO THE SUBAPTEROUS TIPULIDE}

1. Frontal prolongation of head with nasus ('Tipulinæ).......Tipula Linnæus Frontal prolongation of head (or rostrum) without nasus...........2

2. Eyes with numerous short erect setre between ommatidia (Pediciini).

Tricyphona Zetterstedt

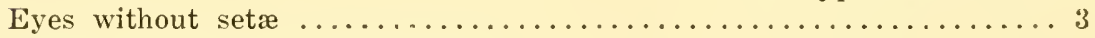

3. Tibial spurs present. (Hexatomini)............. Limnophila Maccuart Tibial spurs lacking. (Eriopterini) ............................ Dalman

\section{TYPE SPECIES OF THE NEW GENERA AND SUBGENERA PROPOSEi)}

Dicranota: Eudicranota; type, Dicranota notabilis Alexander.

Dicranota: Paradicranota; type, Dicranota rivularis Osten Sacken.

Archilimnophila; type, Limnophila unica Osten Sacken.

Limnophila: Idiolimnophila; type, Limnophila emmelina Alexander. 


\section{BIBLIOGRAPHY OF IMMATURE STAGES}

Alexander, C. P.

1920. The crane-flies of New York. Part II. Biology and Phylogeny. Cornell Univ. Agric. Expt. Sta. Mem. 38; pp. 691-1133, 87 pls. (bibliography to 1920).

1931. Deutsche Limnologische Sunda-Expedition. The Crane-flies. Archiv für Hydrobiologie, Suppl. Bd. IX, Tropische Binnengewässer, 2; pp. 135-191, 51 figs., 1 pl. (bibliography of biology, 1920-30).

Rogers, J. S.

1933. The ecological distribution of the crane flies of northern Florida. Ecological Mon., 3, No. 1, pp. 1-74, figs. 1-25.

\section{BIBLIOGRAPHY OF KEYS TO SPECIES OF NORTH AMERICAN TIPULIDEE}

The genera of which Keys are given follow the reference and the regions covered are indicated: Neo., Neotropical; Nea., Nearctic.

Alexander, C. P.

1912a. On the tropical American Rhipidiæ. Bull. Brooklyn Ent. Soc., VIII, pp. 6-17, 1 pl.

(Limonia: Rhipidia, Neo.).

1912b. A revision of the genus Brachypremna Osten Sacken. Journ. New York Ent. Soc., XX, pp. 225-236, 1 pl.

(Brachypremna).

1912c. New species of Furcomyia. Canadian Ent., XLIV, pp. 333-334. (Limonia: Dicranomyia, Neo., in part).

1913a. New Neotropical Antochini. Psyche, XX, pp. 40-54, 1 pl.

(Orimarga; Toxorhina, Neo.).

1913b. A synopsis of part of the Neotropical crane-flies of the subfamily Limnobinæ. Proc. United States Nat. Mus., XLIV, pp. 481-549, 4 pls.

(Epiphragma; Polymera; Lecteria; Trentepohlia; Gonomyia ; Gnophomyia; Cryptolabis; Molophilus; Erioptera; Mesocyphona, Neo.).

1913c. The Neotropical Tipulidæ in the Hungarian National Iusem. I, 1I. Ent. News, XXIV, pp. 404-412, 439-449.

(Limonia: Peripheroptera; Teucholabis: Paratropesa).

1914a. New or little-known Neotropical Hexatomini. Psyche, XXI, pp. $33-45,1$ pl.

(Hexatoma: Eriocera, Penthoptera, Neo.).

1914 b. A revision of the American species of Tanypremna Osten Sacken and Mlegistocera Wierlemann. Journ. New York Ent. Soc., XXII, pp. 205-218, 1 pl.

(Tanypremna).

1914c. On a collection of crane-flies from British Guiana. Trans. American Ent. Soc., XL, pp. 223-255. 2 pls.

(Psaronius; Trentepohlia, part; Sigmatomera; Teucholabis: Teucholabis; Gonomyia: Lipophleps, part, Neo.).

1915. Two new crane-flies from Porto Ricn. Insec. Inscit. Menst., III, pp. 104-107.

(Hexatoma: Eriocera, part). 
Alexander, C. P. (Continued)

1916a. New Limnophiline Crane-flies from the United States and Canada. Journ. New York Ent. Soc., XXIV, pp. 118-125, 1 pl.

(Limnophila: Prionolabis, part: Nea.)

1916b. New species of Crane-flies from the West Indies. Ent. News, XXVII, pp. $343-347,6$ figs.

(Hexatoma: Eriocera).

1916c. New or little-known crane-flies from the United States and Canada. Part 3. Proc. Acad. Nat. Sci. Philadelphia, 1916, pp. 486$549,7 \mathrm{pls}$.

(Dicranota: Rhaphidolabis; Gonomyia, Nea.).

1917. New Nearctic crane-flies. Part 3. Canadian Ent., XLIX, pp. 199-211.

(Erioptera: Empeda, Nea.).

1919a. Notes on the genus Dicranoptycha Osten Sacken. Ent. News, XXX, pp. 19-22.

(Dicranoptycha).

1919b. Records and descriptions of Neotropical craneflies. Journ. New York Ent. Soc., XXVII, pp. 132-154, 1 pl.

(Trentepohlia, part; Gnophomyia, s.l.).

1919c. The crane-flies of New York. Part I. Distribution and taxonomy of the adult flies. Cornell Univ. Agr. Expt. Sta., Mem. 25; $765-993,55$ pls.

('Tanyptera; Ctenophora; Nephrotoma; Tipula; Dolichopeza; Oropeza; Phalacrocera; Cylindrotoma; Limonia: Dicranomyia, Rhipidia, Geranomyia, Limonia; Helius; Dicranoptycha; Pedicia: Pedicia, Tricy phona; Dicranota: Dicranota, Rnaphidolabis; Ula; Adelphomyia; Epiphragma; Limnophila, s.l.; Eriocera; Chionea; Cladura; Gononyia; Teucholabis; Rhabdomastix; Molophilus; Ormosia; Erioptera; Toxorhina).

1920a. Undescribed Tipulidæ from western North America. Proc. California Acad. Sci., (4), X, pp. 35-46.

(Ulomorpha).

1920b. New or little-known crane-flies from tropical America. Canarl. Ent., LII, pp. 141-144.

(Polymera, part, Neo.).

1926a. Studies on the crane-flies of Mexico. Part II. Ann. Ent. Soc. America, XIX, pp. 158-179, 2 pls.

(Atarba; Nea., Neo.).

$1926 \mathrm{~b}$. Undescribed species of crane-flies from Cuba ar J Jamaica. Journ. New York Ent. Soc., XXXIV, pp. 223-230.

(Gonomyia, part, Neo.).

1927. Undescribed species of the genus Limnophila from eastern North America. Part II. Bull. Brooklyn Ent. Soc. XXII, pp. 56-64. (Limnophila: Elaephila)

1929. The crane-flies of New York: Fourth Supplementary List. Bull. Brooklyn Ent. Soc., XXIV, pp. 295-302.

(Pedicia, Nea.)

1930. The genus Sigmatomera Osten Sacken,-with observations on the biology by Raymond C. Shannon. Encycl. Entomol., Diptera, V, pp. $1-8,8$ figs.

(Sigmatomera). 
Dietz, W. G.

1913. A symopsis of the described North American species of the Dipterous genus Tipula L. Ann. Ent. Soc. America, VI, pp. 461484.

(Tipula, Nea.).

1914. The hebes group of the Dipterous genus Tipula Linnæus. Trans. American Ent. Soc., XL, pp. 345-363, 2 pls.

(Tipula, part; Nea.)

1916. Synoptical table of the North American species of Ormosia Rondani (Rhypholophus Kolenati), with descriptions of new species. Trans. American Ent. Soc., XLVII, pp. 135-146, 1 p!.

(Ormosia, Nea.).

1917. Key to the North American species of the tricolor group of the Dipterous genus Tipula Linnæus. Ent. News, XXVII, pp. 145-151, 1 pl.

(Tipula, part; Nea.).

1918. A revision of the North Anerican species of the Tipulid genus Pachyrhina Macquart, with descriptions of new species. Trans. American Ent. Soc., XLIV, pp. 105-140, 4 pls.

(Nephrotoma, Nea.).

1919. The streptocera group of the Dipterous genus Tipula Linnæus. Ann. Ent. Soc. America, XII, pp. 85-94, 1 pl.

(Tipula, part; Nea.).

1921a. The impudica group of the Dipterous genus Tipula Linnæus. Ann. Ent. Soc. America, XIV, pp. 1-15, 1 pl.

(Tipula, part; Nea.).

1921b. Description of two new species of the angustipennis group of the Dipterous genus Tipula Linnæus, with table of species. Ent. News, XXXII, pp. 299-302.

(Tipula, part; Nea.).

Doane, R. W.

1908a. Notes on the Tipulid genus Dicranomyia. Ent. News, XIX, pp. $5-9$.

(Limonia: Dicranomyia, Nea.).

1908b. New North American Pachyrhina, with a table for determining the species. Ent. News, XIX, pp. 173-179.

(Nephrotoma, Nea.).

1908c. New species of the Tipulid genus Rhypholophus, with a table for determining the North American species. Ent. News, XIX, pp. 200-202.

(Ormosia, N€a.).

Garrett, C. B. D.

1922. New Tipulida from British Columbia. Proc. Ent. Soc. Washington, XXIV, pp. 58-64, 13 figs.

(Limonia: Alexandriaria, Nea.)

Hine, J. S.

1903. The genus Peditia, with one new species. Ohio Nat., III, pp. 416-417.

(Pedieia, Nea.) 
Johnson, C. W.

1909. New and little known Tipulidæ. Proc. Boston Soc. Nat. Hist., XXXIV, pp. 115-135, 2 pls.

(Dolichopeza: Oropeza, Nea.)

Osten Sacken, C. R.

1869. Diptera of North America, Part 4. Smithson. Miscel. Coll. 219, pp. 1-345, 4 pls., 7 figs.

(Limonia: Geranomyia, Dicranomyia, Rhipidia, Limonia; Pedicia: Tricyphona; Limnophila; Eriocera; Gononyia; Ormosia; Erioptera).

1886. Biologia Centrali-Americana. Insecta, Diptera, I, pp. 1-216, 3 pls.

(Nephrotoma; Hexatoma: Eriocera, Neo.)

\section{GENERAL BIBLIOGRAPHY OF MORPHOLOGICAL TERIS OF ESPECIAL VALUE IN A STUDY OF THE TIPULIDA.}

Alexander, C. P.

1927. The interpretation of the radial field of the wing in the Nematocerous Diptera, with special reference to the Tipulidæ. Proc. Linn. Soc. New South Wales, LII, pp. 42-72, 92 figs.

1929. A comparison of the systems of nomenclature that have been applied to the raclial field of the wing in the Diptera. IVth Internat. Congress Ent., Trans., II, pp. 700-707, 3 pls.

Cole, F. R.

1927. A study of the terminal abdominal structures of the male Diptera. Proc. California Acad. Sci., (4), XVI, pp. 397-499, 287 figs.

Crampton, G. C.

1923a. The genitalia of male Diptera and Mecoptera compared with those of related insects, from the standpoint of phylogeny. Trans. American Ent. Soc., XLVIII, pp. 207-225, 3 pls.

1923b. Preliminary note on the terminology applied to the parts of an insect's leg. Canadian Ent., LV, pp. 126-132, 1 pl.

1925. Evidences of relationship indicated by the thoracic sclerites of certain Eriopterine Tipuloid Diptera. Insec. Inscit, Menst., XIII, pp. 197-213, 2 pls.

1926. The external anatomy of the primitive Tanyderid Dipteran Macrochile spectrum Loew, preserved in Baltic Amber. Bull. Brooklyn Ent. Soc., XXI, pp. 1-14, 2 pls.

1928. The eulabium, mentum, submentum and gular region of insects. Journ. Ent. and Zool., XX, pp. 1-18, 3 pls.

1931. A phylogenetic study of the posterior metathoracic and basal abdominal structures of insects, with particular reference to the Holometabola. Journ. New York Ent. Soc., XXXIX, pp. 323357,4 pls.

Snodgrass, R. E.

1903. The terminal abdominal segments of female Tipulidx. Journ. New York Ent. Soc., XI, pp. 177-183, 2 pls.

1904. The hypopygium of the Tipulidæ. Trans. American Ent. Soc., XXX, pp. 179-236, 11 pls. 
SYSTEMATIC ARRANGEMENT OF GENERA AND SUBGENERA, WITH CITATIONS TO THE ABOVE BIBLIOGRAPHY OF KEYS

Tipulinæ

Ctenophora (Alexander, 1919c)

Tanyptera (Alexander, 1919c)

Nephrotoma (Alexander, 1919c; Dietz, 1918; Doane, 1908b; Osten Sacken, 1886.)

Tipula, s.l. (Alexander, 1919c; Dietz, 1913, 1914, 1917, 1919, 1921a,

Brachypremna (Alexander, 1912b) 1921b.)

Tany premna (Alexander, 1914b)

Dolichopeza: Oropeza (Alexander, 1919c; Johnson, 1909)

Cylindrotominæ

Phalacrocera (Alexander, 1919c)

Cylindrotoma (Alexander, 1919c)

Limoniinæ

Limoniini

Limonia: Limonia (Alexantler, 1919c; Osten Sacken, 1869)

Dicranomyia (Alexander, 1912c, 1919c; Doane, 1908a;

Alexandriaria (Garrett, 1922)

Osten Sacken, 1869)

Peripheroptera (Alexander, 1913c)

Rhipidia (Alexander, 1912a, 1919c; Osten Sacken, 1869)

Geranomyia (Alexander, 1919c; Osten Sacken, 1869)

Orimarga: Orimarga (Alexander, 1913a)

Dicranoptycha (Alexander, 1919a, 1919c)

Helius (Alexander, 1919c)

Pedicini

Pedicia: Pedicia (Alexander, 1919c, 1929; Hine, 1903)

Tricyphona (Alexander, 1919c; Osten Sacken, 1869)

Dicranota: Dicranota (Alexander, 1919c)

Rhaphidolabis (Alexander, 1916c, 1919c)

Plectromyia (Alexander, 1919c)

Ula (Alexander, 1919c)

\section{Hexatomini}

Adelphomyia (Alexander, 1919c)

Epiphragma (Alexander, 1913b, 1919c)

Polymera (Alexander, 1913b, 1920b)

Dactylolabis (Alexander, 1919c; Osten Sacken, 1869)

Pseudolimnophila (Alexanter, 1919c)

Limnophila, s.l. (Alexander, 1919c; Osten Sacken, 1869) Prionolabis (Alexander, 1916a, 1919c; Osten Sacken, 1869)

Eutonia (Alexander, 1919c)

Lasiomastix (Alexander, 1919c; Osten Sacken, 1869)

Phylidorea (Alexantler, 1919c)

Elaophila (Alexander, 1919c, 1927; Osten Sacken, 1869)

Idioptera (Alexander, 1919c)

Dicranophragma (Alexander, 1919c)

Pilaria (Alexander, 1919c)

Ulomorpha (Alexander, 1920a) 
Psaronius (Alexander, 1914c)

Hexatoma: Eriocera (Alexander; 1914a, 1915, 1916b, 1919c;

Penthoptera (Alexancler, 1914a)

Osten Sacken, 1869, 1886)

Atarba: Atarba (Alexander, 1926a)

Eriopterini

Chionea (Alexander, 1919c)

Cladura, s.l. (Alexander, 1919c)

Lecteria (Alexander, 1913b)

Sigmatomera (Alexancler, 1914c, 1930)

Trentepohlia: Paramongoma (Alexander, 1913b, 1914c, 1919b)

Teucholabis: Teucholabis (Alexander, 1914c, 1919c)

Paratropesa (Alexander, 1913c)

Gonomyia, s.l. (Alexander, 1916c, 1919c; Osten Sacken, 1869)

Progonomyia (Alexander, 1916c)

Lipophleps (Alexander, 1914c, 1916c, 1919c)

Gonomyia (Alexander, 1913b, 1916c, 1919c, 1926b; Osten Sacken,

Ptilostena (Alexander, 1916c)

1869)

Gnophomyia, s.l. (Alexander, 1913b, 1919b)

Rhabdomastix: Sacandaga (Alexancler, 1919c)

Erioptera, s.l. (Alexander, 1919c; Osten Sacken, 1869)

Erioptera (Alexander, 1919c; Osten Sacken, 1869)

Mesocyphona (Alexander, 1913b, 1919c; Osten Sacken, 1869)

Ilisia (Alexander, 1919c)

Empeda (Alexander, 1917, 1919c)

Cryptolabis (Alexander, 1913b)

Ormosia (Alexander, 1919c; Dietz, 1916; Doane, 1908c; Osten Sacken,

Molophilus (Alexander, 1913c, 1919c)

Toxorhina: Toxorhina (Alexander, 1913a, 1919c) 


\section{Family Anisopodidæ}

Moderately small, elongate flies with long legs and three oeelli.

Head subspherieal or hemispherieal, the eyes of the males holoptie or diehoptic, usually rounded. Proboseis moderately prominent, with small labella; palpi long, four segmented. Antennæ usually about as long as the thorax, eylindrieal, eomposed of twelve to sixteen segments. Thorax eonvex, without distinet transverse suture; seutellum semicireular, short and broad, the metanotum well developed. Abdomen more or less eylindrieal, flattened below, the genitalia small. Legs slender, without spines; anterior coxæ and the basal segment of the tarsi elongated; tibiæ with or without apieal spurs; pulvilli absent, the empodia pad-like. Wings rather large, lying flat on the abdomen when at rest; aluxiliary vein present; radius with 3 or 4 (Axymyia, Fig. 15*) branches; eell 1st $\mathrm{MI}_{2}$ closed or open (Figs. 14, 16\%); a single anal vein reaches the margin.

The adults are frequently common, partieularly those belonging to the genus Anisopus which sometimes oeeur in small swarms near the edges of woods in the vieinity of swamps and also on the trunks of trees. The other genera occur in moist places, partieularly upon foliage. The members of this family, insofar as known, breed in wet or moist deeaying organie matter, as fermenting sap, rotten wood and similar situations.

There are about 80 deseribed species, distributed in 6 genera and 3 subfamilies, all of the latter being found in the North American famn.

* Plate II, Tipuloidea.

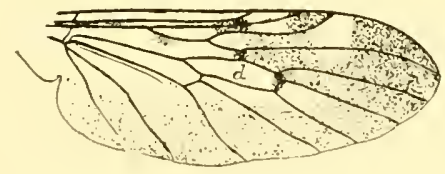

Fig. 1. Anisopus species.

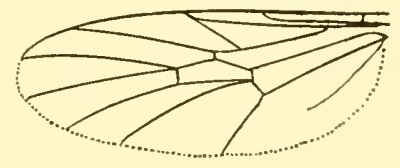

Fig. 2. Olbiogaster species. 


\section{KEY TO GENERA}

1. Wings with cell 1 st $M_{2}$ present. (Anisopodinæ) .............. Wings with cell 1st $M_{2}$ open by the atrophy of basal section of $\mathbf{M}_{3} \ldots \ldots 3$

2. Wing-membrane with macrotrichia $\left(14^{*}\right.$; also 1$)$; posterior tibia with a

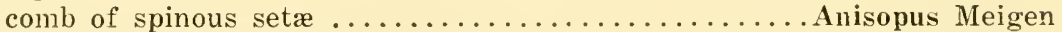
Wing-membrane without macrotrichia; posterior tibia without spinous comb; tropical (2)................... Olbiogaster Osten Sacken

3. Wings with vein $R_{3}$ present as a nearly transverse element, connecting with vein $R_{1+2}$ at margin $\left(15^{*}\right)$; eastern (Axymyiinæ)..Axymyia McAtee Wings with vein $R_{3}$ lost by atrophy, there being only two branches of Rs $\left(16^{*}\right)$; north temperate (Mycetobiinæ) ............. Iycetobia Meigen

The most important paper:

Eiwaris, F. W.

1928. Diptera. Fam. Protorhyphidæ, Anisopodiclæ, Pachyneuridæ, Trichoceridæ. Genera Insectorum, Fasc. 190, pp. 1-41, 2 pls.

* Plate II, Tipuloidea. 


\section{Family Blephariceridæ-The Net-Winged Midges}

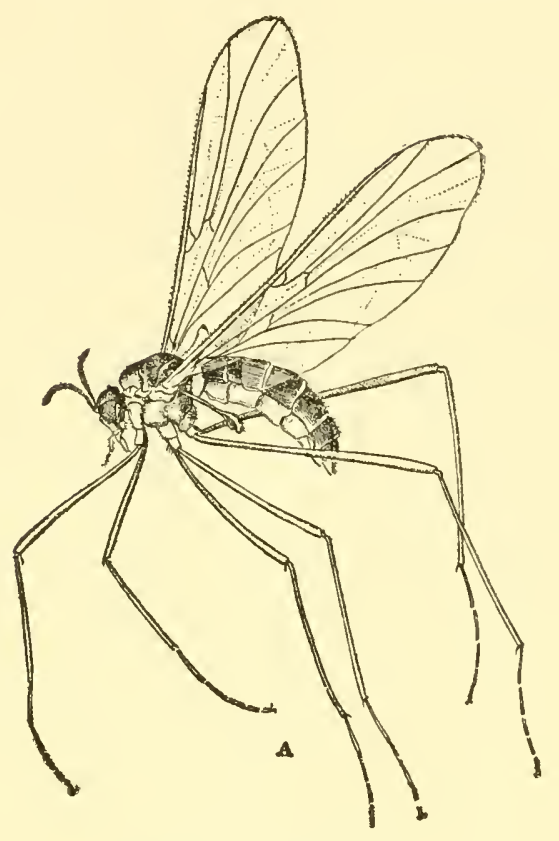

Agathon elegantula.

Noderate sized, elongate, nearly bare species with long logs and rather wide, delicate wings.

Eyes sometimes holoptic in one or both sexes and usually bisected below the middle by a narrow, unfaceted line below which the faces are smaller; three oeclli present. Antenna slender, eomposed of nine to fifteen segments and clothed with pubeseence. Mouth parts more or less elongate, the females with slender, flattened alongate serrate mandibles. Mosontum with distinet, broadly intermpted transverse situture. Legs rather slender, the posterior pair longer than the others; tibia with or without spurs; pulvilli and empodium absent or nearly so. Wings broad, bare, the anal angle projecting, almost always with a network of delieate lines due to the ereasing of the folded wings in the pupal case.

The adults are not common in most collections bul are often fomnd in large numbers near fast-flowing streams. I have found them chiefly on the foliage of evergreens or on the sides of cliffs or rocks. 
The larve live in swift water, clinging to the rocks or stream bed by a series of ventral suckers, pupation taking place in the stream. The immature stages are even more easily identified than the adults. The latest revision of the family is contained in Williston s Mannal of North American Diptera, 3rd edition.

\section{KEY TO GENERA}

1. An incomplete longitudinal vein between the fourth and fifth longi-

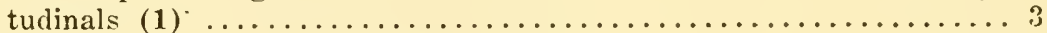

No incomplete vein between these veins $(2) \ldots \ldots \ldots \ldots \ldots \ldots \ldots 2$

2. Proboscis long; palpi but little developed $(2,5) \ldots \ldots$. Paltostoma Schiner Proboscis not longer than the vertical diameter of the head; palpi well developed, four-segmented .................... Kellogina Williston

3. Second basal cell closed apically........................ 4 Second basal cell open apically (1)............ Blepharicera Macquart

4. Second longitudinal vein branched, the branch either simulating a crossvein near the base of the second vein, or elongate............ 5

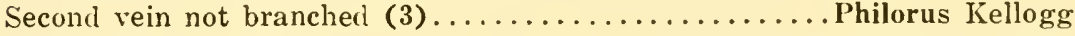

5. Pleura pilose or haired (4) ...........**ibiocephala Osten Sacken

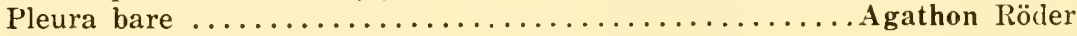

* Bibionus Curran is a synonym but the two snecies unon which the genera were based are distinct.

1

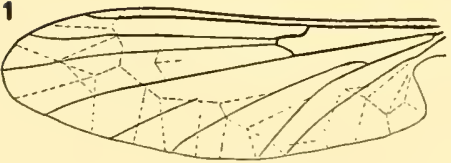

3

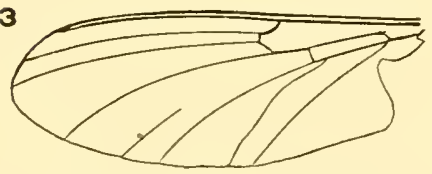

2

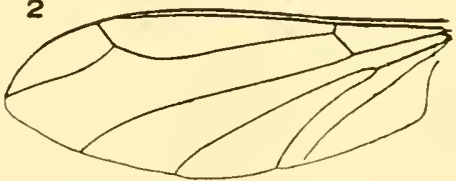

4

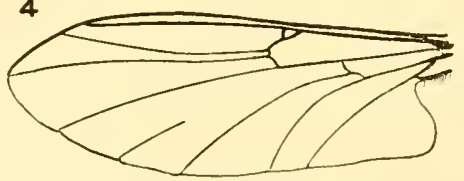

Blephariceridx.-1, Blepharicera; 2, Paltostoma; 3, Philorus; 4, Bibiocephala; 5, Paltostoma argyrocincta.

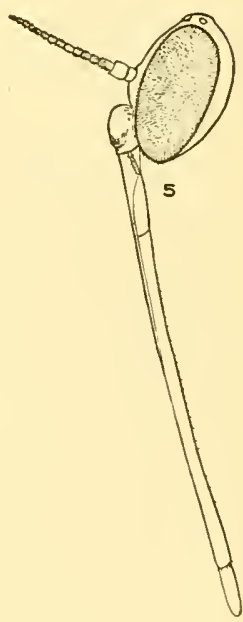




\section{Family Simuliidæ-The Black Flies}

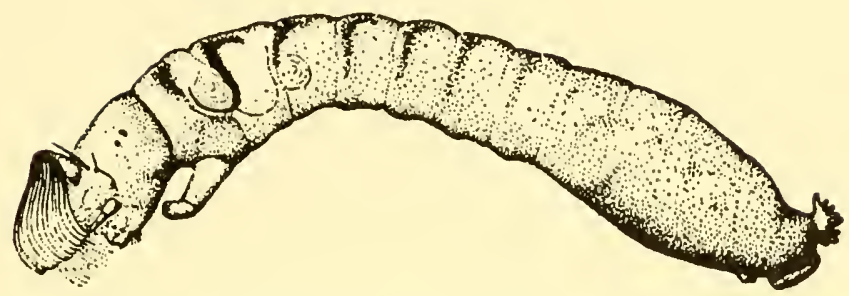

Larva of Simulium venustum showing the mouth fans (left) used for securing food. (After Metcalf and Sanderson).

Small, usually dark colored flies, rarely over $5 \mathrm{~mm}$. in length, with short, thick legs.

Head rather hemispherical; face short, eyes round or reniform, holoptic in the males; ocelli absent. Proboscis rather short, with small, horny labellæ, palpi incurved, four segmented, the basal segment short, the two following of equal length, the fourth longer and nore slender than the preeeding. Thorax arched, without transverse suture; sentellum small. Abdomen rather eylindrical, tapering in the males, composed of seven or eight segments; genitalia concealed. Legs short and strong, the femora broad and flat; tibia usually with terminal spurs; basal segment of the tarsi elongate, the apieal segment small. Wings large and broad, with distinct allula, the anterior veins thickened, the others weak. Auxiliary vein ending in the costa near the middle of the wing, the second vein absent, the first and third approximate; anterior crossvein very short; fourth vein curved, forked nearly opposite the anterior eross-vein, the branches terminating near the apex of the wing.

The Black-Flies, Buffalo rnats, Turkey Cinats, to use somo of the eommon names for these pests, need no introduction to the hunter or fisherman. To most people they are extremely annoying and as they frequently ocenr in enormous numbers in the neighborhoor of streams fishermen are only too well aequainted with them. As a rule their bites do not attract immediate attention but after a short time they eause painful swellings and, if in sufficient numbers, may result in the serious illuess of the sufferer and even death. The adults attack all warm blooded animals and are known from all parts of the world, being particularly abundant in the north temperate and subaretic zones. 
In addition to the irritation eaused by their bites some members of the family earry disease. In Afriea Onchoccrciasis. a disease eaused by a worm (Onchocerce volvulus Leuckart) of the family Filariidx is transmitted by Eusimulium damnosum Theobald. In man the disease takes the form of small to rather large, subcutaneous swellings and may or may not be apparent without careful examination. From 40 to 50 per cent of the natives of Sierra Leone were said by Blacklock to be infected in 1926.*

*Ann. Trop. Med. \& Parasit., xx, pp. 1-48, 203-218.
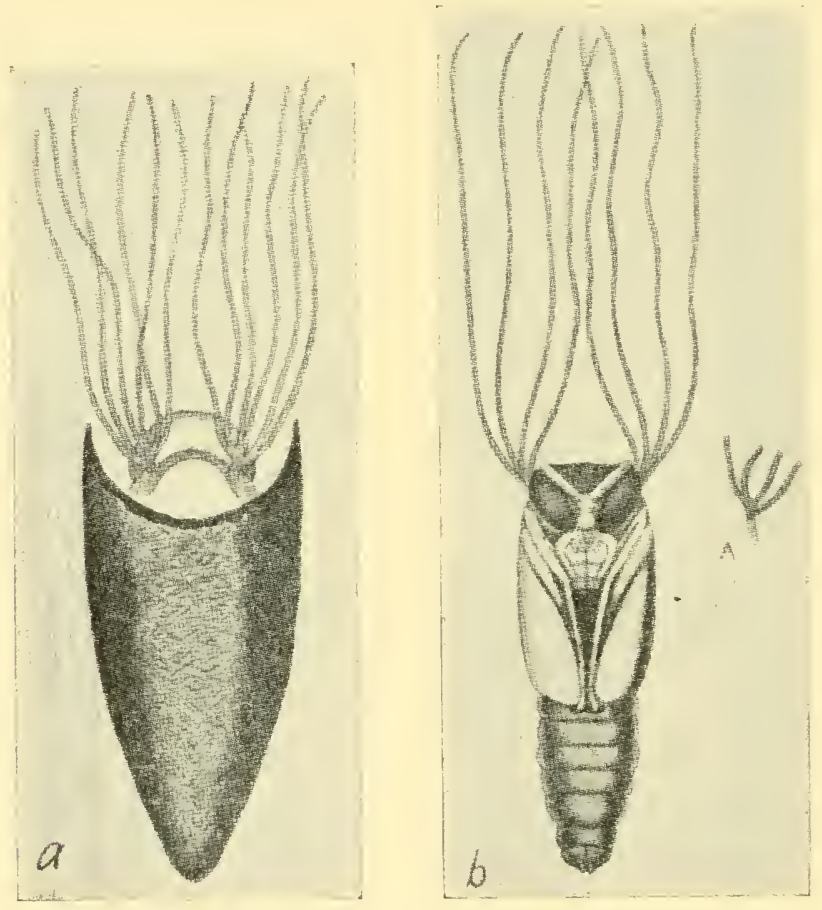

(a) pupa of Simulium venustum in pupal cocoon and (b) pupa of S. bracteatum, with cocoon removed. (After Metcalf and Sanderson). 
In Central America three speeies of Simulium have been shown to earry a disease displaying various symptoms and sometimes resulting in blindness. The eausative agent is related to the form deseribed above and was named Onchocerce cucutirus by Brumpt. In some eases of infection there are no elinical symptoms but in others there are erysipelas-like swellings, the name coastal erysipelas being applied to the disease in sueh cases. Nodular swellings may oeeur on the head. shoulder blades, ribs iliae erests, ete. In the eye the mierofilarix may cause conjunctivitis, lieratitis and iritis, bhindness sometimes resulting.

Both the fly and man are neeessary for the development of the disease. After being ingested by the fly the mierofilariæ pass from the intestine to the museles of the thorax where further development takes place. The infective stages oceur in the proboseis of the fly and are transferred to man during feeding by the insect. Strong has diseussed Onchocerciasis in Cuatemala.*

The larvæ live in streams where they attach themselves to stones, plants, etc. and eolleet their food from the flowing water. Pupation takes place within the larval cocoon, the adults emerging under water and, quiekly reaching the surface, fly away. Tnder favorable conditions many thousands of larvæ may be found together, being so numerous as to entirely eonceal the surface to which they are attached.

The latest revision of the North Ameriean species is by Dyar and Shannon. $\dagger$ Unfortunately these anthor's apparently took greater pains to find fault with the work of others than to clarify their own conclusions and only a study of their material and amplifieation of the deseriptions will result in a elear understanding of the speeifie limits. In some eases the drawings were evidently made from freshly prepared slides and these show charaeters which gradually disappear, with the result that the same characters cannot be found in old slides and may not even be present in freshly prepared ones made from old speeimens. . Just what effect this will have on the validity of several of the forms reeognized by the authors it is impossible to say. Nalloeht has also rerised the family: the two contributions should be used together.

* 1931, Science, N. S., Ixxiii, pp. 593-594.

† 1927. Dyar and Shannon. Proe. U. S. N. M., lxix, Art. 10, pn. 1-54, 7 plates.

$\ddagger 1914$, Malloch, Bull. U. S. Dept. of Agric., Bur. Ent., Tech. Ser., No. 26. 


\section{KEY TO GENERA}

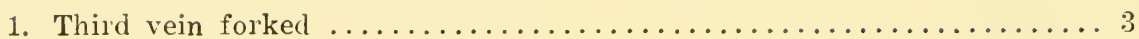

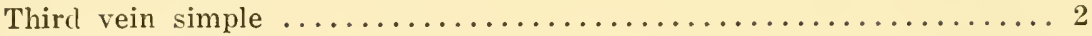

2. Petiole of the second and third veins setulose above... Eusimulium Roubaud Petiole of the second and third veins bare (1)........ Simulium Latreille

3. Fifth vein not forked $(3) \ldots \ldots \ldots \ldots \ldots \ldots$. . Parasimulium Malloch Fifth vein forked $(2) \ldots \ldots \ldots \ldots \ldots \ldots \ldots$. Prosimulium Roubaud
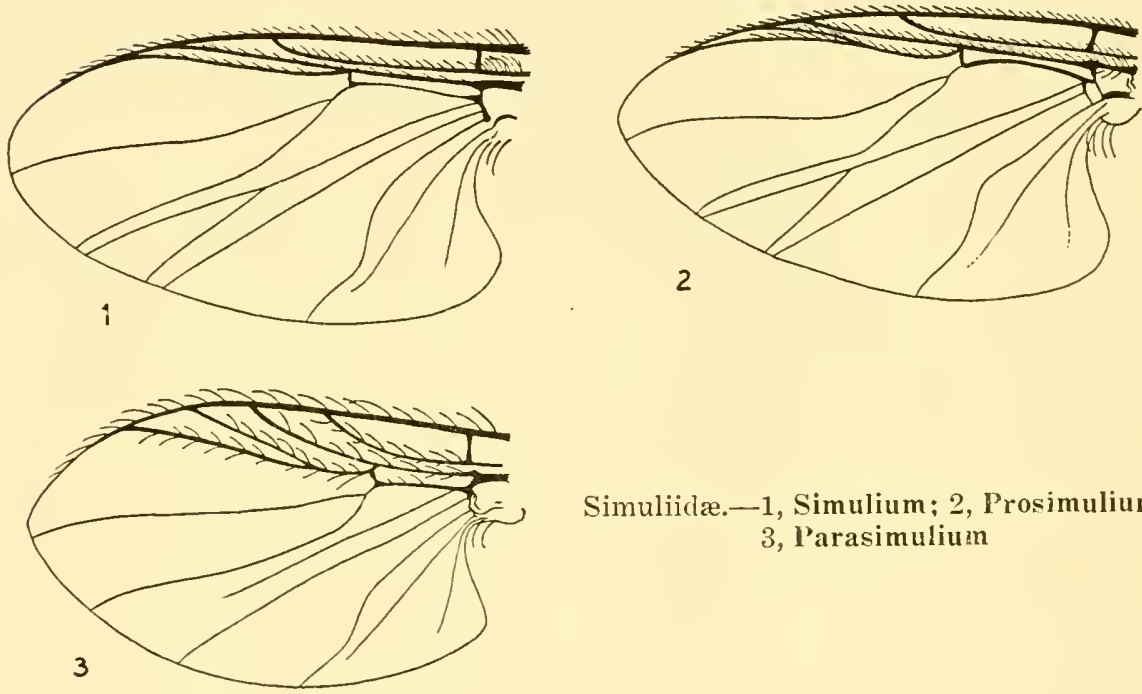

Simuliidæ.-1, Simulium; 2, Prosimulium; 3, l'arasimulium 


\section{Family Thaumaleidæ}

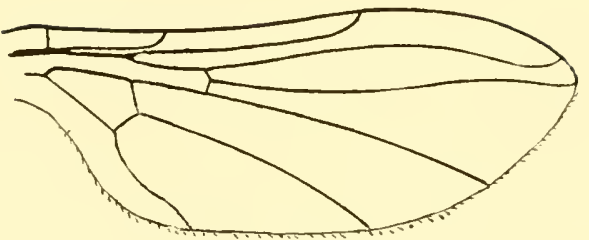

Thaumalea species.

Small, bare, obscurely reddish yellow or brownish flies of peculiar appearance.

Head small, round; eves holoptic in both sexes; ocelli absent: proboscis short; palpi longer than the antemne, composed of five segments, the first short, the second thickest; antenna situated near the oral margin, composed of a scape, pedicel and flagellum, the latter very compact and arista-like, but eomposed of ten distinct segments, the basal two rather larege and globose. Thorax robust, strongly convex, without transverse suture, somewhat depressed before the rather large, obtusely triangular scutellum; metanotum arched. Abdomen narrower than the thorax, eylindrical, composed of seven segments; male genitalia large, the hasal piece swollen, bladeler-like; oripositor with broad, rounded lamelle. Ieos simple, comparatively short; coxa short; tibix without spurs; tarsi of moderate length, the anterior pair abont as long as the tibia, the penultimate segment short; empodia vestigial; claws small. Wings longer than the abdomen; auxiliary vein short, terminating in the costa; second longitudinal vein curved; the third and fourth reins simple; basal cell short; anal angle rounded.

There are about three dozen described species belonging to this family, most of them occurring in the Old World. The adults are found along the edges of streams, particularly those with mossy banks, and are not common in collections. They are small flies, under $6 \mathrm{~mm}$. in length, and the wings bend sharply near the base in death, folding downward as in the Psychodida.

The larra, which resemble those of the Chironomida, are found in small brooks and streams where the clear water flows very thinly orer the rocks, so that the back of the larra is always exposed above the surface. They feed on detritus and diatomes, and move about in search 
of food. The pupæ are found in the bottom of the stream between stones, ete.

The following key will separate the described genera, two of which oceur in America. The family has been revised by Edwards.*

\section{KEY TO GENERA}

1. Subcostal vein ending in the costa or first vein................ 2 Subcostal vein obsolete apically, ending free. (North America, pluvialis

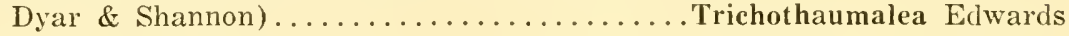

2. Subcostal vein ending in the first vein, very short (Australia, N. Zea-

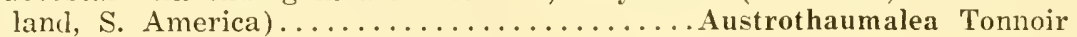

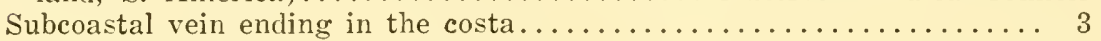

3. Basal segment of $\sigma^{*}$ palpi greatly swollen, the second and third segments not much longer than broad; subcosta weak apically (Europe).

Androprosopa Mik

Palpi rather stout, alike in both sexes, somewhat longer than the an-

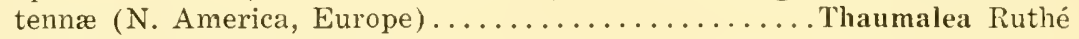

\section{North American Species of Thaumalea}

1. Thorax and abdomen brown or blackish.................. 2 Thorax reddish yellow, the abdomen brown........elnora Dyar \& Shannon

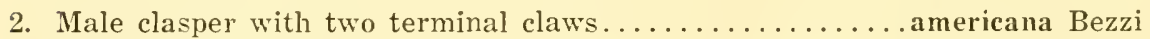
Male clasper with about six terminal claws......johannis Dyar \& Shannon

* Edwards, 1929, Zool. Anzeiger, np. 121-142. 


\section{Family Chironomidæ-The Midges}

Small, stender flies, rarely over $10 \mathrm{~mm}$. in length, thorax large, the legs slender, antenna of males plumose.

Head small, more or less spherical, partly concealed from dorsal view by the projecting thorax. Antenne slender, with five to fourteen segments, the basal segment enlarged and globular, plumose in the males, more or less haired in the females. Lyes reniform or oval, the ocelli absent or rudimentary. Proboseis short, not adapted for piereing; palpi with three or four segments. Thorax sub-ovate, or moderately long, more or less projecting in front, without a transverse suture but with a wide, longitudinal impression in front of the scutellum; metanotum with a more or less distinct longitudinal groove in the middle; scutellum smalt and hemispherieal. Legs stender and rather long, especially the front pair; the tarsi often very long; empodium and pulvilli present or absent. Wings bare or haired, long and narrow, usually with a strong anal angle; anterior veins strong; auxiliary vein complete though slender; seeond longitudinal rein weak or absent, the third rein often forked and eonneeted with the first by a erossvein; fourth vein often with two branches which may or may not be petiolate basally, the fifth vein usually fureate; seeond basal eell open or elosed apieally; costa usually ending at the termination of the third vein, usually well before the tip of the wing. Abdomen narrow and long, especially in the males, shorter and more robust in the females, the hypopygium exposed; ovipositor short.

The Certatopogonida, formerly ineluded in this family by most authors, have been recognized as a distinet family by Malloeh and Edwards, and are so treated here. They may be distinguished by the shape of the thorax and absence of the metanotal depression.

The midges bear little resemblanee to mosquitoes when viewed by a eareful observer, but to the layman they show no differences and are not differentiated. Nany people believe that they are "young" mosquitoes and that they will "grow up", but there is, of eourse, no justifieation for such a belief. In mosquitoes the eosta extends entirely around the wing and the wing reins and costa are usually scaled.

The family is a very large one and comprises elose to two thousand deseribed species. Midges are found almost everywhere, but since the larve are aquatic their distribution is limited to the vieinity of water, although they are frequently found in large numbers at a eonsiderable distance from any visible water supply. While they are not strong 
fliers they can remain in the air for long periods of time and they often oceur in large numbers. Williston states that in the Rocky Mountains he has observed them dancing in the air in incredible numbers and producing a noise like a distant waterfall. As a rule they swarm in the evening, but swarms are not uncommon in sheltered places during the day. For the most part only the males swarm, although an occasional female may be found with them. While, as a rule, only one species will be found in a swarm it is not nmusual to find other species among them. The females are found mostly on foliage, where they rest on the meler surface during the day. Some forms oceur commonly on tree trunks, logs, and in grass. They are attracted to light, frequently in very large numbers.

Since many of the Chironomids are rery small they must be handled with eare. The larger ones may be pinned in the usual manner, provided fine pins are used: the smaller shonld be attached to the side of a pin by a ring of shellac, eare being taken to leave one wing and the tarsi free. Specimens without front tarsi are almost useless and, since the insects dry quickly, they must be mounted within an hour or two.

The larve are elongate, eylindrical, slender and curved more or less downward, particularly when preserved. The head and legs are conspicuous and there may be one or more pairs of leg-like pads posteriorly. They are seavengers and live in water everywhere, also in mud and have been dredged from a depth of nearly a thousand feet in Lake Superior. Some are also found in decaving regetation, in moss, ete. Many of them are free-living while other's make mud eases on stones, leaves and pieces of wood and I have found one undetermined species building almost colorless cases in spirogyru. Nany of the larra contain hamoglobin and are red in color, the name "blook-worms" being applied to these.

The classification of the family is not entirely satisfactory and characters for the limitation of genera are few. Edwards" has utilized the tibial spurs and combs for the separation of genera, in addition to other characters. However, the classification must be considered as very artificial, although losing nothing on that account. Since the object of taxonomy is the identification of species the means of obtaining the end is not important. Many papers dealing with the American species have been published since the appearance of Johannsen's monographic revisiont in 1905, by Kieffer, Nalloch, Johannsen, etc. Some of the more important are listed below.

* 1929. British non-biting midges, Tr. Ent. Soc. London, Dec. 1929.

1905. New York State Museum Bulletin No. 86.

1915. Bull. 111. State Lab. Nat. Hist., x, Art. 6. 


\section{KEY TO GENERA*}

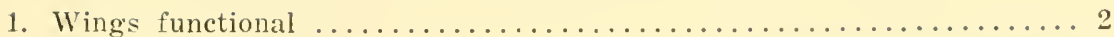
Wings greatly reduced, strap-like, not more than half as long as the

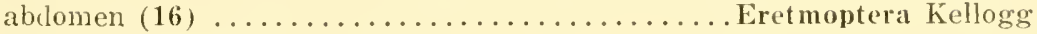

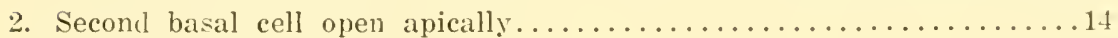

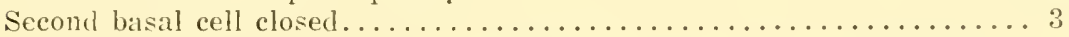

3. Second vein either present and forked near tip or else indistinct or

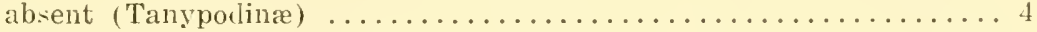

Second vein not forked apically, simple, and always distinct (Dia-

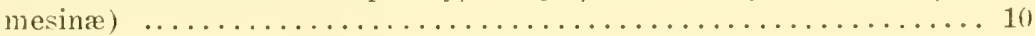

4. Costa not produced beyond end of third vein, wing hairy; fourth tarsal segment linear (Abiabesmyia Johannsen) (11).....Pentaneura Philippi Costa distinctly produced beyond the end of the third vein........5

5. Second vein wanting, the space between first and third veins broad;

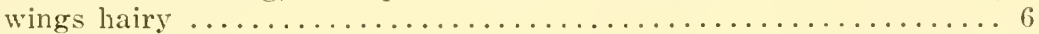

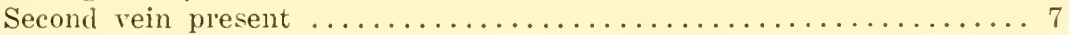

6. Fifth vein with long petiole (7)............ Trichotanypus Kieffei Fifth vein without petiole (Linacerus, Paratanypus) (15).

Podonomus Philippi

7. Fourth tarsal segment cordiform; wings bare, branches of fifth vein either with or without petiole (Colotanypus)....... Clinotanypus Kieffer Fourth tar'sal segment not cordiform; wings hairy or bare......... \&

8. Fifth vein not petiolate $(6) \ldots \ldots \ldots \ldots \ldots \ldots \ldots$ Anatopynia Johannsen

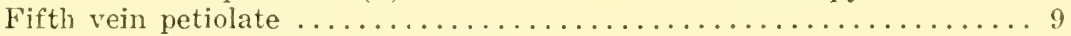

9. Petiole of fifth vein not one-third as long as the posterior branch;

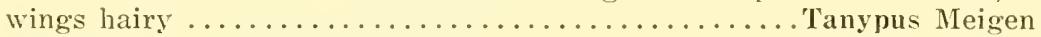

Petiole of fifth vein at least half as long as posterior branch of this vein; wings bare or hairy $(12) \ldots \ldots \ldots \ldots \ldots \ldots$. . Procladius Skuse

10. Posterior crossvein intersecting the petiole of the fiftl vein; eyes bare; fourth tarsal segment cylindrical (14)...........Prodiamesa Kieffer

Posterior crossvein intersecting the anterior branch of the fifth vein

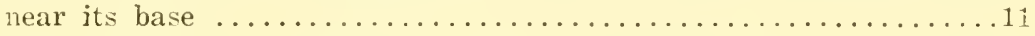

11. Fourth segment of tarsus more or less cordiform, shorter or at least

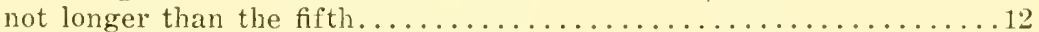

Fourth tarsal segment cylindrical, longer than the fifth.

Syndiamesa Kieffer

12. Eyes finely pubescent; antennæ of male plumose (3) ... Diamesa Meigen

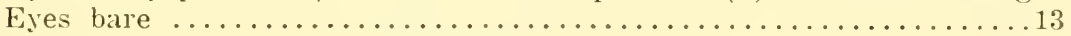

13. Legs annulate; male antennæ not plumose (8)....... Heptagyia Philippi

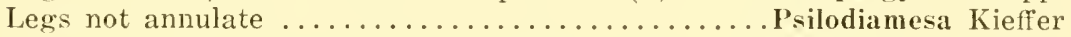

14. Terminal segment (style) of hypopygium of male directed rigidly backwarls; basal segment of anterior tarsi longer than the tibia, the anterior tibia without distinct spur except in Psendochironomus

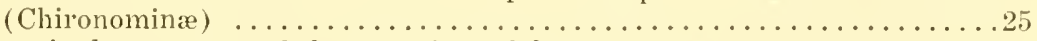

Terminal segment of hypopygium folded inwarls; first segment of anterior tarsus shorter than the tibia; anterior tibia with spur (Ortho-

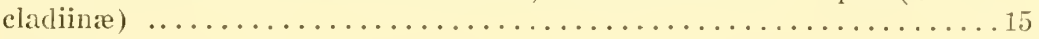



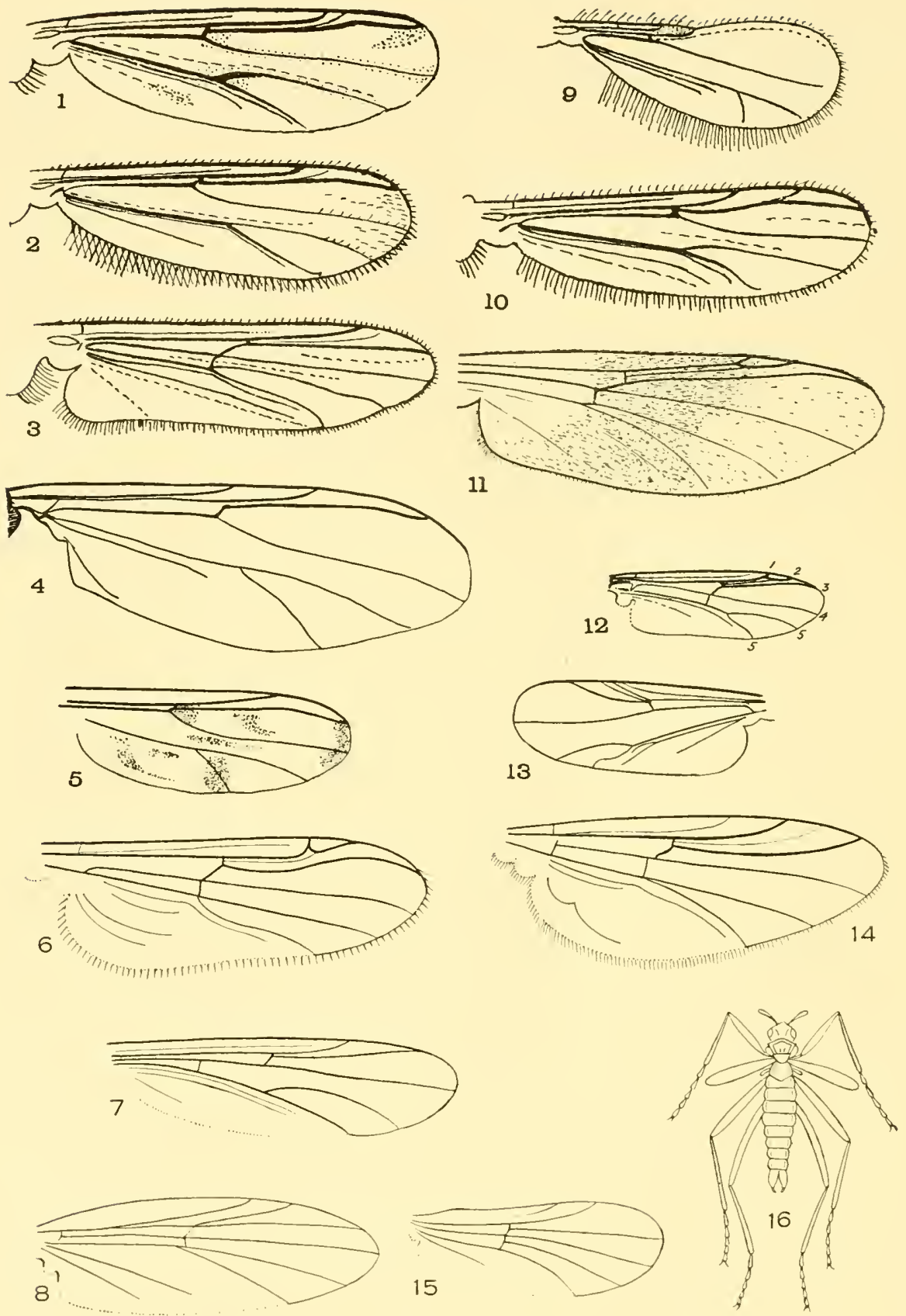

Chironomide, -1, Pentapedilum, hairs omitted; 2, Tanytarsus; 3, Diamesa; 4, Crictopus insolitus; 5, Chironomus; 6, Anatopyuia; 7. Trichotanypus; 8, Heptagyia; 9, Corynoneura; 10 , Orthocladius; 11, Pentaneura algens; 12, Procladius; 13, Metriocnemus; 14, Prodiamesa; 15. Podonomus: 16, Eretmoptera. 
15. Third vein fused with the costa and not reaching beyond the apical three-fourths of the wing; a false vein running close to anterior margin of wing $(9) \ldots \ldots \ldots \ldots \ldots \ldots$ Corynoneura Winnertz

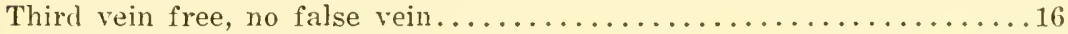

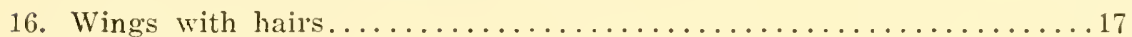

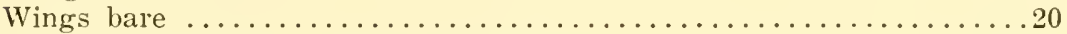

17. The thick crossvein joining the third and fourth vein very long and

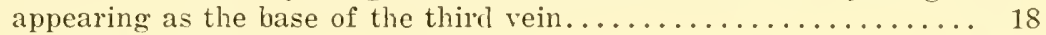

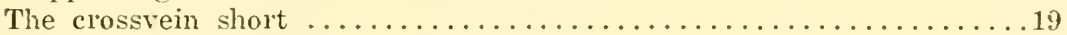

18. Mesonotum conically produced in front; wings spotted.. Eurycnemus Wulp Mesonotum not produced; wing unicolored..............Billia Kieffer

19. Pulvilli absent; wing hairs decumbent (13).........Metriocnemus Wulp Pulvilli present though small; wing hairs suberect (Spaniotoma Edwards $(10) \ldots \ldots \ldots \ldots \ldots \ldots \ldots \ldots \ldots \ldots \ldots \ldots \ldots \ldots \ldots \ldots \ldots \ldots$ Orthocladius Wulp

20. Mesonotum with a longitudinal fissure; wings black with white markings

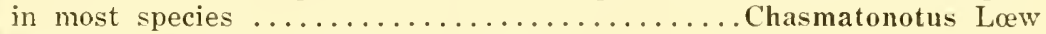
Mesonotum without longitudinal fissure...................

21. Claws cleft; large marine species (Telmatogeton Coquillett, not

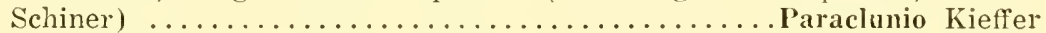

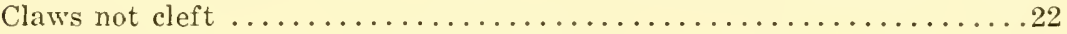

22. Palpi porrect, 3 segmented (Symbiocladius).......Trissocladius Kieffer

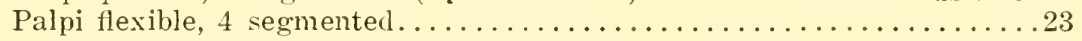

23. Fourth segment of at least the hind tarsi cordifcrm, shorter than the fifth (Thalassomyia Johannsen, not Schiner)...... Cardiocladius Kieffer

Fourth tarsal segment linear...........................

21. Dorsocentral hairs minute and decumbent; tibia usually banded with white; genitalia in most cases in part pure white (1)... Crictopus Wulp

Dorsocentral hairs larger and suberect; tibiæ not banded (Spaniotoma Philippi) Edwards, Psectrocladius, Trichocladius, Dactylocladius, Camptocladius $)(10) \ldots \ldots \ldots \ldots \ldots \ldots \ldots \ldots \ldots \ldots \ldots \ldots \ldots \ldots \ldots \ldots$ Orthocladius Wulp

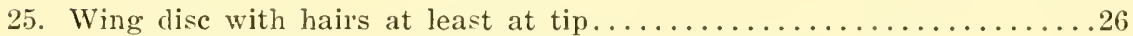

Wings quite bare, the anterior crossvein distinct and oblique......27

26. Squamæ fringed; anterior crossvein distinct and oblique (1).

Pentapedilum Kieffer

Squamæ quite bare, anterior crossvein longitudinal in position or indistinct $(2) \ldots \ldots \ldots \ldots \ldots \ldots \ldots \ldots \ldots \ldots \ldots \ldots \ldots \ldots \ldots \ldots \ldots \ldots$ Tanytarsus Wulp

27. Eyes widely separated, reniform; all tibiæ with long conspicuous spurs; pronotal collar large; basal segment of anteriol tarsus not longer

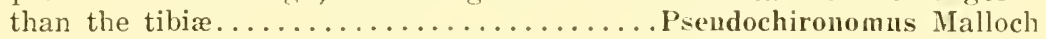

Eyes with dorsal projection; front tibial spur inclistinct or absent; basal segment of anterior tarsus longer than the tibia (5).

Chironomus Meigen

The genus Chirocladius Picalo, represented by a species from Costa Rica, and which seems to belong among the Chironominæ, is too briefly described to place in the key.

* Pscudochironomus Malloch, with widely senarated reniform eyes and rery large rronota] collar, in spite of short basal segment of the anterior tarsi and the tibial sprurs, helongs with the next section. 


\section{Family Ceratopogonidæ-The Biting Midges}

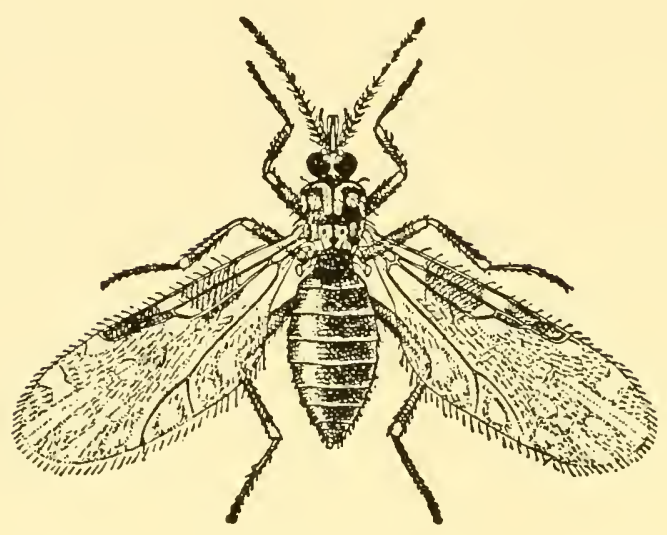

Culicoides species.

Very small, slender flies, rarely $5 \mathrm{~mm}$. in length.

Head small, spheroidal and rounded behind or hemispherieal and flattened behind; ocelli absent or practically so; antennæ slender, usually with fourteen segments and a fifteenth mieroseopic one, the apieal three to five segments lengthened, the basal swollen; mouth parts complete. adapted for biting. Thorax rather oval, shorter than in the Chironomida; pronotum never prominent; metanotum rather rounded, never with a longitudinal groove; scutellum small, hemispherieal, usually bearing distinct bristles. Wings of moderate width, folded flat over the hack when at rest; second rein absent, fourth vein generally fureate; alula very narrow; squame never eompletely fringed. Legs moderately long, the posterior pair longest; femora and tibix sometimes swollen, the former sometimes with spines beneath; pulvilli present or absent. Abdomen elongate; genitalia exposed; ovipositor small.

The Ceratopogonidx may be readily distinguished from the Chironomide by the eharacters enumerated above. They are mimute or quite small flies and are often serious pests, especially along the seashore, in the tropies and along our river's and lakes, but are not limited in distribution to large bodies of water. The adults are either predaceons or externally parasitic althougl no real differentiation can be made. The larger speeies are known to prey upon small insects while the small 
forms suck blood and they have been observed more than once attached to "mantids" or "walking sticks", upon which they feed. Warm blooded animals are freely attacked by representatives of the wenera Culicoides, Lasiohelea and Leptoconops and the tiny ereatures sometimes make man miserable by their uneeasing attention. They are known commonly as "punkies" and "no-see-nms", the latter name because of their small size, and they are mnwitting jokers since almost any large inseet is liable to be blamed for the bites of these lilliputians. They are attraeted to light in large numbers and are diffieult to keep from houses owing to their small size.

In Africa Culicoides ansteni is known to be the intermediate host of a parasitie worm (Acanthocheiloneura perstens), a form oceurring also in South Ameriea, but the worm is not known to eanse any speeifie disease. Further study may link the members of this family with the transmittal of diseases of a speeifie nature.

The larva are aquatic or semi-aquatic being found in moist places, in mud, sand, deearing vegetation and in tree-holes. It seems likely that most of the marine species live within the tide-zone and for that reason there is no practical means of eontrol, while those living in decaring vegetation form an equally serious problem. The species living in tree holes are seldom abundant and the elimination of their breeding places is a simple matter. It is not known whether the larve are scavengers or predators and it may be that they include both gromps.

The insects are difficult to eapture and require speeial eare in handling. Those which bite may be eaptured by placing a bottle over them as they suek blood, but the collector will no doubt find it necessary to excreise great self control during the process owing to the numbers which begin feeding at the same time. Speeimens seem best when mounted on the side of a pin but some may be kept in alcohol and mounted on slides. Owing to the delicate nature of the hairs on the wings they are easily abraded and the characteristie wing pattern disappears. For this reason dried specimens should always be preserved. Edwards" has dealt with the British species and his paper will be found invalnable. Nallocht, Johannsenț Root, Hoffman and other's have published on the North Ameriean forms and a great deal of researeh is being conducted at the present time by the last two mentioned anthors. I am indebted to Drs. Johannsen and Root for checking and rerising the key to this family.

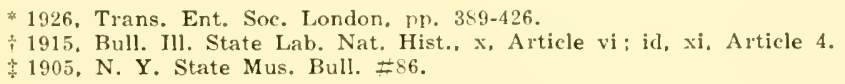




\section{KEY TO GENERA}

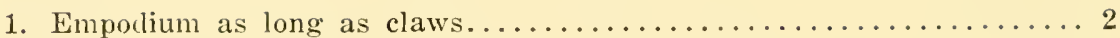

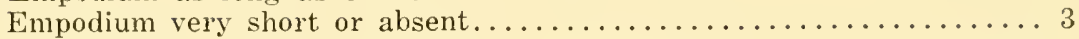

2. Costa extending to about midldle of wing; wings with dense macrotrichia all over (Euforcipomyia Malloch) (3)...........Forcipomyia Meigen

Costa extending well beyond middle of wing; macrotrichia sparser, sometimes absent (4) .................. Atrichopogon Kieffel

3. A fold looking like a simple vein between third and fourth veins; first and third veins indistinct, more or less fused. (Tersesthes Townsend).

Leptoconops Skuse

No vein-like fold between third and fourth veins.............. 4

4. Costa extending to about middle of wing; second radial cell short and square-ended, first radial cell obliterated; macrotrichia usually dense (Pseudoculicoides Malloch, Isoecacta Garrett) (5).... Dasyhelea Kieffer

Costa extending well beyond middle of wing; radial cells usually other-

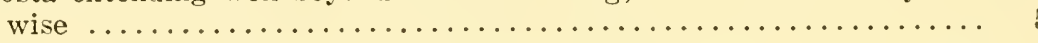

5. Humeral pits present and conspicuous; microtrichia of wings distinct; claws of female small and equal; at least some macrotrichia present.

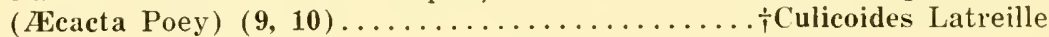

Either humeral pits absent or else microtrichia absent or else claws of

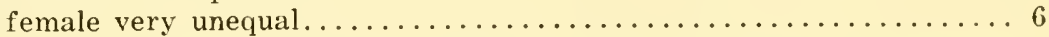

6. The two radial cells small and equal or one or both of them obliterated; wings finely punctuate but without distinct microtrichia; legs not

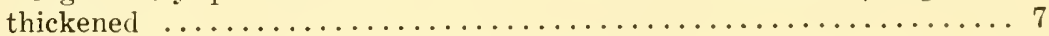

Either second radial cell much longer than broal or else wings with distinct microtrichia or else legs modified................ 8

7. Wings with at least one lark spot and with some macrotrichia; female claws unequal (Neoceratopogon Malloch).........Alluaudomyia Kieffer

Wings whitish, without dark markings, and without macrotrichia; female claws equal $(8) \ldots \ldots \ldots \ldots \ldots \ldots$ Ceratopogon Meigen

8. Hind femora noticeably thicker than the others............... 9

Hind femora not thickened............................. 10

9. Hind femora much thickened and spinose beneath; hind tibiæ not thickened (Ceratolophus Kieffer) (1).............. Serromyia Meigen Hind femora not spinose; both hind femora and hind tibiæ moderately

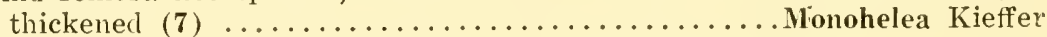

10. First and third veins connected by a crossvein, 2 radial cells.........11 First and third veins not connected, one long radial cell........... 15

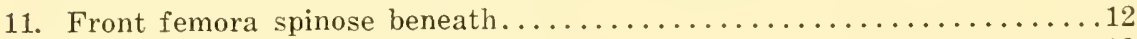

Front femora not spinose beneath....................... 13

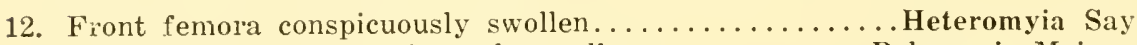

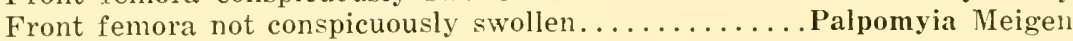

13. The branches of the fourth vein petiolate basally (Hartomyia Malloch).

Stilobezzia Kieffer The branches of the fourth vein arise at or before the cross vein......14

14. Last segment of front tarsi much swollen (2)......... Clinohelea Kieffer Last sezment of front tarsi not swollen (6)..... Johannsenomyia Malloch

* Malloch, 1915, Bull. Ill. State Lab. Nat. Hist., x, p. 304 (Ceratopogon).

+ Hoffman, 192,. Amer. Journ. Hygiene, v, pp. 274-301. 


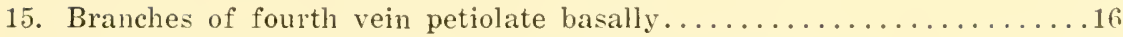
Branches of fourth vein arise at or before the crossvein............17

16. At least one pair of femora with spines beneath.....Pseudobezzia Malloch

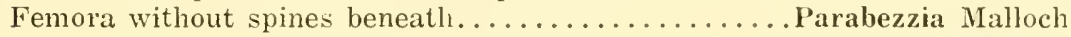

17. Posterior branch of the fourth vein elbowed basally in the female (12). Stenoxenus Coquillett Posterior branch of fourth vein not elbowed.................... 18

18. At least one pair of femora, with spines beneath (11)......Bezzia Kieffer Femora without spines beneath................ Probezzia Kieffer
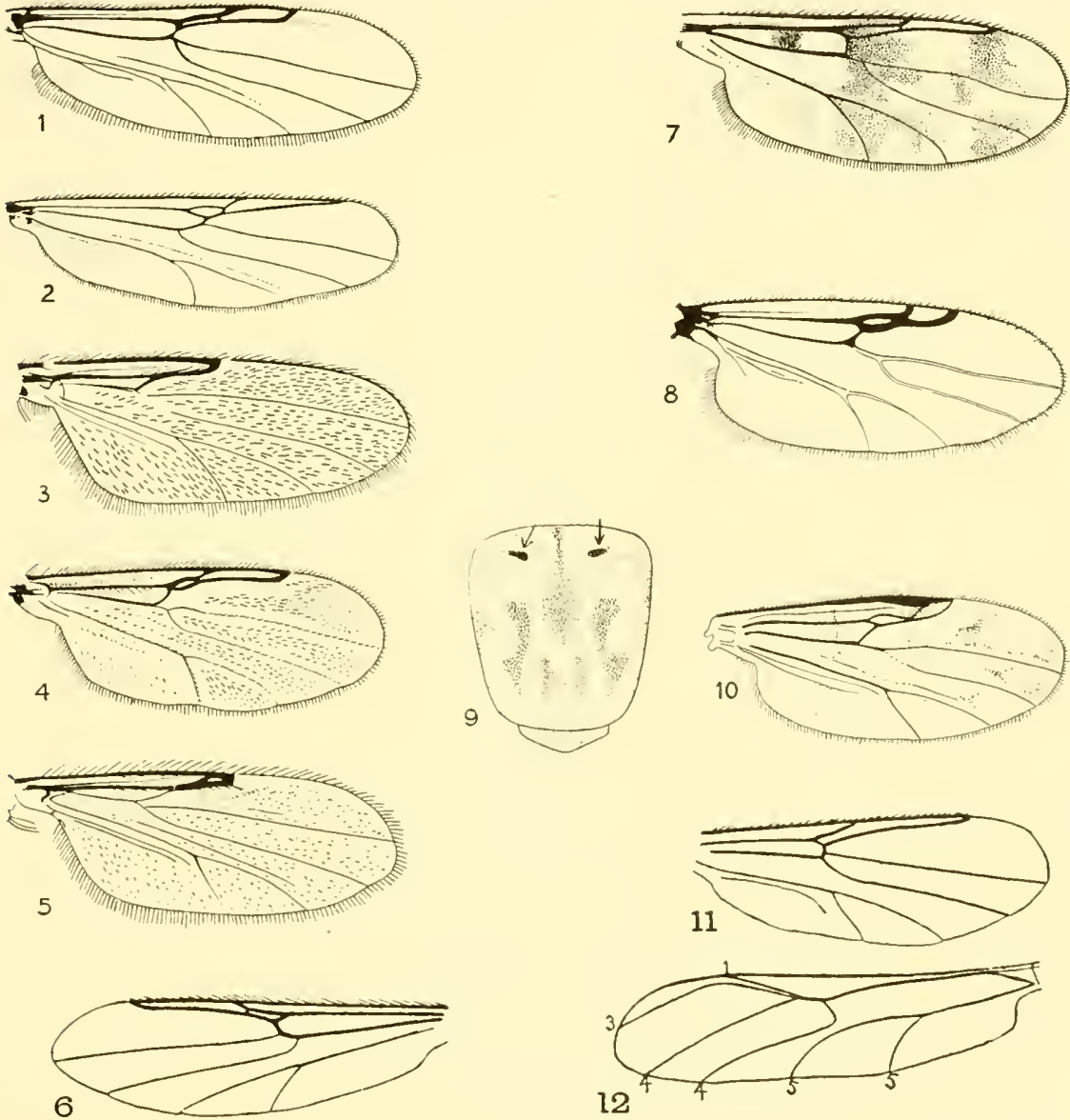

Ceratopogonida.-1, Serromyia; 2, Clinohelea; 3, Forcipomyia: 4, Atrichopogon; 5. Dasyhelea; 6, Johannsenomyia; 7, Monohelea; 8, Ceratopogon; 9, Culicoides, thorax; 10, Culicoides cockerelli; 11, Bezzia; 12, Stenoxenus. 


\section{Family Psychodidæ-The Moth Flies}

Thickly haired, small flies, rarely exceeding $5 \mathrm{~mm}$. in length, the wings elothed with hairs or seales and folded roof-like over the back.

Head small; ocelli absent. Antennæ usually as long as the head and thorax together, the segments usually bead-like and sometimes so densely haired as to appear very thick; composed of from twelve to sixteen segments, the basal segments usually short and cylindrical. Proboseis usually short but more or less elongate and rigid in Flebotomus: palpi composed of four segments, hairy. Thorax without transverse suture, not very convex; seutellum rounded. Abdomen rather eylindrieal, composed of six to eight segments; male genitalia prominent, the female ovipositor usually projecting. Wings large, ovate, often pointed, when at rest lying roof-like over the abdomen, the base being bent at more than a right angle, the reins and border densely haired, the integument often with hairs or seales; reins strong, usually concealed by the dense hair; erossveins restrieted to the basal third of the wing; two or three of the reins furcate. Legs rather short, elongate in Flebotomus and usually thickly haired.

The adults oceur commonly in shady plaees in the vieinity of water and may often be found in large numbers on dense foliage in swamps, where they erawl about on the under surface of leaves, oecasionally alighting on the upper surface after a short flight. I have seen them in thousands on tree-trunks after a heavy rain and they are not rare on logs and fallen trees where they walk about in a peenliar, jerky manner or remain perfectly still. One or more speeies of Psychoda breeds in drain pipes and they often eause umeasiness by appearing in the bath room. Their presence should ineite interest rather than fear as the larve survive hot water and soap alike, and do no harm. The adults are not common in collections, chiefly because they are so easily damaged. The hairs brush off and they become useless unless unusual care is taken of the speeimens. No recent revision of the family has appeared and the synonymy is badly mixed and is not to be trusted. The male genitalia offer excellent characters. There are dozens of species and the family offers an excellent opportunity for a thorough, monographic work.

In America two diseases are known to be carried by species of Flebotomus. The disease known as Vermga Peruicana, Oroya Fever or Carrion's Diseuse has been found only in narrow valleys on the western slopes of the Peruvian Andes. Terruga is said not to be serious but Oroya Fever (Carrion's Disease), the malignant form, is responsible for many deaths annually. Locul Leishmaniusze or Espundiu 
occurs in South and Central America. The causative organism is Leishmaniu brazitionsis but it is not known definitely which species of Flcbotomus carry the disease. It is possible that most of them are capable of doing so. The statement has been made that the adults of Flebotomus are noeturnal and that protection against disease may be obtained by remaining indoors at night. Most of the nocturmal bloodsuckine flies may be found on the wing on dull eloudy days.

The larve live in decaying vegetable matter, dung, or water and are peculiar in possessing both open spiracles and tracheal gills; the head bears eye-spots; in the aquatic forms there are sucking dises on the segments behind the head, but no feet.

\section{KEY TO GENERA}

1. Two longitudinal veins behind the posterior forked vein......... 2 Three longitudinal veins behind the posterior forked vein.......... 3

2. Two forked veins in front of the middle of the wing. ${ }^{*}$ Flebotomus Rondani One forked vein in front of the middle of the wing (3)...Maruina Müller

3. Wings with scales or scale-like hairs on the veins or membrane..... 4

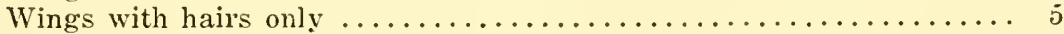

4. Wing membrane with broad scales over most of the surface. Wings with scales on the veins only.............. Brunettia Annandale

5. Two longitudinal, unforked veins between the anterior and posterior

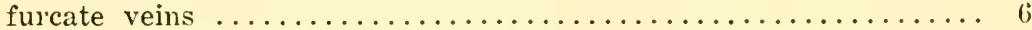
Only one longitudinal vein between the anterior and posterior furcate veins $(4) \ldots \ldots \ldots \ldots \ldots \ldots \ldots \ldots \ldots \ldots \ldots \ldots \ldots \ldots \ldots \ldots \ldots$ Trichomyia Haliday

6. The second simple vein behind the anterior furcate vein ends in the

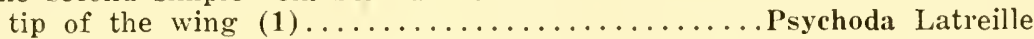
The second simple vein ends behind the tip of the wing (2).

Pericoma Walker

* Phlebotomus of authors.
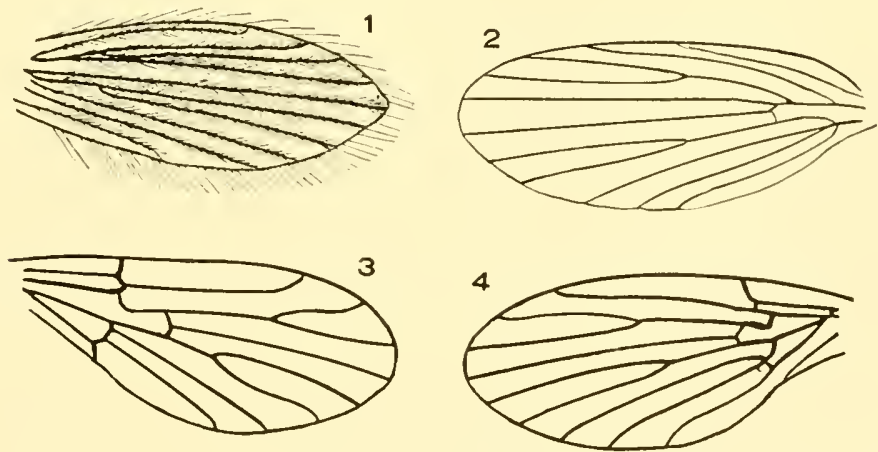

Psychodidxe-1, Psychoda; 2. Pericoma; 3, Maruina; 4, Trichomyia. Hairs omitted from figures 24 . 


\section{Family Dixidæ}

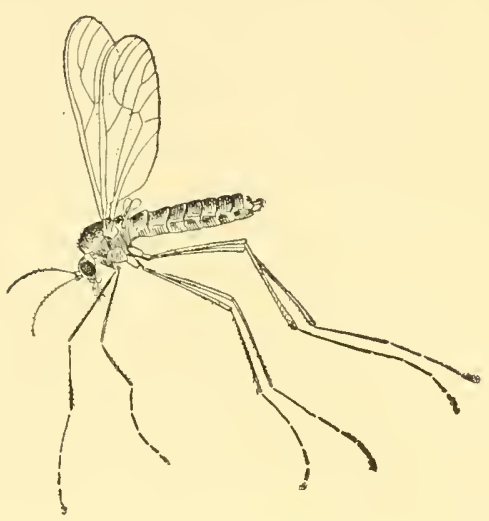

Dixa species.

Rather small, slender, nearly bare speeies oceurring near rumning water.

Proboseis somewhat projecting; palpi four-segmented: antemne long, the basal segments swollen, the flagellar segments hair-like and poorly separated; ocelli absent; eyes round. Thorax strongly convex, without transverse suture; metanotum arehed; seutellum transverse. Abdomen long and slender, composed of seven or eight segments, thickened posteriorly in the male, pointed in the female. Legs long and slender, the coxæ somewhat elongated; tibiæ without terminal spurs. Wings rather large; auxiliary vein present, ending in costa before the middle of the wing; two complete basal cells.

This family may be readily recognized by the wing venation. The adults often dance in swarms at a height of a few inches to a few feet above the surface of small streams in swampy or wooded areas and occur also along the edges of ponds.

The larve are aquatic and resemble those of mosquitoes but the thorax is not broadened. They are eylindrieal, somewhat flattened beneath, and n-shaped.

There are but two known genera, Ncodixa oceurring only in New Zealand, and Dixu, which is cosmopolitan. I present a key, adapted from Edwards, to the genera and subgenera of the world. 


\section{KEY TO GENERA}

1. Second vein branched $\ldots \ldots \ldots \ldots \ldots \ldots \ldots \ldots \ldots$ Dixa Meigen Second vein simple (New Zealand) .............. Neodixa Tonnoil

\section{Subgenera of Dixa}

1. Hind margin of the wing evenly rounded $\ldots \ldots \ldots \ldots \ldots \ldots \ldots \ldots$ 2 Hind margin of wing produced at end of fifth vein; all veins in apical part of wing parallel................ Dixapuella Dyar \& Shannon

2. Crossvein connecting the fourth vein and anterior branch of the fifth

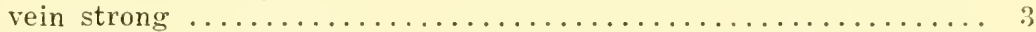
Crossvein connecting anterior branch of the fifth vein and the fourth

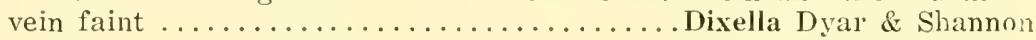

3. First flagellar segment fusiform or oval ................ 4 First flagellar segment cylindrical, five times as long as wide.

Paradixa Tonnoir

4. First flagellar segment oval, about two and one-half times as long as

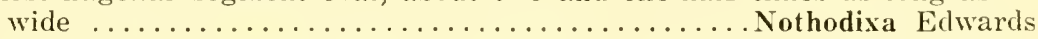
First flagellar segment fusiform; at least three times as long as wide.

Dixa Meigen 
LIFE STAGES OF MOSQUITOES

Culex

Amopheles

Aedes

Algypti
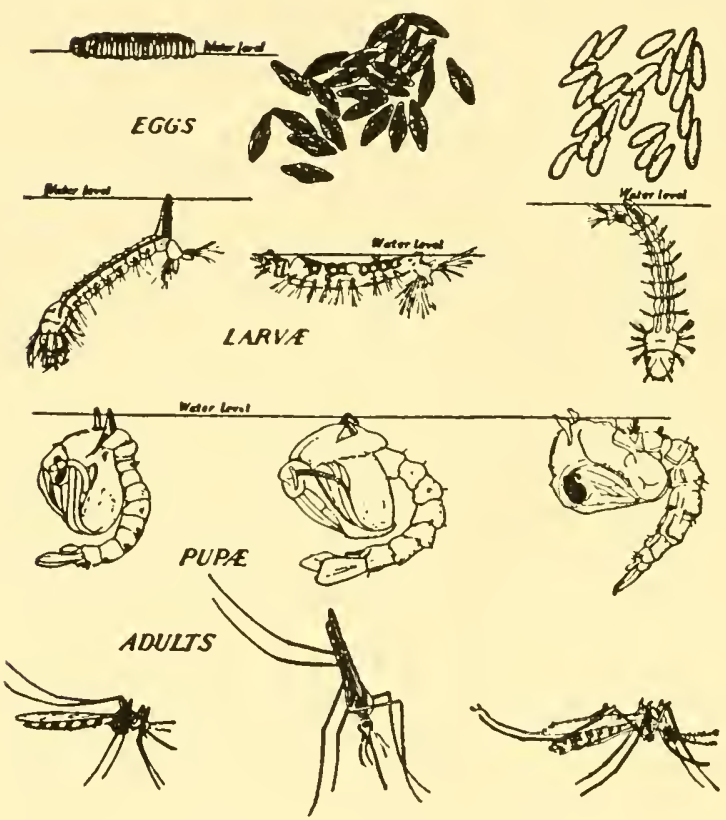

The life stages of three different genera of mosquitoes showing characteristic types of each and resting position of the adults (After Pieper and Beauchamp, from Metcalf and Sanderson). 


\section{Family Culicidæ-The Mosquitoes}

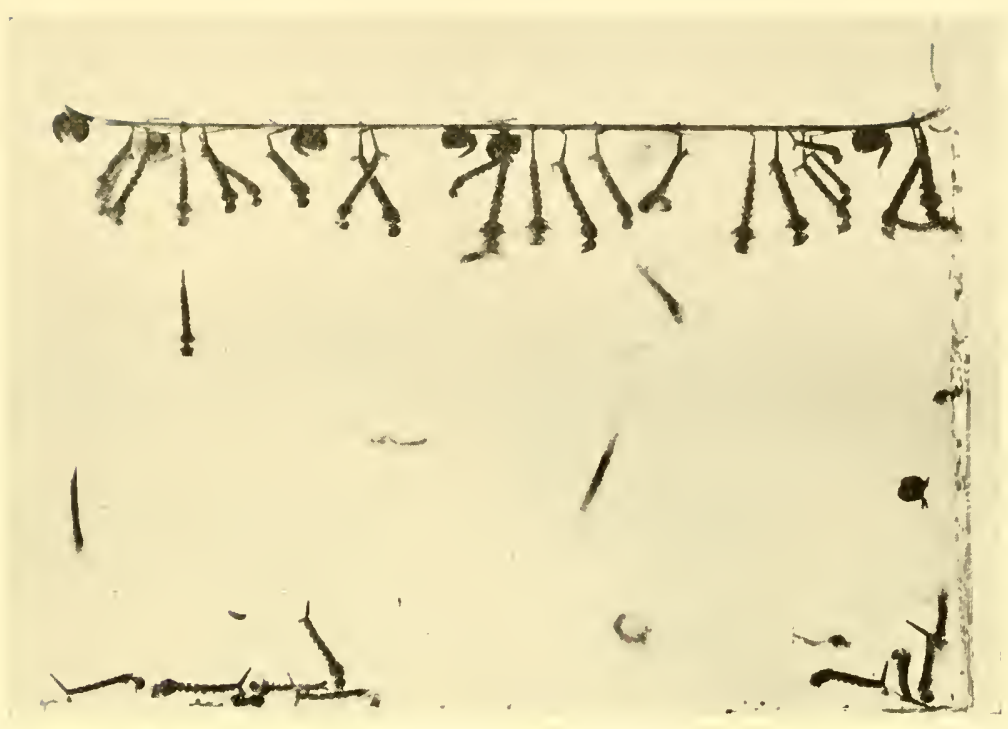

Aëdes larvæ. Note position at surface of water characteristic of the Culicini. (After Matheson, courtesy C. C. Thomas).

Slender, delieate flies, with stender legs and usually with seales upon the body and appendages.

Head small, subspherieal; eyes reniform; ocelli alsent. Antenna slender, elongate, composed of fourteen or fifteen segments, densely phumose in the makes; first segment reduced to a narrow ring, second globose, the following elongated, nearly or quite eylindrieal and with whorls of hairs, in the male the apieal two segments elongated and nearly bare. Thorax ovate, arched but not projeeting over the head, without transverse suture; sentellum short, evenly rounded or trilobate: metanotum usually arehed. Abdomen long and narrow, somewhat arehed, composed of nine or ten segments; male genitalia prominent but not large; ovipositor short. Legs long and slender, the coxæ not clongate; tarsi long, the claws often denticulate. Wings long and narrow, at rest lying flat orer the abdomen, with six fully developed longitudinal reins reaching the margin, the posterior margin fringed with hairs or seales, the costal rein extending around the wing; renation as in figure; two basal cells, the reins usually elothed with seales. 


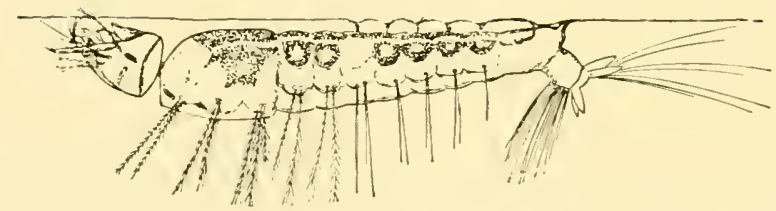

Anopheles larva. Compare position at surface of water with that of Aëdes. (After Matheson, courtesy C. C. Thomas).

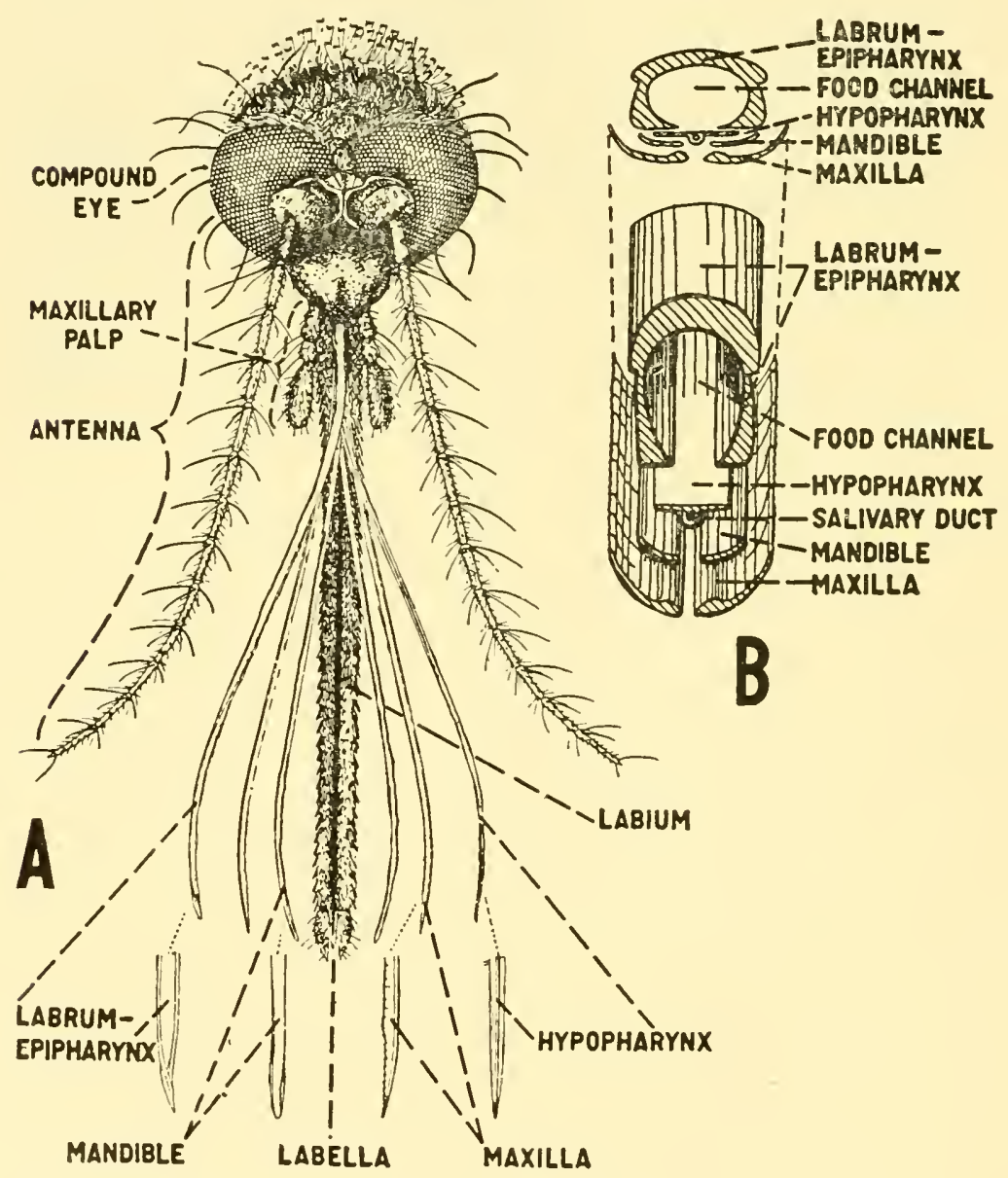

Hearl and mouth-parts of a mosquito.

(After Metcalf and Sanderson). 
The mosquitoes are too well known to require hints as to where they may be found although it may be well to remark that a "swatted" mosquito does not make a suitable study speeimen. Despite the fact that these flies are not altogether fragile it is nevertheless true that most specimens in collections are in poor condition beeause the preservation of the insects in good state depends upon eare in handling immediately after capture. Few speeimens should be placed in a killing bottle and they should be mounted while fresh. All but the very small species should be pinned on fine steel pins and not mounted on points; the small ones should be fastened on the sides of pins. using a ring of white shellar. With areful collecting, are in pinning and proper preservation, a collection of these insects may be rery attraetive. Many of the adults are extremely beautiful althongh it must be admitted that most of those in the Nearetic region do not go in for fine color's: in the tropies many of the species are clothed in nature 's most beautiful colors.

All mosquitoes are not injurious and many of them do not bite. Some are predaceous upon other mosquitoes in the larval stage and this is true of the Chaoborine, which should, perhaps, be ranked as a distinct family, sinee they almost entirely lack seales. Their larræ are called "Phantoms" beeause they are practically colorless.

So much has been written about mosquitoes during the present century that it would be impossible to review the entire literature in the space available but mention may be made of two books which will furnish a basis for intensive study for anyone interested. Matheson's "Handbook of the Mosquitoes of North Ameriea" deals with most of the species oceurring in the Tnited States and Canada and gives a thorough resume of the medieal and control aspeets of the subject. Dyar"s "The Mrosquitoes of the Americas" deals entirely with the taxonomy of the group, but the deseriptions are too brief and often omit important details: nevertheless it is an indispensable work and with careful study and use of the figures will be found fairly: satisfactory.

I may say that the Cnlieida are one of the most important families of the Diptera insofar as human welfare is conecrned. The diseases earried by them are not only lethal but canse extreme suffering and agony. Without doult a much more extensive accomnt of these insects might well be included in this work but space does not permit.

The diseases known to be transmitted by mosquitoes are Matlaria. Blactiuater Fever. Yollow Fever. Dengue. Fitariasis. Bird Malaria and Foul-pox. Of these Analaria and Jellow Ferer are the most widely distributed and much has been written about them. In at least the first five both the mosquito and man are essential in the life cycle of the 

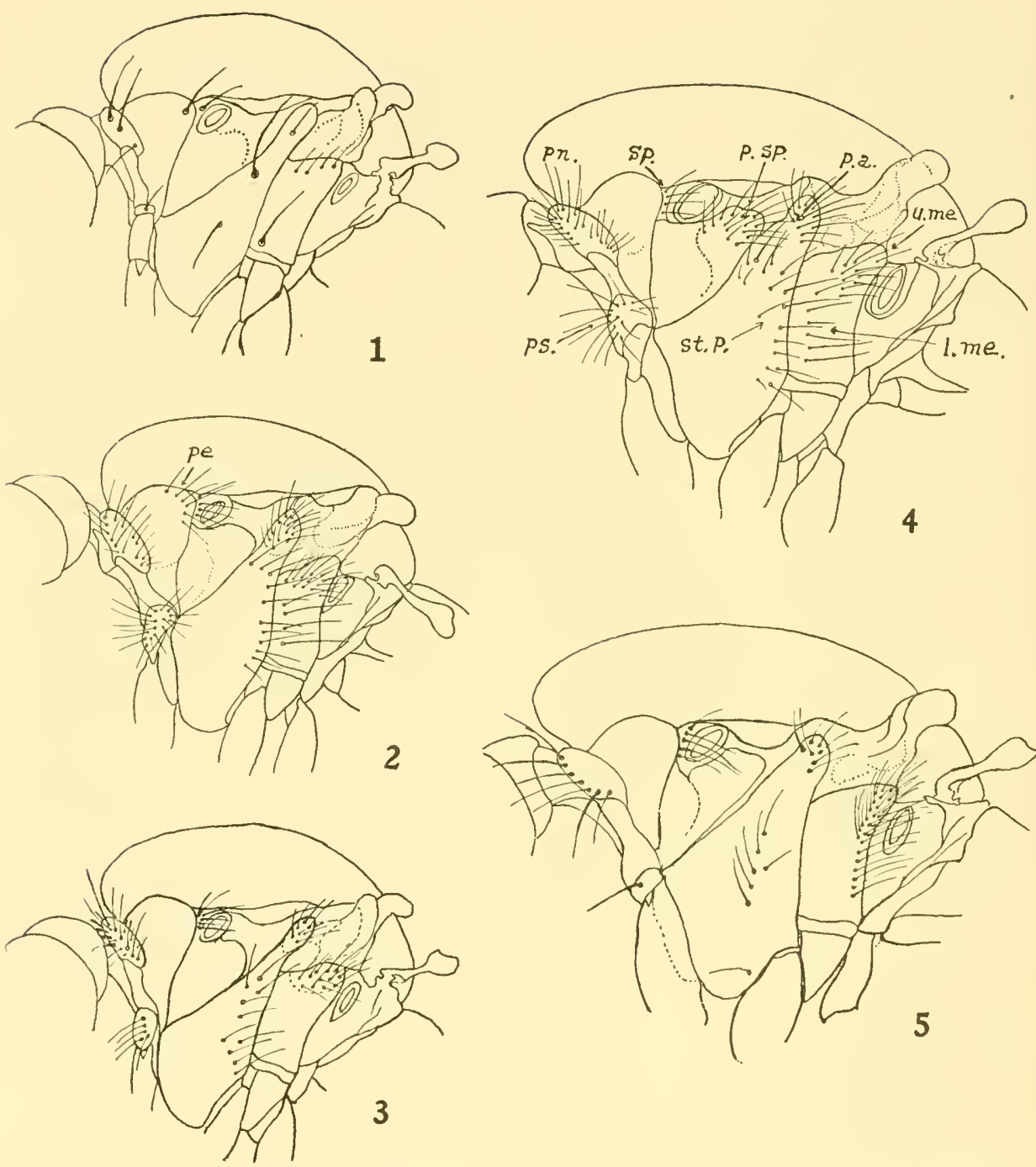

Culicida I.-Lateral view of thorax of: 1, Uranotrnia lœwii; 2, Theobaldia morsitans: 3. Anopleles punctipennis; 4, Psorophora ciliata; 5, Megarhinus septentrionalis. (After Matheson, courtesy C. C. Thomas).

l.m.e., lower mesepimeral bristles; na., prealar bristles; ne., prothoracic bristles; pn.. pronotal bristles; p.sp., postspiracular bristles; ps., prosternal or propleural bristles; sp., spiracular bristles; st.p., sternopleural bristles; u.me., upper mesepimeral bristles. 

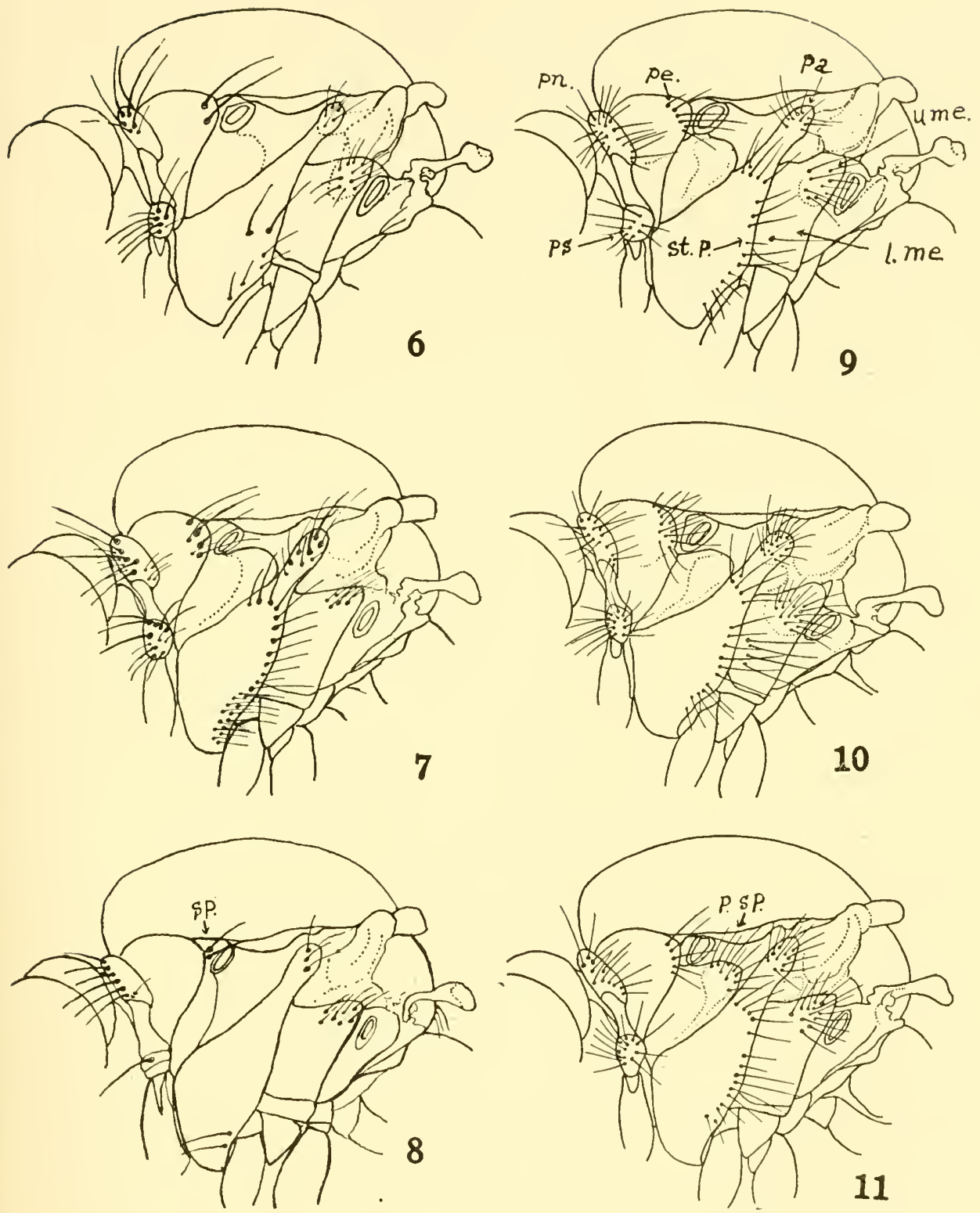

Culicida II.-Lateral view of thorax of: 6 , Orthopodomyia signifer; 7 . Deinocerites pseudes: 8, Wyeonyia smithii ; 9. Culex pipiens; 10, Mansonia perturbans; 11, Aedes vexans. (After Matheson, courtesy C. C. Thomas). 
eausative organism, although other warm blooded animals may take the place of man. If the mosquitoes essential for the derelopment of the organisms causing the disease were destroyed the disease would disappear entirely and it is because of this that such vigorous steps have been taken to stamp out mosquitoes in various parts of the world. The complete destruction of all disease earrying mosquitoes is scarcely possible but it has been demonstrated in the Panama Canal Zone that they ean be kept under control to such an extent that the diseases they earry are no longer a serious menace to residents of the region. It is now so well known that the construction of the Panama Canal was made possible only by the control of mosquitoes that no more than mention of the fact need be made here.

Malaria is still a common disease in many parts of the United States. Many of us think of it as a tropical or subtropieal disease, but nothing could be further from the truth. Malaria has raged at one time or another over rather large areas of the northern states and may do so again if patients suffering from the disease in its active stage should be bitten by our native Anopheles mosquitoes and they have the opportunity of developing and injecting the protozoan causing the ferer into the blood stream of uninfeeted persons.

The North American Anopheles known to transmit the disease are quadrimaculatus, maculipennis, punctipennis, crucians, and atropus in the United States, albimanus, pseudopunctipennis and quadrimaculatus in Mexieo, and albimanus and tarsimaculatus in Central America and the West Indies. The last three species named for the United States are not considered important rectors of the disease.

The causative organisms of Malaria are Plasmodimm vivax for tertian, $P$. malaria for quartan, and $P$. falciparum for the pernicious type. Tertian is our commonest type, being approximately three times as prevalent as the other two combined, while the pernicious form is almost twice as prevalent as the quartan.

An idea of the essential part played by inseets which act as intermediary hosts for parasites eausing human diseases, may be obtained from a brief outline of the life eycle of Plasmodium vivax. The organism passes an asexual stage in man, developing and multiplying in the red corpuscles, causing them to enlarge. In a little less than two days the trophozoites are mature, having absorbed the contents of the cell and the term schizont is now applied to them. These divide into from 15 to 24 merozoites and are diseharged into the blood stream by rupturing of the cell wall. The eycle now begins over again and the same proeess is repeated, but after a time certain of the merozoites develop into male (microgametocytcs) and female (macrogametocytes) which 
remain in the red blood cells, no further development taking place. From this point on the mosquito becomes an essential faetor since, unless they are ingested by a mosquito, the gametocytes are capable of no further development.

When the gametocytes are taken into the mosquito further develop. ment oeeurs, commeneing in the stomaeh of the host. The female (macrogametocytes) mature into what is called a macrogamete, eorresponding to a ripened but unfertilized ovule, while the microgumetocytes give off a number of thin, elongate, worm-like bodies, the male elements or microgametes. These travel about by a lashing motion until they come in contaet with a macrogamete, when they penetrate the cell wall and fertilization takes place, producing a zygote, a round body which soon elongates into an ookinete which beeomes active, penetrates the wall of the stomach and establishes itself between the epithelial and muscular layers. In this position it absorbs food from the surrounding tissue, becomes spherical and very large, and in this stage is termed an oocyst. In this stage the spores (eorresponding to eggs) are developed, and are ealled sporozoites. They escape by the breaking of the oocyst and enter the body eavity, where they are earried to all parts of the body by the free-flowing blood, many of them finding their way to the salivary glands and into the blood streams of human beings where they penetrate the red blood cells and develop into schizonts.

It will be seen from this that the sexual stage oeeurs in the mosquito, oeeupying from eight to fourteen days, and probably results in no ill effeets to its host, since it is a eold-blooded ereature.

In tertian malaria a ehill is produced about every three days, followed by fever, while in quartan malaria the chill oeeurs every four days, due to the longer incubation period of the merozoites, while in pernicious malaria the ehills and fever are irregular.

Blackwater Fever is now believed to be the result of numerous attacks of malaria or a more or less contimuous infection and derives its name from the fact that the patient's urine is of a dark mahogany color due to the presence of broken down red corpuscles.

Yellow Fever may be earried by at least three species of mosquitos in Ameriea Ä̈des (Stegomyia) aegypti, Ä̈des flurialtitis and Ä̈des scapularis. Possibly other species might earry the disease as well but we fortunately do not have it in the United States, even though A. aegypti is common in the south. With present facilities for rapid transportation there is danger of travellers from yellow fever areas entering the country and developing the disease after arrival. If we were sure that the disease would be quickly diagnosed and the patient isolated in a mosquito-proof room we might feel much more certain 


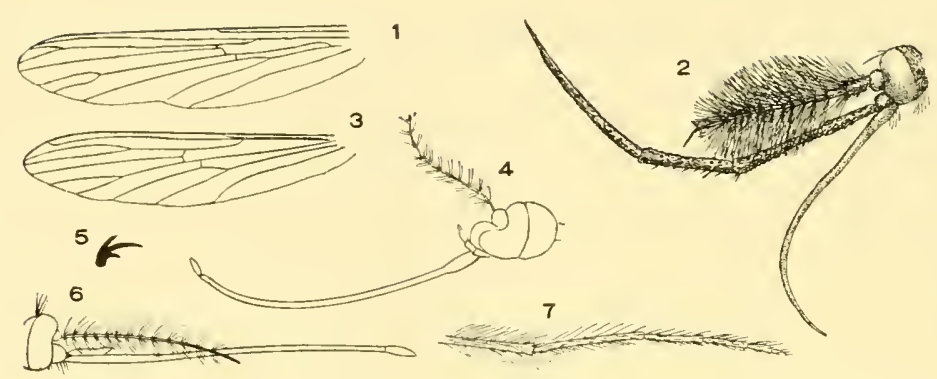

Culicidæ III.-1, Megarhinus; 2, Megarhinus, ơ head; 3, Aëdes, wing venation; 4, Hæmagogus; 5, Hæmagogus, front claws of $8 ; 6$, Wyeomyia, $;$;, Chaoborus, posterior tarsus.

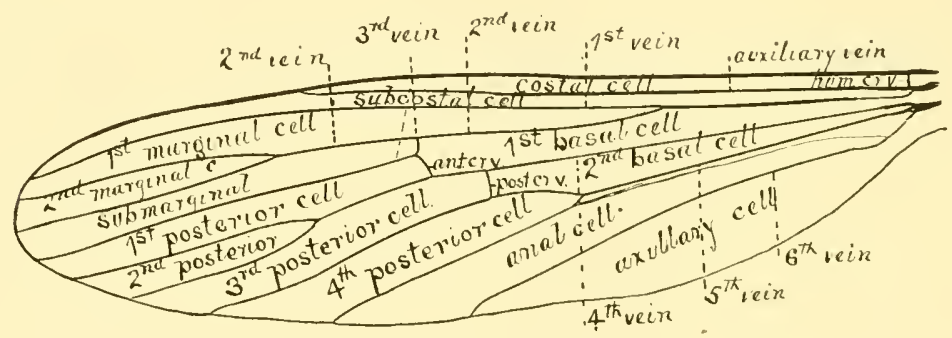

Venation of Aëdes.

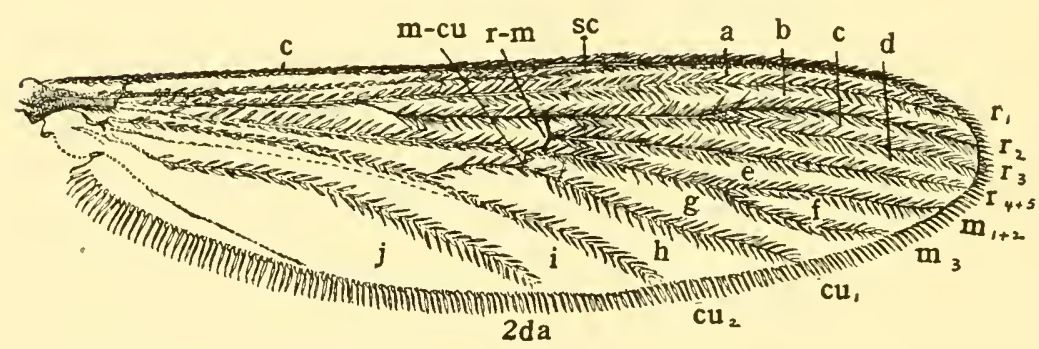

Venation of Anopheles, giving Comstock-Needham terminology and that of Schiner, etc. (in blackets). Veins.-C, costal; Sc., subcostal (auxiliary); $\mathrm{R}$, (first longitudinal); $\mathrm{R}_{2}, \mathrm{R}_{3}$, (second longitudinal); $\mathrm{R}_{++5}$, (thisd longitudinal); $\mathrm{M}_{1+2}, \mathrm{M}_{3}$ (fourth longitudinal); $\mathrm{Cu}_{1}, \mathrm{Cu}_{2}$ (fifth longitudinal); 2 da., (sixth longitudinal); $r-m$, radio-medial crossvein (anterior crossvein); $m-c u$, medio-cubital crossvein (posterior crossvein). Cells.-a, Sc., (subcostal); b, $R_{1}$, (first marginal); $c, R_{2}$ (second marginal); $d, R_{3}$ (submarginal); $e, R_{5}$ (first posterior); $f$, $\mathrm{I}_{2}$, (second posterior); $\mathrm{g}, \mathrm{M}_{3}$ (third posterior); $\mathrm{h}$. $\mathrm{Cu}$, (fourth posterior) ; $\mathrm{i}, \mathrm{Cu}_{2}$ (anal); j, 2a, (axiliary). (After Matheson, courtesy C. C. Thomas). 
that the disease would not become established in this country, but, unfortunatery, few doctors are familiar with the symptoms of yellow fever and there is grave danger of the disease remaining undiagnosed until it is too late to take preeautionary measures. Wren though steps have been taken to quarantine all persons coming from known yellow fever areas the danger of introduction of the disease is an ever present menace.

Dengue or Break-bone Fever is another disease earried by the Yellow Fever mosquito (Aëdes aegypti). It is a common tropical and stibtropieal disease and there are occasional outbreaks in the Southern States, corresponding to the distribution of the mosquito. After biting a patient it requires from eight to eleven days before the mosquito is capable of transmitting the disease.

The mierofilariae of Wuchereria bancrofti Cobbold are taken up (in America) by Culex fatigans Wiedemann and undergo development in the museles of the mosquito, in mueh the same way as described for Malaria but there is no inerease in numbers and they do not become sexually mature until they have been returned to the human body. The worms oeeur in the lymphatie system and may be responsible for a number of organie disturbanees. The region about Charleston, South Carolina is the only area in the United Staates where Filariasis is prevalent but it is common in the tropies of both hemispheres.

Since writing the foregoing and preparing the following key, Edwards' faseiele in the "Genera Insectorum" (194), has appeared. In this work the Dixidx are included as a subfamily of the Culicidæ, a course I do not follow. An examination of this important fasiele of "Genera Insectorum" will disclose the fact that Edwards makes free use of subgenera. My views on this question are expressed elsewhere in this work. With the author's view that genera should be limited to groups readily characterized in both sexes I most heartily agree. The quality of the seientifie work of this author is of too high a standard to warrant eriticism exeept of a most favorable nature and one ean disangee with him only on questions of minor importance. The question of subgenera is really one of likes and dislikes, and I prefer to keep as close as possible to a binomial system of nomenelature.

Most of the ents used to illustrate this family are from "A Handbook of the Mosquitoes of North America" by Dr. Rohert Matheson and I wish to express my indebtedness to him and to $\mathrm{Mr}$. C. C. Thomas, the publisher, for furnishing them, and also my appreciation of their wholehearted cooperation. 


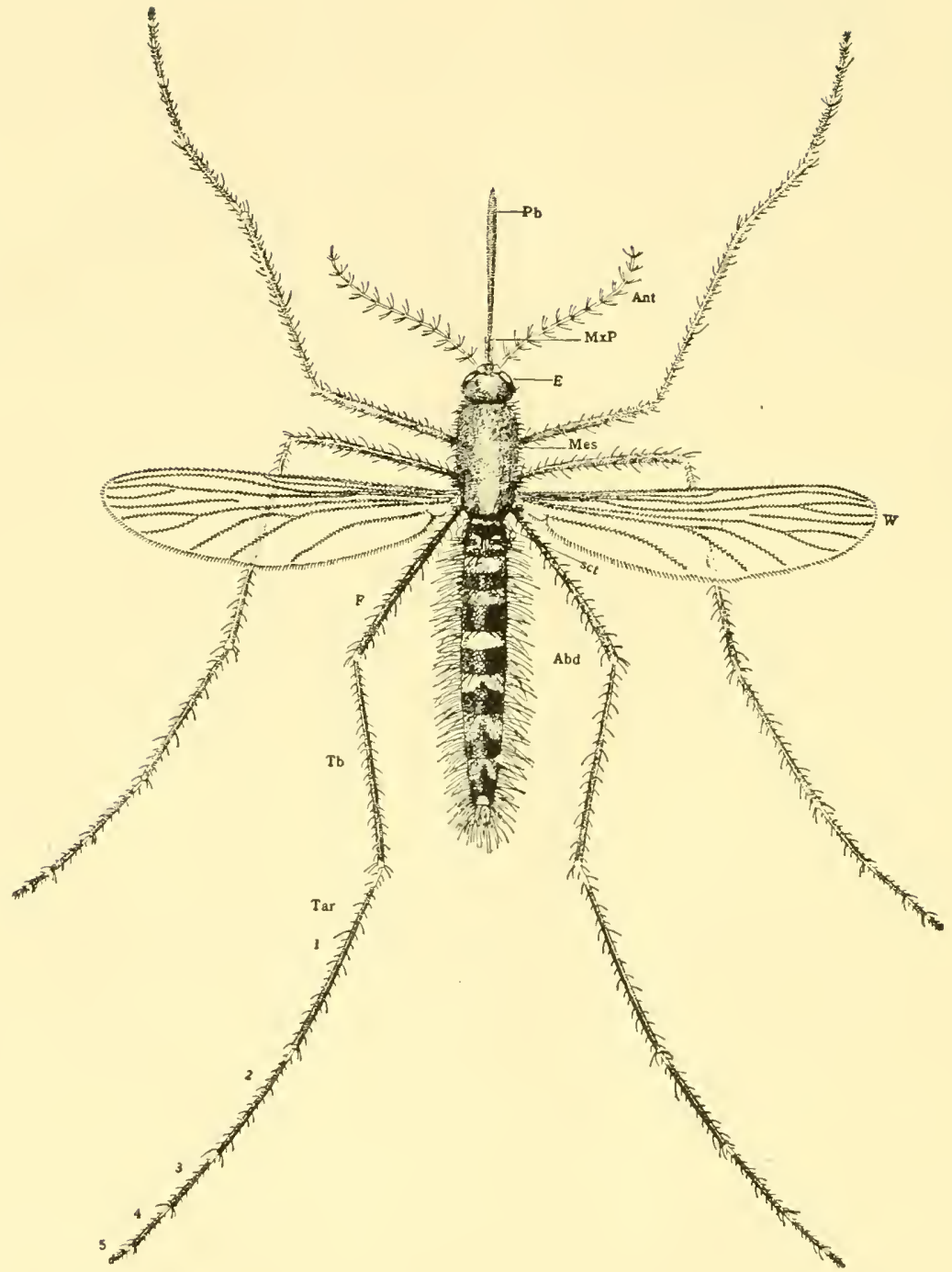

Aëdes vexans. (After Matheson, courtesy C. C. Thomas). 


\section{KEY TO GENERA*}

1. Proboscis not elongate, extending but little beyond the clypeus; wings with scales (when present) confined mostly to the fringe. (Chaoborinx)

Proboscis elongate, extending far beyond the clypeus; wings with the

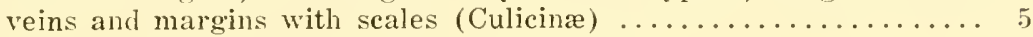

2. Anal vein ends beyond the fork of the fifth vein............... 3 Anal vein ends before the fork of fifth vein....... Eucorethra Underwood

3. First tarsal segment longer than the second.............. 4 First tarsal segment shorter than the second..........Mochlonyx Lœw

4. First vein ending much closer to the tip of the anterior branch of second vein than to that of the auxiliary vein (III-7).

Chaoborus Lichtenstein

First vein ending nearer to tip of auxiliary vein than to anterior branch

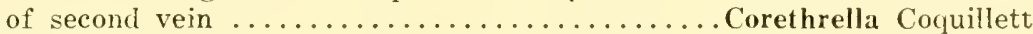

5. Abdomen without scales, or at least with the sternites largely bare; scutellum with the margin convex, evenly setose; never a spurious vein behind fifth vein (I-3, and text figure of larva)..Anopheles Meigen

Abdomen with both tergites and sternites completely clothed with scales; scutellum trilobed, the lobes alone setose; if scutellum evenly convex then a spurious vein behind fifth vein................

6. Proboscis rigid, the outer half more slender and bent backwards; a spurious vein behind the fifth vein (I-5, III-1, III-2).

Megarhinus Desvoidy

Proboscis more flexible, of uniform thickness (at times swollen at tip), outer half not bent back; never a spurious vein behind fifth vein... 7

7. Base of hind coxæ in line with or above the upper margin of the meta-

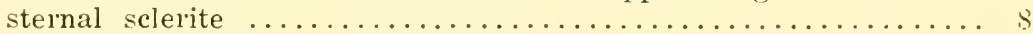

Base of hind coxæ below upper margin of metasternal sclerite...... 16

8. Pronotal setæ absent; prothoracic lobes not widely separated....... 9 9 Pronotal setre present; prothoracic lobes widely separated......... 14

9. Prealar setæ absent ............................ 10

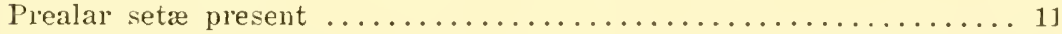

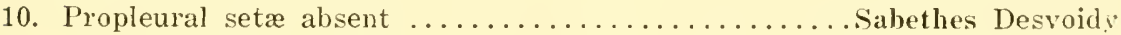

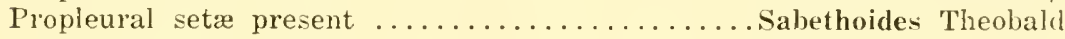

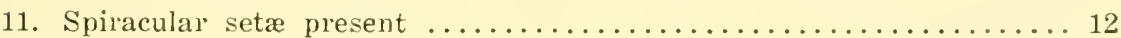

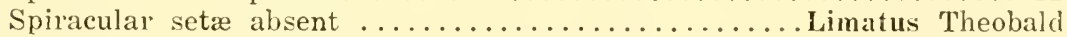

12. Lower sternopleurals distinctly below the upper margin of metasternal

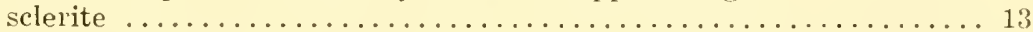

Lower sternopleurals extending to or above the upper margin of the

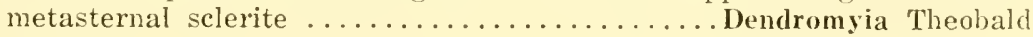

13. Outstanding scales on at least the basal portion of the second and third veins broad............................................ Dyar These scales usually narrow (II-8, III-6) .........Wyeomyia .Theobald

* Checked by Dr. R. Matheson. 


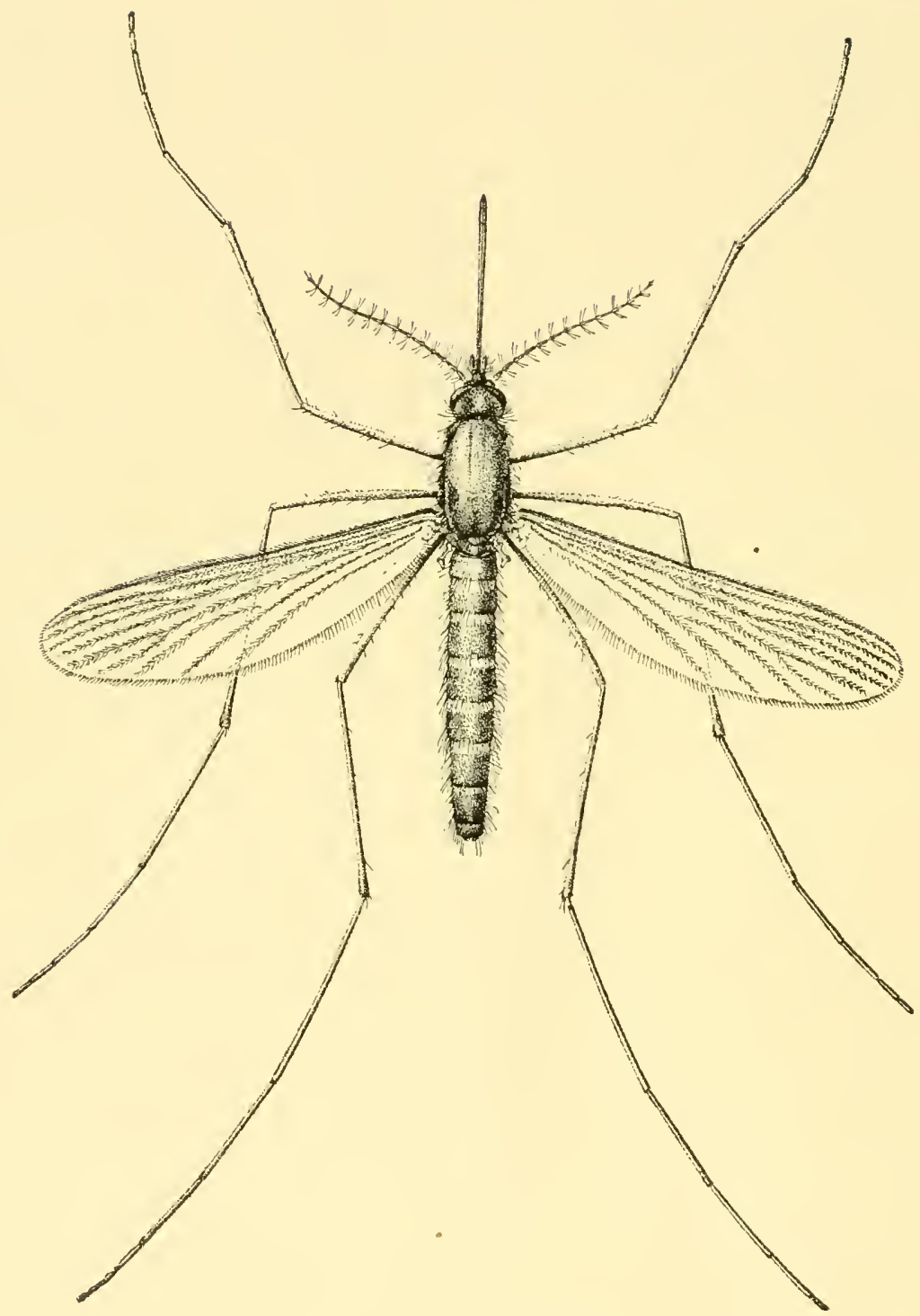

Culex pipiens. (After Matheson, courtesy C. C. Thomas). 


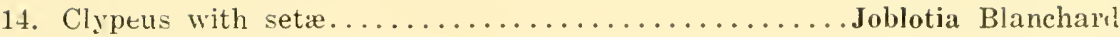

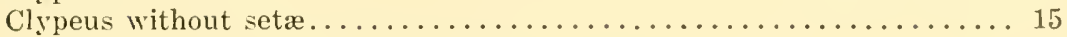

15. Lower sternopleural setæ extending above the upper margin of the

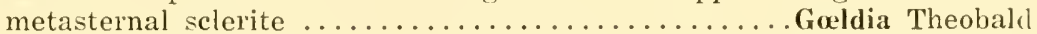

Lower sternopleural setæ not extending above the upper margin of the metasternal sclerite $(\mathrm{I}-1) \ldots \ldots \ldots \ldots \ldots$. Isostomyia Coquillett

16. Anal vein ending opposite or before the fork of the fifth vein.

Uranotania Arribalzaga Anal vein ending well beyond the fork of the fifth vein.......... 17

17. Prescutellar setæ and postspiracular setæ absent (III-4, III-5).

Haemagogus Williston

Prescutellar setæ present ....................... 13

18. Postspiracular setæ present ........................ 19

Postspiracular setæ absent ........................ 21

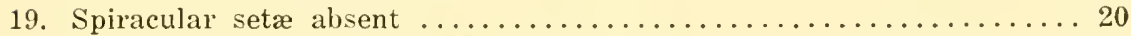
Spiracular setæ present (I-1 and text figure)....... Psorophora Desvoidy

20. Wing scales narrow (rarely broad) or the base of first vein with setæ posteriorly on the upper side (II-11, III-3, and text figs.). Aëdes Meigen Wing scales broad; base of first vein bare (II-10) . . . Mansonia Blanchard

21. Spiracular setæ present (I-2) ............ Theobaldia Neveu-Lemaire

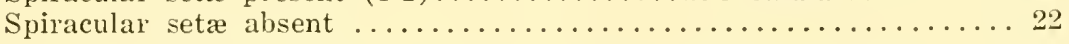

22. First vein without setæ basally on upper side; wing scales broad.... 23 First vein with setæ basally on upper side; wicle scales narrow...... 25

23. Fourth segment of front tarsi at least as broad as long (II-6).

Orthopodomyia Theobald

Fourth segment of front tarsi longer than wide.............. 24

24. Antennal segments little longer than wide..........Aedeomyia Theobald Antennal segments much longer than wide (II-10).... Mansonia Blanchard

25. Antennæ much longer than the length of the proboscis (II-7).

Deinocerites Theobald Antennæ not longel than the length of the proboscis...........26

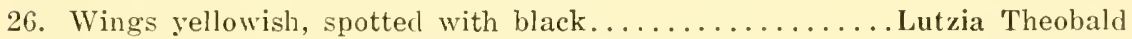
Wings never black-spotted (II-9 and text figure)....... Culex Linnæus

\section{IEY TO THE GENERA OF' THE WORLD}

1. Scales almost confined to the wing-fringe; mouth-parts short, the

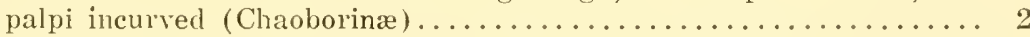
Wing-veins and legs scaled; proboscis long; palpi not incurved

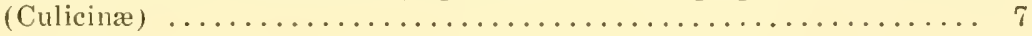

2. Clypeus large and hairy; $R_{1}$ ending close to tip of $R_{2} \ldots \ldots \ldots . \ldots$ Clypeus small and nearly bare; $R_{1}$ ending far from tip of $R_{2}$.

Corethrella Coquillett

3. First tarsal segment much shorter than the second............. 4 First talsal segment longer than the second................ 6

4. Tibiz spurred ............................... 5 Tibiæ not spurred; metapleural hairs absent........... Mochlonyx Lœw 


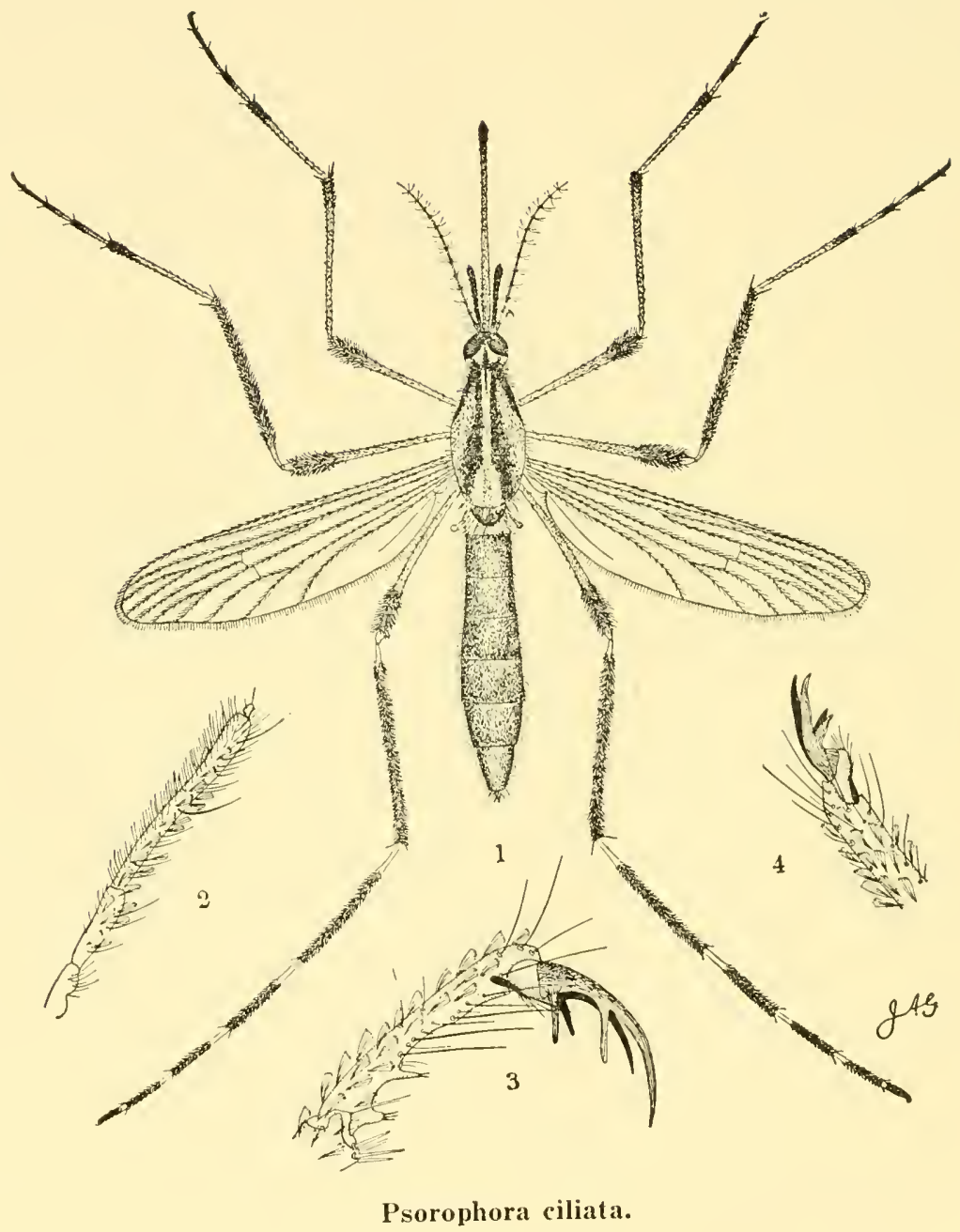


5. Tibial spurs 1-2-2*; metapleural hairs present....... Cryophila Edwards Tibial spurs 1-1-1; metapleura bare...........Promochlonyx Edwards

6. Clypeus as long as the hear; claws larger and toothed.

Eucorethra Underwood Clypeus shorter than the head; claws small and simple.

Chaoborus Lichtenstein

7. Abdomen without scales; or at least with the sternites largely bare

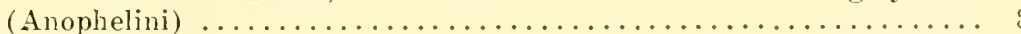

Abdomen with both tergites and sternites completely clothed with

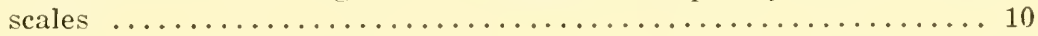

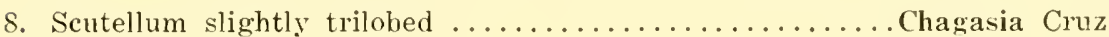

Scutellum evenly rounded ........................ 9

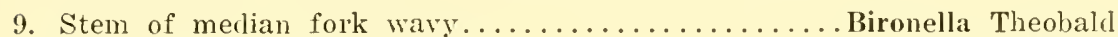
Stem of median fork straight............... Anopheles Meigen

10. Proboscis not rigid, of uniform thickness (unless swollen at tip), outer

half not bent backwards (Culicini) .................... 11

Proboscis rigid, outer half slender and bent backwards (Megarhinini).

Megarhinus Desvoidy

11. Squama fringerl (fringe usually complete, rarely interrupted); vein An reaching well beyond base of cubital fork................ 12

Squama bare or rarely with $1-4$ short hairs.................. 30

12. Pulvilli present; pleural chætotaxy well developerl, but spiracular and post-spiracular bristles absent ......................... 13

Pulvilli absent or rudimentary....................... 14

13. Second antennal (first flagellar) segment short in both sexes; antennæ of $\delta$ nearly always plumose......................... Lulmaus

Second antennal (first flagellar) segment elongate in both sexes; antennæ of $\sigma^{7}$ not plumose.................. Deinocerites Theobald

14. Post-spiracular bristles absent; claws of $q$ simple (except in Leicesteria, Hrmagogus, and Heizmannia) . ................. 15

Post-spiracular bristles present, even if only one or two; claws of $q$ usually toothed; dorsocentral and upper sternopleural bristles nearly

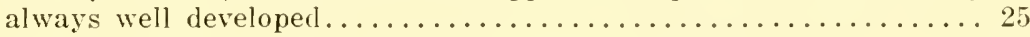

15. Spiracular bristles present (sometimes only one or two) ......... 16

Spiracular bristles absent.......................... 19

16. Several upper sternopleural bristles; stem-vein usually hairy beneath. Theobaldia Neveu-Lemaire

At most one or two upper sternopleural bristles; stem-vein bare be-

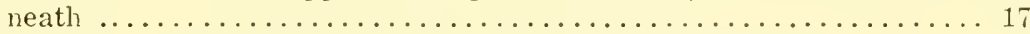

17. Postnotum nearly always bare (Oriental and Australasian).

Tripteroides Giles

Postnotum with bristles (Neotropical).................. 18

18. Clypeus with setæ.................. Trichoprosopon Theobald

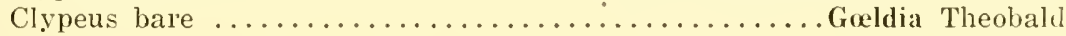

* Posterior four tibia each with two apical spurs. 


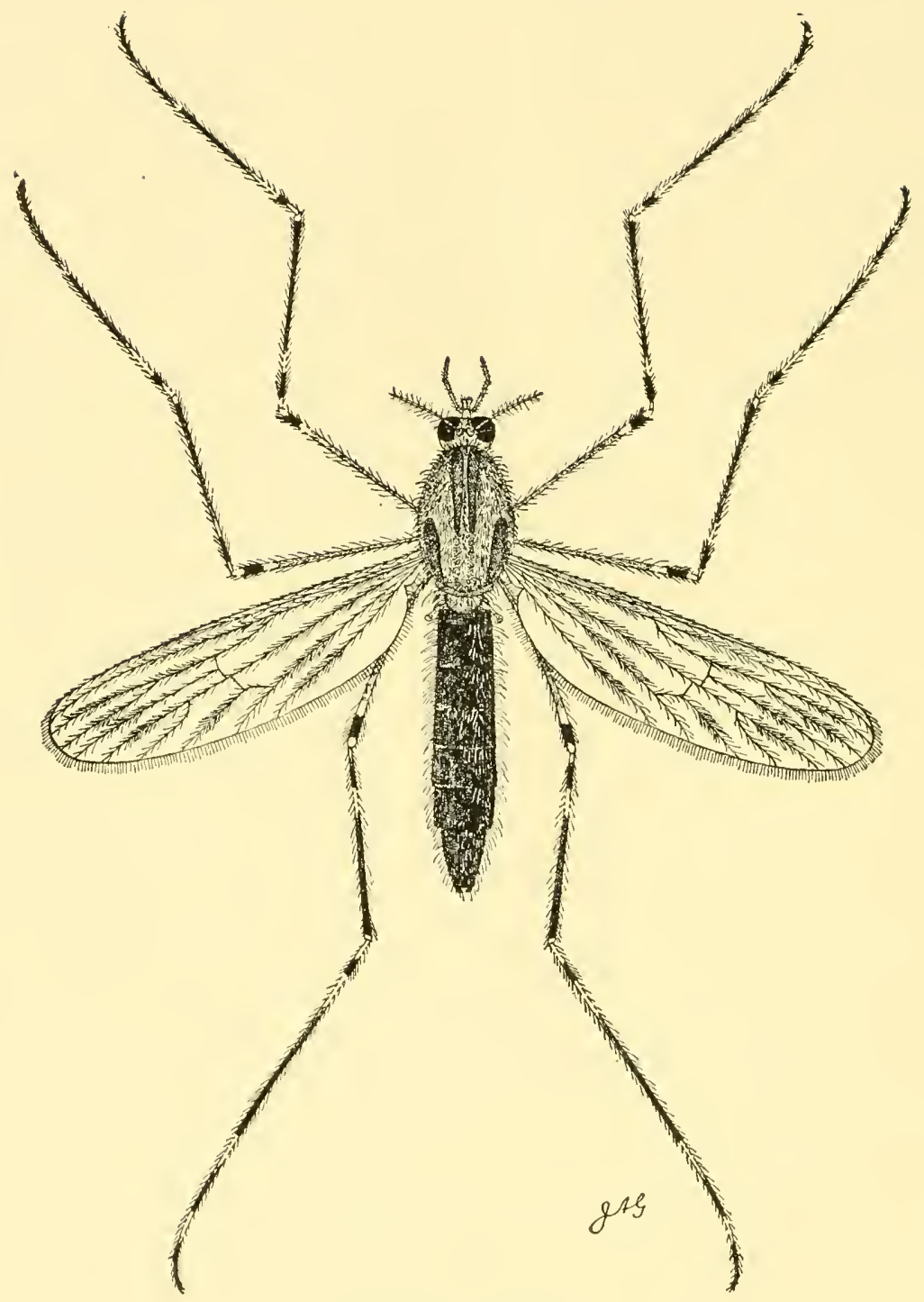

Corethra cinctipes. 
19. Dorsocentral and pre-scutellar bristles absent; pronotal lobes approxi-

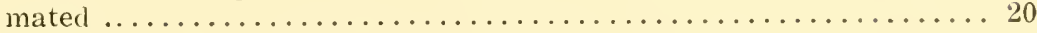

Dorsocentral and pre-scutellar bristles well developed; pronotal lobes

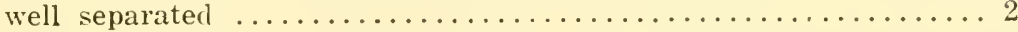

20. Postnotum usually bare (Neotropical)........... Hamagogus Williston Postnotum usually with bristles (Oriental)......... Heizmannia Lu(llow

21. Post-spiracular area scaly; + claws usually toothed; $q$ palpi more than

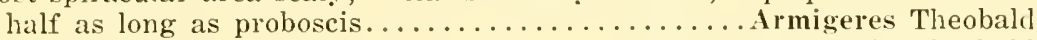
Subgen. Leicesteria Theobald

Post-spiracular area bare; + claws simple.................... 22

22. All segments of $q$ antenna, and last two of 0 antenna short and thick;

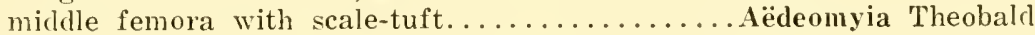
Antennæ normal, slender; middle femora without scale-tuft. . . . . . . . 23

23. First segment of front tarsi longer than the last four together; fourth very short in both sexes..............................

First segment of front tarsi not longer than last four together; fourth

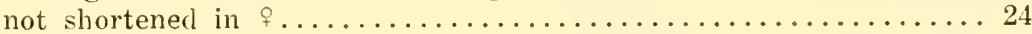

24. Proboscis of 0 much swollen apically, of + slightly so, or else cell $R_{2}$

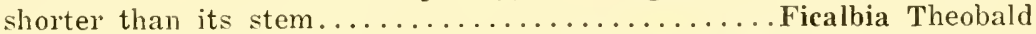
Proboscis not swollen apically; cell $R_{2}$ at least as long as its stem.

\section{Mansonia Blanchard}

25. Head with numerous short hairs on vertex in addition to the orbital row; antennæ thick in both sexes, not plumose in 0 ..... Opifex Hutton Head without hairs on vertex apart from the orbital row; antennæ slender in $\$$, nearly always plumose in $\sigma^{*} \ldots \ldots \ldots \ldots \ldots \ldots$

26. Spiracular bristles present, even if few (American).. Psorophora Desvoidy Spiracular bristles absent........................ 27

27. Eyes widely separated, space between them clothed with metallic

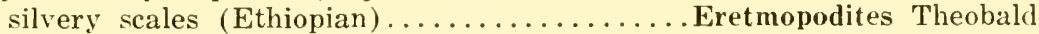
Eyes less widlely separated (sometimes touching), space between them not covered with metallic silvery scales................. 28

28. Wing-scales generally mostly narrow (when, rarely, all are broad, the o claws are toothed); usually a few hairs on upper surface of stem-

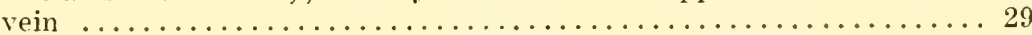
Wing scales all very broad; $\uparrow$ claws simple; stem-vein bare.

Mansonia Blanchard

29. Proboscis more slender, not recurved at tip in repose; ornamentation

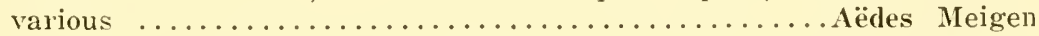

Proboscis rather stout, recurved at tip in repose; lark species with

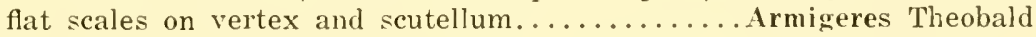

30. Wing-membrane without microtrichia (or these only risible under a high magnification); cell $R_{2}$ shorter than its stem; An ends about opposite base of cubital fork............. Uranotania Arribalzaga

Wing-membrane with distinct microtrichia (visible under a magnifica-

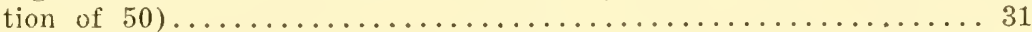

31. Postnotum bare; An (except in some species of Topomyia) ending little if at all beyond base of cubital fork; two or more posterior pronotal

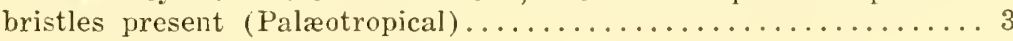


Postnotum with,bristles; An ending well beyond base of cubital fork; posterior pronotal bristles usually absent; spiracular bristles present

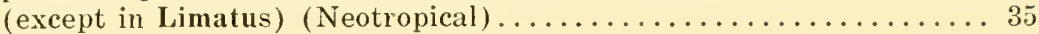

32. Spiracular bristles absent; clypeus normal.......................... 33

Spiracular bristles present (one or more); clypeus rather small and narrow; cell $R_{z}$ longer than its stem..................... 34

33. Cell $R_{2}$ shorter than its stem; several posterior pronotal bristles; wing

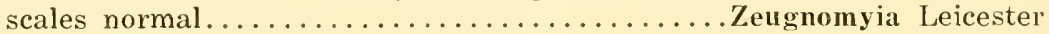
Cell $R_{2}$ longer than its stem; two posterior pronotal bristles; wingscales emarginate at tips.............................. Theobald

34. Proboscis very hairy, much enlarged at tip......Harpagomyia de Meijere Proboscis not hairy, rarely enlarged at tip..........Topomyia Leicester

35. Middle legs with "paddles" formed of very lorg erect scales.

Sabethes Desvoikly Middle legs without "paddles".............................. 36

36. Clypeus with hairs; large species with long $o^{x}$ palpi.

Trichoprosopon Theobald Clypeus bare, or with scales only........................... 37

37. Hind tarsi with long suberect scales; large species with long o palpi. Goeldia Theobald

Hind tarsi with appressed scales only; smaller species with short 0

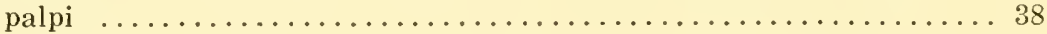

38. No bristles on subalar knob; pronotal lobes large and almost in contact; mesonotal scales all metallic.............. Sabethoides Theobald

Bristles present on sub-alar knob; pronotal lobes more widlely separated; mesonotal scales rarely metallic................. 39

39. Spiracular area with scales only; hind tarsus with one claw.

Limatus Theobald Spiracular area with 1-4 bristles, no scales; hind tarsus with two claws. 


\section{Family Cecidomyidæ-The Gall Midges}

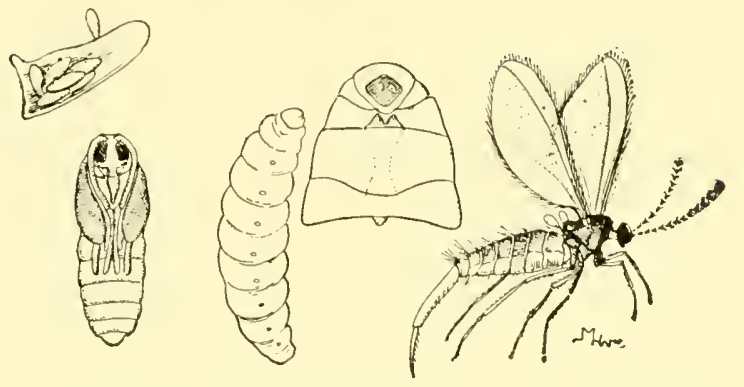

Cecidomyidæ-Thecodiplosis piniradiatæ Snow and Mills. Eggs, pupa, larva, "breast-bone" and imago. (Williston).

Small, delieate flies with broad wings and long antemme and legs.

Ifead small; eyes round or reniform, sometimes holoptic; ocelli usually absent; antemuz long, eylindrieal, the segments usually with bead-like swellings, ten to thirty-six in number; proboseis short, rarely (longated: palpi with one to four segments. Thorax ovate, more or las convex, without transierse suture: abdomen composed of eight segments; hypoprgium small hut projecting; ovipositor sometimes very lomg. Leas long and slender; coxie lather short; tibia without terminal spurs, basal tal'sal segment sometimes very short. Wings large, nsually hairy, narrowed basally and withont alula; three to five longitudinal veins, nswally with only the first, third and fifth; humeral crossvein indistinet or alsent; costal vein extending around the entire wing, the reins all weak, the fifth ustually fureate; anterior crossvein situated very near the base of the wing, often appearing as the begimning of the third rem, the base of the third vein having the appearance of a crossvein: only one basal cell present.

These small flies may be found everywhere but the most satisfactory means of collecting them is to rear them. The larve of most of the species live in living plants where they form walls, or deformities of rarions kinds, in the axils of the leaves, ete. Others live under bark, in deraying vegetation and in fungi while a few live npon plant lice, being foumd for the most part under the colony of aphids or in axils of the leaves during the diy. Many of the spereses are incuilines in the galls formed by other members of the family or even by other orders of insects. The galls oeenr on all parts of plants, on the flower's, leaves, 

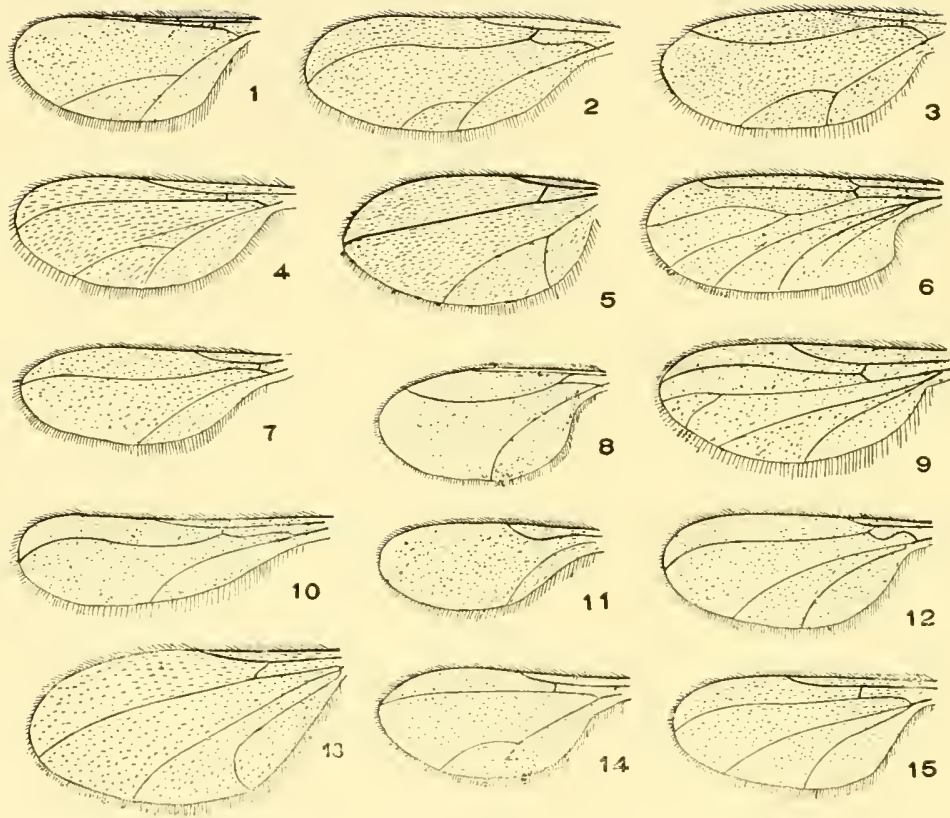

Cecidomyidæ I.-1, Lasioptera; 2, Porricondyla?; 3, Cecidomyia; 4, Hormomyia; 5, Trichopteromyia; 6, Lestremia; 7, Niastor; 8, Spaniocera?; 9, Catocha; 10, Colpodia; 11, Heteropeza; 12, Asynapta; 13, Winnertzia; 14, Lestodiplosis; 15, Winnertzia. 
stems and roots and are nsually characteristic for cach species. The larve may be recognized by the presence of a "breast bone" or ehitinized process lying within the thorax and terminating behind the head. The phenomenon of padogenesis oeeurs in some species belonging to the genus Miastor, that is the larra produce egos from ovary-like organs, the eggs hateh within the body and the young larre devour the parent, later eseaping and completing their development externally; several generations may be produced in this way, before the development of adult insects ocenrs.

The classification of the family is difficult and I have merely emended the key given by Dr. Felt.* For the most part little can be done without preparing slides of the adults, the whole insect being mounted. It is advisable to preserve dried specimens as well as the mounts, and the galls should always be kept along with the adults. Study of the group should not be attempted by anyone who is not prepared to spend years of painstaking work on his hobby. Such a study would prove of inestimable value and would fully repay the student for the time spent. Many of the speeies are serious pests, the chicf among these being the Hessian fly.

I may add that the study of the galls themselves constitutes a fascinating past-time and Dr. Felt has given us an excellent treatise

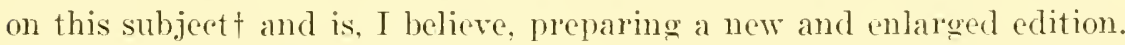
The series of papers published by Dr. Felt is eopionsly illustrated and I have made free use of these illustrations. In comnection with their use I cannot help but call attention to the splendid cooperation of Dr. C. C. Adams, of the New York State Museum, in furnishing the cuts used for this family and of $\mathrm{Wr}$. Felt for assistance and suggestions. Most of the illustrations of Cccidomyider are from cuts furnished by the New York State Museum.

\section{KEY TO GENERA}

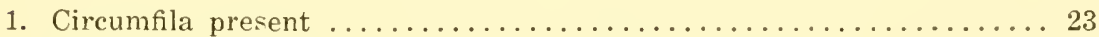

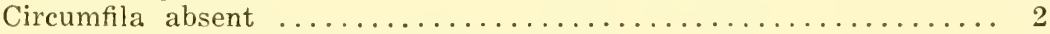

2. Wings with four longitudinal veins.................. 3 Wings with at most three longitudinal veins................ 17

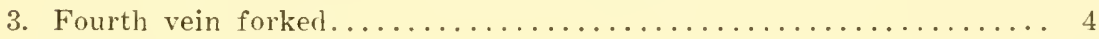

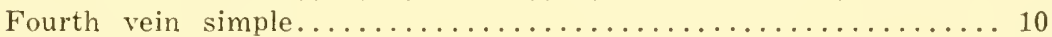

4. Second antennal segment greatly enlarged............... 5 Second antennal segment normal.................... 7

* 1925. Key to Gall Midges (A resume of Studies, i-vii, Itonididæ), N. Y. State Mus.

Bull. No. 257. References to Parts $\mathrm{i}$-vii will be found in this Bulletin.

$\dagger$ 1918. Key to American Gall Insects, N. Y. State Mus. Bull. No. 200. 


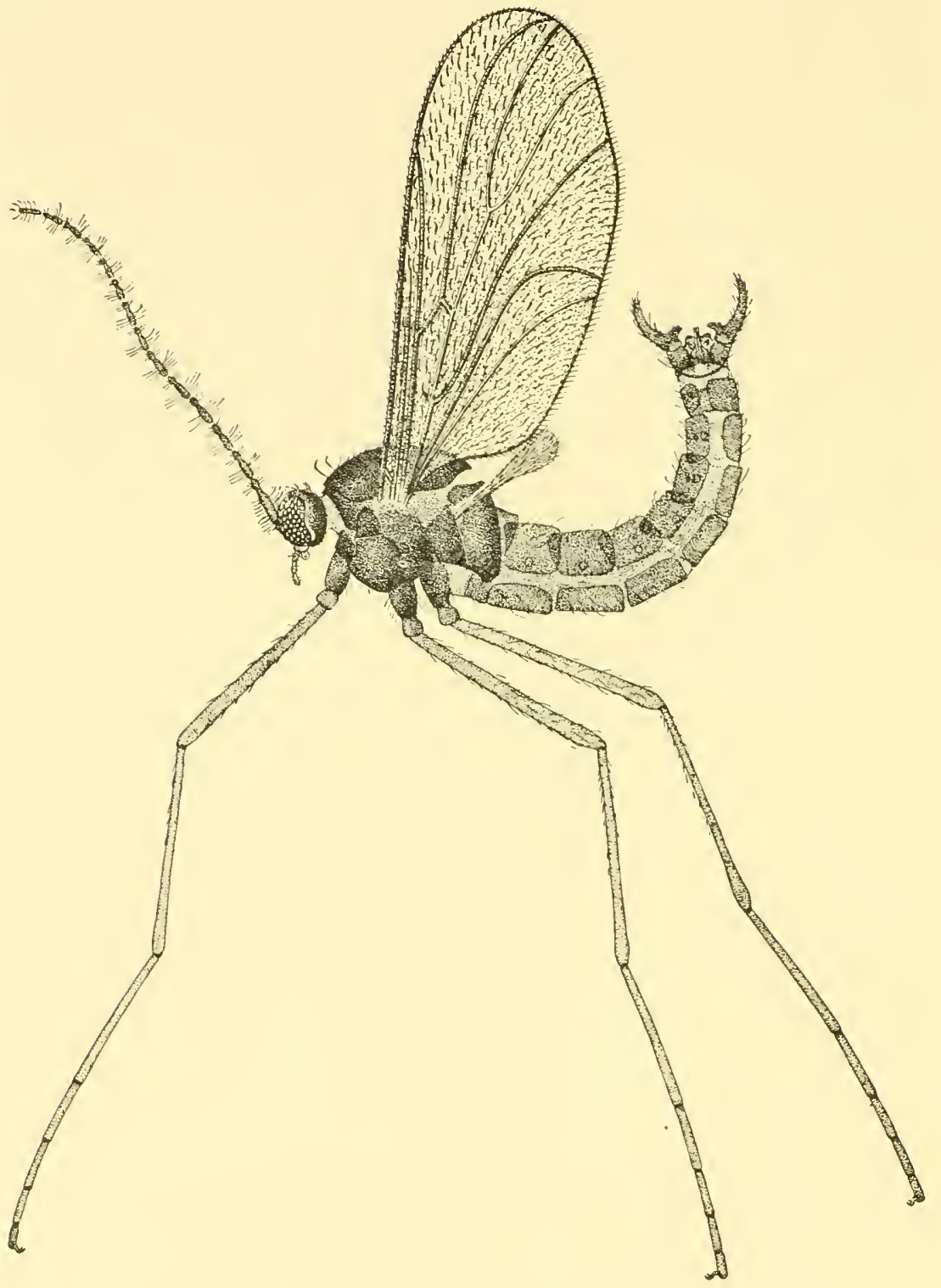

Cecidomvidæ II. 16, Catocha Americana.

(Courtesy New York State Museum, Albany, N. Y.) 
5. Subcosta and third rein united as though by a very short crossvein.

Microcerata Felt

Subcosta and third vein separate and with no trace of a crossvein... is

6. Branches of the fork of the fourth vein even.......... Konisomyia Felt Branches of the fork of the fourth vein irregular (22)...Tritozyga Lœw

7. Flagellate antennal segments sessile, with a length only a little

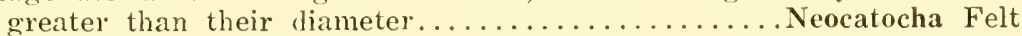
Antennal segments not sessile, more elongate............ 8

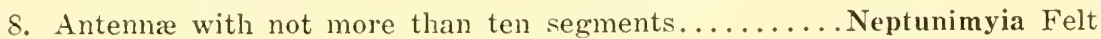
Antennæ with at least eleven segments................. 9

9. Costa ending at or a little beyond the tip of the third vein $(6,26)$.

Lestremia Meigen Costa extending beyond the apex of the wing $(9,16) \ldots$ Catocha Haliday

10. Third vein usually well separated from the costa and frequently uniting with it at or beyond the apex................. 11 Third vein rarely extending to the apex of the wing; flagellate antennal segments subsessile in female, ornamented with crenulate whorls or structures more complex than irregular whorls of simple hairs. . 14

11. Flagellate antennal segments globose, stemmed in both sexes, or the

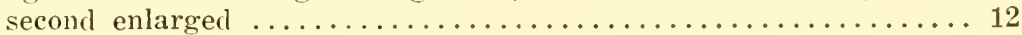

Flagellate antennal segments cylinılrical, sub-sessile, the second not

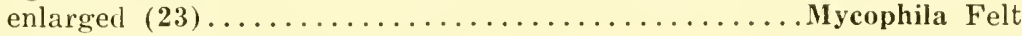

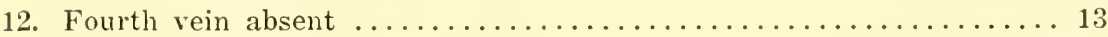
Fourth vein present $(28) \ldots \ldots \ldots \ldots \ldots \ldots \ldots \ldots \ldots \ldots \ldots \ldots$ Joannisia Kieffer

13. Antennal segments stemmer (5)...........Trichopteromyia Williston Antennal segments sessile, the second enlarged........ Ceratomyia Felt

14. Flagellate antennal segments with a more or less distinct subapical collar forming a more or less cup-shaped cavity; claws denticulate.

Prionellus Kieffer Flagellate segments with subapical whorl of stemmed disks or spines. 15

15. Flagellate segments with subapical whorl of stemmed disks; claws

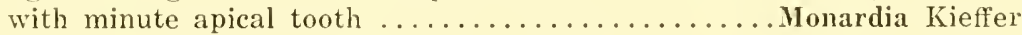
Flagellate segments with spines ...................... 16

16. Flagellate segments with short, stout, usually recurved spines (24,

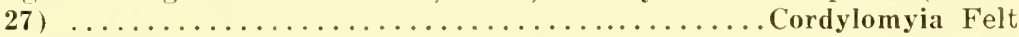
Flagellate segments with short, stout, curverl spines (32).

Corinthomyia Felt

17. First segment of the tarsi shorter than the second............. 19

First segment of the tarsi longer than the second............. 18

18. Tarsi with four segments; three longiturlinal veins $(7,18)$.

Tarsi with three segments; two longitudinal veins (11).

Miastor Meinert

Heteropezal Winnertz

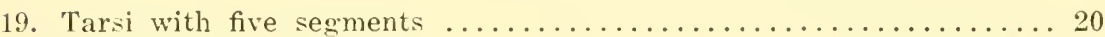

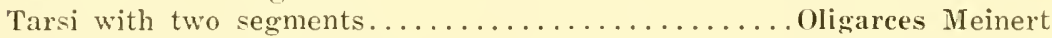

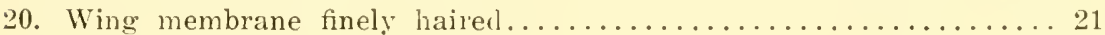

Wing membrane scalesl .................. K ronomyia Felt 

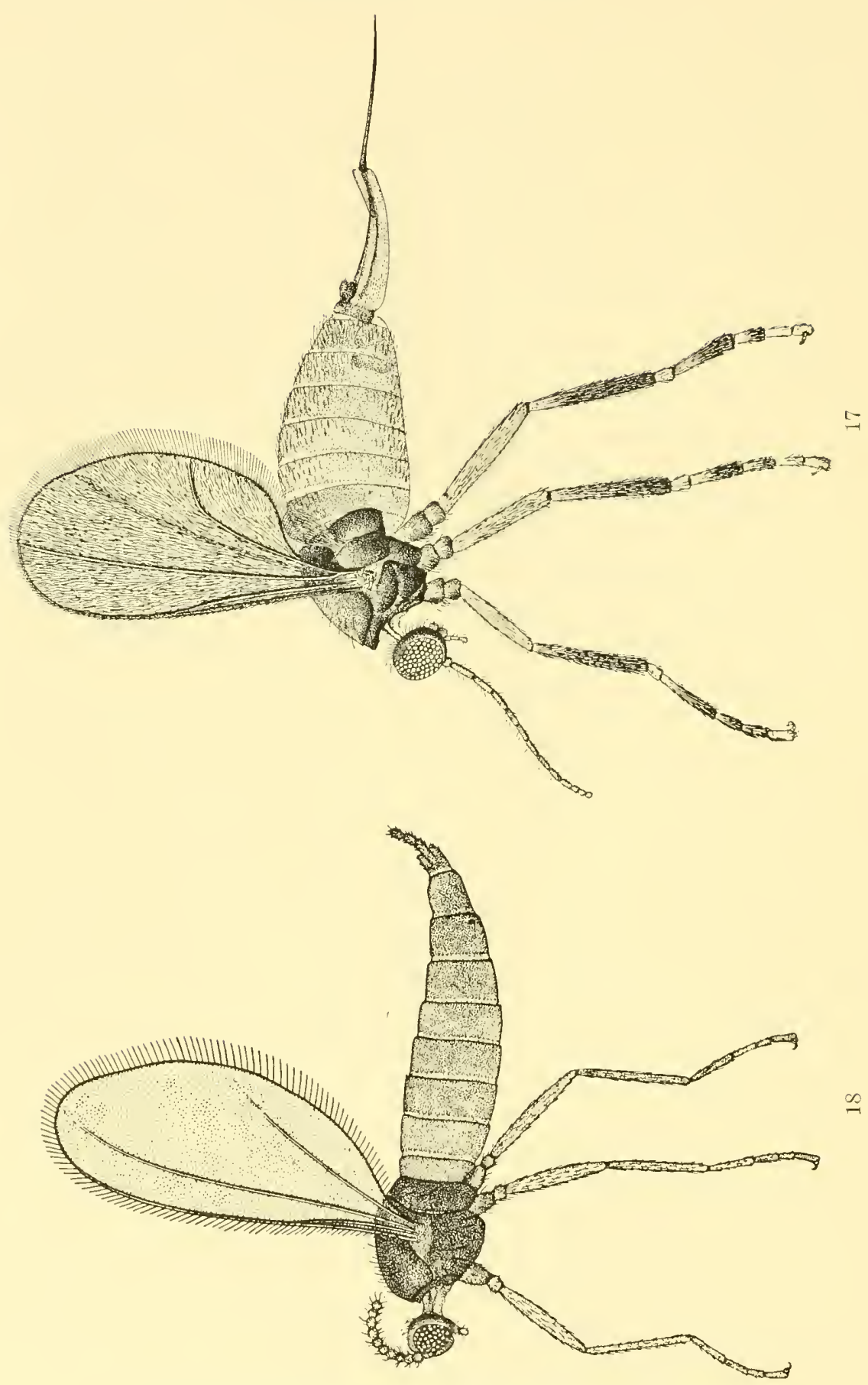

Cecidomyidxe III.-17, Asphondylia monacha; 18, Miastor americana. (Courtesy New York State Museum, Albany, N. Y.) 
21. Third vein extending to the apex of the wing .............. 22 Third vein not extending to the apex of the wing.........Epimyia Felt

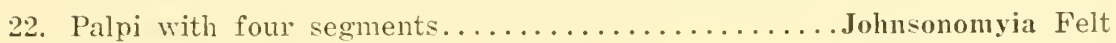

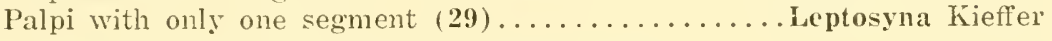

23. No crossvein uniting the third and first veins............... 29 A distinct crossvein uniting the third and first veins...........

24. Crossvein parallel or nearly so with the costa and apparently forming a continuation of the third vein......................... 27 Crossvein forming a well-marked angle with the costa.......... 25

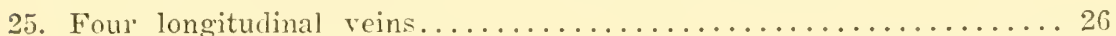
Three longitudinal reins $(10) \ldots \ldots \ldots \ldots \ldots \ldots$ Colpodia Winnertz

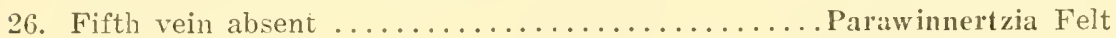
Fifth vein well developed $(13,15,25) \ldots \ldots \ldots \ldots$ Winnertzia Rondani

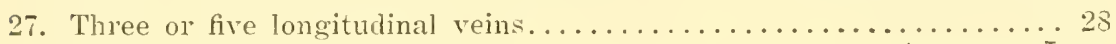
Four longitudinal veins $(12) \ldots \ldots \ldots \ldots \ldots \ldots \ldots \ldots \ldots$. . . . . . . . .

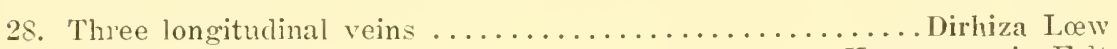

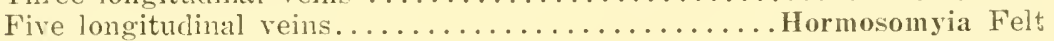

29. Costa thickly scaled; third vein usually very close to anterior margin of wings; antennal segments cylindrical, sessile, short, never pro-

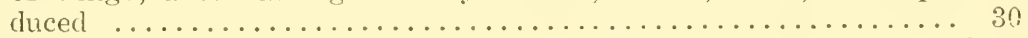

Costa rarely thickly clothed with scales, the thind vein well separated from it; antennal segments usually longer than wide.......... 35

30. Third vein. lying very close to the costa and uniting with it at or before the midlde of the wing, rarely at the distal third........ 32 Third vein well separated from the costa and uniting with it beyond

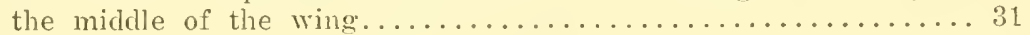

31. Third rein and body thickly clothed with scales......'Trotteria Kieffer. Third rein and body not thickly clothed with scales.

Camptoneuromyia Felt

32. Mouth parts and thorax normal, not greatly prolonged.......... 33 Mouth parts and thorax prolonged............... Clinorhyncha Low

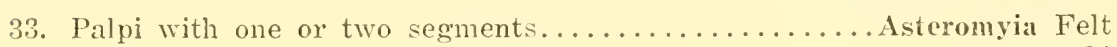
Palpi with three or four segments.................... 34

34. Third and fourth antemal segments coalescent or closely fused..... 35 Third and fourth antennal segments at least separated by a distinct

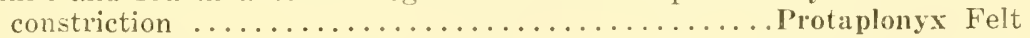

35. Three longitudinal veins, the fifth forked $(1,21) \ldots$... Lasioptera Meigen Four simple longitudinal veins................ Neolasioptera Felt

36. Flagellate antemal segments cylindrical, never binodose in the male. . 37 Flagellate antennal segments in the male greatly produced, binodose; circumfila usually forming long loops..................6 60

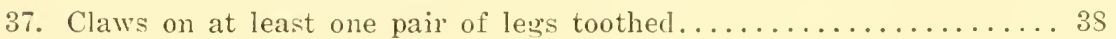

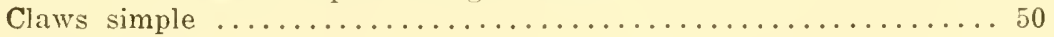

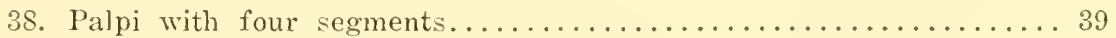

Palpi with not more than three segments................ 45 

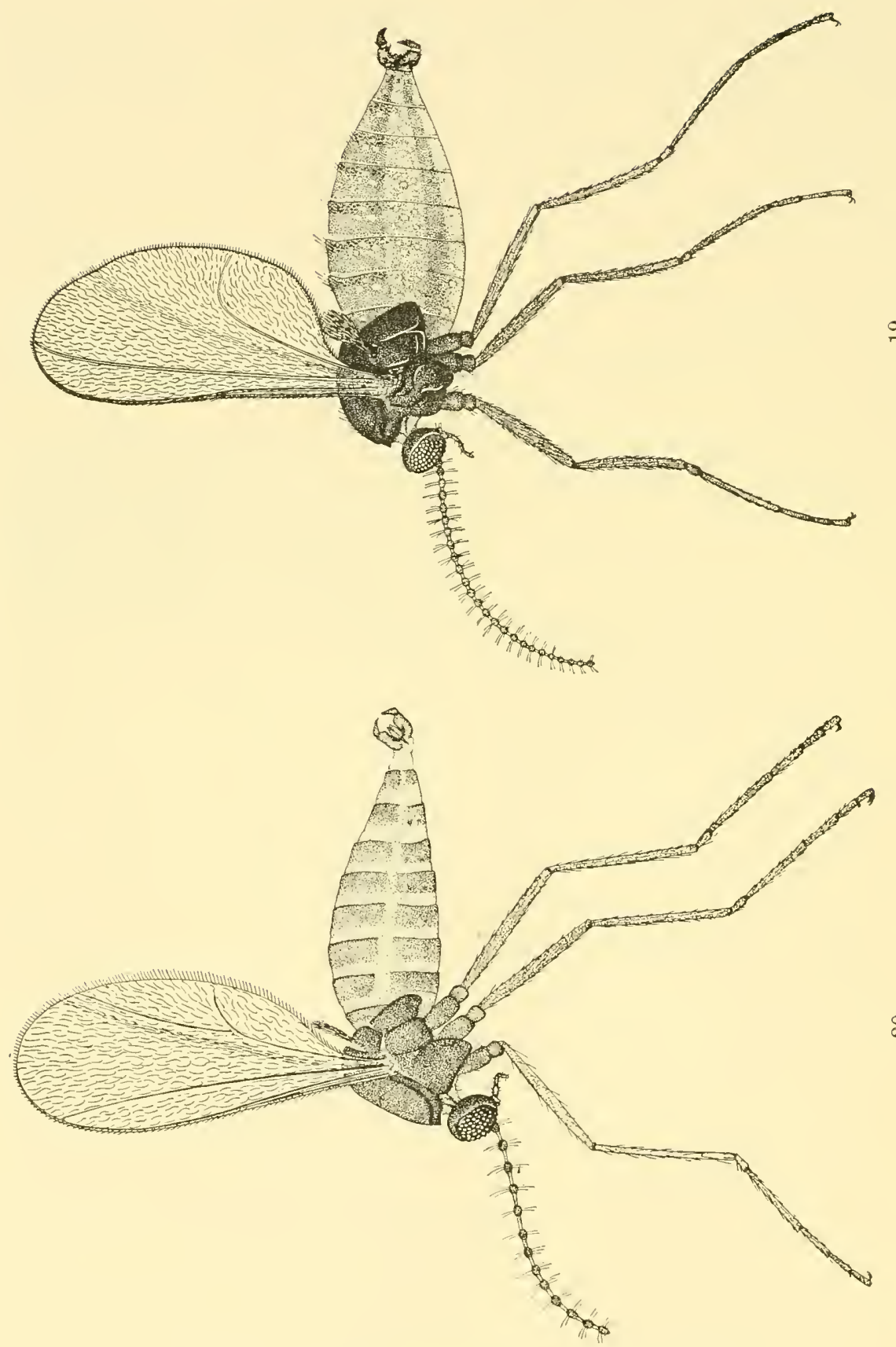

Cecidomyidx IV.-19, Rhabdophaga sp,; 20, Dasyneura gibsoni.

(Courtesy New York State Museum, Albany, N. Y.) 
39. Antennæ with fourteen or more segments.................. 40 Antennæ with ten to thirteen, rarely with fourteen segments...... 43

40. Third vein uniting with the costa at or near the apex of the wing... . 41 Third vein uniting with the costa well before the apex of the wing... 42

41. Ovipositor not chitinized apically; claws with one strong tooth (19).

Rhabdophaga Westwood Oripositor chitinized apically, blade-like, the claws weakly toothed.

Procystiphora Felt

42. Wing veins scaled, the membrane more or less brownish.

Veins not distinctly scaled, the membrane hyaline $(20)$.

Lasiopteryx Stephens Dasyneura Rondani

43. Third vein uniting with the costa near the apex of the wing....... 44 Third vein uniting with the costa well before the apex of the wing.

Neuromyia Felt

44. Antennæ with thirteen or fourteen segments.......... Cystiphora Kieffer Antennæ with twelve segments, genital harpes sickle-shaped, greatly

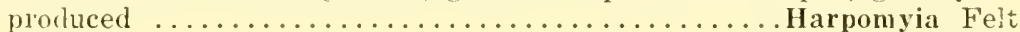

45. Palpi with two or three segments................... $4 r_{i}$ Palpi with only one segment......................

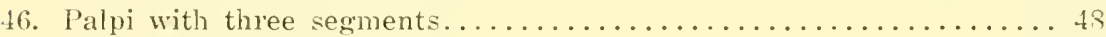
Palpi with two segments............................ 47

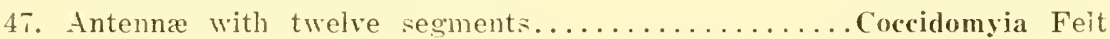
Antennæ with fourteen to eighteen segments.....Diarthronomyia Felt

48. Claws with a single tooth.......................... 49

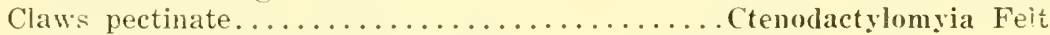

49. Oripositor with apical spine; male clasper short, swollen.

Cystiphora Kieffer

Oripositor without apical spine; pulvilli nearly three times as long

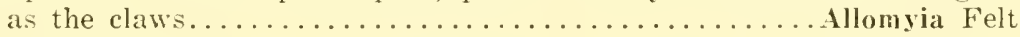

50. Flagellate antennal segments cylindrical, not greatly elongated, usually stalked in the male; oripositor not aciculate............ 51

Flagellate segments cylinhlical, elongate, sessile; ovipositor usually

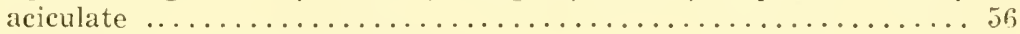

51. Palpi with one to thee segments.................. 53

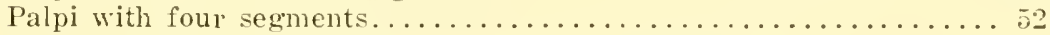

52. Third vein joining the costa at or near the apex of the wing (34). Phytophaga Ronclani Third vein joining the costa well before the apex of the wing.

Janetiella Kieffer

53. Ovipositor distinctly chitinized, aciculate or cultriform.

Sackenomyia Felt Oripositor not chitinized........................ 54

54. Palpi with only one or two segments................ 55 Palpi with three segments................. Oligotrophus Latreille

55. Pulvilli nearly twice as long as the empodium........Walshomyia Felt Pulvilli shorter than the empodium..........Rhopalomyia Rübsaamen 

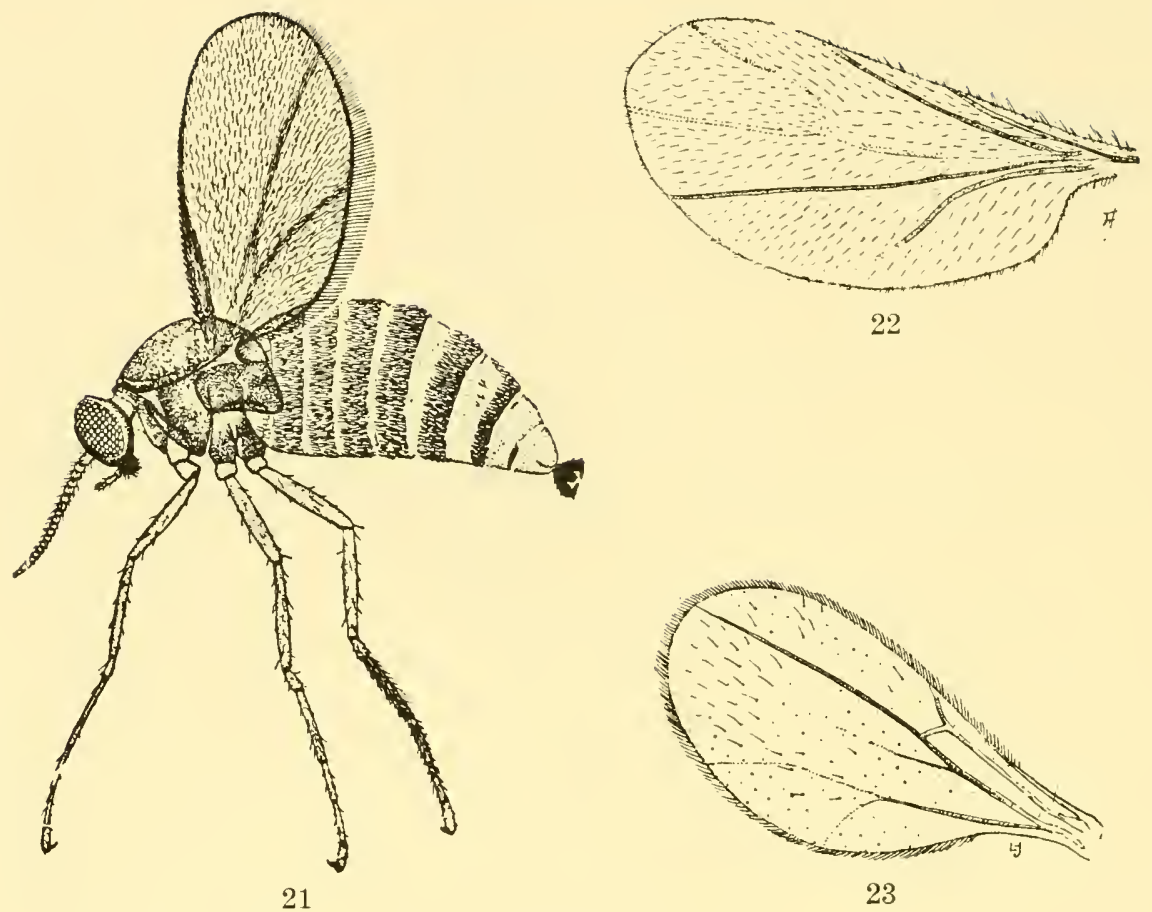

23

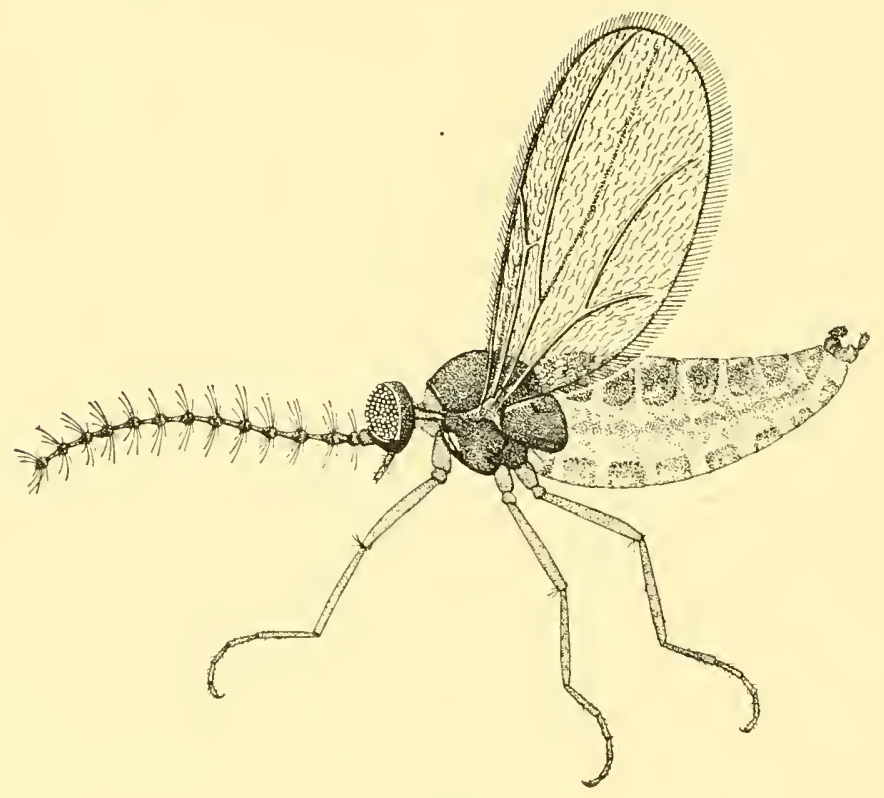

Cecidomyidx V.-21, Lasioptera veroniæ; 22, Tritozyga sackeni; 23, Mycophila fuugicola; 24, Cordylomyia coloradensis.

(Courtesy New York State Museum, Albany, N. Y.) 
56. Ovipositor protractile, aciculate or nearly so; terminal clasper of male usually uniclentate or bidentate.................. 57

Ovipositor exserted, with lobes or triangular plates apically; telminal clasper of male usually serrate apically................ 58

57. Palpi with four segments $(33) \ldots \ldots \ldots \ldots \ldots \ldots$ Schizomyia Kieffer Palpi with two or three segments $(17) \ldots \ldots \ldots \ldots$ Asphondylia Lœw

58. Palpi with four segments...................... 59 Palpi with three segments....................... Keltomyia Kieffer

59. Flagellate antennal segments cylindrical, not strongly constricted; cilcumfila usually with many fine reticulations in the male; pulvilli usually shorter than the claws $(31) \ldots \ldots \ldots \ldots \ldots$ Cincticornia Felt

Flagellate segments cylindrical, sometimes rather strongly constricted; circumfila forming transverse series of low lines or loops; lobes of ovipositor subtriangular.....................

60. Noles of the male flagellate antennal segments equal, only two cir-

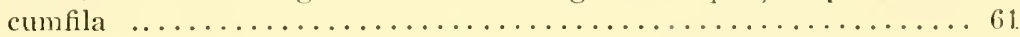

Nodles of male flagellate segments plainly unequal, three circumfila. 71

61. Palpi with three or four segments.................. 62 Palpi with one segment .................. Kronodiplosis Felt

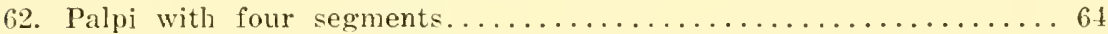

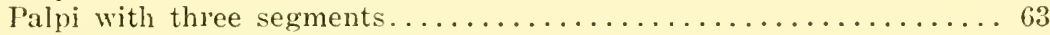

63. 'Terminal clasp segment irregular, pectinate apically.

Pectinodiplosis Felt

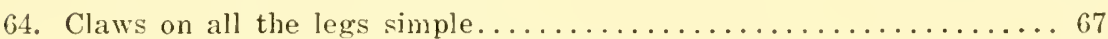

Claws on at least the front legs toothed..................65

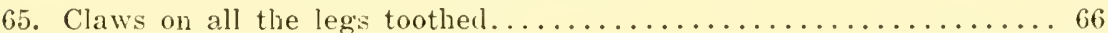

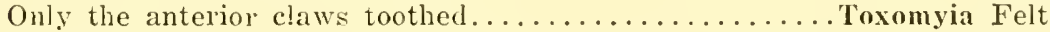

66. Internal basal lobe of the basal clasp segment smooth, the dorsal and ventral plates broadly and slightly emarginate, the ovipositor with a length one-half that of the abdomen, protractile... Erosomyia Felt

Internal basal lobe of the basal clasp segment rudimentary, smooth; dorsal plate truncate, ventral plate broadly and roundly emarginate; ovipositor morlerately long............Mangodiplosis Tavares

67. Wings of males with the posterior area greatly produced and broadly

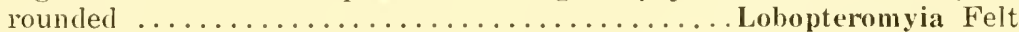

Wings normal, not unusually broad................... 68

68. Costa not clothed with scales....................... 69

Costa thickly clothed with scales............... Endaphis Kieffer

69. Thirel vein interrupting the costa at its union with the margin..... 70 Third vein not interrupting the costa at its union with the margin

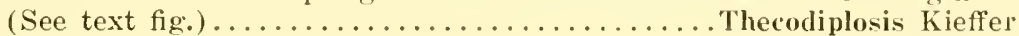

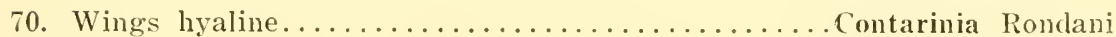

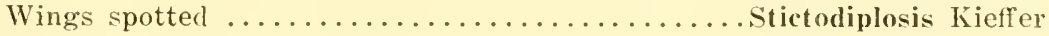

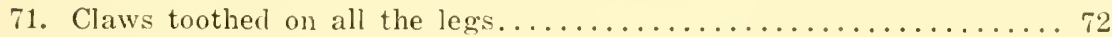
Claws of at least the posterior legs not toother.............. 84 

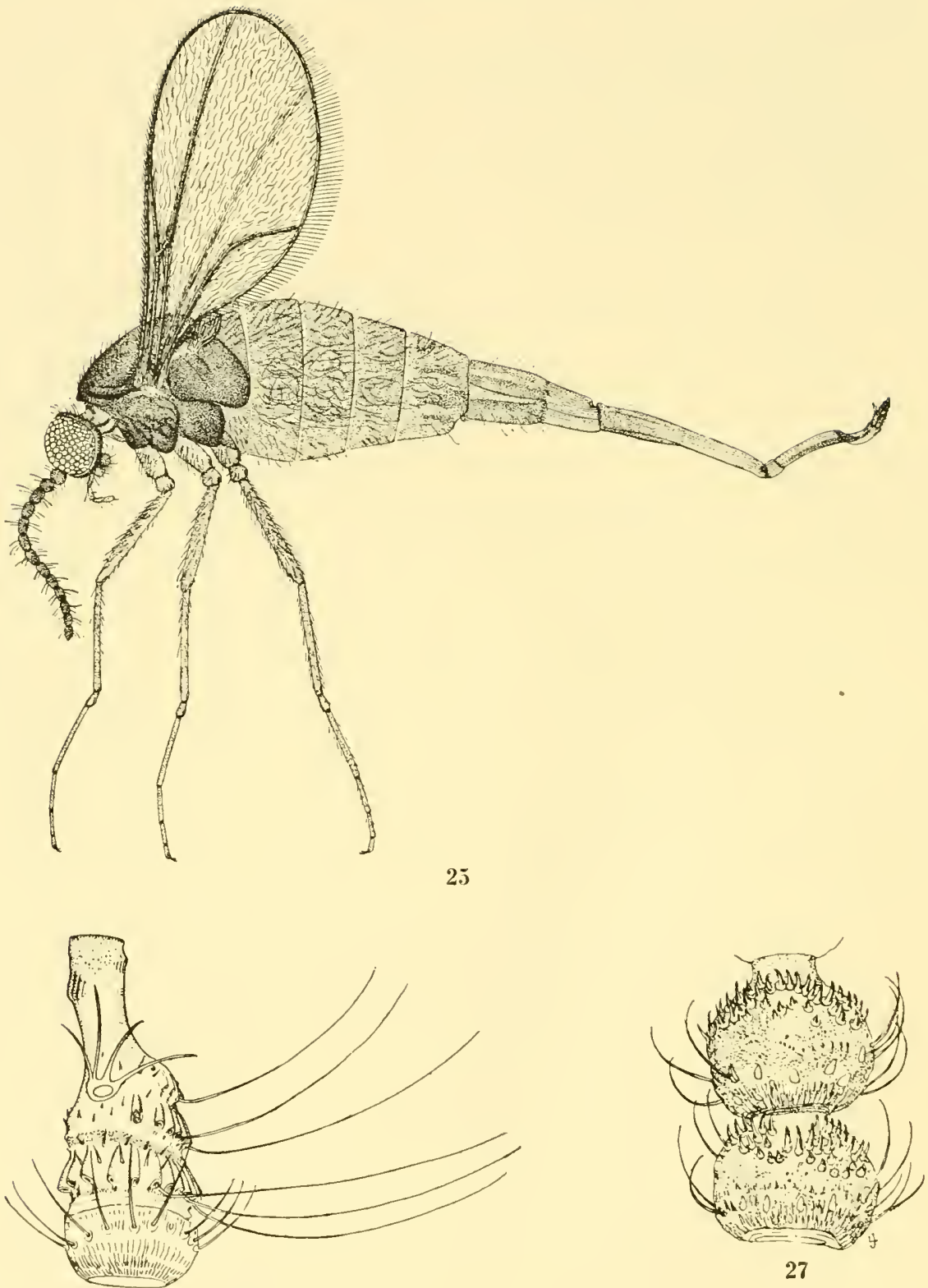

27

26

Cecidomyid:e VI.-25, Winnertzia pectinata; 26, Lestremia pini, fifth antennal segment of $0: 27$. Cordylomyia brevicornis, fourth and fifth antennal segments of 3 .

(Courtesy New York State Museum, Albany, N. Y.) 


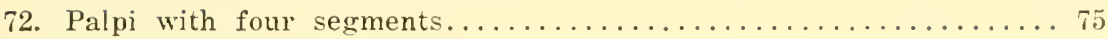

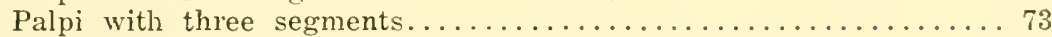

73. Basal clasp segment of male distinctly lobed...........Peridiplosis Feit Basal clasp segment of male not lobed.................... 74

74. Flagellate antennal segments of female subcylindrical.

Flagellate antennal segments of female binodose (Brit. Guiana).

Epihormomyia Felt

75. Circumfila with one or more greatly produced bows or loops having a length five to ten times that of the enlargement and extending at

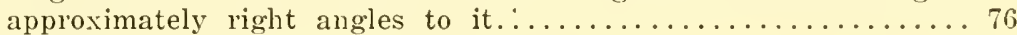

Circumfila all about equal, nearly regular............... 80

76. Three well-developed circumfila on each flagellate antennal segment. . 77 Two well-developed, irregular circumfila; basal circumfila on the distal enlargement forming a low band; pulvilli small.Bremia Rondani

77. All three circumfila irregular, the pulvilli rudimentary.

Tribremia Kieffer At most two circumfila irregular.................... is

78. Pulvilli shorter than the claws; two circumfila irregular.......... 79 Pulvilli as long as or longer than the claws; one circumfila irregular.

Aphidoletes Kieffer

79. Pulvilli slightly shorter than the claws, conspicuous... Isobremia Kieffer Pulvilli rudimentary or wanting....................

80. Basal clasp segment of male genitalia with basal lobe; ovipositor short and with large, orbicular lobes............ Youngomyia Feit Basal clasp segment without basal lobe................. 81

81. Claws curved at nearly right angles................... 82

Claws curved but not at nearly right angles............... 83

82. Ventral plate moderately long, broadly emarginate; dorsal plate moderately long, broad, deeply triangularly emarginate, the lobes triangular; ovipositor short........................ Dorsal and ventral plates short, broad, deeply emarginate.

Thomasia Rübsaamen

83. Ovipositor slightly protractile, the lobes long, curved, and with two or three subventral rows of obtuse spines........ Dicrodiplosis Kieffer

Ovipositor about half the length of the abdomen, the lobes with a length about six times the width; mouth parts prolonged (Brit.

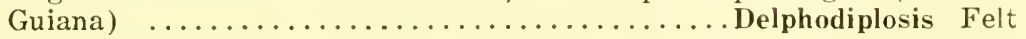

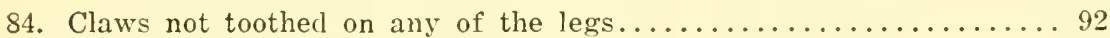

Claws toothed on at least the front legs.................. 85

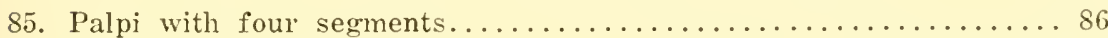

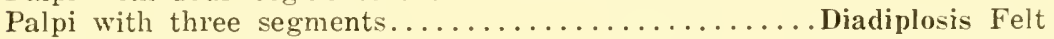

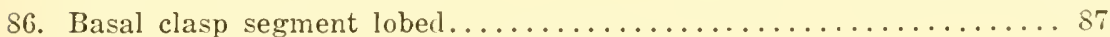
Basal clasp segment not distinctly lobed................. 89

87. The lobe basal or sub-basal ............................ 88 The lobe apical, setose or spinose; terminal clasp segment subapical. 
114

NORTH AMERICAN DIPTERA
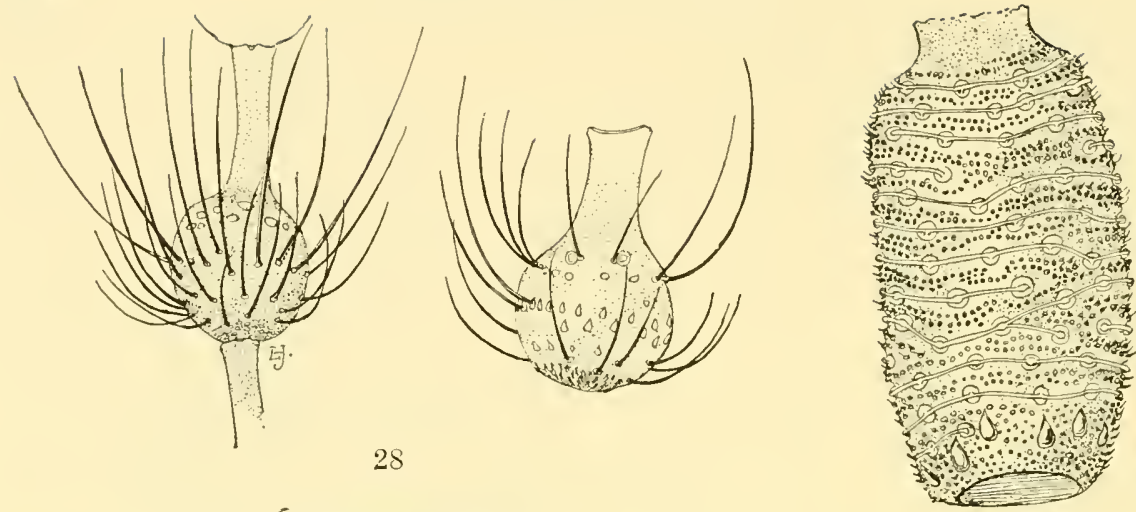

31

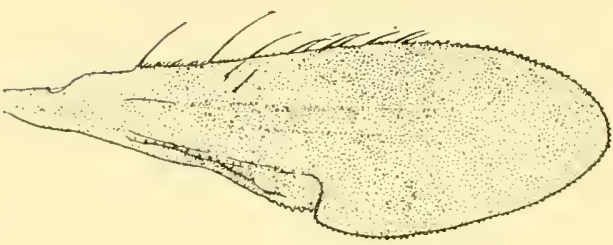

29
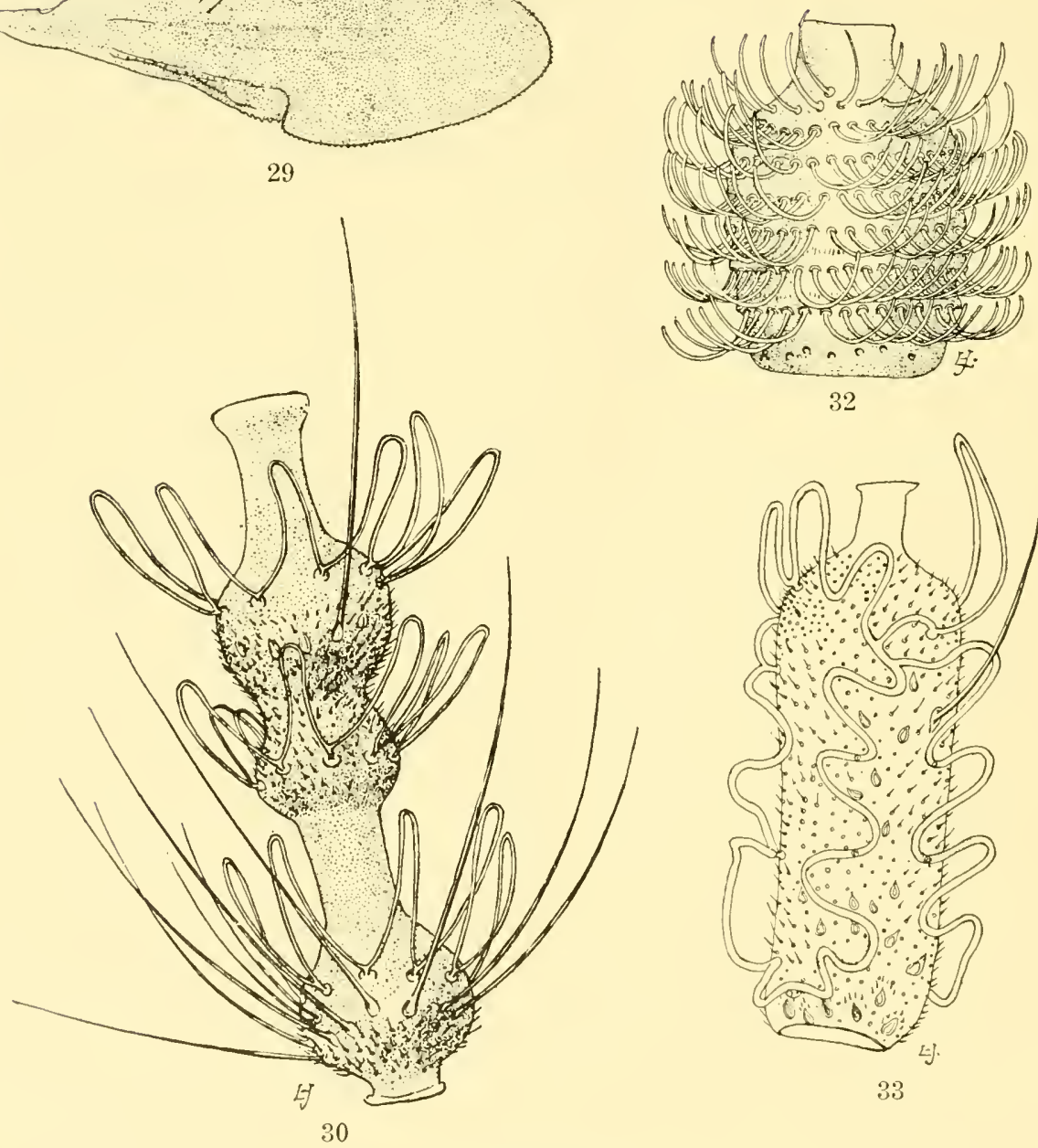

32

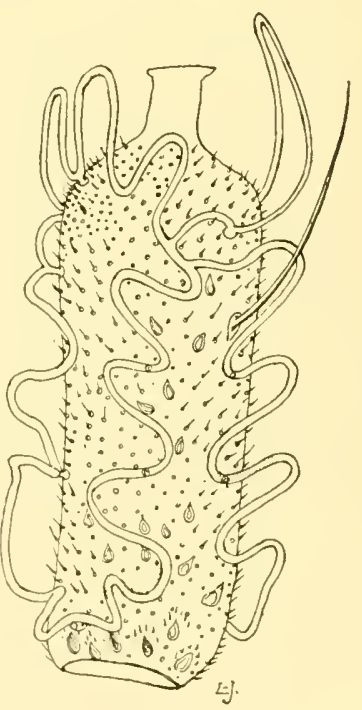

Cecidomyidx VII. 
88. Ventral plate or harpes strongly chitinized........ Coquillettomyia Felt Ventral plate or harpes not chitinized.............Feltiella Rübsaamen

S9. Terminal clasp segment sub-fusiform, distinctly dilated; harpes strongly chitinized and very complex (30)........Karschomyia Felt

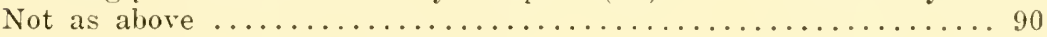

90. Claws curved at nearly right angles............ Clinodiplosis Kieffer Claws not curved at nearly right angles.................. 91

91. Ventral plate almost linear, straight and much longer than the clorsal

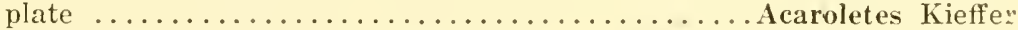
Ventral plate not greatly produced...........Mycodiplosis Rübsaamen

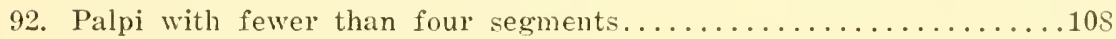

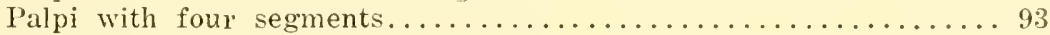

93. Third vein uniting with the costa behind the apex of the wing..... 91 Third vein uniting with the costa before the apex of the wing.

Arthrocnodax Rübsaamen

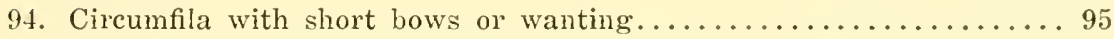
Circumfila well developed and not conspicuously irregular, the loops mostly as long as or longer than the diameter of the enlargement.. 97

95. Some of the flagellate antennal segments cylindrical........... 96 Flagellate antennal segments binodose in the male or presumably so.

Caryomyia Felt

96. Circumfila rudimentary or wanting; tenth to fourteenth segments cylindrical; harpes somewhat inflated.............Prodiplosis Felt

Circumfila distinct though low, all the flagellate or only the distal segments cylindrical; ovipositor short...................

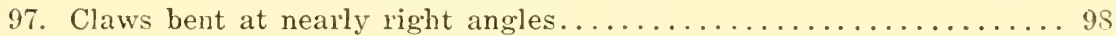

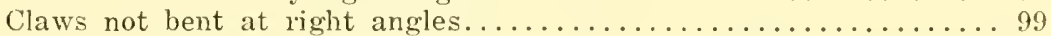

$9 S$. Ventral plate long, slender, slightly expanded and roundly emarginate apically; dorsal plate short, triangularly emarginate. Giardomyia Felt Ventral plate long, broad, very deeply and broadly emarginate; dorsal plate deeply and roundly emarginate..........Hyperdiplosis Felt

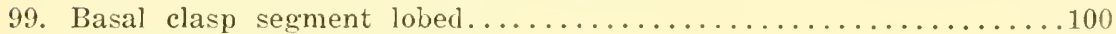

Basal clasp segment not lobed...................................

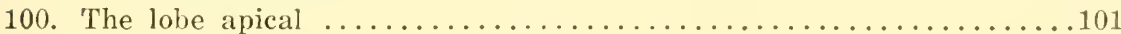

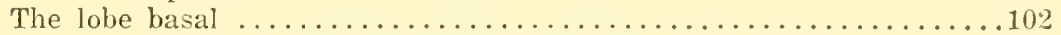

101. The lobe very long, curved, setose; terminal clasp segment swollen

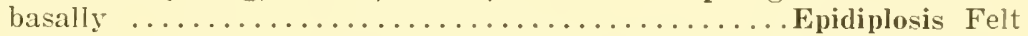

The lobe triangular; terminal clasp segment short, greatly constricted near the middle and enormously swollen and recurved

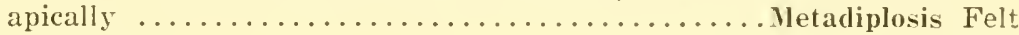

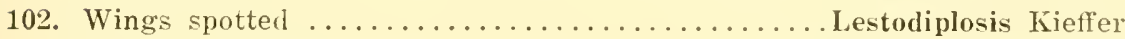
Wings not spotted ....................... Coprodiplosis Kieffer

103. Antennal segments plainly trinorlose............ Obolodiplosis Felt Antennal segments not plainly trinodose........................

Cecidomyide VII. - 28, Joannisia photophila, fifth and tenth antennal segments of male 29. Leptosyna quercivora: 30 . Karchomyia viburni, fifth antennal segment of $\checkmark$; 31 . Cincticornia transversa, sixth antennal segment of $c^{7}: 32$. Corinthomyia cincinna, fourth antennal segment of 3 ; 33 . Schizomyia macrotila, sixth antennal segment of 8 .

(Courtesy New York State Museum, Albany, N. Y.) 


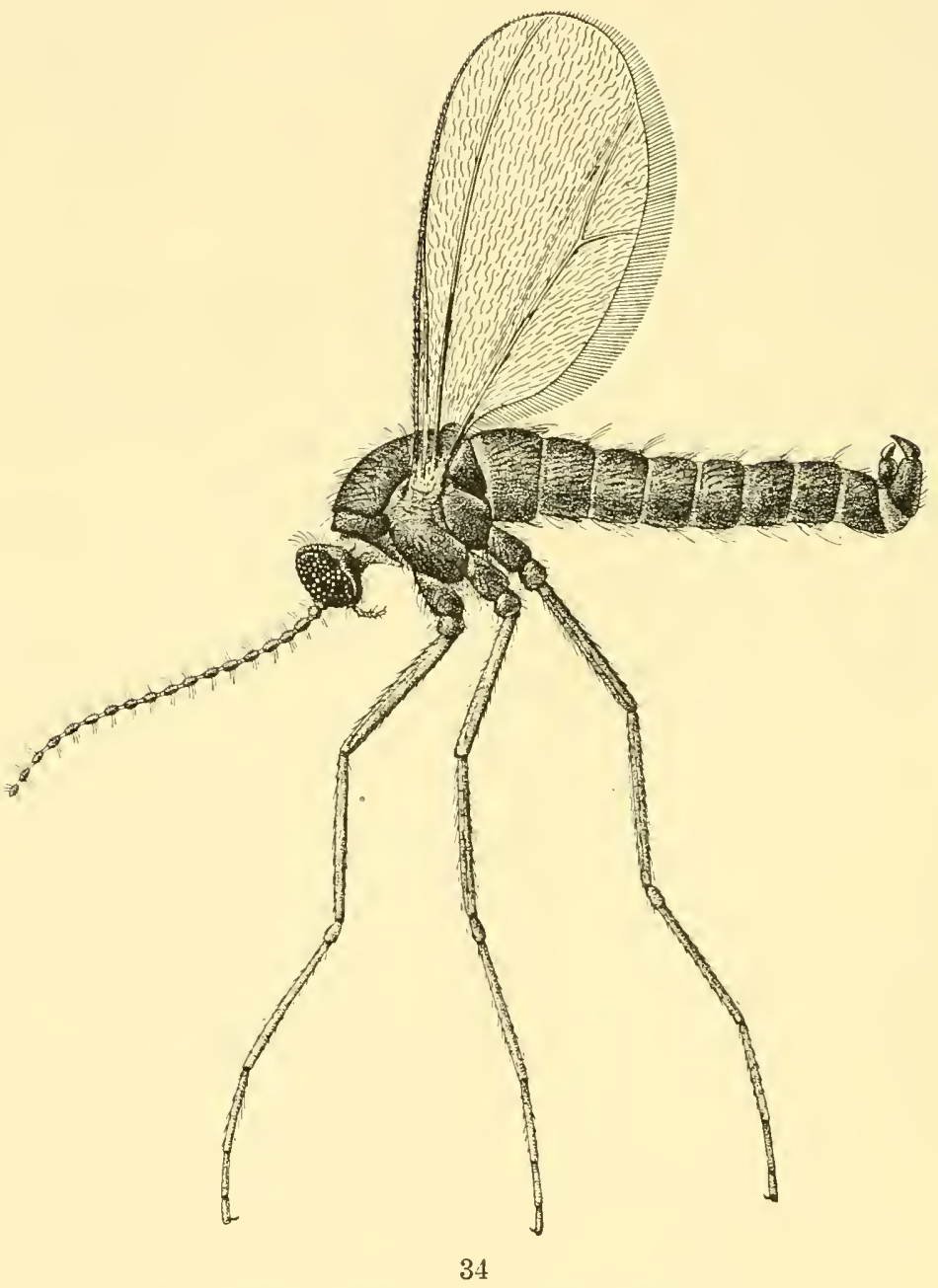

Cecidomyidæ VIII.-34, Phytophaga destructor.

(Courtesy New York State Museum, Albany, N. Y.) 
104. Antennal segments short, thick, the stems transverse, the enlargements short and broad; circumfila fine, rather short, each with

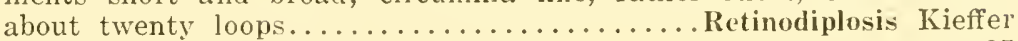

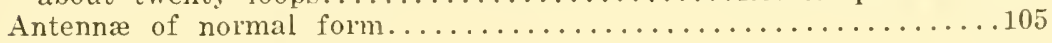

105. Ventral plate linear or long and spatulate.................. 106

Ventral plate broad and broadly or triangularly emarginate.......107

106. Ventral plate linear, rounded apically; clorsal plate shorter than the ventral, the lobes truncate.............Parallelodiplosis Rübsaamen

Ventral plate spatulate, the dorsal plate moderately long, deeply and triangularly emarginate, the lobes broad, obliquely and roundly

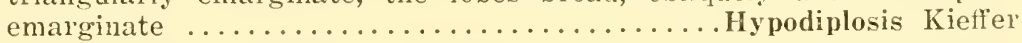

107. Dorsal plate deeply incised, the lobes narrowly rounded; terminal clasp segment with serrate margin.............Paradiplosis Felt

Dorsal plate not incised or very narrowly emarginate; terminal clasp segment smooth $(3) \ldots \ldots \ldots \ldots \ldots \ldots \ldots \ldots$ Cecidomyia Meigen

108. Palpi with three segments.......................... 10:

Palpi with only one or two segments........................

109. Circumfila with short bows or loops, their length being one-half the diameter of the enlargement or less....................

Circumfila loops with a length equal to the diameter of the enlarge-

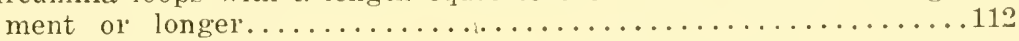

110. Thorax plainly extending over and concealing the head to a certain

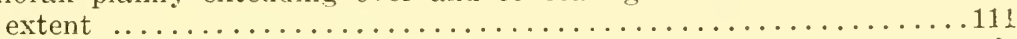
Thorax not produced over the head to a marked degree. . Caryomyia Felt

111. Males with fifteen to at least twenty-seven antennal segments; female with fourteen or more antennal segments; ovipositor short (4).

Male and female with fourteen or fifteen antennal segments, the fifteenth rudimentary; ovipositor moderately long.

Trishormomyia Kieffer

112. Basal clasp segment lobed.................. Odontodiplosis Felt

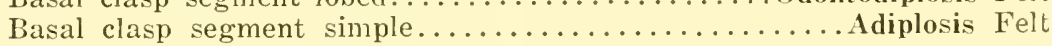

113. Palpi with two segments.............. Dishormomyia Kieffer

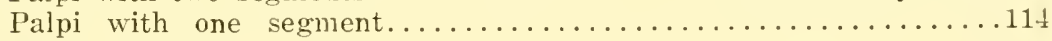

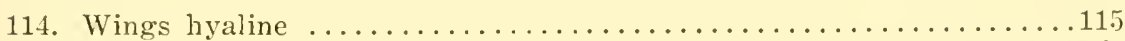

Wings marked with black and yellow.............. Astrodiplosis Felt

115. Fourteen antennal segments in both sexes.................. 115

Thirteen segments in female, the third and fourth fused, the basal and distal nodes in the male flagellate antennal segments globose and ovoid respectively; dorsal and rentral plates bilobed; ovipositor

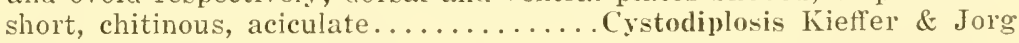

116. Both dorsal and ventral plates deeply emarginate; ovipositor short,

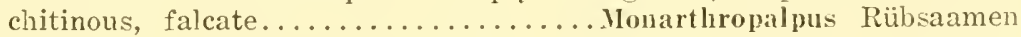

Ventral plate not deeply emarginate........................

117. Dorsal plate deeply and ventral plate broadly emarginate; ovipositor stout, half as long as the abdomen, the distal part thickly clothed

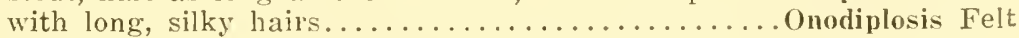

Dorsal plate deeply, broadly and roundly emarginate, the lateral margin extended ventrally; ventral plate broadly emarginate; oripositor stout, about two-thirels as long as the abrlomen.

Horidiplosis Felt 


\section{Family Sciaridæ-The Dark Winged Fungus Gnats}

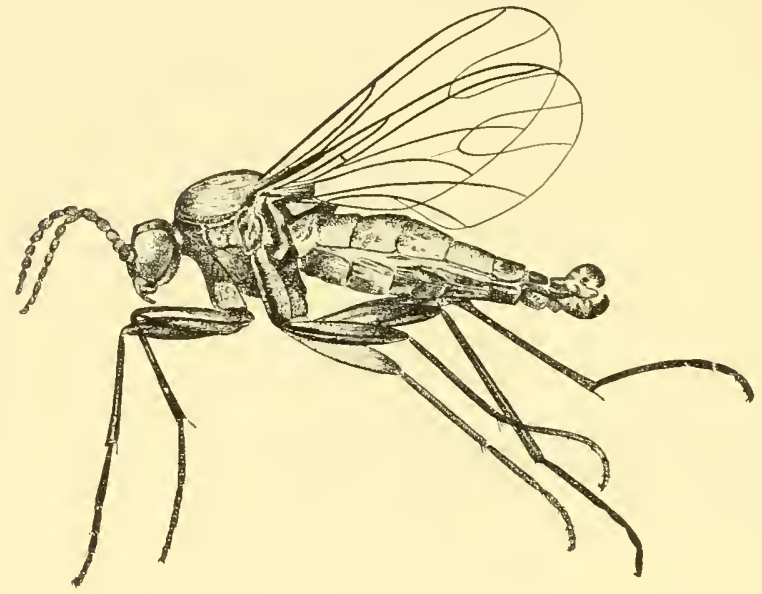

Sciara o

Usually small, blackish, brownish or testaceous species, the abdomen cylindrical and tapering, especially in the females.

The inseets belonging to this family are related to the Mreetophilidæ, with which they have, until recently, been united. They differ in having the eyes produced toward each other above the antennæ, instead of being regularly convex in outline, and in having shorter coxæ. As a general rule the wing venation is typical although a very few genera of the Mycetophilidæ have similar venation.

The adults inhabit moist places or any place where fungus growth oecurs, particularly manure. The larvæ frequently become pests in mushroom cellars, feeding upon the myeelium of the fungi. The females are diffieult to determine, the elassifieation being based mainly on the male genitalia although the ovipositors of the females also offer good characters. The larva, like those of the Myeetophilidæ, have some very interesting habits, some of them sometimes travelling over the ground in snake-like masses. The family is treated by Johannsen in the referenee given under the Mycetophilidx. 


\section{KEY TO GENERA}

1. Proboscis longer than the thorax (2).......... Eugnoriste Coquillett

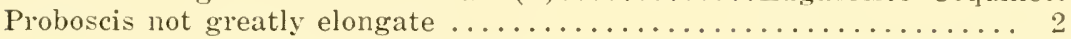

2. Wings conspicuously hairy; claws never denticulate...Trichosia Winnertz Wings with microscopic setulæ but not hairy............... 3

3. Claws toothed ................................. 4

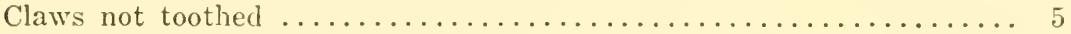

4. Forks of the fourth vein arcuate.............. Metangela Rübsaamen Forks of the fourth vein not arcuate............Phorodonta Coquillett

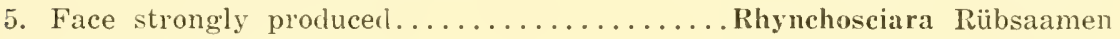

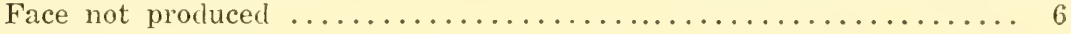

6. Forks of the fourth vein arcuate; antennæ of the male pedicellate and with whorls of hair (1).................. Zygoneura Meigen Forks of the fourth vein not arcuate; antennæe never pedicellate (Neosciara) $(6,7$, Mycetophiliclæ $) \ldots \ldots \ldots \ldots \ldots$. Sciara Meigen
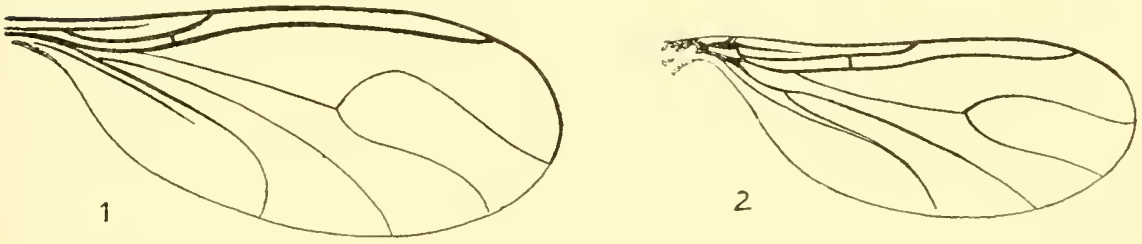

Sciaridæ.-1, Zygoneura; 2, Eugnoriste. 


\section{Family Mycetophilidæ-The Fungus Gnats}

Moderately small, rather delicate, slender flies with elongated coxæ.

Head small, rounded or somewhat elongate, usually closely applied to the thorax. Eyes round, rather prominent; ocelli three, two or none, the median one often small, the lateral ones frequently close to the orbits; front broad in both sexes. Antennæ elongated, composed of twelve to seventeen segments, the two basal segments large or differentiated, the others cylindrical, flattened or petiolated. Proboscis usually short, rarely greatly lengthened; palpi rarely absent, composed of three or four segments, usually inflexed. Thorax distinctly to strongly arched, without transverse suture; seutellum small; metanotum large. Abdomen composed of six or seven segments, cylindrical or compressed either laterally or dorsoventrally, sometimes narrowed basally; male genitalia projecting; ovipositor pointed, usually with two terminal lamellæ. Legs more or less elongated, the femora usually thickened; coxæ elongated; tibiæ with spurs and usually with series of short or conspicuous bristles. Wings large; anxiliary rein present though sometimes very short; second longitudinal vein absent, or simulating a crossvein; third vein arising from the first vein, usually at such an angle as to simulate a crossvein, the erossvein sometimes appearing to form the base of the third vein; fourth and fifth veins usually fureate, sometimes simple; sixth vein sometimes rudimentary, never furcate; the seventh usually short, often rudimentary or entirely absent; discal cell absent, the second basal cell often open apically.

The adults are found in moist places, especially abont decaying wood, on mossy rocks or moist humus, and prefer dark places. Many of the species are quite small only a few being large and eonspicnous. They oceur in a variety of habitats and some species are very restricted in habitat although oceurring over a very wide geographical range. They may be collected throughout most of the year and when encountered often oceur in large numbers. The larva live in moist soil, wood, fungi, etc., and probably feed upon fungus growth. Pupation takes place outside the larval skin, some species spimning cocoons. The habits of the larvæ are particularly interesting and their investigation should provide an entertaining and profitable field of study to some one interested in pure science for the fun of the thing. Johamnsen* has monographed the family and only a small number of North American species have been described since.

* Maine Agric. Exp. Sta. Bulls. 172, 180, 196, 200, 1909-12. 


\section{KEY TO GENERA*}

1. Second basal cell closed apically..................... 2

Second basal cell open apically....................... 12

2. Anterior branch of third vein at least half as long as posterior branch; auxiliary vein short, ending free; posterior divisions of pronotum with one or more long bristles (Ditomyiinæ)................. 11

Anterior branch of third rein less than half as long as posterior branch, in some cases vestigial or absent; auxiliary vein in most cases long and ending in the costa; posterior divisions of pronotum

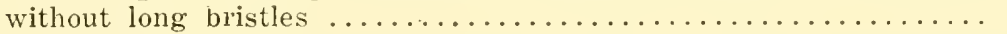

3. The second basal cell much shorter than the first; first and second basal cells separated (Bolitophilinæ) (18)............. Bolitophila Meigen

The second basal cell almost as long as the first or the basal sections of the third and fourth veins fused for a short distance.............

4. Both crossveins closing the basal cells present, nearly in a straight line; basal section of fourth vein lacking (Diactocidina) (19).

Diadocidia Ruthé

Basal sections of third and fourth reins fused for a short distance except in Palaeoplatyura in which basal section of fourth vein is present

5. Antennæ long and slender, in most cases longer than the boty (Macro-

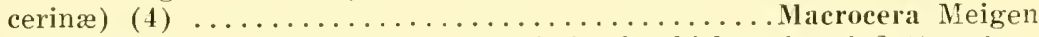

Antennæ more robust, in some cases distinctly thickened and flattered

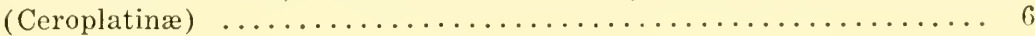

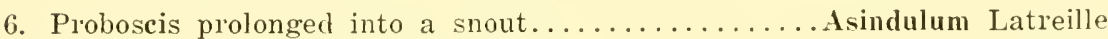
Proboseis not prolonged into a snout.................. 7

7. Antennæ conspicuously flattened; palpi porrect (Heteropterma, Cerote-

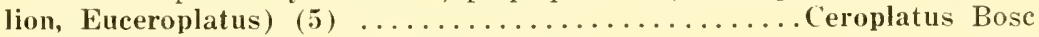
Antennæ not conspicuously flattened, palpi curved.............. 8

8. The anterior crossvein not obliterated by the fusion of the bases of the third and fourth veins $(20) \ldots \ldots \ldots \ldots \ldots$................ The anterior crossvein not obliterated by the fusicn of the base of the

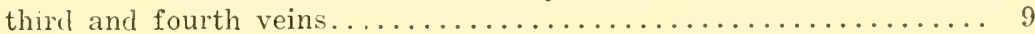

9. Basal section of fourth vein absent (Isoneuromyia, Neoplatyura, Proceroplatus, Lapyruta, Vicrapemon) $(9) \ldots \ldots \ldots \ldots \ldots$ Platyura Meigen

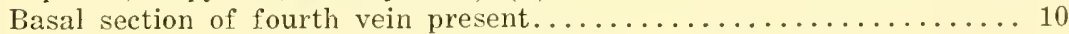

10. Ocelli wanting; anterior branch of third rein ending in the costa.

Hesperodes Coquillett

Ocelli present, anterior branch of thirt vein ending in the first vein

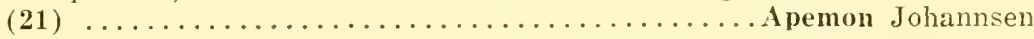

11. Fork of fourth vein distal of fork of third vein (22)... Ditomyia Winnertz Fork of fourth vein basal of fork of third vein (14)...Symmerus Walker

i2. First and third veins arising separately at base of wing; venation defective; proboscis elongate (Lygistorihinæ) (l'robolixus) $(2,3)$.

Lygistorrhina Skuse

First and third veins arising from a common stem well beyond base

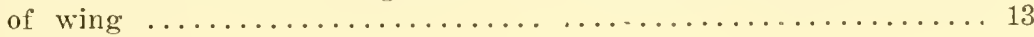

* Checked by Dr. O. A. Johannsen. 
13. Eyes joined above the antennæ by a narrow bridge; anterior crossvein long, appearing like the base of the third vein, the latter short and

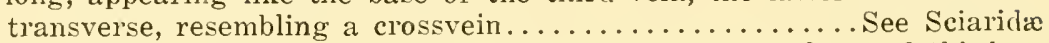

Eyes not joined by a narrow band above the antennæ; base of third vein and the anterior crossvein in most cases oblique.......... 14

14. Prothorax without long bristles, antennæ inserted above the midulle of the head, occiput flat or concave, venation defective (Manotinæ) (1).

Ilanota Williston

Prothorax with long bristles, occiput convex, antennæ inserted at or below the middle of the head..................... 15

15. Microtrichia of wings irregularly arranged or absent; auxiliary vein usually long; lateral ocelli in most cases far from margin of compound eyes (Sciophilinæ Edwards = Sciophilinæ Johannsen + Series I of Mycetophilinæ Johannsen 1911) ................... 16

Microtrichia in more or less definite longitudinal lines; auxiliary vein usually short; lateral ocelli touching compound eyes (Mycetophilinæ Edwards, Mycetophilinæ Johannsen 1911, Series II) ............ 44
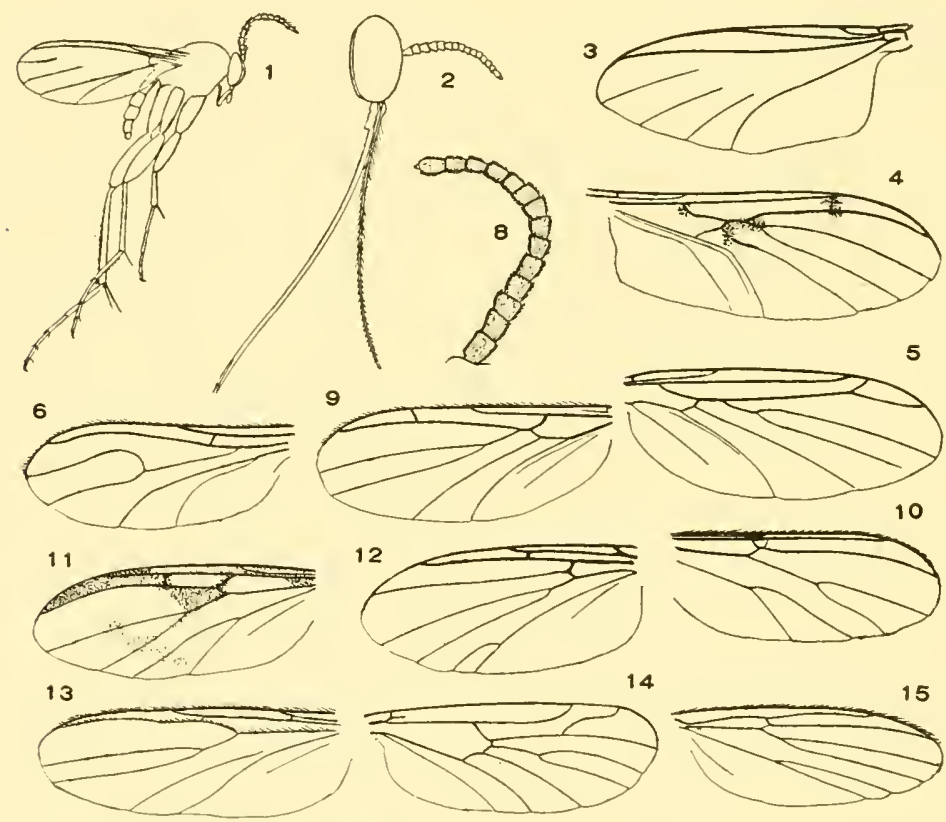
16. Ocelli two, approximated; wings without macrotrichia (hairs) on membrane; auxiliary vein reaching at least the base of the third vein; fine tibial setæ in regular longitudinal rows................. 19 Ocelli three, if but two (in Eudicrana) they are close to the eye margin. 17

17. Wing with macrotrichia (hairs) on membrane.............. 20 Wing without macrotrichia on membrane................ 18

18. Apical segment of first vein several times longer than the anterior crossvein; branches of fourth vein longer than the petiole....... 32 Apical segment of first vein short, in most cases not much longer than the crossvein, or if longer the branches of fourth vein scarcely

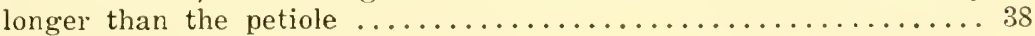

19. Costa not produced beyond tip of third vein; no spurious vein between third and fourth veins; wing not banded $(23) \ldots . .$. Mycomya Rondani Costa produced beyond tip of third vein; spurious vein usually present between third and fourth veins; wing banded or spotted (11).

Neoenpheria Osten Sacken

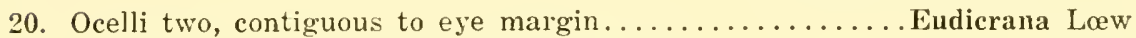
Ocelli three, remote from compound eyes.................. 21

21. Fork of fifth vein situated nearer to wing base than is the fork of

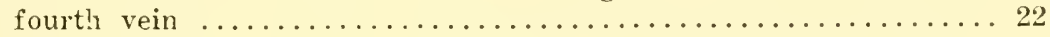
Fork of fifth vein, if present, situated beyond fork of fourth vein... 27

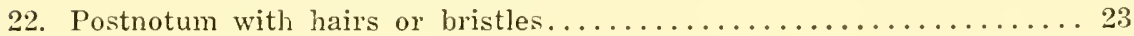

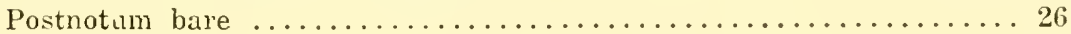

23. Anterior branch of fourth vein complete or nearly so.......... 24 Anterior branch of fouth vein faint or defective at base; third vein undulate (Odontopoda). (24) ................... Neuratelia Rondani

24. Subcostal crossvein before middle of auxiliary vein (25)...Allocotocera Mik Subcostal crossvein beyond middle of auxiliary vein............ 25

25. Third vein straight; costa not produced beyond its tip (Diomonus) (26). Third vein undulate; costa produced beyond its tip (27).

Leptomor phus Curtis Polylepta Winnertz

26. Metapleura hairy; auxiliary vein ending in first vein; body stout (28).

Syntemua Winnertz Metapleura bare; auxiliary vein ending in the costa; body long and

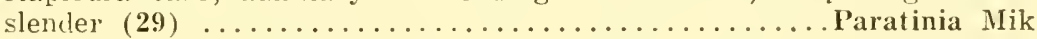

27. Legs slender and extremely long; basal tarsal segment of anterior legs twice as long as the tibia; fourth vein forks broadly (12).

Phthinia Winnertz

Legs normal; fork of media pointed $\ldots \ldots \ldots \ldots \ldots \ldots \ldots \ldots \ldots$

28. Second branch of fourth vein complete..................... 29

Second branch of fourth vein detached, present only as a short element on the wing margin $(30, \ldots \ldots \ldots \ldots \ldots \ldots \ldots$. . . Wana Walker 


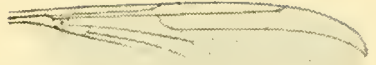

18

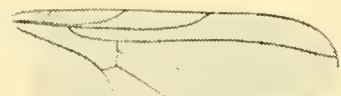

19

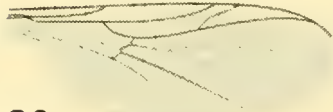

20
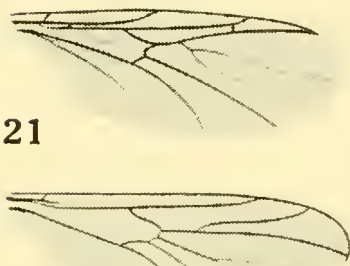

22

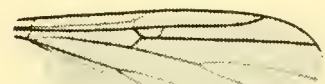

23

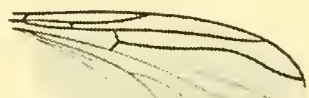

24

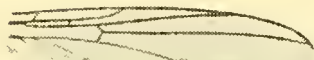

25

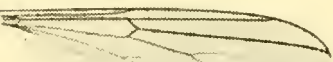

26

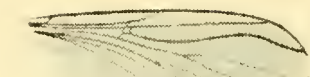

27

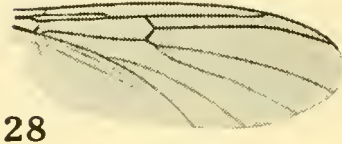

36

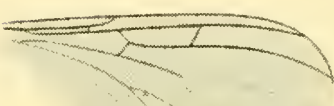

29
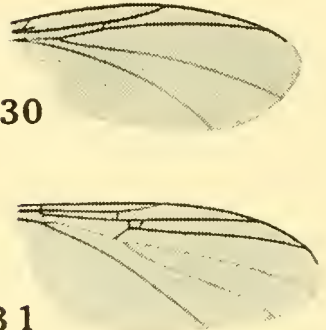

\section{1}

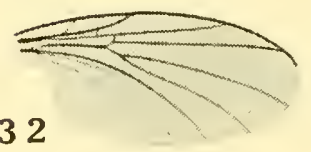

40
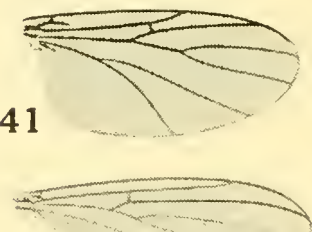

42

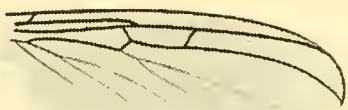

34

35

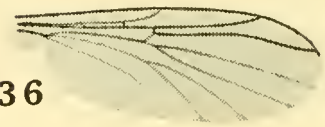

37

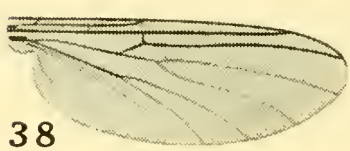

39
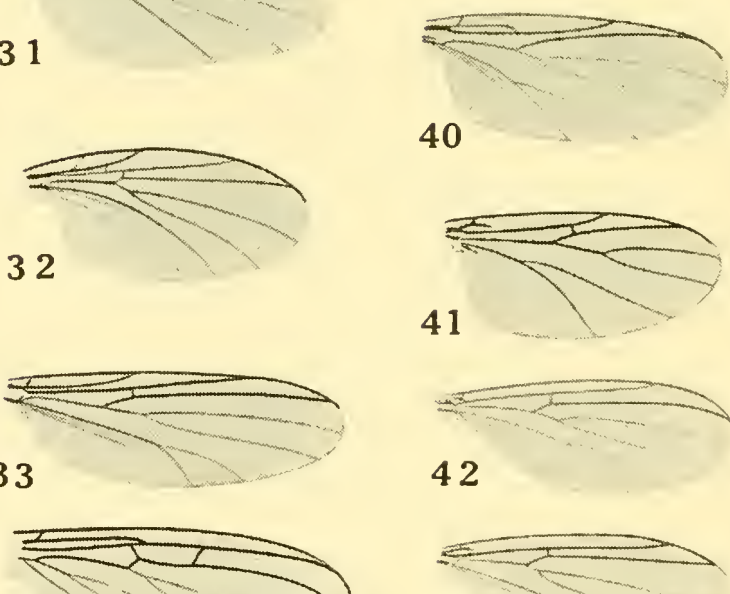

43

Mycetophilidx II.-18, Bolitophila; 19, Diadocidia; 20, Paleoplatyura; 21, Apemon; 22, Ditomya; 23, Mycomya; 24, Nenratelia; 25, Allocotocera; 26, Leptomorphus; 27, Polylepta; 28. Syntemna; 29, Paratinia; 30, Azana; 31, Monoclona; 32 , Acnemia; 33, Coelosia; 34, Hadroneura; 35 , Dziedzickia; 36 . Gnoriste; 37 , Synapha; 38 , Boletina; 39 , Rondaniella; 40 , Docosia; 41, Megophthalmidia; 42, Anatella; 43. Exechia. 
29. Subcostal crossvein well beyond origin of third vein; mesopleura bare.

Megalopelma Enderlein Subcostal crossvein just before, above or inmediately beyond origin of

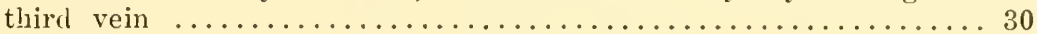

30. Fifth vein forked; mesopleura with small hairs (10)...Sciophila Meigen Fifth vein simple; mesopleura bare................... 31

31. Macrotrichia (hair) reflexed toward base of wing (31)... Monoclona Mik

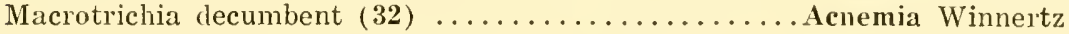

32. Seventh abdominal segment large in both sexes (for Polylepta lepto-

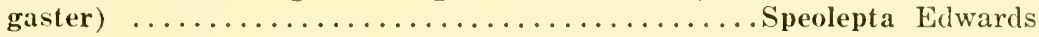
Seventh abdominal segment small and retracted, at least in the male.. 33

33. Fifth vein forks well beyond fork of fourth (33) ...... Colosia Winnertz Fifth vein forks before, below or just beyond fork of fourth....... 34

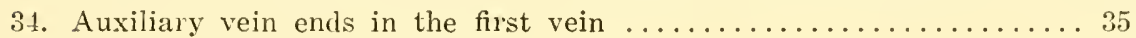

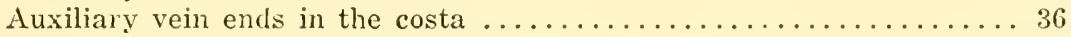

35. Proboscis prodluced, about as long as the head (34) Hadroneura Lundstrom Proboscis not produced $(35) \ldots \ldots \ldots \ldots \ldots \ldots$ Dziedzickia Johannsen

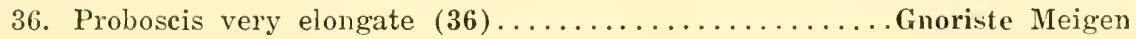

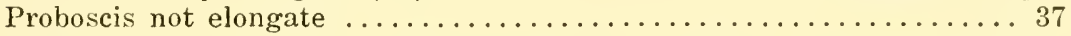

37. Subcostal crossvein well beyond middle of auxiliary vein (Empalia)

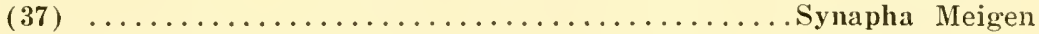
Subcostal crossvein absent or near middle of auxiliary vein $(38,55)$.

Boletina Stæger

38. Auxiliary vein ends in the costa (extremity may be faint in species

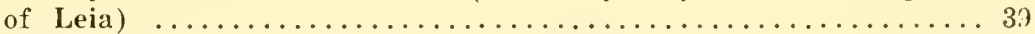

Auxiliary vein short, ending free or in the first vein.......... 40

39. Last section of first vein over twice as long as anterior crossvein; anterior branch of fourth vein in most cases detached at base; subcostal crossvein wanting $(39) \ldots \ldots \ldots \ldots \ldots$ Rondaniella Johannsen Last section of first vein scarcely longer than the crossvein, in some cases shorter $(13) \ldots \ldots \ldots \ldots \ldots \ldots \ldots \ldots \ldots \ldots \ldots \ldots \ldots \ldots \ldots \ldots$ Meigen

40. Palpi minute, consisting of a single segment; female wingless; in the male the basal section of fourth and fifth veins are coalescent so that both branches of the fifth appear to arise from the basal section of the fourth vein $(47) \ldots \ldots \ldots \ldots \ldots \ldots$. . . . . . Jyxia Johannsen Palpi well developed, female winged, venation various..........4 41

41. Lateral ocelli contiguous with the margin of the compound eyes; last section of first vein long, petiole of fourth vein short; hypopleura hairy $(40) \ldots \ldots \ldots \ldots \ldots \ldots \ldots \ldots \ldots \ldots \ldots \ldots \ldots \ldots \ldots \ldots \ldots$ Docosia Winnertz

Lateral ocelli remote from eye margins; last section of first vein

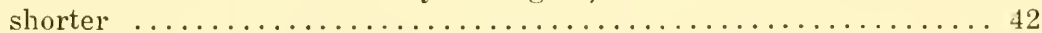

42. Hypopleura hairy; hind tibial comb present (11).

Megophthalmidia Dziedzicki

Hypopleura bare; no tibial comb ..................... 43

43. Auxiliary vein rather long, ending in first vein; fifth vein forks near

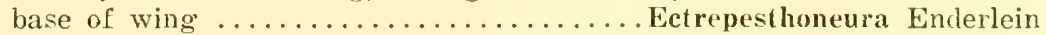
Auxiliary vein very short, ending free; fifth vein forks near the middle

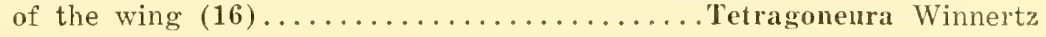




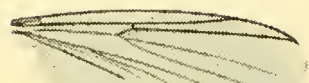

44

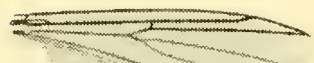

45

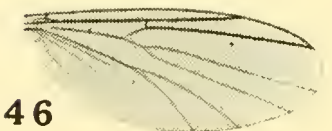

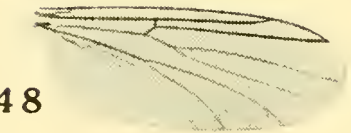

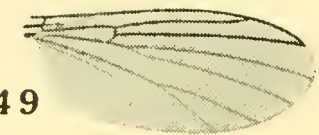

50

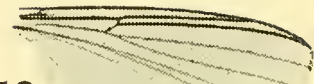

52

53

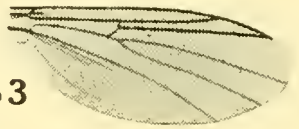

54

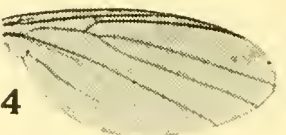

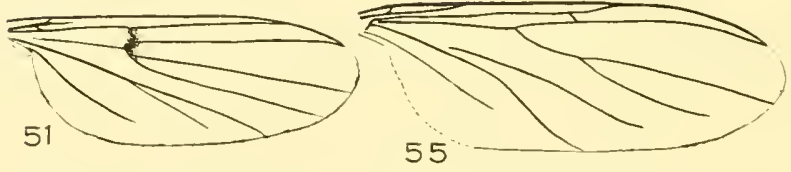

Mycetophilidæ III.-44, Rhymosia; 45, Brachypeza; 46, Allodia; 47. Pnyxia scabei; 48 . Cordyla; 49. Phronia; 50 , Trichonta ; 51 , Mycetophila dominicana; 52 , Epicypta ; 53, Zygomyia ; 54, Sceptonia; 55; Boletina incompleta. 
44. Mesopleural and hypopleural bristles absent; hind coxa with a fairly

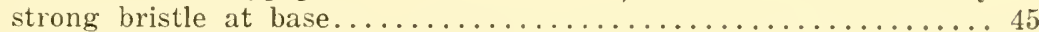
Mesopleural bristles present; hind coxa usually without basal bristle... 49

45. Costa produced beyond tip of third vein $(42) \ldots \ldots \ldots$ Anatella Winnertz Costa ends at tip of third vein.......................46

46. Fifth vein forks beyond fork of fourth (43)........ Exechia Winnertz Fifth vein forks below or before fork of fourth ............... 47

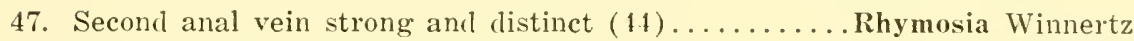

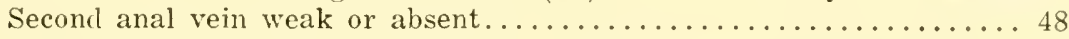

48. First anal vein very long and distinct, attaining the micldle of the fork

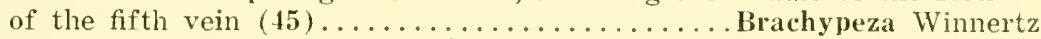
First anal vein shorter and less distinct $(46) \ldots \ldots \ldots$. Allodia Winnertz

49. Pteropleural bristles present; tibial bristles long and strong........ 53

Pteropleural bristles absent ....................... 50

50. Tibial bristles long and strong; auxiliary vein ends in first vein (= Johannsenia) (17) ................... Dynatosoma Winnertz Tibial bristles small, at most a little longer than the diameter of the

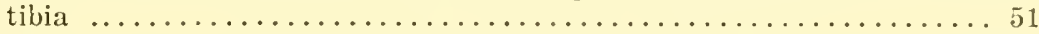

51. Second palpal segment greatly thickened $(48) \ldots \ldots \ldots \ldots$ Cordyla Meigen

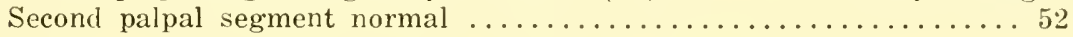

52. Fifth vein forks beyond fork of fourth; auxiliary vein ends free

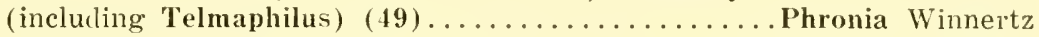
Fifth vein forks below or before fork of fourth; auxiliary vein ends normally in the first $(50) \ldots \ldots \ldots \ldots \ldots \ldots$ Trichonta Winnertz

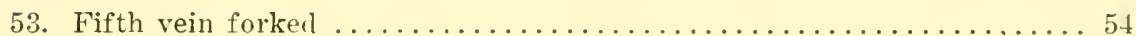

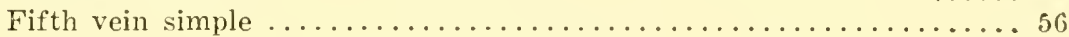

54. Anterior branch of fifth vein slightly divergent apically from second branch of fourth but parallel with or convergent towards second branch of fifth; hypopleura and pteropleura generally quite large (including Mycothera and Opistholoba) $(15,51) \ldots$. Hycetophila Meigen Anterior branch of fifth parallel with second branch of fourth but slightly divergent from second branch of fifth............. 55

55. Pronotal lobes with long bristles; fifth vein forks scarcely if any before the anterior crossvein $(82) \ldots \ldots \ldots \ldots \ldots \ldots \ldots$ Epicypta Winnertz

Pronotal lobes without long bristles; fifth vein forks well before the

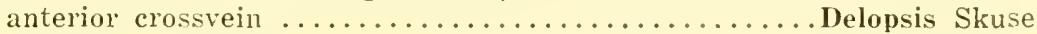

56. Second branch of fourth and first branch of fifth vein slightly divergent; hypopleura and pteropleura large; middle tibia with ventral

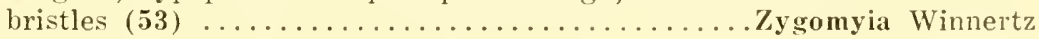
Second branch of fourth and first branch of fifth vein parallel; hypopleura and pteropleura small; middle tibia withcut ventral bristles (54) $\ldots \ldots \ldots \ldots \ldots \ldots \ldots \ldots \ldots \ldots \ldots \ldots \ldots \ldots \ldots \ldots \ldots \ldots$ Sceptonia Winnertz 


\section{Family Bibionidæ-The March Flies}

Slender flies of small to medium size, ranging from four to twelve millimeters in length.

Head usually somewhat flattened; eyes of the males approximate or contiguous, of the females, broadly separated; face rather short, sometimes elongate in Dilophus; eyes round; ocelli large. Antennæ composed of eight to twelve segments, cylindrical or somewhat flattened, the segments rather closely united. Proboseis short, with thickened, hairy labellæ; palpi with two to five segments, usually short, sometimes long. Thorax without transverse suture; seutellum hemicircular. Abdomen composed of seven to nine segments, more or less flattened, the male genitalia rather small. Legs moderately long, the anterior femora usually thickened, sometimes greatly swollen, the other femora usually somewhat swollen; anterior tibiæ usnally modified, often greatly swollen in Bibio; legs slender in Plecia. Pulvilli and usually the empodium distinct. Wings large, the anterior veins stout, the others usually considerably weaker; costa ending at or before the wing-tip; seeond rein present or absent; fourth rein furcate; basal cells complete; anal cell rarely closed; posterior crossvein absent.

The larvæ feed upon decaying vegetable matter, especially upon the roots of grass, and pupation takes place in the soil. The adults are frequently very common and may be found almost anywhere in the open. The name "March Flies" has been given the family in this country because of the frequent occurrence of Bibio albipennis Say in large numbers during this month. "Itarlequin Flies" is used in England, while "Mareh Flies" is applied to other flies in Anstralia. The family has been reviewed by MaeAtee*.

\section{KEY TO GENERA}

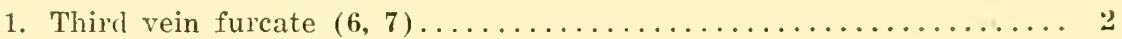

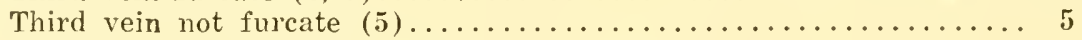

2. Fourth and fifth veins forked...................... 3

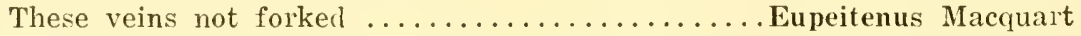

3. Antennæe with not more than 12 segments................ 4 Antennæ with 16 segments $(7) \ldots \ldots \ldots \ldots$ Cramptonomyia Alexander

* 1921. Proc, U. S. N. M. lx, Art. 11.

+ For a discussion of the position of this genus and its allies see Alexander, 1931, Bull. Brooklyn Ent. Soc, xxvi, pp. $i-11$. 
4. Distance between the fork of the fourth rein and the anterior crossvein more than twice the length of the crossvein (4).

Hesperinus Walker

Distance between fork of fourth vein and anterior crossvein much less than twice the length of the crossvein (6)........Plecia Wiedemann

5. Anterior tibire produced apically to form two spurs (3)......... 6 Anterior tibire without such spurs but with two or three series of teeth

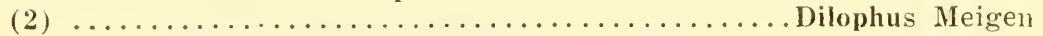

6. Third and fourth longitudinal veins coalescent for a short distance

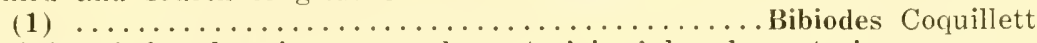

Third and fourth veins not coalescent, joined by the anterior cross-

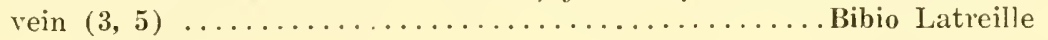
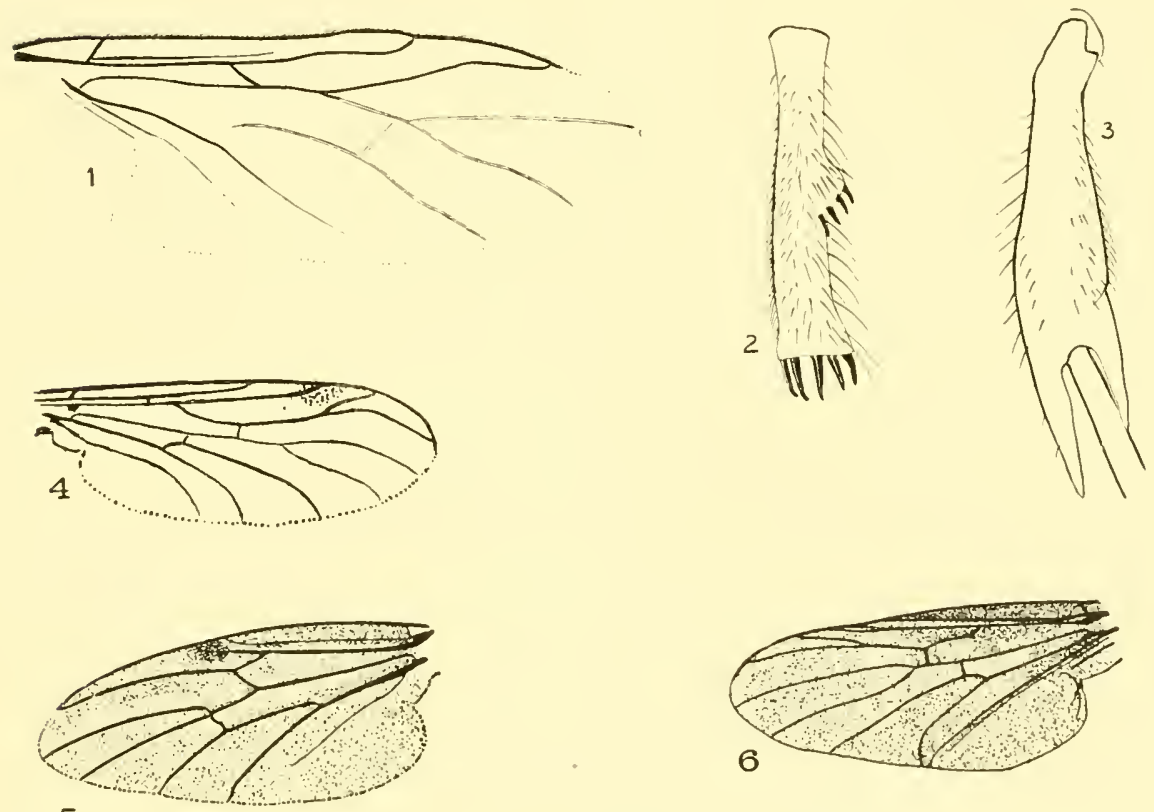

5

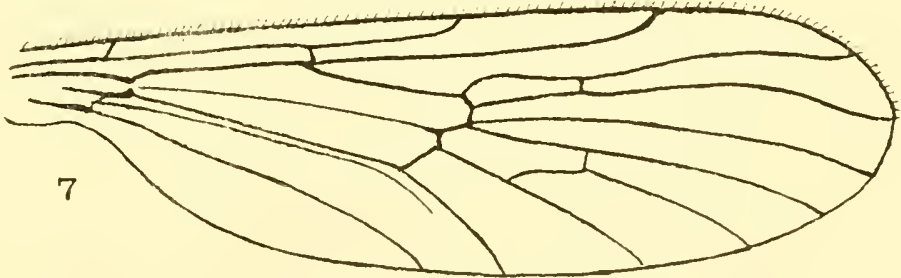

Bibionidæ.-1, Bibiodes; 2, Dilophus, front tibia ; 3, Bibio, front tibin; 4, Hesperinus; 5 , Bibio; 6, Plectia; 7, Cramplonomyia. 


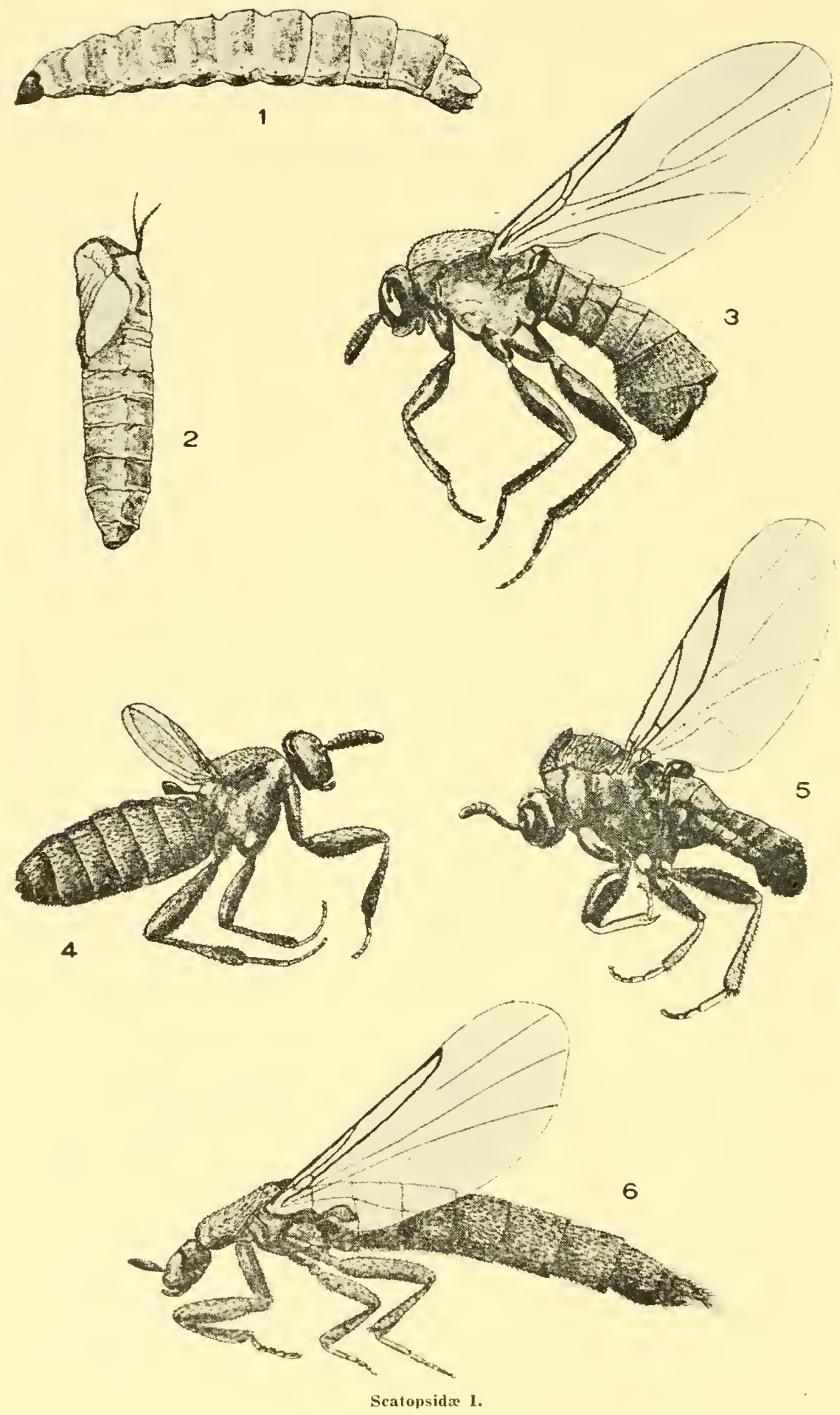




\section{Family Scatopsidæ-The Minute Black Scavengers}

Small black or brownish flies, the appendages and thorax often partly yellowish.

Head more or less orbicular-subquadrate or elongate oval; anterna composed of seven to twelve segments; usually slightly longel than the head; three ocelli; proboseis short and stont. Thorax gently convex, rarely flattened. Legs short, the femora robust. Wings with the reins thin, the first and third strong, the second simulating a crosswein, the fourth rein furcate or simple. Abdomen subeylindrical, composed of six or seren segments, the male genitalia larece.

The Seatopsida breed in decaying regetable and animal matter and exerement. They often breed in sewers and privies and frerpuently become very numerous in houses, where they cause more anxiety than harm. In the autumn they are frequently common on windows, when they are most easily eollected. The species range in size from .75 to 3 $\mathrm{mm}$. in length and the family may be readily recognized by the wing venation. Melander* has rerised the North American species.

\section{KEY TO GENERA}

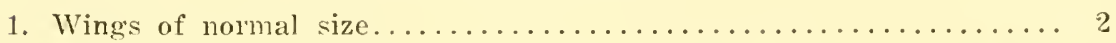
Wings about half normal size, the adults flightless (4).

Cobaldia Melander

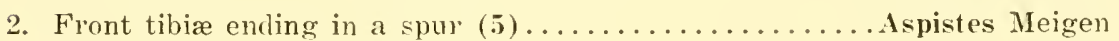
Front tibiæ without apical spur...................... 3

3. Anterior branch of the fourth vein without appendage.......... 4 Anterior branch of the fourth vein with an appendage near the base

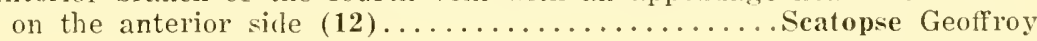

4. Anterior branch of the fourth rein not disconnected at the base (10). 5 Anterior branch of the fourth vein disconnected basally (7)....... 7

5. Petiole of the fourth vein more than twice as long as the anterior

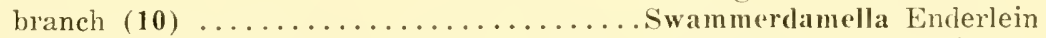
Petiole of the fourth vein at most a little longer than the anterior

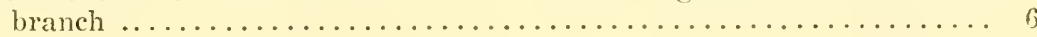

* 1916, Bull. 130, State Coll. Wash., Agric. Exp. Stction.

Scatopsida I.-1. 2. 3. Rhegmoclema atrata, larva, pupa, adult; 4, Coboldia formicarum; 5. Aspistes berolinensis; 6 , Psectrosciara californica. 
6. Third vein ending well beyond the middle of the wing (9).

Reichertella Enderlein

Third vein ending before or at the middle of the wing $(1,2,3,11)$.

Rhegmoclema Enderlein

7. Third vein ending at or near the midlle of the wing (7).

Aldrovandiella Enderlein

Third vein ending at the apical fourth of the wing $(6,8)$.

Psectrosciara Kieffer
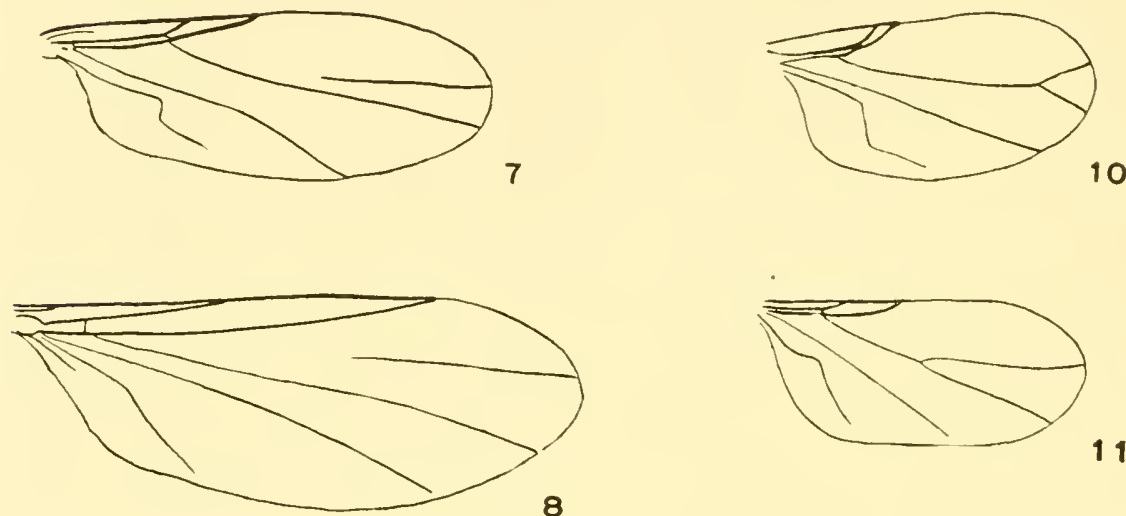

8

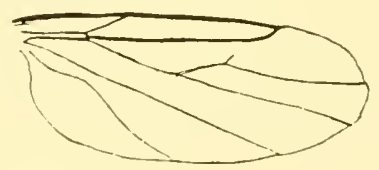

Scatposidæ II.-7, Aldrovandiella; 8, Psectrosciara; 9, Reichertella uncinata; 10, Swammerdamella brevicornis; 11 , Rhegmoclema aterrima; 12, Scatopse notata. (All figures after Melander.) 


\section{Family Rachiceridæ}

Flies of medium size, clongated, rery thinly pilose, resembling sawflies.

Males dichoptic. Empodium dereloped pulvilliform, the pulvilli present. Intemme composed of twenty to thirty-eight segments, often strongly serrate. Squama small or ludimentary. Veins strong; discal cell three times as lomg as wide: fomth posterior eell elosed and petiolate: anal cell closed apically. Legs moderately long.

The only genus belonging to this family is Rachicerus Walker of which only about a score of speeies are known. Six species have been described from the Nearctic region, but one is unreconizable.

The larve are found in deearing wood and are presumed to be predaceous.

Rachicerus has usually been placed in the Rhagionidx (s. 1.) but should no doubt be isolated since the large number of antemal segments, all of which are freely articulate, indieates a more primitive eondition than that accorded even the Conomyiida of the present work.

\section{KEY TO NEARCTIC SPECIES OF RACHICERUS}

1. Antennæ reddish toward the base, pectinate below, the lower processes conspicuously longer than the upper...............

Antenne not reddish basally, the lower processes on the segments short, at most slightly longer than the upper............... 2

2. Mesonotum brownish rellow, sometimes with brown vittæ, never

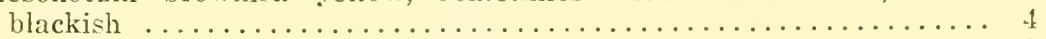

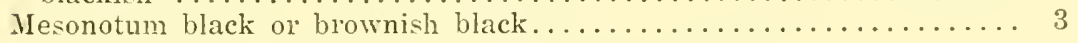

3. Halteres yellow; wings hyaline with a dark median cloud in front;

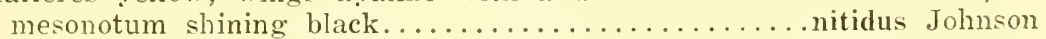

Halteres brownish; wings tinged with brown; mesonotum shining

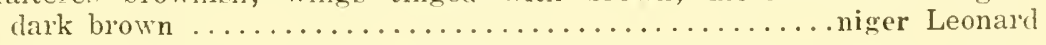

4. Mesonotum without blown vittæ; i antennæ serrate, with 21 or 22 segments, o antemn sub-pectinate below, with 28 to 35 segments.

fulvicollis Haliday

Mesonotum with two broad brown vittæ; antennæ sub-pectinate below, with 22 or 23 segments.............honestus Osten Sacken

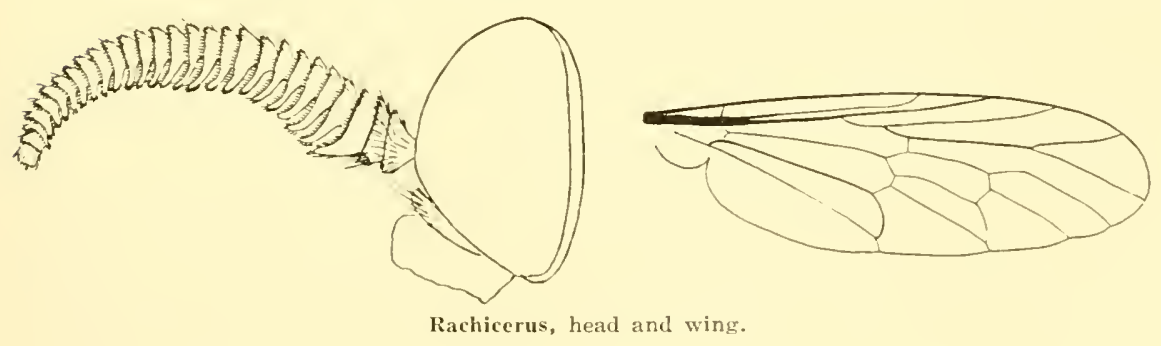




\section{Family Stratiomyidæ-The Soldier Flies}

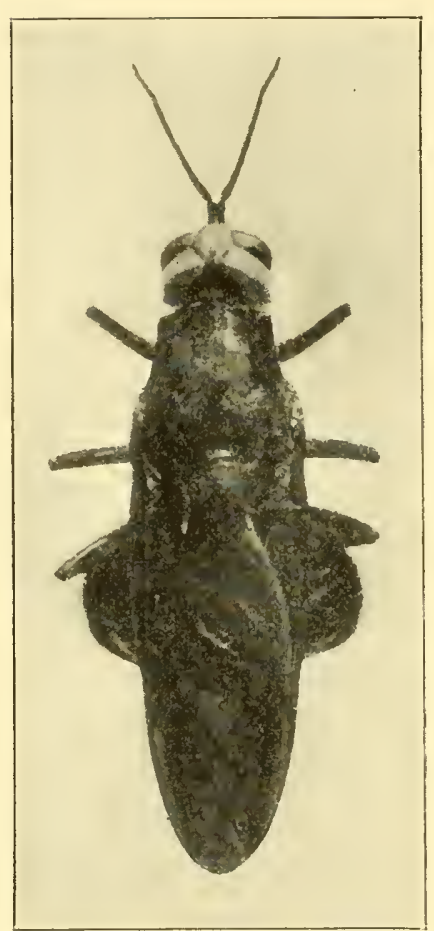

Cyphom yia species.

Small to moderately large, nearls bare or thinly pilose flies, without bristles.

Head usually short, sometimes produced either at or below the antemie, usually wider than the thorax; ocelli present; eyes dichoptic in the females, usually holoptic in the males; proboseis short, never longer than the headheight. palpi two segmented or rudimentary. Antennæ with three to ten segments, the third always ammlate and usually bearing an apical style or arista or a dorsal arista. Thorax never strongly convex, often clongate; scutellum often with spines, tubercles or projections on the margin. Abdomen composed of five to seven segments, variable in shape, sometimes short and rery broad or long and narrow, rarely petiolate. Legs thinly soft haired; pulvilli and empodium padlike, the tibia without spurs. Costal vein not reaching beyond the tip of the wing, the reins crowded anteriorly, the posterior ones weak; discal cell present and of charaeteristic shape; four or five posterior cells and one or two submarginals; anterior branch of third vein short and often indistinct or wanting.

The name "soldier flies" has been given to this family because of their conspicnous markings. Most of the species may be found on flowers, some of them hover, while others may be found on foliage and in long grass near water.

The larve are predaceous or live in decaring vegetation, under bark, in rotting fruit, ete. A few species are confined to the sea coast while others ocenr in fresh water or mud.

I have adopted a number of changes in the nomenclature, and, as I do not use the names proposed in Meigen's "1800" paper" Eutulia does not replace the well-known Odontomyia. The name Stratiomyia is an emendation of the original spelling, Stratiomys, and not only 
changes the spelling but also the meaning. I suspect that Cieoffroy had in mind the monse-like character of the typieal species of the family when he proposed the name, and that he was better aware of his intentions in this eonnection than those who have followed the spelling of Maequart. It is unfortunate that such a well known name as Clitellaria Meigen must be replaced by Adoxomyia for the American species previously listed under Clitellario. The other changes are mostly a return to the original spellings or the realignment of genera based upon struetural characters.

The family is a difficult one, the generie limits being, often, diffieult to define if they actually exist. Unfortmuately I lack representatives of a few of the genera and must rely upon deseriptions, so that some charaeters which might be used have, of necessity, been omitted.

There is great need of a monograph of the American speeies of this family : my synopsis of the Canadian species* may prove helpful but it contains only keys and these are incomplete for most of the genera.

\section{KEY TO GENERA}

1. Abdomen with seven visible dorsal segments $\ldots \ldots \ldots \ldots \ldots \ldots \ldots \ldots 2$ Abdomen with five or six segments ..................

2. Three posterior veins or stumps of veins, the third usually arising from the discal cell ................................... 4 Four posterior veins or vestiges of them, all arising from the discal

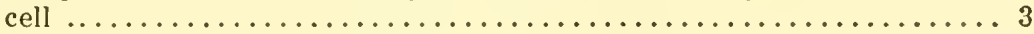

3. Posterior femora thickened ............. Neœxaireta Osten Sacken Posterior femora but little thickened, the posterior tibiæ noticeably thickened $(82) \ldots \ldots \ldots \ldots \ldots \ldots \ldots \ldots \ldots \ldots \ldots \ldots \ldots \ldots \ldots \ldots \ldots \ldots \ldots$ Metina

4. Scutellum with spines or denticulations $\ldots \ldots \ldots \ldots \ldots \ldots \ldots \ldots \ldots$

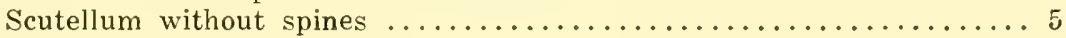

5. Third vein branched $(33) \ldots \ldots \ldots \ldots \ldots \ldots$. . . . . . Third vein not branched $(1,87) \ldots \ldots \ldots \ldots \ldots \ldots$ Chiromyza Wiedemann

6. Scutellum with fewer than ten spines.................... 7 Scutellum with ten or twelve spines or teeth............... 8

7. Head hemispherical; antennæ situated near the middle of the head

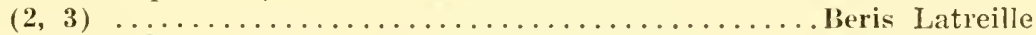
Head not hemispherical; antennæ situated well below the middle of the

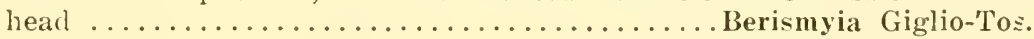

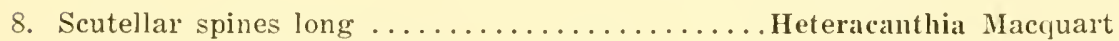
Scutellum with about twelve short teeth ........... Antissops Enderlein

9. Three posterior veins, all arising from the discal cell.............

Four posterior veins, the first and third sometimes vestigial but at least represented by angulations of the discal cell.............22

* Curran, 1927, Tr. Roy. Soc. Can., Sec. v, 1927, pp. 191.228. 

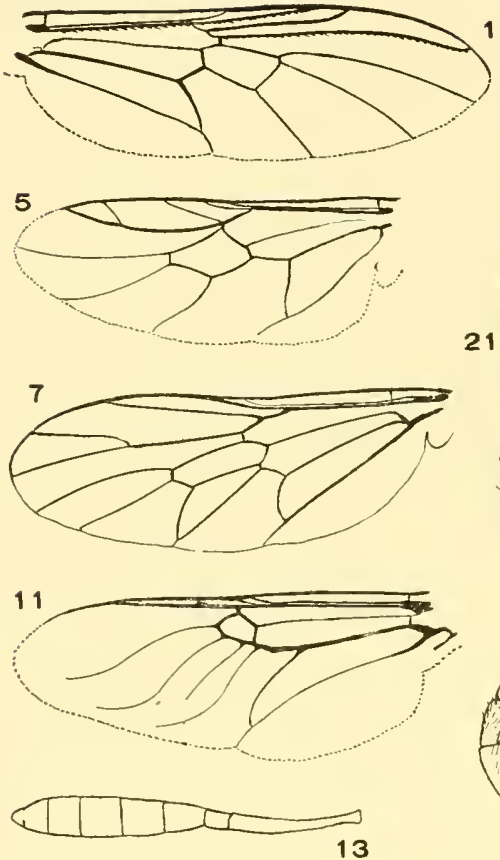

13
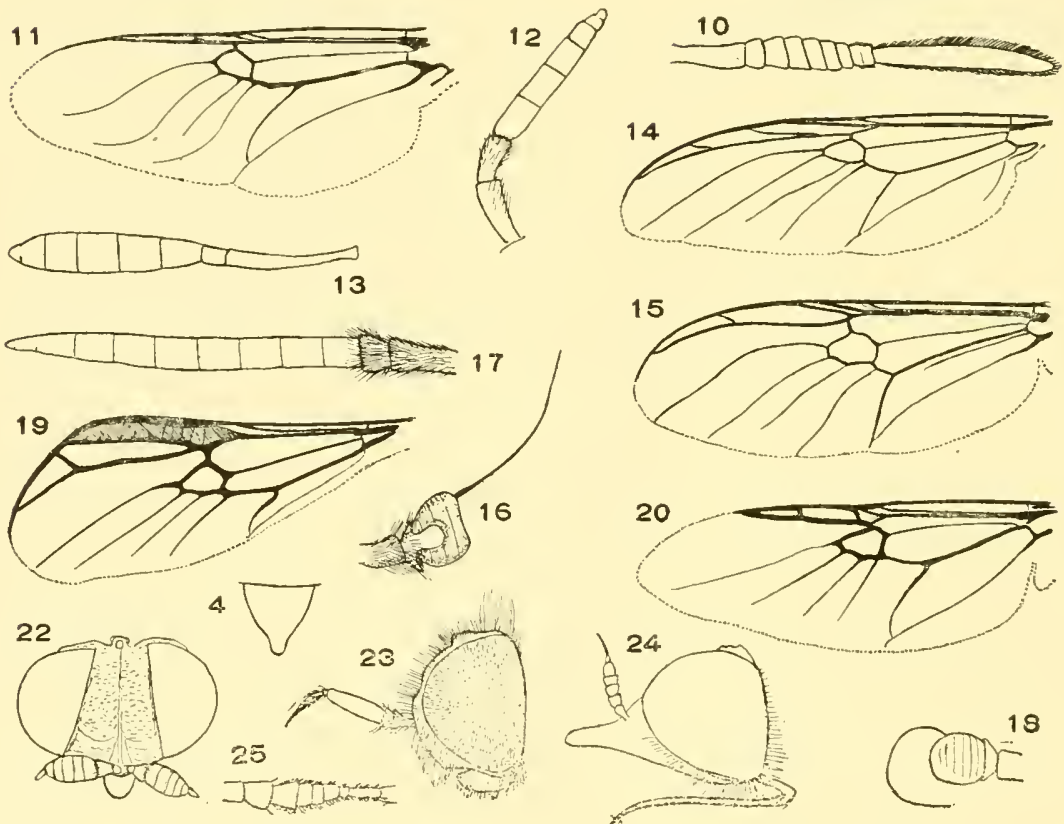

Stratiomyida 1.-1, Chiromyza; 2, Beris; 3, Beris, antenna; 4, Psephiocera, scutellum: 5. Psephiocera, wing; 6, Acanthinomyia; 7, 8. Solva aterrima (Coenomyidæ); 9, Hermetia; 10. Hermetia, antenna; 11, Odontomyia; 12 , Odontomyia, antenna : 13 . Stratiomys, antenna; 14 , Pedicella, antenna; 15, Ptecticus; 16. Ptecticus; antenna ; 17. Cyphomyia, antenna ; 18. Merosargus, antenna; 19, Histiodroma : 20, Euparyphus; 21, Euparyphus, antenna; 22 , Euryneura, head from in front; 23, Pelagomyia; 24, Nemotelus: 25, Aochletus, antenna. 

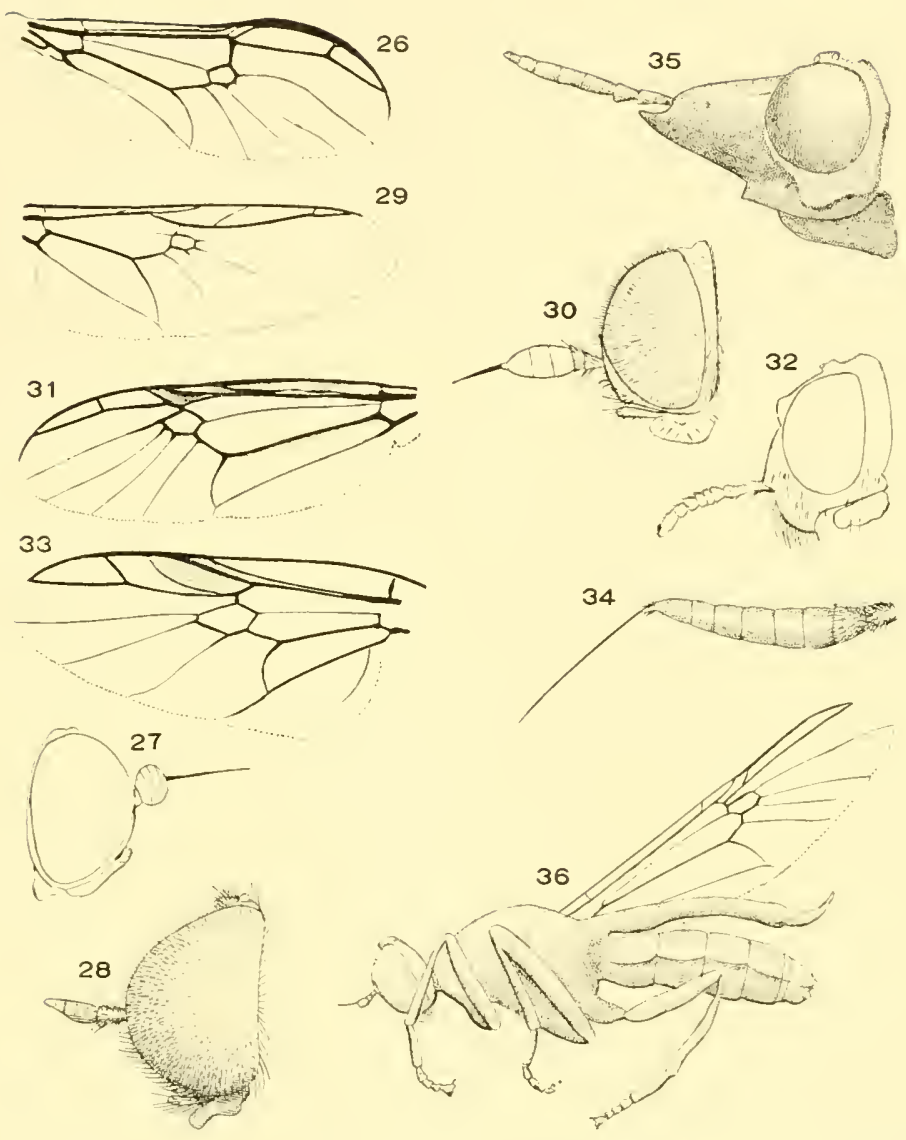

Stratiomyide II. 26, Analcocerus, wing: 27, Neopachygaster; 28. Scoliopelta ; 29, Microchrysa; 30, Euclitellaria; 31. Khaphiocera; 32, Myxosargus; 33, Allognosta; 34, Chrysochlora, antenna; 35, Rhingiopsis; 36, Dicranophora (Brazil). 

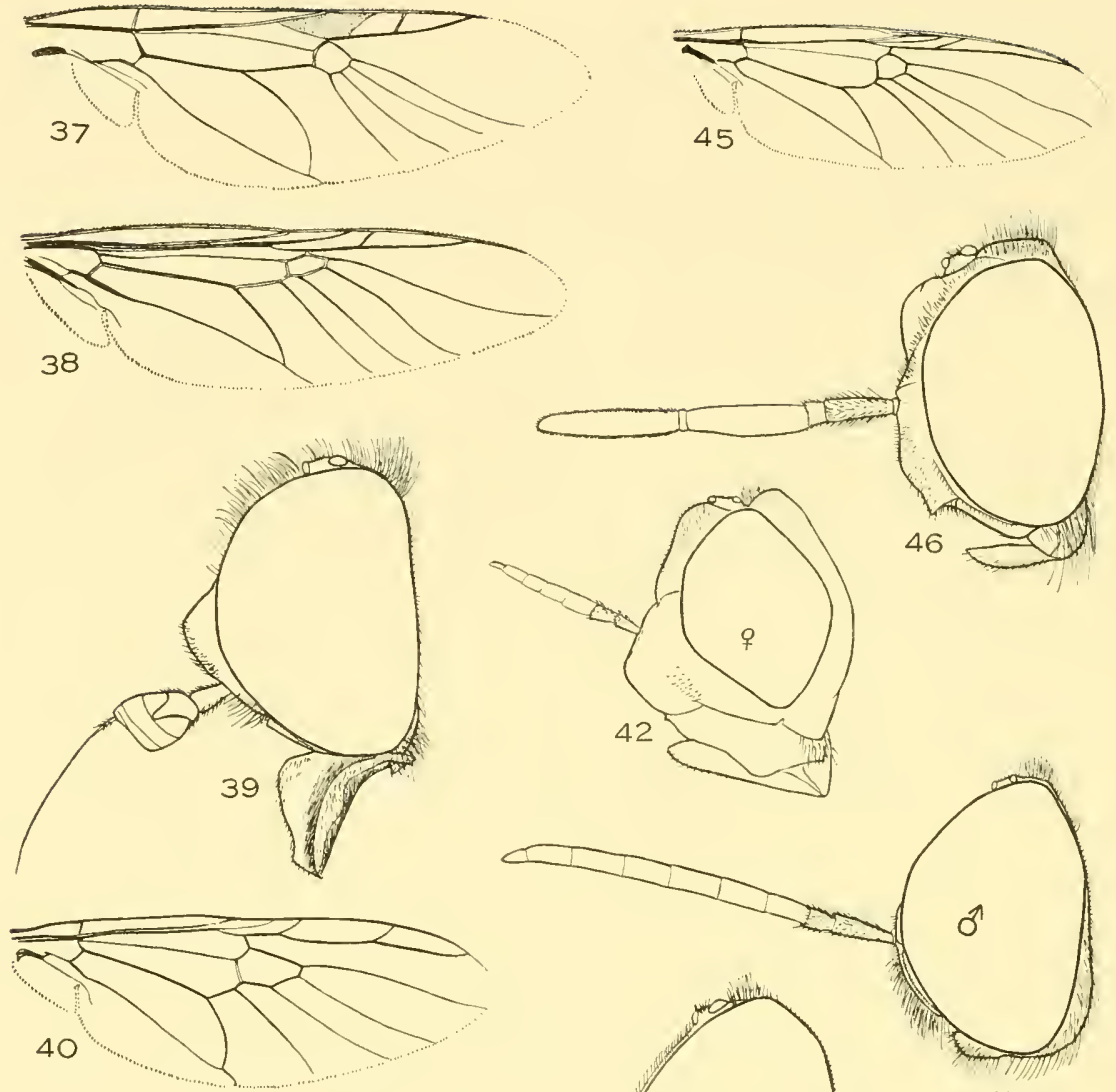

42
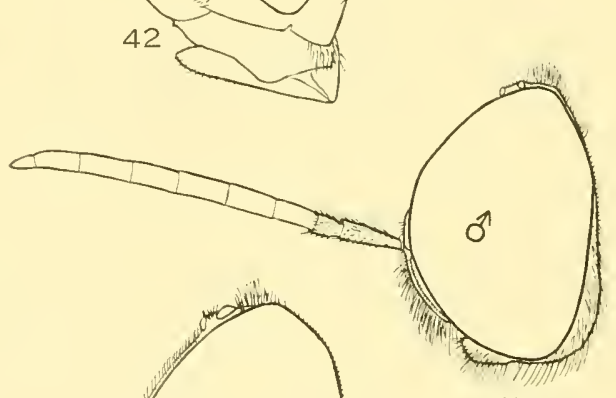

47
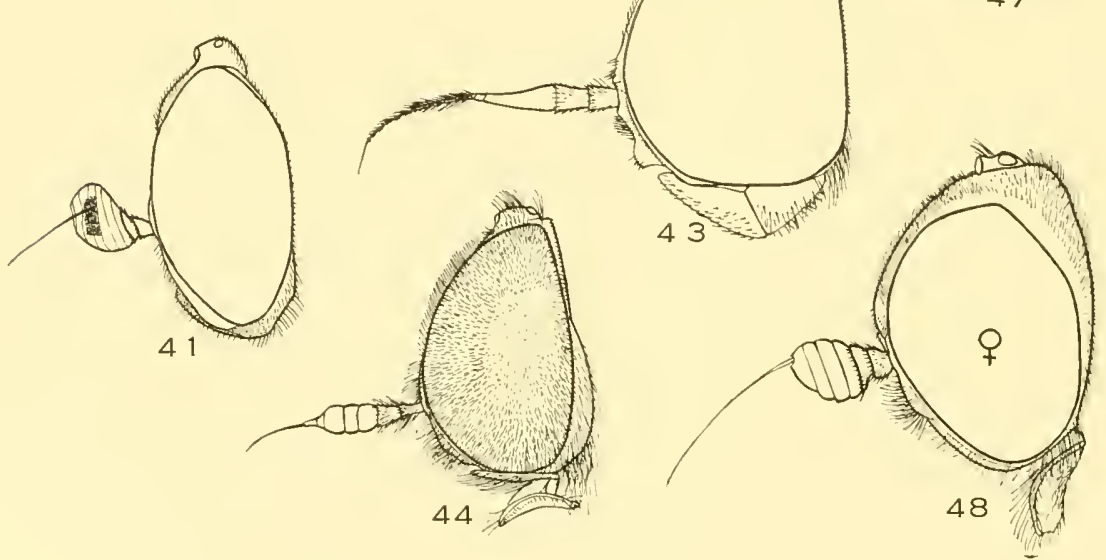

Stratiomyide III.-37, Oxycera albovittata; 38, Rhingiopsis rostrata; 39, Ptecticus testaceus; 40. Neorondania chalybea; 41, Gowdeyana mirabilis; 42, Odontomyia (sp). Panama): 43. Cacosis; 44, Euclitellaria; 45, Chrysochroma nigricornis; 46, Hermetia (n. su. Panama) : 47. Cyphomyia; 4s, Microchrysa polita. 
10. Antennæ situated at most a little below the middle of the head in pro-

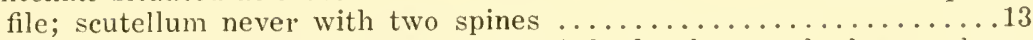
Antennæ situated far below the middle of the head, near the lower edge of the eyes; scutellum with at least a pair of spines.............11

11. Third antennal segment not furcate; scutellum bispinose...........12 Third antennal segment furcate, the upper branch with a terminal arista and a lateral process $(72,78) \ldots \ldots \ldots \ldots \ldots \ldots$ Neochauma Williston

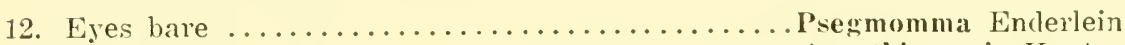
Eyes pilose $(6,86) \ldots \ldots \ldots \ldots \ldots \ldots \ldots \ldots$ Acanthinomyia Hunter

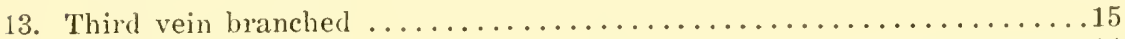

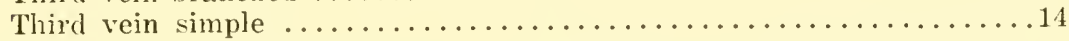

14. Third antemnal segment elongate $(5.5,56)$.

Berkshiria Johnson Third antennal segment short, as broad as long $(54,58)$.

Zabrachia Coquillett

15. Third antennal segment elongate.........................

Third antemnal segment as wide as long or nearly so............

16. Scutellum prolonger and obtusely pointed, without conspicuous rim on

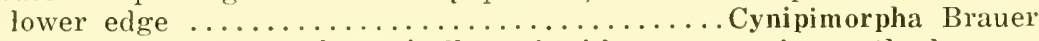
Scutellum broadly rounded apically and with a strong rim on the lower margin $(55,56) \ldots \ldots \ldots \ldots \ldots \ldots \ldots \ldots \ldots$ Berkshiria Johnson

17. Scutellum prolonged, its sides more or less parallel apically or triangular with a very broad preapical depression, the lower edge not margined $(4,5,60) \ldots \ldots \ldots \ldots \ldots \ldots \ldots \ldots \ldots$. . . . . Scutellum rounded apically, its lower edge sometimes very strongly

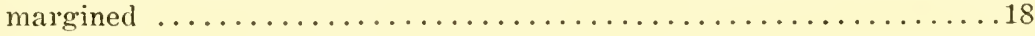

18. Arista short plumose or with very long pubescence of isolated hairs

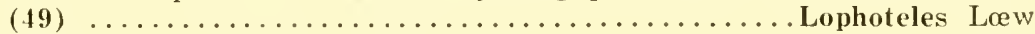

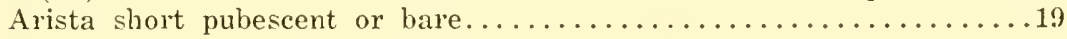

19. Antennæ arising at most slightly below the middle of the head.......20 Antennx arising conspicuously below the middle of the head (61).

Pachygaster Meigen

20. Scutellum with a strong marginal rim below.................... Scutellum with at most a very weak rim below $(27,57)$.

Neopachygaster Austen

21. Rim of scutellum strongly serrate $(62) \ldots \ldots \ldots{ }^{*}$ Eupachy gaster Kertesz Rim of scutellum so finely serrate as to appear smooth except under high magnification $(41,51) \ldots \ldots \ldots \ldots \ldots$. Gowdeyana Curran

22. All the posterior veins arise from the discal cell.............. The fourth posterior vein arises from the second basal cell..........39

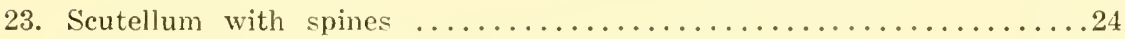

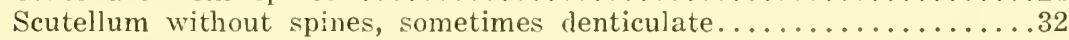

* I have not seen the type of this European genus and it may be that the species described by Malloch as belonging here belongs to Vittiger Kertesz. 

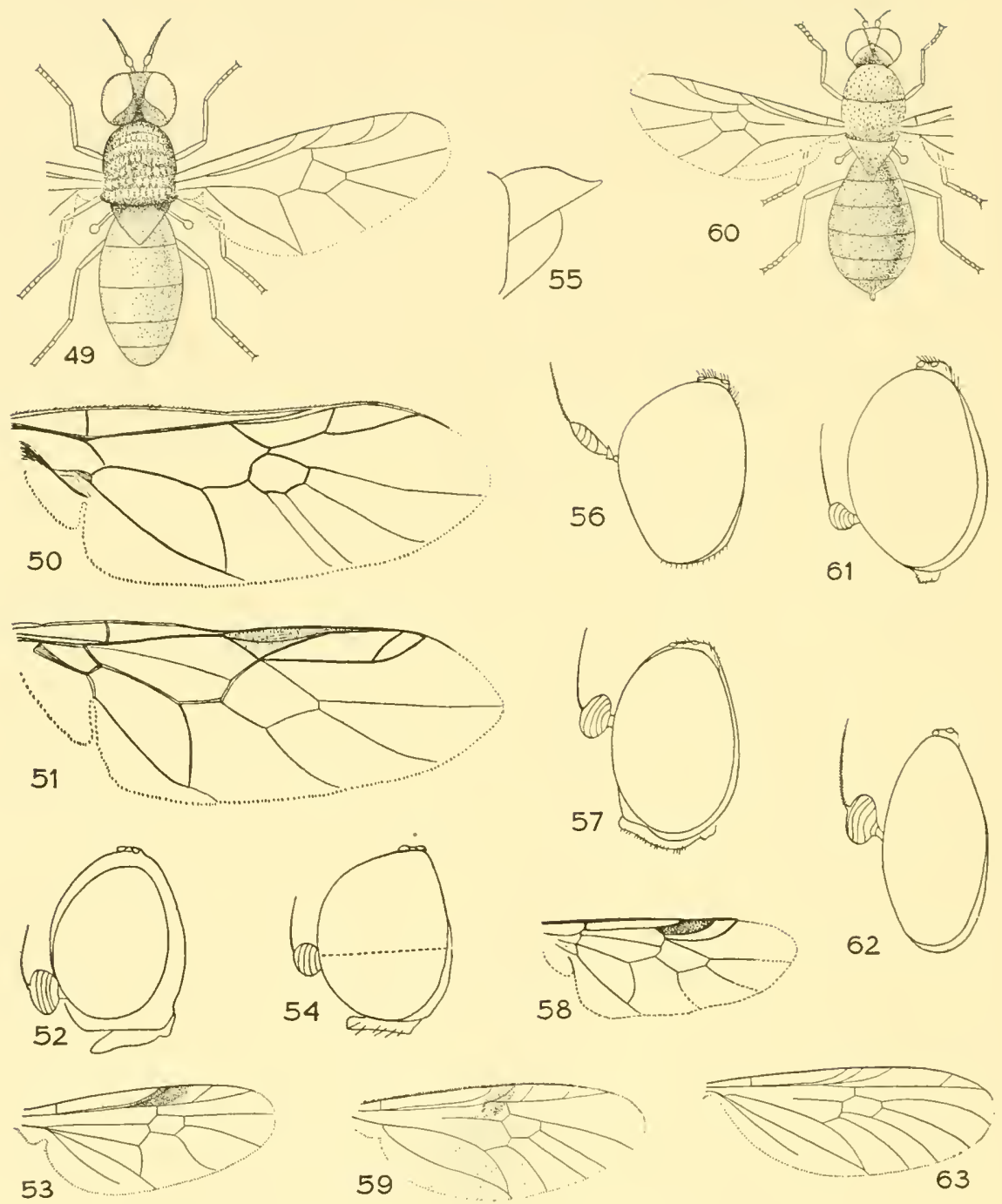

Stratiomyidre IV, -49 , Lophoteles pallidipennis, after Williston; 50 , Neurota tricolor: 51. Gowdeyana mirabilis; 52 , Zabrachia polita +53 , Berismyia nigrofemorata; 54 , Zabrachia polita $0^{x} ; 55$, Berkshiria, scutellum: 56, Berkshiria; 57, Neopachygaster maculicornis; 58 , Zabrachia polita: 59, Gyneuryparea lasiophthalmus ; 60, Psephiocera minuta, after Williston ; 61 , Brachygaster pulcher; 62, Eupachygaster punctifer; 63 , Merosargus bulbifrons. 
24. Antennæ short, with a sub-terminal arista $(37,81) \ldots$ Oxycera Meigen

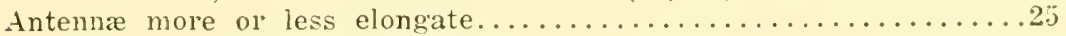

25. Antennæ inserted near the middle of the head.................

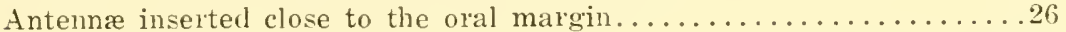

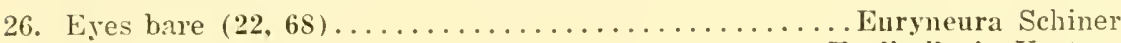
Eyes pilose $(30) \ldots \ldots \ldots \ldots \ldots \ldots \ldots \ldots \ldots \ldots \ldots \ldots \ldots \ldots \ldots \ldots$ Euclitellaria Kertesz

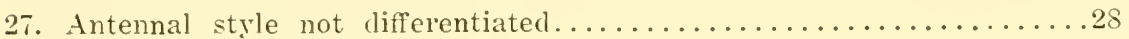
Antennal style distinctly difierentiated........................ 30

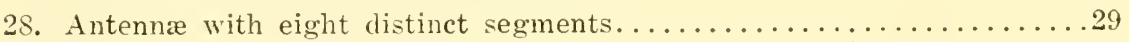
Antennæ with three segments, the third annulate (28).

Scoliopelta Williston

29. Second antennal segment twice as long as the first......Glaris Kertesz Second antennal segment not longer than the first $(\mathbf{2 0}, \mathbf{2 1}, \mathbf{9 0})$.

Euparyphus Gerstæcker

30. Eyes bare (Clitellaria auct).................. Adoxomyia Kertesz

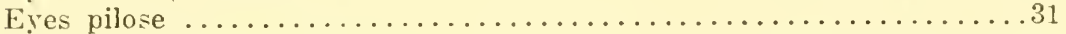

31. Third vein branched $(14,65) \ldots \ldots \ldots \ldots \ldots \ldots$ Euclitellaria Kertes $z$ Third vein simple $(25) \ldots \ldots \ldots \ldots \ldots \ldots$....................... Osten Sacken

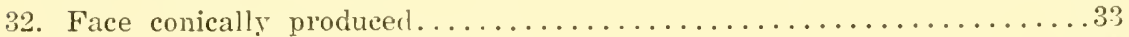

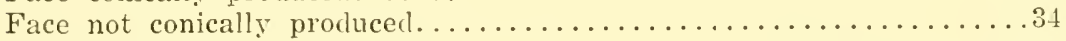

33. Males holoptic $(24,64) \ldots \ldots \ldots \ldots \ldots \ldots \ldots \ldots$ Nemotelus Geoffroy

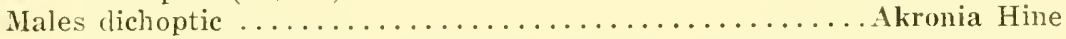

34. Antennal style almost as long as the third antennal segment, quite flat and shining; the thin sides densely fringed with long pubescence $(9,10,46) \ldots \ldots \ldots \ldots \ldots \ldots \ldots \ldots \ldots \ldots \ldots \ldots \ldots \ldots \ldots \ldots$ Hermetia Latreille Antennal style different in structure or the antennæ with an arista....35

35. Eyes pilose on practically the whole surface................. Eyes bare, or very thinly pubescent on the upper half only...........

36. Antennæ with a bristle-like style (23)...........Pelagomyia Williston Antennal style not well differentiated........................

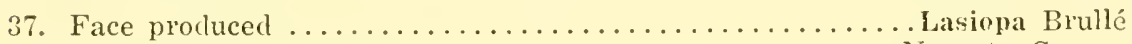
Face recerling $(50,66) \ldots \ldots \ldots \ldots \ldots \ldots \ldots \ldots \ldots \ldots \ldots \ldots \ldots \ldots \ldots \ldots$ Neurota Curran

38. Arista apical and clensely plumose on basal half or more $(43,81)$.

Cacosis Walker Arista apical but bare $(34,91) \ldots \ldots \ldots \ldots \ldots *$ Chrysochlora Latreille

39. Third antennal segment without an arista, the style absent or but poorly differentiated, rarely short and bristly ............... 40 Third antennal segment with an arista.......................

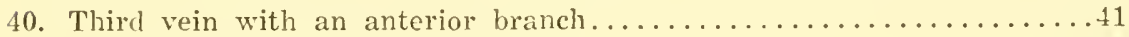
Third vein without anterior branch....................... 44

41. Hearl strongly produced anteriorly and with a porrect spine or protuberance below the antennæ $(35,38,83) \ldots \ldots \ldots+$ Rhingiopsis Röder Hearl not produced, the face sometimes produced conically downward. . .42

* Curran, 1929, Amer. Mus. Novitates No. 339, 1) 2.

$\dagger$ Curran, 1932, Amer. Mus. Novitates No. 526, p. 1. 


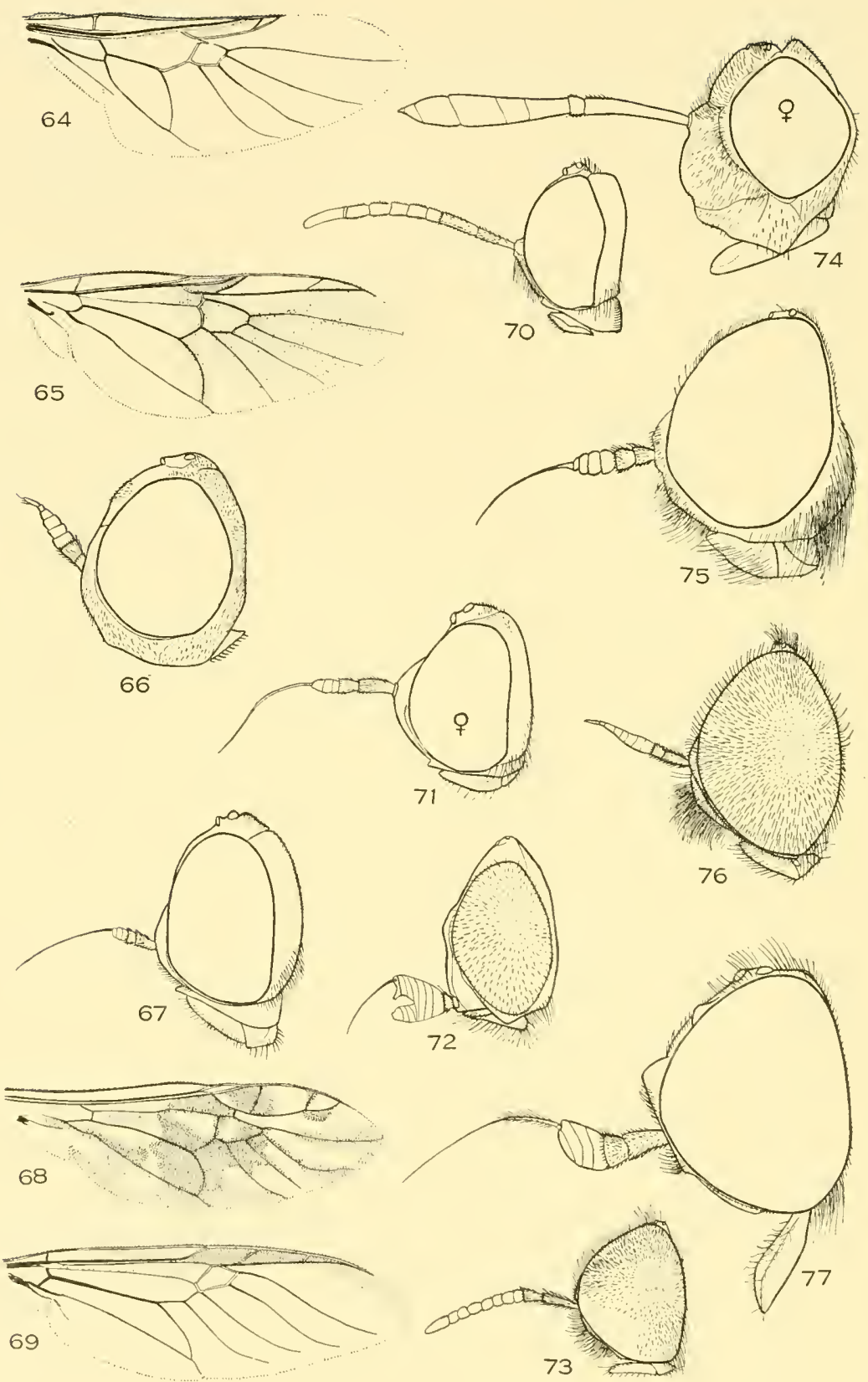

Stratiomyidæ V.-64. Nemotelus arator; 65. Euclitellaria subulata; 66 . Neurota tricolor; 67. Rhaphiocera armata; 68, Eurymeura panamensis, n. sp. ; 69, Premeransa nasuta; 70, Analcocerus: 71, Histiodroma inermis; 72 , Neochauna; 73 , Chordonota: 74 . Strationys mutabilis; 75. Nothomyia calopus; 76 . Gyneuryparea lasiophthalmus; 77 , Aloipha cingulatus. 


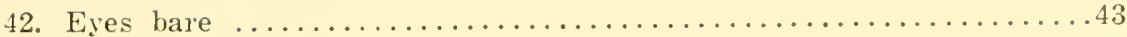

Eyes thickly pilose in the $\sigma^{*}$, pilose on lower half in $f(59,76)$.

Gyneuryparia Enderlein

43. Antenna situated near the lowest level of the eyes (32).

* Myxosargus Brauer Antennæ situated near the middle of the eves in profile $(17,47)$.

Cyphomyia Wiedemann

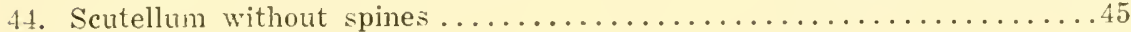

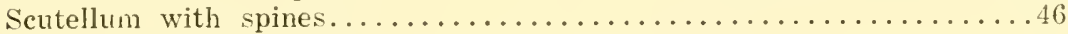

45. Third antennal segment with eight annuli $(73,80)$.. Chordonota Gerstæcker Third antennal segment with five or six anmuli $(11,12,42)$.

Odontomyia Meigen

46. Costa not thickened distally ............................. 47 Costa strongly thickened distally $(26,70) \ldots \ldots \ldots$ Analcocerus Loew

47. Third antennal segment composed of seven or eight annuli........50 Third segment composed of not more than six annuli.............48

48. Head very strongly produced forward, the face strongly receding $(69,85)$.

Promeranisal Walker Head rarely produced forward, if so the antennal prominence not con-

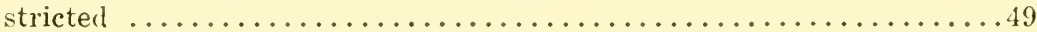

49. First antennal segment three times as long as the second $(13,74,79)$. $\doteqdot$ Stratiomys Geoffroy First segment less than three times the length of the second $(11,12,42)$.

Odontomyia Meigen

50. First antennal segment two or three times as long as the second.

Campeprosopa Macquart First antennal segment but little longer than the second, the third terminating in a bristle $(40) \ldots . . . \ldots . .$. . Neorondania Osten Sacken

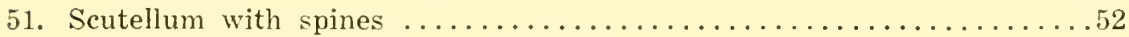

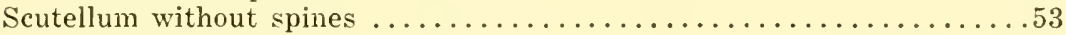

52. Third vein not furcate $(\mathbf{7 5}) \ldots \ldots \ldots \ldots \ldots \ldots \ldots \ldots \ldots$ Nothomyia Lœw Third vein furcate $(31,67) \ldots \ldots \ldots \ldots \ldots \ldots$ Raphiocera Macquart

53. Space between the second vein and the costa chitinized, the costa expanded on the apical half $(19,71) \ldots \ldots \ldots \ldots \ldots$.............

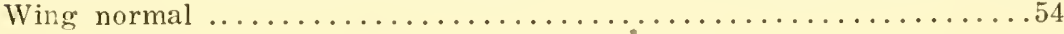

54. Arista terminal, thick and long pubescent on the basal fourth.

Acrocheta Wielemann Arista terminal or dorsal, normal in shape and practically bare......55

55. Lower lobe of the squamæ with a strap-like prolongation near the outer

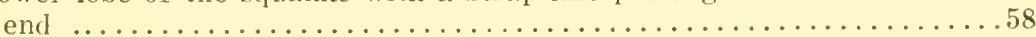

Lower lobe of squamæ transverse apically ................ 56

* Curran, 1929. Amer. Mus. Novitates No. 378.

$\dagger$ In a fortheoming contribution Ml. M. T. James will propose a new genus for $S$. constans, mutabilis, etc. 

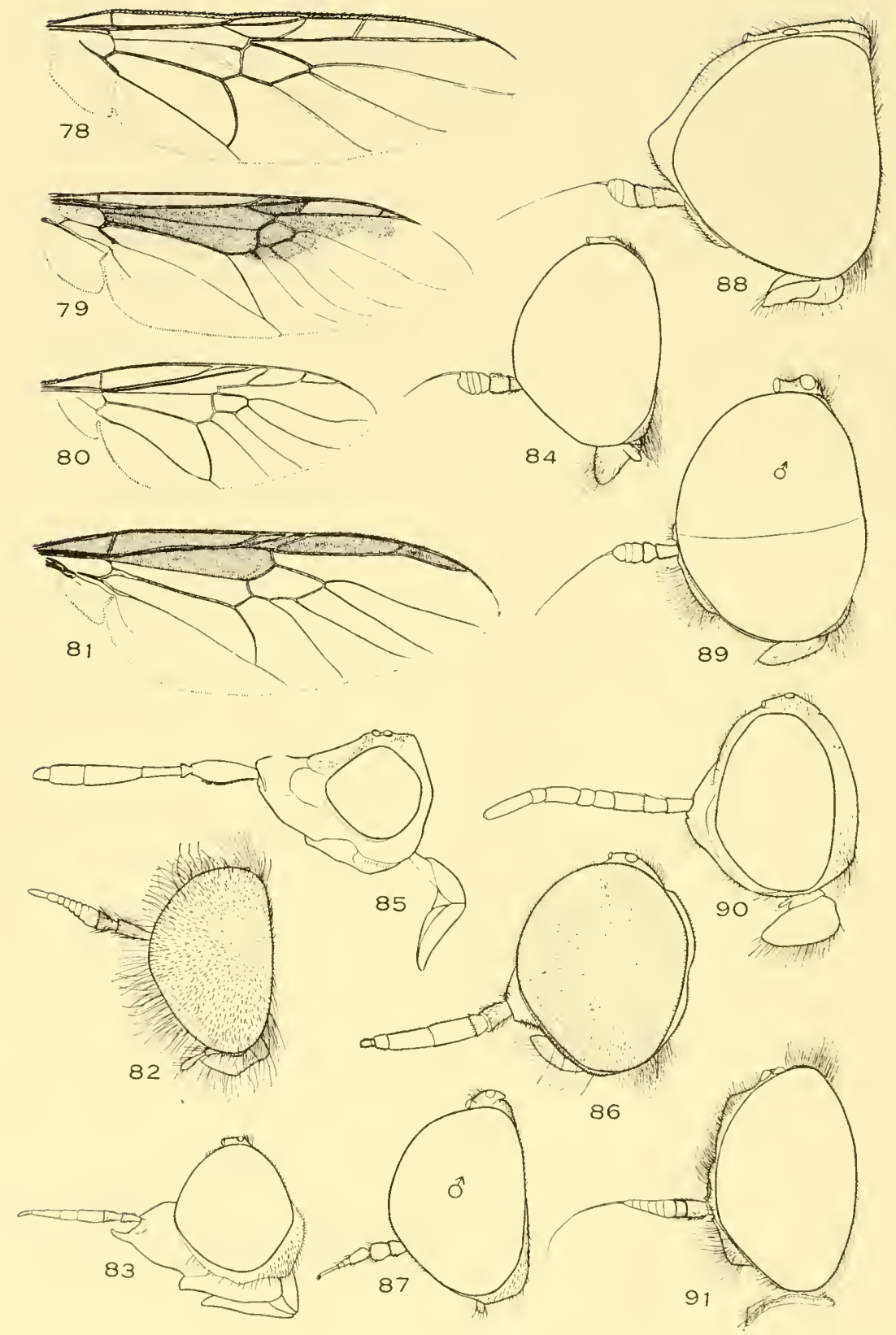

Stratiomyidx VI-78, Neochauna; 79, Stratiomys mutabilis; 80 , Chordonota carbonaria : 81. Cacosis nigra; 82, Actina viridis: 83, Rhingiopsis rostrata; 84 , Oxycera albovittata; 85 , Promeranisa nasuta; 86 . Acanthinomyia; 87 . Chiromyza; 88 , Pedicella lucens; 89, Chrysochroma nigricorıis; 00 , Euparyphus; 91, Chrysochlora. 
56. Third vein with a branch near the end of the first vein...........57 Thirl vein without the basal branch $(77) \ldots \ldots \ldots \ldots$. Aloipha Enderlein

57. Second antennal segment surbtriangularly produced into the third on the inner side $(15,16,39) \ldots \ldots \ldots \ldots \ldots \ldots \ldots \ldots \ldots$. . . .

Second antennal segment at most moderately convex on its inner end, never subtriangular $(18,63) \ldots \ldots \ldots \ldots \ldots \ldots \ldots$ Merosargus Lœw

58. Ocellar triangle situated far from the vertex and almost or quite twice as long as wicle $(14,88) \ldots \ldots \ldots \ldots \ldots \ldots \ldots \ldots$ Pedicella Bigot

Ocellar triangle not or but little longer than wide, in the female partly behind the upper angles of the eyes, in the male usually somewhat in front of this point................................... 59

59. Ocellar triangle in female lying almost all in front of the posterior angle of the eyes, the males without the eyes divided into definite zones of differently sized facets; anal cell much narrower than the combined basal cells $(45,89) \ldots \ldots \ldots \ldots \ldots$ Chrysochroma Williston

Ocellar triangle in female lying mostly behind the posterior angles of the eyes; males with the facets enlarged on the upper half; anal cell quite as wide as the combined basal cells $(29,48) \ldots$ Microchrysa Low

* Curran, 1932, Amer. Mus. Novit. No. 534. 


\section{Family Cœnomyiidæ}

Flies of medium to large size, the antennæ clongate, with the third segment annulate and more or less elearly subdivided.

Males holoptie or diehoptic. Antennæ never with a distinetly differentiated style although the terminal annulus may resemble one to a certain extent. Empodium developed pulvilliform, the pulvilli present. Squamæ small. Wing venation well developed, the diseal cell always present, the fourth posterior eell sometimes closed.

As here defined this family includes inseets of diverse structure but there seems to be no good character for their separation. The genus $C x$ nomyia has been placed in various families, including the Rhagionide, Tabanidx and Stratiomyidx. It appears, however, because of the facial structure, to be best placed between the two last mentioned families. Upon general strueture alone Conomyia might well be isolated from the remainder of the other ineluded genera except that Arthropeas magnus Johnson is very similar in appearance, differing only in having bare eyes and in lacking the scutellar spines.

The adults are found in woods, especially near moist places, while the larve mostly occur in decaying wood, under the bark of trees or in the soil and are carnivorous and predaceous. The opinion has been expressed that the larve of Canomyia may live upon the immature stages of Cieadas. A revision of the North Ameriean speeies will be found in Leonard" "Revision of the Rhagionidx in the United States and Canada."

I might add that I cannot agree that the genus Solv'a Walker belongs to the Stratiomyidæe although there is no doubt that there is some relationship. Both the facial shape and wing venation exelude it from that family.

\section{KEY TO GENERA}

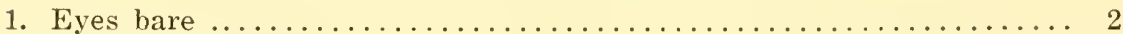
Eyes pilose $(9,11) \ldots \ldots \ldots \ldots \ldots \ldots \ldots \ldots \ldots \ldots \ldots$ Conomyia Latreille

2. Anterior tibiæ with one terminal spur.................. 3 Anterior tibiæ without terminal spur..................... 4

3. Antennæ acute at the tip, the apical annulus elorgate $(1,8)$. Arthropeas Lnw Antennæ obtuse at the tip, the apical annulus short and broad $(3,7)$.

$\doteqdot X y l o p h a g u s$ Meigen

4. Fourth posterior cell open ....................... 5 Fourth posterior cell closed $(5,12) \ldots \ldots \ldots \ldots \ldots \ldots$. Solva Walker

5. Face with a very large, prominent pilose swelling on either side $(2,10)$.

Glutops Burgess Face not strongly swollen laterally, bare $(4,6) \ldots$ Arthroceras Williston

* 1930. Mem. Amer. Ent. Soc., No. 7.

$\dagger$ Curran, 1933. Amer. Mus. Novitates No. 673, p. 1. 

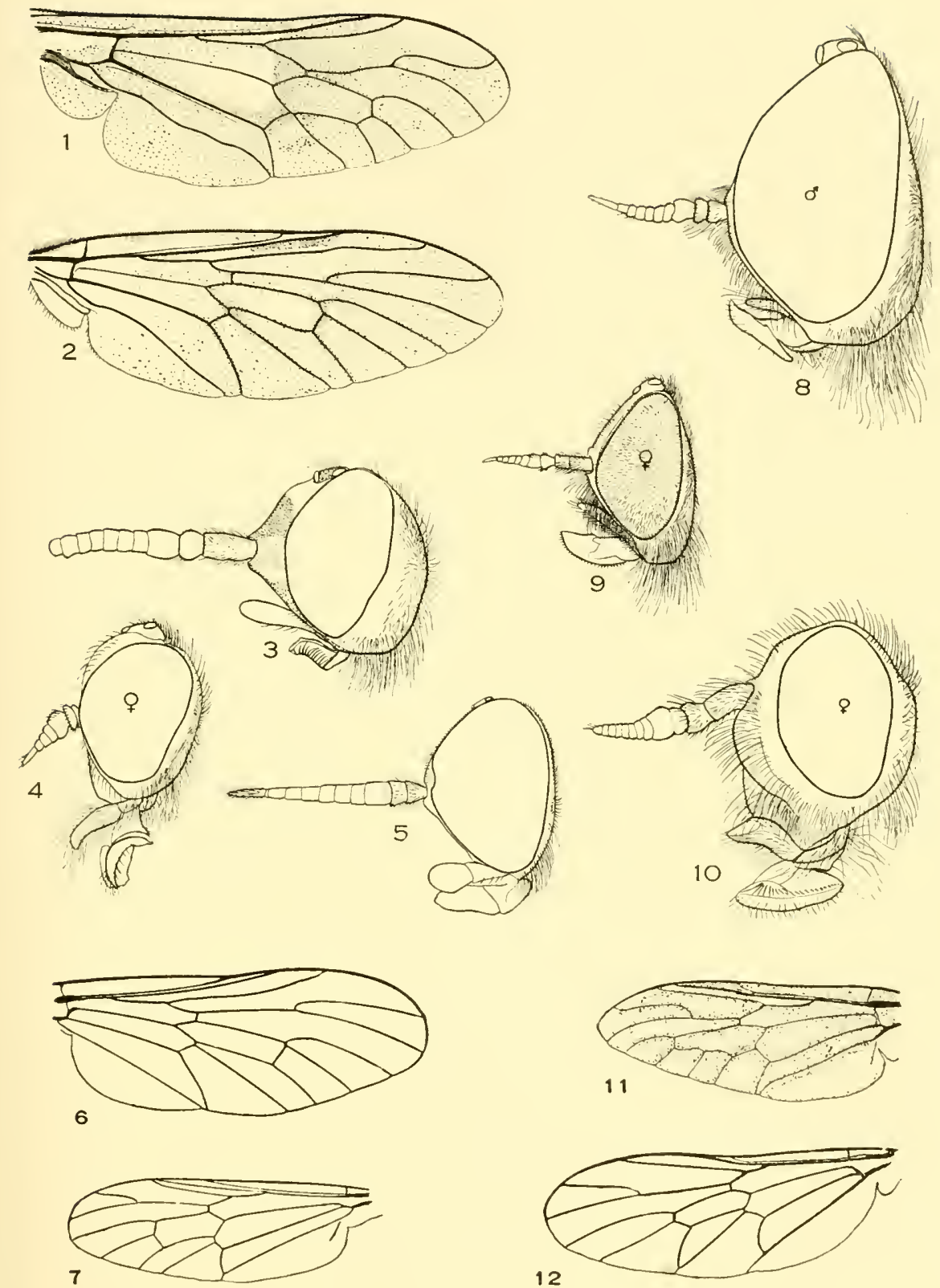

Coenomyiidar,-1, Arthropeas magnus; 2, Glutops singularis; 3, Xylophagus laceyi: 4, Arthroceras leptis; 5, Solva aterrima; 6. Arthroceras: 7 , Xylophagus; 8 , Aithropeas magnus; 9. Cenomyia pallida; 10. Glutops singularis; 11, Conomyia pallida; 12, Solva. 


\section{Family Tabanidæ-The Horse Flies}

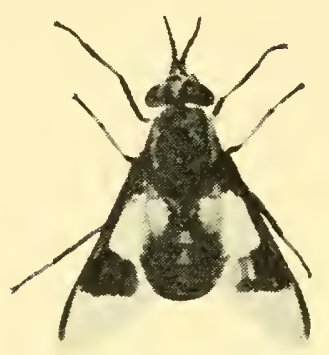

Chrysops species.

Bristleless flies of medium to large size, the eyes usually bi-colored in life.

Head large, the occiput flattened or concave. Eyes large, short pilose or bare, usually holoptic in the males and often with some of the facets much larger than the others; ocelli present or absent. Proboseis projecting, sometimes longer than the body; palpi with two segments, the second segment variable in different genera and sometimes in the two sexes. Antenux porrect, composed of three segments, the third composed of three to eight annuli. Thorax and abdomen clothed with fine hairs. Abdomen broad, composed of seren visible segments; genitalia never prominent. Legs moderately stout, the tibire sometimes much dilated; middle tibiæ always with two spurs at the tips; empodium developed pulvilliform, the pulvilli always present. Wings with two submarginal and five posterior cells; basal cells large; anal cell usually closed near the wing margin; costa extending around the entire wing. Squamæ large.

The Tabanids are common in all parts of the world. They have been given various common names, such as Horse Flies, Deer Flies, Greenheads, Bullheads, ete. The adults of most species are serious pests of mammals and man is not excepted. One type of filariasis is transmitted by the adults and both the fly and host are essential in the life cycle of the parasite causing the disease. One of the best ways of collecting these insects is to capture those causing irritation during collecting trips. Since the larva of many species are aquatic the adults may usually be found near water and in the ease of some species the males are rare except adjacent to the breeding places, and, as this sex does not suck blood they must be looked for in places other than in the vieinity of warm blooded animals, the same being true for most of the genera of the Pangoniinx, although the genus Chrysops of this 
subfamily contains some of the most serious pests of man. The males of some species feed upon pollen and neetal and may be found upon most melliferous flowers, hovering orer streams or pools or eren along paths. The sexes are frequently rery different in appearance and difficult to associate.

The transmittal of disease by Tabanids may be a purely mechanieal operation or the flies may serve as intermediate hosts of the parasitic organisms causing disease. Tularemia is spread mechanically and is transmitted by Chrysops discalis Williston. Normally it is a disease of rodents (particularly rabbits) but man sometimes develops the disease after being bitten by the fly. It has also been demonstrated that Anthrux may be earried on the proboseis of Tabanids and eause infection as a result of the bite of the fly and various species of trypanosomes are transmitted. In Africa a filarial disease caused by Lou loa Cobbald, and known by that name, is transmitted by two species of Chrysops. The details have been worked ont by A. and S. A. Commal (Trans. Roy. Soe. Trop. Med. Hỵg., xr, plr. 131-134, 1913).

The eggs are laid, as a rule, in large masses on leaves and stems of plants overhanging water and are usually brown or black in eolor. 'They show eharacteristie generic arrangement and sometimes specifie characters but too little is known about them to permit of their identification. The larra are predaceous. Larve have been found in rotten wood. under stones, in mud, ete. Pupation takes places near the surface of the soil. There are many papers dealing with the biology of North American Tabanida, hut most of them are quite short. Papers by Cameron* and Narehandt on the immature stages are the most comp)ehensive.

The number of species of Tabanitla is large, the genus Tabanus alone containing about 1200 deseribed speeies. The first (and only) North Ameriean monograph of the family was published by Osten Sacken in 1875 and 1878 . Since that time the number of species has greatly inereased and the difficulty of identifying speeimens is relatively greater. Hine has published on the Tabanidx of Ohiot, while there are numerons short papers seattered through the literature.

Fascicle 175 of "Fenera Insectorum", by lor. .J. Surcouf, deals with this family but the treatment has been rather unfarorably criticized by other workers in the field. Serelal American students are now studying the family and excellent revisions of the nearetic species may be expected to appear in the near future.

\footnotetext{
* Cameron, 1926. Bull. Ent. Res., xvii, pp. 1-42, 5 plates,

¿ Marchand, 1920, Mon. Rockefeller Inst. Med. Res., No. 13, n'. 1-203, 15 plates.

\$ Hine, 1903, Ohio State University Bulietin, Ser. 7 . No. 19.
} 


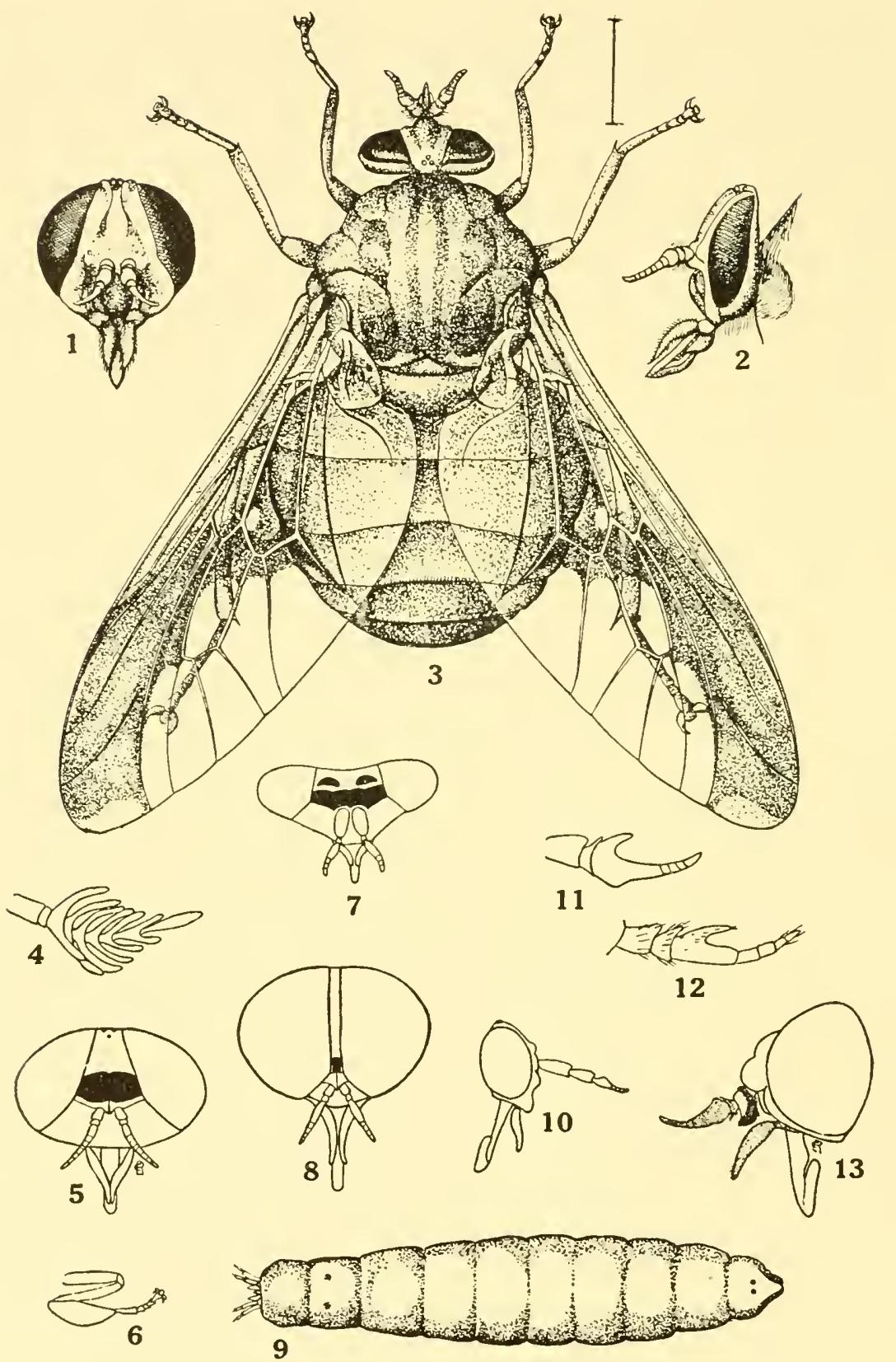

Tabanidx I-1, 2, 3, Goniops chrysochroma; 4, Pityocera, antenna; 5, Apatolestes: 6 , Lepiselaga crassipes; 7, Hæmatopota punctulata; 8, Diachlorus; 9, Goniops chrysochroma, larva: 10 , Chrysops: 11,12 , Tabanus, antenna ; 13 , Snowiellus. 


\section{KEY TO GENERA*}

1. Hind tibire with apical spurs, which may be quite small (Pangoniinæ) 2 Hind tibiæ without apical spurs (Tabaninæ) $\ldots \ldots \ldots \ldots \ldots \ldots \ldots \ldots \ldots$

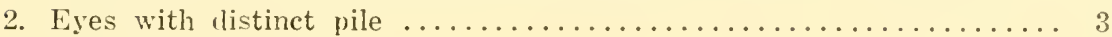

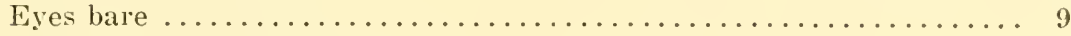

3. First posterior cell open........................ 4

First posterior cell closed........................ 5

4. Face not produced, at most slightly convex (Osca Walker) (22).

Scaptia Walker Face much produced, snout-like ............. Neopangonia Ad. Lutz

5. Fourth posterior cell closed $(15,20) \ldots \ldots \ldots \ldots \ldots \ldots$. . . . . W Walker Fourth posterior cell open......................... 6

6. Third antennal segment furcate.................... 7

Third antennal segment not branched................... 8

7. Third antennal segment branched.dorsally and ventrally (4).

Pityocera Giglio-Tos

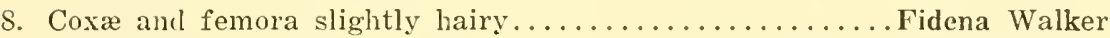
Coxæ and femora densely covered with long pile (Erephopsis Rondani)

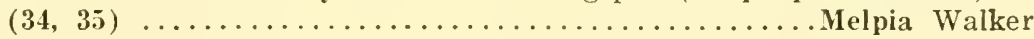

9. First posterior cell closed; face merely convex, not snout-like; ocelli present; palpi long, sabre-shaped $(25,29) \ldots \ldots \ldots$ Esenbeckia Rondani

First posterior cell open.......................... 10

10. Third antennal segment composed of at least seven annuli.........11 Third antennal segment composed of not more than five annuli; pro-

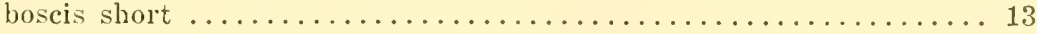

11. Posterior border of eye acutely angulate in female; proboscis very short; fork of third longitudinal vein without appendix; wings brownish in front, hyaline behind $(1,2,3,9) \ldots \ldots \ldots$ Goniops Aldrich Eyes of female not acutely angulate above; wings not so marked.... 12

12. Proboscis but little longer than palpi; frons of female very wide below; fork of third longitudinal vein with appendix (5)....Apatolestes Williston

Proboscis much longer than palpi; frons of female narrow and almost parallel-sided $(31,33) \ldots \ldots \ldots \ldots \ldots \ldots \ldots \ldots \ldots \ldots$ Buplex Austen

13. Second antennal segment only half as long as the first $(\mathbf{1 6}, 26)$.

Silvius Meigen

Second antennal segment much more than half as long as the first.... 14

14. Abdomen inflated, much wider than thorax; fork of third longitudinal vein with long appendix............................ Weosops Walton

Abdomen normal, depressed, not much wider than thorax; fork of third longitudinal vein without appendix $(10,19) \ldots \ldots \ldots$ Chrysops Meigen

* Checked by Dr. J. Bequaert.

† Föher, 1926. Stctt. Ent. Zeitung, Ixxxvii, pp. 211-353, two plates; and, Neotropical. 1925, Konowia, iv, py. 210-375, five plates. 

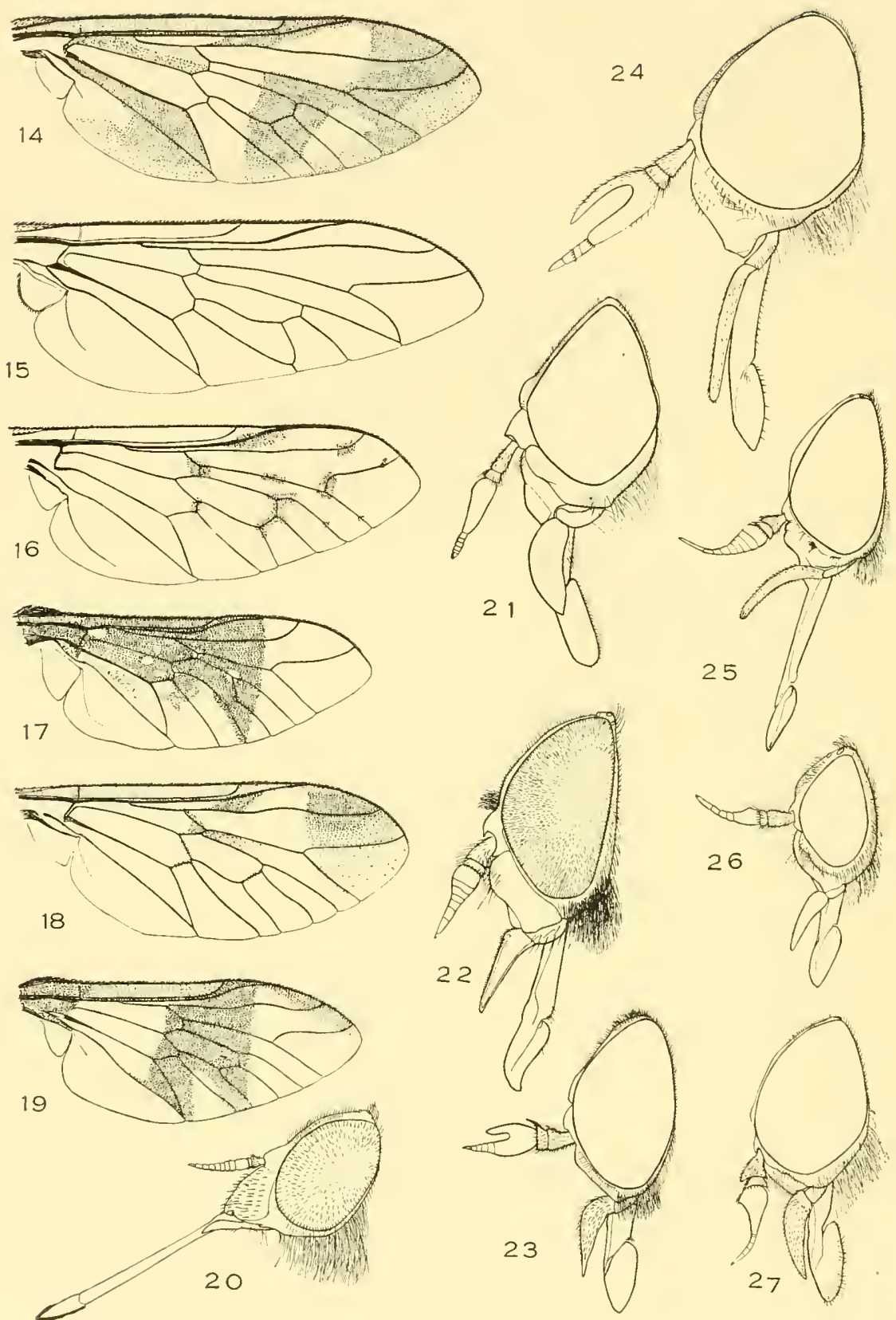

Tabanide II-14, Dichelacera analis; 15 , Scione aurulans; 16 , Silvius pollinosus: 17, Lepiselaga crassipes; 18 Diachlorus ferrugatus: 19, Chrysops melæna; 20, Scione aurulans; Lepiselassipes: 22 Scaptia: 23, Stibasoma theotænia panamensis; 24, Dichelacera analis: 25 , Esenbeckia prasiniventris; 26 , Silvius gigantulus; 27 , Tabanus albocirculus. 
15. Third antennal segment with four annuli; frons of female wide; fork of third longitudinal vein with appendix $(7,28)$... Hamatopota Meigen Third antemnal segment usually with five annuli; when with less the frons of female is narrow and the fork of third longitudinal vein

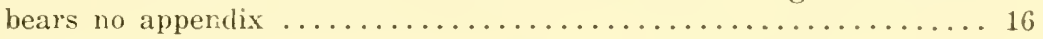

16. Third antennal segment not at all or barely angulated above....... 17 Third antennal segment with distinct angle or process near the base above; ocelli rudimentary or absent................... 20

17. Ocelli present and of nomal size; all tibiæ not or hardly swollen.

Merycomyia Hine

Ocelli absent; at least fore tibiæ swollen.................. 18

18. Fore tibiæ swollen; mid and hind tibiæ normal; palpi swollen at base, pointed at apex $(8,18) \ldots \ldots \ldots \ldots \ldots \ldots \ldots$ Diachlorus Osten Sacken

All tibiæ swollen, the fore pair most; palpi flat and broad......... 19

19. Third antennal segment broad and flat; subcallus divided by a median

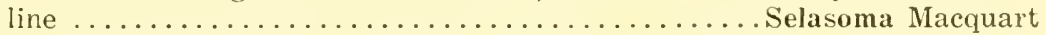

Third antennal segment narrow and slender; subcallus not divided medially $(6,17,21) \ldots \ldots \ldots \ldots \ldots \ldots \ldots$ Lepiselaga Macquart
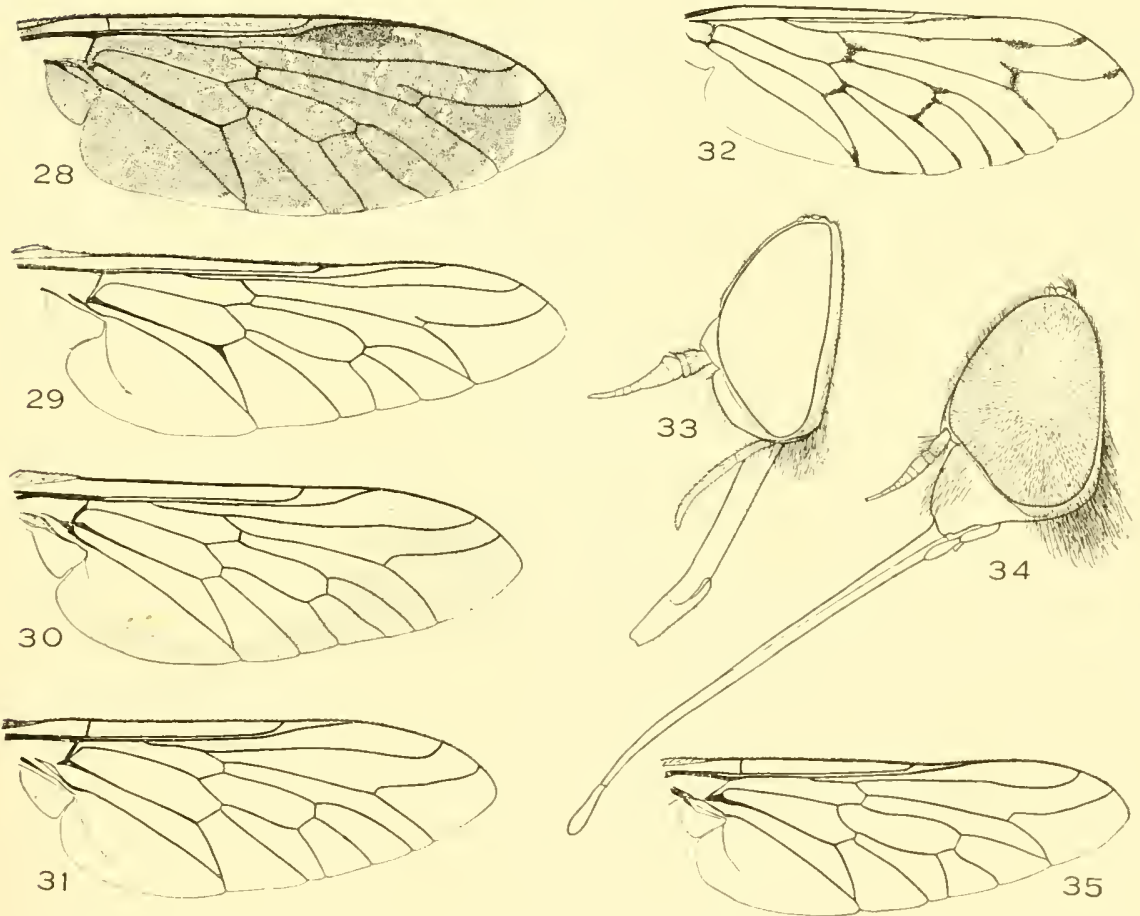

Tabanidæe III.-28. Hæmatopota punctulata; 29, Esenbeckia prasiniventris: 30, Stibasoma fulvohirtum; 31 , Buplex rasa; 32, Tabanus nervosus; 33 , Buptex rasa; 34 , Melpia venosa: 35. Helpia. 
20. Dorsal process of third antennal segment unusually long, extending to

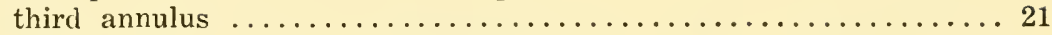

Dorsal process moderately long or forming a tooth, sharp edge, or

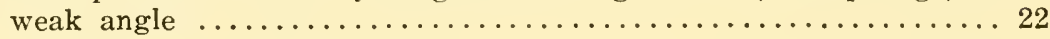

21. Fore tibiæ strongly swollen; hind tibiæ ciliate with long hairs $(23,30)$.

Fore tibiæ not or hardly swollen; hind tibiæ not ciliate $(\mathbf{1 4}, \mathbf{2 4})$.

Stibasoma Schiner

Dichelacera Macquart

22. Subcallus strongly swollen; first antennal segment much enlarged.... 23 Subcallus normal; first antennal segment not or slightly enlarged

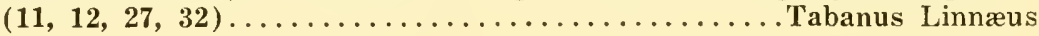

23. First antennal segment subglobular as well from above as from the

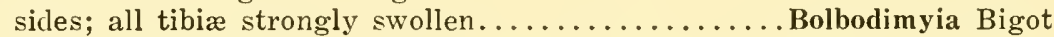

First antennal segment much procluced downward (in sicle view), but not widlened seen from above; tibiæ not or hardly swollen (13).

Snowiellus Hine 


\section{Family Pantophthalmidæ}

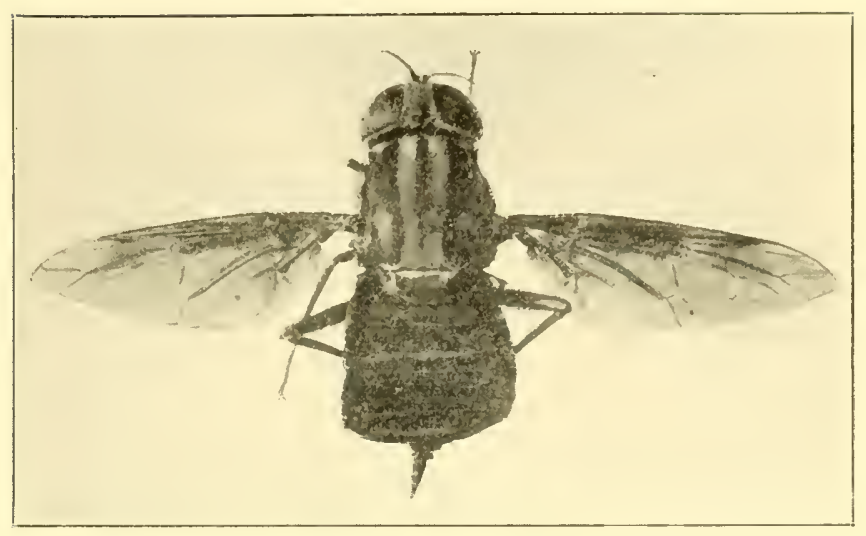

Pantophthalmus sp., natural size.

Tery large, usually broad, bristleless flies.

Eyes large, contiguous above the antenne in the male; faee rather short but often produced below into a distinet beak. Proboseis short, not adapted for piercing, with fleshy labella; palpi three-segmented, the basal segment short; ocelli present. Antemna elongate, the third segment ammulate and with a style-like apical section which may or may not be well differentiated. Siflame small. Wings with two submarginal and five posterior cells, the fourth posterior cell and the anal cell closed. Tibire without apical spurs; posterior femora usually with a strong spur on the under surface beyond the middle; empodia pardilike.

The three genera placed in this family are elosely related and there has always been much doubt eoncerning the validity of Rhaphiorhynchus which is undoubtedly but poorly separated from Puntophthalmus (Acanthomeru Wiedemam). The genus Atopom!ju Ansten contains one speeies which is readily recognized by its slender, Mydas-like form. Austen has revised the family but does not present kers to the speeies.

The Pantophthalmida oecur only in the American tropies. The larve bore in solid wood (often in living trees) and the rasping sound made by them may be andible for a distanee of several feet.

* 1923, Proc. Zool. Soc. London, pl). 551-598. 


\section{KEY TO GENERA}

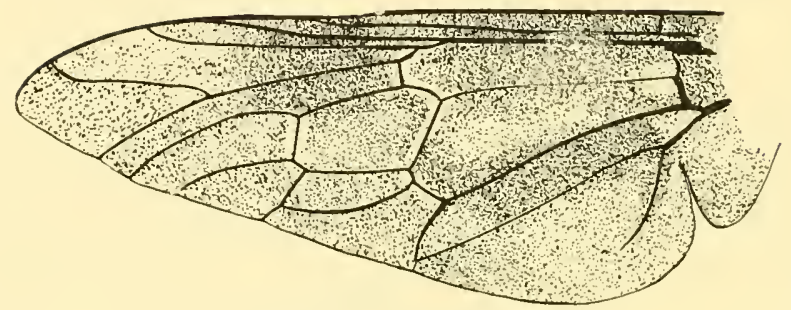

Pantophthalmus species.

1. Abdomen not or scarcely more than twice as long as wide, short and

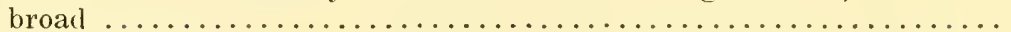

Abdomen three times as long as wide, long and narrow; Mydas-like

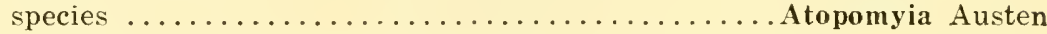

2. Third palpal segment almost always cylindrical, even when somewhat swollen and more or less pointed below, usually obtuse apically; facial beak, if present and fairly long, strongly tapering and the ventral spur on the posterior femora greatly reduced or almost absent.

Pantophthalmus Thunberg

Third palpal segment broadened and laterally compressed, especially in the female, pointed below; face with a long, narrow beak and the posterior femora with a strong ventral spur.

Rhaphiorhynchus Wiedemaun 
Family Rhagionidæ-The Snipe Flies

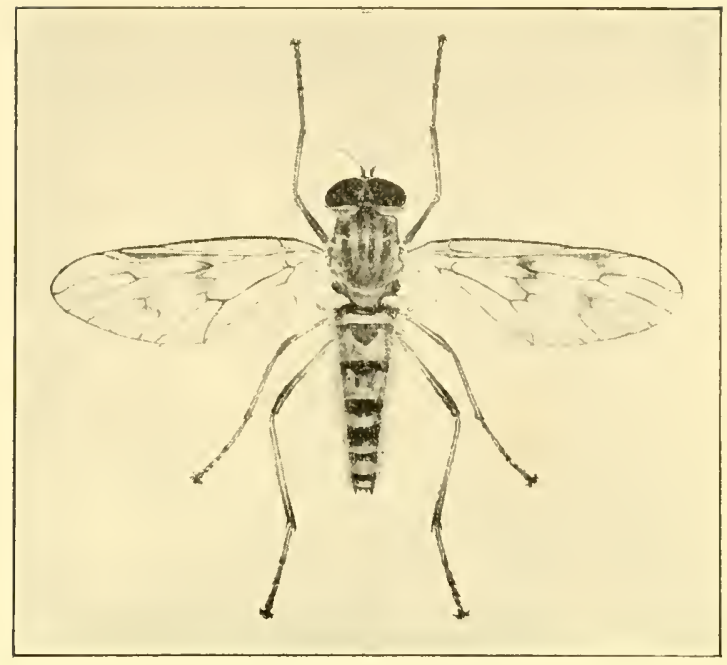

Rhagio mystacea.

Small to medium sized, nearly bare or thinly pilose flies.

Face very strongly receding, the middle convex but lying much below the level of the exes in profile; males holoptic or the eyes very narrowly separated. Antemix composed of three segments, the third bearing a terminal or dorsal arista or rather slender style. Scutellum marmed. Legs long; empodium developed pulvilliform (but slightly dereloped in Hilarimorpha). Wing venation strong; four or five posterior cells, the discal cell absent only in Hilarimorpha. Abdomen long and usually tapering.

The Snipe rlies are eommon in woods, especially near moist places and may be found on foliage, in long grass and on tree trunks. They are predaceous in both the adult and larral stages. Leonard* has revised the Nearetie species.

There has been much confusion in regard to the limits of this family, those genera which I have placed in the Conomyida being inchuded by Williston. IItarimorpha has been placed in the Empidax, and Bombyliida but from its general structure $I$ feel certain that it belongs here, despite the poorly developed empodium. The shape of the face excludes it from both families mentioned and the wing venation cannot be considered of prime importance.

* 1930. Mem. Amer. Ent, Soc, No. 7. 

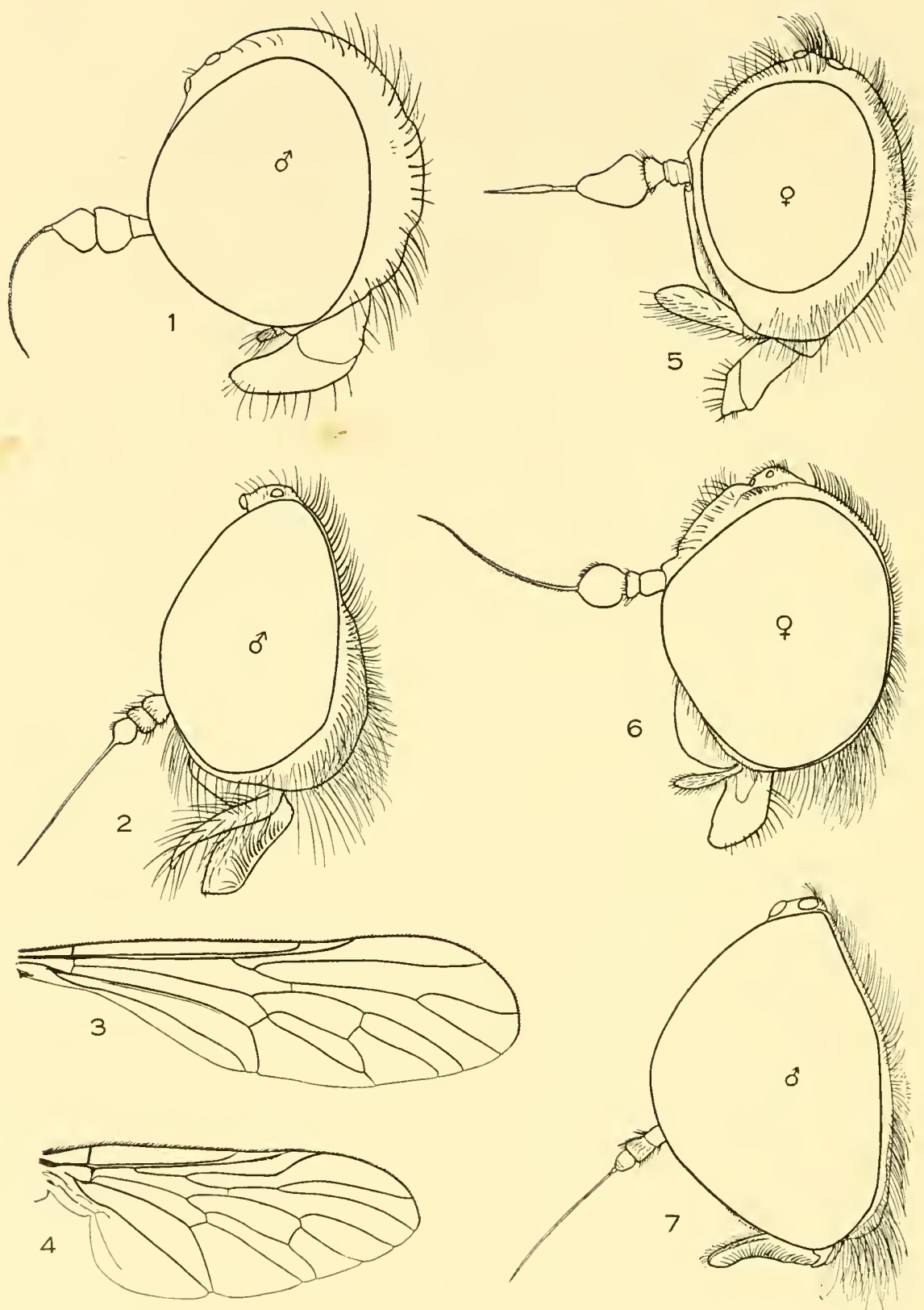

Rhagionide I-1, Vermileo; 2, Rhagio punctipennis; 3, Vermileo; 4, Symphoromyia pleuralis; 5, Ptiolina majuseula; 6, Chrysopilus quadratus; 7, Dialysis elongata. 


\section{KEY TO GENERA}

1. Anterior tibiæ without terminal spur................... 4

Anterior tibiæ with one or two terminal spurs................. 2

2. Antennæ with a long terminal arista or style which is very much

longer than the antenna proper (1); alula present or absent... 3 Antennæe with a short, thick terminal style; alula present.

Bolbomyia Lœw

3. Alula present; scutellum haired; males holoptic $(7,14)$ (Triptotricha

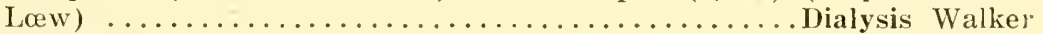
Alula absent; scutellum bare; males dichoptic (1,3) (Pheneus Walker).

Vermileo Macquart

4. Discal cell present; five posterior cells................... 5 Discal cell absent; four posterior cells (11)... .... Hilarimorpha Schiner
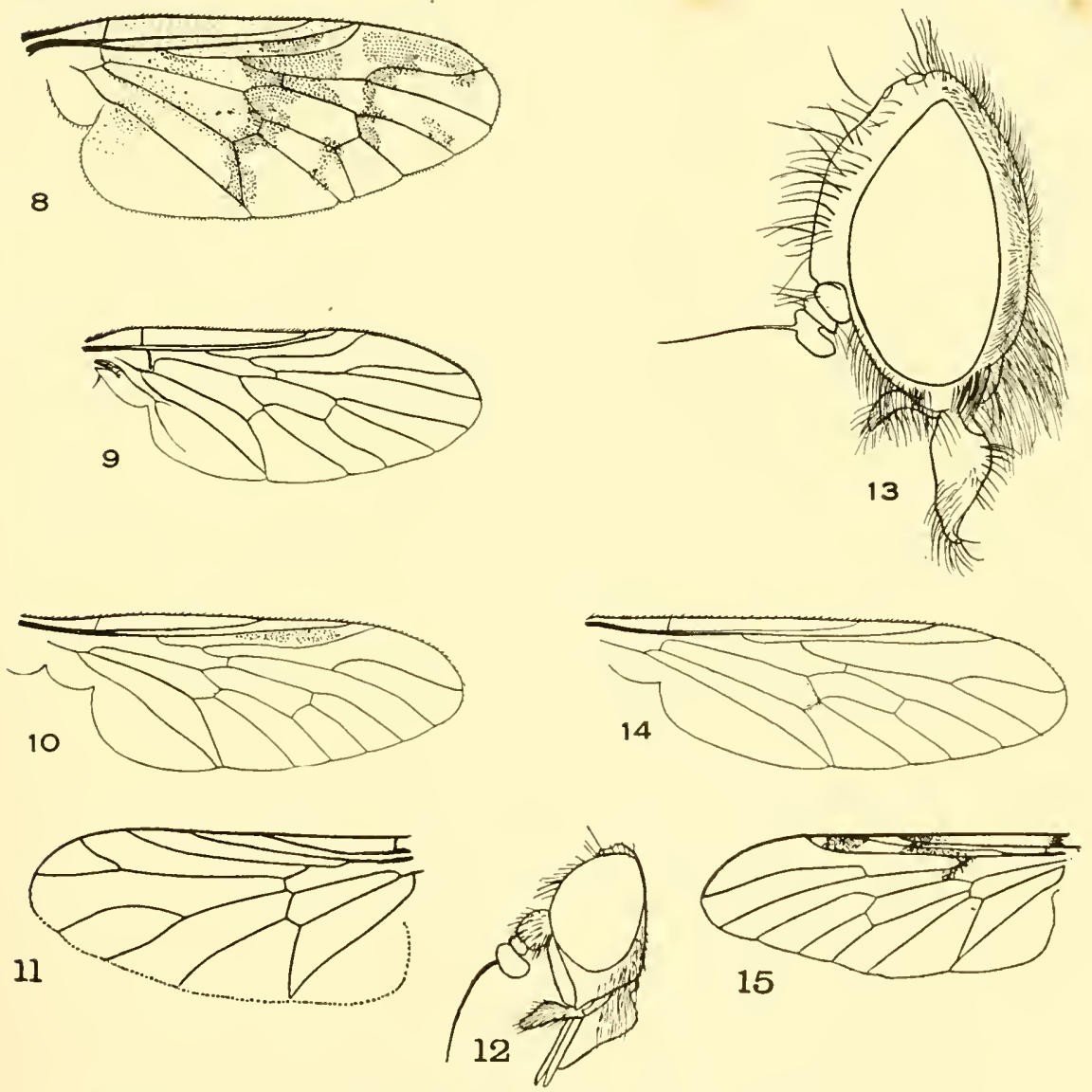

Rhagionidæ II. -8 , Atherix variegatus; 9, Ptiolina majuscula; 10, Rhagio incisus; 11, Hilarimorpha; 12 , Symphoromyia; 13 . Atherix variegtaus; 14, Dialysis elongata; 15, Chrysopilus. 
5. Third antennal segment round, oval or conical............... 7 Third antennal segment kidney-shaped, with dorsal or subdorsal arista. 6

6. Posterior tibiæ with two terminal spurs $(8,13) \ldots \ldots \ldots$. Atherix Meigen Posterior tibiæ with one terminal spur $(4,12)$... Symphoromyia Frauenfeld

7. Posterior tibiæ with one terminal spur $\ldots \ldots \ldots \ldots \ldots \ldots \ldots \ldots$ Posterior tibiæ with two terminal spurs $(2,10) \ldots \ldots$. Rhagio Fabricius

8. Antennæ bearing a terminal style.................... Antennæ with a long, slender terminal arista which is decidedly longer than the basal three segments combined $(6,15) . .{ }^{*}$ Chrysopilus Macquart

9. Style situated near the middle of the third antennal segment $(\mathbf{5}, \mathbf{9})$.

†Ptiolina Zetterstedt Style situated at the lower end of the third antennal segment.

* Curran, 1931, Amer. Mus. Novit. No. 462 (Tropical).

† Curran, 1931. Can. Ent., Ixiii, p. 249. 


\section{Family Scenopinidæ-The Window Flies}
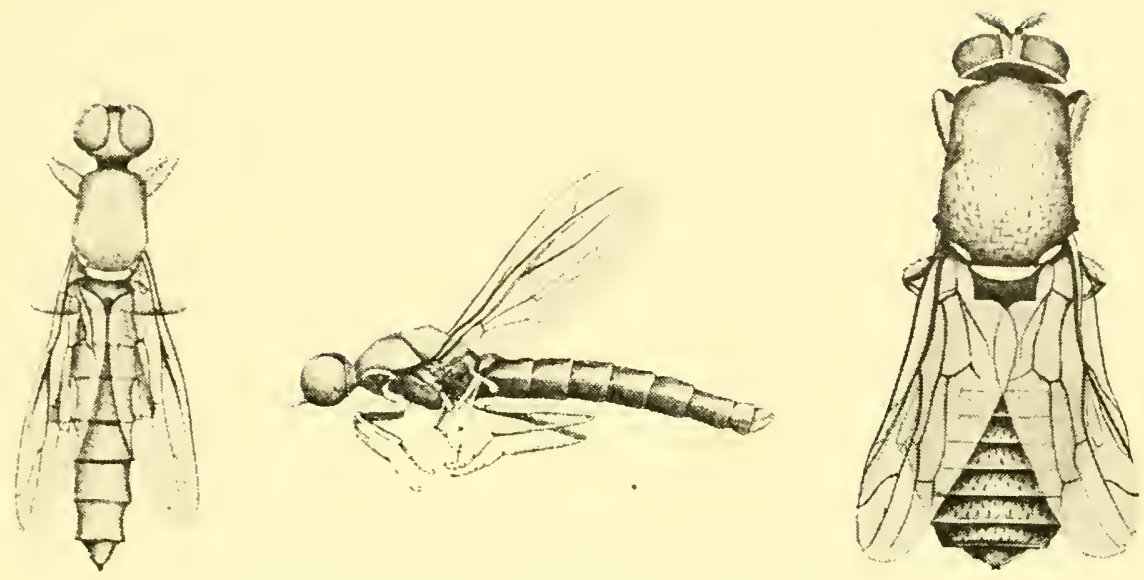

Pseudatrichia longurio, dorsal and lateral view, and Scenopinus fenestralis (right), dor'sal view.

Flies of moderate or small size, usually blackish in color.

Front not excavated; face hare, short and hroad: acelli present; males usually holoptic: proboscis coneealed; palpi eylindrical, bristly at the apex. Antenna approximated at the base, the basal two segments short, the third elongate, simple, withont style or arista. Thorax rather long, moderately convex above, the head situated low on the thorax; scutellum broad and short, eonvex apieally and unarmed. Abdomen flattened or eylindrieal, composed of seven segments. Legs short; empodia absent. Wing venation simple, the third rein branehed; apical rell open or closed: basal eells long, the first much longer than the seeond.

The adults, with the exreption of scenopinus fenestralis Limners, are not common in collections. The larra have been recorded as livinge in decaring fongi and wood and under earpets. S. fonestralis is sometimes eommon on windows and is said to live upon carpet beetle lanver, being predaceous. The eommon name of the family is derived from the window-frepuenting habit.

Some authors have nsed the name Omphrale Meigen instead of Scenopinus latreille, but I do not reeognize Xeigen 's "1800" names. The family has been treated by Kröber in Genera Inseetorum* and kers to the species are given.

Fascicle 161, 1914. 


\section{KEY TO GENERA}

1. Antennæ longer than the willth of the heal (Brazil)..Cerocatus Rondani Antennæ at most half as long as the width of the head........... 2

2. Apical cell closed and petiolate ....................... 3 Apical cell open $(1,2) \ldots \ldots \ldots \ldots \ldots \ldots \ldots \ldots$. Scenopinus Latreille

3. Body with metallic scales $(3,4) \ldots \ldots \ldots \ldots \ldots$ Metatrichia Coquillett Body without metallic scales (5)..........Pseudatrichia Osten Sacken
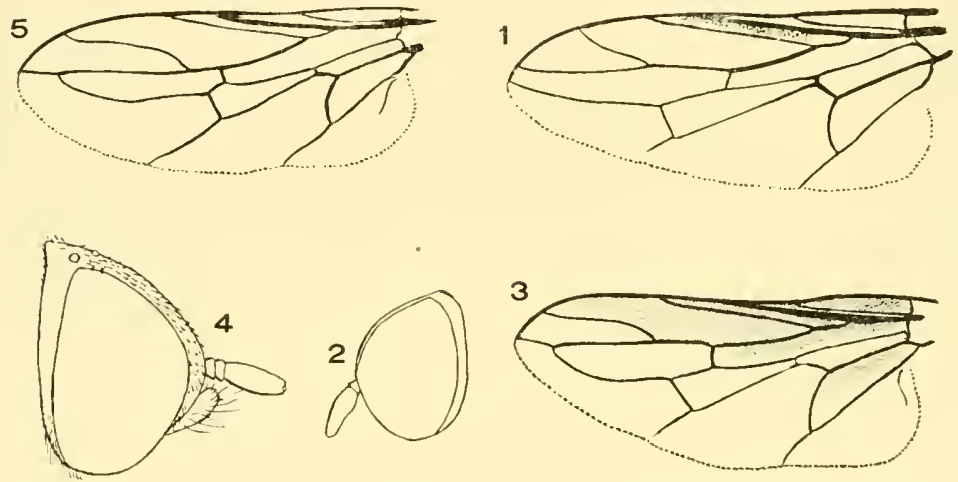

Scenopinidæ.-1, 2, Scenopinus fenestralis; 3, 4, Metatrichia; 5, Pseudatrichia. 


\section{Family Mydaidæ-The Mydas Flies}

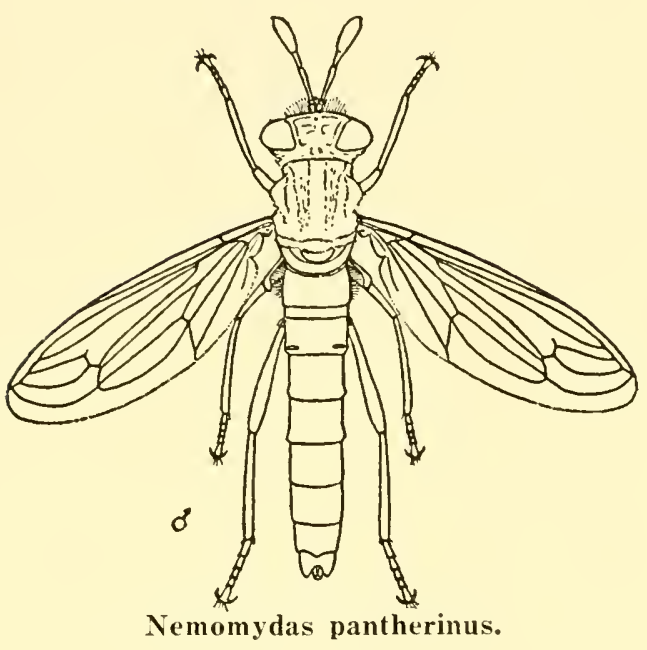

Large to very large, thinly haired or nearly bare, elongated flies.

Venation complicated, the basal cells long, the fourth vein always ending at or before the tip of the wing. Antennæ composed of four segments, the fourth always elongate. Both sexes dichoptie, the front excarated between the eyes; ocelli, except the anterior one, absent. Proboseis with fleshy labellæ, or rudimentary; palpi usually absent or extremely small, rarely long and slender. Empodia not developed pulvilliform.

The Mydas flies are easily recognized by the shape of the head, four-segmented antemne and peculiar venation. The majority of the species are tropieal in distribution and it is probable that the larve of all live in decaying wood.

The generie limits in the family are but poorly understood and only an abundance of material will enable one to properly limit the genera. Johnson * has dealt with the Nearetic forms, while papers by Bezzif and Seguy must receive attention in any attempt to deal with the family.

\footnotetext{
\# Johnson, 1926, Proc. Bost. Soc. Nat. Hist., xxuviii, pp. 131-145.

$\dagger$ Bezzi, 1924, Ann. S. Afr. Mus., xix, pp. 191-234.

5eguy, 1928, Encycl. Ent.. Diptera, iv, pp. 129-156.
} 

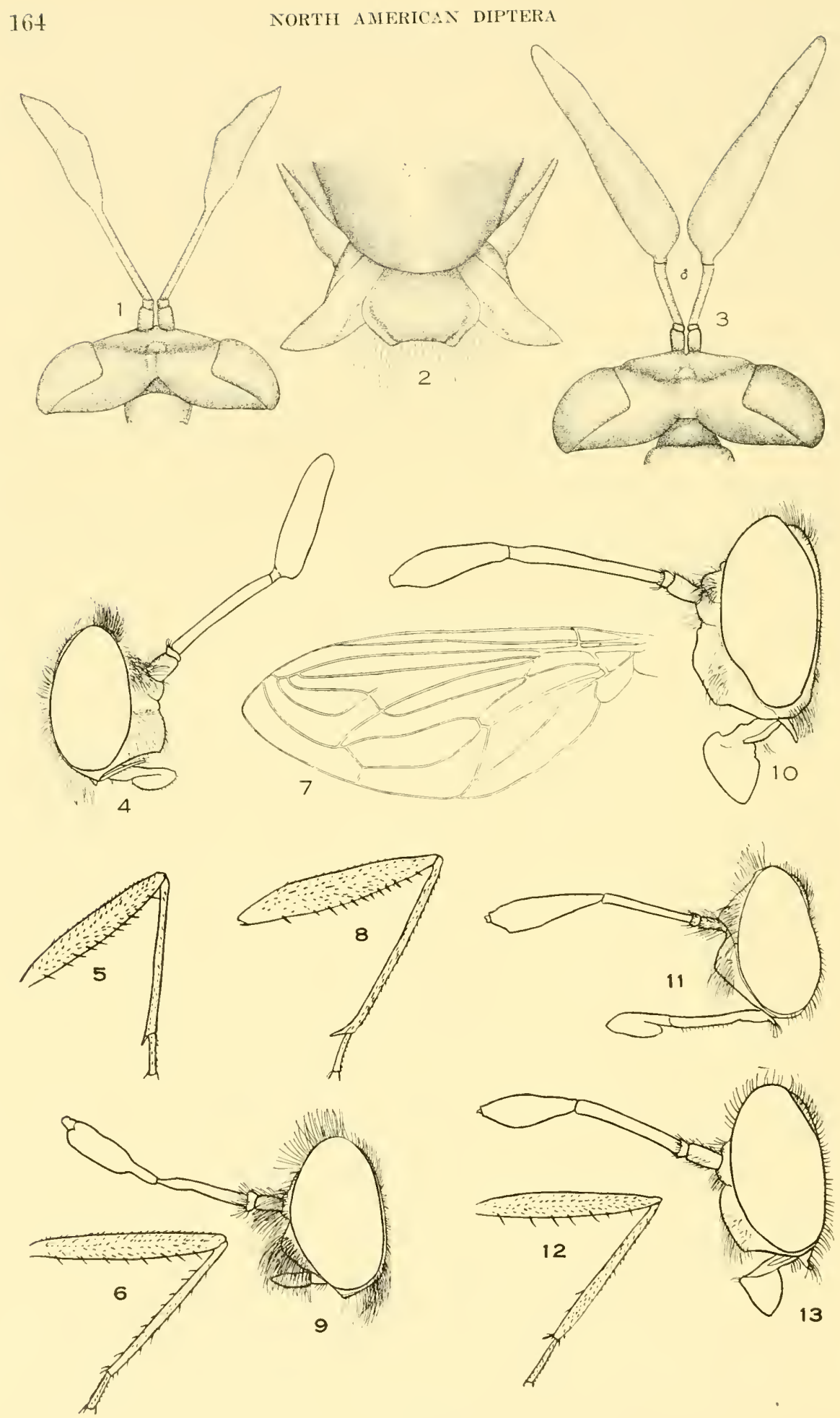

Mydiadæ. 


\section{KEY TO GENERA}

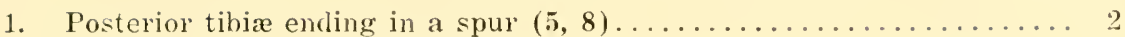

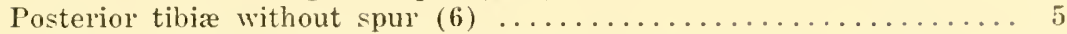

2. Spur of the posterior tibir longer than the width of the first tarsal segment, giving the tibix an arcuate appearance, the terminal bristle shorter than the spur; antennæ (always?) similar in both sexes....

Spur small and straight, shorter than the tarsal thickness or the terminal bristle; antennæ differing in the two sexes; palpi absent

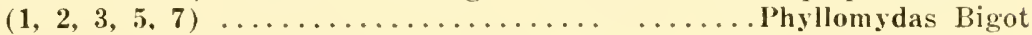

3. Palpi wholly absent or represented by a bulbous swelling $(8,10$; see colored plate $\ldots \ldots \ldots \ldots \ldots \ldots \ldots \ldots \ldots \ldots \ldots \ldots \ldots \ldots \ldots$ Mydas Fabricius

Palpi well developed, slender and sometimes half as long as the

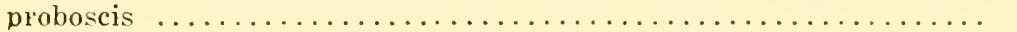

4. Posterior femora rather strongly swollen; posterior trochanters without bristles $(13) \ldots \ldots \ldots \ldots \ldots \ldots \ldots \ldots \ldots \ldots \ldots$ Lampromydas Seguy

Posterior femora not swollen; posterior trochanters bearing short, stout bristles $(4,12) \ldots \ldots \ldots \ldots \ldots \ldots \ldots \ldots \ldots \ldots$. $\ldots$ pomydas, n. g.

5. No vein reaching the posterior border between the anal cell and tip

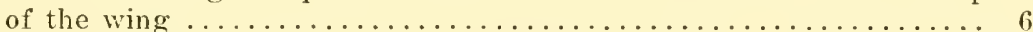

A vein (the fifth) extends to the wing margin $(1,12) \ldots$ opomydas, $n$. $g$.

6. Proboscis extending well beyond the oral opening $(6,11)$.

tNomoneura Bezzi

Proboscis small, not extending beyond the oral opening (9).

+Nemomydas, n. g.

* Lampromydas was based on specimens in which there is no vein extending to the wing margin between the anal vein and the tip of the wing but the character is not generic in this case. Of two specimens of (Mydas) luteipennis Lœw, one has a vein in one wing while the other specimen has none. This snecies and maculiventris Westwood, as well as two unidentified species before me, belong to Lampromydas unless the genotype of Lampromydas lacks palpi.

T Ectyphus Gerstacker is not known from North America but apparentiy occurs in South America. The three described North American species belong to Oponydas of which E. limbatus Williston is the genotype.

$¥$ Leptonydas Gerstacker is not known from America. The genus is distinguished by the hairy pleura, both the above genera having pile only on the nteropleura and supraspiracular. convexities. The genotyne of Nemomydas is Leptomydas pantherinus rerstrecker.

Mydaidæe,-1, Phyllomydas phyllocerus, $q$; 2, Phyllomydas phyllocerus, $q$ genitalia from below: 3, Phyllomydas phyllocerus; of 4, Opomydas limbatus; 5, Phyllomydas phyllocerus, hind leg; 6, Nomoneura, hind leg: 7, Phyllomydas phyllocerus; 8 , Mydas clavatus, hind leg: 9. Nemomydas pantherimus; 10, Mydas clavatus; 11, Nomoneura pananensis; 12, Opomydas townsendi, hind leg; 13, Lampromydas maculiventris. 

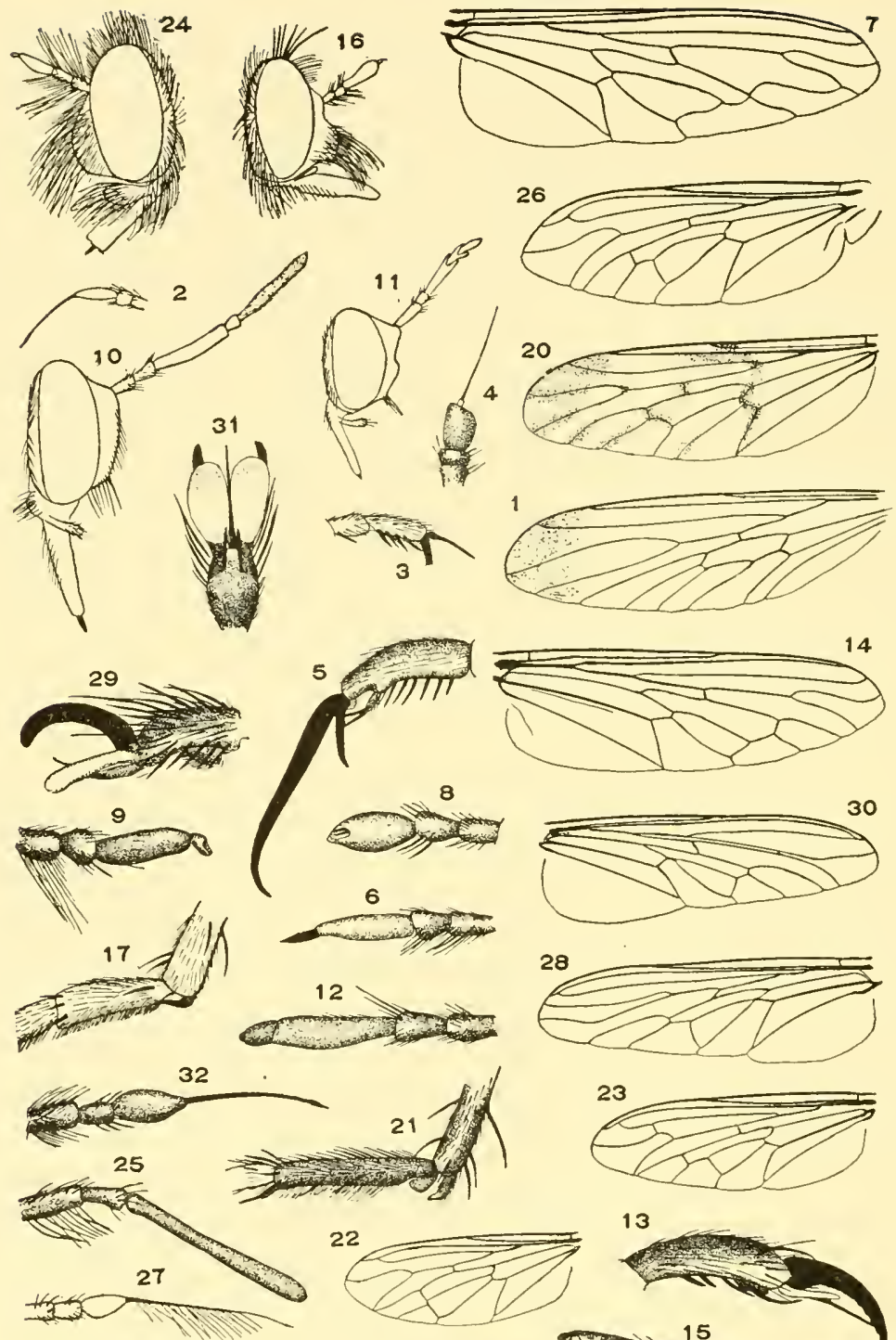

8
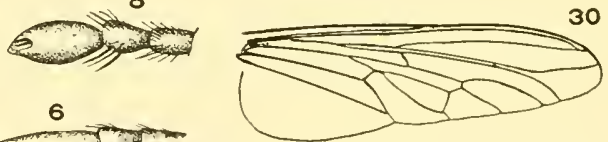

6
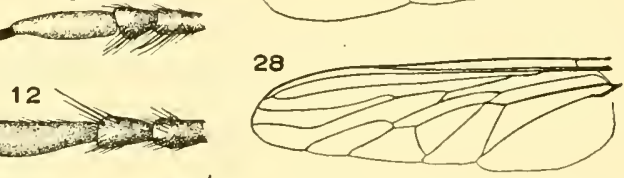

12

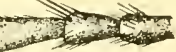

23

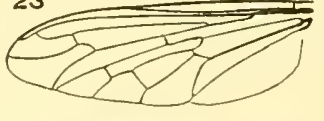

13
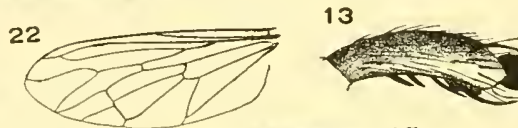

15

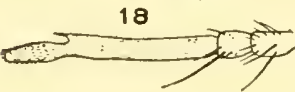

19
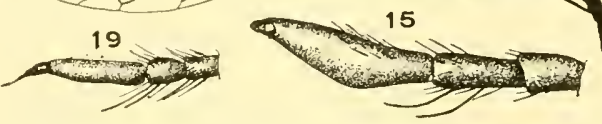

Asilidæ I.-1, Leptogaster; 2, Leptogaster, antenna; 3, Leptogaster, end of tarsus ; 4 . Damalis, antenna: 5, Dicranus, claw ; 6, Selcropegon, antenna; 7 , Microstylum galactoides; 8. Psilocurus, antenna: 9, Laphystia, antenna; 10, Ceraturgus cruciatus; 11, Myelaphus melas: 12. Dioctria, antenna; 13 , Blepharepium coaretatum, elaw; 14, Diogmites winthemia; 15. Diogmites, antenna; 16, Lestomyia fraudigera; 17. Taracticus, end of tibia; 18, Taracticus, antenna : 19, Buckellia, antenna; 20, Nicocles rufus; 21, Pseldorus, tibial spur; 22, Atomosia puella; 23, Pogonosoma dorsata; 24, Dasylechia atrox; 25. Bombonima, antenna; 26, Laphria, Lampria; 27, Ommatius, antenna : 28. Eccritosia; 29. Mallophora, claw; 30 . Promachus; 31 . Promachus, claws; 32 , Promachus, antenna. 


\section{Family Asilidæ-The Assassin Flies}

Species of moderate to large size, rarely small, usually rather elongate in form, often thickly hairy and always with bristles, entirely predaceous in habit.

Head flattened, broad and short, separated from the thorax by a neck (the prothorax) and freely movable. Front exeavated above, usually broad in both sexes, rarely narrow. Ocelli present, usually situated upon a rounded tubercle; front with bristles. Antennæ porrect, ustally composed of three simple segments, the third more or less elongate and with or withont a terminal style or arista, the latter very rarely pectinate, the style rarely strongly thickened and forming one or two additional segments. Proboseis of moderate length, horny and adapted for piereing, direeted downward or forward; labellæ never fleshy; palpi eomposed of two segments, the basal one often small and not freely artienlated with the second. Thorax variable in shape, convex, usually bearing bristles. Abdomen composed of eight segments, the hypopygium and ovipositor usually prominent. Legs strong, usually bristly, of moderate length, the femora often, the posterior tibia sometimes thiekened, the legs sometimes very long and rather slender; empodium present or absent; the purilli rarely absent or greatly reduced. Wings lying parallel over the abdomen when at rest; basal eells long; two or three submarginal cells, five posterior cells (four in a very few genera); first and fourth posterior cells and the anal cell either open or closed.

The members of this family have usually been termed "Robber Flies" but I adopt "Assassin Flies" as much more suitable as a eommon name. All the Asilide are predaceous in the adult and probably in the larval stages. The adults are found everywhere but many grouns of genera are restricted in habitat. Some will be found in clearings in and around the edges of woods, some on sand near water, others in open fields or on fallen trees or fenceposts. Some of the species are found almost entirely on tree trunks while others sit on the tips of dead branches of trees or the tops of dead weeds. The species of Leptoguster prefer long grass, particularly in moist places. Sandy beaches will usually yield a few species. The speeies of Laphria and Bombomima will usually be found resting upon leaves in the sun in or at the edges of woods while the genera related to Asitus mostly frequent open fields. 


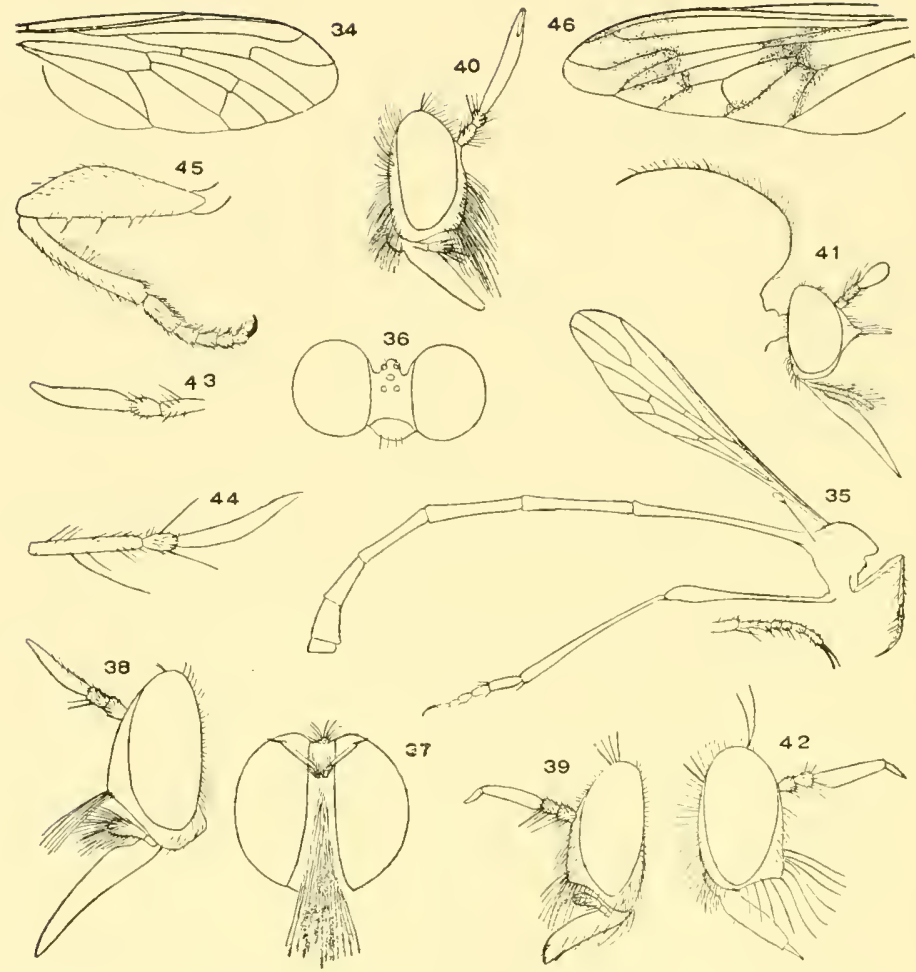

Asilidæ II.-34, Psilocurus caudatus; 35, Leptopteronyia gracilis (Brazil); 36. Holcocephala, head from in front. 37. Scleropogon turquii; 38, A rchilestris magnificus; 39 . Chry. soceria picitarsis; 40, Dizonias; 41, Pseudorus bicolor; 42, Atonia mikii; 43, Atomosıa macquartii, antenna; 44, Cerotainia, antenna; 45, Lampria, hind leg; 46, Andrenosoma. 
Many of the Asilids resemhle hees and are quite powerful. They devour insects of all kinds, catehing them during flight, and bees form the principal article of diet of some speceses although the variety of food is usually limited only by the intended victim's ability to escape. The prey is piereed by the powerful proboseis and the juices sucked ont, the digestion taking place by the injection into the vietim of a powerful "anzyme" which breaks down the musenlar tissue. 'The collector should be careful in handling the larger species as they not infrequently bite, resulting in a painful, if not serious, wound.

The family is a large and popular one and includes many fine species. For the most part the classifieation is simple but in some genera it is difficult to separate the species by means of the available literature. There has been no monograph of the Nearetic species although Back* has dealt with about half the family. However, sinee the appearanee of his contribution very many additional species have been described. Otherwise the literature is seattered althongh not diffierilt to obtain.

In the key will be found many leferenees to keys to species which should prove very helpful in tracing out the species. I have not followed the practice of recognizing subfamilies as the characters previonsly used obviously separate related senera and some genera are diffeult to place where the system is followed. For Cuban species see Bromley "The Isilide of C"uba," (Ann. Ent. Soc. Amer', xxii, pp. 272-294); also Texas Asilide by the same anthor.†

\section{KEY TO GENERA}

1. Anterior tibiæ with a terminal, sharply curved, ventral spur....... 2 Anterior tibiæ with only straight or gently curving apical bristles.... 17

2. Marginal cell closed and petiolate $(121) \ldots \ldots \ldots \ldots \ldots \ldots \ldots \ldots \ldots$

Marginal cell open ............................ 4

3. Face bare except for a very few hairs on the oral margin $(121,122)$.

Doryclus Jaennicke

Face with strong hairs and many on the oral margin $(21,41)$.

Pseudorus Walker

4. Middle of mesonotum raised and bearing a crest of long, dense hairs

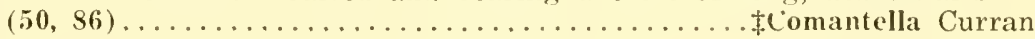

Mesonotum never with crest of dense hair................ 5

5. Antennæ with distinct, two-segmented apical style............ 13

Antennæ either with a short, broad, one-segmented style bearing a spine in the depression, without style, or excised and bearing a spine

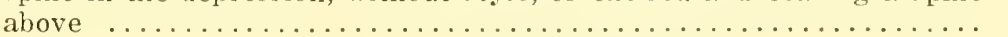

* 1909, Tr. Amer. Ent. Soc., xxxv, 1p. 137-400, plates IT-XII.

† Bromley, 1934, Ann. Ent. Soc. Amer., xxvii, pp. 74-114.

‡ Curran, 1926, Can. Ent., lviii, p. 311. 

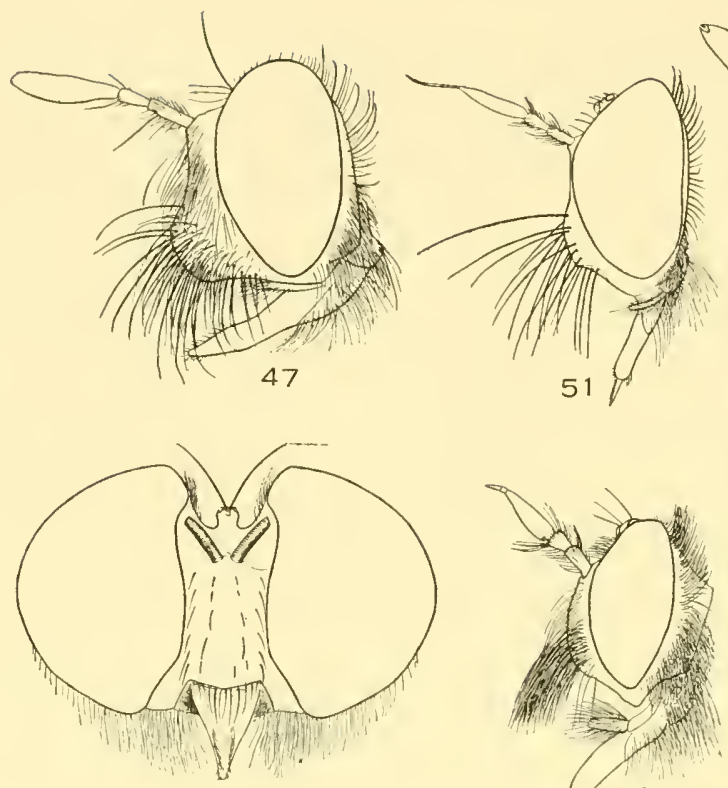

48
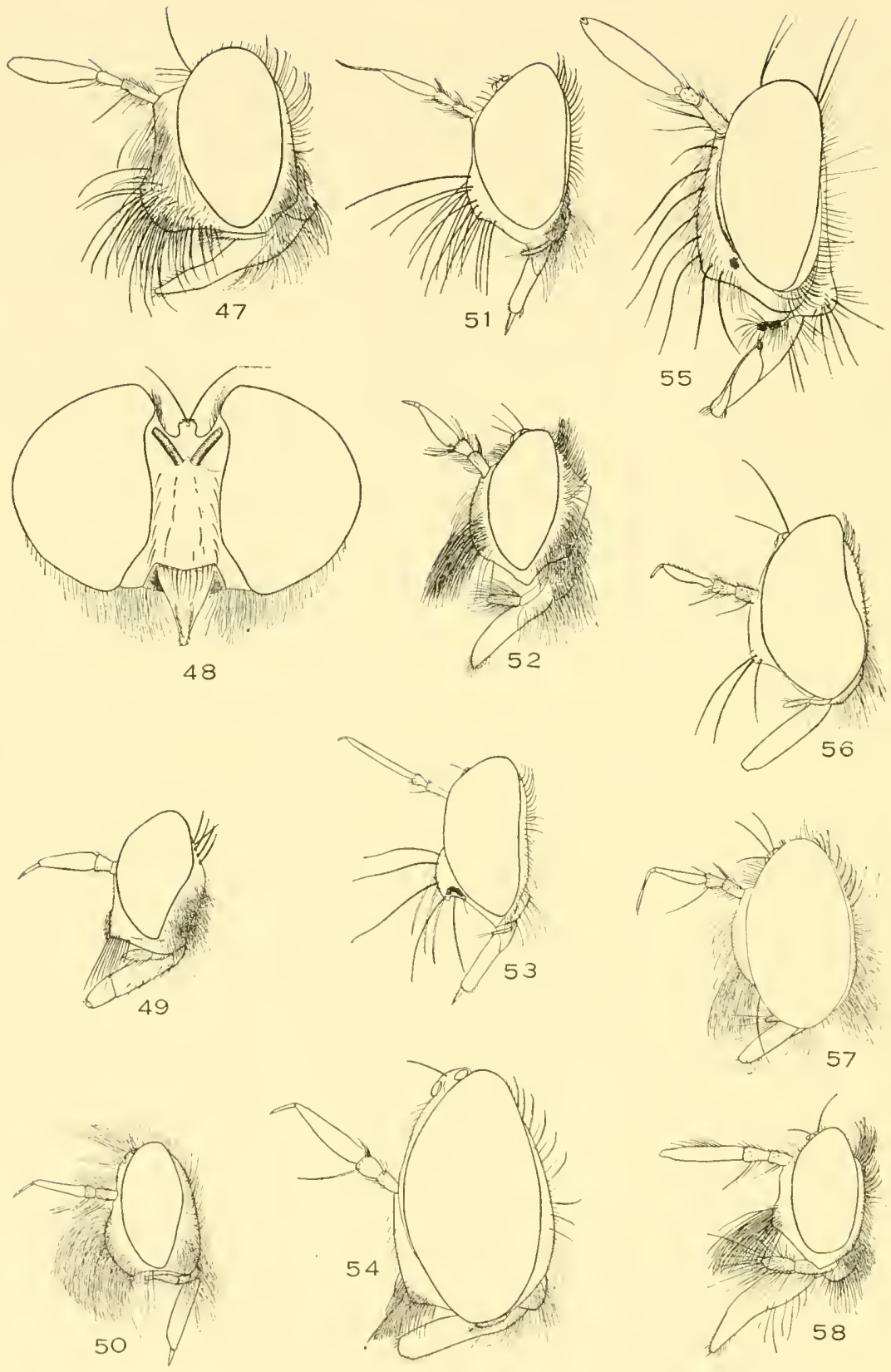

Asilidæe Ill,-47, Pilica sp. (Panama): 45, A tomosia tibialis, head from in front: 49. Neopogon: 50. Comantella fallei; 51 . Cerdistus dolichomerus; 52, Callinicus calanus; 53. Senoprosopis (Panama): 54, Hodophylax aridus; 55, Panamasilus xylota; 56. Plesioma; 57. Hetelopogon macerinus; 58 , Lastaurus. 
6. Third antennal segment with an apical depression or style in which is inserted a small short spine ........................ 8 Third antennal segment excised above beyond the midlle and bearing a

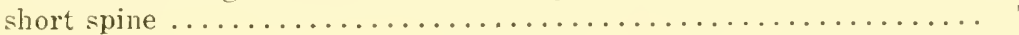

7. Pulvilli present and large $(17,18,7 i, 142) \ldots \ldots \ldots \ldots$. Taracticus $I_{\alpha} \alpha^{2}$

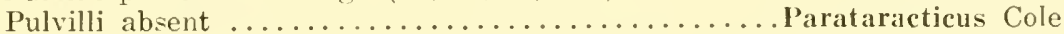

8. Posterier pulvilli not more than one-third as long as the claws, (13,

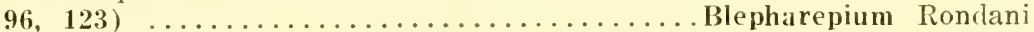
Posterior pulvilli more than half as long as the claws.......... 9

9. Abdomen thickly pilose, at least laterally ................. 10

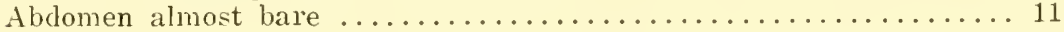

10. Face convex, pilose on lower two-thirds (Brazil) ........ Lastaurina, n. g. Face flat above, pilose on less than lower half $(58,95)$. Lastaurus Lœw

11. Fourth posterior cell closed and petiolate at apex............ 12 Fourth posterior cell open or closed in the wing margin $(88,102)$.

†Siapogon $L \alpha \cdot w$

12. Abdomen clavate; scutellum without bristles $(138,153)$

Senobasis Macquart Abromen not clavate; scutellum with bristles $(\mathbf{1 4}, \mathbf{1 5}, \mathbf{1 5 0})$.

Diogmites Lœw

13. Face gibbous in the middle, leaving a flattened space immediately below the antennæ $(16,91) \ldots \ldots \ldots \ldots \ldots \ldots \ldots \ldots$ Lestomyia Williston Face evenly convex or prominent below ................... 14

14. The dense mystax occupies the lower half of the face $(81,87)$.

Aphamartania Schiner The dense mystax is limited to the lowest fourth ................ 15

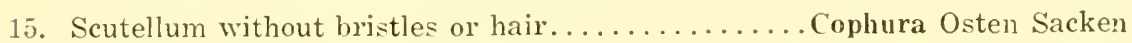
Scutellum with bristles or hair ...................... 16

16. Scutellum with fine hair on the disc $(20,97) \ldots . . \ldots$. Nicocles Jænnicke Scutellum with bristles only $(19,83,98) \ldots \ldots \ldots \ldots$ \&l Buckellia Curran

17. Marginal cell open or closed in the costa $\ldots \ldots \ldots \ldots \ldots \ldots \ldots \ldots \ldots$ Marginal cell closed and petiolate ..................... 59

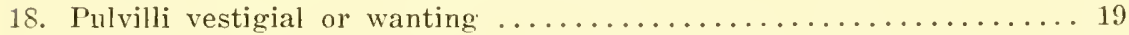
Pulvilli normal, the posterior pair sometimes shortener........... 25

19. Third antennal segment with a terminal arista or arista-like style,

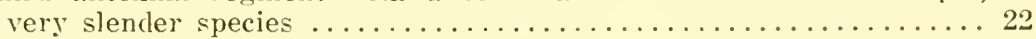
Third antennal segment with or without terminal style, if stylate the

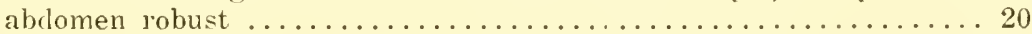

20. Claws very long and with an elongated tooth at the base of each claw

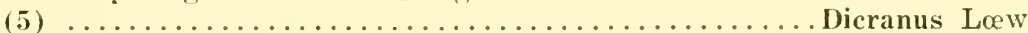

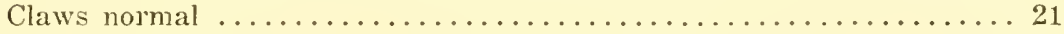

* Curran, 1930. Amer. Mus. Novit. No. 425. D. 4.

$\dagger$ Curran, 1931, Amer. Mus. Novit. No. 487, p. 1.

† Curran, 1931. Amer. Mus. Novit. No. 487, p. 3.

\$ Curran, 1931, (Cophura), Amer. Mus. Novit. No. 487, p. 5; Melander, 1923, (Cophura), Psyche, yxx, p. 208 (includes Cophura). 

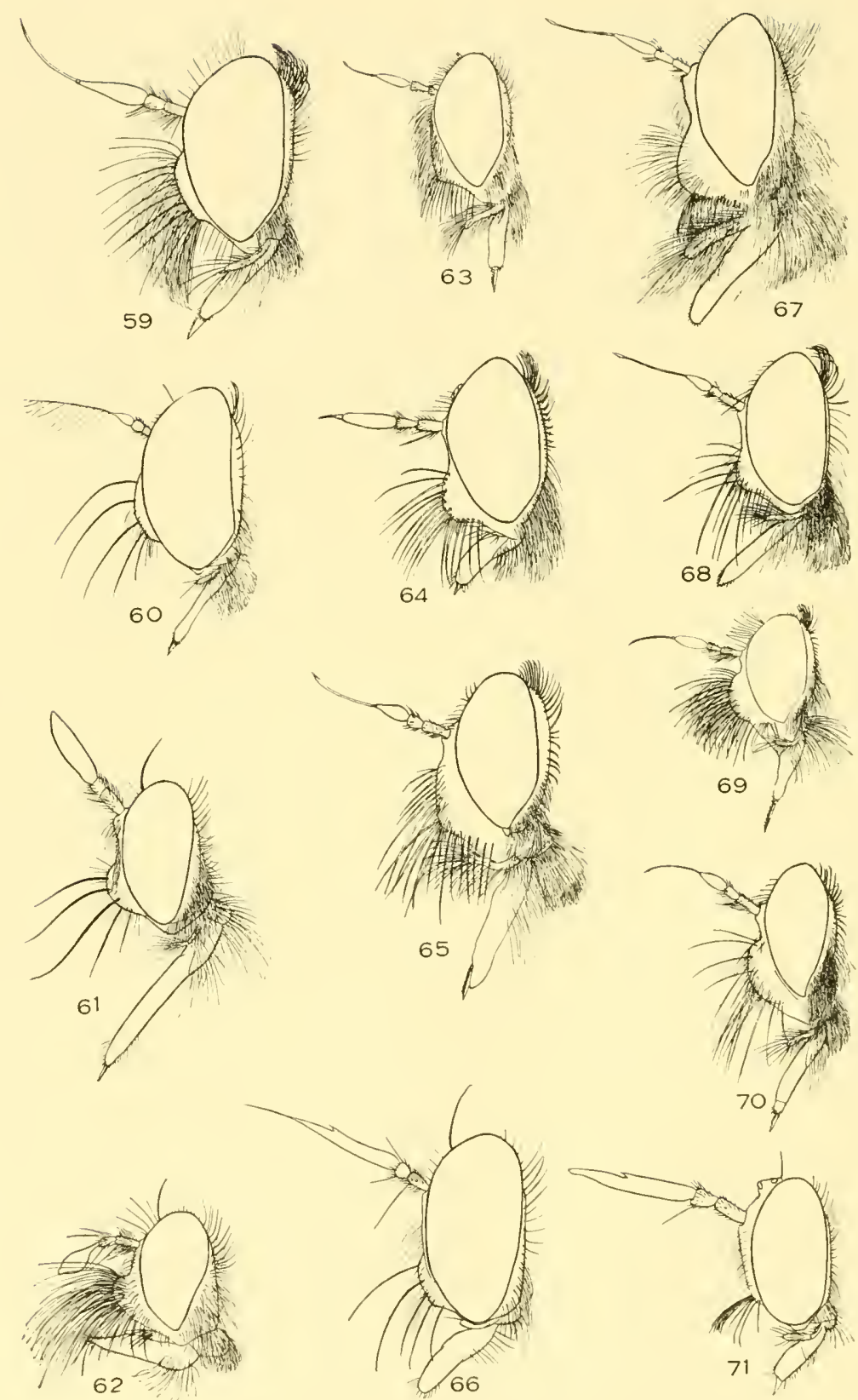

Asilidæ IV. -59, Neoitamus flavofemoratus; 60, Ommatius; 61, Lampria mexicana; 62. Pogonosoma melanoptera; 63, Mallophorina clausicella; 64. Negasilus belli; 65, Proctacanthus micans; 66. Atractia dispar; 67. Mallophora orcina; 68. Pachycheta copulata; 69. Machimus occidentalis; 70 . Erax (Panama): 71 , Taracticus octopunctatus. 
21. Face wholly thickly pilose ................................. Lew Mystax limited to the lowest fourth of the face, the face sparsely haired above $(54,100) \ldots \ldots \ldots \ldots \ldots \ldots \ldots$. . . . . . . . . . . James

22. Anal cell absent, the wings extremely narrow at the base (140).

Eurhabdus Aldrich

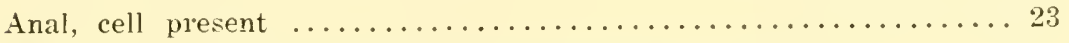

23. Mesonotum without dorsocentrals in front of the mirldle.........24 Mesonotum with a pair of dorsocentrals in front of the middle.

Schildia Aldrich

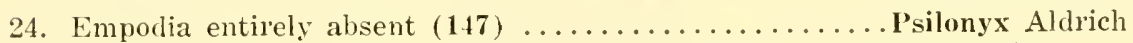
Empodia present, about half as long as the claws $(1,2,3,148,149)$.

Leptogaster Meigen

25. Antennæ with a slender terminal arista $(4,89) \ldots \ldots *^{*}$ Damalis Fabricius

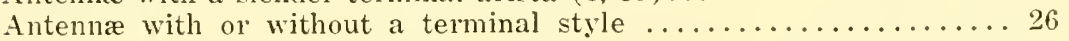

26. Only four posterior cells $(93) \ldots \ldots \ldots \ldots \ldots$ Townsendia Williston

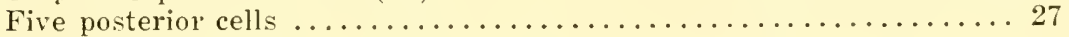

27. Head slightly higher than broad; face narrow above, swollen and

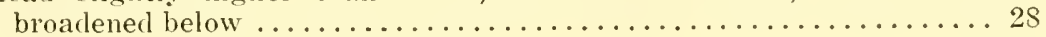
Head obviously broader than high $\ldots \ldots \ldots \ldots \ldots \ldots \ldots \ldots \ldots \ldots \ldots \ldots \ldots \ldots \ldots$

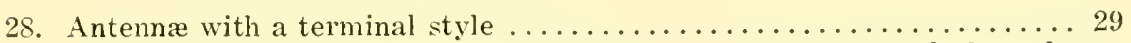
Antennæ without visible style; fourth posterior cell closed before the border of the wing $(118) \ldots \ldots \ldots \ldots \ldots \ldots \ldots$. $\ldots$ spriocerus Lœw

29. Metapleura bare $(6,37,130) \ldots \ldots \ldots \ldots \ldots \ldots \ldots$ tStenopogon Lœw Metapleura with hair or bristles $(6,37,130) \ldots \ldots \ldots$ t Scleropogon Lœw

30. Antennze apparently five segmented, the segments of the style simu-

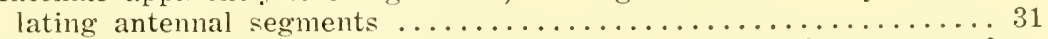
Antennal style usually strongly differentiated from the third antennal segment, absent, or the fifth segment longer than the second......33

31. Third and fourth antennal segments very deeply emarginate apically

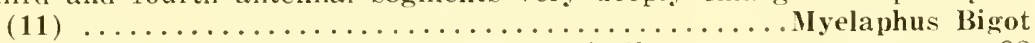
Third and fourth segments not concave apically ............. 32

32. Fifth antennal segment not longer than the second (103).

Ceraturgopsis Johnson Fifth antennal segment about as long as the third $(\mathbf{1 0}, 132)$.

Ceraturgus Wiedeman!

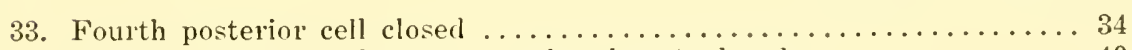

Fourth posterior cell open, rarely almost closed............. 40

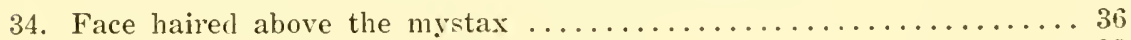

Face bare except along the oral margin....................

35. Metanotal callosities bare $(38,136)$

Metanotal callosities with hair or short bristles $(7,101)$

Microstylum Macquart

36. First posterior cell closed and long petiolate (109)........ Triclis Lœw First posterior cell open or closed in the wing margin.......... 37

* Curran, 1930, Amer. Mus. Novit. No. 425, 1) 5.

$\dagger$ Bromley, 1931, Amer. Ent. Soc. Amer., xxiv, 1p. 427-428. 

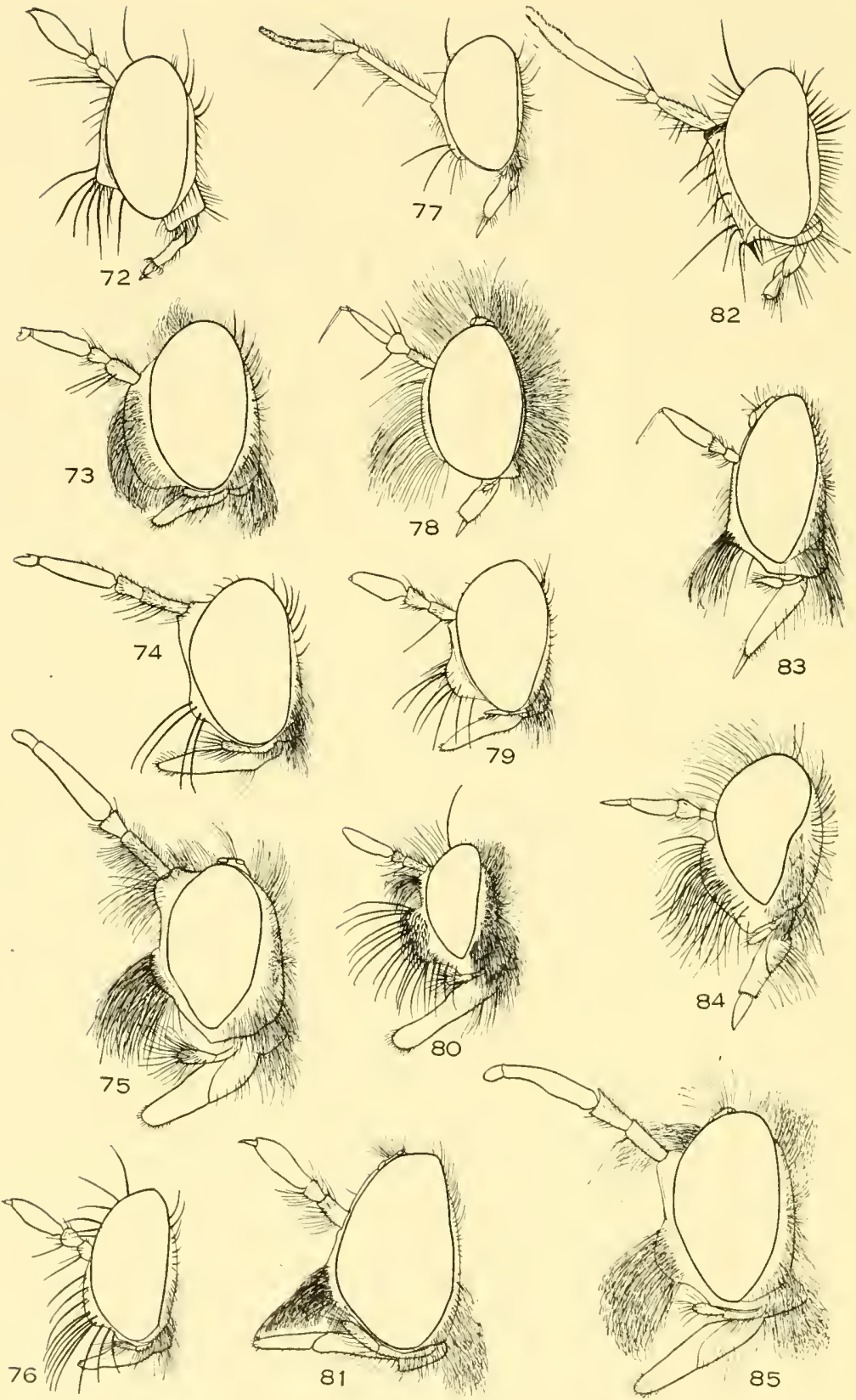

Asilidx V.-72, Eumecosoma shropshirei; 73, Laphystia sexfasciata; 74, Dioctria baumhaneri: 75, Dicolonus simplex; 76, Metapogon; 77, Cerotainia propinqua; 78, Holopogon guttula; 79, Psilocurus birdi; 80, Bombomima flavicollis: 81, Aphamartania; 82, Bathropsis basalis; 83 , Buckellia stylosa ; 84 , Laisopogon opaculus; 85 , Echthodopa. 
37. Antennæ without distinct style ......................... 38 Antennæ with the style short and broad, two-segmented, easily distinguishable $(9,73,92) \ldots \ldots \ldots \ldots \ldots \ldots \ldots \ldots$ thaphystia Lœw

38. Anterior femora on the basal half of the under side with a large patch

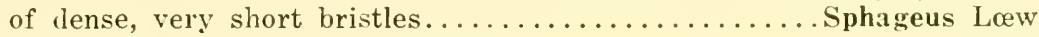
Anterior femora without such bristles.................. 39

39. Third antennal segment very much longer than the basal two combined

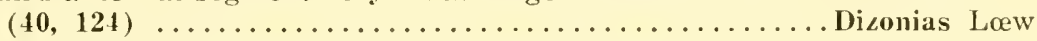
Third antennal segment not or scarcely longer than the basal two combined, elongate oval, swollen $(8,34,79) \ldots \ldots \ldots *$ Psilocurus Lœw

40. Antennal style as broad as the third antenral segment and simulating a segment, sometimes closely appressed and not easily diflerentiated. 41 Antennal style narrower than the third segment or absent......... 44

41. Lateral slopes of the metanotum bare................ 42 Lateral slopes of the metanotum with pile $(75,91) \ldots \ldots$ Dicolonus Lœw

42. Face bare except below .......................... 43 Face haired between mystax and antennæ (103).... Ceraturgopsis Johnson

43. Posterior femora with very short, stout bristles below on the apical half $(85) \ldots \ldots \ldots \ldots \ldots \ldots \ldots \ldots \ldots \ldots \ldots \ldots \ldots \ldots \ldots \ldots \ldots \ldots \ldots \ldots \ldots$ Ecthodopa Lœw

Posterior femora without short, stout bristles below, but with short, erect pile on the whole length $(12,74,90) \ldots \ldots \ldots \ldots$ Dioctria Meigen

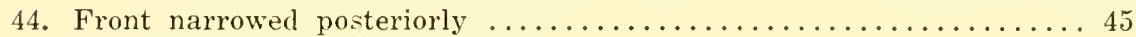

Front not narrowed posteriorly...................... 46

45. Ocelli situated far forward on the front $(56,133) \ldots$. . Plesioma Macquart Ocelli situated near the vertex................ Dolichodes Macquart

46. Face bare except on the oral margin (cf. Holcocephala) ........ 47 Face with hair between the mystax and antennæ, or evenly haired... 49

47. Third antennal segment swollen, about twice as wide as the second.

Willistonina Back

Third antennal segment elongate, more or less tapering from the base or only slightly wider than the second..................448

48. Third antennal segment elongate, longer than the basal two combined

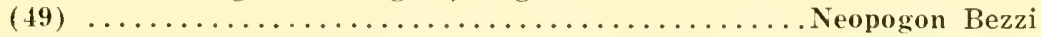
Third antennal segment oval, not as long as the basal two combined.

Lissoteles Bezzi

49. Head very wide, the face with a deep, transverse groove above the oral margin and with only two to six hairs above the mystax $(36,111)$.

Holcocephala Jænnicke

Head narrower, the face without the transverse depression........ 50

50. Mlesonotum with the dorsocentral bristles strong and extending in front of the suture, if rather weak anteriorly there are no acrostical

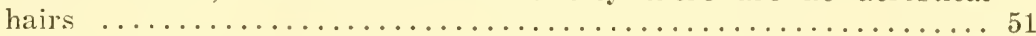

Dorsocentrals absent or not strongly differentiater; mesonotum hairy, the acrostical hair always present.................... 52

* Curran, 1931, Amer. Mus. Novit. No. 487, 1. 8.

† Melander, 1923. Psyche, xxx, p. 212. 

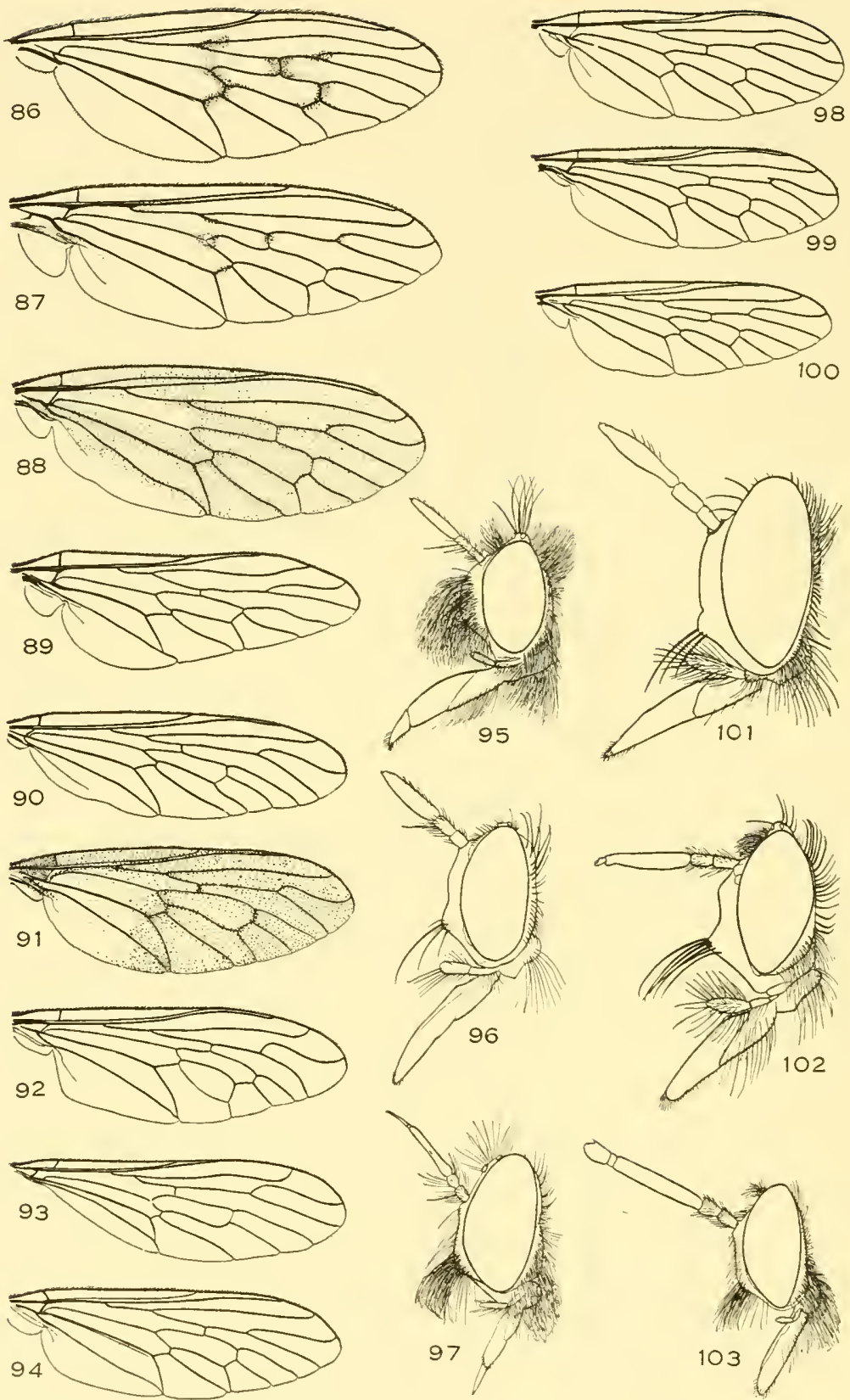

Asilidæ VI.-86, Comantella fallei; 87. Aphamartania murina; S8. Saropogon luteus; 89 , Damalis; 90, Dioctria baumhaueri; 91. Dicolonus simplex; 92, Laphystia sexfasciata; 93. Townsendia argyrata; 94, Lestomyia sabulonum; 95, Lastausus; 96, Blcpharepium secabilis: 97, Nicocles politus; 98, Buckellia pollinosa; 99, Lasiopogon tetragrammus; 100, Hodophylax aridus; 101, Microstylum galactoides; 102, Saropogon birdi; 103, Ceraturgopsis cornutus. 
51. No acrostical hairs $(76, \mathbf{1 1 2}) \ldots \ldots \ldots \ldots \ldots \ldots$ Metapogon Coquillett Acrostical hairs present, usually abundant but short (81, 99).

†Lasiopogon LœW

52. Mesonotum with the hair appressed and usually with distinct, subappressed dorsocentral bristles posteriorly.............. 53

Mesonotal hair erect, the bristles, if present, very fine and erect.... 56

53. No trace of dorsocentral bristles (type Lasiopogon terricola Johnson)

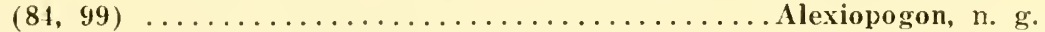

Distinct, though weak dorsocentrals posteriorly............. 54

54. Abdomen elongate, more or less narrowed basally in the males....... 55

Abdomen short and broad, rather strongly tapering in both sexes; hair

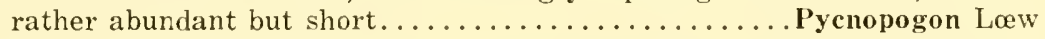

55. Disc of scutellum with hairs toward either side $(52,126)$. Callinicus Lœw Scutellum with marginal bristles and hairs only (39).

Chrysoceria Williston

56. Face decidedly gibbous, the swelling clearly limited above....... 57

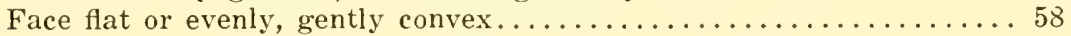

57. The third vein branches before the apex of the discal cell; style long $(129,151) \ldots \ldots \ldots \ldots \ldots \ldots \ldots \ldots \ldots \ldots \ldots \ldots \ldots \ldots \ldots \ldots \ldots \ldots$ Eucyrtopogon Curran The third vein branches conspicuously beyond the apex of the discal cell; style short $(128,152) \ldots \ldots \ldots \ldots \ldots \ldots \ldots \ldots$ Cyrtopogon Lœw

58. Posterior tibiæ strongly swollen, about twice as large as the anterior ones $(78,143) \ldots \ldots \ldots \ldots \ldots \ldots \ldots \ldots \ldots \ldots \ldots \ldots$. . . . . . . . . . . . . Posterior tibiæ not enlarged $(57,127) \ldots \ldots \ldots \ldots \ldots$ Heteropogon Lœw

59. Antennæ with a terminal arista......................... 77 Antennæ with or without a terminal style which is never bristle-like. 60

60 . Wing with only two submarginal cells.................. 61 Wing with three submarginal cells $(23,62) \ldots \ldots \ldots$. Pogonosoma Rondani

61. Third antennal segment with an apical style, which is rarely difficult

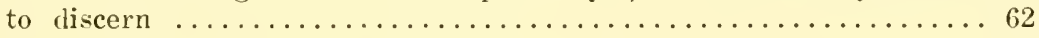
Third antennal segment without style................... 66

62. Third antennal segment excised and bearing a very short bristle beyond the middle on the upper side, the style slender $(66,108)$.

Atractia Macquart

Third antennal segment not excised above................. 63

63. Face with strong, isolated bristles and short, fine hair......... 65

Face with soft hair, which may be long and contain some coarse ones.. 64

64. Face perpendicular, more prominent above or almost evenly convex; mesonotum not with dense, long yellow pile $(9,73,92)$.

Face most prominent below the middle with dense, long yellow pile $(24) \ldots \ldots \ldots \ldots$ Dasylechia Williston

* Melander, 1923, Psyche, xxx, p. 210.

$\dagger$ Melander, 1923, Psyche, xxx, p. 136.

$\ddagger$ Curran, 1923, Can. Ent. 1v, 1). 95.

\$ Curran, 1923, Can. Ent. lv, p. 123; Melander, 1923, Psyche, xxx, p. 102.

- Curran, 1931. Amer. Mus. Novit. No. 487, p. 11. 

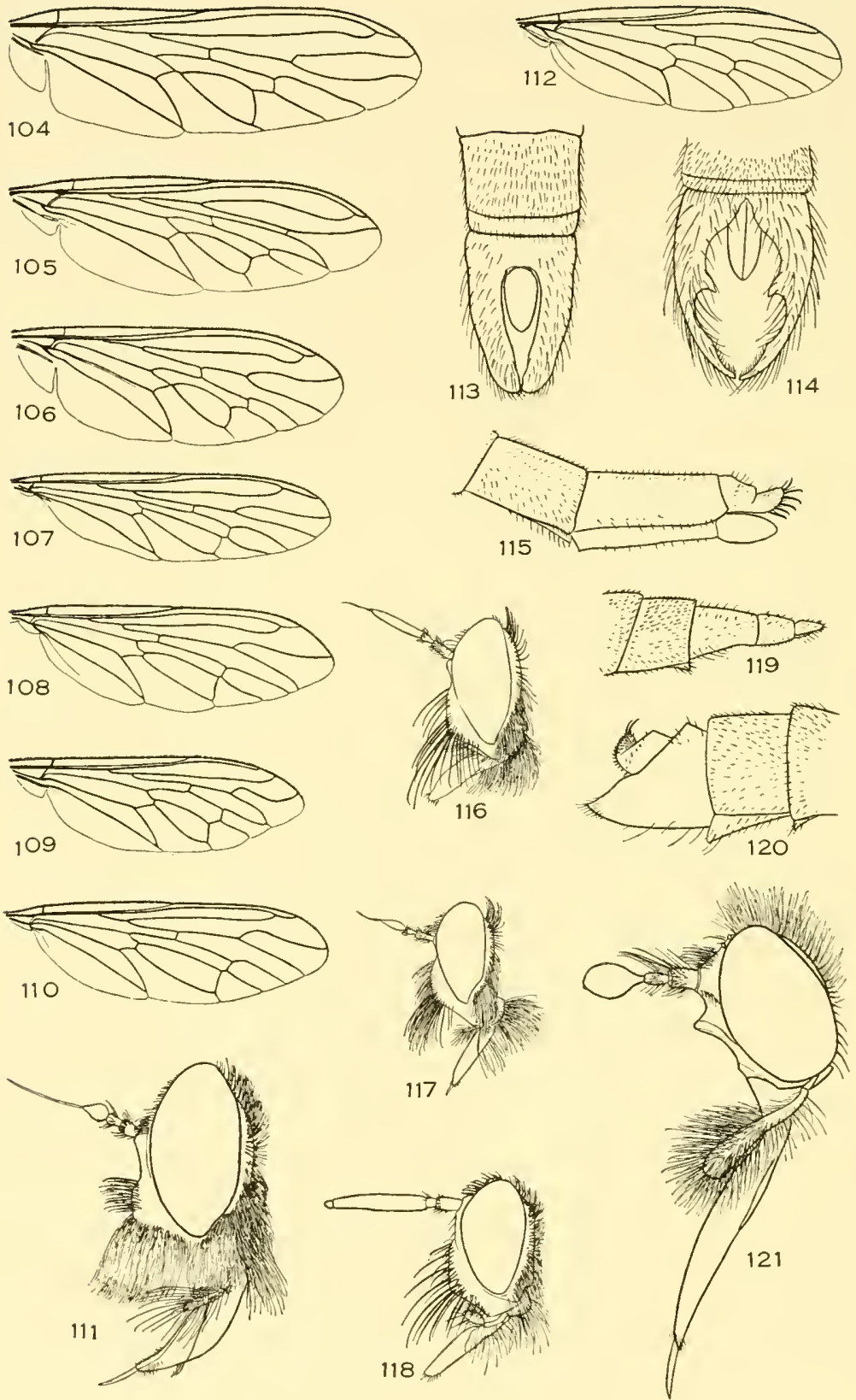

Asilidæ VII.-104, Proctacanthella cacopilogus; 105, Mallophorina laphroides; 106, Vegasilus belli; 107, Protichisma albibarbis; 108, Atractia dispar; 109, Triciis tagax; 110 Atonia (n. sn. Brazil); 111. Eccritosia barbata; 112, Metapogon; 113, Heligmoneura; 114, (15) Proctanthella cacopilogus: 16. Asilus sericeus; 117. Proctacanthella Philonicus albiceps; 11, Proctacalthella cacopiloge, Heligmoneura rubicunda; 120, Philnnicus cacopilogus; 118 , 
65. First antennal segment less than twice as long as the second; style strongly differentiated $(12,110) \ldots \ldots \ldots \ldots \ldots \ldots \ldots$ Atonia Williston

First antennal segment more than three times as long as the second; style poorly differentiated $(82,145) \ldots \ldots \ldots \ldots \ldots$ Bathropsis Hermann

66. Third antennal segment at least three times as long as the basal two

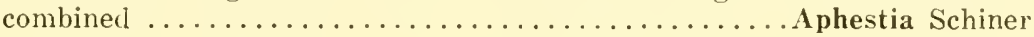

Third antennal segment not more than twice as long as the first two

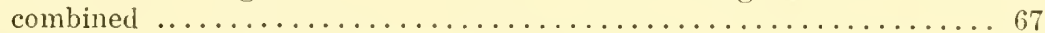

67. Metanotal slopes or callosities bearing pile or short, stout bristles... 68 Metanotal callosities without pile or bristles.............. 73

68. Mesonotum evenly clothed with clense pile, most of which is yellow, some erect and some appressed; no bare areas outsicle the dorsocentral area; large species $(25,80) \ldots \ldots \ldots \ldots *$ Bombomima Enderlein Mesonotum without dense hair concealing the ground color........69

69. Front at least slightly widening above, never narrowed........... 70 Front narrowed above $(22,43,48) \ldots \ldots \ldots \ldots \ldots$ Atomosia Macquart

70. First antennal segment at least three times as long as the second... 71 First antennal segment not twice as long as the second......... 72

71. Seventh abdominal segment elongate (107)........Protichisma Hermann Seventh abdominal segment short, three or four times as wide as long, or apparently absent $(44,77,146) \ldots \ldots \ldots \ldots \ldots \ldots$ t⿱t十Cerotainia Schiner

72. Face strongly gibbous below and with rather abundant hair above

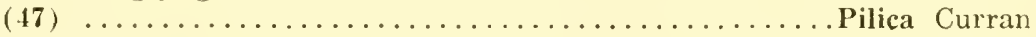
Face weakly gibbous below and with only a row of hairs on either side $(72,144) \ldots \ldots \ldots \ldots \ldots \ldots \ldots \ldots \ldots \ldots \ldots$ Eumecosoma Schiner

73. Face with a strong swelling occupying the lower half, most prominent

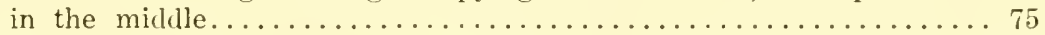

Face very gently convex or concave and most prominent just above the oral margin................................ 74

74. Scutellum with long marginal bristles; large, elongate species (55).

Panamasilus Curran

Scutellum with extremely short, upturned marginal hair; smaller, robust species $(135) \ldots \ldots \ldots \ldots \ldots \ldots \ldots$. Cerotainiops Curran

75. Proboscis laterally compressed.......................... 76 Proboscis dorsoventrally compressed (46)...... TAndrenosoma Rondani

76. Metasternum with long hairs $(26,45,61) \ldots \ldots \ldots$. Lampria Macquart Metasternum bare $(26) \ldots \ldots \ldots \ldots \ldots \ldots \ldots \ldots \ldots \ldots \ldots$ Laphria Meigen

77. Arista pectinate below $(27,60) \ldots \ldots \ldots \ldots \ldots 0^{\circ}$ Ommatius Wiedemann

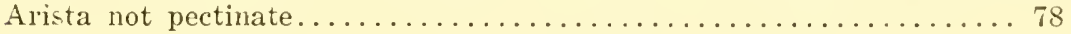

* This name replaces Dasyllis, a strictly South American genus. Unless the mesence of metanotal hairs is a valid character the genus does not differ from Laphria. For key see Banks, 1917 (Dasyllis) Bull. Brooklyn Ent. Soc., xii, n. 52.

† Curran, 1930, Amer. Mus. Novit. No. 425, p. 15.

+ Curran, 1930. Amer. Mus. Novit. No. 425, p. 11.

$\S$ Curran, 1930. Amer. Mus. Novit. No. 425, p. 8.

S Curran, 1931, Amer. Mus. Novit. No. 487, D. 19.

II McAtee, 1918, Ohio Journ. Sci., xix, p. 143.

- Curran, 1928. Amer. Mus. Novit. No. 327. 

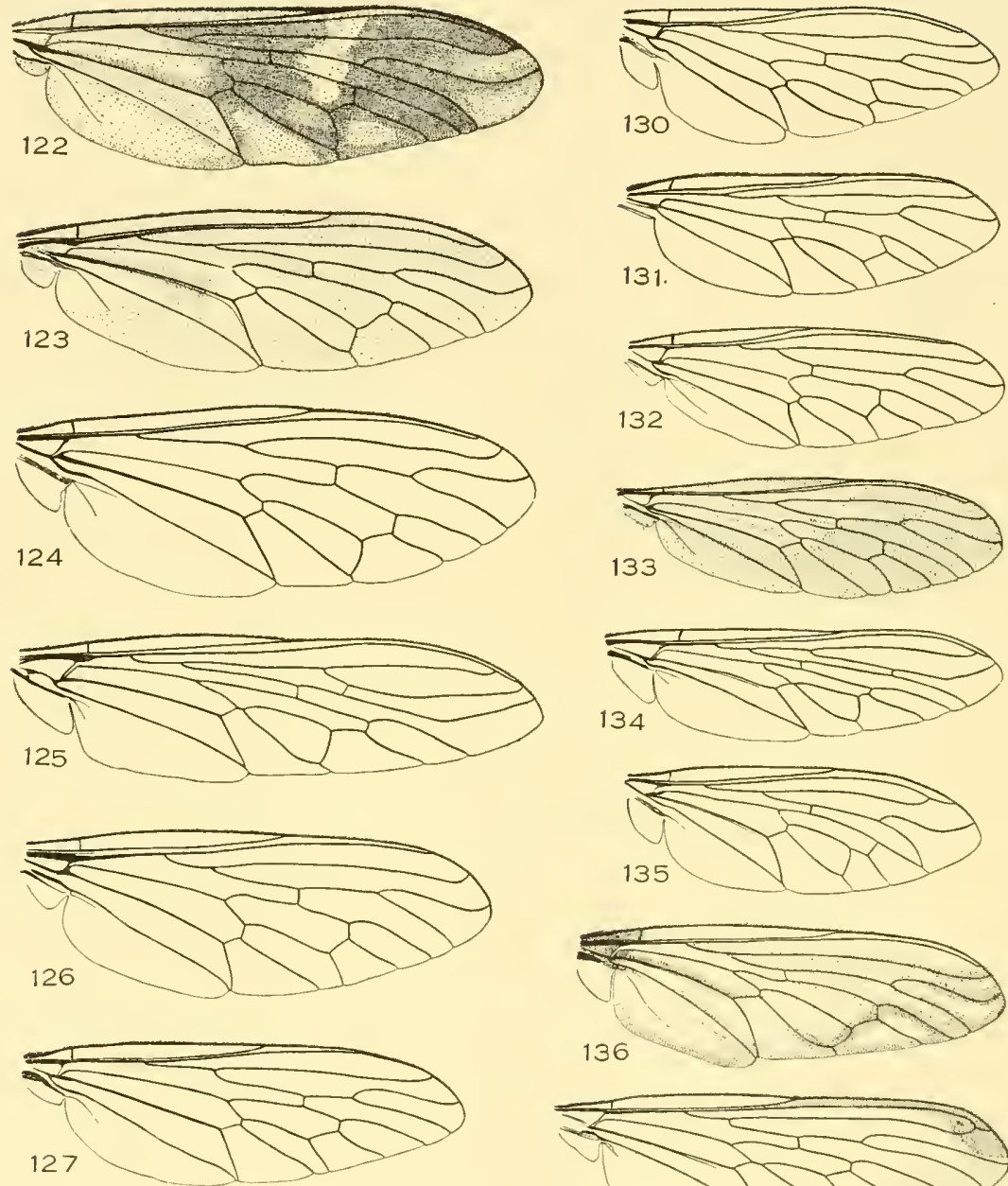

134
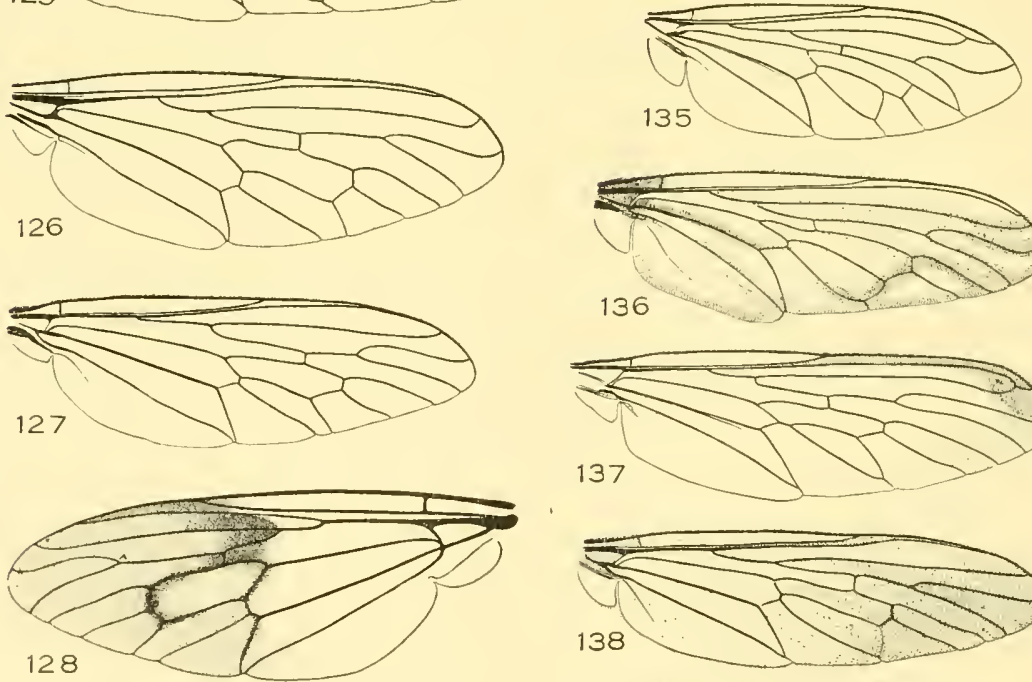

137
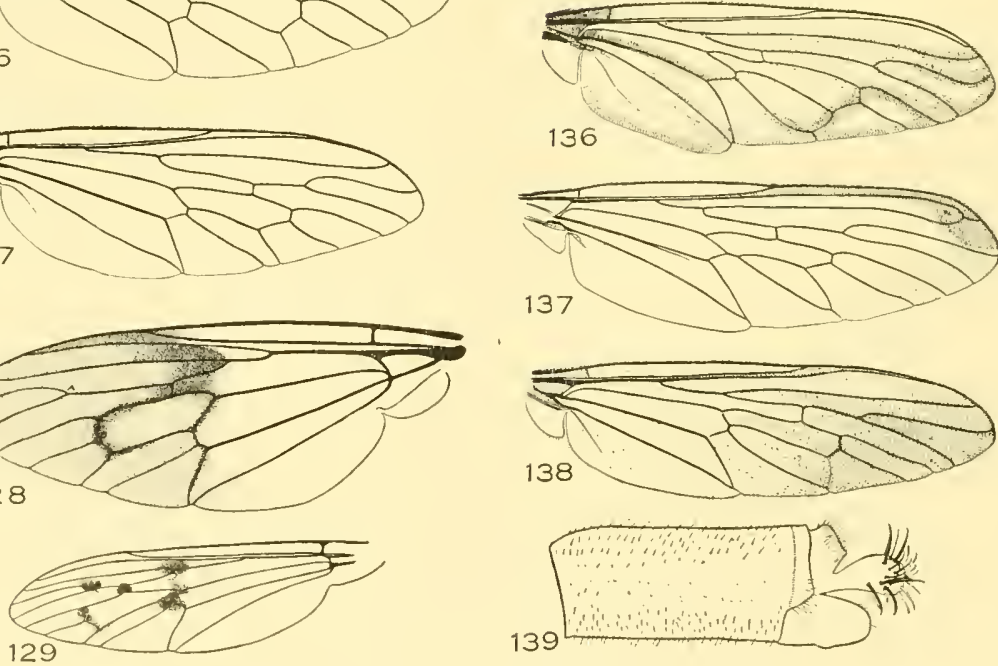

Asilidæ VIII.-122, Doryclus (n. sp.) : 123, Blepharepium secabilis; 124, Dizonias lucasi; 125. Erax automalus; 126, Callinicus calanus; 127, Heteropogon sp. (Utah): 128, Cyitopogon cuitistylus; 129, Eucyrtopogon; 130, Scleropogon; 131, Neopogon; 132, Ceratirgns nigripes: 133. Plesioma lineata: 134, Promachina nimius; 135, Cerctainiops; 136, Archilestris magnificus; 137. Senoprosopis; $13 \AA$, Senobasis mendax; 139, Proctacanthus micans. 
78. Third antennal segment long, with a bristle-bearing excision above $(66,108) \ldots \ldots \ldots \ldots \ldots \ldots \ldots \ldots \ldots \ldots \ldots \ldots \ldots \ldots \ldots \ldots$ Atractia Macquart 'Third antennal segment usually short, never with a bristle-bearing

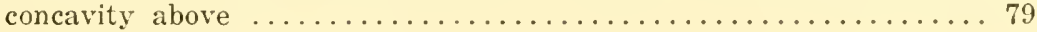

79. Slopes or lateral swellings of the metanotum pilose........... 92 Slopes or lateral swellings of the metanotum bare............ 80

80. Third antennal segment very long and narrow, tapering, with a short, thick arista; face very narrow $(53,137) \ldots .$. . Senoprosopis Macquart Third antennal segment short, with long arista; face not unusually

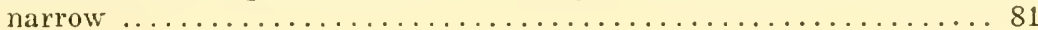

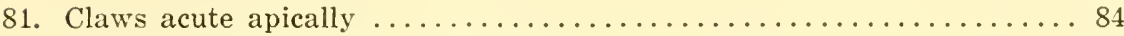

Claws obtuse apically, thick almost to the apex............. 82

82. Front and face wide; space between antennæ and posterior ocelli strongly transverse ................................ 83

Front and face narrow; space between the antennæ and posterior ocelli as great as the width or practically so $(134)$......Promachina Bromley

83. Face evenly, gently convex, evenly pilose, the oral margin with bristles

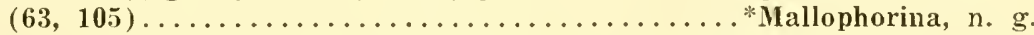
Face more or less strongly gibbous below, not uniformly pilose $(29,67)$.

$\dagger$ Mallophora Macquart

84. Third antennal segment strikingly haired above.......Anarmostus Lœw Third antennal segment bare or with only a few short hairs above... 85

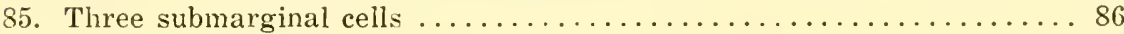

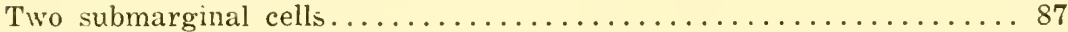

86. The crossvein separating the second and third submarginal cells is situated well beyoni the apex of the discal cell $(30,31,32)$.

Promachus Lœw

This crossvein is situated well before the apex of the discal cell $(\mathbf{7 0}, \mathbf{1 2 5})$

$\ddagger$ Erax Scopoli

87. The posterior branch of the third vein meets the costa before the apex

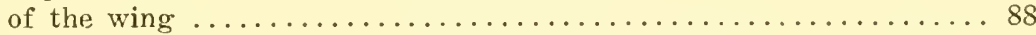

The posterior branch of the third vein reaches the wing margin behind

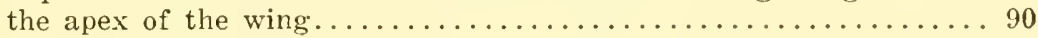

88. The $q$ ovipositor ends in a circlet of spines; abdomen of males longer than the wings $(65,139) \ldots \ldots \ldots \ldots \ldots \ldots$. Proctacanthus Macquart The of ovipositor is laterally compressed or bears many short spires above; wings reaching beyond the tip of the abdomen in males... 89

89. Female ovipositor with many short, stout spines above; upper ocelli situated on the front slopes of the ocellar swelling $(28,111)$.

Eccritosia Schiner

Female ovipositor laterally compressed; upper ocelli on the top of the

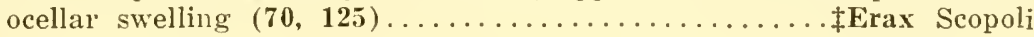

\footnotetext{
* See page 183. Key, Curran, 1931. (Mallophora), Amer. Mus, Novit. No. 487, p. 21. † Curran. 1930. Amer. Mus. Novit. No. 415, p. 12.

\$ine, 1919, Ann. Ent. Soc. Amer., xii, pp, 103-154.
} 

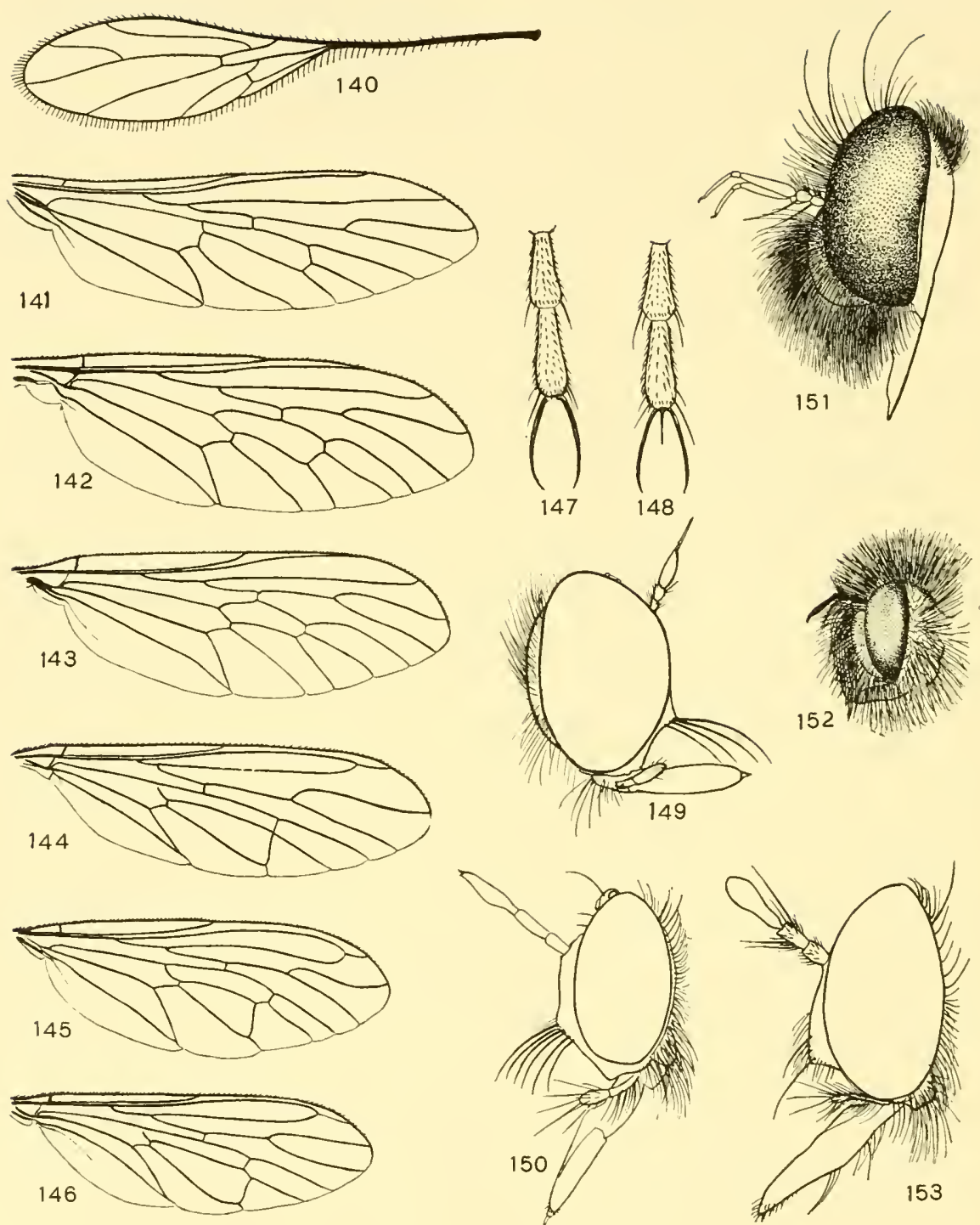

Asilidx IX.-140, Eurhabdus zephyrea; 141, Holcocephala calva; 142 Taracticus octopunctatıs: 143, Holopogon guttula: 114, Eumecosoma gibbus; 145, Bathropsis basalis: 146. Cerctainia propinqua; 147. Psilonyx, front tarsal claws: 148, Leptogaster, front tarsal claws ; 149, Leptogaster; 150, Deromyia litoralis; 151, Eucyrtopogon varipenuis; 152, Cyrtopogon willistoni; 153 Senobasis analis. 
90. Face with a strong gibbosity occupying the lower half or more

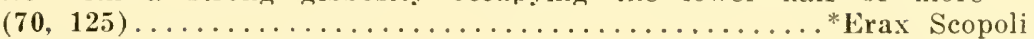

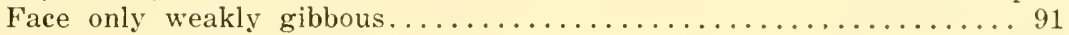

91. Mystax dense, extending to above the middle of the face $(104,115,117)$.

Proctacanthella Bromley Mystax sparse, composed of bristles $(68) \ldots \ldots \ldots$...........

92. Abdomen without bristles .............................. 93 Abdomen with bristles laterally before the segmental apices........ 96

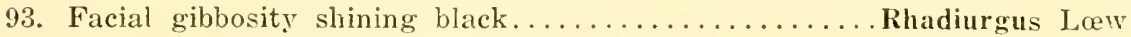
Facial gibbosity pollinose, weakly developed............... 94

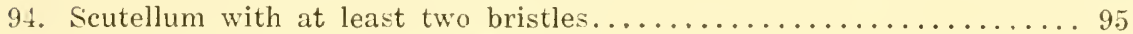
Scutellum without bristles $(64,106) \ldots \ldots \ldots \ldots \ldots \ldots \ldots$ Negasilus, $n$. g.

95. Mystax composerl of bristles only $(116) \ldots \ldots \ldots \ldots \ldots$ Asilus Linnæus Mystax composed mostly of very fine hair...........Antiplurisson Løw

96. Occipital cilia abundant, rather long and curved at almost right angle at or near the apical third $(59) \ldots \ldots \ldots \ldots$ † $\ldots$ Neoitamus Osten Sacken Occipital cilia shorter and stouter, not strongly curved............ 97

97. Facial gibbosity strongly developed and reaching at least to slightly above the middle of the face (Tolmerus Lœw) (69) . . .† †lachimus Lœw

Facial gibbosity weakly developed, not extending above the lower third

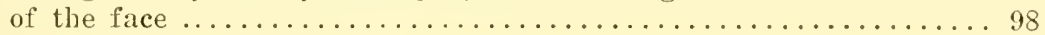

98. Dorsocentrals extendirg in front of the suture $(51) \ldots \ldots .+$ Cerdistus Lœw Dorsocentrals not extending in front of the suture.............. 99

99. Female ovipositor armed at the apex with four or six stout, short bristles; forceps of male genitalia strongly curved and leaving a large open space on the apical half $(114,120) \ldots \ldots . \dagger$ Philonicus Løw Female ovipositor without bristles; male genitalia compact, never leaving a large open space from dorsal view $(113,119)$.

$\dagger$ Heligmoneura Bigot

\section{Alexiopogon, new genus}

Jist inguished from Lasiopogon Lew by the absence of dorsocentral bristles. The figures of Lasiopogon will serve also for this genus. Genotype:-Lasiopogon tericola. Johnson.

\section{Mallophorina, new genus}

Claws robust, obtuse apically; marginal cell closed and petiolate, the first posterior cell open or closed; antenne with lone, triminal aristalike stỵle; face erenly gently convex or almost flat, and with almost uniform hair; front and face wide; body rather thickly pilose. Fenotype,

* Hine, 1919, Ann. Ent. Soc. Amer. xii, np. 103-154.

$\dagger$ Hine, 1909, (Asilus), Ann. Ent. Soc. Amer., ii, pp. 136-170. 
-Mallophora guildiana Williston. Speeies included: laphroides Wiedemann, clausicella Maequart, acra Curran, all previously placed in Mallophora.

\section{Negasilus, new genus}

Related to Asilus Linnæus but at once distinguished by the absenee of seutellar bristles. Artista short and style-like; face moderately convex on the lower half, the mystax composed of bristles only; occipital bristles straight; four pairs of dorsocentrals on the posterior half of the mesonotum; mesonotal hair all short and appressed; abdomen elongate and without bristles on the second and following segments. Genotype:N. belli, n. sp.

$N$. belli is black, einerous-yellowish pollinose, the male genitalia, apiees of the femora and the tibiæ reddish. 


\section{Family Therevidæ-The Stilleto Flies}

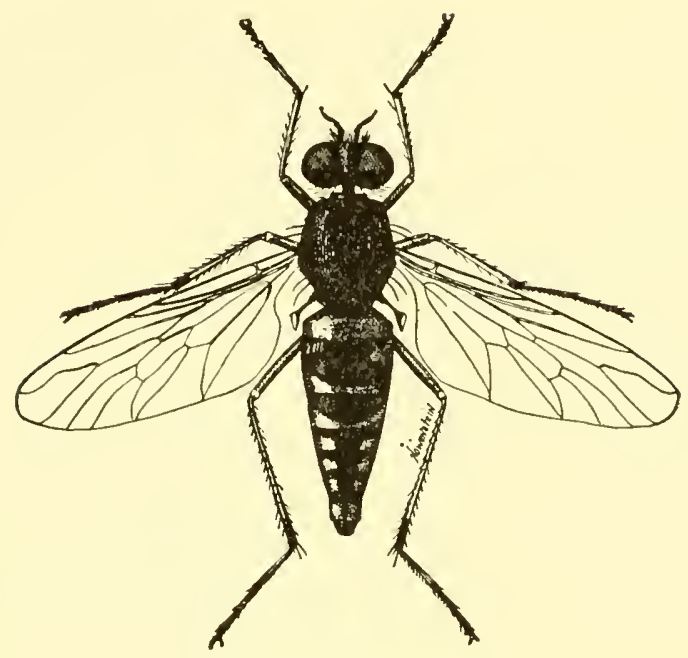

Thereva species.

Flies of moderate size, more or less bristly and often pilose, with predaceous habits.

Front not excavated, the eyes of the males usually holoptic or nearly so; proboseis projecting, the labella broad; palpi two-segmented; ocelli present. Antemna with three segments and usually a sharp terminal style. Abdomen elongate, the genitalia small but exposed, the ovipositor with a eirclet of spines. Legs with bristles; empodia absent: pulvilli usually present. Third vein fureate; five posterior eells, the fourth sometimes closed; anal cell elosed toward the margin of the wing or narrowly open.

The adults are found in various places but are most abundant in dry areas, such as meadows, pastures and along sandy beaches. They often occur in considerable numbers in burnt-over areas and are always most abundant during hot weather. Cole* has revised the family and given keys to the North American species. A number of speeies have been deseribed during recent years but most of the species will be found in Cole's paper.

The larvæ are not well known but are all believed to be predaceous and they may prove to be of considerable importanee in the control of certain insects. 

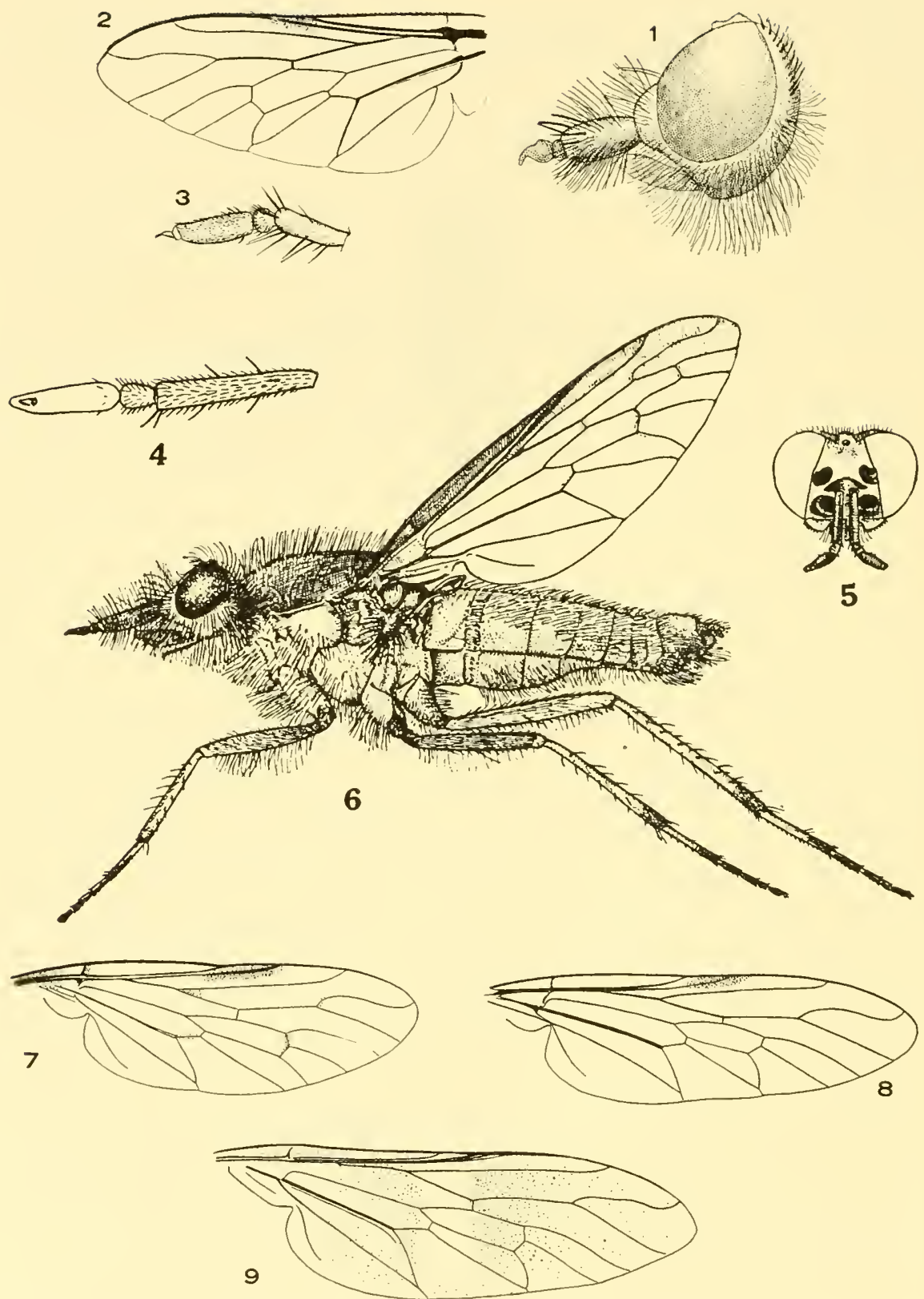

Therevidx I.-1, Tabuda; 2, Psilocephala; 3, Psilocephala, antenna; 4, Chromolepida bella, antenna; 5, Chrmomolepida bella, head from above; 6 . Metaphragma planiceps; 7 , Tabuda fulvipes; 8 , Thereva melaneura; 9, Epomyia sumichrasti. 


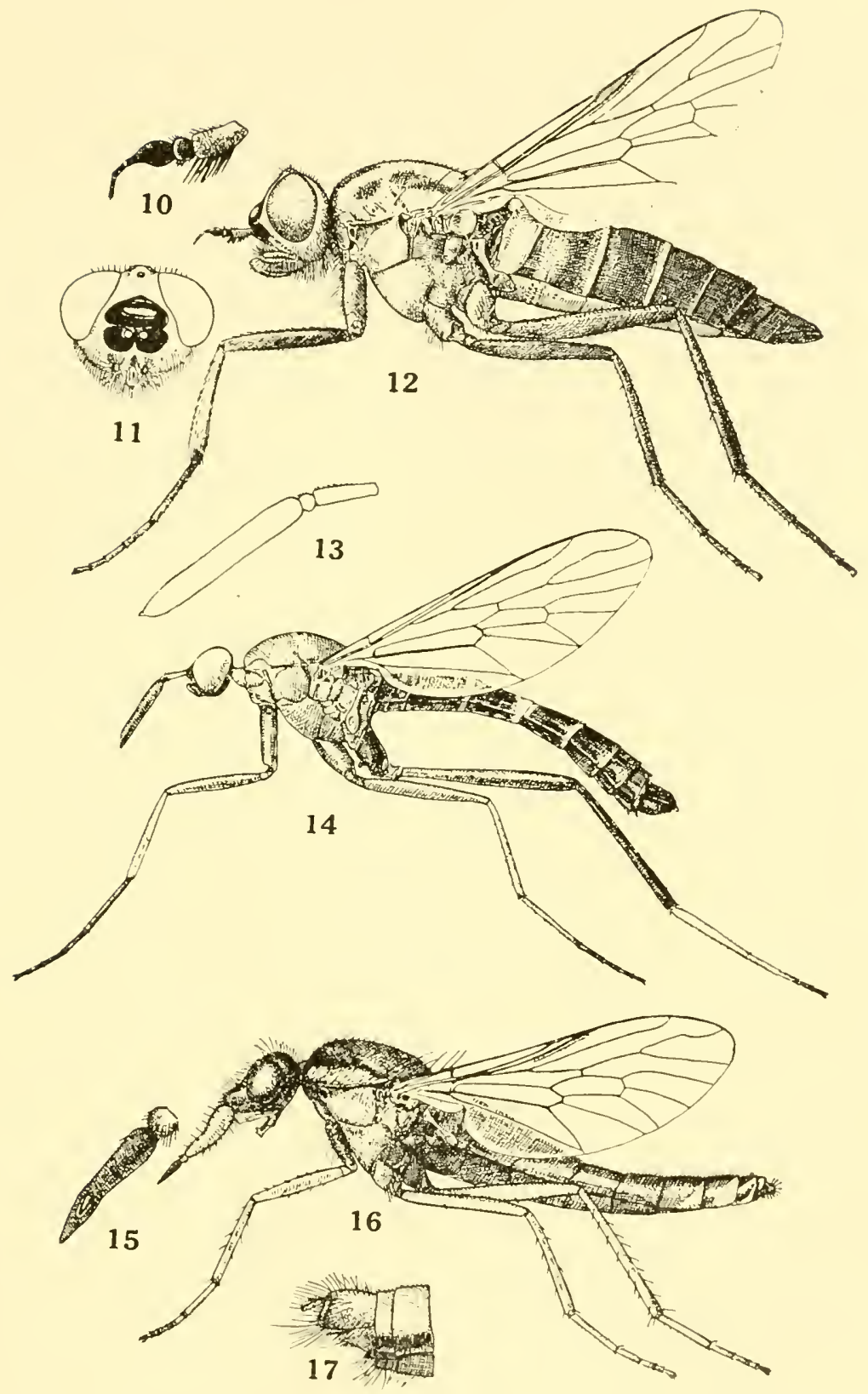

Therevidx 1I.-10, 11, 12, l'heroccra signatifrons; 13, 14, Henicomyia hubbardi; 15, 16, Nebritus pellucidus; 17 , Nebritus pellucidus, genitalia. 


\section{KEY TO GENERA}

1. Body largely clothed with scales $(4,5) \ldots \ldots \ldots \ldots \ldots$ Chromolepida Cole Body with tomentum but never with irridescent scales.......... 2

2. Third antennal segment appearing annulated; labrum narrow (Mexico). Ozodiceromyia Bigot Third antennal segment not annulated, usually with a terminal style

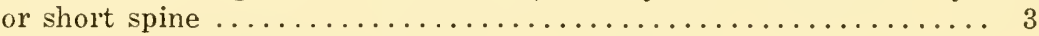

3. First antennal segment longer than the head and bristled (Mexico; cf. Metaphragma Coq.) .....................Euphycus Kröber First antennal segment rarely as long as the head............. 4

4. Five posterior cells ............................ 5

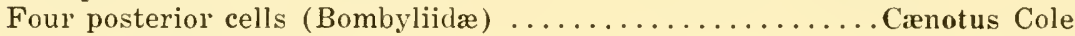

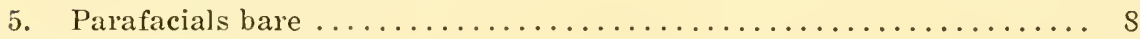

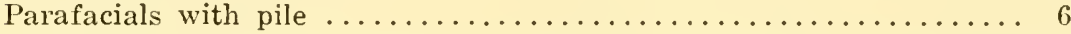

6. Basal antennal segment long and greatly swollen, much larger than the second and third combined $(1,7) \ldots \ldots \ldots \ldots \ldots$ Tabuda Walker Basal antennal segment not unusually large, never greatly swollen.. 7

7. Third and fourth veins connected by a crossvein beyond the furcation

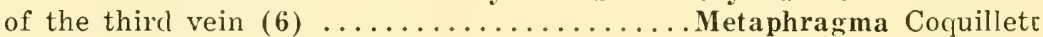
Wings without such crossvein (8) ............ Thereva Zetterstedt

8. Third antennal segment not more than twice as long as the first.... 9 Third antennal segment at least two and a half times as long as the first (Southern) $(13,14) \ldots \ldots \ldots \ldots \ldots \ldots$. . . . . . . . . . .

9. Basal antennal segment large and shining $(15,16,17)$. . Nebritis Coquillett Basal antennal segment pollinose ...................... 10

10. Basal antennal segment swollen and hairy $(1) \ldots \ldots \ldots \ldots \ldots \ldots \ldots 11$ Basal antennal segment not strongly swollen................ 12

11. Males dichoptic; lower front pilose $(1,7) \ldots \ldots \ldots \ldots \ldots *^{*}$ Tabuda Walker Males holoptic or nearly so; lower front bare of pile.. Dialineura Rondani

12. Intercallary and fifth veins reaching the wing margin........ 13 Intercallary and fifth veins not reaching the wing margin $(10,11,12)$.

Pherocera Cole

13. Antennal style projecting from under the tip or from the apex of the

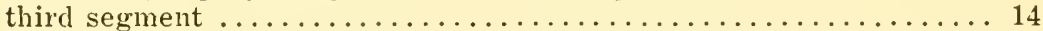
Style arising from a hollow near the apex of the third segment (9).

Epomyia Cole

14. Antennal style projecting from under the tip of the third segment.

Furcifera Kröber Antennal style apical $(2,3) \ldots \ldots \ldots \ldots \ldots$ Psilocephala Zetterstedt

* Tabuda fulvipes Walker, 1852, is a synonym of Thereva nervosa Walker, 1848. The latter becomes the genotype. 
Family Apioceridæ

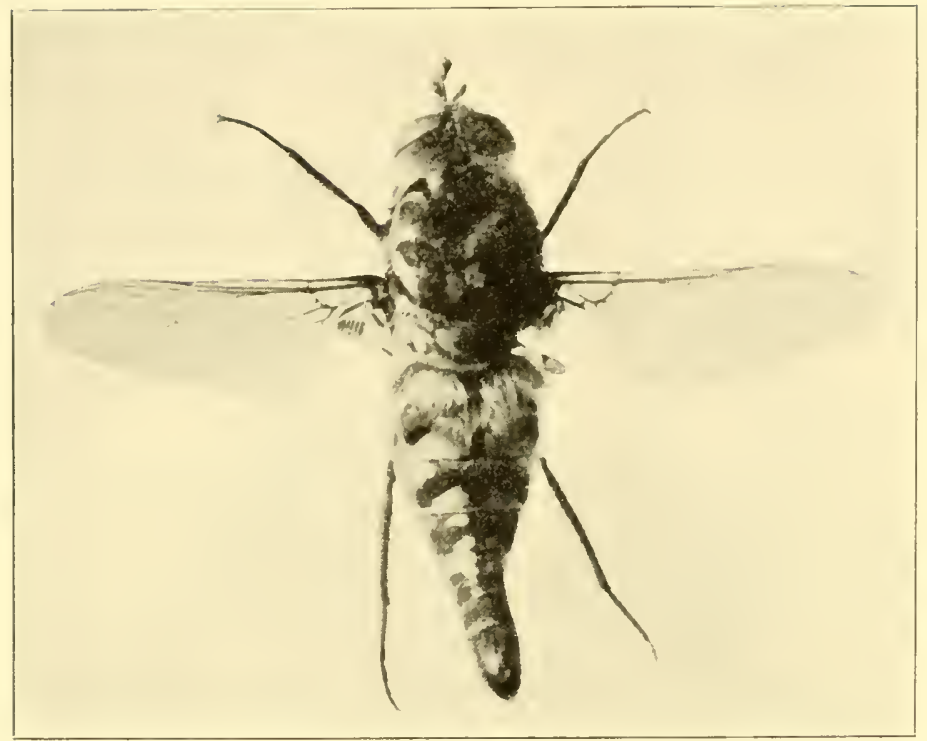

Apiocera species.

Large, elongate flies, with three-segmented antennæ and rather thinly pilose.

Antenne with or without a short, terminal style. Front not exeavated, wider in the female; ocelli present; face short; proboseis longer than the length of the head, not adipted for picreing, the labella not horny. Empodia wanting. Third vein usually fureate; basal cells long; five posterior cells, the fourth closed. Nale forceps enlarged.

These flies are apparently restrieted to arid or semi-arid regions and are not at all common in collections. Like the Nemestrids they are great hoverers and make a loud noise while in flight. The immature stages are unknown. 


\section{KEY TO GENERA}

1. Proboscis more than twice as long as the head-height ......... 2 Proboscis not longer than the heacl-height $(1,2) \ldots *$ A piocera Westwood.

2. Anal cell closed before the wing margin $(3,4)$.

Rhaphiomidas Osten Sacken

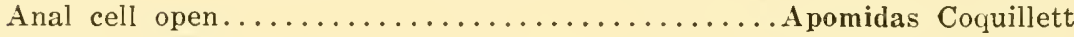

* Painter, 1932, Ann. Ent. Soc. Amer., xxv, p. 351.
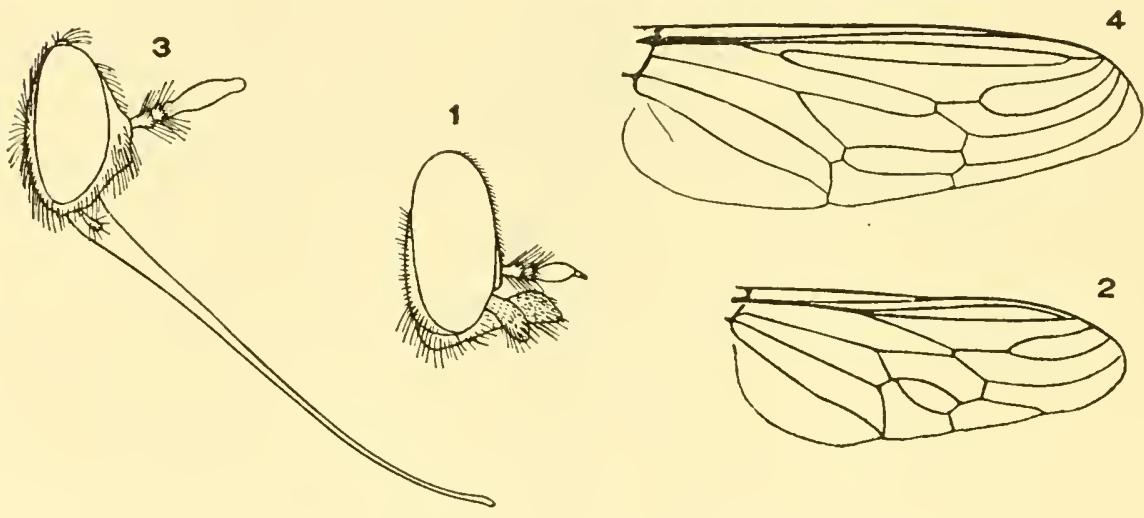

Apioceridæ.-1, 2, Apiocera haruspex; 3, 4, Rhaphiomydas acton. 


\section{Family Bombyliidæ-The Bee Flies}

Small to moderately large flies, often with pietured wings and frequently clothed with abundant, delicate hairs or seales whieh are easily abraded, rarely with conspicuous bristles.

Head narrower than or as broad as the thorax, more or less hemispherieal in shape; usually closely applied to the thorax. Face variable, usually short, often prominent below. Eyes large, often contiguous in the male, rarely so in the female. Antennæ three-segmented, porreet, rarely long, usually of moderate length, sometimes small; third segment simple; style usually small, never more than two-segmented, sometimes absent. Ocelli present. Proboseis sometimes short and with broad labellæ, usually more or less elongate and projeeting from the oral eavity. Thorax convex above, sometimes strongly so, usually with bristles. Abdomen eomposed of six to eight segments, slender in a few genera, usually depressed but often eylindrieal and more or less tapering. Legs moderately long and weak, usually with short, weak bristles or spines; pulvilli sometimes rudimentary, the empodia usually absent. Squame small. Wings often pietured; two to four submarginal cells (rarely with only one) diseal cell almost always present (absent in some genera oceurring outside North America); anal eell elosed or narrowly open.

The family eomprises almost two thousand described species and oceurs throughout the world, being most abundantly represented in the tropical and subtropical regions. They are found partieularly in warm spots, a relatively small number oceurring in woods, and I have taken none in heary shade. They like the warmest time of the day and most of them rest upon the dry soil, dried grass or upon grass in sandy places when not visiting flowers. Some speeies are found mostly at bloom, others but rarely. They are (mostly) great hoverers and generally very rapid fliers although they frequently fly but a short distance when disturbed. In the tropies I found many speeies in sunny places near the trees at the edge of the beach and along the trails in the forest, and similar plaees are produetive in the north. Many of the species buzz persistently when captured.

Taxonomically the family is (in North America) in almost hopeless condition, the literature being extremely seattered. Only a few of the deseribed species have been properly figured and without illustrations and usable keys the student is greatly handicapped. In addition to this unfortunate state of affairs the flies themselves present an obstacle, as the hairs are easily abraded and great eare must be exereised in collecting them. Only a very few speeimens should be placed 


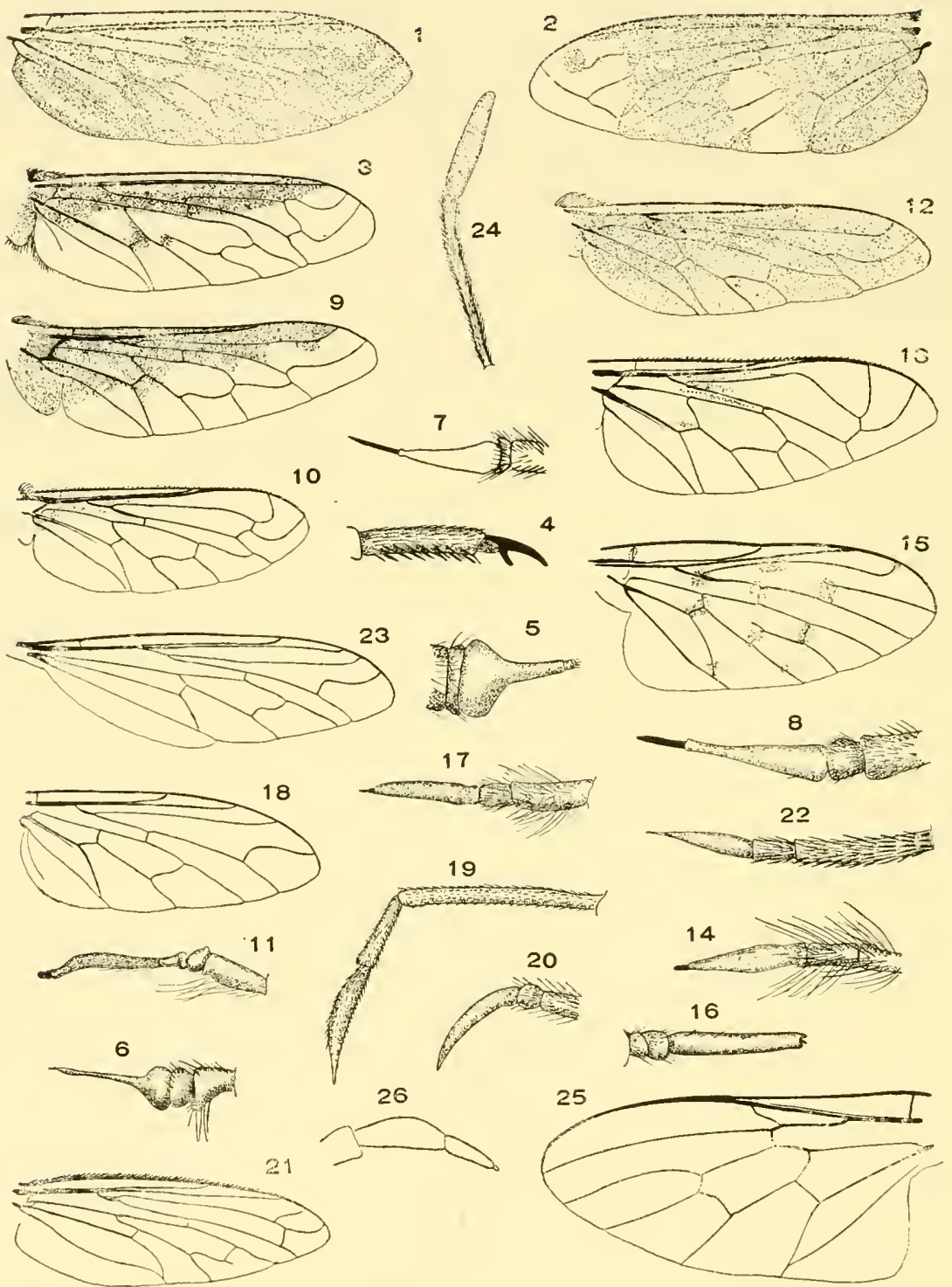

Bombylider I-1, Genus incerte ; 2, Hyperalonia; 3, Litorhynchus; 4, Exoprosopa, hind claw; 5, Anthrax, antenna; 6, Villa, antenna; 7, 8, Exoprosopa, antenna ; 9, Bombylius major; 10, Pantarbes; 11, Pantarbes, antenna; 12, Systæchus; 13, Lordotus; 14, Lordotus, major, 15. Phthiria; 16, Phthiria, antenna; 17. Sparnopolius, antenna; 18, Geron; 19, 20, antenna; 15, Phthiria; 16, Phthiria, antenna; antenna ; 25, Mythicomyia, wing; 26, Mythicomyia, antenna. 
in the killing bottle and they must never be placed with other insects else they be ruined for all practical purposes. Withont the hairs they are of no value and camnot be properly identified.

The larva are parasitic upon bees, wasps, grasshoppers and eertain Lepidoptera, but not a great deal is known about most of the genera.

\section{KEY TO GENERA}

1. The second vein arises transversely opposite or almost opposite the

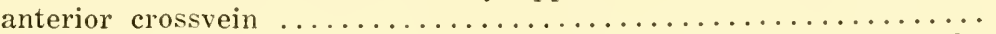

The second vein arises at an angle at a considerable distance from the

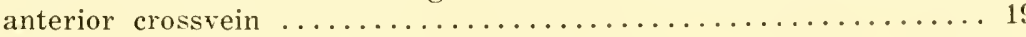

2. Antennal style separated from the third segment by a distinct suture,

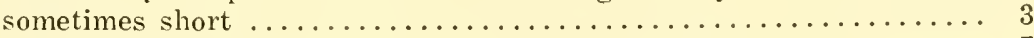

Antennal style not separated from the third segment........... 7

3. Antennal style terminating in a pencil of hairs $(5,54,64)$.

* Anthrax Scopoli Antennal style not terminating in a pencil of hairs............ 4

4. Pulvilli vestigial or absent...................... 5 Pulvilli large $(49,52) \ldots \ldots \ldots \ldots \ldots \ldots \ldots \ldots \ldots \ldots \ldots \ldots$ Aldrichia Coquillett

5. Four submarginal cells $(2) \ldots \ldots \ldots \ldots \ldots \ldots \ldots$. . . . . . . . .

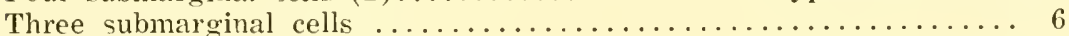

6. Proboscis projecting more than the length of the labellæ beyond the anterior oral margin (3) ............. Litorhynchus Macquart Proboscis projeciing less than the length of the labellix $(4,7,8,57)$.

$\dagger$ Exoprosopa Macquart

7. Anal cell open; eves of o not contiguous................. 8 Anal ceil closed; eyes of $\sigma^{\prime}$ contiguous at the vertex.

Astrophanes Osten Sacken

8. Anal cell widest at the middle........................ 9 Anal cell widest at the wing margin $(36) \ldots \ldots \ldots \ldots$ Mancia Coquillett

9. Second vein strongly contorted and $\longrightarrow$ shaped at the apex........ 10 Second vein not strongly contorterl....................... 11

10. Three submarginal cells ................. Dipalta Osten Sacken Two submarginal cells................. Neodiplocampta, n. g.

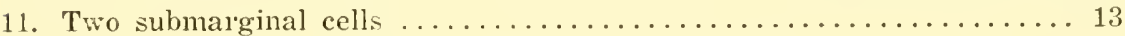

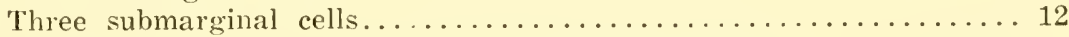

12. Proboscis extencling but little beyond the oral opening (6).... Villa Lioy Proboscis extending far beyond the anterior oral margin $(34,51)$.

Stonyx Osten Sacken

13. Face wholly without scales; labellæ long and narrow.

Pocilanthrax Osten Sacken

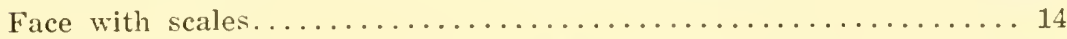

14. Anterior tibia with spicules in regular rows.................. 16 Anterior tibiæ with at most two or three very small spicules...... 15

* Curran, 1927, Can. Ent. lix, p. 84 (partial key).

$\dagger$ Curran, 1930, Amer. Mus. Novit. No. 415. p. 2. 

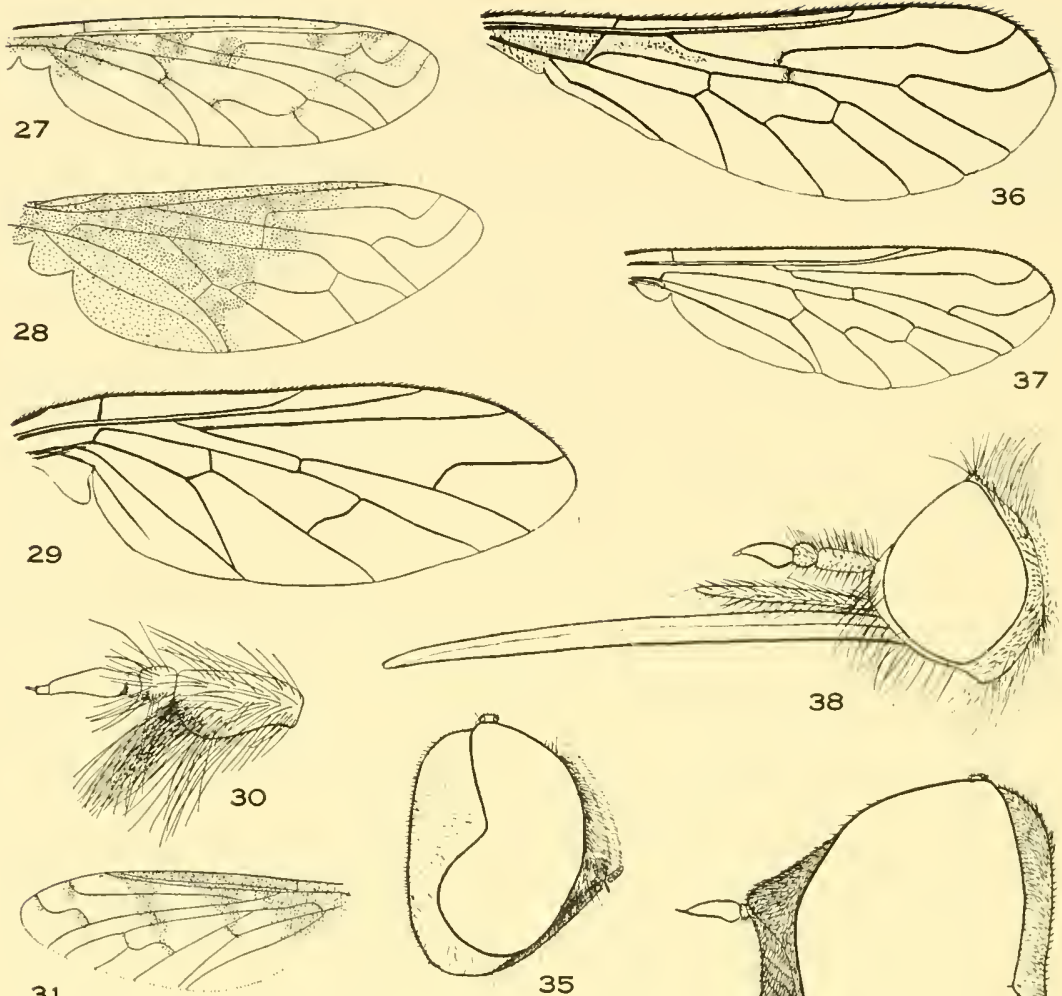

31
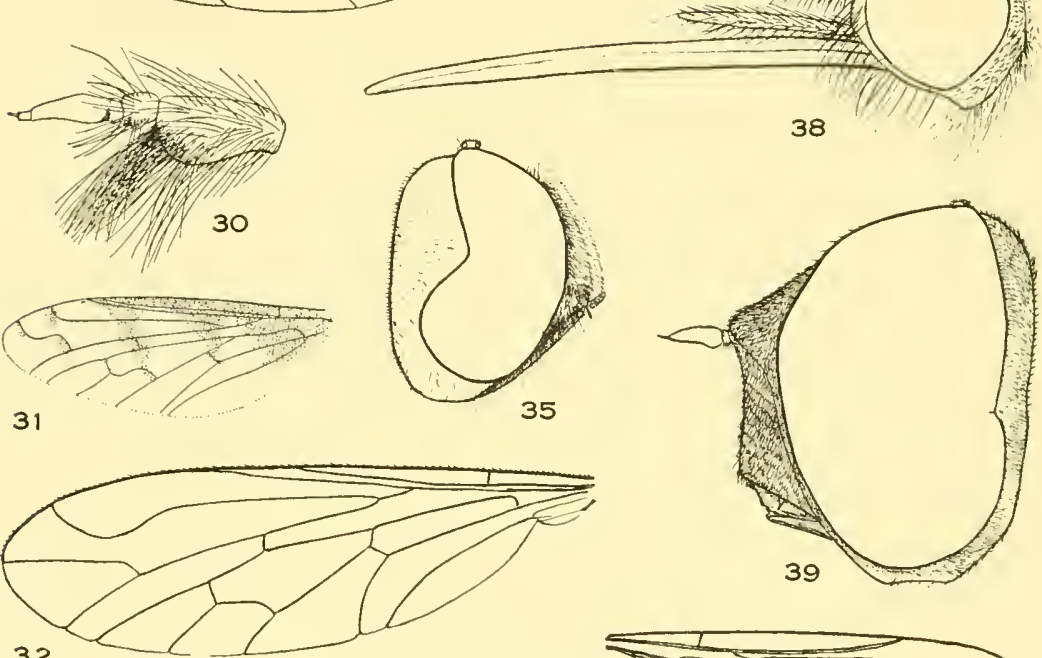

32
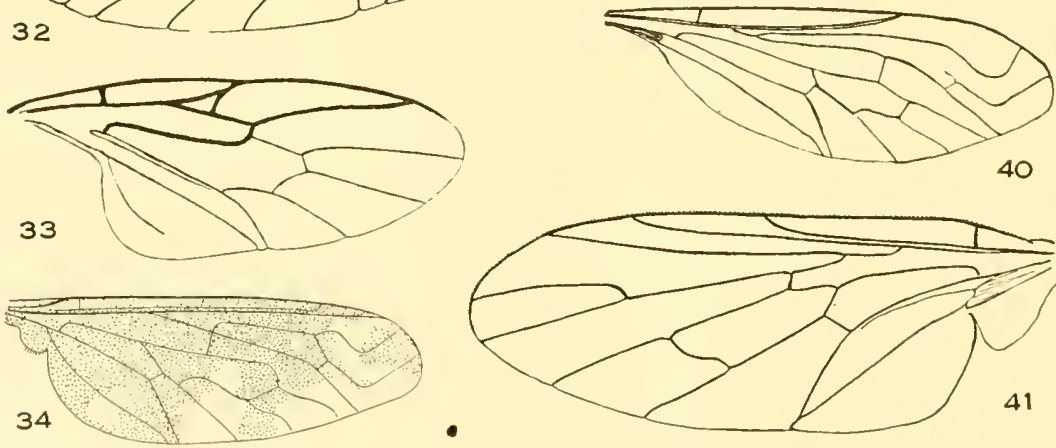

Bombyliidæ II,-27, Lepidanthrax proboscidea; 28, Thyridanthrax sclenc; 29. Geron; 30. Calopelta fallax, antenna; 31 , Sphenoidoptera varipennis; 32 , Metacosmus. mancipennis: 33. Glabellula crassicornis; 34, Stonyx clelia; 35, Ogcodocera; 36, Mancia nana; 37 . Eucessia, n. sp. : 38, Geminaria canalis; 39, Eucessia, n, sp.; 40 Paracosmus morrisonia; 41 Rhabdoselaphus sigma. 


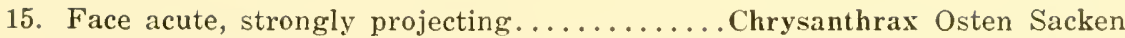
Face not strongly projecting, the oral margin rounded (28).

Thyridanthrax Osten Sacken

16. Proboscis projecting fal beyond the anterior oral margin......... 17 Proboscis projecting but little bevond the oral margin............ 18

17. Abdomen with broad scales on basal half (27).

* Lepidanthrax Osten Sacken Abdomen without broad scaies on basal half..... Rhynchanthrax Painter

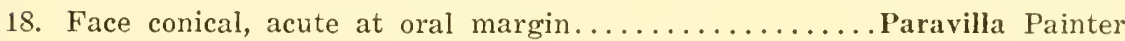
Face obtuse below, the oral margin rounded.............. Villa Lioy

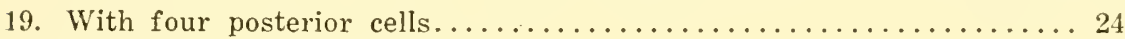

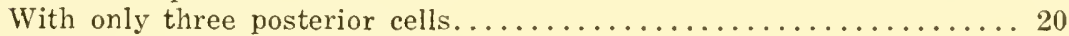

20. Slender, elongate species, with long, slender legs............. 21 Shorter, more thick-set species, the abdomen tapering apically..... 22

21. Abdomen enlarged apically; eyes holoptic $(23,24)$... Systropus Wiedemann Abdomen not enlarged apically, cylindrical; males only holoptic.

Dolichomyia Wiedemann

22. Three submarginal cells or the third antennal segment obtuse......223 But two submarginal cells; third antennal segment acute $(\mathbf{1 8}, \mathbf{1 9}, \mathbf{2 0 , 2 9 )}$.

†Geron Meigen

23. Body clothed mostly with scales, the thorax with bristles; abclomen decumbent; antennæ long $(21,22) \ldots \ldots \ldots \ldots \ldots$ Toxophora Meigen Body clothed chiefly with hair; abdomen not decumbent $(41,66)$.

Rhabdopselaphus Bigot

24. Apical (first posterior) cell open or closer in the wing margin.....31 Apical cell closed before the margin of the wing and petiolate...... 25

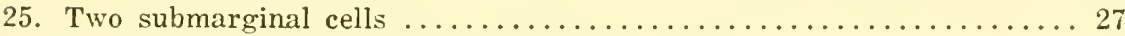

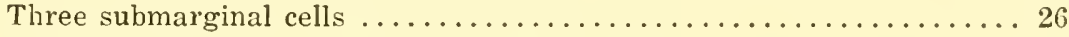

26. Head bloader than the thorax; posterior orbits not excised $(10,11)$.

Pantarbes Osten Sacken Head narrower than the thorax; posterior orbits excised...Triplasius Lœw

27. Proboscis protruding far beyond the anterior oral margin......... 28 Proboscis not protruding beyond the oral margin.... Anisotamia Macquart

28. First basal cell much longer than the second................... 29 First basal cell not longer than the second................. 30

29. Posterior orbits of the eyes convex or only slightly emarginate in the middle; head small $(9,63) \ldots \ldots \ldots \ldots \ldots \ldots$ Bombylius Linnaeus Posterior orbits broadly and deeply emarginate; head as wide as the

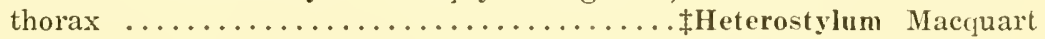

30. Shape of the face concealed by dense hair; vein closing the discal cell anteriorly lialf as long as the ultimate section of the vein behind it.

Anastoechus Osten Sacken

Shape of the face plainly visible; vein closing the discal cell anteriorly not nearly half as long as the ultimate section of the vein behind it

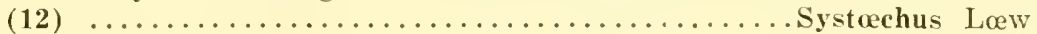

\footnotetext{
* Curran, 1930, Amer. Mus. Novit. No. 409, ก. 1.

$\dagger$ Painter, 1932, Tr. Amer. Ent. Soc., lviii, pp. 139-167.

+Painter, 1930, J. Kans. Ent. Soc., iii, p. 1.
} 

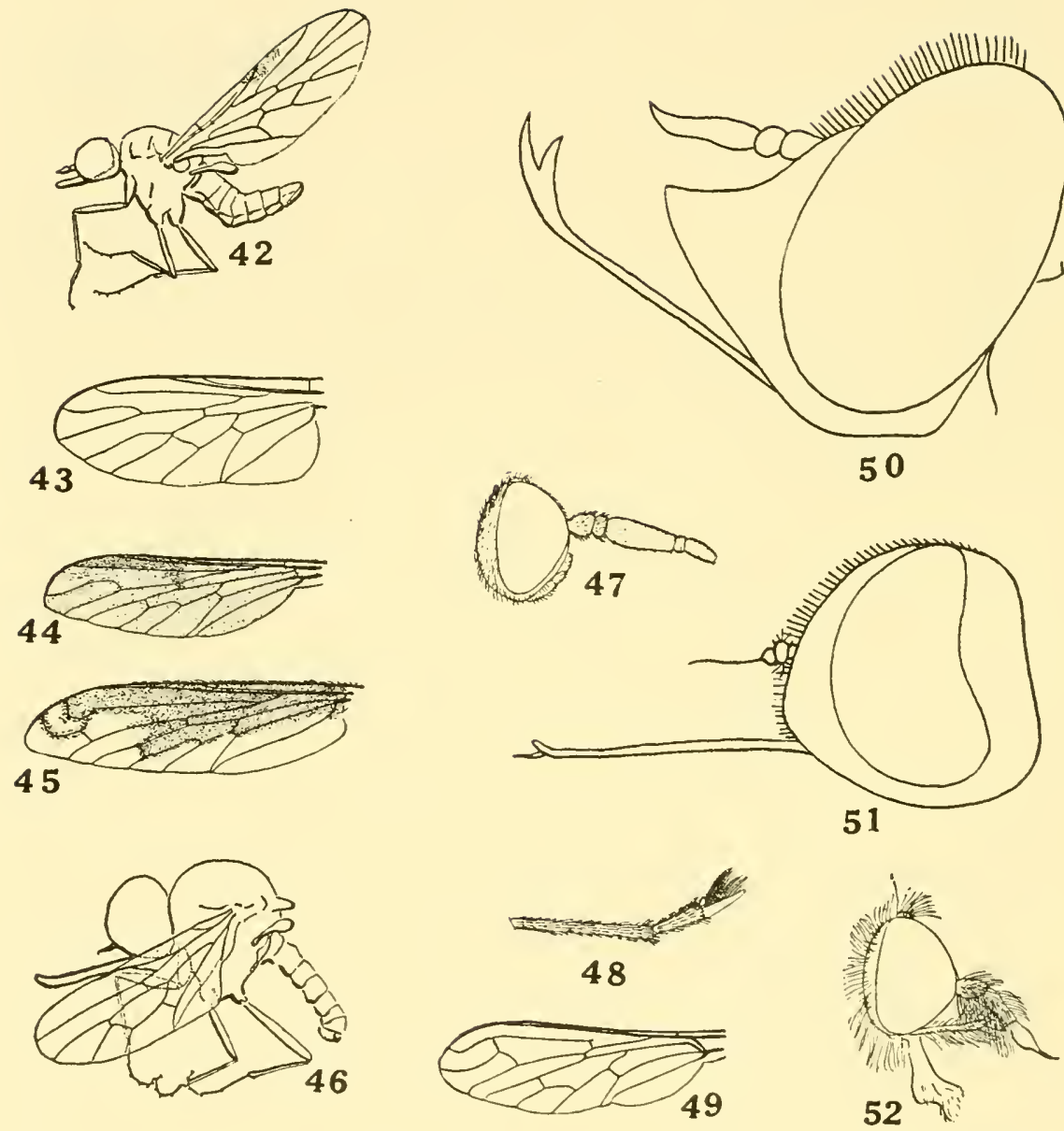

Bombyliide III.-42, Prorates; 43. Desmatomyia; 44, Eclimus : 45, Lepidophora vetusta; 46. Mythicomyia; 47, Desmatomyia; 48. Lepidophora vetusta; 49, Aldrichia; 50. Amphicosmus cincturus; 51 , Stonyx clelia; 52 , Aldrichia. 


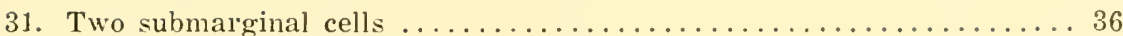

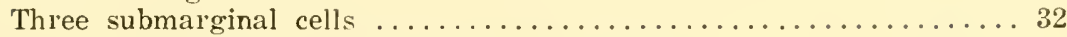

32. Abdomen very elongate, slender and almost bare; tibiæ without spicules

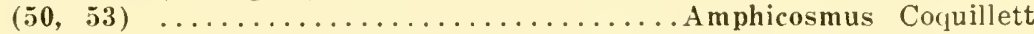
Abrlomen robust and short; pilose species; tibiæ with spicules........ 33

33. Antennæ as long as the head, the third segment not longer than the basal two together ................................. 3 . Antennæ shorter than the head, the third segment twice as long as

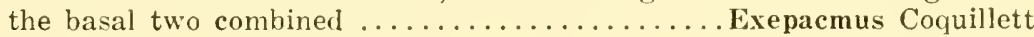

34. Scutellum deeply sulcate longitudinally $(38) \ldots \ldots$. Geminaria Coquillett Scutellum not sulcate . . . . . . . . . . . . . . . . . 35

35. First antennal segment greatly swollen (Ploas Latreille) $(60)$.

Conophorus Meigen First antennal segment not thickened $(13,11) \ldots \ldots \ldots \ldots$ Lordotus Lœw

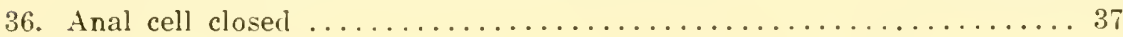

Anal cell open ................................. 41

37. Proboscis projecting beyond the anterior oral margin.......... 39 Proboscis short, not projecting beyond the anterior oral margin.... 38

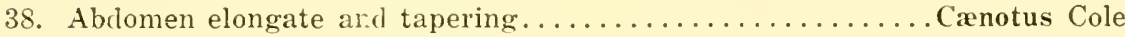
Ablomen short and broad, thickly pilose (35) .... Ogcodocera Macquart

39. The intercallary vein between the fourth and fifth vein arises from the

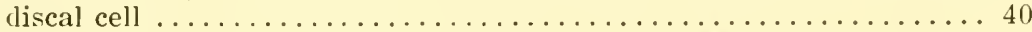
The intercallary vein arises from the fourth vein (42 Empidæ 5, 10).

Prorates Melander

40. Face bare or short pilose; third antennal segment bare or with short, bristly hairs above $(15,16) \ldots \ldots \ldots$......... Face with long hair; third antennal segment with long, bristly hairs.

Neacreotrichus Cockerell

41. The second vein ends in the first vein.................... 42

The second vein ends in the costa ...................... 43

42. Discal and second basal cells united (33) (Pachyneres Greene).

Discal and second basal cells separated $(25,26,46)$.

Glabellula Bezzi

Mythicomyia Coquillett

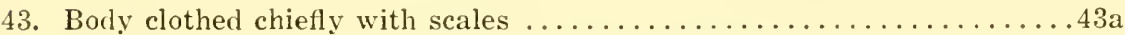

Body clothed with hair or nearly bare, sometimes with some scales.. 44

43a. First antennal segment at least as long as the third, densely clothed with scales; abdomen elongate $(45,48) \ldots . . . *$ Lepidophora Westwoor First antennal segment not half as long as the third, without scales;

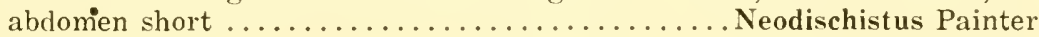

44. First basal cell much longer than the second............... 46

First basal cell only slightly longer than the second............ 45

45. First antennal segment greatly swollen, widest apically (30).

Calopelta Green

First antennal segment only a little swollen, widest in the middle.

Sparnopolius Lœw

* Painter, 1925, Tr. Amer. Ent. Soc., li, n. 120. 

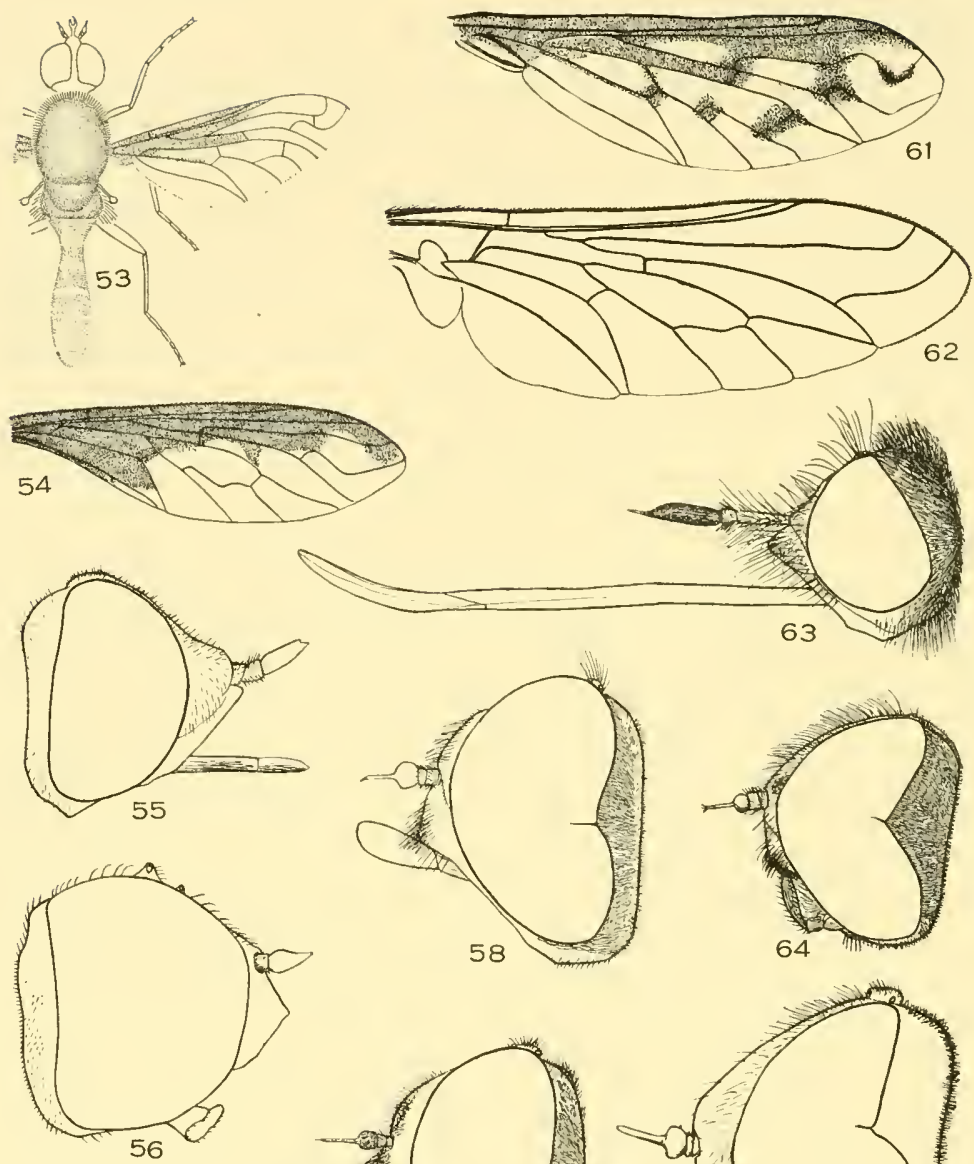

63
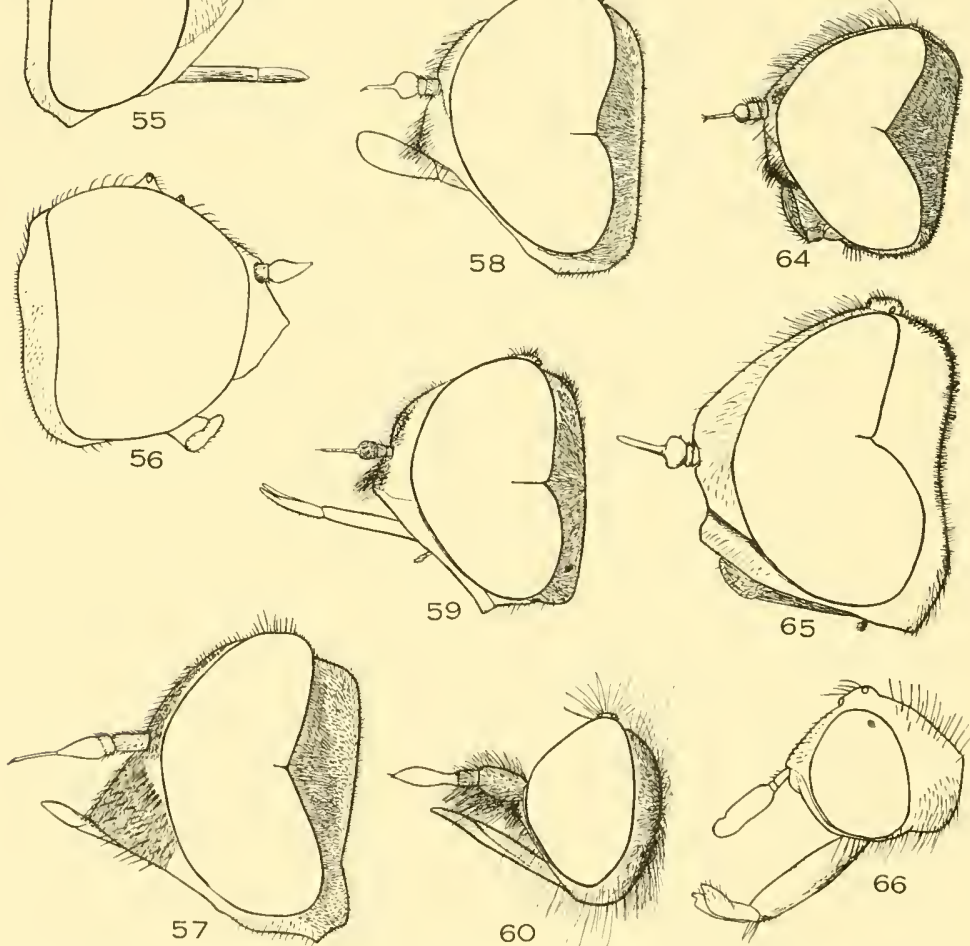

59
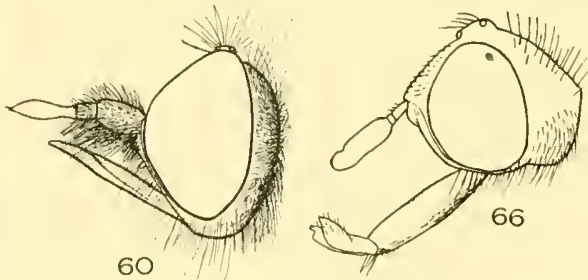

Bombylidas IV.-53, Amphicosmus cincturus; 54, Anthrax; 55, Paracosnus morrisoni ; 56. Metacosinus mancipennis; 57, Exoprosopa; 58, Aphrbantus cervinus; 59, Epacinus modestus; 60, Conophoras; 61, Neodiplocampta roderi; 62, Parabombylius; 63, Bombylius; 64, Anthrax irroratus; 65 , Desmatoneura argentifrons; 66 , Rhabdoselaphus sigma. 

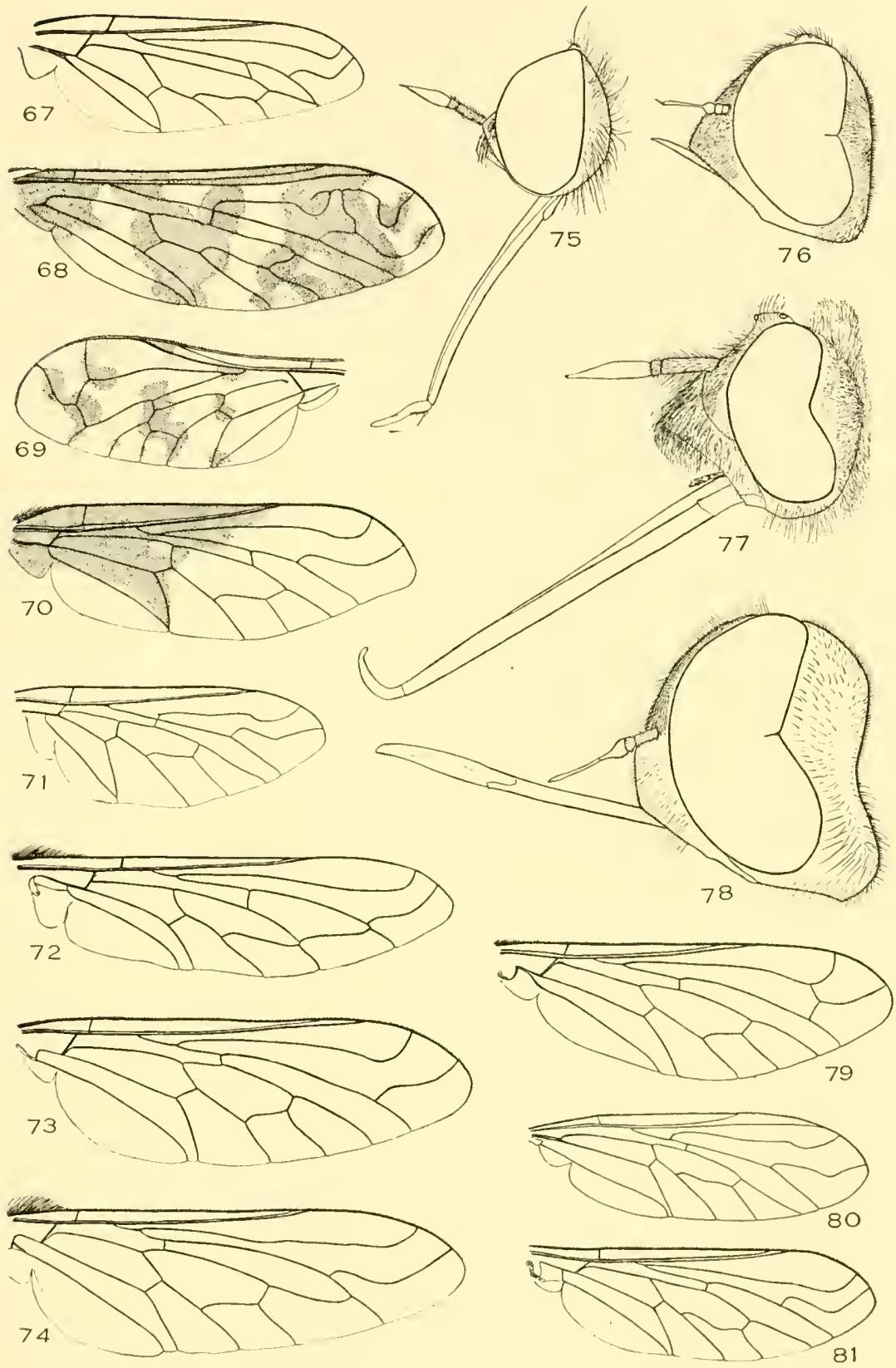

Bombyliidx V.-67, Anisotamia; 68, Dipalta; 69, Geminaria canalis; 70, Ogcodocera; 71 , Astrophanes; 72, Heterostylum; 73. Sparnopolius; 74, Anastechus; 75, Geron; 76, Maneia nana; 77. Heterostylum; 78. Litorhynchus; 79, Conophorus; 8n, Desmatoneura; 81 , Epacinus, Aphabantus. 
46. Proboscis projecting strongly beyont the anterior oral margin, the labellæ long and pointed .......................... 47

Proboscis not or scarcely projecting beyond the oral margin, the labellæ short and broad.......................... 51

47. Face bare, the sides above, or the clypeus with hair............ 49

Face with hair in the middle at least below................ 48

48. Posterior border of the eyes emarginate, the facets bisected by a short bare line opposite the emargination ............... 53

Posterior border of the eyes not emarginate, the eyes without a bare, bisecting line posteriorly $(62) \ldots \ldots \ldots \ldots \ldots$ *......... Pabombylius Williston

49. Anterior crossvein situated beyond the basal third of the discal cell... 50 Anterior crossvein situated at or before the basal fourth of the discal

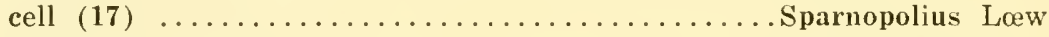

50. The anterior branch of the third vein arises only a little before the apex of the second vein (31) ............. Sphenoidoptera Williston

The anterior branch of the third vein originates only a little beyond the apex of the discal cell and far before the apex of the second vein

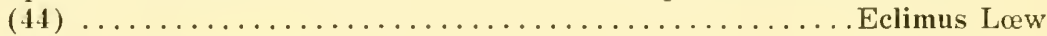

51. Ocellar tubercle situated near the middle of the front $(32,56)$.

Metacosmus Coquillett

Ocellar tubercle situated near the vertex ................ 52

52. Style of antennæ broad and flattened, two segmented, simulating segments $(43,47) \ldots \ldots \ldots \ldots \ldots \ldots \ldots \ldots$. . . . . . . . . . .

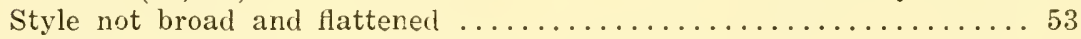

53. Posterior border of the eyes at least weakly indented and with a short,

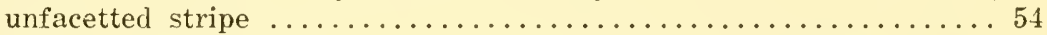

Posterior borter of the eyes not at all indented and without any unfacetted stripe $(40,55) \ldots \ldots \ldots \ldots \ldots$. . . . . .

54. Third antennal segment bulbous basally and with a long, almost par-

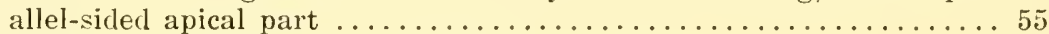

Third antennal segment sub-triangular, tapering ........... 57

55. The second vein arises at an almost right angle beyond the base of the discal cell $(65) \ldots \ldots \ldots \ldots \ldots \ldots \ldots \ldots \ldots$ Desmatoneura Williston

The second vein arises at an acute angle before the base of the discal

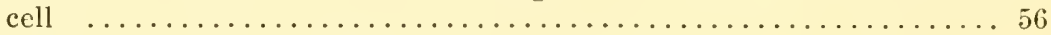

56. Proboscis strongly projecting beyond the anterior oral margin, the labella long and narrow; face produced; pulvilli absent (59).

Epacmus Osten Sacken

Proboscis rarely strongly projecting, the labellæ broad; face usually receding; pulvilli present if the face projects (58).

Aphœbantus Lœw

57. Anterior oral margin close to the base of the antenna.

Anisotamia Macquart

Anterior oral margin very far from the antennal base $(37,39)$.

Eucessia Coquillett

\section{Neodiplocampta, new genus}

Proposed for Diplocampta roderi Cuman. The genus differs from Diplocrmpte Schiner in having the face produced, the third antennal segment rather long and conical, broad abdomen, different wing venation, cte. Anthrax paradoxa Jiennicke also belongs to this genus.

* Painter, 1926, Ent. News, xxxvii, 1. 74; Curran, 1930. Amer, Mus. Novit. No. 404, p. 7. 


\section{Family Nemestrinidæ}

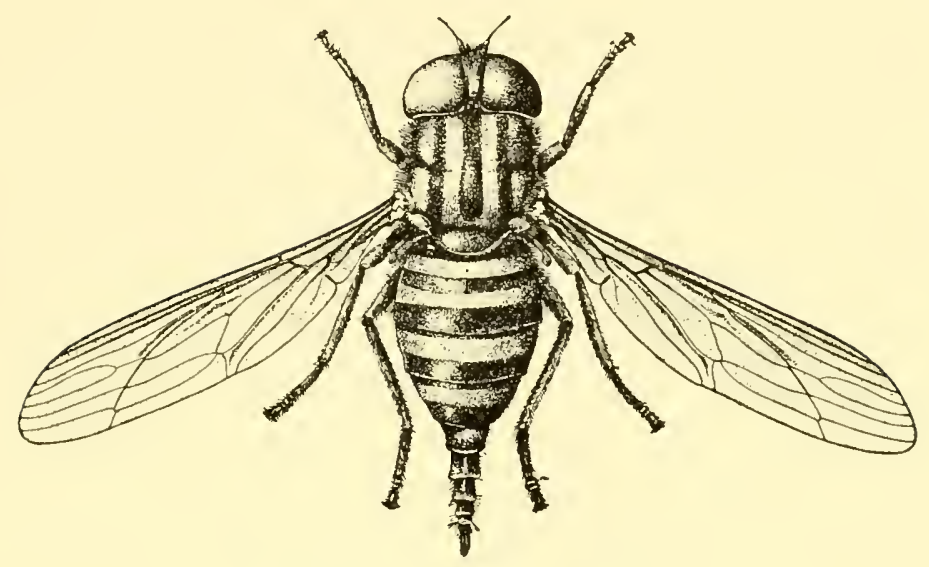

Neohirmoneura bradleyi Bequært.

Flies of moderate size, rather stout and compact in appearance, with many veins; thinly or densely pilose.

Head moderate in size, narrower or slightly wider than the thorax; eyes holoptic or dichoptic in the males, females dichoptic except in Hyrmophlaba; proboscis long to rudimentary. Antenna short and small, three segmented, and with a stout, jointed terminal arista. Tibiæ without spurs: empodia pulvilliform but the pulvilli often minute. Venation complicated, the fourth and fifth reins enrving forward to terminate before the apex of the wing; anterior crossvein very oblique and simulating a longitudinal vein, the basal cells both long; five or six posterior cells and two or three submarginals.

The Nemestrinids are not numerons in collections and are usually difficult to eatch. I have found them only in open fields in which the vegetation is of considerable height and have observed them in considerable numbers. They hover persistently and dart quickly away at the least motion: when present in numbers their "buzz" is very obvious and they may he heard at a considerable distance. Those with long proboseis often visit flower's. In the Ameriean speeies the venation is relatively simple but in some species of the genus Nemestrinus there are numerous crossveins in the wings, and some of them have the proboseis greatly elongated. The genus IIrmoncura is known to live upon root feeding beetle larve in the larval stage and it is probable that all the species are parasitie.

Three papers by Bequaert* eover the North Ameriean speeies, of which there are about a dozen.

* Bequaert, 1919, Journ. N. Y. Ent. Soc., xxvii, pp. 301-307; 1930, Psyche, pp. 286-297; 1934, Journ. N. Y. Ent. Soc. xlii, pp. 163-184. 


\section{KEY TO GENERA}

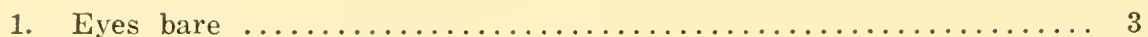

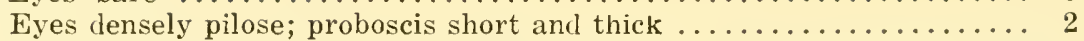

2. Three submarginal cells, both sexes holoptic $(3,4)$.Hyrmophloba Rondani Two submarginal cells ...................Hirmoneura Meigen

3. Three submarginal cells . ....................... 4 Two submarginal cells; proboscis short ard thick (text figure).

Neohirmoneura Bequaert

4. Proboscis very small, hardly visible, without fleshy labellae; alula

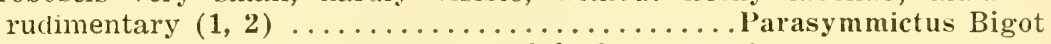
Proboscis elongate and protruding; alula broad (5 6).

Neorhynchocephalus Lichtwardt

* No North American species are at present known.
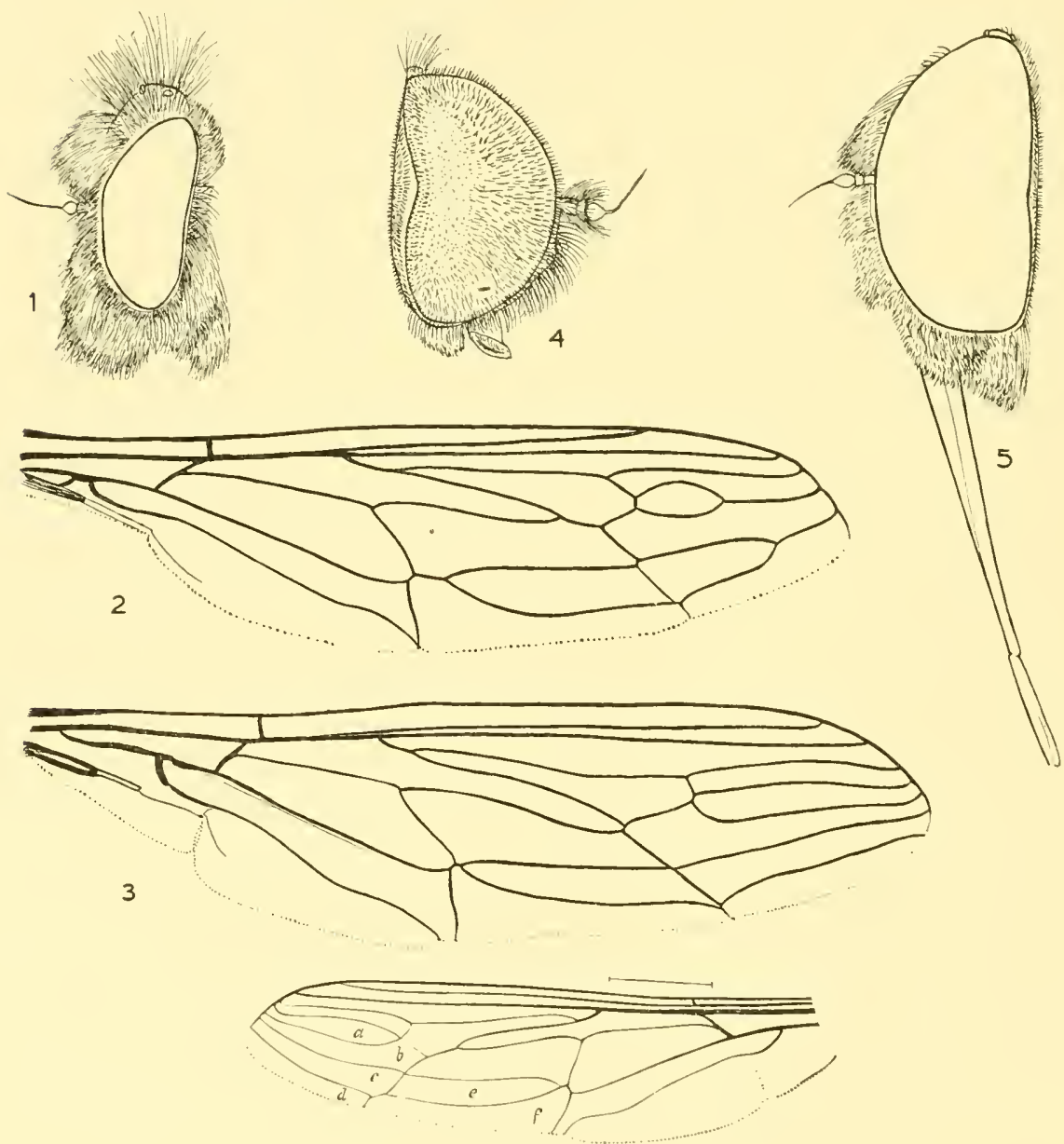

6

Nemestrinidx.-1, 2, Parasymmyctus clausa O. S. : 3, 4, Hirmophloba texana; 5, 6. Neorhynchocephalus volaticus, a third submarginal cell, b-f posterior cells. 


\section{Family Cyrtidx}

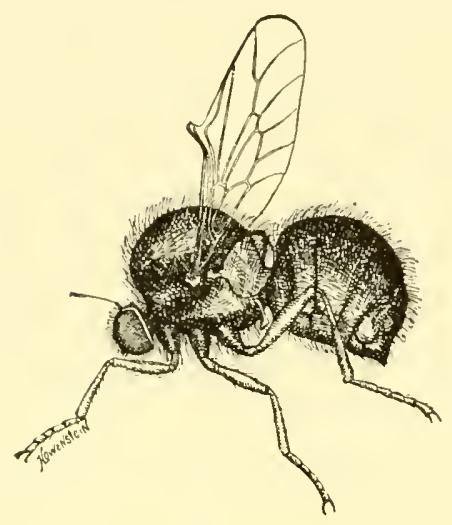

Opsebius pterodontinus.

Small to moderately large flies, never elongate, pilose or nearly bare.

Head small to very small, composed chicfly of the compound eyes which are nsually contiguous in both sexes, the front, face or both obliterated; none, two or three oeelli present. Antemna composed of two or three segments, with or without an apieal arista, the third segment sometimes with apieal bristles. Proboseis rudimentary or long, sometimes greatly exceeding the length of the body. Thorax large and convex, the squamr and scutellum large. Abdomen inflated, convex, rather orbicular. Legs moderately stout, the empodia and pulvilli padlike. Tenation variable, the reins sometimes weak and indistinet; often a supermmerary erossvein between the thind and fourth veins.

This family contains a small number of species and may be recognized by the swollen thorax, inflated abdomen and small head. Ten genera are known to ocenr in North America. Cole* has revised the family. Insofar as known the members of the family are parasitic on spiders.

\section{KEY TO GENERA}

1. Prothoracic lobes greatly enlarged and meeting in front of the mesonotum; proboscis elongate $(3,4) \ldots \ldots \ldots \ldots \ldots$............ Prothoracic lobes not forming a shield in front of the mesonotum... 2

2. Proboscis small and aborted ............................ 4

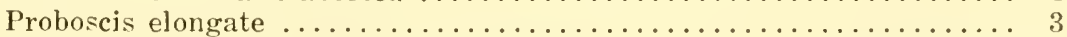

3. Palpi absent; usually two ocelli $(13,14) \ldots \ldots \ldots \ldots$. Lasia Wierlemann Palpi present; three ocelli situated on a more or less prominent tubercle $(11,12) \ldots \ldots \ldots \ldots \ldots \ldots \ldots \ldots$. . . . . . . . . . . . 
4. Antennæ elongate, the third segment large $\ldots \ldots \ldots \ldots \ldots \ldots \ldots \ldots$ Antennæ short, the third segment small $\ldots \ldots \ldots \ldots \ldots \ldots \ldots \ldots \ldots 7$

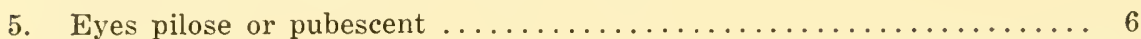

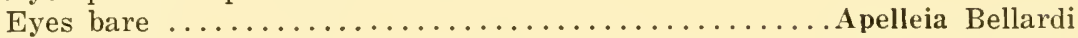

6. Third antennal segment without terminal bristles $(9,10)$

*Ocnaa Elickson Third antennal segment with terminal bristly hairs. .Pialeoidea Westwood

7. Antennæ inserted below the middle of the head $\ldots \ldots \ldots \ldots \ldots \ldots . . .6$ Antennæ inserted above the middle of the head $\ldots \ldots \ldots \ldots \ldots \ldots . . . \ldots$

8. Third antennal segment with three terminal setæ $(7,8)$.

Pterodontia Gray Third antennal segment with an apical arista $(5,6) \ldots$ Ogcodes Latreille

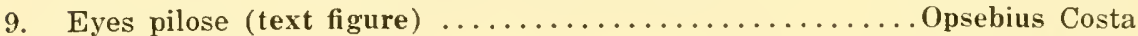
Eyes bare $(1,2) \ldots \ldots \ldots \ldots \ldots \ldots \ldots \ldots \ldots \ldots \ldots \ldots \ldots \ldots \ldots \ldots \ldots \ldots$ Acrocera Meigen

* Aldrich, 1932, Proc. U. S. N. M.. Ixxxi, Art. 9. p. 3.

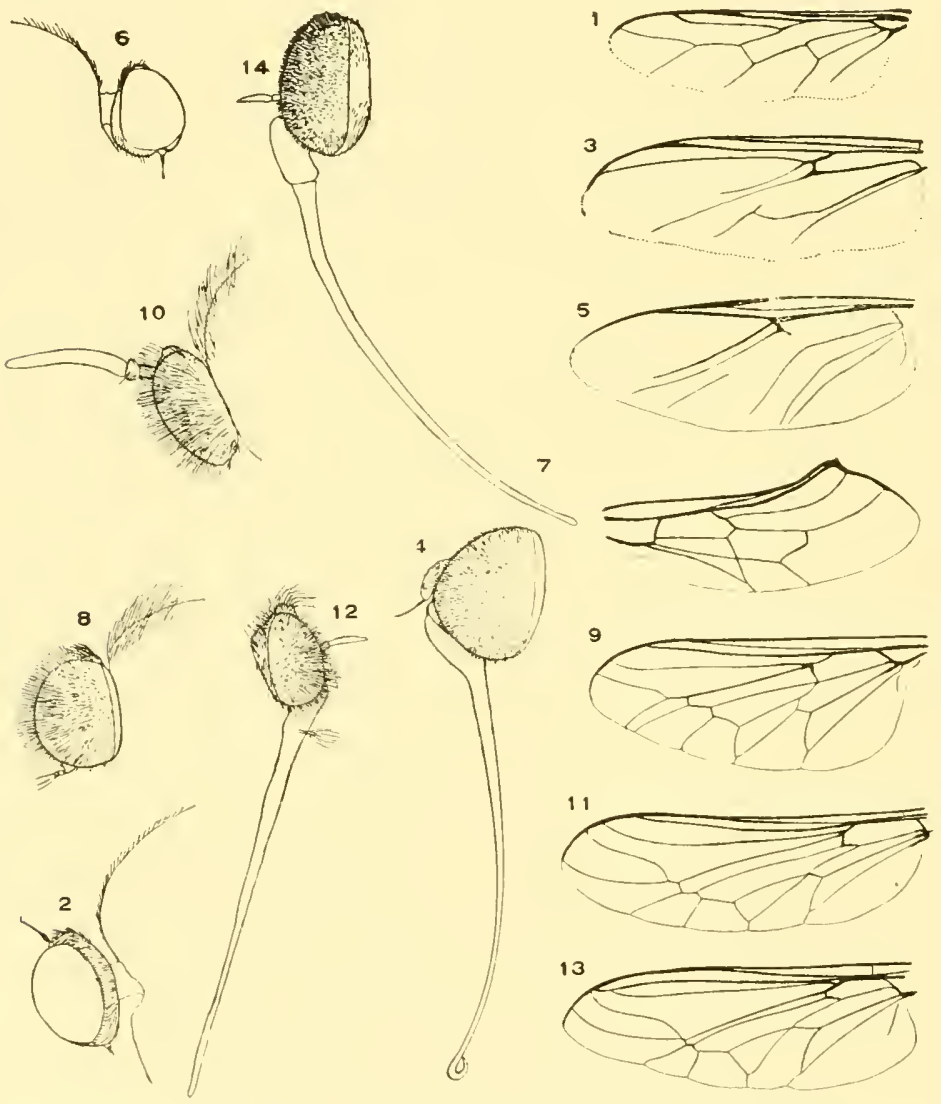

Crytidx.-1, 2, Acrocera; 3, 4, Philopota: 5, 6, Ogcodes; 7, 8. Plerodontia; 9, 10, Ocnæa; 11. 12. Eulonchus; 13, 14, Lasia. 


\section{Family Empidæ-The Dance Flies}

Flies of small to medium size, though rarely over $10 \mathrm{~mm}$. in length. Head more or less spherieal, loosely connected with the thorax; males holoptic or dichoptie, the face sometimes almost obliterated by the approximate eyes; ocelli present. Antemne porrect, composed of two or three segments, with or without an apical style or arista, or with dorsal arista; face receding or slightly prominent below, never with a strong mystax. Proboseis short or long, usually rigid. Thorax sometimes long and narrow, usually short, often strongly convex above. Male genitalia generally of complicated structure, often large or very large; oripositor sometimes long and chitinized. Wing renation simple, the wings rarely absent or redueed in size; squame small; anal and second basal cell sometimes absent or incomplete. Legs usually slender, sometimes with structural peenliarities such as elongated coxe or femora, the femora or tibia often thickened and with spines or tubercles or with processes or fringes of scales; pulvilli distinct; empodia nsually membranons and linear.

The adults are found almost everywhere but the Empids are rare in arid regions. They are most abundant in moist places, especially in woods, along streams and on the shores of ponds and lakes. All are predaceous, feeding upon smaller insects, mites, ete. As a general rule they are olserved upon foliage and grass but many of them are confined to restrieted habitats and others appear to be rery local in distribution. Certain genera are found almost entirely on the trunks of trees and may be collected most easily by placing the month of the killing bottle over them, while others oceur in large numbers on small flowers, notably Prumus rirginimu. A few genera are fomm only along the seashore where they dart about among the pebbles, feeding upon small insects or upon freshly killed invertehrates.

The mating habits of the Empride are extremely interesting, but no more than mention of them ean be made here. In some eases the males capture prey and use this food as a lure to attract the females. Sometimes the females devour the offering or it may be discarded an soon as the mating is completed. In other cases the male provirles a balloon like bubble to attract the female. In some eases it is believed that copulation eannot be completed unless foot is provided.

The immature stages are not well known but the larvar live in deeaying regetation, under bark, and in streams. 

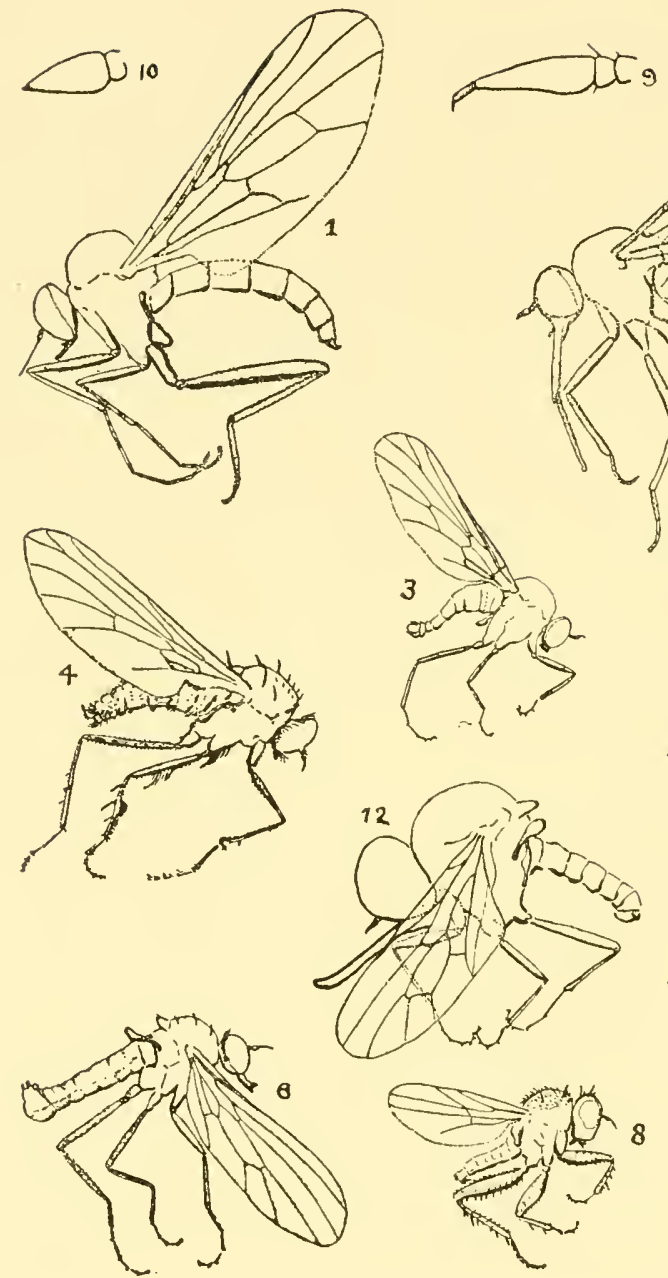

2

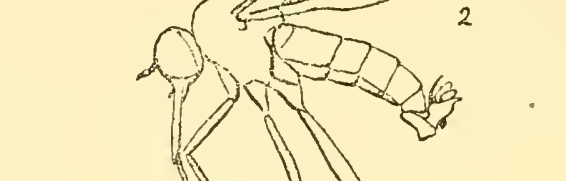

Empidæ I.-1, Hybos; 2, Toreus: 3, Hesperempis : 4, Oreogeton: 5, Prorates (Bombyliidæ) : 6, Heleodromia : 7, Ocydromia; 8, Coloboneura; 9, Toreus, antenna; 10, Prorates (Bombyliidæ); 11, Hesperempis, 12: Mythicomyia (Bombyliidæ). 
Melander has covered this family in Cenera Insectorum* describing many new North American genera and species and presenting keys. Unfortmately the price of this work is prohibitive to the average worker so the family will no doubt receive little attention until a more readily accessible work is available.

\section{KEY TO GENERA}

1. Discal cell always united with the second basal, the anal cell always incomplete ................................... 55

Second basal closed apically or the anal cell complete $\ldots \ldots \ldots \ldots \ldots .2$

2. Mesopleura obliquely longer than high $\ldots \ldots \ldots \ldots \ldots \ldots \ldots \ldots . \ldots . \ldots$

Mesopleura distinctly higher than long.................... 4

3. Anterior pair of legs far from the middle pair, raptorial......... 52

Anterior legs not distant from the middle pair and not raptorial... 43

4. Auxiliary vein distinct and separated from the first vein.......... 5

Auxiliary vein weak and lying close to the first vein............ 13

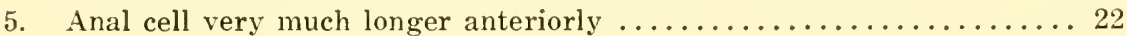

Anal cell longest posteriorly, transverse apically or but little longer in

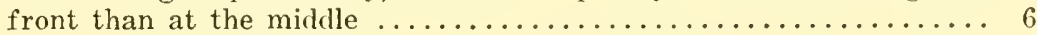

6. Costa ending at the thirl or fourth vein; two veins emitted by the discal cell ....................................... 8

Costa continuing around the wing; three veins emitted by the discal cell 7

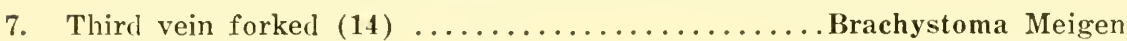
Third vein simple $(28) \ldots \ldots \ldots \ldots \ldots \ldots \ldots$. Anomalempis Melander

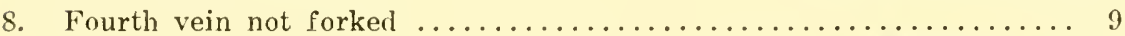

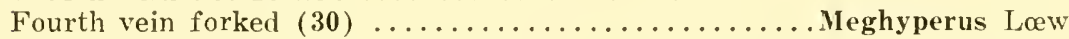

9. Pedicel of the second and third veins arising beyond the middle of the second basal cell ................................... 10

Pedicel arising near the basal fourth of the second basal cell (25).

Syneches Walker

10. Vein between the first and second basal cells distinct, the first basal cell not much wider than the second..................... 11

Vein between the first and second basal cells very weak, the first basal very much wider than the second $(31) \ldots \ldots \ldots \ldots$........ Syndyas Low

11. Third and fourth veins convergent apically $\ldots \ldots \ldots \ldots \ldots \ldots \ldots . \ldots \ldots$ Third and fourth veins parallel or diverging $(1,21) \ldots \ldots$. Hybos Meigen

12. Disc of mesonotum without pile; palpi elongate (35).

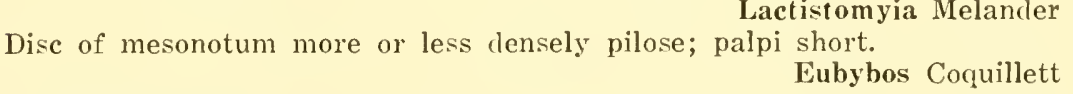

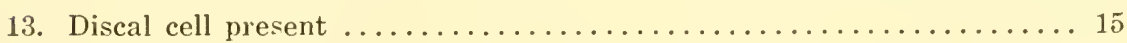

Discal cell absent .................................. 14

$\div$ Fascicle $185,1927$. 

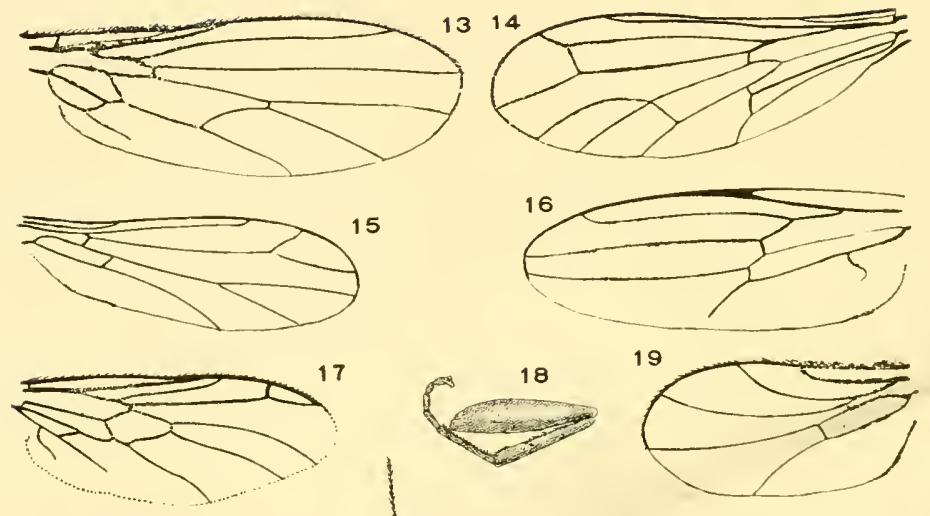

20

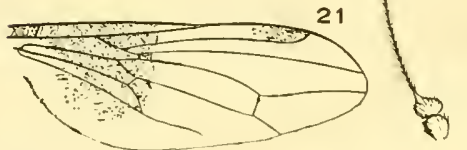

22

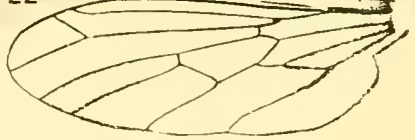

23

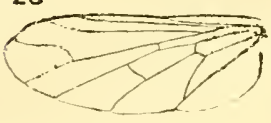

26

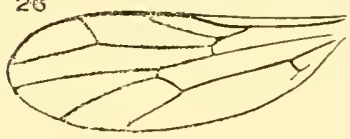

24
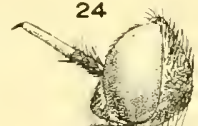

25

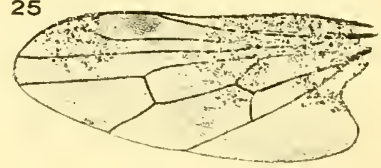

27

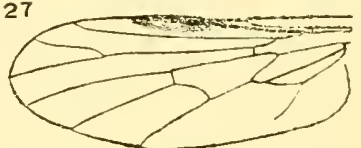

Empidæ II.-13, Oreothalia; 14, Brachystoma; 15, Hemerodromia; 16, Tachypeza; 17 , Lampremis; 18. Tachypeza, front leg; 19, Drapetis; 20. Drapetis, antenna; 21, Hybos; 22,

Empis; 23, Geron (Bombyliidæ) ; 24, Empimorpha; 25, Syneches; 26. Chelifera; 27, Hilara. 


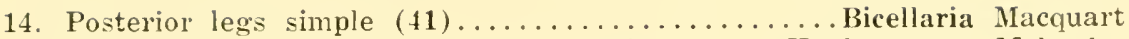
Posterior femora much enlarged and spinose .....Hoplocyrtoma Melander

15. Discal cell emitting three veins apically or, if open, the fourth vein

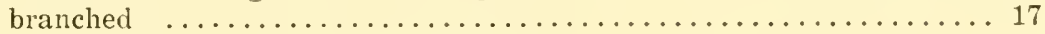

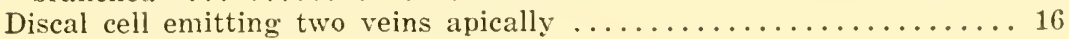

16. Third antennal segment conical, the arista apical; middle tibiæ with

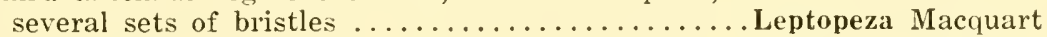
Third antennal segment oval; the arista sub-dorsal; middle tibiæ with

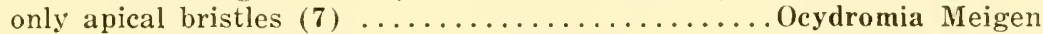

17. Posterior femora enlarged and spinose beneath $(53,57)$.. Edalia Meigen

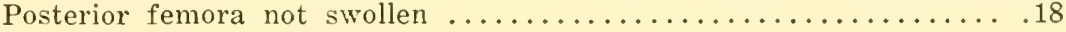

18. Posthumeral bristles present; antennæ apparently two segmented.... 19 Posthumeral bristles usually absent, the antennæ with three segments.

Euthyneura Macquart

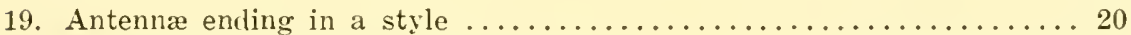
Antennæ without style or arista $(51,59) \ldots \ldots \ldots$ Allanthalia Melander

20. Antennæ situated near the middle of the head, the third segment

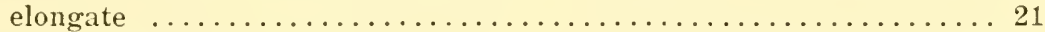
Antennæ situated much below the middle of the head, the third segment broad $(60,63) \ldots \ldots \ldots \ldots \ldots \ldots \ldots$ Anthalia Zetterstedt

21. Third antennal segment extremely long (45, 52)....Axelempis Curran Third antennal segment normal ................ Trichina Meigen

22. Basal and anal cells very small; third vein never forked; abdomen

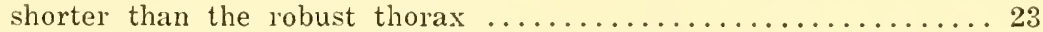
Basal and anal cells not unusually short; third vein often furcate; abdomen as long or longer than the thorax .............. 25

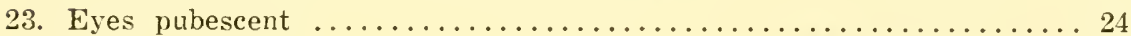

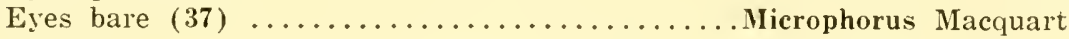

24. Face broadened below and more or less hairy; costa continuing around the wing $(48,55) \ldots \ldots \ldots \ldots \ldots \ldots \ldots \ldots$ Parathalassius Mik Face not broadened below and with only oral hairs.. Microphorella Becker

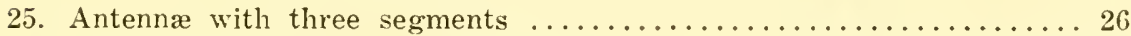
Antennæ apparently two-segmented ..........Hormopeza Zetterstedt

26. Proboscis directed obliquely forward or horizontal, the face broad,

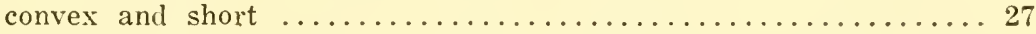
Proboscis normally vertical, if more or less oblique the face is long

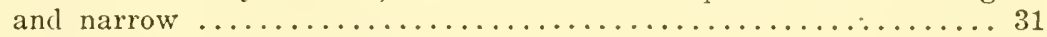

27. Auxiliary vein entire, ending in the costa.................. 28 Auxiliary vein obsolete apically........................... Melander

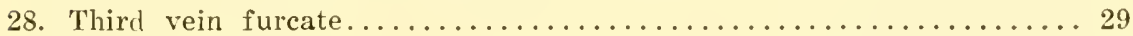

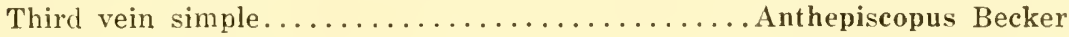

29. Arista terminal, sometimes style-like................. 30

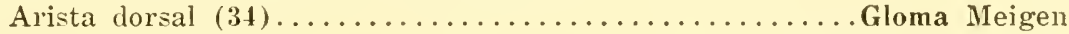

30. Hypopleura bare $(38) \ldots \ldots \ldots \ldots \ldots \ldots \ldots \ldots \ldots$ Iteaphila Macquart Hypopleura haired $(4) \ldots \ldots \ldots \ldots \ldots \ldots \ldots$ Oreogeton Schiner 


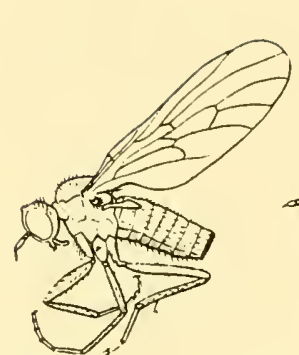

28
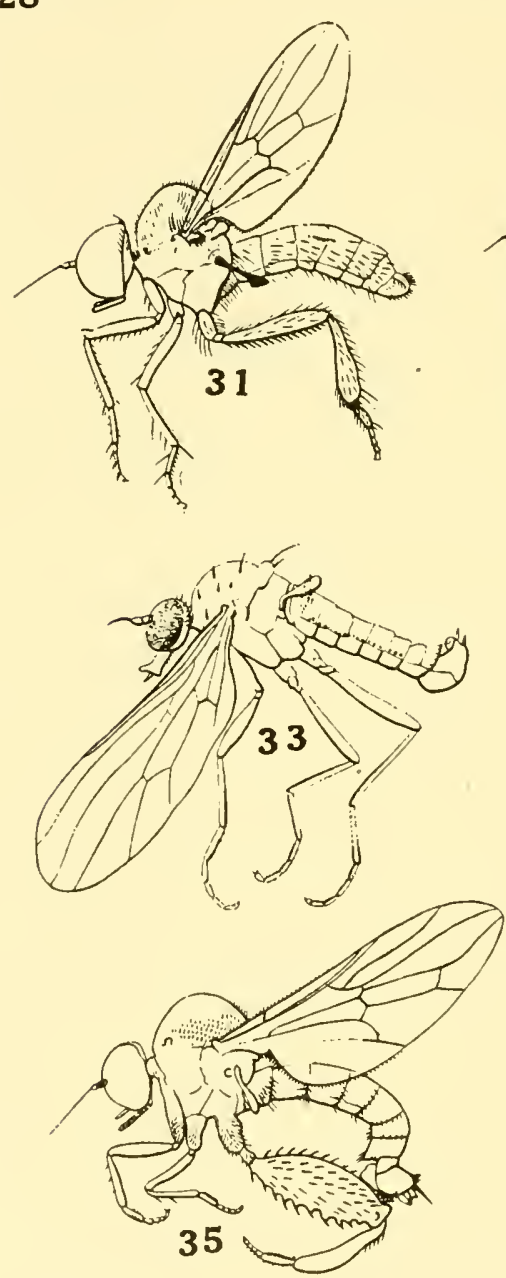
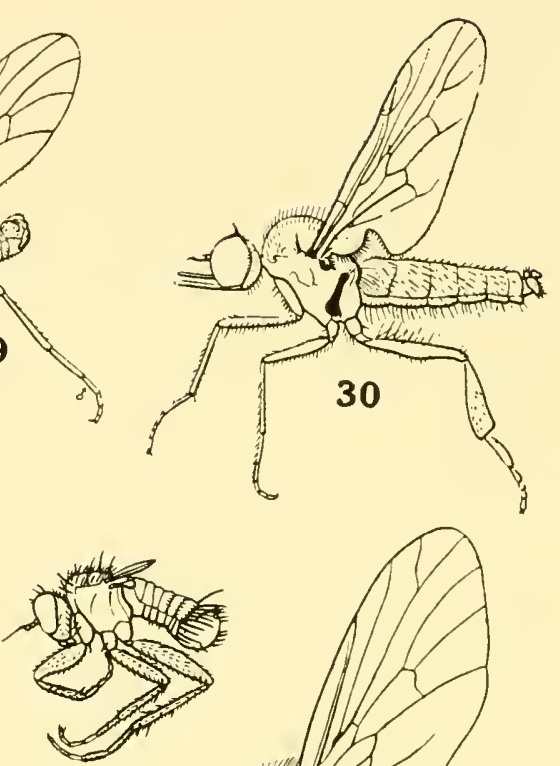

32
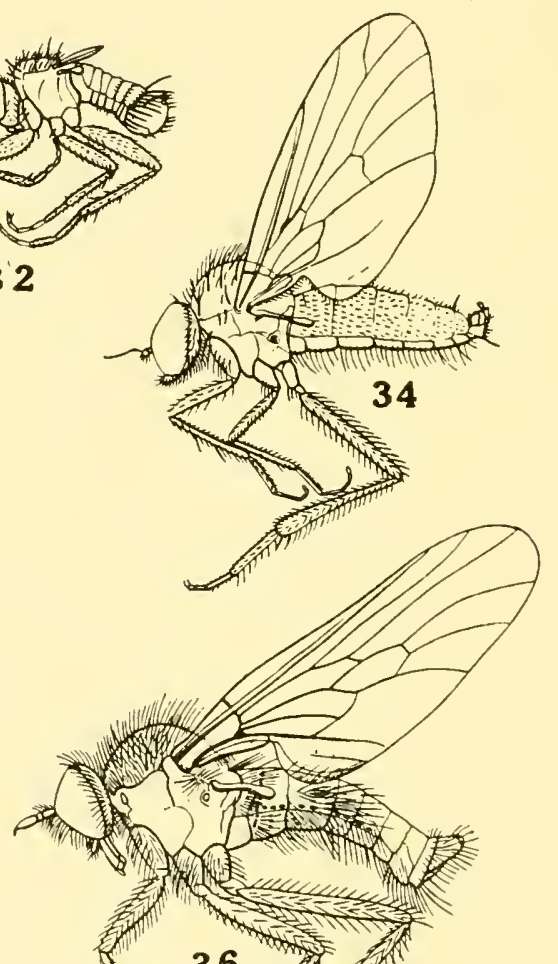

36

Empidx III.-28, Anomalempis tacoma: 29, Philetus memorandus: 30, Meghyperus occidens: 31, Syndyas polita; 32 , Thinodromia inchoata; 33 , Heleodromia pullata; 34 , Gloma fuscipennis; 35 , Lactistomyia insolita; 36 , Neocota weedii. 
31. Metapleura with hairs or bristles in front of the halteres......... 35

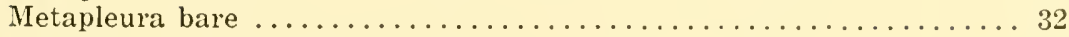

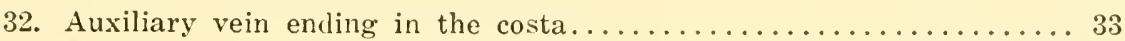
Auxiliary vein obsolete apically $(2,9) \ldots \ldots \ldots \ldots$ Toreus Melander

33. Auxiliary vein bending apically to meet the costa; anal angle promi-

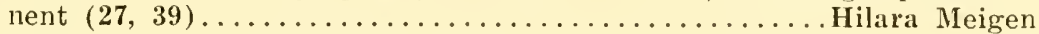
Auxiliary vein almost straight, the anal angle broally rounded...... 34

34. Thoracic bristles strong; antennæ below the middle of the head (29).

Philetus Melander Thoracic bristles almost absent; antennæ at the micllle of the head

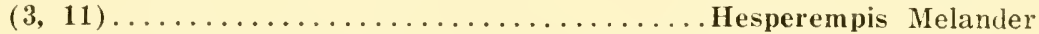

35. Style three times the length of the third antennal segment.

Opeatocerata Melander Style not longer than the third segment................... 36

36. First antennal segment nearly or quite as long as the third, the an-

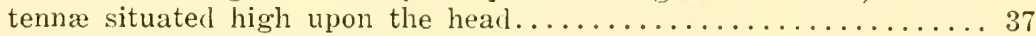
First segment much shorter than the third, situated at most a little

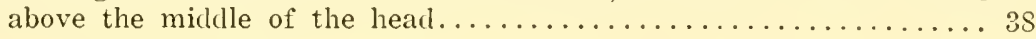
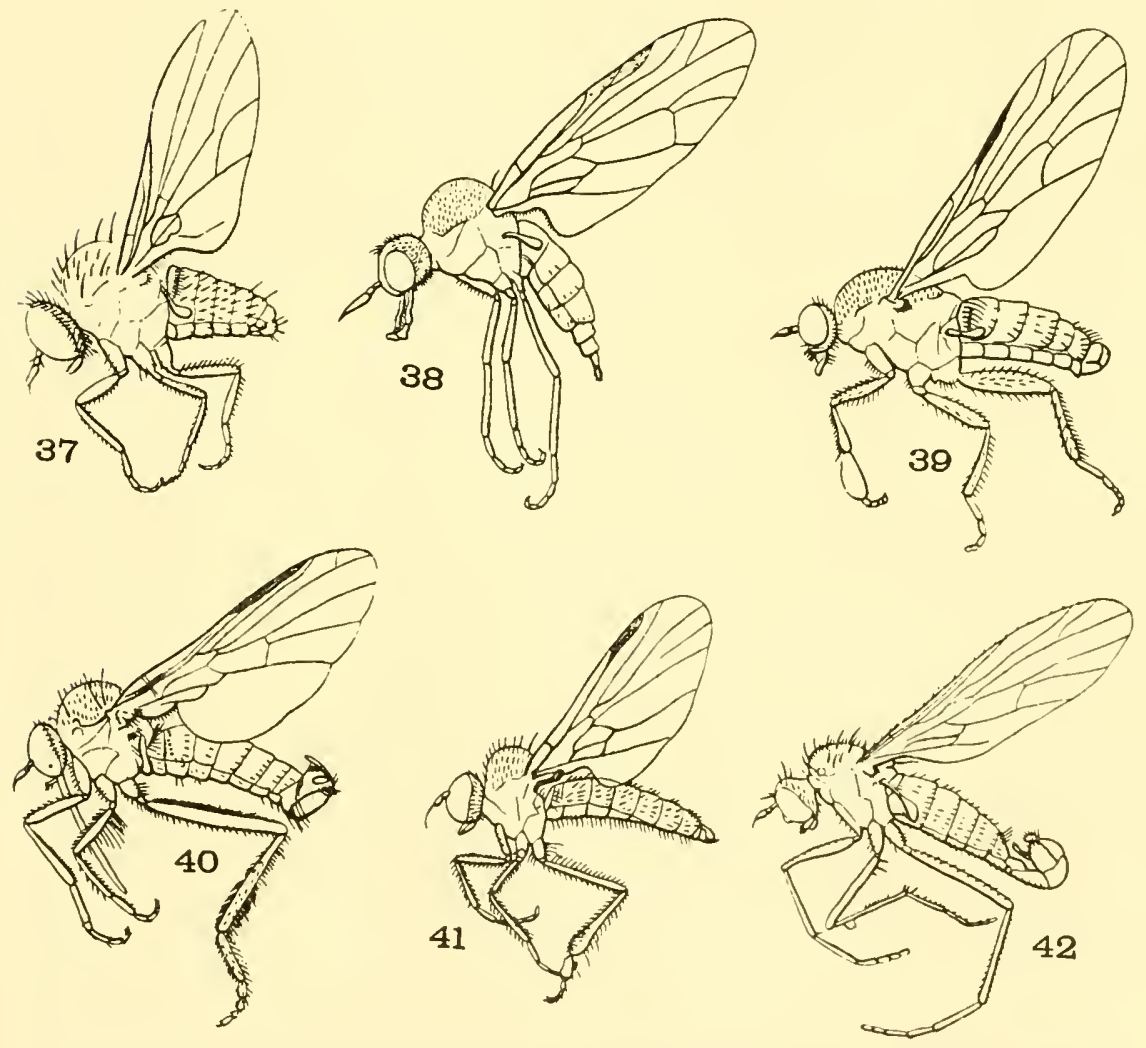

Empide IV - 37, Yicrophorus velutiuns; 25, Iteaphila unacquarti: 39 , Hilara; 40, Empis: 41, Bicellaria; 42, Proclinopyga amplectans.

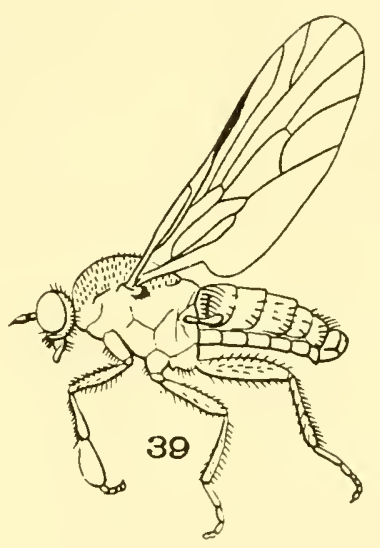


37. Arista much shorter than the third antennal segment (17).

Lamprempis Wheeler and Melander Arista much longer than the third segment......Porphyrochroa Melander

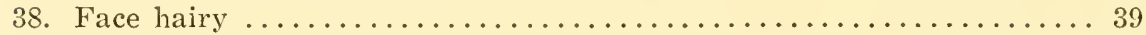

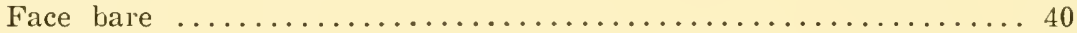

39. Third vein furcate $(24) \ldots \ldots \ldots \ldots \ldots \ldots \ldots$ Empimorpha Coquillett Third vein simple $(36) \ldots \ldots \ldots \ldots \ldots \ldots \ldots \ldots \ldots$ Neocota Coquillett

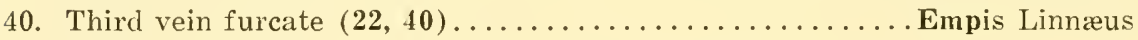
Third vein simple................................. 41

41. Third antennal segment many times longer than wicle (45,52).

Axelempis Curran

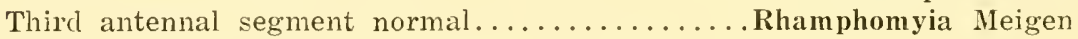

43. Third antennal segment remarkably lengthened, strap-like, and without

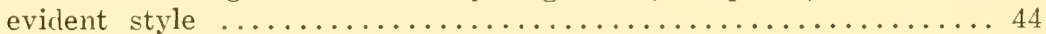
Third antennal segment not remarkably long................ 45

44. Antennæ inserted above the midlle of the head..... Niphogenia Melander Antennæ inserted below the midcle of the head..... Ceratempis Melander

45. Antennæ situated at the middle of the head, the third segment with a short style which terminates in a bristle-like segment.

Boreodroma Coquillett

Antennæ situated above the middle of the head, the third segment

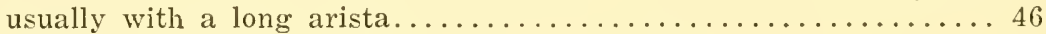

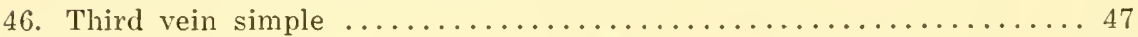

Third vein branched $\ldots \ldots \ldots \ldots \ldots \ldots \ldots \ldots \ldots \ldots \ldots \ldots$
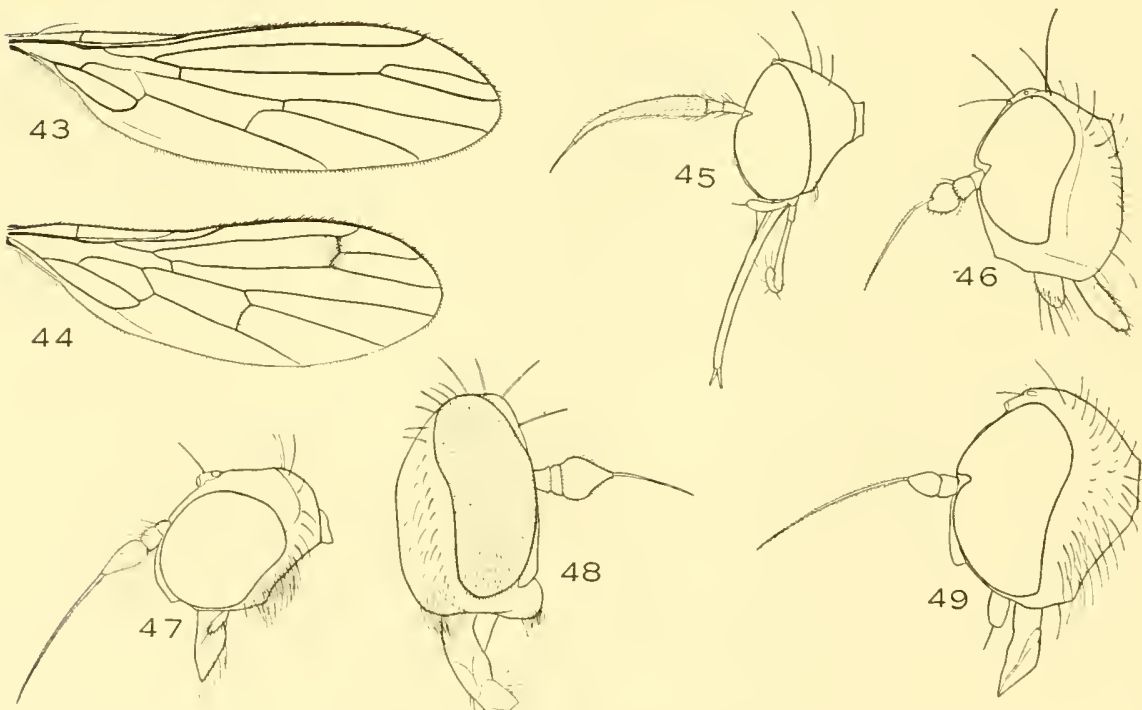

Empidæ V.-43 Wiedemannia hamifera; 44, Clinocera binotata; 45, Axelempis fulvithorax; 46. Chersodromia houghi; 47, Chelipoda elongata; 48, Parathallasius aldrichi; 49, Platypalpus cocuilletti. 

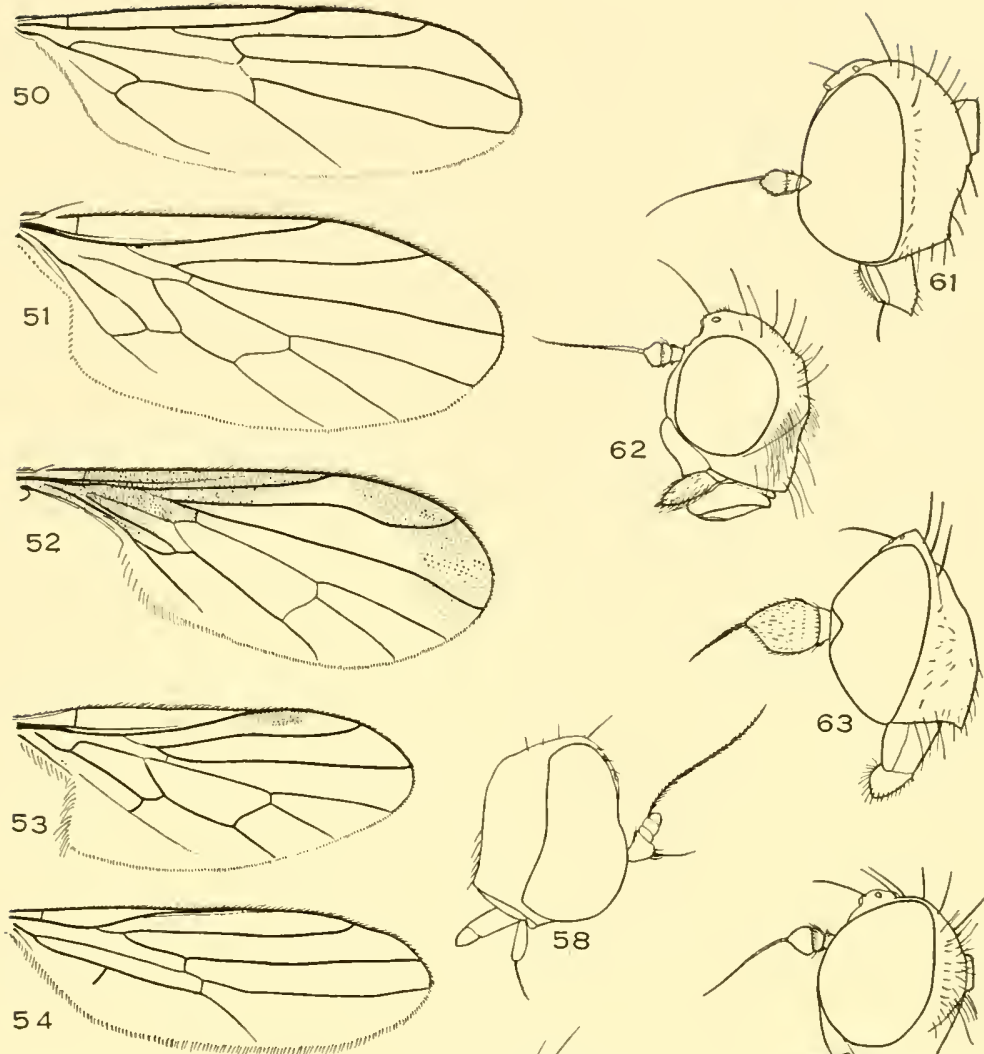

62
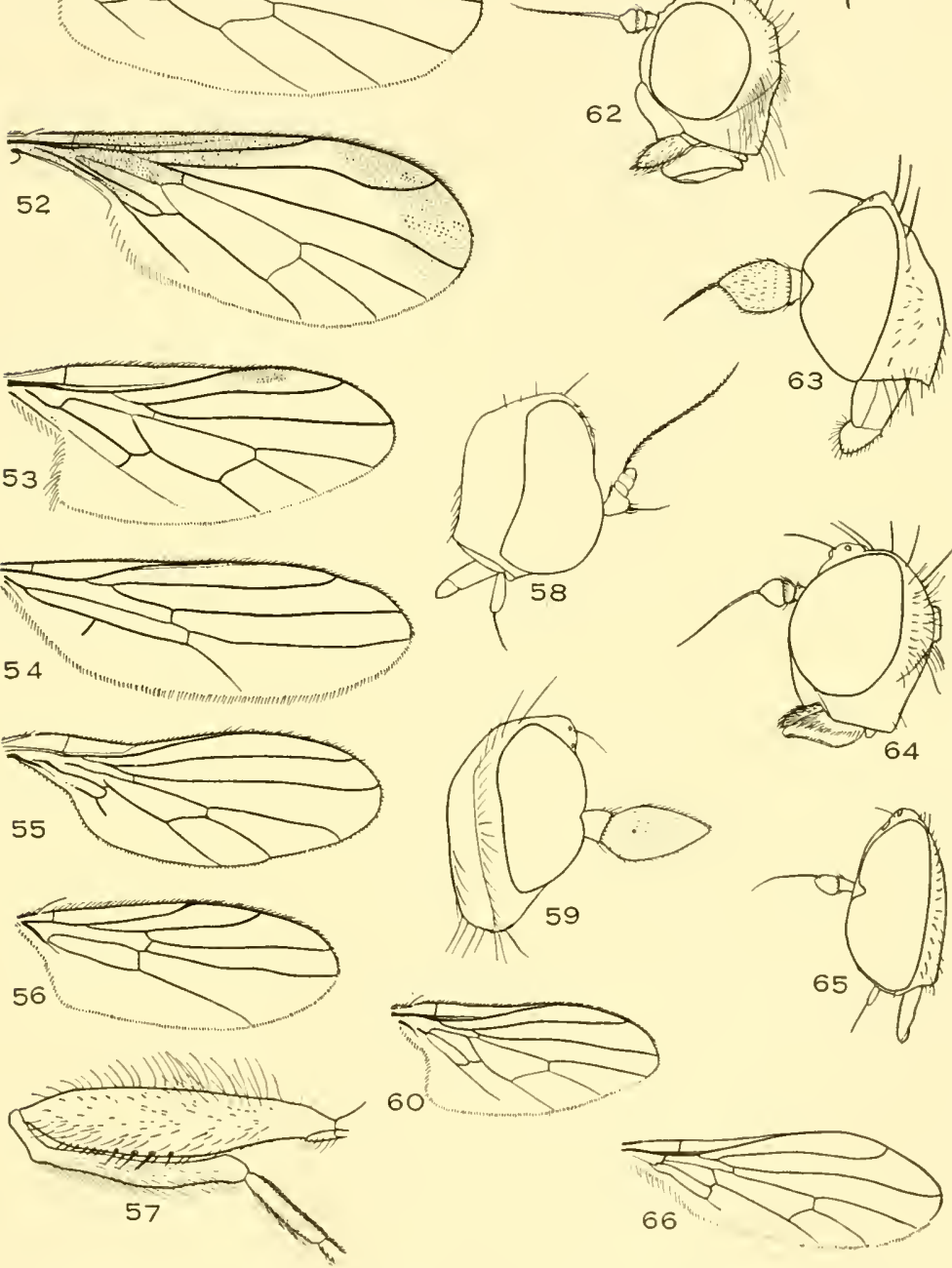

Empidæ VI.-50. Platypalpus coquilletti; 51, Allanthalia pallida; 52, Axelempis fulvithorax: 53, Edalia ohicensis; 54, Tachydromia postica; 55, Parathallasius aldrichi; 56 Chersodromia houghi; 57, (Edalia ohioensis; 58, Stilpon pectiniger; 59, Allanthalia pallida: 60, Anthalia bulbosa; 61, Tachydromia pusilla; 62, Wiedemannia hamifera; 63, Anthalia lacteipennis; 64, Clinocera taos; 65 , Tachyempis simplicior; 66, Chelipoda elongata. 


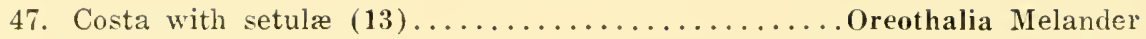
Costa without setulæ $(6,33) \ldots \ldots \ldots \ldots \ldots \ldots \ldots$ Heleodromia Haliday

48. Auxiliary vein obsolete apically $(42) \ldots \ldots \ldots \ldots$ Proclinopyga Melander Auxiliary vein ending in the costa..................... 49

49. Cheeks very wide $\ldots \ldots \ldots \ldots \ldots \ldots \ldots \ldots$ Rœderioides Coquillett

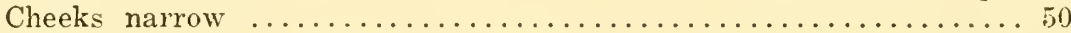

50. Body shining or sub-shining............ Dolichocephala Macquart

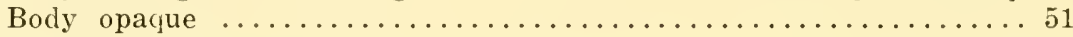

51. Face not prominent below; no acrostical setæ $(44,64)$. . Clinocera Meigen Face prominent below; acrosticals present or absent $(43,62)$

Wiedemannia Zetterstedt

52. Style shorter than the third antennal segment.............. 53 Arista more than twice as leng as the third antennal segment $(47,66)$.

Chelipoda Macquart

53. Humeral crossvein absert........................ 54 Humeral crossvein present $(26) \ldots \ldots \ldots \ldots \ldots$ Chelifera Macquart

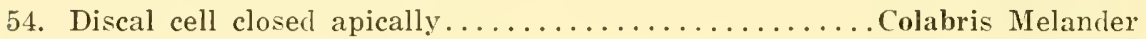
Discal cell open apically $(15) \ldots \ldots \ldots \ldots \ldots \ldots$ Hemerodromia Meigen

55. Thorax very elongate, the humeri large; proboscis slender and not

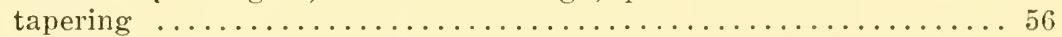
Thorax more robust, the humeri rarely large; proboscis thick basally

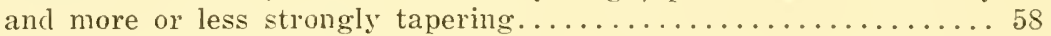

56. Anal crossvein completely absent.................... 57 Anal crossvein present $(16,18) \ldots \ldots \ldots \ldots \ldots \ldots \ldots$ Tachypeza Meigen

57. Front narrow, its sides nearly parallel $(54,61) \ldots$. Tachydromia Meigen Front V-shaped, wide above $(65) \ldots \ldots \ldots \ldots$ Tachyempis Melander

58. First basal cell equal to or longer than the second............. 59 First basal cell decidedly shorter than the second...............6 64

59. Legs with strong bristles........................ 60

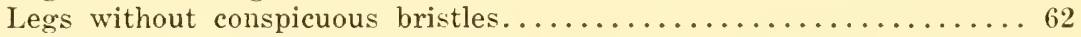

60. Wings about one-third normal length $(32) \ldots \ldots$. . Thinodromia Melander

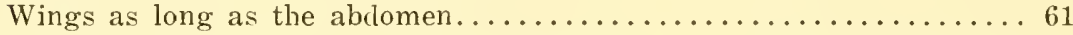

61. Two pairs of presutural dorsocentrals (8)....... Coloboneura Melander One pair of presutural dorsocentrals $(46,56) \ldots$ Chersodromia Walker

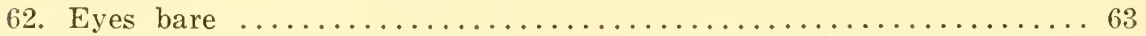

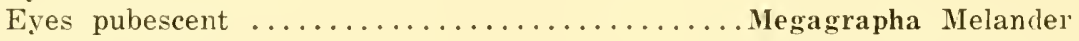

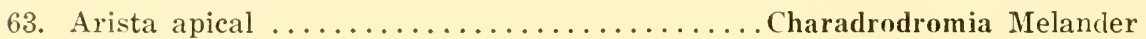

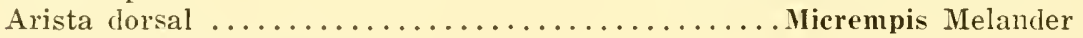

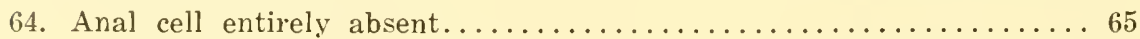
Anal cell partly formed $(19,50) \ldots \ldots \ldots \ldots \ldots$ Platypalpus Macquart

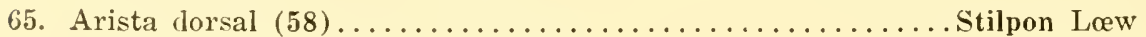
Arista apical or subapical $(19,20) \ldots \ldots \ldots \ldots \ldots$ Drapetis Meigen 


\section{Family Dolichopidæ-The Long-headed Flies}

Small flies rarely exceeding $10 \mathrm{~mm}$. in length, usually metallie green or blue, partly dusted with whitish, brownish or grayish, rarely yellow or blackish. Diseal cell united with the seeond basal cell.

Head about as wide as the thorax, sometimes a little wider, usually a little higher than wide; face rariable in widtl, sometimes practically eliminated by the approximation of the eyes, generally wider in the females than in the males; front usually wide and widening above, rarely obliterated by the approximation of the eyes in the males; with bristles above. Posterior orbits usually with orbital cilia which may be replaced below by fine liair. Proboscis fleshy, short, usually retracted; palpi flat, usually reposing on the proboseis, sometimes modified and highly ornamental. Antennæ composed of three segments, bearing a dorsal or apieal arista; third segment usually more or less oral, sometimes elongated, especially in the males. Thorax convex above, sometimes with a conspienous depression before the seutellum. Abdomen with five or six segments, conical, eylindrical, flattened, laterally compressed or more or less iaterally compressed apically; hypopygium large, or small and eoncealed. Coxa usually short, rarely a little elongate, the legs of moderate length, the femora usually somewhat enlarged, the tarsi of the males frequently beautifully modified, the tibiæ rarely so although sometimes brightly colored. Wings hyaline or with dark markings, sometimes ornamented with black and white or of peculiar shape. Seeond basal and discal eells united, the anal cell short, the sixth vein short or absent, the fourth vein usually straight or only gently eurved forward, rarely forming a crossvein.

The adults oecur everywhere in the vicinity of water and are partieularly abundant in swamps and along lightly shaded streams where they ocem on mud or sand; on foliage, usually in the sum; on stones in streams; on the trunks of trees and on fallen logs. Speeies of Medeterus and Teurigonu are normally foune on tree trunks, especially those having smooth bark: IIydrophorus and Campsicnemus oeeur on the surface of small pools; most genera oceur on mud along water, some only on sand; Diuphorus, Chrysotus and IIerenstomus oceur chiefly on foliage and the sime is tme of Condylostylus. ete. Many of the speces are extremely local in habitat. ocemring only where conditions are perfectly suitable. The adults are all predaceous, feeting upon smaller insects and mites. I have frequently observed them devouring mides and also small larve ocenuring in the mud. 
Many of the adults have very unusual mating danees which may be observed without diffieulty as the speeies are common and soon return to their "mud flats" if disturbed. An excellent account of several of the species is given in the revision of Dolichopus by Tan Duzee, Cole and Aldrich.

Little is known about the immature stages which are passed, for the most part, in mud, although some species live in the stems of grass and those of Medeterus live under the bark of trees and are definitely predaceous. Some speeies are said to feed upon decaring regetation but they are probably predaceous.

The males are easily determined but the females are often diffienlt to name as they present less striking characters than the males. The Ameriean speeies were revised hy Becker* but so many new forms have been deseribed since that this work will furnish only a basis for the study of the family. The females present few structural characters and it is difficult to separate a few of the genera except by association and familiarity with the group. Several characters not previously used are employed in the key presented and most of the females are keyed out separately. With a little experience this sex should be as easily located in the correet genus as is the opposite sex and the males will trace ont quite readily in this section of the key. although two or three genera are omitted as females are not available.

\section{KEY TO GENERA广}

1. Fourth vein with a widely divergent fork beyond the posterior crossvein and with an appendage at the bend (16); mesonotum scarcely

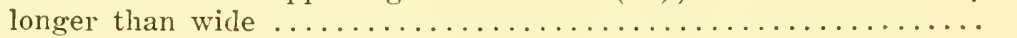

Fourth vein without such fork though often with strong curvature; mesonotum usually conspicuously longer than wide.......... 8

2. Front scarcely excavated above from anterior view............ 3 Front strongly excavated above from anterior view............ 4

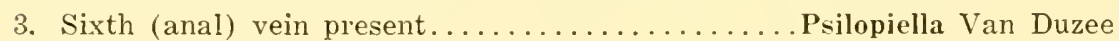

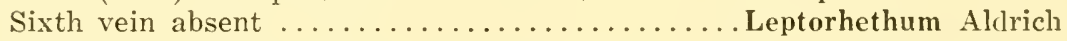

4. Arista not differentiated from the third antennal segment which is produced style-like and extremely long...........Megistostylus Bigot Arista clearly differentiated ....................... 5

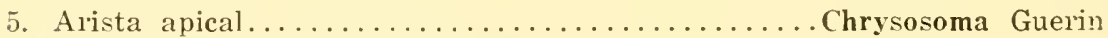
Arista lorsal, rarely sub-apical.................... 6

6. Lower part of the face with hairs $(83) \ldots \ldots \ldots \ldots \ldots$ Laxina, $n . g$. Lower part of the face without hair.................. 7

7. Scutellum with four bristles $(16,85) \ldots \ldots \ldots \ldots$ Condylostylus Bigot Scutellum with a pair of strong bristles and sometimes a weak basal hair on either side $(17,71) \ldots \ldots \ldots \ldots \ldots \ldots \ldots$ Sciapus Zeller

* 1922 (1921). Abh. Zool.-bot., Gesselsch., Wien, xiii, pp. 1-395. belong.

i Syntormon Low appears to be distinct from Synarthrus to which our American species 
8. Thorax almost as broad as long; hearl wider than high; the front deeply excavated from anterior view; face wille $(48,51)$.

* Mesorhaga Schiner

Thorax and head different........................ 9

9. Basal segment of the posterior tarsi with stout bristles above $(24$, $42,57) \ldots \ldots \ldots \ldots \ldots \ldots \ldots \ldots \ldots \ldots \ldots \ldots \ldots \ldots \ldots \ldots \ldots \ldots \ldots$ Dolichopus Latreille

Basal segment of the posterior tarsi without bristles above........ 10

10. Mesopleura produced as a finger-like strip along the posterior edge of the anterior coxæ $(20) \ldots \ldots \ldots \ldots \ldots \ldots \ldots \ldots$ Liancalus Lœw

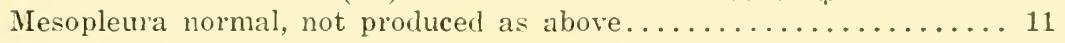

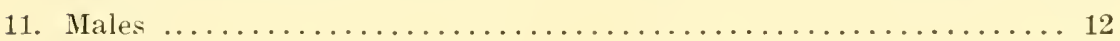

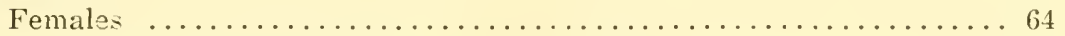

12. Hypopygium long, extending forward under the venter.......... 13 Hypopygium short, only the lamellæ sometimes extending forward... 25

13. Arista long pubescent, sub-plumose..................... 14

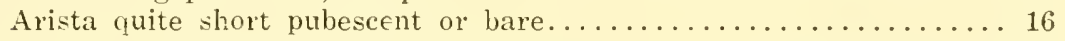

14. Third antennal segment very large, acuminate..... Leptocorypha Aldrich Third antennal segment normal, short and somewhat pointed....... 15

15. Face wide below, roof-like over the mouth, concave in the middle $(22,25,46,77) \ldots \ldots \ldots \ldots \ldots \ldots \ldots \ldots \ldots \ldots$ Pelastoneurus Lœw Face narrow, especially below $(66,79) \ldots \ldots \ldots \ldots$ Sarcionus Aldrich

16. About the posterior third of the mesonotum concave or fiattened.... 17 Mesonotum flattened only immediately before the scutellum........ 20

17. Second antennal segment prolonged along the inner side of the third $(67,73) \ldots \ldots \ldots \ldots \ldots \ldots \ldots \ldots \ldots \ldots \ldots \ldots \ldots \ldots \ldots$ Cologlutus Aldrich Second antennal segment not prolonged along the third.......... 18

18. Hypopygium pedunculate, at least not sessile, reaching almost to the

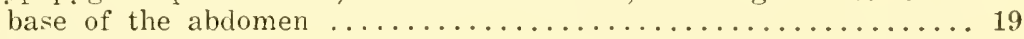

Hypopygium sessile, the basal part not reaching half way to the base of the abdomen although the lamellæ may do so $(45,81)$.

"Paraphrosylus Becker

19. Third and fourth veins strongly converging apically, the distance between them at their apices not more than half as great as opposite the posterior crossvein; bristles rarely yellow $(63,86)$.

IIedeterus Fischer

Third and fourth veins separated apically by at least two-thirds the distance separating them opposite the anterior crossvein; hair and bristles yellow $(31,59) \ldots \ldots \ldots \ldots \ldots \ldots \ldots{ }^{\circ}$ Thrypticus Gerstæcker

20. The face hangs down apron-like below the eyes $(15,38)$.

oPolymedon Osten Sacken

The face is not produced as a long, thin ribbon.............. 21

* Van Duzee, 1917, Ent. News, xxviii, p. 123.

$\div$ Van Duzee, Cole and Aldrich, 1921, Bull. 116, U. S. N. Mus.: Van Duzee and Curran.

1934, Amer. Mus. Novit. Nos. 683, 684.

țan Duzee, 1917, Ent. News, Xxviii, p. 126.

$\$$ Van Duzee, 1923, Ann. Ent. Soc. Amer., xvi, 1) 30.

- Van Duzee, 1924, Pan-Pac. Ent.. i, p. 73.

Van Duzee, 1928. Psyche, xxxv, p. 38.

- Van Duzee, 1921. Psyche, xxriii, p. 124.

$\oint$ Van Duzee, 192\%. Ann. Ent. Soc. Amer., xx, p. 123. 

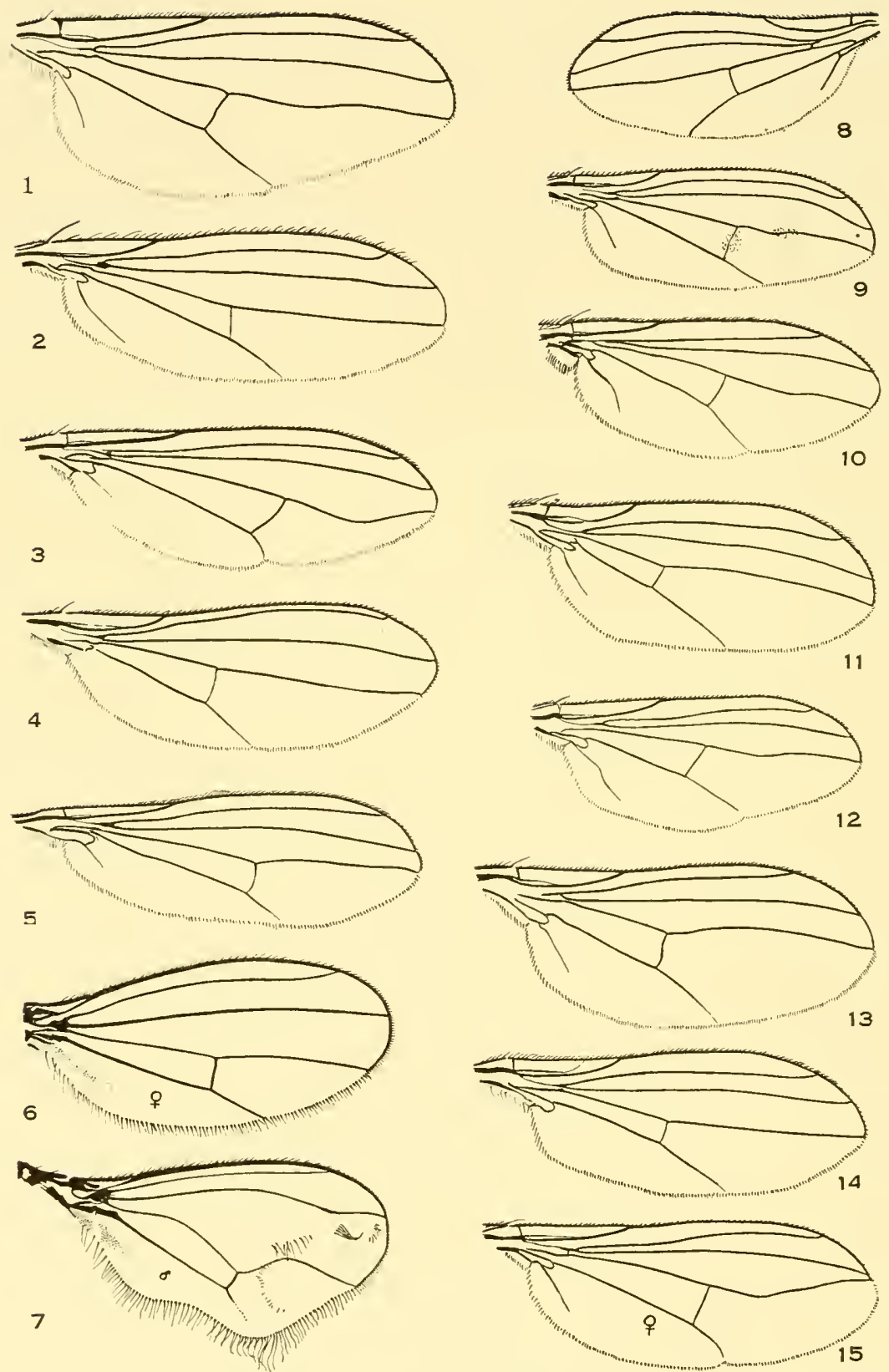

Dolichopidæ I.-1, Anepsiomvia linearis: 2, Campsienemus latipes; 3, Stolidosoma permutatum: 4, Xanthina nigromacula; 5 , Diostracus prasinus; 6,7 , Collinellula magistri; 8 , Peloropeodes brevis: 9. Synarthrus tricoloripes: 10, Keirosoma albicinctum: 11, Chrysotimus luteus: 12. Nematoproctus flavicauda; 12, Chrysotus discolor; 14, Thinophilus ochreifacies; 15, Polymedon dilaticosta. 
21. Third and fourth veins parallel apically............... 22

Third and fourth veins strongly converging apically or the fourth

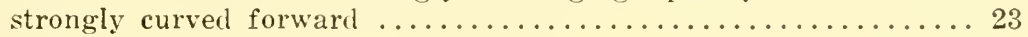

22. First antennal segment bare above $(8,33) \ldots \ldots *$ Peloropeodes Wheeler First antennal segment haired above at apex (5.5, 70).

†Gymnopternus Lœw

23. Fourth vein with a rather sharply rounded curvature and parallel

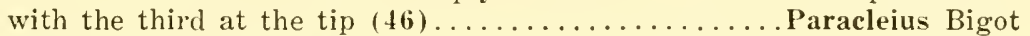

Fourth vein straight beyond the crossvein or with a gentle curvature

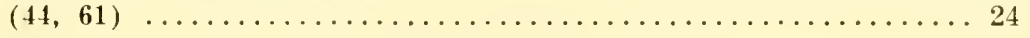

24. Head conspicuously higher than wide, the face extending to the lower edge of the eyes; fourth vein curvel beyond the posterior crossvein $(29,44) \ldots \ldots \ldots \ldots \ldots \ldots \ldots \ldots \ldots \ldots \ldots \ldots \ldots \ldots \ldots \ldots \ldots$ Tachytrechus Walker Head but little higher than wide, the face not reaching the lower elge of the eyes; fourth vein straight beyond the crossvein $(61,76)$.

Hercostomus Lœw

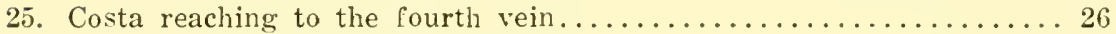

Costa ending at the third vein $(58) \ldots \ldots \ldots \ldots \ldots \ldots$ Asyndetus Lœw

26. First antennal segment bare above........................ 34

First antennal segment haired above, at least apically.......... 2;

27. Arista dorsal, rarely subapical.................... 29

Arista apical or practically so............................. 28

28. Third antennal segment bilobed or with a strong anuglar projection below on the basal thirel $(30,40) \ldots \ldots \ldots \ldots \ldots$.......... Third antennal segment triangular or subtriangular $(18,74)$.

firgyra Macquart

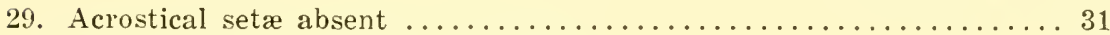

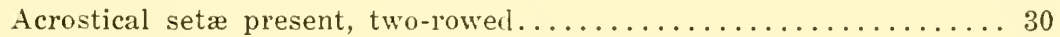

30. Fourth vein doubly bent at rearly right angles $(68,82)$.

Syntomoneurum Becker Fourth vein not sharply curved $(3,37) \ldots \ldots \ldots \ldots$ Stolidosoma Becker

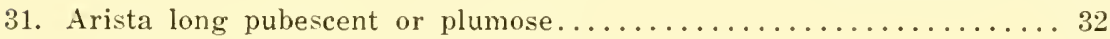

Arista very short pubescent or bare................... 33

32. Third and fourth veins parallel or only a little convergent.

Phylarchus Aldrich

Fourth vein strongly curved forward, very close to the third at its apex; (Some species of Sarcionus and Pelastoneurus might come here as a few have short genitalia).

33. Palpi very small; face very narrow (1)........... Anepsiomyia Bezzi Palpi larger; lower section of face twice as wicle as long $(\overline{5}, 34)$.

Diostracus Lœw

34. Mesonotum with an elongate, longitudinal depression on the nosterior

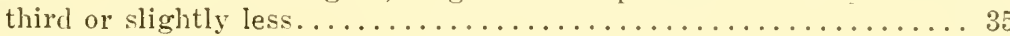

* Van Duzee, 1926, Tr. Amer. Ent. Soc., liii, 1p. 39-46 (Kophosoma).

† Curran, 1933, Amer. Mus. Novit. No. 682, 1. 2.

$\$$ Green, 1922, Proc. U. S. N. M., Ix, Article 17.

\$ Van Duzee, 1919, Ent. News, xxx, 1). 248.

- Van Duzee, 1925, Proc. U. S. N. M., livi, Art. 23. 


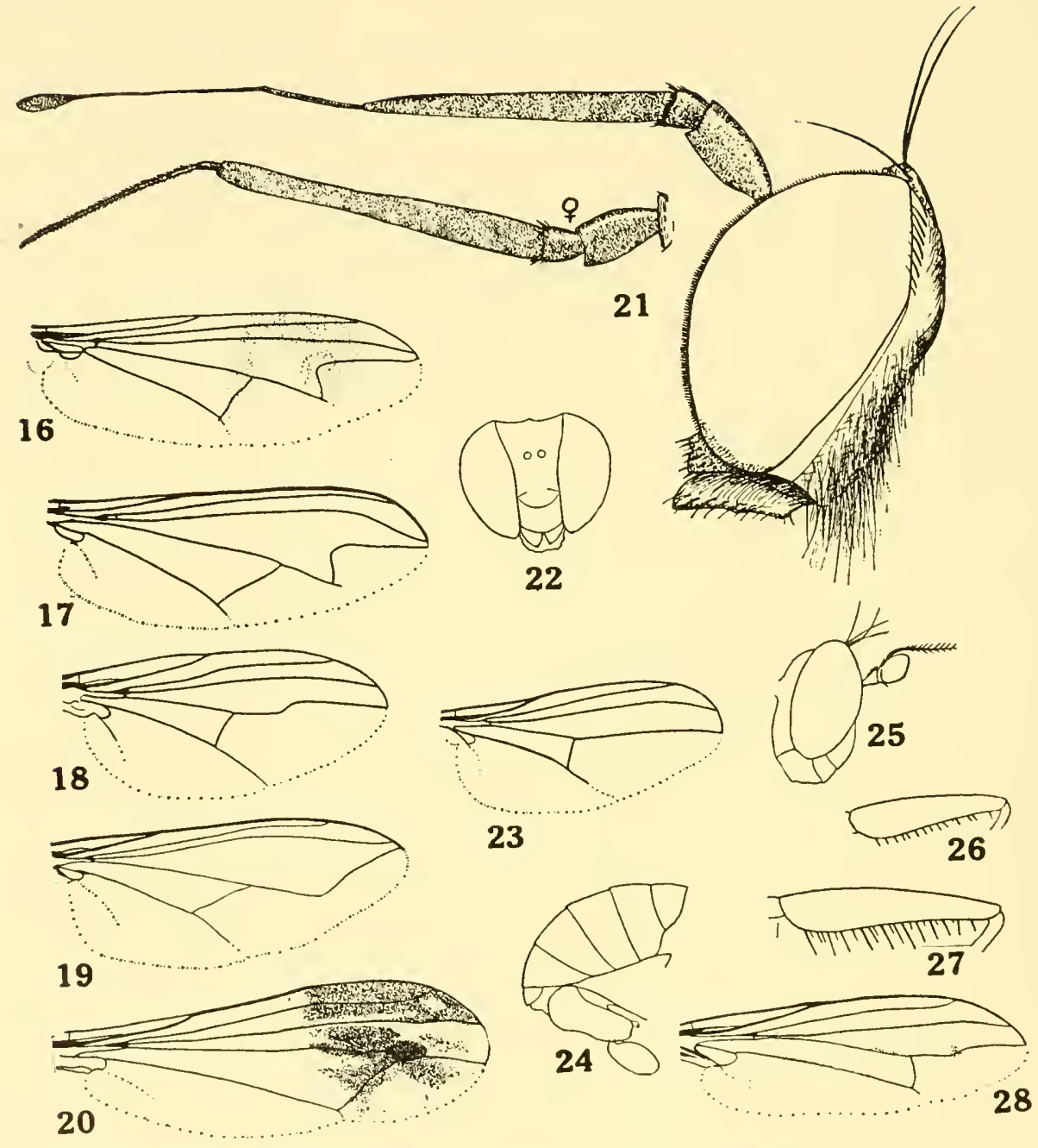

Dolichopidx II-16, Condylostylus sipho; 17, Sciapus unifasciatus; 18, Argyra; 19 , Plagioneurus univittatus; 20, Liancalus similis ; 21, Rhaphphium; 22, Pelastoneurus vagans; 23. Plagioneurus univittatus; 20 , Liancalus similis; 21 , Rhaphphium; 22, Pelastoneurus vagans;
Diaphorus; 24, Dolichopus, $\delta$ abdomen; 25 , Pelastoneurus vagans; 26 . Hydrophorus, front femur; 27 , Scellus, front femur ; 28 , Scellus vigil. 
Mesonotum without such depression, usually with a slight, transverse

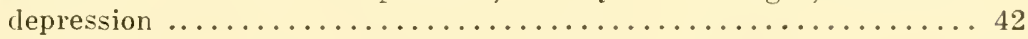

35. Acrostical setulæ present, at least at the anterior edge of the thorax. 36

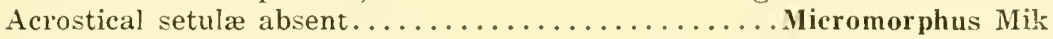

36. Third and fourth veins almost parallel beyond the crossvein....... 37 Third and fourth veins converging before the apex (52).

*Neurigona Rondani

37. Acrostical setulæ present only on the anterior margin of the mesonotum $(60) \ldots \ldots \ldots \ldots \ldots \ldots \ldots \ldots \ldots \ldots \ldots \ldots \ldots \ldots \ldots$ Xanthochlorus Low Acrostical setulæ extending at least to the suture.............. 38

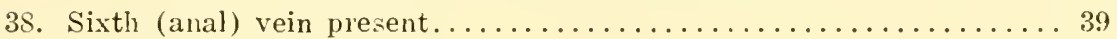

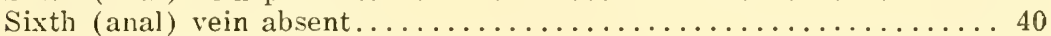

39. Hair and bristles wholly rellow (11)................... Chrysotimus Lœw Hair and bristles not yellow $(52) \ldots \ldots \ldots \ldots \ldots$ Neurigona Rondani

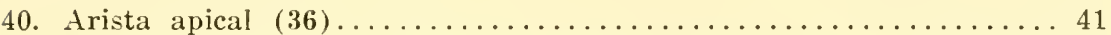
Arista sub-apical; third antennal segment pointed (62). † Achalcus Lœw

41. Pleura metallic $(6,7) \ldots \ldots \ldots \ldots \ldots \ldots \ldots \ldots \ldots \ldots \ldots \ldots \ldots$ Collinellula Aldrich Pleura yellow; third antennal segment rounded apically $(4,36)$.

$\dagger$ Xanthina Aldrich

42. Fourth vein ending well before the tip of the wing; posterior cross-

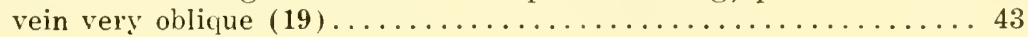

Fourth vein ending but little before the tip of the wing, usually in or

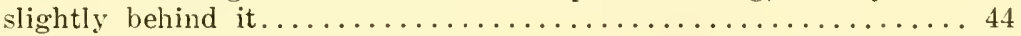

43. Dorsocentral bristles strong (19) .............Plagioneurus Lœw Dorsocentral bristles hair-like.............Edematopus Van Duzee

44. Posterior crossvein situated less than its own length from the wing margin along the fifth vein, the basal segment of the posterior tarsi

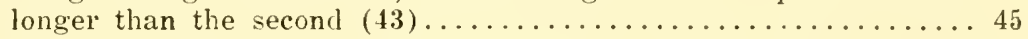

Posterior crossvein much shorter than the ultimate section of the fifth vein, or the first segment of the posterior tarsi decidedly

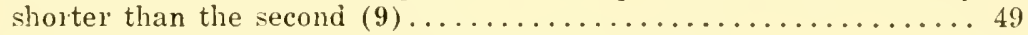

45. Pteropleura haired in front of the posterior spiracle............46

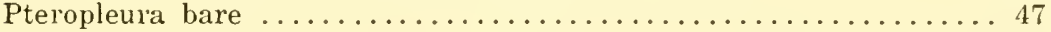

46. First antennal segment with stout setulæ below (72).. Melanderia Aldrich First antennal segment bare below (Hydrophorus pt) (80).

Millardia, n. g.

47. Pteropleura produced to form a mammiform projection in front of the posterior spiracle $(27,28) \ldots \ldots \ldots \ldots \ldots \ldots \ldots \ldots$ t. Scellus Low

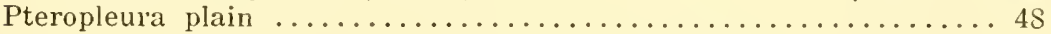

48. Middle of the propleura haired; third antennal segment subrectangular, the arista dorsal $(26,43,56,78) \ldots \ldots \ldots \ldots$ Hydrophorus Fallér

* Van Duzee, 1913, Ann. Ent. Soc. Amer., vi, pp. 22-61.

$\uparrow$ The only difference in these two genera appears to be in the shape of the third antennal segment. They should probably be united.

$\$$ Greene, 1924, Proc. U. S. N. M.. lxv, Art. 16.

$\S$ Van Duzee, 1926. Pan.-Pac. Ent., iii, 1). 5. 

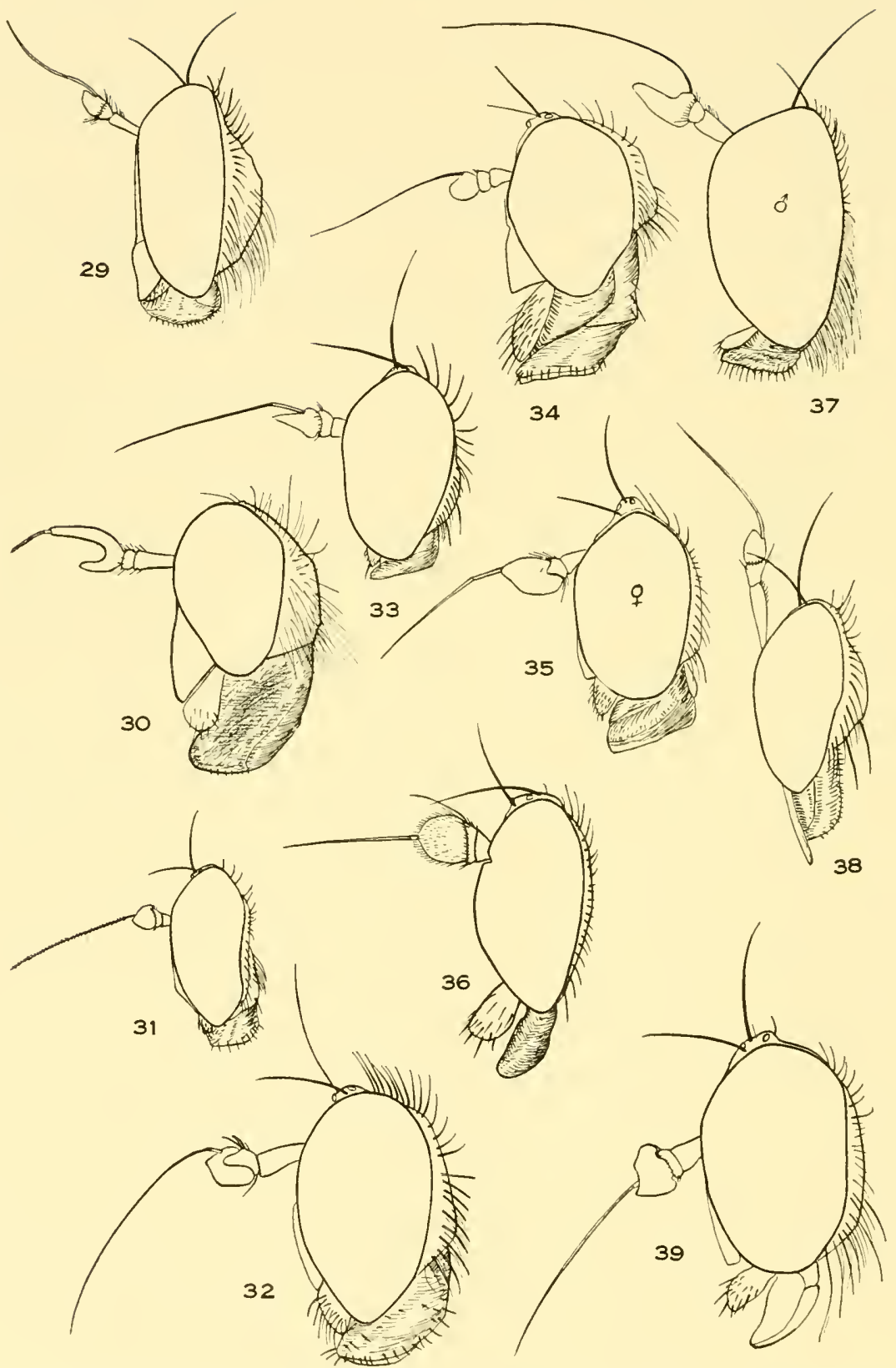

Dolichopidæ III.-29, Tachytrechus; 30 , Hypocharasus; 31 , Thrypticus; 32 , Neosyntormon ; 33. Peloropeodes brevis; 34 , Diostracus prasinus; 35 , Parasyntormon asellus; 36 , Xanthina subcurva; 37 , Stolidosoma permutatum; 38 , Polymedon dilaticosta; 39 , Chrysotus discolor. 
Middle of propleura bare; third antennal segment rather triangular, the arista apical $(45,81) \ldots \ldots \ldots \ldots \ldots \ldots *$ Paraphrosylus Becker

49. Acrostical setulæ present, though weak................. 50 Acrostical setulæ absent (14)........... † Thinophilus Wahlber's

50. Arista apical or practically so, sometimes arising a little above the tip of the pointed third antennal segment............... 51

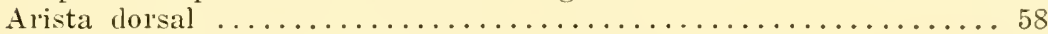

51. Propleura bare or with a single bristly hair in the middle........ 53

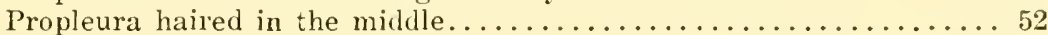

52. Second antennal segment produced thumb-like into the third on the inner surface $(9,84) \ldots \ldots \ldots \ldots \ldots \ldots \ldots \ldots$ fSynarthrus Lœw Second antennal segment not strengly convex apically $(21,47,49)$.

$\S$ Rhaphium Meigen

53. Second longitudinal vein very strongly sinuous (65) (Eutarsus Aldrich, Van Duzee, not Lœw)............... Diaphorus Meigen Second vein at most gently undulate................. 54

54. Second antennal segment produced thumb-like into the third; abdomen elongate and not tapering apically $(35,54)$.

Parasyntormon Wheeler

Second antennal segment usually transverse, rarely strongly convex apically, if so the abdomen short, cylindrical and tapering from base

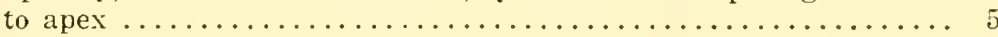

55. Body silvery white pollinose; middle of propleura with a single bristle (64) ............................... Leucostola Low Body rarely silvery pollinose; middle of propleura bare......... 56

56. Lower section of face not differentiaterl................... 57 Lower section of face strongly differentiated and large $(45,81)$.

*Paraphrosylus Becker

57. Front narrow, if wide the apex of the abdomen with four bristles $(23,75) \ldots \ldots \ldots \ldots \ldots \ldots \ldots \ldots \ldots \ldots \ldots \ldots \ldots \ldots \ldots \ldots \ldots \ldots$ Diaphorus Meigen Front wide, the face usually very narrow, the apical abdominal segment without strong bristles $(13,39) \ldots \ldots \ldots \ldots$ Chrysotus Meigen

58. Second antennal segment produced thumb-line into the third on the inner surface $(32,50,69) \ldots \ldots \ldots \ldots \ldots \ldots \ldots$ Neosyntormon, n. g. Second antennal segment transverse or gently convex apically...... 59

59. Middle of propleura bare...................... 60 Middle of propleura haired........................6. 63

60. Abdomen flattened dorsoventrally (2)....... Campsicnemus Walker Abdomen not flattened dorsoventrally ..................6 61

* Van Duzee, 1924. Pan.-Pac. Ent.. i, 1. 73.

$\div$ Van Duzee, 1926. Ann. Ent. Soc. Amer. xix, p. 35.

+ Van Duzee. 1925, Tr. Amer. Ent. Soc. 1, pN. 257-2st (Syntormon).

\$ Curran, 1926-1927, Tr. Roy. Can. Inst., xv, pt. 2, pv. 249-260; xvi. pt. 1, pp. 99-179.

- Van Duzee, 1922, Bull. Buff. Soc. Nat. Sci., xi, pp. 161-194.

Van Duzee, 1924. Bull. Butf. Soc. Nat. Sci., xiii, pp. 1-53; 1931, Amer. Mus. Novit. No. 483 (Neotinnical)

- Van Duzee, 1917. Ent. News, p. 124; Curran, 1933, Amer. Mus. Novit. No. 682, p. 5. 

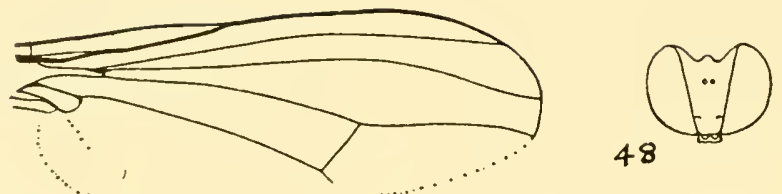

40
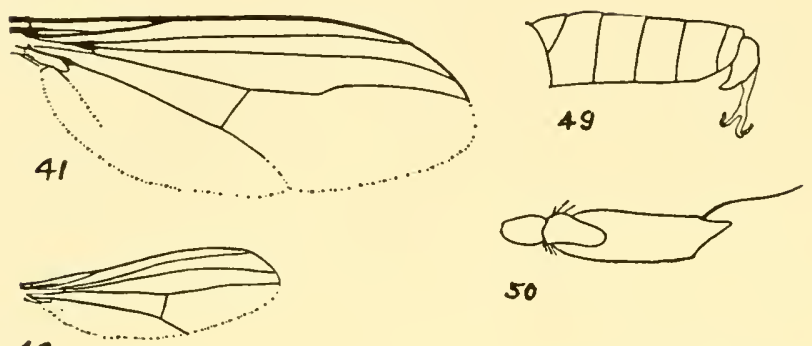

50

42
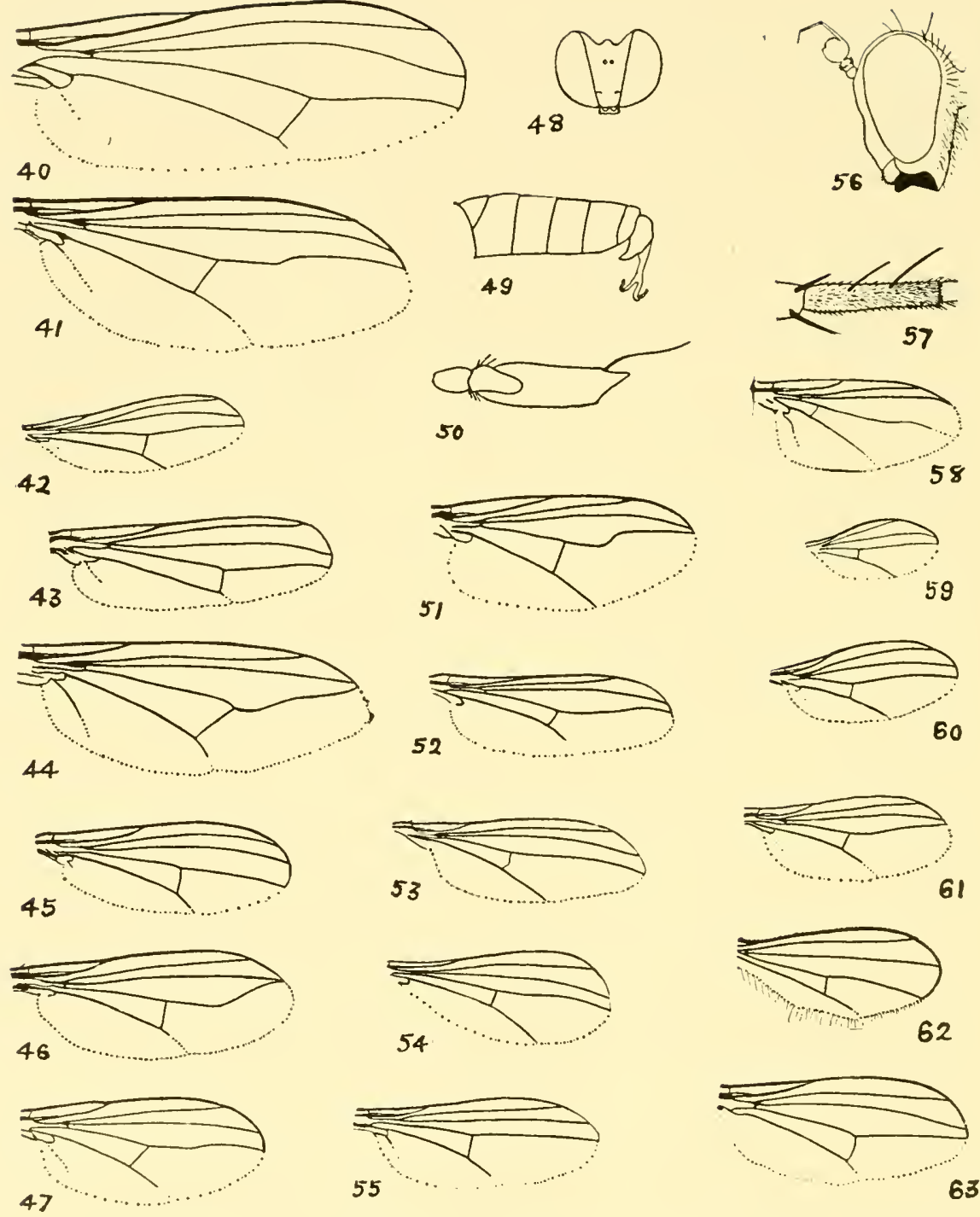

Dolichopidæ IV.-40, Hypocharassus; 41, Dolichopus; 42, Sympycnus; 43, Hydrophorus ; 44, Tachytrechus sanus; 45, Paraphrosylus; 46. Petastoneurus; 47, Rhaphium; 48, Mesorhaga, head from in front; 49. Rhaphium abdomen from side; 50. Neosyntormon; 51, Mesorhaga; 52 , Neurigona; 53, Sympycnus; 54, Parasyntormon; 55, Gymnopternus; 56, Hydrophorus; 57. Dolichopus, 1 st segment of posterior tarsus : 58 , Asyndetus syntormoides; 59, Thrypticus; 60, Xanthochlorus; 61, Hercostomus; 62, Achalcus; 63, Medeterus. 
61. Abdomen long and slender, more or less cylindrical, the genitalia

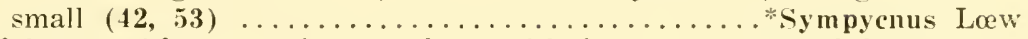
Abilomen either tapering or short with large, asymetrical hypopy-

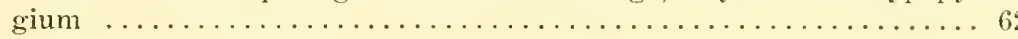

62. Abclomen tapering; genitalia small; scutellum without secondary basal

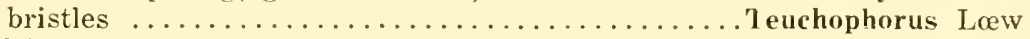
Abdomen short and chunky, the genitalia large, asymetrical (Kophosoma Van Duzee, Pachypyga Parent) $(8,33) \ldots$ † Peloropeodes Wheeler

63. Third and fourth veins rather approximate apically (12).

Third and fourth veins almost parallel beyond the crossvein $(10)$.

\$Nematoproctus Lœw Keirosoma Van Duzee

\section{Females}

64. Costa continuing to the fourth vein.......................... 65 Costa ending at the third vein $(58) \ldots \ldots \ldots \ldots \ldots \ldots$ Asyndetus Lœw

65. Pteropleura produced to form a mammiform protuberance in front of the posterior spiracle $(27,28) \ldots \ldots \ldots \ldots \ldots \ldots \ldots \ldots$.

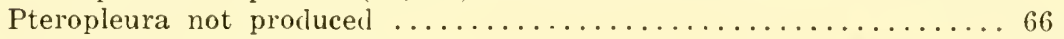

66. First antennal segment haired above................. 67 First Antennal segment bare above.................... 80

67. Arista plumose or very long pubescent................ 68 Arista short pubescent or bare....................... 70

68. No acrostical setulæ................. Phylarchus Aldrich

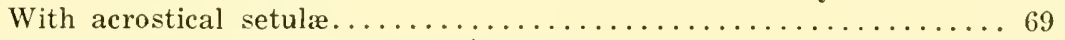

69. Face widle, bulging below $(22,25,46,77) \ldots \ldots \ldots$ Pelastoneurus Lœw Face narrower, never strongly bulging below the middle $(66,79)$.

Sarcionus Aldrich rLeptocorypha Aldricis

70. Arista dorsal .................................... 72

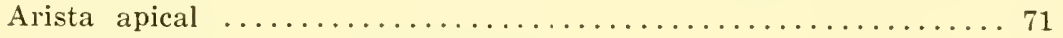

71. Third antennal segment subtriangular or triangular $(18,74)$.

Argyra Macquart Thirl antennal segment either furcate or with a strong, angular projection basally $(30,40) \ldots \ldots \ldots \ldots \ldots \ldots \ldots$ Hypocharassus Mik

72. Propleura with hair or a single bristly hair on the median portion... 73 Propleura entirely bare on the median portion $(5,34)$... Diostracus Lœw

73. Pteropleura with a small tuft of very fine short hairs in front of the posterior spiracle (these are sometimes difficult to discern in most views); fourth vein not curved forward near the apex $(55,70)$.

Gymiopternus Lœw

Without such hairs, or the fourth vein strongly curved forward

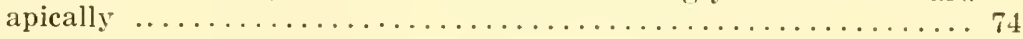

\footnotetext{
* Van Duzee, 1930, Pan-Pac. Ent., vii, p). 35-36.

$\uparrow$ Van Duzee, 1926. Tr. Amer. Ent. Soc., lii, pp. 39-46 (Kophosoma).

$\ddagger$ Van Duzee, 1930, Psyche, xxxvii, p. 167 .

$\$$ Van Duzee, 1919, Ent. News, xxx, p. 248.

Female unknown.
} 


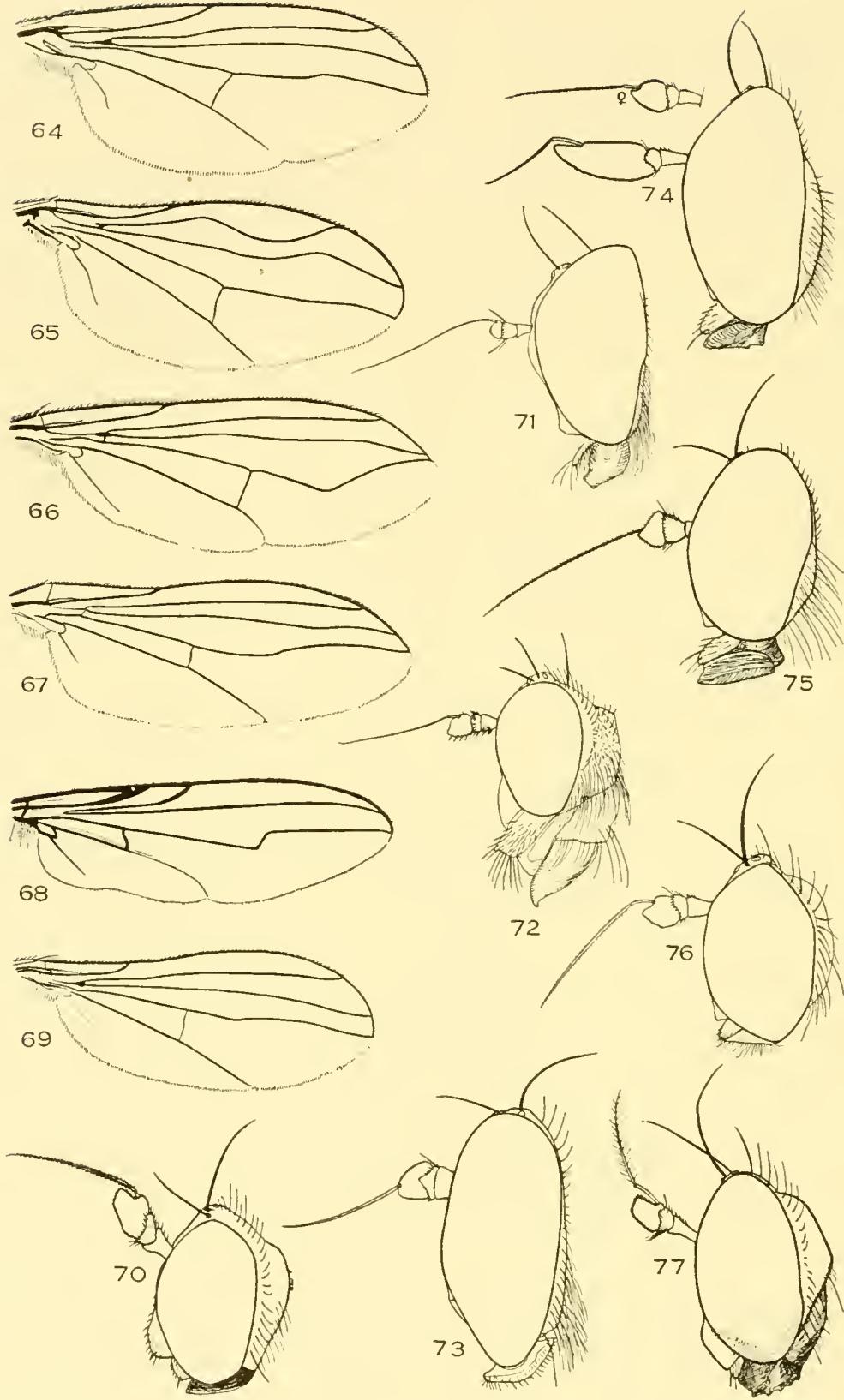

Dolichopidx V.-64, Leucostola cingulata; 65, Diaphorus nigripennis: 66, Sarcionus pectinatus; 67, Ceeloglutus bicoloripes; 68, Syntomoneurum alatum; 69, Neosyntormon; 70 , Gymnopternus; 71 . Sciapus tener; 72, Melanderia mandibulata; 73, Celoglutus bicoloripes; 74 , Argyra; 75 , Diaphorus; 76 , Hercostomus; 77 , Pelastoneurus abbreviatus. 
74. Third and fourth veins conspicuously converging apically or the fourth

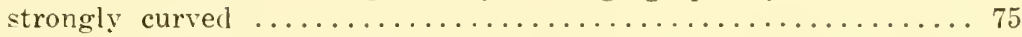

Third and fourth veins parallel beyond the posterior crossvein, or

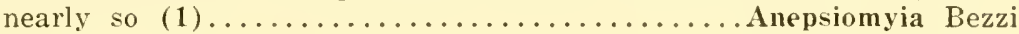

75. Fourth vein approaching the third in a broad curve and running paral-

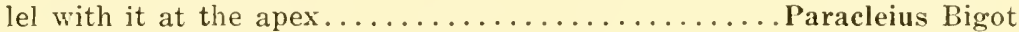

Fourth vein not so strongly approaching the third or not parallel with

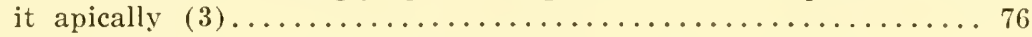

76. A second pair of weak scutellar bristles or hairs; metapleura bare; fourth vein sometimes angularly curved................ 7 7

A single pair of scutellar bristles; metasternum with two or three minute hairs in front of the posterior spiracle, visible only in some lights; fourth vein with single curve $(3,37) \ldots .$. . Stolidosoma Becker

77. Fourth vein straight beyond the posterior crossvein, though approaching the third $(61,76) \ldots \ldots \ldots \ldots \ldots \ldots \ldots \ldots$ Hercostomus Lœw

Fourth vein curved beyond the crossvein............... 78

78. Sixth (anal) vein extending close to the margin of the wing (68)... 79 Sixth (anal) vein extending little more than half way to the margin of the wing beyond the anal cell $(15,38) \ldots$...Polymedon Osten Sacken

79. Fourth vein bent twice in midule of apical section $(68,82)$.

Syntomoneurum Becker Fourth vein not bent at nearly right angles $(29,44)$. .'Tachytrechus Lœw

80. A longitudinal flat or slightly concave area on the posterior third of

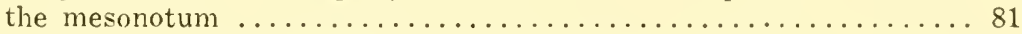

No such area although there is usually a more or less distinct transverse depression immediately before the scutellum........... 91

81. Third and fourth veins parallel or almost so beyond the posterior

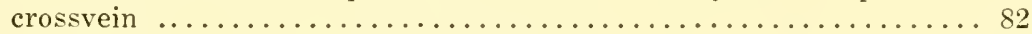

Fourth vein converging toward the third.............. 86

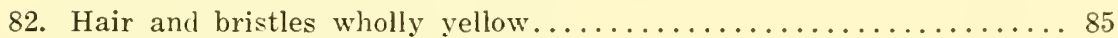
Hair and bristles partly or wholly black or brown........... 83

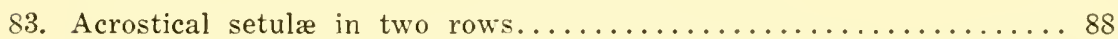
Acrostical setulæ distinct only on the anterior border of the mesono-

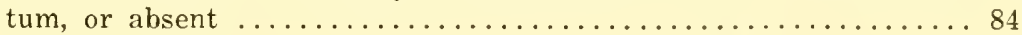

84. Yellowish species $(60) \ldots \ldots \ldots \ldots \ldots \ldots \ldots \ldots \ldots$ Xanthochlorus Lœw Black or green species.................... Ilicromorphus Mik

85. Sixth (anal) vein absent $(31,59) \ldots \ldots \ldots \ldots$ Thrypticus Gerstæcker Sixth vein present $(11) \ldots \ldots \ldots \ldots \ldots \ldots \ldots \ldots \ldots \ldots \ldots \ldots$ Chrysotimus Lœw

86. Fourth vein conspicuously doubly curved forward beyond the crossvein; sixth (anal) vein reaching the wing margin or practically so, strong and curved backward at the tip; usually large species (52).

* Neurigona Rondani

Fourth vein straight beyond the posterior crossvein; sixth rein weak, sometimes represented by a fold and usually curving toward the

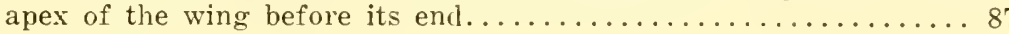

* Van Duzee, 1913, Ann. Ent. Soc. Amer.. vi, pp. 22-61. 


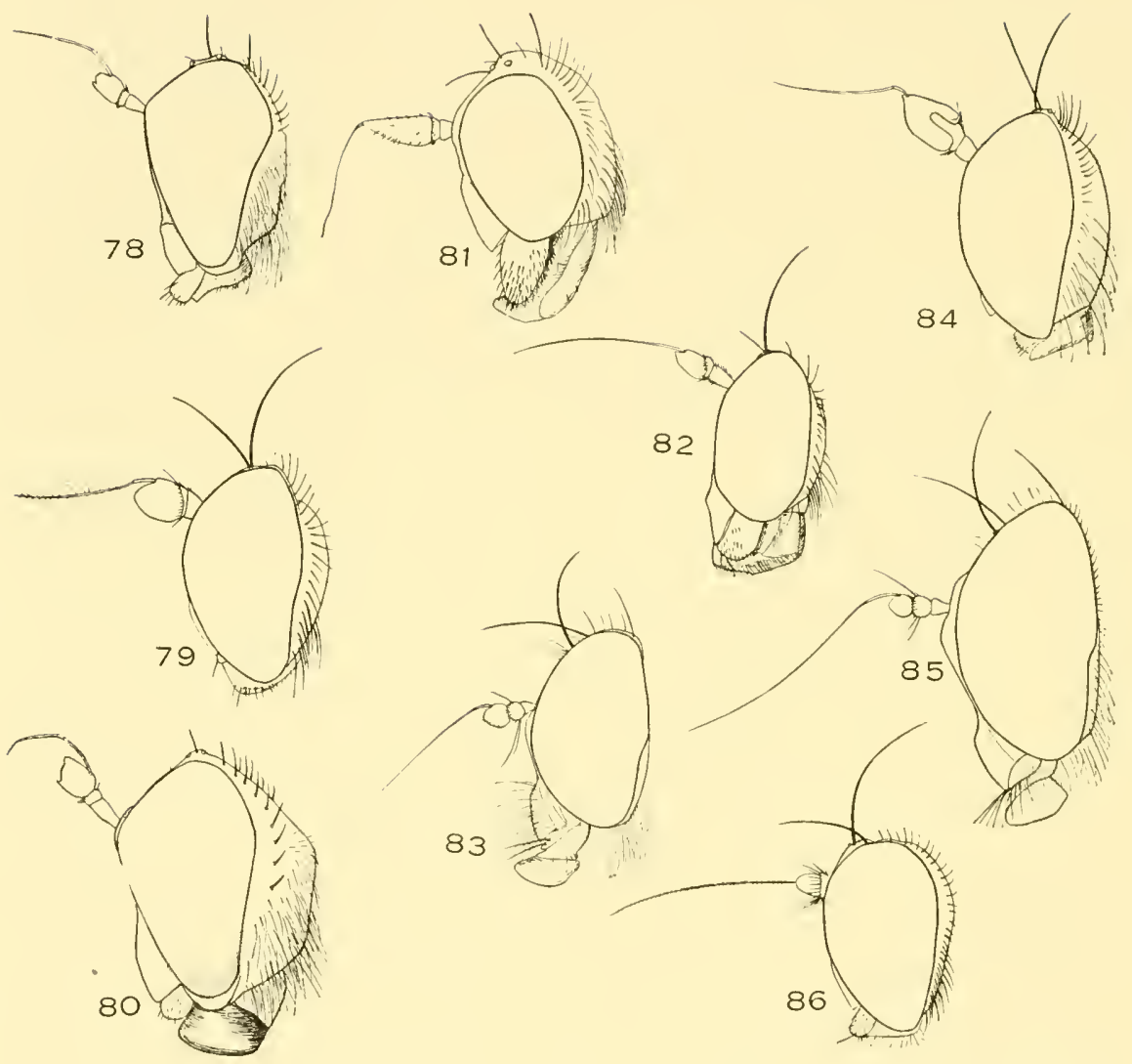

Dolichopidze VI.-78, Hydrophorus extrarius; 79, Sarcionus actutispina; 80, Millardia viridiflos; 81, Paraphrosylus prædator; 82, Syntomoneurum alatum; 83, Laxina caudatus; 84, Synarthrus tricoloripes; 85 , Condylostylus sipho; 86 , Medeterus nigrimana. 
87. Second antennal segment produced along the inner side of the third $(67,73) \ldots \ldots \ldots \ldots \ldots \ldots \ldots \ldots \ldots \ldots \ldots \ldots \ldots \ldots \ldots \ldots \ldots$ Creloglutus Aldrich Second antennal segment liot produced along the third $(63,86)$.

Medeterus Fischer

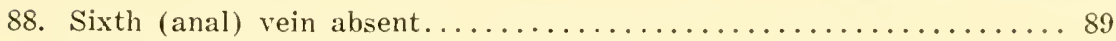

Sixth (anal) vein extendling almost to the wing margin (52).

* Neurigona Low

89. Arista subapical $(62) \ldots \ldots \ldots \ldots \ldots \ldots \ldots$. . . . . . . . . . . . . .

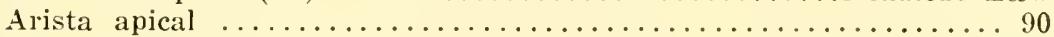

90. Pleura yellowish $(4,36) \ldots \ldots \ldots \ldots \ldots \ldots \ldots \ldots \ldots$ Xanthina Aldrich Pleura metallic green $(6,7) \ldots \ldots \ldots \ldots \ldots \ldots \ldots$ Collinellula Aldrich

91. Fourth vein ending well before the tip of the wing, its outer edge

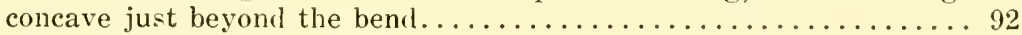

Fourth vein ending but little before the tip of the wing, if curved beyond the posterior crossvein there is no concavity on the outer

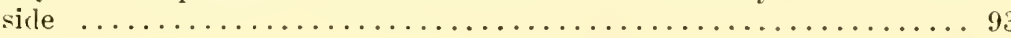

92. Dorsocentral bristles strong $(19) \ldots \ldots \ldots \ldots \ldots \ldots$. . . . . . . . . . . . . .

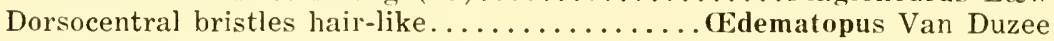

93. Posterior crossvein as long or longer than the ultimate section of the fifth vein; basal segment of the posterior tarsi longer than the

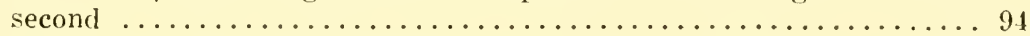

Posterior crossvein rarely as long as the ultimate section of the fifth vein, if so, the basal segment of the posterior tarsi shorter than the

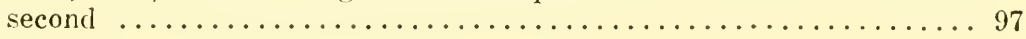

94. Pteropleura haired in front of the posterior spiracle........... 95 Pteropleura bare in front of the posterior spiracle............ 96

95. First antennal segment with stout setulæ below (72). Melanderia Aldrich First antennal segment bare below (Hydrophorus pt) (80).

Millardia, n. g.

96. Middle of the propleura haired $(26,43,56,78) \ldots$ Hydrophorus Meigen Midlde of the propleura bare $(45,81) \ldots \ldots \ldots$. Paraphrosylus Becker

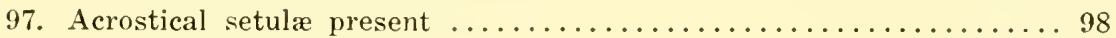
Acrostical setulæ absent (14) ............. Thinophilus Wahlberg

98. Arista apical or practically so, sometimes arising a little above the tip of the pointed third antennal segment................ 99

Arista dorsal, rarely arising a little beyond the middle of the third

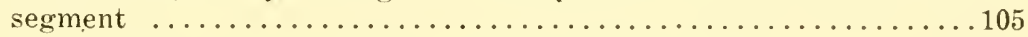

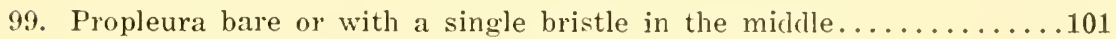

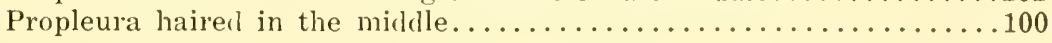

100. Second antennal segment projecting thumb-like into the thirr on the inner side $(9,84) \ldots \ldots \ldots \ldots \ldots \ldots \ldots \ldots \ldots$. Synarthrus Lœw Second antennal segment transverse or only gently convex apically

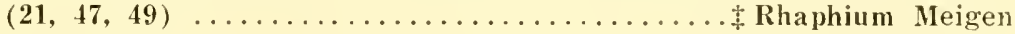

* Van Duzee, 1913, Ann. Ent. Soc. Amer., vi, pr. 22-61.

$\dagger$ I have not seen specimens of Collinellula but the genus is very rlose to Xanthina and no structural differences are mentioned in the description.

$\ddagger$ Curran, 1926-1927, Tr. Roy. Can. Inst., xv, pt. 2, rp. 249-260; xvi, pt. 1, pp. 99-173. 
101. Second antennal segment produced thumb-like into the third on the inner side $(35,54) \ldots \ldots \ldots \ldots \ldots \ldots \ldots$. Parasyntormon Wheeler Second antennal segment transverse or only gently convex apically ...102

102. Middle of propleura wholly bare........................ 103 Middle of propleura with a single bristly hair (64).... Leucostola Lœw

103. Lower section of the face not differentiated, the face short.........104 Lower section of the face strongly differentiated, the face reaching practically to the lower level of the eyes $(45,81)$.

Paraphrosylus Becker

104. Diaphorus Meigen and Chrysotus Meigen come here but there are no good characters for the separation of the females.

105. Second antennal segment produced thumb-like into the third on the inner side $(32,50,69) \ldots \ldots \ldots \ldots \ldots \ldots \ldots$ Neosyntormon, $n$. $g$. Second antennal segment with the apex at most a little convex on the

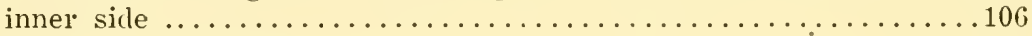

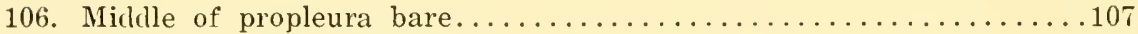

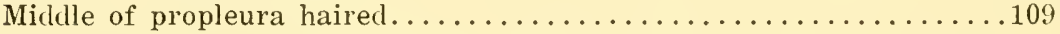

107. Abdomen fiattened dorsoventrally, rarely swollen; face narrowest in

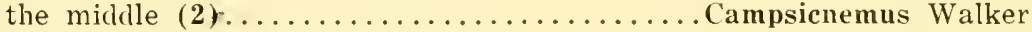

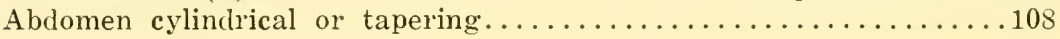

108. Abdomen short and tapering......................... 110

Abdomen long and slender, usually cylindrical or laterally compressed

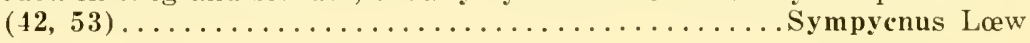

109. Third and fourth veins parallel or nearly so beyond the posterior crossvein $(10) \ldots \ldots \ldots \ldots \ldots \ldots \ldots \ldots \ldots$ Keirosoma Van Duzee Third and fourth veins rather approximate apically (12).

Nematoproctus Lœw

110. Scutellum with a secondary pair of weak marginal scutellar's situated between the base and the strong pair; sixth vein strongly developed; anal lobe distinct $(8,33) \ldots \ldots \ldots \ldots \ldots \ldots$. Peloropeodes Wheeler Scutellum without secondary basals, but with a pair of apical hairs; sixth vein weakly developed; anal lobe very weak... Teuchophorus Lœw

\section{Laxina, new genus}

This genus is erected for those species, formerly placed in Condylostylus. Sciapus and Psilopus, in which the lower section of the face is hairy. The arista is dorsal: mesonotum rather square; seutellum with four bristles and the wings either hyaline or variegated with brown. Cienotype:-Dolichopus patibulatus Say.

\section{Neosyntormon, new genus}

1)iffers from Parasyntormon Wheeler in having the arista dorsal, eren though situated towand the apex of the third antemal segment. The proplema is bare and the hypoplenra lacks hair. Both these char- 
acters are true of Parasyntormon also, but all the species of Synarthrus Loew have both the propleura and hypoplemra haired. Genitalia small. Genotype:-Parasyntormon montiuagum Whecler.

$P$. asellus Wheeler is the only speeies I have seen belonging to Parasyntormon. The genus Eutasus Loew is close to Neosyntormon but both the propleura and pteroplenra bear fine hair, as in Synurthrus. Eutursus does not oceme in Ameriea.

\section{Peloropeodes Wheeler}

In his original description of this genus one might infer that the arista is apical, but I believe this is erroneous and that the arista is inserted towarl the end of the third segment in the male. The type males of sular Wheeler, the senotype, all lack the third antemnal segment so the point camnot be elened up at present. Both females, however, are in excellent condition and since no trpe has been selected for the species, I now select one of the females. On general structure there ean be no doubt that both Pachypyga Parent and Kophosomu Tan Dnzee are symonyms.

\section{Teuchophorus Lœw}

Wheeler has described a speeies from South Dakota which appears to have been correctly placed. The trpe is not in good condition, both wings being absent and part of the abdomen eaten away, but from what can be seen the specimen aprees well with European material taken near Leningrad. This genus is rery close to Peloropeodes differing in having small genitalia, as in sympyenus, less evident anal angle to the wings with less developed sixth rein, and the absence of a pair of small basal bristles on the sentellum in addition to the large pair. As a rule there is a pair of small hairs on the apical portion of the seutellum, absent in the species of Prloropeodes I have seen.

\section{Millardia, new genus}

This genus is proposed for the reception of species formerly placed in IIydrophorus Teigen in which the pteroplema bears conspicuous fine hairs and most. if not all of the speeies have several pairs of postvertical bristles instead of a single pair. Genotype:-IIydrophorus viridiflos Walker. 


\section{Family Lonchopteridæ-The Pointed-wing Flies}

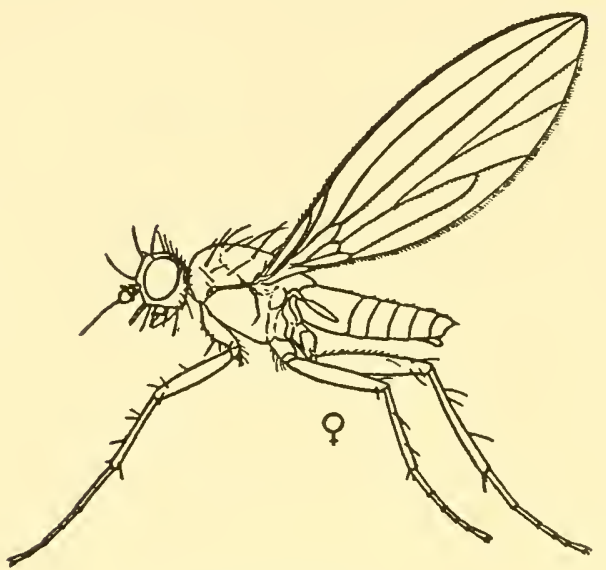

Lonchoptera sp.

Small, slender bromish or yellowish flies, the length 2 to $5 \mathrm{~mm}$.

Head bristly; ocelli present; antenna short, the third segment rounded, with a terminal arista. Legs moderately long, bristly, the pulvilli very small; empodia absent. Wings pointed apically, with only the basal crossreins, the anal cell closed; first rein very short, the fourth furcate.

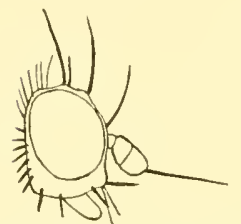

The adults are found in moist places and especially along shady brooks. The larra live nnder leaves and decaying regetation: they are flat, with long bristles on the anterior two and apical segments; ten segments, the head not differentiated; posterior apiracles broadly separated on the apical segment. The larra Lonchoptera, head transforms into a prepupa within the larval skin ant later into a true pupa.

The family contains less than two dozen species, all belonging to the genus Lonchoptera Meigen. A key to the American species is given below. Descriptions of them are contained in American Musenm Novitates No. 696. 


\section{TABLE OF SPECIES}

1. Bristles of the vertex and the orbital cilia wholly yellowish........ A At least several of the upper orbital cilia black.............. 2

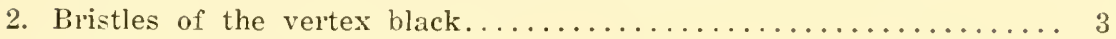
Bristles of the vertex yellowish; about half the orbital cilia black... 4

3. Wings very sharply pointed, very slightly concave posteriorly toward the apex, or at any rate not generally convex.......... uniset a Curran Wings broader and much less sharply pointed, gently convex before

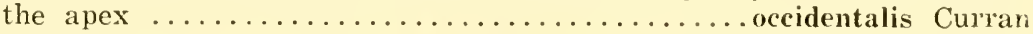

4. Anal vein widely remover from the border of the wing; base of fifth vein with four or five long bristles............... borealis Curran Anal vein fused with the posterior border of the wing; base of fifth vein with numerous setulæ...................dubia Curran
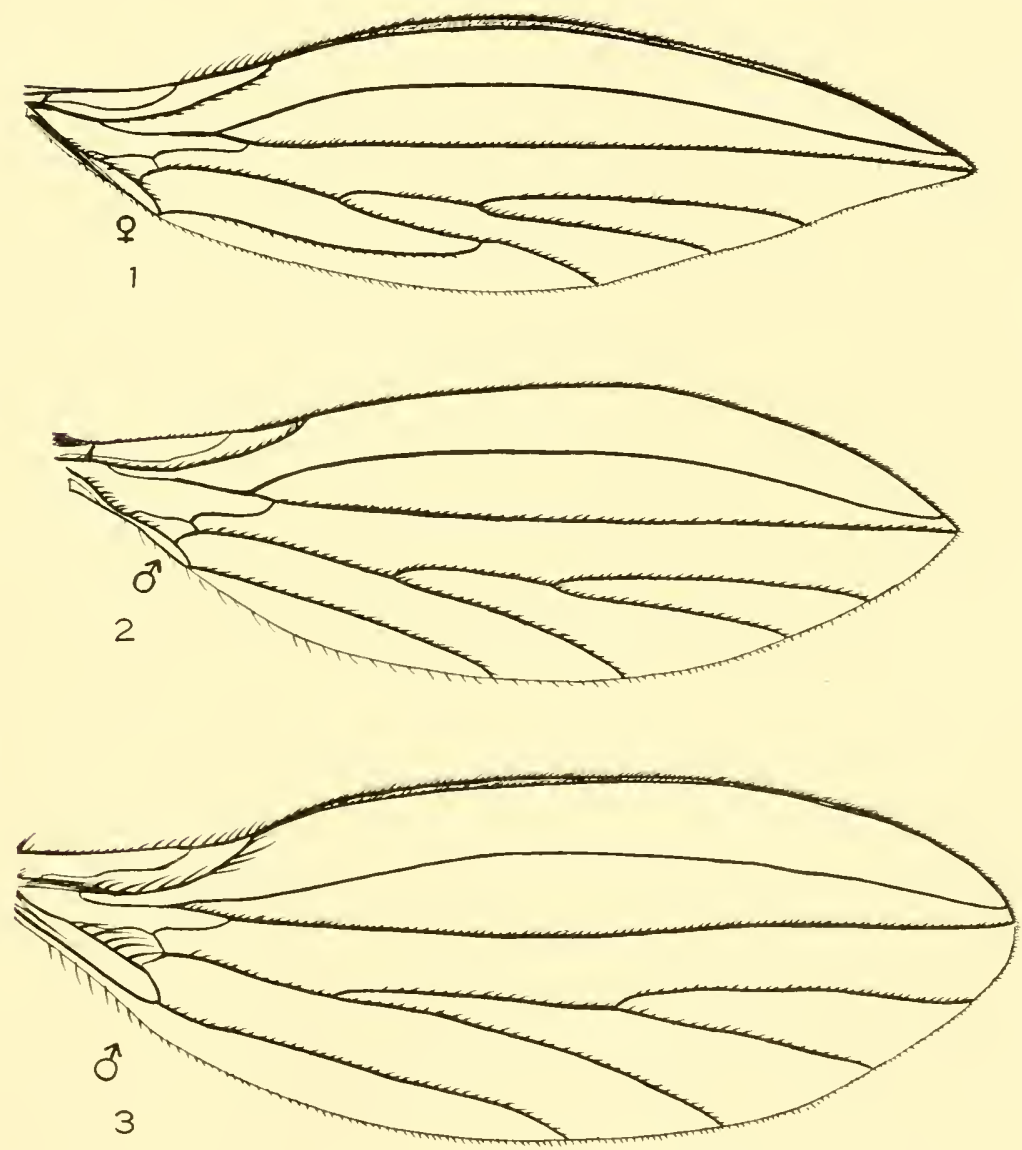

Wings of Lonchoptera.-1, uniseta Curran; 2, occidentalis Curran; 3, borealis Curran. (Courtesy American Museum of Natural History.) 


\section{Family Phoridæ}

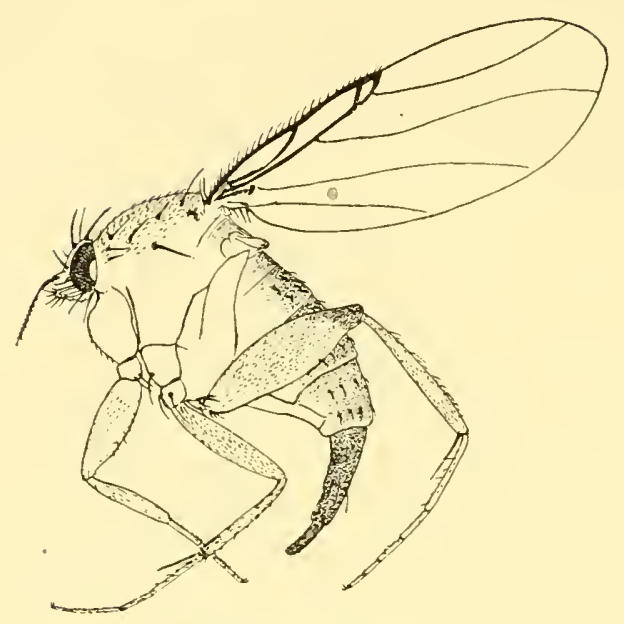

Megaselia species.

Small or minute flies, often wingless, usually with a hunch-baeked appearance.

Head small, rather flattened; front wide, usually bristled; face short and coneave; oral opening large, the proboscis usually fleshy; palpi large, usually bristled; eyes never large, the ocelli sometimes absent in the apterous forms. Antennæ with three segments, the third large, the basal two small; arista dorsal or apieal. Thorax usually arched, the scutellum absent in some wingless forms. Abdomen short, usually tapering posteriorly, sometimes partly membranous, especially in the wingless forms; male genitalia often large, in the female small and projecting. large and adapted for piereing in some genera. Legs short, well developed, the tibe with or withont bristles; posterior femora usually more or less laterally compressed. Wings large, poorly developed or absent, the fully developed wings with two strong longitudinal veins and four or fire fine ones.

The adults are readily recognized by their characteristic antenmæ and wing renation. They are found almost everywhere but are particularly abundant about decaying vegetation, on leares and windows or in the nests of termites and ants, and following armies of ants. The alate adults move about on leaves with a quiek, jerky movement which is quite characteristic of the family. 
The larval habits are diverse. Some are parasitic while others are unquestionably scavengers. The larva of Apocephulus lives in the heads of ants, the head dropping off when the larra is mature, while that of Cataclinusa pachychondyla lives curled about the necks of ant larve and feeds upon the food proffered the latter by the ants. Some species live on decaying animal matter and at least one species has been reared from honey comb. The family is one of great interest and offers an excellent field of study for patient, careful students of animal behavior.

The latest revision of the North American species is by Malloch.: The following key is adapted from Schmitz $\rightarrow$ and may prove msatisfactory in some respects, hut as I lack very many of the genera I am unable to improve upon it. Some of the characters used appear to be of little value from a generic standpoint but the species included in the genera present differences in addition to those given. Despite the title, Schmitz paper is little more than a senerie revision insofar as the taxonomist is concerned but a complete bibliography is included.

\section{KEY TO GENERA}

1. Prothoracic spiracle lateral......................... 2 Prothoracic spiracle dorsal (18).............Enigmatias Meinert

2. Supra-antennal bristles proclinate, if absent the tibiæ lack isolated

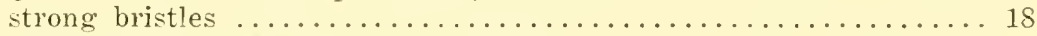

Supra-antennal bristles erect, divergent or reclinate, if absent the tibiæ bear strong bristles; never wingless................. 3

3. Third vein with very evident branch................... 4 Third vein not forked or only obscurely so................ 11

\$1912. Proc. U. S. N. M., xliii, pp. 411-529.

$\dagger$ 1929. Rev. der Phoriden, privately published (Dümmler. Berlin \& Bonn).

t Checked by Dr. C. T. Brues.
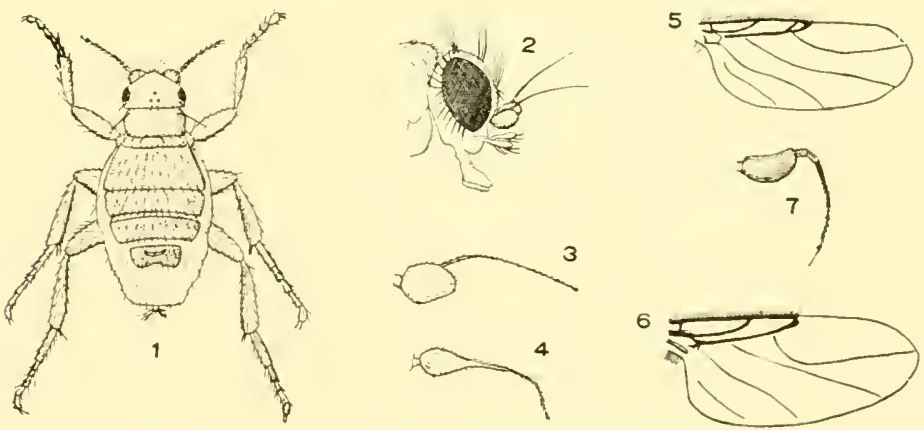

Phorida I.-1, Pulicophora, 우 2 , Megaselia; 3, Phora, antenna; 4, Conicera, antenna: 5. Megaselia; 6, Hypocera; 7 , Apocephalus, antenna. 

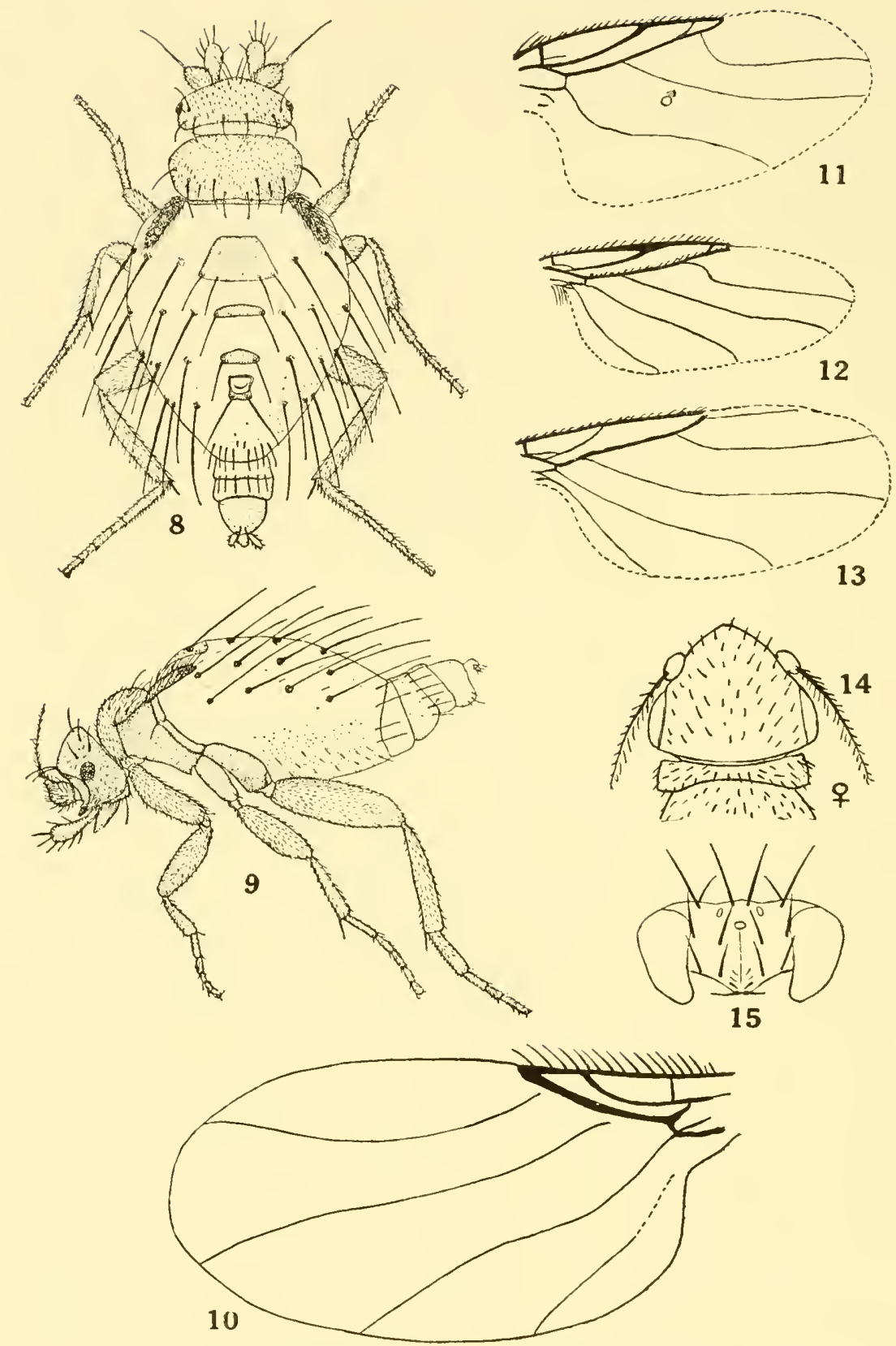

5 Photidx II.-8, 9, Ecitomyia spinosa, Chonocephalus, head of $q: 15$, Beckerina, head showing bristles. 
4. At least the middle tibia with strong bristles............. 5 Tibiæ without conspicuous bristles $(\mathbf{1 5}, 21) \ldots \ldots \ldots$ Beckerina Malloch

5. Mesopleura haired, at least in front near the spiracle.......... 6 Mesopleura bare ............................... s

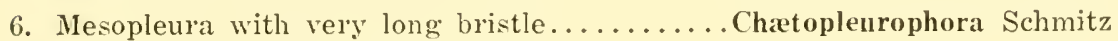
Mesopleura without long bristle................... 7

7. Posterior tibia with from one to three rows of closely placed short

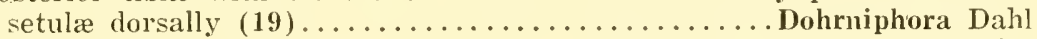
Posterior tibiæ without such ciliate rows..Chæetocnemistoptera Borgmeier

S. Third vein with closely placed setulæ above $(12) \ldots \ldots \ldots$. Aneurina Lioy Third vein bare or very sparsely setulose................ 9

9. Middle tibiæ with a strong anterior bristle beyond the middle. Middle tibiæ with a very weak bristle beyond the middle, or bare....10

10. Posterior tibiæ with one to three rows of conspicuous, short setulæ

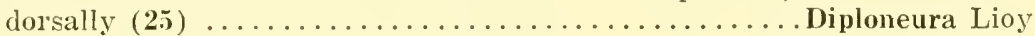
Posterior tibiæ without such setulæ $(11) \ldots \ldots \ldots \ldots$. Triphleba Rondani

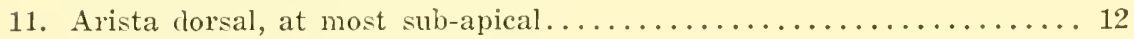

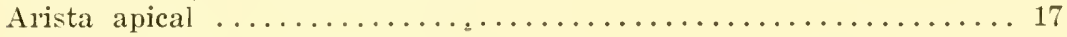

12. Middle tibiæ without dorsal bristles beyond the basal third........ 13 Middle tibiæ with more than one pair of dorsal bristles........... 14

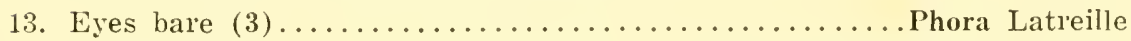

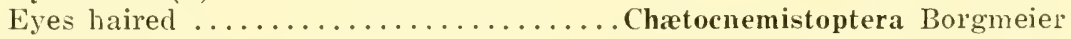

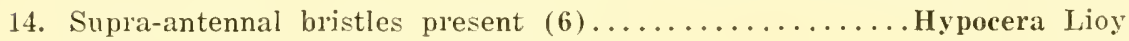
Supra-antennal bristles absent .......................... 15

15. Ocelli widely separated, their triangle separated from the front anteriorly by a three-ridged depression............. Stichillus Enderlein Ocelli normal, or the triangle forming a tubercle............. 16

16. Eyes very large; front very narrow $(26) \ldots \ldots$. Trineurocephala Schmitz

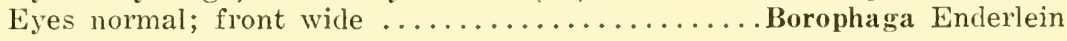

17. Posterior tibiæ with a pair of bristles on the basal half $(4,24)$. Conicera Meigen Posterior tibiæ otherwise $(22) \ldots \ldots \ldots \ldots \ldots$ Coniceromyia Borgmeier

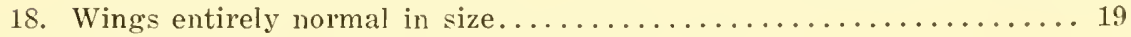

Wings smaller than normal or absent................. 46

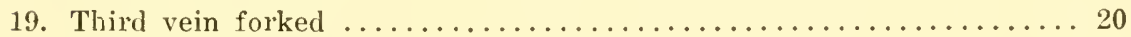

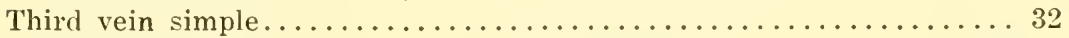

20. Posterior tibiæ with a dorsal row of contiguous hairs and a posterodorsal row of short cilia or at least one or two short bristles......2 23

Posterior tibiæ without the dorsal row of setulæ and the postero-dorsal

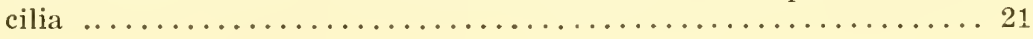



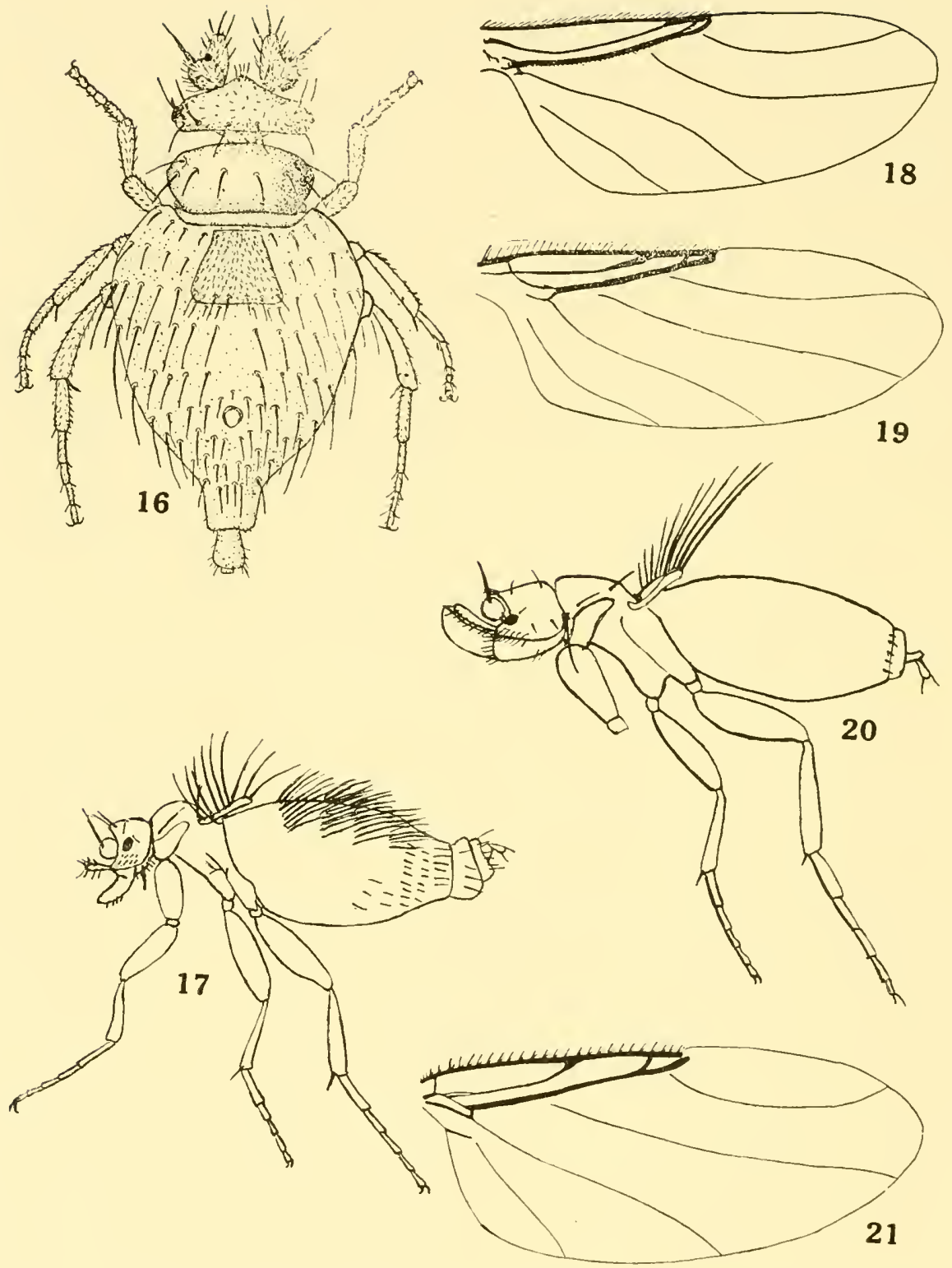

Phoridæ III,-16, Ecituncula setosa; 17, Xanionotum; 18, Enigmatias, $\sigma^{\circ}$; 19, Dohrniphora alleni; 20, Acontistoptera melanderi; 21, Beckerina neotropica. 
21. Anterior orbital bristle present............Woodiphora Schmitz At least the anterior orbital bristle absent................. 22

22. All the bristles on the anterior half of the front missing (23).

Gymnophora Macquart

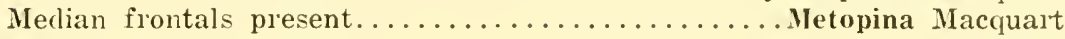

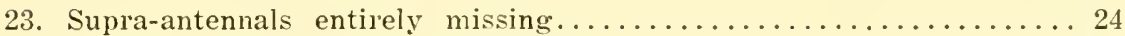

At least one pair of supra-antennals........................ 26

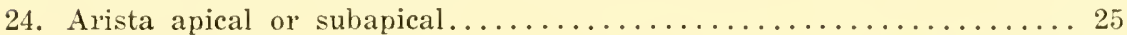

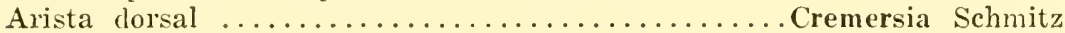

25. Hypopygium large; anal segment laterally compressed, the outline lancet-shaped; fifth sternite with long apical hairs.

Neodohrniphora Malloch

Hypopygium small, the anal segment long and linear; ovipositor of female chitinized and projecting............A pocephalus Coquillett

26. Front with four rows of bristles............................ 27

Bristling of the front incomplete; arista apical.

Acanthophorides Borgmeier

27. Upper pair of post-antennal bristles erect, directed more or less out-

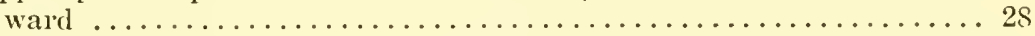

Upper pair of post-antennals proclinate or reclinate, not directed out-

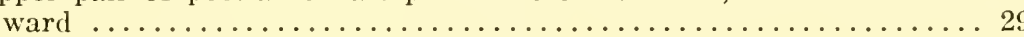

28. Upper post-antennals distinctly proclinate and directed a little out-

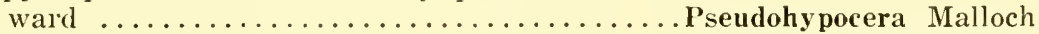
Upper post-antennals directed outward $(7) \ldots \ldots$.... A pocephalus Coquillett

29. Weak vein beyond the third vein weak or absent......... Syneura Brues

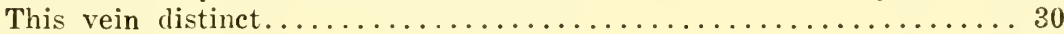

30. Epistoma strongly produced, tube-like......... Trophithauma Schmitz

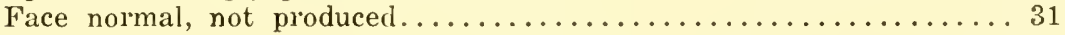

31. Proboscis very long and thin (o unknown)..... Rhyncophoromyia Malloch Proboscis normal (Phalocrotophora Enderlein) $(2,5) \ldots$ Megaselia Rondani

32. Bristling of the front complete (as in Megaselia) or with additional

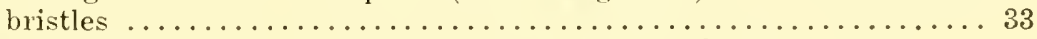
Bristling incomplete, the anterior orbital or other bristles absent.... 37

33. Front with additional bristles on the median area.

Pseudacteon Coquillett Front with normal number of bristles................... 34

34. The weak rein lying parallel with the costa absent or indistinct..... 35 This vein distinct $(2,5) \ldots \ldots \ldots \ldots \ldots \ldots \ldots \ldots$. $\ldots \ldots \ldots$ egelia Rondani

35. Costa short, widened and almost filling the costal cell.

Paranıetopina Borgmeier Costa short but not abnormally widened................. 36

36. Apices of first and third veins approximate............ Syneura Brues Apices of first and third veins not approximated (10).

Plastophora Brues 
37. Bristles of the front normal except for the absence of the anterior

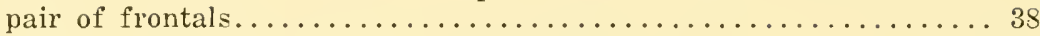

Bristles of the front differing in other ways................ 44

38. A weak vein lies parallel with the costa beyond the third vein...... 39

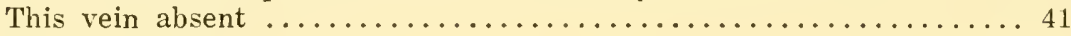

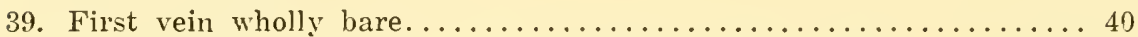
First vein with one or two small bristles basally (20).

\section{Acontistoptera Brues}

40. Third and fourth weak veins very strongly curved toward each other.

Third and fourth veins normal $(1,13) \ldots \ldots \ldots \ldots$

41. First vein present.......................... 42 First vein absent $(8,9) \ldots \ldots \ldots \ldots \ldots \ldots \ldots \ldots \ldots \ldots \ldots \ldots \ldots \ldots$ Ecitomyia Brues

42. Front with two pairs of post-antennal bristles............. 43 Front with one pair of post-antennal bristles (17)..... Xanionotum Brues

43. Post-antennal bristles of equal size.............. Ecitophora Schmitz Post-antennal bristles of two sizes.. Ecitoptera Borgmeier and Schmitz
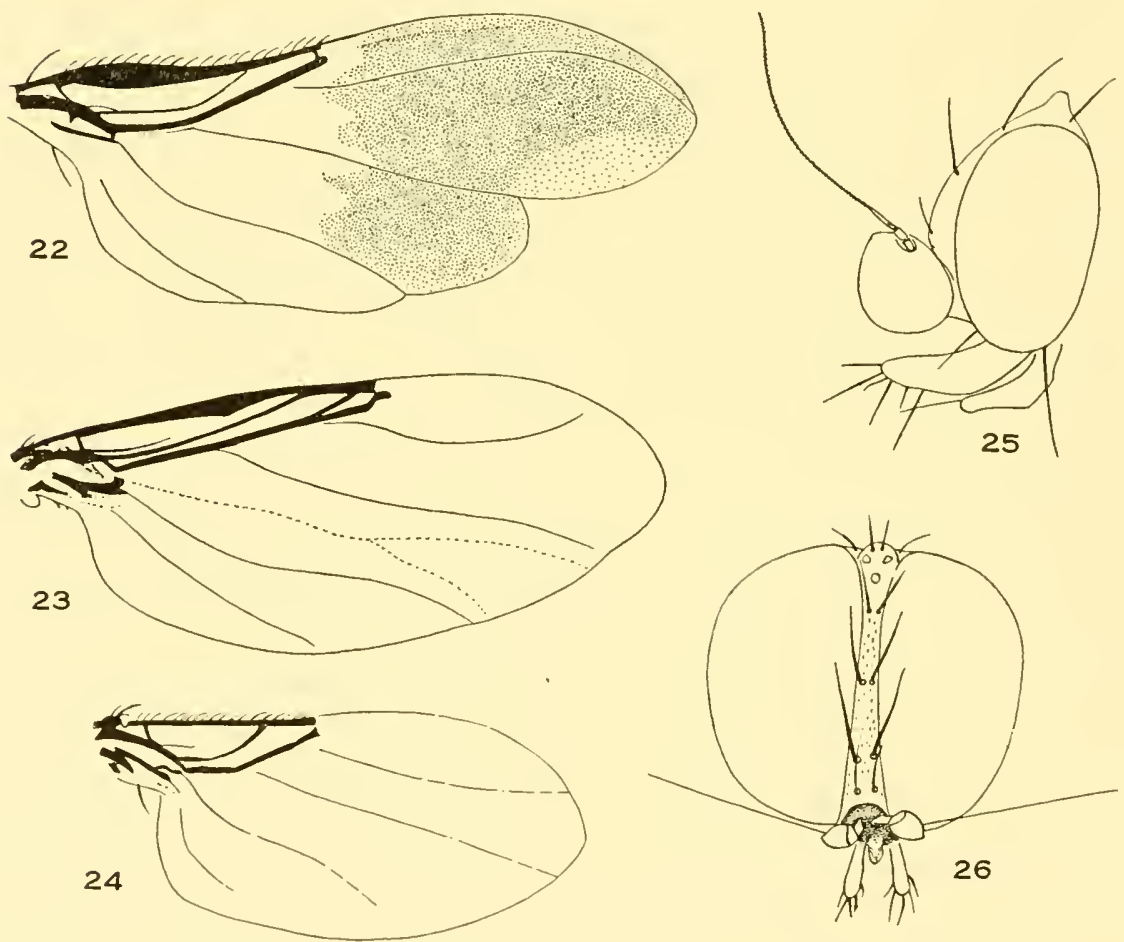

Phoridx IV.-22, Coniceromyia vespertilio; 23. Gymnophora verrucata; 24, Conicera : 25. Diploneura; 26, Trineurocephala. 
44. Post-antennal bristles not distinguishable from other's along the an-

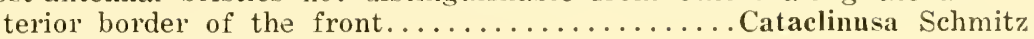

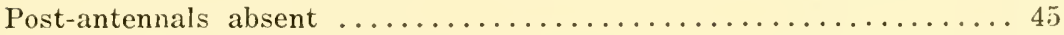

45. Front bristled only at the vertex and along the upper, inner margins of the antennal grooves which are narrower than the space between them; wings without basal transverse vein (14).

Chonocephalus Wandolleck

Front narrow, only the post-antennal and pre-ocellar bristles absent.

Melaloncha Brues

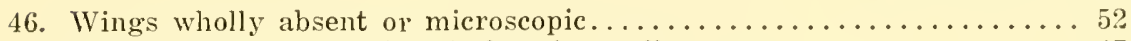

Wings distinctly developed though small...................... 47

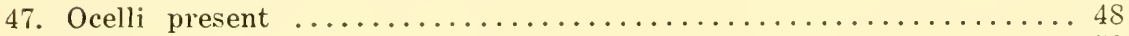

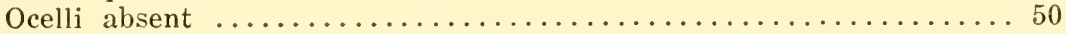

48. Wings with trace of several veins................... 49

Wings with at most the costal vein visible; halteres absent.

Ecitophora Schmitz

49. Proboscis geniculate or bent, distinctly elongate.

Ecitoptera Borgmeier \& Schmit\%

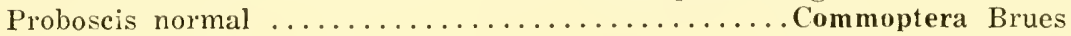

50. Wing rudiments with long bristles..................... 51 Wing rudiments with hairs or cilia $(8,9) \ldots \ldots \ldots \ldots$ Ecitomyia Brues

51. Eyes situated well behind the front margin of the head in profile; halteres present, though small $(17) \ldots \ldots \ldots \ldots \ldots$ Xanionotum Brues Eyes situated at the front margin of the head in profile; halteres

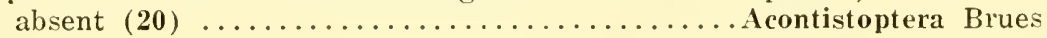

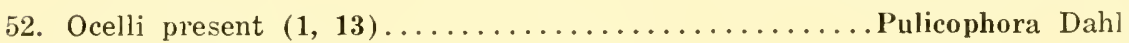

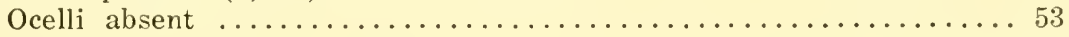

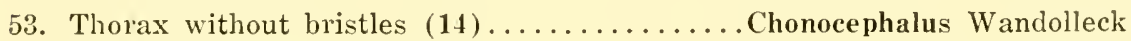
Thorax with bristles $(16) \ldots \ldots \ldots \ldots \ldots \ldots \ldots$ Ecituncula Schmitz 


\section{Family Platypezidæ-The Flat-footed Flies}

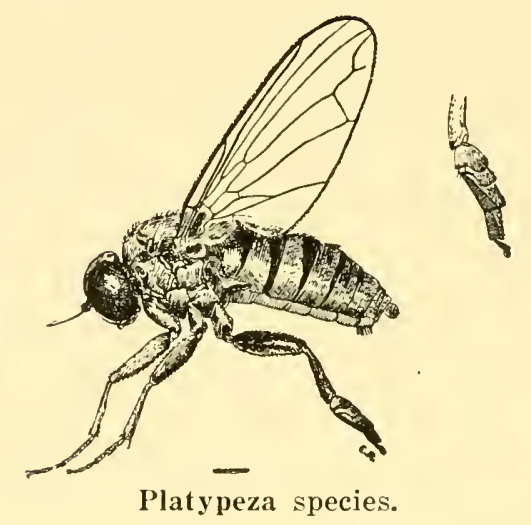

These are small flies with short hair and bristles, characterized by the wing renation and peenliarly shaped posterior tarsi, the basal segment being (usually) much flattened and sometimes strikingly ornamented.

Head hemispherieal, as broad or broader than the thorax and closely applied to it; face depressed, short and broad; eyes bare, holoptic in the males and in some females; ocelli present. Antemre porrect, the basal two segments short, the third more or less clongate-oval, pyriform or conieal, with a terminal arista. Thorax rather stout, the mesonotum and seutellum with bristles. Legs short and strong, the posterior pair more or less thickened and at least the basal segment of their tarsi thickened or variously ornamented. Wings rather large; third rein simple, the fourth sometimes forked; apieal cell open; basal cells rather small; posterior crossvein rarely absent. Abdomen rather short, broad and tapering or laterally compressed; hypopygium generally small.

The larve have been found in fungi and are flat, oval in ontline, with jointed thread-like appendages on the sides of the segments. The puparia are rather similar to the larra in appearance.

For the most part the Platypezids are not common in collections nor are they often met with in the field. Williston states that they have been observed dancing in small swarms but they are usually found upon the leaves of bushes and low trees where they move about in a characteristic, jerky but remarkably agile mammer. Mr. Johnson has obtained most of his speeimens of Agathomyia by sweeping foliage. The species of Callimyia prefer moist woods. Fewer than thirty North Imerican species are known. 

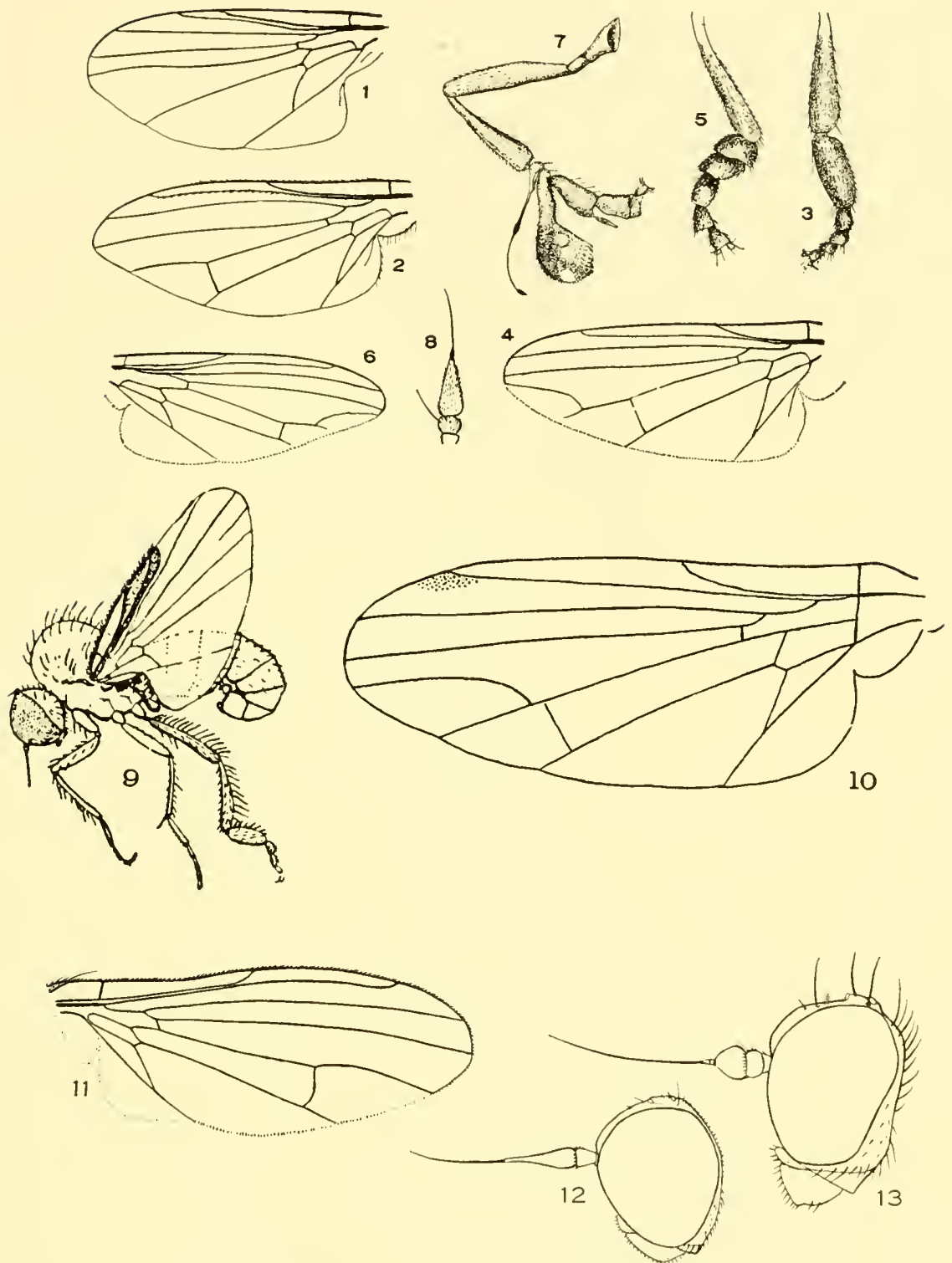

Platypezidx.-1, Platycnema; 2. Callimyia ; 3, Callimyia, hind tarsus of $\delta^{*}$; 4-7. Platypeza, wings and posterior legs; 8. Agathomyia, antenna; 9, Microsania pectipennis; 10 . Platypezoides diversa; 11, 12, Agathomyia; 13 , Callimyia. 


\section{KEY TO GENERA}

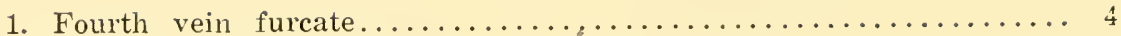

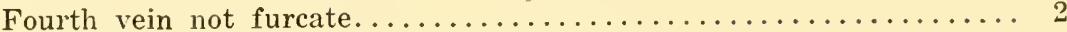

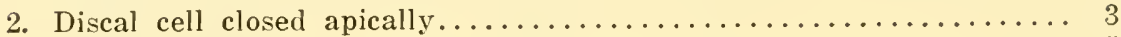

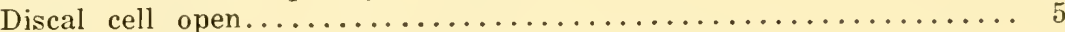

3. First vein bare; third antennal segment elongate conical $(8,11,12)$.

* Agathomyia Verrall

First vein setulose above; third antennal segment rather short (2, $3,13) \ldots \ldots \ldots \ldots \ldots \ldots \ldots \ldots \ldots \ldots \ldots \ldots \ldots \ldots \ldots \ldots \ldots \ldots$ Callimyia Meigen

4. The fourth vein branches close to the posterior crossvein, the posterior branch reaching the wing margin $(10) . . . \ldots$. Platypezoides Johnson The fourth vein branches nearer to the wing margin than to the posterior crossvein, the posterior branch not reaching the wing margin

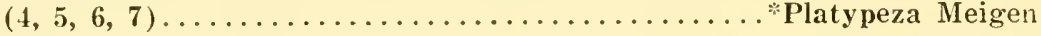

5. Third vein obsolete except apically (9)..........Microsania Zetterstedt Third vein complete; three closed cells (1).......Platycnema Zetterstedt

Johnson, 1923, Oce. Pap. Bost. Soc. Nat. Hist., v, pp. 51-58.

$\div$ Johnson, 1916, Psyche, xxiii, pp. 27-33. 


\section{Family Pipunculidæ-The Big-headed Flies}

This family is characterized by the very large head and thinly pilose or practically bare body.

Head broadel than the thorax, nearly spherieal, eomposed chiefly of the large eyes; eyes of the male contiguous above the antenna or closely approximated, in the female separated by a narrow front; face narrow. Antenne small, three segmented, the third segment oval, reniform or aculeate below; arista dorsal. Oeelli present; proboseis small, usually eoneealed. Abdomen eomposed of six or seven segments, small, eylindrical; hypopygium conspicuous, often large; ovipositor usually elongate and extending forward under the abdomen. Leas simple; tarsi broad, the basal segment dongate; pulvilli present. Wings mueh longer than the abdomen: basal cells elongate; anal cell reaching close to the wing margin, rarely incomplete; apical cell narrowed apieally but always open; three posterior cells: renation incomplete in Chalurus Walker. Squame restigial. The wings are held flat over the abdomen when the insect is at rest.

The larve are parasitic on bugs of the families Cicadellide and Mirida, and perhaps on other Homoptera and IJeteroptera. The larvæ are elliptical, thick. depressed and narrowed at either end, naked and smatl. The oval, shining black puparia are obtuse at either end and somewhat smaller than the larve.

Pipunculidie are found eommonly wherever their hosts are to be found, but more especially near the edges of woods, in clearings and along shaded lanes. I have foumd them in large numbers in a small elearing in which the ground was kept constantly moist from a spring at one end and also along the edges of streams. Almost one hundred species are known from North America, most of which belong to the genus Pipunculus. Cresson* has monographed the family.

* Trans. Amer. Ent. Soc. xxxvi, pp. 267-329. 


\section{KEY TO GENERA}

1. Discal cell closerl ................................ 2 Discal cell open apically the venation incomplete $(3) \ldots$. Chalarus Walker

2. Scutellar bristles present............................. 3 Scutellar bristles absent $(1,2) \ldots \ldots \ldots \ldots \ldots \ldots$ Pipunculus Latreille

3. Ocellar bristles absent; occiput widely visible from the side $(6,7)$.

Nephrocerus Zetterstedt Ocellar bristles present; occiput narrow $(4,5) \ldots \ldots \ldots \ldots$ Verrallia Mik
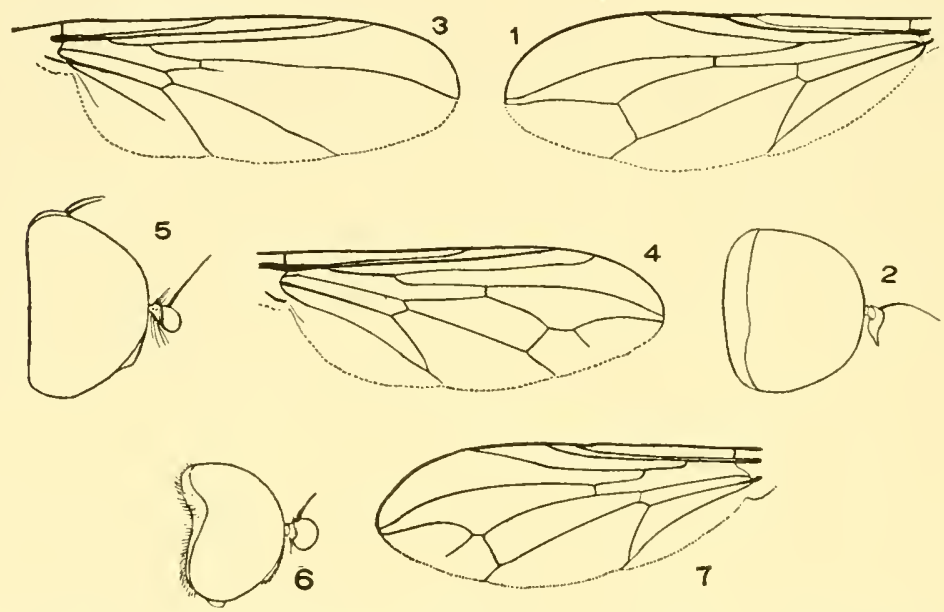

Pipunculidæ.--1, 2, Pipunculus ; 3, Chalarus; 4, 5, Verrallia ; 6, 7. Nephrocerus. 


\section{Family Syrphidæ-The Flower Flies}

Small to large flies, the wing with a "spurious rein" lying between the third and fourth longitudinal veins.

Head variable, but never elongated, except rarely the produced epistoma. Face moderately wide to wide; eyes usually holoptie in the males, always dichoptic in the females. Oral opening large; proboscis usually short. Antemnx short or elongate, composed of three segments, usually with a dorsal arista, rarely with a terminal style. Ocelli present. Thorax rather large and robust, rarely with bristles. Abdomen composed of four to six visible segments; hypopyoinm rarely prominent, though often large. Legs rariable but never elongate. Wings comparatively large; third rein never branched, straight or dipped into the apieal cell, the apical cell elosed; basal cells long; anal cell elosed before the margin of the wing, always long; between the third and fourth veins a strong fold or "spurious vein", rarely absent, which is charaeteristic of the family.

The Srrphidæe comprise one of the largest and most popular groups of Diptera. They may be foumd anywhere and many speeies are very common. Most of them visit flower's but some oceur only in woods, in moist places, in fields, or near ants' nests, depending upon their habits. The adults display great rariation in liabitus but may be recognized at once by their characteristic wing renation. Any locality with varied habitat should yield at least a hundred speeies and the general eollector is certain to have many of them in his collection. Nost of the eommon species are easily reeognized by the use of "Williston's Synopsis' but on the whole the family is a difficult one, many of the genera and species being diffieult to separate by means of keys and deseriptions. Unfortumately there is no recent revision of the North Ameriean forms of whicl less than half are included in Williston's work. The number of short papers dealing with the family is rery large and the literature scattered through numerous periodicals. Nany attempts have been made to divide the Srrphida into subfamilies but with little suecess. Some of the groups mas be well lefined in one region but almost every eharacter thus far used is found to lose its ralue when the study is extended to include the world fauna.

Almost all of the Syrphids are beneficial and they are second in importance only to the bees as pollinators of plants. Many of them live upon aphids, (plant lice) and mealy bugs in the larval stages. A few are known to be definitely injurious. 


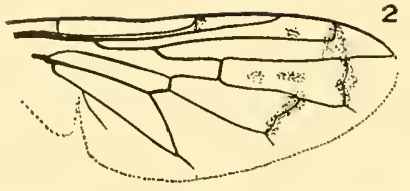

15

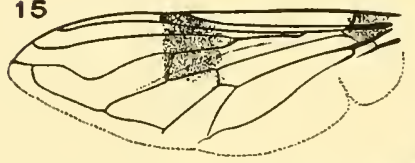

22

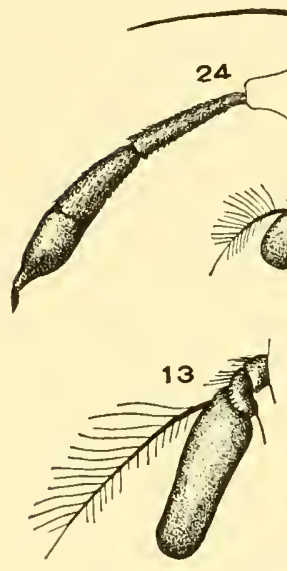

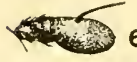

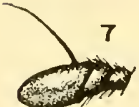

8

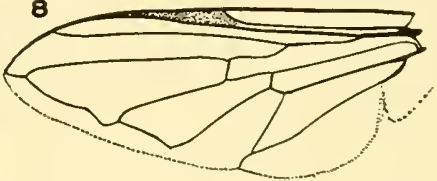

5

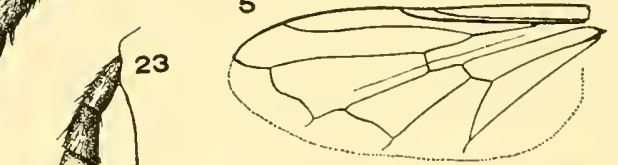

11

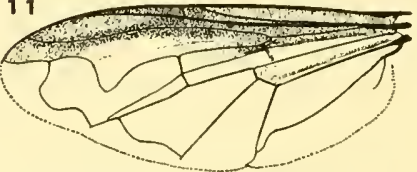

12
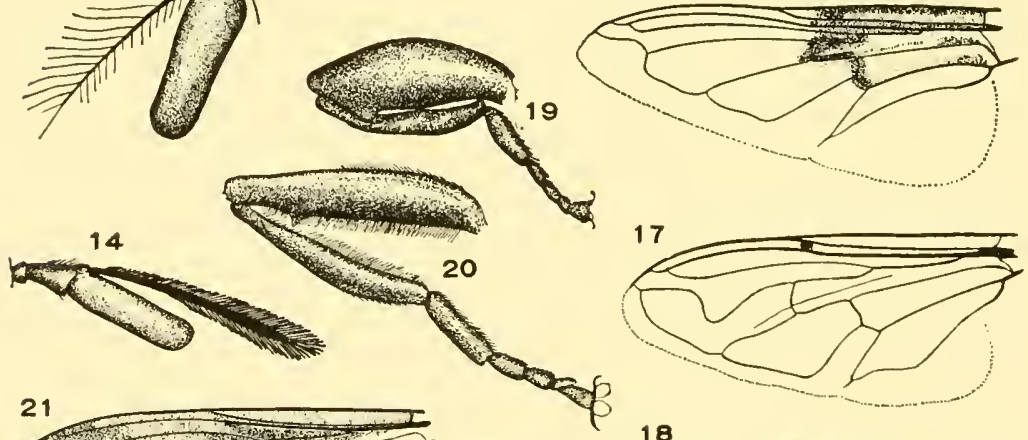

17

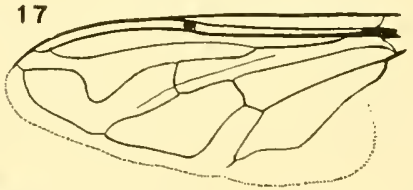

18
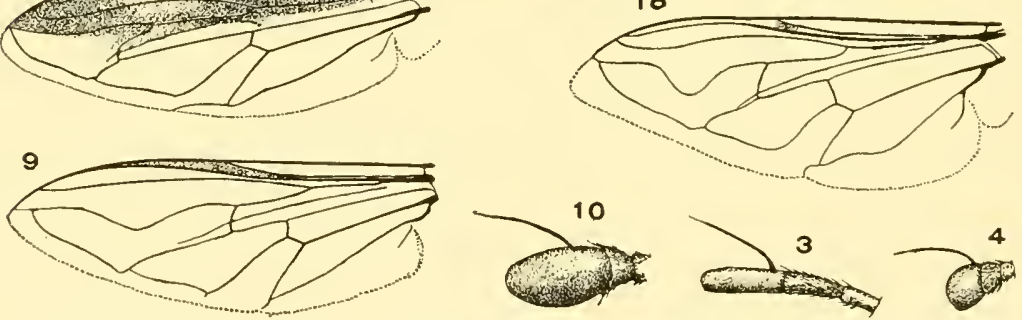

Syrphide I.-1, Microdon; 2, Orthoneura nitida; 3, Orthoneura nitida, antenna; 4, Chrysogaster nigripes, antenna; 5, Paragus; 6, Pipizella, antenna; 7. Paragus, antenna: 8, Cheilosia; 9, Syrphus laxus; 10, Syrphus laxus, antenna; 11, Salpingogaster; 12, Volucella; 13, Volucella, antenna: 14, Copestylum marginatum, antenna; 15, Arctophila flagrans; 16, Sericomyia militaris, antenna; 17, Eristalis; 18. Elophilus fasciatus; 19, Tropidea quadrata, hind leg; 20, Milesia, hind leg; 21. Spilomyia longicornis; 22, Spilomyia longicornis, antenna; 23, Chrysotoxum, antenna; 24, Cerioides, antenna. 
The larve are variable in habits and form. Some live in the nests of ants, termites, bees, ete., but nothing is known regarding their relationship to their hosts. Most of them live in decaring vegetation, while a very few are injurious to growing plants and bulbs. Among the well-known larral forms are the rat-tailed maggots which may be found in liquid media containing decaying regetation and very rarely in earrion. The lanve may be divided into four types: the Hierodon type, with an unusually hard, convex upper surfice and flat, soft ventral surface; the syrphus type, some of which aprroach the first group in appearanee, living upon aphids, decaring vegetation and plants; the short-tailed maggots, living in decaying regetation; and the rat-tailed maggots which live in liquid media.

In the key to the genera several minute charaeters are used. These mar prove diffieult at first but once the student is familiar with them they will be found to be most liseful. In some eases there may be difficulty in deciding the genus to which a speeies belongs but comparison with specimens of known genera will aid in reaching a decision. The final recourse, after careful study, is to send the puzzle to a specialist and reeeive his opinion. Nlost of them will gladly tell you what it is and return the slecimen.

\section{KEY TO GENERA}

1. Antennæ with a terminal style, the third antennal segment tapering.. 2 Antennæ with a dorsal arista, if sub-apical the third segment is not tapering from the base............................ 3

2. Eyes bare $(24,46,51) \ldots \ldots \ldots \ldots \ldots \ldots \ldots \ldots \ldots$ Cerioides Rondani

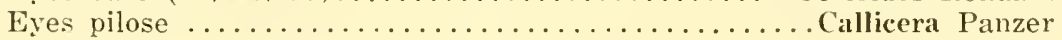

3. Arista bare; antennæ usually longer than the convex, pilose face; third vein usually with a stump of vein extending into the apical cell; anterior crossvein situated before the millle of the discal cell;

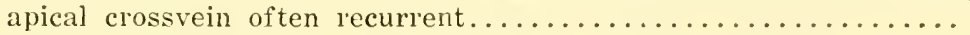

Arista variable; antennæ usually shorter, if elongate the humeri are bare, or the arista plumose; face concave, tuberculate or carinate, never rather evenly convex .......................6 6

4. Third vein with a stump of vein extenting into the apical cell..... 5 Third vein without such stump but there may be one from the fourth vein and from the apical crossvein............ Mixogaster Macquart

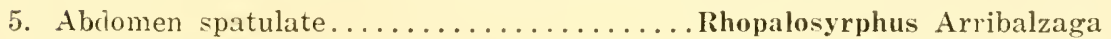
Abdomen not spatulate $(1,53,59) \ldots \ldots \ldots \ldots \ldots \ldots+$ Microdon Meigen

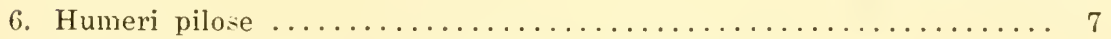
Humeri bare, often mostly concealed by the occiput............ 18

* Curran, 1925, Kans. Univ. Sci. Bull., xv, p. 25.

† Curran, 1925, Kans, Univ, Sci. Bull., xv, p. 49 . 


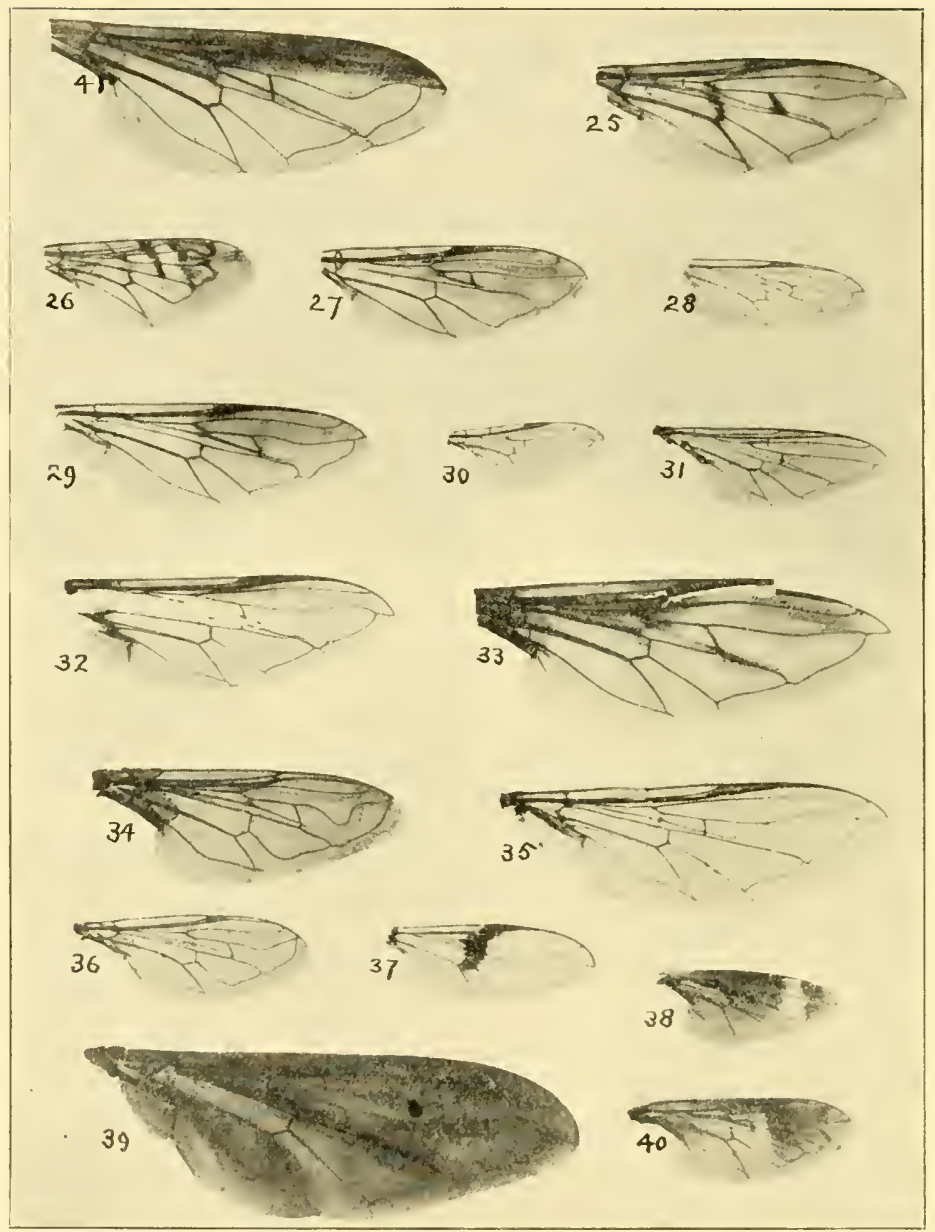

Syrphide II.-25, Ferdinandea; 26, Volucella fasciata; 27 , Eumyiolepta auricaudata; 28 , Syritta pipiens; 29, Xylota pigra; 30 , Pipizella; 31 , Platycheirus erraticus; 32 , Syrphus wiedemanni; 33 , Sericomyia militaris; 34 , Polydontonyia curvipes; 35 , Scæra pyrastri; 36 , Tropidea quadrata; 37, Baccha lemur; 38. Trichopsomyia; 39, Baccha; 40, Apophysophora (S. Amer.) ; 41, Chrysotoxum. 
7. Face perpendicular, with a swelling above; anterior crossvein at the basal fourth of the discal cell; antennæ elongate and porrect; abdomen strongly constricted basally.............. Mixogaster Macquart

Face more or less tuberculate or carinate or the oral margin at least

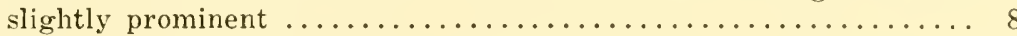

8. All the femora with a patch of black setulæ on their bases anteriorly; third vein strongly curved into the apical cell............... 91 Posterior femora never with such setulæ; third vein at most morler-

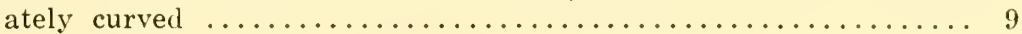

9. Arista plumose, rarely pectinate; legs never with bristles........ 10 Arista bare or pubescent, if short plumose the legs bear bristles.... 16

10. Apical crossvein recurrent.......................... 11 Apical crossvein not recurrent, the apical cell never longest at its

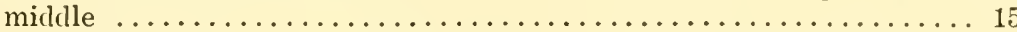

11. Face with three strong tubercles, one on either side of the median tubercle (76)................. Ornidia St. Fargeau and Serville Face with only one tubercle or almost flat................. 12

12. Arista bushy plumose, appearing more or less strap-like $(\mathbf{1 4}, 65,75)$.

$\dagger$ Copestylum Macquart Arista loosely plumose or pectinate................... 13

13. Arista pectinate, the upper rays long, the lower ones extremely short. Arista plumose Volucellosia Curran

14. Eyes of the male widely separated, the front much longer than the

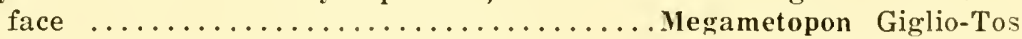

Eyes of male contiguous, the front at most slightly longer than the face $(12,13,26,77) \ldots \ldots \ldots \ldots \ldots \ldots \ldots \ldots \ldots \ldots \ldots \ldots \ldots$ Volucella Geoffroy

15. Facial side margins very distinct and extending almost to the base of

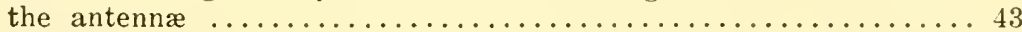

Side margins not extending above the middle of the facial convexity.. 88

16. Apical crossvein strongly recurrent, the first posterior cell longest in the middle and usually with an appendage at this point $(66,78)$.

Citibæna Walker

First posterior cell not longest in the middle, the apical cell not

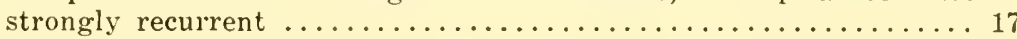

17. Genitalia entirely concealed by the strongly convex abclomen when seen from the side; third antennal segment orbicular, very large; anterior crossvein situated before the middle of the discal cell $(67,79)$.

Nausigaster Williston

Genitalia visible from lateral view; third antennal segment never orbicular and abnormally large...................... 42

18. Antennæ elongate and porrect; thorax and abclomen with bright yellow

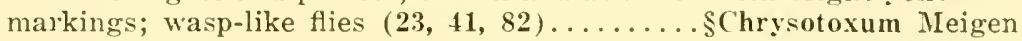

\footnotetext{
* Curran, 1930. Amer. Mus. Novit. No. 413, n. 2.

† Curran. 1930. Amer. Mus. Novit. No. 413. p. 3.

+ Curran, 1930. Amer. Mus. Novit. No, 413, 1, 6.

§ Shannon, 1926, Pr. U. S. N. M., lxix, Art. 11, p. 3.
} 

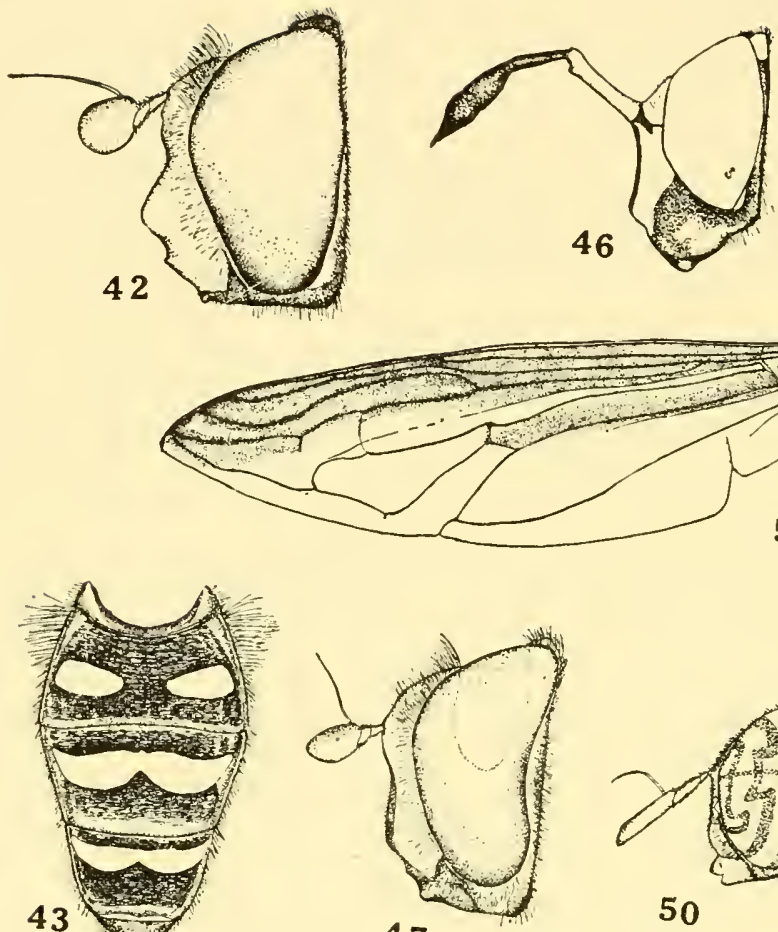

43

47

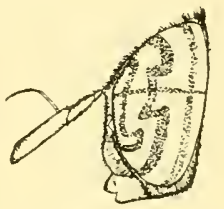

51
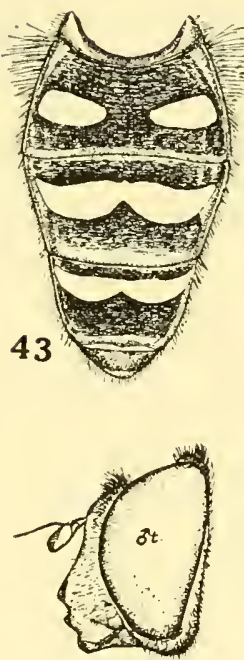

44
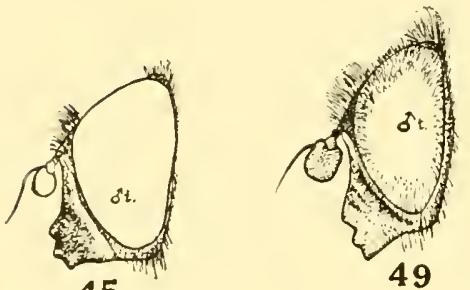

50
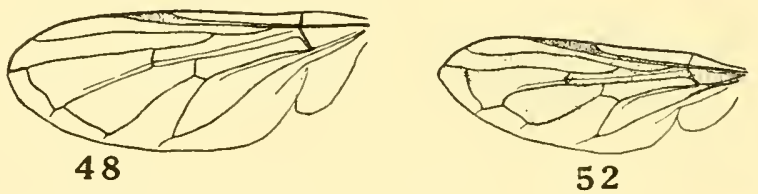

45

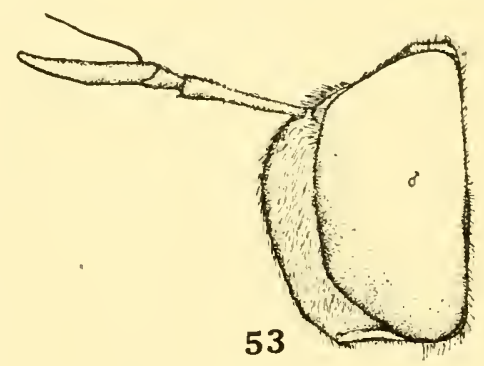

Syrphide III-42, Epistrophe submarginalis; 43, Syrphus aberrantis; 44, Melanostoma 45. Cartosyrphus tarda: 46. Ceriodes ancorata; 47, Syrohus aberrantis: 48, Melanoconfusa; 45. Cartosyrphus tarda ; 46. Ceriodes ancorata; 4 , Sydula; 51 . Cerioides abdominalis ; stoma luteipennis: 49 , Cheilosia ferruginea; 50 , 
Antennæ shorter, if somewhat elongate they are decumbent and the abdomen drooping or wholly black................... 19

19. Face and scutellum more or less yellowish or translucent (if the face is entirely black the abdomen is oval and little more than twice as

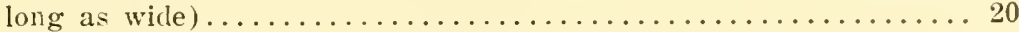

Face wholly black, the scutellun rarely with a yellow tip........ 38

20. Abclomen drooping, never with yellow fasciæ in American species though often largely reddish; third antennal segment more than twice as long as broad; small species $(\mathbf{7}, 80) \ldots . .$. Paragus Latreille

Abdomen not normally drooping; antennæe usually short, the third segment rarely twice as long as wide, the abdomen usually with yellow

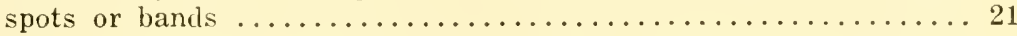

21. Abrlomen margined (the immediate lateral margins raised and not

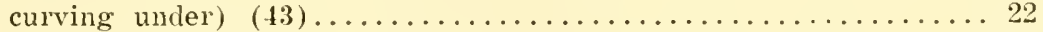
Abdomen not margined, the thin side margins curving under....... 27

22. Species with long pile, the base of the abdomen broadly pale yellowish, the abdomen moderately broad; eyes pilose $(68,81)$.

Leucozona Schirer

Species with shorter pile and usually with yellow markings beyond the

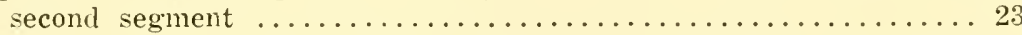

23. Pleura with very bright, sharply limited yellow markings; front long

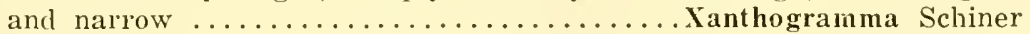

Pleura with diffuse yellowish markings or none; sides of mesonotum

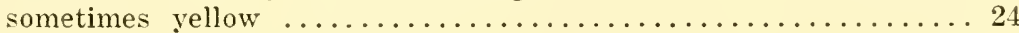

24. Third vein dipped into apical cell; third antennal segment long, robust, pointed; front not inflated; eyes bare; abclomen broad and ilat, with

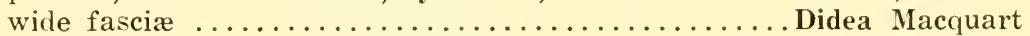

Third vein rarely dipped into apical cell, if so the eyes are pilose or the abdominal spots are arcuate and the front more or less inflated. 25

25. Male genitalia projecting, long and cylindrical; abdomen of female broadly oval, the fifth segment half as long as the fourth $(81,85)$.

Eupeodes Osten Sacken

Male genitalia normal; if the fifth segment of the female is about half as long as the fourth the abdomen has sub-parallel sicles and the front is not whitish yellow immediately above the antennæ... 26

26. Wings practically without villi; front very much swollen; apical cell much broadened on the apical half $(35,86,87) \ldots \ldots$. Scava Fabricius Wings largely villous; front seldom much swollen; apical cell widened in only a few species $(9,10,32,43,47) \ldots \ldots \ldots *$ Syrphus Fabricius

27. Pleura with sharply limited yellow markings; no yellow prescutellar spots; mesonotum without cinereous vitta; ablomen elliptical.

Xanthogramma Scliner

Pleura with or without sharply limited yellow markings, if present the abdomen is long and narrow or the mesonotum bear's a cinerous

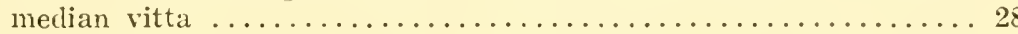

28. Ablomen dark except for a pair of large, basal yellowish spots; eyes

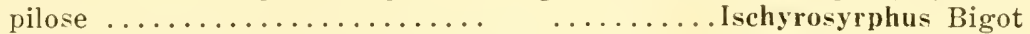

Abdomen differently marked; eves bare.................. 29

* Curran, 1930, Bull. Amer. Mus. Nat. Hist., 1xi, p. 56; Fluke, 1933. Trans. Wisc. Acad. Sci., Arts \& Letters, 28, p1. 63-126. 


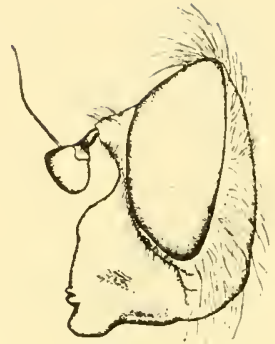

54

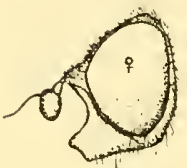

58
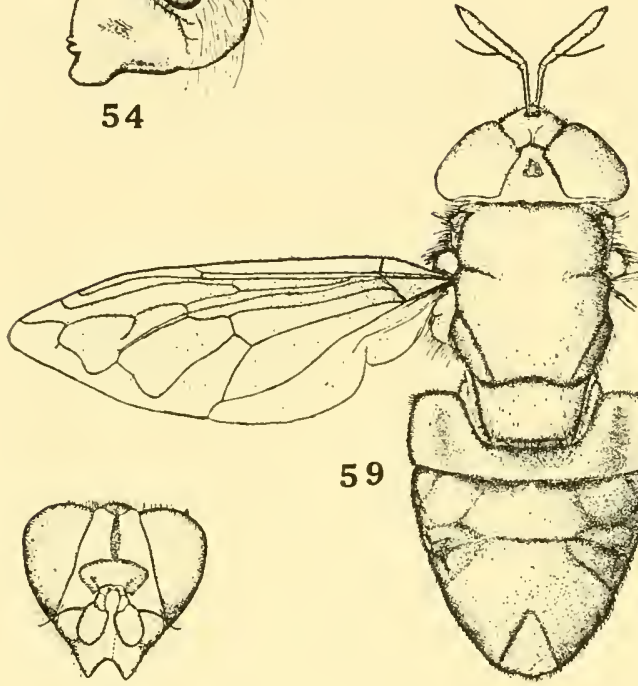

55

59

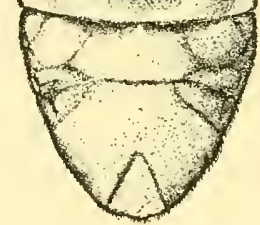

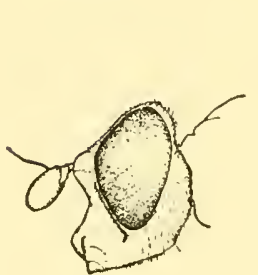

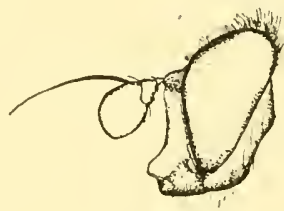

60
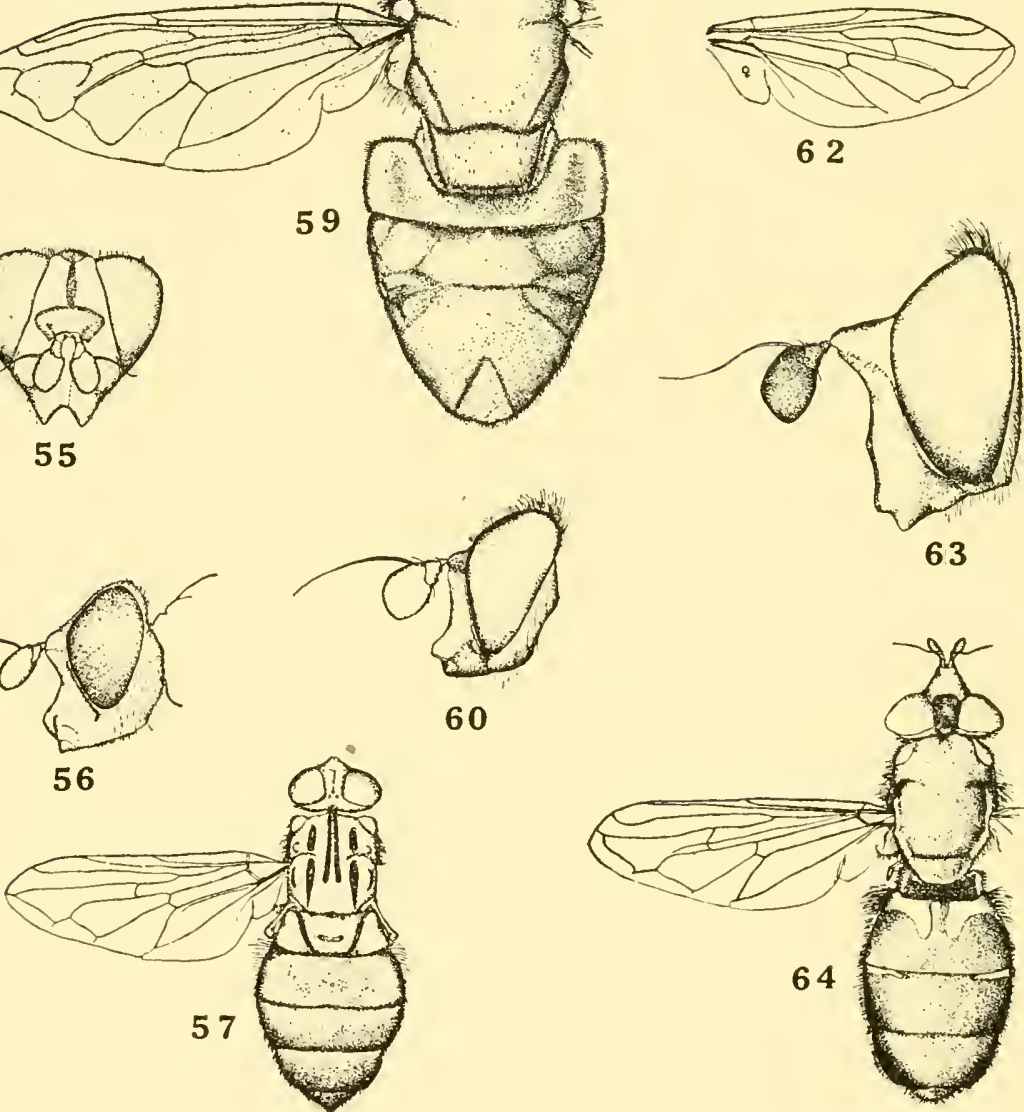

62

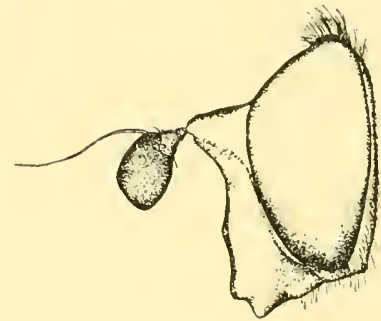

63

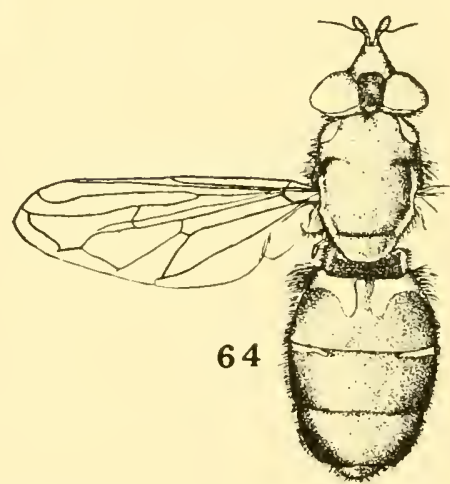

Syrphidæ IV. - 54, Criorrhina caudata; 55, Brachyopa basilaris, head from in front; 56 , Brachyopa basilaris; 57, Brachyopa nigricauda; 58, Chalcosyrphus depressus; 59, Microdon fulgens; 60, Cynorhina nigripes; 61 , Chalcosyrphus depressus; 62, Chalcomyia ærea; 63, Cynorhina metcalfi; 64 , Cynorhina pictipes. 
29. Pleura with sharply limited yellow markings or largely yellow, or the abdomen very long and often spatulate................... 31

Pleura blackish with at most diffuse yellow markings; rarely a pair of small yellow prescutellar spots; abdomen elliptical or with parallel sides

30. Abdomen very long, the face and front narrow, the former narrowed below $(37,39,71) \ldots \ldots \ldots \ldots \ldots \ldots \ldots \ldots \ldots \ldots \ldots \ldots \ldots$ Baccha Fabricius Abdomen not remarkably long, the face not narrowed below (42).

$\dagger$ Epistrophe Walker

31. Abrlomen very long, club-shaped, spatulate or with parallel sides; face strongly narrowerl below; if the abclomen is rather short it is almost

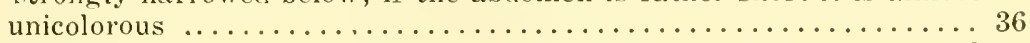

Abdomen of moderate length; never spatulate, if rather short and with parallel sides it bears bright yellow markings........... 32

32. Large wasp-like species; a pair of small yellow prescutellar spots

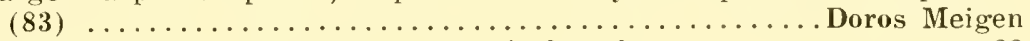

Smaller species, never over $10 \mathrm{~mm}$. in length.............. 33

33. Mesonotum with a median cinereous or metallic vitta; abdomen usually short oval, always very much flattened.............. 34

Mesonotum without such vitta; abdomen with parallel sides or pointed

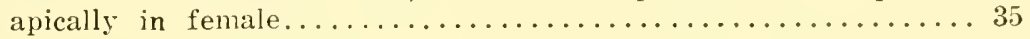

34. Posterior femora strongly arcuate in male, the female abdomen tapering apically $(89,90) \ldots \ldots \ldots \ldots \ldots \ldots$ Toxomerus Macquart Posterior femora simple; female abdomen obtuse apically.

tllesogramma Lœw

35. Male hypopygium globosely enlarged; fifth abrlominal segment of the female with fasciæ which may be broken into spots $(72,88)$.

\$Sphrerophoria St. Fargeau and Serville

Male genitalia small; fifth segment of female with four spots, the median pair longitudinally placed, the outer pair oblique.

FAllograpta Osten Sacken

36. Third vein rather deeply looped into the apical cell (Tropical) (11).

|Salpingogaster Schiner Third vein not deeply looped into the apical cell............... 37

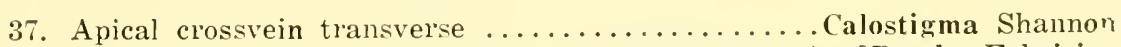
Apical crossvein oblique, usually curved $(37,39,71) .{ }^{\circ}$ Baccha Fabricius

38. Abclomen cylindrical basally $(37,39,71) \ldots \ldots \ldots{ }^{\circ}$ Baccha Fabricius Abdomen witl parallel sides or elliptical................ 39

39. Wings shorter than the abdomen $(69,70,73,74) \ldots$. Pyrophæna Schiner

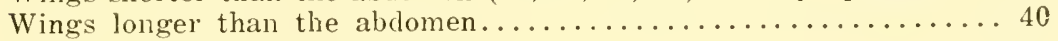

Curran, 1930. Amer. Mus. Novit. No. 403, 1) 1.

$\dagger$ Curran, 1925, (Stenosyrphus). Kans. Univ. Sci. Bull, xv, p. 95.

- ef. Calostigma Shannon; Key, Curran, 1930. Amer. Mus. Novit. No. 405, p. 1.

\$Curran, 1930, Bull. Amer. Mus. Nat. Hist.. 1xi, 1. 61.

Curran, 1932, Amer. Mus. Novit. No. 519. p. 2.

Curran, 1932, Amer. Mus. Novit. No. 519, p. 5.

- Curran, 1930, Amer. Mus. Novit. No. 403, p. 1. 

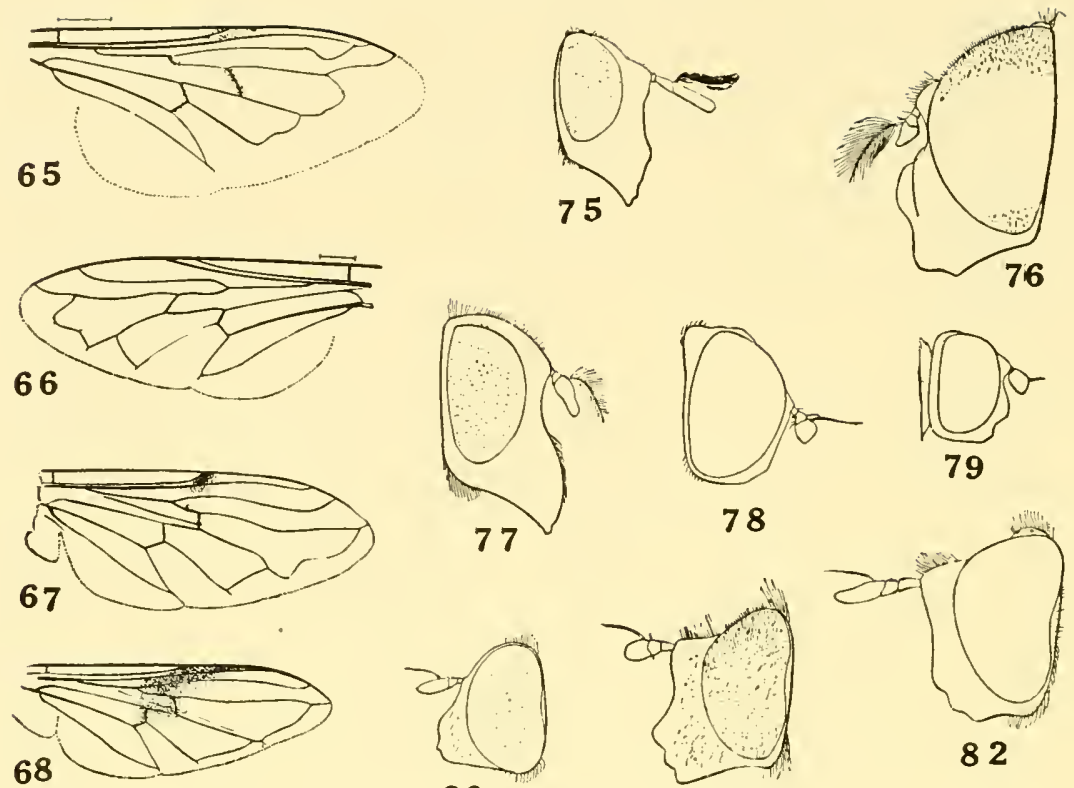

68

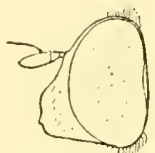

80
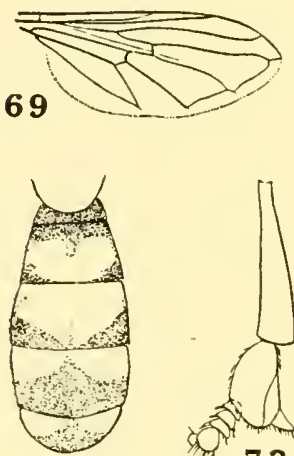

70

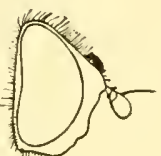

83
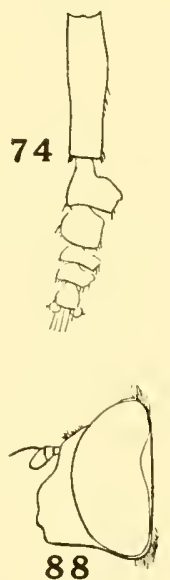

81

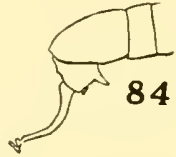

84
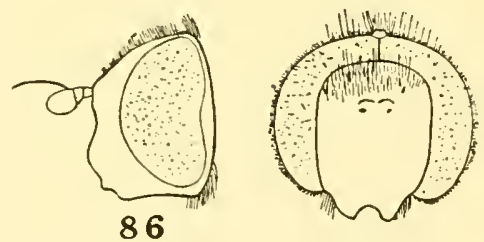

87

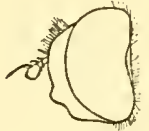

71

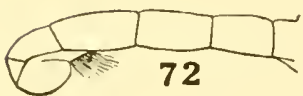

Syrphidre V.-65, Copestylum marginatum; 66, Citibana; 67, Nausigastcr punctulata; 68, Leucozona americanum; 69, Pyrophæna granditarsis; 70, Pyrophana granditarsis, abdomen; 71. Baccha fuscipennis; 72, Sphrerophoria cylindrica, abdomen; 73, 74, Pyrophana granditarsis, front and middle tibire and tarsi: 75, Copestylum marginatum: 76 , Ornidia obesa; 77 , Volucellá bombylans; 78, Citibana; 79 , Nausigaster; 80 , Paragus tibialis; 81, Leucozona americanum; 82, Chrysotoxum ; 83 , Doros apualis ; 84,85 , Eupeodes volncris, $\sigma^{7}$ abdomen and genitalia; 86,87 . Scava pyrastri; 88 , Sphærophoria cylindrica; 89 , 90, Toxomerus gemimatus, hind leg and head. 
40. Abdomen broad and flat; face narrowed below; tip of scutellum usu-

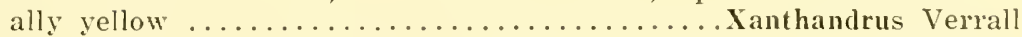
Abdomen with parallel sirles, less flattened; face at most parallel sided, usually widened below; scutellum wholly black......... 41

41. Male with the anterior tibire or tarsi, or both, dilated $(31,100,101)$.

* Platycheirus St. Fargeau and Serville Legs simple $(44,48) \ldots \ldots \ldots \ldots \ldots \ldots \ldots \ldots+$ Melanostoma Schiner

42. Anterior crossvein situated well before the middle of the discal cell, or the mesonotum with bristles $(91) \ldots \ldots \ldots \ldots \ldots \ldots \ldots \ldots$

Anterior crossvein situated at or beyond the middle of the discal cell,

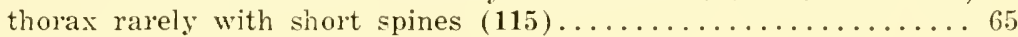

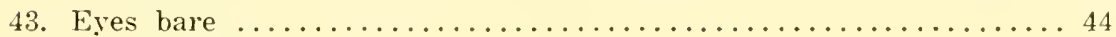

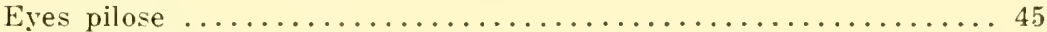

44. Facial grooves extending almost to the antemn; fourth vein joining the third well before the wing-tip; thorax often with bristles; anterior crossvein near the basal third of the discal cell; arista often plumose $(45,91,104) \ldots \ldots \ldots \ldots \ldots \ldots \ldots \ldots$ Cartosyrphus Bigot

Facial grooves less distinct or the anterior crossvein near the middle

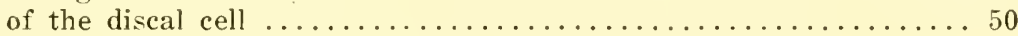

45. Facial grooves distinct and extending almost to the antennæ $(8,49)$.

$\S$ Cheilosia Meigen

Facial grooves usuaily forming pits below and never extending dis-

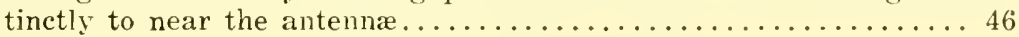

46. Face evenly receding, the anterior oral margin projecting. Psilota Meigen Face tuberculate, or the oral margin not conspicuously projecting... 47

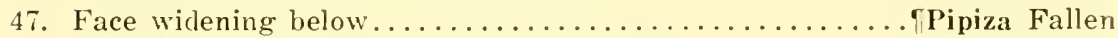

Face not wider below than at the antennæ................ 48

48. Middle tibiæ slender, not convex anteriorly from dorsal view........ 49

Middle tibiæ in male conspicuously broadened, in the female slightly broadened and gently convex anteriorly from dorsal view; middle coxæ of male with small slender process near their inner end.

Cnemodon Egger

49. Fifth sternite only half as long as the fifth tergite in the male; antennæ of female elongate oval............ ${ }^{\circ}$ Heryngia Rondani Fifth sternite three-fourths as long as the tergite; antennie of female more than twice as long as wille; eyes usually with an indistinct, transverse, less thickly pilose stripe $(6,30) \ldots \ldots$ Pipizella Rondani

50. Mesonotum with strong bristles, the legs never bristled; abdominal pile erect; face tuberculate $(25,99) \ldots \ldots \ldots \ldots$ Ferdinandea Scopoli Mesonotum without bristles or the legs also with bristles.......... 51

* Curran, 1927, Amer. Mus. Novit. No. 247, p. 1.

† Curran, 1930. Bull. Amer. Mus. Nat. Hist., Ixi, p. 64.

Shannon, 1922, Ins. Ins. Mens., x, 1). 131.

$\$$ Shannon, 1922, Ins. Ins. Mens.. x, 1. 127.

- Curran, 1921, Pr. Calif. Acad. Sci., xi, p. 374.

Curran, 1921. Pr. Calif. Acad. Sci., xi, p. 358.

- Curran, 1921. Pr. Calif. Acad. Sci., xi, -. 354.

o Curran, 1924, Tr. Amer. Ent. Soc., xlix, p. 340. 

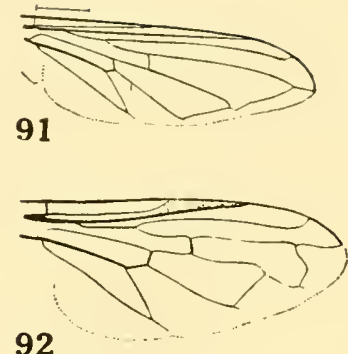

92
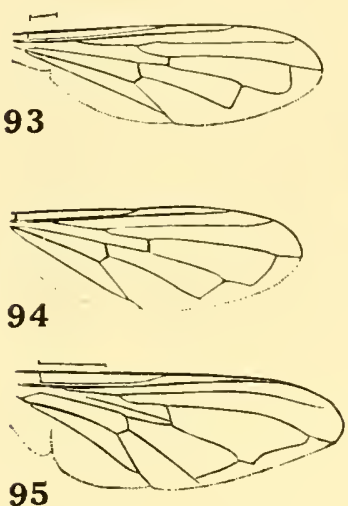

95

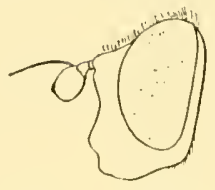

99

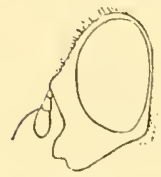

102

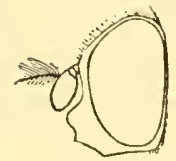

104

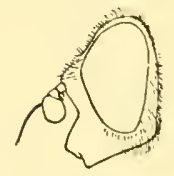

107

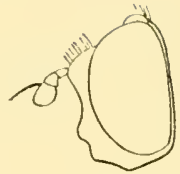

100
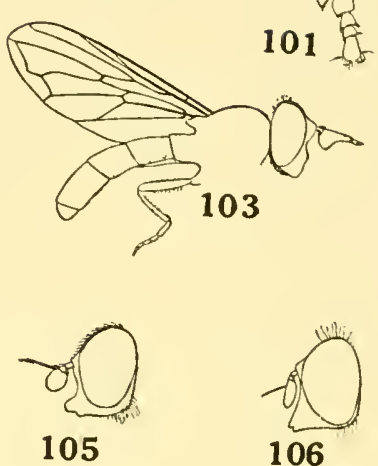

105

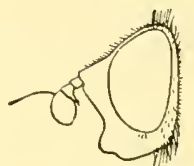

108

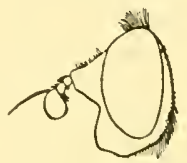

109
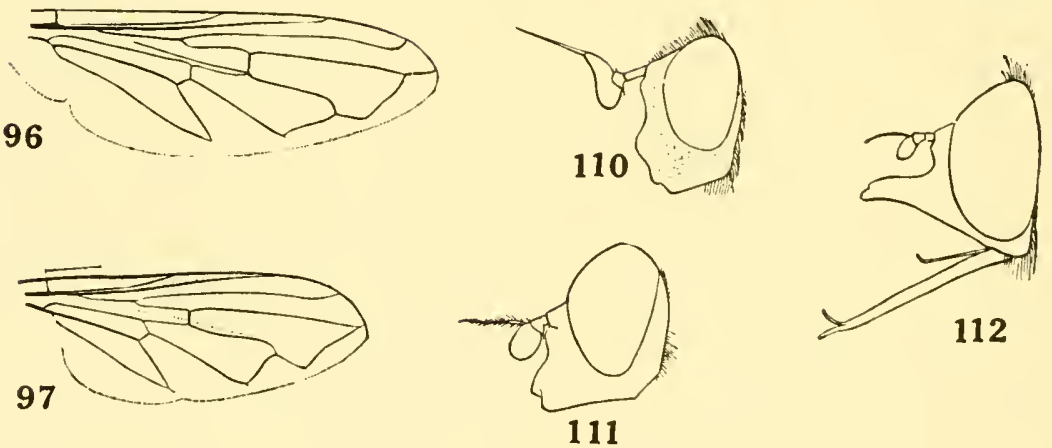

97

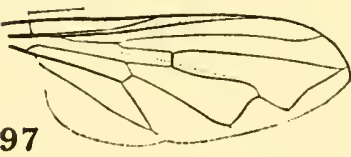

111
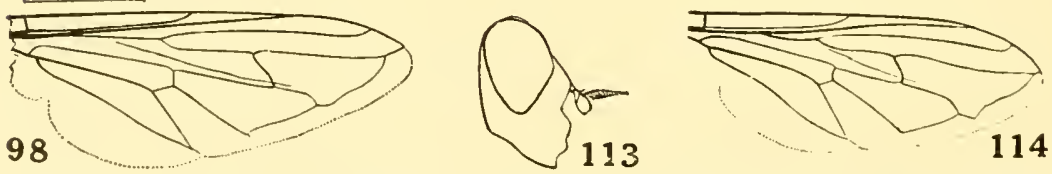

Syrphidæ V.-91, Cartosyrphus; 92, Chrysogaster nigrovittata; 93, Neoascia globosa; 94. Sphegina infuscata; 95, Rhingia nasica; 96 , Hammerschmidtia ferruginea; 97 , Brachyopa notata; 98. Merapioidus villosus; 99, Ferdinandea crosus; 100, Platycheirus quadratus; 101, Platycheirus peltatus, front tibia and tarsus; 102. Chrysogaster; 103, Pelecocera pergandei; 104 . Cartosyrphus; 105, Sphegina infuscata; 106, Neoascia globosa; 107. Myiolepta nigra; 108, 109, Chalcomyia rea, $q \sigma ; 110$. Merapioidus villosus; 111, Brachyopa notata: 112, Rhingia nasica; 113. Hammerschmidtia ; 114, Criorrhina. 
51. Third antennal segment elongate; apical crossvein more or less recurrent $(2,3,50) \ldots \ldots \ldots \ldots \ldots \ldots \ldots \ldots \ldots$ Orthoneura Macquart Third antennal segment never twice as long as wide........... 52

52. Disc of abdomen opaque black, the sides shining (4, 52, 92, 102).

Chrysogaster Meigen Disc of abdomen either wholly shining or with shining spots or bands. 53

53. Abdomen constricted basally or the third antenual segment very large 54 Abdomen broad; third antennal segment of normal size........... 57

54. Antennæ with a terminal arista on the produced upper angle (103).

Pelecocera Meigen Antennæ with dorsal arista, the third antemnal segment not produced

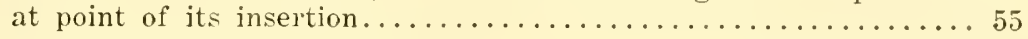

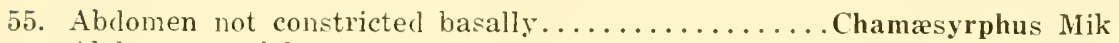

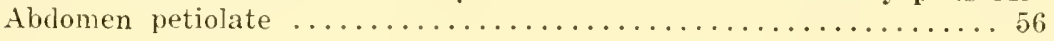

56. Third antennal segment longer than wide; arista shorter than antennæ $(93,106) \ldots \ldots \ldots \ldots \ldots \ldots \ldots \ldots \ldots \ldots \ldots \ldots \ldots \ldots \ldots \ldots$ Neoascia Williston Third segment at most slightly longer than wide, the arista longer than antenna $(94,105) \ldots \ldots \ldots \ldots \ldots \ldots \ldots \ldots$ Sphegina Meigen

57. Face wholly black in ground color....................... 58

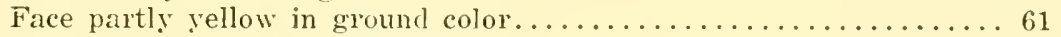

58. Hair of the thorax and abdomen scale-like and appressed.

Lepidostola Williston

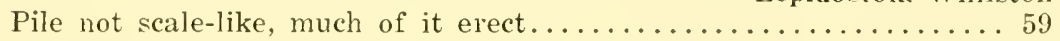

59. Scutellum large, subquadrate; male dichoptic.............. 60 Scutellum rounded apically; male holoptic (107)..... Myiolepta Newman

60. Mesonotum with a large, flattened rectangle posteriorly $(58,61)$.

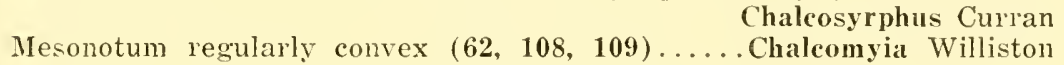

61. Pile mostly scale-like and closely appressed $(27,124,125)$.

+Eumyiolepta Shannon

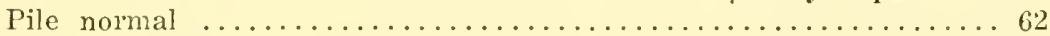

62. Legs bearing distinct bristles $(96,113) \ldots$ Hammerschmidtia Schummel

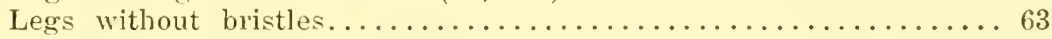

63. Epistoma produced into a long, porrect snout $(95,112)$. Rhingia Scopoli Epistoma not produced snout-like..................... 64

64. The costal vein ends at the tip of the wing $(55,56,57,97,111)$.

§Brachyopa Meigen The costal vein ends before the tip of the wing $(\mathbf{6 0}, 63,64)$.

' Cyuorhina Williston

* Curran. 1925, Pr. Ent. Soc. Wash., xxvii, 1, 51.

$\div$ Shannon, 1923, Bull. Brooklyn Ent. Soc., xvii, p. 19.

$\div$ Malloch, 1922, Ent. News, xxiii, 1. $26 \%$.

\$Curran, 1922, Ann. Ent. Soc. Amer.. xv, 1) 243.

f Curran, 1924, Can. Ent., Ivi, n. 195. 
115
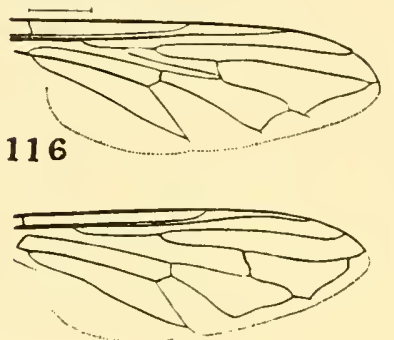

117

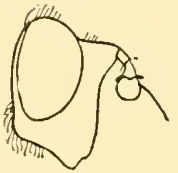

123

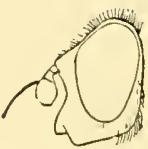

124

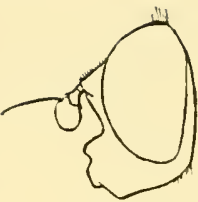

125

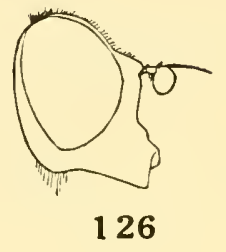

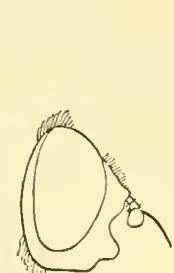

127

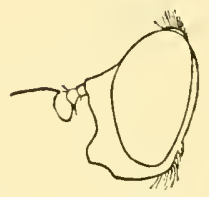

128
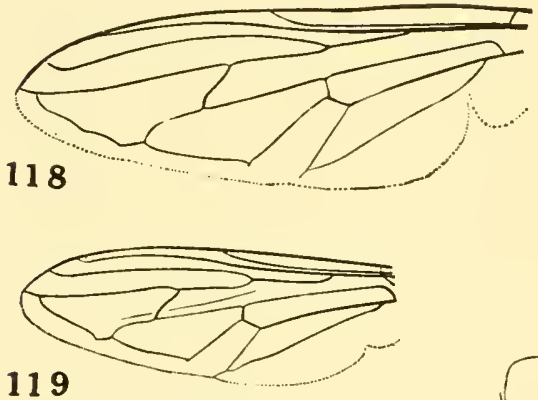

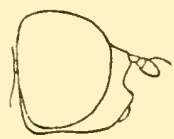

131
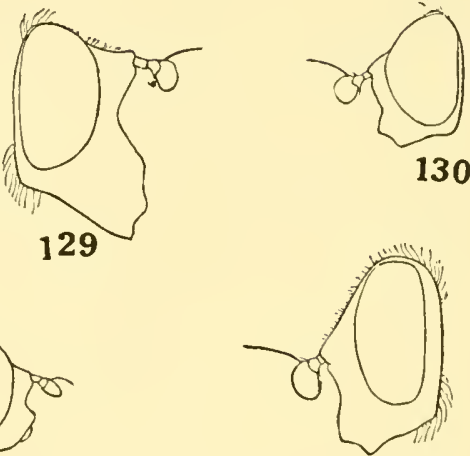

132

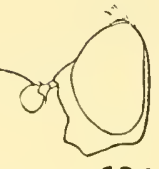

130

\section{0}

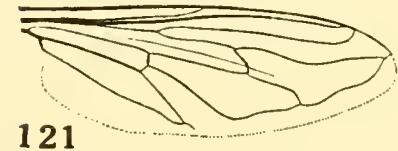

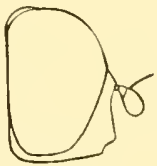

133
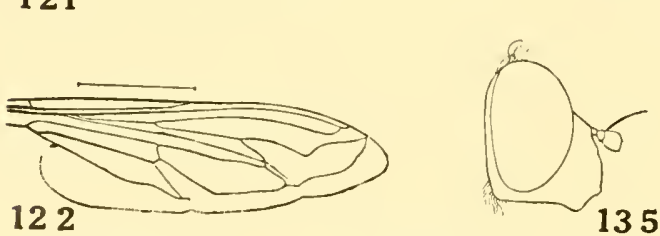

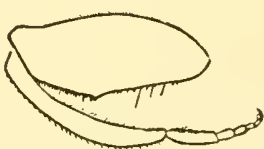

134

\section{2}

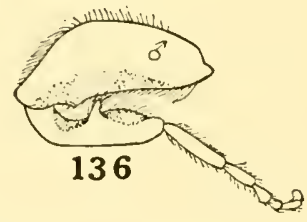

Syrphidæ VII.-115, Somula decora; 116, Cynorhinella bella; 117, Crioprora cyanella; 118. Pocota grandis; 119, Chrysosomidia pulcher; 120, Sphecomyia pattoni; 121, Senogaster; 122. Milesia; 123. Somula decora; 124, 125, Eumyiolepta, + , $\delta$, head; 126, Cyniorhinella bella; 127. Pocota; 128, Chrysosomidia pulcher; 129. Sphecomyia pattoni; 130 . Heliophilus pigra; 131 . Senogaster; 132, Temnostoma alternans; 133, 134, Syritta pipiens, head and hind leg: 135, Tropidia quadrata; 136, Teuchociemis, hind leg. 
65. Mesonotum with distinct yellow markings in addition to those on the

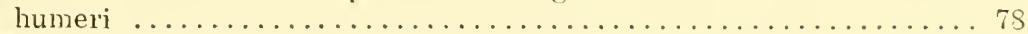

Mesonotum without distinct yellow markings, although the humeri may be yellow, sometimes partly or wholly pollinose.........66

66. Third longitudinal vein moderately curved into the apical cell...... $\$ 3$ Third longitudinal at most slightly curved into the apical cell.....66 67

67. Face produced downward; usually an indication of facial tubercle... 68 Face produced well forward and somewhat downward or evenly concave and not produced downward..................... 72

68. Pile long and furry; flies bumble-bee-like in appearance.......... 69 Pile shorter; flies not bumble-bee-like................... 70

69. Arista placed at the tip of a conically produced third antennal segment $(98,110) \ldots \ldots \ldots \ldots \ldots \ldots \ldots \ldots \ldots \ldots$. . . . . . . . . . Arista dorsal, not situated on a prominence $(54,114)$. "Criorrhina Meigen

70. Antennæ inserted on a long, conical prominence; face retreating below $(115,123) \ldots \ldots \ldots \ldots \ldots \ldots \ldots \ldots \ldots$. . . . . . . . . . . . . . Antennæ not situated on a strong prominence, inserted lower down on the head; abdomen shorter and broader................ it

71. Posterior femora swollen and with an apical projection below; abdomen of the male rather slender, wholly black $(116,126)$.

Cynorhinella Curran Posterior femora simple $(60,63,61) \ldots \ldots \ldots \ldots$ Cynorhina Williston

72. Epistoma produced forward and downward $(117,152)$.

Crioprora Osten Sacken Epistoma not produced downward or forward beyond the antennal

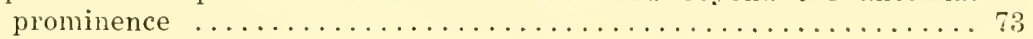

73. Bumble-bee-like flies, the pile very thick $(118,127)$.

Pocota St. Fargeau and Serville

Not bumble-bee-like, the pile rather thin................. 74

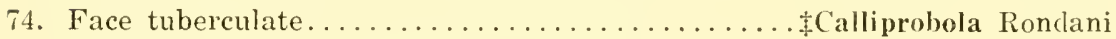
Face concave or carinate............................. 75

75. Face carinate; posterior femora greatly swollen...... §llames Rondani

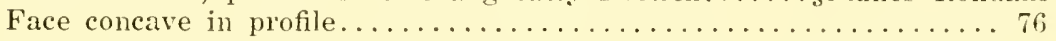

76. Pile of the scutellum thick and rather long but not concealing the ground color; hearl quite flat or gently concave above from anterior view; posterior femora with small tubercles below.

Brachypalpus Macquart

Pile thinner and shorter, few of the hairs as long as the scutellum;

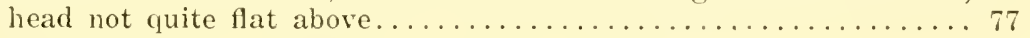

77. Abdomen bright metallic æneous with opaque-black bands and brassy or golden yellow pile; posterior femora slender and with black setæ beneath on almost the whole length; abdomen subcylindrical (Genotỵpe, Calliprobola crawfordi Shannon) $(119,128)$.

'Chrysosomidia, n. g.

* Curran, 1925, hans. Univ. Sci, Bull., xv, p. 141.

$\dagger$ Curran, 1924, Can. Ent., lvi, p. 195.

$¥$ No North American spccimens 1 have seen belong to this genus.

$\S$ Shannon, 1926, Pr. U. S. N. M., lxix, Art. 9, p. 12.

Shannon, 1916, (Calliprobola), Fr. Ent. Soc. Wash., xviii, p. 109. 
Abdomen differently colored; posterior femora usually with low ridge on the apical fourth bearing stout, short, spinose setæ; head gently convex above from anterior view; abdomen not wholly pale pilose $(29,130) \ldots \ldots \ldots \ldots \ldots \ldots \ldots \ldots \ldots \ldots \ldots \ldots \ldots \ldots \ldots \ldots \ldots \ldots \ldots \ldots$ Heliophilus Meigen

78. Face produced downward, longer than the front; pale mesonotal markings pollinose $(120,129) \ldots \ldots \ldots \ldots \ldots$ \$Sphecomyia Latreille

Face not conpicuously produced, shorter than the front; if doubtful the pale mesonotal markings are of the ground color.......... 79

* Shannon, 1926, Proc. U. S. N. M., Lxix, Art. 9, pp. 16, 26 (Xylotomima, Xylota).

$\dagger$ Curran, 1932, Amer. Mus. Novit. No. 519, p. 8 .

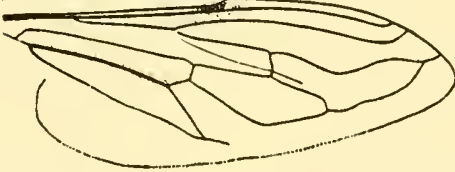

137

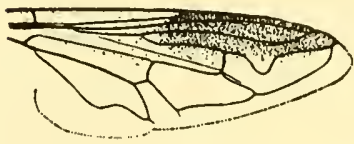

140

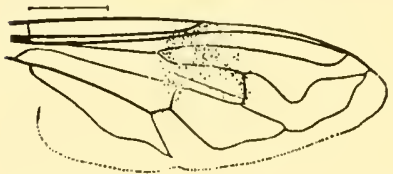

141

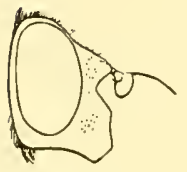

145

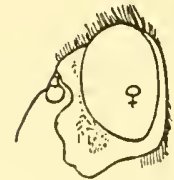

149

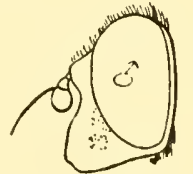

146

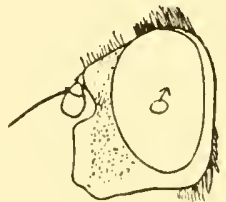

150

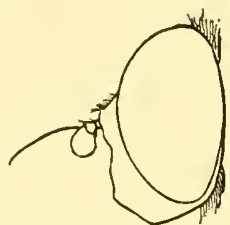

138

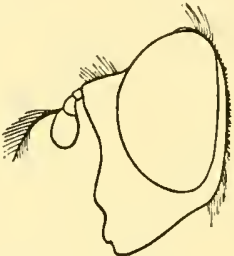

139

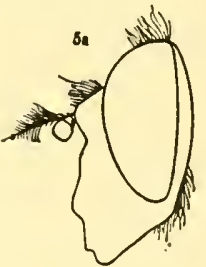

144

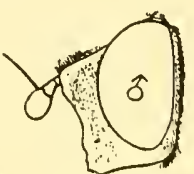

142

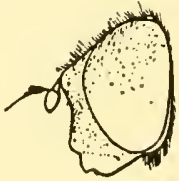

143

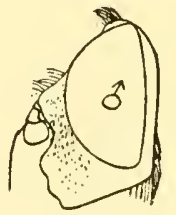

147

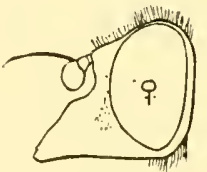

151
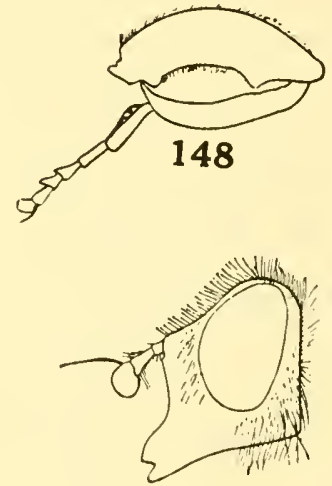

152

Syruhidre VIlI. - 137, Teuchocnemis lituratus; 139, Pterallastes thoracicus; 139, Sericomyia militaris; 140. Mecromacrus cinctus; 141, Mallota sackeni; 142 , Mecromacrus cinctus; 143: Eristalis transversus; 144, Arctophila flagrans; 145, Polydontomyia curvipes; 146. Parhelophilus latus; 147, Mallota cimbiciformis; 148, Polydontomyia, hind leg; 149, Lunomyia; 150, Asemosyrphus mexicanum; 151, Lejops stipatus; 152, Crioprora. 


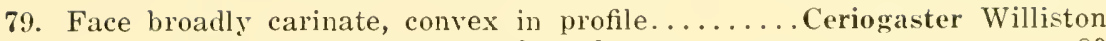
Face concave or more or less tuberculate ................ 80

80. Face produced somewhat downward and weakly tuberculate $(60,63$,

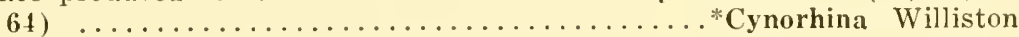
Face concave, not tuberculate...................... 81

81. Abdomen with yellow pollinose fasciæ................ 82 Abdomen brassy, with opaque black fasciæ $(119,128)$.

†Chrysosomidia, n. g.

82. Posterior femora with a tooth-like projection below near the apical

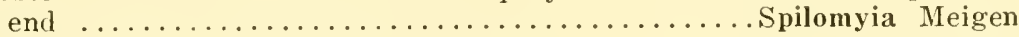
Posterior femora simple $(21,22,132)$.

\$Temnostoma St. Fargeau and Serville

83. Posterior femora with a bifid spur below; face concave, subcarinate

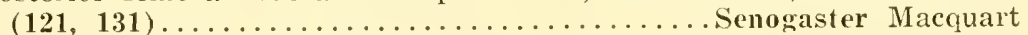
Posterior femora without such spur................... 84

84. Posterior femora very greatly swollen, never with a triangular preapical protuberance, though usually spinose; head almost circular, the cheeks linear $(28,133,134)$...Syritta St. Fargeau and Serville

Posterior femora much less swollen; head not globose........... 85

85. Posterior femora with a small, toothlike projection below toward the

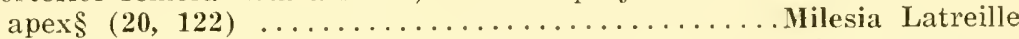

Posterior femora not toothed, sometimes with a triangular process

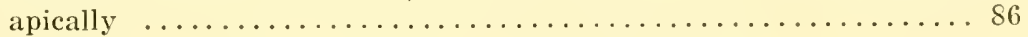

86. Posterior femora with a triangular projection apically $(19,36,135)$. f'Tropidia Meigen

Posterior femora without such process................ 87

87. Posterior femora strongly swollen and strongly arcuate, their tibiæ with a median internal spur in the male $(136,137)$.

Teuchocnemis Osten Sacken

Posterior femora much less swollen and but little curved; tibiæ simple; mesonotum ochraceous pollinose (138)......Pterallastes Lœw

88. Abdomen with pale spots or fasciæ................... 89

Abdomen without pale spots or fasciæ, rarely reddish in ground color beneath thick reddish pile on the second segment...........90

89. Posterior calli with short, stout bristles; abdominal spots more or

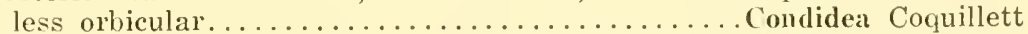

Posterior calli without bristles; abdomen with narrow pale fasciæ at least beyond the second segment $(16,33,139)$. . Sericomyia Meigen

90. Face very broad and swollen; body pile almost unicolorous.

Pyritis Hunter Face not unusually broad; pile bicolored $(\mathbf{1 5}, 144)$... Arctophila Schiner

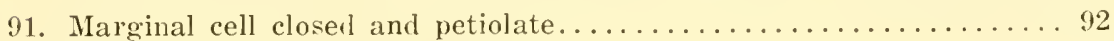

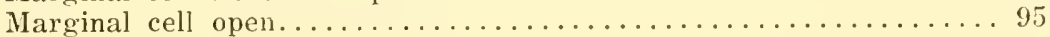

* Curran, 1924, Can. Ent. lvi, p. 195.

$\uparrow$ Shannon, 1916, (Calliprobola), Pr. Ent. Soc. Wash., xviii, 1) 109.

+ Curran, 1930, Bull. Amer, Mus. Nat. Hist., lxi, D. 72.

$\$$ Absent in some Oriental species.

- Shannon, 1926, Pr. U. S. N. M., lxix, Art. 9, p. 9.

Curran, 1934. Amer, Mus. Novit. No. 724, 1. 6. 
92. Epistoma produced into a long, porrect snout.... Lyeastrirrhyncha Bigot

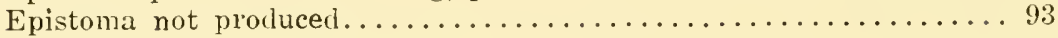

93. Eyes light brown with numerous small brown spots.

Lathyrophthalmus Mik

94. Thorax with yellow markings of short, squamose hairs (140, 142).

Meromacrus Rondani

Hair of the thorax never squamose or forming clense yellow patches $(17,143) \ldots \ldots \ldots \ldots \ldots \ldots \ldots \ldots \ldots \ldots \ldots \ldots \ldots \ldots \ldots \ldots \ldots \ldots \ldots \ldots$ Eristalis Latreille

95. Posterior femora before the apex with a strongly raised, sub-triangular ridge, the base with a distinct spur..............Merodon Meigen

Posterior femora variable, but never with a spur bearing triangular

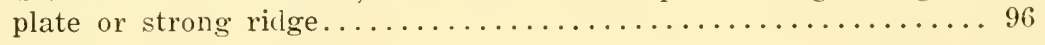

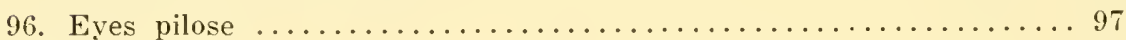

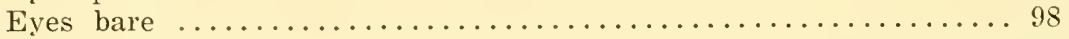

97. Third antemnal segment not longer than wile $(111,147)$. Mallota Meigen Third antennal segment twice as long as wicle........ Quichnana Knab

98. Mesonotum densely and evenly vellow pollinose. the ground color concealed; face concave in female; with a tubercle but receding below in the male $(138) \ldots \ldots \ldots \ldots \ldots \ldots \ldots \ldots \ldots$. . . . . . . . . . . . Mesonotum differently colored ....................... 99

99. Large robust species, the thorax thickly yellow or orange pilose, rarely whitish; posterior femora swollen and arcuate in both sexes; rather bumble-bee-like flies $(141,147) \ldots \ldots \ldots \ldots$. . llallota Meigen Usually smaller and always more slender; if the posterior femora are arcuate the tibiæ end in an apical spur................... 100

100. Posterior tibiæ ending in a spur or triangular production, never transverse on the ventral apex..............................

Posterior tibiæ transverse or rounded apically, never produced...... 102

101. Large species, at least $12 \mathrm{~mm}$. in length, the mesonotum at most obscurely vittate $(34,145,148) \ldots \ldots \ldots \ldots \ldots$. Polydontomyia Williston Smaller, more slender species, the mesonotum usually with two or more cinereous or yellowish vitæ $(151) \ldots \ldots \ldots \ldots \ldots$ Lejops Rondani

102. Face entirely pollinose $(\mathbf{1 4 6}) \ldots \ldots \ldots \ldots \ldots$ Parhelophilus Girschner Face with a shining median vitta on at least the lower half .......103

103. Stigma simulating a crossvein........................ Stigma at least twice as long as wile, although often paler apically, never simulating a crossvein (18) ...........t. Elophilus Meigen

104. Ocellar triangle extremely large in both sexes, the outer ocelli lying very close to the eyes $(\mathbf{1 5 0}) \ldots \ldots \ldots \ldots \ldots \ldots$ Asemosyrphis Bigot Ocellar triangle smaller (149) ..........tumomyia Curran and Fluke

* Curran, 1930, Amer. Mis. Novit. No. 411, p. 3.

$\dagger$ Curran, 1930, Bull. Amer. Mus. Nat. Hist., lxi, n. 74.

\$ Curran and Fluke, 1926, Trans-Wisconsin Acad. Sci., Arts \& Letters, xxii, pp. 207-2S1. 


\section{Family Conopidæ-The Thick-headed flies}

Rather thinly pilose or nearly bare, elongate flies of moderate size. Head broad, the front broad in both sexes; ocelli present or absent. Antenne with three segments, the third bearing a dorsal arista or terminal style. Oral opening large, the proboseis long and slender, often geniculate. Abdomen often constricted basally, the genitalia of both sexes conspienous, often large or greatly elongated in the females. Anal eell elosed, the first basal cell always very long, the second moderately long; apical cell closed or much narrowed. Above the antennæ an inflatable ptilinum.

The Conopids are eommonly found about flowers and are sluggish in flight. They oceur from spring to antumn but are much more eommon during the spring and early summer. The species of Stylogaster are rapid in flight, the flies being great hoverers. I have found them in the tropies in rather large numbers hovering over ant armies where they usually remain a few inches above the ground, suddenly disappearing, only to reappear in another patch of sunlight. In the north I have found them only about flowers of the Labiatere and have observed them hovering as they sucked the nectar. Many of the species resemble Hymenoptera.

The members of this family are parasitic, mostly upon bees and wasps, oriposition usually occurring during flight. There are also records of parasitism on Orthoptera and the species of Styloguster are in some way connected with ants but the exact relationship is unknown.

The generie and specifie limits in the family are, for the most part, not sharply drawn, and this is especially true in the case of Conops and Physocephalu. There have been a number of papers published dealing with the family in whole or in part; the most important of these is referred to in the footnote.*

\section{KEY TO GENERA}

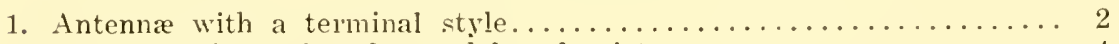

Antennæ with a dorsal or subdorsal arista................. 4

2. Face with deep lateral grooves..................... 3

Face without lateral grooves, the median carina strong; ocelli vestigial

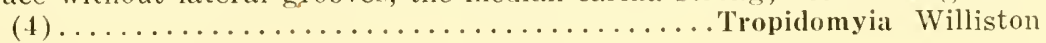

* Van Duzee, 1927, Proc. Calif. Acad. Sci., xvi, yp. 573-604. 

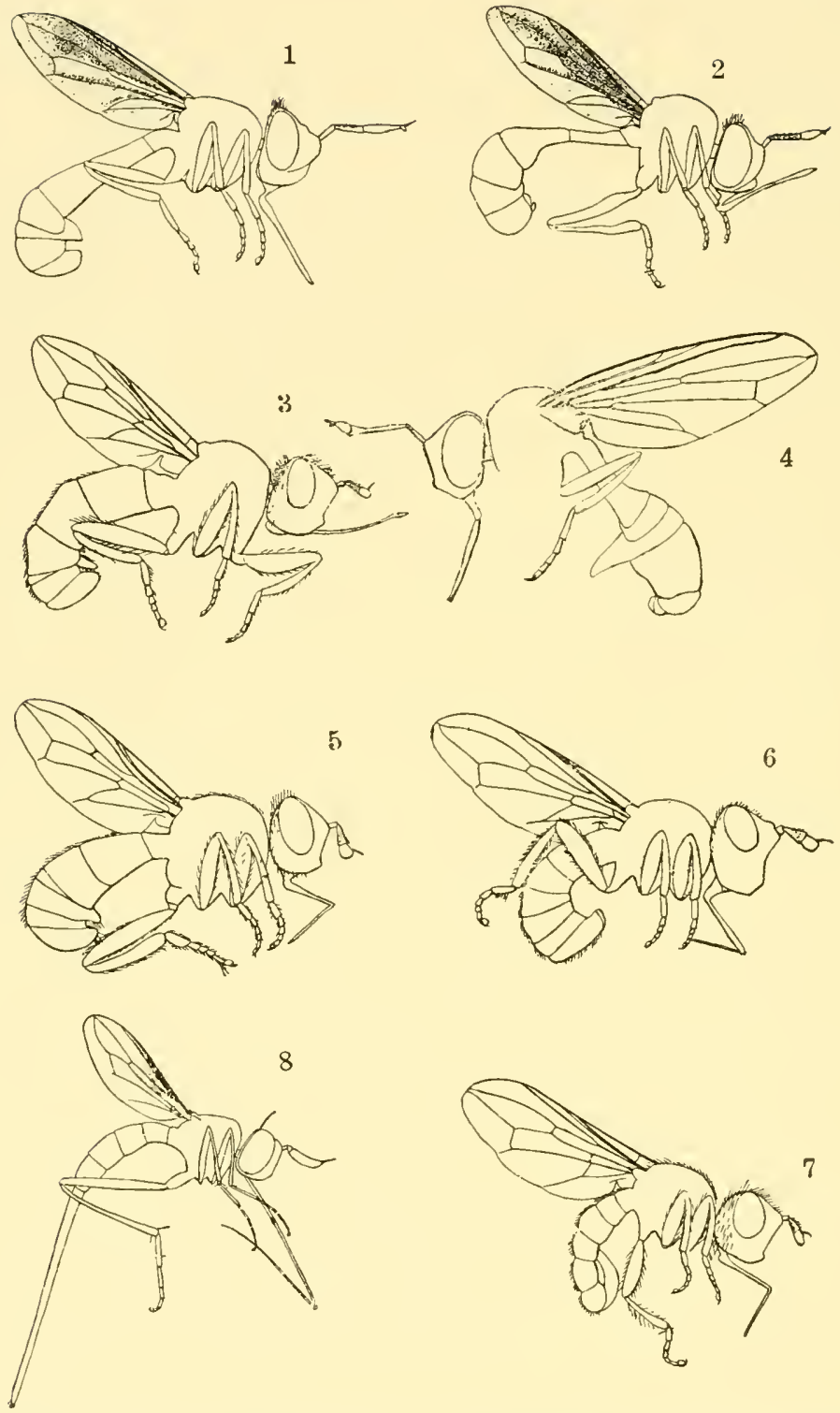

Conopidxe,-1, Conops xanthopareus; 2, Physocephala furcillata; 3, Zodion fulvifrons; 4. Tropidomyia bimaculata; 5 , Occentya modesta; 6 . Myopa clausa; 7 . Dalmannia picta; 8, Stylogaster neglecta. 
3. Anterior crossvein situaterl at most a little beyond the midlle of the discal cell; femora regular in outline .................. Anterior crossvein situated well beyond the midlle of the discal cell; femora swollen basally, narrowed on the apical half or more (2).

* Physocephala Schiner

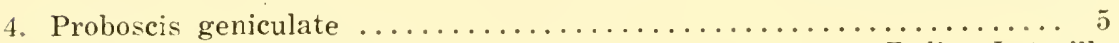
Proboscis straight, directed forward (3).............. Zodion Latreille

5. Vertex and tibiæ without bristles; face grooved............. 6 Vertex and the apex of the tibiæ with bristles; face not grooved (8).

† Stylogaster Naccuart

6. Anal cell much longer than the second basal................ 7 Anal cell but little longer than the second basal (7).. Dalmannia Desvoidy

7. Cheeks narrower than the eye-height................... 8 Cheeks at least as widle as the eye-height $(6) \ldots \ldots \ldots$.....

8. Antennæ longer than the front; propleura haired (5)... Occemya Desvoidy Antennæ shorter than the front; propleura bare........... Sicus Scopoli

9. Third antennal segment much longer than either the first or second.

Aconops Krober Third antennal segment at most slightly longer than the first or

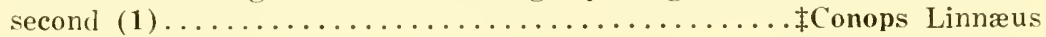

* Van Duzee, 1934, Ann. Ent. Soc. Amer., xxvii, p. 320.

† Aldrich, 1930. Proc. U. S. N. M., lxxviii, Art. 9, pp. 1-27.

†röber, 1927, Konowia, vi, p. 139. 


\section{Family Pyrgotidæ}

Elongate flies of moderate size, the oeelli absent in the North Ameriean genera, present only in Teretrura Bigot of the American forms: wings long, the leags somewhat elongate.

Head large, the front more or less produced, without frontal bristles; ocelli absent (present in only one American genus); cheeks wide; proboscis thick, the labella well developed; palpi large, flattened, or the proboseis narrow and short without labella and the palpi narrow; antenna short to moderately long, the second segment withont a dorsal exeision, the third usually larger than the second, rarely minute. Legs moderately long. Wings long: auxihiary rein long, ending free or in the eosta; apical cell widely open, not narrowed apically: anal eell usually triangular apically. Abdomen long, sometimes elavate in the males; female genitalia large, more or less eylindrieal.

Speeies of the genus Pyrgota are parasitic in the larral stage on Jume beetles (Searabeide) and the flies are sometimes common in the rieinity of badly infested ficlds. I suspeet that Pyrgotella chagnoni Johnson is parasitic on species of Dichelony.r hut my suspicion is based merely upon the fact that I have observed this species commonly in an open woods where the adult beetles were very common. The flies apparently are most aetive on dark days, in the evening or at night and they frequently are attracted to light. They are nocturnal and $P$. undutu Wriedemann has been observed ovipositing on adult Jume beetles during flight. The flies seleet the soft part of the abdomen beneath the opened elytra in order to lay their eggs and the beetles have been observed on the ground making a loud noise as they struggled to eseape the fly.

The exact limits of this family have not been definitely determined, and it is not eertain that the species possessing ocelli should be retained in the family. Nothing of a definite nature is known of the immature stages of any of the American genera other than Pyrgota. There are two North American genera and three from Sonth Ameriea that have been assigned to the family. 

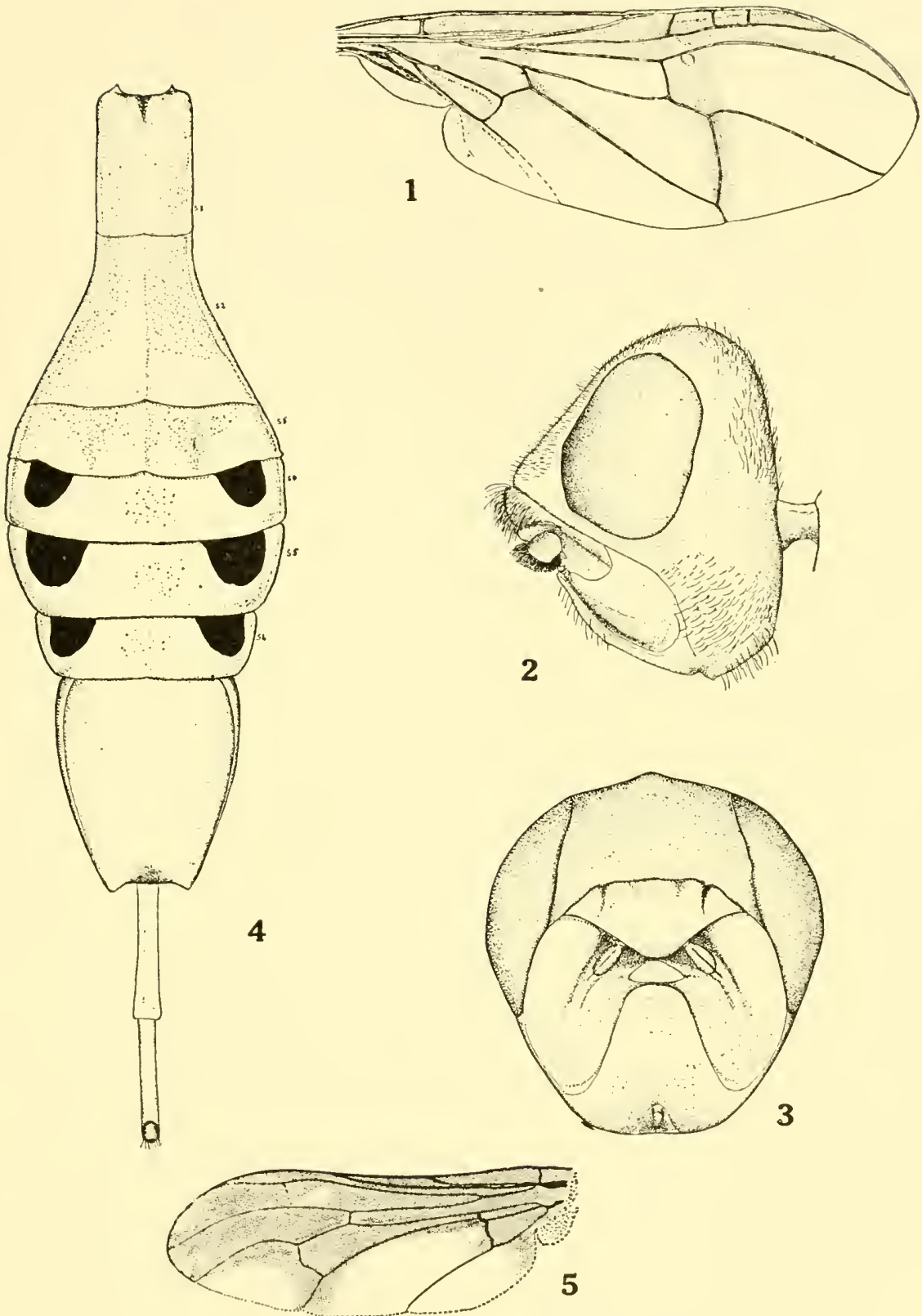

Pyrgotidx.-Figures 1-4, Tauroscypson guiana; 5, Pyrgota undata. 
KEY TO AMERICAN GENERA

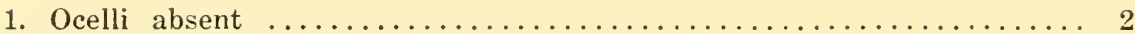

Ocelli present (Chile)........................... Teretrura Bigot

2. Third antennal segment as large as the second............... 3 Third antennal segment minute, the arista curved over the second segment and with long rays on the free side (British Guiana) (1-4).

Tauroscypson Curran

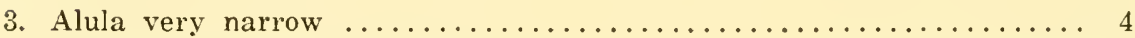
Alula large, convex behind (5).................. Pyrgota Wiedemann

4. Apex of anal cell transverse (Type: Pyrgota chagnoni Johnson).

Pyrgotella, n. g. Apex of anal cell with triangular production behind (Bolivia).

Leptopyrgota Hendel 


\section{Family Otitidæ-The Pictured-wing Flies}

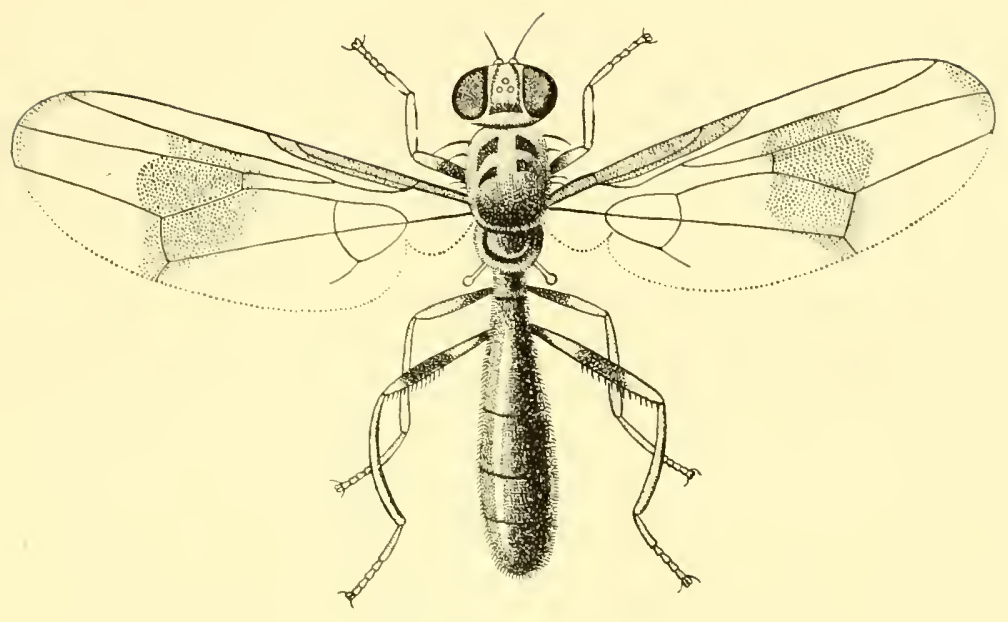

Paneryma elongata.

Rather small to moderately large flies, the wings usually marked with brown, black or yellowish.

Wyes separated in both sexes; frontals usually limited to the upper part: face variable, the oral vibrisse always absent; elypens ustally well dereloped; proboseis short and stout; palpi large. Abdomen with five or six segments, the basal two more or less coaleseent; male with long, enrled penis, the female with a flattened, three segmented ovipositor. Legs short and stont or moderately long, the preapical tibial bristle present or absent. Wing venation usually complete, the anal cell absent in one genus; auxiliary vein separated from the first vein though often approximated to it, second hasal and anal cells of moderate size.

The adults are usually foumd in moist places and many of the species are very common. This family is cosmopolitan but the species are most numerous in the tropies, particularly in South and central America. Several of the species have the head strongly produced laterally and one fairty common species of Richardio has the eyes situated on long stalks, but this is a male character only.

Little is known ahout the immature stages although the larva of Tritora are said to damage onions and others have been reared from decaying plant produets. 

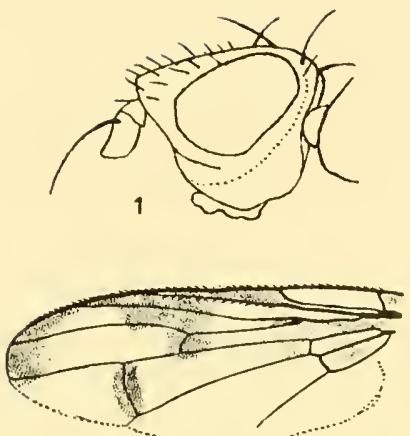

2
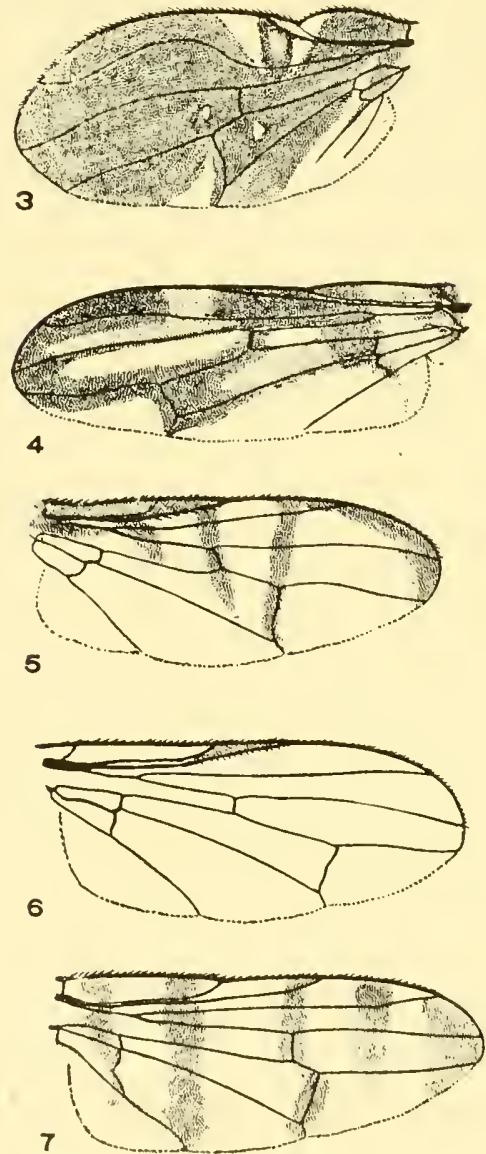

Otitidæ I.-1, Macrostenomyia : 2, Senopterina; 3, Delphinia picta; 4, Idana; 5, Rivellia ; 6. Tetanops: 7, Pseudotephritis; 8, Psairopterella macrocephala: 9, Chætopsis; 10, Coilometopia ; 11. Pterocalla; 12, Melieria; 13 , Eumetopiella; 14, Richardia.
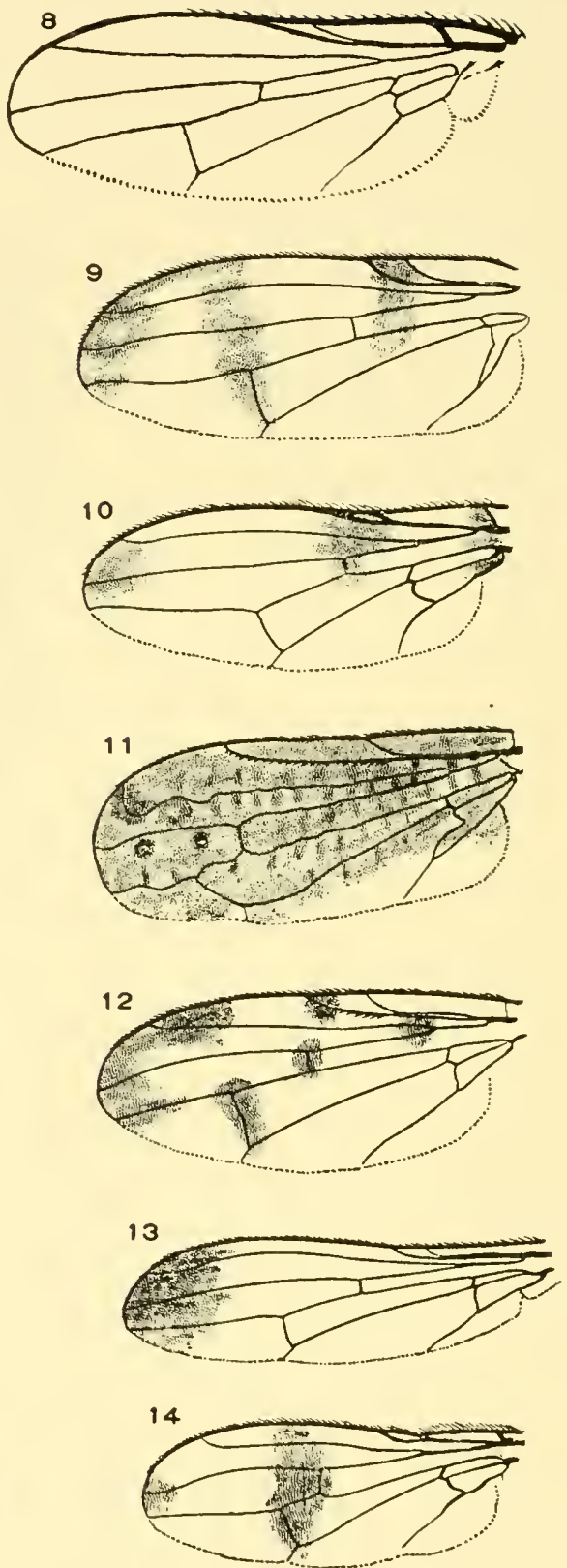
In the following key I have not followed the usual praetice of reeognizing the subfamilies, which Hendel has raised to family rank, for the very good reason that I do not believe the characters used are of mueh importance. The subfimily "Ortalina" (the name Ortalis is preoceupied in Ornithology and is not avalable) is distinguished by the presence of a propleural bristle, ret this is present, though less developed, in the Pterocallina, which is distinguished by its long stigmatal cell, a charaeter which is also subject to variation. As in the Trupaneida several of the genera in this family have been based upon wing pattern. The charaeter's at present in use are undoubtedly fairly stable but some of the generic characters are admittedly weak inasmuch as the differences in renation might easily be commected by the discovery of new forms. Hendel has published several papers dealing with the family and has treated all but the "Ortalinæ" in Fenera Insectorum (fascicles 96, 106, 113, 157).

The genus Otites was established by Latreille in 1804 (Nouv. Diet. d'Hist. Nat., xxiv, p. 196) and not in 1805 as given in catalogues. The type named was musca porcus, eredited to Bose, but this species is the same as formosa Panzer. Platystomida eamnot be used for the family name as Platystoma is preoceupied in Mollusea.

\section{KEY TO GENERA*}

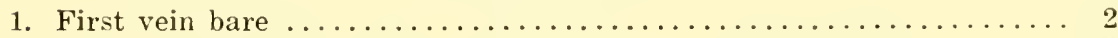

First vein with dorsal setulæ at least on the apical third......... 34

2. Costa greatly weakened or broken at end of the auxiliary vein (Rich-

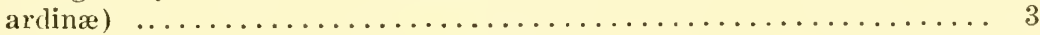

Costa not weakened or broken (Ulidinæ)................... 17

3. Posterior femora with short spines below ................ 5

Femora without spines below....................... 4

4. Head about twice as long as high $(56) \ldots \ldots \ldots \ldots \ldots$ Coniceps Lœw Head not as long as high $(38,92) \ldots \ldots \ldots \ldots \ldots \ldots \ldots$. Epiplatea Lœw

5. Posterior femora swollen, much larger than the others; eyes sometimes

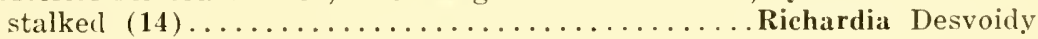
Posterior femora not conspicuously swollen.............. 6

6. Anal vein reaching the wing margin, at least as a fold $\ldots \ldots \ldots \ldots . . . .9$ Anal vein not nearly reaching the wing margin.............. 7

7. Occiput very strongly narrowed at the upper third $(80,97)$.

Odontomera Macquart Occiput regular in outline $\ldots \ldots \ldots \ldots \ldots \ldots \ldots \ldots \ldots \ldots$

* Pareuxesta Coquillett is omitted. 

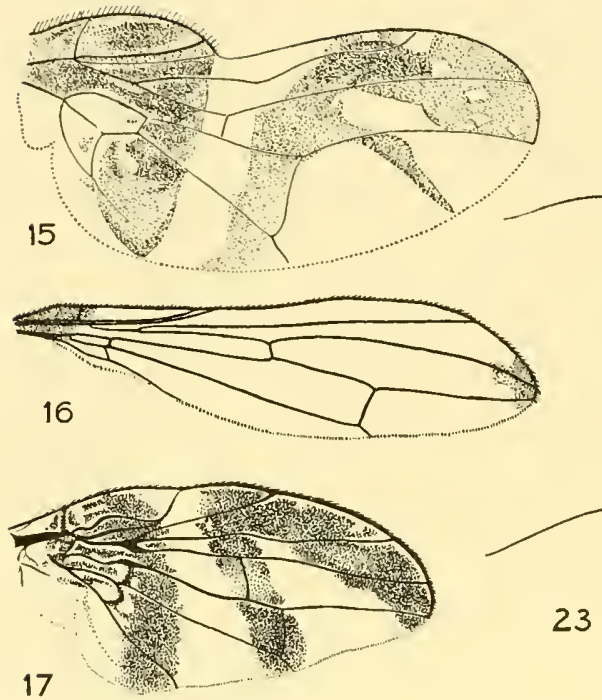

17

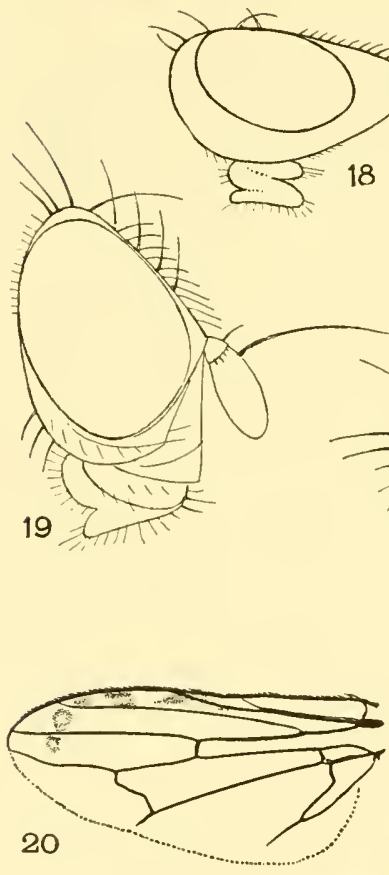

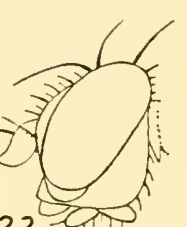

22

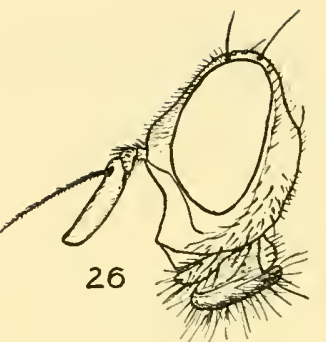

3
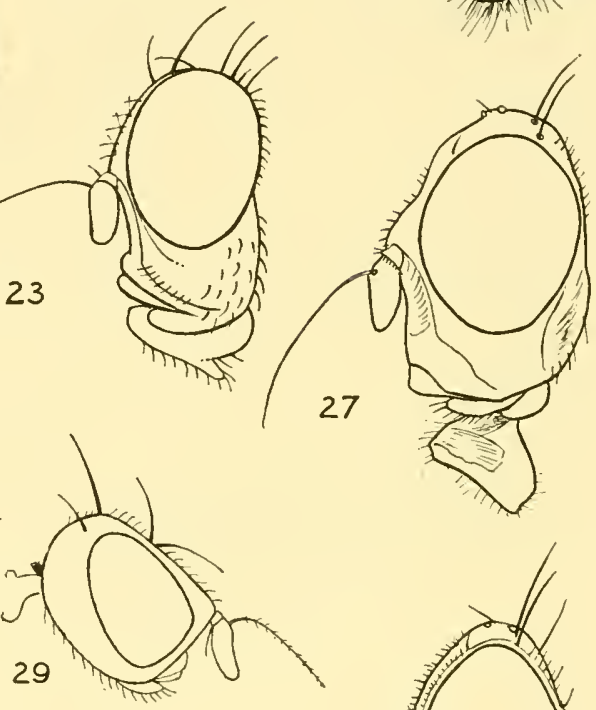

28

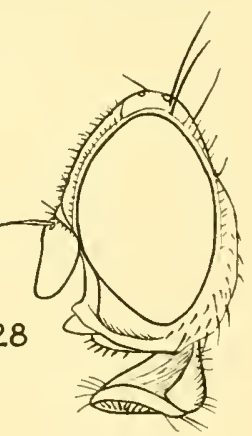

25
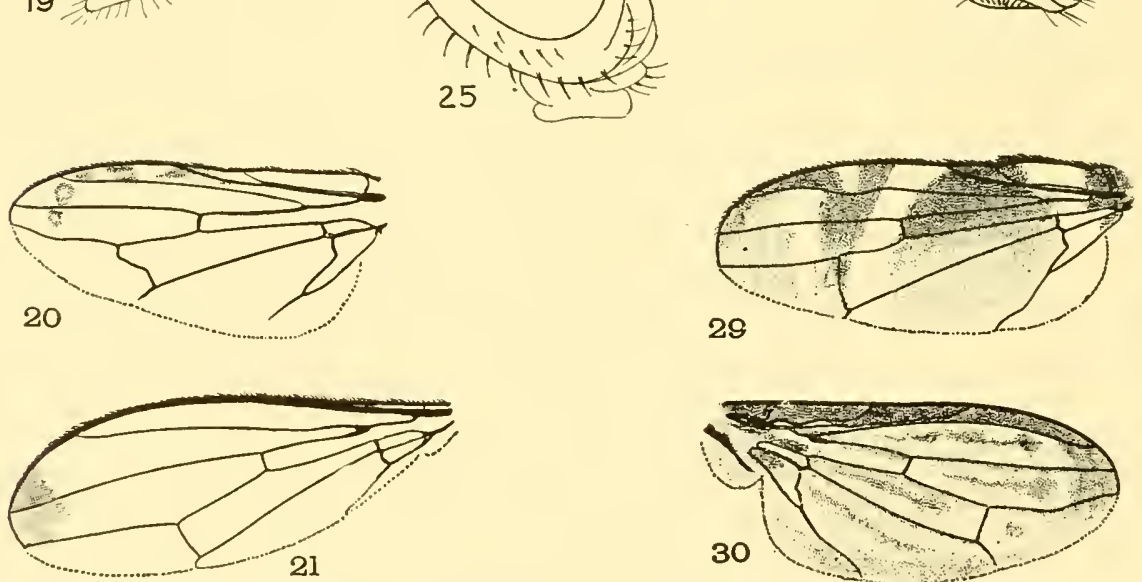

Otitidæ 1I.-15, Ostracocoelia mirabilis; 16, Myrmecothea; 17, Dyscrasis hendeli; 18 . Eumetopiella rufipes; 19, Acrosticta foveolata; 20, Edopa; 21, Macrostenomyia; 22, Eumecosomyia gracilis; 23, Paragorgopsis maculata; 24, Sepsisoma sepsioides; 25. Steneretma; 26 , Rivellia; 27, Chrysomyza; 28, Xanthacrona bipustulata; 29, Euphara; 30, Notogramma. 
8. Occiput, from lateral view, strongly convex above the neck (24).

Occiput flat or slightly concare above the neck $(1,21)$.

Sepsisoma Johnson

Macrostenomyia Hendel

9. Anterior crossvein situated farther from the posterior crossvein than

the length of the latter............................. 10

Crossveins situated closer to each other than the length of the posterior

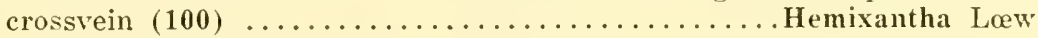

10. Abdomen with almost parallel sides or coarctate basally.......... 11

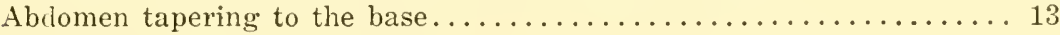

11. Anterior crossvein situated before the middle of the discal cell $(31,68)$.

Setellida Hendel

Anterior crossvein situated beyond the middle of the discal cell...... 12

12. Anterior femora without spines beneath $(78,96)$. Neoidioty pa Osten Sacken All the femora with spines beneath...............Paneryma Wulp

13. First antennal segment short........................... 14 First antennal segment as long as the second $(19,93)$. Poecilomyia Hendel

14. Anterior crossvein situated at or before the middle of the discal cell;

front concave above from anterior view $(10,73)$. Coilometopia Macquart Anterior crossvein situated well beyond the middle of the discal cell.. 15

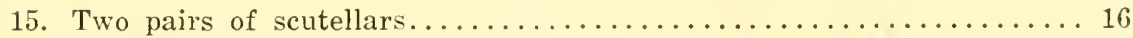
Only one pair of scutellars $(63,76,98,107) \ldots \ldots \ldots$. Ielanoloma Lœw

16. Front much wider than either eye $(12,105) \ldots \ldots \ldots \ldots$ Zetekomyia, n. $g$. Front narrower than either eye...................

17. Antennæ widely separated, situated in deep grooves, the face strongly convex in profile $(50) \ldots \ldots \ldots \ldots \ldots \ldots \ldots \ldots \ldots \ldots$ Ulidia Meigen Antennæ not situated in deep grooves or the face not strongly convex. . 18

18. Anal vein absent or not extending beyond the anal cell.......... 19 Anal vein extending well beyond the anal cell.............. 20

19. Anal cell absent, the wings very narrow $(25,36) \ldots \ldots$. Steneretma Lœw Anal cell present $(22,45) \ldots \ldots \ldots \ldots \ldots \ldots \ldots$ Eumecosomyia Hendel

20. Front with large rather deep pits or with strong transverse ridges or

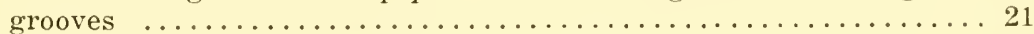
Front normal, sometimes with four longitudinal grooves above...... 22

21. Auxiliary vein forming a rather acute angle with the costa $(19,37)$. Acrosticta Lœw Auxiliary vein forming an obtuse angle with the costa $(30,89)$.

Notogramma Lœw

22. Antennæ as long as the head, the third segment four times as long as

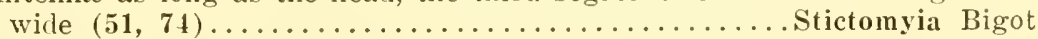
Antennæ much shorter, the third segment never three times as long:

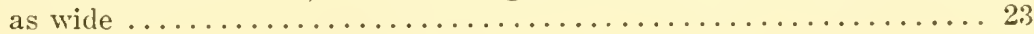

23. Face convex in the middle in profile...................... 24

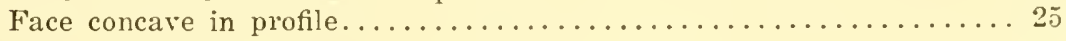



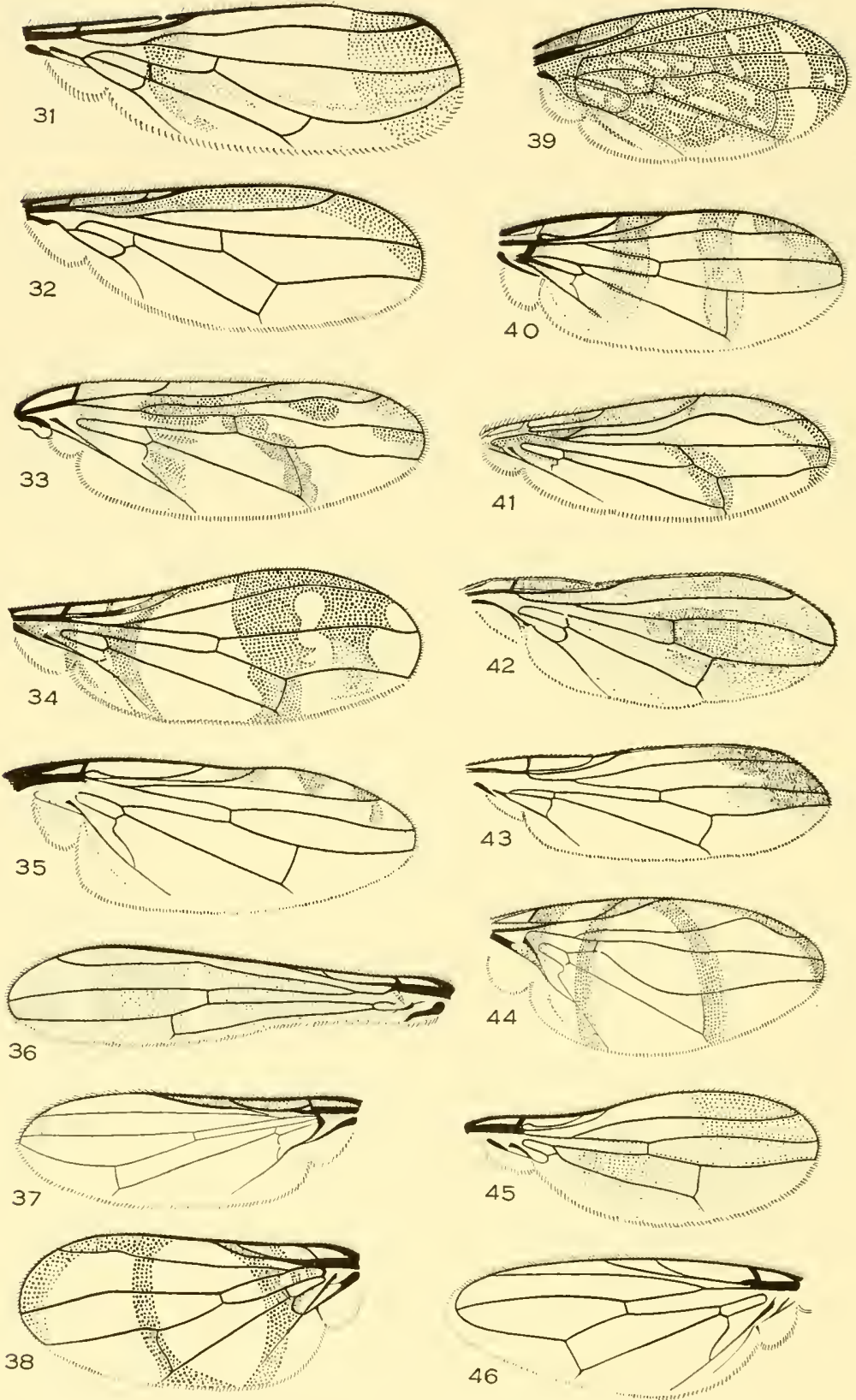

Otitidæ III,-31, Setellida corulescens; 32, Setellia costalis; 33 , Myennis; 34 , Automola automaria; 35 . Paredopa punctigera; 36 , Steneretma ; 37 , Acrosticta foveolata; 38 , Epiplatea arcuata; 39, Amphicnephes pullus; 40, Pareuxesta latifasciata; 41. Xanthacrona bipustulata; 42, Zetekomyia banksi; 43, Stenomyia; 44, Axiologina ferrum-equinum; 45, Eumecosomyia gracilis; 46, Chrysomyza ænea. 
24. Eyes conspicuously higher than long, the face gently concave above $(35,67) \ldots \ldots \ldots \ldots \ldots \ldots \ldots \ldots \ldots \ldots \ldots \ldots \ldots \ldots \ldots \ldots \ldots$ Paroedopa Coquillett Eves about as long as high, the face not concave above $(20,69)$.

(Edopa Lœw

25. Head not or scarcely longer than high.................... 26 Head nearly twice as long as high $(13,18) \ldots \ldots$ Eumetopiella Hendel

26. Third antennal segment with the apex rounded above.......... 27 Third antennal segment with the apex angulate above........... 32

27. Anterior crossvein situated near or beyond the middle of the discal

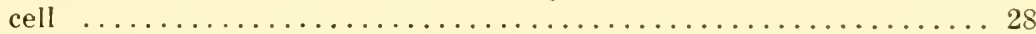
Anterior crossvein situated near the basal sixth of the discal cell $(44,82) \ldots \ldots \ldots \ldots \ldots \ldots \ldots \ldots \ldots \ldots \ldots \ldots \ldots \ldots \ldots \ldots \ldots \ldots \ldots \ldots \ldots$ Axiologina Hendel

28. Mesopleura bare; two sternopleurals $(84,102) \ldots \ldots \ldots$ Seioptera Kirby Mesopleura haired; one sternopleural..................... 29

29. Frontal vitta with hairs or bristles.................. 30 Frontal vitta bare $(27,46) \ldots \ldots \ldots \ldots \ldots \ldots \ldots \ldots *^{*}$ Chrysomyza Fallén

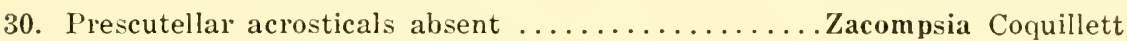
Prescutellar acrosticals present...................... 31

31. Bristles arising from black spots $(29) \ldots \ldots \ldots \ldots \ldots$............... Frontals not arising from conspicuous black spots $(64,85)$. †Euxesta Lœw

32. Frontal vitta with at most two pairs of cruciate bristles or the face

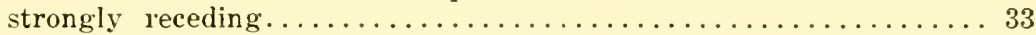
Frontal vitta with hairs or several bristles $(64,85) \ldots \ldots$. Euxesta Lœw

33. Face strongly receding $(43,104) \ldots \ldots \ldots \ldots \ldots \ldots \ldots$ Stenomyia Lœw Face perpendicular below $(9,83) \ldots \ldots \ldots \ldots \ldots \ldots$ Chætopsis Lœw

34. Costa fractured or greatly weakened at the end of the auxiliary vein. 35

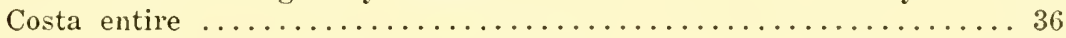

35. Abdomen petiolate $(32,72) \ldots \ldots \ldots \ldots \ldots \ldots \ldots \ldots$ Setellia Desvoidy Abdomen oval, not narrowed sub-basally............Epiplatea Lœw

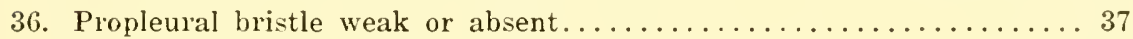
Propleural bristle strong......................... 59

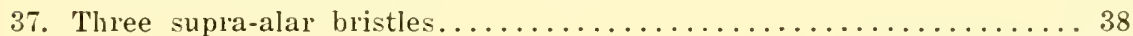
Four supra-alar bristles............................. Tanypezidæ

38. Subcostal (stigmatal) cell usually extremely large; antennal grooves

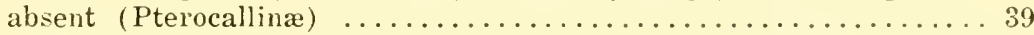

Subcostal cell usually normal; antennal grooves well developed, often

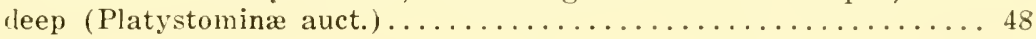

39. Posterior crossvein more or less recurrent, never forming a sharp

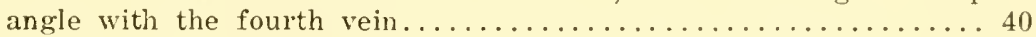

Posterior crossvein not recurrent, forming less than a right angle with

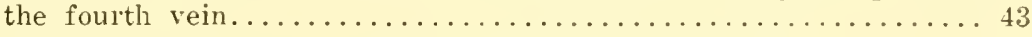

40. Anterior crossvein situated beyond the middle of the discal cell.....41 Anterior crossvein situated before the middle of the discal cell (58).

Hendel, 1909. Zool. Anzaiger, xxxiv, p). 612-622.

† Hendel, 1909. Ann. Mus. Nat. Hung., ix, p. 151. 


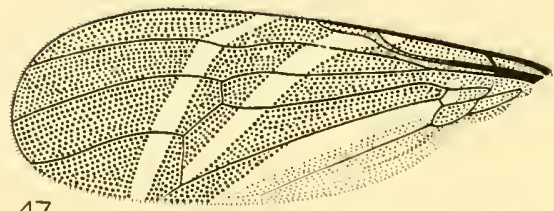

47

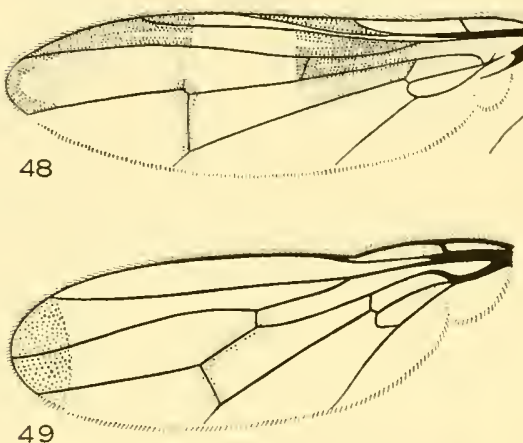

49
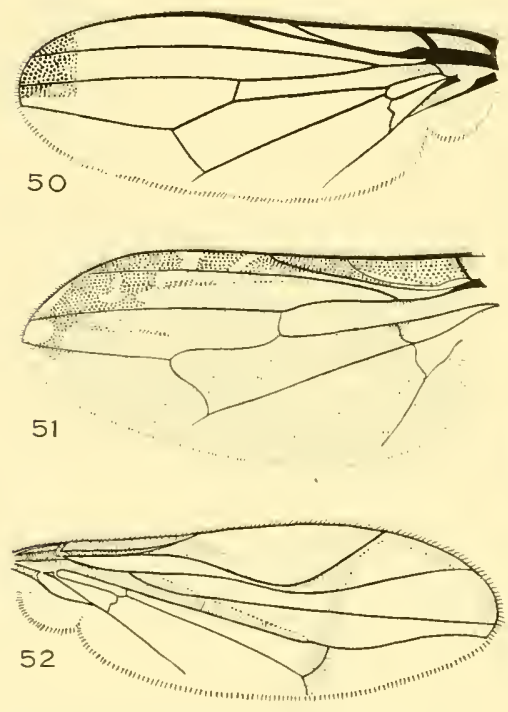

56
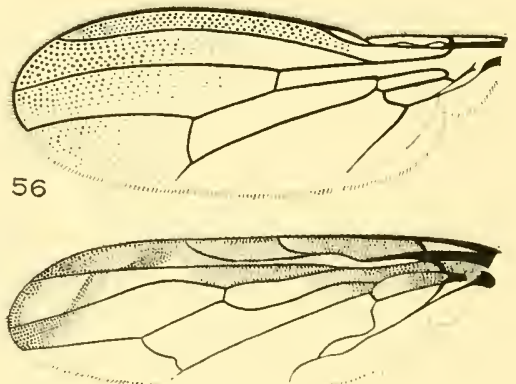

57
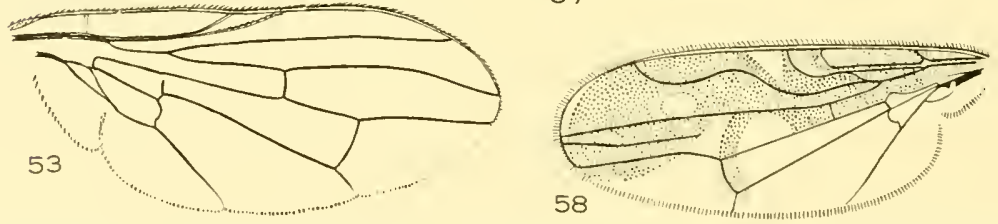

Otitide IV.-47, Tritoxa flexa; 48, Himeroessa pretiosa; 49, Pecilomyia longicornis; 50 , Ulidia apicalis; 51 , Stictomyia punctata; 52 ; Dasymetopa stigma; 53 , Califortalis hirsutifrons; 54. Ortalimyia aldrichi; 55. Delphinia; 56, Coniceps niger; 57, Diacrita costatis; 58, Megalamyia; 59, Melieria similis; 60 , Califortalis hirsutifrons; 61 , Tetanops luridipennis. 
41. Tip of the anal cell extending beyond the apex of the second basal

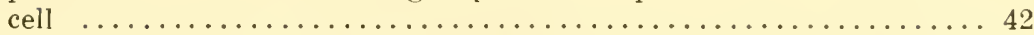

Tip of the anal cell not produced beyond the apex of the second basal

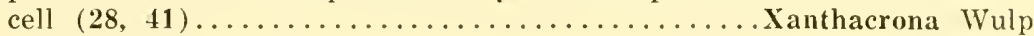

42. Five pairs of dorsocentrals and acrosticals $(17,90) \ldots$ Dyserasis Aldricin Two pairs of dorsocentrals $(33) \ldots \ldots \ldots \ldots \ldots \ldots$ Myennis Desvoidy

43. Triangle of the anal cell almost as long as the basal section........ 44 Triangle much shorter than the basal part................ 45

44. Wings with parallel sides $(11,108) \ldots \ldots \ldots \ldots \ldots$. Pterocalla Rondani Wings widest sub-basally $(99,106) \ldots \ldots \ldots \ldots$ Callopistromyia Hendel

45. Anal cell convex apically, sometimes transverse on the posterior third, but never with a produced angle $(23,101) \ldots$ Paragorgopsis Giglio-Tos Anal cell at least somewhat produced posteriorly............. 46

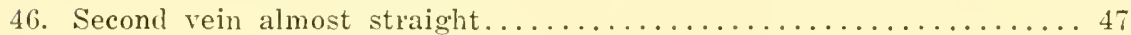
Second vein strongly sinuous apically $(91,103)$. Pseudopterocalla Hendel

47. Anterior crossvein situated at or before the middle of the discal cell

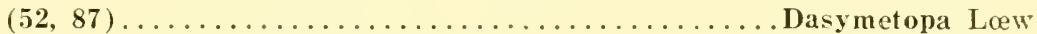
Anterior crossvein situated beyond the middle of the discal cell (7,

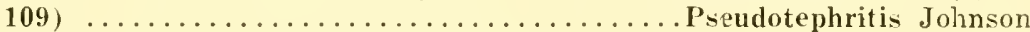

48. Occiput very broad and convex from lateral view. . . . . . . . . . . 49

Occiput narrow, usually flattened................... 52

49. Without sternopleurals $(\mathbf{1 6 , 7 5}) \ldots \ldots \ldots \ldots \ldots \ldots$ Myrmecothea Hendel

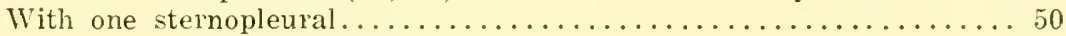

50. Posterior crossvein situated more than its own length beyond the anterior crossvein $(62,79) \ldots \ldots \ldots \ldots \ldots$ Myrmecomya Desvoidy Posterior crossvein situated less than its length beyond the anterior.

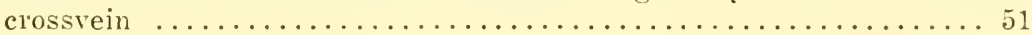

51. Costal cell wide, convex anteriorly $(3,55) \ldots \ldots \ldots$ Delphinia Desroidy Costal cell narrow, its anterior edge straight $(47,70) \ldots \ldots$ Tritoxa LœW

52. Abdomen somewhat laterally compressed; one pair of weak frontal bristles above; third antennal segment elongate; arista bare (2).

Senopterina Macquart Abdomen cylindrical or flattened, if slender the arista is plumose, the antennæ are short or there are two pairs of frontals.......... 53

53. Abdomen elongate, more or less cylindrical basally........... 55 Abdomen short and rather flattened................... 54

54. Costal cell widened, anal cell angled posteriorly (15).

Ostracocœlia Giglio-Tos Costal cell normal; anal cell rounded posteriorly $(39,65)$.

Amphicnephes Lœw

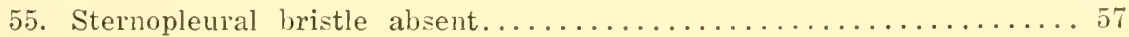

Sternopleural bristle present...................... 56

56. Anal cell rounded apically $(4,71) \ldots \ldots \ldots \ldots \ldots \ldots \ldots$ Idana Lœw Anal cell angulate posteriorly $(57,66) \ldots \ldots \ldots \ldots$ Diacrita Gerstæcker 

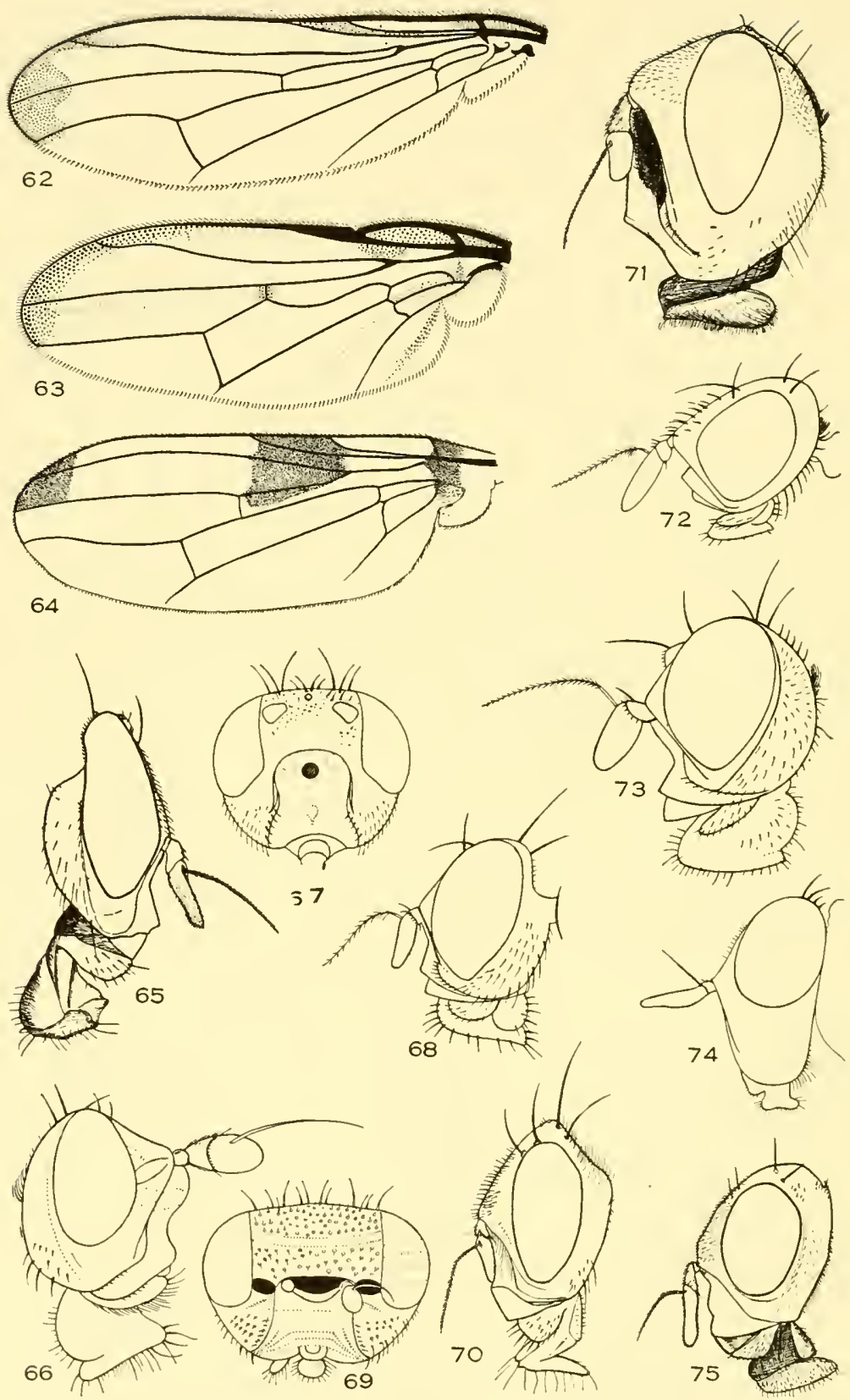
57. Discal cell conspicuously widened before the anterior crossvein $(5,26)$.

Rivellia Desvoidy Discal cell not conspicuously widened, rarely widest at the middle.... 58

58. Anterior crossvein oblique, at the midlle of the discal cell $(48,86)$.

Himeroëssa Lœw Anterior crossvein transverse, well beyond the middle of the discal

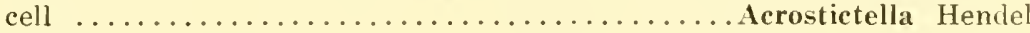

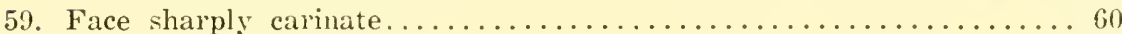

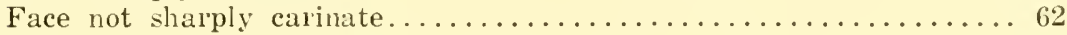

60. Third antennal segment angulate above or elongate............61 Third antennal segment orbicular............... Tetropismenus Lœw

61. Third antennal segnent angulate at upper apex........ Tephronota Lœw

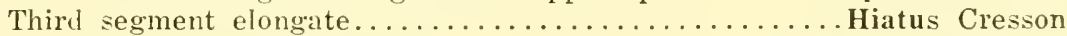

62. Mesonotum with presutural bristles $(\mathbf{1 2}, \mathbf{5 9}) \ldots \ldots \ldots$ Melieria Desvoidy Mesonotum without presutural bristles................6. 63

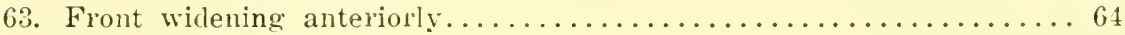

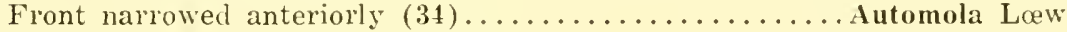

64. Three or four pairs of scutellar bristles; postocellars long and fine; hair of front long and rather abundant $(53,60) \ldots \ldots$ Califortalis, $\mathrm{n} . \mathrm{g}$. Two pairs of scutellars; postocellars short; hair of front short, sparse

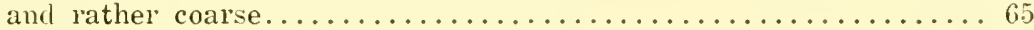

65. Verticals long and strong; cheeks much narrower than the eye-height

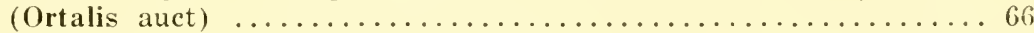
Verticals short; cheeks almost or quite as wicle as the eye-height

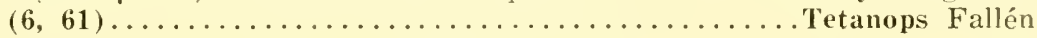

66. Two pairs of well developed frontals; lunule haired $(\mathbf{7 7}, 95)$.

Ceratoxys Rondani Only one pair of well developed frontals; lunule bare $(54,94)$.

Ortalimyia, n. g.

\section{Melanolomina, new genus}

Differs from Melanoloma Loew in possessine two pairs of scutellar bristles. In the two species before me the mesonotum is more or less reddish and not metallic. Genotype:-Odontomera iarians Schiner.

\section{Zetekomyia, new genus}

Differs from Melanolomina in having the front more than twiee as wide as the eyes (from dorsal riew) and a somewhat mole elongate and more distinctly clatate abdomen. The head bears only four pairs of bristles: a pair of frontals, pair of ocellars, sitnated behind the anterior ocellus, and inner and outer verticals; hair very short; antemm sepa- 

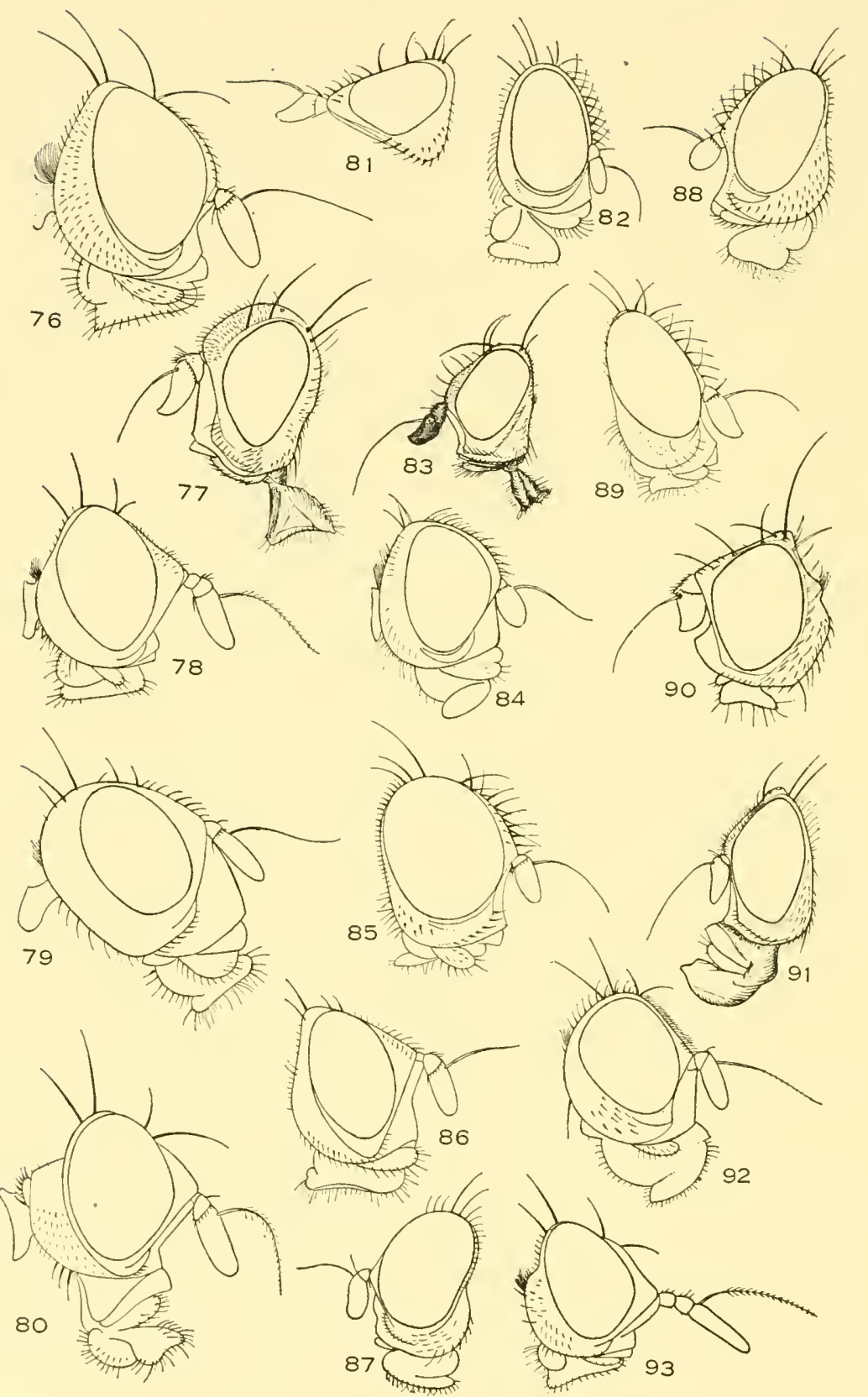

Otitide VI.-76, Melanoloma affinis; 77, Ceratoxys latiuscula; 78, Neoidiotypa appendiculata; 79, Myrmecomya; 80, Odontomera nitens; 81, Acrometopia (Chamæmyidæ); 82, Axiologina ferrum-equinum; 83 , Chætopsis enea; 84 , Seioptera vibrans; 85 . Euxesta annonæ; 86 , Himeroëssa pretiosa; 87 , Dasymetopa; 88 . Pareuxesta latifasciata; 89 . Notogramma stigma; 90, Dyscrasis; 91. Pseudopterocalla ; 92, Epiplatea arcuata; 93, Pœcilomyia longicornis. 

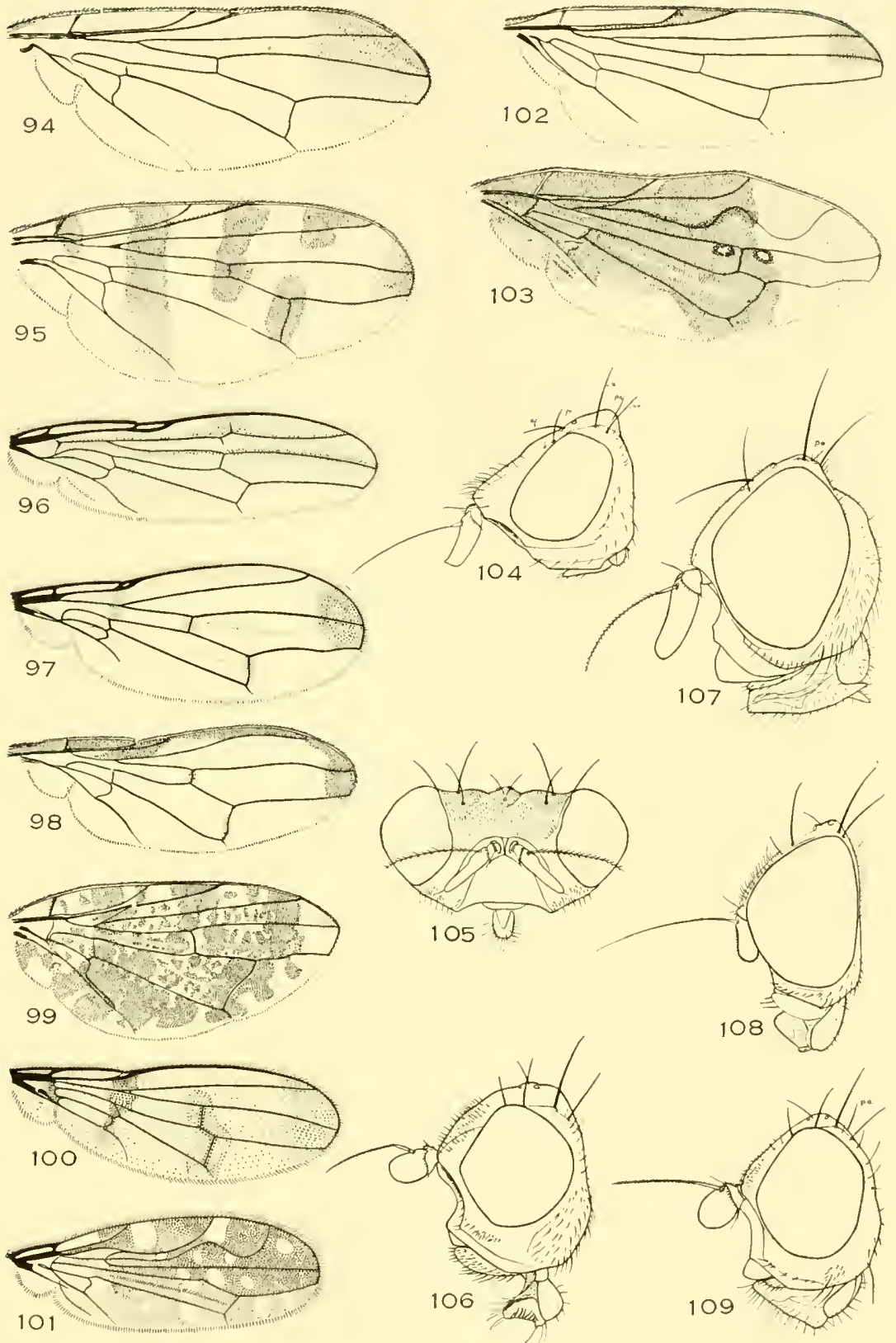

Otitidæ VII.-94, Ortalimyia; 95, Ceratoxys latiuscula; 96, Neoidiotypa appendiculata ; 97. Odontomera nitens; 98. Melanoloma decrepita; 99, Callopistromyia annulipes; 100, Hemixantha spinipes; 101, Paragorgopsis maculata; 102, Scioptera vibrans; 103, Pseudopterocalla; 104. Stenomyia; 105. Zetekomyia hanksi; 106. Callopistromyia annulipes; 107, Melanoloma decrepita; 108, Pterocalla; 109. Pseudotephritis vall. 
rated by a narrow earina, reaching to the oral margin, the third segment three times as long as wide; arista short plumose; facial grooves absent; two pairs of dorsocentrals; propleural and sternopleural bristles absent; seutellum with two pairs of bristles; posterior femora with bristles beneath; first vein bare above; anal cell rounded apically. Genotype:Z. bankisi, n. sp.

\section{Califortalis, new genus}

Related to Ceratoxys Rondani (Anacampta Lnw) but readily distinguished by the presence of three or four pairs of marginal scutellars, a single, hair-like frontal and the very hairy front. The single species has somewhat the aspect of certain species of Tetanops Fallén but the bristles of the vertex are long and fine. Genotype:-C. Tirsutifrons, n. sp., from California.

\section{Ortalimyia, new genus}

Related to Ceratoxys Rondani but the front bears only one pair of strong frontals and at most a very weak second pair, the head is longer, the facial carina higher, the face more retreating and the front narrower and less hairy. The bristles of the vertex are long and moderately strong. Genotype:-Ortulis snowi Cresson.

There has been much confusion concerning the identity of the genera mentioned in these notes. Cerutoxys differs from the other genera in the group by its conspicuously haired lumule. This leaves Califortalis, Tetanops and Ortalimyia and I think the characters in the key will serve to separate them. The front in T'tanops is always winkled or pitted and frequently pollinose except for the pits. 


\section{Family Trupaneidæ-The Fruit Flies}

Mostly rather small flies, usually with pictured wings, the anxiliary rein eurving forward at a right angle.

Head hemispherieal, ustally short; oral vibrissa not distinct, the face vertical or somewhat retreating. Front broad, with bristles laterally, the anterior orbitals situated close to the orbits. Antenure decumbent, short, rarely elongated. Proboseis of moderate length, rarely elongate and with the labella folding back, the labella usually broad and fleshy. Thorax with bristles although the anterior ones may be absent. Legs of molerate length, the tibie without preapical bristles. Wings large, usually with dark pattern, the auxiliary vein eurving forward at right angles and sometimes evanescent at the tip: bisal eells and anal cell always present, the latter often drawn out posteriorly into a long point or triangle. Abdomen composed of four or five segments; male genitalia small and only partly exposed; ovipositor segmented, usually exposed.

The adults are found in various habitats, often upon flowers. The larva live in the seeds and fruits of plants of varions kinds or form galls. One of our commonest species lives in the heads of thistles, several make galls on golden rod, while others, like the fruit maggots, live in apples, cherries, eitrus fruits, ete. Still others are leaf miners. The family is of considerable economic importance and has received a great deal of attention during recent years.

Among the papers essential to a study of the family are those listed below." Other referenees will be found given in the key. Infortunately the classification of this family is extremely artificial, being based largely upon the type of wing markings. In the key I have, in places, ignored the classifieation based upon wing maculation and a number of species must be shifted to genera in which they belong strueturally, although differing to a certain degree, in wing pattern. Only the fact that I do not have access to all the North American genera prevents a more thorough revision of the genera. Recognition of many of the deseribed species is difficult because they are not illustrated.

For many suggestions and the generons loan of material in this family I am greatly indebted to Mr. Marston Bates.

Loew, 1873, Mon. N. A. Nipt., iii, np. 211-351. Phillips, 1923, Rev. Trynet. N. E. Amer., Journ. N. Y. Ent. Soc., xxxi, 1). 119.155. Hendel, 1927, Flieg. Palæarht. Reg.Trypeticle. 

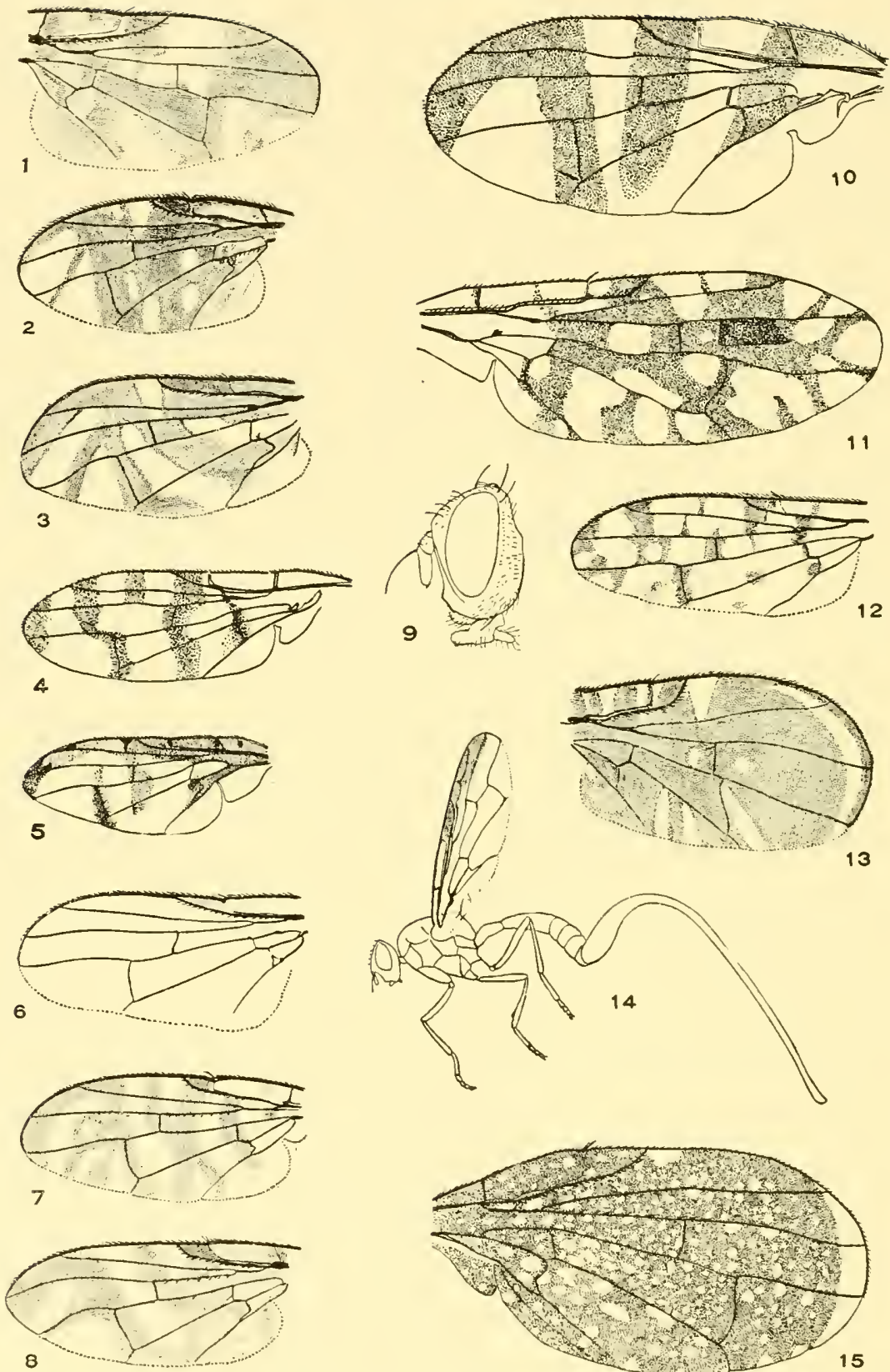
Trypaneidæ $1,-1$, Xenochata; 2, Hexachata; 3, Anastrepha; 4, Euribia rufipes; 5 ,
Acidia versatilis; 6, Neaspilota; 7 , Edicarena; 8 , Straussia; 9. Anastrepha; 10, Rhagoletis indifferens: 11, Tephritis jonesi; 12, Tephritis sp.; 13, Polymorphomyia basilica; 14, Toxotrypanea curvicauda; 15 , Eutreta pacifica. 


\section{KEY TO GENERA*}

1. Scutellum with six strong, regularly placed bristles............. 2 Scutellum with not more than two pairs of bristles or they are weak and not regularly placed, the apical pair being very widely separated 4

2. Front more than half as wile as the head (1)......... Xenochata Snow Front decidedly less than half as wide as the hearl.............. 3

3. Triangle of the anal cell longer than the petiole $(46,70)$.

Blepharoneura Lœw Triangle of the anal cell shorter than the petiole $(2,69)$. Hexachrta Loew

4. Scutellum with two pairs of bristles, the apical pair strong......... 5 Scutellum with one pair of strong bristles or if with two pairs the apical pair is absent and there are two pairs on the basal half..... 36

5. Fourth vein not or scarcely curved forward at the apex.......... 6 Fourth vein strongly curved forward at the apex $(3,9)$.

Anastrepha Schiner

6. Anterior pair of dorsocentrals situated far in front of a line drawn between the anterior pair of supra-alars..................24

Anterior dorsocentrals situated at most slightly in front of such a line,

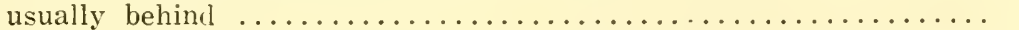

7. Proboscis very long and slender, geniculate; (Asimoneura Czerny; Rhynencina Johnson; Aleomyia Phillips) $(4,42) \ldots .$. Euribia Latreille Proboscis short and thick, not geniculate in the middle........... 8

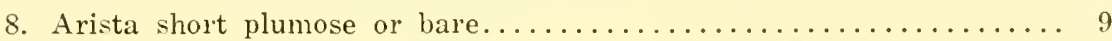
Arista long plumose.................... Mlolynocolia Giglio-Tos

9. Scutellum not mostly shining black or the apex yellow or sulcate.... 10 Scutellum mostly shining black, the base narrowly yellow, the apex never sulcate $(29,66) \ldots \ldots \ldots \ldots \ldots \ldots \ldots \ldots$ Ceratitis McLeay

10. Acrostical and dorsocentral bristles in an almost transverse row $(5,60)$. † Acidia Desvoidy

Dorsocentrals placel far in front of the acrosticals so that there appear to be two pairs of clorsocentrals....................... 11

11. Notopleura with several setulæ near the posterior bristle $(24,63)$.

12. Cheeks at most slightly more than one-fourth as wide as the eyeheight, if cloubtful the scutellum is sulcate.................... 13

Cheeks at least two-fifths as wide as the eye-height; oral margin not

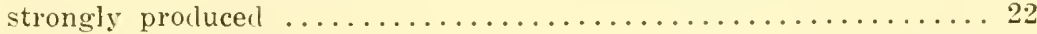

13. Stigmatal cell long and narrow, four times as long as wicle; wings reticulate $(21,36) \ldots \ldots \ldots \ldots \ldots \ldots \ldots \ldots \ldots \ldots \ldots \ldots \ldots \ldots \ldots$ Icterica Low

Stigmatal cell shorter and broader, not over three times as long as widle; wings not reticulate......................... 14

* Baryplegma Wulp is omitted.

$\doteqdot$ Trypeta versatilis Curran is a true Acidia while Acidia fratria Low is a true Trypeta. 


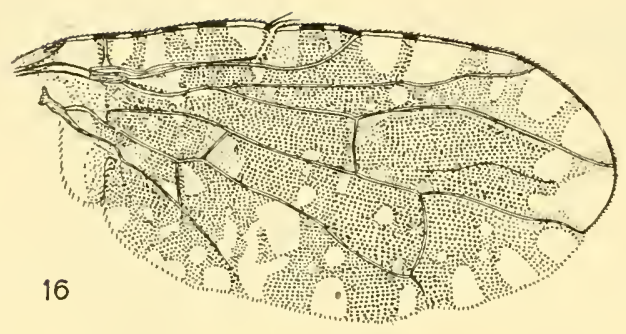

22
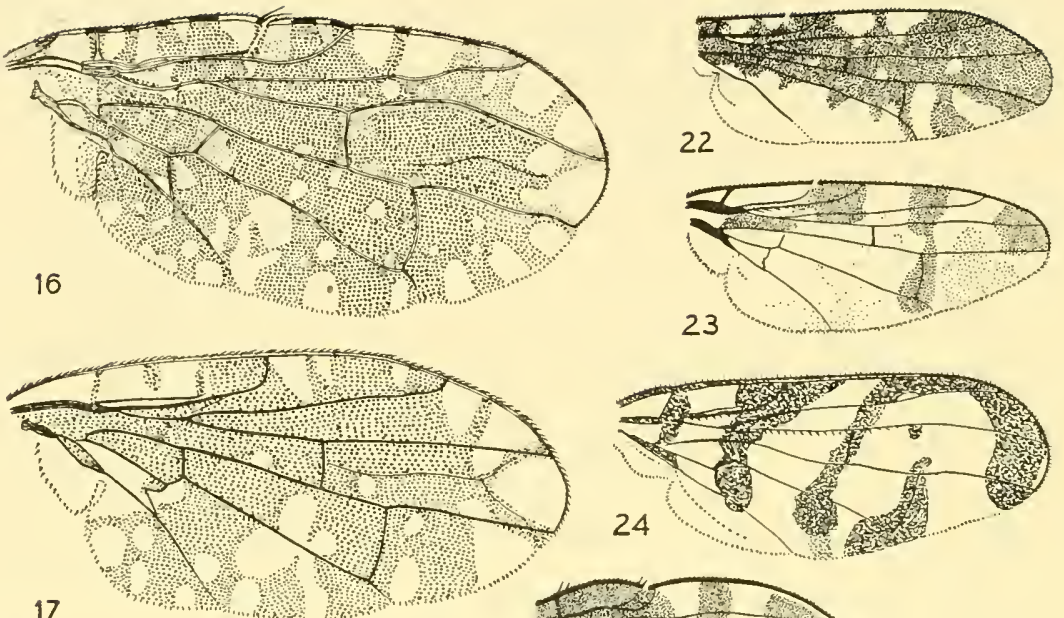

17
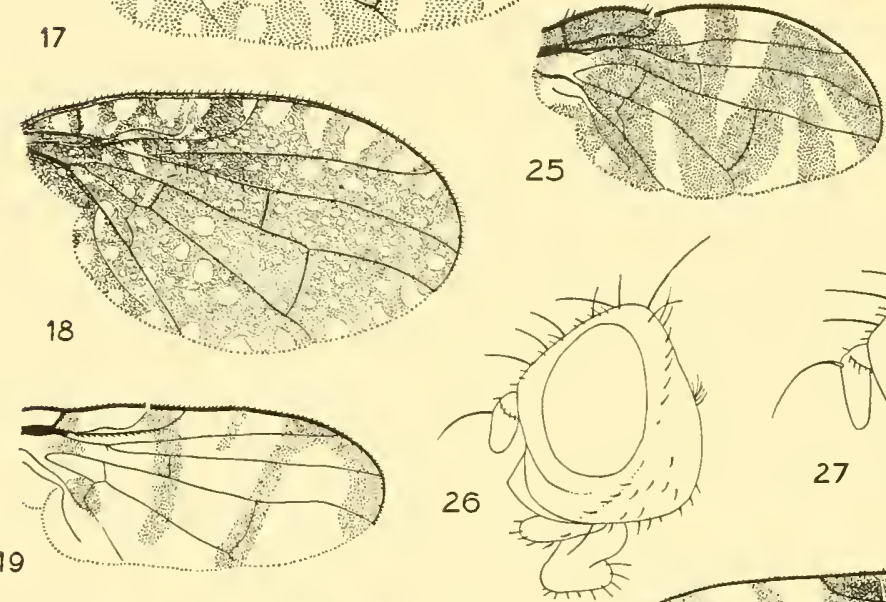

25
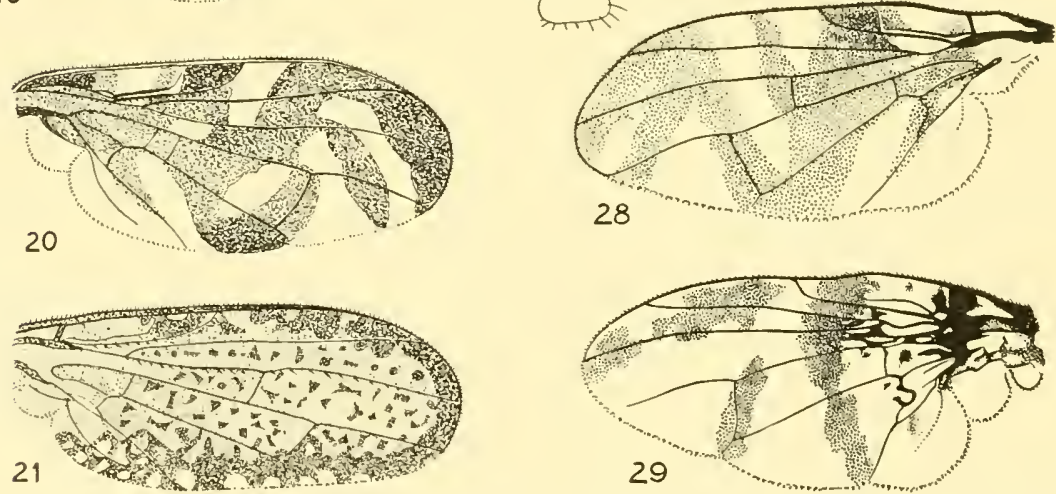

Typaneide II.-16, Eurostina confusa ; 1 \%, Tetreuaresta obscuriventris; 18 , Xanthomyia platyptera; 19, Zonosema; 20. Trypeta fratria; 21, Icterica circinata; 22, Eucosmoptera tetraspina; 23, Terellia floriscentiz; 24, Epochra canadensis; 25. Stenopa vulnerata; 26, Orellia; 27,28 , Myoleja cresio; 29, Ceratitis capitata. 


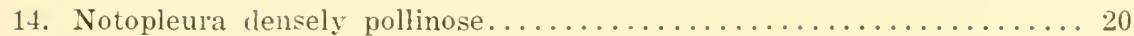

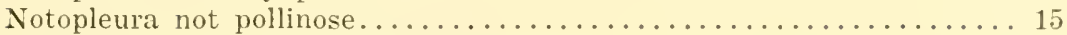

15. Third antennal segment little longer than the basal two combined, never triangularly produced at the tip................... 18

Third antennal segment elongate, usually produced as a sharp triangle

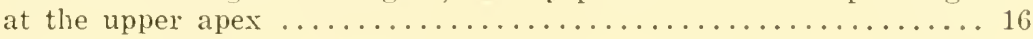

16. Postcallar (postalar) bristle situated far in front of the posterior

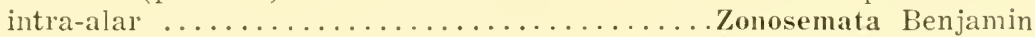

Postcallar, intra-alar and acrostical bristles in almost straight line...16a

16a. Dorsocentral bristles situated well behind the supra-alar bristles

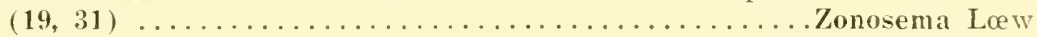

Dorsocentral bristles situated at most very slightly behind the supraalar's, usually slightly in front of them..................

17. Third longitudinal vein with at most two basal setulæ, usually bare; anterior crossvein situated but little bevond the midlle of the cliscal cell $(10,43) \ldots \ldots \ldots \ldots \ldots \ldots \ldots \ldots \ldots \ldots \ldots \ldots \ldots \ldots \ldots \ldots \ldots$ Rhagoletis Lœw

Third rein with several strong setulæ on basal part; anterior crossvein situated well beyond the middle of the discal cell (Euleia Walker)

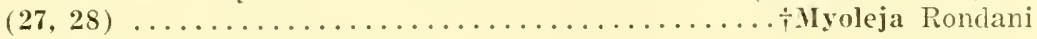

18. Scutellum swollen, convex, more or less deeply longitudinally groover apically (Tomoplagina Curran) $(58,65) \ldots \ldots \ldots \ldots$. Peronyma Lœw

Scutellum flat dorsally, not at all grooved................. 19

19. Face more or less carinate, not concave in profile, the oral margin not produced $(20,49) \ldots \ldots \ldots \ldots \ldots \ldots \ldots \ldots \ldots \ldots \ldots \ldots \ldots \ldots \ldots \ldots \ldots$ Trypeta Meigen Face concave in profile, the oral margin protuced $(23,62)$.

Terellia Desvoidy

20. Costal spine not longer than the thickness of the costa; wings narrow. 21 Costal spines more than twice as long as the costal thickness; wings very broad, reticulate $(18,37) \ldots \ldots \ldots \ldots \ldots \ldots$ Xanthomyia Phillips

21. Wings reticulate; abdomen with paired shining black spots; oral margin not procluced $(47,53) \ldots \ldots \ldots \ldots \ldots \ldots \ldots \ldots$ Acidogona Low

Wings hyaline, rarely banded; abrlomen without paired black spots; oral margin conspicuously produced $(6,34)$... \$Neaspilota Osten Sacken

22. Scutellar bristles longer than the scutellum; antennal pits limited be-

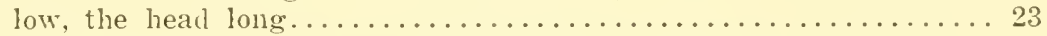
Scutellar bristles very short; antennal pits almost obsolete; thirl antennal segment with several hairs above; tibire swollen $(40,57)$.

FPrgotoides, 11, g.

23. Fourth vein ending at or near the tip of the wing $(7,30)$.

(Edicarena Snow

* Cresson, 1929, Tr. Amer. Ent. Soc., lv, pl. 401-414, 1 plate. Curran, 1932, Amer. Mus. Novit. No. 526, n. 5.

$\rightarrow$ Euleia Walker is the older name but there is considerable doubt about the identity of the genotype and I use Myoleja to avoid confusion.

t Acidia fratria Lew belongs here.

$\$$ Curran, 1932. Amer. Mus. Novit. No. 526. p. 3.

- A large species resembling the species of Pyrgota but distinguished by wing venation, viesence of strong ocelli, shape of the hearl, etc. The genotype is crassipes n.sp. from Panama. 


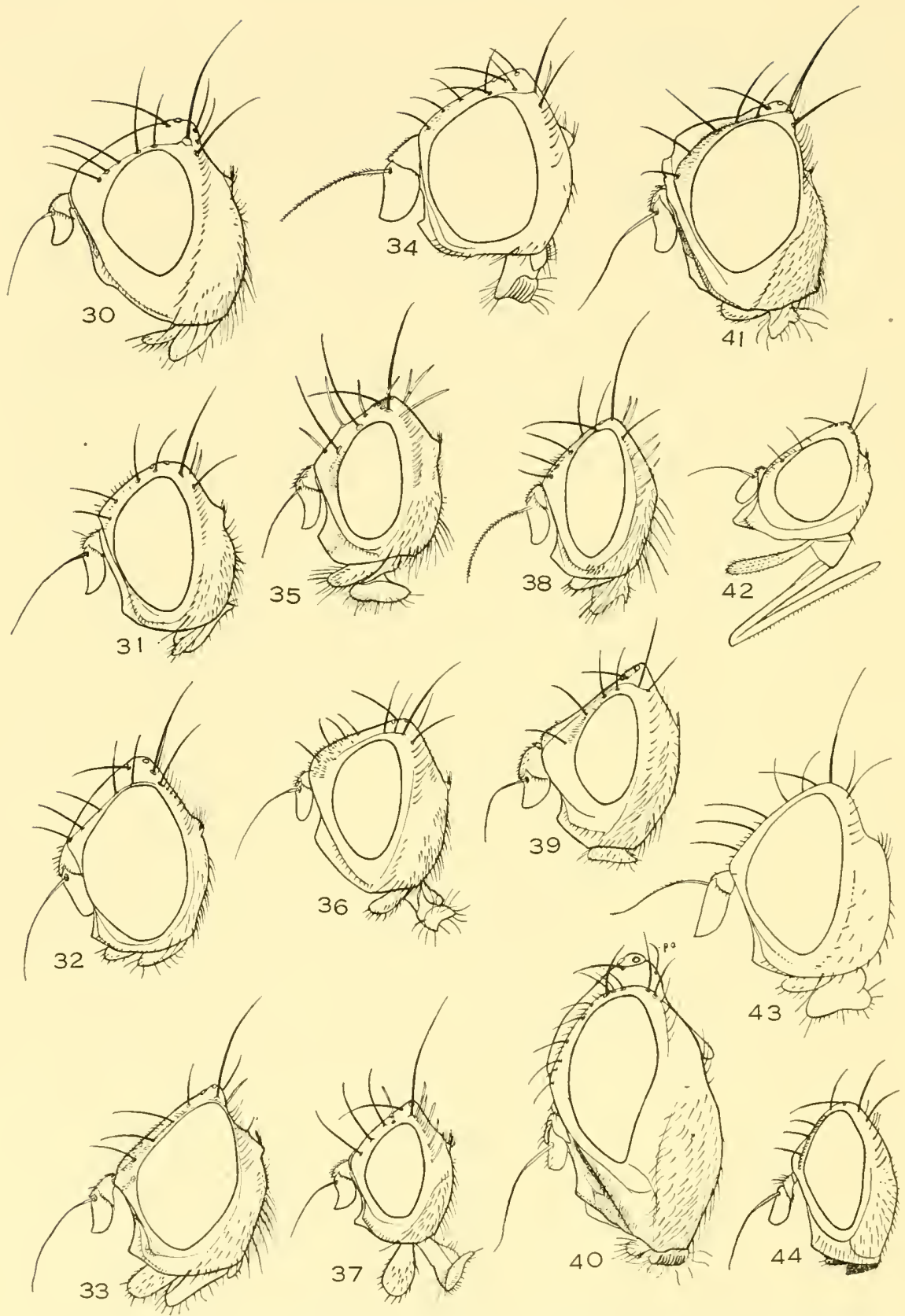

Trypaneidx MI.-30, Edicarena diffusa ; 31, Zonosema electa; 32, Toinoplagia; 33 , Eutreta; 34 . Neaspilota albidipennis: 35 . Paracantha; 36 . Icterica sericata; 37 , Xanthomyia platyptera; 38 , Stenopa vulnerata ; 39 , Eurostina confusa; 40, Pyrgotoides clavipes; 41, Polionota; 42 , Euribia; 43, Rhagoletis cerasi; 44, Procecidochares. 
Fourth vein ending behind the tip of the wing, the wing-apex near the third vein; wings rather pointed $(8,50,51) \ldots \ldots$. Straussia Desvoidy

24. Anterior and posterior crossveins separated from each other by much less than half the length of the anterior crossvein; posterior crossvein very strongly recurrent (13)............Polymorphomyia Snow

Crossveins much less approximate; posterior crossvein not strongly

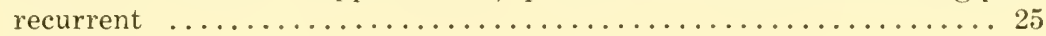

25. Scuttellum strongly shining black, swollen and hemispherical....... 26 Scutellum more or less dull, more or less flattened or at most moder-

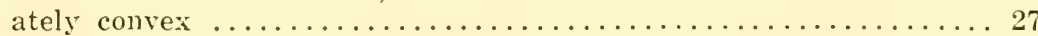

26. Parafacials bare $(44,79) \ldots \ldots \ldots \ldots \ldots \ldots$ Procecidochares Henclel Parafacials with a row of rather long pale hairs (61)...Callachna Aldrich

27. Notopleura cinereous pollinose....................... 28

Notopleura bare or rather thinly brownish pollinose........... 31

28. Anal cell drawn out posteriorly into an elongate triangle.......... 29 Anal cell not drawn out apically, or with a short, transverse triangle (Euaresta Lœw; Urophora Lœw) $(11,12,61) \ldots .$. . Tephritis Latreille

29. Antennal pits not deep, not separated and strongly marked........ 30 Antennal pits deep, separated and strongly defined $(41,48)$.

"Polionota Wulp

30. Face and front rather strongly narrowed to the antennæ; oral margin with hair only on the anterior half $(17,54) \ldots \ldots$ Tetreuaresta Hendel

Face and front not strongly narrowed to the antennæ; oral margin with bristles almost to the oral angles $(45,59) \ldots \ldots \ldots \ldots$ Acrotænia Lœw

31. Anterior crossvein situated not more than its own length from the posterior, both strongly oblique $(32,72) \ldots \ldots \ldots$ Tomoplagia Coquillett

Anterior crossvein situated more than its length from the posterior,

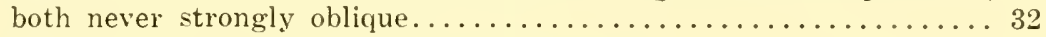

32. Stigmal cell scarcely longer than wide $(25,38) \ldots \ldots \ldots \ldots$. . . . Stigmal cell usually twice as long as wide, always much longer...... 33

33. Front with two pairs of black reclinate bristles, none converging (35,

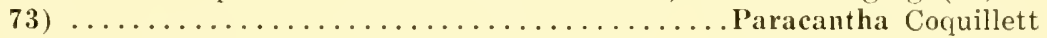
Front with three pairs of convergent frontals.............. 34

34. Costal spires short and not very conspicuous............... 35 Costal spines rather long arch conspicuous $(15,33) \ldots \ldots \ldots$. $5 u$ treta Lœw

35. Wings with crossbands $(26) \ldots \ldots \ldots \ldots \ldots \ldots \ldots$ Orellia Desvoidy Wings with a brown pattern containing hyaline inlentations and spots (22) Eucosmoptera Phillips

* The single specimen I have before me is loaned by Dr. Aldrich and is determined as mucida Giglio-Tos. The figure by Giglio-Tos shows the anterior crossvein in the hyaline costal triangle and much farther from the posterior crossvein than I find it. The species I have illustrated may not be mucida, and may even belong to a different genus, denending upon the shape of the head. Mr. Van der Wulp's drawing is noor in regard to the anal cell.

$\uparrow$ This genus is very doubtfully distinct from Acrotania.

$¥$ Curran, 1932, Amer. Mus. Novit. No. 556 . 

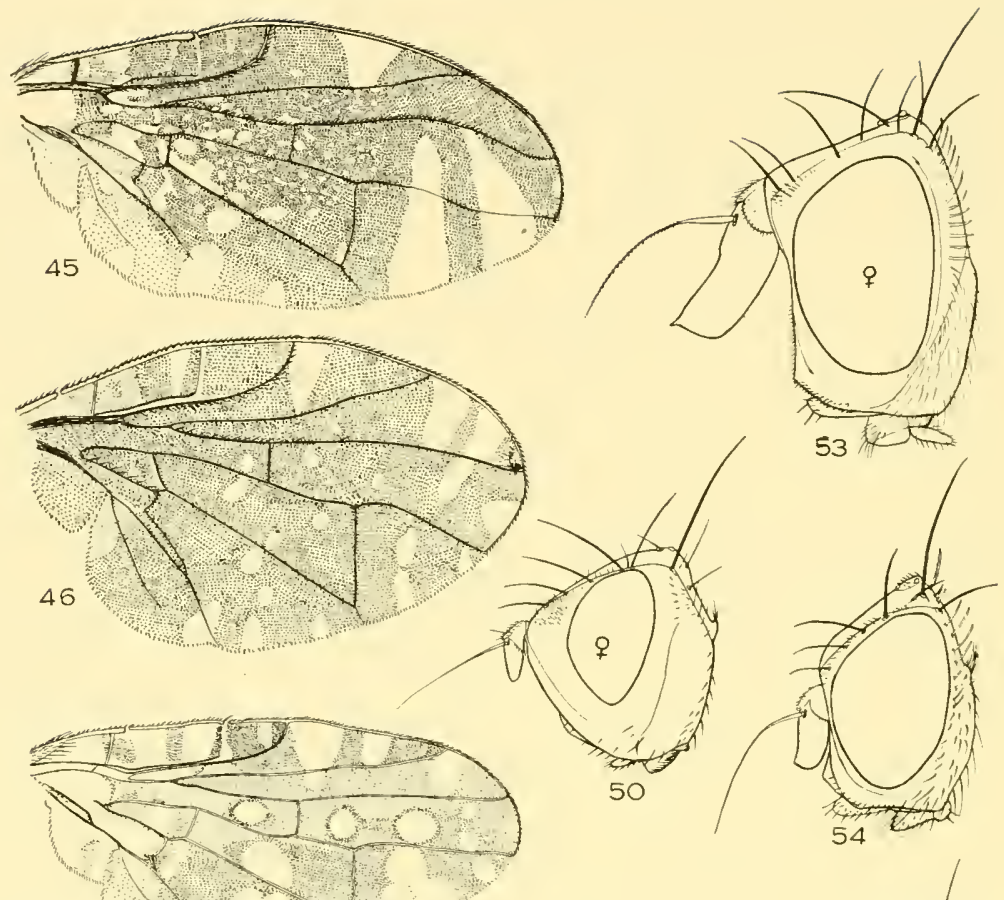

47
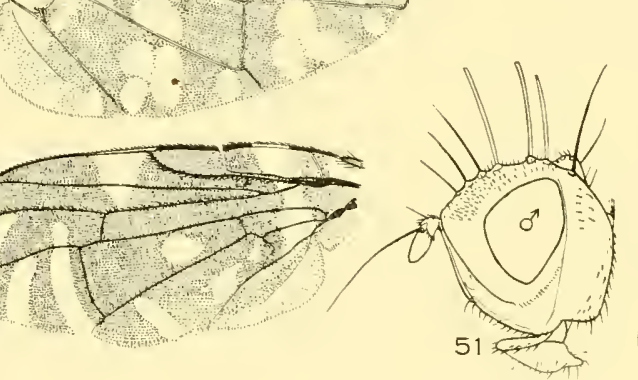

48
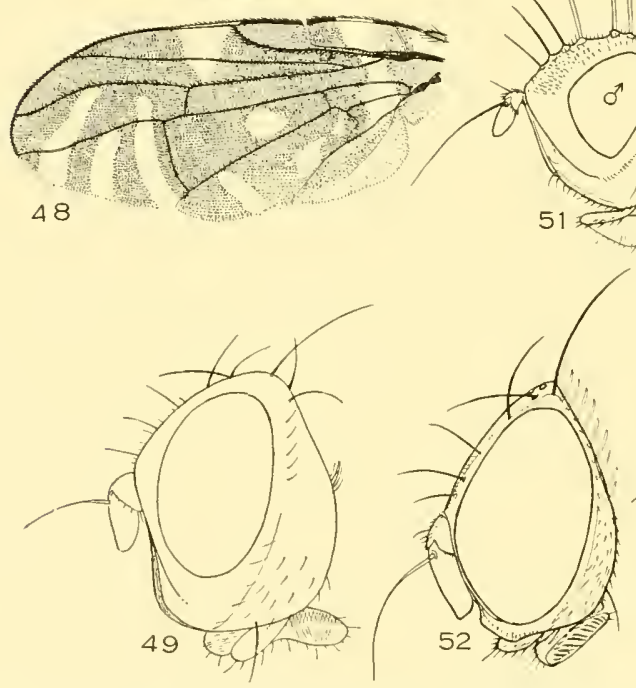

53 तोin

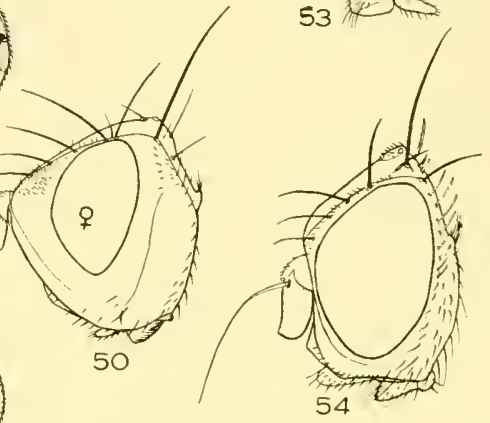

Trypaneidæ IV. -45, Acrotænia; 46. Blepharoneura; 47. Acidogona; 48. Polionota; 49, Trypeta: 50, 51. Straussia longipennis; 52 , Xanthaciura insecta; 53. Acidogona melaneura; 54 . Tetreuaresta obscuriventris; 55 , Eurosta comma; 56 . Trypanea. 
36. Front bristles well developed; ocellars present.............. 37 Frontals weak; ocellar's absent; ovipositor very long and cylindrical (14) Toxotrypanea Gerstæcker

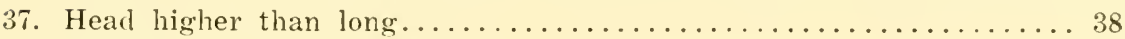

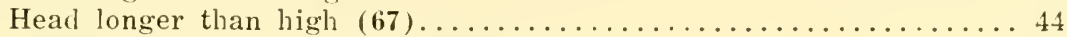

38. Scutellum without a leep longitudinal furrow................ 39 Scutellum swollen and with a deep longitudinal furrow $(\mathbf{5 8}, \mathbf{6 5})$.

Peronyma Lœw

39. Front immediately above the antennæ almost half as wide as the head and very much wider than either eye................... 40

Front much less than half as wide as the head and, anteriorly, little if any wider than one eye from anterior view.............. 41

40. Anterior pair of dorsocentrals situated far in front of a line drawn between the anterior pair of supra-alar bristles $(16,39)$.

* Eurostina Curran

Anterior pair of dorscentrals situated at most slightly in front of a line drawn between the anterior supra-alars or behind such a line

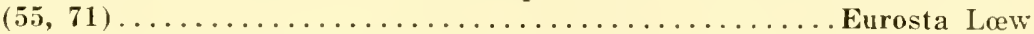

41. Front twice as long as the width at vertex $(52,74) \ldots$ Xanthaciura Hendel Front much less than twice as long as the wilth at vertex......... 42

42. Front with at least three pairs of convergent frontal bristles........ 43 Front with two pairs of convergent frontals (76).... Dyseuaresta Hendel

43. Head almost as long as high, the oral margin projecting; eyes oblique, broadly oval $(56,75) \ldots \ldots \ldots \ldots \ldots \ldots \ldots \ldots$ Trupanea Schrank Head much higher than long, the oral margin but little projecting; eyes perpendicular, rather narrowly oval $(68,78) \ldots \ldots \ldots$ Aciurina Curran

44. Third antennal segment short, the apex rounded (Europe) (67).

Third antennal segment rather long, the upper apex angulate (77).

Ensina Lœw

Paroxyna Hendel

The student will find it difficult to locate many species described in genera other than those to which they are now assigned. In the following list are given (1) the present genus and (2) in ( ) the genera in which species may be found.
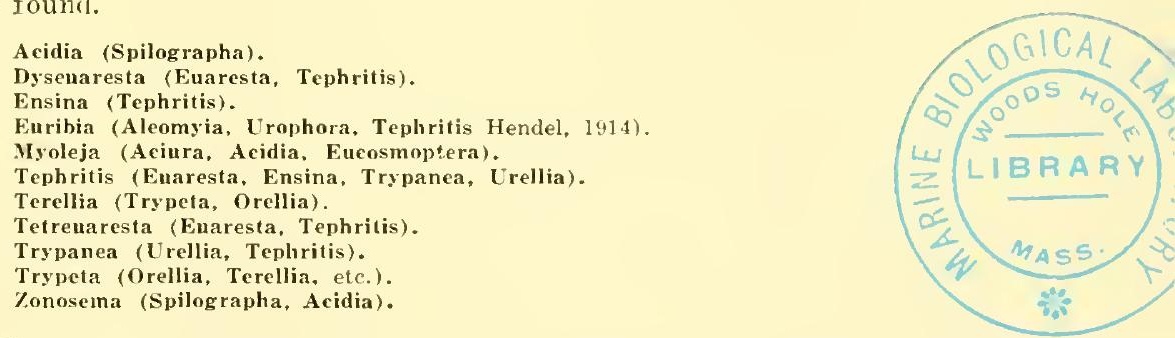

\footnotetext{
* Originally Eurosta latifrons Low was named as type of this genus but the species is a true Eurosta and does not possess the generic characters of Eurostina. The type of the genus should be known as Eurostina confusa, Slosson Collection, Delaware Water Gap.

† Curran, 1932. Amer. Mus. Novit. No. 556 (Trypanea).

t Curran, 1932, Amer. Mus. Novit. No. 556. In a letter to the author Dr. Hendel suggested the synonymy of this genus with Tephrella Bezzi and this is quite possible. However, 1 am retaining Aeiurina on the suggestion of $\mathrm{Mr}$. Bates, as a comparison of specimens with the genotype of Tephrella, a little known species, may prove that two genera exist.
} 

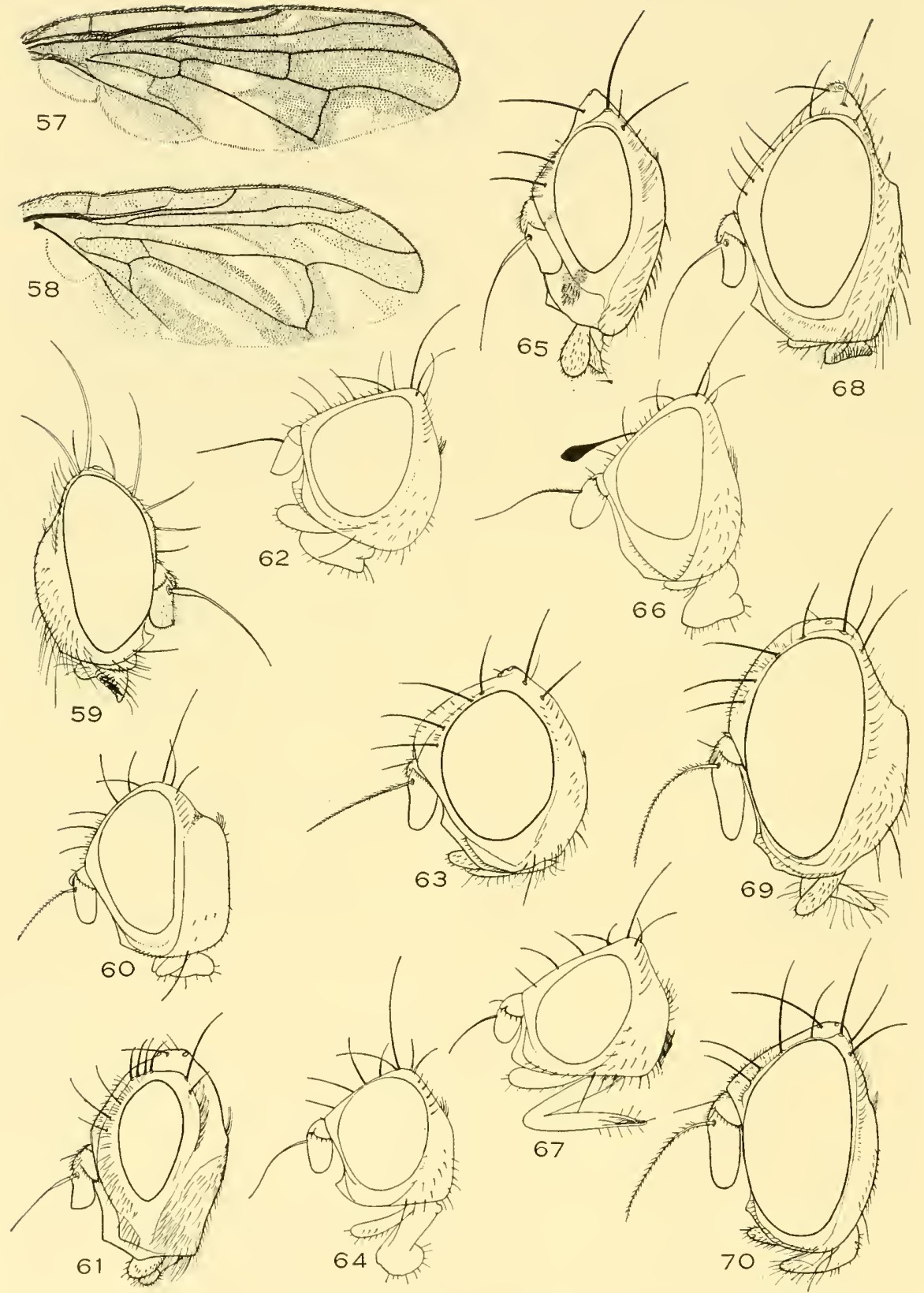

Trypaneide V. 57. Pyrgotoides clavipes: 58. Peronyma; 59, Acrotænia; 60, Acidia ; 61 . Callacilia; 63 , Epochra canadensis; 64, Tephritis; 65. Peronyma maculata; 66 . Ceratitis capitata; 67, Paroxyna; 68, Aciurina; 69. Hexachefa; 70, Blepharoneura (sp. Panama). 
Mr. Bates has furnished the following list of species giving the correct generic position according to our present concepts:

Acidia johnsoni Thomas = Aciurina.

Aciura limata Coquillett (Eucosmoptera Phillips) = Myoleja.

Aciura nigricornis Doane (Eucosmoptera Phillips) = Myoleja.

Rhagoletis formosa Coquillett $=$ Euribia.

Rhagoletis grindelia Coquillett = Euribia.

Rhynencina longirostris Johnson = Euribia.

Trypeta baccharis Coquillet $=$ probably Tephritis.

Trypeta bigelovize Cockerell (Eurosta Townsend) = Aciurina.
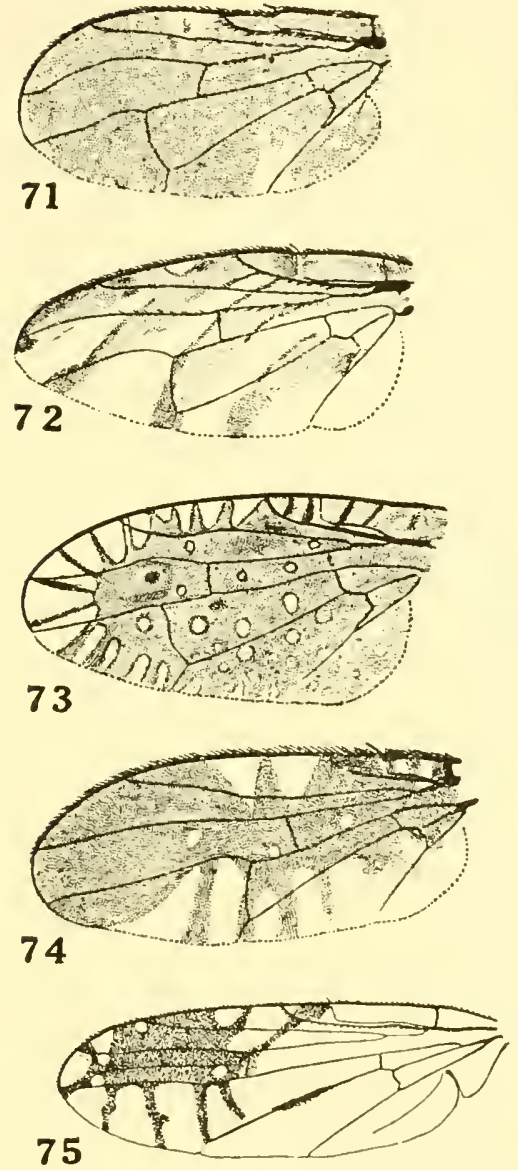
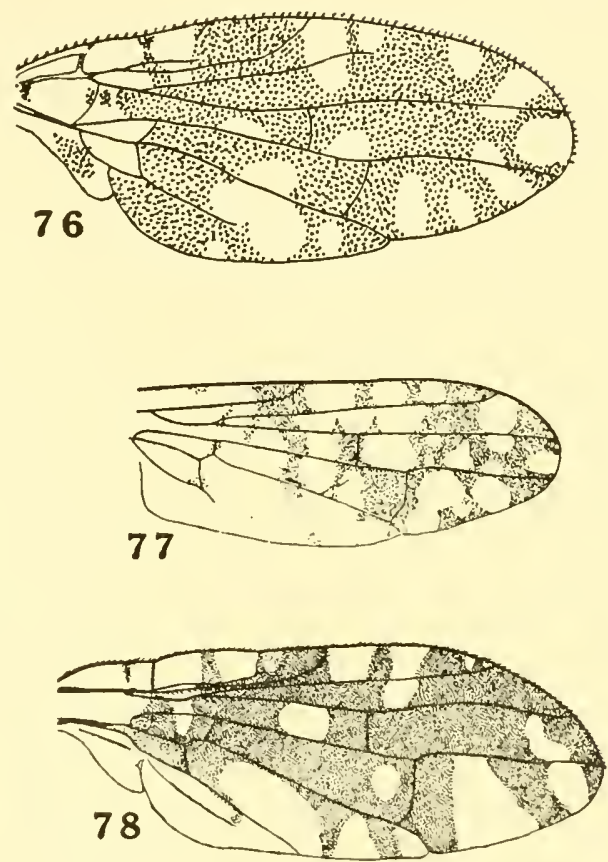

79

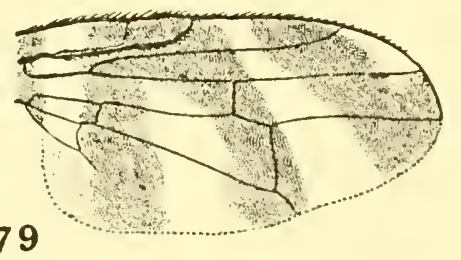

Trypaneida V1.-71, Eurosta; 72, Tomoplagia; 73, Paracantha; 74, Xanthaciura insecta; 75. Trypanca wheeleri; 76 , Dyseuaresta plesia; 77 , Ensina; 78 , Aciuriua trixa; 79 . Procecidochares. 


\section{Family Pallopteridæ}

Flies of mediun size, usually with pictured wings, the auxiliary vein entire.

Head higher than long; oral vibrissæ absent; a single pair of frontal bristles; ocellar's present; post-ocellars parallel; face slightly receding; anteme rather short, the third segment oval; arista short plumose or bare. Mesonotum bristled in front of the suture (except in two species); propleural bristle usually absent; one stemopleural bristle. liegs of moderate length; tibia without preapical bristle. Wings rather large; anal cell short, the anal vein extending to the wing margin; auxiliary vein free but ending close to the first vein, the costa weakened or broken at the point of union; apical cell not narrowed apically. Abdomen elongate oval, sub-cylindrical, the ovipositor flattened and elongate.

These flies are found in moist and shady places, ustually upon foliage, and along the sea-shore.
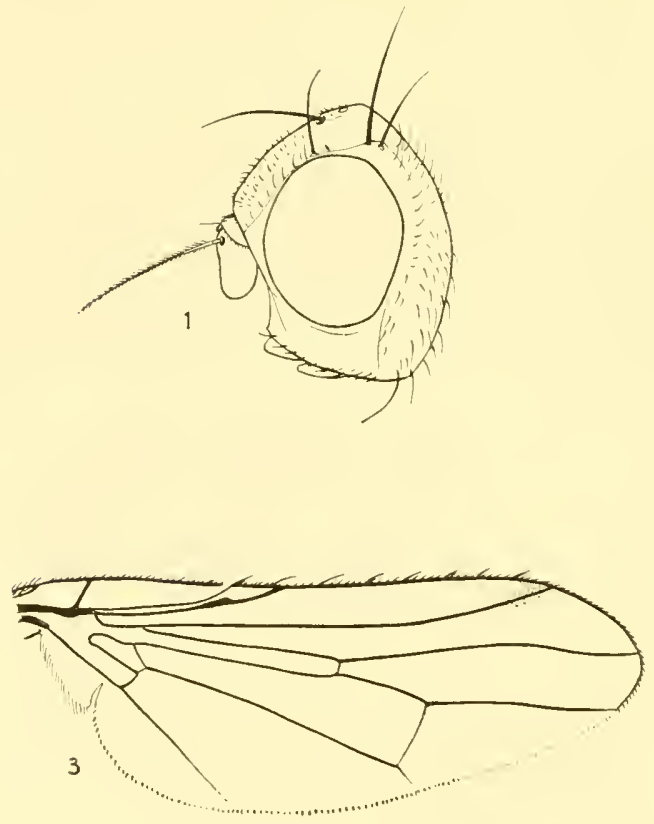

4
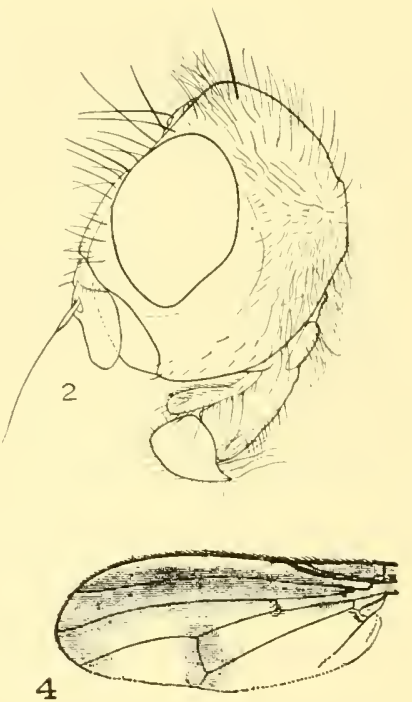

Pallopterida.-1, Palloptera arcuata ; 2. 3, Omomyia hirsuta ; 4, Palloptera jucunda. 
Palloptera Fallén has been considered the only genus and has been reviewed hy Malloch. * The genus has been placed in the lauxaniida and Lonchaida. It difters from the former in lacking preapical tibial bristles and from the latter in having the front transverse anteriorly, the lumule being eoncealed. In many respects it shows a relationship to the Helomyzida but is excluded from the group by its flattened ovipositor and is, perhaps, more closely allied to the Otitidx. The genus Omomyia, placed in the C'olopide by Coquillett, belongs here. It shows a remarkable sexual dimorphism, the males bearing long, woolly pile while the females show little trace of it.

\section{KEY TO GENERA}

1. Facial carina strong, the antennal grooves deep; males densely pilose $(2,3) \ldots \ldots \ldots \ldots \ldots \ldots \ldots \ldots \ldots \ldots \ldots \ldots \ldots \ldots \ldots \ldots$. . . . . . . . . . . . . Facial carina quite weak; antennal grooves shallow; never densely pilose $(1,4) \ldots \ldots \ldots \ldots \ldots \ldots \ldots \ldots \ldots \ldots \ldots \ldots \ldots \ldots \ldots \ldots \ldots \ldots \ldots$ Palloptera Fallén

* 1924. Proc. U. S. N. M., lxv, Article 12, pp. 6-7. 


\section{Family Lonchæidæ}

Small shining blackish flies, the anxiliary rein entire: the tibia withont preapical bristles.

Head shorter than high; face and front moderately wide; oral vibrissa absent; front with a single orbital, clothed with short hairs; ocellars present; postocellars divergent; antemne elongate, decumbent. Thorax bristled posteriorly; mesopleura with bristles behind; one or two sternopleurals; propleural present, the propleura without hair. Legs short; tibia without preapical bristle. Wing venation complete; second basal and anal cells short, the anal vein reaching the wing margin faintly, and bisinuate. Abdomen oval, rather flat; ovipositor rather long and triangular.

The adults occur almost everywhere but prefer moist or shady places. The larva live in plants or decaying regetation. They have been reared from under bark and may be predaceous.

This family is readily distinguished from the Periscelide by its entire auxiliary vein; from the Sapromyzida by the absence of preapical tibial bristles on at least the anterior and posterior tibia and from the Pallopteride by the presence of a propleural bristle and the exposed frontal lunule.

Lonchau Fallén is the only genus recognized although Earomyia Zetterstedt may be distinguished by having the frontal lunule bare. Malloch" has reviewed the species. A few have been deseribed since the publication of his paper.

*3 1924. Proc. U. S. N. M., lxv, Art. 12, Dr, 3-6.
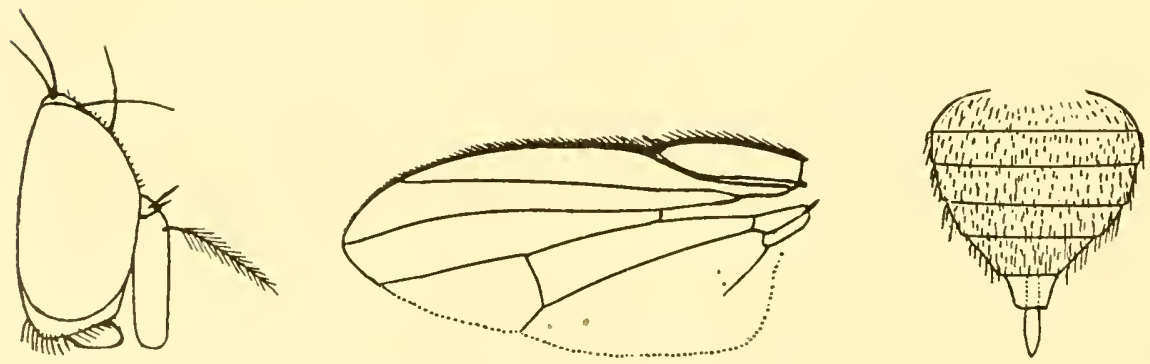

Lonchiea, head, wing and abdomen. 


\section{Family Ropalomeridæ}

Moderately large tropical flies of a brownish and grayish color.

Front broad, exeavated, with or without bristles; face broad, carinate, tuberenlate or the oral margin prominent; eheeks broad, hairy; elypeus projeeting; oral vibrisse absent; proboseis short, the palpi slender or dilated; antemna short; arista dorsal, bare or plumose. Thorax elongate; mesonotum with but few bristles, usually more or less mottled with gray and brown: scutellum often prominent and grooved. Abdomen shorter than the wings, flattened; hypopyginm moderately large, largely concealed; ovipositor telescopie, projecting. Femora all
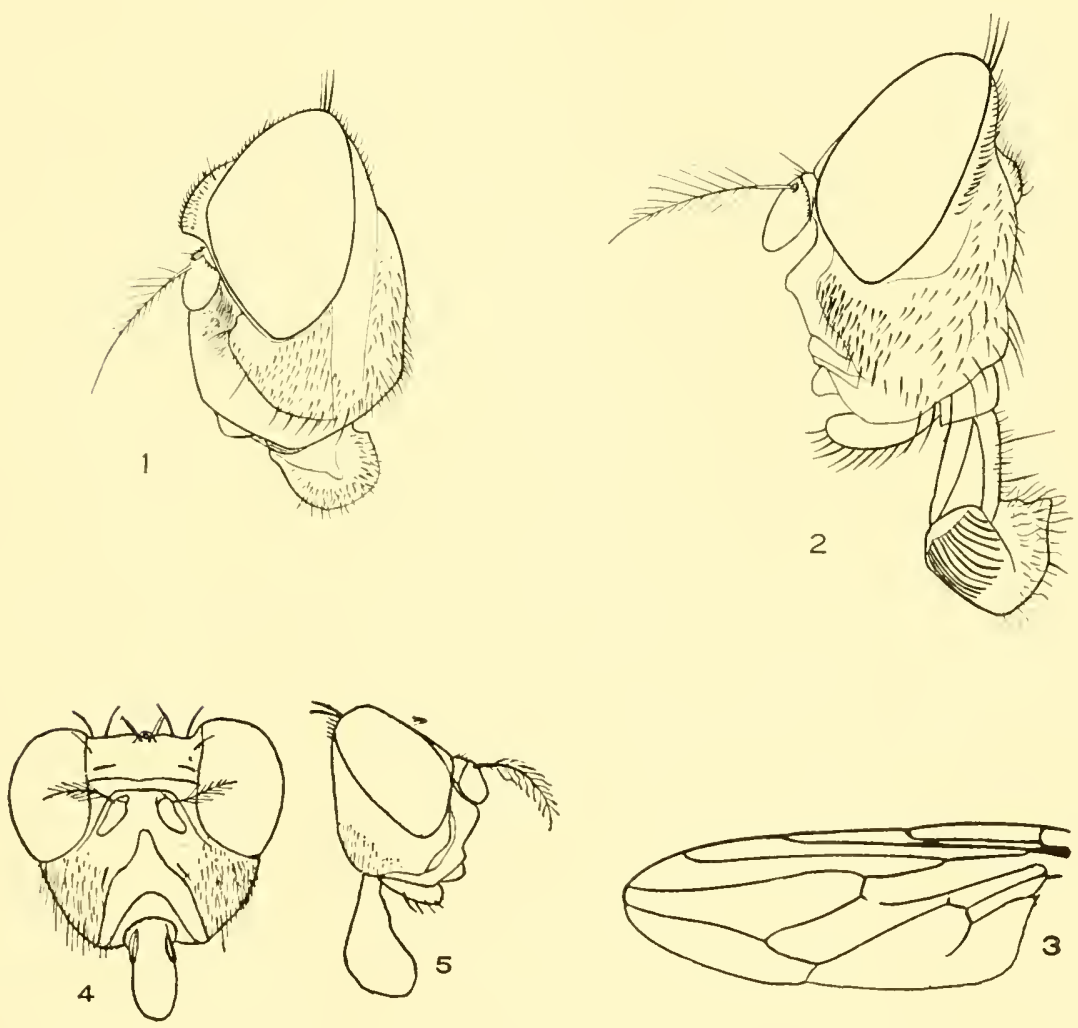

Ropalomeridæ.-1, Willistoniella ; 2, 3, Ropalomera ; 4, Willistoniella; 5, Apophorhynchus. 
thickened; posterior tibir often dilated. Apical cell narrowed apieally; auxiliary rein absent or present: seeond basal and anal eells present.

Only about a dozen species are known, all oceuring in Central or Sonth America. Evidently they are not uneommon at certain seasons of the year as Mr. Banks seeured a number of speeimens in Panama during July and August although I saw only two from Deeember to Mareh. They are evidently seashore inhabitants which extend their range up the rivers. The adults are fast in flight and are exeellent hoverers. There is a reeent revision of the family by Lindner.*

\section{KEY TO GENERA}

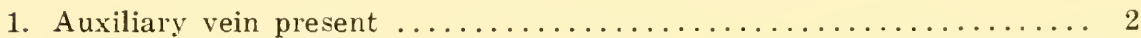

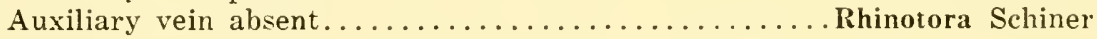

2. Scutellum oval ............................... 3 Scutellum pyramidal, directed obliquely upward; arista plumose or bare

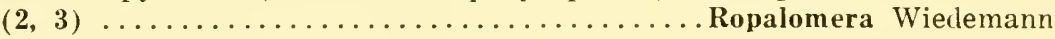

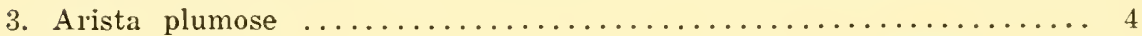
Arista bare ........................ Këberia Lindner

4. Face tuberculate; frontal bristles absent (5)....Apophorhynchus Williston Face carinate; frontals present $(1,4) \ldots \ldots \ldots \ldots \ldots$ Willistoniella Mik

* 1930. Deutsch. Ent. Zeitschr.. 1930-31, pp. 122-137. 


\section{Family Tanypezidæ}
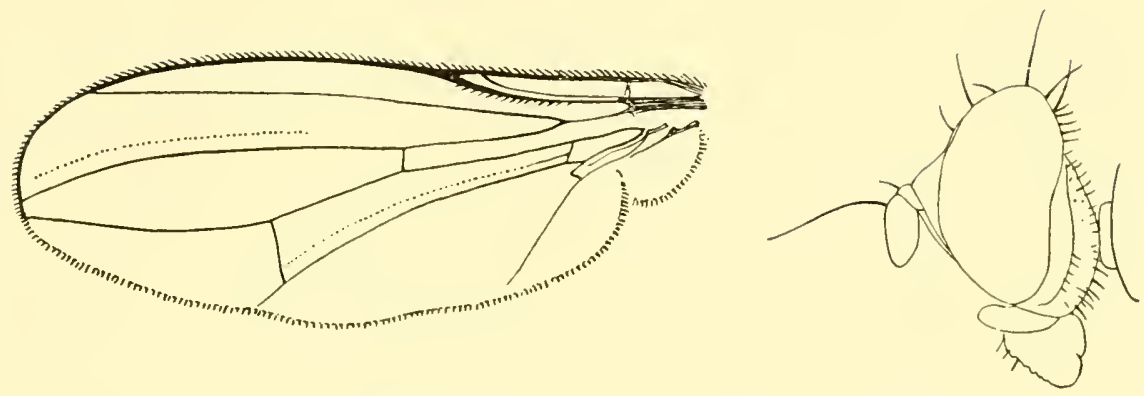

Tanypeza, head and wing.

Medium sized flies, with rather long, slender legs.

Head higher than long; face retreating below; two pairs of frontals: ocellars proelinate; antenna pendulous, the third segment oval, moderately large; oral vibrissa absent; palpi broadened. Thorax with only one pair of dorsoeentrals; one humeral; no sternopleurals, one or two bristles on the mesoplema above, the mesoplema and pteroplemra haired. Legs long, slender, withont bristles. Wings with the apieal cell narrowed; anal cell rounded apieally, about as long as the second basal; first vein setulose above; anxiliary vein entire, tonching the first rein before its end.

The adults ocemr in moist woods and are by no means numerous in collections. The inmature stages ase unknown.

Tanypeza Fallén is the only known genus muless Tctiadiscus Bigot is distinct. Mowever, Tetradiscus may not helong to this family and is too poorly deseribed to be recognizalble. There are fewer tham a dozen known species belonging to the family, most of them occurring in the Neotropical region while one is known from Europe. 

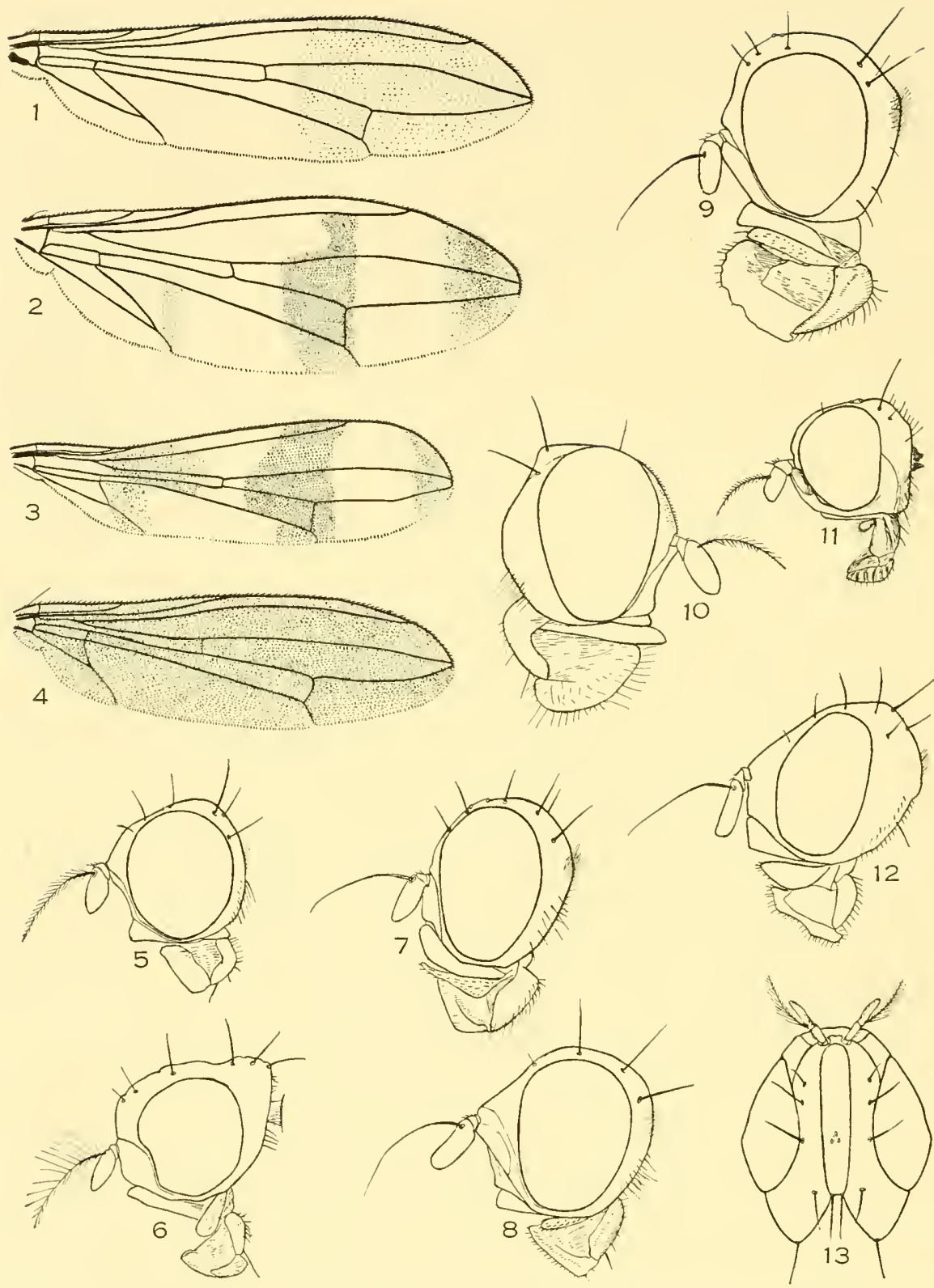

Calobatidx I.-1, Parasphen ruficauda; 2, Ptilosphen; 3, Rainieria; 4, Scipopus diversus; 5. Grallipeza; 6, Cardiacephala; 7, Grallomya; 8, Hoplocheiloma; 9, Scipopus; 10, Parasphen; 11, Calobata univittata; 12 . Tæniaptera; 13 , Cardiacephala. 


\section{Family Calobatidæ-The Stilt-legged Flies}

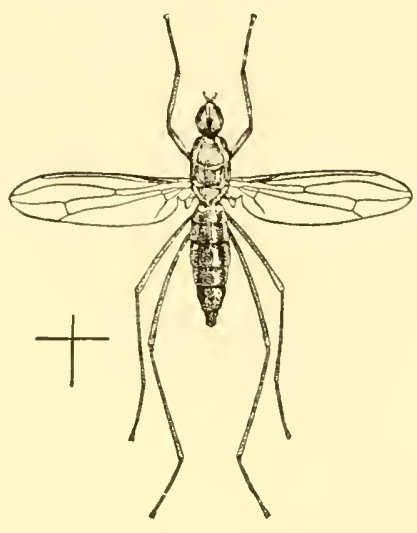

Calobata univittata.

Elongate flies with very long legs and dorsal, bare to plumose arista.

Head higher than long, rather orbicular or elongate, the front wide in both sexes and usually with bristles; face usually reeding, the oral margin more or less produced, the elypens large and polished; palpi flat and broad; antenne of moderate length, pendulous, with dorsal, bare to plumose arista. Thorax elongate, bristled posteriorly and on the sides; stemopleura with long bristly hair behind; true sternopleural bristles absent; pteroplema hare. legs very long, the anterior pair widely separated from the middle pair, femora rarely with small bristles, the posterior four tibia usually with tiny bristles. Wings long, usually marked with brown or black, the anal eell rectangular or angulate apically; apical cell usually narrowed apically; auxiliary vein lying very close to the first vein and usually partly tonehing it, rarely ending well before the first rein. Abdomen long and narrow, the ovipositor long.

The adults are found near moist places in the Neartic region but seem to oceur everywhere in the tropies, where they are seavengers, and eridently the larve live in exerement. Some species have been reared from exerement and the adults are attracted to it in very large numbers. However, I have found a few of the tropical speeies only on foliage near streams and these may have a different habit. Enderlein* has reviewed the group and Cresson has deseribed many species.

* 1922, Arch. für Naturg., lxxxiii, Abt. 5, ly. 140-229. 
As here understood this family comprises the genera Calobata, and Cardiuccphala of the old family Hieropezidx. They really have little in common with this latter group exeept a superficial resemblance. The classification of the family is poor and several of the genera are based upon what appear to be trivial charaeters. Several of the genera oecurring in South Ameriea, as well as a few included in the following key, are unknown to me so I am unable to do more than use the charaeters eited by their deseribers although I think that most of the genera are well founded and eould be readily reeognized upon eharacters other than those used. The genus Cardiacephala Sehiner, of whieh I consider both Plocoscelus Enderlein and Rhocius Enderlein to be synonyms, merely displays a diversity in head shape not found in other groups, but no sharp lines can be drawn between the three proposed genera. Some insects show speeialization along one line, others in other ways.
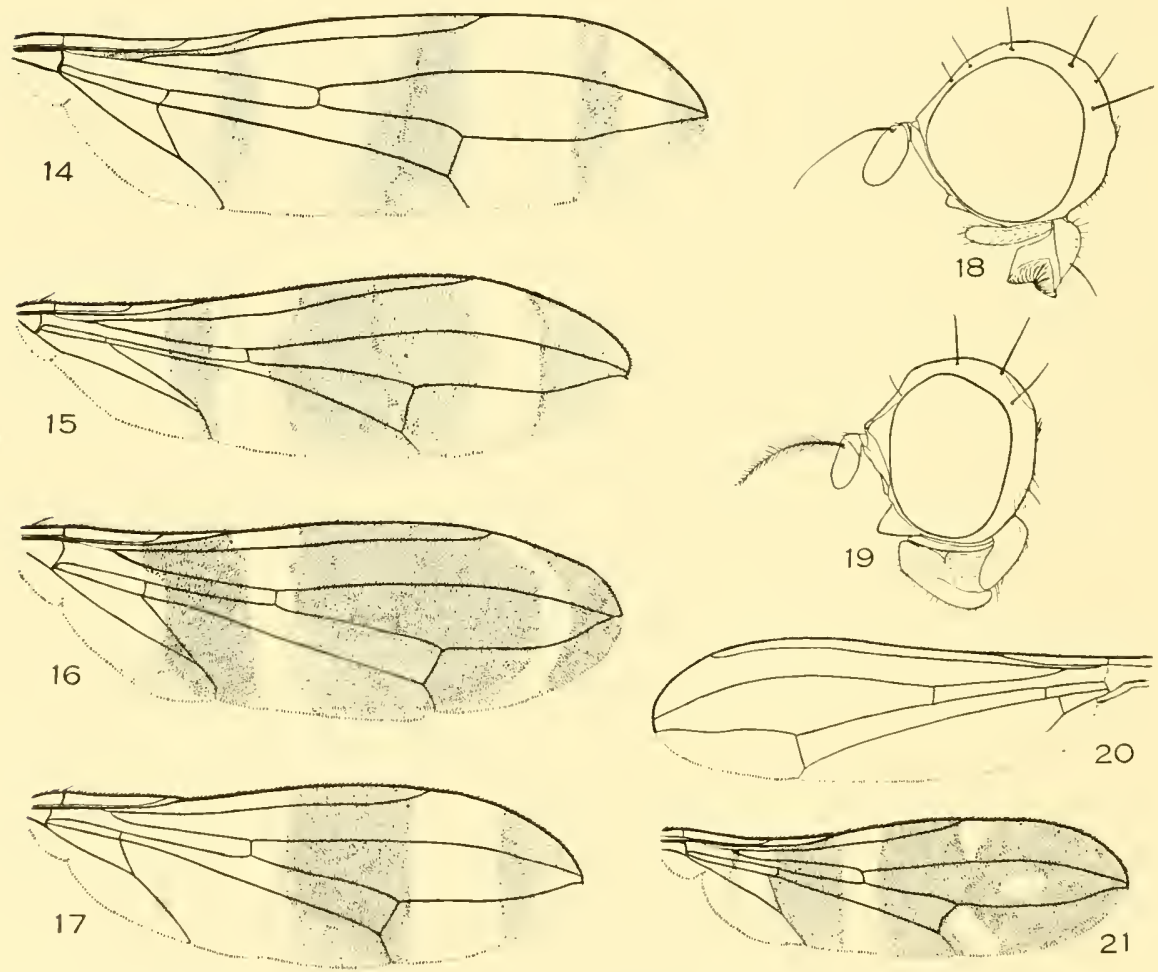

Calobatidæ 1I.-14, Hoplocheiloma; 15, Grallomya annulata; 16, Tæniaptera; 17, Grallipeza ; 18, Rainieria; 19, Ptilosphen; 20, Calobata univittata; 21, Cardiacephala. 


\section{KEY TO GENERA}

1. Anal cell extending two-thirds the distance to the wing margin, its

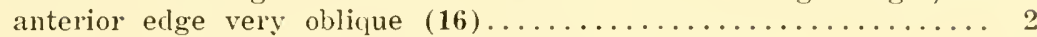

Ansl cell much shorter, the crossvein much less oblique.......... 5

2. Distance between the tips of the second and third veins more than half as great as the length of the ultimate section of the fourth

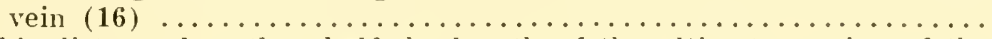

This distance less than half the length of the ultimate section of the

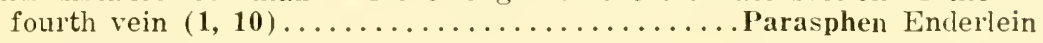

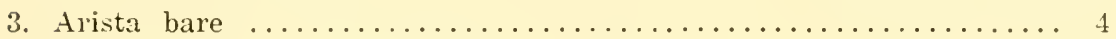
Arista plumose or long pubescent $(2,19) \ldots \ldots \ldots$. Ptilosphen Enderlein

4. Apical cell closerl and short petiolate $(12,16) \ldots$. Taniaptera Macquart Apical cell open $(7,15) \ldots \ldots \ldots \ldots \ldots \ldots \ldots \ldots$ Grallomya Rondani

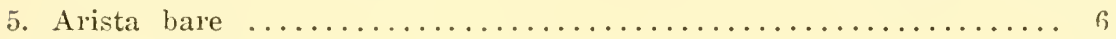

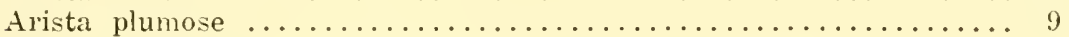

6. Distance between the tips of the second and third veins equal to less than half the length of the ultimate section of the fourth vein

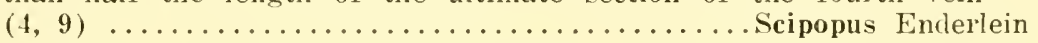
This distance greater than half the length of the ultimate section of

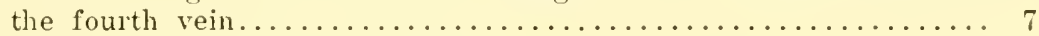

7. Postocellar bristles aljsent $(8,14) \ldots \ldots \ldots \ldots \ldots$ Hoplocheiloma Cresson Postocellar bristles present, vertex with six bristles.......... 8

8. Occiput strongly produced on either side of the vertex, concave in the middle from dorsal view........................ Occiput at most weakly produced and very greatly concave from dorsal view $(3,18) \ldots \ldots \ldots \ldots \ldots \ldots \ldots \ldots \ldots \ldots \ldots \ldots \ldots \ldots \ldots \ldots \ldots \ldots \ldots \ldots$ Rainieria Rondani

9. Posterior femora very conspicuously swollen on the apical third (6, $13,21 \ldots \ldots \ldots \ldots \ldots \ldots \ldots \ldots \ldots \ldots \ldots \ldots \ldots \ldots \ldots \ldots \ldots \ldots$ Cardiacephala Schiner Posterior femora regular in outline.................... 10

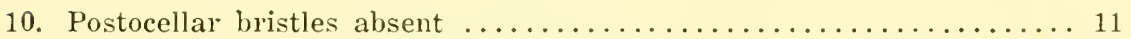
Postocellar bristles long and strong $(5,17)$........Grallipeza Rondani

11. Stigmal cell long, the first vein ending in front of the anterior cross-

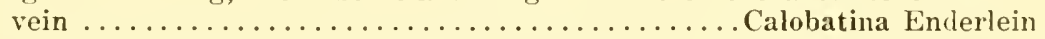
Stigmal cell short and not distinct, the first vein ending well before the anterior crossvein $(11,20) \ldots \ldots \ldots \ldots \ldots \ldots$ Calobata Meigen

* Tanypoda Rondani is a synonym and I do not believe that the characters cited by Cresson for his genus Meganeria are of sufficient value to constitute a genus.

$\dagger$ The dorsal view of the head shows the extreme development of the lobe-like nroduction of the posterior orbits which may not be producerl beyond the vertex. Rhocins (Enderlein) has been proposed for this latter group but there is every gradation between the two extremes. 


\section{Family Micropezidæ}

Slender flies of moderate size, their legs long, the second basal cell united with the diseal eell.

Head orbieular or elongate and subtriangular; front without bristles; face receding, without oral vibrissæ; antemne short, the arista dorsal. Thorax elongate, the front and middle coxæ widely separated; posterior portion of the pteropleura with long hairs; one sternopleural bristle. Legs long and slender, the tibiæ with bristles. Wings long, the seeond basal eell united with the diseal cell; apieal cell narrowed or closed and petiolate apically; anxiliary vein not distinetly separated from the first vein. Abdomen long and slender, the female ovipositor large, pendulous; male genitalia rather small, the fifth sternite usually with long pendulous lobes.

The adults are found in marshes and moist places in woods. There are three or four Nearetic, one Palararctie and many speeies in the Ameriean tropies. I have seen only Micropeza from the United States and Canada. The immature stages are unknown. Enderlein* has reviewed the family. I give the charaeters of his genera although I scareely agree that there are four genera represented. The appendiculate apieal eell does not seem to me to be of generie importance and I am inclined to recognize only Micropeza and Metopobrachia.

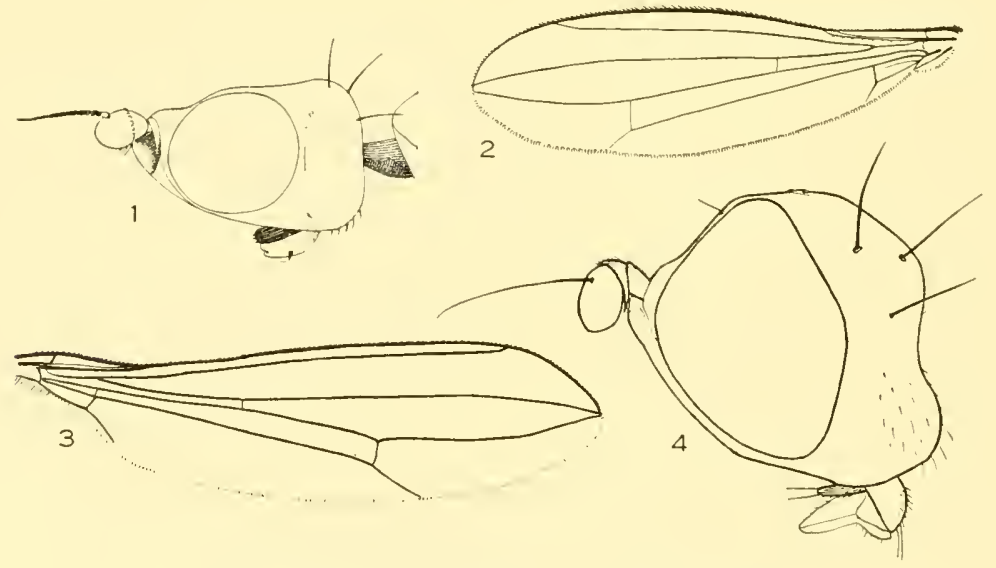

Micropezidæ.-1, 2, Micropeza ; 3, 4, Metopobrachia. 


\section{KEY TO GENERA}

1. Head subtriangular, much longer than high............... 2 Head orbicular, but little longer than high................ 3

2. Apical cell open or closed in the wing margin $(1,2) \ldots$ Micropeza Meigen Apical cell closed and petiolate............... Neriocephalus Enderlein

3. Apical cell open $(3,4) \ldots \ldots \ldots \ldots \ldots \ldots \ldots$ Metopobrachia Enderlein Apical cell closed and petiolate.....................

* 1922, Arch. für Naturg., lxxxviii, Abt. 5, p). 140-229. 


\section{Family Neriidæ}

Slender flies of moderate size, with long legs and an apical arista. Head longer than wide; two pairs of frontal bristles, the front wide in both sexes; face reeeding,* without oral vibrissæ; antennæ porreet, with a terminal bare or pubeseent arista. Thorax long, the front and middle legs widely separated, the prosternum as long as the mesosternum; pteropleura bare; with or without a sternopleural bristle. Legs long and slender, the femora with short spines beneath. Wings long, the apical cell usually narrowed apically; anal and second basal cells short; anxiliary vein ending in the first vein. Abdomen long, rather flattened above; ovipositor long and pendulous, earried under the abdomen in life.

The adults are found near water or moist places. The family is strictly tropieal, four of the nineteen genera oecurring in North Ameriea.. The immature stages are not known. Enderlein $\rightarrow$ has reviewed the group.

* In the old world Telostyline the oral margin is prominent while in the Neriinæ it is not conspicuous.

$\dagger$ 1922, Arch. für Naturg., lxxxviii, Abt. 5, pp. 140-229.
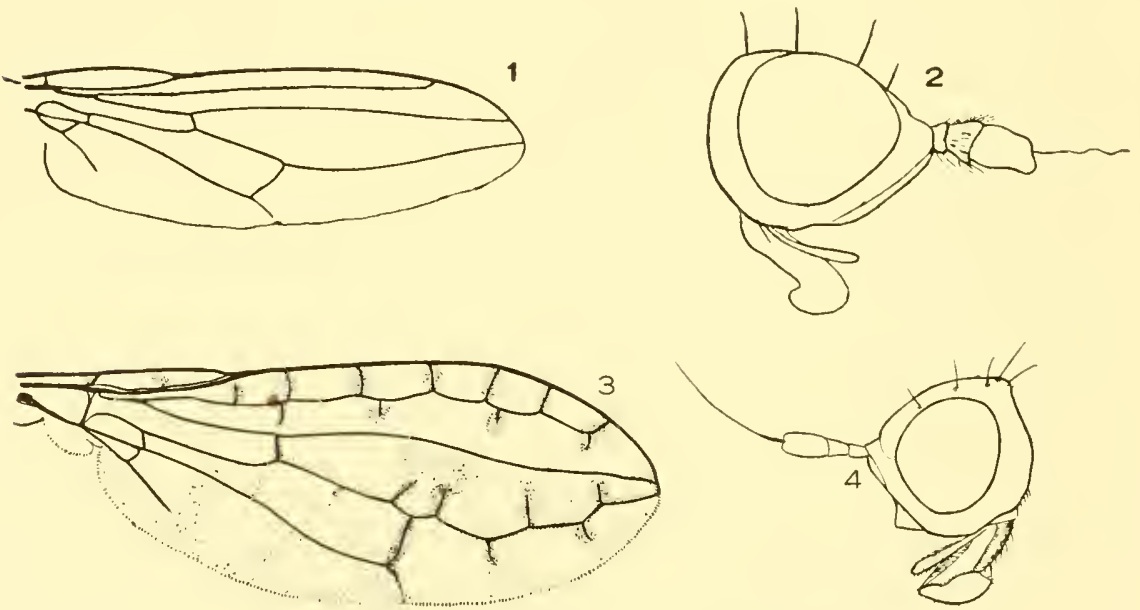

Neriidæe.-1, 2, Nerius; 3, 4, Dictyonerius. 


\section{KEY TO GENERA}

1. Wings with numerous crossveins $(3,4) \ldots \ldots \ldots$ Dictyonerius Enderlein Wings with normal venation....................... 2

2. Third antennal segment pointed apically; scutellum with one pair of

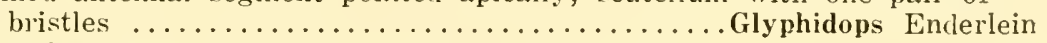
Third antennal segment rounded or obtuse apically........... 3

3. Ventral surface of the anterior femora with setigerous tubercles on

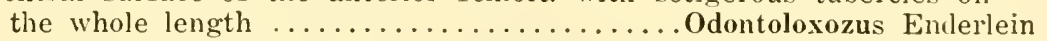
Anterior femora with bristles only apically $(1,2) \ldots \ldots$ Nerius Fabricius 


\section{Family Piophilidæ}

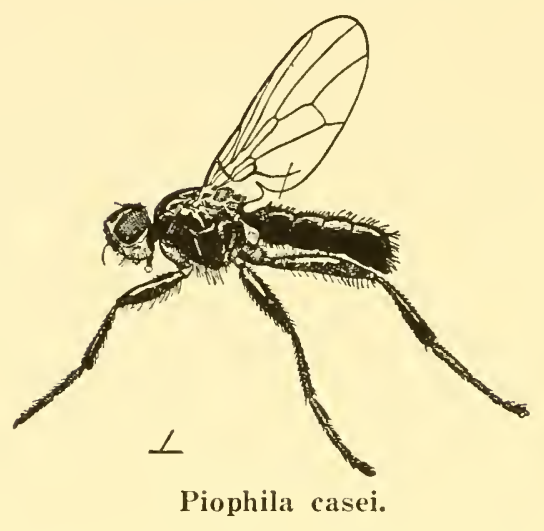

The flies ineluded in this family rarely exeeed five millimeters in length, and are usually glistening black or slightly bluish metallie in lustre.

Face not earinate, oceiput more or less flattened; always two pairs of vertical bristles; postrertical bristles divergent; fronto-orbital bristles varying from two pairs to none; antennæ deeumbent, the third segment elongate oval, arista bare in the Ameriean species; cheeks rarely fringed with hairs, the oral vibrissæ usually prominent, parafacials not differentiated as a linear orbital boundary; palpi well developed. Mesonotum almost always finely pubescent and polished; sternopleura never pruinose; one pair of dorsocentral bristles, four scutellar bristles. Legs of the male never toothed or deformed, the front femora usually furnished with long but delieate bristles. Abdomen more or less polished, pubeseent but without bristles, broad, depressed, not eonstricted at the base; genitalia of the male more or less hidden asymmetrieal; oripositor extensile. Auxiliary rein terminating elose to the end of the first vein, the costa broken at or near the termination, third and fourth veins parallel or more or less diverging, anal vein usually curved and evaneseent apically, diseal cell usually large, with the posterior erossvein usually long.

The larve are, in general, seavengers but some of them live in cheese and preserved meats. Piophila casci, the eheese-skipper, has a rather conieal larva, pointed anteriorly and truneate posteriorly: body shining and smooth: antenne two segmented: month hooks separated and divergent; anterior spiraeles whitish, the abdominal travelling 

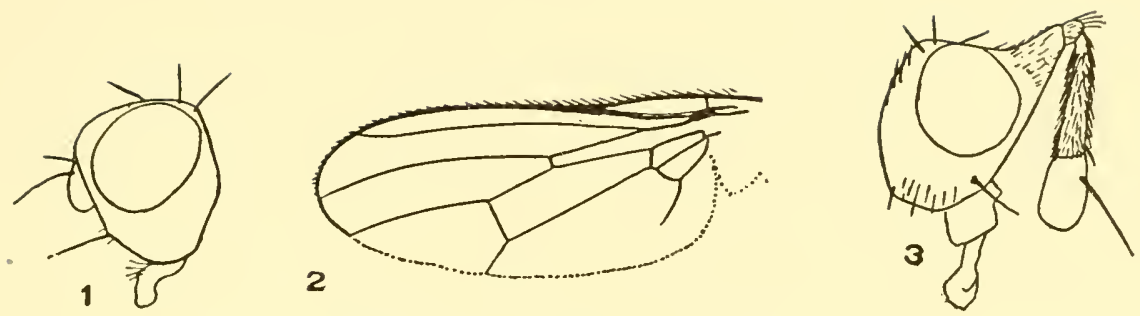

Piophilide.-1, 2, Piophila; 3, Prochyliza.

folds roughened, the posterior segment with four fleshy protuberances. The larva jumps by grasping the edge of the posterior truncature of the body with its mouth hooks and suddenly releasing it. The puparium is rugose and elliptic.

The members of this family have been placed in the Sepsida by most authors. The family differs from the Sepside in several characters, particularly in having the costa broken at the end of the auxiliary vin, setulose mesonotum and the absence of a hair or fine bristle arising on the posterior edge of the posterior spiracle of the thorax. Melander* has reviewed the family.

\section{KEY TO GENERA}

1. One or two pairs of frontal bristles..................... 2 No frontal bristles; face strongly receding; antennæ variable in length

Prochyliza Walker

2. Two pairs of dorsocentral bristles.................... 3 One pair of dorsocentral bristles (1,2 and text fig.).......Piophila Fallén

3. One pair of frontal bristles (text fig.)..........Amphipogon Wahlberg Two pairs of frontal bristles................... Mycetaulus Lœw

* 1924, Psyche, xxxi, pp. 78-86.

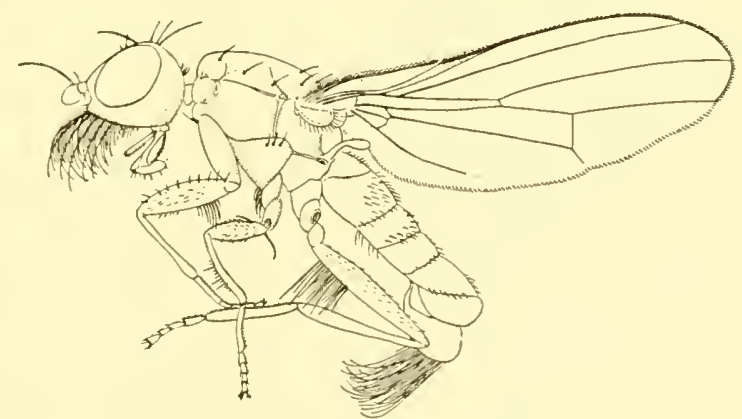

Amphipogon spectrum. 

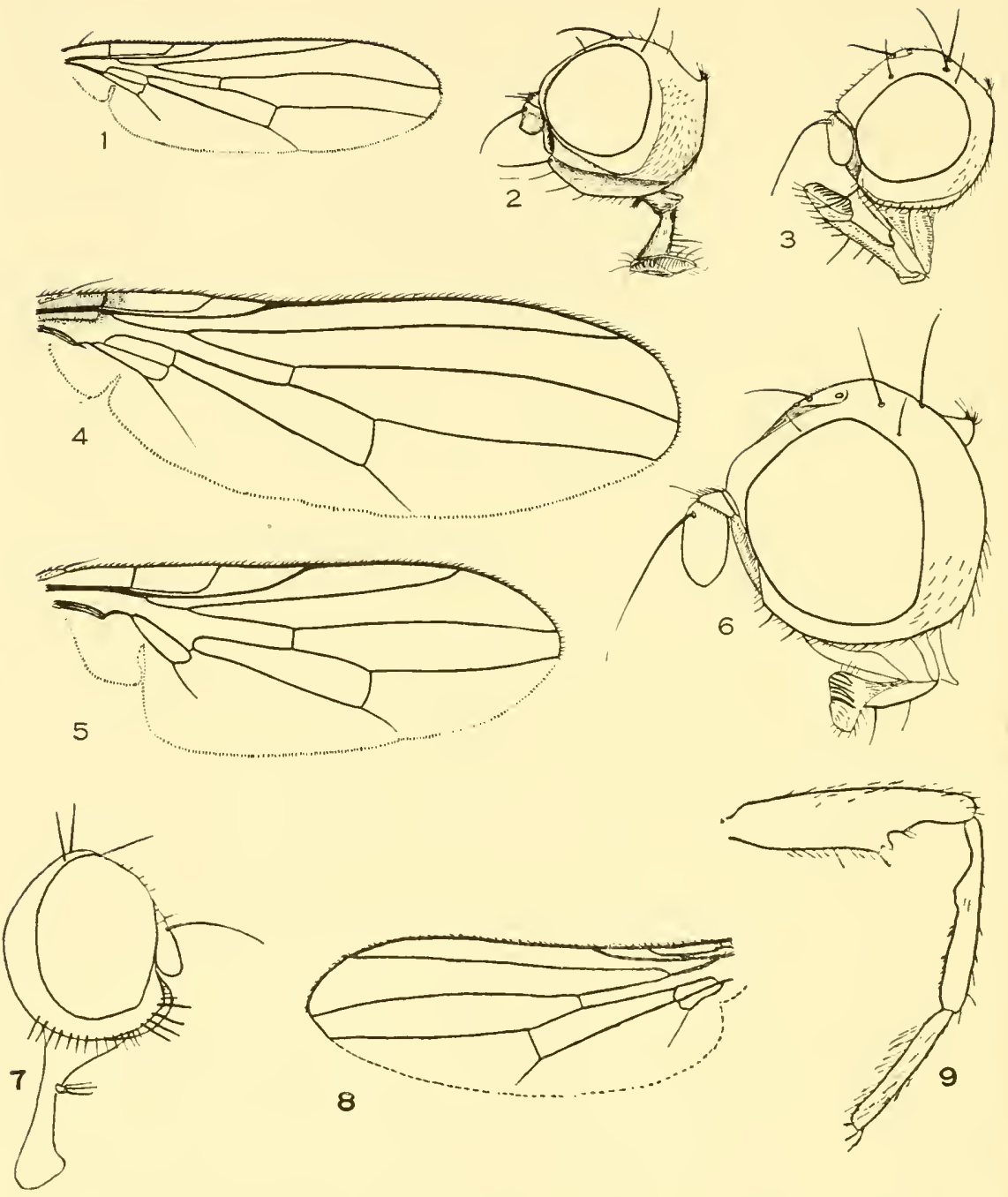

Sepsidæ,-1, 2, Themira minor; 3, Pandora; 4, Nemopoda minuta; 5, Pandora; 6 , Nemopoda minuta; $7,8,9$, Sepsis. 


\section{Family Sepsidæ}

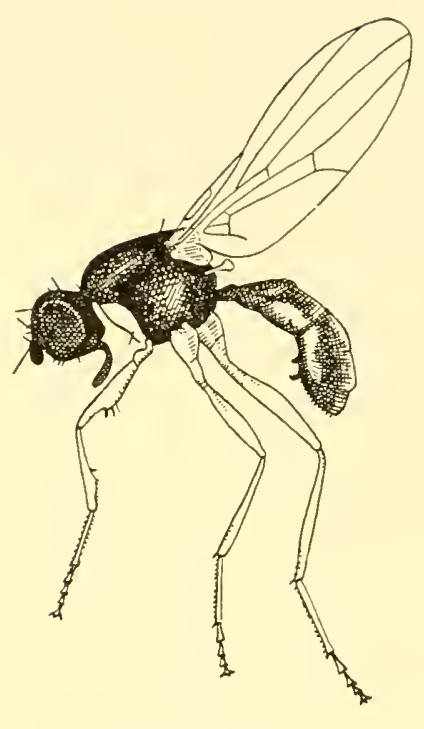

Meroplius stercorarius.

Small, shining black or reddish flies.

Head more or less spherical, the occiput usually quite convex, face carinate; one or two pairs of vertical bristles, one or no orbitals, postvertical bristles divergent; antennæ decumbent, the third segment oval, the arista nsually bare; parafacials very narrow, reduced to an orbital line; palpi restigial. Mesonotum ustally aciculate or pollinose and not pubescent, its setule usually in three longitudinal rows; seutellar bristles usually two, rarely four in number; either one or two pairs of dorsocentral bristles; sternopleura usually in part or entirely pruinose. Auxiliary vein curving so as to terminate obviously before the end of the first longitudinal rein, rosta not broken, the third and fourth reins more or less convereing: anal rein straight and abbreviated. Legs of the male usually deformed and armed with spines or thorn-like projections, usualIr located on the front pair. Abdomen with but sparse pubeseence or fine setula, often constricted at the second segment and bearing a few bristles; male genitalia usually prominent, symmetrical, comprising a hypopygium with paired lateral valves, each tipped by a prong or flat 
blade of distinctive structure; ovipositor not extended, the female abdomen with bluntly rounded termination.

The adults are found about excrement, carrion and decaying vegetation, in which the larve live, and many of the species are very common. There are between forty and fifty deseribed species from North America. Melander and Spuler* and Dudat have dealt with the species.

\section{KEY TO GENERA}

1. First and second basal cells separated.................... 2 First and second basal cells united $(3,5) \ldots \ldots \ldots \ldots$. Pandora Haliday

2. Outer verticals present......................... 3

Outer verticals absent......................... 5

3. Anterior femora of both sexes with a close-set row of spinules ventrally, never with stout spines or thorns $(4,6) \ldots$ Nemopoda Desvoidy Anterior femora never with such a row of spinules, often with coarse spines, sparse hairs or more or less deformed............. 4

4. No frontal bristles $(7,8,9) \ldots \ldots \ldots \ldots \ldots \ldots \ldots \ldots \ldots \ldots \ldots \ldots \ldots \ldots \ldots$ Sepsis Fallén One frontal bristle; anterior femora never tuberculate.

Meroplius Rondani

5. Postocellar bristles long and strong; one frontal $(1,2)$. Themira Desvoidy Postocellars very weak; frontals not developed......... Enicita Westwood

* 1917, Wash. Agric. Exp. Sta.. Bull. No. 143.

† 1925. Ann. Naturh. Mus. Wien, xxxix, pn. 1-153, and 1926, xl, pp. 1-110.

t The genus Sepsidimorpha Frey I cannot senarate from Sepsis and I do not consider the absence of tubercles on the anterior femora of generic importance. Those species of Sepsis which have a frontal bristle I would place in Meroplius even though the front femora are nimed beneath. 


\section{Family Lauxaniidæ}

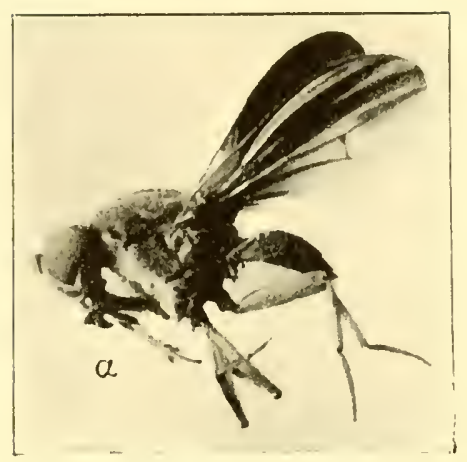

Homoneura species.

Rather small flies, rarely more than $6 \mathrm{~mm}$. in length, the auxiliary vein entire and ending in the costa.

Head variable, the face projecting or retreating, convex, flat or coneave, without oral vibrisse although these are rarely poorly developed. Front wide, with two pairs of frontals, the upper pair always reelinate, the lower pair sometimes decussate; ocellars present or minute. Antemnæ variable, the arista plumose to bare. Thorax with bristles, at least behind the suture; sentellum usually bare except for the marginal bristles; propleural bristle present or absent; one or two sternopleurals. Tibix all with preapieal bristle. Wing venation eomplete, the seeond basal and anal cells short; apieal cell usually widely open. Abdomen oval, rarely elongate.

The adults may be found almost everywhere, but particularly in moist places where they may oceur in large numbers. Many of the speeies are more in evidence in the evening than during the rest of the day. They are not very aetive and are therefore easily eaptured.

The larve of at least some of the speeies mine in plants and are eeonomically important; others live upon dreaying vegetation.

Sapromyzida has been used for this family by most Ameriean anthors but Lauxania is older and should be used. Hendel has published extensively on the family: many ehanges have been made since his contribution in Genera Inseetorum* and he recognizes many additional genera in his key to genera.t 

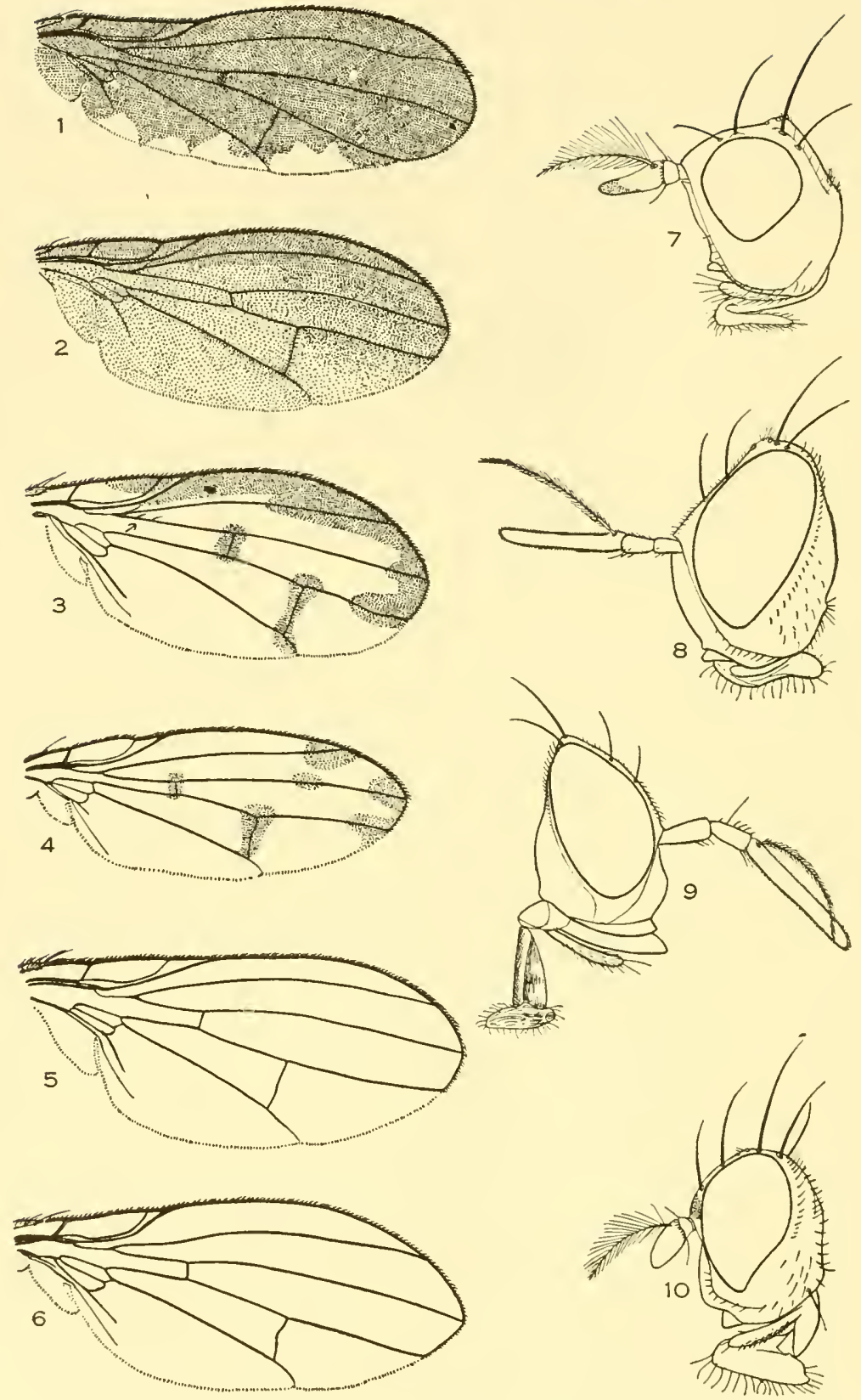

Lauxanidæ I.-1, Chætocœlia sp.; 2, Physegenua vittata; 3, Chætominettia latelimbata; 4. Homoneura philadelphica; 5, Pseudogriphoneura; 6. Neogriphoneura; 7, Camptoprosopella vulgaris; 8, Lauxaniella opaca; 9. Steganolauxania latipennis; 10, Deutominettia bimaculata. 


\section{IEYY TO GENERA}

1. Antennæ long and slender, the first segment two-thirds as long as the

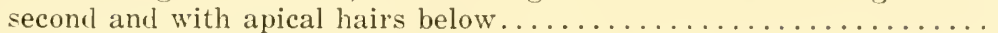

Antennæ not unusually elongate, the third segment usually more or less oval, rarely twice as long as wicle, the first short or without bristles below

2. Sternopleura with a single bristle..................... 3 Two sternopleural bristles $(17,18) \ldots \ldots \ldots \ldots \ldots$ Lauxania Latreille

3. Propleural bristle present....................... 4 Propleural bristle absent $(23,26) \ldots \ldots \ldots \ldots \ldots \ldots$ Asilostoma Hendel

4. Anterior pair of frontals decussate; face with transverse striæ $(\mathbf{9}, \mathbf{2 2})$. Anterior pair of frontals reclinate.... Steganolauxania Fres

5. Submarginal cell but little wider than the marginal $(8) \ldots \ldots \ldots \ldots 6$ Submarginal cell more than twice as wide as the marginal.

Steganopsis de Meijere

6. Face with a large, rounded convexity on either side... Cephalella Malloch Face without such swellings $(8,21) \ldots \ldots \ldots \ldots \ldots$ Lauxaniella Malloch

7. Third vein setulose either above or below................ 8

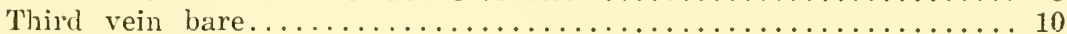

8. First vein setulose above.............. Dryomyzothea Hendel First vein bare...............................
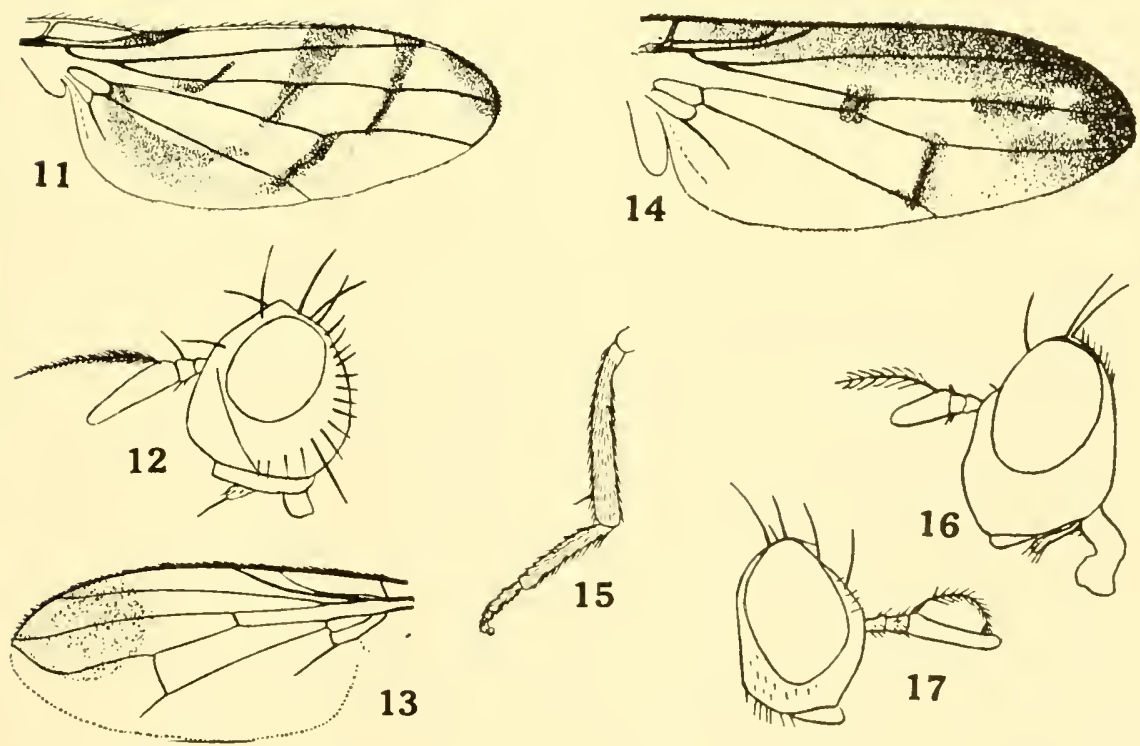

Lauxanidze II.-11, Xenopterella; 12, Pachycerina; 13, Griphoneura; 14, Minettia evittata; 15 . Sapromyza; 16 , Physegenua; 17 , Lauxania. 

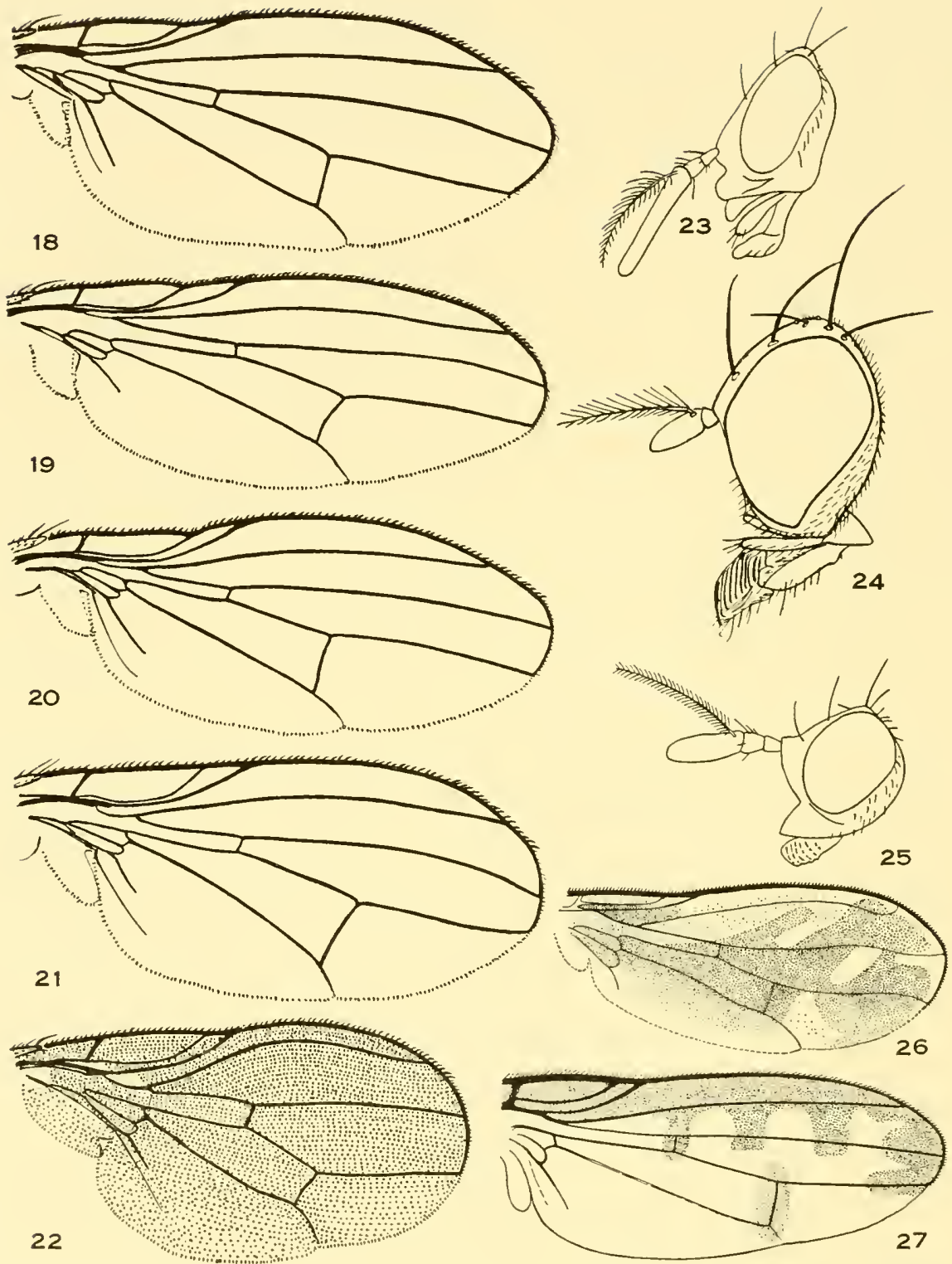

Lauxanidie III.-18, Lauxania cylindricornis; 19, Trigonometopus vittatus; 20, Camptoprosopella vulgaris; 21, Lauxaniella opaca; 22. Steganolauxania latipennis; 23. Asilostoma; 24, Griphoneura; 25, Freyia nigrita; 26. Asilostoma palpalis; 27 . Neominettia contigua. 
9. Third vein setulose below to beyond the anterior crossvein (27).

Neominettia Hendel Third vein setulose above and below before the anterior crossvein $(3,31) \ldots \ldots \ldots \ldots \ldots \ldots \ldots \ldots \ldots \ldots \ldots \ldots \ldots \ldots \ldots \ldots \ldots \ldots$ Chrominettia Malloch

10. Second vein setulose before the origin of the third vein $(30,34)$.

*Xenochxtina Malloch

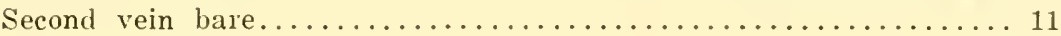

11. First vein setulose posteriorly before the humeral crossvein $(28,36)$.

Setulina Malloch

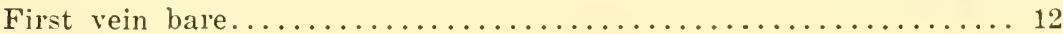

12. Wings with a crossvein dividing the apical cell beyond the posterior

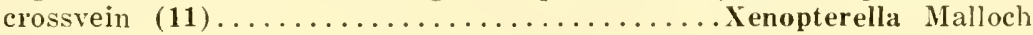
Wings with only the usual crossveins................... 13

13. Anterior frontal bristle directed inward; first antennal segment as long

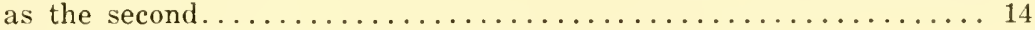
Anterior frontals reclinate; first antennal segment short......... 17

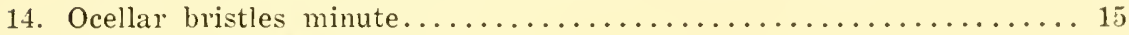

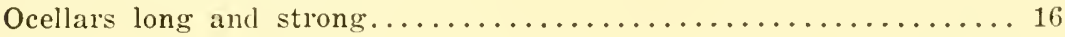

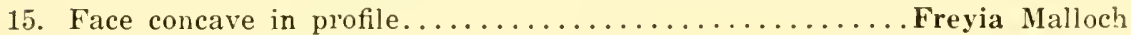
Face convex $(2,16) \ldots \ldots \ldots \ldots \ldots \ldots \ldots$ Physegenua Macqual't

16. Face strongly convex; anterior frontals half way between the antennæ

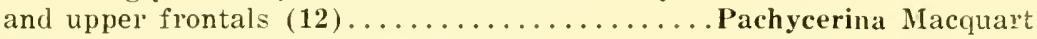
Face gently convex or plane; anterior frontals closer to upper frontals than to antennæ $(\mathbf{7}, 20) \ldots \ldots \ldots \ldots \ldots$. Camptoprosopella Hendel

17. First antennal segment as long as the second (25)....... Freyia Malloch

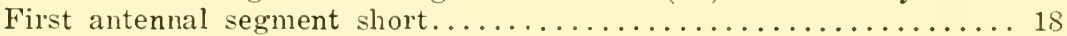

18. Presutural bristle present......................... 19 Presutural bristle absent; face strongly retreating $(19,33)$.

$\dagger$ Trigonometopus Macquart

19. Apical cell very strongly narrowed apically, almost closed $(13,24)$.

Griphoneura Schiner

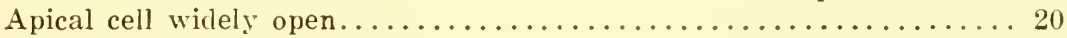

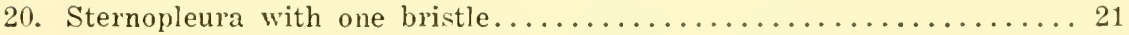
Sternopleura with two bristles, the anterior one weaker.......... 22

21. Front much broader than long, concave in front from dorsal view (6,

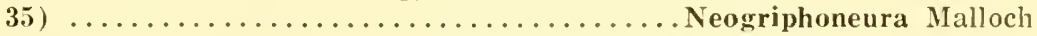
Front rarely broader than long, not concave in front $(5,38)$.

+ Pseudogriphoneura Hendel

22. Face convex and glossy $(29,37) \ldots \ldots \ldots \ldots$ Pseudocalliope Malloch

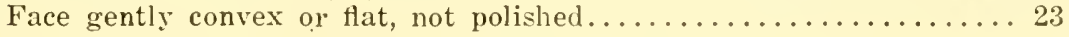

* Malloch, 1923, Proc, Ent. Soc. Wash., xxv, 1. 49.

† Malloch, 1923, Proc. Ent. Soc. Wash., xxv, 1. 48.

$\doteqdot$ Curran, 1934, Bull. Amer. Mus. Nat. Hist., Ixvi, p. 445. 


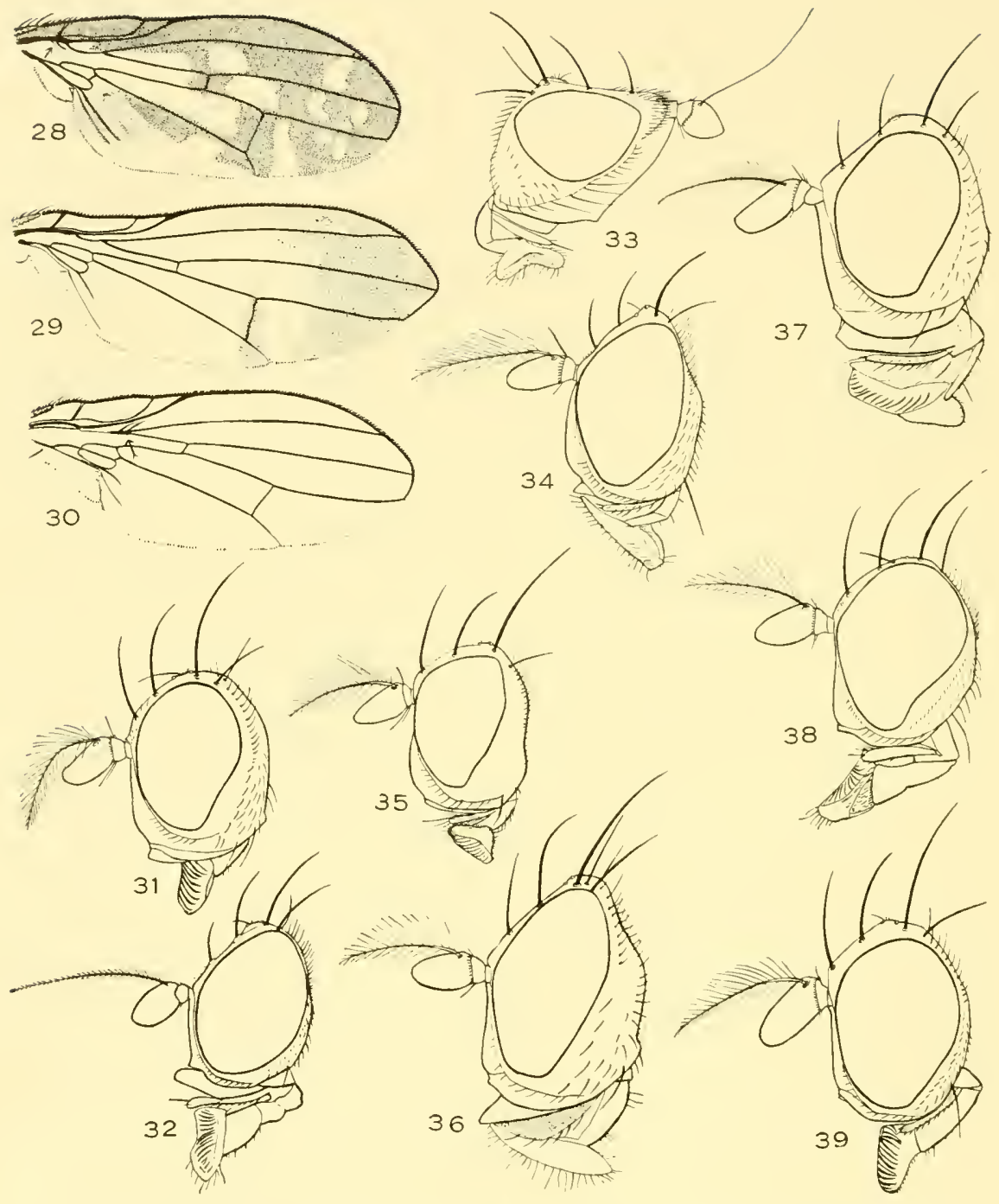

Lauxaniidæ IV.-28, Setulina geminata; 29. Pseudocalliope; 30. Xenochætina; 31 . Chætominettia; 32 , Chætocolia ; 33 . Trigonometopus: 34 , Xenochætina; 35 , Neogriphoneura ; 36 . Setulina; 37 , Pseudocalliope: 38 , Pseudogriphoneura; 39 , Sapromyza. 


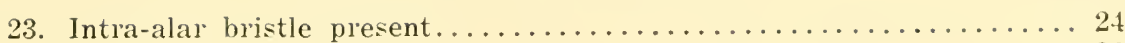

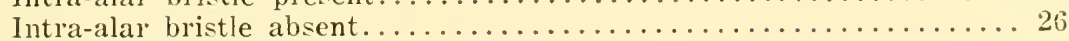

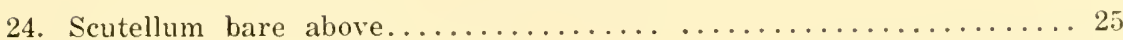

Scutellum setulose above $(\mathbf{1 0}) \ldots \ldots \ldots \ldots \ldots$ Deutominettia Hendel

25. Frontal bristles arising from tubercles $(1,32) \ldots$ Chretocœlia Giglio-Tos Frontal bristles not arising from tubercles (14)....... Minettia Desvoidy

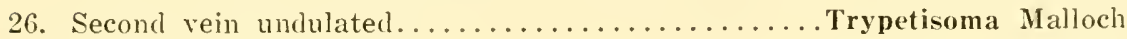

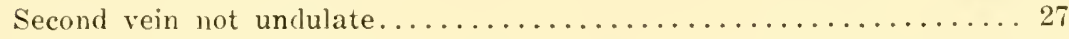

27. The tiny black costal setulre continued to the apex of the third vein (4).

Homoneura Wulp

The black setulæ extend to only a little beyond the apex of the second vein, never to the third $(15,39) \ldots \ldots \ldots \ldots \ldots$ Sapromyza Falléu

* Hendel has recognized two segregates of this gerus, Lycia Desvoidy and Cnemacantha Macquart, both of which have four dorsocentral bristles. The former has the acrostical hair's two or four rowed and rather long while the latter has them six rowed and very short. 

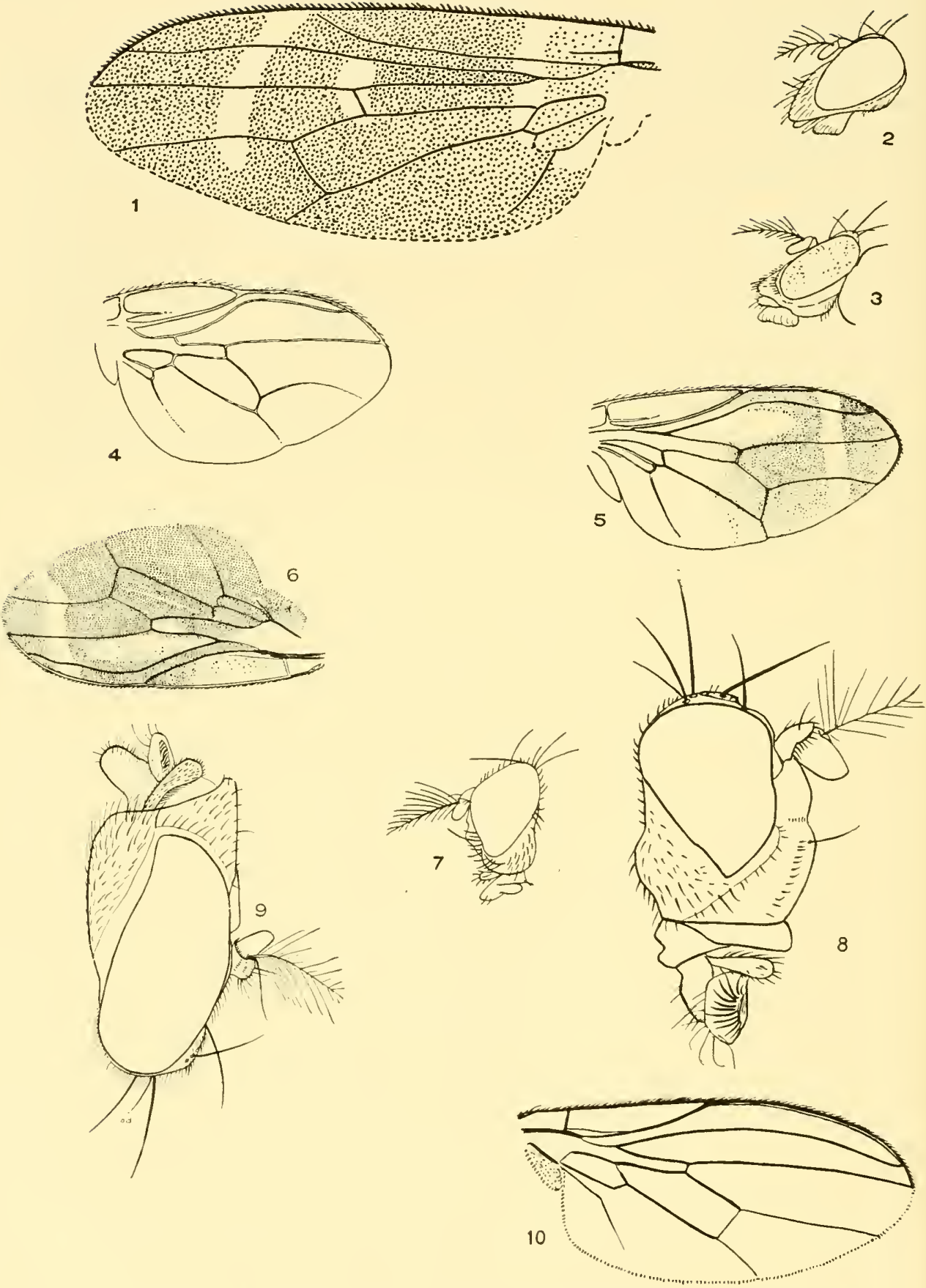

Periscelidx.-1, Marbenia peculiaris; 2, Neoscutops rotundipennis; 3, Scutops fascipennis; 4, Neoscutops rotundipennis; 5 , Scutops fascipennis; 6 . Panamenia chapmani; 7 , Marbenia peculiaris; 8 , Sphyroperiscelis sp.: 9. Panamenia chapmani; 10, Sphyroperiscelis sp. 


\section{Family Periscelidæ}

Small flies resembling the Lanxaniidx, ete.

Face wide, more or less produced below; front with a single pair of bristles; postocellars divergent; arista plumose. Wing venation complete, the auxiliary vein short. Abdomen oval, somewhat depressed.

IIembers of this family are not numerous in collections and little is known about them. Nalloch wonld retain the genera in the Sapromyzide and Melander included Scutops in his revision of the Geomyzidx. The family eontains seven genera, all occurring in America, Periscelis also being found in Europe.

\section{KEY TO GENERA}

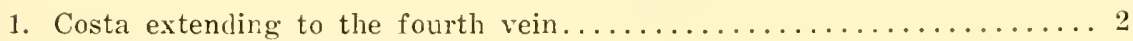

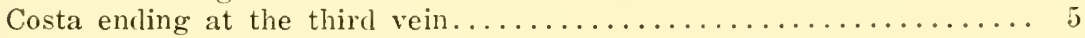

2. Face very strongly protruding below; auxiliary vein not curved forward

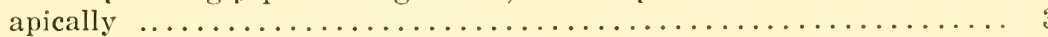

Face somewhat protruding below; auxiliary vein with a distinct forward

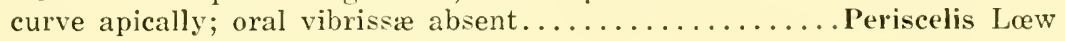

3. Face evenly convex.............................. 4 Face flattened and bare in the middle above $(3,5) \ldots$. . Scutops Coquillett

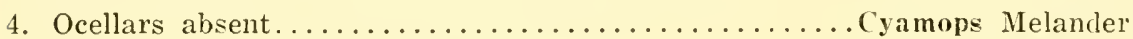
Ocellars long and strong (21)............... Neoscutops Malloch

5. Face most prominent below; veins strong $(6,9) \ldots \ldots \ldots$ Panamenia, n. g. Face not prominent below, more or less convex in the midlle....... 6

6. Head almost or quite twice as wide as high; face very widle $(8,10)$.

Sphyroperiscelis Sturtevant Head not nearly so wide; face and eyes of moderate width $(1,7)$.

Marbenia Malloch

\section{Panamenia, new genus}

This gemus is, perhaps, most closely related to sphyroperiscelis sturtevant but the shape of the head is distinctive. The face is shieldshaped, the point below, the sides sharply limited and haired. Abdomen as broad as long, tapering sharply from near the base. Sertellum flat, hearing two pairs of marginals. Wings as in figure. (renotype:I'. chapmani, n. sp.

Head stramineous, the upper oceiput and a hoad frontal triangle Black; tholax deep brown or blackish, the plema yellowish; humeri, a large rectangle on the posterior half of the mesonotum and the seutellum, except the sides, stramineons; legs reddish fellow, the tibixe with two brown bands, the anterior femora brown basally: wings brownish, with a preapieal hyaline band; abdomen blackish or dark brown. Male, Barro Colorado Island, Canal Zone, (Curran). 


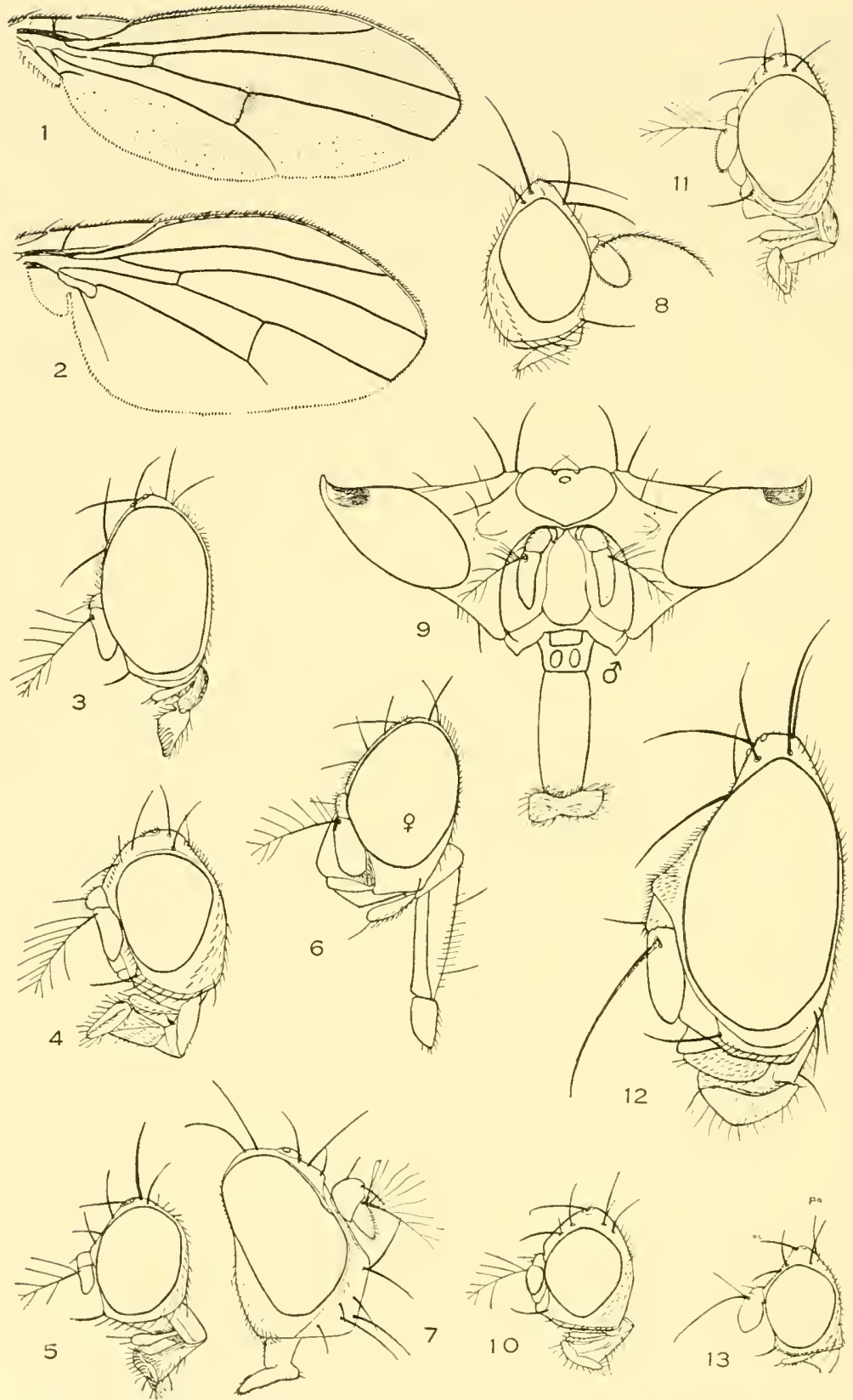

Durosophilidæ I.-1, Cladochæta nebulosa; 2, Rhinoleucophenga obesa; 3, Leucophenga maculosa ; 4, Drosophila funebris; 5, Chymomyza amona; 6, Zygothrica dispar; 7. Planinasus ambiguus; 8, Diastata; 9, Zygothrica dispar; 10. Scaptemyza gramineum; 11, Mycodrosophila; 12. Rhinoleucophenga obesa: 13 , Cladochæta nebulosa. 


\section{Family Drosophilidæ-The Small Fruit Flies}

Small flies, rarely exeeeding a length of $5 \mathrm{~mm}$. the head sometimes very broad, the wings often pietured.

Face nearly vertical in profile, rarely prominent, oral vibrissæ present, though sometimes weak; front with three pairs of bristles; postocellar bristles eonvergent, larely ahsent. Third antemnal segment oval or rounded, the basal two short; arista usually plumose, rarely pubescent or with a single long ray. Abdomen usually short, rather elongate and pendulous in Curtonotum. Auxiliary vein usually very short and ending in the first vein; costa broken twice; first vein short; second basal cell usually united with the discal cell; anal cell present, rarely incomplete.

The adults are found around decaying vegetation, flowing sap, fungi and ripe fruit, the larve being found in these substances. They are often pests to the housewife, since they apparently appear from nowhere when fruit is brought into the house and some of the fungus inhabiting speeies have the habit of hovering around the eyes during warm weather, eausing not only irritation by their anties but pain when they get into the eye. In the tropies they sometimes oceur in such numbers as to completely eover large fungi. There have been frequent complaints about them in milk bottles, the puparia becoming attached to the bottles and requiring special treatment for their removal.

One of the species, Drosophila mclanogaster Meigen, has been used extensively for the study of inheritanee, being exeeedingly well suited for this purpose because of the very short life eycle and large chromosomes. The general belief has been that the larvae live upon fruit but it has been shown that they actually live upon the yeasts developing in it.

Sturtevant* has reviewed the North Ameriean species and Dudat has dealt with the Neotropical forms. In addition there are numerous small papers seattered throngh the literature. In addition to the genera given in the key several others, as well as a number of subgenera, have been proposed but most of them appear to be too poorly differentiated to deserve reeognition. Alhicht has diseussed the ocomrenee in North Ameriea of the genus Leiomyza Macenart and deseribed two species. As I have no specimens I am unable to place the genus in the ker. Sturterant* has referred this genus to the Asteiida but this disposition of it does not agree with my interpretation of that family.

* 1921. The North American Snecies of Drosophila, Carnegie Inst. of Wash., rub. No. 301. $150 \mathrm{mp}$.

†1927. Die Sudamerikanischen Drosophiliden, etc., Arch für Naturgesichte, 1925, Hefts 11-12, pr. 1-229.

$\$ 1919$. Ent. News, xxx, p. 137. 

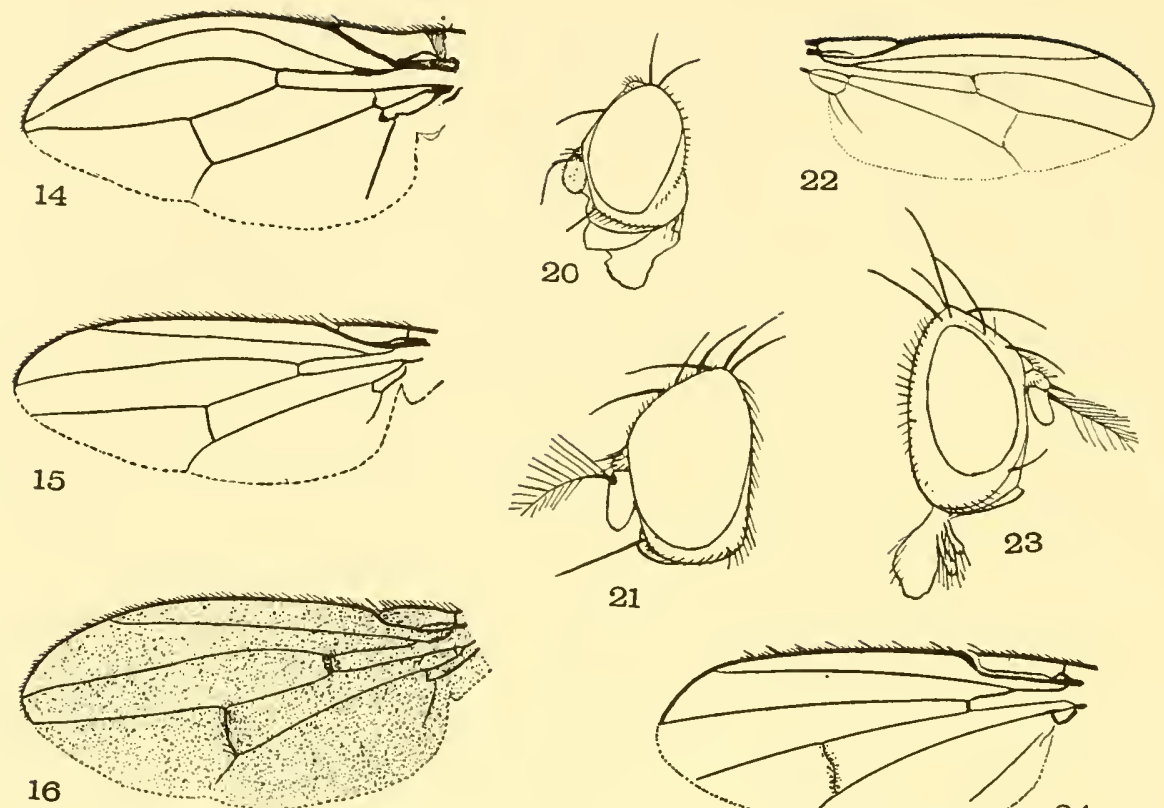

21
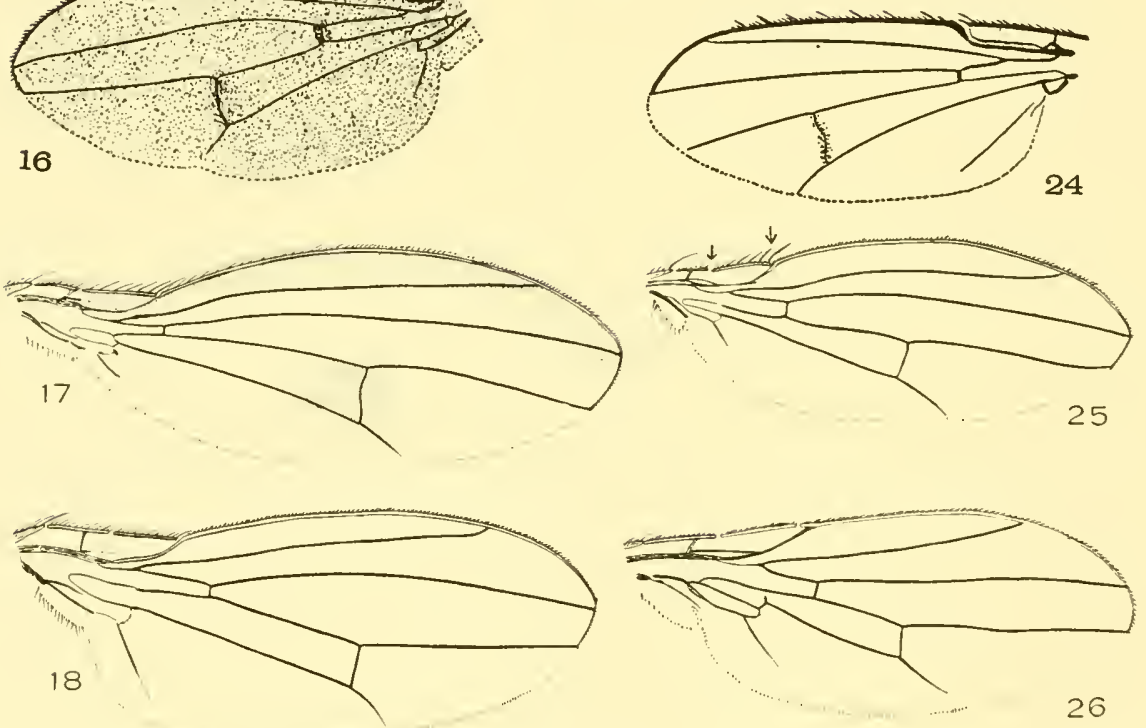

26
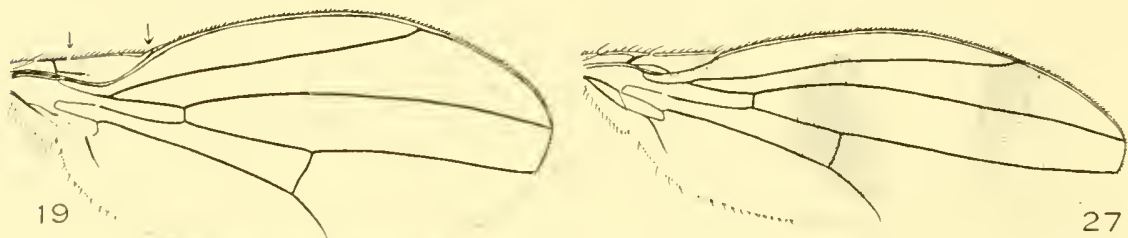

Drosophilidæ II.-14, Stegana; 15, Lencophenga; 16, Drosophila; 17, Diastata vagans; 18, Zygothrica dispar; 19, Mycodrosophila dimidiata; 20, Sinophthalmus pictus; 21, Stegana; 22, Sinophthalmus pictus; 23, Curtonotum; 24, Curtonotum; 25, Scaptomyza gramineum; 26, I'laninasus ambiguus; 27, Chymomyza amœna. 


\section{KEY TO GENERA}

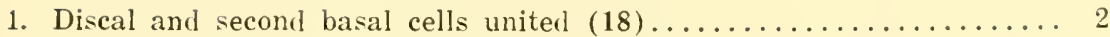

Discal and second basal cells separated $(17) \ldots \ldots \ldots \ldots \ldots \ldots \ldots \ldots$

2. Auxiliary vein ending in the first vein near its base............ 4

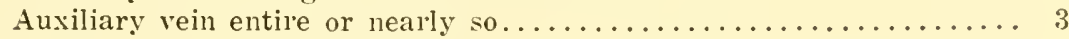

3. Arista plumose; prescutellar acrosticals strong; costa pectinate (23,

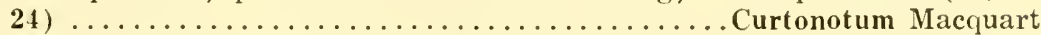
Arista pubescent; prescutellar acrosticals absent...Aulacigaster Macquart

4. Arista pubescent or bare with one long ray above............ 5

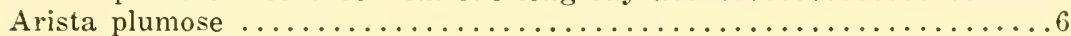

5. Arista with one long ray above $(1,13) \ldots \ldots \ldots \ldots$ Cladochæta Coquillett

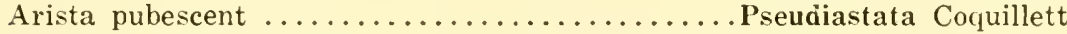

6. Proboscis longer than head-height; head broader than the thorax (6,

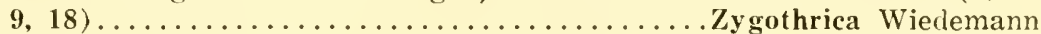
Proboscis shorter than the head; head rarely broader than the thorax. 7

7. Lower reclinate frontal bristle as far from the proclinate as from the

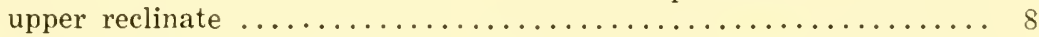

Lower reclinate frontal situated nearer to the proclinate than to the

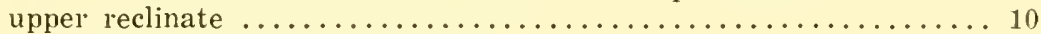

8. Prescutellar acrosticals strong; face not protuberant........... 9 Prescutellar acrosticals weak or absent; face produced.

Pararhinoleucophenga Duda

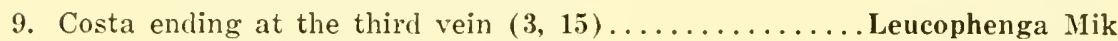
Costa extending to the fourth vein $(2,12) \ldots$. . Rhinoleucophenga Hendel

10. Lower reclinate frontal situated in front of the proclinate $(5,27)$.

Chymomyza Czerny Lower reclinate situated behind the proclinate................ 11

11. One large pair of dorsocentrals; mesonotum and scutellum usually convex; a single bristle at the second costal break $(11,19)$.

Mycodrosophila Oldenberg

Usually two pairs of dorsocentrals........................ 12

12. Acrostical hairs moderately long and not very numerous, never in more than four rows anteriorly $(\mathbf{1 0}, \mathbf{2 5}) \ldots \ldots \ldots \ldots$. Scaptomyza Hardy Acrostical hairs short and appressed, always in six or more rows

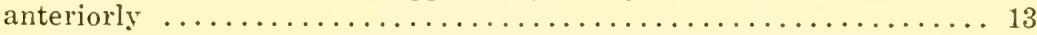

13. Prescutellars long and strong........Clastopteromyia Malloch \& MicAtee Prescutellar acrosticals quite weak or absent $(4,16) \ldots$ Drosophila Fallén

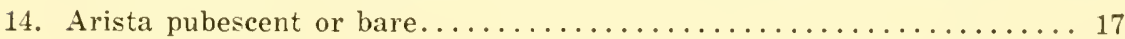

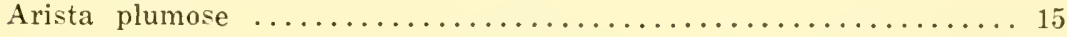

15. Propleural bristle present but weak $(8,17) \ldots \ldots \ldots \ldots$ Diastata Meigen

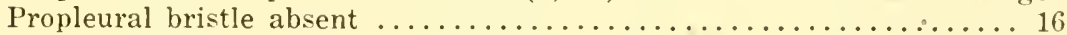

16. Face flat on upper half, prominent in the middle $(7,26)$. Face concave, the oral margin the most prominent $(14,21)$.

Stegana Meigen

17. Antennæ extending to the oral margin, the third segment twice as long

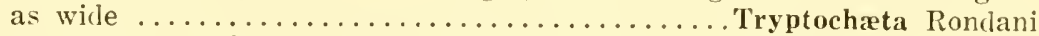
Antennæ not reaching the oral margin $(20,22)$. . Sinophthalmus Coquillett 


\section{Family Asteiidæ}

Small flies, with the seeond vein ending only slightly beyond the first.

Head higher than long; face coneave; oral vibrissa well developed; front wide, with one or two pairs of bristles; thorax bristled posteriorly. Legs short. Wings long, with only one or two erossveins, before the basal third; auxiliary vein incomplete; costa entire, anal cell absent, the seeond basal sometimes open apieally. Abdomen narrow.

This family comprises but few genera, three of which are recorded from Ameriea. The family may be at onee reeognized by the peenliar wing venation. Williston placed the two genera known to him in both the Drosophilide and Chloropide and there has been mueh doubt as to where they belong.

\section{KEY TO GENERA}

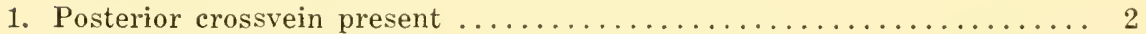
Posterior crossvein absent, only one crossvein (3).......*Asteia Meigen

2. Front with two bristles near the middle, half way between the ocellar triangle and antennæ................... Crepidohamma Enderlein Front with only weak bristles laterally $(1,2) \ldots \ldots$. Sigaloessa Coquillett

* Aldrich, 1915, Psyche, xxii, p. 96.
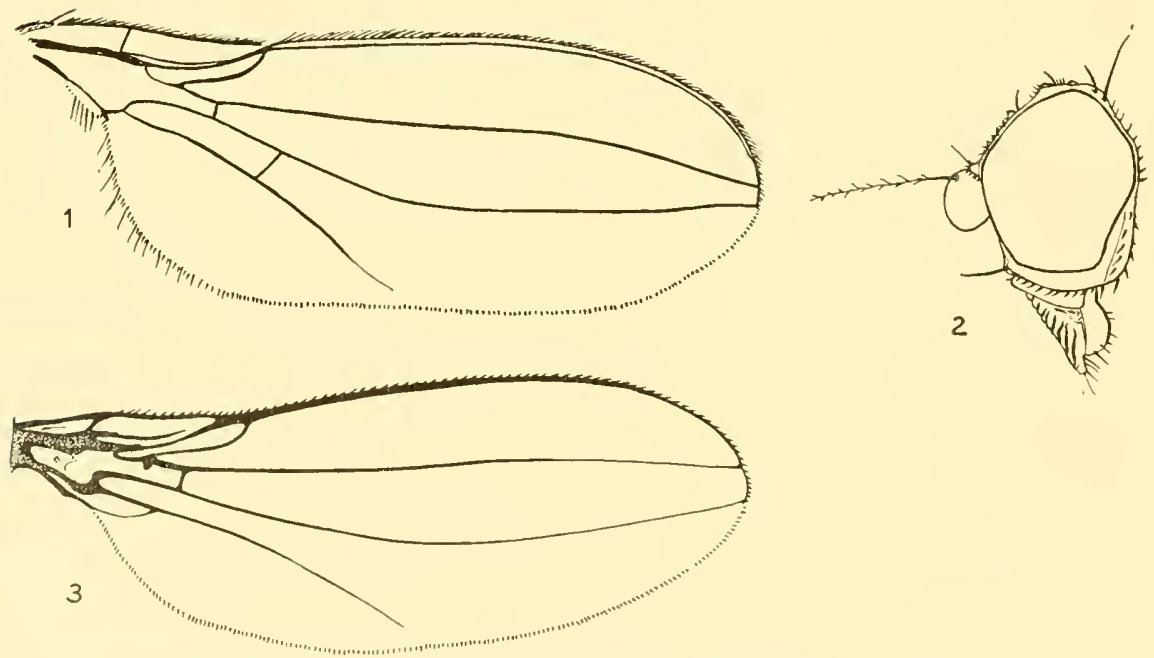

Asteiidæ,-1, 2, Sigaloëssa rica (insularis Curran, not Malloch); 3, Asteia sp. 


\section{Family Opomyzidæ}

Small, rather elongate flies, sometimes with pietured wings.

Iead not longer than high, the face long, often narrow; one or more pairs of frontal hristles; postocellars divergent, convergent, or absent; oral vibrisse absent or differentiated, never strong; palpi small. Presutural dorsocentrals present or absent; mesoplenra bare; sentellum with or without hair in addition to the bristles; preapieal tibial bristles absent. Subeosta incomplete or vestigial; anal and second basal cells eomplete, the first rein ending before the middle of the wing. Abdomen moderately long, the segments with marginal bristles; genitalia small.

Various anthors have recognized three families for this group, the Anthomyzidx and Tethinidx in addition to the Opomyzida or Geomyzidx. Despite the differences I believe that the genera should be grouped together, as otherwise there is sufficient grounds for the ereation of a family for each of the genera. It any rate we may safely mite the Anthomyzide and Tethinida since both gromps possess oral vibrisse. Ilowever the vibrisse are weak and the characters by which these groups are separated from Opomyza do not appear to be important in this (ase.

The flies ocenr ehiefly in moist places and along the seashore. Practically nothing is known about the life histories, but it is known that species of Opomyza live in grass.

\section{KEY TO GENERA}

1. Oral ribrissæ differentiated; post ocellar bristles converging, though

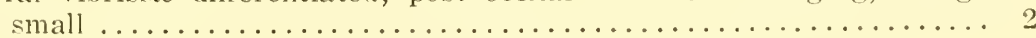
Oral vibrissæ absent; post ocellars diverging or absent......... a

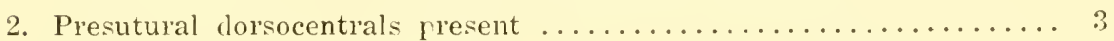
Presutural dorsocentrals absent ..................... 4

3. Cheeks haired only along the lateral oral margin............. Cheeks with hairs over much of the surface or at least towarl the eyres 7

4. One pair of strong frontals $(4,7) \ldots \ldots \ldots \ldots \ldots$ Mumetopia Melander Two pairs of strong frontals........................

5. Posterior crossvein situated only about its length from the wing mar-

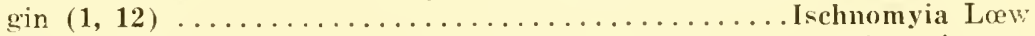
Posterior crossvein situated almost twice its length from the wing margin $(6,11) \ldots \ldots \ldots \ldots \ldots \ldots \ldots \ldots \ldots \ldots \ldots \ldots \ldots \ldots \ldots \ldots \ldots$ Anthomyza Fallén 

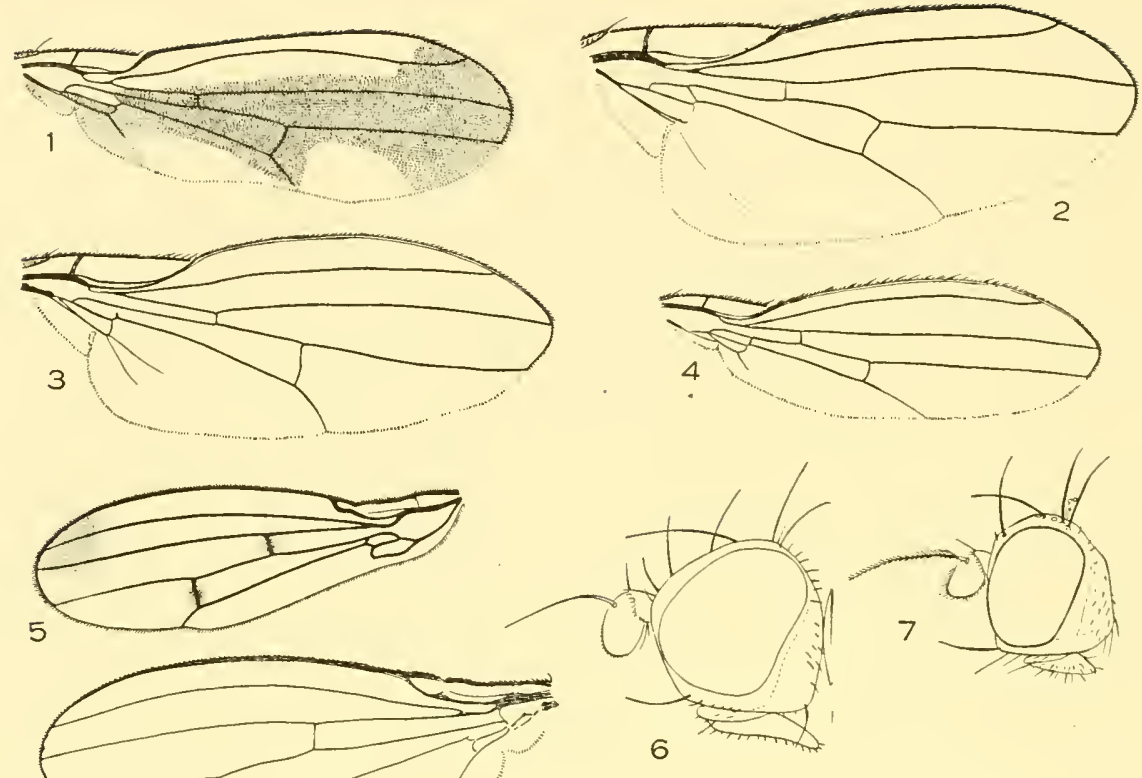

8
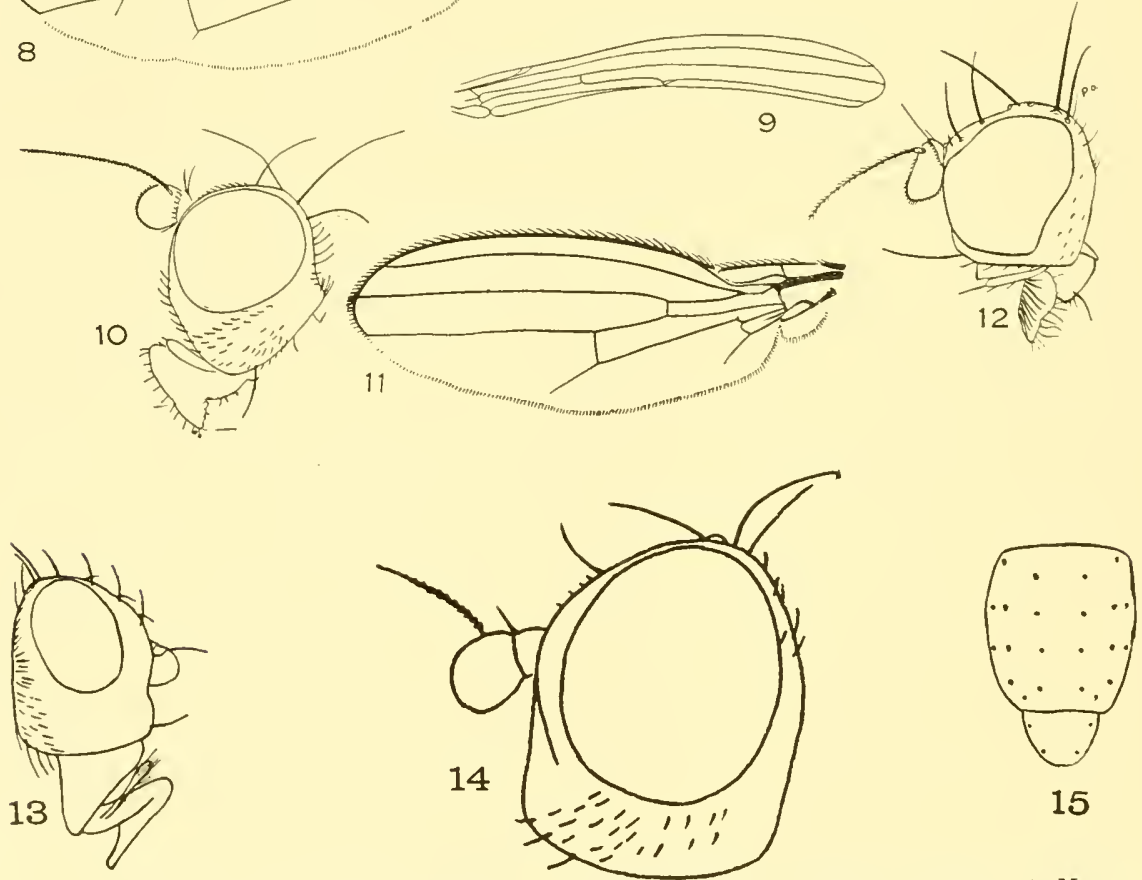

( Pelomyia coronata; 4, Mumetopia nigrimana; 5, Geomyza; 6, Anthomyza; 7 , Mumetopia occipitalis; 8. Opomyza; 9. Mutilloptera apicalis: 10 ; Opomyza; 11, Anthomyza; 12. Ischnomyia vittata; 13, Tethina; 14, Pelomyia occidentalis; 15 , Pelomyia, chrtotaxy. 
6. Frontal vitta with bristles $(2,13) \ldots \ldots \ldots \ldots \ldots \ldots$ Rhicnoëssa Lœw Frontal vitta without bristles (Chyromyidæ)....... † Neossos Malloch

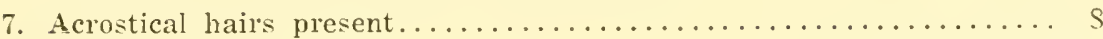
Acrostical hairs absent....................... Pelomyiella Henclel

8. Oral margin strongly produced forward; lower edge of head straight

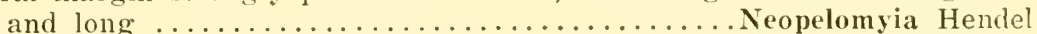
Face not strongly produced below, the lower edge convex $(3,14,15)$.

*Pelomyia Williston

9. Scutellum with hair; wing with anal angle $(8,10) \ldots \ldots$ Opomyza Fallén Scutellum with bristles only; no trace of anal angle............. 10

10. Hind margin of the wing strongly concave (9).... Mlutiloptera Coquillett. Hind margin of the wing at most very weakly concave (5).

Geomyza Fallín

* Hendel, 1934, Tijd. v. Ent., lxxvii, m1. 35-54.

$\dagger 192 \pi$, Proc. Ent. Soc. Wash. 


\section{Family Agromyzidæ-The Leaf Miners}

Small flies, blackish or yellowish in color, the postocellar bristles always present.

Head usually higher than long: front with at least three pairs of bristles; ocellars and postoeellars present, the latter divergent; face receding or coneave in profile; antenna deenmbent, the third segment rarely much longer than wide; arista pubeseent or bare: oral vihrissæ present. Eyes large, the eheeks rarely half as wide as the eye-height. Legs short, the femora with bristles. Wings of moderate size, the venation eomplete or with the posterior crossvein absent; auxiliary vein more or less fused with the first rein or incomplete. Abdomen more or less depressed.

The adults oceur everywhere and there are few deeiduous plants which are not mined by their larve. Owing to their small size they are easily overlooked although easily recognized.

The larra make characteristie mines in the leaves of plants and most of them may be identified by the mines.

\section{KEY TO GENERA}

1. Arista absent (See Ochthiphilidæ, 3 and 5).....* Cryptochatum Rondani

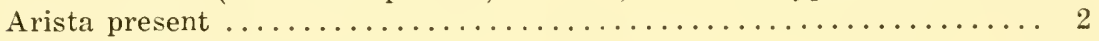

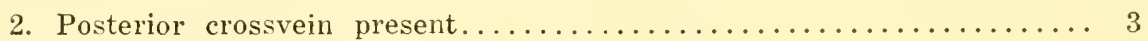

Posterior crossvein absent......................... 7

3. Posterior crossvein situated beyond the anterior crossvein.......... 4 Posterior crossvein situated nearer to the base of the wing than the anterior crossvein $(10) \ldots \ldots \ldots \ldots \ldots \ldots \ldots \ldots \ldots \ldots \ldots$ Napomyza Haliclay

4. Mesopleura with one or more bristles................... 5

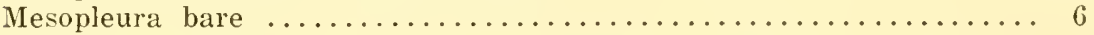

5. Third antennal segment with the upper apex acutely pointed $(3,5)$.

Cerodontha Rondami Third segment not with an acute point, though sometimes angular $(6,7)$.

Agromyza Fallén

6. Front strongly produced forward, the ocelli situated on the anterior part

$(1,9) \ldots \ldots \ldots \ldots \ldots \ldots \ldots \ldots \ldots \ldots \ldots \ldots \ldots \ldots \ldots \ldots$ Traginops Coquillett Front regular in outline, the ocelli situated near the vertex......... 8

7. Fourth vein ending before the wing-tip ............ Antineura Melander Fourth vein ending behind the wing-tip $(8,11) \ldots \ldots$ Phytomyza Fallén

8. Apical cell slightly narrowing apically............ Schildomyia Malloch Apical cell widening apically, the costa not extending to the fourth vein

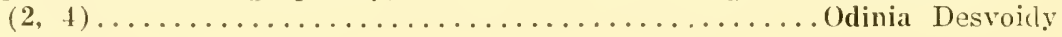

* 1 have not seen this genus and its relationship is somewhat doubtful. 

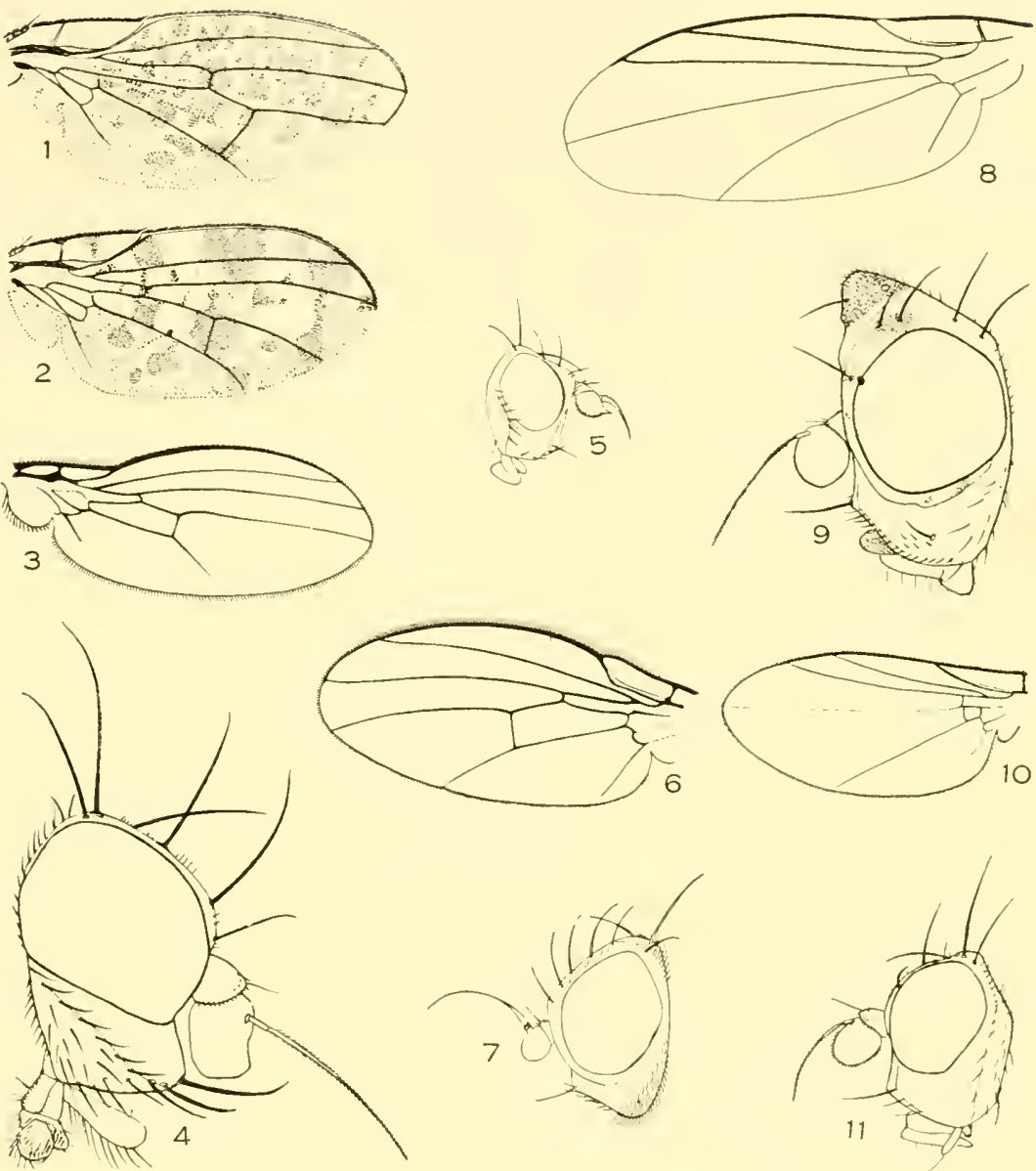

Agromyzidæ.-1, Traginops irrorata; 2, Odinia williamsi; 3, Cerodontha dorsalis; 4 , Odinia williamsi; 5, Cerodontha dorsalis; 6, Agromyza kincaidi; 7, Agromyza waltoni; 8, Phytomyza flavicornis; 9, Traginops irrorata; 10, Napomyza lateralis; 11, Phytomyza. 


\section{Family Phyllomyzidæ}

Small flies, usually black, sometimes silvery pollinose.

Costa broken at the humeral crossvein and at the apex of the auxiliary vein; postocellar bristles eonvergent or parallel; anterior frontals eonvergent, the others divergent, proelinate or reelinate; interfrontals present or there are rows of hairs; oral vibrissæ present though sometimes but poorly differentiated from the other bristles; proboseis long and geniculate, or short; antennæ not elongate, often small. Hesonotum with one to four pairs of dorsoeentrals; mesopleura with or without bristles; pteropleura sometimes with distinct bristles. Legs moderately short. First vein ending near the basal third of the wing: seeond basal and anal cells small; posterior crossvein absent in Paramyia; costa usually bristly basally. Abdomen short and rather broad, the bristles weak or absent.

These flies were included by Williston in the Agromyzidx while other authors have recognized the Miliehiide and Carnida. Phyllomyza is an older generie name than Milichia and I do not consider the differences between the genera placed in the Carnida and Phyllomyzidx as of more than generie value.

The adults are rather eommon and may frequently be found on fence posts, fences, logs, tree-trunks, ete. in the hot sum, or they may be taken by sweeping, on foliage or in grass. I have collected them only during dry weather and always in the bright sunlight. Keys to the speeies will be found in Melander's revision of the family, and in a paper by Malloeht.

\section{KEY TO GENERA}

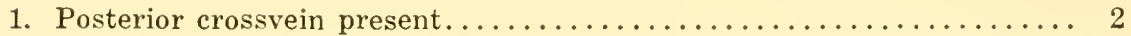
Posterior crossvein absent $(4,26) \ldots \ldots \ldots \ldots \ldots$ Paramyia Williston

2. Costa extending to the fourth vein.................... 5

Costa stopping at the third vein......................... 3

3. Proboscis very elongate and geniculate $(3,20) \ldots \ldots$ Aldrichiella Hendel

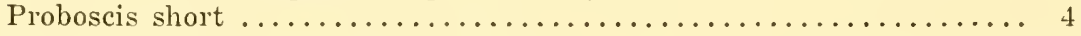

4. Mesopleura bare $(2,9,13) \ldots \ldots \ldots \ldots \ldots \ldots \ldots \ldots$ Euchlorops Malloch Mesopleura with two or three bristles $(6,21) \ldots \ldots \ldots$ Meoneura Rondanj

*1913. Journ. N. Y. Ent. Soc., xxi, pp. 234-246.

$\div$ 1913, Proc. U. S. N. M., xlvi, pp. $127-152$. 

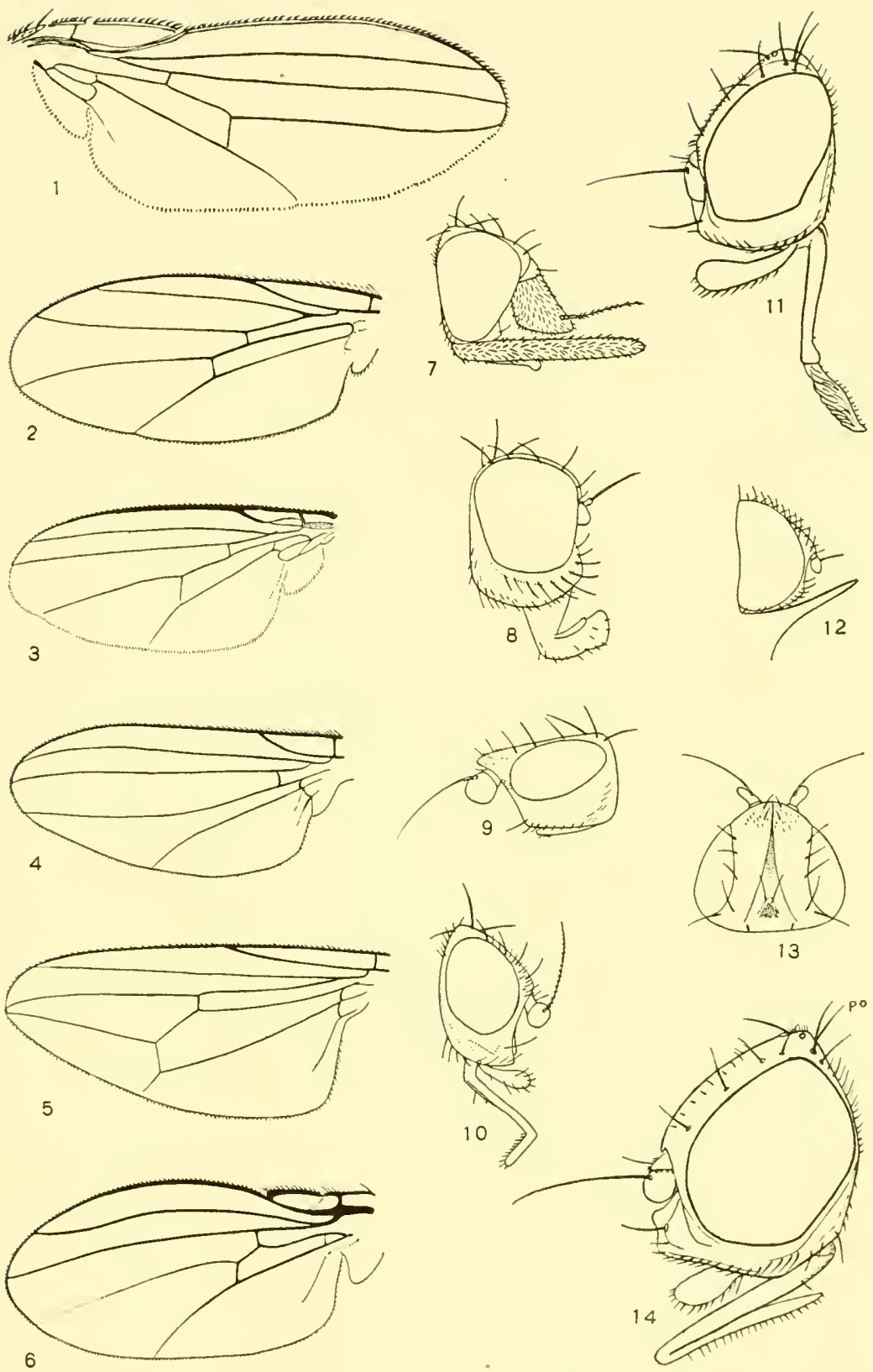

Phyllomyzidx I.-1, Hypaspistomyia latipes; 2, Euchlorops vittata ; 3, Aldrichiella agromyzina; 4, Paramyia nitens; 5, Eusiphona mira; 6, Meoneura vagans; 7, Phyllomyza hirtipalpis: 8, Hemeromyia nitida; 9. Euchlorops vittata; 10, Desmometopa M-nigrum; 11 . Hypaspistomyia latipes; 12 , Eusiphona mira; 13 , Euchlorops vittata; 14, Desmomyza confusa. 
5. Costa with a very deep excision at the apex of the auxiliary vein; cruciate interfrontals developed $\ldots \ldots \ldots \ldots \ldots \ldots \ldots \ldots \ldots \ldots \ldots$

Costa broken but the excision not extending into the cell; interfrontal

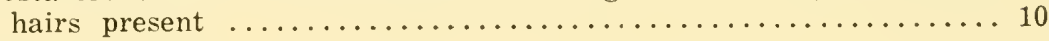

6. Mesopleura with strong bristles..................... 7

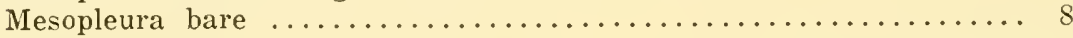

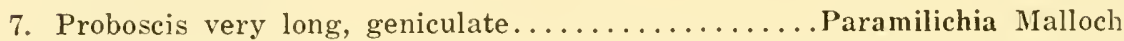
Proboscis geniculate, but not unusually long $(19,23)$. Pholeomyia Bilimek

8. Posterior margin of the eye excised at the midlle............. 9

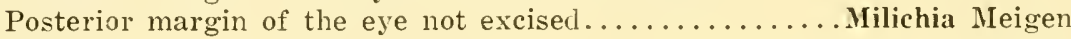

9. Four pairs of dorsocentrals $(18,22) \ldots \ldots \ldots \ldots \ldots$ Eccoptomma Becker One or two pairs of dorsocentrals $(17,22) \ldots \ldots \ldots$ Milichiella Giglio-Tos

10. Apical cell very widely open, at most a little narrowed apically....... 11 Apical cell only narrowly open $(5,12) \ldots \ldots \ldots \ldots$ Eusiphona Coquillett

11. Bristles of the head and thorax strong; eyes at most short haired.... 12 Bristles of head and thorax not strongly differentiated from the hair;

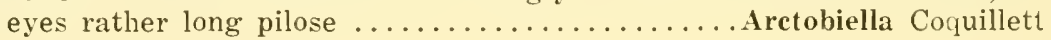

12. Proboscis geniculate, long and chitinized; vibrissal angle usually dis-

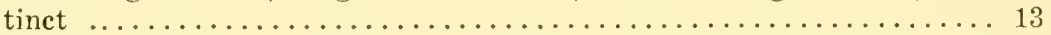

Proboscis shorter and more or less fleshy, the labellæ not elongate though folding back; vibrissal angles not developed; face strongly carinate $(8) \ldots \ldots \ldots \ldots \ldots \ldots \ldots \ldots \ldots \ldots \ldots \ldots \ldots \ldots \ldots \ldots$ Hemeromyia Coquillett

13. Posterior tibiæ flattened and broadened..................... 14

Posterior tibiæ not unusually flat and wide................. 16

14. Pteropleura with one or more small bristles (Paramadiza Malloch;

Mallochiella Melander $)(1,11) \ldots \ldots \ldots \ldots \ldots$ Hypaspistomyia Hendel

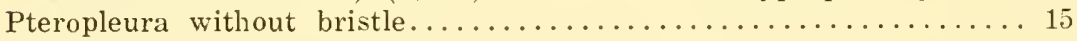

15. Glossy black; frontal bristles weak $(14,15) \ldots \ldots \ldots$. . Desmomyza, n. g. Dull colored; frontals stronger; two pairs of divergent frontals; interfrontals in differentiated rows $(16,10) \ldots \ldots \ldots$ Desmometopa Lœw

16. Lower edge of the head horizontal and long $(24,25)$.

Platophrymyia Williston Lower edge of the head rounded or short.................. 17

17. Eyes hairy; palpi very large, projecting far beyond the oral margin

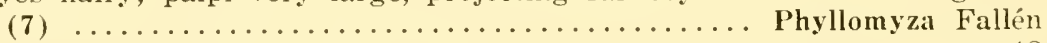
Eyes bare or nearly so; palpi not projecting.............. is

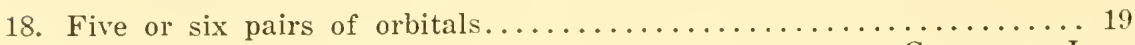

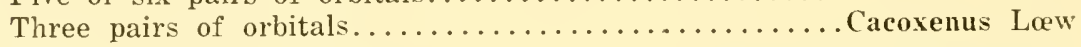

19. Apical scutellars converging............... Neophyllomyza Melander

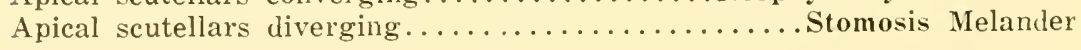



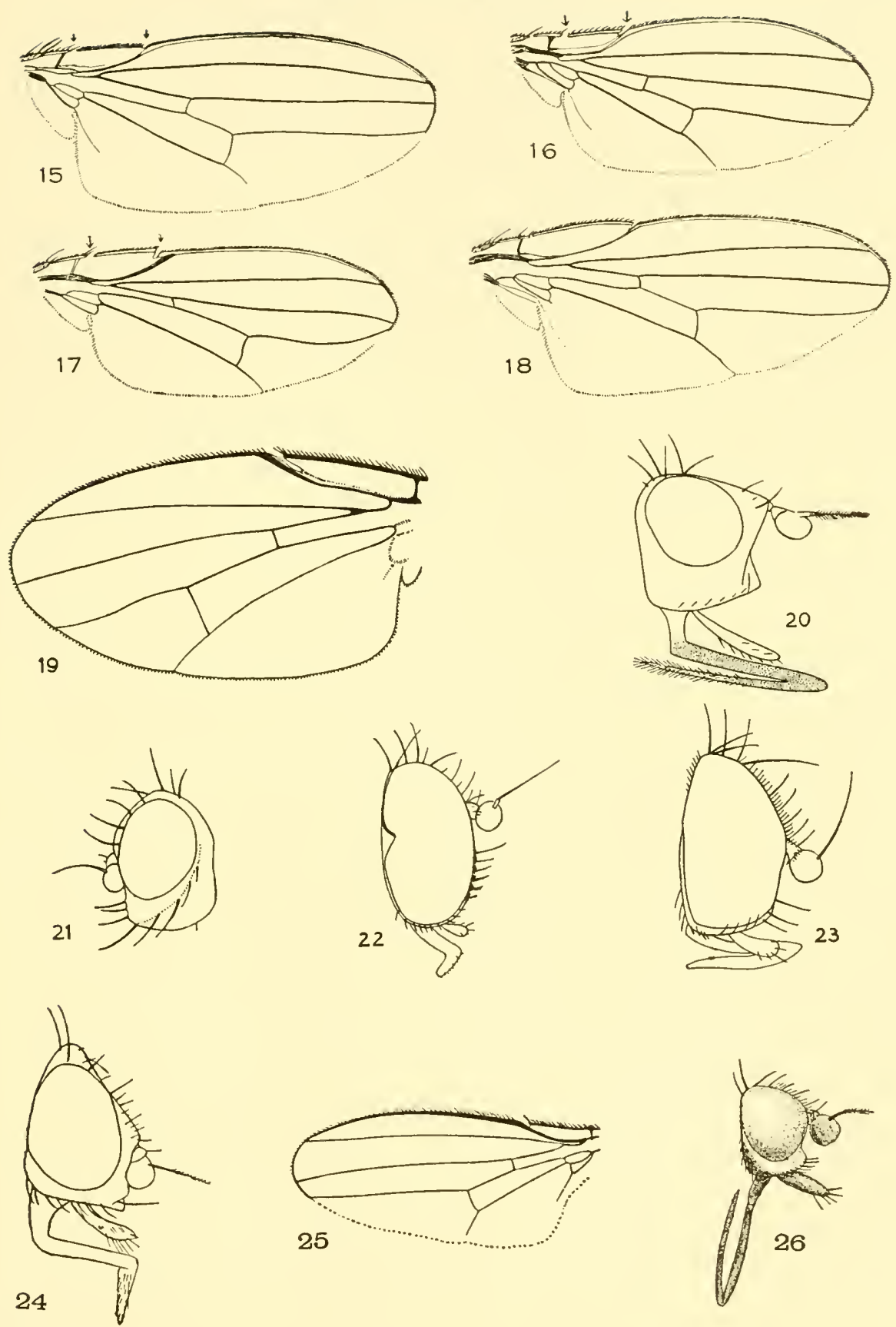

Phyllomyzid:e II,-15, Desmomyza confusa; 16, Desmometopa; 17. Milichiclla; 18, Eccoptomma; 19, Pholeomyia indecora; 20, Aldrichiella agromyzina; 21, Mconeura vagans; 22, Milichiella lacteipennis; 23 , Pholeomyia indecora; 24, 25, Platophrymyia nigra; 26, Paramyia nitens. 


\section{Desmomyza, new genus}

Related to Hypaspistomyia Hendel but differing in having the pteropleura entirely bare instead of having some setulæ above. Genotype:-D. confusa n. sp. (New York).

The genotype is extremely like $H$. glabra Fallén, of which I believe Desmometopa halteralis Coquillett to be a synonym. It is entirely shining black except the base of the tarsi, the wings are milky white with yellowish veins. The only difference between Desmomyza and Hypaspistomyia, to which I refer glabra, lies in the presence in the latter of pteropleural setules. The type of halteralis has these, as do European specimens of glubra examined by me, hence my belief that Coquillett's species is the same as glabra. The weaker frontals will separate Desmomyza from Desmometopu. 


\section{Family Chloropidæ-The Frit Flies}

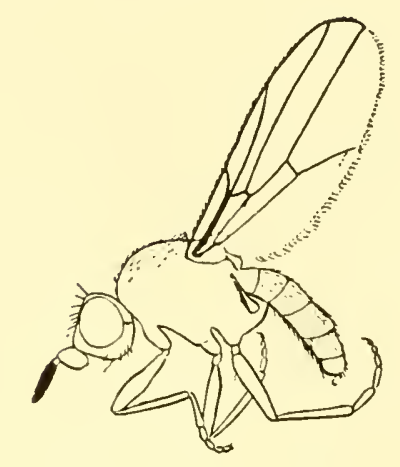

Crassiseta species.

Small to very small, bare or nearly bare flies.

Head usually rather hemispherical, sometimes more or less triangular or rectangular, the face usually nearly rertical or receding; oral vibrissa weak or absent; front broad, sometimes with bristles, the vertical triangle very large, often extending to the anterior margin of the front. Antennæ usually short, with rounded third segment, sometimes elongate. Wings of moderate length or rather short, auxiliary rein restigial; second basal cell united with the diseal eell; anal cell absent; fifth rein almost always with a slight, characteristie irregularity near the middle of the discal eell. Legs short, the femora rarely greatly thickened.

These flies are very eommon and representatives of the family may be collected almost anywhere. The family will be readily recognized as the large vertical or frontal triangle is characteristic and the peculiar gentle eurve of the fourth rein is typieal of the group.

The larva live in grass and other plants and some of them are economic pests of cereals. They are thick and eylindrieal, with stout mouth hooks, two segmented antemnæ and fleshy abdominal protuberances for locomotion.

The generic limits in some cases are eridently weak and it is not always easy to place some species with certainty. I am not certain that the so-called horny genienlate proboseis of Madiza Fallén constitutes a generic character in this case since there is a gradual evolution to the normal trpe found in Oscincllu Becker. The apical section of the pro- 

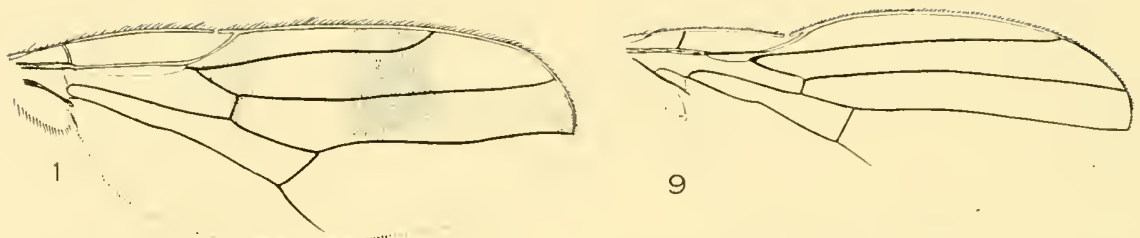

9
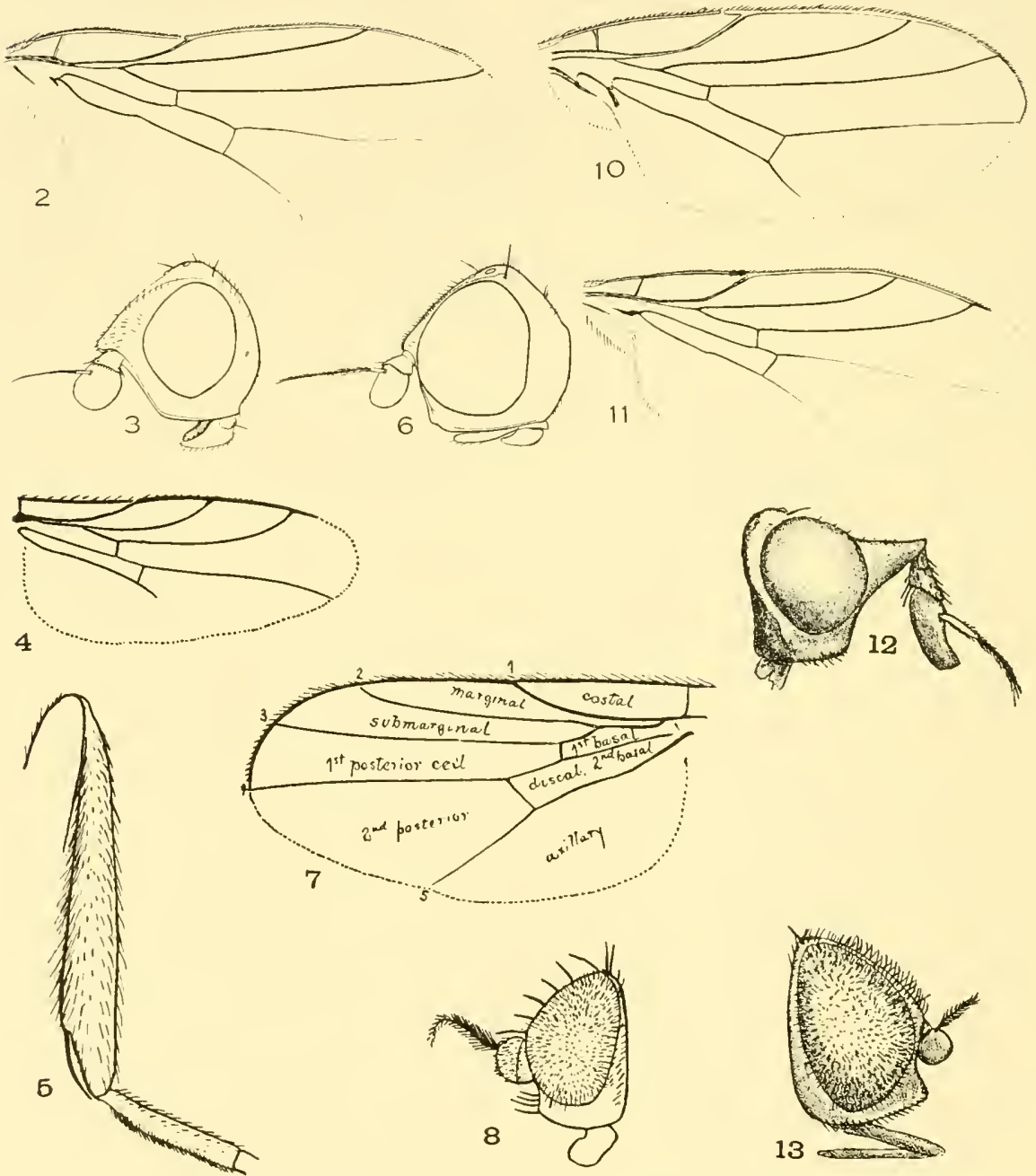

Chloropidæ I.-1, Dactylothyrea curvinervis; 2, Chlorops sulphurea; 3, Chlorops; 4, Meromyza americana; 5 , Hippelates collusor; 6 , Cetema hypocera; 7 . Madiza; 8, Pseudogaurax ; 9. Dicreus; 10. Pseudogaurax; 11, Diplotoxa pulchripes; 12, Ectecephala; 13, Madiza. 
boscis is nothing more than the labella which are lengthened and narrowed and it is not always easy to decide whether the proboscis is geniculate or not. Trouble will also be experienced in ennection with the pubeseence of the arista and the presence of frontal bristles, both of which are characters which show gradual development in the presence of extensive collections. The only revision of the North American species of this family is by Becker." In a recent paper on the Neotropical forms Dudat has proposed many new genera but his contribution has been so badly mangled by deletion neessitated in order to reduce its size to the absurd limits set by most publications that it is almost impossible to follow his keys.

\section{KEY TO GENERA}

1. Costa extending to the fourth vein $\ldots \ldots \ldots \ldots \ldots \ldots \ldots \ldots \ldots \ldots \ldots$ Costa ending at the third vein or slightly beyond it ............ 2

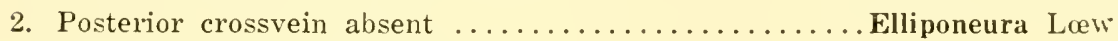

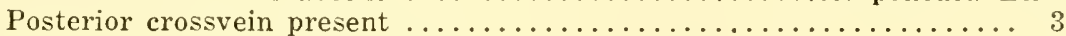

3. Posterior femora greatly thickened, their tibiæ strongly arcuate

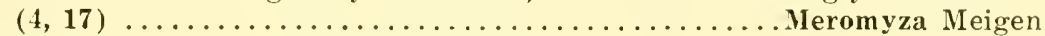
Posterior femora only moderately thickened, their tibiæ but little

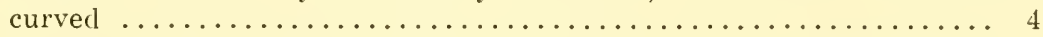

4. Middle tibiæ with a strong, curved apical spur; male genitalia large, carried forward under the abdomen $(6,14,21) \ldots \ldots \ldots$. Cetema Hendel Middle tibiæ with normal terminal bristles ................. 5

5. Posterior tibiæ with an oval, opaque "sensory organ" posterodorsally, the tibiæ somewhat broadened $(18,23,26) \ldots \ldots \ldots \ldots$ Chloropisca Lœw Posterior tibæ without velvety sensory area............... 6

6. The distance between the crossveins along the fourth vein is not greater than the length of the posterior crossvein (11). Diplotoxa Lœw The distance is equal to at least twice the length of the posterior

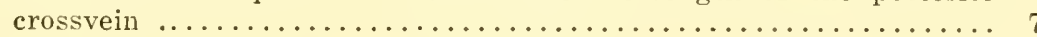

7. Mesonotum entirely black, coarsely punctured.......Ephichlorops Becker Mesonotum usually vittate, not wholly black nor coarsely punctured... \&

8. Third antennal segment conspicuously longer than broad........... ? Third segment rather circular in outline, often broader than long, never conspicuously longer than broad $(2,3) \ldots \ldots$ Chlorops Meigen

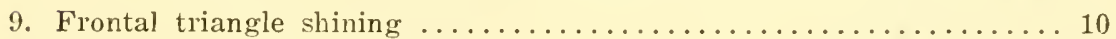
Frontal triangle opaque $(28) \ldots \ldots \ldots \ldots \ldots$. Anthracophaga Low

10. Frontal triangle very long and broad, ending in a broad, obtuse point a little before the base of the antennæ, convex in cross-section

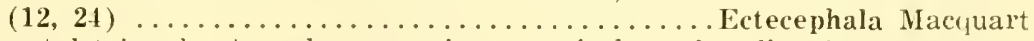

Frontal triangle strongly narrowing anteriorly and ending in an acute point, flat in cross-section $(16,25) \ldots \ldots \ldots$. Parectecephala Becker

* 1912. Ann. Mus. Nat. Hung., x, 11). 21-.

$\dagger$ 1930, Fol. Zool. Hydrobiol., ii. p1. 46-12s. 

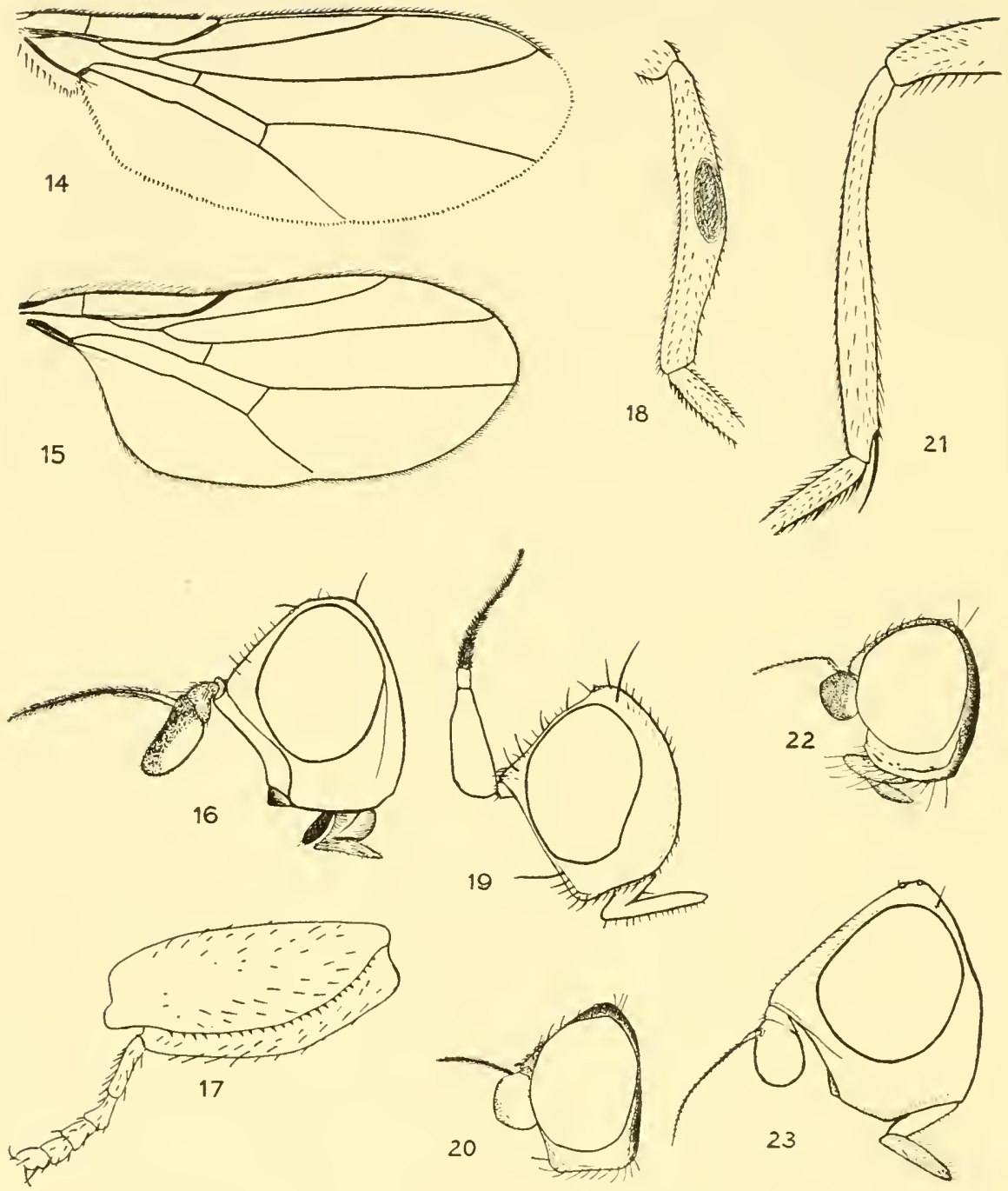

Chloropidæ II.--14, Cetema hypocera; 15 , Oscinella varipalpus; 16. Parectecephala: 17. Mcromyza americana, hind leg; 18. Chloropisca variceps, hind tibia; 19, Ceratobarys pulophus: 20, Oscinella tripunctata; 21 , Cetema, middle tibia: 22, Oscinella magnipalpoides; 23 , Chloropisca. 
11. Posterior tibiæ with a strong, curved ventral spur at or before the

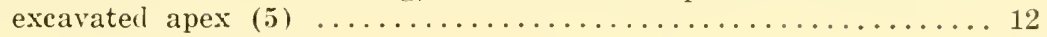

Posterior tibiæ normal ........................... 15

12. Arista flattened and strap-like (19) ........... Ceratobarys Coquilletl Arista of ordinary shape, practically bare................. 13

13. Scutellum elongated, with flattened disc .........Prohippelates Malloch Scutellum with convex disc and of normal length.............. 11

14. Front with distinct bristles toward the orbits. Pseudohippelates Malloch

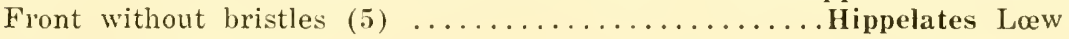

15. Distance between the tips of the second and third veins at least twice that between the first and second ............. Sipnunculina Rondani

Distance between tips of second and third veins but little more than that between the first and second .................... 16

16. Arista bare or quite short pubescent ................... 20

Arista broadened or long pubescent . . . . . . . . . . . . . . 17

17. Arista appearing broadened and strap-like due to the arrangement of

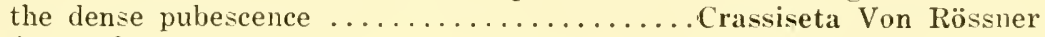
Arista pubescent ............................... 18

18. Scutellum with strong marginal processes $(1,27) \ldots$ Dactylothyrea Duda Scutellum without marginal processes .................. 19
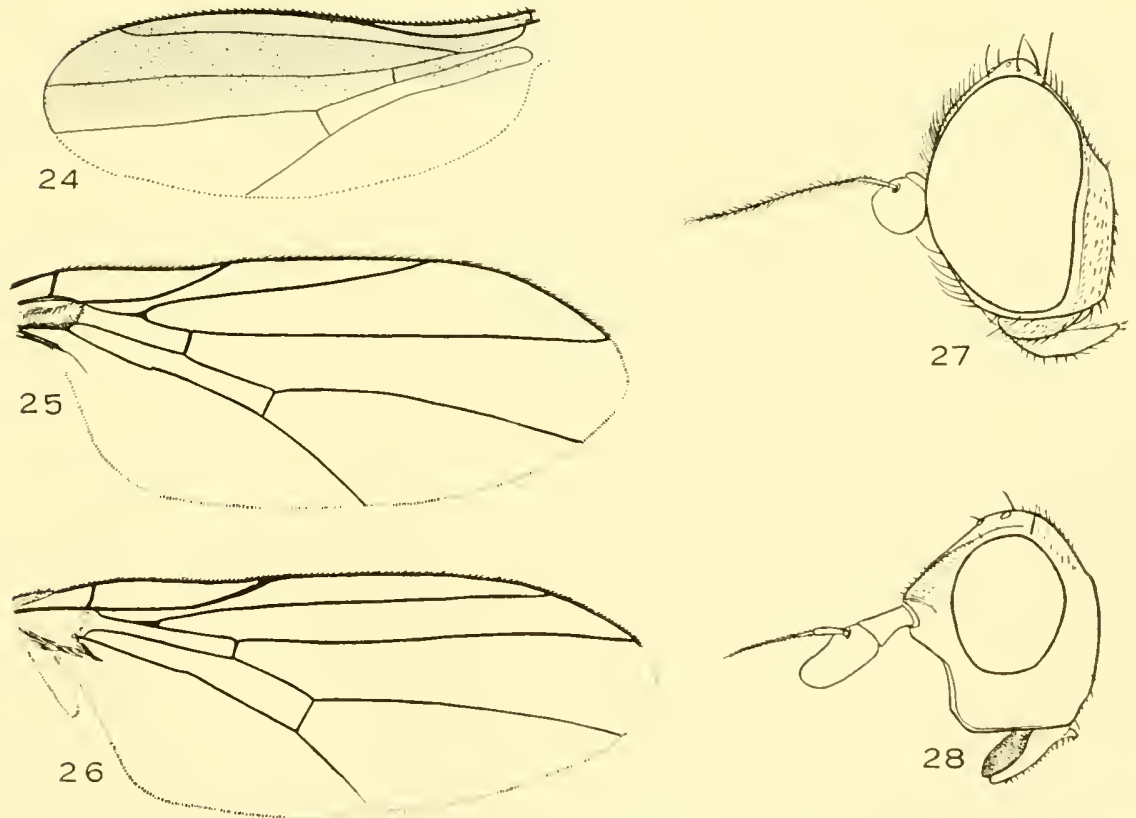

Chloropida III.-24. Ectecephala; 25. Parectephala; 26. Chloropisca; 27, Dactylothyrea curvinervis; 28, Anthracophaga sanguilenta. 
19. Scutellum elongated, the disc flattened $(8,10) \ldots$ Pseudogaurax Mallocin Scutellum normal, the disc gently convex .............Gaurax Lœw

20. Only two notopleural bristles on posterior part............ 22 At least four notopleural bristles ....................... 21

21. Notopleural bristles four in number; mesonotal setulæ in rows. Notopleural bristles very numerous; mesonotum thickly setulose.

Chrtochlorops Malloch

22. Distance between the tips of the first and second veins three or four times that between the second and third (9) .......... Dicraus Lœw Distance between tips of first and second veins not more than twice

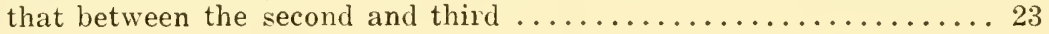

23. Proboscis elongated and geniculate, the terminal section about as long as the precelling section $(7,13) \ldots \ldots \ldots \ldots \ldots \ldots$ Madiza Fallén Proboscis shorter, the apical section shorter and more fleshy...... 24

24. Mesonotum with three broad longitudinal punctured grooves. Tricimba Lioy Mesonotum with only two narrower grooves or they are weak or absent

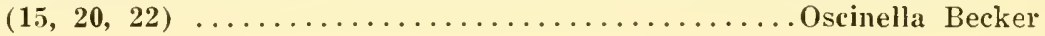




\section{Family Ephydridæ-The Shore Flies}

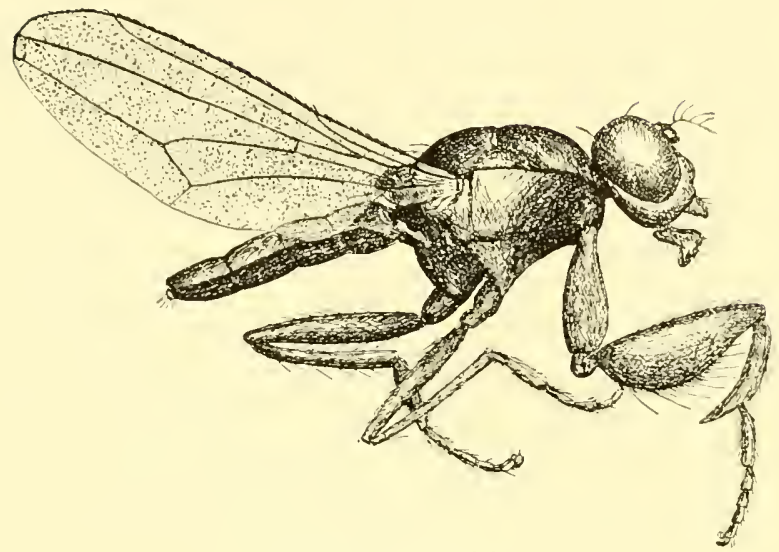

Ochthera humilis.

Small to very small flies, the anal eell absent, the second basal an! discal eells mited.

Face more or less, often remarkably convex, the oral eavity rounded, sometimes very large; clypeus distinct but often retracted within the oral eavity; no distinct oral vibrissa but the sides of the face often with bristles or hairs. Antemex short; arista bare, pubeseent or pectinate, always dorsal. Thorax gently convex, bristled. Legs short; tibix withont preapical bristle, the middle pair with apical spur. Wings rarely aborted; anxiliary rein united with the first rein except basally; costa broken before the tip of the first rein and weakened berond the humeral erossrein; sceond basal and diseal eells united; anal cell absent or extremely small and incomplete. Abdomen composed of six segments in the males, seren in the females, the number sometimes apparently redueed to three, viliable but never elongate, often quite wide; genitalia usually retracted; body nsually with but few hairs.

The adults are found in moist plares, inhabiting marshes, swimps and the shores of lakes, ponds, and streams, along the rdges of brooks and the sea shore. Many of the species are of loeal habitat but most of them are widely distributed. Some species oecur in the flowers of water plants and have been found nowhere ase. Water lilies are usually frequented by sereral species while in bloom and many oceur on the 

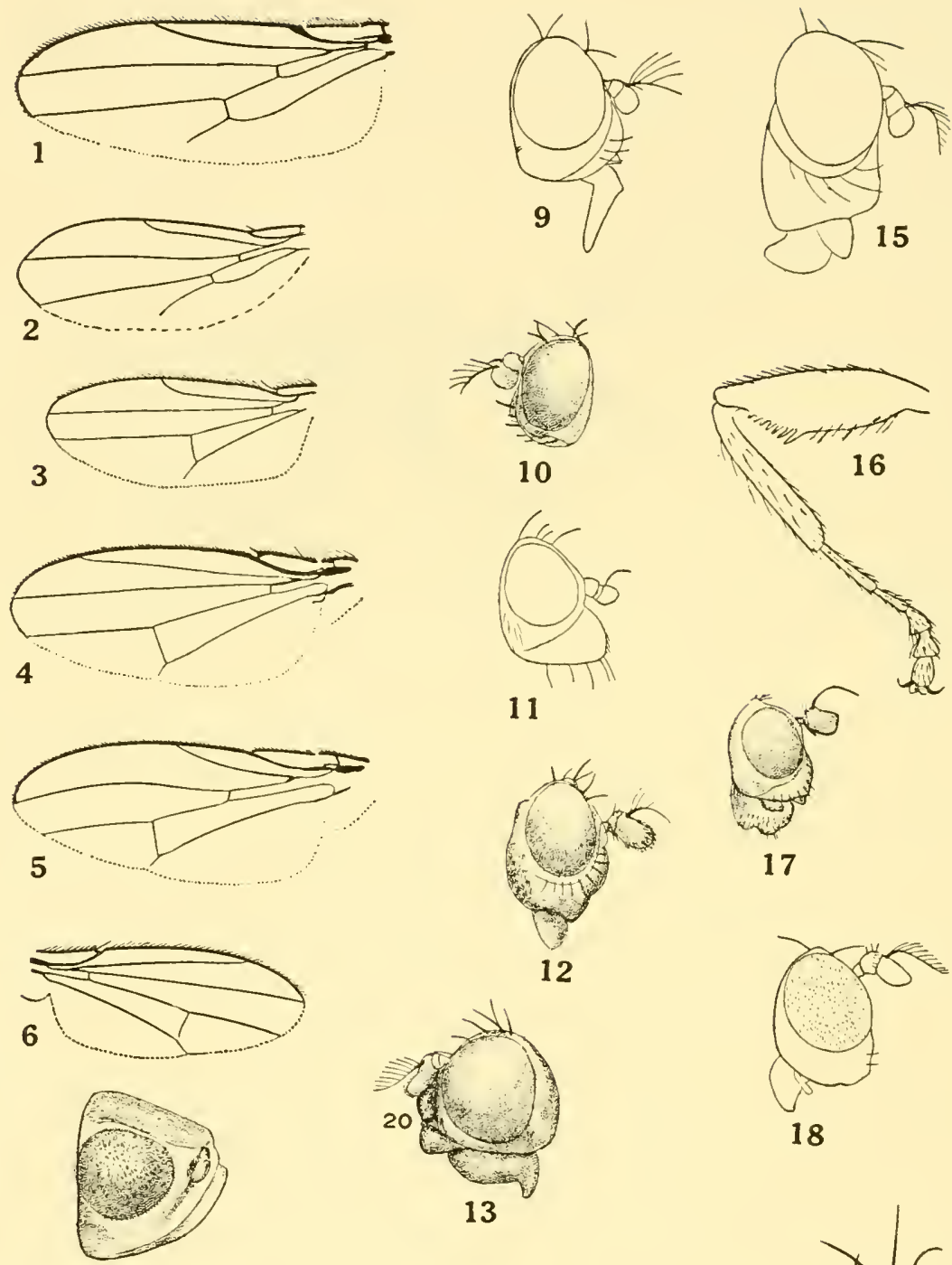

\section{7}

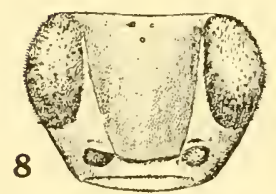

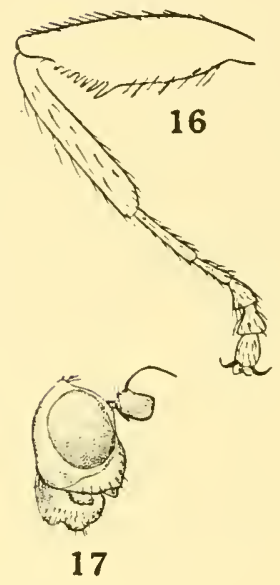

13
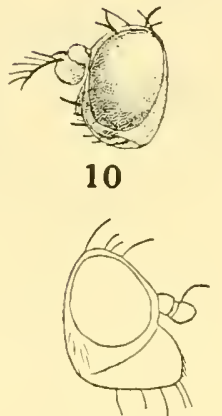

11

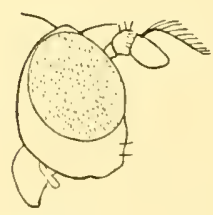

18

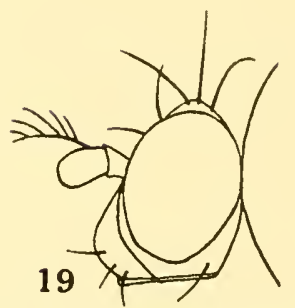

Ephydridze I.-1, Lytogaster; 2, Hydrina ; 3, Ochtheroidea atra ; 4, Parydra ; 5, Brachydeutera argentata; 6, Notiphila; 7, S, Lipocheta ; 9, Allotrichoma; 10, Discocerina; 11, Ephydra; 12, Gastrops; 13, Brachydeutera; 14, Lytogaster; 15, Athyroglossa; 16, Ochtheroidea ; 17, Lytogaster; 18 , Hydrina ; 19, Atissiella. 
leaves. Some of the species are able to walk on the surfice of water and many of them will alight upon it if disturbed but they usually quickly return to the shore.

The larve live in various habitats, many are aquatic or live in mud, others in the stems of aquatic or semi-aquatic plants, a few in flowing sap. Many of them live in brackish, but may also oceur in fresh, or eren in alkaline water. One species, Psilopa petrolei Coquillett, occurs in the pools of crude petroleum found in California, breathing by projecting the posterior spiracles ahove the surface of the oil, but its food is unknown. Other speeies are found in the warm waters of geysers.

Many new genera have been described sinee the publication of Williston's Mamual and some authors have recognized the Notiphilidxe as a separate family but there appears to be no good basis for this. Jones* reviewed the family in 1906. Since then there has been no comprehensive publication although Cresson has published several large papers containing deseriptions of new species and genera and some keys.

\section{KEY TO GENERA.}

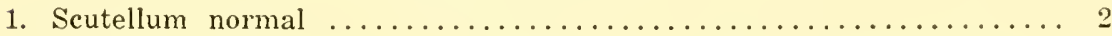
Scutellum as large as the mesonotum and almost concealing the abdomen, from dorsal view (see text figure)........Peltopsilopa Hendel

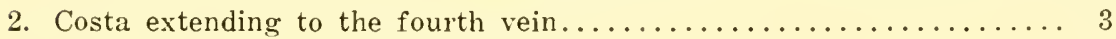

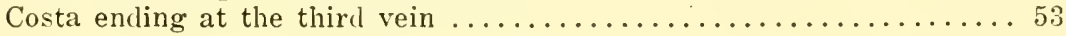

3. Antennæ small, inserted very far apart in cavities, the arista atrophied, very short and blunt $(7,8,71) \ldots \ldots \ldots \ldots \ldots$ Lipochæt a Coquillett Antennæ normal; arista always long $\ldots \ldots \ldots \ldots \ldots \ldots \ldots \ldots \ldots \ldots \ldots \ldots \ldots \ldots \ldots \ldots$

4. Middle tibiæ with dorsal bristles $(30,57) \ldots \ldots \ldots \ldots+$ Paralimna Lœw Middle tibiæ without bristles except at the apex $\ldots \ldots \ldots \ldots \ldots \ldots 5$

5. Second antennal segment with a spinous bristle at the upper apical

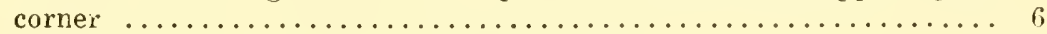
Second antennal segment without such bristle.................... 31

6. First and fifth abdominal segments exceptionally short, the abdomen apparently composed of three long segments, the lateral margins

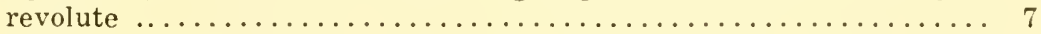
Abdomen with five distinct segments, the lateral margins not margined. 8

7. Face with two pairs of bristles below.......... Trimerinoides Cresson Face with one pair of bristles below (48) .......... Trimerina Macquart

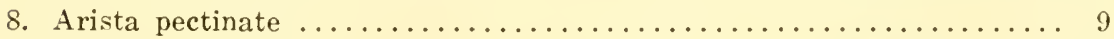

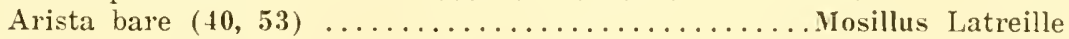

* Tech. Bull. Calif. Exp. Sta., i. No. 2.

† Cresson, 1918. Trans-Amer. Ent. Soc., xliv, 1). 45 (Costa Rica). 

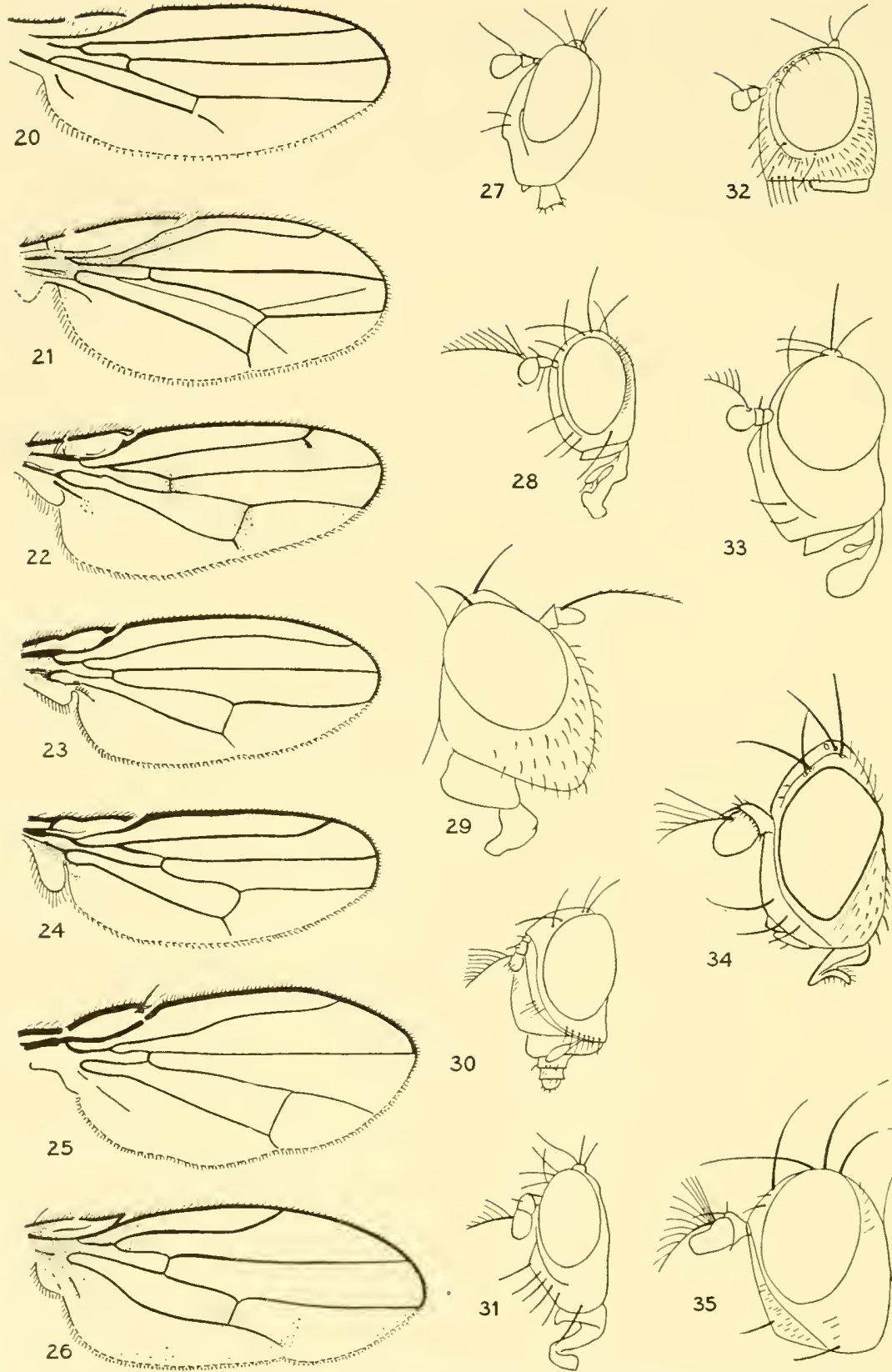

Ephydridre II - 20, Glenanthe; 21, Clanoneurum ; 22, Parydra; 23 , Cenia ; 24, Pelina ; 25 , Dichrta: Hyadina: 27, Axysta; 28, Dichæta; 29, Psilephydra; 30, Paralimna; 31 , Hecamedoides; 32 , Lamproscatella; 33 , Cdenops; 34 , Ditıichophora valens; 35 , Notiphila. 
9. Wings with a strong fold extending the length of the discal cell near the midcle and another in the apical cell $(21,49)$. Clanoneurum Becker

Wings without such folds ............................ 10

10. Arista without rays below $\ldots \ldots \ldots \ldots \ldots \ldots \ldots \ldots \ldots \ldots \ldots \ldots \ldots$ Arista with two or three rays below $(38,44) \ldots \ldots$. Ptilomyia Coquillett

11. Face with transverse ridges, at least laterally, which may be very broad, or fine and numerous, usually limited to the lower half of

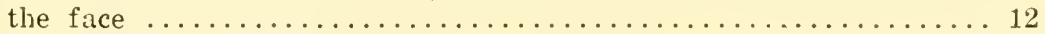

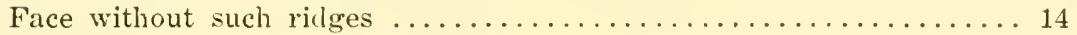

12. Facial ridges very fine, extending across the face, sometimes not continuous on the lower part $(58,66) \ldots \ldots \ldots \ldots \ldots$ Leptopsilopa Cresson

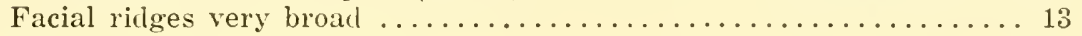

13. Facial ridges strong, extending across the face (68). Cerometopum Cresson Facial ridges resulting from sub-lateral pits and not extending over the middle of the face $(37,52) \ldots \ldots \ldots \ldots \ldots$ Discomyza Meigen

14. With only one pair of dorsocentral bristles............... 21

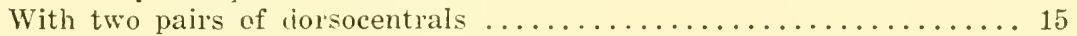

15. Ocellar bristles widely separaterl, situated opposite the anterior ocellus. 16 Ocellars normal, situated above the anterior ocellus............ 19

16. Bristles on the sides of the face all convergent.............. 17 Bristles on the sides of the face partly divergent, partly convergent.

Polytrichophora Cresson

17. Face with two rows of bristles on either sille............... 18 Face with one row of bristles on either side $(\mathbf{1 0}, 56)$. Discocerina Macquart

18. Posterior tibiæ with a strong, curved apical spine (31).

Hecamedoides Hendel. Posterior tibiæ without apical spine ............. Diclasiopa Hendel

19. Interfrontalia with two pairs of bristles $(67,72) \ldots$ Paratissa Coquillett Interfrontalia without bristles, the ordinary frontals present...... 20

20. Face rather strongly carinate above, the carina ending prominently at the midlle of the face $(41,63) \ldots \ldots \ldots \ldots \ldots \ldots \ldots$. Ilythea Haliday Face very gently convex longitulinally, not carinate (Typopsilopa Cresson) $(54) \ldots \ldots \ldots \ldots \ldots \ldots \ldots \ldots \ldots \ldots$ Psilopina Becker

21. Oral opening large, the clypeus always prominent, the middle of the

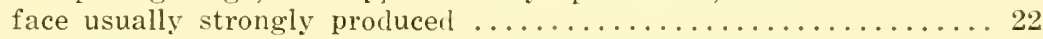
Oral opening smaller, the face usually convex and receving below, the face never strikingly produced in the midalle............... 24

22. Third costal section Ionger than the second $(19) \ldots \ldots$. Atissiella Cresson Third costal section shorter than the second................ 23

23. Ocellars inserted opposite the anterior ocellus (45) ...... Atissa Haliday Ocellars inserted above the anterior ocellus (9)....Allotrichoma Becker

* Cresson, 1918. Trans. Amer. Ent. Soc., xliv, p. 50 (Costa Rica). 

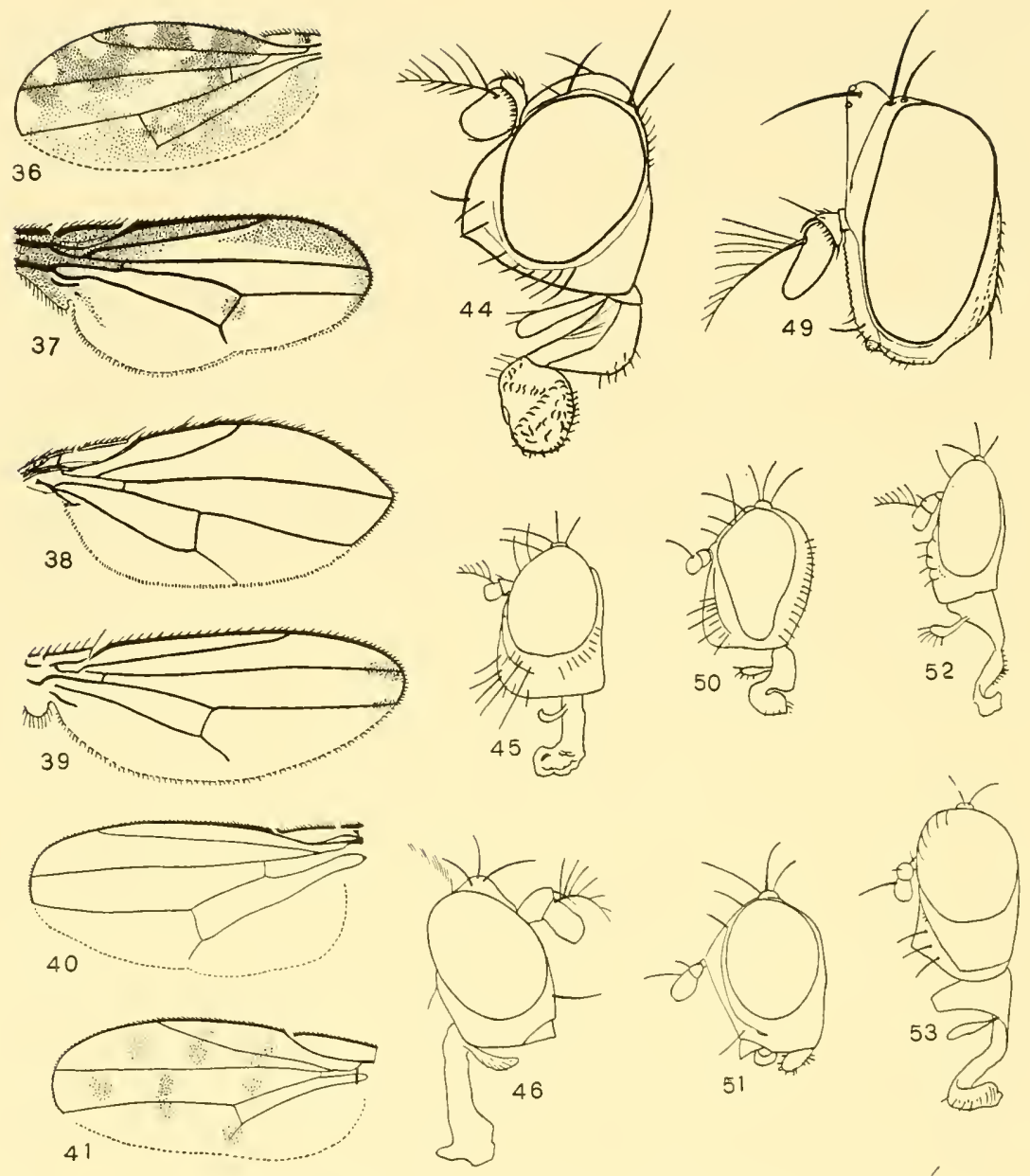

41
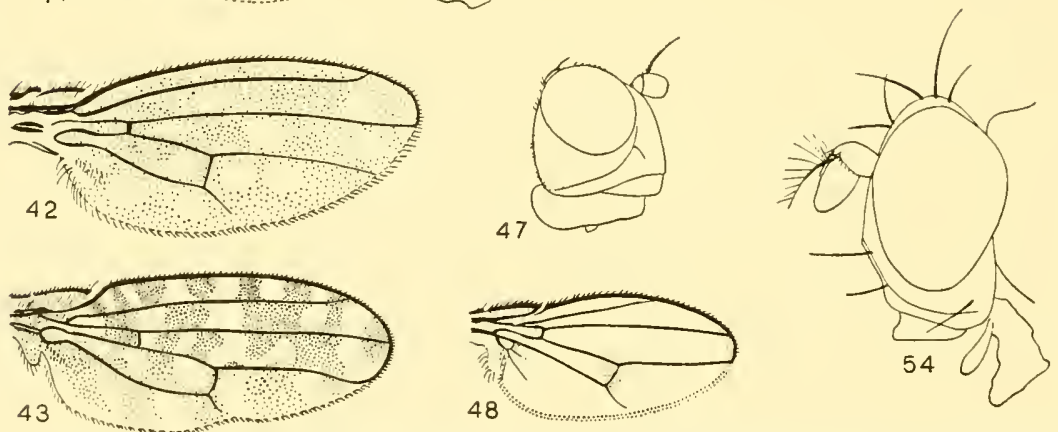

Elhydridæe III.-36, Nostima slussonæ; 37. Discomyza; 38, Ptilomyia renigma; 39, Psilopa ; 40. Mosillus: 41, Ilythea; 42, Scatophila; 43, Scatella; 44, Ptilomyia renigma; 45, Atissa; 46 , Plagiops; 47, Parydra; 48. Trimerina; 49, Clanoneurum; 50, Glenanthe; 5I, Pelina; 52 , Discomyza ; 53 , Mosillus; 54 , Psilopina. 


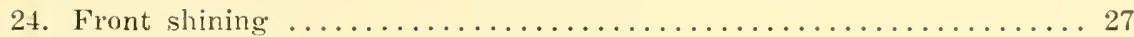

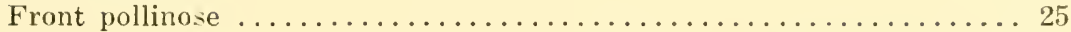

25. Face with longitudinal ridges below $(59,73) \ldots \ldots$ Rhysophora Cresson

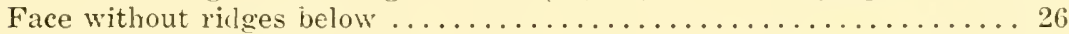

26. Eyes longitudinally oval $(31) \ldots \ldots \ldots \ldots \ldots \ldots$ Ditrichophora Cresson Eyes not regularly oval, widened below the middle and narrowing the face above $(\mathbf{1 0}, 56) \ldots \ldots \ldots \ldots \ldots \ldots \ldots \ldots \ldots \ldots \ldots$ Discocerina Macquart

27. Face carinate above $(15) \ldots \ldots \ldots \ldots \ldots \ldots \ldots$ Atlyyroglossa Lœw Face very gently convex above, without a distinct ridge.......... 28

28. Face and front on the same plane, flat, the face slightly convex be-

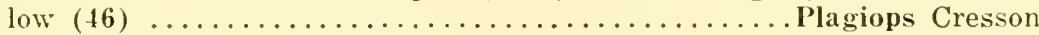
Face, front or both conspicuously convex .................. 29

29. Second and third antennal segments pendulous, the third more than

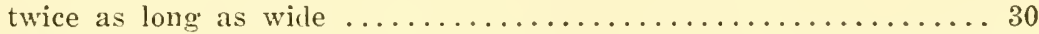

Antennæ not pendulous, the third segment not twice as long as wide

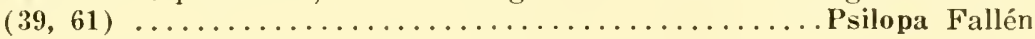

30. Spine of second antennal segment long and strong (62).

Clasiopella Cresson Spine of second antennal segment fine $(77) \ldots \ldots \ldots$ Ceropsilopa Cresson

31. Oral opening small; eyes usually with distinct hair $\ldots \ldots \ldots \ldots \ldots . \ldots 32$

Oral opening large; eyes usually bare $\ldots \ldots \ldots \ldots \ldots \ldots \ldots \ldots \ldots \ldots$

32. Anterior femora greatly enlarged, their tibiæ ending in a spur....... 33 Anterior femora not remarkably enlarged, their tibiæ not ending in a

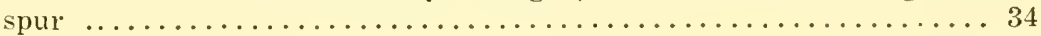

33. Scutellum with four marginal bristles (see text figure). Scutellum with two marginal bristles $(64) \ldots . .$. . St enochthera Hendel

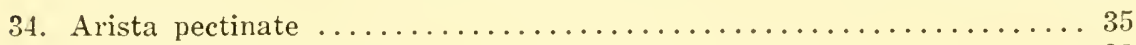

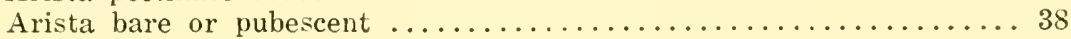

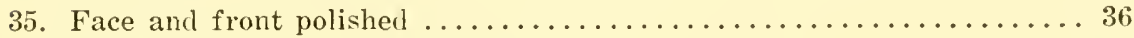

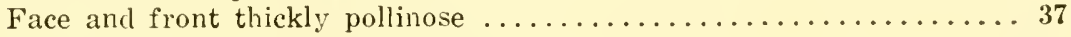

36. Sides of the face with deep punctures resulting in short, transverse ridges $(3,16,65) \ldots \ldots \ldots \ldots \ldots \ldots \ldots \ldots *^{*}$ Ochtheroidea Williston Sides of face without pits or winkles............. Ceropsilopa Cresson

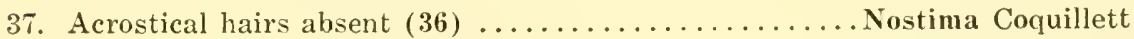

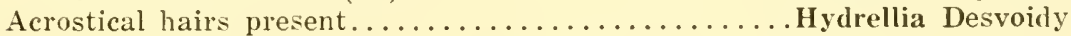

38. Mesonotum with three pairs of dorsocentrals, a strong one near the inner end of the suture, another in front; four scutellars $(2,18)$.

Hydrina Desvoidy

Mesonotum with at most one pair of strong dorsocentrals, rarely an extremely weak second pair . .......................... 39

* Cresson, 1918, Trans-Amer. Ent. Soc., xliv, M1) 56, 60 (Costa Rica). 

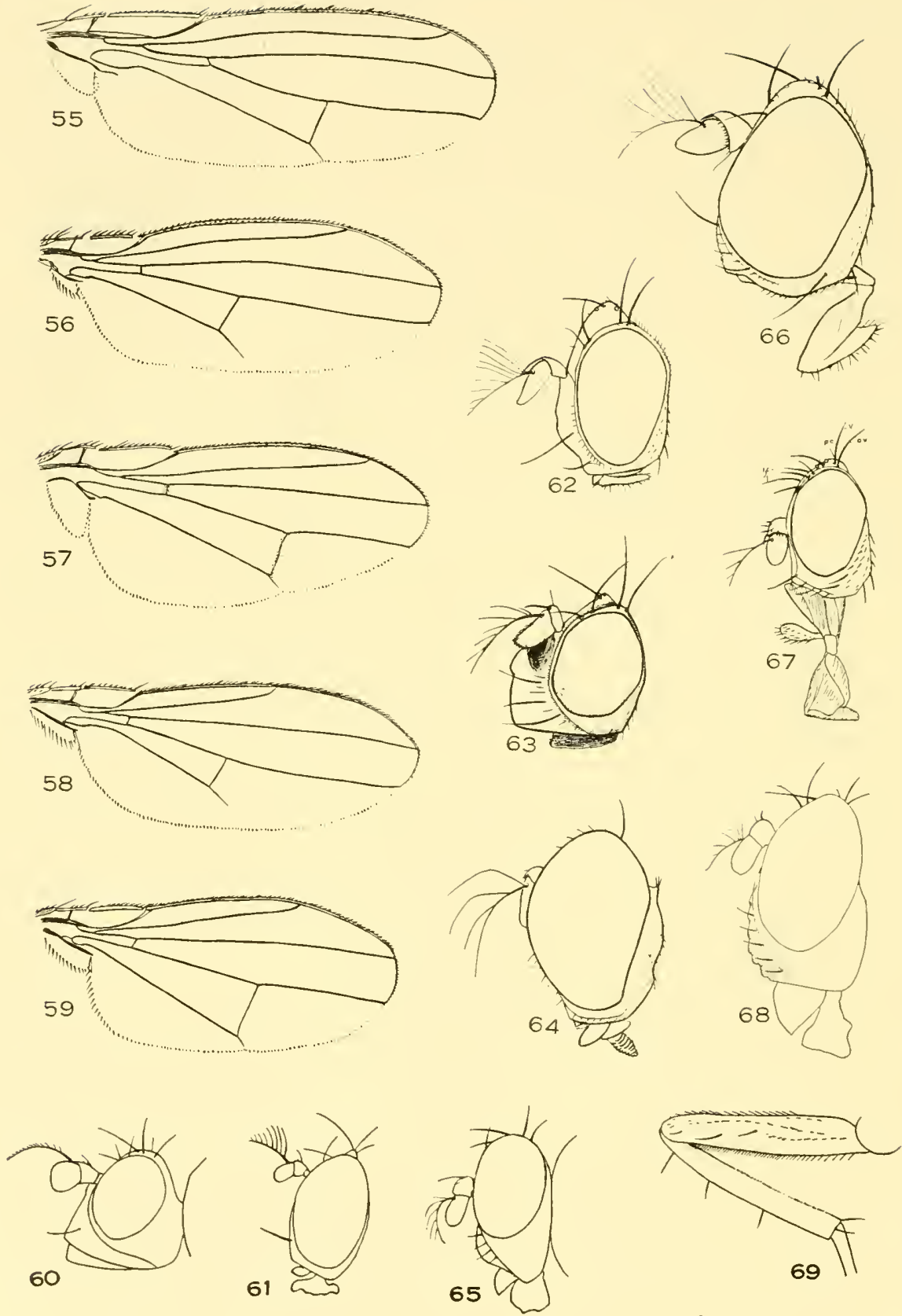

Ephydridæ IV.-55, Ephydra milbræ; 56, Discocerina obscurella; 57, Paralimna texana ; 58, Leptopsilopa nigra; 59, Rhysophora aspersa; 60. Parydra; 61. Psilopa; 62, Clasiopella; 63, Ilythea; 64, Stenochthera; 65, Ochtheroidea centralis ; 66, Leptopsilopa nigrimana; 67, Paratissa pollinosa; 68 , Cerometopum mosilloides: 69 , Notiphila erythrocera, middle leg. 
39. Scutellar bristles arising from very strong tubercles; two pairs of frontal bristles $(12,74) \ldots \ldots \ldots \ldots \ldots \ldots \ldots$ Gastrops Williston Scutellar bristles not arising from strong tubercles, if from weak tubercles there is but one pair of weak frontals............40

40. Third antennal segment with the upper apex more or less elongate... 41 Third antennal segment with the apex rounded ............. 42

41. Scutellum shining $(1,14,17) \ldots \ldots \ldots \ldots \ldots \ldots \ldots$ Lytogaster Becker Scutellum opaque black or with an opaque black spot on either sicle

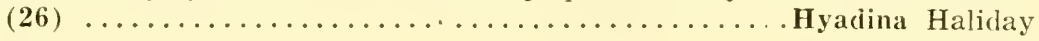

42. With one or two pairs of weak frontals $(24,51) \ldots \ldots$. . Pelina Haliday With one pair of strong and two pairs of weak frontals $(20,50)$.

Glenanthe Haliday

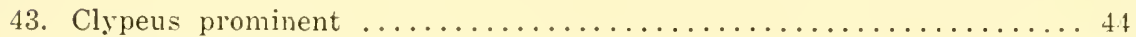

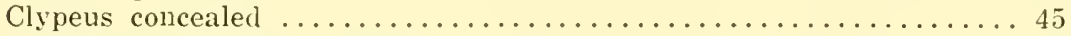

44. Arista with long rays $(33,75) \ldots \ldots \ldots \ldots \ldots \ldots \ldots$ Edenops Becker Arista bare or pubescent (Napea Desvoidy, preoc) $(4,22,47,60)$

Parydra Stenhammer

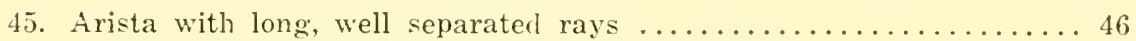
Arista bare or with the rays short and numerous............. 47

46. Pulvilli absent ..................... Dimoccenia Cresson Pulvilli well developed $(23) \ldots \ldots \ldots \ldots \ldots \ldots \ldots \ldots$ Conia Desvoidy

47. Mesonotum with two or more pairs of clorsocentrals; micldle of face without a cluster of bristles . ..................... 48

Mesonotum with only one pair of dorsocentrals; middle of face with a cluster of bristles on either side; large species (Pogonephydra Hen-

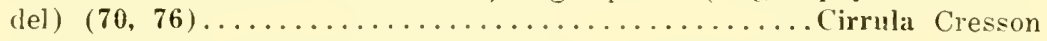

48. Arista minutely pubescent or pectinate on its whole length....... 50 Arista with long, abundant rays on the basal half above......... 49

49. Third antennal segment bearing a long hair on the outer surface.

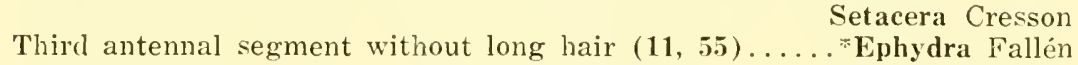

50. Sternopleural bristle present; face with bristles............. 51 Sternopleural bristle absent; face without bristles (29).

Psilephydra Hendel

51. Two pairs of divergent frontals . . . . . . . . . . . . . 52

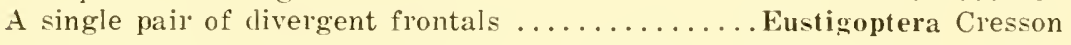

52. A pair of strong acrosticals nearly opposite the inner ends of the

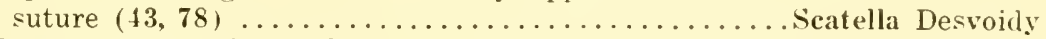
No strong acrosticals, these all short and continuing in two rows to

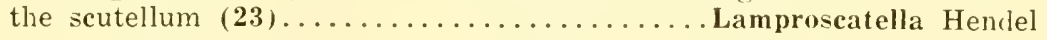

53. Second antennal segment with an apical spine above........... 54 Second antennal segment without apical spine above........... 55

* Curran, 1933, Amer" Mus. Novit. No. 6s2, n. 8. 

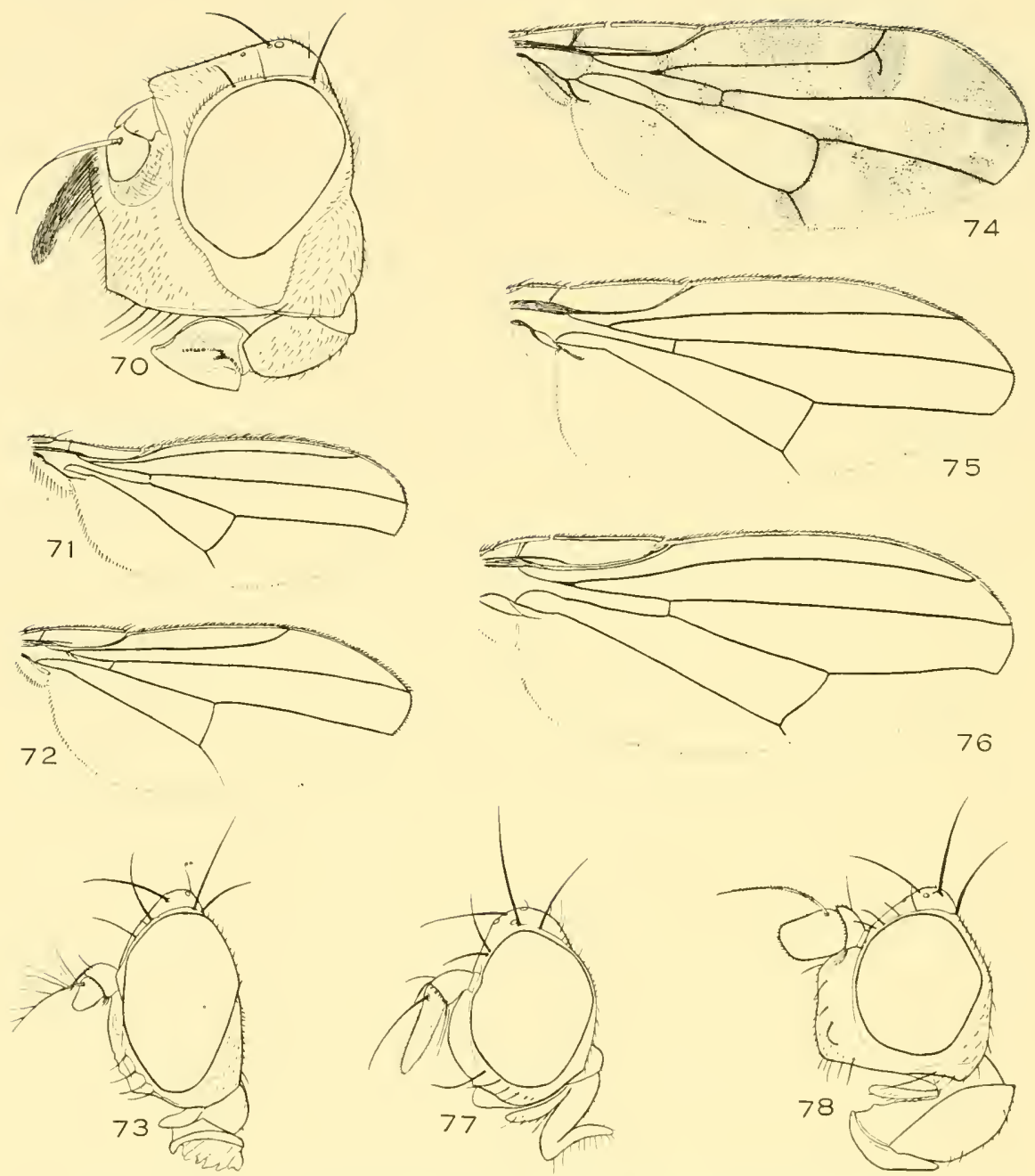

Ephydridæ V.-70, Cirrula gigantea; 71, Lipochæta; 72, Paratissa pollinosa; 73, Rhysophora aspersa; 74, Gastrops nebulosa; 75 , CEdenops nuda; 76, Cirrula gigantea; 77. Ceropsilopa ; 78 , Scatella. 
54. Front with a conspicuous proclinate orbital on either sile; bristles of the face situated close to the facial grooves and strong $(25,28)$.

*Dichata Meigen

Front with hair-like orbitals in front; bristles of the face situated twice the wilth of the parafacial from the facial groove, rarely strong $(6,35,69) \ldots \ldots \ldots \ldots \ldots \ldots \ldots \ldots \ldots \ldots \ldots \ldots \ldots \ldots \ldots \ldots \ldots \ldots \ldots$ Notiphila Fallén

55. Oral opening small; face most prominent in the midlde (27).

Axysta Haliday

56. Clypeus prominent $(5,13) \ldots \ldots \ldots \ldots \ldots \ldots \ldots$ Brachydeutera Lœw

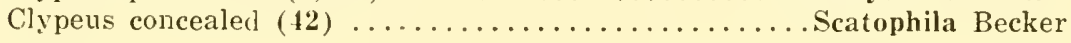

*Cresson, 1917, Trans.-Amer. Ent. Soc., xliii, pp. $27-66$.

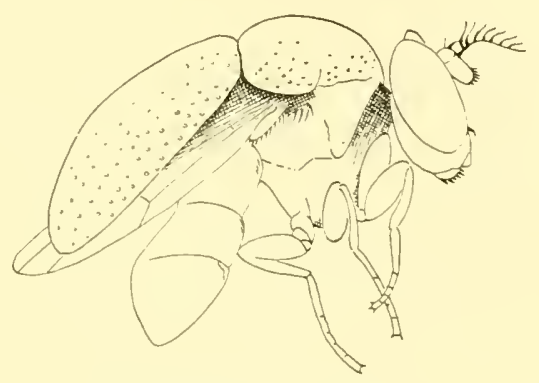

Peltopsilopa species. 


\section{Family Canaceidæ}
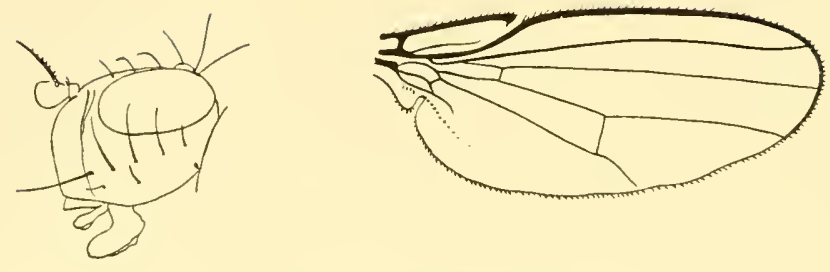

Canace, head and wing.

Tery small flies, not more than $3.5 \mathrm{~mm}$. in length, rery similar to certain Ephydrida but with the anal cell complete.

Head large, the oral opening very large; clypeus prominent; proboscis large, with fleshy labellax; palpi well developed; front wide in both sexes, with three or four pairs of divergent orbitals, the ocellar triangle sometimes extending to the base of the antemna; cheeks wide, bearing bristles; oral vibrissæ present; face gently convex in profile; antema short, the arista bare or pubescent. Thorax short, bearing four pairs of dorsoeentrals and a pair of prescutellar acrosticals; scutellum with one or two pairs of bristles. Leg's rather short. Auxiliary rein eranescent apically, the costa broken before the end of the first rein; basal and anal cells complete; anal vein short. Abdomen composed of seven segments, the first not strongly differentiated from the second which is elongate.

The members of this family oceur along the seashore, the larva living in brackish water.

I believe that there is but one genus in the Nearetic Region. In 1921 Malloch described a species moler the name Canacea macateei. and Johnson, in his "List of the Insects of New England" reeognized the genus Canacea. However, I was informed by Mr. Malloch during a conversation several years ago that "Canacea" was a slip of the pen, that he had no intention of establishing a new name, and that he was extremely doubtful that his species differed generically from Canace Haliday. I lave not seen representatives of Canace but I can find nothing in the descriptions to warrant the recognition of Canacea. There are three species known from the United States, one from the 
Ilawaiian Islands (Procenuee) and one from Panama (Neoctenace) and at least two from South America (Canace and Veocanace).

The following key includes the described gemera of which I have records.

\section{KEY TO GENERA}

1. First vein haired above on the apical half

Macrocanace Tonnoir and Malloch

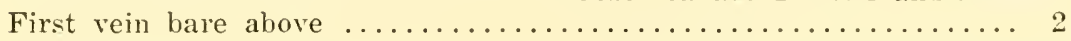

2. Four pairs of dorsocentral bristles ..................... 3

Only two pairs of dorsocentral bristles...........Xanthocanace Hendel

3. Pleura bare.................................. 4

Pleura with bristles and bristly hairs.......................

4. Frontal triangle extending to about the middle of the front; antemnx reaching to the oral margin (Dinomyia Becker)....... Procanace Hendel Frontal triangle extending to the anterior margin of the front or almost so; one pair of scutellar bristles.......... Chrotocanace Hendel

5. Face evenly convex....................................... Haliday Face concave below the middle, convex above (Procanace Curran, not

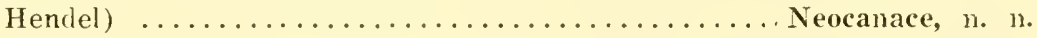




\section{Family Diopsidæ-The Stalk-eyed Flies}

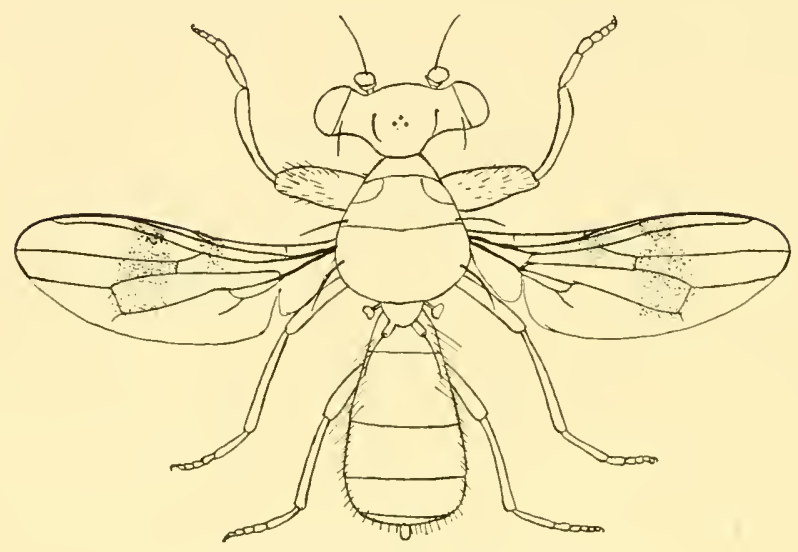

Sphyrocephala brevicornis Say.

The members of this family are mostly rather small, with the eyes situated on the ends of long stalks, a eharaeter not developed in our one genus.

Weakly haired, almost bare, the head transverse, short, eonspieuously produced toward either side so that the eyes are separated by about four times their width; antemne rery widely separated, the basal segments short, the third roundish, with dorsal arista; front bare except at the vertex; oral vibrissa absent. Legs of moderate length, the anterior femora thickened and with short spines beneath. Auxiliary vein elosely approximated to the first vein for most of its length but ending far before it; second basal cell mited with the discal cell; apieal eell somewhat narrowed apically; anal cell long, the anal vein short.

The only Ameriean representative of this family is Sphyracephata brevicomis Say, a quite small and ineonspieuous species. In the Nearetic region there are no flies which resemble it in the shape of its head but in the Neotropical region there are many Otitida and Drosophilida which have the eyes more or less stalked, one Otitid having mueh longer stalks than any true Diopsid I have seen.

Our single species is found along the edges of streams, ponds and marshy lakes and oeeurs from early spring to late autumn and has been taken in numbers about a privy and on skunk-cabbage. The immature stages are unknown.

This family has a particular fascination for most people owing to the peculiar strueture of the head. Why the eyes are stalked we do not know and there may be no reason for it. 


\section{KEY TO GENERA OF THE WORLD}

1. Mesopleura not produced to form a strong spine.............. Mesopleura produced and forming a strong spine similar to that on

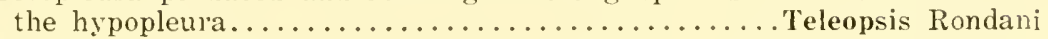

2. Mesonotum with a pair of long, black intra-alar bristles.......... 3 Mesonotum without intra-alar bristles............. Diopsis Linnæus

3. Scutellum longer than deep, without bristles except on the ends of the

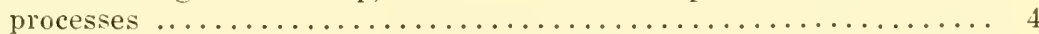

Scutellum very short, as deep as long, with a pair of erect black bristles

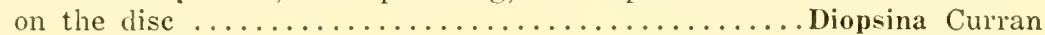

4. Eye-stalks little longer than wide, with a strong bristle behind each antenna in addition to that behind the eye......... Sphyracephala Say

Eye-stalks longer, usually very long, either with a bristle near the middle and far before the base of the antennæ or without frontal bristles, only the one behind the eye being present.............

5. Eye-stalks short, not over three times as long as wide, without median bristle; steropleural spine short; bend of fifth vein without appendage; anal vein contimued beyond the anal cell......Microdiopsis, n. g.

Eye-stalks very long, with a mellian bristle; pteropleural spine long and acute; bend of fifth vein with appendage; anal vein not continued beyond the anal cell.................... Diasemopsis Rondani

\section{Microdiopsis, new genus}

Proposed for syhyracephala cothurnata Bigot, from the East Indies. The genus differs from sphyracephula in having longer eyestalks, with the antennæ close to the eyes, no bristle on the midale of the stalk, no appendage at the bend of the fifth rein. ete.
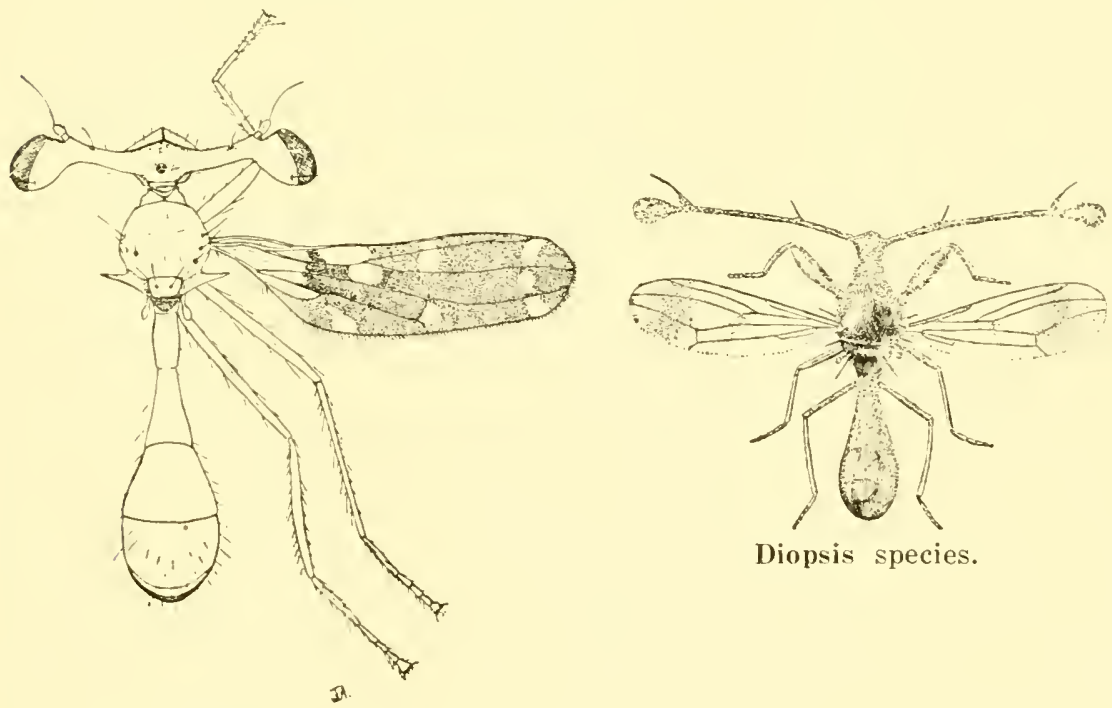

Diopsis species.

Diopsina ferruginea. 


\section{Family Borboridæ}

Rather small to very small, usually black or brown flies.

Head hemispherieal, the face rather perpendienlar, eoneave or somewhat retreating; oral vibrisse present; front broad, usually with bristles. Antennæ short, rounded or oval, with dorsal, pubeseent or bare arista. Wings rarely alosent; auxiliary vein ineomplete or praetieally absent; seeond basal and anal cells often ineomplete or abserit. Legs of moderate length, the femora strong; basal segment of the posterior tarsi short and usually dilated.

The Borborids are almost always found abont decomposing organie matter, in swampy places and abont excrement.

The larve of Borborus live in excrement and refuse and are cylindrieal, their skin roughened by minute bristles; antenna two segmented; month hooks well developed; posterior segment with a eonieal protuberance and smaller tubereles about the spiracles. In Limosina the posterior spiraeles are tube-like and the larre are found in fungi, algw, ete.
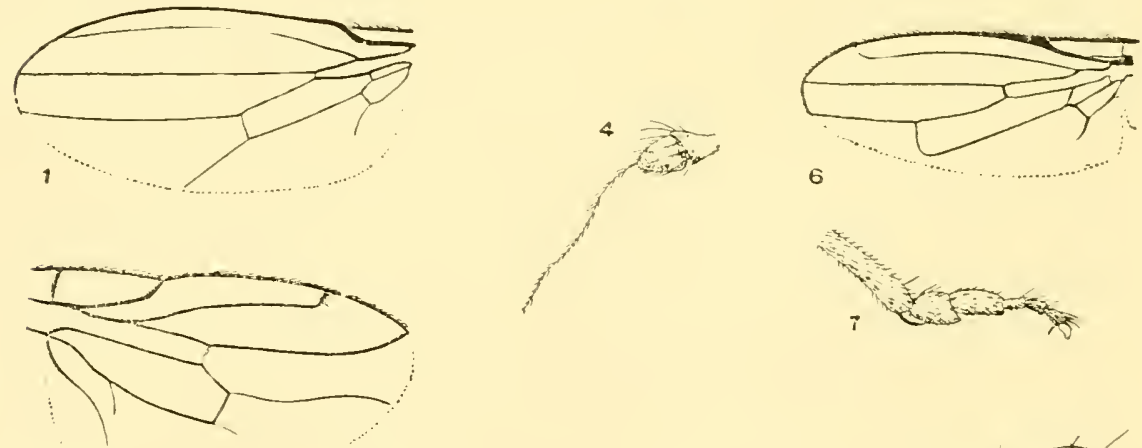

6

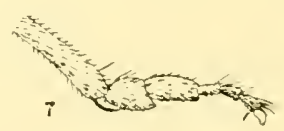

2
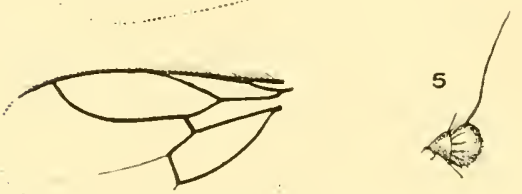

3

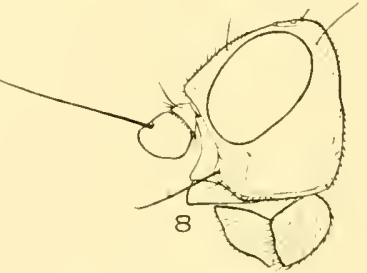

Borboridæ.-1, Spherocera; 2, 3, 4, Leptocera; 5, 6, 7, Borborus ; 8, Scatophora. 
The North American speeies have been monographed by Spuler.* Here is one of the best examples of the short sighted policy of Entomological publieations in refusing to accept long papers and Spuler's work has lost much of its ralue. The work appeared in seven different journals (of various sized pages) and in nine parts and the entire sequence has been lost.

\section{KEY TO GENERA}

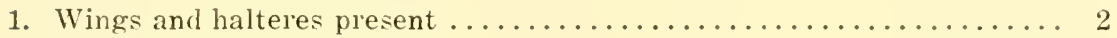

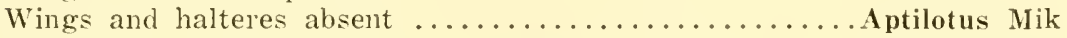

2. Mesonotum and scutellum with bristles.................. 3 Mesonotum and scutellum without bristles (1)......................

3. Fourth rein reaching the margin of the wing............... 4 Fourth vein not nearly reaching the wing margin $(2,3,4)$.

Leptocera Olivier

4. Posterior tibiæ with an apical spur below $(5,6,7) \ldots$ Borborus Meigen Posterior tibire without apical spur (8).......... Scatophora Desvoidy

* 1923, Proc. Acad. Nat. Sci. Phila., lxxv, pp. 369-378; 1924 (Leptocera, part), Psyche, xxxi. pl. 121-134; 1924, (Lel,tocera, part) Ann. Ent. Soc. Amer., xvii, pp, 106-116; 1924, (Sphacrocera and Aptilotus), Pan. Pac. Ent., i, pp. 66-71; 1925, (Leptocera, part), Can. Ent., Ivii, 1p. 99-104, 116-124; 1925, (Leptocera, part), Journ. N. Y. Ent. Soc., xxxiii, pp. 70-84, 147162; 1925, (Borborus and Scatophora), Bull, Brooklyn Ent. Soc., xx, pp. I-16. 


\section{Family Clusiidæ}

Rather small flies in which the wings are almost always marked with black or brown.

Head broad, sub-hemispherieal; face short, nearly vertical or gently receding below; front broad, with three or four pairs of frontals and often with a pair of eruciate interfrontals; ocellars present or absent; postrerticals divergent, rarely absent. Antemne porrect, the basal two segments short, the third rounded, with a terminal or subapieal arista which may be bare, pubescent, or thickly long haired. Proboseis short, the palpi rather broad. Abdomen of moderate length, rather slender. Legs of moderate length, slender, the tibire with or without a preapical bristle. Wing venation eomplete, the seeond basal and anal cells very small; first rein ending near the basal fourth of the wing, the auxiliary vein narrowly separated from it.

The adults are found in moist places and about decaring wood, sometimes occurring in large numbers, although most of the species are not common.

The larve oceur in deearing wood and under the bark of trees. They are white, slender, eylindrieal and slightly thiekened posteriorly. Mouth hooks small, the segments not distinctly separated but with transverse ventral swellings for locomotion. They have the power of leaping, aceomplishing this by grasping the hooklets on the apical segment with their mouth hooks and suddenly letting go. The puparia are yellowish, ellipsoidal and with horns on the apieal segment as in the larva.

Melander and Argo* have revised the American species of the family including many speeies from other regions. The vast majority of the species are tropieal. Of the seventy known American species only a small number ocen in the Nearetic region.

\section{KEY TO GENERA}

1. Eyes with microscopic pubescence; costa broken near the humeral crossvein $(8,11) \ldots \ldots \ldots \ldots \ldots \ldots \ldots \ldots \ldots$. . . . . . . . . . Eves bare; costa weakened or broken near the end of the auxiliary vein. 2

2. Anterior pair of frontal bristles convergent or proclinate......... 4

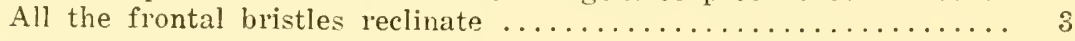

* Proc. U. S. N. M., 1924. Vol. xliv, Article 11, pp. 1-54. 

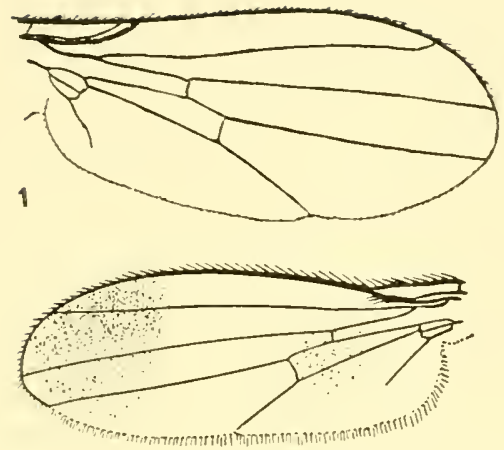

2
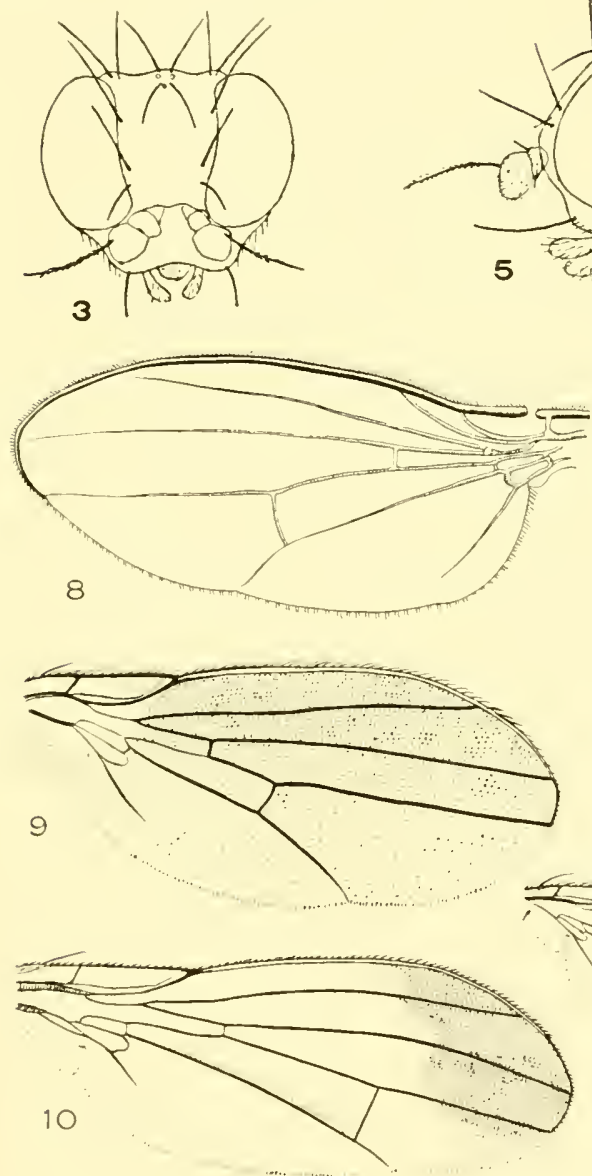
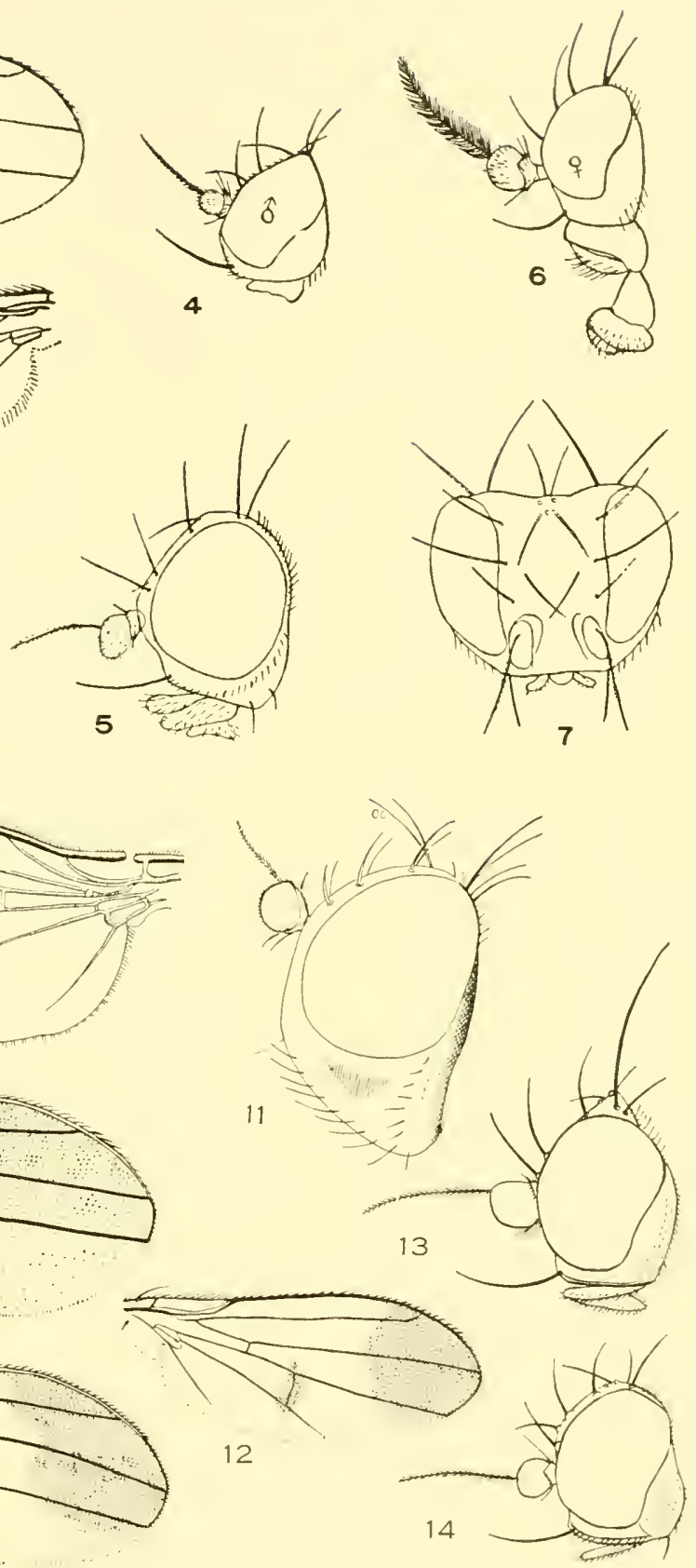

Clusidæe-1, Clusioides; 2, Chretoclusia; 3, Heternmeringia; 4, Clusioides; 5, Clusia ; 6. Chroctusia; 7 , Clısioides; 8 . Acartophthalıus; 9. Czernyola atra; 10, Clusia lateralis: 11. Acartophthalmus; 12 , Sobarocephala variegata; 13 , Sobarocephala; 14 , Czernyola. 
3. Cruciate interfrontals arising from the orbits $(9,14) \ldots$ Czernyola Bezzi Cruciate interfrontals arising on the frontal vitta $(1,4,7)$. Clusioides Coquillett

4. Cruciate interfrontals absent ...................... 5 Cruciate interfrontals present $(5,10) \ldots \ldots \ldots \ldots \ldots$ Clusia Haliday

5. First vein with dorsal setæ; postrerticals absent $(2,6)$. First vein bare; postverticals present $\ldots \ldots \ldots \ldots \ldots \ldots \ldots \ldots \ldots 6$

6. Preapical bristles on middle tibiæ and prescutellar acrostical bristles present; presutural dorsocentrals absent $(12,13)$.. Sobarocephala Czerny Preapicals and prescutellar acrosticals absent (3)..Heteromeringia Czerny 


\section{Family Chamæmyidæ}

Small flies, usually grayish in rolor.

Front wide, with at most two pairs of bristles, often bare; face gently concave or strongly receding; oral vibrisse absent; postrerticals "onvergent or absent; proboseis short: antennæ short. Nesonotum with or withont bristles; prothoracie bristle absent; one sternopleural; mesopleura usually bare, rarely setulose. Front femora with bristles; tibia withont preapieal hristle. Wings with the anxiliary vein entire, sometimes touching the first vein before its end; anal vein not reaching nearly to the wing margin, the anal and seeond basal cells always complete: costa not broken. Abdomen short or slightly elongate.

The larve of Lencopis are predaceous upon aphids and I have found them commonly on plant lice attacking thistle, Oenothera, burdock, ete. 'They are somewhat triangular in outline, the posterior' spiraces being located at the posterior eorner's of the body and strongly projecting. All I have seen have been pale yellowish, with a darker mediam vita. They nsially enceal themselves under the aphids or in the axils of leaves. Pmpation msmally takes place in the axils, the head pointing upward on the stem, but the location is raliable.

\section{KEY TO GENERA}

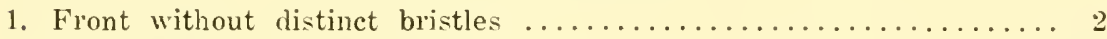
Front with one or two pairs of strong bristles .............. 4

2. Arista absent (Agromyzidæ) $(3,5) \ldots \ldots \ldots \ldots$ Cryptochætum Rondani

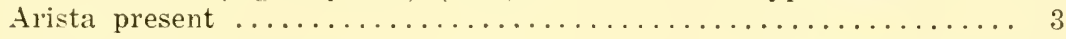

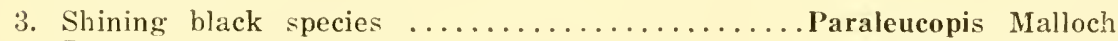
Densely cinereous pollinose species $(2,13) \ldots \ldots \ldots \ldots$. Leucopis Meigen

4. Face very strongly receling, the head pointed $(1,10)$.

Acrometopia Schiner

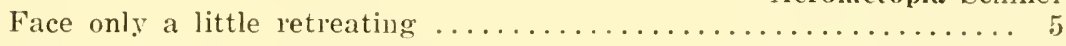

5. Three or four pairs of dorsocentrals................. 6 Two pairs of dorsocentrals $(4,8) \ldots \ldots \ldots \ldots \ldots+$ Pseudodinia Coquillett

6. Three pairs of dorsocentrals (Ochthiphila Fallén) $(6,7,12)$.

Chamæuyia Meigen Four pairs of dorsocentrals $(9,11) \ldots \ldots \ldots \ldots \ldots \ldots+$ Plumomia, n. g.

* Malloch, 1921, Bull. Ill. Nat. Hist. Survey, xiii, 1). 349.

i A naratype of Pseudodinia polita Malloch lacks the two strong frontals and I would nlace it in Paraleucopis but it lacks the setule on the underside of the costa.

Fol Chamrmyia elegans Malloch, 1921, not Panzer. 

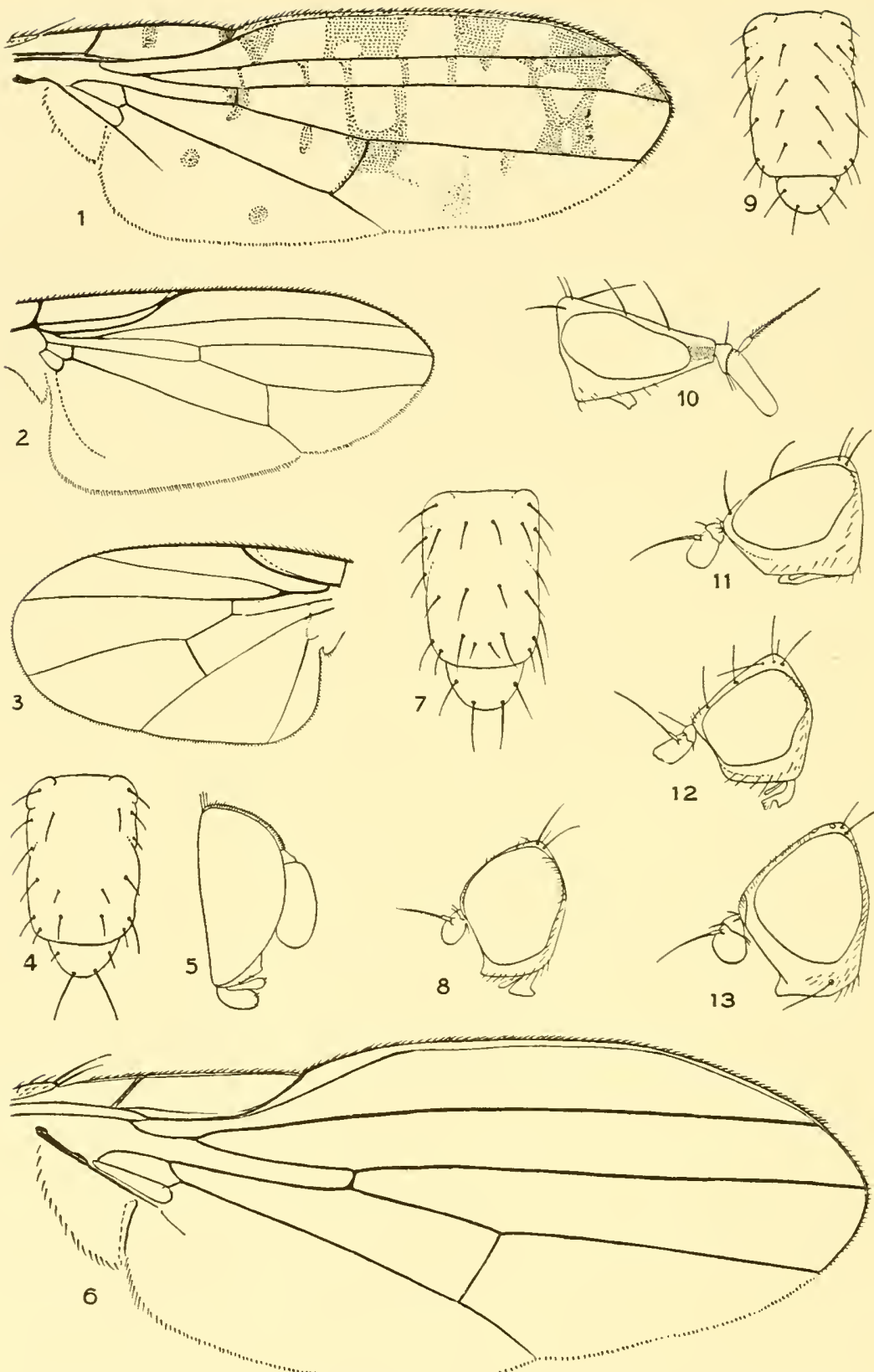

Chamæmyidæ.-1, Acrometopia maculata; 2, Leucopis major; 3, Cryptochatum iceryz; 4, Pseudodinia polita chrtotaxy; 5, Cryptochetum iceryæ; 6, Ochthiphila polystigma; 7 , Ochthiphila, chrtotaxy; 8, Pseudodinia polita; 9, Plunomia elcgans, chxtotaxy: 10, Acrometopia maculata; 11, Plunomia elegans: 12, Ochthiphila polystigma; 13, Leucopis major. 


\section{Family Tetanoceridæ-The Marsh Flies}

Head short, as broad or broader than the thorax; face retreating, more or less perpendieular below; oral vibrissæ absent. Abdomen eomposed of six segments, rather long and narrow, sub-cylindrical. Wings longer than the abdomen: auxiliary vein entire, wholly separated from the first rein; posterior basal and anal cells complete, small. Legs of moderate length, the femora with hristles, the middle pair with a short bristle near the middle of the anterior surface; tibie with preapical bristle.

The adults are found in moist places, along the banks of streams, ponds, ete. and most of them may be recognized on sight by the shape of the head.
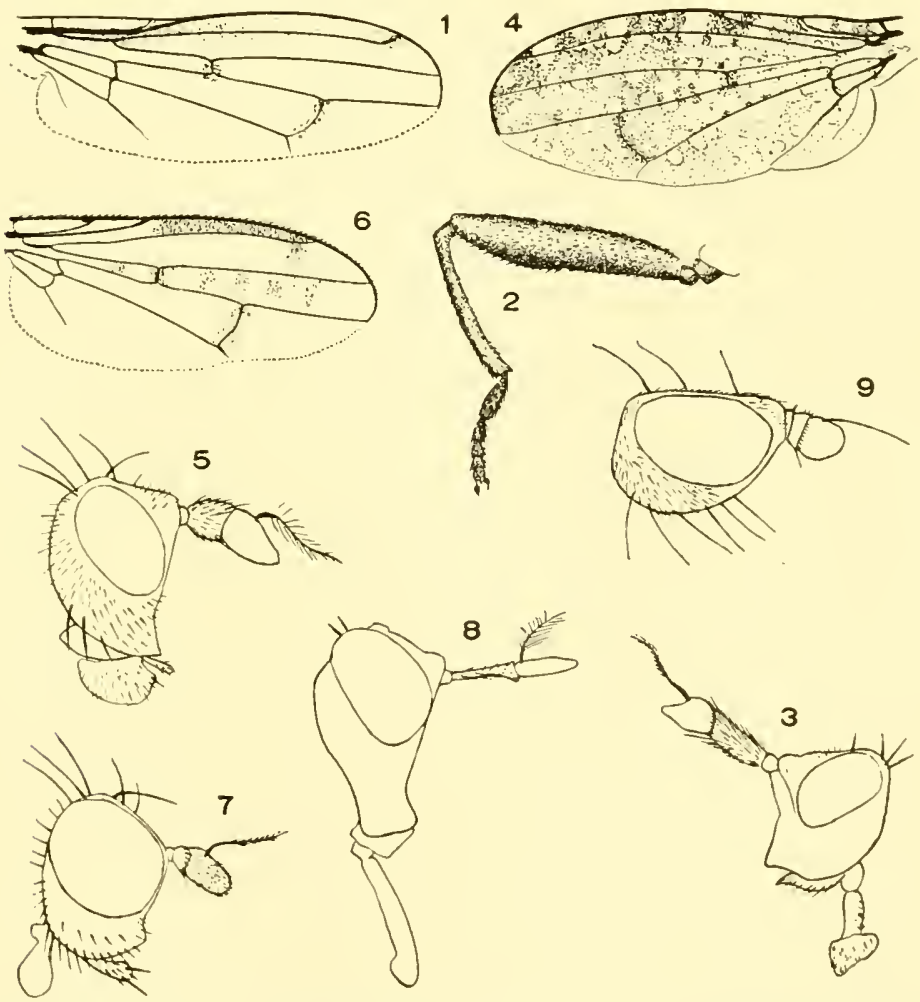

Tetanoceridx I.-1, 2, 3, Sepedon, wing, hind leg and head; 4, Dictya sp, ; 5, Tetanocera ; 6, Dyctia nana; 7 , Dyetia; 8. Thecomyia (S. America) ; 9, Trigonometopus (Samromyzidæ) (Williston). 

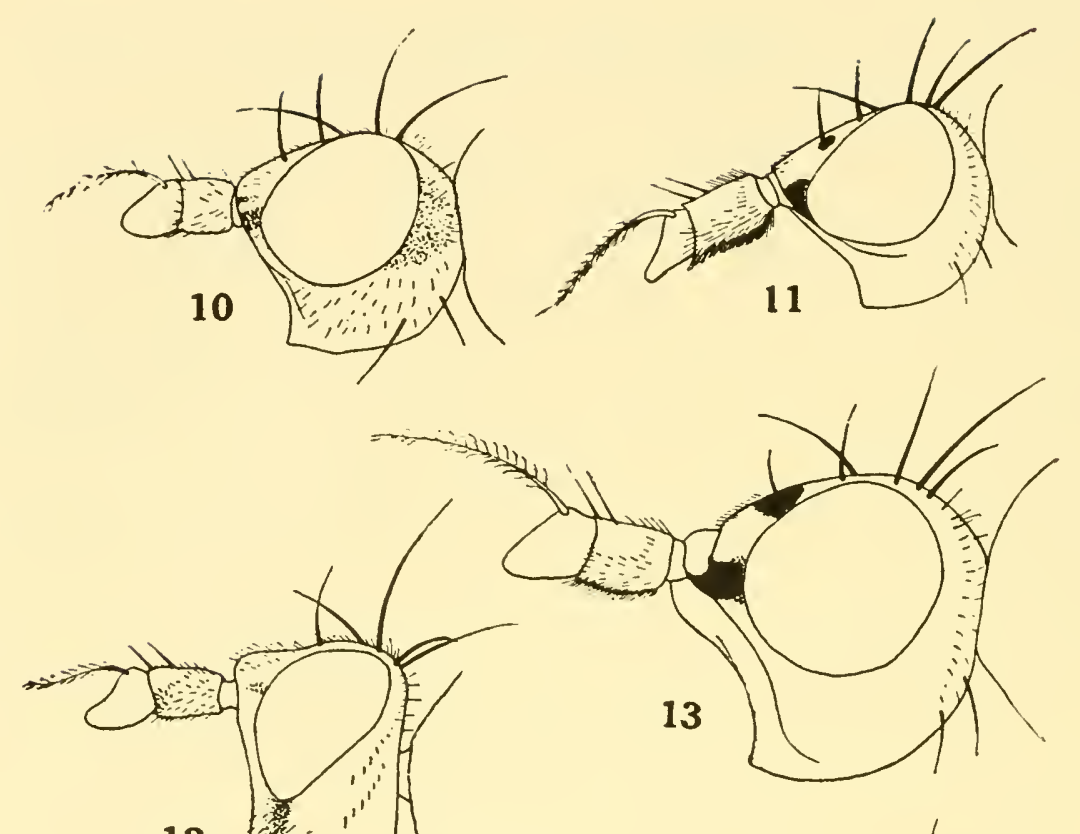

12
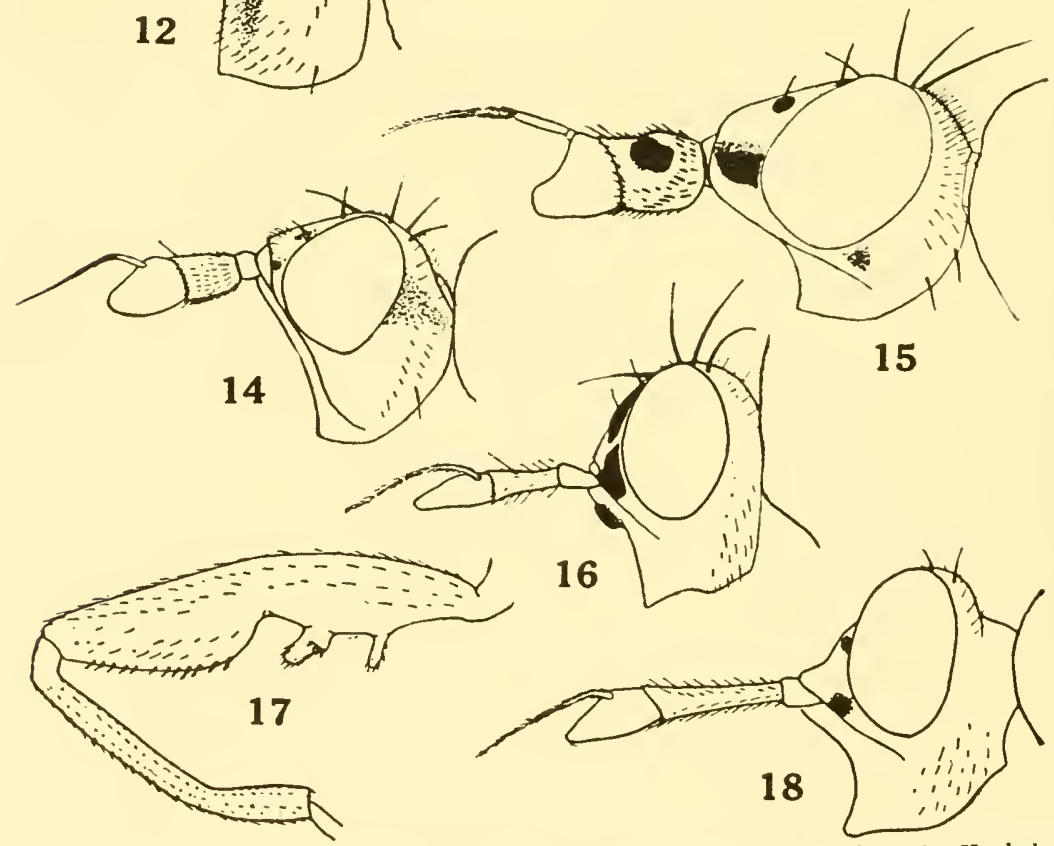

15

Tetanoceridæ II.-10, Trypetoptera pallida; 11, Limnia saratogensis; 12, Hoplydyctia setosa; 13 . Euthycera arcuata; 11 . Hedroneura; 15 , Limnia shannoni; 16 , Dictyomyia ambigua; 17 . Sepedon armipes, posterior femur and tibia of $\sigma^{7}: 18$. Sepedon tenuicornis. 
The larre are slender, eylindrical, thin anteriorly, the terminal segment with six or eight conical, fleshy tubereles. They are aquatic.

The North American speeies have been reviewed by Cresson (1920, Trans. Amer. Ent. Soc., xlvi, pp. 27-S9) and Melander (1920, Am. Ent. Soc. Amer. xiii, pp. 305-332), the former under the name sciomyzidæ.

\section{KEY TO GENERA}

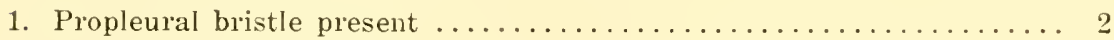

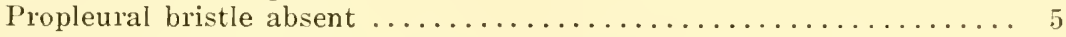

2. Anterior tibiæ with two approximate preapical bristles clorsally...... 3 Anterior tibiæ with one dorsal preapical bristle............... 4

3. Arista densely short white haired (19)............ Oidematops Cresson Arista with long, blaçk rays $(20) \ldots \ldots \ldots \ldots \ldots \ldots$. Sciomyza Fallén

4. Front polished black; cheeks narrow (21)............... Front dull; cheeks morlerately broad $(22) \ldots \ldots \ldots \ldots$...........

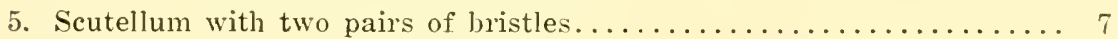
Scutellum with one pair of bristles.................... 6

6. Second antennal segment longer than the third $(1,2,3,17,18)$.

Sepedon Latreille Second antennal segment shorter than the third...Hemitelopteryx Cresson

7. Third antennal segment oval, three times as long as the second; front distinctly narrowed anteriorly .................... 8 Third antennal segment rarely oval, usually flattened or concave above, the second segment at least half as long as the third.......... 9

8. Posterior tibiæ with two preapical dorsal bristles $(2,3)$.

Posterior tibiæ with one preapical dorsal bristle..... Antichæeta Haliday

9. Mesopleura and pteropleura with one or more bristles........... 19

Mesopleura and pteropleura at most with short hairs............. 11

10. One sternopleural bristle $(12) \ldots \ldots \ldots \ldots \ldots \ldots \ldots$ Hoplodictya Cresson No sternopleural bristle $(4,6,7) \ldots \ldots \ldots \ldots \ldots \ldots \ldots$ +Dictya Meigen

11. Two or three pairs of dorsocentrals...................... 12 One pair of dorsocentrals (14) ...................

12. Two pairs of dorsocentrals............................ 13 Three pairs of dorsocentrals (25) ...........Pocilographa Melander

13. Mesopleura and pteropleura bare........................ 14

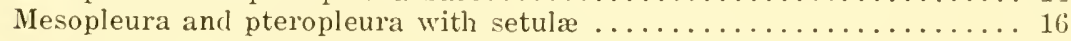

14. Frontal lunule exposerl; wings brown with rounded clear spots..... 15 Frontal lunule mostly concealerl; wings never with rounded, clear spots $(5,24,26,27) \ldots \ldots \ldots \ldots \ldots \ldots \ldots$ Tetanocera Dumeril

\footnotetext{
* Dyctia Desvoidy is an older name but its use conflicts with Dictya Meigen.

†urran, 1933. Amer. Mus. Novit. No. 682, p. 9.

Curran. 1932. Amer. Mus. Novit. No. 517.
} 
15. Second antennal segiment slender, much longer than the third (16).

Dictyomyia Cresson Second antennal segment broad, slightly longer than the third (13).

Euthycera Latreille

16. Arista practically bare; infrasquanal swellings with bristles.

Elgiva Meigen Arista with long rays or long pubescent................ 17

17. Arista with long, black rays $(10) \ldots \ldots \ldots \ldots$ Trypetoptera Hendel Arista white pubescent $(11,15) \ldots \ldots \ldots \ldots \ldots \ldots$. Limnia Desvoidy

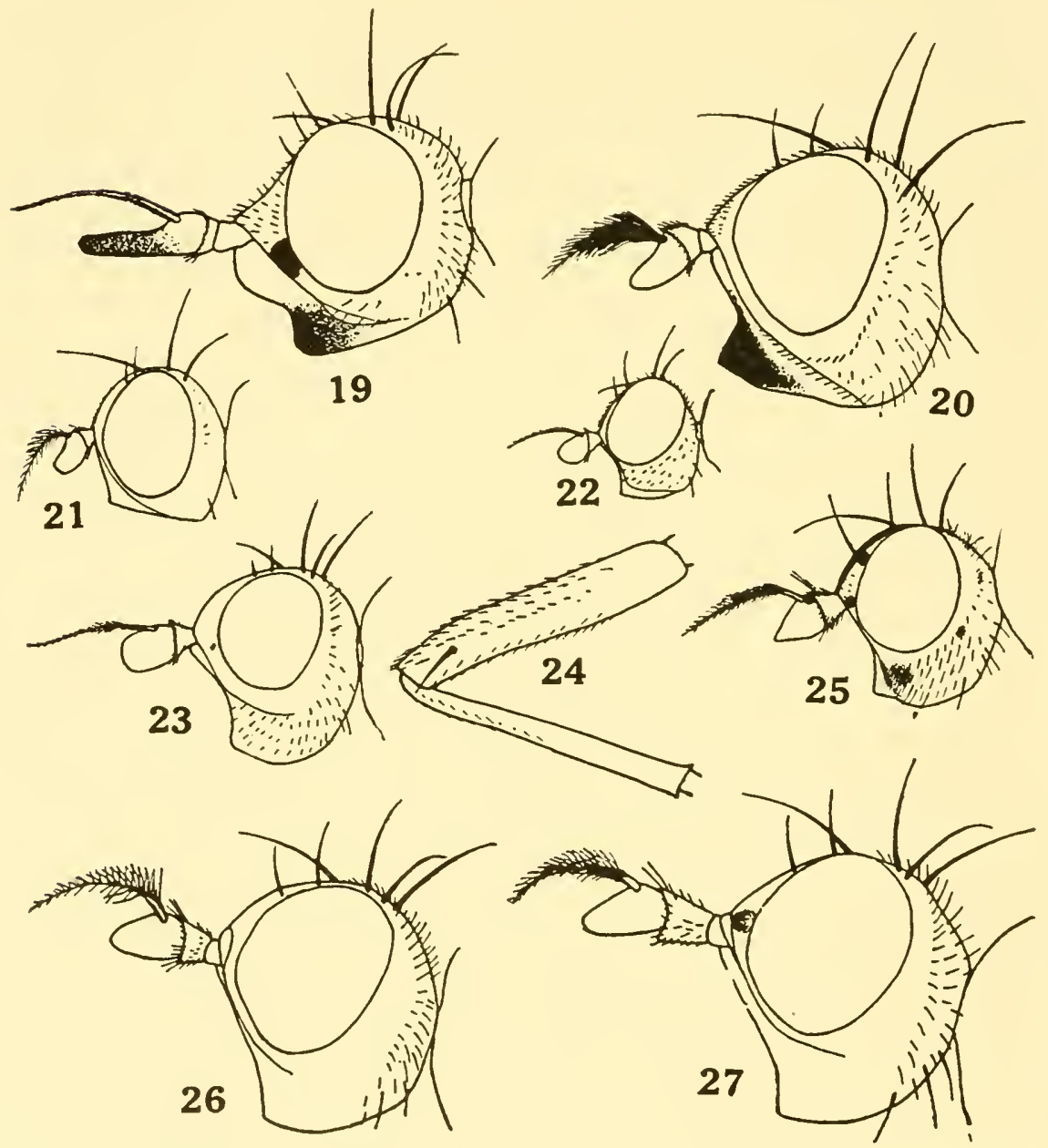

Tetanoceridx III.-19, Oidematops ferruginea; 20, Sciomyza aristalis; 21, Pteromicra; 22. Dyctia nana; 23, Renocera johnsoni; 24, Tetanocera, middle femur and tibia; 25 , Pecilographa decora; 26 , Tetanocera valida; 27 , Tetanocera plebeja (10-27 after Cresson). 


\section{Family Chyromyidæ}

Small flies, the wings sometimes pietured.

Subcosta entire, free and ending in the costa, the costa weakened before its end; postocellar bristles convergent; plates of the orbital bristles extending almost to the anterior border of the front; head higher than long, more or less receding below, the oral margin never conspicuonsly produced; two pairs of frontal bristles; palpi not large: proboseis short and fleshy; antennæ shorter than the face; arista pubescent. Mesonotum usually with five pairs of dorsocentrals, two pairs of seutellar bristles; mesopleura with one or more bristles; sternopleurals, two to four in a straight line along the upper edge; proplemral bristle present. Tibix usually with preapical bristles. Anal and second basal cells complete: costa with spines. Abdomen rather narrow, bearing bristles on the apices of the segments; genitalia small.

The species of Chyromya differ from those of the other genera in having three pairs of frontal bristles, the anterior pair convergent, four pairs of dorsocentrals and no preapical tibial bristles. There are at least two North Ameriean species, flov' Limmeus, and another that is either minima Becker or an undeseribed form since it bears only a single pair of dorsoeentrals. Some speeies placed in the genus Aphaniosoma Becker have five pairs of dorsocentrals or the number may be redneed to one or two distinct pairs with a row of bristly hairs in front of the suture. These two genera have been placed in a separate family, hased upon the absenee of preapical bristles on the tibix, but I do not see how the family ean he maintained.

I am not well aequainted with the habits of these insects but believe that all are found on foliage near the sea coast and in moist places. The number of known species is not large and most of the Ameriean species are southern in distribution or oeeur along the coastal regions.

Malloch would unite this family with the Helomyzidæ but the head characters appear to indicate a very distinet difference and I fail to see any really elose relationship. Melander included the genera in the Geomyzide" and keys to the species will he foumd in his work.

* 1913, Journ. N. Y. Ent. Soc., xxi, [p. 283-300. 


\section{KEY TO GENERA}

1. All the tibiæ with preapical bristles.................... 2

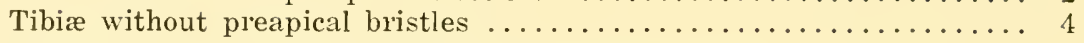

2. Cheeks half as wide as the third antennal segment............. 3 Cheeks not over one-third as wide as the third antennal segment.

Spilochroa Williston

3. Cheeks not half as wide as the eye-height; bristles black......... 5 Cheeks almost as widle as the eye-height; bristles wholly yellow $(3,4)$. Zagonia Coquillett

4. Anterior pair of orbitals convergent $(5,6) \ldots \ldots \ldots$ Chyromya Desvoidy

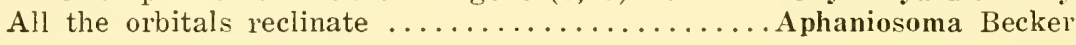

5. Mesopleura with hairs and a strong bristle $(1,2) \ldots$ Trixoscelis Rondani

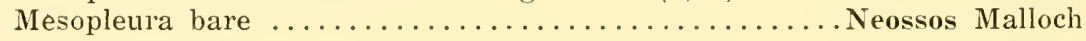

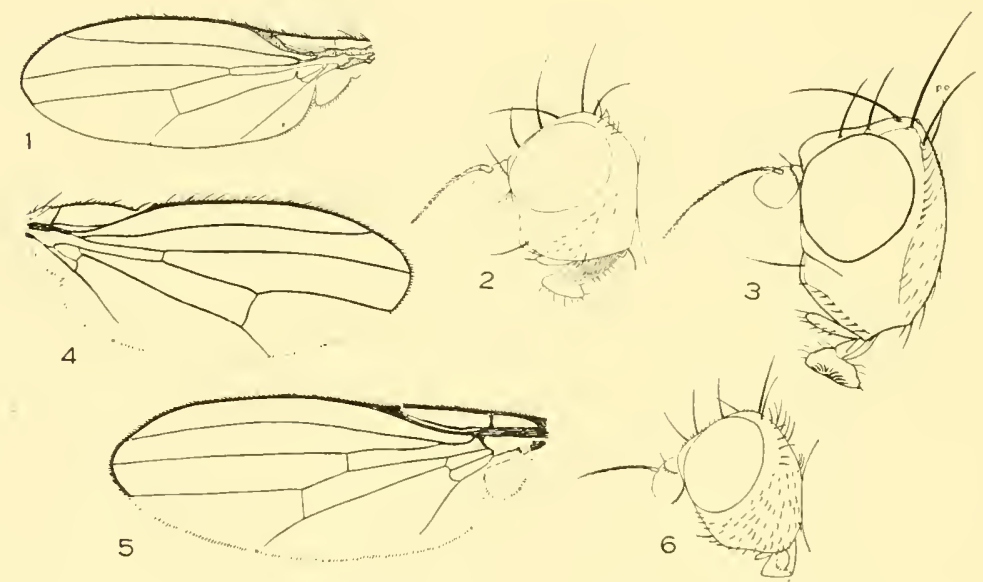

Chyromyidr.-1, 2, Trixoscelis ; 3, 4, Zagonia flava; 5, 6, Chiromya flava. 


\section{Family Megamerinidæ}

Small, elongate, slender flies with petiolate abdomen and incrassate posterior femora.

Head nearly spherical, broader than high; front moderately broad in both sexes; frontal bristles absent, the ocellars and verticals strong: face very gently eonvex, without vibrisse; antemne of moderate lengtl, decumbent. Thorax elongate and narrow, with bristles posteriorly: mesosternum long, the posterior two pairs of legs approximate; seutellum short and broad. Abdomen elongate and clavate, the basal segments slender and fused. Legs of moderate length, the posterior femora strongly swollen and with bristles below on the apieal half. Wings narrow; anxiliary rein absent; first vein ending at basal third of the wing; first basal cell long, the anal cell as long as the second basal, more or less rounded apically.

The single genus representing this family in Ameriea oceurs in the tropies. I have seen only fom specimens collected on Bar'ro Colorado Island, Canal Zone, and Cresson had the same number from Costa Riea. I found the speeimens among rather thick foliage in moist places. They resemble species of Sphegina (Syrphide) although much smaller, but, of course, the resemblance is only superficial.

Syringogaster Cresson is our only genus and is represented by two described species, both of which oceu in Panama.

I am not certain that this genus belongs to the Megamerinida as the speeies show striking differences from a species of Hegamerina (so named) in the American Musenm of Natural IIistory.

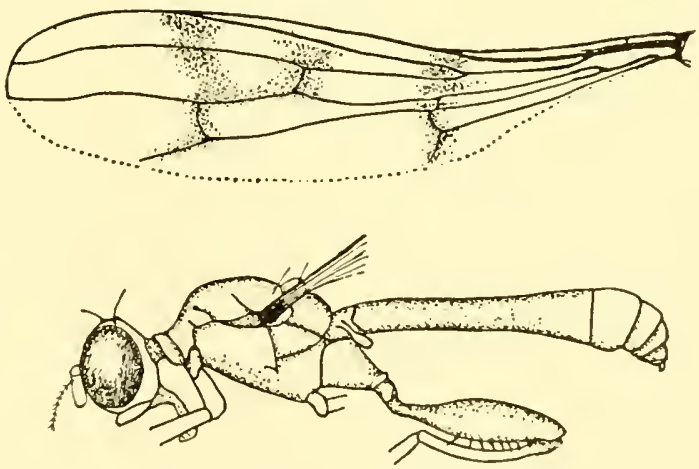

Syringogaster, wing, body.

(Cresson) 


\section{Family Psilidæ}

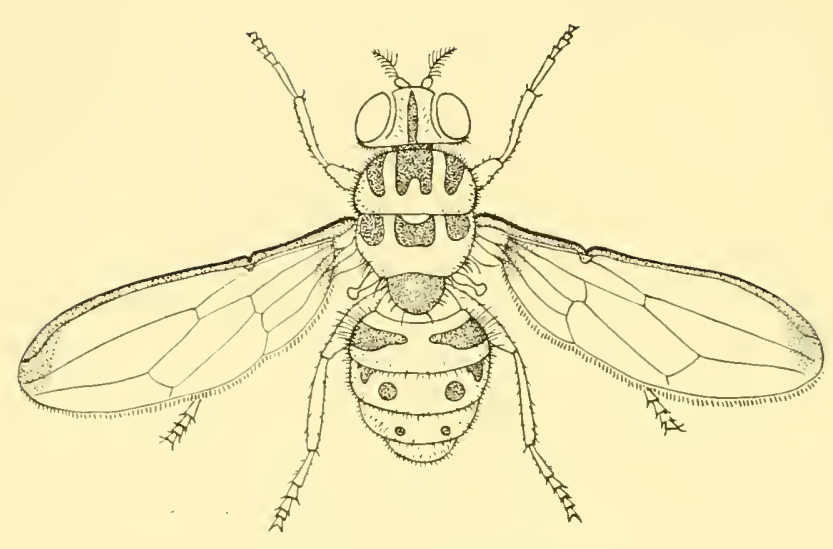

- Somatia xanthomelas.

Flies of medium or small size.

Front broad, with bristles on the upper part; face perpendieular or receding in profile; oral vibrissæ absent; antennæ decumbent, rather short to very long; arista pubescent, rarely long plumose. Abelomen slender or moderately slender; genitalia not prominent, the ovipositor usually elongate. Wings moderately large, the anxiliary vein absent or ineomplete; apical cell not narrowed apically; second basal and anal cells large. Legs rather elongate; tibia without preapical bristles.

The adults are usually found in moist places or shady woods. The Psilide are not always easy to recognize but all the known speeies have a peculiar ridge or weakening across the basal third of the wing extending from the end of the incomplete auxiliary vein. The character is not at all conspienous but its presence is sufficient to place the insects.

The larve live in the roots or galls of plants and one of them is known as the carrot rust fly, often doing eonsiderable damage to this crop. The larve of Psila are slender, bare, cylindrical and of a pale yellowish color, the posterior spiracles forming small rounded or buttonlike processes.

Melander* has published a synopsis of the known speeies.

1920, Psyche, xxvii, pp. 91-101. 


\section{KEY TO GENERA}

1. Third antennal segment shorter than the arista............... 2 Third antennal segment longel than the arista $(4,5)$..Loxocera Meigen

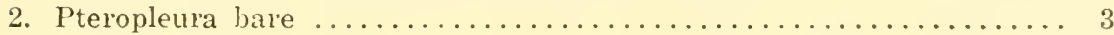
Pteropleura with hairs ................. Strongylophthalmyia Heller

3. A pair of dorsocentrals in front of the suture $(1,6)$. Onty the prescutellar torsocentrals present ....................... Pseudopsila Johnson

4. Cheeks almost half as widle as the eye-height $(3,7) \ldots \ldots \ldots$ Psila Meigen Cheeks at most one-sixth as wide as the eye-height............ 5

5. Arista pubescent $(2,8) \ldots \ldots \ldots \ldots \ldots \ldots \ldots \ldots \ldots$ Chyliza Fallén Arista long plumose (Tropical) (Text figure) ..........Somatia Schiner
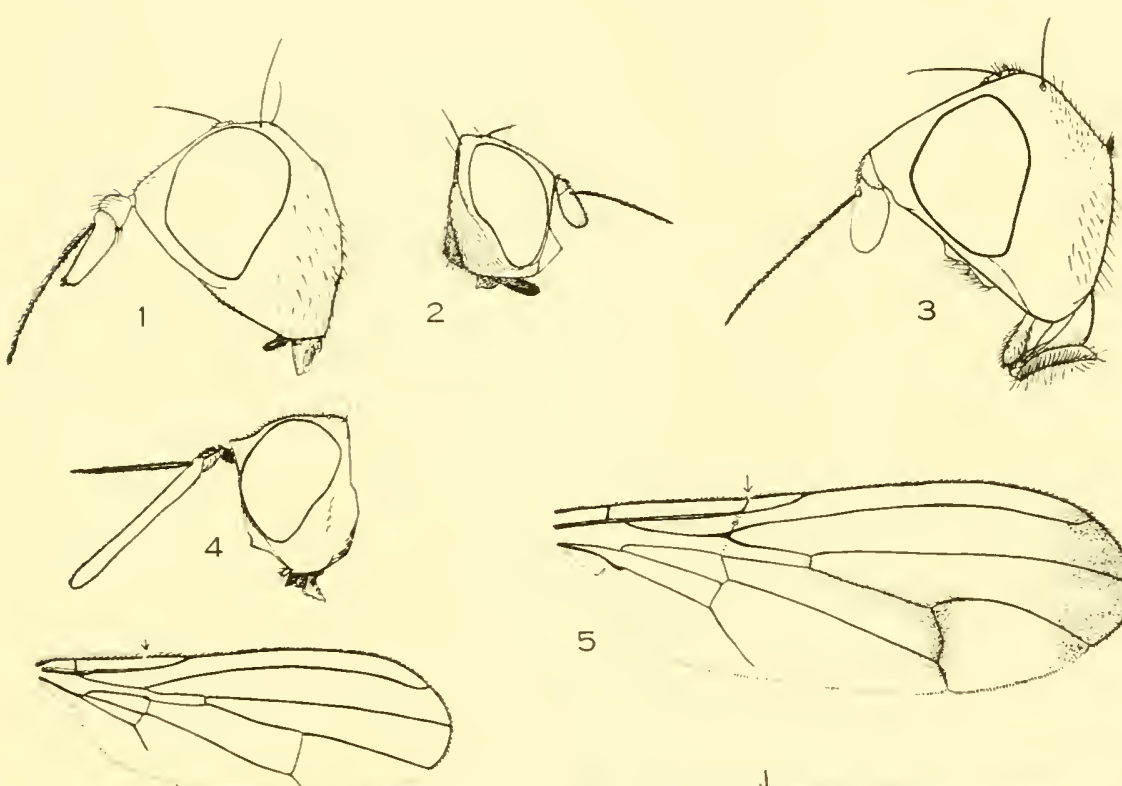

2

6
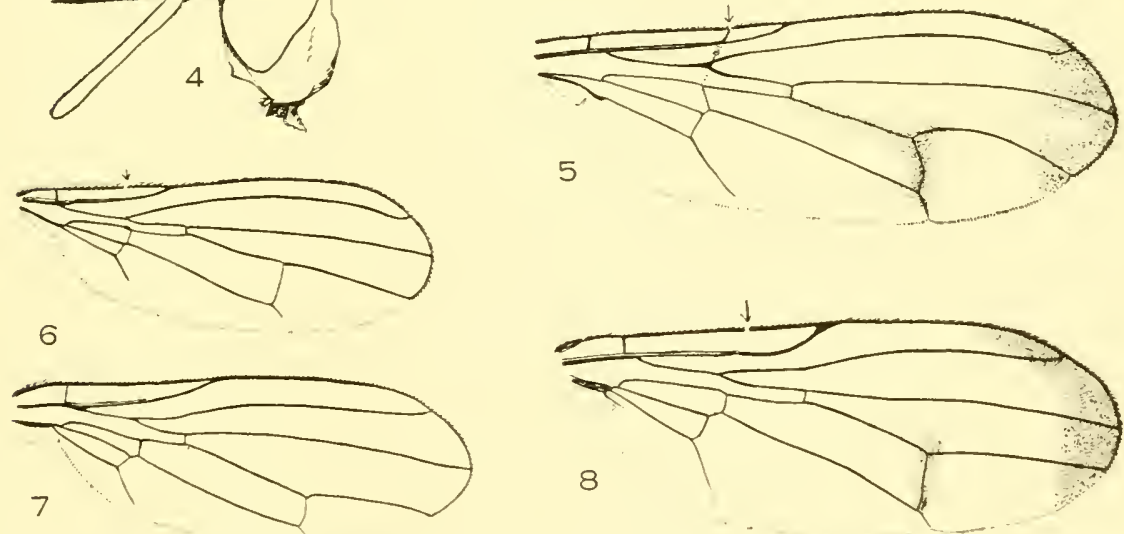

Psilidæ.--1. Pseudopsila; 2, Chyliza; 3, Psila; 4, 5, Loxocera; 6, P'seudopsila; 7, Psila Iævis; 8, Chyliza. 


\section{Family Colopidæ}
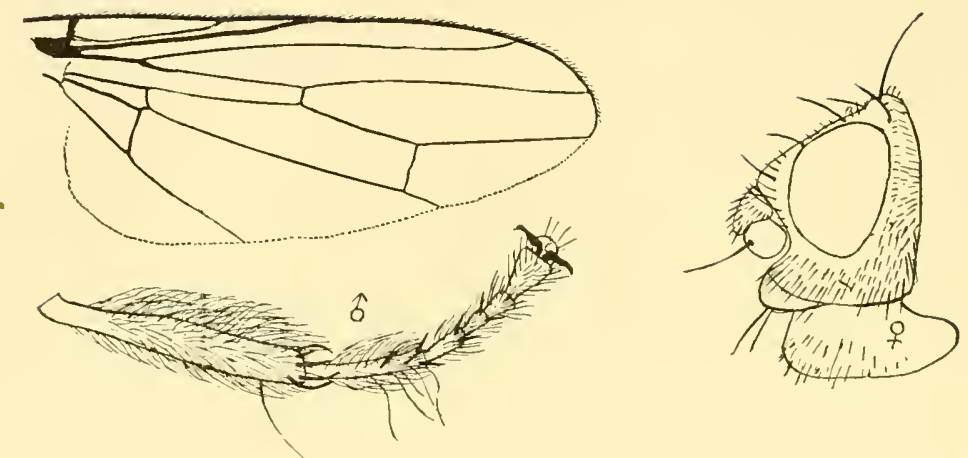

Coelopa, wing, head and front tibia and tarusus of $s$.

Flies of moderate size, living along the sea-shore.

Thorax and abdomen flat, the former depressed, with bare, shining mesopleura, the scutellum flat above. Front with bristles; cheeks with hairs and bristles, the face deeply concave; oral vibrisse absent or extremely weak; antemua short, pendulous, the second segment as larwe as the first. Legs msually stout, with bristles and hairs, all the tibire with dorsal preapical bristles; basal tarsal segment long; apical tarsal segment broadened and with stout claws. Wing venation complete, the second basal and anal cells of equal length; auxiliary vein entire, the first vein ending at the middle of the wing.

The larve live in kelp washed up on the sea-shore and sometimes occur in countless numbers.

The genus Omomyia Coquillett, placed in this family by its describer, belongs to the Pallopterida. There is but one North American genns, Colopa Meigen. Aldrich" has recently reviewed the American species.

\section{KEY TO AMERICAN SPECIES OF COELOPA.}

1. First vein with a few hairs on apical section above (California, Ore-

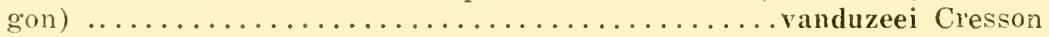

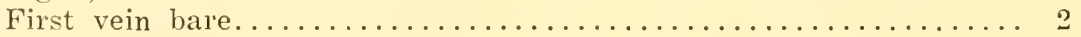

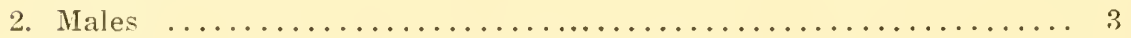

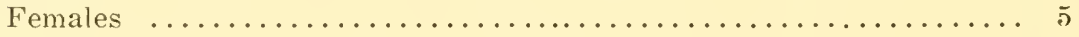

* Revision ** Co!opa, Proc. U. S. N. M., lxxvi, Article 11, pp. 1-6. 
3. Legs with spines, bristles or bristly hairs............... 4

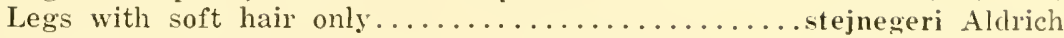

4. Abdomen with bristles on the disc of the apical segments.

nebularum Aldrich Abdomen with bristles only on the sides and apices of the segments

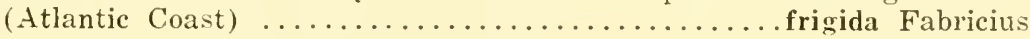

5. Legs usually blackish (western coast).................. 6 Legs reddish yellow................... frigida Fabricius

6. Cheeks with dense, soit, rather short hair; arista pubescent under high

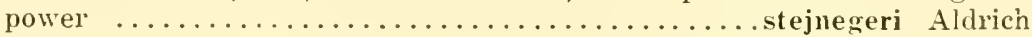
Checks with sparse hair which is coarse above; arista quite bare.

nebularum Aldrich 


\section{Family Helomyzidæ}

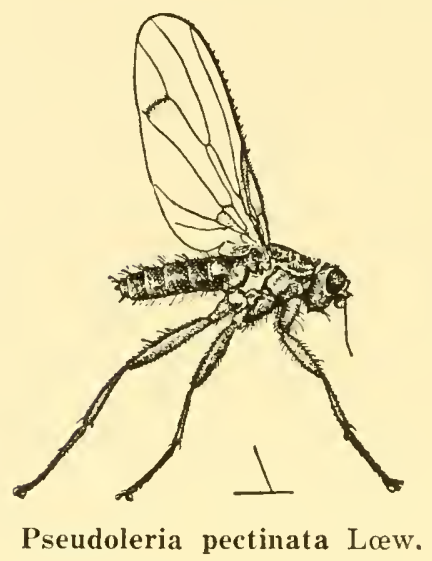

Flies of moderate size, with oral vibrisse.

Face vertical or retreating; front bristly on a little more than the posterior half; antemne short, the third segment more or less rounded. Abdomen composed of six segments, the male genitalia conspicuous. Wings moderately large, the costa usually with short bristles; second basal and anal cells small; first vein bare. Tibiæ with preapical bristle.

The so-called frontal plates, characteristic of this family and poorly developed in most other families are actually a differentiated, broad, pollinose strip on either side of the front. They are slightly oblique, diverging from the eyes anteriorly and the frontal bristles are situated on them. The presence of these "plates", in conjunction with the shape of the antennæ serve as a ready means of identifying a Helomyzid.

The flies are found in various habitats, yenerally in shady or damp places. Adults have been collected by burying a tin ean with its open end flush with the ground and examining it early in the morning.

The larve are scavengers and live upon decaying animal and regetable substances, in fungi, excrement, etc. They are eylindrical, rather pointed anteriorly, obtuse behind; antennæ situated upon long conical processes; mouth hooks large; abdominal segments widened in front laterally, with bristly pseudopods ventrally.

Czerny* has monographed the family while Garrett and others have published papers dealing with the North American species since that time.

* 1924, Abh. zool.-bot. Gesellsch., Wien., xv, pn. 1-166; also, 1926, Konowia, v. pp. 53-56 ; 1927. Konowia, vi, pp. $35-49$; 1928, Konowia, vii, pp. 52-55. 


\section{KEY TO GENERA}

1. Propleural bristle absent; anal vein not reaching wing margin....... 2 Propleural bristle present; anal vein reaching wing margin....... 4

2. Humeral bristle absent ........................... 3 Humeral bristle present $(12) \ldots \ldots \ldots \ldots \ldots \ldots \ldots \ldots \ldots$ Allophyla Lœw

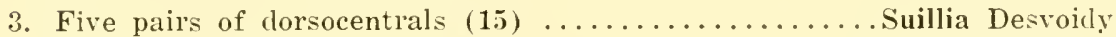
One pair of dorsocentrals (14) ................ Porsenus Darlington

4. Middle tibiæ with several bristles on dorsal surface .......... 5 Midclle tibæ with only the preapical bristle dorsally........... 6

5. Two pairs of fronto-orbitals; one pair of presutural dorsocentrals; wings usually mutilated $(4, \mathbf{1 6}) \ldots \ldots \ldots \ldots \ldots$ Criddleria Curran One pair of fronto-orbitals; no presuturals; wings entire (10, 13).

* Ecothea Haliday

6. Pteropleura in part bristly or hairy...............

Pteropleura bare .............................. 9

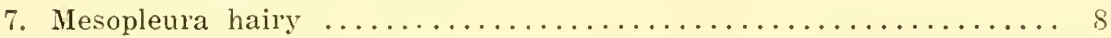
Mesopleura bare $(8,11) \ldots \ldots \ldots \ldots \ldots \ldots \ldots$ Pseudoleria Garrett

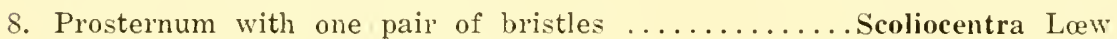
Prosternum with several bristles ........... Trichochlamys Czerny

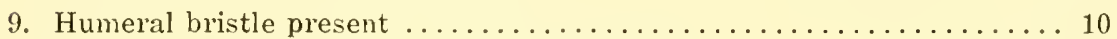
Humeral bristle absent; 3 pairs of scutellars.......... Orbellia Desvoidy

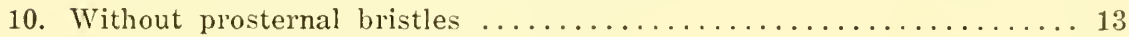
With one or more pairs of prosternals................ 11

11. With one pair of prosternals .......................... 12 With two or more pairs of prosternals (2) ........... Helomyza Fallén

12. Anterior orbital bristle as long as the posterior ........ Anypotacta Czerny Anterior orbital bristle much shorter than the posterior (9).

$\uparrow$ Amobaleria Garrett

13. Middle tibiæ with several apical bristles on ventral surface....... 15 Middle tibiæ with only one apical bristle on ventral surface......... 14

14. First vein ending opposite or before the small crossvein $(1,6)$.

Tephrochlamys Low First vein elongate, ending distinctly beyond the anterior crossvein.

Heteromyza Falléu

15. Second vein joining the costa far beyond the tip of the first....... 16 Second vein joining the costa only a little beyond the tip of the first.

Lutomyia Aldrich

16. Third antennal segment more or less angulate dorsally; middle femora with several partial rows of bristles anteriorly; micldle tarsi with

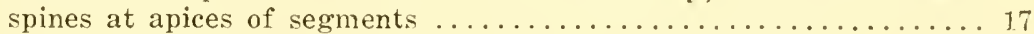
Third antennal segment evenly rounded; otherwise different....... 18

\footnotetext{
* Czerny, 1928, Konowia, vii, p. 52.

† Czerny, 19:7, Konowia, vi, p. 38 .
} 


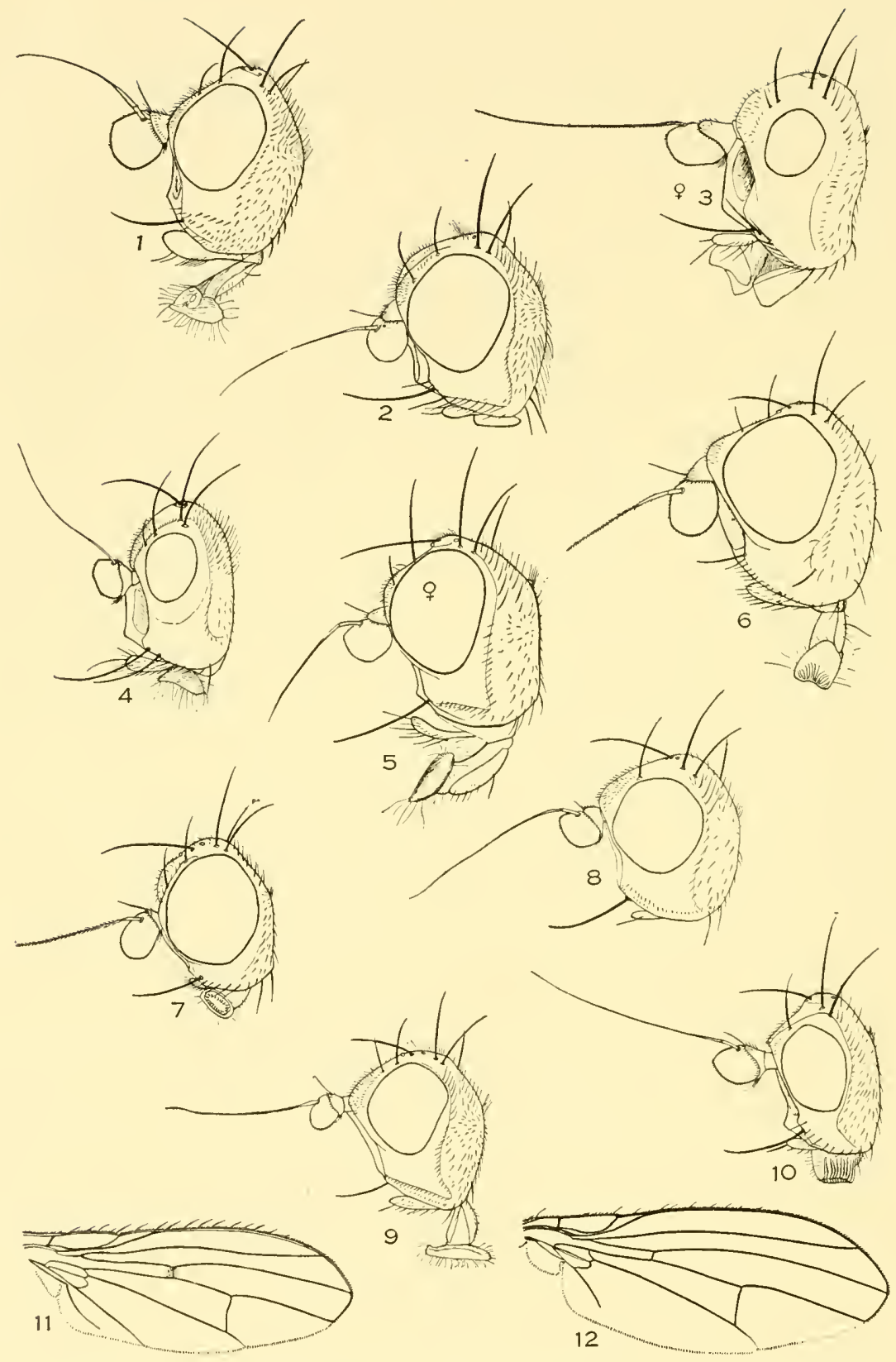

Helomyzidæ I.-1, Tephrochlamys borealis ; 2, Helomyza sp. ; 3, Eccoptomera simplex; 4. Criddleria hemiptera; 5, Acantholeria sp.; 6, Tephrochlamys canescens; 7, Neoleria leucostoma; 8. Pseudoleria pectinata; 9. Amobaleria helvola; 10, Ecothea fenestralis; 11. Pseudoleria pectinata: 12 , Allophyla sp. 
17. One frontal bristle; eyes very small (3) ......... Eccoptomera Lœw Two frontals; eyes of moderate size .............. Viatica Garrett

18. Anterior frontal bristle much shorter than the posterior.......... 19 Anterior frontal bristle as long as the posterior (Postleria Garrett)

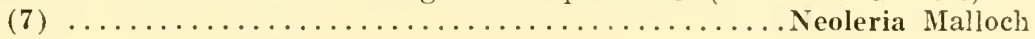

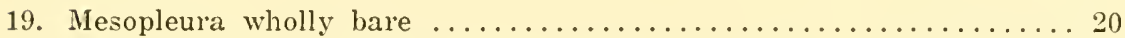
Mesopleura with some bristles posteriorly $(17,18) \ldots$ Anorostoma Lœw

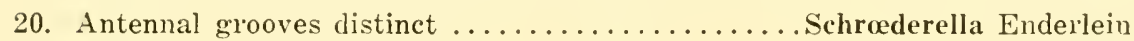
Antennal grooves not distinctly outlined .................... 21

21. Antennæ separated from each other by about half the width of the

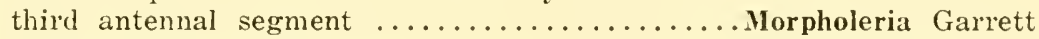
Antennæ separated from each other by more than the width of the

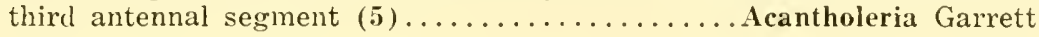

* Czerny, 1927, Konowia, vi, 1. 36 : Curran, 1933, Amer. Mus. Novit. No. 676. pp. 1-9.
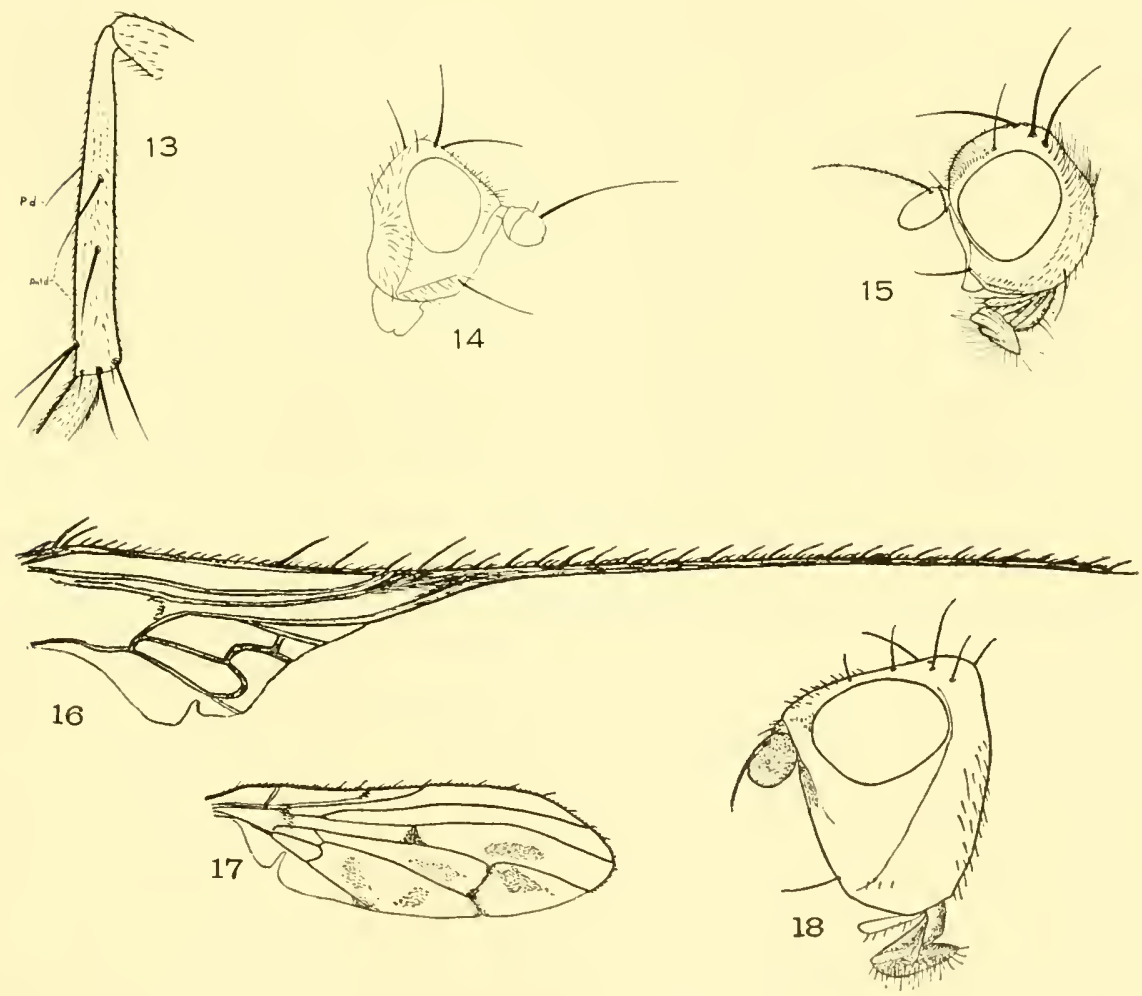

Helomyzidre 11.-13, Ecothea fenestralis; 14, Porsenus johnsoni; 15, Suillia fuscicornis; 16, Criddleria hemiptera; 17,18 , Anorostoma cinereum. 


\section{Family Dryomyzidæ}

Flies of moderate size, the femora without bristles.

Head short, as broad or broader than the thorax, the face retreating, more or less perpendicular below, without oral vibrissæ. Abdomen composed of six segments, moderately long and narrow, more or less cylindrical. Wings longer than the abdomen, the auxiliary rein separated from the first vein; posterior basal and anal cells complete. Legs of moderate length, the tibiæ with a preapical bristle.

The adults are found in moist places, along the edges of streams, ponds, ete. Swampy woods are excellent collecting spots.

The larvæ are aquatic. They are slender, cylindrical, thin anteriorly, the terminal segment with six or eight conical, fleshy tubercles.

The flies placed in this family have been included in the Tetanoceridx and Helomyzidx. From the former they are separated by the absence of femoral bristles and from the latter by the absence of oral vibrissæ. The latest revision of the family is by Melander* who included the genera in the Tetanoceridx.

* Review of the Nearctic Tetanoceridæ, 1916, Ann. Ent. Soc. Amer., xiii, pp. 305-322.
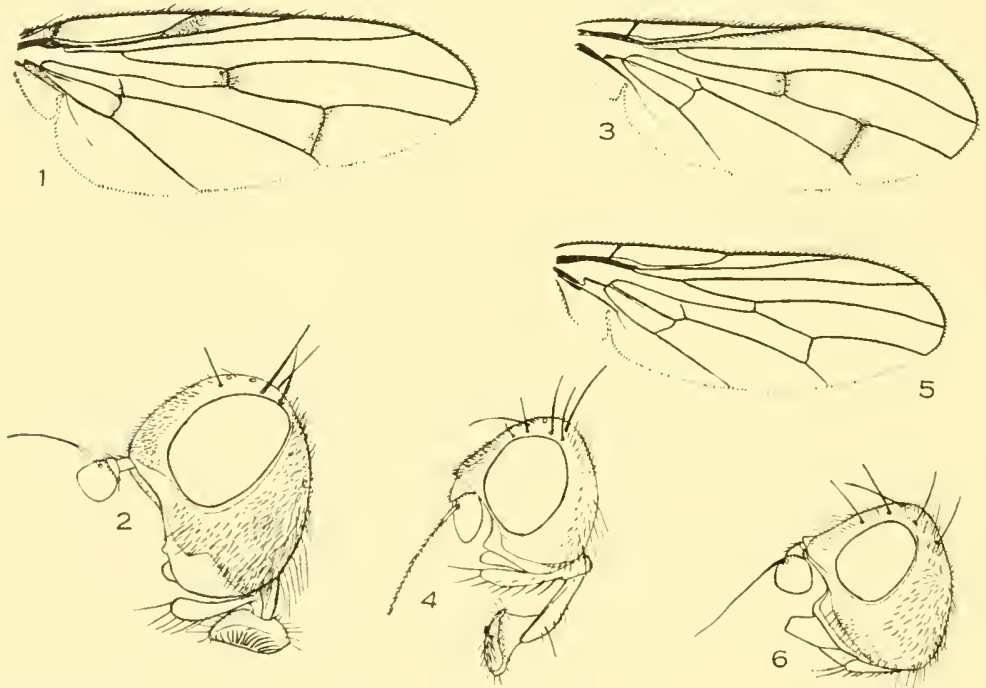

Dryomyzidæ.-1, 2, Macromelanderia mirabilis; 3, 4, Neuroctena anilis; 5, 6, Edoparena glauca. 


\section{KEY TO GENERA}

1. First longitudinal vein bristled $(3,4) \ldots \ldots \ldots \ldots$ Neuroctena Rontani First vein wholly bare

2. Only two pairs of scutellar bristles .................. 3 Three pairs of scutellars (Edoparea glauca Coquillett) $(5,6)$.

(Edoparena, n. g.

3. Costa not bristled ............................. 4 Costa with conspicuous short bristles on the apical half (Helcomyza mirabilis Melander) $(1,2) \ldots \ldots \ldots \ldots \ldots \ldots$ Macromelanderia, n. g.

4. Two pairs of dorsocentrals; face concave........... Dryomyza Fallén At least seven pairs of dorsocentrals; face not concave in profile.

Heterocheila Rondani 


\section{Family Muscidæ}

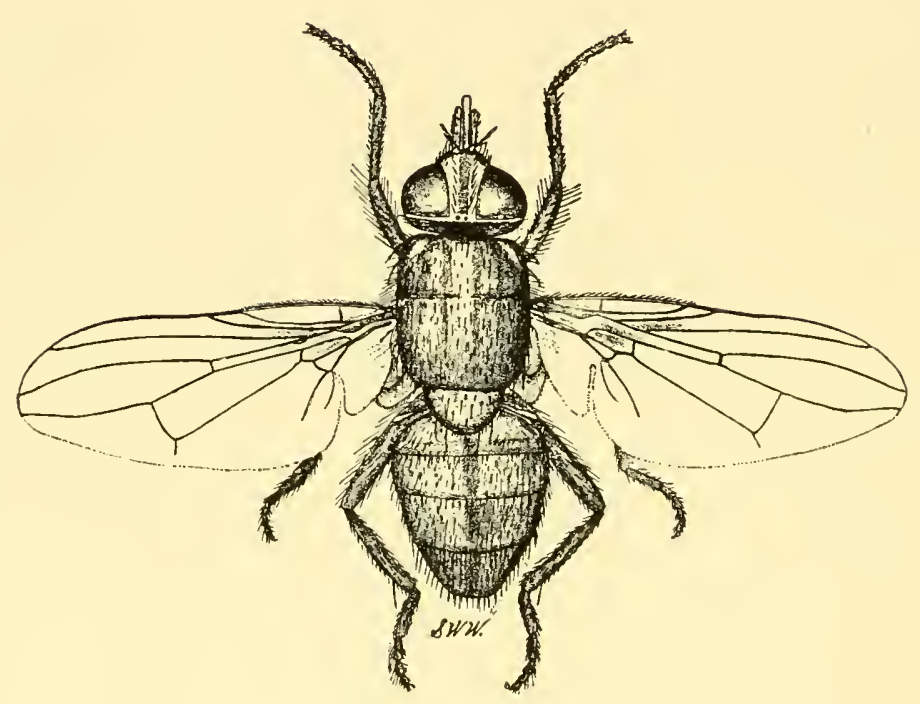

Lyperosia irritans L.

Flies of medium to small size, usually dull colored, the squamæ large or of medium size, hypopleural bristles absent, the second antennal segment grooved above.

Arista plumose, pubeseent, bare or pectinate, eyes approximate or widely separated in the males, the front rarely narrowed in both sexes; frontal bristles always present, intrafrontals frequently present; orbitals developed but rarely in the males. Abdomen composed of four segments in the male, five in the female. Male genitalia usually not prominent but sometimes conspicuons; fifth sternal lobes sometimes prominent.

As here understood this family ineludes the Seatophagidx, Anthomyidx and those Museidx (of the Williston Manual) lacking hypopleural bristles. In some eases the hypopleura is haired but there need be no question in eonnection with known North Ameriean genera about intergradation with the Metopiidæ. There is no means by which the Seatophagidx can be separated from the Anthomyidx, unless the size of the lower lobe of the squame is used, in which ease the genus Anthomyin must be assoeiated with the Seatophagids while many of the other genera 
would form a different family. Wing venation is not a character to be used in separating families in this group, nor ean the character of the plumosity of the arista be used.

The Muscida are found everywhere and many of them are serious pests. The raddish maggot, cabbage maggot, onion maggot, seed corn magoot, and many others take annual toll of our erops. So much has been witten about the house fly as a carrier of disease that only a brief review need be given here. Others are pests of domestic animals and also par attention to man. The Tse-tse flies, formerly considered as belonging to this family, and not oreatly distinct at best, are carriers of trypanosomes causing sleeping sickness.

Many entomologists believe that the IIouse Fly (II usca domestica) has been responsible for more human suffering than any other insect and the evidence in support of this is very strong. It is said that deaths due to diseases earried by flies have exceeded those caused by wounds during the wars preceding the world war (1914-1918), whereas during this latter conflict the mortality from such diseases was neyligible, due to efficient sanitary practices. The House Fly breeds in manure, sarbage and almost any decaying matter and its control consists of the sercening and disposal of such material at frequent intervals. Manure should be kept, as much as possible, either on such a maggot trap as recommended by Hutchison*, sprayed oceasionally with a mixture of one pound of powdered hellebore to twenty gallons of water at the rate of one gallon of the spray to one enbic foot of manure, or sprinkled with powdered borax at the rate of one pound to 16 cubic fect of manure. The borax treatment must not be repeated, the fresh manume being piled in such a way that it may be treated separately. All garbage should be destroyed at least twice a week.

Because the House Fly feeds on filth of all kinds and visits our foodstuffs, alighting with impunity upon the things we would at, it is particularly loathsome. It is attracted to almost anything that is moist, such as sputum, feces, sarbage, ete., and may fly directly from any of these to food used for human consumption. The diseases carried on its body (in the form of the causative organisms) are Typhoid Fever. Dysentery, Cholera. Yau's, Anthrax and some forms of Conjunctivitis. Many other bacteria, some of them undoubtedly capable of causing disease, are also carried.

In addition to destroying the breeding places of flies efforts should be made to prevent them from coming in contact with toodstuffs by screening all buildings. Siekrooms should be particularly well screened in order to prevent flies from earrying the disease to other indiridnals.

* U. S. Dent. Agric. Bull. 200. 1915. 
The Stable Fly (Stomoxys calcitrans) is a biting insect and is sometimes known as the Biting House Fly. It is not a general visitor in houses but may be eommon in rards and on porches near stables, and is most active in the hot sum. It is also a pest on beaches and along streams on bright, sumny days. It breeds in manure and decaymo regetation so may be eontrolled by measures taken against the House Fly. Domestic animals suffer greatly from its bites and milk production may be greatly reduced when the fly is abundant. The flies enter the stable on eattle and horses and many of them remain there orer night. Use of a fly spray in stables will greatly reduce their numbers. The view has been expressed that infantile paralysis is earried by this fly but the accusation has not been proved. Howerer, under eertain conditions it may transmit sleeping siekness.

The Horn Fly (Lyperosia irituns) so named because of its habit of feeding about the base of the horms of eattle, is also a biting fly. It rarely attacks man.

The classification of this family is still in an unstable condition and it is seldom that two authors use the same generic limits and rero frequently different names are used for the same generie concept. Infortumately several of the genera are not arailable for study and I have been forced to include about a seore of them from deseriptions only, while four of those recorded from North Ameriea are excludect. A half dozen genera oceurring in South America and not yet reeognized from our region are keyed ont as it is likely that they oecur in the tropics. In one or two eases the eharacters I have used will change the limits of genera, and I have reeognized as genera groups sometimes considered to be no more than subgenera.

In order to facilitate the use of the Key I have prepared a synoptic key leading to the main subdivisions employed.

\section{SYNOPTIC TABLE}

A. With at most one sternopleural bristl $\ldots \ldots \ldots \ldots \ldots \ldots \ldots \ldots \ldots \ldots 1$

With two or more sternopleurals $\ldots \ldots \ldots \ldots \ldots \ldots \ldots \ldots \ldots \ldots \ldots \ldots$

B. Anal vein extending to the wing-margin. . . . . . . . . . . . 39 Anal vein not extending to the wing-margin...............

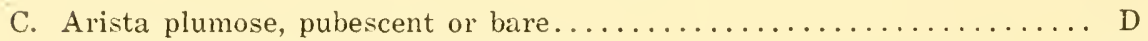
Arista pectinate, without rays below. . . . . . . . . . . . . . 144

D. First vein setulose on most of its length................ 7 . First vein bare beyond the humeral crossvein.............. E 


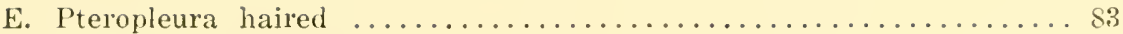

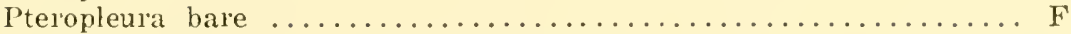

F. One pair of presutural dorsocentral bristles.................. 98 More than one pair of presutural dorsocentrals................ 106

\section{KEY TO GENERA.}

1. With at most one stemopleural (c. f. Lispoides)............ 2

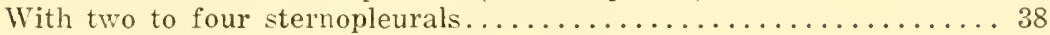

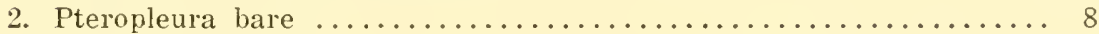

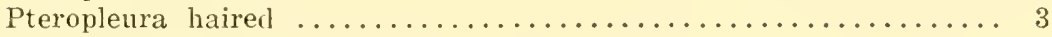

3. Anterior tibiæ without abundant ventral setulæ.............. 4 Anterior tibiæ beneath with abundant black setulæ..*Allomyella Malloch

4. First vein bare ................................ 5

First vein setulose apically; sixth vein not reaching wing margin.

Dasypleuron Malloch

5. Sixth vein reaching wing margin $\ldots \ldots \ldots \ldots \ldots \ldots \ldots \ldots \ldots$ Sixth vein not reaching wing margin.......... Eugenacephala Johnson

6. With distinct sternopleural bristle ................... 7 Without sternopleural bristle; wings with several brown spots.

Ernoneura Becker

7. Propleural bristle long and strong; arista short plumose on whole length ...................... Megraphthalma Becker Propleural bristle very weak or absent; arista long plumose or bare

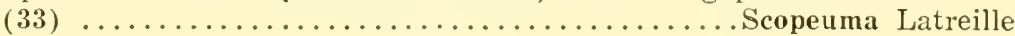

8. Head at least as high as long; face at most moderately retreating.... 11 Hearl decidedly longer than high, the face strongly retreating below.. 9

9. Stigmatal bristle absent .......................... 10

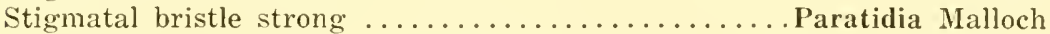

10. Third antennal segment with a fine, long hair on the outer surface near the insertion of the arista $(41) \ldots \ldots \ldots$. Acicephala Coquillett Third antennal segment without such hair..... +Pseudacicephala Malloch

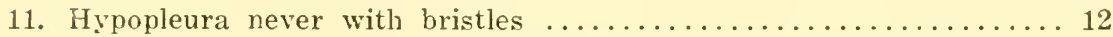
Hypopleura with a row of bristles; costa ending at third vein, the fourth vein incomplete; front half as wide as head (Eginiinæ).

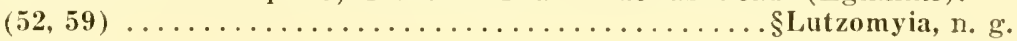

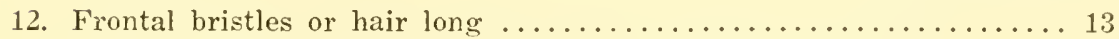
Frontal bristles extremely short, the front nearly bare $(40)$.

Hydromyza Fallén

* Curran, 1927, Can. Ent., lix, p. 260.

† Curran, 1933, Amer. Mus. Novit. No. 682, p. 10.

Curran, 1927, Can. Ent., lix, p. 259 (Acicephala).

$\$$ Differs from Eginiella Malloch (China) in having the front of the male half as wide as the head and in lacking bristles on the legs, with the exception of the apical tibial bristles. Lutzomyia americana, n. sp. from Arizona. 
13. Anterior tibiæ without a short, rectangular apical spine below...... 14 Anterior tibiæ with a short, stout, rectangular spine at apex of ventral

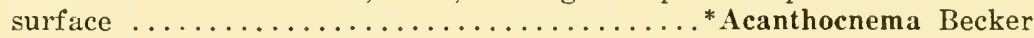

14. Anteroventral surface of the anterior femora and tibiæ without stout bristles, the front tibiæ rarely with a single bristle on this surface. 15 Anteroventral surface of the anterior femora and tibiæ with stout

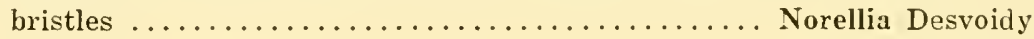

15. Prothoracic bristle always, the stigmatic usually, present........ 16 Prothoracic and stigmatic bristles absent............... 28

16. Palpi long and slender, armed at the apex with a long, outstanding

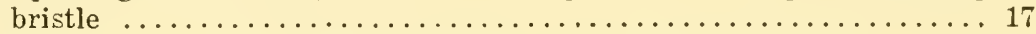
Palpi more or less broadened, without an outstanding bristle...... 20

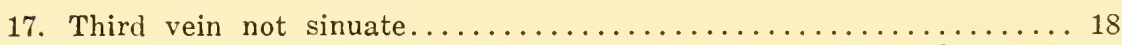
Third vein rather strongly sinuate............. Scoliaphleps Becker

18. Stigmatal bristle weak or hair-like, usually absent. . . . . . . 19 Stigmatal bristle strong $(46,60) \ldots \ldots \ldots \ldots \ldots \ldots \ldots$ Cordilura Fallén

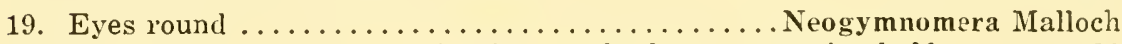
Eyes with a slight emargination on the lower posterior half ...... 36

* Curran, 1929, Can. Ent., Ixi, p. 132.

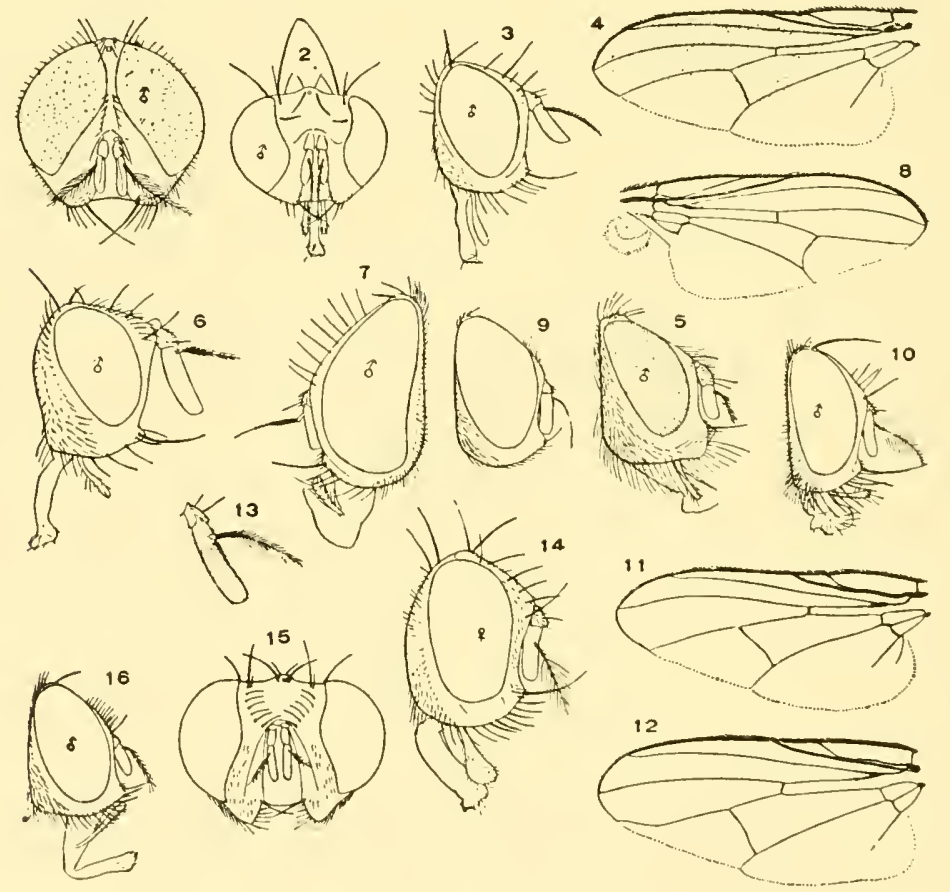

Muscida I.-1, Helina lucorum; 2, Schœnomyza chcrysostoma; 3, Limosia; 4, 5, Lasiops spiniger; 6, Phyllogaster cordyluroides; $\tau$, S. Fannia; 9, Ophyra enescens; 10. Helina; 11, Spilaria; 12, Pseudolimnophora; 13, Pseudolimmophora, antenna; 14, 15, Lispe; 16. Limnophora. 
20. Cheeks usually less than one-thirl the eye-height; face as long as the

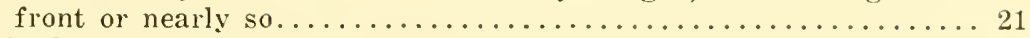
Cheeks more than half as wide as the eye-height; face shorter than the front, slightly retreating below; intra-alar bristles absent; scutellum with four bristles..................mnomera Rondani

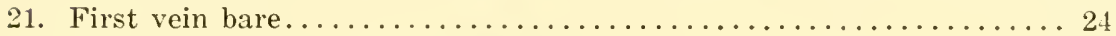

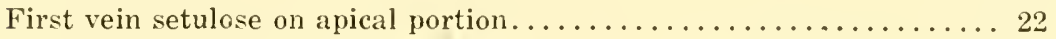

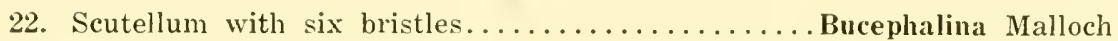

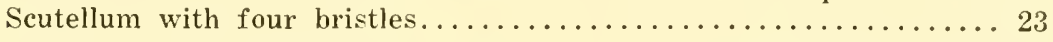

23. Palpi strongly widened and spatulate.........*Cordylurella Malloch

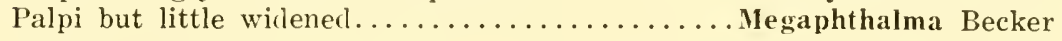

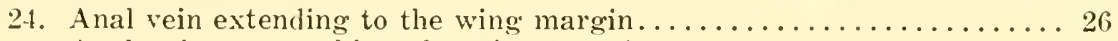

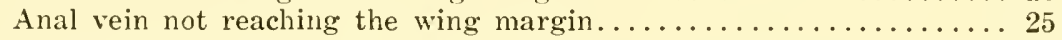

25. Third antennal segment four times as long as wide. Micropselapha Becker Third antennal segment less than three times. as long as wide.

Cordylurella Malloch

26. With two or more rows of acrostical hairs................. 27 Without acrostical hairs.......................... Fallén

27. With more than two rows of acrostical hairs (57)... Ceratinostoma Meacle With only two rows of acrostical hairs........... Opsiomyia Coquillett

28. Third antennal segment angulate at upper apex............. 29 Third antennal segment rounded apically................. 33

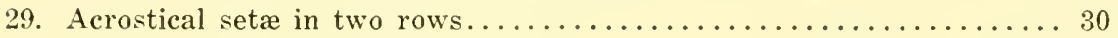
Acrostical setæ in several rows (34)........... Spaziphora Rondani

30. Anterior tibiæ clothed beneath with dense, black setulæ.......... 31 Anterior tibiæ not clothed beneath with dense, black setulæ....... 32

31. Male wing broadly emarginate between the fourth and fifth veins.

Pleurochata Becker Male wing normal in outline............... Pogonota Zettersterlt

32. Palpi spoon shaped, narrow basally............ Pseudopogonota Malloch Palpi broad, tapering basally but the base broad.... Trichopalpus Ronclani

33. Mesopleura with an extensive bare area above the anterior coxæ... 34 Mesopleura haired on almost the whole surface (33). . Scopeuma Latreille

34. Fourth vein strongly approaching the third at the wing-tip.

Lasioscelus Becker Fourth vein not strongly approaching the third apically......... 35

35. Anterior tibiæ without rense, short setulæ beneath........... 36 Anterior tibiæ with (lense, short setulæ beneath.....Microprosopa Becker

36. Anal vein almost reaching the wing margin (39).... Achetella Malloch Anal vein not nearly reaching the wing margin............. 37

37. Arista plumose or very long pubescent...........Parallelomma Becker

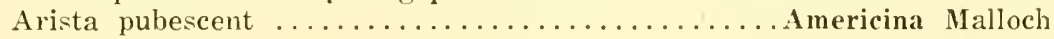

* Curran, 1929, Can. Ent., lxi, 1. 133. 
38. Anal vein extending to the margin of the wing, at least weakly ..... 39 Anal vein never extending to the margin of the wing........... 75

39. Under surface of the scutellum with fine, soft, erect hairs........ 51

Under surface of the scutellum bare................... 40

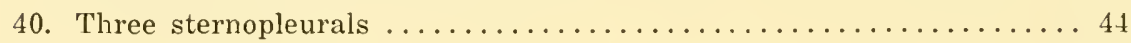

Two sternopleurals (cf. Fucellia).................... 41

41. Upper apex of third antennal segment acute or angulate; scutellum

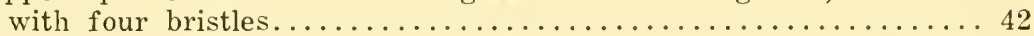

Third antennal segment rounded apically; scutellum with one pair of

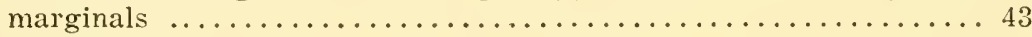

42. Arista thickened on basal half, its penultimate segment much longer

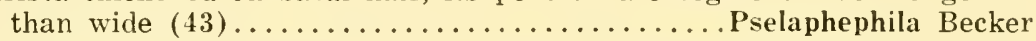
Arista thickened on basal fourth, its penultimate segment short.

Chretosa Coquillett

43. Three pairs of postsutural dorsocentral bristles.... Hexamitocera Becker Two pairs of postsutural dorsocentral bristles...... Cleigastra Macquart

44. Scutellum with one or two pairs of marginal bristles; palpi without long outstanding apical bristle...................... 45 Scutellum with six marginals; palpi with strong apical bristle.

Plethochata Coquillett

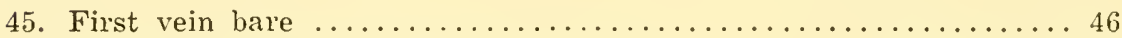
First vein setulose on apical third (38)........... Orthacheta Becker

46. Anterior femora without strong bristles on the anterior surface.... 47 Anterior femora with strong bristles on the anterior surface, propleura

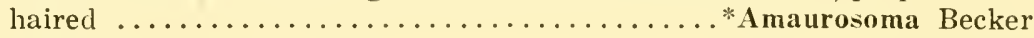

* Curran, 1927, Can. Ent., lix, p. 293.

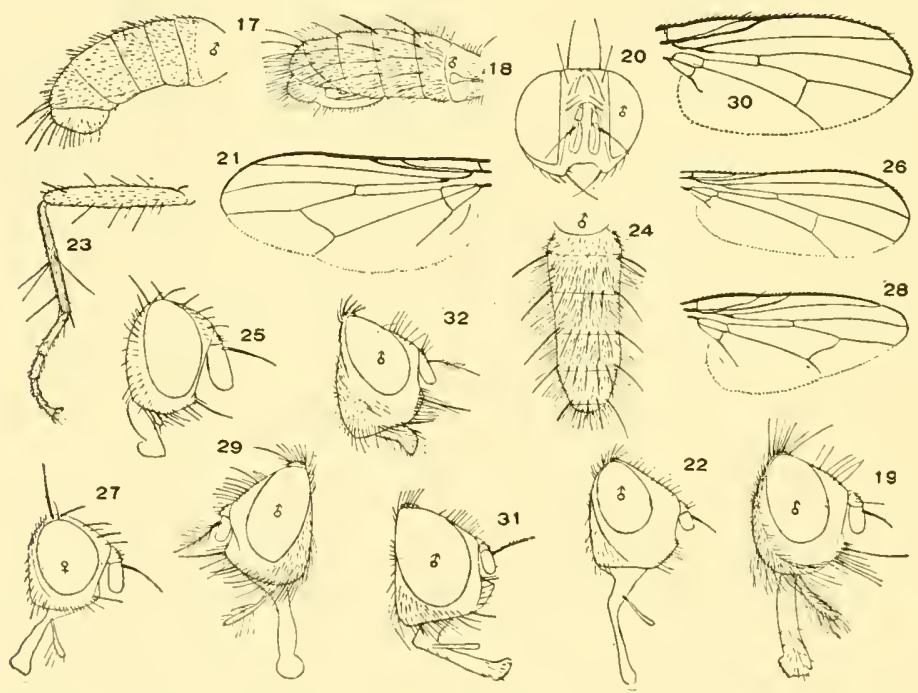

Muscidæ II.-17, Pentacricia aldrichi, $\sigma^{7}$ abdomen; 18, Eremomyia humeralis, $\sigma^{7}$ abdomen: 19. Eremomyia humeralis; 20, Neodexiopsis; 21, 22, Hammomya; 23, Coenosia, hind leg; 24, Hylemya, abdomen; 25, Tetracheta unica; 26, Hoplogaster; 27, Pegomya bicolor; 2S, 29, Hydrophoria divisa; 30 , Platycnenosia pokornyi; 31,32 , Hylemya. 
47. Palpi short, normal......................... 48 Palpi very long; stigmatal bristle strong......... Pselaphephila Becker

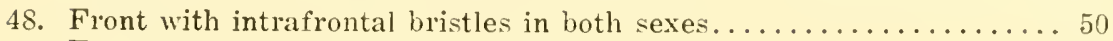

Front without intrafrontal bristles....................... 49

49. Third antennal segment sharply angulate at upper apex; arista dis-

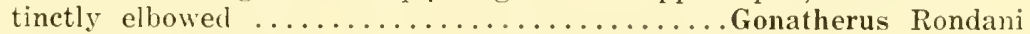
Third antennal segment obtusely angulate or rounded; arista never

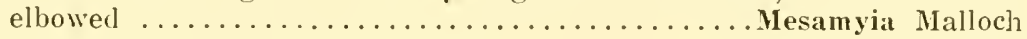

50. Acrosticals strong but short, paired............Fucellia Desvoidy Acrosticals fine, short and irregular.............. Myopina Desvoidy

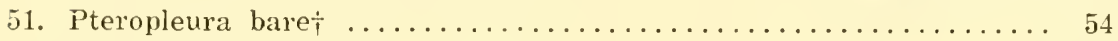
Pteropleura with hair or bristles....................... 52

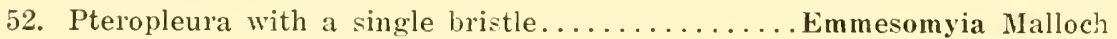
Pteropleura with several hairs........................... 5 s

53. Propleura bare....................... Treniomyia Stein Propleura haired on the median portion.......t.temomyioides Malloch

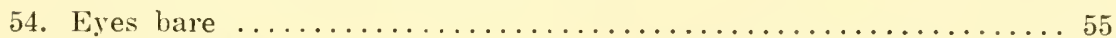

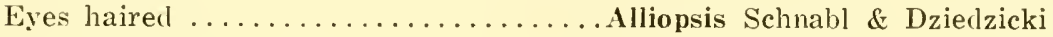

55. Propleura bare in the midlle......................... 57 Propleura haired on the median portion................ 50

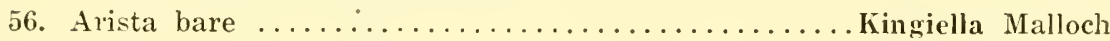
Arista distinctly plumose................ Anthomyia Meigen

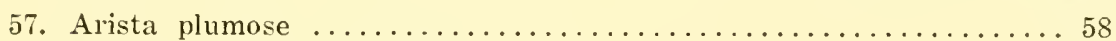

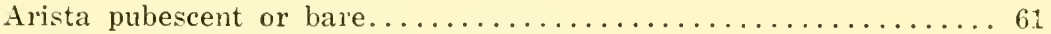

58. Scutellum cinerous, with an opaque black spot on either side. Eustalomyia Kowarz
Scutellum without Scutellum without opaque black spot on either side.......... 59

59. Lower lobe of the squamæ conspicuously longer than the upper (28, 29).$\ldots \ldots \ldots \ldots \ldots \ldots \ldots \ldots \ldots \ldots \ldots$. $\ldots \ldots$ Hydrophoria Desvoidy Lower lobe of the squamæ not as large as the apper............60 60

60. Proboscis elongate and slender, as long as the thorax or nearly so... 61 Proboscis short and thick, not nearly as long as the thorax.......62

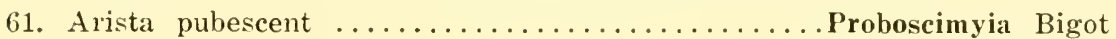

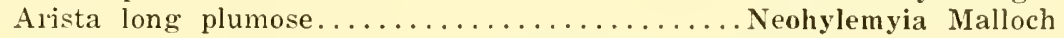

62. Hypopleura haired in front of the posterior spiracle.

Calythea Schnabl \& Dzierlzicki Hypopleura bare in front of the posterior spiracle............6. 63

63. Anterior tibiæ with an extremely long dorsal bristle at the apical fourth in the male and with two or three strong dorsal bristles at the apical fifth in the female................ Anthomyella Malloch Anterior tibiæ without such bristles................... 64

* Aldrich, 1918, Proc.-Calif. Acad. Acad. Sci., viii, p. 160.

$f$ The genera in couplets 51 to 74 commrise the Anthomyina. lieys to the Eastern suecies will be found in Huckett, Cornell Uni. Agr. Exp. Sta. Mem. 77.

\$ Malloch, 1920, Can. Ent. liii, p. 76 .

$\$$ Malloch, 1924, Ann. Mag. Nat. Hist., xiv, 1, 267.

i Malloch, 1920, Can. Ent. liii, 1) 103. 

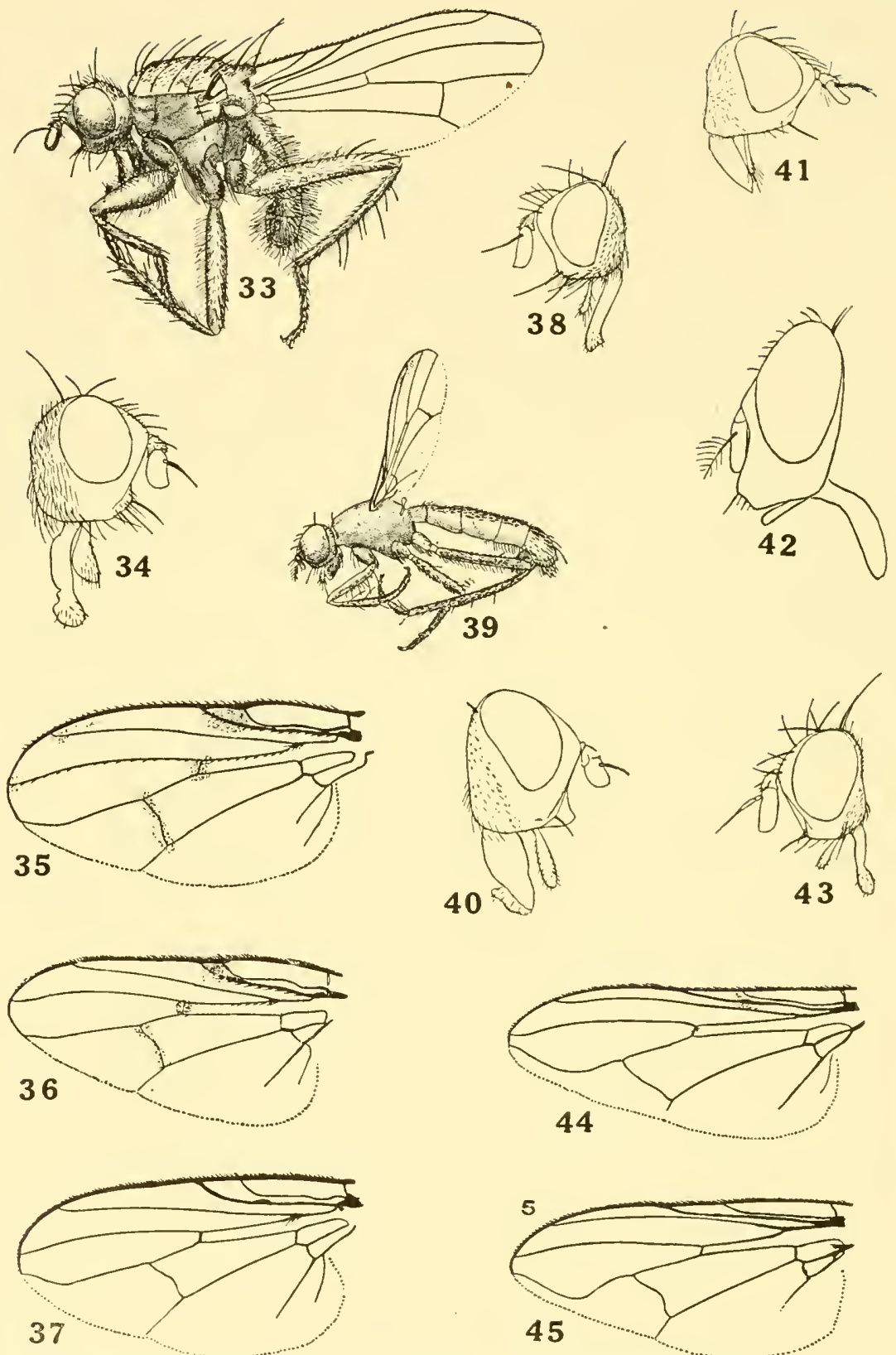

Muscidæ III.-33, Scopenma; 34, Spaziphora; 35, Cyrtoneurina; 36, Cyrtoneuropsis rescita; 37, Myospila nieditabunda; 38, Orthacheta; 39. Achætella varipes; 40, Hydromyza confluens; 41, Acicephala polita, hair on third antennal segment not shown; 42, Morellia; 43 , Pselaphelphila; 44, Morellia; 45, Graphomya maculata. 
64. Facial depression with almost parallel sides on more than the lower half or conspicuously narrower between the vibrissæ than at the

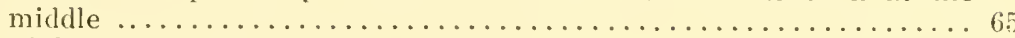

Facial depression widening below, wider at the vibrisse than at a

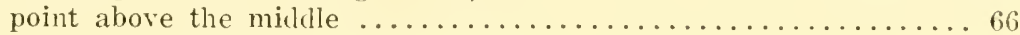

65. No bristly hairs on posteroventral surface of posterior tibiæ in male; ovipositor not terminating in two or more spines (27).

*Pegomya Desvoidy

A series of long hairs on posteroventral surface of hind tibiæ; ovipositor bearing two or more apical spines $(21,22)$.

Hammomya Rondani

66. Antennæ separated from each other by a distinct elevation which continues onto the face..................... Egle Desvoidy Antennæ not conspicuously separated from each other at the base... 67

67. Oral margin strongly produced, the hairs surrounding the vibrissæ extending well onto the sides of the face..........Macateeia Malloch Oral margin not unusually produced, the hairs not extending onto the

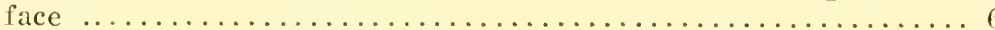

68. Middle tibiæ with anteroventral bristle near the middle.

Paregle Schnabl \& Dziedzicki

Midlle tibiæ without such bristle................... 69

69. Three pairs of postsutural dorsocentrals................. 70 Four pairs of postsutural dorsocentrals...........Macrophorbia Malloch

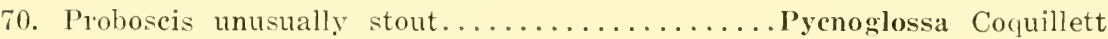
Proboscis not unusually robust...................... 71

71. Posterior tibiæ with two long bristles near the middle, on the upper surface, each at least half as long as the tibia...Prosalpia Pokorny Posterior tibiæ without such bristles................... 72

72. Sirles of the scutellum with more than a single row of hairs below the marginals; interfrontals absent in both sexes; posthumeral and anterior sublateral bristles equally strong $(18,19)$..Eremomyia Stein Not with this combination of characters................... 73

73. Eyes of males broadly separaterl; acrosticals hair-like and short.

Chirosia Rondani

Eyes of males approximate, very rarely separated by much more than the distance between the posterior ocelli................. 74

74. Posterior tibiæ without posterodorsal bristles, or with two (27).

+Pegomya Desvoidy

Posterior tibiæ with one posterodorsal bristle or with more than two $(24,31,32) \ldots \ldots \ldots \ldots \ldots \ldots \ldots \ldots \ldots \ldots \ldots$ Hylemya Desvoidy

75. Arista plumose, pubescent or bare................... 76 Arista pectinate, with rays on the upper side.................

76. First vein setose, on most of its length................. 77 First vein bare, or with setulæ only before the humeral crossvein... \& 82

\footnotetext{
*alloch, 1920, Bull. Brooklyn Ent. Soc., av, 1), 121.

* Malloch, 1920, Can. Ent., liii, 1). 7.

F Malloch, 1920, Bull. Brooklyn Fint. Soc., xv, 1) 121.

§ Malloch, 1920, Ohio Journ. Sci., xx, 1), 274.
} 


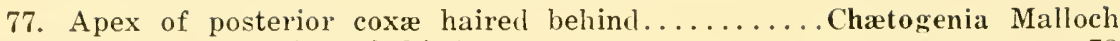

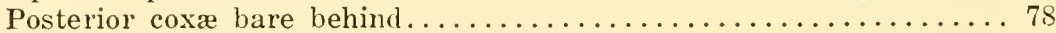

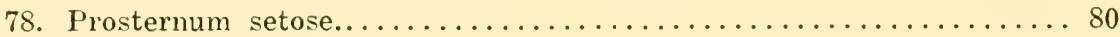

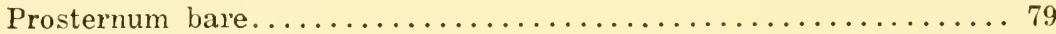

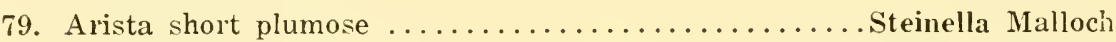
Arista long plumose $(36) \ldots \ldots \ldots \ldots \ldots \ldots$ Cyrtoneuropsis Malloch

80. Fourth vein curved forward apically................. 81 Fourth vein not curved forward apically........... Smithomyia Malloch

81. Posterior tibiæ with a strong posterodorsal bristle near the apical

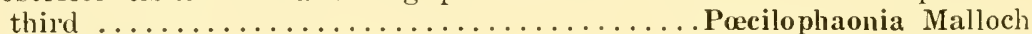
Posterior tibiæ without calcar (35) ........... Cyrtoneurina Giglio-Tos

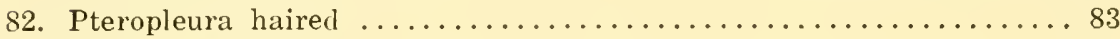

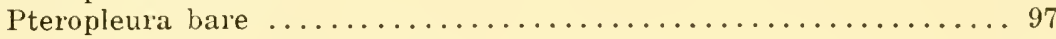

83. Propleura haired in the middle........................... 84

Propleura bare in the middle............................ 85

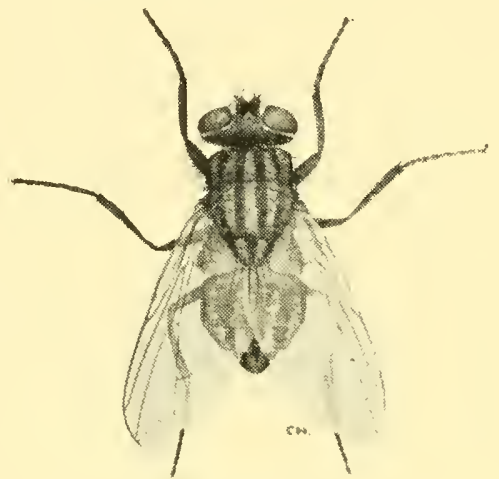

Musca domestica L.

84. Fourth vein ending well before the apex of the wing.... Musca Linnæus Fourth vein ending well behind the apex of the wing.Mallocharia Curran

85. Proboscis tapering from the base, long, adapted for biting (as in

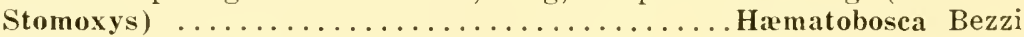
Proboscis short and stout, the labellæ large.............. 86

86. Ridge at inner edge of lower squamal lobe bare............. 88 Ridge at inner edge of lower squamal lobe with hairs.......... 87

87. Fourth vein ending before the wing-tip........... Orthellia Desvoidy Fourth veing ending behind the wing-tip $(51,54) \ldots *$ Philornis Macquart

88. Fourth vein ending distinctly behind the wing-tip ........... 90 Fourth vein ending distinctly before the wing-tip............ 89

89. Middle tibiæ with a strong anteroventral bristle beyond the middle.

Pyrellia Desvoidy Middle tibiæ without anteroventral bristle beyond the middle $(42,44)$.

$\uparrow$ Morellia Desovidy

* Aldrich, 1923, Ann. Ent. Soc. Amer., xvi, p. 308.

$\dagger$ Malloch, 1923. Ann. Mag. Nat. Hist., xii, pp. 520, 523. 


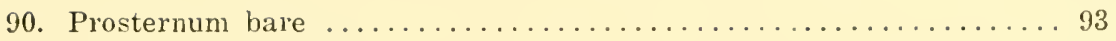

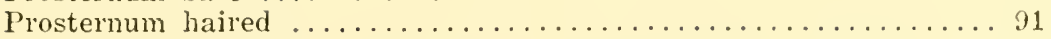

91. First vein with setulæ opposite the humeral crossvein...Clinopera Wulp First vein bare above on the whole length................ 92

92. Facial depression extremely deep, with almost parallel sides; cheeks wide $(49,53) \ldots \ldots \ldots \ldots \ldots \ldots \ldots \ldots \ldots \ldots$ Charadrella Wulp Facial depression very shallow, widening below; cheeks narrow (55).

Dichretomyia Malloch

93. Palpi spatulate, flattened, always strongly widening apically $(\mathbf{1 4}, \mathbf{1 5})$.

* Lispe Latreille Palpi not unusually widened, not flattened apically............ 94

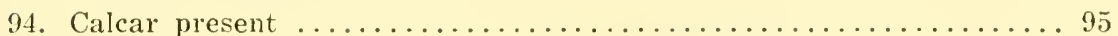
Posterior tibir without strong posterodorsal bristle beyond the middle.101

95. Fourth vein very strongly curved forward at the apex.......... 96 Fourth vein not curved forward at the apex...Pseudophaonia Malloch

96. Third and fourth veins equidistant from the wing-tip.

Hy podermodes Knab . Mesembrina Meigen

97. A single pair of presutural dorsocentral bristles............. 98 Two pairs of presutural dorsocentrals or they are absent.........106

98. Lower lobe of the squamæ much longer than the upper...........100 Lower lobe of the squamæ scarcely longer than the upper.........99

99. Front decidedly longer than wide $(26) \ldots \ldots \ldots \ldots+$ Hoplogaster Rondani Front wider than long, narrowing anteriorly (2).. †Schonomyza Haliday

100. Costa extending to the fourth vein............................ Costa ending at the third vein or a little beyond...... Allognota Pokorny

101. Three postsutural dorsocentrals........................... Two pairs of postsutural dorsocentrals...........Bithoracochata Stein

102. Posterior tibiæ with three long median bristles, one on the posterodorsal surface although this latter may be short.............103 Posterior tibiæ without a single posterodorsal bristle at the middle,

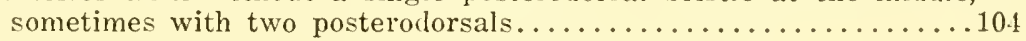

103. Anterior tibiæ with an anterodorsal beyond the middle.

Macrocenosia Malloch Anterior tibiæ without an anterodorsal bristle (20). \$Neodexiopsis Malloch

104. Posterior tibiæ with an anteroventral bristle................. 105 Posterior tibæ without an anteroventral bristle... +Xenoconosia Malloch

105. Posterior tibiæ with a long anterodorsal and long anterior bristle situated very close to each other $(23) \ldots . \ldots \ldots$..... $\$$ Coenosia Meigen Posterior tibiæ with anterodorsal and anteroventral bristle, their bases not close together $(3) \ldots \ldots \ldots \ldots \ldots \ldots$ Limosia Desvoidy

- Aldrich, 1913, Journ. N. Y. Ent. Soc., xxi, p. 131.

† Huckett, 1934. Trans. Amer. Ent. Soc., Ix, pp. 87, 106.

+ Huckett, 1934. Trans. Amer. Ent. Soc., lx, p. 74 (Neodexiopsis).

$\S$ Huckett, 1934, Trans. Amer. Ent. Soc., Ix, p. 83.

I Huckett, 1934, Trans. Amer. Ent. Soc., 1x, p. 135. 
106. Sternopleural bristles situated in a nearly equilateral triangle, almost

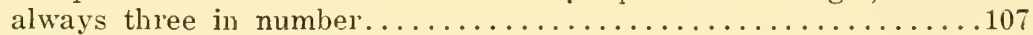

Sternopleurals not forming a nearly equilateral triangle, if only three are present the lower one is decidedly farther from the anterior...11i

107. Dorsocentrals very weak, poorly differentiated......Atherigona Rondani Dorsocentrals strong . . . . . . . . . . . . . . . . . . 108

108. Anterior tibiæ with a posterior bristle near or beyond the middle...109 Anterior tibiæ without posterior bristle except at apex.

Lispocephala Pokorny

109. Four sternopleurals, the posterior three in a straight line.

110. Posterior bristle on front tibiæ very long, situated before the middle.

Posterior bristle on front tibiæ short, situated beyond the middle.

Dialyta Meigen

Limnospila Schnabl

111. Sixth vein very short, the seventh curved strongly forward so that it would bisect the sixth only a little beyond the end of the latter...112 Sixth vein not unusually short, the seventh never curved so that it

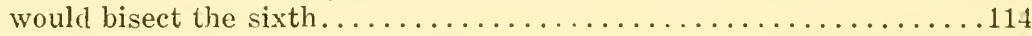
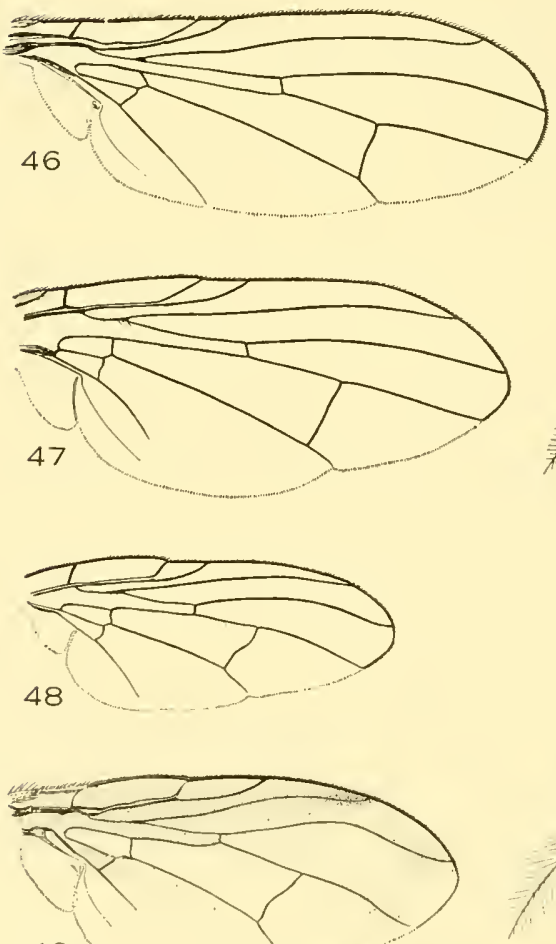

49
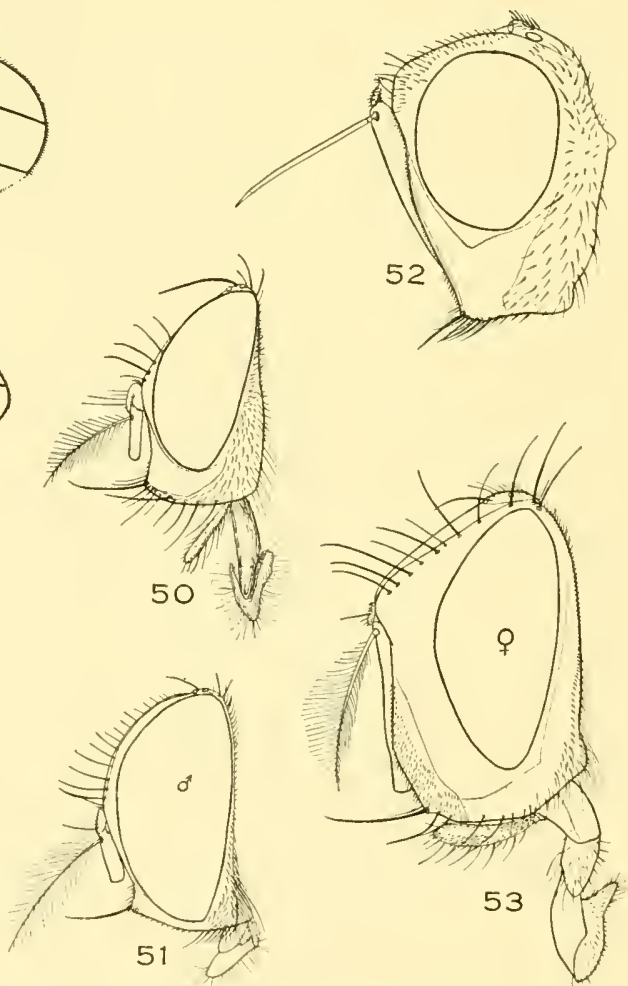

Muscida IV. -46, Cordilura; 47, Limnophora; 48, Phaonia; 49, Charadrella macrosoma; 50. Phaonia; 51, Philornis spermophilæ; 52, Lutzomyia latifrons; 53, Charadrella macrosoma. 
112. Posterior tibiæ with dorsal bristle near or somewhat beyond the middle, or with two posterodorsal bristles.....................

Posterior tibiæ without dorsal or posterodorsal bristles. Azelia Desvoidy

113. Eyes of male very broadly separated; posterior tibiæ sometimes with two posterodorsal bristles and without the dorsal....Euryomma Stein

Eyes of male approximate, the front at least narrowed; dorsal tibial bristle always present $(7,8) \ldots \ldots \ldots \ldots \ldots \ldots \ldots$ Fannia Desvoidy

114. Proboscis long and narrow, widened basally, adapted for blood-suck-

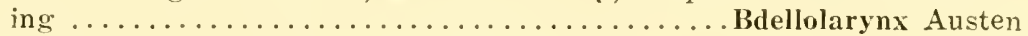

Proboscis short and thick, the labellæ fleshy..................115

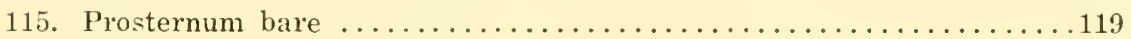

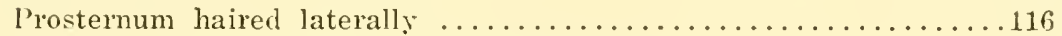

116. Posterior thoracal spiracle long and narrow.

Synthesiomyia Brauer \& Bergenstamm

Posterior thoracal spiracle little longer than wide...............117

117. Hypopleura hairy in front of and below the spiracle...Ariciella Malloch

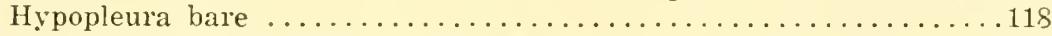

118. Basal abdominal sternite bare $(16,47) \ldots \ldots \ldots \ldots$ Limnophora Desvoidy Basal abdominal sternite with several hairs $(12,13)$.

$\dagger$ Pseudolimnophora Schnabl

119. Third vein with setæ basally on the upper margin or before the furca-

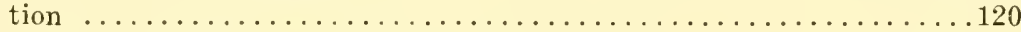

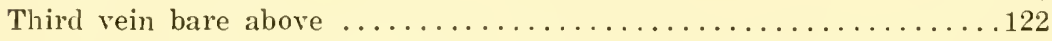

120. Lower lobe of the squamæ large, its inner end reaching the base of the scutellum $(45) \ldots \ldots \ldots \ldots \ldots \ldots \ldots$. . . . . . . . . . . .

Lower squamal lobe narrow, not produced inwardly............121

121. Fourth vein ending in the wing tip or very close to it $(37,56)$.

Myospila Rondani

Fourth vein ending far behind the wing tip, not conspicuously curved

forward apically ........................

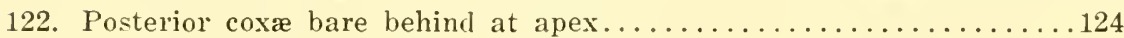

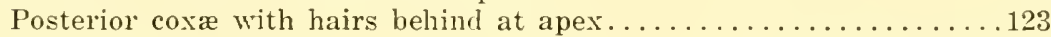

123. Eyes pilose $(4,5) \ldots \ldots \ldots \ldots \ldots \ldots \ldots \ldots \ldots \ldots \ldots \ldots \ldots \ldots \ldots \ldots \ldots$ Lasiops Meigen

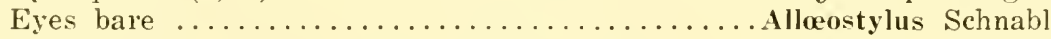

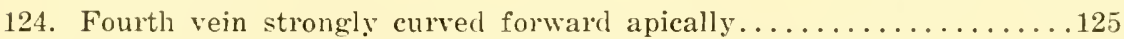

Fourth vein not or very slightly curved forward apically..........127

125. Fourth vein ending well behind the tip of the wing ............ 126 Fourth vein ending before the tip of the wing.

Pararicia Brauer \& Bergenstamm

126. Posterior spiracle twice as long as wide, with black hairs extending

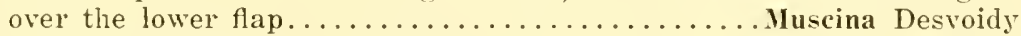
Posterior spiracle not nearly twice as long as wide. Bigotomyia Malloch

127. Posterior tibiæ, posterodorsally, bare or with two or more bristles..129

Posterior tibiæ with only the calcar, rarely with a very short postero-

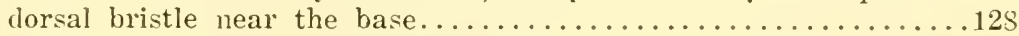

128. Cheeks below with two to five upwardly curving bristles on the an-

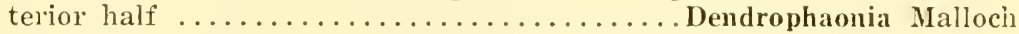
Cheeks with at most one upwardly curving bristle............ 133

\footnotetext{
* Malloch, 1924, Ann. Mag. Nat. Hist., xiii, p. 116 ; xiv, 1. 515.

$\div$ Huckett, 1932, Journ. N. Y. Ent. Soc., גi, l). 25-76, 105-15s, 279-325.

Malloch. 1923, Can. Ent., lvi, 1. 2200.

$\$$ Malloch, 1920, Can. Ent., liii, 1) 272 (Trichopticus).
} 
129. Front with an outwardly clirected orbital bristle, wide in both sexes

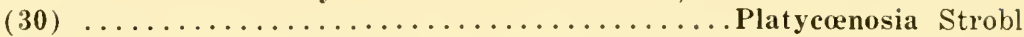
Front without true orbital bristles, or they are not divergent; usually

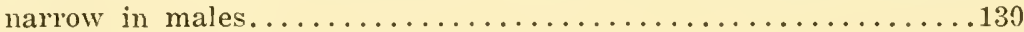

130. Parafrontals polished; frontal lunule shining white; thorax and abclomen without pollen $(9) \ldots \ldots \ldots \ldots \ldots \ldots \ldots \ldots$. Ophyra Desvoidy Parafrontals pollinose on most of their length................. 131

131. Hypopleura haired below the spiracle (11).

†Spilaria Schnabl \& Dziedzicki

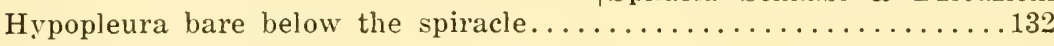

132. Hypopleura haired in front of the spiracle $(1,10) \ldots \ldots+$ Helina Desvoidy Hypopleura bare in front of the spiracle................... 136

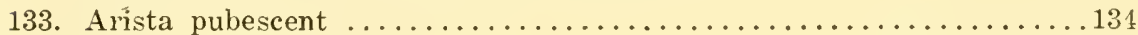
Arista with long rays $(48,50) \ldots \ldots \ldots \ldots \ldots \ldots \ldots$ \#haonia Desvoidy

134. Hypopleura bare in front of the spiracle....................... Hypopleura haired in front of the spiracle ..........Achrtina Malloch

135. Prealar more than half as long as the following bristle.

Prealar less than half as long as the following bristle.

Neohydrotaea Malloch

$\S$ Hydrotæa Desvoidy

* Malloch, 1923, Ann. Mag. Nat. Hist., xi, p. 664.

$\uparrow$ Malloch, 1920, Can. Ent., liii, p. 103.

Malloch, 1923, Tr. Amer. Ent. Soc., xlviii, pp. 239-.

$\S$ Malloch, 1916, Bull. Brooklyn Ent. Soc., xi, p. 109, xiii, pp. 30-33.
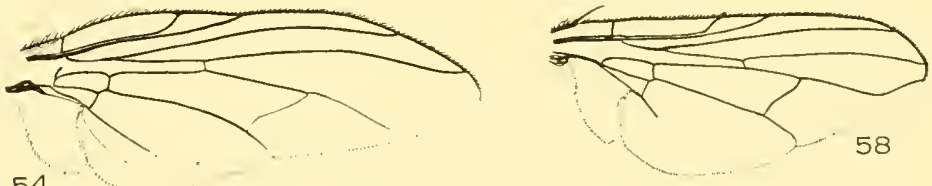

54
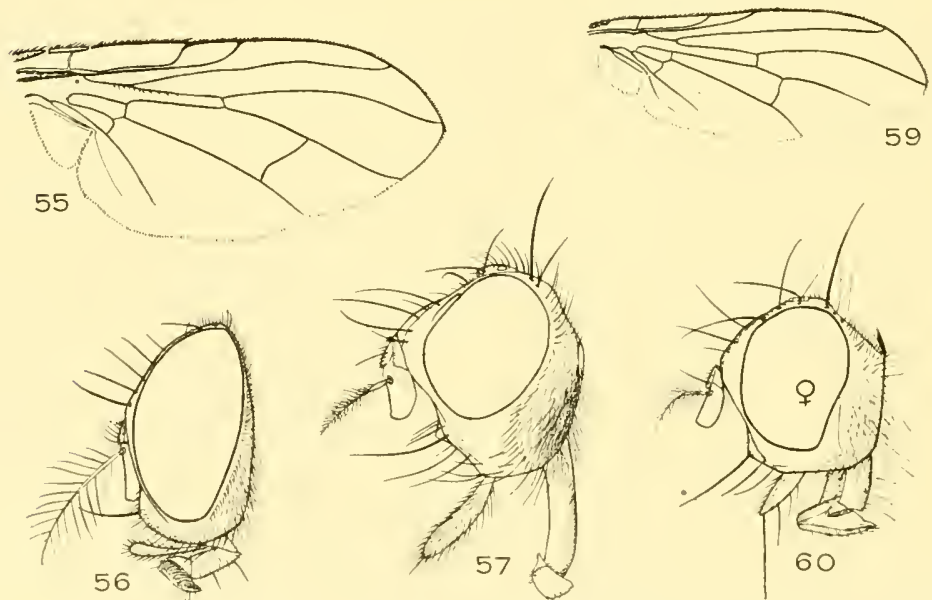

Muscidæ V.-54, Philornis spermophilæ; 55, Dichætomyia; 56, Myospila meditabunda; 5\%, Ceratinostoma ostiorum; 58, Muscina stabulans; 59, Lutzomyia latif rons; 60, Cordilura. 


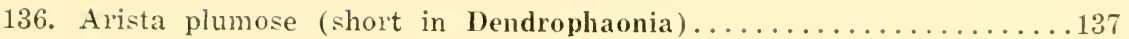

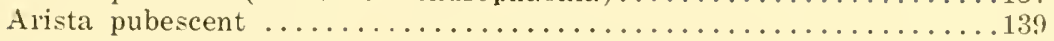

137. Cheeks below with two or more strong, upcurved bristles on the an-

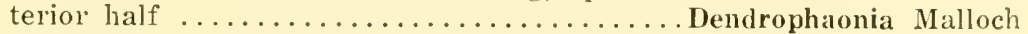

Cheeks without outstanding, upcurved bristles below, though usually

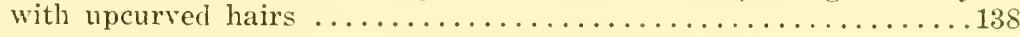

138. Eyes of males with enlarged facets in front on the upper part and quite evidently flattened; posterior tibiæ without posterodorsal bristles, the front tibiæ bristleless; small species, the females shin-

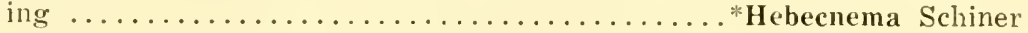

Eyes of males not strikingly flattened; usually larger species $(1,10)$.

$\doteqdot$ Helina Desvoidy

139. Cheeks half as wide as the eye-height, with bristles along the oral

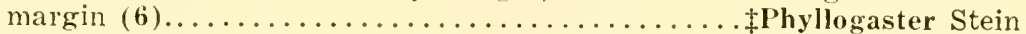
Cheeks narrower, with hair on lowest three-fourths or more.......140

140. Fourth vein conspicuously curverl forward apically.

Neomuscina Townsent Fourth vein at most weakly curved forward apically.............141

141. Prealar bristle absent .............................

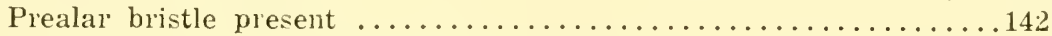

142. Lower squamal lobe produced inwardly $(51,54)$ Lower squamal lobe small and not produced inwardly.

$\S$ Philornis Macquart

TPogonomya Rondani

143. Two strong intra-alar bristles................ Lispoides Coquillett At most one weak intra-alar............... Pogonomyioides Malloch

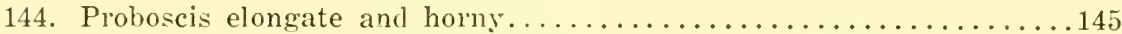
Proboscis short and thick, the labellæ fleshy........... Hemichlora Wulp

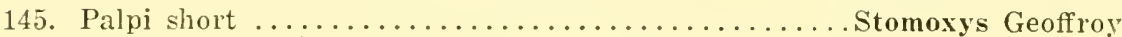
Palpi very long and narrow........Hrematobia St. Fargeau \& Serville

* This genus cannot be distinguished from Helina with any degree of success and should no doubt be united with it.

$\div$ Malloch, 1920, Can. Ent. liii, 1) 103.

† Malloch, 1923, Can. Ent. lvi, p. 11.

$\$$ Aldrich, 1923, Ann. Ent. Soc. Amer., xvi, 1. 308.

Malloch, 1918, Tr. Amer. Ent. Soc., xliv, 1. 277.

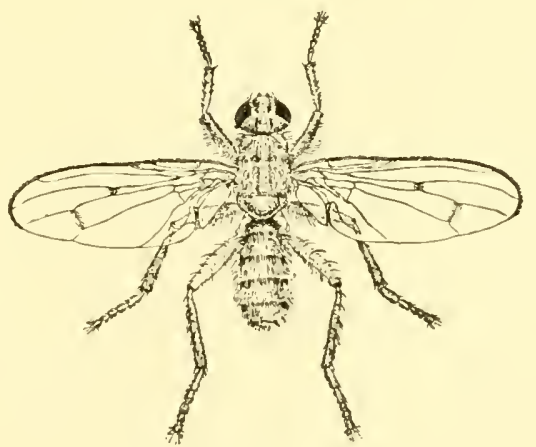

Scopeuma furcata Say. 


\section{Family Gasterophilidæ-The Horse Bot Flies}
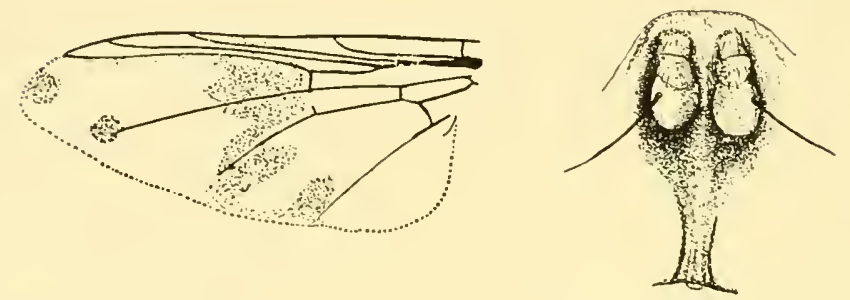

Gasterophilus intestinalis, wing and part of head showing antennæ.

Flies of moderate size, without bristles, the thorax pilose; mouth parts very small; apical erossvein absent.

Head short and deep, pilose; front broad; antennæ small, situated in deep pits separated by a carina; second segment withont groove; arista bare; mouth parts very small, the palpi swollen, though short, larger than the proboseis; ocelli present. Seutellum large; postseutellum absent. Legs of moderate length. Apieal erossvein absent, the vein closing the discal cell also absent and the fourtl and fifth veins evaneseent apieally. Squama small. Abdomen elongate oval in the male, slightly tapering, in the female tapering apieally, the ovipositor large and protuberant.

The bot flies are frequently serious pests of horses and may be collected in the neighborhood of these animals, although they are remarkably good fliers. The larre live in the stomach, throat and nasal passages of horses and related animals and reports of their oceurrence in other animals are very rare. The eggs are laid by $G$. intestinalis on the legs or shoulders of the vietim and are taken into the month when the animal lieks these parts; G. veterinus lays its eggs on the underside of the head and it is believed that the larve make their way throngh the skin and into the mouth and thenee to the pharynx where they attach themselves. G. hamorrhoidalis lays its eggs about the lips of the horse and the young larve pass to the reetum where they fasten themselves to the walls. Horses apparently reeognize the flies, at least those of veterinus, and it is not an uneommon sight to see horses with their heads resting on each other's backs as a protection against egg laying.

Gasterophilus has usually been placed in the Estridae but Girschner long sinee pointed out that it was more elosely related to the Museidx (Anthomyidæ) and it has been included in that family. Other 
authorities have plaeed it in the Acalypterx where it would seem to belong on account of the shape of the second antennal segment. However, the species possess strong posterior ealli and it is possible that the family is, despite the antemal character, more nearly related to the Muscidx.

The family contains but one genus, Gasterophilus Clark, and there are three North American species.

\section{IEY TO THE NEARCTIC SPECIES OF GASTEROPHILUS}

1. Wings with dark spots..................... intestinalis Degeer Wings without dark spots....................... 2

2. Discal cell closed beyond the first basal cell; apex of abdomen broarlly

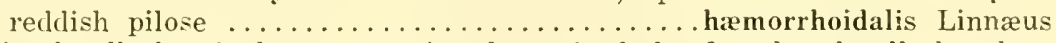
Discal cell closed almost opposite the end of the first basal cell; basal cells of equal length; abdomen with whitish pile crossed by a black

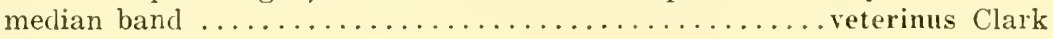




\section{Family Metopiidæ-The Flesh Flies}

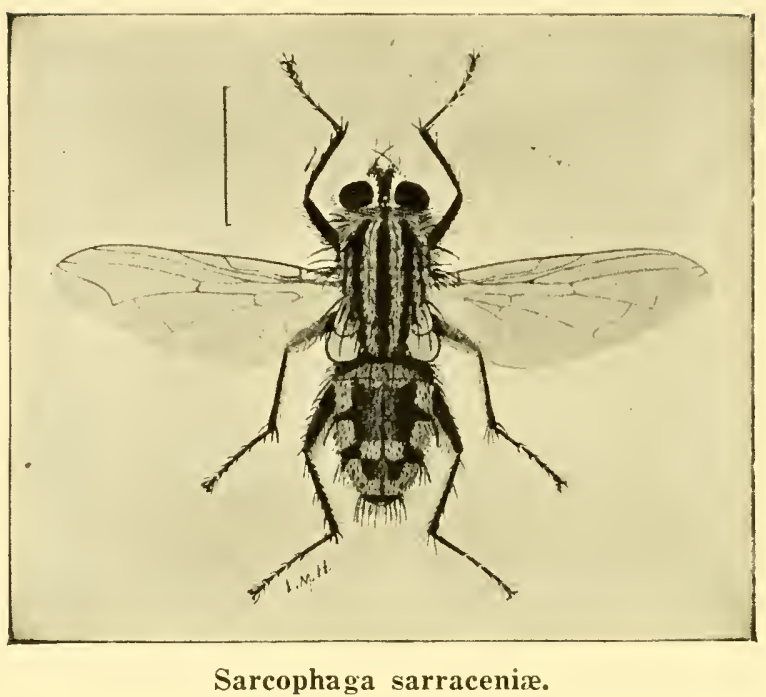

Flies of medium to moderately small size, the abdomen usually dark and tessellate or metallie green or blue.

Front in both sexes broad, usually somewhat narrowed in the males, rarely very narrow; face variable; vibrissæ present; antennæ long or short, the arista plumose, pubeseent or bare. Abdomen composed of four segments in the males, the fifth short in the females; abdominal bristles usually strong, at least on the apieal segments. Hypopleura with a row of bristles; postseutellum developed only in Mesembrinella. Apical cell usually open, rarely elosed and petiolate, usually ending far before the apex of the wing.

As here considered this family eomprises the Sarcophagidx, part of the Museida and part of the Tachinidie of Williston's Manual. The absenee of the postseutellum distinguishes it from the Tachinidie while the presence of hypopleural bristles separates it from the Iuscide and the well developed mouth parts from the Estride. A study of pupal and larval characters indicates that the association of the genera now included in the family is a natural one, although the genus $14 \mathrm{cscm}$ brinella is a doubtful member.

Insofar as known the larve are flesh feeders, parasites or seavengers on exerement and all have the posterior spiracles situated within a deep depression. 
As indieated in the introduction 1 consider. Myasis in man is generally an accidental oceurrence. There is evidence that it may oceur under conditions where an open wound is not dressed and ineidents of this kind were not lare during the World War. Indeed, the condition of maggot-infested wounds led to the discovery of the value of flies as an aid in curing serious wounds and also in the treatment of Osteomyelitis. It is true that some medical men express doubt about the efficalcy of the magrot treatment of this disease but the evidence seems to be in its faror. The maggots feed, for the most part at any rate, only on decared tissue and the bacteria present in the wound. Whether healing results from the consumption of bacteria or the secretion of a substance stimulating the erowth of new flesh is immaterial.

The larra of the screer Worm Flics (Cochtiomyia macellaria and americana) oecasionally attack man. The egos are laid in open wounds or nasal or other discharges from the boty and the larve quickly bore into healthy tissue. From fifty to more than two hundred eggs may be laid at a time. There have been a number of fatal cases in the United States while, in the tropies, death from the attacks of the maggots is said to be not rare. Sheep and range animals are normally attacked when wounded or when the wool beeomes fetid due to filth.

The classification of the erroup is in ehaotic condition. A great many genera have been proposed upon characters possessed by one sex or the other and upon eharacters which are apparently of not more than specific or group value and which, when large collections are studied, are found to be entirely unsatisfactory. There are no doubt several North Ameriean genera not included in the key but, without speeimens, it is impossible to locate them. I have included all the North American genera known to me but am aequainted with several others occurring in South America which may possibly oceur in the North American Tropies although there are, as yet, no records.

There are three papers which will be found most useful in the study of the insects belonging to this family, published by Aldrich*, Allent and Shammont. In the former many of the specific names have been replaced by older names as the result of a study of the types of species described by older authors. For these corrections see Aldrich*.

It is unfortunate that the name of this family must be changed to Metopiida, but sinee there has been no previous grouping of the included genera into a single family the shock should not be great. The basic use of Hiltogramma for tribal name has always been erroneous

\footnotetext{
* 1916. Sarcophaga and Allies. (Thomas Say Foundation, Vol. i). 1930, Notes on Types. etc., Pros. U. S. N. M.. Ixxviiı, Art. 12.

† 1926, N. Amer. Miltogrammini, Proc. U. S. N. M., lxviii, Art. 9.

1926, Syn. Amer. Calliphoridæ, Proc. Ent. Soc. Wash., xx viii, pl. 115-139.
} 

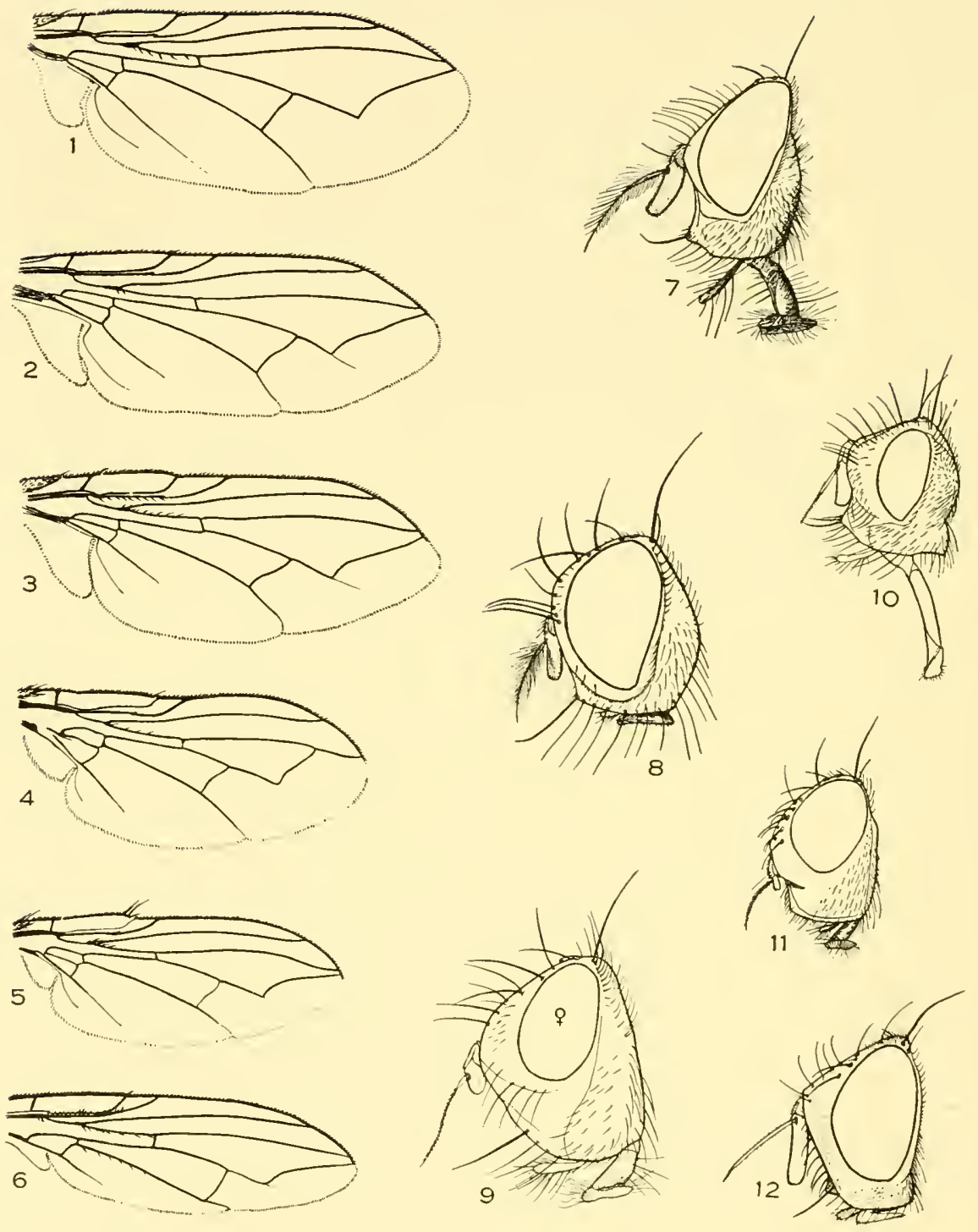

Metopiidæ I.-1, Metopia; 2, Euaraba ; 3. Helicobia; 4, Phytodes herculus; 5, Neophyto setosa; 6, Johnsonia; 7, Opsodexia; 8, Johnsonia; 9, Neophyto setosa; 10, Brachicoma devia ; 11, Melanophora, (Tachinidæ) ; 12, Euaraba. 
and the same is true of Calliphora as Onesia has page priority. Since Sacrophaga was proposed long after Metopia and Calliphora the name could scarcely be used in any event.

\section{KEY TO GENERA}

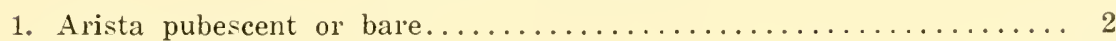

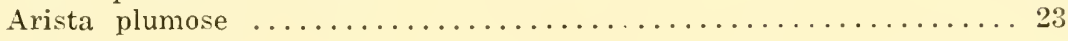

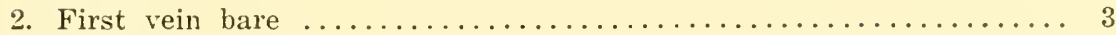

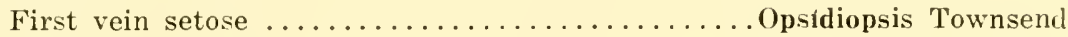

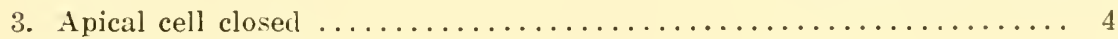

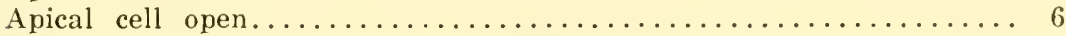

4. Distal section of the fifth vein longer than the penultimate section

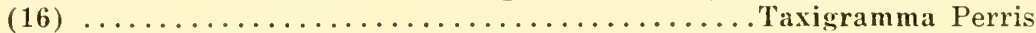
Distal section of the fifth vein little more than half as long as the

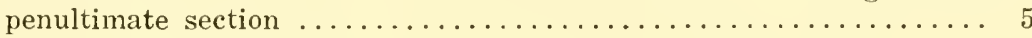

5. Apical cell ending far before the wing tip, short petiolate (19).

Hilarella Rondanj Third vein ending only a little before the wing tip, the apical cell long

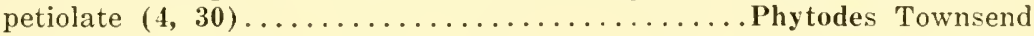

6. Facial ridges without bristles or they are short and hairlike, the parafacials often bristly....................... 7

Facial ridges with bristles on lower half or more $(12) \ldots \ldots \ldots \ldots$ a

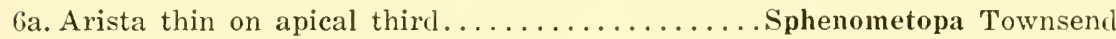
Arista wholly thickened $(2,12) \ldots \ldots \ldots \ldots \ldots \ldots \ldots$ Euaraba Townsend

7. Parafacials with only fine hair, without bristles, or with only one below. 11 Parafacials with a row of bristles (cf. Camptopyga)............ \&

8. Antennæ reaching almost to the oral margin................ 9 Antennæ very short, the third segment scarcely longer than the second

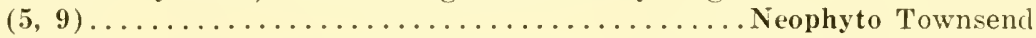

9. Facial ridges divergent below, the depression wider than parafacial.... 10 Facial ridges with parallel sides, the depression deep, narrow and not as wide as either parafacial $(18) \ldots \ldots \ldots \ldots \ldots$. Opsidea Coquillett

10. Third antennal segment not more than twice as long as the second; face

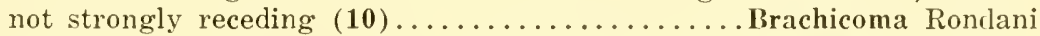
Third antemal segment more than three times as long as the second; face very strongly receding $(1,20) \ldots \ldots \ldots \ldots \ldots$. Ietopia Miegen

11. Apical cell ending in the wing tip............... Opelonsia Townsend Apical cell ending far before the wing tip................. 12

12. Head at vibrissæ much shorter than at base of antennæ, the oral margin

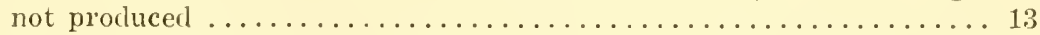

Head at vibrissæ almost or quite as long as at base of antennæ, the oral margin usually prominent..................... 17

13. Abrlominal bristles strong............................ 14 Abdominal bristles poorly differentiated from the hair; abdomen sub-

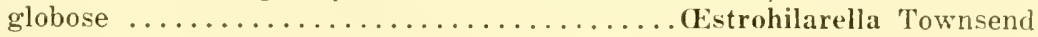

14. Frontals not extending below the base of the antennæ........... 15 Frontals descending to the middle of the second antennal segment. 

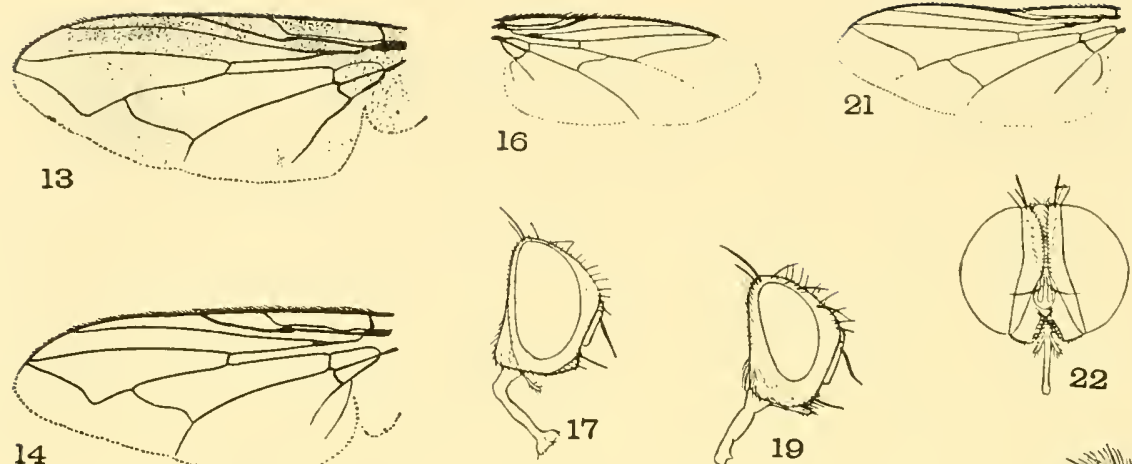

14
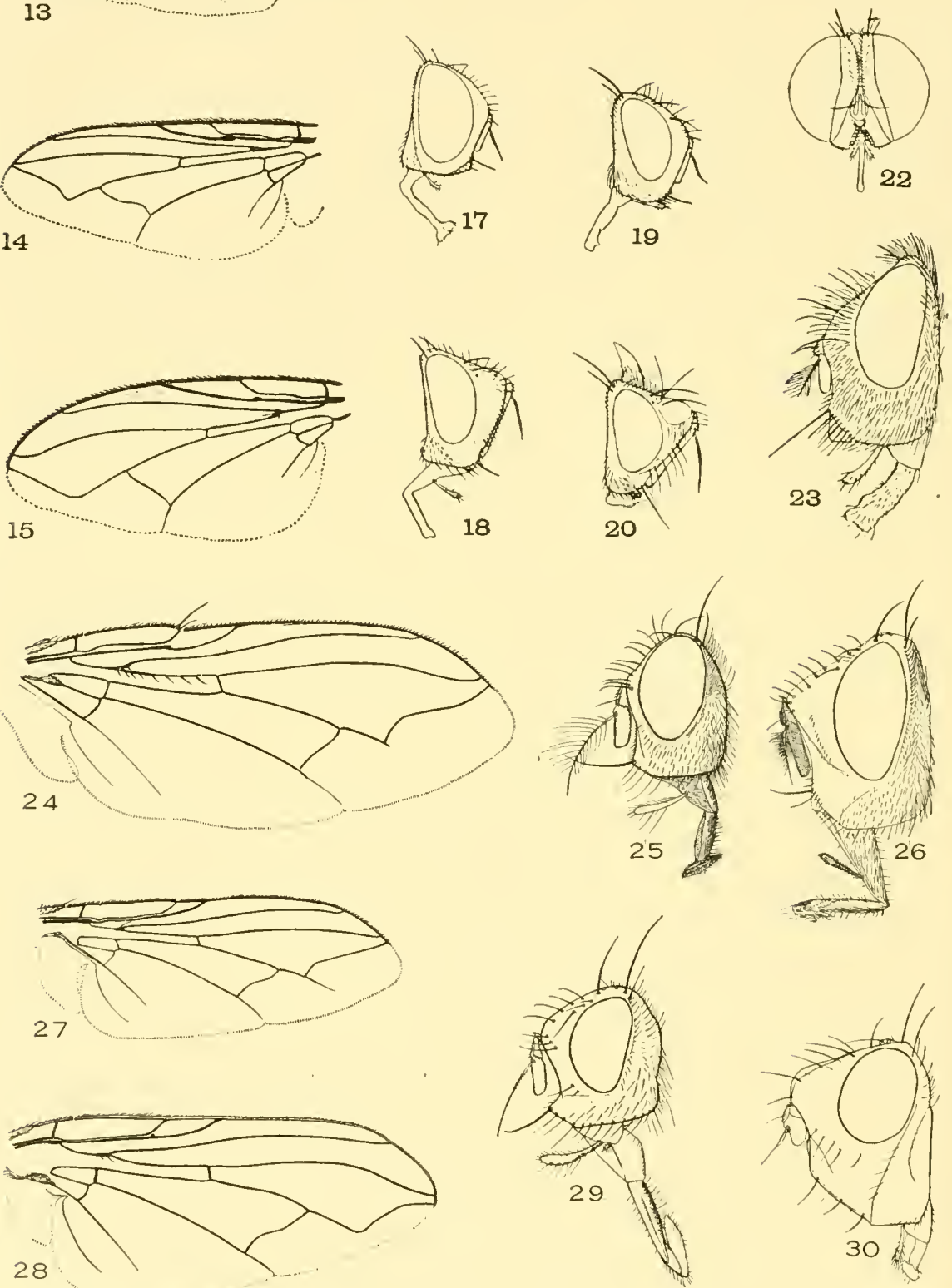

Metopiidæ II,-13, Hemilucilia; 14, Pollenia rudis; 15, Mesembrinella; 16, Taxigramma ; 17. Senotainia; 18, Opsidea; 19, Hilarella; 20, Metopia leucocephala, $0+21,22$, Pachyophthalmus: 23, Pollenia rudis; 24, Camptopyga; 25, Sarcophaga; 26, Raviniopsis; 27, Senotainia; 28, Opsodexia; 29, Camptopyga; 30 , Phytodes herculus. 
15. Third vein usually bristled half way to the crossvein or the arista thickened on not more than the basal half..................... 16 Third vein with only one to three small basal setulæ, the arista thickened on almost its whole length; third antennal segment five times

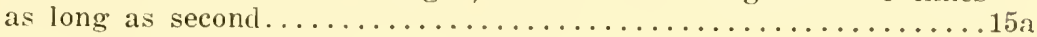

15a. Vibrissæ situated level with the anterior oral margin..... Ouelletia, n. 3 . Vibrissæ situated almost the length of the second antennal segment

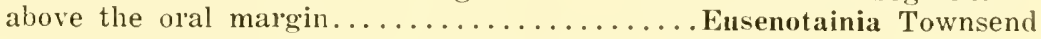

16. Three pairs of almost equally strong marginal scutellars.

Gymnoprosopa Townsend Apical pair of scutellars weak or absent....... Eumacronychia Townsend

17. A row of proclinate hairs on the parafrontals close to the frontals (21, 22) ..................Pachyophthalmus Brauer \& Bergenstamm No such row of hairs, the parafrontals sometimes haired over most of the surface or bearing one or more pairs of orbitals.......... 18

18. Costal spine very long and strong; two pairs of strong scutellars (24,

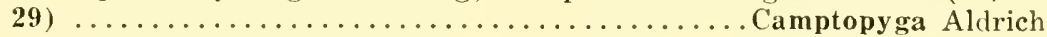

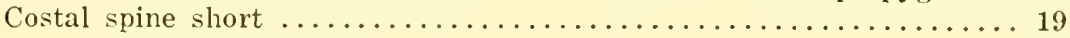

19. Parafacial hairs conspicuous, moderately long.............. 20

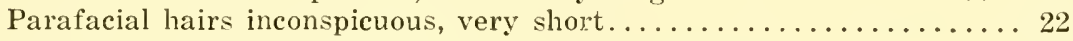

20. Second abdominal segment with erect median marginals.......... 21 Second abdominal segment without median marginals.

Wohlfahrtia Brauer \& Bergenstamm

21. Frontals not descending below the base of the antennæ. A mooia Desvoidy Frontals descending below the base of the antennæ and divergent below

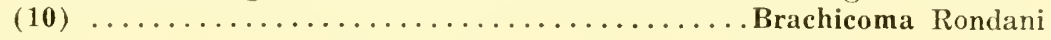

22. Three pairs of almost equally strong scutellars $(17,27)$.

Senotainia Macquart Apical scutellars very much weaker than the other two pairs.

Eumacronychia Townsend

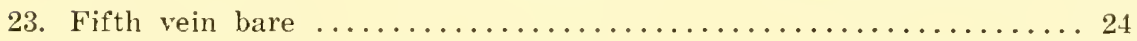
Fifth vein bristled $(6,8) \ldots \ldots \ldots \ldots \ldots \ldots \ldots \ldots \ldots$ Johnsonia Coquillett

24. Lower lobe of the squamæ haired above at least on basal half...... 25 Lower lobe of the squamæ bare or pubescent above............. 29

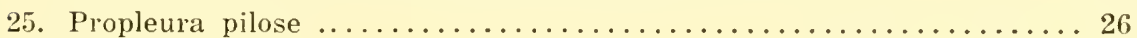
Propleura bare ...................... Adiscochæta Enderlein

26. First vein setose posteriorly before the humeral crossvein.

*Paralucilia Brauer \& Bergenstamm

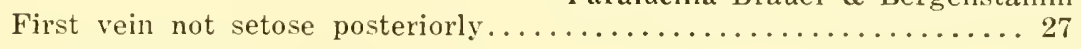

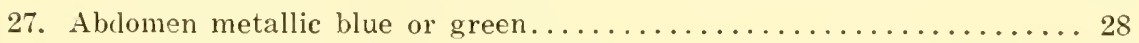
Abdomen black in ground color, tessellate.......... Squamatoides Curran

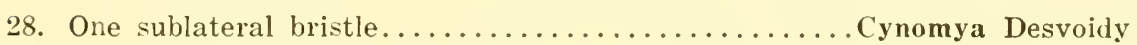
Two or three sublateral bristles............. Calliphora Desvoidy

* Chrysornya desvoidyi belongs here.

Steringomyia Pokorny is a synonym and Onesia Desvoidy is very doubtfully distinct. If the two genera are united Onesia will have priority. 
29. First vein setose posteriorly between the humeral crossvein and base of

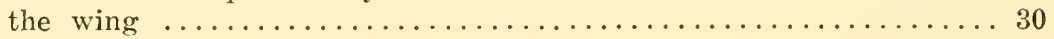

First vein bare posteriorly............................ 37

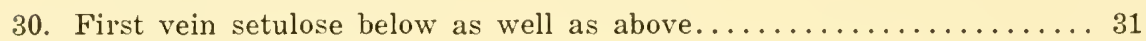

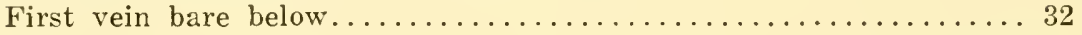

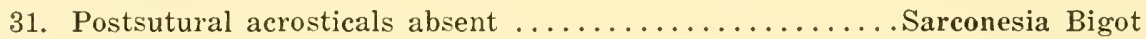

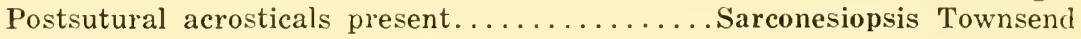

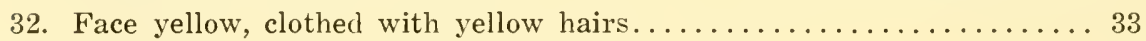

Face black, the hairs black......................... 35

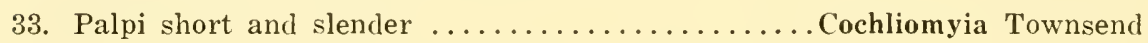

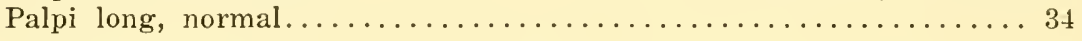

34. Vibrissæ situated the length of the second antennal segment above the

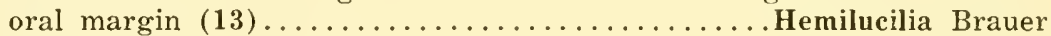
Vibrissæ almost on a level with the oral margin...... Chloroprocta Wulp

35. Aristal rays quite short and appressed; head almost as long as high.

Boreëllus Aldrich \& Shannon Aristal rays long, not appressed; head decidedly higher than long.... 36

36. Upper lobe of the squamæ haired above.........**hormia Desvoidy Upper lobe of the squamæ haired only on the margin.

Protocalliphora Hough

37. Antennæ very short, the third segment little longer than the second; face receding below, the vibrissæ closely approximate.

Neophyto Townsend

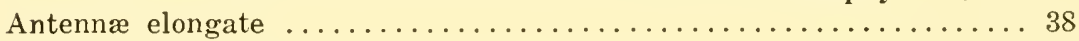

38. Suprasquamal ridge with erect black hairs.............. 39

Suprasquamal ridge bare or pubescent................ 40

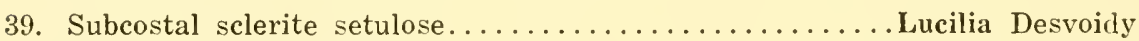

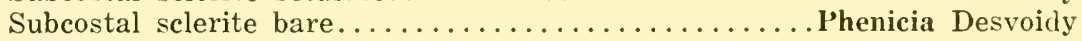

40. Thorax with abundant yellow tomentose hairs among the black hairs

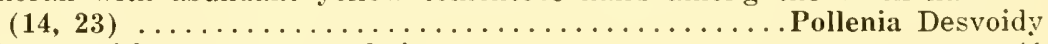
Thorax without tomentose hairs..................... 41

41. Postscutellum strongly developed; propleura bare; prosternum setulose laterally; bend of fourth vein broadly rounded (15).

Mesembrinella Giglio-Tos

Postscutellum not developed........................ 42

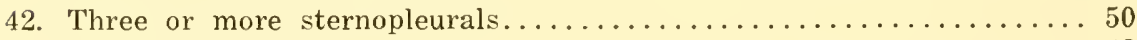

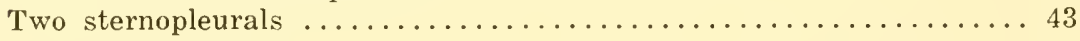

43. Fourth vein ending almost in the tip of the wing ............. 44

Fourth vein ending well before the tip of the wing............ 45

44. Arista long plumose $(7,28) \ldots \ldots \ldots \ldots \ldots \ldots$ † Oposodexia Townsend

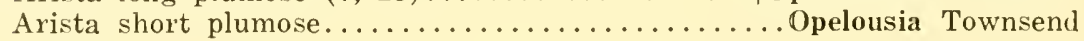

* Protophormia Townsend is separated by the absence of strong acrostical bristles but the character is of not more than specific value in this instance, some specimens possessing distinct acrosticals.

$\doteqdot$ Reinhard, 1929. Pr. U. S. N. M., lxxvi, Art. 20, p. 6. 
45. Abdomen largely pollinose...................... 46

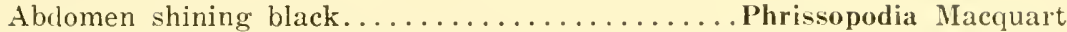

46. Hairs on sides of the scutellum extending to the lower edge....... 47 Scutellum without hairs outside the marginals......... Camptops Aldrich

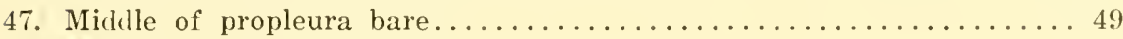

Middle of propleura haired.......................... 48

48. Frontal bristles not extending below the base of the antennæ.

Harpagopyga Aldrich

Frontal bristles extending below the base of the antennæ and diverging

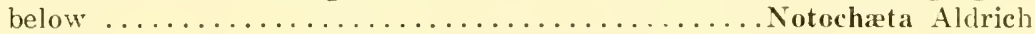

49. Parafacial hairs inconspicuous; large species......... Sthenopyga Aldrich Parafacial hairs evident; small species.................. 58

50. First vein not setose.............................. 51 First vein setose $(3) \ldots \ldots \ldots \ldots \ldots \ldots \ldots \ldots \ldots \ldots \ldots$ Helicobia Coquillett

51. Propleura haired on median portion....................... 52

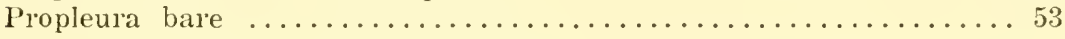

52. Third antennal segment but little longer than the second; arista short

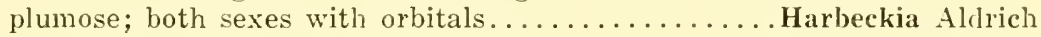
Third antennal segment usually twice as long as the second; males without orbitals (Bottcheria Parker) (25)...... † Sarcophaga Meigeu

53. Sternopleurals arranged in a nearly equilateral triangle.......... 54 Sternopleurals not arranged in a nearly equilateral triangle........55

54. Costal spine long and strong.............. Hypopelta Aldrich

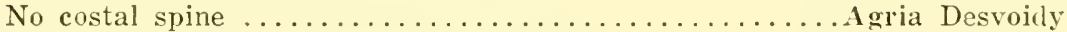

55. Third antennal segment more than twice as long as the secord; cheeks less than half as wide as eye-height; parafacials rarely with more

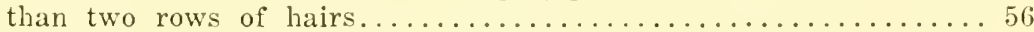

Third antennal segment less than twice as long as the second; cheeks more than half as wide as eye-height; parafacials with several irregu-

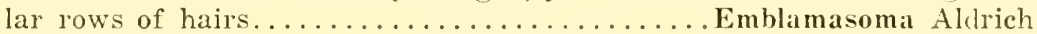

56. Arista with several rows of hairs dorsally and a single row of shorter hairs vertrally; vibrissæ situated far above the oral margin (26).

Raviniopsis Townsend

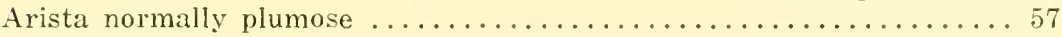

57. Front of male with one or two orbitals; at most a single hair on the notopleura in addition to the two bristles; fourth vein ending rather

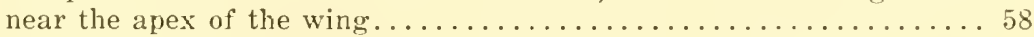

Front of male without orbitals; always more than a single hair on the notopleura in addition to the two bristles or the sternopleurals are all strong and the fourth vein ends far before the apex of the wing

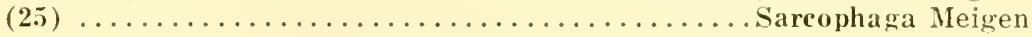

58. Parafacials with two or three rows of hairs; metacephalon swollen.

Sarothromyia Brauer \& Bergenstamm

Parafacials with a single row of hairs; metacephalon not conspicuously

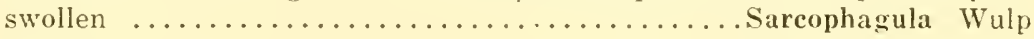

\footnotetext{
* If there are orbitals in the male see Sarcophagula.

$\dagger$ In some species the males have the propleura haired while the females do not.
} 


\section{Ouelletia, new genus}

Rather similar to Senotainiu but the facial ridges are liaired on almost the lower half, the arista is wholly thickened and the face retreating. Differs from Euscnotainia in having the vibrissie more widely separated and situated level with the anterior oral margin. Differs from Eutraba in the haired facial ridges and much narrower frontal vitta. Front three-fourths as wide as either eye, slightly more than onethird as wide as the head, the parafrontals wider than the vitta, frontals ending at base of antenna; two pairs of orbitals in the male and a reclinate frontal in the orbital row, ocellars long; onter verticals weak. Cheeks one-fifth as wide as the eye-height. Parafacials wide, setulose on upper half. Palpi of moderate length. Facial depression very deep. Antenna elongate, the third segment very long and broad: arista wholly thickened, the penultimate segment short. Acrosticals 1-1, weak, dorsocentrals 2-3, the front ones fine; three pairs of marginal sentellars; sternopleurals 1-1. Bend of fourth vein with a slight fold: base of third vein with a single bristle. Squame produced inwardy. Abdomen oval, without diseals, the apical two segments with weak marginals. Black, with whitish pollen; frontal pollen mostly brownish yellow, the mesonotal pollen with brownish yellow tinge. Abdomen with a broad median dark vitta and large black triangles on the second and third segments. Genotype, O. aristalis. new species, from Lanzon, Quebre, June.

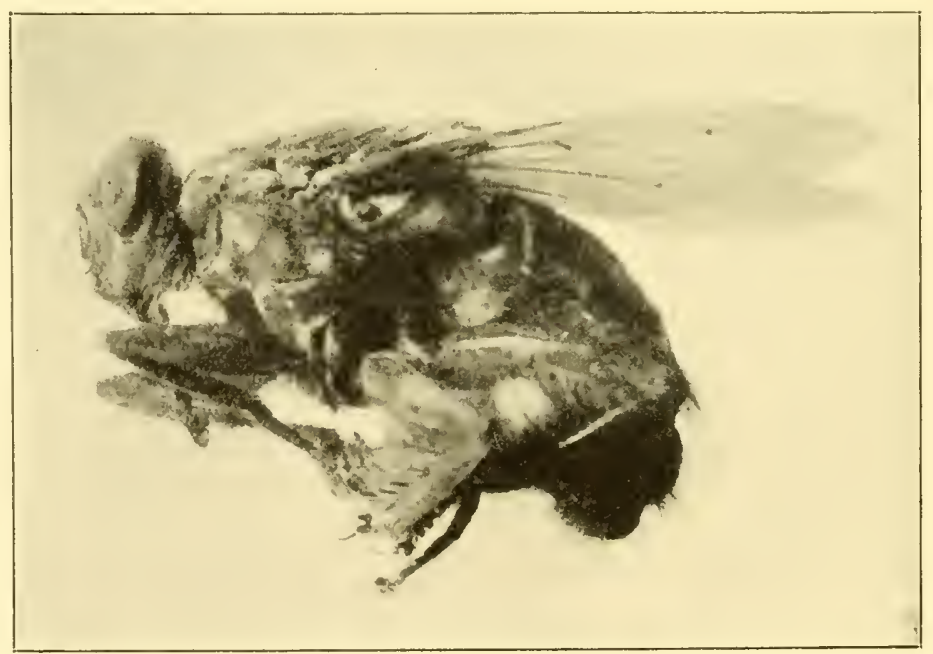

Phrissopodia præceps Wiedemann. 


\section{Family Cuterebridæ-The Robust Bot Flies}

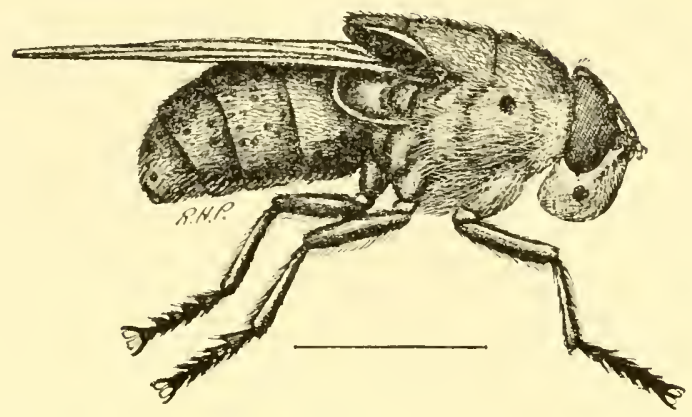

Cuterebra sp.

Flies of large size, the hair very short, sparse except on the thorax; squamæ large; metasentellum not at all developed.

This family differs from the Estrida in having the seutellum elongate, the postsentellum entirely undeveloped, the arista is usually plumose or pectinate, the form is generally more robust and the body less evidently hairy. In addition the oral opening is larger, subtriangular (produced in front toward the vibrissal angles) and the palpi are always small.

The remarks concerning the Estridx apply fairly well to this family. These flies are, in North America at least, mostly parasitic upon rodents and they have been reared from rabbits, rats, mice and squirrels. The larva have been found along rabbit runs, but the adults are only infrequently encountered.

It seems probable that this family is an offshoot of the Metopiidæe type rather than of the Tachinid stock as is evidenced by the alsenee of the postscutellum and the usually feathered arista. There does not. seem to be a close relationship between these insects and the Estrider despite the similar habits and reduced month parts while the Gasterophilide are still further removed, coming, as they do, elose to the Inseidx. The Tachinidæ having reduced mouth parts have more or less distinct abdominal bristles.

Probably the most unusual habit in the insect world is that of Dirmatobia hominis (cyaniventris), the human bot fly. The fly lays its egas on other inserts. usually mosquitoes, and they are carried by the latter to the host. The exgs contain mature first stage larve and these emerge from the eags when the carrier begins feeding and pene- 
trate the skin. The maggots remain in the host for from forty-five to fifty-five days and cause rather severe museular pains as well as inducing drowsiness. It is said that the adult flies lurk in the vieinity of mosquito infested pools and capturc the mosquitoes as they emerge, laying from ten to thirty eggs on each. I have seen mosquitoes heavily laden with the eggs. Ticks and species of Muscidæ are also carriers.

\section{KEY TO GENERA}

1. No facial carina; antennæ elongate, the third segment three times as

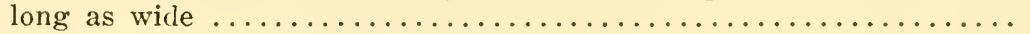

Facial carina developed, though low; antennæ short, the second segment rarely over twice as long as wide......................

2. Arista rather thickly long plumose............Pseudogametes Bischof Arista with rays on upper side only $(1,2,4) \ldots \ldots \ldots$ Dermatobia Brauer

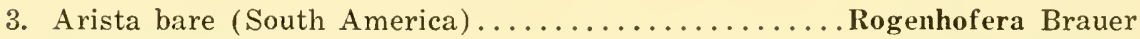
Arista pectinate above and usually with one or more rays below on the apical part $(3,5,6) \ldots \ldots \ldots \ldots \ldots \ldots \ldots \ldots \ldots \ldots \ldots \ldots \ldots \ldots \ldots$ Cuterebra Clark

* I can find no character by which to separate Bogeria Austen, described from a damaged specimen lacking the aristal rays and based upon the bare arista. Townsend (lns. Ins. Mens., v, p. 23) attempts to separate the two genera on the shape of the facial depression but I cannut follow him in this.
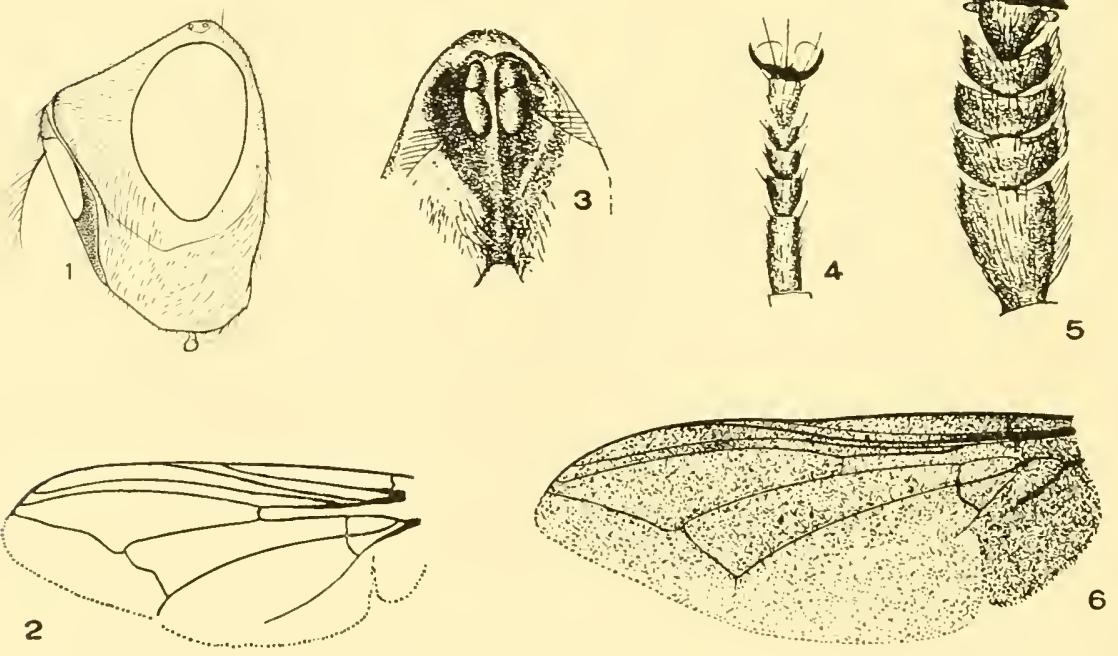

Cuterebridæ.-1, Dermatobia cyaniventris; 2, Dermatobia; 3, Cuterebra, antennæ: 4. Dermatobia, tarsus ; 5, Cuterebra, tarsus ; 6, Cuterebra.

(1)
. 


\section{Family Estridæ-The Bot Flies}

Flies of moderate to large size, thick set and for the most part mole or less pilose, the squama large.

Head large, the lower part more or less swollen; mouth opening small, the mouth parts reduced in size, very small. Front broad in both sexes, widening anteriorly in the male; ocelli present. Antenua short, composed of three segments, deeumbent and partly sunken in the facial depression or antennal srooves; arista bare. Eyes bare, rather small. Thorax robust, with transverse suture; hypoplenta bearing dense, long hair. Abdomen short, conical or but little elongate; genitalia hidden. Squama large. Wing venation as in the Tachinidr, the first rein ending beyond the middle of the wing, the anxiliary rein long and ending in the costa; fourth rein ending before the apex of the wing, close to the third; both hasal eells present, the second hasal and anal cell short.

The (Estrids are not common in collections and good series of all but a rery few species are unusual. The adults are remarkably good fliers, are excellent hoverers and extremely diffienlt to catch as well as being rarely encountered. Some collectors have had success in locating larve and pupe in pastures, and rearing the adults. Otherwise one usually rums aeross them only by aceident.

In some cases the egos are laid on the hind legs, the larva working their way under the skin and through the muscles until they reach the back, where they make an opening through which to breath. The larve of some species live in the nasal sinuses and, in sheep, are lesponsible for "stagers". The exact means by which some of the species reach their feeding places is not known, and, in fact, relatively little is known about most species which have been described.

In America the larva of (Estrus ou is have been formed in the eye of man. Normally the living larve are deposited in the nostrils or eyes of sheep, the fly dashing in and depositing a maggot. The larra work their way to the nasal sinuses and mature the following spring when they either drop out or are ejecting during sneezing. In man they have been found only in the eye, larviposition probably having taken place as described for sheep. However, there are no records of the rictim having been aware of the attack so it is possible that the larra was deposited while the victim was sleeping. 
The literature dealing with the family is seattered and a thorough revision of the American species is badly needed. The genitalia of both sexes furnish good taxonomic charaeters.

It is not an casy matter to deeide the relationship of this family but it seems probable that it originated from Tachinid stock, sinee the postscutellum is strongly developed, and the scutellum usually short and broad. The Tachinidæe with reduced mouth opening and mouth parts are more or less bristled and are eonsequently easily distinguished. However, as these are inhabitants of the Old World tropies we need not discuss them here. More is said about the affinities of the old family Estrida under the Cuterebride.

\section{KEY TO GENERA}

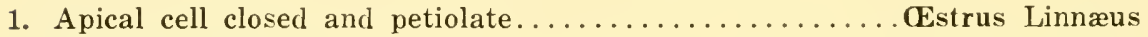
Apical cell open.................................. 2

2. Facial grooves only narrowly separated below (2)... Cephalemya Latreille Facial grooves very broadly separated................... 3

3. Palpi absent; scutellum bare on apical third (3) ....... Hypoderma Clark Palpi small, globular; scutellum pilose apically (1)... Edamagena Latreille
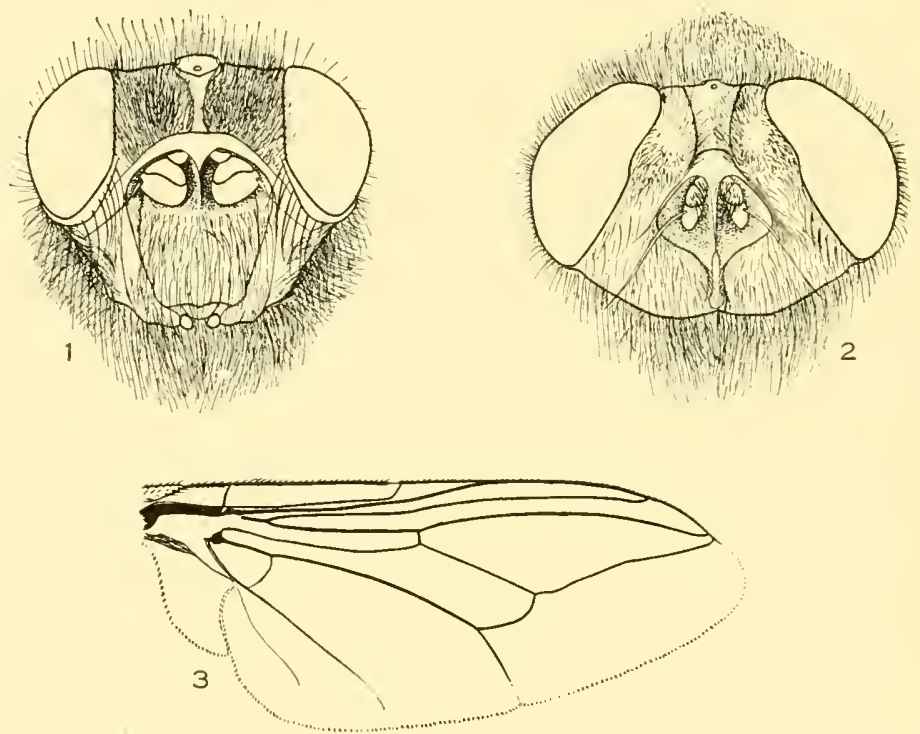

Estrida.-1, Edemagena tarandi; 2, Cephalemya abdominalis; 3, Hypoderma lineatum. 


\section{Family Tachinidæ-The Tachinids}

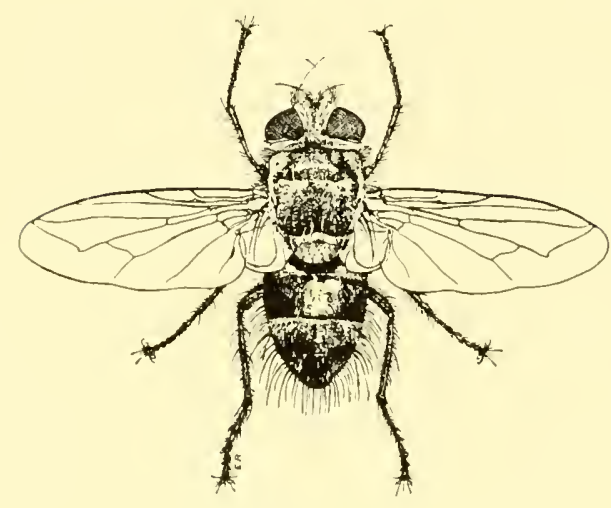

Zenillia species.

Small to rather large flies, the thorax with bristles, the head and abdomen generally witl bristles.

Head variable in size, sometimes narrower than the thorax, at other times conspicuously wider; both sexes dichoptic although the eyes of the males are sometimes closely approximated, rarely so in the females; front often wide in both sexes, usually wider in the female than in the male of the same speeies; frontal bristles almost always present, orbital bristles usually present in the females and often in the males; ocellars present or absent; outer verticals present or not distinguishable from the postocular cilia; cheeks variable in width; oral margin variable, sometimes strongly produeed, at other times receding; oral vibrissa usually present; proboseis variable in length and thiekness, sometimes very elongate, on the other extreme very small; palpi present or absent; antenna variable, eonsisting of three segments, the second with a longitudinal seam above on the outer side and usually bearing stout hairs and one or more bristles; arista eomposed of two or three obvious segments, plumose, pubescent or bare. Thorax with bristles; hypopleural bristles present, rarely weak, postscutellum well dereloped. Legs variable, bearing bristles; pulvilli alwars present on at least the posterior four legs, often elongate. Wings variable in shape, sometimes pietured; all the veins simple; apical crossvein nsually present, formed 
by the eurvature of the fourth longitudinal vein, this vein rarely straight or almost so, sometimes obsolete apieally; posterior crossvein rarely absent; first, third and fifth veins sometimes bristled; basal and anal cells complete. Squame almost invariably large. Abdomen variable in shape, usually bearing conspieuous bristles on the sides, apex and dise, but these variable; genitalia variable in both sexes.

The Taehinids are, insofar as known, all parasitic on other insects, particularly Lepidopterous, Tenthredinid, and beetle larve and adult beetles, as well as Hemiptera, Orthoptera and possibly some other orders of insects. One or two speeies are known to be parasitie on other

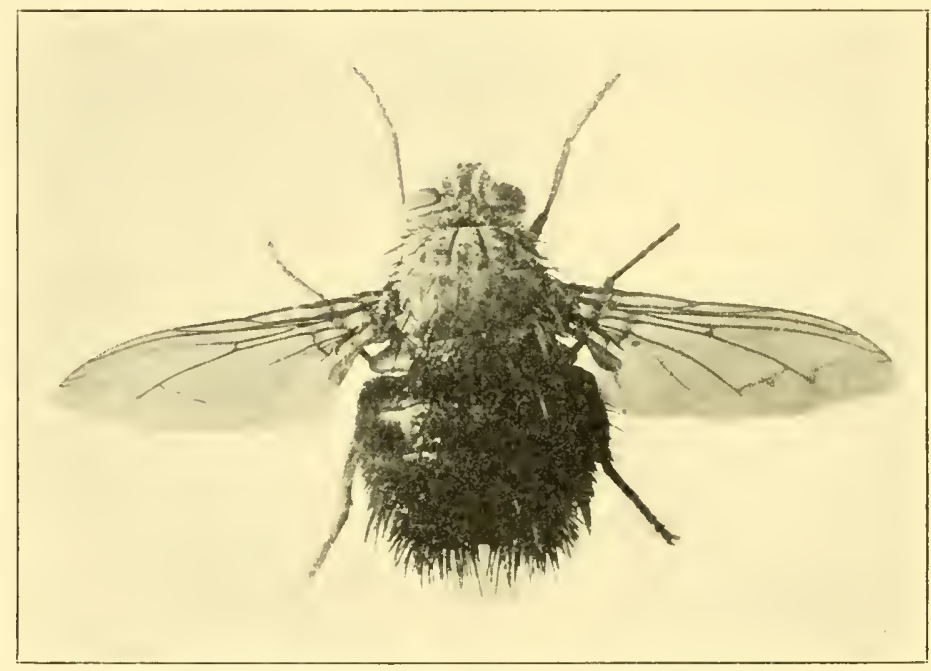

Paradejeania species.

flies (Syrphidx). The species parasitie on Ifemiptera usually have a bristleless, or near bristleless abdomen while many of those parasitizing beetles have a long, piercing ovipositor, but this eharaeter is not limited to such speeies. The eggs are variable, some being very small (mierotype), while others are large (macrotype). A small number of species deposit living larva or eggs just ready to hatch. The study of the immature stages of the Taehinids should prove to be a most fascinating one as is indicated by such work as has already been done. The species of Goniu. which lay microtype eggs, seatter hundreds of them (as many as a thousand) over vegetation and the ground; they are eaten by fecding caterpillar's and ultimately destroy their host. This may seem a haphazard way of doing things but the flies are efficient parasites as 
evidenced by their numbers. In at least one species the lanva, resembling little coiled cones, remain for long poriods on leaves, unt il they are brushed by the hair of a caterpillar, when they suddenly become aetive, make their way up the hair and enter the boly. Most species, however, apparenty oviposit in or on the host and in the case of many eateruillars the ego shells remain attached to the larva for long periods, and may be found on them as long as the larval skin exists. This is eommonly the ease with silk worm eaterpillars parasitized by speeies of Achactoncura, but the characteristic is not restrieted to this genus. The literature on this subject is more extensive than one might imagine although I must confess that I. am not familiar with it in its entirety.

The study of the immatule stages has been greatly stimulated becatuse of the economic importanee of these insects. A goodly number of speeies have been imported to America in conneetion with the natural control of foreign pests which have become established here and the study of the group has resulterl. The best known of the imported Tachinids is Compsitura concinnata Bonche, which is now well established in the northeastern states and parts of eastern Canada, and is spreading rapidly. This species is one of the chief parasites of the fypsy Ioth hut it apparently attacks almost any kind of caterpillar. Hicrophthrelma michiganensis Townsend, has been established in New Zealand from shipments made hy the Canadian gorernment. Some of the speeies imported have oecurred in this country for many years aud are perhaps indigenous but it is not by any means eertain that the native flies will attack the alien hosts. This point is mentioned merely to illustrate the fact that the same species may have different habits in different regions. It also demonstrates on lack of knowledge concerning these inseets. Parasites are searched for in all parts of the world, but most of those we have introdueed are from Enrope and Asia. Just how many of these introductions lave resulted in the definite establishment of speeies in this country we do not know, but there are some fajlunes as well as notable suecesses. Immediate results in eontrol must not be expected, but it seems likely that in due time a natural control of the pests will oeenr. To expect the Tachinids, or other parasites, to control the pests they are hrought to fight within a few years is just as absurd as to have expected the Pilgrim Father's to have eompletely settled this eountry in ten year's.

Tachinids ocent ererohere and many species are common. Clearings or lanes in woods are excellent for some species: most of them risit flowers at some time or other, and many ale found in grass. A few speries are nocturnal, other's fly at dusk or on dark days and a number 
of them are attracted to light. "Honey dew" is very attractive to many of the species. The adults are frequently very busy creatures and many females seem to fly incessantly in search of a suitable host for their offspring.

It is extremely unfortunate that this important family is in such a hopeless state taxonomically. The forms I include were at one time placed in two distinct families, the Tachinidæ and Dexiidx, and some authors have recognized a number of families for the group. The Dexiids were separated because of the plumose or haired arista but the character is not of value. During my studies of this family $I$ have searched in vain for reliable characters by which to differentiate groups. Many characters are good up to a certain point but beyond that they cease to be of real value. In many genera the propleura is haired but in some this character is not reliable. The same is true in regard to the hairiness of the lower squamal lobe, a character occurring in but a few genera in the world. The chætotaxy is variable and there is every gradation between extremes.
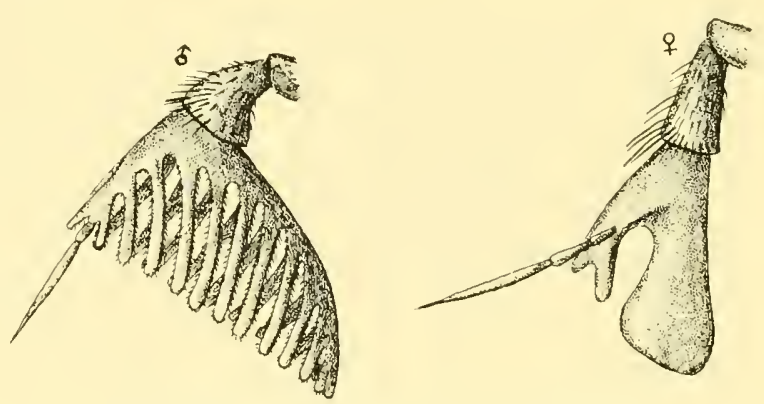

Complex antennæ found in Tachinidæ.

The question of generie limits in this family is a most perplexing one. No two people have the same conception of generic limits and it will be found that I disagree in many respects with Townsend, Villeneuve, Aldrich and other's, although agreeing rather well with Dr. Aldrich. I have been unable to correlate all of Townsend's genera with my eonception of genera but I have indicated, in the index, a great many which I think shoukd be placed in the synonymy. It might be, of course, that I have gone too far in reducing the number of described genera and that some of those relegated to the synonymy should be recognized as distinct. I feel, however, that the number of genera recognized is still too large and that we may safely reduce it to the benefit of the taxonomy of the family. It is true that in the present work I have added a number of new names and my excuse for doing so is to be found in the fact that I am unable to place the speries in any described 
genus known to me. No one ean correct the classification of this family without a very large eollection from all parts of the world and a very extensive study will be neeessary before any satisfactory generic limitation ean be fixed. Indeed, the classification can never be settled because we are continually discovering new connecting links between genera and speeies. Some genera are well established and fairly well limited but the number is small.

It is unfortunate that Dr. C. II. T. Townsend has been unable (up to the present time) to find a publisher for his volumes on the classification of this family. No one has ever equalled Townsend in knowledge of the Tachinida and his keys would prove to be of inestimable value and would throw light on the position of the hundreds of genera deseribed in various places. At the present time one is absolutely lost unless specimens are available, and it is only by chance that an occasional specimen ean be determined.

The student will find a number of ehanges in nomenclature incorporated in this work and I fear that this will eause some confusion. However, due to the work of Townsend and others we have now discovered older names for many of our species and genera and many misconceptions in identification have been corrected. It is suggested that, if a name occurs in literature and cannot be found in the key, it he looked for in the index. In this way most of the names will be found. Nevertheless, there will be confusion becanse most of the older anthors had little coneeption of the position of the species described and many very different forms have been placed in the same genus. Things are not quite as hopeless as they may seem, but the beginner will find himself badly handicapped, at least until a catalogne is published.

A preliminary key has been prepared in order to obviate the necessity of going through the entire key and turning many pages before arriving at suitable couplet. Any figures on the right of the page of the abbreviated key refer to a couplet in the key proper and the search for the genus should be taken up from that point.

\section{SYNOPTIC TABLE OF KEY GROUPS}

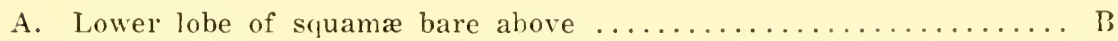

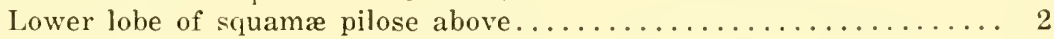

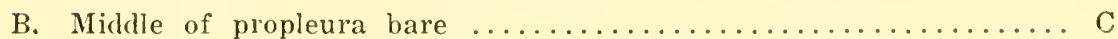

Middle of propleura with pile or hair................. 4

C. Infrasquamal setulæ absent; abdomen with bristles.......... E Infrasquamal setulæ present or the abdomen without dorsal bristles.. D

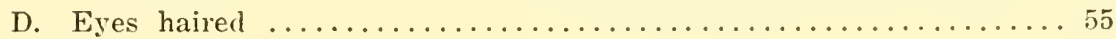

Eyes bare or almost so.............................. 84 
E. Eyes bare or with inconspicuous short hair................ ;

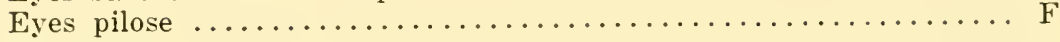

F. Parafacials with hairs or bristles extending to the lower half......161 Parafacials bare at least on the lower half ....................

G. Parafacials with hairs or bristles.......................... Parafacials bare on at least the lower half ............... H

H. Thorax without plumose hairs $\ldots \ldots \ldots \ldots \ldots \ldots \ldots \ldots \ldots \ldots$ I

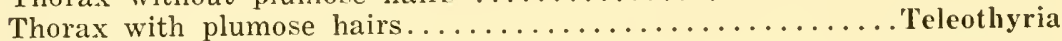

I. Facial ridges bristled on less than the lower half............. J Facial ridges with strong bristles on lower half or more..........293

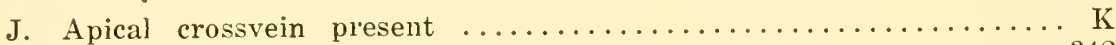

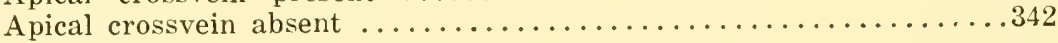

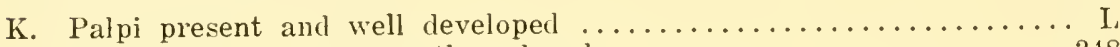
Palpi absent or very greatly reduced........................ 348

L. Apical cell at most with an extremely short petiole............ M

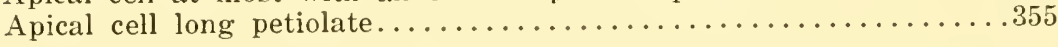

M. Ultimate section of fifth vein less than half as long as the preceding

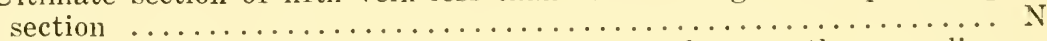
Ultimate section of fifth vein three-fourths as long as the preceding

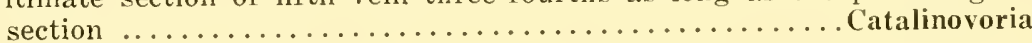

N. Penultimate aristal segment not over twice as long as wide....... 0 Penultimate aristal segment three times as long as wide..........361

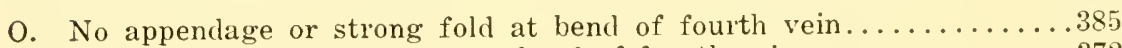
A strong appendage or fold at bend of fourth vein............ 372

\section{KEY TO GENERA}

1. Lower lobe of squamze bare or pubescent above............. 3 Lower lobe of squamæ with long, fine hairs above............ 2

2. Parafacials haired to below the midlle (113).... Bombyliopsis Townsend Parafacials with but a few hairs below the frontals (91).

Hystricia Macquart

3. Midldle of propleura bare.......................... 58

Middle of propleura with pile or hair................. 4

4. Eyes thickly hairy, the heal almost as long below as at base of

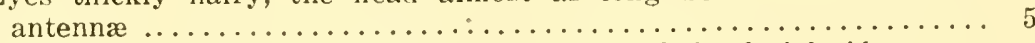

Eyes bare, or, if pilose, the face retreating and the facial ridges usually bristled on the lower half ...................... 8

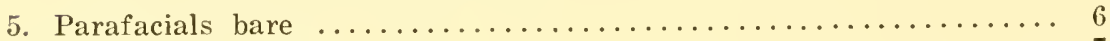

Parafacials haired on lower half $\ldots \ldots \ldots \ldots \ldots \ldots \ldots \ldots \ldots \ldots \ldots$

6. Facial ridges bristled on lowest three-fourths; first vein setulose.

Facial ridges and first vein bare $(100)$.

Hypochæta Brauer \& Bergenstamm Pseudohystricia Brauer \& Bergenstamm 
7. Palpi well dereloped.............Arthrochata Brauer \& Bergenstamm Palpi absent or extremely small; large, robust species.

Tachinomima Brauer \& Bergenstamm

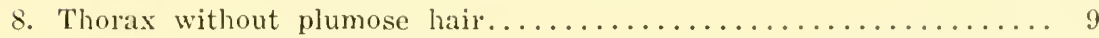

Thorax, at least on the pleura, clothed with plumose hairs (Genotype:

Ptilomyia bequarti Curran)............... Ptilomyioides, n. g.

9. Palpi present, strongly developed, at least as long as the second an-

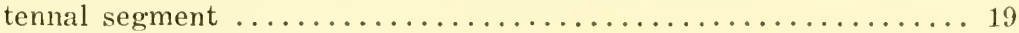

Palpi absent or very small......................... 10

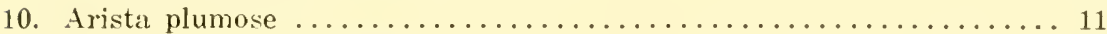

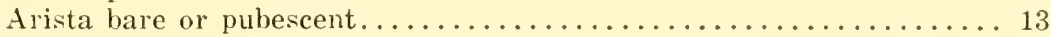

11. Posterior tibiæ rather closely ciliate.......... Opsotheresia Townsend

Posterior tibiæ not ciliate.......................... 12

12. Palpi absent ........................ Atelogossa Coquillett

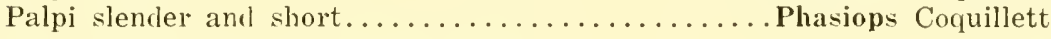

13. Parafacials with hairs or bristles....................... 14 Parafacials bare; ocellars strong (54)....... Cylindromyia Meigen

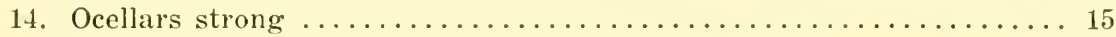

Ocellars weak or absent; parafacials without bristles........... 18

15. Parafacials with strong bristles below; apical cell petiolate.

Antillicolla Curran

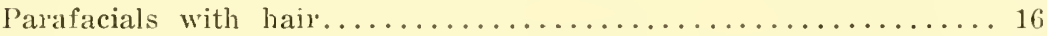

16. Apical cell ending very close to wing-tip; hearl short.

Phosocephala Townsend

Apical cell ending far before the wing-tip; head long........... 17

17. Abclomen with ordinary bristles below, rounded apically.

Gymnomma Brauer \& Bergenstamm Abdomen with spines ventraliy, emarginate apically.Juriniopsis Townsend

18. With ordinary bristles on the abdomen............ Epalpus Rondani With blunt spinose bristles on the lorsum of the abdomen.

Rhachoëpalpus Townsend

19. Parafacials hairy or bristly to well below the midclle........... 20 Parafacials with at most a few hairs below the lowest frontals...... 33

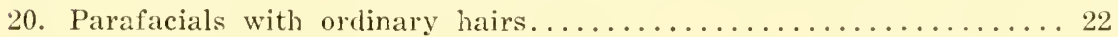

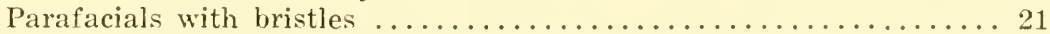

21. Apical cell open $(73,74) \ldots \ldots \ldots \ldots \ldots \ldots \ldots$ Goniochata Townsend

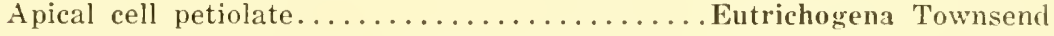

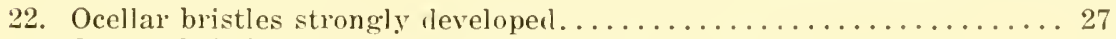

Ocellar bristles extremely weak or absent.............. 23

23. Palpi but little longer than the length of the oral opening, enlarged

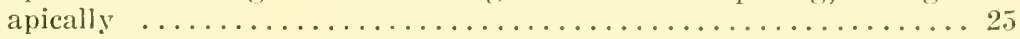

Palpi very much longer than the length of the oral opening, with parallel sides or somewhat narrowerl apically.............. 24

* Curran, 1930, Bull. Amer. Mus. Nat. Hist., lxi, p. 92.

$\dagger$ Aldrich, 1926, Pr. U. S. N. M., lxviii, Art. 23, np. $1=27$. 


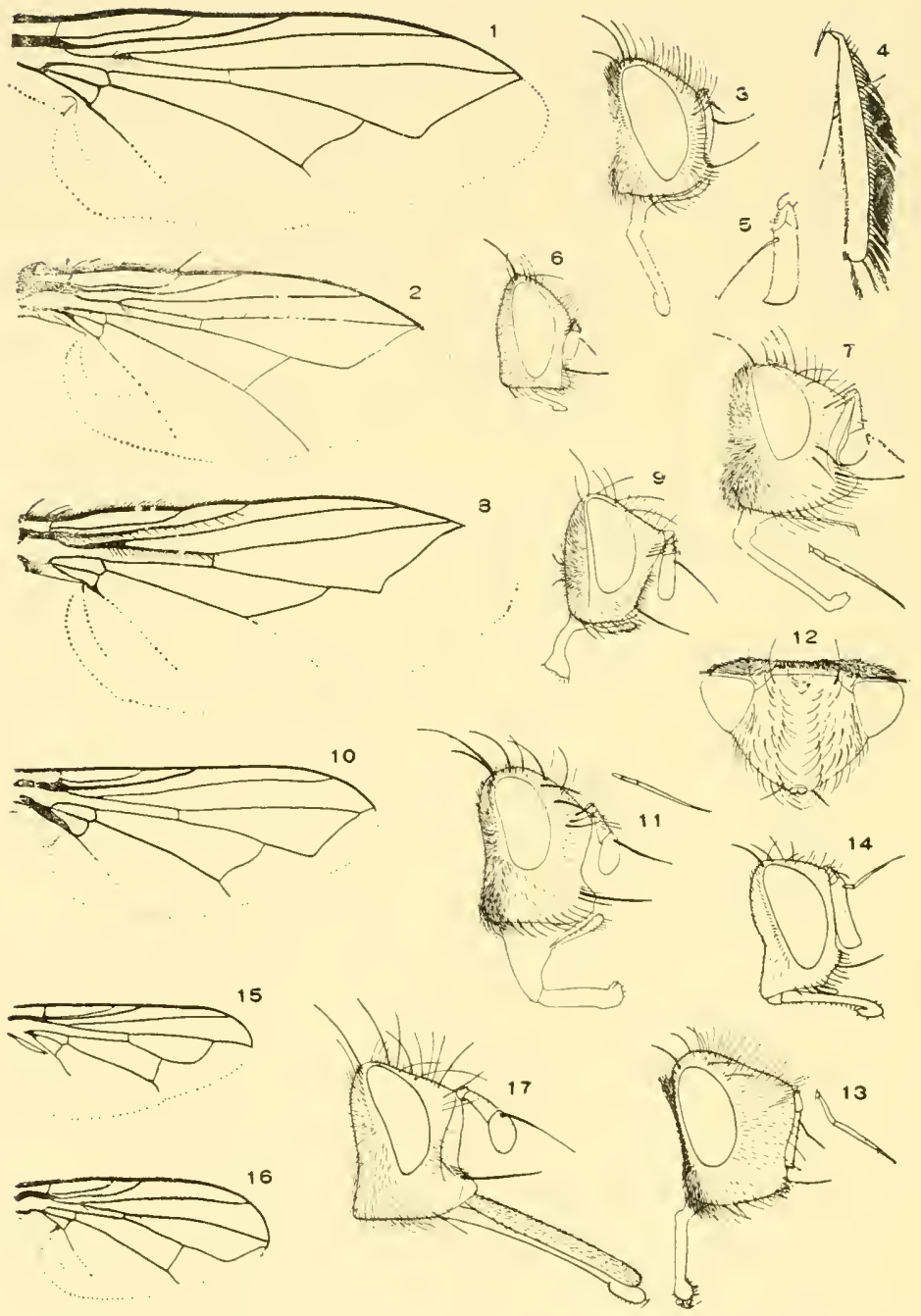

Tachinide I.-1, Lydella; 2, Aphria occidentalis; 3, Spallanzania hebes; 4, Leschenaultia adusta; 5, Acemya dentata, antenna; 6. Atacta; 7. Peleteria; 8, Voria ruralis; 9, Tachinomyia robusta; 10, Cistogaster; 11, Archytas; 12, 13, Gonia, head, dor'sal and lateral views; 14. Epigrimyia?; 15 , Alophora; 16 , Plectops; 17 , Dejeania vexatrix. 


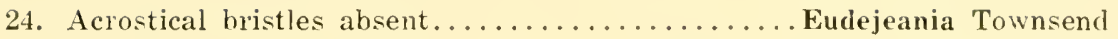
Acrostical bristles present (17) ........ Dejeania Brauer \& Bergenstamm

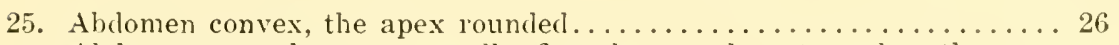

Abclomen very large, unusually flat above, sub-rectangular, the apex strongly emarginate $(60)$....... Paradejeania Brauer \& Bergenstamn

26. Second abdominal segment with at most four median marginals, if with discals they are arranged in pairs $(11,102) \ldots$ *Archytas Jænnicke

Second abdominal segment with many marginals, numerous discals or

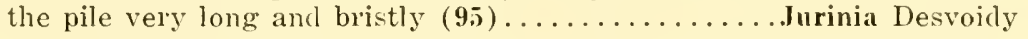

27. Ultimate section of fifth vein two-thirds as long as preceling section.

Netaplagia Coquillett

Ultimate section of fifth vein not one-third as long as preceding sec-

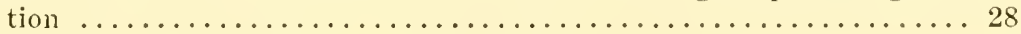

28. Abdomen without discals, or they are fine and hair-like......... 29 Second and third abdominal segments with strong discals.

Protodejeania Townsend

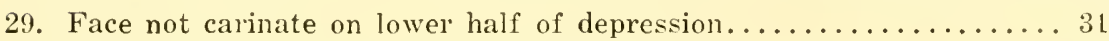

Face carinate on whole length of depression............... 30

30. Hair of parafacials inconspicuous.... Myiomima Brauer \& Bergenstamm

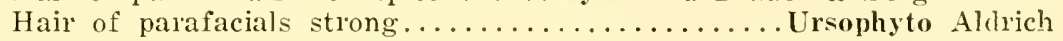

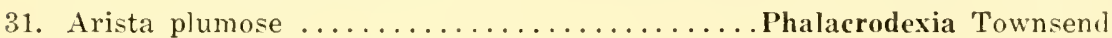
Arista bare or pubescent........................

32. Posterior sublateral bristle present.

$\dagger$ Cnephaliodes Brauer \& Bergenstamm Posterior sublateral bristle absent; proboscis long, the labellæ small.

Phytopsis Townsend

33. Frontal bristles not or scarcely extending below the base of the antennæ; arista strongly pubescent or plumose.............. 38 Frontal bristles usually extending to the base of the third antennal segment; arista not conspicuously pubescent.............. 34

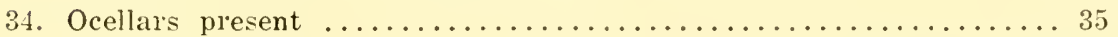

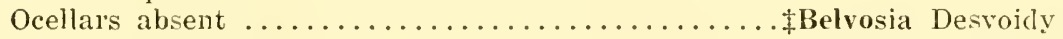

35. Facial ridges with strong bristles on at least the lower half....... 37 Facial ridges with only a few hairs above the vibrissa......... 36

36. Eyes pilose (Zenillia submissa A. \& W.)............. Collatia, n..

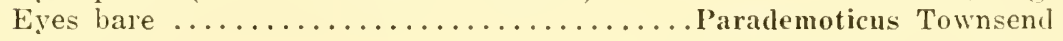

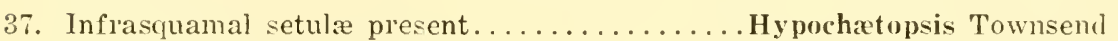
Infrasquamal setulæ absent....................

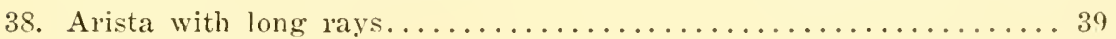

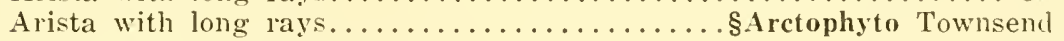

39. Infrasquamal setulæ absent ..................... 40 Infrasquamal setulæ present (Metopiidæe........ Opsodexia Townsend

\footnotetext{
* Curran, 1928, Can. Ent., lx, p. 202.

$\dagger$ Rowe, 1931. Ann. Ent. Soc. Amer., xxiv, D. 647 (Fabriciella).

\$ Aldrich, 1928, Pr. U. S. N. M., Ixxiii, Art. S, pl). 1-45.

\& Curran, 1924, Can. Ent., Ivi, 1. 302.
} 

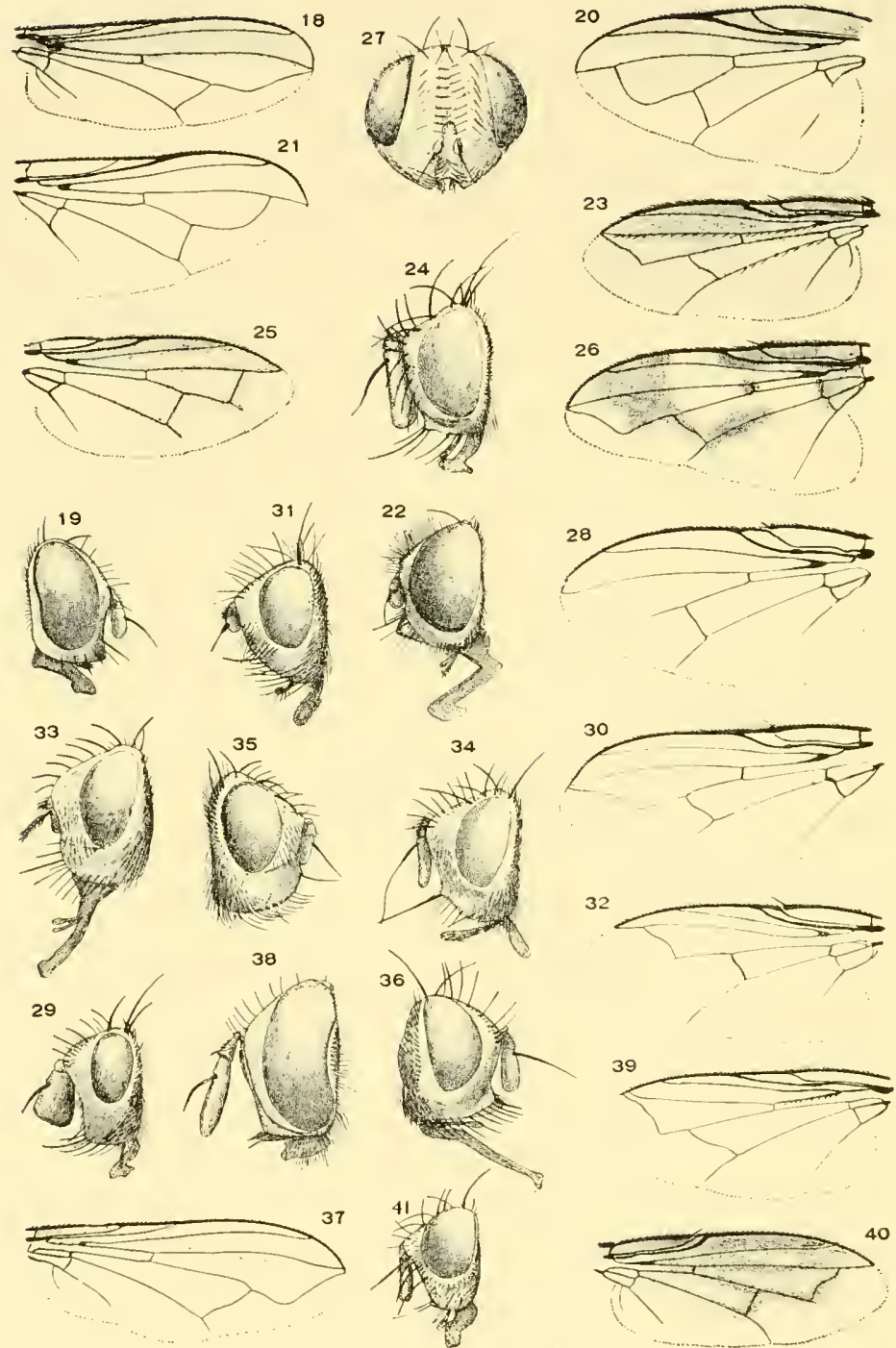

Tachinide II.- 18, 19, dcaulona costata; 20. Alophora fumosa; 21, 22, Alophora; 23, 24, Ceratomyiella; 25, Euscopolia dakotensis; 26, 27, Estrophasia calva; 28, 29, Euryceromyia robertsoni, bristles omitted from third vein of wing; 30,31 , Neophyto setosa (Metopiidæ): 32. 33, Rhinophora mexicana; 34, Cryptomeigenia; 35 . Myiophasia; 36 , Binghamimyia; 37,38 , Heinyda aurata; 39 , Cuphocera; 40, 41, Wagneria, bristles omitted from veins. 
40. Second abdominal segment with dorsal bristles............ 46

Second abdominal segment without dorsal bristles............. 41

41. Sides of face diverging below; cheeks wider than length of third an-

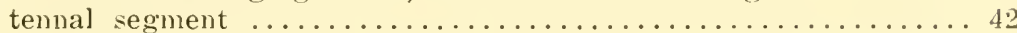

Sides of face slightly converging below; cheeks about as wide as width of third antennal segment.............. Xanthodexia Wulp

42. Face strongly calinate......................... 44

Face at most weakly carinate........................ 43

43. Proboscis decidedly longer than the head-height... Prosenoides Townsend Proboscis shorter than the head-height $(118,122) \ldots . .$. Billaa Desvoidy

44. Antennæ not nearly reaching the vibrissæ................ 45 Antennæe reaching almost to the vibrissæ........Theresiopsis Townsend

45. Facial carina not convex in profile...................... 4 S Facial carina convex in profile.............. Opsotheresia Townsend

46. Facial carina strong and prominent................... 51

Facial calina weak, obsolete or nearly so.............. 47

47. Apical cell ending in or near the wing-tip.

Stomatodexia Brauer \& Bergenstamm Apical cell encling far before the wing-tip.................... 48

48. Antennæ reaching about half way to the oral margin.

Phalacrophyto Townsen:l Antennæ reaching more than half way to the oral margin.......... 49

49. Abdomen broally oval; larger, more or less castaneous species.

Theresia Desvoidy Abromen narrower; smaller, non-castaneous................ 50

50. Second abdominal segment without strong marginals.

Paratheresia Townsent
Second abdominal segment with a pair of strong marginals.

*Eutheresia Townsend

51. Second abdominal segment with only one pair of marginals, or they

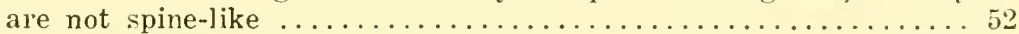

Second abdominal segment with three or more pairs of marginal spines; large, robust species....... Chatogyne Brauer \& Bergenstamm

52. Claws short and thick basally, bent at almost a right angle at their middle; parafacials with inconspicuous hairs.

Myiomima Brauer \& Bergenstamm Claws normal, moderately curved apically $(118,122)$... Billaxa Desvoidy

53. Infrasquamal setulæ absent, abılomen always with bristles, at least

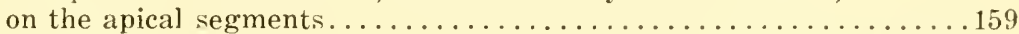

Infrasquamal setulæ present or the abclomen without well-developed

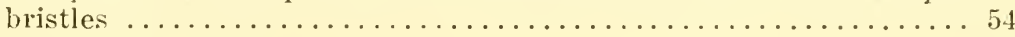

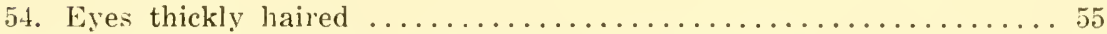

Eyes bare or with inconspicuous, short, sparse hair........... 84

55. Parafacials with hairs or bristles on at least the upper half...... 56

Parafacials bare or with only a few hairs below the frontals....... 65

* Curran, 1929, Can. Ent., 1xi, 1) 33. 


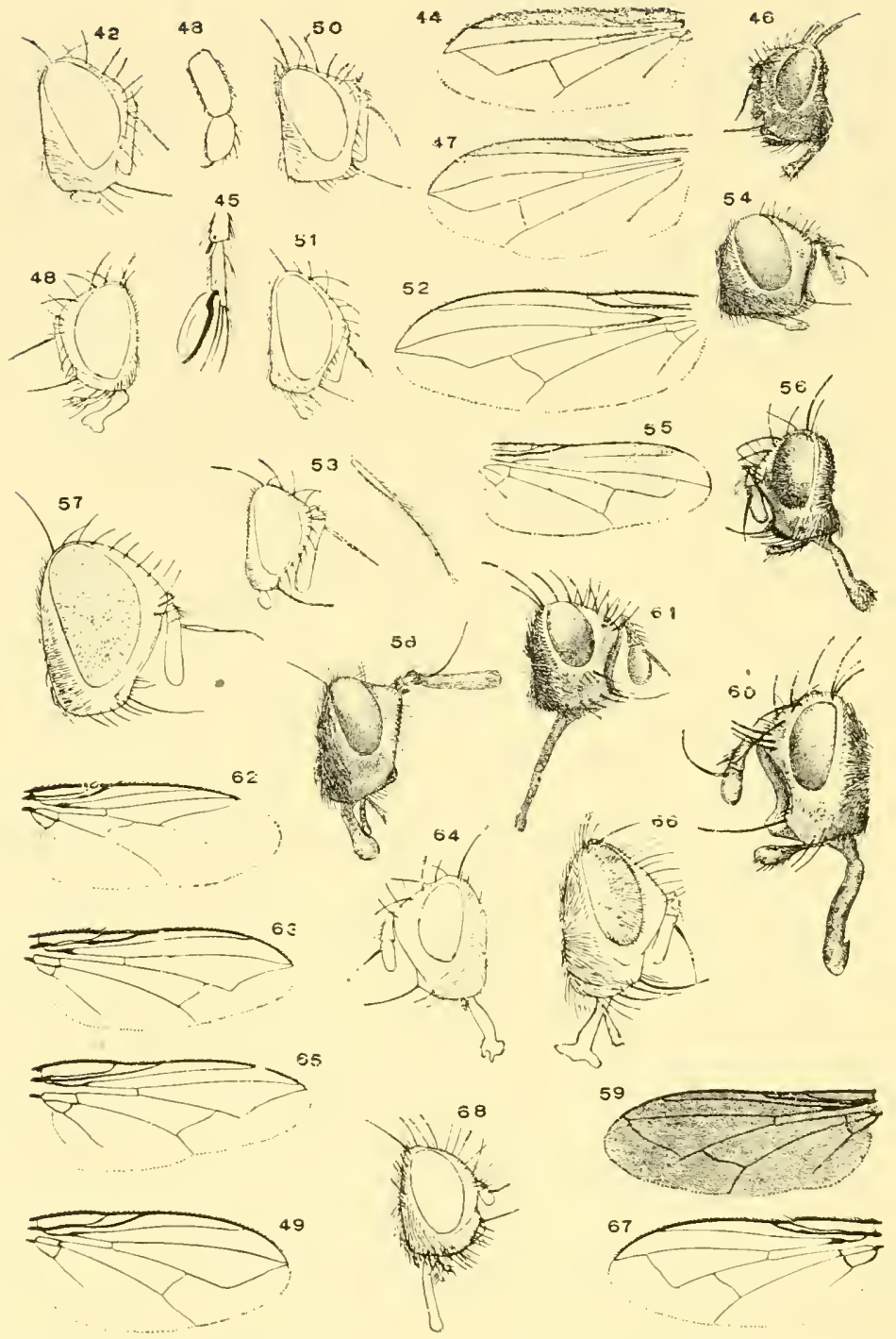

Tachinidæ III. - 42, Paradidyna braueri; 43, Paradidyma, anex of front tarsus of $q: 44$. Vanderwulpia townsendi; 45, Paradidyma braueri, front tarsus of male; 46, Spallanzania; 47, Beskia cornuta; 45, 49, Spathidexia dunningi; 50, 51, Genera incert. : 52, Paradidyma braueri; 53, Vanderwulpia townsendi; 54, Cylindromyia; 55, Catharosia nebulosa; 56, Gymnochxta; 57, Zenillia 58, 59. Penthosia satanica; 60, Paradejeania; 61, Cuphocera; 62, Taxigramina (Metopiidæ): 63, 64, Icelia triquetra; 65, 66, Uramya halesidotæ; 67, 63, Leucostoma. 
56. Ultimate section of fifth vein not over one-third as long as the preceding section, or the parafacials without bristles........... 5 s

Ultimate section of fifth vein at least half as long as the preceling section; parafacials with one or more proclinate bristles........ 57

57. Inner end of posterior crossvein lying immediately behind the an-

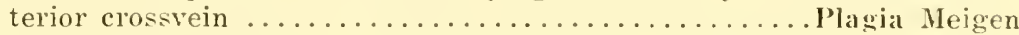
Discal crossvein lying well beyond the anterior crossvein.

Cyrtophlebal Ronclani

58. Fourth vein angulate or with sharp curve; abdomen with strong bristles ............................... 59

Fourth vein approaching the third in a gentle curve; abdomen with only weak bristles apically...... Gymnophania Brauer \& Bergenstamm

59. Parafacials without bristles along their inner edges, sometimes with bristly hairs along their middle....................61 61

Parafacials with a row of bristles along their inner edges......... 60

60. Basal two aristal segments short; antennæ simple in both sexes.....60a Basal aristal segments very elongate; third antennal segment of male

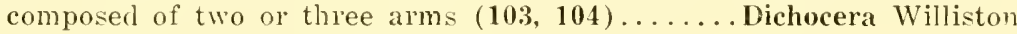

60a. Third antennal segment but little longer than the second.

Muscopteryx Townsend

Third antennal segment several times as long as the second $(42,43$, 45, 52,96)...............Paradidyma Brauer \& Bergenstamm

61. Parafacials without strikingly long hair, or it is irregularly spaced....62 Parafacials with the hairs arranged in a median series and increasingly long and strong below..............Enlasiona Townsenıl

62. Bend of fourth vein with at most a distinct fold..............63 Bend of fourth vein with a long appendage.

Metopomuscopteryx Townseni

63. Three pairs of presutural acrostical bristles or three presutural dor-

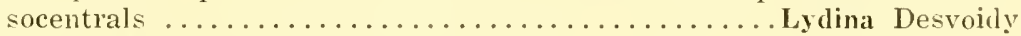
At most two pairs of presutural acrostical bristles............64

64. Two pairs of presutural acrosticals and dorsocentrals $(35,139)$.

\section{Myiophasia Brauer \& Bergenstamm}

A single pair of presutural acrosticals and two pairs of dorsocentrals.

Townsendina, n. g.

65. Facial ridges without strong bristles.................... 69

Facial ridges with strong bristles on lower half or more......... fif

66. Parafacials not wider than antennæ...................67

Parafacials much wider than antennæ; oral margin scarcely produced.

Myiopharus Brauer \& Bergenstamm

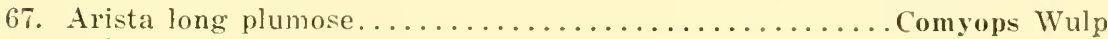
Arista at most very short plumose................... 68

68. Ocellars strong; face not strongly retreating below; female piercer as long as the abdomen.................. Spathimyia Townsend Ocellars absent or hairlike; face strongly retreating.

Paralispe Brauer \& Bergenstamm

* Curran, 1927, Bull. Brooklyn Ent. Soc., xxii, p. 149. 

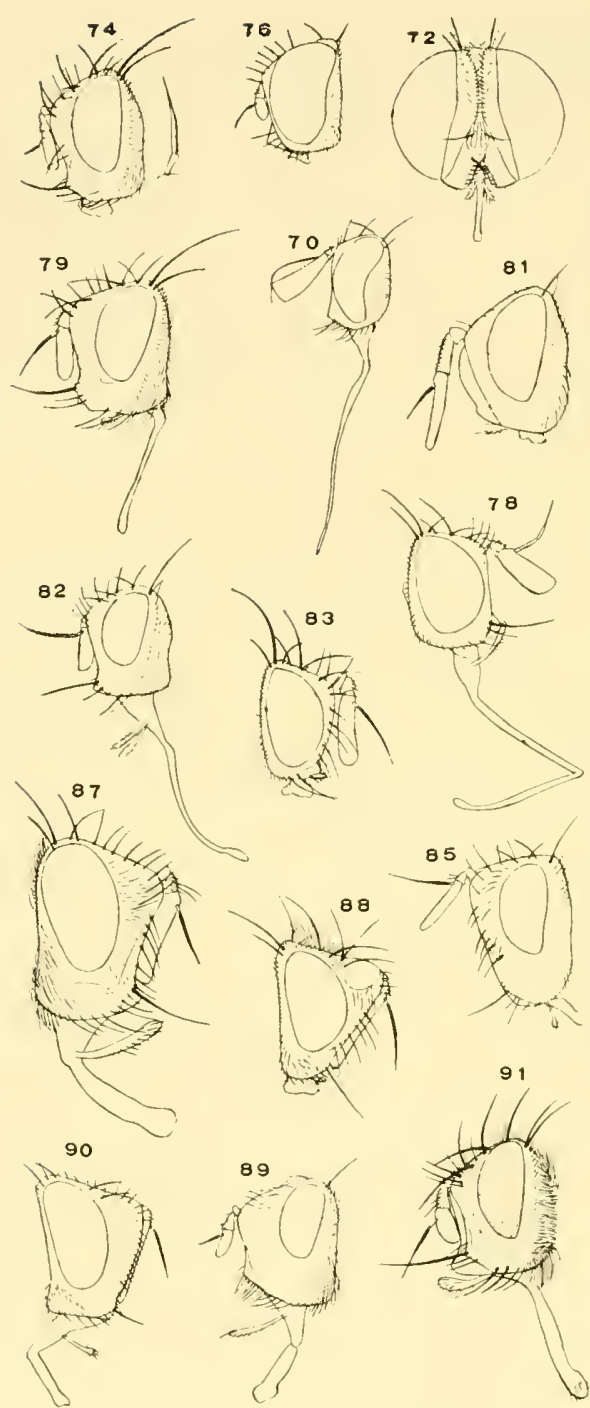

69
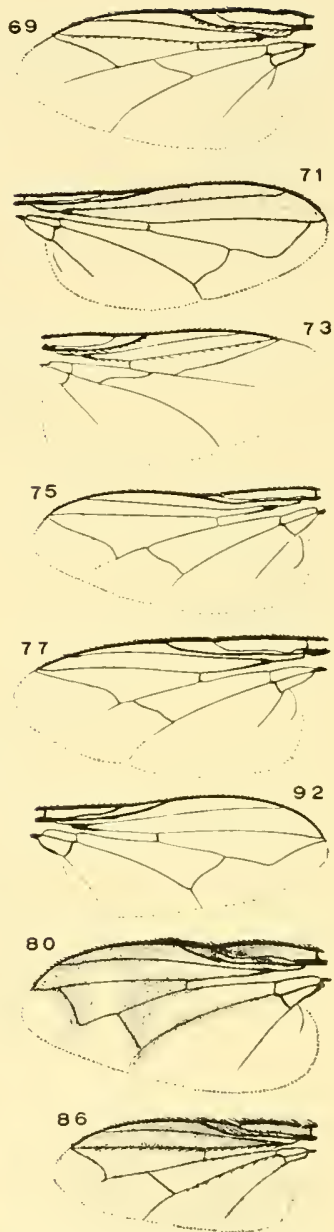

84

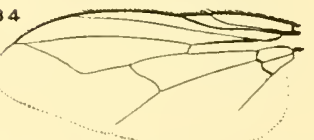

Tachinidx IV. - 69, Plagiomima anomala; 70, Beskia cornuta; 71 , Xanthomelana arcuata; 72, Pachyophthalmus floridensis (Metopiidx); 73, 74, Goniochata plagioides; 75, Pachyophthalun floridensis (Metopiidæ): 76, Xanthomelana arcuata; 77, Linnæmya; 78, Siphona; 79. Plagionima anomala; 80,81 , Euthera tentatrix; 82 , Epigrimyia; 83 , Chætoplagia; 84. 85. Euthyprosopa petiolata; 86. Chætoplagia; 87, Chætogædia analis; 88, Metopia (Metopiidæ) ; 89, Melanophrys insolita; 90, Opsidia gonioides (Mefopiidæ); 91, Hystricia; 92. Chryseria flava. 
69. Not metallic green or blue........................ 70

Metallic green or blue......... Chrysotachina Brauer \& Bergenstamm

70. Parafrontals pollinose, at most bare at the vertex........... 71 Parafrontals shining black ...................................

71. Oral margin not strongly oblique in front nor carried strongly upward toward the base of the antennæ; antennæ situated at or above the middle of the eyes; oral margin produced or not.......... 72

Oral margin and antennal base unusually approximated, the oral margin strongly oblique in front; antennæ situated below the middle of the eyes; parafacials always with many hairs below the frontals.

Lydina Desvoidy

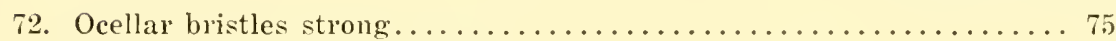

Ocellars absent or very weak................................ 73

73. Antennæ inserted at upper fourth of eyes; bend of fourth vein with stump $(141,167) \ldots \ldots \ldots \ldots \ldots \ldots \ldots \ldots \ldots$ Xanthophyto Townsend Antennæe inserted at middle of eyes; bend of fourth vein without

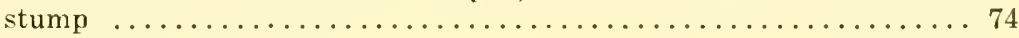

74. Arista plumose $(188,195) \ldots \ldots \ldots \ldots \ldots \ldots \ldots$ Zonalia, $n$. g. Arista short pubescent or bare $(116,161,166,187) \ldots$. Corozalia, n. g.

75. Head almost as long below as at the antennæ, the oral margin produced; vibrissæ usually situated above oral margin.......... 77

Face retreating below; vibrissæ level with oral margin......... 76

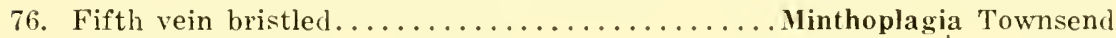

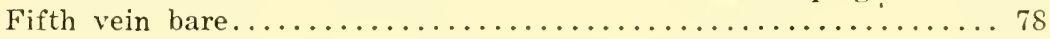

77. Palpi of normal length, more or less swollen apically.......... 78 Palpi not more than half the usual length, never widlened apically; fourth vein with long appendage at bend (77)....Linnæmya Desvoidy

78. Pteropleural bristle extending to the apex of the squamæ......... 81 Pteropleural bristle rormal........................... 79

79. Face about as long below as at the antennæ............... 80

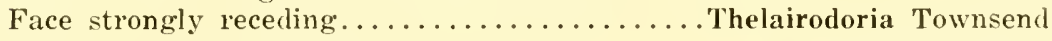

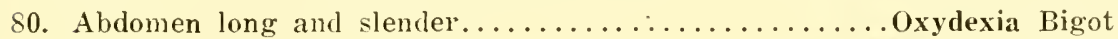

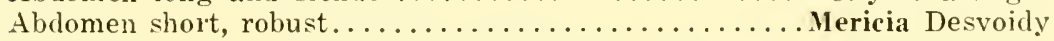

81. Posterior pair of presutural acrosticals situated very close to the

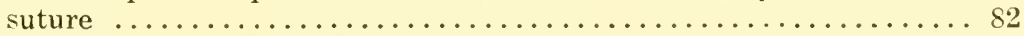

Posterior pair of presutural acrosticals situated far before the suture; female ocellars reclinate; male with outer verticals.

Trafoia Brauer \& Bergenstam

82. Pleura with fine, pale pile below; third antennal segment rounded

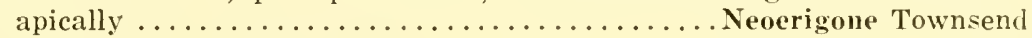

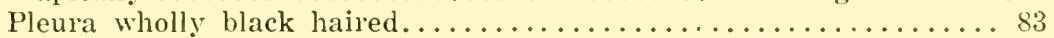

83. Front tarsi of female broadened; third antennal segment rectangular at upper apex (142) (Exoristoides Coquillett, Exoristopsis Town-

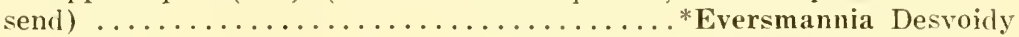
Third antennal segment rounded at upper apex......... Mericina Curran

* The genera Neoerigone, Eversmannia and Mericina are so noorly distinguished that I think they should be united. For key to species see Aldrich, Proc. U. S. N. M., lxxi, Art.9. p. 24 (Exoristoides). 


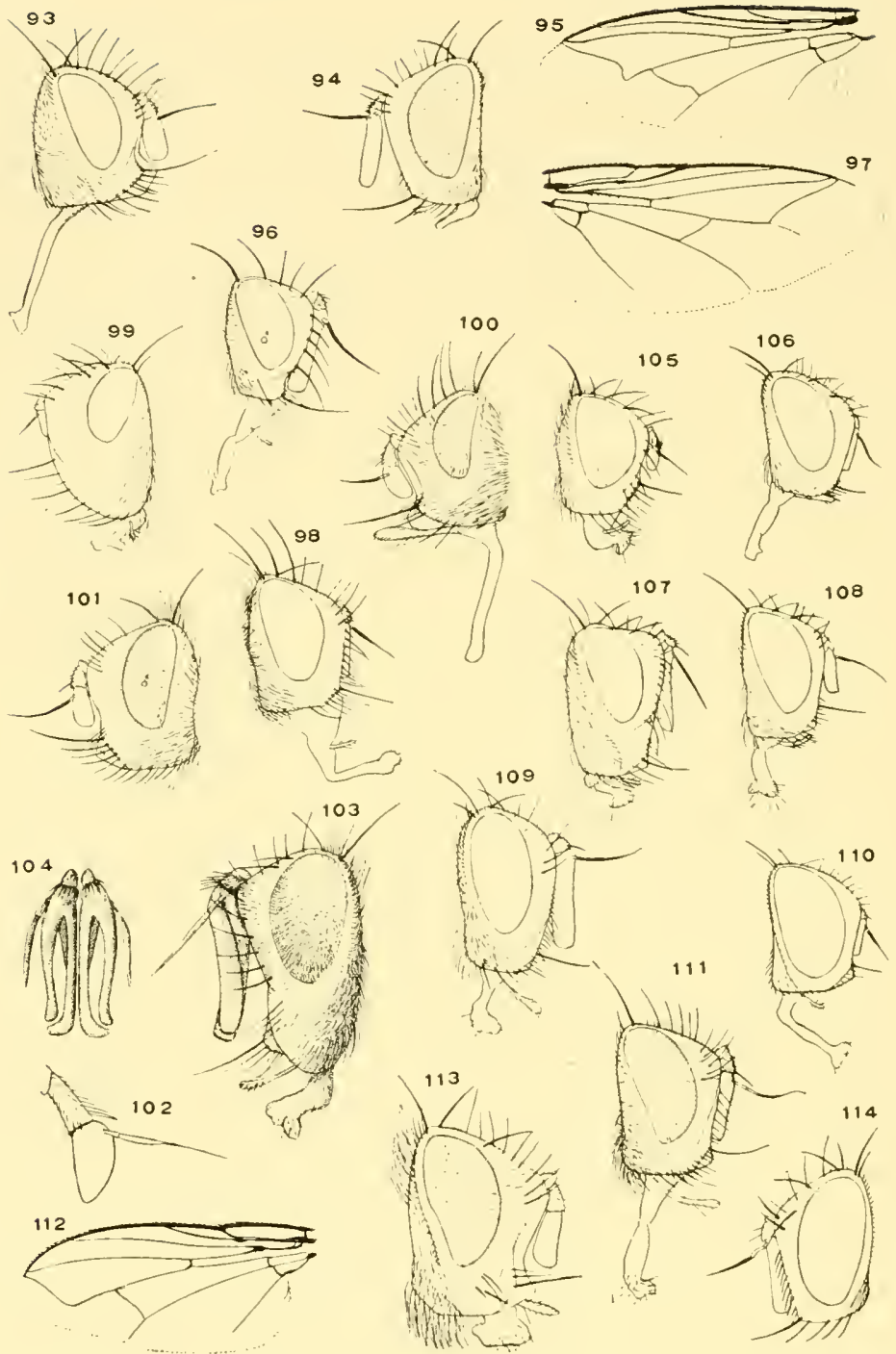

Tachinidæ V.-93. Fischeria flava; 34. Zenillia; 95, Jurinia; 96, Paradidyma singularis: 97. 98, Stomatomya parvipalpis; 99, Microphthalma disjuncta; 100, Pseudohystricia; 101, Microtrichoma?; 102, A rchytas californica; 103, Dichocera lyrata; 104, Dichocera lyrata, antenna: 105, Muscopteryx; 106, Hilarella (Metopidex); 107, Neotractocera; 108, Viviania ; 109. Achætoneura; 110, Senotainia (Metopiidæ); 111. Gadiopsis; 112, Genea analis; 113, Bombyliopsis; 114, Chætoglossa, proboscis omitted. 


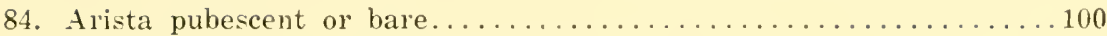

Arista at least short plumose on basal half............... 85

85. Oral margin distinctly produced...................... 96 Oral margin scarcely prominent, the face almost vertical......... $\$ 6$

86. Width of clypeus much greater than wirlth of third antennal segment. 87 Width of clypeus not greater than width of third antennal segment.

llacrometopa Brauer \& Bergenstamm

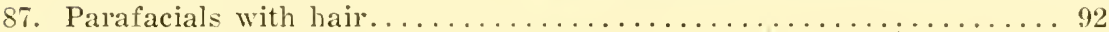

Parafacials bare ............................. 88

88. Ocellars long and strong......................... 91

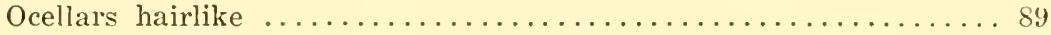

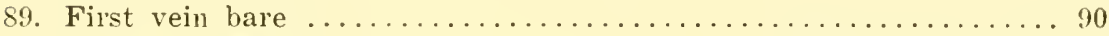

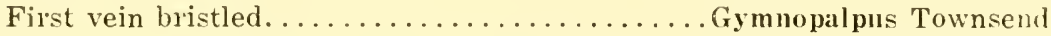

90. Arista short plumose on whole length; no discals on intermediate segments; first segment without marginals..... Pseudochætona Townsend

Arista short plumose on basal half only; abdomen with discals, the first segment with marginals $(186,190) \ldots \ldots \ldots \ldots$ Chætonalia, n. g.

91. Aristal rays as long as the width of the third antennal segment.

Alistal rays about half abenia Macquart

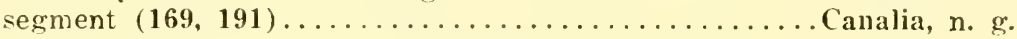

92. Antennæ reaching more than half way to the oral margin........ 93 Antennæ reaching only half way to oral margin; prosternum with a

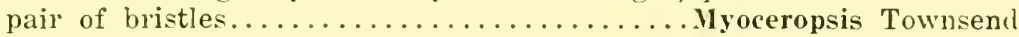

93. Hair of parafacials coarse...................... 94 Hair of parafacials very fine; first vein bare $(121,131)$. Cholomyia Bigot

94. Apical cell ending near the wing-tip...................... 95 Apical cell ending far before the wing-tip........... Microchatina Wulp

95. First vein setose $(154,180) \ldots \ldots \ldots \ldots \ldots \ldots \ldots \ldots$ Schwarzalia, 11. g.

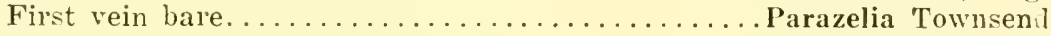

96. Proboscis, measured from base of apical section, at most slightly longer than length of oral opening...................... 97 Proboscis twice as long as length of oral opening.

Mochlosoma Brauer \& Bergenstamm

97. Apical cell closed and short petiolate....................... 98 Apical cell broadly open (Clinoneura, B.B.; Paramyocera Towns.)

$(119,124,125,133) \ldots \ldots \ldots \ldots \ldots \ldots \ldots \ldots \ldots \ldots \ldots \ldots$ Rhynchiodexia Bigot

98. Third vein setose less than half way to the anterior crossvein....... 99 Third vein setose to the anterior crossvein............. Megerlea Desvoidy

99. Bend of fourth vein with long appendage......... Hypenomyia Townsend Bend of fourth vein with at most a very short appendage.

Dinera Desvoidy

100. Face without a very prominent carina appearing above the antennæ

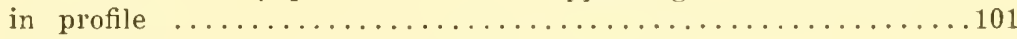

* Curran, 1930, Bull. Amer. Mus. Nat. Hist., 1xi, 1. 93. 


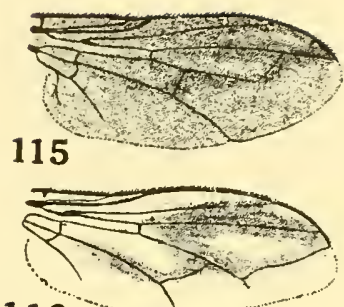

116

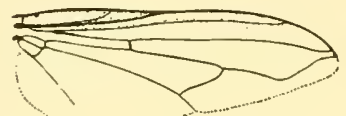

\section{7}

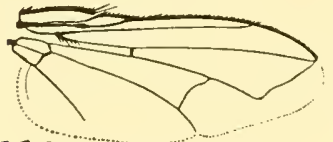

\section{8}

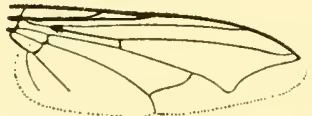

119
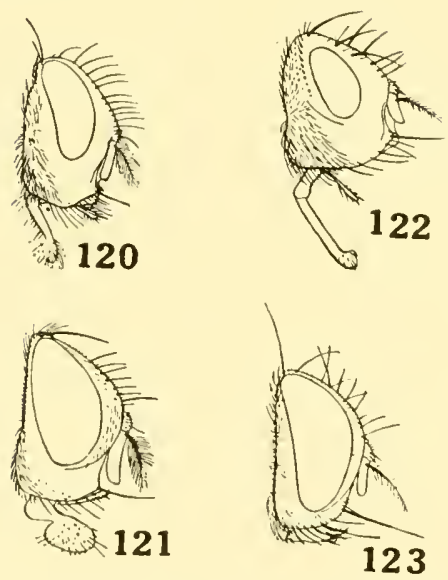
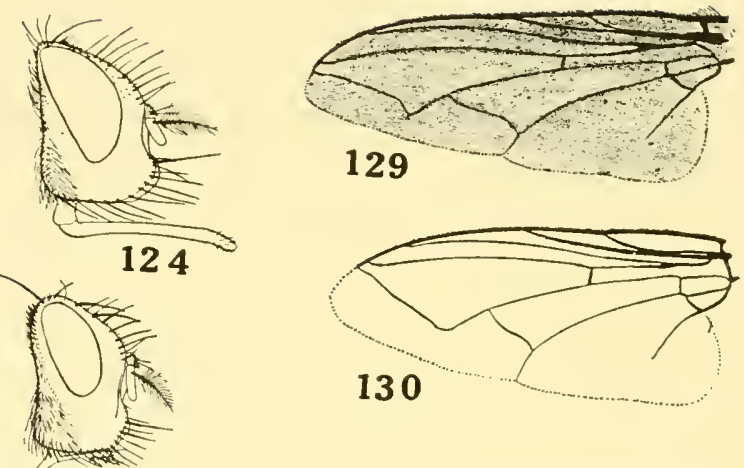

125

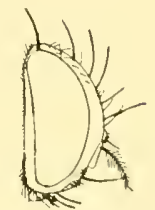

126

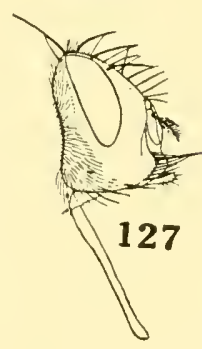

132
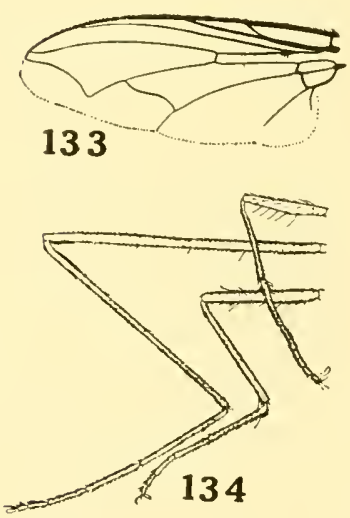

Tachinidæ VI.-115, Melanophora; 116, Sophia; 117, Calodexia; 118, Billæa; 119, Rhynchiodexia; 120, Scotiptera; 121, Cholomyia; 122, Billae; 123, Thelaira; 124, 125, Rhynthiodexia; 126, Calodexia; 127, Hystrichodexia; 128, Zelia; 129. Scotiptera melaleuca; 130. Hystrichodexia; 131, Zelia; 132, Chætona; 133, Rhynchiodexia; 134, Cholomyia, legs. 
Face short, with a strong facial carina, the antennal grooves deep; proboscis one-half longer than the head-height; abdomen without bristles, the apical segments with longish hairs; female genitalia with stout spines on the sides.............. Initomyia Townsend

101. Second abdominal segment with at least well developed median mar-

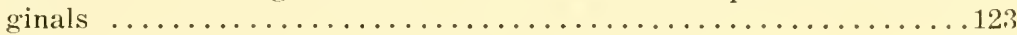

Second abdominal segment without dorsal bristles.............102

102. Posterior tibiæ without flattened bristles.................. 103 Posterior tibia ciliate dorsally with scale-like bristles $(163,161)$.

Trichiopoda Latreille

103. Facial depression shallow or somewhat carinate, if deep not sub-oval in outline; arista, if wholly thickened, reddish in color.........104

Facial depression very deep and sub-oval; arista black, wholly thickened; shining black flies $(89) \ldots \ldots \ldots \ldots$. Melanophrys Williston

104. Arista not wholly thickened; parafacials without transverse furrows. .105 Arista wholly thickened; parafacials shining black, with many trans-

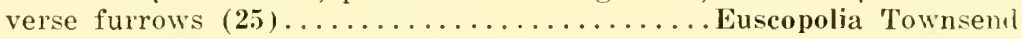

105. Fourth vein strongly curved beyond the crossvein............. Fourth vein gently curved, the apical cell open in the wing-tip.

Gymophania Brauer \& Bergenstamm

106. Face not or but little retreating, the vibrissæe situated well above the

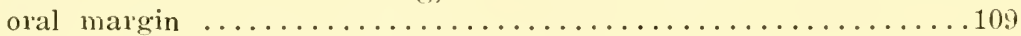

Face strongly retreating, oral vibrissæ strongly differentiated and on a level with the oral margin, or absent....................

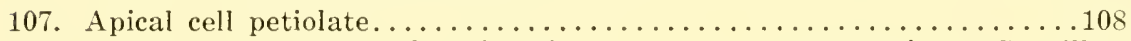
Apical cell open near the wing-tip............Pseudapinops Coquillett

108. Apical cell ending well before the wing-tip...**Hesperophasia Townsend Apical cell ending in the wing-tip (5.5) ............. Catharosia Rondani

109. Oral vibrissæ, if strongly differentiated, situated almost level with the oral margin; abdomen short, oval, spherical or flattened, rarely

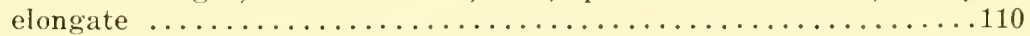

Oral vibrissæ strongly developed, sometimes duplicated, situated well above the oral margin and without hairs above or below; abdomen long and narrow $(71,76) \ldots \ldots \ldots \ldots \ldots \ldots$ Xanthomelana Wulp

110. Abdomen short, or if elongate not flattened.................11 Abrlomen elongate and flattened; oral margin produced; apical cell petiolate; wing veins broadly bordered with black.

Bibiomima Brauer \& Bergenstamm

111. Sternites broad, the female genitalia not remarkably large; oral vibrissæ usually strongly differentiated, their angle high above the oral margin; abdomen short, rather spherical in outline, strongly

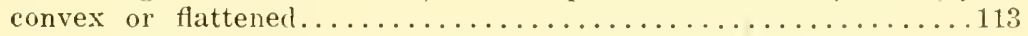

Sternites linear, thread-like; second sternite large, produced downward and with very short, stout setulæ on the lower part; female genitalia very large; vibrissæ distinct, situated but little above the

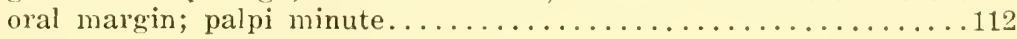



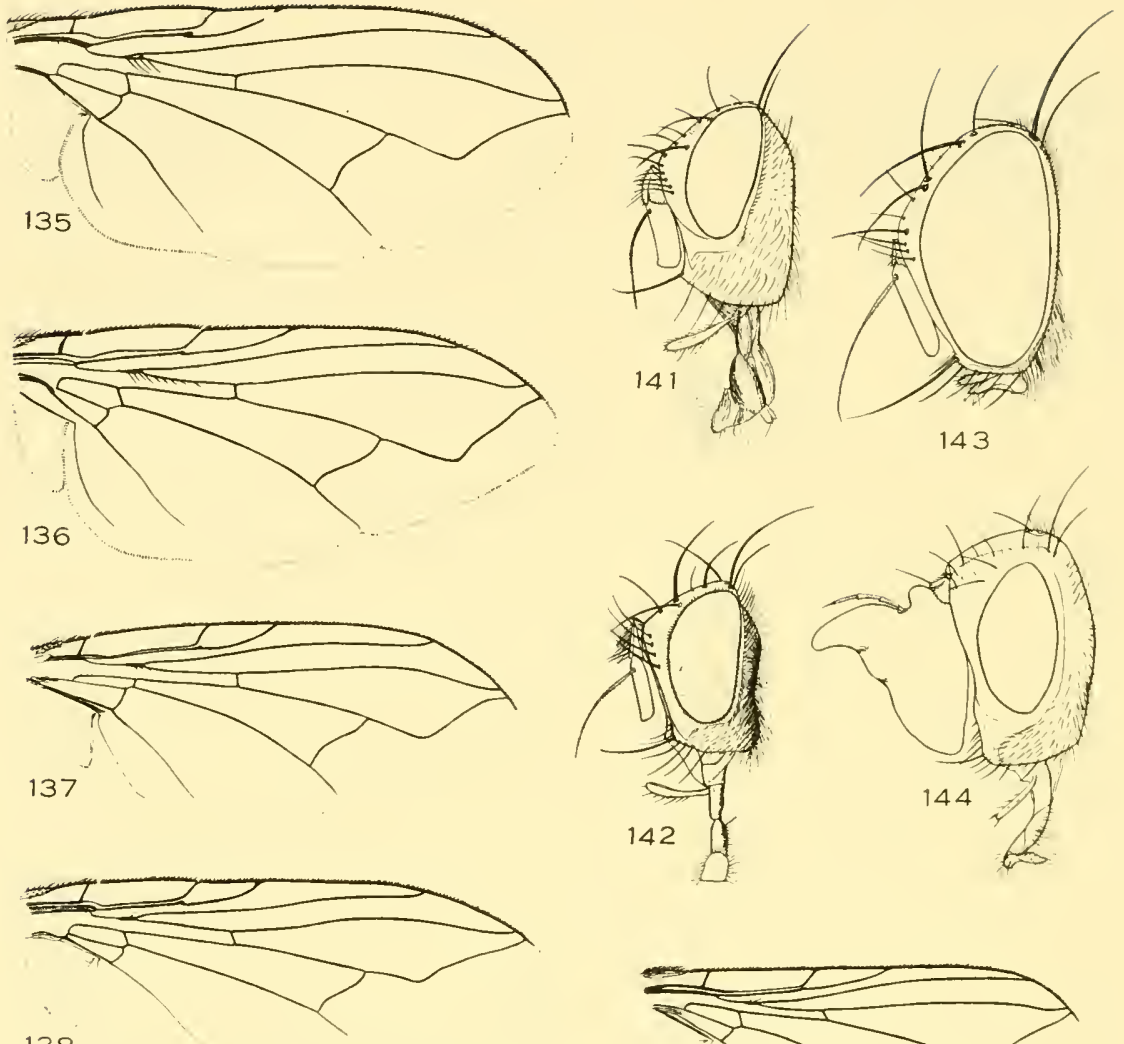

138
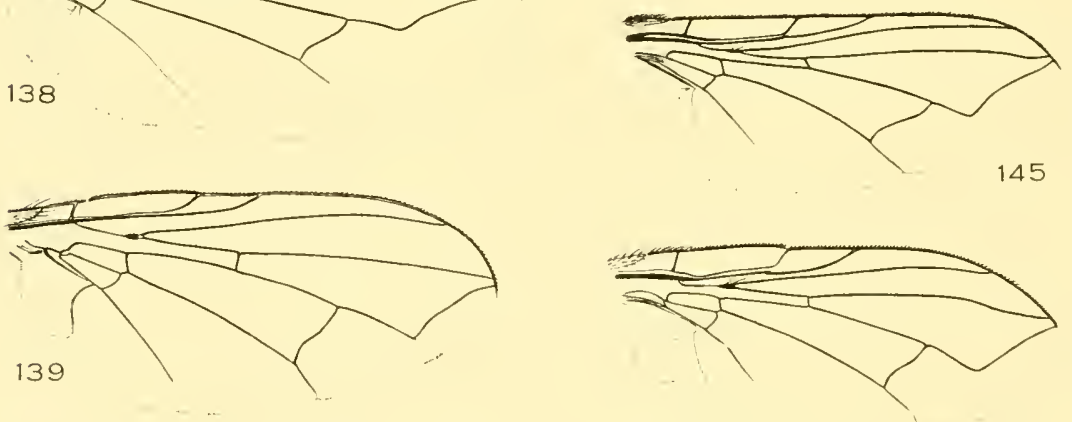

146
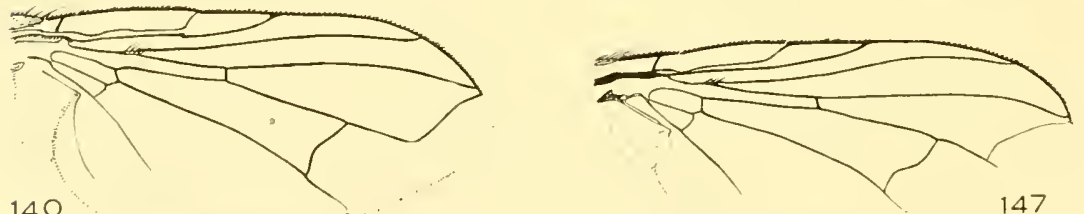

Tachinidæ VII.- 135, Blondelia; 136, 137, Doryphorophaga; 138, Pelecotheca; 139, Myiophasia; 140, Compsilura; 141, Xanthophyto; 142, Eversmannia; 143, Aridalia; 144, Euryccromyia; 145 , Winthemia; 146 , Corozalia rufiventris; 147 . Zuanalia. 
112. Apical cell long petiolate or the apical crossvein absent.

Besseria Desvoidy Apical cell open near the wing-tip............... Apinops Coquillett

113. Oral vibrissæ situated high above the oral margin or not strongly differentiated; if the abdomen bears bristles the apical cell is open.117 Oral vibrissæ strongly developed, level with the strongly produced

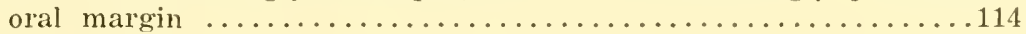

114. Apical cell long petiolate $(55) \ldots \ldots \ldots \ldots \ldots$ Catharosia Rondani Apical cell open or closed in or near the wing-tip............... 115

115. Parafacials bare on lower half........................

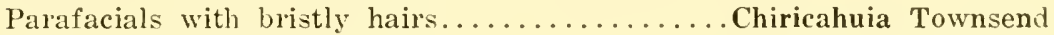

116. Abdomen with bristles................Erythromelana Townsend Abdomen with weak, bristly hairs apically; apical crossvein absent.

Bezzimyia Townsend

117. Anterior femora with only the usual fine or bristly hairs beneath..118 Anterior femora on the apical half of the ventral edges with row of short stout, bristly setulæ.............. Gymnosoma Meigen

118. Abdomen flattened or twice as long as wide.................. 119 Abdomen strongly convex, hemispherical (10).... Cistogaster Latreille

119. Apical cell broadly open or closed in the costa near the wing-tip.....120)

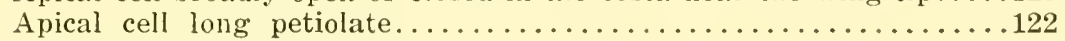

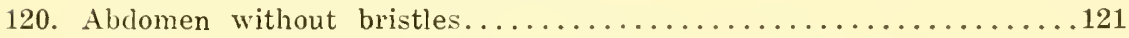
Abdomen with well developed bristles on the apical segments.

Trichoclytia Townsend

121. A row of dorsocentrals, one situated in front of the suture (92).

Chryseria Desvoidy At most two pairs of conspicuous dorsocentrals........ Phasia Latreille

122. Pleura with very dense pale hairs above $(15,20,21,22)$.

Alophora Desvoidy Pleura with ordinary black hairs and bristles....... Hyalomya Desvoidy

123. Parafacials with one or more downwardly directed bristles below the frontal row or with hairs extending to or below the middle......12! Parafacials with at most a few hairs below the lowest frontals......138

124. With one or more downwardly directed parafacial bristles.........125 Without strong parafacial bristles, the hairs sometimes stout but

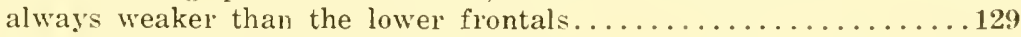

125. Apical cell open; apical section of fifth vein over half as long as the

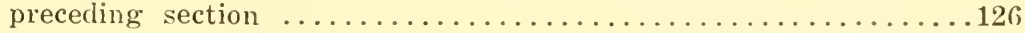
Apical cell long petiolate.............. Hesperophasia Townsend

126. Parafacials with several downwardly directed bristles............ 127 Parafacials with a single downwardly directed bristle (8). 

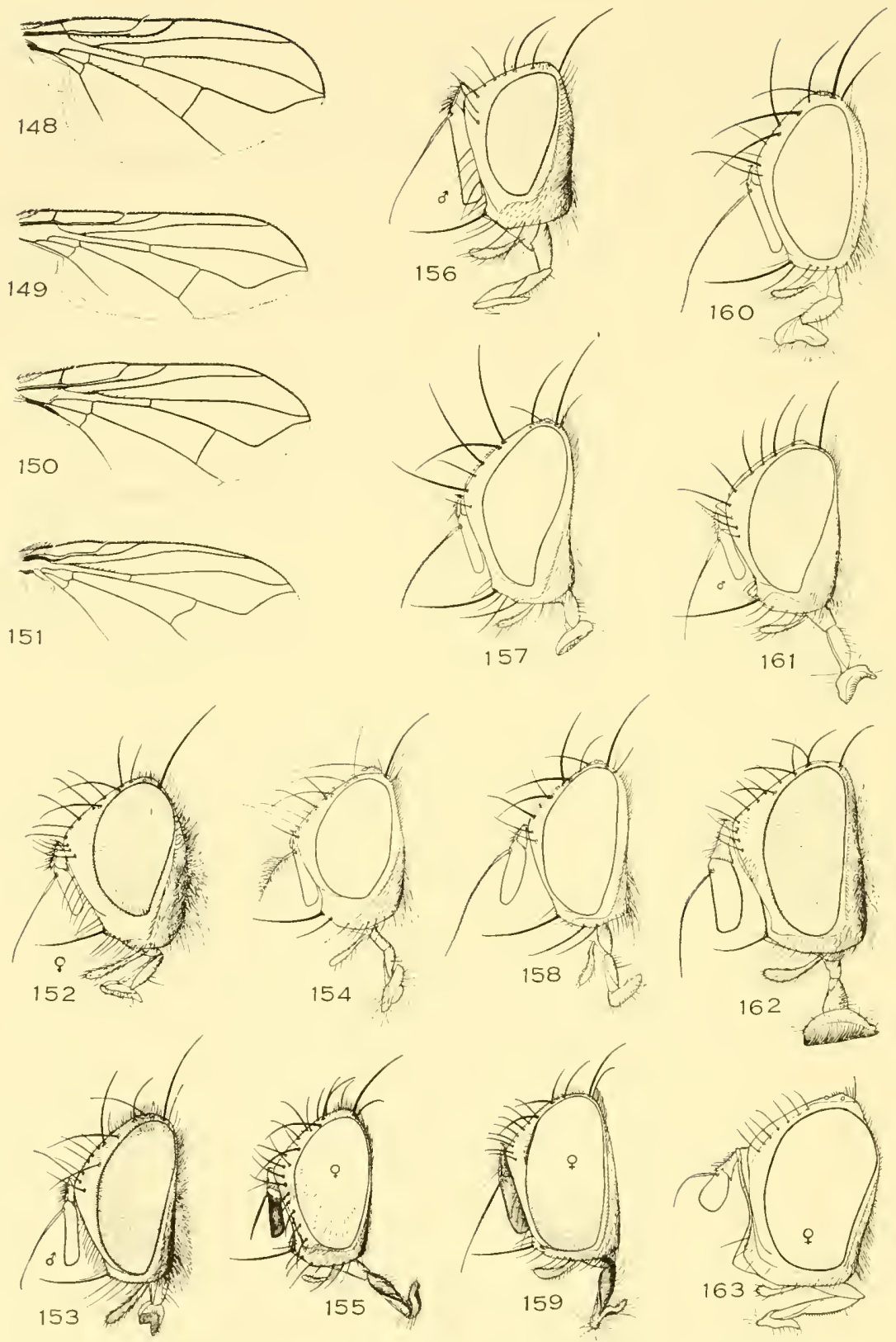

Tachinidre VIII.-148, Actia; 149, Elodia; 150. Epigrimyia; 151, Thelairalia; 152, Pelecotheca: 153, Doryphorophaga; 154. Schwarzalia; 155. Ricosia; 156. Compsilura; 157, Thelairalia; 158, Patillalia; 159, Anacamptomyia americana; 160, Agrarialia; 161, Corozalia; 162, Winthemia; 163, Trichiopoda. 


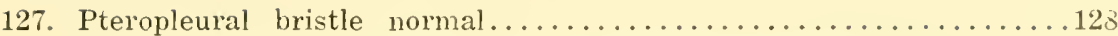
Pteropleural bristle reaching to the apex of the squamæ.

Meleterus Aldrich

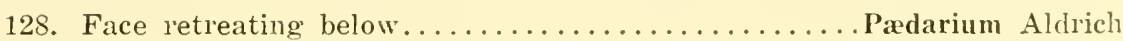
Face as long below as at the antennæ......... Chatovoria Villeneuve

129. Oral vibrissæ situated level with the oral margin; posterior crossvein situated near the middle of the wing............................ Oral vibrissæ either situated well above the oral margin or the posterior crossvein near the apical third of the wing.............

130. Cheeks very much narrower than the eye-height................ Cheeks almost or quite as wide as the eye-height....* Uclesia Girschner

131. Facial depression broad and shallow, the edges rather flattened......132 Facial depression deep and narrow, the edges prominent.

Menetus Aldrich

132. Parafacials rather narrow, with small hairs over a considerable part

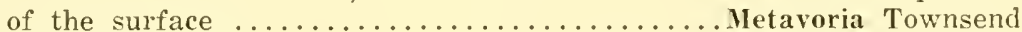

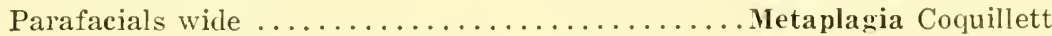

133. Apical cell at most extremely short petiolate................. 134

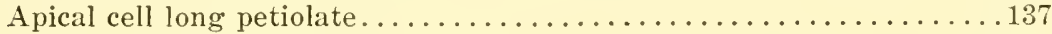

134. Face strongly receding below; third antennal segment about three times as long as the second; three pairs of strong scutellars, the apical pair widely spaced and divergent......................

Face usually but little receding; third antennal segment less than twice

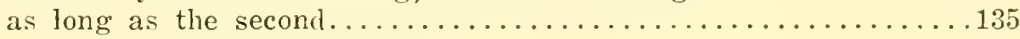

135. Costal spine short; facial depression rather narrow $(35,139)$.

Myiophasia Townsend Costal spine long and strong; facial depression wide.... Lasionalia, n. g.

136. First vein setulose on apical half............ Meigeniella Coquillett First vein bare $(34) \ldots \ldots \ldots$ † Cryptomeigenia Brauer \& Bergenstamm

137. Third vein ending near the wing-tip $(32,33) \ldots \ldots$ Rhinophora Desvoidy Third vein ending far before the wing-tip........ Steveniopsis Townsend

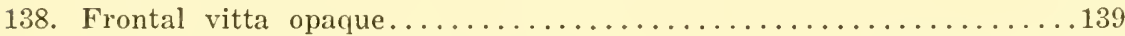
Frontal vitta shining black $(37,38) \ldots \ldots \ldots \ldots \ldots$ Hemyda Desvoidy

139. Posterior tibiæ without scale-like bristles....................140 Posterior tibiæ ciliate above with scale-like bristles $(102,139)$.

Trichiopoda Latreille

140. Anterior femora with a row of long bristles on at least the apical half of the posteroventral surface, appearing as widely spaced cilia.141 Anterior femora with at most two or three posteroventral bristles apically; the hairs on the posterior surface wholly appressed (18,

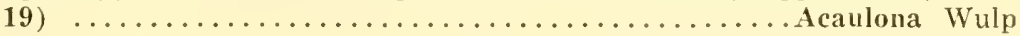

141. Apical cell open, or if closed in the wing margin there are hairs about

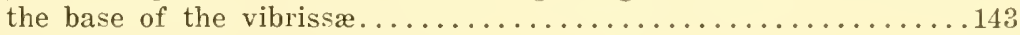

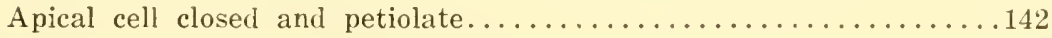

* Curran, 1927, Can. Ent.. D. 299.

† Curran, 1926. Tr. Roy. Soc. Canada, Sec. v, p. 156.

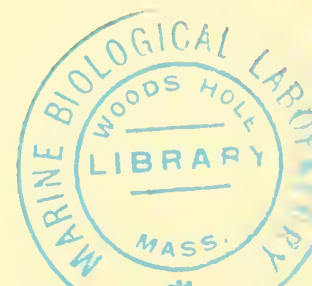



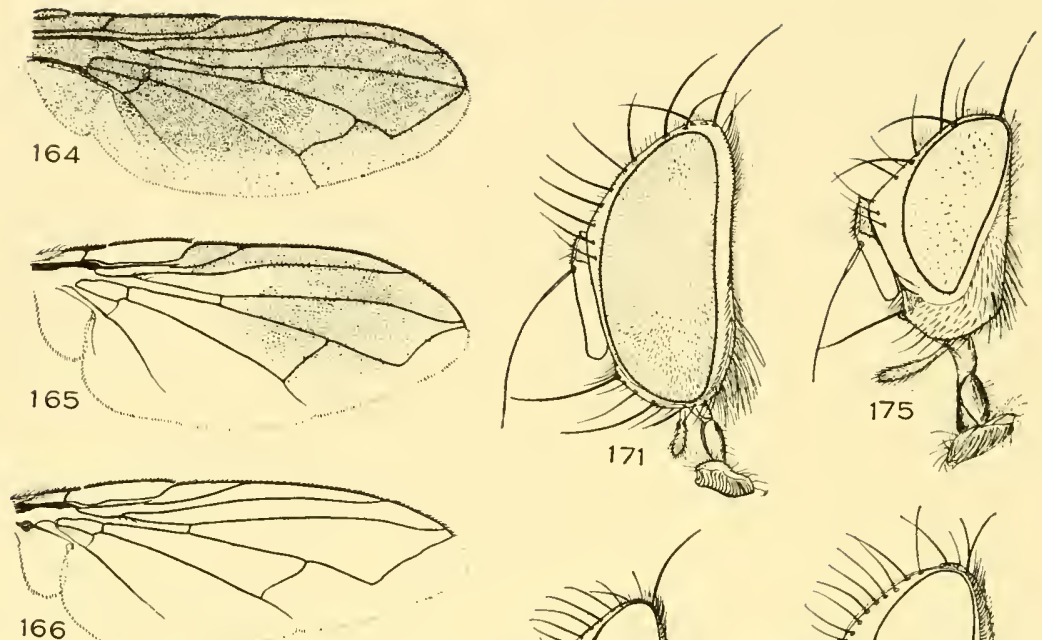

166
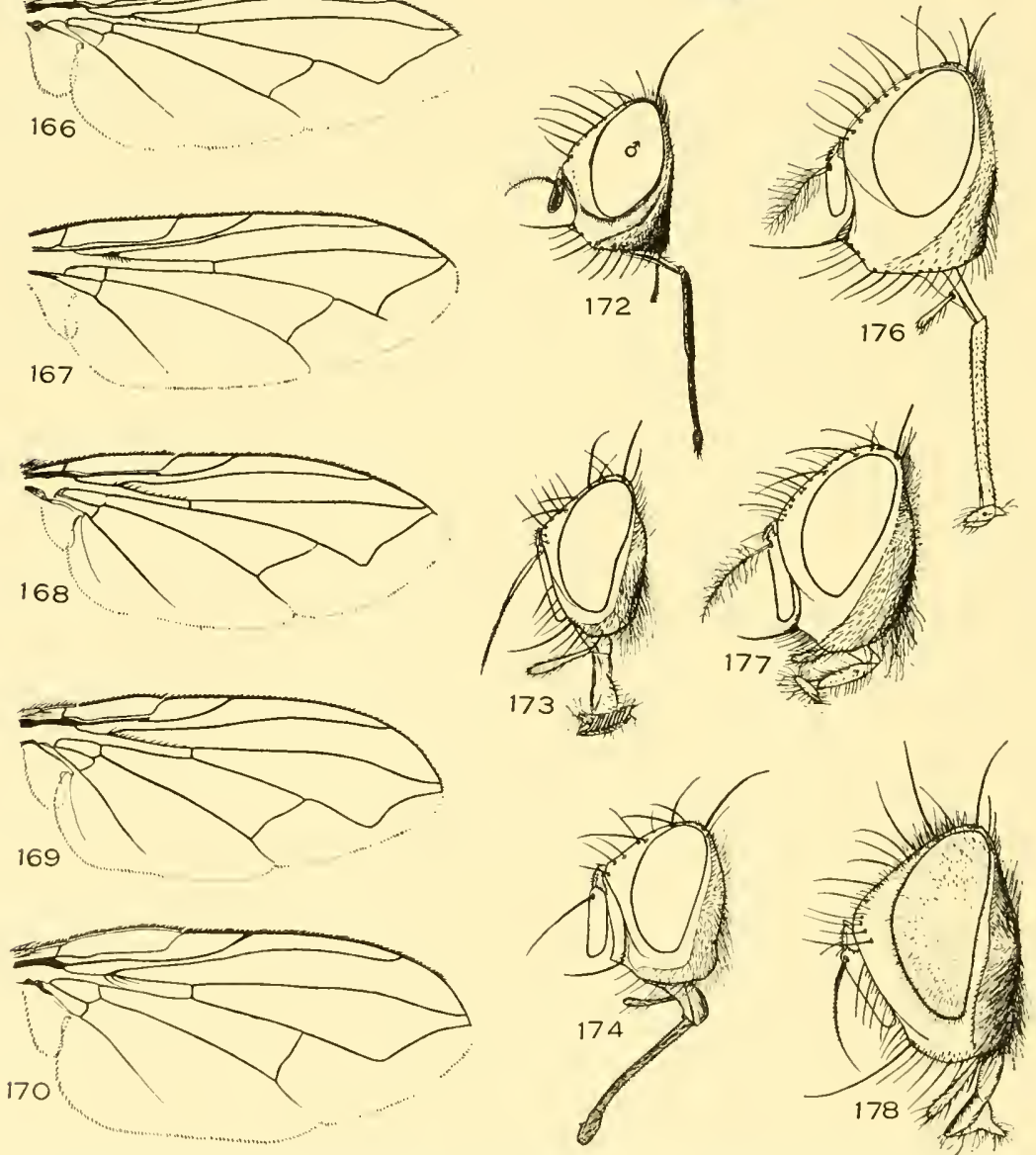

Tachinidæ IX.-164, Trichiopoda; 165, Patillalia; 166, Corozalia panamensis; 167, Xanthophyto; 168, Aridalia; 169. Canalia; 170, Oxynopsalia; 171, Anadiscalia; 172, Prorhynchops? errans: 173, Elodia; 174, Epigrimyia: 175, Doryphorophaga; 176, Shermanalia; 177, Zuanalia : 178. Pseudeuantha. 
142. No hairs surrounding the oral vibrissæ which are situated high above the oral nargin; abdomen long and slender $(71,76)$.

Xanthomelana Wulp

Vibrissæ situated level with the oral margin, or if somewhat above with a few hairs near their base; abclomen, from dorsal view, spherical in outline.................... Clistomorpha Townsend

143. Oral vibrissæ differentiated; oral margin not rounded anteriorly in

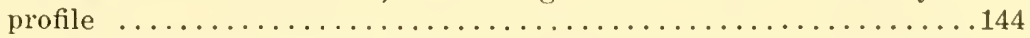

Oral vibrissæ not differentiated, or only very weakly so; head convex below in profile; clypeal region narrow and at least two-thirds as

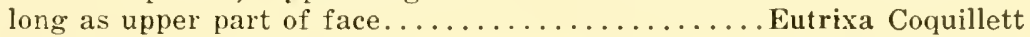

144. Costal spine not greatly developed, never longer than the width of the costal cell and not conspicuous..............................

Costal spine as long as wilth of costal and subcostal cells combined; vibrissæ level with oral margin; parafacials gently convex in profile.

Phrynof rontina Townsend

145. Face strongly retreating, vibrissæ level with oral margin or situated moderately above; three or four pairs of marginal scutellars and sometimes a weak apical pair which may be cruciate; arista rarely thickened to beyond the middle, the penultimate segment never

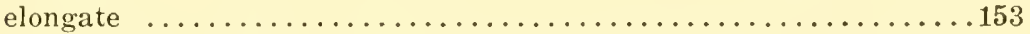

Face almost as long below as at base of antennæ; arista often thickened to the apical fourth and with the penultimate segment elon-

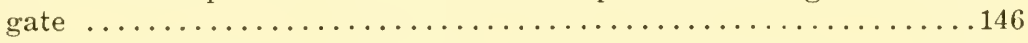

146. Arista not thickened on its whole length; facial depression not oval

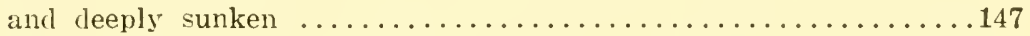

Arista thickened on its whole length; facial depression oval and very

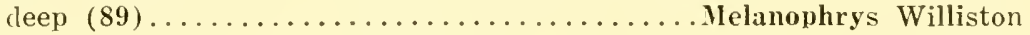

147. Parafacials more or less yellowish in ground color; abdomen usually largely yellow and extensively pollinose..........................

Parafacials silvery pollinose on a black ground; abdomen shining black, the sicles sometimes broarlly reul; vibrissæ level with oral

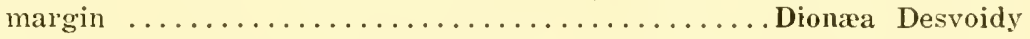

148. Cheeks more than one-tenth as wide as the eye-height; female abdomen not truncate at apex from lateral view.............. 149

Cheeks at most one-fifteenth as wide as the eye-height; arista short plumose; ocellars absent or very weak (117)....... f Calodexia Wulp

149. Vibrissal angles not approximated, or if so the vibrissæ situated level

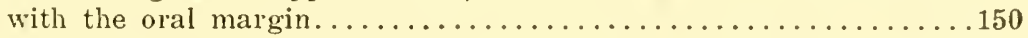

Vibrissal angles conspicuously approximated, the vibrissæ situated above the oral margin $(92) \ldots \ldots \ldots \ldots \ldots \ldots$ Chryseria Desvoidy

150. Anterior crossvein situated half way between the tip of the auxiliary and first veins; posterior crossvein but little oblique..........151

Anterior crossvein situated behind the tip of the first vein; posterior

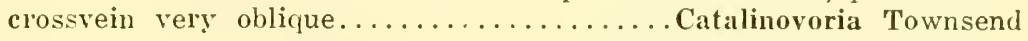

151. Vibrissæ situated distinctly above the oral margin; oral margin not prominent $(108) \ldots \ldots \ldots \ldots \ldots \ldots \ldots \ldots \ldots$ Viviania Rondani

Vibrissæ level with oral margin............................. 152

* Curran, 1927, Can. Ent., lix, p. 297.

$\dagger$ Curran, 1934. Amer. Mus. Novit. No. 685. 

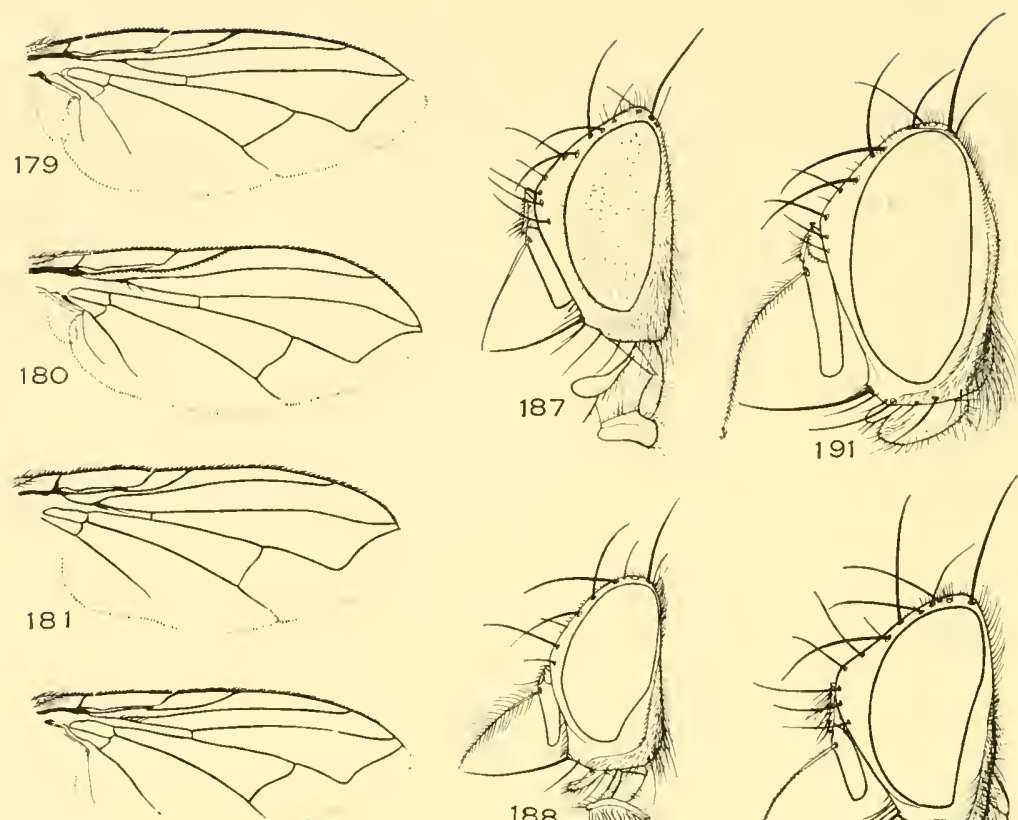

182
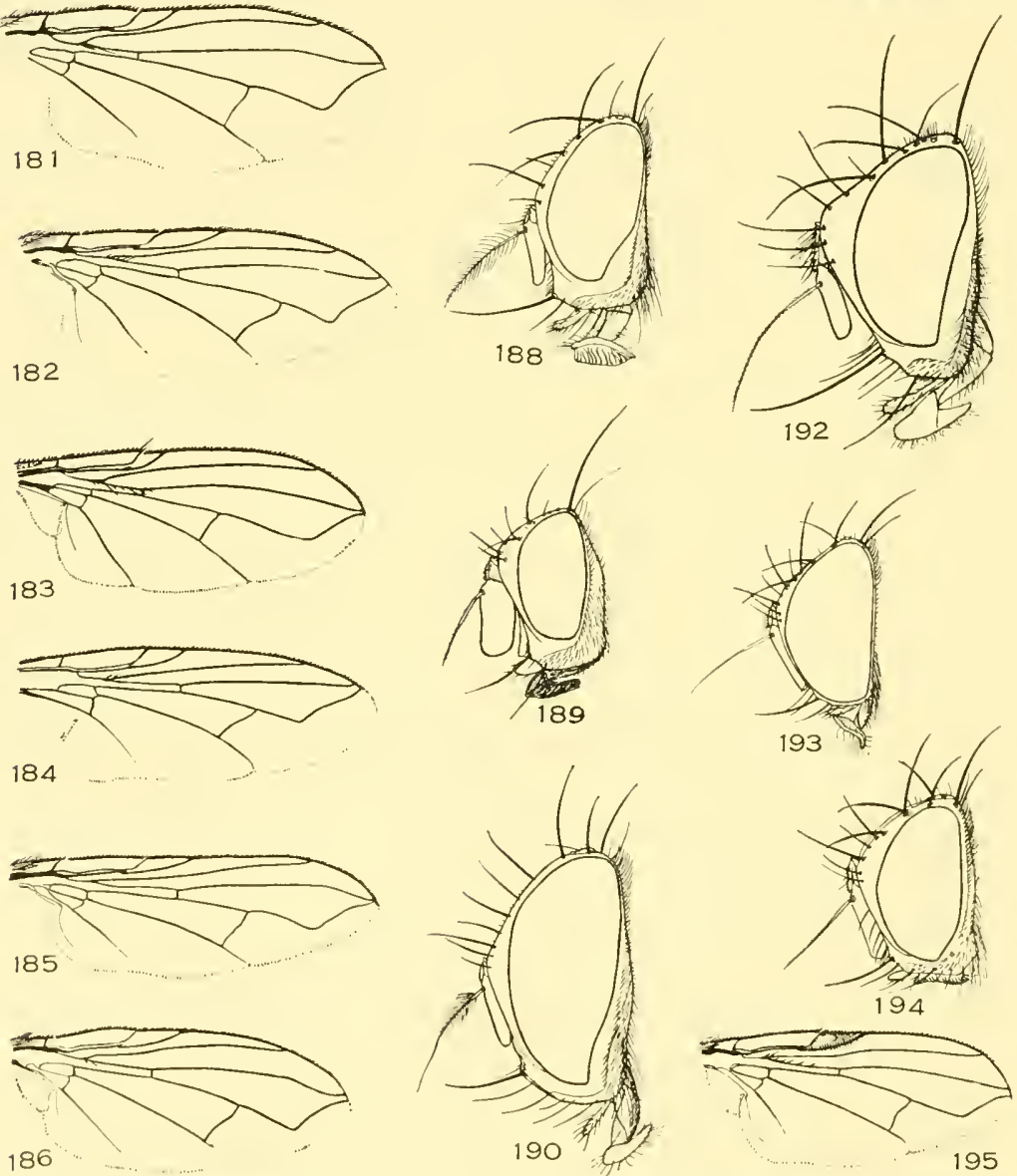

186

Tachinidæ X.--179, Agrarialia; 180 , Schwarzalia; 181 , Microtownsendia ; 182, Anadiscalia; 183. Siphona; 184, Pseudeuantha; 185, Shermanalia; 186, Chætonalia; 187, Corozalia; 188, Zonalia; 189. Actia; 190, Chæetonalia; 191, Canalia; 192, Blondelia: 193, Microtownsendia; 194. Oxynopsalia; 195. Zonalia. 
152. Proboscis very long and slender; ovipositor normal. Ginglimyia Townsend Proboscis short, the labellæ fleshy; ovipositor as long as abdomen.

Xiphomyia Townsend

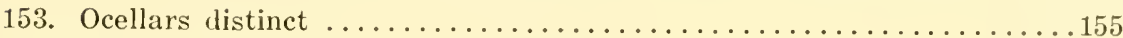

Ocellars absent; three sternopleurals...................... 154

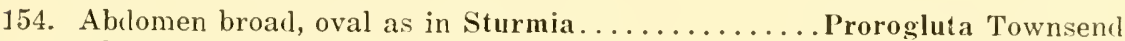

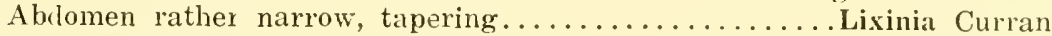

155. Vibrissa situated above the oral margin, the oral margin not promi-

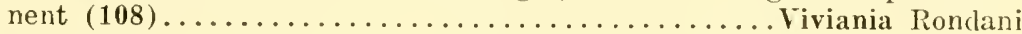
Vibrissæ practically level with the oral margin, the oral margin slightly

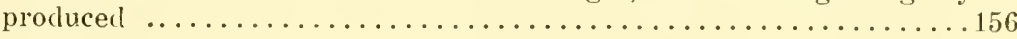

156. Two or three pairs of presutural acrosticals, the midclle pair always

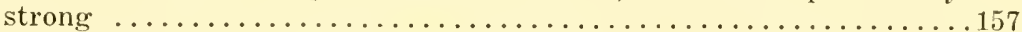
One or two pairs of weak presutural acrosticals. Ochromeigenia Townsend

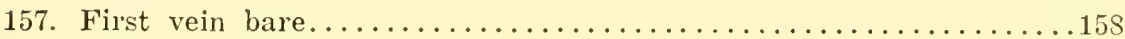

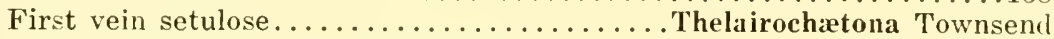

158. Anterior tibiæ with a single posterior bristle..........Erycioides Curran Anterior tibiæ with two posterior bristles (Lydella auct.) (135, 192).

*Blondelia Desvoidy

159. Eyes with long or dense hair...........................

Eyes bare or with inconspicuous, short sparse hair............235

160. Parafacials with hairs or bristles extending to the lower half.......161 Parafacials with at most a few hairs below the frontals...........181

161. Palpi normal in length, usually thickened apically...............162

Palpi greatly reluced, slender, never much more than twice the length of the thickness of proboscis at point of attachment; bend of fourth vein with long appendlage $(77) \ldots \ldots \ldots \ldots \ldots$ Linnamya Desvoidy

162. Frontal bristles not extending below the upper third of the face, normally only one situated below the base of the third antennal segment, the parafacials with other hairs or bristles at least above...163

Frontals extending to the middle of the third antennal segment; pteropleural reaching to the apex of the squamæ...... Lypha Desvoidy

163. Facial ridges not bristled on more than the lowest fourth or the

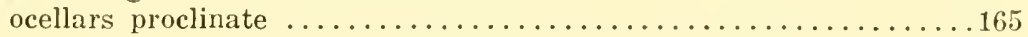

Facial ridges bristled on at least the lower half; ocellars absent or

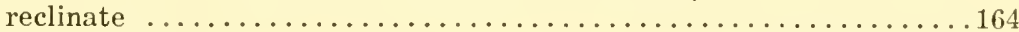

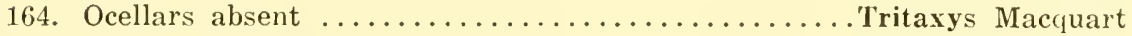

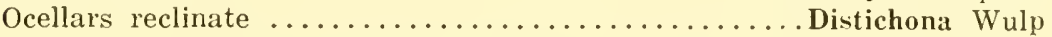

165. Penultimate aristal segment rarely twice as long as wide, the precerl-

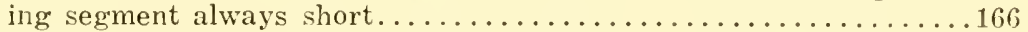
Basal two aristal segments greatly elongate....... Digonichreta Ronclani

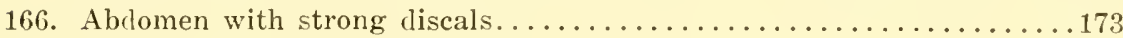

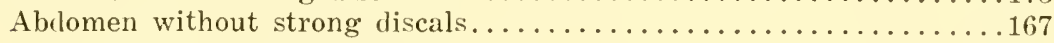

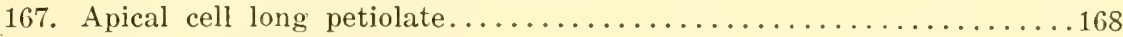

A pical cell open.................................. 169

* Curran, 1927, Can. Ent. lix, p. 12 (Lydella). 
168. Penultimate aristal segment elongate..........Paradmontia Coquillett Penultimate aristal segment very short, the arista strongly thickened

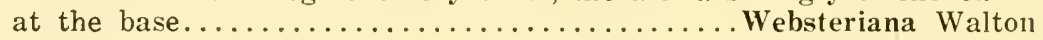

169. Posterior tibiæ evenly and closely ciliate with bristles; hair of para-

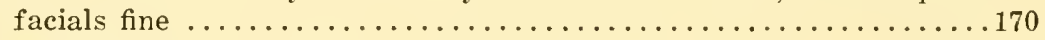
Posterior tibiæ not ciliate or the parafacial hair coarse............. 171

170. Facial ridges bristled on almost the lower half.... Sturmiopsis Townsend Facial ridges bristled on net more than the lowest third $(145,162)$.

* Winthemia Desvoidy

171. Parafacials with bristly hair or a row of bristles.............. Parafacials with two bristles below............ Chromatocera Townsend

172. Ocellars proclinate $(42,43,45,52,96)$.

Paradidyma Brauer \& Bergenstamm Ocellars reclinate $(155) \ldots \ldots \ldots \ldots \ldots \ldots \ldots \ldots \ldots \ldots$ Ricosia Curran

173. Third antennal segment not more than twice as long as the second...178 Third antennal segment more than twice as long as the second......174

174. Apical cell long petiolate............................ 175 Apical cell not long petiolate............................. 176

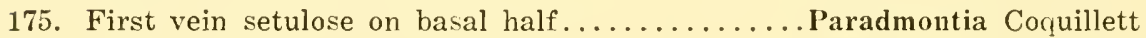

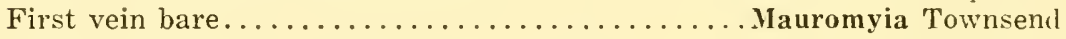

176. Penultimate aristal segment short........................ 177 Penultimate aristal segment elongate; parafacials with two bristles

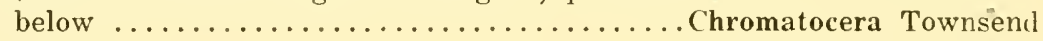

1.77. Two presutural acrosticals.............. Ictericophyto Townsend Three presutural acrosticals (111).... Gædiopsis Brauer \& Bergenstamm

178. Second antennal segment, if elongate, clothed with sparse, fine bristly hairs on the upper surface............................... Second antennal segment as long as the third, very densely bristled above; cheeks one-third as wide as the eye-height (105).

Muscopteryx Townsend

179. Vibrissæ situated on a level with the oral margin............. 180 Vibrissæ situated well above the oral margin; parafacials almost as wide as the third antennal segment.................

180. Ocellars absent; prosternum bare. Bombyliomyia Brauer \& Bergenstamm Ocellars long, though weak, prosternum pilose........ Tachinalia, n. g.

181. Palpi of rormal length and shape, if apparently short, broadened

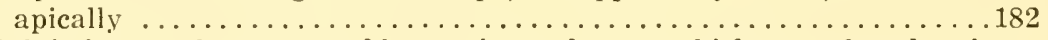

Palpi short and narrow, seldom twice as long as thickness of proboscis at point of attachment; bend of fourth vein with appendage (77).

Linnæmya Desvoidy

182. Facial ridges with strong bristles on lower half or more......... 183 Facial ridges with bristly hairs decreasing in length upwardly, rarely

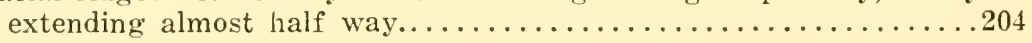

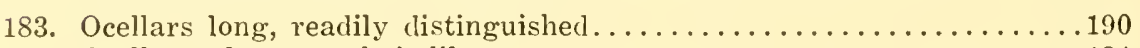
Ocellars absent or hair-like................................ 184 
184. Three sternopleurals; face strongly receling, gently convex in profile;

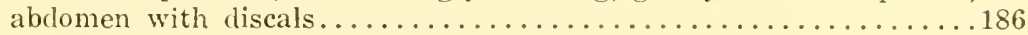

Sternopleurals 1-1; face receding, not convex................... 185

185. Front slightly longer than the face, the antennæ arising near the middle of the eyes in profile $(138,152) \ldots \ldots \ldots .$. Pelecotheca Townsend

Front much shorter than the face, the antennæ arising near the upper fourth of the eyes in profile $(140,156) \ldots \ldots \ldots \ldots$ Compsilura Bouché

186. Face strongly recerling; basicosta black..................... 187 Face gently receding; basicosta yellow (159).... Anacamptomyia Bischoff

187. With only two pairs of orbitals in both sexes or the frontal vitta half

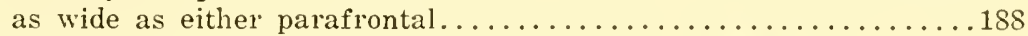
With a row of orbitals in both sexes; frontal vitta narrow.

Metopiops Townsend

188. Fourth abdominal segment with discals..................... 189 Fourth abdominal segment without discals......... Phrenopsis Townsend

189. Frontal vitta two-thirds as wide as either parafrontal.

Frontal vitta not half as wide as either parafrontal.

Paralispe Brauer \& Bergenstamm *Argyrophylax Brauer \& Bergenstamm

190. Pteropleural bristle not nearly reaching the apex of the lower squamal

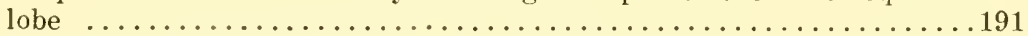

Pteropleural bristle extending to the apex of the lower squanal lobe;

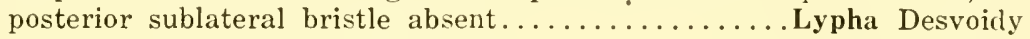

191. Penultimate segment of arista not over twice as long as wide......193 Penultimate segment of arista at least three times as long as wide..192

192. Front with a row of bristles outside of the frontals. Madremyia Townsend Front without a row of bristles outside the frontals.

Murdockiana Townsend

193. Third antennal segment never with more than three branches........194 Third antennal segment with a large number of branches on either

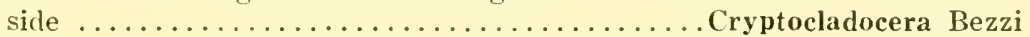

194. Head decidedly more than half as long as high; parafacials wide or the face much wider than either eye, always wider than the front..195

Head half as long as high; parafacials less than half as wide as the elongate third antennal segment; face but little wider than the front, scarcely retreating, its sides parallel on the lower threefourths $(159) \ldots \ldots \ldots \ldots \ldots \ldots \ldots \ldots$ Anacamptomyia Bischoft

195. Frontal bristles not extending below the base of the arista.........196 Frontal bristles extending to the middle of the third antennal seg-

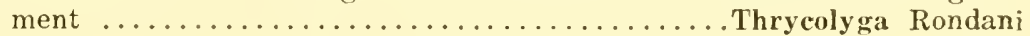

196. Two or more bristles below the base of the antennæ.............97 A single bristle below the base of the antennæ........ Cyzenis Desvoidy

197. Abciomen of ordinary form, decidedly wider than deep, the genitalia usually exposed, at least not enclosed in a slit-like opening.....198

* Curran, 1929. Suppl. to Gowdey's Catalogue Dipt. Jamaica, p. 23. 
Abdomen in both sexes wide and deep, the terminal segment large, normaliy concealing the genitalia within a slit-like opening.

*Pateloa Townsend

198. Middle coxæ of female with normal bristles; males without orbitals..199

Middle coxæ of female with closely placed, curved apical spines; males with two pair's of orbitals $(136,137,153,175)$.

Doryphorophaga Townsend

199. Posterior sublateral bristle present.................... 200

Fosterior sublateral absent .............. † Phorocera Desvoidy

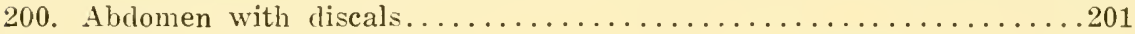

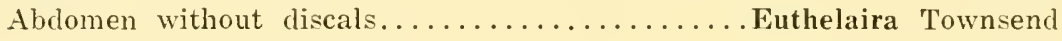

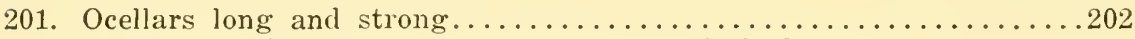

Ocellars weak; posterior presutural acrostical absent.

Eupelecotheca Townsend

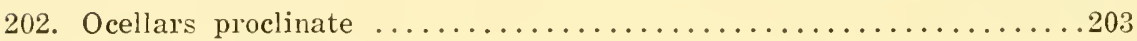

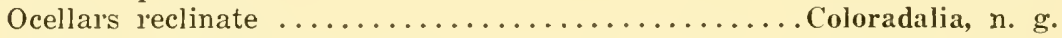

203. Anterior tibiæ with two posterior bristles; apical cell ending far before the wing-tip (Amphichrta B. B.)........ † Phorocera Desvoidy

Anterior tibiæ with a single posterior bristle; apical cell ending close to the wing-tip $(170,194) \ldots \ldots \ldots \ldots \ldots \ldots \ldots$ Oxynopsalia, n. $g$.

204. Not metallic green or blue.............................

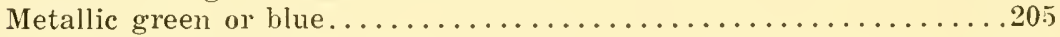

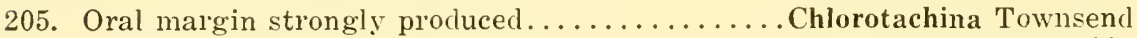
Oral margin scarcely produced $(56) \ldots \ldots \ldots \ldots$. Gymnochæta Desvoidy

206. Pteropleural bristle of normal length or weak, if long the parafrontals are shining black or the frontal bristles do not extend

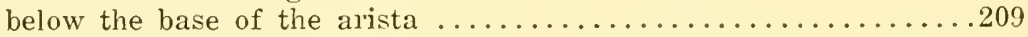

Pteropleural very long and strong, extending to the apex of the squamæ; frontals usually extending to the middle of the third antennal segment; parafrontals pollinose................207

207. Male without orbitals; parafacials almost or fully half as wide as

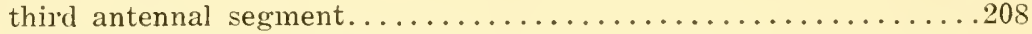

Male with orbitals; parafacials below not over one-fourth as wide as the elongate third antennal segment; front wide in both sexes.

Homalactia Townsend

208. Frontal bristles extending to the middle of the parafacials.

Lypha Desvoidy Flontals not extending below the base of the arista.Hineomyia Townsend

209. Palafrontals pollinose ................................

Parafrontals bare; pteropleural long; apical cell terminating near the wing-tip; abdomen shining black............... Polidaria n. g.

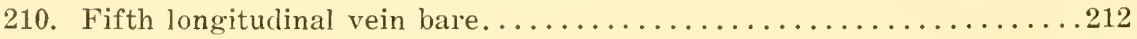

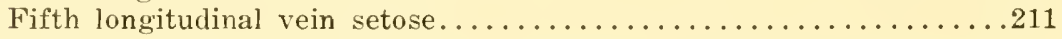

* Aldrich and Webber, 1924, Pr. U. S. N. M., lxiii, Art. 17, pp. 45, 51 (Phorocera).

$\dagger$ Aldrich and Webber, 1924, Pr. U. S. N. M., lxiii, Art. 17, pp. 45, 51. 
211. Penultimate aristal segment nearly three times as long as wide.

Acronaristopsis Townsend Penultimate aristal segment less than twice as long as wide.

Minthoplagia Townsend

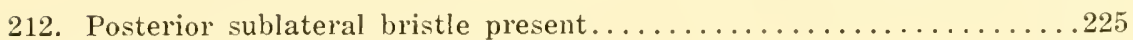

Posterior sublateral bristle absent........................ 213

213. Penultimate aristal segment not over twice as long as wide.........214 Penultimate aristal segment and the preceding one more than twice

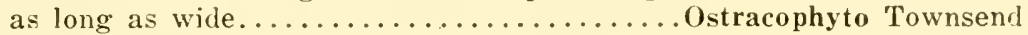

214. Oral margin strongly produced; face never carinate............215 Oral margin not or but little produced; face sometimes carinate. . . 217

215. Abdomen broad and thick; robust species, usually with four postsutural dorsocentrals; three or more sternopleurals...........216 Abdomen elongate and narrow; three sternopleural and three pairs of postsutural dorsocentrals............................. Meigen

216. Normally only three postsutural dorsocentrals; parafacials almost as wide as the length of the third antennal segment.

Metaphyto Coquillett

Four postsutural dorsocentrals; parafacials narrower than width of third antennal segment.................................. Desvoidy

217. Posthumeral bristle present; bend of fourth vein sub-angulate....218

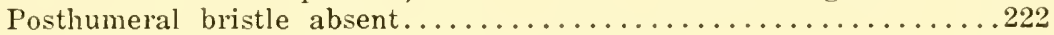

218. Two sternopleurals, rarely a very weak third ...............221 Three sternopleurals; male abdomen strongly produced apically....219

219. Apical cell ending very close to the wing-tip......... Cleonice Desvoidy Apical cell ending far before the wing-tip . . . . . . . . . . . 220)

220. Prosternum with bristly hairs. . . . . . . . . . . . . . . 224 Prosternum bare $(65,66) \ldots \ldots \ldots \ldots \ldots \ldots \ldots \ldots$ Uramya Desvoidy

221. Prosternum bare $(178,181) \ldots \ldots \ldots \ldots \ldots$ Pseudeuantha Townsend Prosternum haired; lower squamal lobe haired above toward the outer edge; large, robust, tropical species...........Tropidopsis Townsend

222. Third abdominal segment with two or three arched rows of long

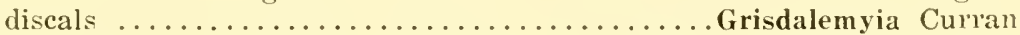
Third abdominal segment with one or two pairs of discals; pro-

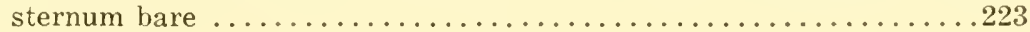

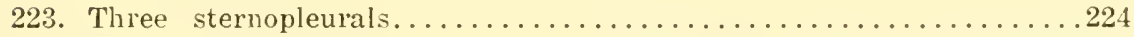
Two sternopleurals............. Hyalurgus Brauer \& Bergenstamm

224. Discals present on second to fourth abdominal segments.

Xanthocera Townsend

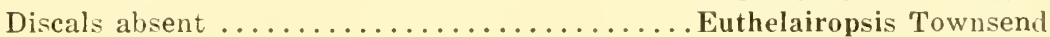

225. Second antennal segment usually less than half as long as the third..227 Second antennal segment almost as long as the third.........226

\footnotetext{
* Aldrich, 1921, Ins. Ins. Mens., ix, p. 85.

$\dagger$ Aldrich, 1921, Ins. Ins. Mens., ix, p. 87.

Pseudeuantha may trace here but has white haired pleura.
} 
226. Head as long below as at the antennæ; antennæ arising below the middle of the eyes.................... Tricogena Rondani Head shorter below than at antennæ; abdomen flattened.

*Nemorilla Desvoidy

227. Vibrissæ situated at most slightly above the oral margin.........229 Vibrissæ situated more than half the length of the second antennal

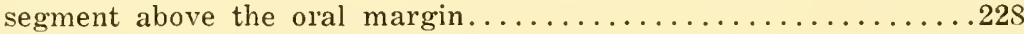

228. Abdomen with strong discals...†Macromeigenia Brauer \& Bergenstanm Abdomen without discals on the intermediate segments.

Bolomyia Brauer \& Bergenstamm

229. Apical abdominal segment closing slit-like, deeper than wide.......230 Apical abdominal segment not closing slit-like, wider than deep at the

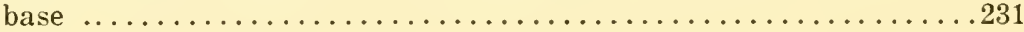

230. Several coarse setulæ below the frontals; facial depression very deep; parafacials as wide as the facial depression...Organomyia Townsend No hairs below the frontals; parafacials not over half as wide as the shallower facial depression...............eptostylum Macquart

231. Anterior tibiæ with at least two posterior bristles. . . . . . . . . . . 232 Anterior tibiæ with a single posterior bristle..............238

232. Third antennal segment more than twice as long as wicle $(57,94)$.

thenillia Desvoidy

Third antennal segment subtriangular, almost as wide as long.

Obolocera Townsend

233. Discals absent; abdomen broad; cheeks linear (171, 182).

Anadiscalia, n. g.

Discals present; cheeks at least one-fifth the eye-height........234

234. Frontal vitta of male very narrow; female with stout spines on the apex of the middle coxæ; abdomen broad $(136,137,153,175)$.

Dory phorophaga Townsend

Frontal vitta not unusually narrow; female without spines on middle coxæ ...................Ptilodegeeria Brauer \& Bergenstamm

235. Parafacials with hair or bristles on the lower half...........236

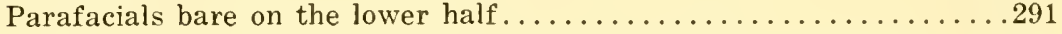

236. Ocellar bristles present, directed obliquely forward or divergent......248 Ocellar bristles directed obliquely backward, absent or hair-like. . . .2237

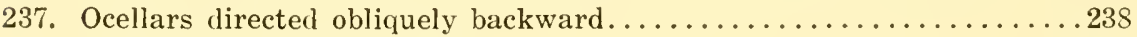

Ocellars hair-like or absent. . . . . . . . . . . . . . . . . . . . . .240

238. Facial ridges with strong bristles on the lower half, or the penultimate aristal segment not over twice as long as wicle; head not

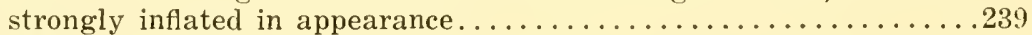

Facial ridges bristled on less than the lowest fourth, the head inflated in appearance; penultimate aristal segment always more than three times as long as wide $(12,13) \ldots \ldots \ldots \ldots \ldots \ldots$ Gonia Meigen

* Aldrich \& Webber, 1924, Pr. U. S. N. M., lxiii, Art. 17, p. 5.

$\div$ Reinhard, 1930, Ent. News, xli, p. 262.

‡ Aldrich \& Webber, 1924, Pr. U. S. N. M., Lxiii, Art. 17, p. 11. 
239. Apical cell open or closed in the wing margin $(3,46)$. Apical cell rather long petiolate................ Aravaipa Townsend

240. Arista plumose or strongly pubescent, the clypeal region as long as the distance from the upper pair of vibrissæ to the antennal base...249

Arista bare or weakly pubescent; oral margin produced and not nar-

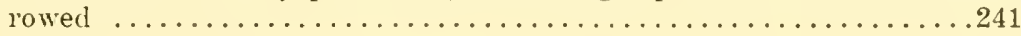

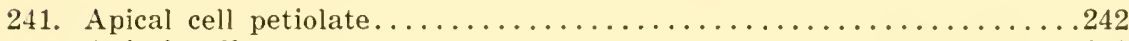

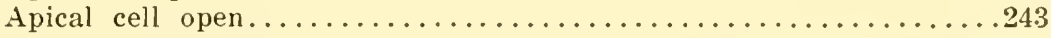

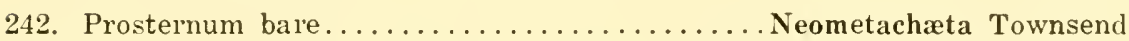
Plosternum with hair and a long bristle on the sides.. Epidexia Townsend

243. Palip absent or very slender on their whole length...............244

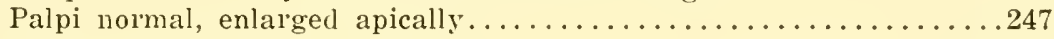

244. Palpi extremely short or absent, never more than twice the length of the thickness of the proboscis at point of attachment. . . . . . . 245 Palpi elongate and slender, very rarely short; parafacials always with two or more bristles below (7) .............. Peleteria Desvoidy

245. Parafacials with one or more bristles below $(39,61)$. Cuphocera Macquart Parafacials without bristles below......................246

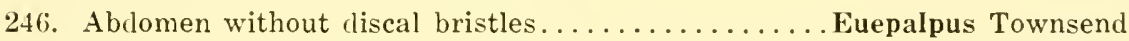
Abdomen with discal bristles on intermediate segments.

Xanthozona Townsend

247. Parafacials with one or more bristles in addition to the hair. Chætoprosopa Townsend Parafacials with fine hair only..... Chætoprocta Brauer \& Bergenstamm

248. Clypeal region not long and narrow, short and not conspicuous, cheeks rarely more than half as wide as the eye-height..............251 Clypeal region long and narrow; cheeks two-thirds as wide as the eye-

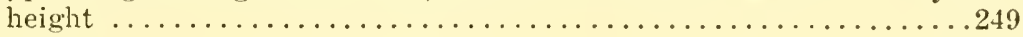

249. Posterior sublateral bristle absent......................... 250

Posterior sublateral bristle present; sternites with at most weak bristles $(99) \ldots \ldots \ldots \ldots \ldots \ldots \ldots \ldots \ldots \ldots$. Hicrophthalma Macquart

250. Sternites with long, very strong bristles........Megaprosopus Macquart Sternites without strong bristles............................. Wulp

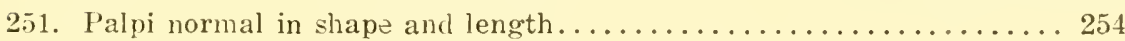
Palpi absent or reduced to about half the normal length, wholly slender and bearing only one or two apical bristles............252

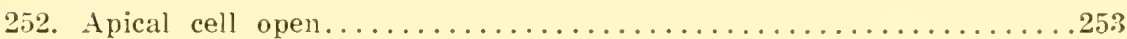

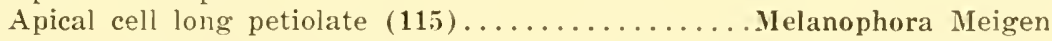

253. Palpi absent or extremely small; large, robust, Archytas-like species, the apical cell ending far before the wing-tip. . Vibrossomyia Townsend Palpi about half the normal length; apical cell ending close to the

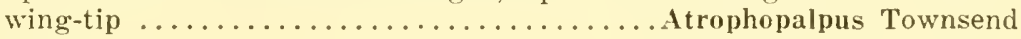

* Curran, 1925, Trans, Roy. Soc. Canada, Section V, 1) 226.

† Aldrich, 1926, Pr. U. S. N. M., lxix, Art. 13, 1. 2. 
254. Ultimate section of fifth vein less than half as long as the preceding

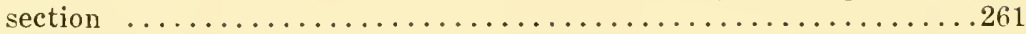

Ultimate section of fifth vein or its fold more than half as long as

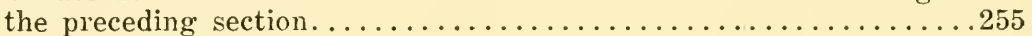

255. Parafacials with one or more downwardly directed bristles.......256 Parafacials with only short hairs.........................

256. Pteropleural bristle extending to the apex of the squamæ........257

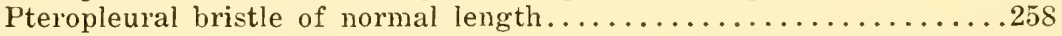

257. Posterior crossvein lying wholly beyond the anterior crossvein.

Blepharigena Rondani Posterior crossvein situated partly before the anterior crossvein $(73,74) \ldots \ldots \ldots \ldots \ldots \ldots \ldots \ldots \ldots \ldots \ldots \ldots \ldots \ldots \ldots \ldots \ldots \ldots \ldots \ldots$ Goniochata Townsend

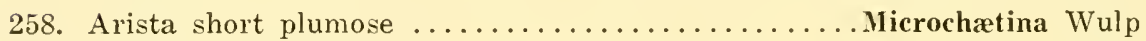

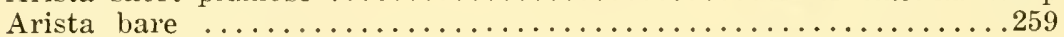

259. Parafacials more than two-thirds as wide as the facial depression.

Cockerelliana Townsend Parafacials narrow (type Voria neotropica Curran)...... Vorialia, n. g.

260. Proboscis long and slender; first vein setulose $(69,79)$.

Plagiomima Brauer \& Bergenstamm Proboscis short and stout; first vein bare.........Metaplagia Coquillett

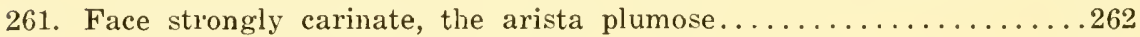
Facial carina weak or absent; arista bare to plumose..........263

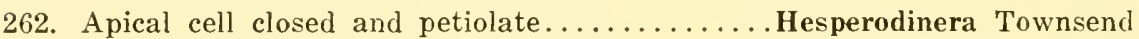
A pical cell open $(119,124,125,133) \ldots \ldots \ldots \ldots \ldots *$ Rhynchiodexia Bigot

263. Facial ridges never strongly bristled on the lower half, if almost so

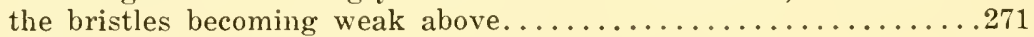
Facial ridges strongly bristled on lower half or more.............264

264. Third antennal segment usually less than three times the length of the second; face only moderately retreating below; usually over $9 \mathrm{~mm}$. in length; posthumeral bristle always strong...........26s Third antennal segment more than four times as long as the second, or if not the posthumeral bristle weak or absent; face very strongly

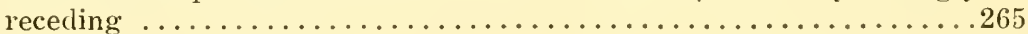

265. Apical cell long petioiate................. Eleodiphaga Walton A pical cell open or very short petiolate.........................

266. Parafacials much narrower than the facial depression.

†Admontia Brauer \& Bergenstamm Parafacials as wide as the facial depression.................. 67

267. Fifth vein setuiose .............Actinochata Brauer \& Bergenstamm

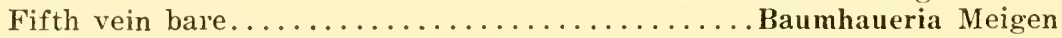

268. Penultimate aristal segment less than twice as long as wide.......269 Penultimate aristal segment at least three times as long as wide (87).

Chætogædia Brauer \& Bergenstamm

* Curran, 1930. Bull. Amer. Mus. Nat. Hist., lxi, p. 93.

$\dagger$ Curran, 1927, Can. Ent., lix, p. 294. 
269. Base of wings leep brown; abclomen piceous or largely castaneous

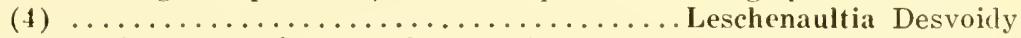
Base of wings never brown; abdomen largely gray pollinose, more or

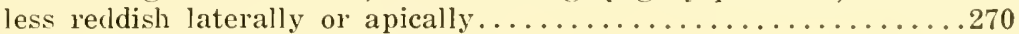

270. Apical cell ending far before the wing-tip; large species. . Gadia Meigen Apical cell ending near the wing-tip; small species.

*Admontia Brauer \& Bergenstamm

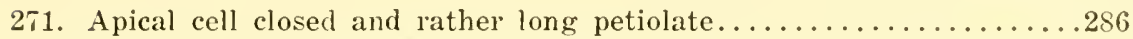
Apical cell open, closed in the margin or extremely short petiolate...272

272. Penultimate aristal segment not over twice as long as wide.......273 Basal two aristal segments each at least three times as long as wide.

Digonichæta Rondani

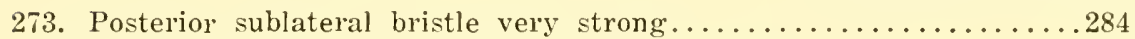
Posterior sublateral bristle absent; face strongly retreating........274

274. Third abdominal segment with at most two pairs of discals........275 Third abdominal segment with a row of discals..... Gibsonomyia Curran

275. At least the third abdominal segment with discals..............276 Intermediate segments without discals, the marginals rarely simulating discals . . . . . . . . . . . . . . . . . . . . 279

276. Both the second and third abdominal segments with discals or the marginals not situated far forward...................277 Second segment without discals but the marginals situated far for-

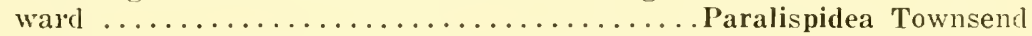

277. Second antennal segment almost or quite half as long as the third...27s Second antennal segment not nearly half as long as the third.

Phyllomya Desvoidy

278. Cheeks about half as wide as the eye-height.... Eubrachymera Townsend Cheeks not one-third as wide as the eye-height........Peteina Meigen

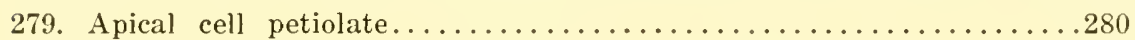

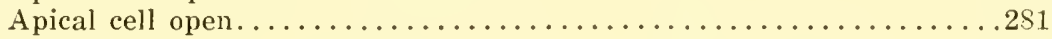

280. Arista almost wholly thickened.............Hypertrophocera Townsend Arista thin on apical fourth or more $(23,24)$... Ceratomyiella Townsend

281. Presutural acrosticals present........................... Presutural acrosticals absent................. Peteina Meigen

282. Arista more or less distinctly plumose..................... Arista bare or practically so, thickened on almost its whole length.

Hy pertrophocera Townsend

283. First and fifth veins setose.........Actinochata Brauer \& Bergenstamm

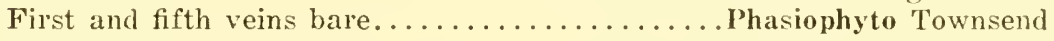

284. Parafacials with fine hairs only....................... Parafacials with three or more downwardly directed bristles $(83,86)$.

Chat oplagia Coquillett

285. Intermediate abdominal segments with discals; no orbitals in male.

†Spathimeigenia Townsend

* Curran, 1927, Can. Ent., lix, p. 294.

$\dagger$ Aldrich, 1931, Pr. U. S. N. M., lxax, Art. 11, p. 3. 
Intermediate abdominal segments without cliscals; a row of orbitals in

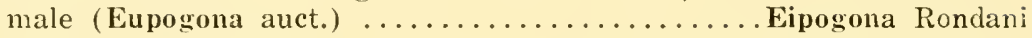

286. Parafacials at least half as wide as median depression, with scattered bristly hairs; abdomen largely pollinose................28s

Parafacials less than one-third the width of the median clepression,

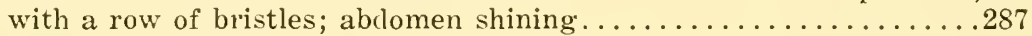

287. Third antennal segment at least twice as long as the second; front of both sexes at least two-thirds as wide as either eye $(40,41)$.

Third antennal segment but little longer than the second; front strongly narrowed in both sexes......... Hesperophasia Townsend

288. Two or three presutural acrosticals and dorsocentrals............289

No presutural acrosticals and only two pairs of weak presutural dorsocentrals $(58,59) \ldots \ldots \ldots \ldots \ldots \ldots \ldots \ldots \ldots$ Penthosia Wulp

289. Proboscis not longel than length of head; parafacials about twothircls as wide as median depression...................290

Proboscis much longer than the head-height; parafacials as wide as

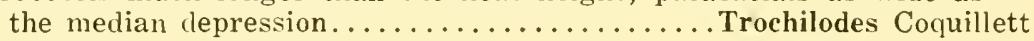

290. Face receding, longer than the front $(84,85) \ldots$ Euthyprosopa Townsend Oral margin prominent, the face shorter than the front.

Steveniopsis Townsend

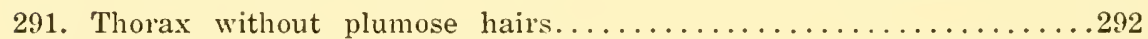

Thorax in part with plumose yellowish hairs......... Teleothyria Wulp

292. Facial ridges bristled on less than the lower half, the bristles almost always decreasing in length above; oral vibrissæ always strongly

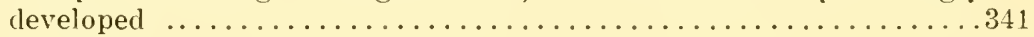

Facial ridges with strong bristles on the lower half or more or the

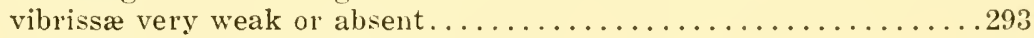

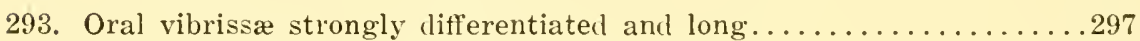

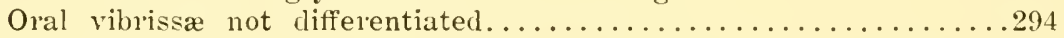

294. Facial ridges with two or three rows of hairs on the lower half, the parafacials "rolled" over the ridges above..........................

Facial ridges with a single row of bristles on the lower half, the ridges continuous to the base of the antennæ, not hidden on the upper half by the parafacials; presutural acrosticals present....296

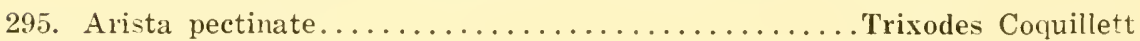

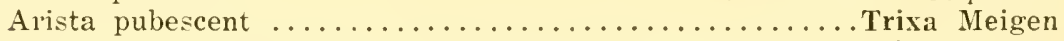

296. Apical cell long petiolate; arista about half as long as the third an-

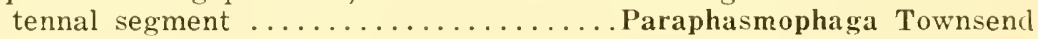
Apical cell short petiolate; arista much longer than antenna $(26,27)$.

Estrophasia Brauer \& Bergenstamm

297. Ocellar's well developed, directed obliquely forward, rarely almost

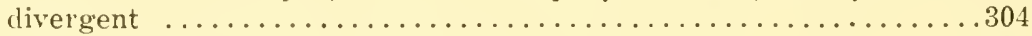
Ocellars reclinate, absent or scarcely differentiated............298

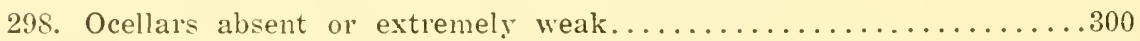
Ocellars reclinate.................................... 299

* Curran, 1928, Can. Ent., Ix, p. 4S.

† Curran, 192\%, Can. Ent., lix, 1. 300. 
299. Penultimate aristal segment elongate............ Distichona Wulp Penultimate aristal segment not over twice as long as wide.

Vibrissovoria Townsend

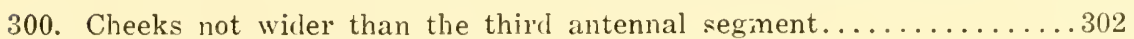

Cheeks much wider than the third antennal segment..............301

301. Posterior tibiæ evenly, closely ciliate; parafacials narrow; smaller

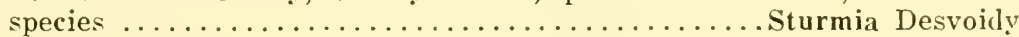
Posterior tibiæ not closely ciliate; parafacials wicle; large species.

*Belvosia Desvoidy

302. Both sexes with reclinate orbital bristles................... 308

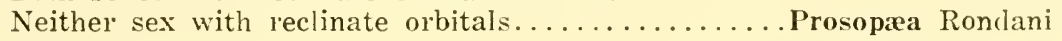

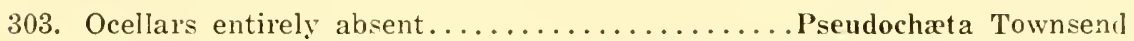
Ocellars very snall but distinct and cruciate; male with two reclinate and one proclinate orbital...............Argyrochæt ona Townsend

304. A pical crossvein present............................... 306

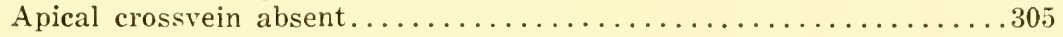

305. Parafacials much wider than antennæ.......... Roeseliopsis Townsend

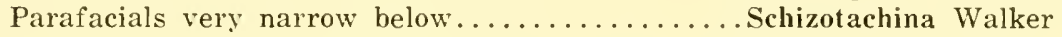

306. Posterior tibiæ not ciliate, or if so the bristles are rather widely separated with two or more of them longer or the parafacials are not hairy below the frontal bristles............................

Posterior tibix evenly closely ciliate, at most one of the bristles conspicuously longer than the rest; parafacials usually haired on the

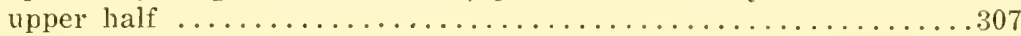

307. Cilia on posterior tibiæ long, very dense and contiguous; parafacials usually with hairs below the frontais (Thysanopsis Tns., Blephari-

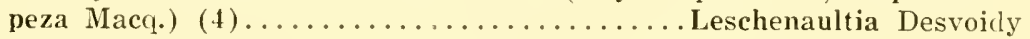
Cilia less numelous, not quite contiguous; parafacials kare (109).

†Achætoneura Brauer \& Bergenstamm

308. Frontal bristles extending but little below the base of the third antennal segment, usually a single bristle below the base; fourth vein without a fold or the facial ridges bristled on more than the lower

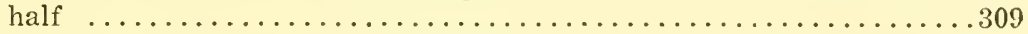

Frontals extending to the middle of the third antennal segment, at least two bristles below the base of the arista; eyes sparsely short haired; bend of fourth vein with a iong fold; facial ridges usually

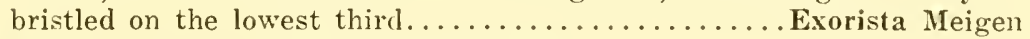

309. Middle coxæ without stout apical spines.................... 310 Mirldle coxæ with short, stout curved spines on the apex $\left({ }^{\circ}\right)(136,137$, $153,175) \ldots \ldots \ldots \ldots \ldots \ldots \ldots \ldots \ldots$ Doryphorophaga Townsend

310. First vein with at most two or three weak bristles.............. 311 First vein bristled on at least the apical half.... Chatophleps Coquillett

311. Appendage or fold of fifth vein less than one-third as long as the

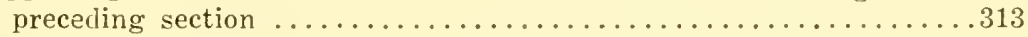

Appendage or fold of fifth vein more than half as long as the preced-

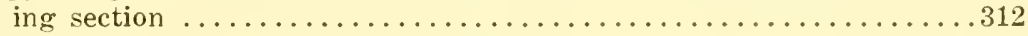


312. Eyes quite bare; ultimate section of fifth vein only about half as long

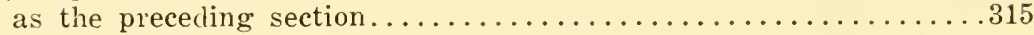
Eyes with short, sparse hair; apical section of fifth vein two-thirds as long as preceding section $(\mathbf{9 7}, 98) \ldots \ldots \ldots$. . Stomatomya Rondani

313. Apical cell open or closed in the wing margin................. 317 Apical cell closed and petiolate................................ 314

314. Arista almost wholly thickened.......................... 315 Arista slender on apical fourth or more.

Anachætopsis Brauer \& Bergenstamm

315. Arista slender on apical half or more.......... Phøeniceomyia Townsend Arista almost wholly thickened............................ 316

316. Penultimate aristal segment four times as long as wide (114).

Penultimate aristal segment not twice as long as wide.

Chætoglossa Townsend Archiclops Bischoff

317. Proboscis shorter than the head-height...................... 318 Proboscis twice as long as the head-height; aristal segments of almost

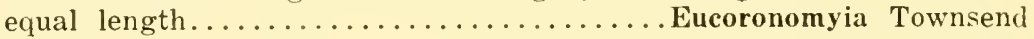

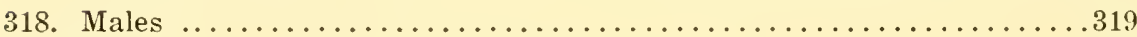

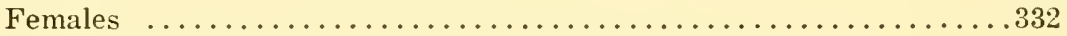

319. Orbital bristles present although sometimes situated almost in the

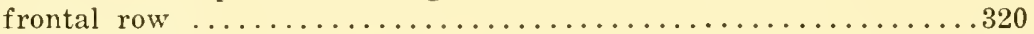

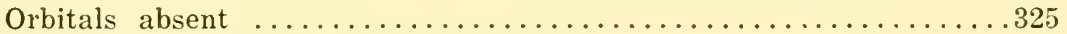

320. Abdomen with discals, not unusually deep..................... 321

Abdomen without discals, elongate and deep; antennæ arising below the middle of the eyes; two pairs of presutural acrosticals and dor-

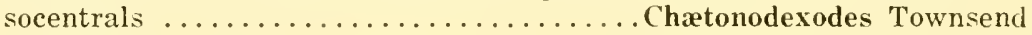

321. Anterior tibiæ with two or three strong posterior bristles..........323 Anterior tibiæ with a single posterior bristle.................... 322

322. Third antennal segment divided into two lobes..... Schizotachina Walker Third antennal segment entire, not unusually wide... Celatoria Coquillett

323. Frontal vitta wider anteriorly than the least width of either para-

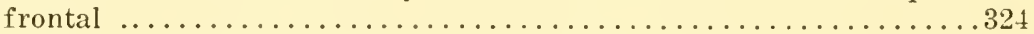

Frontal vitta nowhere wider than the least width of either parafrontal, not widening anteriorly.....Paralispe Brauer \& Bergenstamm

324. Front almost or quite as wide as either eye....... Racodineura Rondani Front less than two-thirds as wide as either eye (Arrhinomyia B. B.) $(149,173) \ldots \ldots \ldots \ldots \ldots \ldots \ldots \ldots \ldots \ldots \ldots \ldots \ldots \ldots \ldots \ldots \ldots \ldots \ldots \ldots$ Elodia Desvoidy

325. Second antennal segment not unusually bristly above but with some

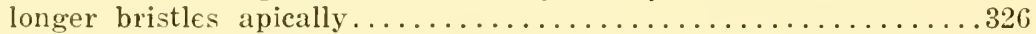

Second antennal segment densely bristled above; facial ridges with bristles on more than the lower half (9).... †Tachinomyia Townsend

* Villeneuve and Aldrich $(1929,1933)$ recognize Arrhinomyia as distinct from Elodia but I see no reason for this.

† Curran, 1926, Tr. Roy. Soc. Canada, Sec. V. p. 168. 
326. Anterior tibire with at least two posterior bristles; species over $5 \mathrm{~mm}$.

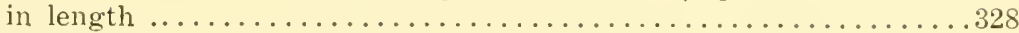

Anterior tibire with a single posterior bristle; species about $4 \mathrm{~mm}$.

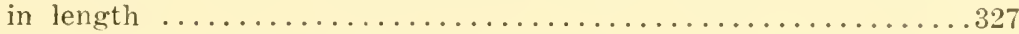

327. Apical cell ending very close to the wing-tip....... Oxynops Townsend Apical cell ending far before the wing-tip.............Bessa Desvoidy

328. Abdomen tapering or not, often with discals; posterior forceps split on apical portion, never laterally compressed...............329 Ablomen elongate, tapering, rarely with discals; posterior forceps of male united into a long, compressed organ (9).*Tachinomyia Townsend

329. Apical scutellars cruciate............................. 330

Apical scutellars absent or divergent...........................

330. Antennæ reaching slightly beyond the oral margin, the third segment at least six times the length of the second (Europe).. Frontina Meigen Antenna not reaching the oral opening; third segment not over four times the length of the second..............Allophorocera Hendel

331. Parafacials wicle, the cheeks two-thirds as wide as the eye-height, the parafacials setulose on the upper half.......... Centeter Aldrich Parafacials narrower, the cheeks less than one-third the eye-height.

Degeeria Meigen

332. Genital opening not slit-like; abdomen broader than leep..........334 Genital opening slit-like; abdomen broad and deep.................333

333. Orbitals scarcely divergent; abdomen rarely with discals (9).

*Tachinomyia Townsend Orbitals conspicuousty divergent; abclomen always with discals.

Allophorocera Hendel

334. Third vein with a single strong basal bristle................... 339 Third vein with two or more basal bristles.......................

335. Arista pubescent or bare; third vein with not more than five bristles

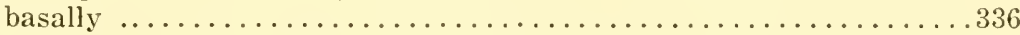
Arista short plumose; third vein bristled almost to the small crossvein.

Paralispe Brauer \& Bergenstamm

336. Parafacials almost as wicle as the median depression, setulose on

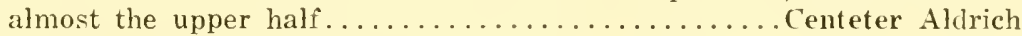
Parafacials narrower, bare below the lowest frontals.............337

337. Penultimate aristal segment very elongate.

Trichopareia Brauer \& Bergenstamm Penultimate aristal segment short; abdomen with or without short

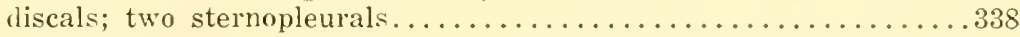

338. Niddle tibiæ with two strong anterodorsal bristles. Frontiniella Townsend Middle tibiæ with only one strong anterodorsal bristle. Oxynops Townsend

339. Lower margins of the second tergite strongly produced downward and with numerous spinose setulæ; oripositor long and slender, often

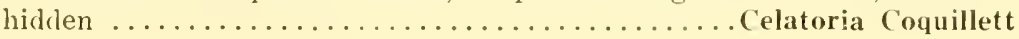


Tergites not producel clownward, the ellges rarely setulose; ovipositor

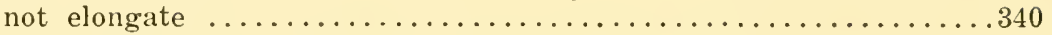

340. Face narrower than either eye; penultimate aristal segment short

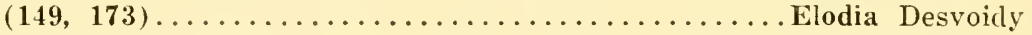
Face wider than either eye; penultimate aristal segment elongate.

Schizotachina Walker

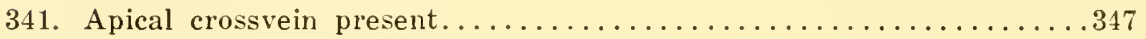
Apical crossvein absent.....................................

342. Posterior crossvein present......................... 343

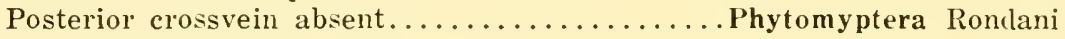

343. Antennæ reaching the lowest fifth of the face.............. 344 Antennæ not reaching below the lowest third of the face.

Hemithrixion Brauer \& Bergenstamm

344. A single bristle at the base of the third vein................. 345 Three or more bristles on the third vein........................ 346

345. Parafacials narrower than the third antennal segment.

Parafacials twice as wide as the third antennal segment.

\section{Schizotachina Walker}

Roeseliopsis Townsend

346. Antenin arising near upper edge of eyes, enormous in size; head almost rectangular"; bristles of thorax not unusually depressed (28, 29, 144) ...................... Euryceromyia Townsend Antennæ arising lower down; head not nearly rectangular; bristles of thorax depressed $(148,189) \ldots \ldots \ldots \ldots \ldots \ldots \ldots$ Actia Desvoidy

347. Palpi present and well developed.......................... 354

Palpi absent or but little longer than the width of the proboscis at

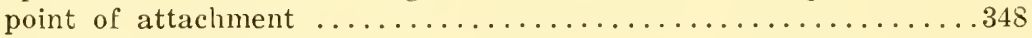

348. Arista bare or pubescent............................... 349 Arista plumose; face strongly carinate............. Prosena Serville

349. Third antennal segment usually less than three times the length of the second, if long the abdomen pedunculate................. 350 Third antennal segment five times the length of the second, broadened apically, concave above $(47,70) \ldots \ldots \ldots \ldots \ldots \ldots$ Beskia Wulp

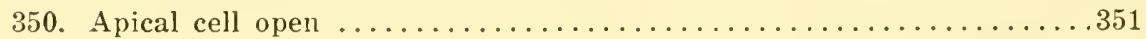
Apical cell closed and petiolate $(54) . . . \ldots \ldots *^{*}$ Cylindromyia Latreille

351. Face not conspicuously receding, concave in profile, the oral margin produced; vibrissæ situated well above the oral margin.........352 Face receding; oral margin not produced; vibrissæ level with oral margin $(63,64) \ldots \ldots \ldots \ldots \ldots \ldots \ldots \ldots \ldots \ldots \ldots \ldots \ldots \ldots \ldots \ldots \ldots \ldots$ Icelia Desvoidy

352. Second abdominal segment strongly narrowed.....Polistiopsis Townsend Second abdominal segment not narrowed, much broader than deep....353

353. Palpi entirely absent.................Paraphasiopsis Townsend Palpi narrow, four times as long as wide, or longer. . Phasiopsis Townsend

* Aldrich, 1926. Pr. U. S. N. M.. Ixviii, Art 23, p1) 1-2i. 
354. Apical cell at most with an extremely short petiole.............. 359 Apical cell with a petiole almost one-third the length of the apical

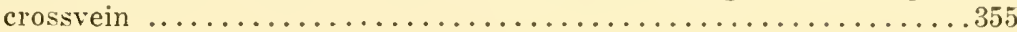

355. Antennæ shorter than the face, the middle of the face depressed; vibrissæ situated on a level with or above the anterior oral margin. 356 Antennæ longer than the face; middle of face longitudinally convex, not depressed; vibrissæ situated below the anterior oral margin; wings pictured $(80,81) \ldots \ldots \ldots \ldots \ldots \ldots \ldots \ldots$ Euthera Loew

356. Ocellar bristles proclinate.............................. 357

Ocellar bristles directed more or less backward $(67,68)$.

Leucostoma Meigen

357. Third vein ending in the wing-tip; oral margin produced.......... 358 Third vein ending well before the wing-tip $(44,53)$.

Vanderwulpia Townsend

358. Front of female wide; four pairs of marginal scutellars.

Psalidopteryx Townsend

Front of both sexes strongly narrowed; three pairs of marginal scutellars .................... Clistomorpha Townsend

359. Ultimate section of the fifth vein less than half as long as the pre-

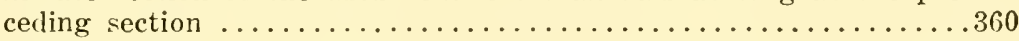

Ultimate section of the fifth vein three-fourths as long as the pre-

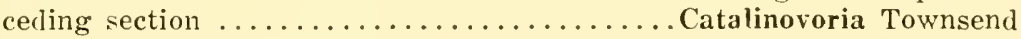

360. Penultimate aristal segment not over twice as long as wide........371

Penultimate aristal segment three times as long as wicle, or if somewhat shorter, widened apically and the proboscis geniculate.....361

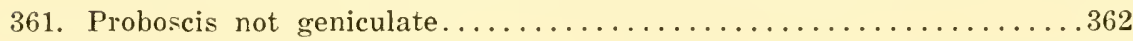

Proboscis long and geniculate, the labellæ turned back, narrow and more or less fused $(78,183) \ldots \ldots \ldots \ldots \ldots \ldots \ldots$ † Siphona Meigen

362. Proboscis, beyond the basal articulation, not as long as the head-

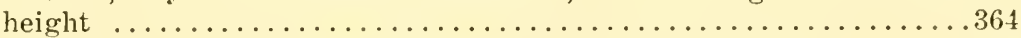

Apical section of the proboscis longer than the head-height........363

363. Antennæ reaching almost or quite to the oral margin; face not receding; parafacials at most one-third as wide as the third antennal segment $(14,82,150,174) \ldots \ldots \ldots \ldots \ldots \ldots$ Epigrimyia Townsend

Antennæ not reaching to the moderately produced oral margin; parafacials more than half as wide as third antennal segment; face re-

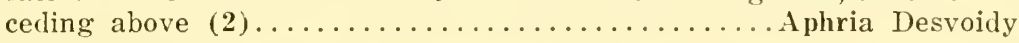

364. Third antennal segment of the male not furcate.............. 365 Third antennal segment of the male furcate......Acronarista Townsend

365. Third vein with not more than three bristles basally ............ 368 Third vein bristled more than half way to the small crossvein......360

366. Bristles of the thorax erect............................... 367

Bristles of the thorax rather appressed $(148,189) \ldots \ldots$ Actia Desvoidy

\footnotetext{
* Curran, 1927, Can. Ent., lix, p. 297.

$\dagger$ Curran, 1932, Amer. Mus. Novit. No. 534, p. 13 (Bucentes).

$\ddagger$ Curran, 1933, Amer. Mus. Novit. No. 614, pp. 1-7.
} 
367. Head about as long as high........Masistylum Brauer \& Bergenstamm Head much higher than long.............. Phantasiomyia Townsend

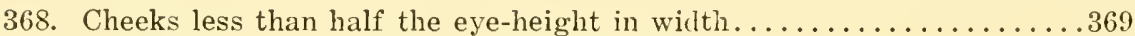
Cheeks nearly as wide as the eve-height $(28,29,144)$.

Euryceromyia Townsend

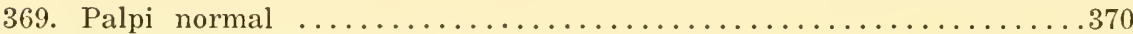

Palpi very greatly swollen, unusually large......... Lispidea Coquillett

370. Third antennal segment more than twice as long as wide.

Clausicella Rondani Third antennal segment less than twice as long as wide (16).

Plectops Coquillett

371. No appendage or fold at bend of fourth vein, if an adventitious appendage is present it is not continued in the same line as the fourth

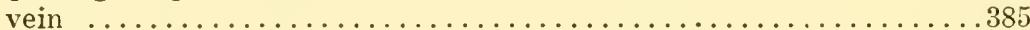

An appendage or distinct fold at the bend of the fourth vein, the appendage continued in almost the same line as the preceding sec-

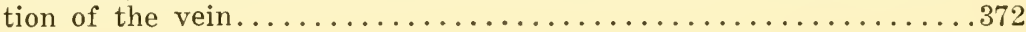

372. Posterior pair of presutural acrostical bristles situated very close to the suture and much behind the posterior pair of presutural dorso-

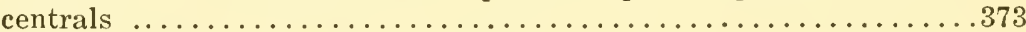

Posterior pair of presutural acrosticals almost in a line with the posterior presutural dorsocentrals or in front of them..........374

373. Frontal bristles extending almost to the middle of the third antennal segment; genital opening not slit-like.............Exorista Meigen

Frontals descending but little below the base of the third antennal segment; genital opening rather slit-like $(9)$.. ${ }^{*}$ Tachinomyia Townsend

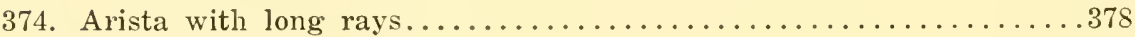

Arista pubescent or bare.................................. 375

375. Intermediate abdominal segments without discals.............. 376

Intermediate abdominal segments with paired discals; fourth vein with very short appendage, or none; face never carinate.

Dexodes Brauer \& Bergenstamm

376. Cheeks not over one-third as wide as the eye-height............. 377 Cheeks about half as wide as the eye-height........ Ochrocera Townsend

377. Abdomen long and narrow; ultimate section of proboscis elongate.

Catenophrys Townsend Abdomen oval; proboscis short and robust......

378. Face not strongly carinate, more or less carinate in the middle above.381 Facial carina strongly developed and reaching to the clypeal region...379

379. Prosternum bare ......................................... Prosternum with two pairs of bristles......... Trichoduropsis Townsend

* Curran, 1926, Tr. Roy. Soc. Canada, Sec. V, p. 168.

† Curran, 1927. Can. Ent., lix, p. 20.

* This genus was described from specimens reared in Massachusetts from material originating in Japan. 
380. Pteropleural bristle extending to beyond the apex of the squamæ; apical abdominal segment of the male very strongly produced.

Trichodura Brauer \& Bergenstamm

Pteropleural bristle short as usual; abdomen not cylindrically pro-

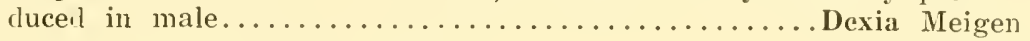

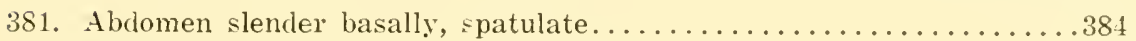

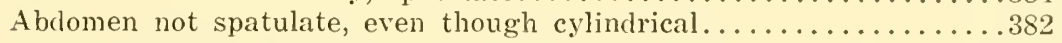

382. Abdomen very slender and not tapering from near the base; costa with an extremely strong bristle near the base on the inner side

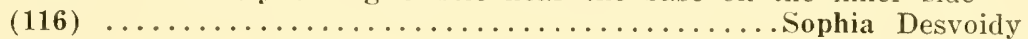
Abdomen broader and more tapering; costal bristles short and fine...383

383. Abdomen metallic blue $(147,177) \ldots \ldots \ldots \ldots \ldots \ldots$ Zuanalia, n. g. Abdomen black in ground color $(128,131) \ldots \ldots \ldots \ldots$ Zelia Desvoidy

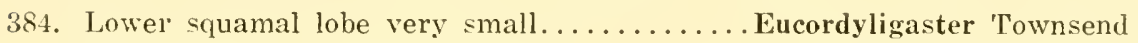
Lower squamal lobe large as usual........... Cordyligaster Macquart

385. Vibrissal angles not unusually prominent, if situated high above the oral margin the facial depression is not deeply sunken below; head not twice as high as lorg, or if so the face strongly retreating....386

Vibrissal angles high, the facial depression carried far below them at a much lower level; head twice as high as long; prosternum

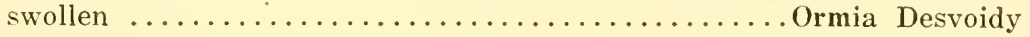

386. Posterior pair of presutural acrostical bristles situated very close to the suture and much behind the posterior pair of presutural dorsocentrals; always three pairs of presutural dorsocentrals.........387

Posterior pair of presutural acrosticals situated but little behind the posterior presutural dorsocentrals, or there are but two pairs of the latter; presutural acrosticals sometimes absent.............422

387. Vibrissæ at most half the length of the second antennal segment above

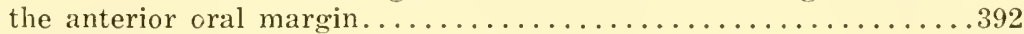

Vibrissæ situated high above the oral margin................... 388

388. Antennæ reaching at least to the lowest third of the face, the second segment not nearly as long as the third; vibrissæ only moderately

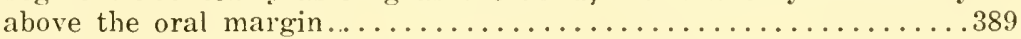

Antennæ unusually small, the second segment almost as long as the third; vibrisse situated very high above the oral margin (6).

† Atacta Schiner

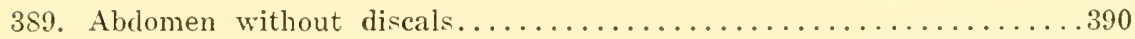

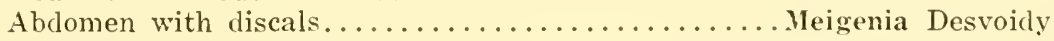

390. Parafrontals with numerous hairs on the anterior half ........... 391 Parafrontals with but few hairs on the anterior half.

Masiphya Brauer \& Bergenstamm

391. Oral margin carried rather strongly forward below the vibrissæ.

tSiphosturmiopsis Townsend Oral margin not conspicuously produced............. Sturmia Desvoidy

* Aldrich, 1927. Journ. Wash, Acad. Sci., xvii, p. 85.

$\div$ Aldrich, 1925. Pr. U. S. N. M.. lxvi, Art. 18, p. 29.

$\ddagger$ Reinhard, 1931, Pr. U. S. N. M., Ixix, Art. 11, n. 9 . 
392. Posterior tibiæ evenly and closely ciliate above with fairly long bristles, only one of which may be longer and stronger.........420 Posterior tibiæ not evenly ciliate................................

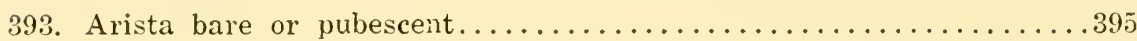

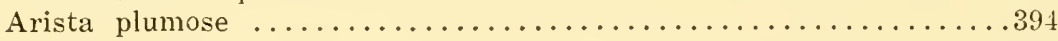

394. Cheeks half as wide as eye-height $(128,131) \ldots \ldots \ldots$. Zelia Desvoidy

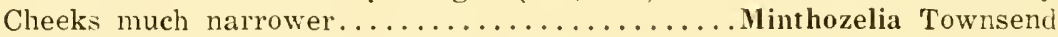

395. Apical cell ending far before the wing-tip . . . . . . . . . . . . . 409 Apical cell ending at or near the wing-tip...................... 396

396. Costal spine not strongly developed, never as long as the width of the costal cell and not outstanding, if somewhat long the parafacials are decidedly narrower than the width of the third antennal seg-

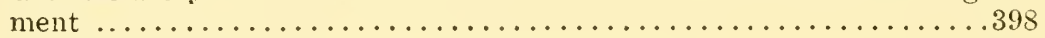
Costal spine longer than the width of the costal cell.............397

397. Facial riuges convex in profile; liscals present.

Phrynofrontina Townsend Facials ridges concave below; discals absent $(48,49)$.

\section{Spathidexia Townsend}

398. Female abilomen not strongly keeled........................ 399 Female abdomen strongly keelerl, the edges of the tergites spined.

Jicalt epecia Townsend

399. First vein bare................................ 400

First vein with strong bristles on the apical half; antennæ arising above the middle of the eyes................ Clausicellana Curran

400. Lower margin of head not strongly oblique on anterior half; posterior sublateral present ...............................

Lower margin of the head strongly oblique on the anterior half; posterior sublateral absent; three pairs of scutellars.

Pelatachina Meade

401. Apical abiominal segment horizontal, the genital opening visible from

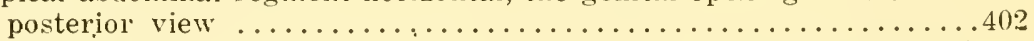
Apical abdominal segment vertical, the genital opening wholly ventral.

Panacemyia Townsend

402. Male with orbitals (rarely with a single one in the frontal row); outer verticals of $\&$ two-thirds as long as the verticals..........406 Male without orbitals; outer verticals of $q$ little more than half as long as verticals .................................

403. Third antennal segment at least three times as long as wide, or not

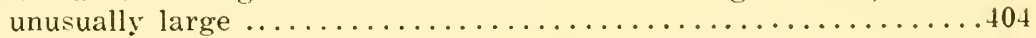

Third antennal segment very large, long and almost half as wide as its

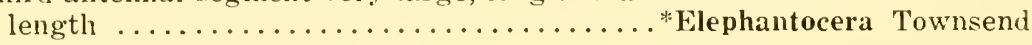

404. Palpi not unusually swollen; third vein with two or three basal

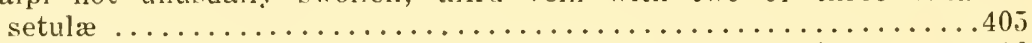
Palpi greatly swollen; third vein setulose to small crossvein........405

* Curran, 1930, Bull. Amer. Mus. Nat. Hist., lxi, p. 96. 
405. Tergites of female produced downward and finely spined.

Schizocerophaga Townsend Tergites of female normal.............. Lixophaga Townsend

406. Third vein bristled to the small crossvein; facial ridges convex in

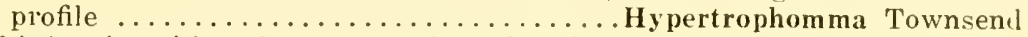
Third vein with only two or three basal bristles; sublateral bristle

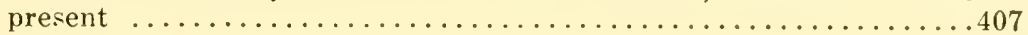

407. Facial depression deep, the parafacials prominent in profile........40s

Facial depression shallow, the parafacials very low in profile, the ridges flat; head short $(158,165) \ldots \ldots \ldots \ldots \ldots \ldots$ Patillalia, n. g.

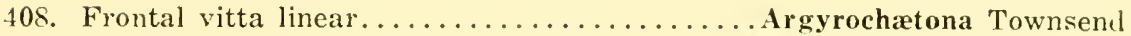
Frontal ritta not remarkably narrow.......Microceromacia Villeneuve

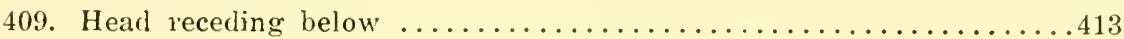

Head as long below as at the oral margin......................... 410

410. Ablomen with strong marginals on the intermediate segments.....411 Abdomen without strong marginals on the intermediate segments; vibrissæ situated far above the oral margin.

Masiphya Brauer \& Bergenstamm

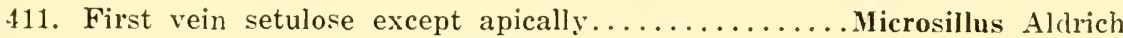

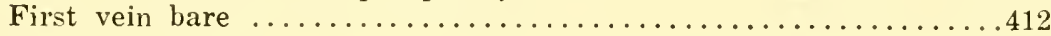

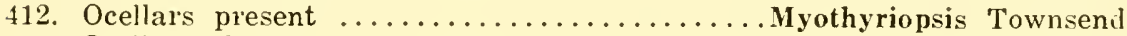

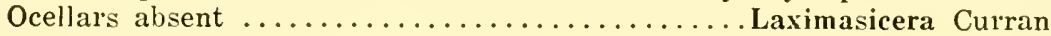

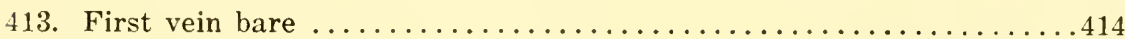

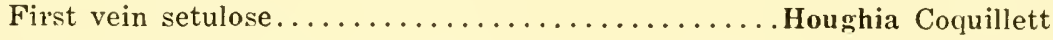

414. Front scarcely longer than the face, more or less convex, not promi-

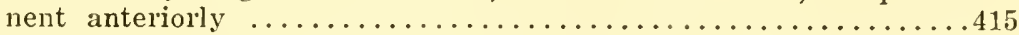

Front longer than the face, not convex in profile, produced anteriorly; abdomen with discals; apical scutellars erect .......Meigenia Desvoidy

415. Ocellars absent or very weak.......................... 419

Ocellars present; discals present or absent................416

416. Face unusually flat, the head short; parafacials very narrow below

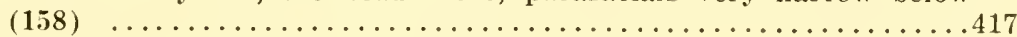
Face not unusually flat, the head more elongate (1)... † Lydella Desvoidy

417. Third vein bristled to small crossvein.................... 418 Third vein with two or three very strong basal bristles $(158,165)$.

Patillalia, n. g.

418. Ocellars very strong $(\mathbf{1 6 0}, \mathbf{1 7 9}) \ldots \ldots \ldots \ldots \ldots \ldots$ Agrarialia, $n$. g. Ocellars short and rather weak $(143,168) \ldots \ldots \ldots \ldots$ Aridalia, n. g.

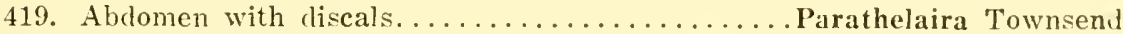

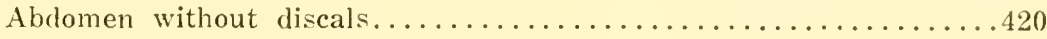

420. Parafrontals each much less than four times as wide as the frontal vitta; front not convex; ocellars present...............421.

Aldrich. 1925. Pr. Ent. Soc. Wash., sxvii, p. 133.

† Curran, 1932. Amer. Mus. Novit. No. 526, p. 11 (Erycia). 
Parafrontals wide, the median vitta less than one-fourth as wide as the parafrontals at the middle; ocellars absent; front gently convex.

Argyrophylax Brauer \& Bergenstamm

421. Oral margin rather strongly procluced........... Siphosturmia Coquillett

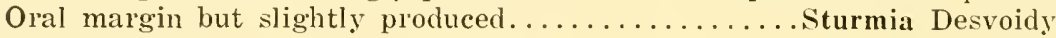

422. Face at least moderately retreating. ..................... 449

Face but little retreating, almost or quite as long below as at base of

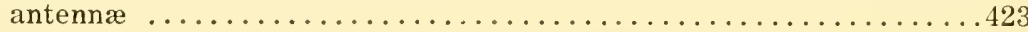

423. Apical section of the proboscis nuch shorter than the head-height or the apical cell ending far before the wing-tip..............427 Apical section of the proboscis at least as long as the head-height; apical cell ending close to the wing-tip................... 424

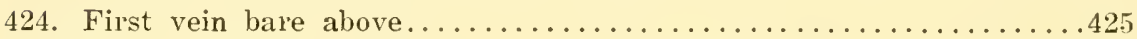
First vein setulose above..........Leskiomima Brauer \& Bergenstanum

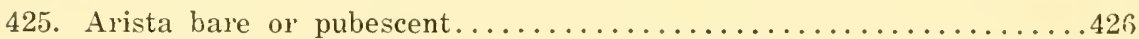
Arista with very long rays $(\mathbf{1 7 6}, \mathbf{1 8 5}) \ldots \ldots \ldots \ldots$. . . . . .

426. Head decicledly higher than long $(14,82,150,174)$. Epigrimyia Townsend Head as long below as its height..............Weberia Desvoidy

427. Parafacial decidedly less than half as wide as the facial depression;

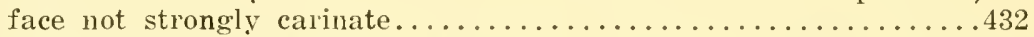
Parafacial at the narrowest part almost or quite half as wicke as the facial depression, or the face strongly carinate.............428

428. A rista long plumose............................. 429 Arista pubescent or bare.................. Apachemyia Townsend

429. Facial carina weak $(128,131) \ldots \ldots \ldots \ldots \ldots \ldots \ldots$. . . . . . . Desvoidy Facial carina strong ......................................

430. Antennæ reaching little more than half way to the oral margin......431 Antennæ reaching three-fourths of the way to the oral margin (120,

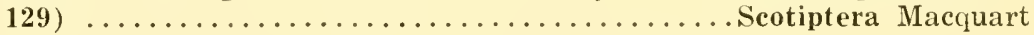

431. Third anteniral segment three times as long as the second.

Eudexia Brauer \& Bergenstamm Third antennal segment not three times longer than wide, in the male only slightly longer than the second $(127,130)$..Hystrichodexia Röder

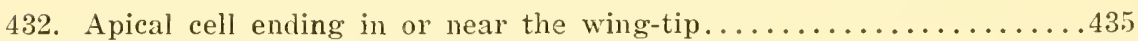
Apical cell ending well before the wing-tip..................... 433

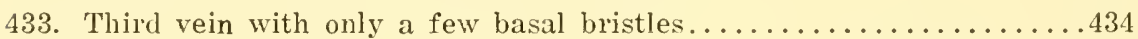
First and fifth veins bristled above $(123) \ldots \ldots \ldots$. Thelaira Desvoidy

434. Frontal vitta not wider than either parafrontal..... Demoticus Macquart Frontal vitta twice as wide as either parafrontal; a row of orbitals.

Euhalidaya Walton

435. Third antennal segment near the base not wider than the second, or if so, the abdomen elongate and narrow.................. 437 Third antennal segment conspicuously wider than the second; abdo-

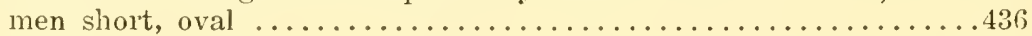

436. Presutural acrosticals scarcely developed.... Chrotostigmoptera Townsend Presutural acrosticals well developed $(148,189) \ldots \ldots *$ Actia Desvoidy

" Curran, 1933, Amer. Mus. Novit. No. 614, pp. 1-7. 
437. Apical ablominal segment horizontal, the genital opening eviclent

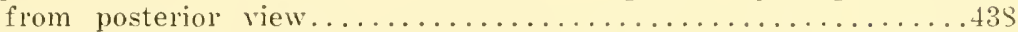
Apical abdominal segment vertical at apex, the genital opening ventral $(117,126) \ldots \ldots \ldots \ldots \ldots \ldots \ldots \ldots \ldots \ldots \ldots \ldots \ldots \ldots$ Calodexia Wulp

438. Costal spine not strongly developed; olal margin prominent; wings not brown with pale spots..............................

Costal spine long; oral margin and vibrissal angles scarcely raised; wings brown with hyaline spots...............Jamacaria Curran

439. Largely yellowish species........................... 441

Wholly black species; wings partly brown................440

440. First vein bare; third with a single basal bristle (Plectops?).

Nephopteropsis Townsend

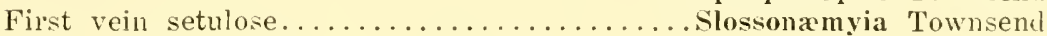

441. Third antennal segment narrower than the second or the fifth vein

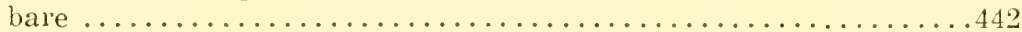
Third antemal segment wider than the second, the fifth vein setulose.

Trichotopteryx Townsend

442. Head at most one and one-half times as high as long............443 Heal almost twice as high as long.............. Xanthodexia Wulp

443. Palpi variable, sometimes shortened, usually curver, never broad and

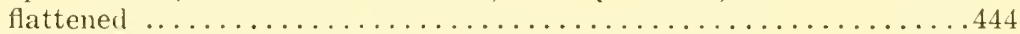

Palpi long, broad and flattened on the apical half or more, never

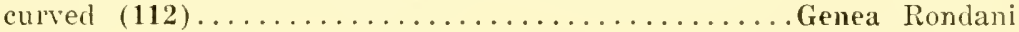

444. At most two presutural acrostical or dorsocentral bristles........446 Three presutural acrostical and dorsocentral bristles............445

445. Abdomen with discals $(36) \ldots \ldots \ldots \ldots \ldots \ldots$ Binghamimyia Townsend

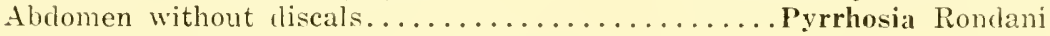

446. Abiomen cylindrical or wirler than deep apically............ 447 Abctomen laterally compressed on the apical half; small, slender

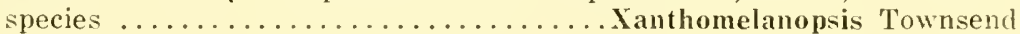

447. First abdominal segment with marginals....................448 First abdominal segment without marginals (93)..... Fischeria Desvoidy

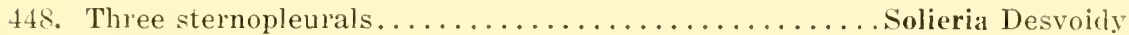
Two sternopleurals................... Opsoleskia Townsend

449. Arista bare or pubescent................................ Arista plumose, rery long pubescent or shert pectinate.........450

450. Arista plumose or pectinate. . . . . . . . . . . . . . . . 451 Arista long pubescent; antennæ arising at the lowest third of the eyes; clypeal region long...............Eumegaparea Townsenel

451. Abromen without discals.......................... . . . . Abromen with discals $(132) \ldots \ldots \ldots \ldots \ldots \ldots \ldots \ldots$ Chrotona Wulp

452. No strong presutural acrosticals...........Phyllophilopsis Townsend At least one pair of strong presutural acrosticals.............453

453. Ocellars weak ol absent................................ 454 Ocellars well developerl...........Psendodexia Brauer \& Bergenstamm

\% Curran, 1934, Amer. Mus. Novit. No. 685, 1p) 1-21. 


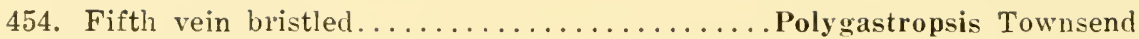

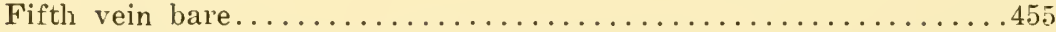

455. Apical abdominal segment of the male very strongly produced posteriorly; ocellars small............... Urophillophila Townsend Apical abdominal segment not produced; ocellars absent.

Opsoleskia Townsend

456. Third antennal segment never with the apical corner acutely pro-

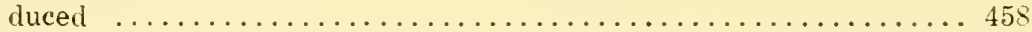
Apex of the third antennal segment produced as a short, sharp spur

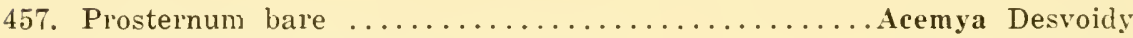
Prosternum haired (Myothyria Wulp)........................ Rondani

458. Apical cell ending at or near the wing-tip................ 458

Apical cell ending far before the wing-tip; cheeks usually twice as wide as third antennal segment; abdomen with discals; two presutural acrosticals and three dorsocentrals.

*Dexodes Brauer \& Bergenstamm

459. Third antennal segment rarely unusually wide and long, if so the palpi yellow or the facial depression not unusually deep........460

Third antennal segment more than six times as long as the second, unusually wide; facial depression very deep; palpi white.

Edematocera Townsend

460. Over $9 \mathrm{~mm}$. in length; apical cell narrowly opened or closed in the costa; discal crossvein joining the fourth vein three-fourths the distance beyond the small crossvein; abdomen with discals.

Pelatachina Meade Usually less than $8 \mathrm{~mm}$. in length; not possessing the above combina-

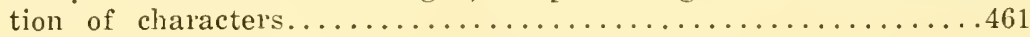

461. Cheeks not over one-third as wide as the eye-height..........462 Cheeks two-thirds as wide as the eye-height............ Clista Meigen

462. Second abdominal segment with dorsal bristles.................463 Second abdominal segment without dorsal bristles. Calpodomyia Townsend

463. Bristles of the thorax suberect; first and fifth veins never bristled....464 Bristles of the thorax subappressed; first and fifth veins often bristled $(148,189)$ (cf.Spathidexia)............. † Actia Desvoidy

464. Ventral margin of at least the second tergite in the female with stout, spinose setulæ; knob of halteres brown in male........465 Tergites without such setulæ in female; halteres yellow.........466

465. Second antennal segment of male large, half as wide as long.

Elephantocera Townsend Second antennal segment of male not large, three times as long as

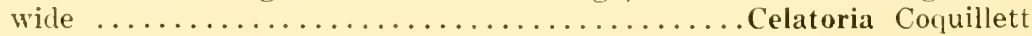

466. Arista bare, short pubescent or extremely short plumose........468 Arista very conspicuously short plumose; genital opening apical....467

467. Three pairs of strong presutural acrosticals $(\mathbf{1 5 1}, 157)$.

Thelairalia, n. g.

* Curran, 1927, Can. Ent., lix, 1. 23.

$\dagger$ Curan, 1933, Amer. Mus. Novit. No. 614, 1pp. 1-7. 
At most two pairs of strong presutural acrosticals, the posterior pair not situated very close to the suture $(132) \ldots \ldots \ldots \ldots$ Chætona Wulp

468. Arista wholly thick, tapering apically........Phantasiomyia Townsend Arista slender apically ............................ 469

469. Genital opening ventral, not visible from behind... Panacemyia Townsend Genital opening apical, visible from behind..................470

470. Frontal vitta linear (very narrow in $f$ )..... Argyrochætona Townsend

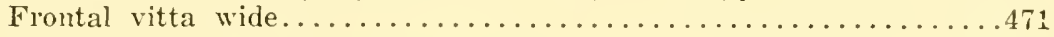

471. Anterior tibiæ with a single posterior bristle................473 Anterior tibiæ with two posterior bristles................. 472

472. Small slender species, under $5 \mathrm{~mm} .(149,173) \ldots \ldots \ldots$ Elodia Desvoidy Larger, robust species, over $6 \mathrm{~mm} \ldots \ldots \ldots \ldots$ Calothelaira Townsend

473. Frontal vitta twice as wide as the parafrontals, not at all narrowed medianly; anterior tibiæ without a conspicuous posterodorsal bristle $(181,193) \ldots \ldots \ldots \ldots \ldots \ldots \ldots \ldots$ Microtownsendia, n. g. Frontal vitta narrower than either parafrontal; anterior tibiæ with a single conspicuous posterodorsal bristle situated near the middle.

Tachinophyto Townsend

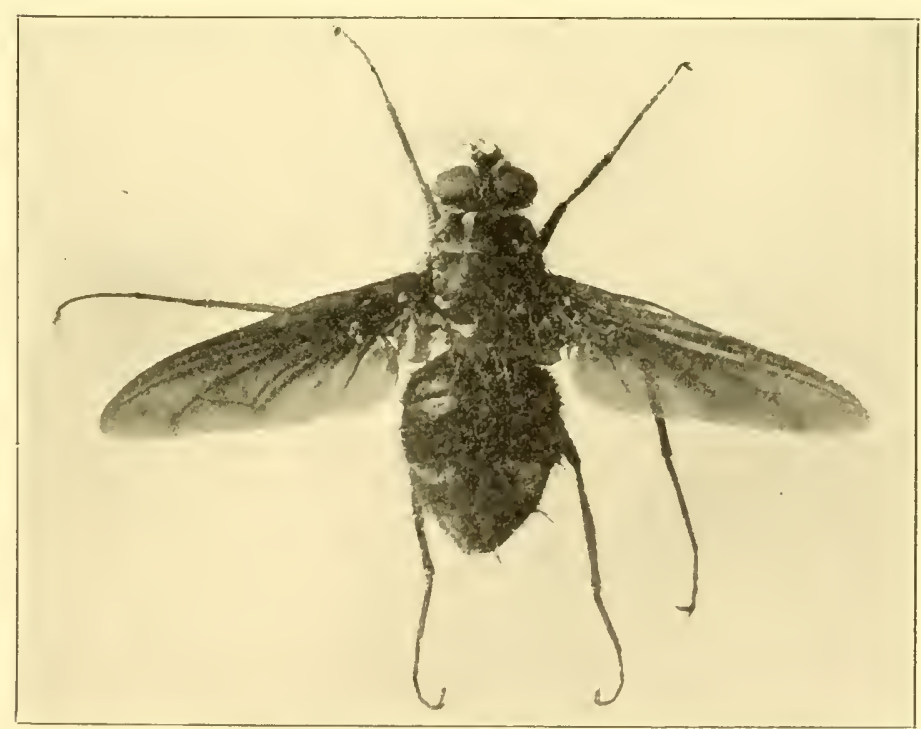

Scotiptera melaleuca. 


\section{Collatia, new genus}

This genus is proposed for the reception of Zenillia submissa Aldrich and Webber. It possesses the characters of Zenillia but has the proplenra haired on the middle portion.

\section{Townsendina, new genus}

Differs from Myiophasia Braner and Bergenstamm in having only one pair of presutural acrosticals and long, bristly hairs on the parafacials. Front narrow above, widening anteriorly; cheeks half as wide as the eye-height; antemnæ reaching four-fifths the distance to the oral margin, the second segment only one-third shorter than the third; arista thickened on basal fourth; proboseis short; eyes short pilose. Dorsocentrals 3-3; acrosticals 1-2; propleura bare; infrasquamal setulx present. Apical cell ending moderately before the wing tip; third vein with two bristles basally. Abdomen with diseals and marginals. Thorax einereous pollinose, weakly vittate: abdomen with broad, basal cinereous fascia on segments two to four. Genotype:- $T$. fasciuta, n. sp., (Colorado).

\section{Polidaria, new genus}

Proposed for Tuchina arcos Walker, a species placed in the genus Polidea by most author's. As it does not belong to Poliden, a new genus is proposed for its reception.

\section{Zonalia, new genus}

Female.-Head short, almost twice as high as long; two pairs of proclinate frontals; ocellars short; outer rerticals absent; cheeks narrow; face slightly retreating below; facial ridges with weak bristles on the lower half; antenne reaching to the oral margin; arista long plumose. Acrosticals 1-0; dorsocentrals 2-3; one sublateral; posthumeral absent; propleura bare; infrastuamal setulæ present; two sternopleurals; prosternum bare; three pairs of marginal seutellars. Anterior tibix with one posterior bristle. Apical cell ending close to the wingtip; third vein bristled more than half way to the anterior erossvein. Abdomen without discals; first scgment without marginals; ovipositor normal. Front, thorax and sides of abdomen with whitish pollen, although the whole insect appears shining hlack from most views. Length, $5 \mathrm{~mm}$. Genotype:-Z. nitens, n. sp. (Panama). 


\section{Corozalia, new genus}

Male-Eyes haired; front moderately narrow, without orbitals or ocellars; onter verticals absent; eheeks narrow; face moderately retreating, the oral margin produced; facial ridges bare; antennæ reaching lowest fifth of face, the second segment somewhat less than half as long as the third; arista practically bare; proboseis short; palpi elavate. Acrosticals and dorsocentrals 3-3, the posterior acrostieals elose to the suture; posterior sublateral present; posthumeral absent; sternopleurals 2-1; infrasquamal setulæ present. Anterior tibiæ with one long posterior bristle. Apieal eell ending moderately before the wing-tip; third vein with two basal bristles. Abdomen elongate, tapering, with paired discals; first segment with marginals. Blaek, with einereous pollen, the mesonotal pollen sometimes with yellowish tinge, with narrow, distinct ritte; apical half of abdominal segments bare. Length, 8 to 10 mm. Cenotype:-C. longula, n. sp. (Panama).

\section{Chætonalia, new genus}

Male.-Head almost twice as high as long; cheeks very narrow; face and front narrow; no orbitals; ocellars very small and hair-like; outer vertieals not developed; face slightly receding below, the ridges bare; antenna long, the second segment short; arista short plumose on basal half; proboseis short; palpi slightly clavate. Aerostieals 1-1; dorsocentrals 2-3; posterior sublateral and posthumeral absent; two sternopleurals; infrasquamal setule present. Apieal eell ending a little before the apex of the wing; third vein with two basal bristles. Abdomen with paired diseals; first segment with pair of marginals. Pollen einereous yellow, yellow on the front; mesonotum strongly quadrivittate; abdominal segments with about the apieal laalf bare. Luength, $5.5 \mathrm{~mm}$. Genotype:-C. lateralis, n. sp. (Panama).

\section{Canalia, new genus}

Female.-Front rather narrow; two pairs of orbitals; ocellars long; outer verticals strong; eheeks very narrow; face gently receding, the oral margin slightly produced; ridges bare; proboseis short; palpi very slightly elavate; antemme reaching almost to the vibrisse, the second segment short; arista short plumose. Acrosticals 2-1; dorsocentrals 2-3; posterior sublateral and posthumeral bristle absent; two sternopleurals; infrastruamal setulie present; prosternum haired. Wings tinged with brown, especially toward the apex: apical cell ending a little in front of the wing-tip; third rein bristled to the anterior crossvein. Abdomen elongate oval, without discals, the first segment without marginals. 
Black, the antennæ, coxæ and base of the abdomen on the broad sides, yellow; apex of abdomen red; pollen of the head white, of the mesonotum einereous yellow, a broad brown faseia immediately behind the suture; abdominal segments narrowly white pollinose basally. Length, $7 \mathrm{~mm}$. Genotype:-C. fasciata, n. sp. (Panama).

\section{Schwarzalia, new genus}

Female--Arista long plumose; parafacials with short, fine hair; front of moderate width, with two pairs of orbitals; ocellar's long; outer verticals weak; eleeks wide; face retreating, the oral margin produced; ridges bare; proboseis short; palpi searcely clavate; antennæ practically reaching the oral margin. Acrosticals weak, 3-1; dorsocentrals 2-3; posterior sublateral and posthumeral bristle absent; two sternopleurals; prosternum bare; infrasquamal setulæ present. Apical cell ending a little before the wing-tip; third vein bristled half way to the anterior crossvein; first vein bristled on whole length. Abdomen elongate oval, without diseals, the first segment without marginals. Black, the palpi, coxæ, femora mostly, humeri and basal half, or less, of the abdomen yellowish-red; head and the broad bases of the abdominal segments white pollinose; thorax cinereous pollinose, mesonotum. with a broad black band behind the suture. Length, $7.5 \mathrm{~mm}$. Genotype:S. Tuteipennis, n. sp. (Panama).

\section{Tachinalia, new genus}

Female--Robust, the abdomen broader than the thorax and not much longer than wide. Eyes with long hair; parafacials haired; front rather narrow, with two pairs of orbitals; ocellars long, outer verticals absent; cheeks wide; face retreating, the oral margin produced; ridges bare; proboseis short; palpi slightly clavate; antennæ reaching the lowest fifth of the face; arista bare. Acrosticals 2-3; dorsocentrals 3-3; posterior sublateral absent; posthumeral present; sternopleurals 2-1; prosternum bare; sentellum with many spinose bristles. Apical cell ending moderately before the wing-tip; third vein bristled basally. Abdomen almost wholly covered with spinose bristles. Head with einereous pollen, thorax thinly pollinose; seutelhum reddish, abdomen castaneous. Length, 10 to $11 \mathrm{~mm}$. Genotype:-T. Hispida, n. sp. (California) 


\section{Coloradalia, new genus}

Male.-Front wide, the frontals not strong; ocellars long, reclinate; chocks one-third as wide as eye-height; face strongly retreating, the ridges bristled on almost their whole length; middle of face deeply sunken, the oral margin not produced; antenmæ almost as long as the face, the second segment short; proboscis short, palpi clavate; eyes with short hair. Acrosticals and dorsocentrals 3-3, the acrosticals not strong; posterior sublateral weak, the posthumeral hair-like; two sternopleurals; prosternum concealed. Apical cell ending a little before the wing-tip; third vein with two basal bristles, one of them long; first vein bristled on its whole length. Abdomen elongate oval, very deep, the genitalia large, but normally mostly eoncealed; discals and marginals on segments two to four. Black, cinereous pollinose; the mesonotum and front with rellowish tinge; apices of segments less thickly pollinose. Length, $5 \mathrm{~mm}$. (Genotype:-C. ocellaris, n. sp. (Colorado).

\section{Lasionalia, new genus}

Male.-Related to Tounsendina, n. ‥, but the apical cell is elosed, the posterior sublateral present, ete. Eyes bare; front narrow, widening anteriorly; ocellars long; outer verticals not developed; eheeks almost half as wide as the eye-height; parafacials with a complete row of bristly hairs and a second partial row on the upper half; ridges bare; face strongly retreating, the oral margin searcely produced; proboseis short, the palpi slightly clavate; antennx not reaching to the vibrisse, the second segment somewhat shorter than the third; arista bare. Acrosticals and dorsocentrals 2-3; posterior sulblateral present, the posthumeral alssent; two sternopleurals: prosternum bare. Apical cell ending a little before the wing-tip, very short petiolate; third vein with one or two basal bristles. Abdomen elongate-oval, each segment with discals and marginals. Black, yellowish cinereous pollinose; palpi yellow; tibia rather reddish. Length, $5.5 \mathrm{~mm}$. Fenotype:-L. cinerea, n. sp. (Minnesota).

\section{Oxynopsalia, new genus}

Female.-Front of moderate width; two pairs of orbitals; ocellars long; outer verticals well developed; eheeks narrow: face strongly receding, the oral margin not produced; ridges bristled on more than the lower half; proboscis short; palpi clavate; antemna reaching to the oral margin, the second segment somewhat elongate; arista bare. Eyes short 
pilose. Acrosticals and dorsocentrals 3-3, the posterior presutural acrosticals situated elose to the suture; posterior sublateral and posthumeral bristle present; two sternopleurals; prosternum bare, narrow. Apical cell ending close to the wing-tip; third vein with three bristles basally. Abdomen elongate oval, each segment with marginals, the second and third with diseals; ovipositor simple. Blaek, the head and thorax cinereous pollinose, the mesonotum mostly brownish; bases of abdominal segments very narrowly white pollinose. Length, $4.5 \mathrm{~mm}$. Genotype:O. nitida, n. sp. (Panama).

\section{Anadiscalia, new genus}

Nale and female.-Head twice as high as long; front narrow, female with two pairs of orbitals; ocellars long; outer verticals weak; cheeks and parafacials extremely narrow; face retreating but slightly; oral margin not prominent, the ridges bare; proboseis short, the palpi clavate; antennæ reaching almost to the oral margin, the second segment short; arista bare; eyes short haired. Acrosticals and dorsocentrals 3-3; posthumeral and posterior sublateral present; two sternopleurals; prosternum haired. Apical cell ending moderately before the wing-tip; third vein with two bristles basally. Abdomen oval, not deep. Black, cinereons pollinose; palpi, humeri and abdomen reddish yellow, the abdomen with a more or less distinct median vitta, the apices of the segments more or less, and the fourth segment almost entirely black. All segments with marginals but without diseals. Length, 6 to $7 \mathrm{~mm}$. Genotype:-A. basalis, n. sp. (Panama).

\section{Zuanalia, new genus}

Female--Arista long plumose; front wide, with two pairs of orbitals; ocellars long; outer verticals moderately strong: eheeks almost half as wide as eye-height; parafacials bare; face strongly retreating on upper part, the oral margin slightly produced; proboscis short; palpi clavate, antenne reaching almost to the oral margin. Aerosticals 3-1, the presuturals very weak; dorsocentrals 3 -4; posterior sublateral absent; posthumeral present; sternopleurals 2-1; prosternum bare. Apieal eell ending a little before the wing-tip; bend of fourth vein with appendage; base of third rein with about four bristles. Abdomen short oval, rather deep. Head, thorax and legs reddish in ground eolor; head yellow pollinose; mesonotum metallie blue, eincreous pollinose, trivittate; abdomen wholly metallic blue, the bases of the segments cinereous pollinose. Length, $10 \mathrm{~mm}$. Genotype:-Z. azurea, n. sp. (Panama). 


\section{Patillalia, new genus}

Female.-Front of molerate width; two pairs of orbitals: ocellars long; outer verticals strong; checks narrow; face receding, the oral margin not produced; proboseis short; palpi clavate; antennx reaching almost to the vibrissax; arista very short pubescent. Dorsocentrals and acrosticals 3-3; posthumeral and posterior sublateral present; two sternoplemals; prosternum haired. Apical cell ending a little before the wing-tip; third vein with two strong basal bristles. Abdomen oval; all segments with marginals, the fourth with discals. Black; head white pollinose; the front yellowish above; thorax with white pollen on the sides, yellowish above, distinctly vittate; abdomen with very broad cincreous bands on the bases of the segments. Jength, $7 \mathrm{~mm}$. Genotype:-P. fasciata, n. sp. (Panama).

\section{Agrarialia, new genus}

Male.-Front wide, only a little narrower than the face; two pairs of strong orbitals; ocellars long; outer vertieals strong; cheeks very narrow; face retreating, the oral margin seareely produced; ridges bare; proboscis short; palpi clavate, hairy; antennæ reaching practically to the oral margin, the second segment short, arista rery short pubeseent. Aerostieals 3-3, dorsocentrals 3-4; posthumeral and posterior sublateral present; sternopleurals 2-1; prosternum haired. Apieal cell ending well before the wing-tip; third rein bristled almost to the anterior crossvein. Abdomen elongate oval, somewhat tapering; each segment with marginals, but no diseals; third segment with large sexual pateh below. Black, einereous pollinose, the head largely silvery; mesonotum with yellowish tinge, strongly vittate; apical third of abdominal segments shining black. Length, $7.5 \mathrm{~mm}$. Genotype:-A. sexutis, n. sp. (Panama).

\section{Aridalia, new genus}

Female.-Front about as wide as the face; two pairs of orbitals: ocellars rather short and weak; onter verticals well developed; eheeks very narrow: face receding, the ridges bare, the oral margin not produced; proboseis short; palpi weakly clavate; antenna reaching to the oral margin; arista short pubeseent. Acrosticals 3-3; dorsocentrals 3-4; posthumeral and posterior sublateral present: sternoplemals 2-1. Apieal cell ending well before the wing-tip: third rein hristled to the anterior erossveill. Abdomen elongate oval, tapering apirally; each 
segment with marginals but without discals. Black with einereous pollen; palpi yellow; sides of the abdomen broadly reddish on the basal half, the apex also reddish; pollen of front rather golden, of mesonotum more or less ochreous and strongly vittate; apices of abdominal segments broadly bare. Length $8 \mathrm{~mm}$. Cienotype:-A. lateralis, n. sp. (Panama).

\section{Shermanalia, new genus}

Male--Arista long plumose; front moderately narrow; oeellars long; outer verticals absent; eheeks one-third as wide as eve-height; face seareely retreating, the oral margin prominent, the ridges bare; apieal section of the proboscis as long as the head-height; palpi somewhat elavate; antennæ not reaching to the oral margin, the second segment short. Acrosticals 1-1, the anterior pair weak; dorsocentrals 2-3; posthumeral and posterior sublateral absent; sternopleurals 2-1; prosternum bare. Apical cell almost elosed a little before the wing-tip; third vein with two weak bristles basally. Abdomen elongate, more than twice as long as wide, rather cylindrical, all the segments with marginals but without discals. Black, clothed with thiek yellowish pollen; mesonotum with three black vittæ, the median one wide; first abdominal segment with an hourglass-shaped black spot, the base black, the following segments broadly black apically, the black expanding triangularly just below the sides. Length, $6 \mathrm{~mm}$. Genotype:-S. pretiosa, n. sp. (Panama).

Prorhynchops errans Curran (fig. 172) traces to this genus but the aristal rays arise from only the upper and lower surfaces. It is probably not a Prorhynchops as it laeks diseal bristles.

\section{Thelairalia, new genus}

Male-Front rather wide, with a single pair of strong orbitals; ocellars short and hair-like; onter verticals distinet; eheeks narrow; face reeeding, the oral margin not produced; proboseis short; palpi weakly elavate; antennix not reaching to the oral margin; arista very short plumose. Acrosticals 3-3; dorsocentrals 2-3; posterior sublateral poorly developed, the posthumeral absent; sternopleurals 1-1; prosternum haired. Apieal cell ending moderately before the wing-tip; third vein bristled more than half way to the anterior erossvein. Abdomen tapering, each segment with marginals, only the fourth with diseals. Black, yellow pollinose; mesonotum with four vittæ which unite to form 
a broad postsutural fascia; first abdominal segment wholly, the others on the apical half, shining. Length, $8 \mathrm{~mm}$. Cienotype:- T. fasciata, n. sp. (Panama).

\section{Microtownsendia, new genus}

Female.-Front as wide as the face; two pairs of orbitals; ocellars moderately strong; outer rertieals strong; cheeks extremely narrow; face receding, the ridges bare; oral margin not produced; proboseis short; palpi clarate; antennæ reaching the oral margin, the second segment short; arista bare. Acrostieals and dorsocentrals 2-3; posthumeral and posterior sublateral present; two sternopleurals; prosternum haired. Apieal cell ending a little before the wing-tip; third vein with two basal bristles. Abdomen oval, the fourth segment elongate; discals absent, each segment with marginals. Black, with einereous white pollen; mesonotum thinly pollinose and weakly vittate; bases of abdominal segments narrowly pollinose; palpi yellow. Length, $3.75 \mathrm{~mm}$. Genotype:-1I. nitens, n. sp. (Panama). 


\section{Family Braulidæ-The Honey-bee Parasite}

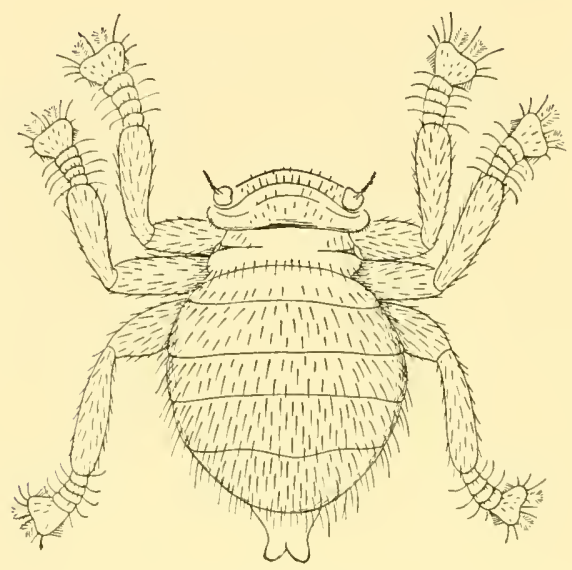

Braula coeca.

This family is comprised of a single speeies of Braula, parasitic upon honey bees.

Seutellum absent, the mesonotum not differentiated from the abdominal segments, the abdomen sessile; eyes minute; ocelli absent; antenna set in lateral grooves; vertex without bristles. Fifth tarsal segment broad and bearing an inflexed comb of many miseroseopic teeth. Wings entirely absent.

The Braulidæ are not larviparous, but lay eggs.

Braula coeca Nitzseh is a small convex insect found only in the hives of honey bees. It is said to be cosmopolitan in distribution but is rare in this country, at least in collcetions. 


\section{Family Hippoboscidæ-The Bird Parasite Flies}

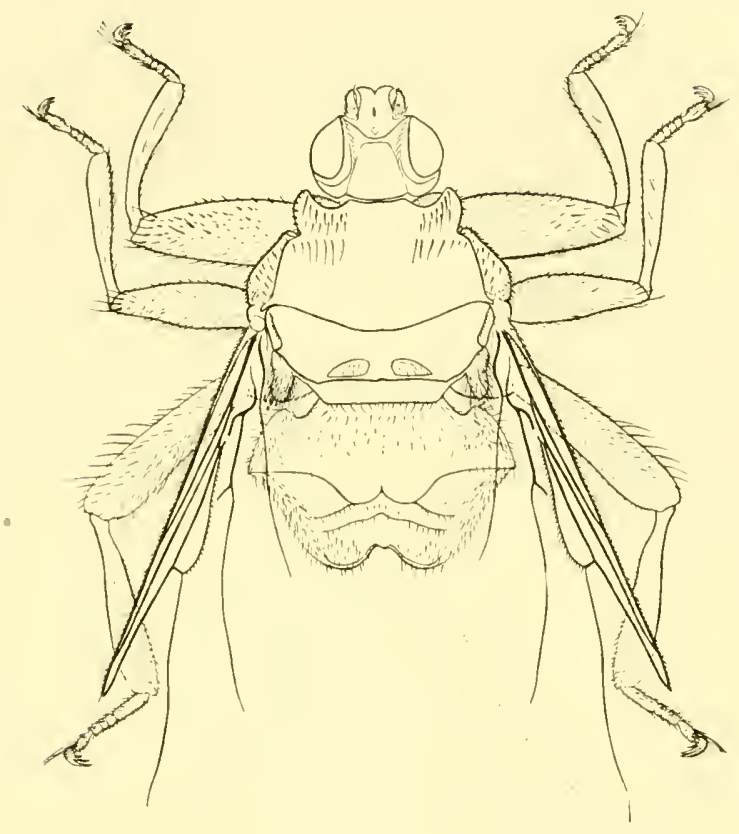

Olfersia sordida.

Small, flat flies of leathery consistency, usually with wings, the posterior veins weaker.

Ilead flattened, nsually attached to an emargination of the thorax. Face short; palpi forming a sheath for the proboseis, projeeting in front of the head; antenna inserted in pits or depressions near the border of the mouth, apparently with a single segment, with or without a terminal bristle or laairs. Eyes round or oval; ocelli present or absent. Thorax flattened; seutellum short and broad. Halteres present or rudimentary, rarely absent. Abdomen sac-like, the sutures indistinet, the basal segments usually fully ehitinized. Legs short and strong, broadly separated by the sternum; tarsi short: claws strong and often with one or two teeth. Wings present or absent, the veins approximated to the anterior border, with weak ones running obliquely across the posterior two-thirds of the wing. Larviparous. 
The adults occur on birds and mammals. They are most frequently found on birds, seldom flying. In the old world species of Hippobosca are found on horses, camels, etc. and often oceur in large numbers, as is the case with the sheep tick, a wingless species occurring wherever sheep are raised.
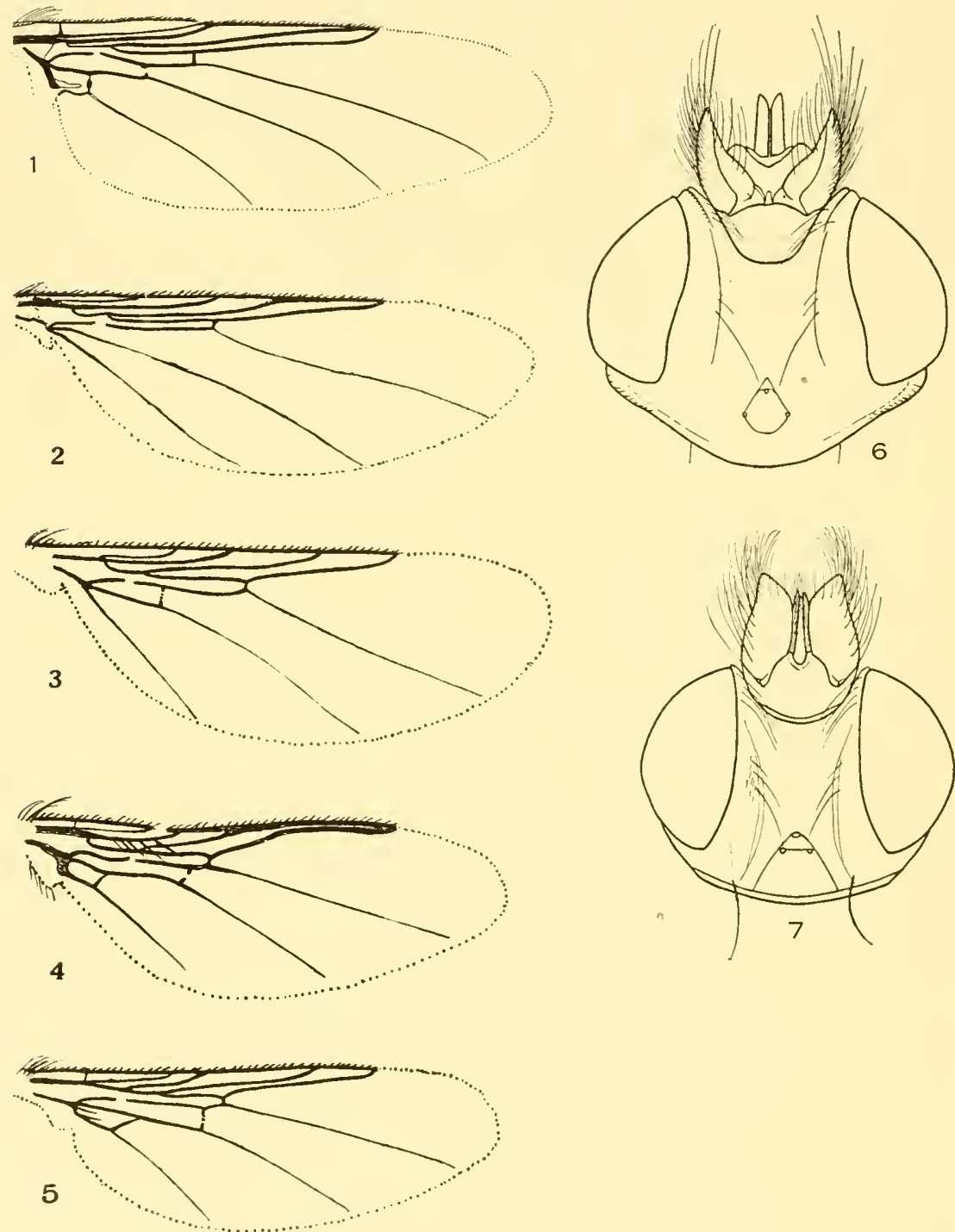

Hippoboscide.-1, Stilbometopa impressa; 2, Pseudolynchia maura; 3, Lynchia americana; 4, Ornithoica; 5,6 , Ornithomyia; 7 , Ornithoctona erythrocephala. 
Aldrich* has published a key to the genera but the species are very difficult to determine, there are no keys to the American species, and although most of them have been figured, the illustrations and descriptions are seattered.

\section{KEY TO GENERA $†$}

1. With functional wings, longer than abdomen................ 2

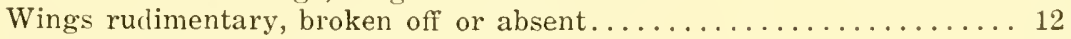

2. Wing with five or six distinct veins behind the costa........... 3 Wing with only three distinct veins behind the costa, the first, third and

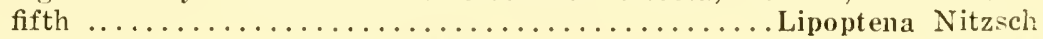

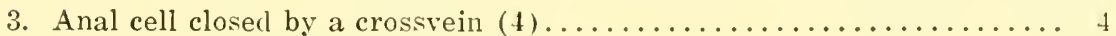

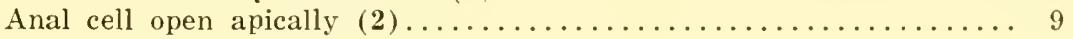

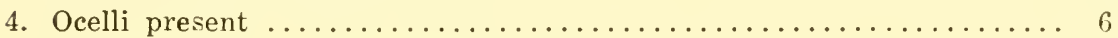

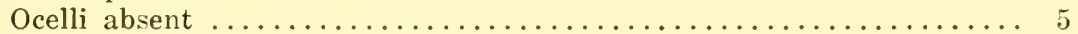

5. Claws bidentate; head rounded behind and free from thorax (not

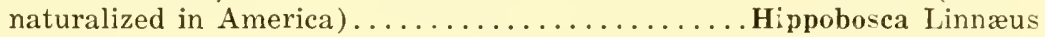

Claws tridentate; head truncate behind, in a deep emargination of the

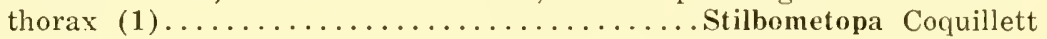

6. Third vein joining the tip of the costal vein at a distinct angle; claws

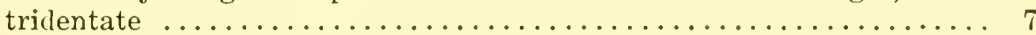

Third vein confluent with the costal vein on the apical third; claws

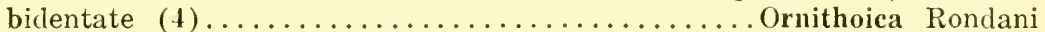

7. Antennal processes two-thirds as long as the head, straight and parallel with each other, broadly rounded at tip......... Ornithopertha Speiser

Antennal processes much shorter, more or less pointed........... 8

8. Antennal processes broad, concave above, with projecting outer rim, curved inwardly so as to almost or quite touch $\in$ ach other (7).

Ornithoctona Speiser

Antennal processes narrow, without outer rim, divergent and curving downward $(5,6) \ldots \ldots \ldots \ldots \ldots \ldots$ Ornithomyia Latreille

9. Crossvein closing the second basal cell entirely absent (2) ........ 11

Crossvein closing the second basal cell at least half present (3) ..... 10

10. Lateral lobe of the metanotum swollen and bearing a mammiform process; fourth vein setulose (see text figure)..... Olfersia Wiedemann

Lateral lobe of metanotum less swollen and without processes; fourth vein bare $(3) \ldots \ldots \ldots \ldots \ldots \ldots \ldots \ldots \ldots \ldots$ Lynchia Weyenbergh

11. Ocelli entirely absent; scutellum angulate laterally (2).

Pseudolynchia Bequaert

Ocelli occasionally present but minute; scutellum convex posteriorly.

Microlynchia Lutz, Neiva and Costa Lima

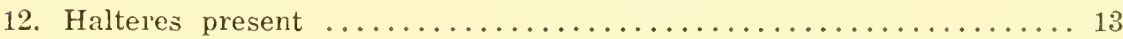

Halteres absent; wings aborted, rerlucerl to short knobs.

Melophagus Latreille

13. Ocelli present, claws bidentate; with basal stumps of broken wings.

Lipoptena Nitsch

Ocelli absent, claws tridentate; wings present, much shorter than the abdomen. (Brachypteromyia Williston)..........Myophthiria Rondani

* 1923. Ins. Ins. Menstr., xi, pp. 75-79.

f Checked by Dr. J. Bequaert. 


\section{Family Nycteribiidæ}

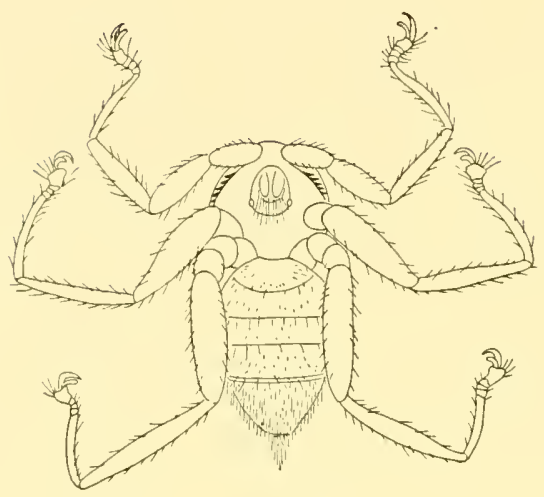

Basilia species.

Small, spider-like, wingless flies.

Head oval, folding back when at rest in a groove on the dorsum of the thorax. Antennæ short, two segmented, the oval terminal segment with bristles, inserted in cavity; eyes and ocelli vestigial. Thorax depressed, laterally and anteriorly with comb-like bristles. Abdomen oval, with more or less distinet segmentation. Legs long, the knees at rest prominent above the thorax; femora broad; tibiæ clubbed or shovelshaped; basal tarsal segment very long. Halteres penduneulate or sessile, often indistinet. Larviparous.

The members of this family are all parasitic npon bats and oeeur throughont the tropies and subtropies but are most numerous in the old World.

Ferris* considers that we have but one genus in North America and perhaps two genera in the western hemisphere. Nycteribia possibly oceurs in Brazil but there are no positive records from other parts of the continent. The two genera are separable as follows:

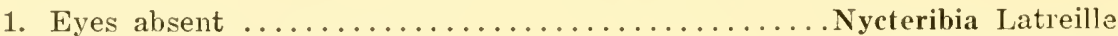
Eyes present, two-facetted ............................. Ribeiro

* 1924. Ent. News, xxxv, pp. 191-199. 


\section{Family Streblidæ-The Bat Flies}

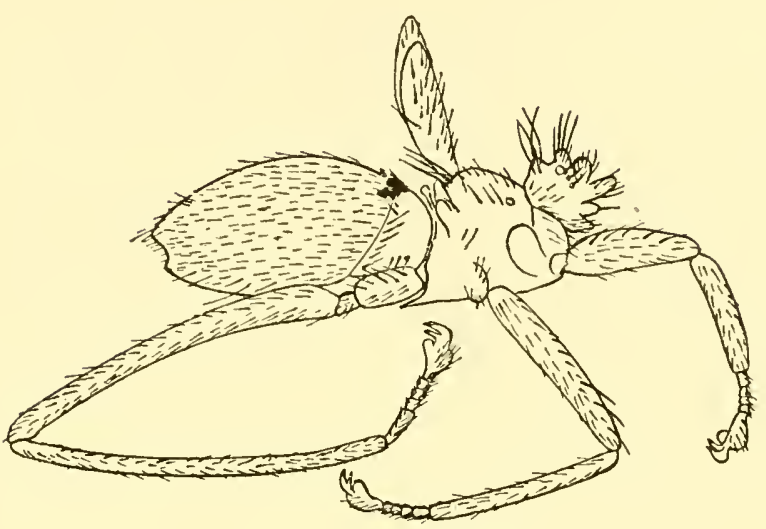

Pterellipsis aranea.

Head of moderate size, with a freely movable neek. Eyes, when present, small, without or with very few facets; ocelli absent. Antennæ inserted in a pit, two segmented, the seeond segment with a bristle. Proboseis short, not protrusille, thickened basally; palpi broader than long, projecting leaf-like in front of the head, not forming a sheath for the proboscis. Abdomen with a distinet basal segment, the other segments rarely distinguishable, the basal segment with special bristles for the protection of the wings when at rest. Posterior coxa always cnlarged; fifth segment of the tarsi usually elongate and enlarged; pulvilli present, the elaws nerer toothed. Wings sometimes vestigial or wanting, when present the veins stont and eovered with hairs. ILalteres present.

All but one species are parasitic upon bats but they are restrieted to the tropies and the subtropico-temperate zones. Kessel* has reviewed the family.

\section{KEY TO GENERA †}

1. With a ctenidium of black bristles on the ventral surface of the head. . 2 Without a ctenidium on uncier surface of head.............. 4

2. Eyes present; wings well-developed, with six veins (1)......... 3 Eyes absent; wings rerlucert to oval parls, much shorter than the thorax.

Metelasmus Coquillett

* 1925. Journ. N. Y. Ent. Soc, xxiii, pp. 11-34, 4 plates.

$\dagger$ Checked by Dr. J. Bequaert. 


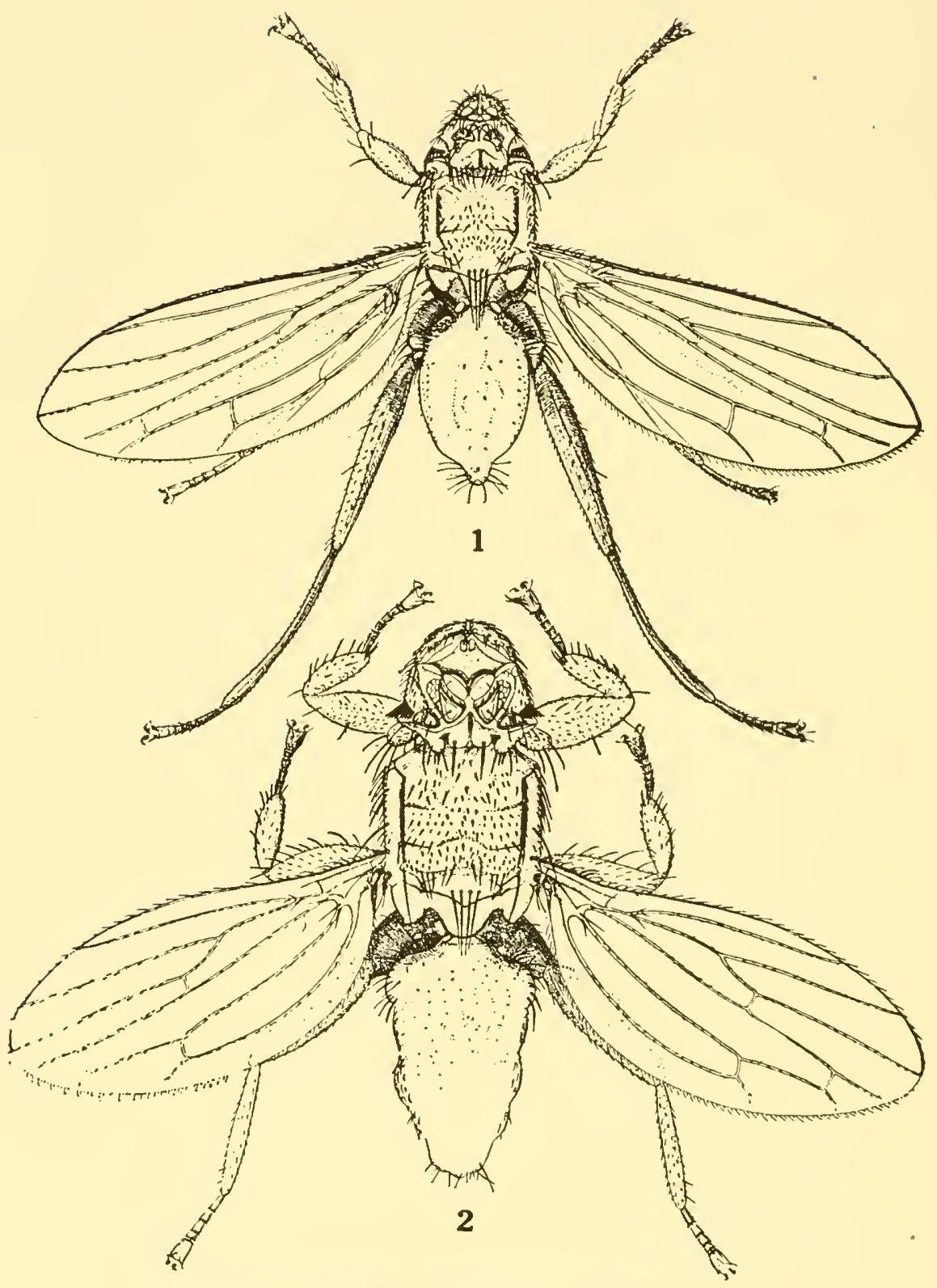

Streblidæ I.-1, Strebla vespertilionis; 2, Euctenodes mirabilis. 
3. Ctenidium extending to the sides of the head and visible laterally from

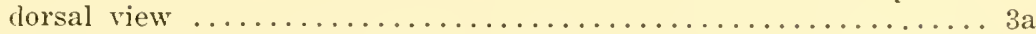

Ctenidium ending far before the sides of the hearl (E. breviceps,

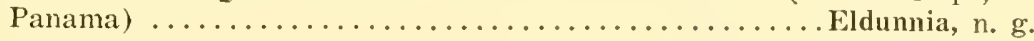

3a. Posterior femora about twice as long as the anterior ones; anterior cross-vein before the middle of the wing (1)......Strebla Wiedemann

Posterior femora decidedly less than twice as long as the anterior ones; anterior crossvein beyond the middle of the wing (2).

Euctenodes Waterhouse

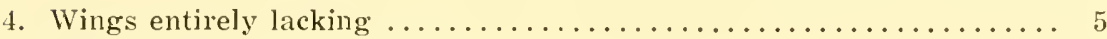

Wings present, though small ....................... 6

5. Posterior legs about twice as long as the anterior ones.

Posterior legs not twice as long as the anterior ones.

Megistopoda Macçuart

Paradyschiria Speiser

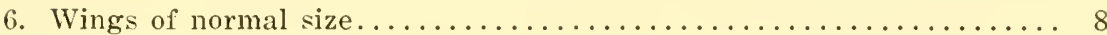

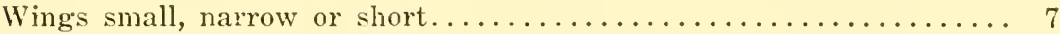

7. Wings erect and narrow; posterior legs about twice as long as anterior ones $(5$, also text figure)................. Pterellipsis Coquilleti

Wings lying flat, short; posterior legs not twice as long as anterior

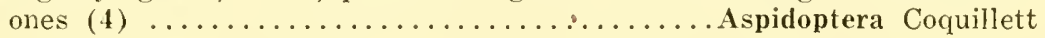

8. Wings with a single crossvein and three longitudinal veins; thorax com-

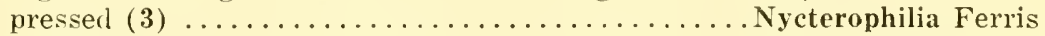

Wings with at least two crossveins and six longitudinal veins; thorax

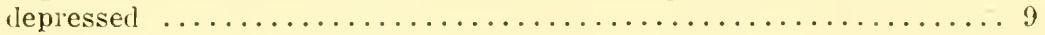

9. Posterior legs at least twice as long as the anterior pair.......... 10 Posterior legs obviously less than twice as long as the anterior pair

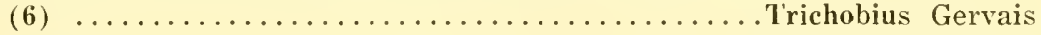

10. Posterior legs three times as long as the body..Paratrichobius Costa Lima Posterior legs about twice as long as the front pair...... Speiseria Kessel
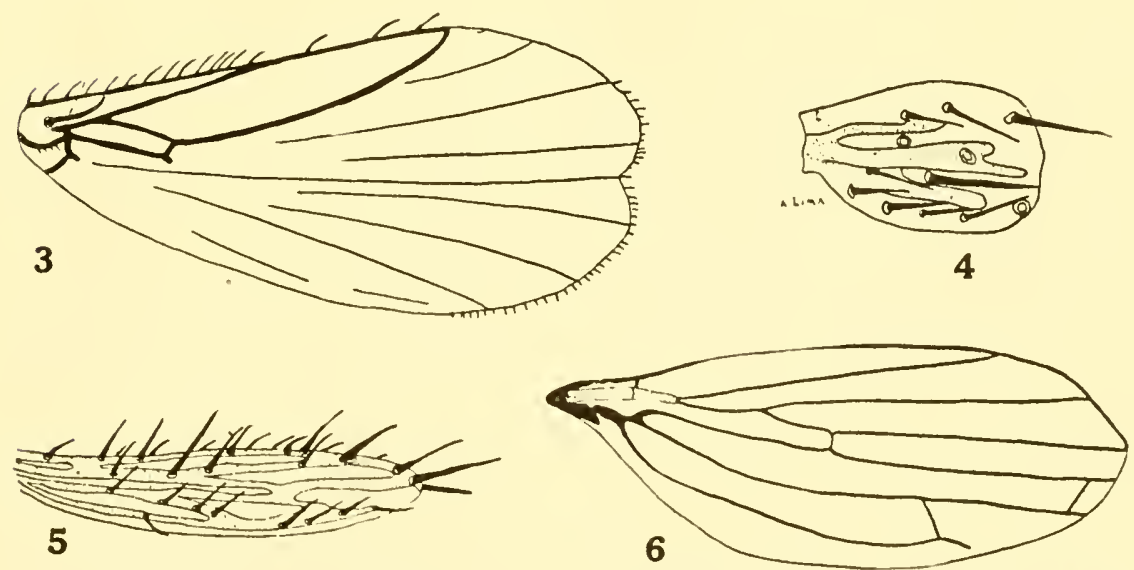

Streblidx II.-3, Nycterophilia coxata; 4, Aspidoptera minuta: 5, Pterellipsis aranea; 6. Trichobius sparsus. 


\section{GLOSSARY OF TERMS USED IN DIPTEROLOGY}

Abrlomen-The hindermost of the three main body divisions.

Acalypteratæ-The Acalypterate Muscoidea-those with very small or linear squamæ.

Acrostical bristles-The rows of mesonotal bristles between the dorsocentralsthe two median rows of bristles of the thorax.

Acrostical hairs-Hairs lying between the dorsocentral bristles.

Acrostical setulæ-Very short hairs between the dorsocentral bristles.

Adventitious veins-Veins occurring in abnormal positions, sometimes rather regularly placed, and sometimes normally present.

Adeagus-Part of the male negitalia: the penis and its sheath.

Alate-Having wings.

Alula-A lobe at the base of the wing posteriorly.

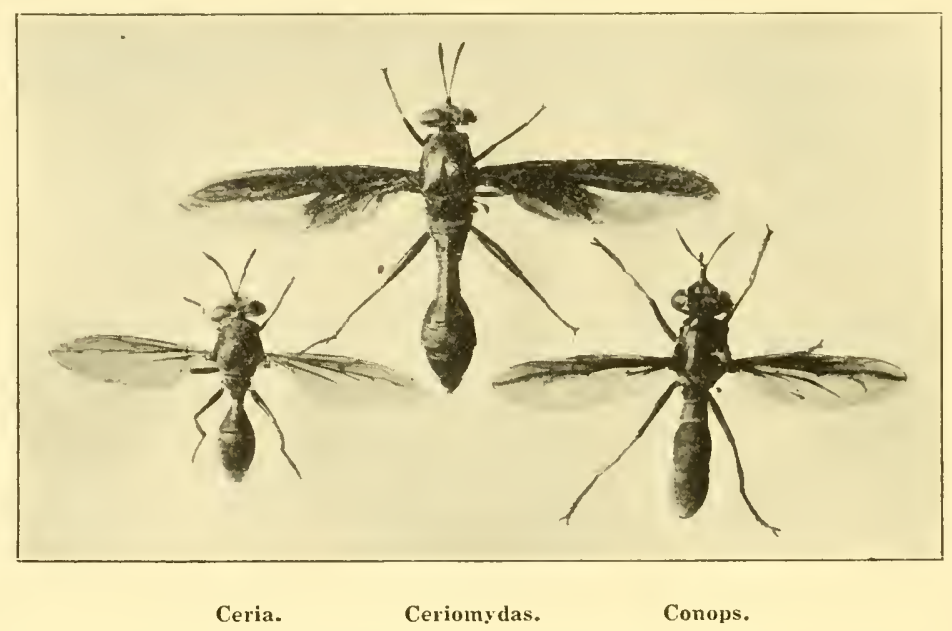

Examples of mimetic resemblances in flies.

Anal cell-The cell lying between the fifth and sixth veins $(\mathrm{Cu})$.

Anal crossvein-The crossvein closing the anal cell apically- $\left(\mathrm{Cu}_{2}\right)$ of $\mathrm{Com}-$ stock-Needham.

Anal lobe-The basal part of the wing behind the anal vein.

Anal vein-The sixth longitudinal vein. The second anal is usually absent or represented by a fold.

Anepisternite-The mesopleura.

Annulate-Having rings, but not completely segmented.

Annulus-A ring or band.

Antennæ-The feelers, attached to the head and separating the face and the front. They are sensory organs and perhaps combine the senses of smell and hearing.

Antennal fovea-See antennal grooves.

Antennal grooves-Definite depressions in the middle of the face in which the antennæ may rest. They are limited laterally by the facial ridges and in the middle, unless they are united, by a carina.

Anterior crossvein-The short crossvein connecting the third and fourth longituclinal veins on the basal half of the wing- $(\mathrm{r}-\mathrm{m})$. 
Apicad-Toward the apex.

Apical cell-The first posterior cell-the space between the third and fourth longitudinal vein beyond the anterior crossvein $\left(R_{5}\right)$.

Apical scutellars-The apical pair of marginal bristles on the scutellum. The term is loosely applied and often means the sub-apical scutellars, in cases where the true apicals are absent.

Apical spurs (of tibia)-Short, rather stout bristles often present on the under or ventral surface of the tibiæ. The number varies, and may differ on different pairs of legs.

Appendage (vein) - The presence of a short vein at the angle of a bend.

Apterous-Wingless.

Arcuate-Arched like a bow.

Arista-A bristle-like portion of the third antennal segment which may be apical or dorsal and sub-basal. It is composed normally of three segments; the first is usually minute and the second short, although all three may be elongate.

Auxiliary vein-The subcostal vein; that vein lying between the costa and first vein, often absent. (Subcostal; mediastinal.)

Axillary cell-The area behind the anal vein.

Axillary lobe-The area behind the aral vein. See axillary cell.

Axillary vein-The second anal vein when this is present (2nd A).

Basad-Toward the base.

Basicosta-The second distinct "scale" at the base of the wing in Muscoids. It is bare. The basal "scale" is the epaulet and is haired.

Basitarsus (si) - A term applied to the basal segment of the tarsi.

Bend of fourth vein-The curve of the fourth vein beyond the posterior crossvein (Muscoids).

Bilobed-Divicled or split into two parts.

Calcar-A single posterodorsal bristle usually strong, situated on the posterior tibiæ at or beyond the mirlde (Muscidæ).

Calypter (Calypters, Calypteræ)-See squamæ.

Calypteræ-See Calypteratæ.

Calypteratæ-The Calypterate Muscoicl-Tachinidæ, Metopiidæ, Muscidæ, Estridæ and Cuterebridæ.

Capitate-Enlarged at the apex.

Carinate-Rilged or bearing a raiser line or keel.

Caudad-Toward the posterior end of the abdomen or hind margin of the wing.

Caudal-Pertaining to the apex of the abdomen.

Cephalad-Toward the front of the head.

Cell-A space in the wing bounded by veins.

Cheeks-The space below the eyes. Sometimes termed the peristoma.

Chitinized-Hardened or horn-like: not membranous. There has been a great deal of discussion as to the proper use of the term chitin. As generally, and I think properly, used jt refers to the leather-like, or hard part of insects; now commonly written sclerotized.

Clavate-Clubbed or enlarger at the apex.

Claws-Tarsal claws, borne on the fifth (or apical) tarsal segment.

Clypeus-A distinct sclerite at the base of the proboscis aljacent to the anterior oral opening. Some authors have contencled that the clypeus is absent and that the middle of the face is the true clypeus. This seems very doubtful and I do not accept the contention. The term has been applied recently to the middle of the face, but epistoma is a much better term for that part.

Coarctate-Narrowed hetween the base and apex at some point.

Comb-A row of closely set, short bristles. (Often occurring on the femora or tarsi: Drosophilidæ, etc.) 


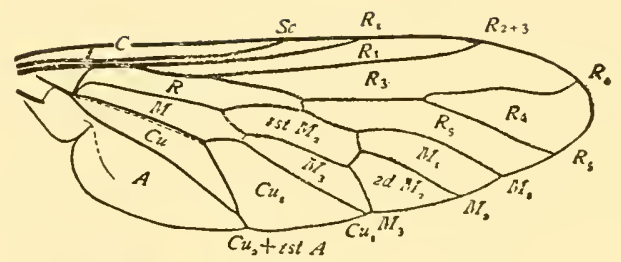

\section{Anisopus}

(Anisopodidæ)

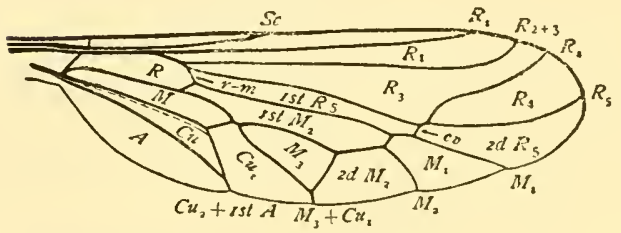

Thereva

(Therevidæ)

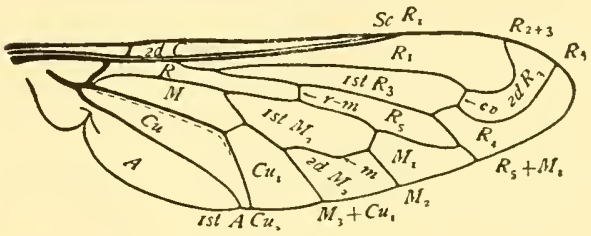

\section{Pantarbes}

(Bombyliidæ)

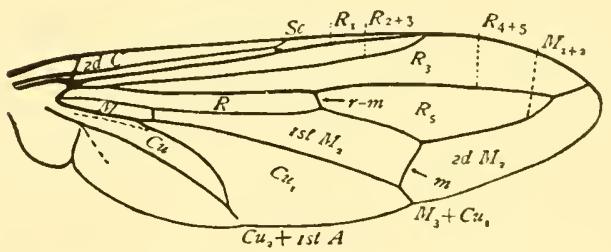

Conops

(Conopidæ)

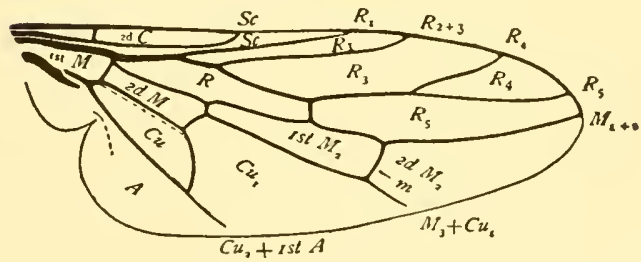

\section{Scenopinus \\ (Scenopinidæ)}

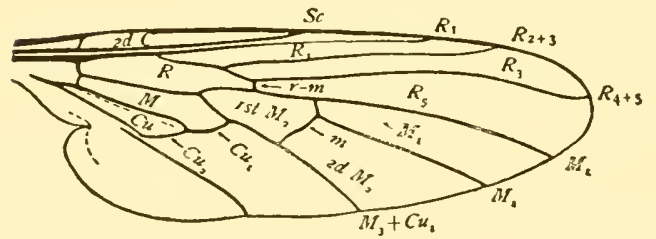

Rhamphomyia

(Empidæ)

THE VEINS AND CELLS, COMSTOCK-NEEDHAM SYSTEM 


\section{COMSTOCK-NEEDHAM SYSTEM OF WING VENATION.}

The comparison of the system here userl is with that of Comstock-Neertham, not as revised by Tillyard and other's.

Anal cell-Cu.

Anal crossvein- $\mathrm{Cu}_{2}$.

Crossveins- $\mathrm{h} ; \mathrm{r}^{-} \mathrm{m} ; \mathrm{m} ; \mathrm{M}_{3} ; \mathrm{Cu}_{2} ; \mathrm{Sc}_{2}$.

Discal cell-1st $\mathrm{M}_{\text {. }}$.

Discoidal crossvein- $M_{3}$.

Fifth longitudinal- $\mathrm{Cu}_{1}$, .

First basal cell-R.

First vein-R plus $R_{1}$. (the main stem of the vein, basad of $R s$, is $R$, - - beyond $\mathrm{Rs}, \mathrm{R}_{1}$ ).

Lar'ge crossvein-m and outer section of $M_{3}$.

Malginal cell- $\mathrm{R}_{1}$.

Posterior cells- $\mathrm{R}_{5}$ to $\mathrm{Cu}_{1}$.

Posterior crossvein-m, and sometimes also outer section of $\mathbf{M}_{3}$.

Præfurca-Rs.

Second vein-Rs, and its anterior branch, $R_{2+3}$.

Small crossvein-r-m.

Subcostal crossvein-Sc.

Submarginal cells $-R_{3}, R_{4}$.

Third long. vein-Posterior branch of $R s,-R_{t+5}$.

Compresserl-Flattened from side to side-laterally compressed.

Connate-Fused and immovable.

Constricted-Narrowed.

Corneous-Horn-like in texture or appearing so.

Costa-See costal vein.

Costal cell-The cell between the costa and subcostal or auxiliary vein.

Costal vein-The vein extending along the front margin of the wing.

Crossveins-There are five typical crossveins in the wings: humeral, anterior, posterior, discoidal and anal (The equivalents of these in the ComstockNeerlham system are, in order, $-\mathrm{h} ; \mathrm{r}-\mathrm{m} ; \mathrm{m} ; \mathrm{M}_{3}$ and $\mathrm{Cu}_{2}$ ). In addition to these there is the subcostal crossvein $\left(\mathrm{Sc}_{2}\right)$, and there may be one or more veins simulating crossveins. The apical crossvein is merely the anteriorly curved fourth longitudinal vein (Muscoids). The base of the third vein, base of posterior branch of the fourth vein and the base of the branches of the fifth vein may simulate crossveins. In some families there may be additional crossveins (see Nemestrinidæ, Bombylii(læ, etc.).

Cruciate-Crossing each other.

Ctenidium-A comb-like row of bristles.

Cubitus-Fifth longitudinal vein.

Decumbent-Depressed; hanging down.

Decussate-Crossing or cruciate.

Depressed-Flattened dorsoventrally, contrasting with compressed.

Dichoptic-Eyes separated by the front.

Digitate-Bearing a finger-like process.

Discal cell-A (usually) closed cell (on the disc of the wing, lying between the fourth and fifth veins). It may be absent, open apically, or united with one of the basal cells, usually the second basal, abnormally with the first basal (1st $\mathrm{M}_{2}$ ).

Discal crossvein-The vein separating the discal and second basal cells. (See (liscoidal crossvein.) ( $\mathbf{M}_{3}$ of Comstock-Needham system).

Discal scutellars-Bristles on the disc of the scutellum.

Discoidal crossvein-The vein separating the discal and second basal cells. (See discal clossvein.) ( $M_{3}$ of Comstock-Needham system).

Dorsad-Toward the upper surface. 


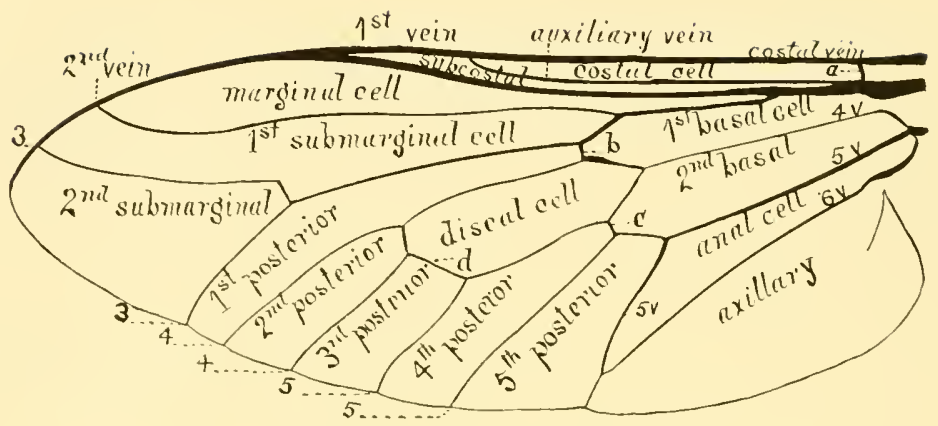

\section{WING OF TABANUS}

The terminology of the veins and parts shown on this figure is that used in the present work, except in the Tipuloidea.

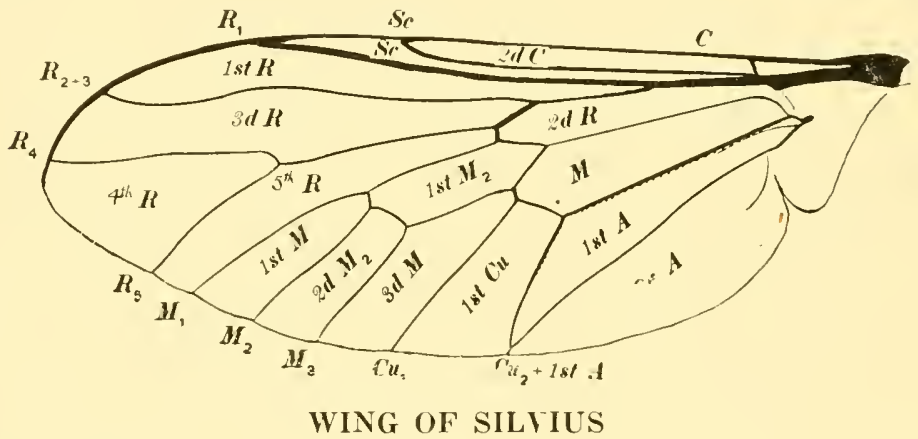

Comstock-Needham system. Veins. C-costa, Sc-subcosta, R-radius. $\mathrm{M}-$ media, $\mathrm{Cu}-$ cubitus, A-anal. Cells. C-costal, Sc-subcostal, R-radial, $\mathrm{M}$-medial, $\mathrm{Cu}$-cubital, $\mathrm{A}$-anal.

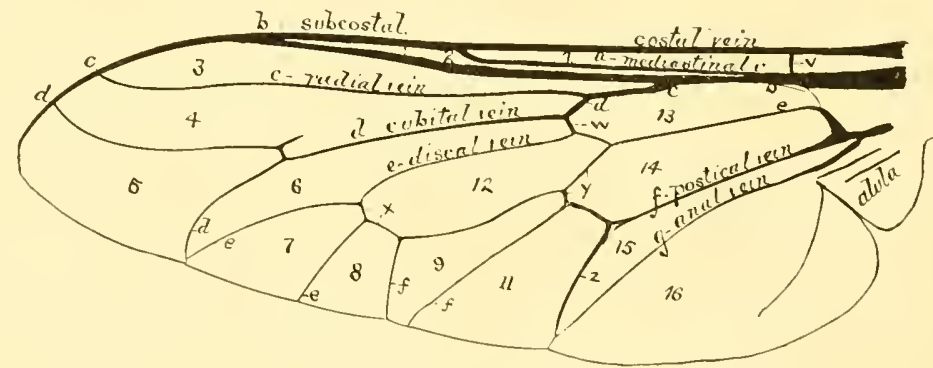

\section{WING OF PANGONIA}

Schiner's system. Cells. 1, costal; 2, mediastinal; 3, subcostal; 4, 5, cubital; $6,7,8,9,11$, first to fifth posterior cells; 12 , discoidal cell; $13,14,15$, first to third basal cells; 16 , axillary cell. 
Dorsal-Pertaining to the upper surface of the body.

Dorsocentrals-Dorsocentral bristles of the thorax.

Dorsopleural suture-See notopleural suture.

Dorsum-Upper surface. Refers to thorax and abrlomen.

Epaulet-The first "scale" at the base of the costa. It is haired and is followed by a bare "scale", the basicosta.

Empodium (ia) - A bristle, hair or pad borne on the apical tarsal segment between the pulvilli.

Epiphysis-A lappet-like process or lobe.

Epistoma-Correctly, the anterior oral margin. Frequently used to denote the facial depression or middle of the face from the oral margin to the antennæ.

Eyes-The compound eyes, composed of, usually, many facets.

Face-The front of the head between the mouth and the antennæ.

Facets-The divisions comprising the compound eyes.

Facial depression-The midlle of the face. Facial plate.

Facial plate-The central part of the face.

Femur (femora)-The long part of the leg nearest the thorax, but separated from the thorax by the coxa and trochanter. The thigh.

Fifth longitudinal vein-The vein running along the posterior side of the second basal cell, and of the discal cell, usually two-branched, the second branch separating the fourth and fifth posterior cells. $\left(\mathrm{Cu}_{1}, 2\right.$; postical. $)$

First basal cell-A cell lying between the first, second and third and the fourth longitudinal veins on the basal half of the wing.

First vein - The vein lying immediately behind the auxiliary vein, or when that is absent, immediately behind the costa. ( $R$ and $R_{1}$.)

Flagellum-In flies having six or more antennal segments the portion beyond the scape.

Fourth longitudinal vein-The vein, usually arising near the base of the wing, separating the two basal cells and bordering the discal cell anteriorly, often branched, the posterior branch often partly closing the discal cell. (Medial, $\mathrm{M}_{1,2,3}$; discoidal.)

Front-The space between the eyes lying above the antennæ and limited by the vertex or top of the head.

Frontalia-The central stripe of the front. Frontal vitta.

Frontal lunule-The space between the bases of the antennæ and the ptilinal or frontal suture, actually cccurring only in Cyclorrhaphous lies, but the term, or "lunula", is loosely applied to some other flies.

Frontal orbits-The space contiguous to the eyes on the front.

Frontals or frontal bristles-Bristles situated along the inner edge of the parafrontals.

Frontal triangle-The triangle in holoptic flies bounded above by the eyes and below by the antennæ.

Frontal vitta-The softer area between the rows of frontal bristles or hairs extending from the antennæ to the ocelli. This allows the head to expand laterally in Cyclorrbaphous Diptera when the ptilinum is expanderl.

Fronto-orbital bristles-The orbitals or orbital bristles. The term is variously used and is often applierl to the frontals in the Acalypteratæ.

Gena (næ)-The cheek. Often refers to the parafacials. The term is best avoided.

Geniculate-Abruptly bent or elbowed.

Genitalia-The external sexual organs together with the adjacent parts.

Gibbous-Puffed out; hunch-backed.

Glabrous-Without hairs; smooth.

Halteres-Appendages arising on the posterior of the pleura, with a long stem and apical knob. These occur in practically all Diptera, rarely being 
reduced to slight swellings in some apterous forms. They are supposed to be the rudiments of the second pair of wings but I loubt this. The removal of the halteres renders the insects unable to fly.

Holoptic-Eyes contiguous, dividing the front into an upper and lower part. Humeral crossvein-A crossvein situated near the base of the wing and extending from the costa to the auxiliary or subcostal vein anil continuing to the first vein.

Humeri-The anterior corners of the mesonotum usually more or less well marked.

Hyaline-Transparent.

Hypopleura-The space below the posterior spiracle and above the posterior coxæ.

Hypopleural bristles-Bristles on the hypopleura, usually in a vertical row.

Hypopygium-The male genitalia together with the adjacent parts. It is composed of several of the apical abdominal segments and is variously modified.

Infra-squamal setulæ-Fine hairs below the point of attachment of the squamæ.

Intercalary vein-A term sometimes applied to the posterior branch of the fourth vein in cases where its base partly closes the discal cell $\left(\mathrm{M}_{2}\right)$.

Interfrontal (bristles or hairs)-Hairs or bristles on the frontal vitta.

Interfrontalia-The frontal vitta.

Intra-alar bristles-Bristles situated behind the suture and between the supraalar and dorsocentral bristles.

Jowls-The cheeks, behind the depressed anterior part. Sometimes termed the peristoma.

Labellæ-The lips of the proboscis. Supposed to be the modified labial palpi. Sometimes b:oadly expanded, at other times much reduced or apparently lacking.

Lamella (e)-A leaf-like plate.

Lamellate-Broadened and flat: leaf-like; bearing lamellæ.

Large crossvein-The crossvein closing the discal cell; posterior crossvein (n and $\mathrm{M}_{3}$ ).

Lateral-At, toward, or pertaining to the sides of the body.

Lunula-A term applied to the more or less crescentric area above the antennæ in some flies, notably in the Syrphidæ. Also a lunulate marking.

Iunule-See lunula.

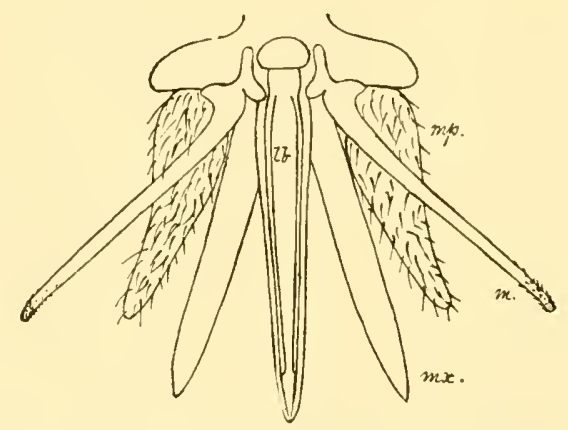

MOUTHPARTS OF FEMALE TABANUS.

lb, labium; $1 \mathrm{n}$, mandible; mp, maxillary palpus; mx, maxilla. 
Macrotrichia-The larger microscopic hairs on the surface of the wings.

Marginal cell-The cell lying between the first and second longitudinal veins $\left(R_{1}\right)$.

Marginal scutellars-Bristles situated close to or on the margin of the scutellum.

Media-The fourth longitudinal vein.

Medial-Pertaining to the media or middle.

Median-Along the midlle.

Mesad-Toward the midllle.

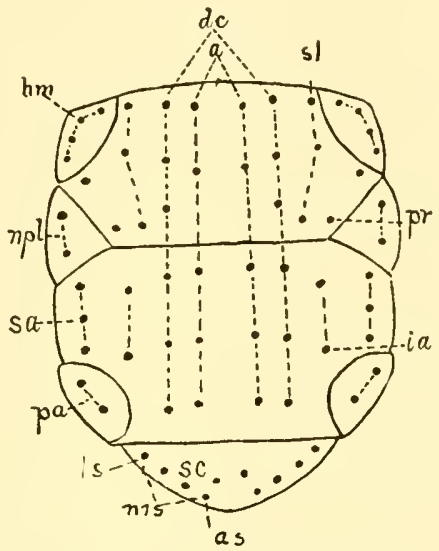

MESONOTAL BRISTLES

a, acrosticals; as, apical scutellars; dc, dorsocentrals; hm, humeral; ia, intra-alar; ls, lateral or basal scutellars; ms, marginal scutellars; npl, notoplcural; pa, postalars; pr, presutural; sa, supra-alars; sc, scutellars; sl, sublaterals.

Mesonotum-The dorsum of the mesothorax or the main part of the back. Sometimes termed the mesoscutum. According to morphological usage the divisions of the mesonotum are, from front to rear, prescutum, scutum, scutellum and postscutellum.*

Mesopleura-A so-called pleurite or sclerite of the pleura bounded above by the mesonotum, in front by the propleura, below by a more or less distinct suture and behind by a suture extending down from in front of the wings. The so-called suture separating the mesoplenra and sternopleura is merely a fold leaving an exterior furrow.

Mesoscutum-See mesonotum.

Mesosternum-The under side of the mesothorax.

Mesothorax-The second and largest segment of the thorax. The wings and second pair of legs arise from this segment.

Metacephalon-The area behind the mouth extending up toward the neck.

Metanotal slopes-Swellings on the sides of the metanotum or its sloping sides (pleurotergite).

* While not professing any great knowledge of morphology I am far from being convinced that the Metanotum, as used by taxonomists is actually part of the Mesonotum: there is a distinct, membranous suture between this part and the scutellum, such as one expects to find between true sclerites. 
Metanotum-The dorsum of the metathorax, lying behind the scutellum. (*According to recent morphological usage this is the postnotum or postscutellum and is part of the mesonotum: the true metanotum is found only in the lower Diptera, as Psychodicl.) See footnote, p. 487.

Metapleura-The part of the metathorax above the hypopleura and outside of the metanotum. It is a poorly defined area and not really separable from the metanotum.

Metasternum-The under side of the metathorax, situated behind the middle coxæ and extending to behind the posterior coxæ.

Metatarsus (si)-A term applied to the basal segment of the tarsi.

Metathorax-The third segment of the thorax. The posterior legs and halteres arise from this segment.

Micropterous-With small or vestigial wings.

Microtrichia-The smaller abundant hairs of the wing. When these are present the wing is said to be villous.

Moniliform-Resembling a string of beads.

Neuration-The arrangement of the veins of the wing.

Node-A swelling or knot-like knob.

Notopleura-A depression, more or less triangular, situated immediately before the transverse suture and behind the humeri.

Notopleural suture-The suture exteriding from the humeri to the base of the wings.

Notum-The dorsal surface; particularly of the thorax.

Ocellar bristles-Bristles arising within the ocellar triangle or on either side of the anterior ocellus.

Ocellar triangle-The triangle formed by the ccelli or the triangular, well marked area surrounding them. This triangle has sometimes been termed the frontal triangle in cases where it extends almost to the antennal base.

Ocellar tubercle-A term applied to the swelling on which the ocelli are sometimes situated, especially in the Asilidre.

Ocelli-The simple eyes, located on the front, usually near the vertex.

Occipital cilia-The row of bristly hairs behind the eyes.

Occipital fringe-The fringe of fine hairs behind the eyes.

Occiput-The back of the head. Morphologically the subtriangular area limited by the vertex between the eyes and the neck.

Onychium (ia) - A pad between the tarsal claws.

Orbit-The part of the head immediately surrounding the eyes.

Orbital bristles-Bristles, usually proclinate or divergent, situated on the parafrontals between the frontals and orbits.

Ordinary crossvein-Anterior or small crossvein, r-m (Schiner).

Ovipositor-The female genitalia with the adjacent parts, composed of several segments and usually telescopic, but often variously modified.

Palpi-The maxillary palpi.

Parafacials, parafacialia-The part of the face between the facial ridges and the eyes.

Parafrontals- The part of the front outsile the frontal bristles.

Pectinate-With branches like a comb.

Pectus-The under side of the thorax.

Pendulous-Hanging from one end.

Peristoma-Correctly, the region surrounding the mouth, but used in various senses. The part of the cheeks nearest the oral opening. The anterior oral opening. The anterior part of the cheeks. The term should be avoided as being too confusing.

Petiolate-Attached by a stalk or stem.

Phytophagous-Feerling on plants. 
Pilose-Having long, fine hair, usually dense. The term is loosely applied to include any hair that is not coarse.

Pleurites-A term applied to the sclerites or sections of the pleura.

Pleurotergite-The hypopleura; morphologically the lateral division of the metanotum (postscutellum), at least in Nematocera.

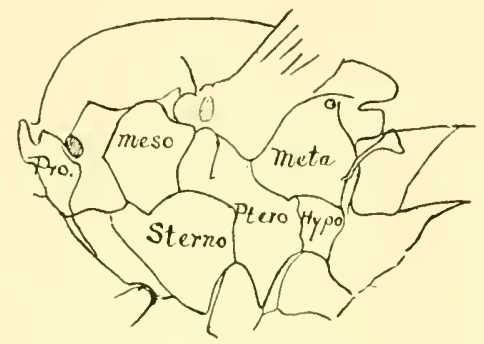

\section{PLEURAL DIVISIONS OF SYRPHUS}

Hypo, hypopleura; Meso, mesopleura; Meta, metapleura; Pro, propleura; Ptero, pteropleura; Sterno, sternopleura.

Plumose-Having rays on both sides like a feather.

Pollen-A fine, dust-like substance on the integument.

Pollinose-Covered with "dust" or "bloom".

Posterior calli-The swellings at the posterior corners of the mesonotum, present in the Calypteratæ, and other families, but absent in the Acalypteratæ as a rule. (Posterior callosities).

Posterior cells-The cells on the apical part of the wing iying between the third and fifth veins, exclusive of the discal cells $\left(R_{-}\right.$to $\left.\mathrm{Cu}_{1}\right)$. Some of these cells may be closed by the union of veins apically.

Posterior crossvein-The vein or veins closing the discal cell apically ( $\mathrm{m}$ and $\mathrm{M}_{3}$ ). According to Schiner the basal section of $\mathrm{Cu}_{1}$ of the ComstockNeedham System.

Posterior orbits-The part of the head immerliately behind the eyes.

Posthumeral bristle-A bristle situated behind the humerus.

Post ocellar(s) (bristles) - A pair (or more) of bristles arising just below the vertex on the occiput and behind the ocellar tubercle, sometimes termed post-verticals.

Postscutellum-A convex, transverse swelling below the scutellum; actually the upper, posteriorly produced section of the metanotum.

Postvertical(s) bristles-See post ocellars.

Præfurca-See prefurca.

Pra-Prealar bristle.

Præscutum-The part of the mesonotum in front of the transverse suture.

Prealar (bristle) - The anterior supra alar bristle. This is frequently absent or reduced. It is used particularly in Muscidæ.

Prefurca-The petiole of the second and third longitudinal veins. Base of $R_{4+5}$ (The Radial sector Rs).

Preapical bristle (of tibia)-A dorsal, short bristle situated before the end of the tibia.

Prescutum-See præscutum.

Presutural bristle-A bristle situated in front of the inner end of the notopleura in front of the suture. The lateral bristle situated in front of but close to the suture. 
Proboscis-The mouthparts exclusive of the palpi; always more or less tubelike. They may be slender and adapted for piercing, or thick and adapted for lapping.

Proclinate-Curving or directed forward.

Pronotum-The dorsum of the prothorax.

Propleura-The sides of the prothorax. This is usually a depressed area, but also includes the area above the front coxæ.

Propleural bristle-A bristle situated on the propleura immediately above the front coxæ.

Prosternum-The under sicle of the prothorax, between and in front of the anterior coxæ.

Prothoracic bristle-A bristle situated immediately above the anterior coxæ (See propleural bristle).

Prothorax-The first segment of the thorax. The first pair of legs arise from the prothorax.

Pruinose-Covered with a hoary dust. (See pollinose).

Pseudosutural foveæ-Impressed polished areas on the humeral portion of the mesonotum (humeral pits); in Tipulidæ and elsewhere.

Pteropleura-A sclerite lying below the base of the wings.

Pteropleural bristle(s)-Bristle or bristles on the pteropleura.

Pteropleurites-The upper and lower sections of the pteropleura.

Ptilinum-An inflatable sac, occurring in Cyclorrhaphous flies and pushed out above the antennæ by the insect in emerging from the pupa (or puparium). This sac is coarsely grained or pubescent and when forced out thrusts the face into a horizontal position and when retracted after emergence leaves the frontal lunule exposed and is concealed in part beneath the facial ridges.

Pubescent-Having very short, fine hair.

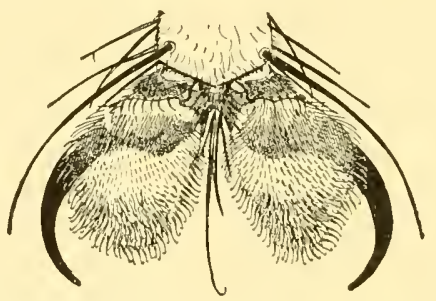

Foot of house-fly, showing claws, pulvilli and the hair-like empodium.

Pulvilli-Pads borne on the apical segment of the tarsus between the claws.

Pulvilliform-Shaped like the pulvilli.

Punctate-Pitted; covered with small pits.

Puparium-The pupa when formed within the hardened larval skin.

Pupiparous-Giving birth to larvæ ready to pupate.

Radial-Pertaining to the radius.

Raclial cell-Any cell bordered in front by a branch of the radius.

Radius-The first to third longitudinal veins. $R_{1}$ to $R_{5}$ of Comstock-Needham system.

Raptorial-Fitted for grasping prey.

Reclinate-Curving or directed backward.

Recurrent-The anterior end nearer the base of the wing than some other part.

Reniform-Kidney-shaped.

Reticulate-Having a network. 
Rostrum-The beak or snout.

Rugose-Wrinkled.

Rugulose-Finely wrinkled.

Scape (of antennæ)-The basal two segments in those flies having six or more antennal segments. These segments are differentiated from the remaining segments, although the first may be small and ring-like; the second segment is sometimes called the perlicel.

Sclerite-Any piece of the body well surrounded by sutures.

Scutellum-A (usually) convex sclerite attached to the back of the mesonotum. Sometimes termed the shield.

Scutum-The part of the mesonotum behind the transverse suture.

Second basal cell-A cell lying immediately behind the first basal, rarely united with it, more often open apically and united with the discal cell, but closed in most cases (Cell M).

Second vein-The vein (frequently absent), lying immediately behind the first vein, its base always united with the base of the third vein ( $R s$ and its anterior branch $R_{2+3}$ ).

Serrate-Toothed along the edge like a saw.

Sessile-Broadly attached; incapable of movement.

Seta-A bristle.

Setaceous-Bristle-like.

Setigerous tubercles-Tubercles, occurring on the scutellum or legs, each bearing a spine or bristle on its top.

Setulæ-Very short hairs, sometimes coarse.

Setules-Setulæ.

Setulose-Bearing setulæ.

Sinuous-S-shaped, winding back and forth.

Sixth longitudinal vein-The first anal vein. The second anal is usually absent or represented by a fold extending around the anterior apex of the alula. (Anal vein).

Small crossvein-The anterior crossvein $(r-m)$.

Spatulate-Broadened apically, narrow basally.

Spiracles-The external openings of the tracheal system.

Spurs-Either movable spines at the end of the tibiæ or strong production of apex of tibiæ or a tapering production of some part of the body, usually on the legs.

Spurious vein-An extra, usually very weak vein crossing the anterior crossvein.

Squamæ-The scales or connecting lobes connecting the wings basally with the thorax. There are two lobes, the upper and lower. The lower lobe is often greatly enlarged and is generally referred to as the squama.

Squamose-Scale-like. Refers particularly to scale-like hairs.

Sternites-Ventral sclerites or the under side of the segments.

Sternopleural bristles-Bristles situated on the upper part of the sternopleura on the posterior half.

Sternum-The under side of the thorax, comprising the pro-, meso- and metasternum.

Stigma-A darkened and often thickened area lying immediately behind the costa, either beyond the tip of the first or second reins.

Stylate-Bearing a style.

Style-A thick, terminal portion of the antennæ arising from the third segment, sometimes simulating segments, but usually tapering.

Stylose-Bearing a style.

Subantennal groove-See facial grooves.

Subcosta-The vein, usually present, between the costa and the first longitudinal vein. 
Subcostal cell-The cell between the subcosta or allxiliary vein and the first vein or radius.

Subcostal crossvein-A crossvein, sometimes present, connecting the subcosta or auxiliary vein and the first vein. This is used taxonomically in the Mycetophilidæ and the Tipuloidea (Morphologically sc: $)$.

Subcostal vein-The vein lying between the costa and the first longitudinal vein. It is sometimes absent or greatly reduced.

Sublateral bristles-Bristles situated in a line with the intra-alars but in front of the suture. The anterior two are sometimes included as posthumerals but the term is deceptive.

Submarginal cell(s)-The cell or cells lying between the second and third longitudinal veins $\left(R_{3}\right.$ and $\left.R_{4}\right)$.

Sulcate-Grooved or furrowed.

Supernumerary cells-Additional cells occurring in the wings due to the presence of extra crossveins (See Nemestrinidæ, Bombyliidæ, etc.).

Supernumerary crossveins-Crossveins, other than those normally present.

Supra-alar bristles-Bristles close to the edge of the thorax behind the suture.

Suture-A line separating the parts of the body wall.

Tarsus (si) - The feet, composed normally of five segments. The apical segment bears the claws, pulvilli and empodium when these are not obsolete. In rare cases the number of tarsal segments is reduced to two. The tarsal segments are numbered from the base, segments one to five, although the first segment is sometimes termed the basitarsus or metatarsus.

Tegulæ-See Squamæ.

Tergites-Dorsal sclerites or the upper side of the segment.

Third longitudinal vein-The vein arising jointly with the second vein and branching from it, sometimes branched. Behind it is the first posterior cell and behind or before its base, the first basal cell $\left(\mathrm{R}_{++5}\right.$; Posterior branch of Rs.; Cubital).

Thorax-The middle part of the body bearing the wings and legs.

Tibia(e)-The part of the leg beyond the femur.

Transverse suture (of thorax)-The depressions extending inward from the sides of the mesonotum near the middle, but not true sutures. In the Muscoids this is said to be complete or extend entirely across, but this is not always the case. Usually the suture is obsolete in the middle. In the Tipulidæ it is V-shaped. The suture divides the anterior series of bristles from the posterior dorsocentrals and acrosticals, whether it is complete or not.

Trichostical bristles-Hypopleural bristles, used especially in the Asilidæ.

Trochanter-The small, ring-like portion connecting the coxæ and femora. This often appears more or less triangular as only part of it is generally visible.

Truncate-Ending transversely or with cut-off apex.

Tubercle-A conspicuous, more or less rounded swelling, sometimes elongate as on the face of Syrphidæ, etc.

Tuberculate pits-Paired shiny dots at or near the anterior margin of the mesonotum, one on either side of the median line; in Tipulidæ.

Ungues-Claws.

Venation-The arrangement of the veins of the wings.

Venter-The under surface of the abdomen.

Ventrad-Toward the venter.

Ventral-Pertaining to the under side of the body.

Vertex-The uppermost edge of the front; usually that part between the ocelli and the back of the head, or behind and between the upper angles of the eyes.

Vertical triangle-The space, in holoptic flies, surrounding the ocelli. 
Vibrissa-The large bristles arising from the vibrissal angles at the sides of the nouth in many Cyclorrhaphous Diptera. This term has been misapplied to include the bristles sometimes found on the facial ridges.

Vibrissal angles-The more or less rounded angles formed by the facial ridges just above the oral margin.

Viviparous-Bringing forth living young. 


\section{LITERATURE}

For the convenience of those who may not be familiar with American literature on Entomology lists of general works on Diptera and periodicals, etc., published in North America is given. This list is not complete but includes the more important publications. Occasionally descriptions are published in other journals but the number is small. Certain journals contain more papers dealing with flies than others, but there is a great deal of variation over a period of years. Monographic work on American insects is greatly handicapped because there is no medium of publication, most journals accepting only short papers.

\section{General Works for Students of Diptera}

Aldrich, J. 11.-Catalogue of North American Diptera.

Lœw, H.-Diptera Americæ Septentrionalis Indigena, I to X. (Latin). 1000 new species. The types are almost all in the Museum of Comparative Zoology, Harvard University.

Loew, H.-Monographs of the Diptera of North America. Dolichopidæ, Ephydridæ, Otitidæ, Tetanoceridæ and Trypaneidæ. Most of the species have been eluciclated in later work.

Lœw, H.--Neue Beitrage zur Kenntniss der Dipteren. (German). Partly North American.

Macquart, J.-Diptêres Exotiques, nouveaux ou peu connus. Vols. I, II and Supplements I to V. (French).

Say, Thomas-The Complete Writings of Thomas Say on the Entomology of North America (Two volumes).

Wiedemann, C. R.-Aussereuropaische Zweiflugelige Insecten. Vols. I, II (German).

\section{Current North American Periodicals Dealing Entirely With Entomology}

Annals of the Entomological Society of America.

Bulletin of the Brooklyn Entomological Society.

Canadian Entomologist.

* Entomologica Americana (Published by Brooklyn Entomological Society).

Entomological News.

$\dagger$ Insecutor Inscitiæ Menstruus.

Journal of Economic Entomology.

Journal of the Kansas Entomological Society.

Journal of the New York Entomological Society.

+ Memoirs of the American Entomological Society.

Pan Pacific Entomologist.

Proceedings of the Hawaiian Entomological Society.

Proceedings of the Entomological Society of Washington (D. C.).

Psyche.

+Thomas Say Foundation of the Entomological Society of America.

Transactions of the American Entomological Society.

* No parts on Diptera published.

† Publication discontinued. Mostly Diptera and Lepidoptera.

† Irregular publications. 


\section{Scientific Publications Containing Entomological Papers}

American Journal of Hygiene.

American Museum Novitates (American Museum of Natural History).

Anales del Instituto de Biologia (Mexico City).

Bulletin of the American Museum of Natural History.

Bulletin of the Buffalo Society of Natural Sciences.

Bulletin of the Illinois State Laboratory of Natural History.

Journal of the Washington Academy of Sciences (D. C.)

Kansas University Science Bulletin.

Occasional Papers of the Boston Society of Natural History.

Ohio Journal of Science.

Proceedings of the Biological Society of Washington.

Proceedings of the California Academy of Sciences.

Proceedings of the United States National Museum.

Transactions of the Royal Canadian Institute.

Transactions of the Royal Society of Canarla.

Transactions of the Wisconsin Academy of Sciences, Arts and Letters.

Zoological Record (London, England). Separate parts may be obtained. Lists all new species described each year.

See also Government publications of the United States, Canada and the States and Provinces.

\section{CORRECTIONS}

Page 327. Leucophanga Mik. Most species of this genus will trace to couplet 10 , where they may be distinguished by having the costa ending at the third vein.

Page 359. For Microdiopsis, n. g. read Pseudodiopsis Hendel. The genotype is the same. 


\section{INDEX.}

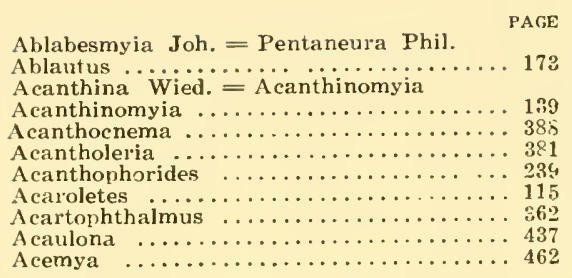

Acemyiopsis Towns. = Ceracia

Achætella ..................... 389

Achrtina .......................... 398 Achretoneura ................... 451

Achxtoneuropsis $\mathrm{T}=$ Achætoneura

Achalcus ...................221, 229

Arhradocera Beck. = Chrysotus

Acicephala ....................... 387

Acidia ....................... 287

A cidogona ............................ 289

Aciura ......................... 293

Aciurina $\ldots \ldots \ldots \ldots \ldots \ldots \ldots \ldots \ldots \ldots . \ldots \ldots 293$

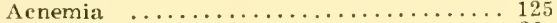

Aconops ............................ 267

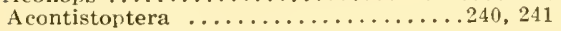

Acreotrichus Macq. = Neacreotrichus

Acrocera ...................... 201

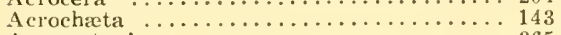

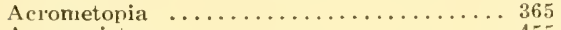

Acronarista $\ldots \ldots \ldots \ldots \ldots \ldots \ldots \ldots \ldots \ldots, 455$

Acronaristopsis ................. 445

Acrosticta ..................... 275

Acrostictella ...................... 281

Acrotrenia ........................ 291

Actia $\ldots \ldots \ldots \ldots \ldots \ldots \ldots, 454,455,460,462$

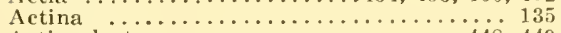

Actinochæta .......................448, 449

Actinomintho $\mathrm{T} .=$ Polygaster

Adelphomyia .................. 45

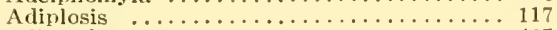

Adiscochæta .................... 407

Admontia .................448, 449

Adoxomyia $\ldots \ldots \ldots \ldots \ldots \ldots \ldots \ldots \ldots \ldots \ldots \ldots \ldots$

Acracta $=$ Culicoides

Aëdeomyia .....................995, 99

Aëdes $\ldots \ldots \ldots \ldots \ldots \ldots \ldots \ldots \ldots \ldots . \ldots . \ldots, 99$

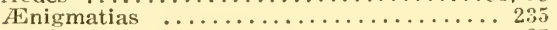

A eschnasoma $\ldots \ldots \ldots \ldots \ldots \ldots \ldots \ldots \ldots .37$

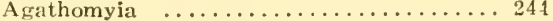

Agathon ....................... 62

Agrarialia $\ldots \ldots \ldots \ldots \ldots \ldots \ldots \ldots \ldots \ldots \ldots \ldots \ldots \ldots \ldots, 469$

Agria $\ldots \ldots \ldots \ldots \ldots \ldots \ldots \ldots \ldots \ldots \ldots, 409$

Agromyza $\ldots \ldots \ldots \ldots \ldots \ldots \ldots \ldots . . . \ldots 332$

Agromyzida ..................... 332

Akronia ............................. 141

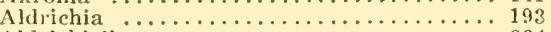

Aldrjchiella ...................... 334

Aldrovandiella $\ldots \ldots \ldots \ldots \ldots \ldots \ldots \ldots \ldots, 132$

Aleomyia Phillips = Euribia

Alexandriaria ................... 43

Alexionogon ...................177, 183

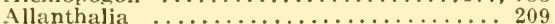

Alliopsis . . . . . . . . . . . . . . . . . . . . 391

Allocotocera .......................... 123

Allodia ........................ 127

Allnostylus .................... 397

Allognosta ........................ 135

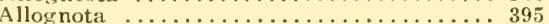

Allograpta ....................... 255

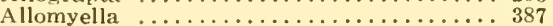

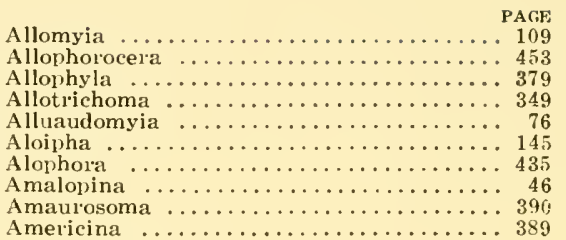

Americina $\ldots \ldots \ldots \ldots \ldots . \ldots . \ldots . \ldots 389$

Amiota $=$ Stegana

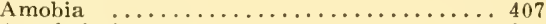

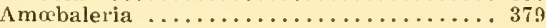

Amphichreta $=$ Phorocera

Amphicnenhes . . . . . . . . . . . . 279

Amphicosomus ..................... 197

Amphipogon ........................ 311

Anacampta $\mathrm{Lw}=$ Meckelia

Anacamptomyia $\ldots \ldots \ldots \ldots \ldots \ldots \ldots \ldots 448$

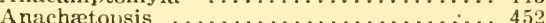

A nadiscalia . . . . . . . . . . . . . . . . .

Analcocerus ...................... 143

Anarmostus $\ldots \ldots \ldots \ldots \ldots \ldots \ldots \ldots \ldots \ldots 181$

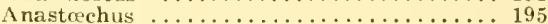

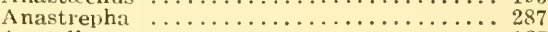

Anatella ........................ 127

Anatopynia ................... 71

Andrenosoma ...................... 179

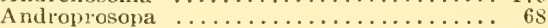

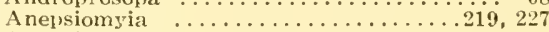

Anemrina .....................237

Anisopodidæ ..................... 59

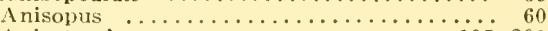

A nisotamia ......................... 200

Aromalempis ..................207

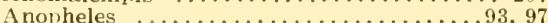

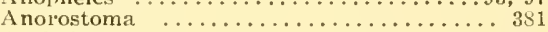

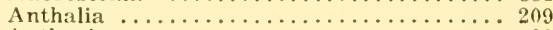

Anthepiscopus ................... 209

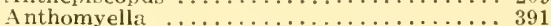

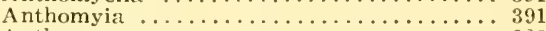

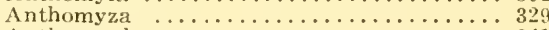

Anthracophaga $\ldots \ldots \ldots \ldots \ldots \ldots \ldots \ldots \ldots 341$

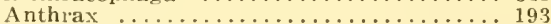

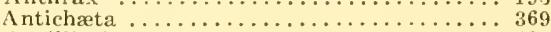

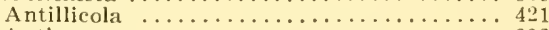

Antineura ........................ 332

Antiphrisson ........................... 183

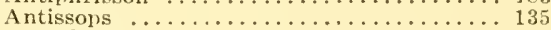

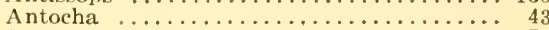

Anypotacta ...................... 379

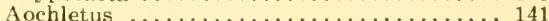

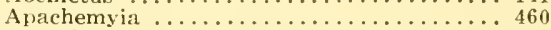

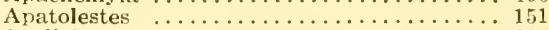

Apelleia .......................204

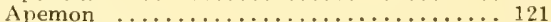

Aphamartania .......................... 171

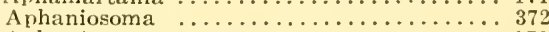

Aphestia ....................... 179

Aphidoletes .................... 113

Aphiochreta $=$ Megaselia

Aphobantus .....................20 200

Aphria ........................ 455

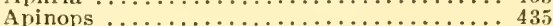

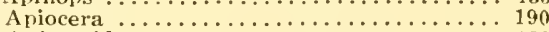

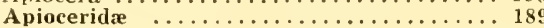

A nocephalus .................... 239

Apomidas

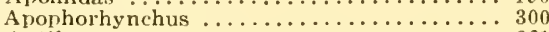

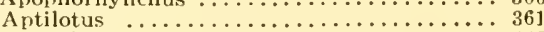

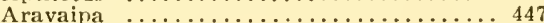

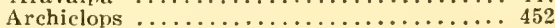


A.chilestris ........................... PAG

Archilimnophila ..................... 173

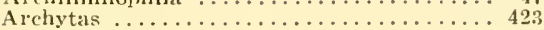

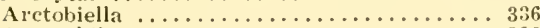

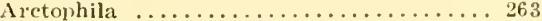

Aretophyto .................... 423

Argentoëpalpus Tns. = Rhachoëpalpus

Argyra ....................219, 225

Argyreomyia Tns. $=$ Leptostylum

Argyrochætona $\ldots \ldots \ldots \ldots \ldots \ldots 451,459,463$

Argyronhylax ....................443,460

Ariciella ....................... 397

Aridalia $\ldots \ldots \ldots \ldots \ldots \ldots \ldots \ldots \ldots \ldots \ldots, 459,469$

Armigeres .................... 99

Arrhinomyia B.B. = Elodia

Arthroceras ................... 146

Althrochata .................. 421

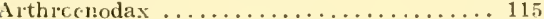

Arthropeas .................... 146

Asemosyrphus .................... 264

Asilida $\ldots \ldots \ldots \ldots \ldots \ldots \ldots \ldots \ldots \ldots \ldots \ldots . \ldots \ldots$

Asilostoma .................... 317

Asilus ....................... 183

Asimoneura Czerny $=$ Euribia

Asindulum ....................... 121

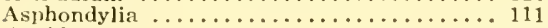

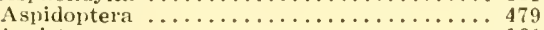

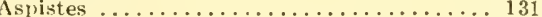

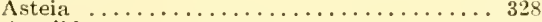

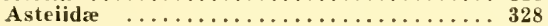

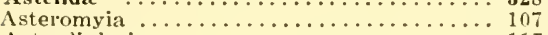

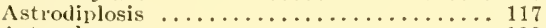

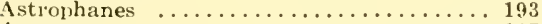

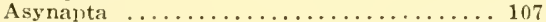

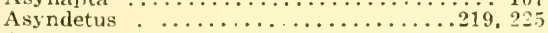

Atacta .................... 457

Atactomima Tns, $=$ Atacta

Atarba .................... 46

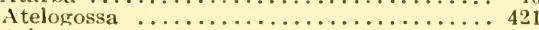

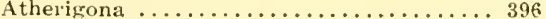

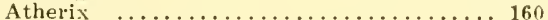

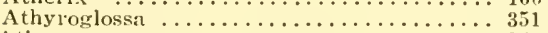

Atiss: ....................... 349

Atissiella ...................... 349

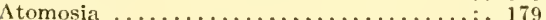

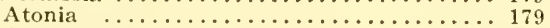

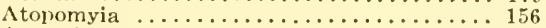

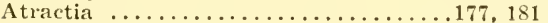

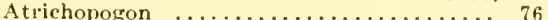

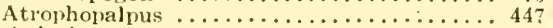

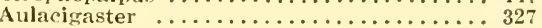

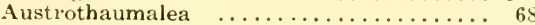

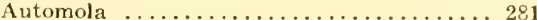

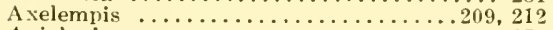

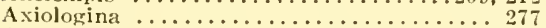

Axymyia ................... 60

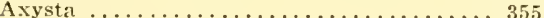

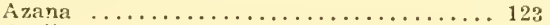

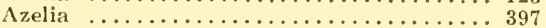

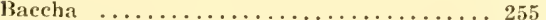

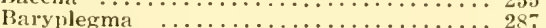

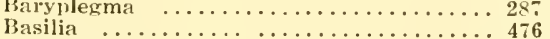

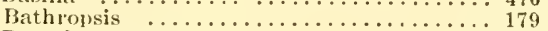

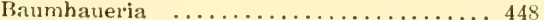

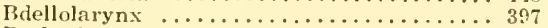

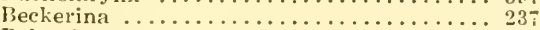

Belvosia .................. 423,451

Belvosiomima Tns. = Belvosia

Belvosiopsis Tns. = Belvosia

Beris

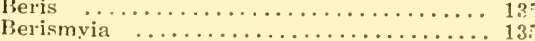

Berkshiria ................... 139

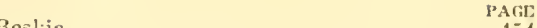

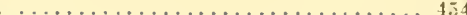

Besseria ................... 43.

Bezzia ..................... 77

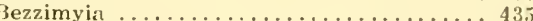

Bibio ......................

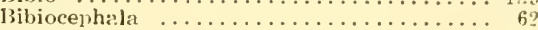

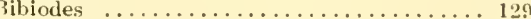

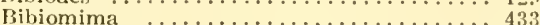

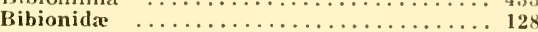

Bicellatia $\ldots \ldots \ldots \ldots \ldots \ldots \ldots \ldots \ldots \ldots \ldots \ldots . \ldots \ldots$

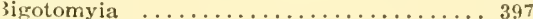

Billaea .................... 425

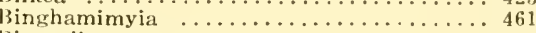

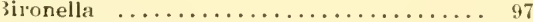

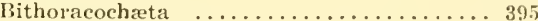

Bittacomorpha $\ldots \ldots \ldots \ldots \ldots \ldots \ldots \ldots$ si

Bittacomorphella ................ 30

Blepharepium .................. 171

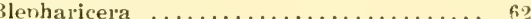

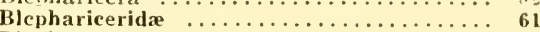

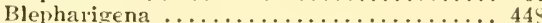

Blepharipeza Macq. = Leschenaultia

Blepharonewra ................ 287

Bloridelia $\ldots \ldots \ldots \ldots \ldots \ldots \ldots \ldots \ldots \ldots . \ldots \ldots$

Bogeria $=$ Cuterebra

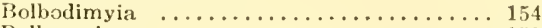

Bolbomyia ................... 159

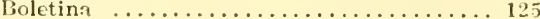

Boletophila ...................... 121

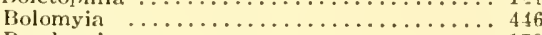

Bombonima .................. 179

Bombyliida 191

Bombyliomyia ................. 442

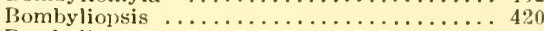

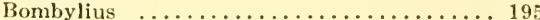

Borborida ................... 360

Borborus .......................... 361

Boreëllus .................. 408

Boreodromia .................. 212

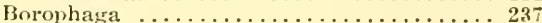

Brachicema .......................

Brachydeutera ................ 355

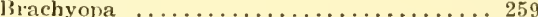

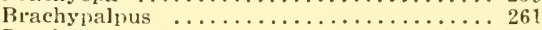

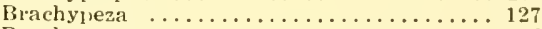

Brarhypremna $\ldots \ldots \ldots \ldots \ldots \ldots \ldots \ldots \ldots$

Brachypteromyia Will. = Myophthiria

Brachystoma .................. 207

Biaula

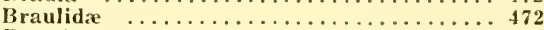

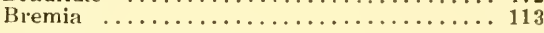

Briciniella $=$ Senopterina

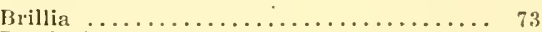

Brochella .................... 209

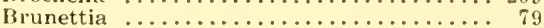

Bucentes = Siphona

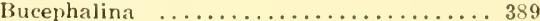

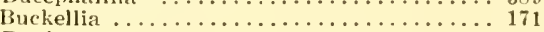

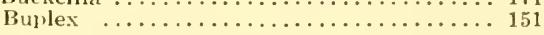

Cacosis .................... 141

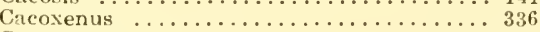

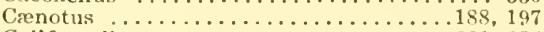

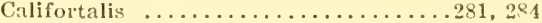

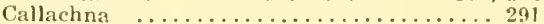

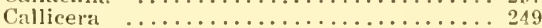

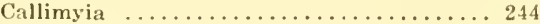

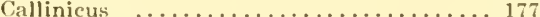

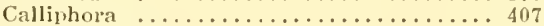

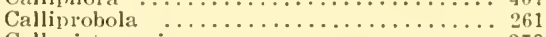

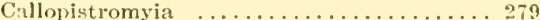

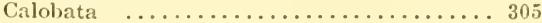




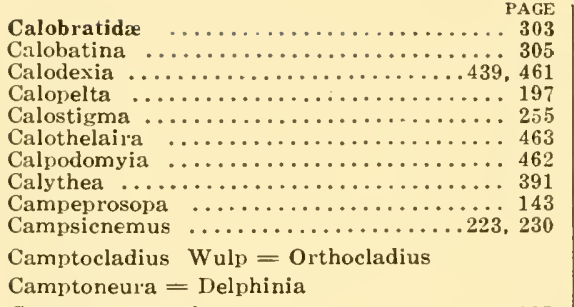

Camptoneuromyia .............. 107

Camptoprosopella ................. 319

Camptops ...................... 409

Camptopyga $\ldots \ldots \ldots \ldots \ldots \ldots \ldots \ldots \ldots \ldots \ldots . \ldots \ldots{ }_{4}$

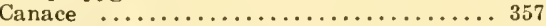

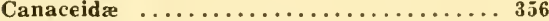

Canacea Malloch $=$ Canace

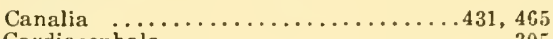

Cardiacephala ................ 305

Cardiocladius $\ldots \ldots \ldots \ldots \ldots \ldots \ldots \ldots \ldots \ldots 73$

Caricea $=$ Canosia

Carpotricha of authors, not Lœw = Paracantha Carpotricha Low = Ditricha

Cartosyrphus .................... 257

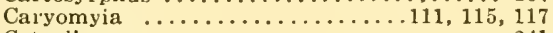

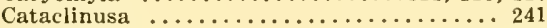

Catalinovoria ................439,455

Catemophrys .................. 456

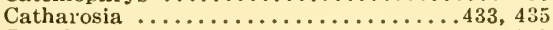

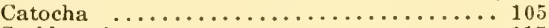

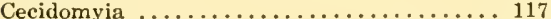

Cecidomyidæ ..................... 101

Celatoria . . . . . . . . . . . . 452,453,462

Centeter ...................... 453

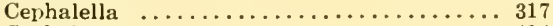

Cephalemya ..................... 411

Cephalia $=$ Setellia

Ceracia ....................... 462

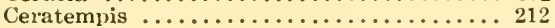

Ceratinostoma ................... 389

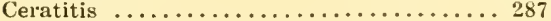

Ceratobarys ..................... 343

Ceratocheilus .................. 49

Ceratolophus $=$ Serromyia

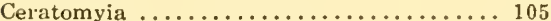

Ceratomyella ..................... 449

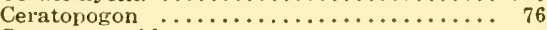

Ceratopogonidze ................ 74

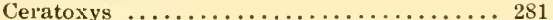

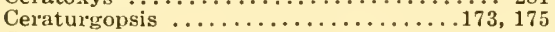

Ceraturgus . . . . . . . . . . . . . . . 173

Cerdistus .................... 183

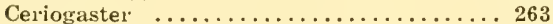

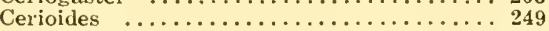

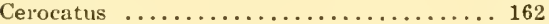

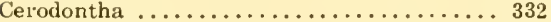

Cerometolum ...................... 349

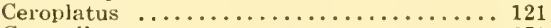

Ceropsilona ...................... 351

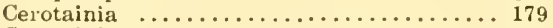

Cerotainiops ........................ 179

Cerotelion Rondani $=$ Ceroplatus

Ceroxys $=$ Melieria

Cetema ........................ 341

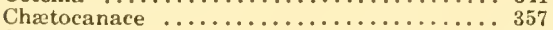

Chretochlorops ..................... 344

Chatoclusia ................... 364

Chretocnemistoptera .................... 337

Chretocolia ..................... 321

Chætogredia ................... 448
Chatogadiopsis Tns. = Gædiophana

PAGE

Chretogenia ..................... 394

Chatoglossa

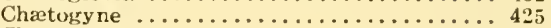

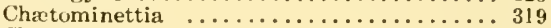

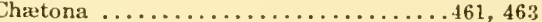

Chatonalia .................431,465

Chrotonodexodes ................... 452

Chretophleps ................. 451

Chretophlepsis .................. 423

Chretoplaria .................... 449

Chætopleurophora .................. 237

Chactoprocta ...................... 447

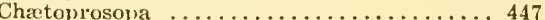

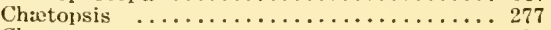

Chactosa . . . . . . . . . . . . . . . 390

Chrtostirmontera ..............460

Chatovoria ................ 437

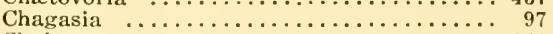

Chalarus ....................... 246

Chalcomyia ..................... 259

Chalcosyrphus . . . . . . . . . . . . 259

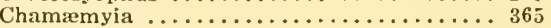

Chamamyida ................. 365

Chamasyrphus .................. 259

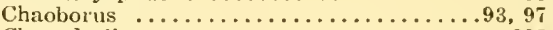

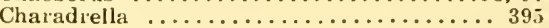

Charadrodromia .................. 214

Charapemyia $\mathrm{T}$. = Trafoia

Chasmatonotus ............... 73

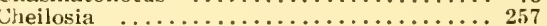

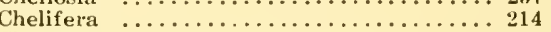

Chelipoda $\ldots \ldots \ldots \ldots \ldots \ldots \ldots \ldots \ldots \ldots \ldots \ldots \ldots . \ldots \ldots . \ldots \ldots$

Chersodromia ................... 214

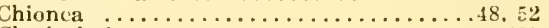

Chricahuia .................. 435

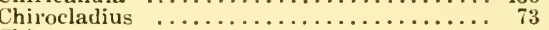

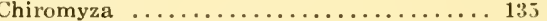

Chironomida $\ldots \ldots \ldots \ldots \ldots \ldots \ldots \ldots \ldots \ldots$

Chironomus .......................... 73

Chirosia ..................... 393

Chloropida $\ldots \ldots \ldots \ldots \ldots \ldots \ldots \ldots \ldots \ldots \ldots . . \ldots 339$

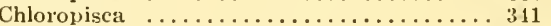

Chloroprocta $\ldots \ldots \ldots \ldots \ldots \ldots \ldots \ldots \ldots \ldots \ldots \ldots . \ldots \ldots$.

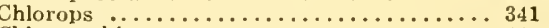

Chlorotachina ................. 441

Cholomyia ...................... 431

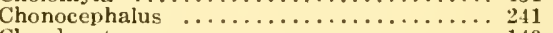

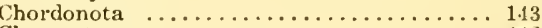

Chromatocera .................. 442

Chromolepida .................... 188

Chrysanthrax .......................... 195

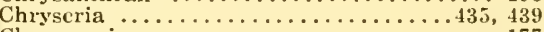

Chrysoceria .................... 177

Chrysochlora $\ldots \ldots \ldots \ldots \ldots \ldots \ldots \ldots \ldots \ldots \ldots 111$

Chrysochroma $\ldots \ldots \ldots \ldots \ldots \ldots \ldots \ldots \ldots \ldots \ldots 145$

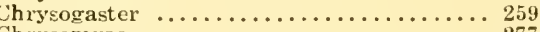

Chrysomyza .................... 277

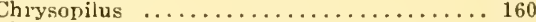

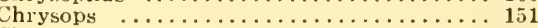

Chrysosoma ...................... 216

Chrysosomopsis $=$ Gymnochata

Chrysosomidia .............. 261, 263

Chrysotachina ...................... . . 429

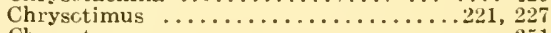

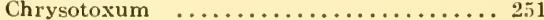

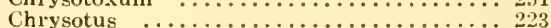

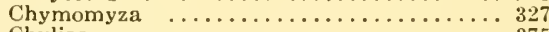

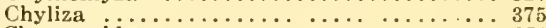

Chyromyidz .................. 371

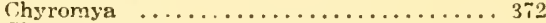

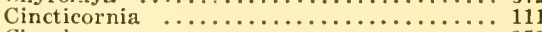

Cirrula $\ldots \ldots \ldots \ldots \ldots \ldots \ldots \ldots \ldots \ldots \ldots . \ldots \ldots$

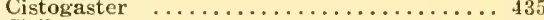

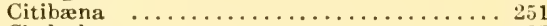

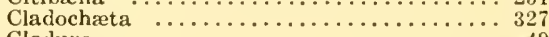

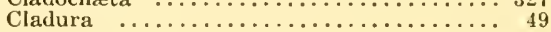


Clairvillia $=$ Dionza

Clanoncurum ................... 349

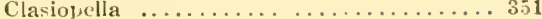

Clastopteromyia ................ 327

Clausicella ................... 456

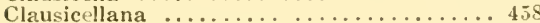

Clcigast 1 a ................... 390

Clelia Des. = Leucostorna

Clcodiplosis .................. 113

Clentee $\ldots \ldots \ldots \ldots \ldots \ldots \ldots \ldots \ldots \ldots \ldots \ldots .445$

Clinocera $\ldots \ldots \ldots \ldots \ldots \ldots \ldots \ldots \ldots \ldots \ldots \ldots .214$

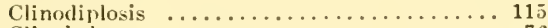

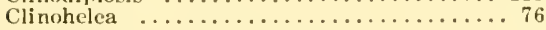

Clinoneura $=$ Rhynchiodexia

Clinopera ..................... 395

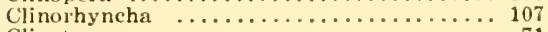

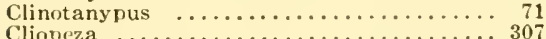

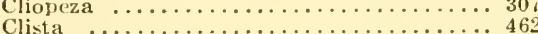

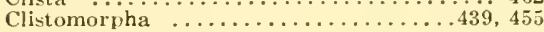

Clitellaria of authors $=$ Adoxomyia

Clitiomya Rond. = Chryscria

Clusia ...................... 364

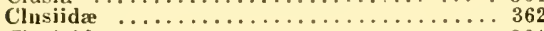

Clusioirles ....................... 364

Clythopsis Tns, = Ceracia

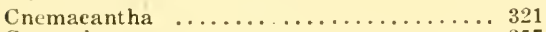

Cnemodon ................... 257

Cnephaliodes $\ldots \ldots \ldots \ldots \ldots \ldots \ldots \ldots \ldots \ldots \ldots .423$

Coboldia ....................... 131

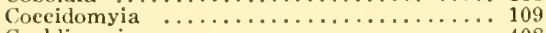

Cochliomyia $\ldots \ldots \ldots \ldots \ldots \ldots \ldots \ldots \ldots \ldots . \ldots 40 . \ldots \ldots$

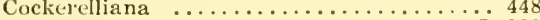

Coeloglutus ..................217, 229

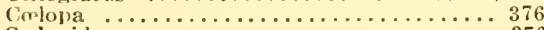

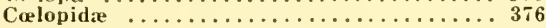

Coclosia ....................... 125

Colotanypus $=$ Clinotanypus

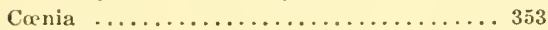

Conomyia ................. 16

Conomyida

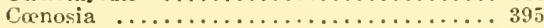

Coilometopia ................... 275

Colabris ...................... 214

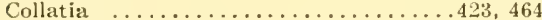

Collinellula $\ldots \ldots \ldots \ldots \ldots \ldots \ldots \ldots \ldots \ldots \ldots .221,229$

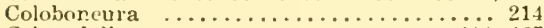

Coloradalia ...............444, $46^{7}$

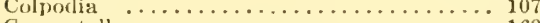

Comantella ................... 169

Comatacta Cor. = Telothyria

Commoptera .................... 241

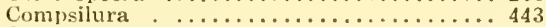

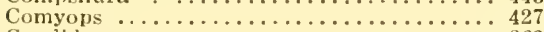

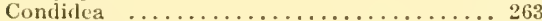

Condylostylus ................... 216

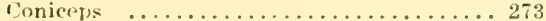

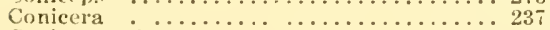

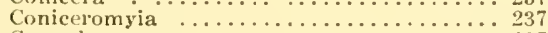

Conoptorus .................. 197

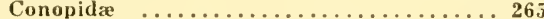

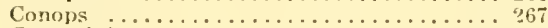

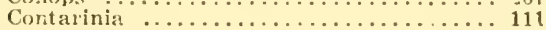

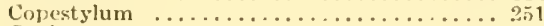

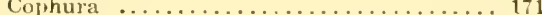

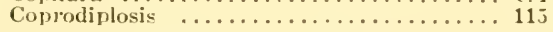

Coquillettina Walton $=$ Hemithrixion

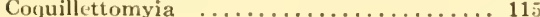

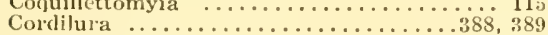

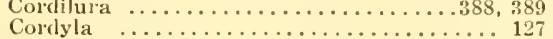

Cordyligaste $\ldots \ldots \ldots \ldots \ldots \ldots \ldots \ldots \ldots \ldots \ldots . . \ldots 457$

Cordylomyia .................... 105

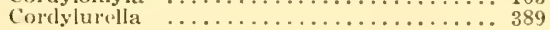

Corethra auct $=$ Mochlonyx

rAGE.

Corethra Meigen $=$ Chaoborus

Corethrella $\ldots \ldots \ldots \ldots \ldots \ldots \ldots \ldots \ldots \ldots \ldots \ldots .93,95$
Corinthomyia $\ldots \ldots \ldots \ldots \ldots \ldots \ldots \ldots \ldots \ldots$

Corozalia ....................429,465

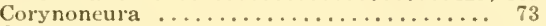

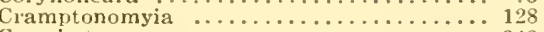

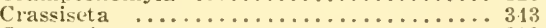

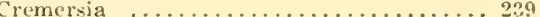

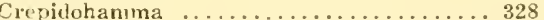

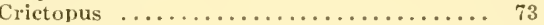

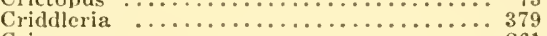

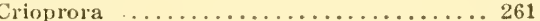

Criorthina $\ldots \ldots \ldots \ldots \ldots \ldots \ldots \ldots \ldots \ldots \ldots \ldots 261$

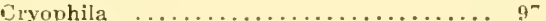

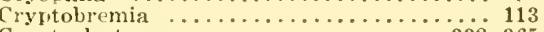

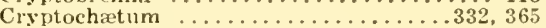

Cryptocladocera .................. 443

Cryptolabis ................... 50

Cryptomeigenia ................. 437

Ctenodactylomyia $\quad \ldots \ldots \ldots \ldots \ldots \ldots \ldots \ldots \ldots \ldots 109$

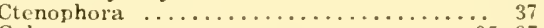

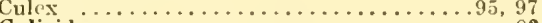

Culicidæe .................... 83

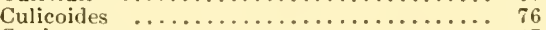

Cuphocera $\ldots \ldots \ldots \ldots \ldots \ldots \ldots \ldots \ldots \ldots \ldots, 47$

Curtonotum ................. 327

Cuterebra .................... 412

Cuterebridæ $\ldots \ldots \ldots \ldots \ldots \ldots \ldots \ldots \ldots \ldots \ldots \ldots .411$

Cyamops $\quad \because \ldots \ldots \ldots \ldots \ldots \ldots \ldots \ldots \ldots . \ldots \ldots$

Cylindromyia .................421.454

Cylindrotoma .................. 41

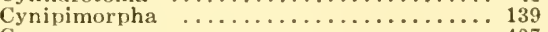

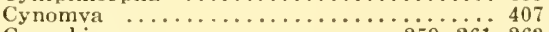

Cynorhina $\ldots \ldots \ldots \ldots \ldots \ldots \ldots \ldots .259,261,263$

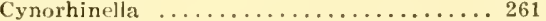

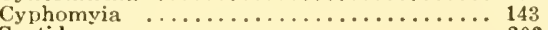

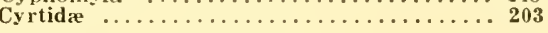

Cyrtometopa $=$ Odontomera

Cyrtoneurina .................. 394

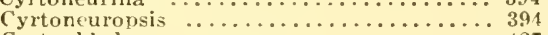

Cyrtophloba ......................... 427

Cyrtonotum $=$ Curtonotum

Cyrtopogon ................. 177

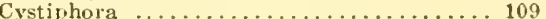

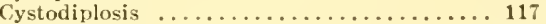

Cyzenis ........................ 443

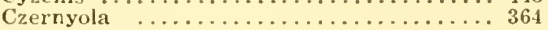

Dactylocladius $=$ Orthocladius

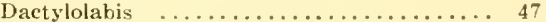

Dactylothyrea .................. 343

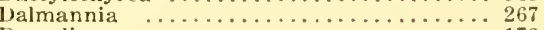

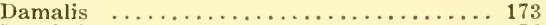

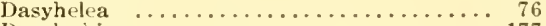

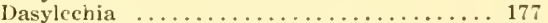

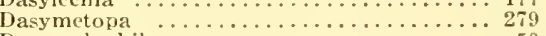

Dasymolophilus ........................ 50

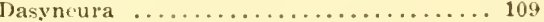

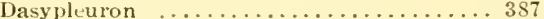

Degeeria ........................ 453

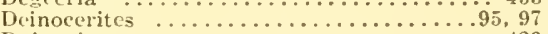

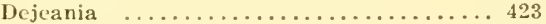

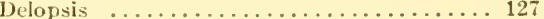

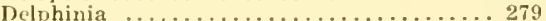

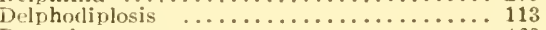

Demoticus . . . . . . . . . . . . . . 460

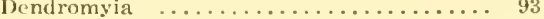

Dendroshaonia .................397, 399

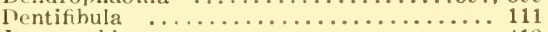

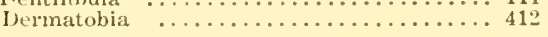

Deromyia $=$ Diogmites

Desmatomyia $\ldots \ldots \ldots \ldots \ldots \ldots \ldots . \ldots 200$

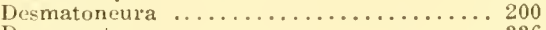

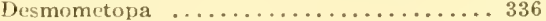

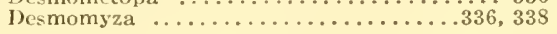




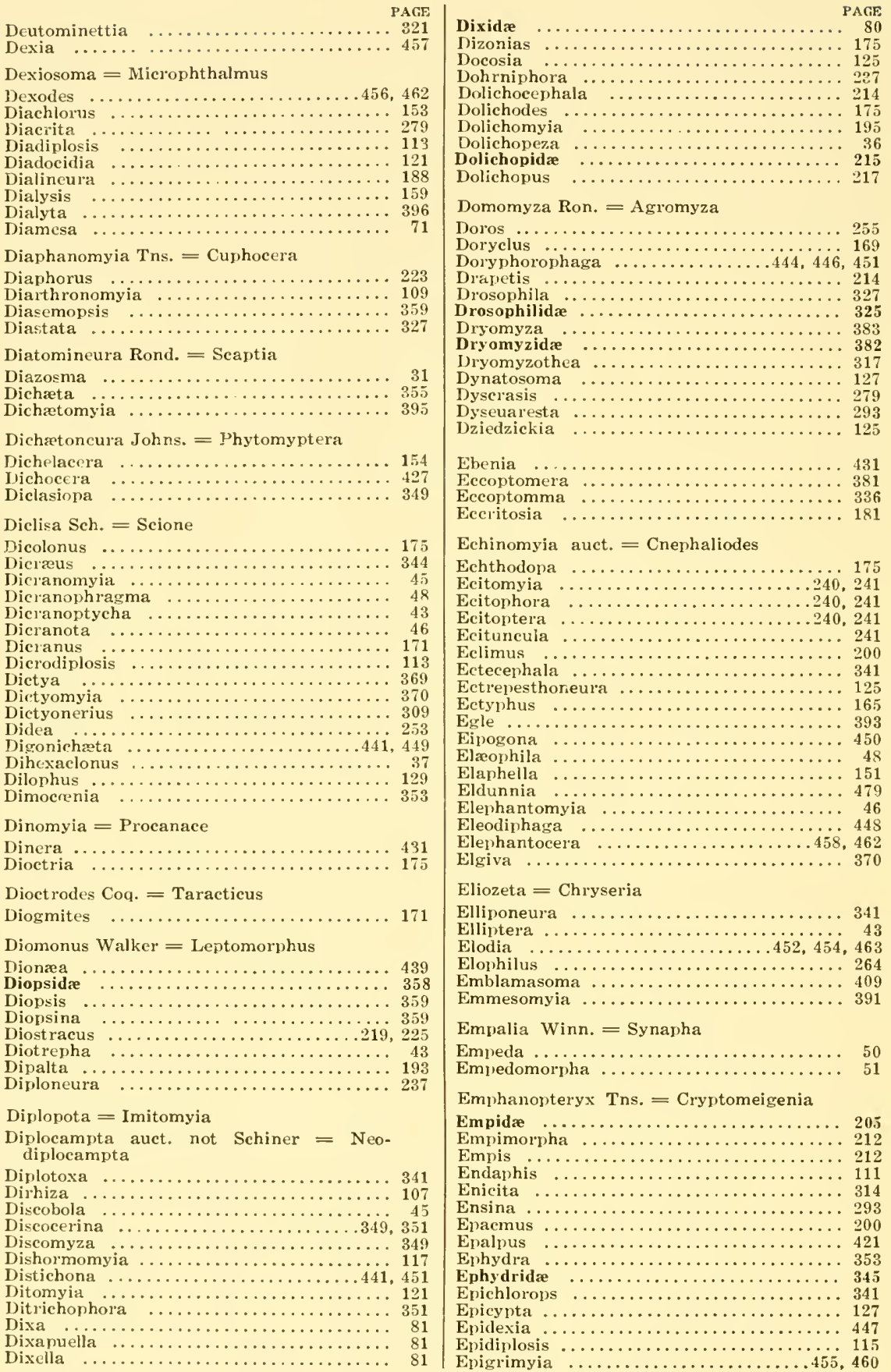




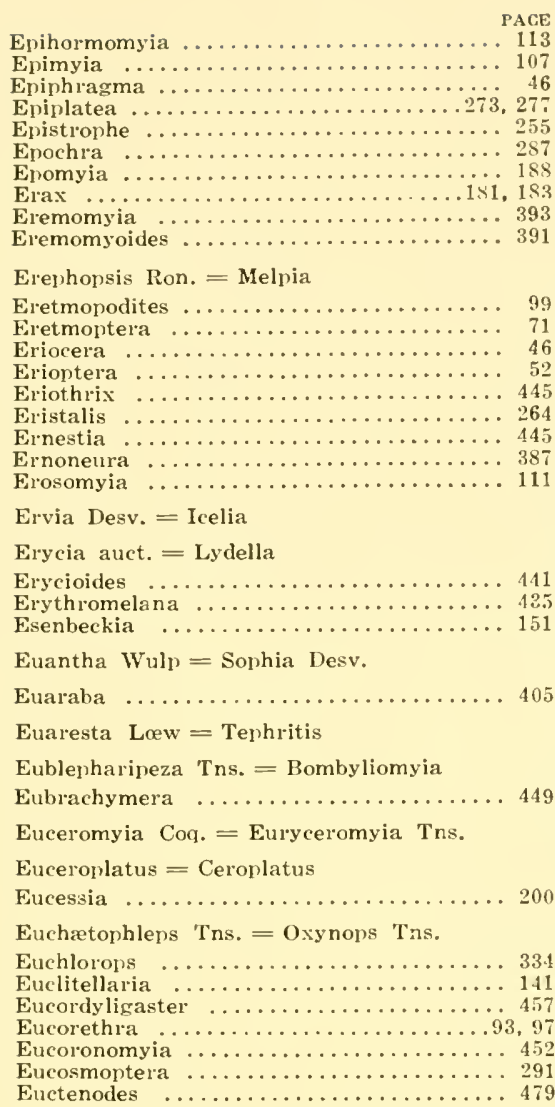

Eucynipimorpha Mall. = Psephiocera End.

Eucy r.tophloeba $=\mathrm{Cy} r$ tophloba

Eucyrtopogon .................. 177

Eudejeania ......................... 423

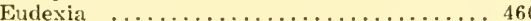

Eudicrana

Eudicranota ................... 46

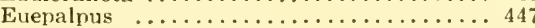

Eufabricia $\mathrm{T}_{\mathrm{.}}=$ Archytas

Euforcipomyia $=$ Forcipomyia

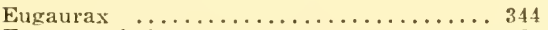

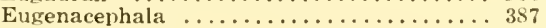

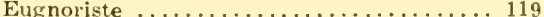

Euhalidaya ....................460

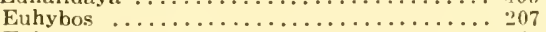

Eulasiona ...................... 427

Eulimnophora Mal. = Gymnodia

Eulonchus ........................ 203

Eumacronychia $\ldots \ldots \ldots \ldots \ldots \ldots \ldots \ldots \ldots, 407$

Eumecosoma ..................... 179

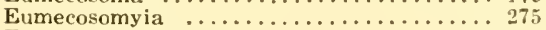

Eumegaparea ................... 461

Eumerus $=$ Heliophilus

Eumetopia $=$ Eumetopiella

Eumetopiella 277
Eumogenia Tns. = Acaulona

Eumyiolenta

Eumyobia T. = Neanhria

Eumyothyria $\mathbf{T}$. $=$ Cryptomeigenia

Eupachygaster

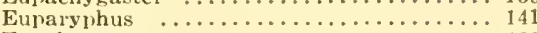

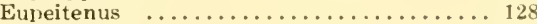

Eupelecotheca ..................... 444

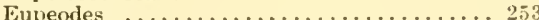

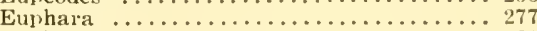

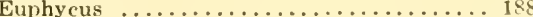

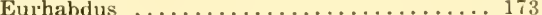

Euribia ...................... 287

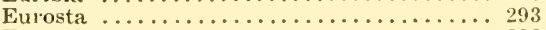

Eurostina ...................... 293

Eurycephala Röder $=$ Tetanons

Eurycephalomyia Hendel = Tetanops

Euryceromyia .................454, 456

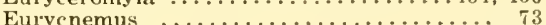

Euryneura ........................... 141

Euryomma .................... 397

Euscopolia ..................... 433

Eusenotainia ................. 407

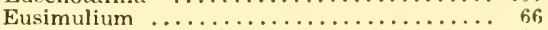

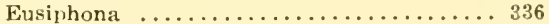

Eustigontera ................... 353

Eutanypus Coq. = Diamesa

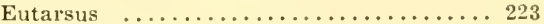

Euthelaira $\ldots \ldots \ldots \ldots \ldots \ldots \ldots \ldots \ldots \ldots, 44$

Euthelairopsis ................... 445

Euthera ........................ 45

Eutheresia ........................ 425

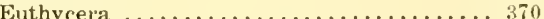

Euthyneura ...................... 209

Euthyprosona .................... 450

Cutonia $\ldots \ldots \ldots \ldots \ldots \ldots \ldots \ldots \ldots \ldots, 4 \mathrm{n}$

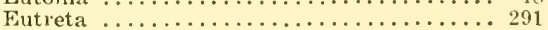

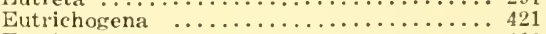

Eutrixa ...................... 439

Euxesta ...................... 277

Euzelia Tns. = Zelia

Euzenillia T. = Lixophaga

Euzenilliopsis T. = Lixophaga

Eversmannia .................. 429

Exechia ........................ 127

Exenacmus ....................... 197

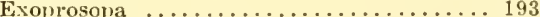

Exorista ..................451, 456

Exoristoides = Eversmannia

Exoristonsis $=$ Eversmannia

Fabriciella $=$ Cnephaliodes

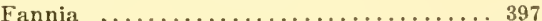

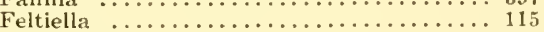

Feltomyia ..................... 111

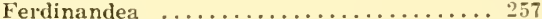

Ficalbia ....................... 99

Ficiomyia ....................... 109

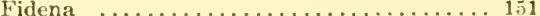

Fischeria

Flebotomus .................... 79

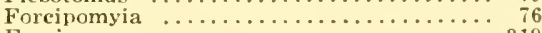

Freyia $\ldots \ldots \ldots \ldots \ldots \ldots \ldots \ldots \ldots \ldots \ldots, 319$

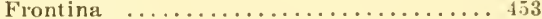

Frontiniclla $\ldots \ldots \ldots \ldots \ldots \ldots \ldots \ldots \ldots \ldots$ 4 43

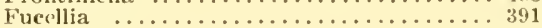

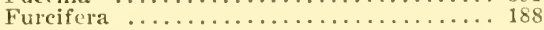

Grdia ..................... 449

Gædiophana B.is. = Tritaxys

Grediopsis ...................... 442

Gasterophilidx ................... 400

Gasterophilus ..................... 401

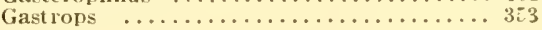




\begin{tabular}{|c|c|}
\hline & \\
\hline inaria . . & 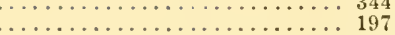 \\
\hline a.... & $\ldots \ldots \ldots \ldots \ldots \ldots \ldots \ldots$ \\
\hline yyza $\ldots .$. & $\ldots \ldots \ldots \ldots \ldots \ldots \ldots \ldots \ldots \ldots \ldots \ldots \ldots$ \\
\hline anomyia & 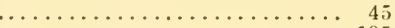 \\
\hline$\ldots \ldots$ & $\ldots \ldots \ldots \ldots \ldots \ldots \ldots \ldots \ldots \ldots .195$ \\
\hline lomyia. & $\ldots \ldots \ldots \ldots \ldots \ldots \ldots \ldots \ldots \ldots \ldots 115$ \\
\hline homyia & $\ldots \ldots \ldots \ldots \ldots \ldots \ldots \ldots \ldots \ldots 449$ \\
\hline omera. & $\ldots \ldots \ldots \ldots \ldots \ldots \ldots \ldots \ldots \ldots \ldots \ldots \ldots$ \\
\hline & Ald. = Chretovoria Vill. \\
\hline yia & $\ldots 441$ \\
\hline ellula ... & $\ldots \ldots \ldots \ldots \ldots \ldots \ldots \ldots \ldots \ldots \ldots 197$ \\
\hline Glaris $\ldots \ldots$ & 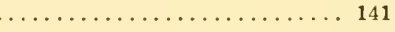 \\
\hline tricha & Thomson $=$ Volucella \\
\hline the .. & $\ldots \ldots .353$ \\
\hline na $\ldots \ldots$ & $\ldots \ldots \ldots \ldots \ldots \ldots \ldots \ldots \ldots \ldots . \ldots \ldots$ \\
\hline tops $\ldots$. & $\ldots \ldots \ldots \ldots \ldots \ldots \ldots \ldots \ldots \ldots \ldots$ \\
\hline phidops . & $\ldots \ldots \ldots \ldots \ldots \ldots \ldots \ldots \ldots \ldots$ \\
\hline Gnophomyia & $\ldots \ldots \ldots \ldots \ldots \ldots \ldots \ldots \ldots \ldots$ \\
\hline riste $\ldots$. & $\ldots \ldots \ldots \ldots \ldots \ldots \ldots \ldots \ldots \ldots \ldots \ldots \ldots$ \\
\hline Goeldia ..... & $\ldots \ldots \ldots \ldots \ldots \ldots \ldots \ldots 95,97,100$ \\
\hline & \\
\hline
\end{tabular}

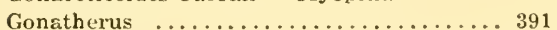

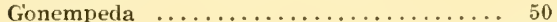

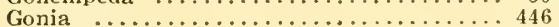

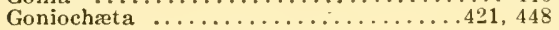

Goniomima Tns. = Belvosia

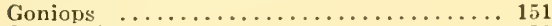

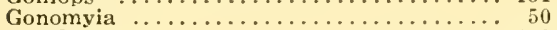

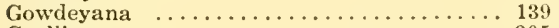

Grallipeza ................... 305

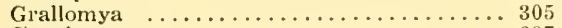

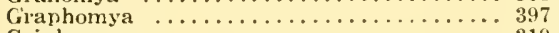

Griphoneura ................... 319

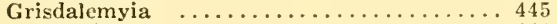

Gymnochæta ................... 444

Gymodexia B.B. = Billea Desv.

Gymnomma .................... 421

Gymnopalpus ................... 431

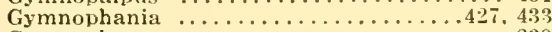

Gymnophora $\ldots \ldots \ldots \ldots \ldots \ldots \ldots \ldots \ldots \ldots . \ldots \ldots$

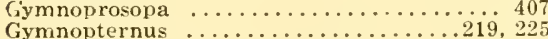

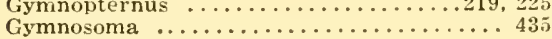

Gymnosturmia T. = Sturmia

Gyneuryparia .................. 143

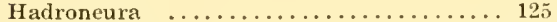

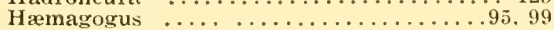

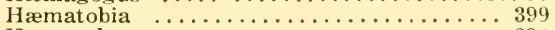

Hrematobosea $\ldots \ldots \ldots \ldots \ldots \ldots \ldots \ldots \ldots \ldots . \ldots \ldots 49 . \ldots \ldots \ldots$

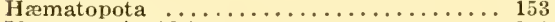

Hammerschmidtia ................. 259

Hammomyia .................... 393

Harbeckia ..................... 409

Harpagomyia .................. 100

Harpagopyga ................. 409

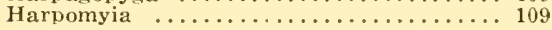

Harrisiopsis T. = Leschenaultia

Hartomyia $=$ Stilobezzia

Hebecnema

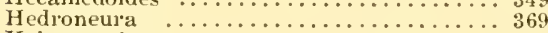

Heizmannia .................. 99

Heleodromia .................. 212

Helicobia ..................... 409

Heligmoncura $\ldots \ldots \ldots \ldots \ldots \ldots \ldots \ldots \ldots \ldots \ldots 183$

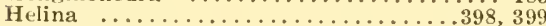

Heliophilus ................. 262

Helius ..........................

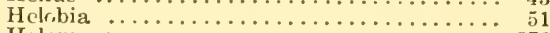

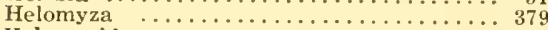

Heloinyzida $\ldots \ldots \ldots \ldots \ldots \ldots \ldots \ldots \ldots . \ldots \ldots$
Helophilus auct. $=$ Elophilus

PAGE

Hemerodromia ................ 214

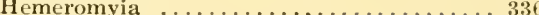

Hemichlora ..................... 399

Hemilucilia $\ldots \ldots \ldots \ldots \ldots \ldots \ldots \ldots \ldots \ldots \ldots \ldots . \ldots \ldots{ }_{0}$

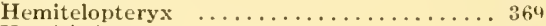

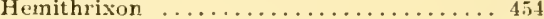

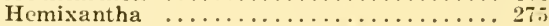

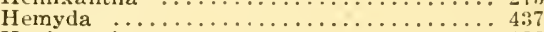

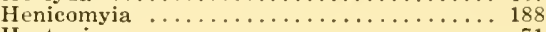

Heptagia ................... 7

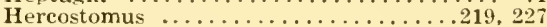

Hermetia $\ldots \ldots \ldots \ldots \ldots \ldots \ldots \ldots \ldots \ldots \ldots \ldots \ldots, 141$

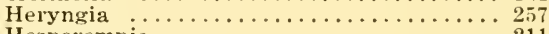

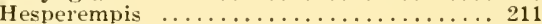

Hesperinus .................. 129

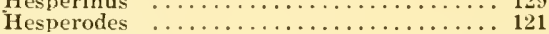

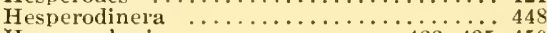

Hesperophasia ............433,435,450

Heteracanthia ............... 135

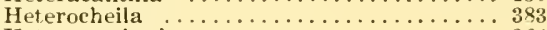

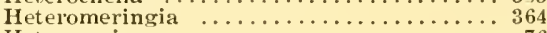

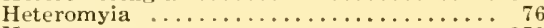

Heteromyza ................... 379

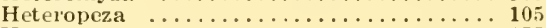

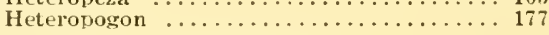

Heteropterna $=$ Ceroplatus

Heterostylum ................... 195

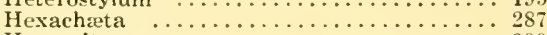

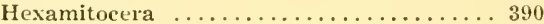

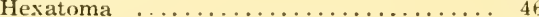

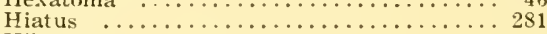

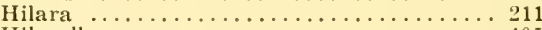

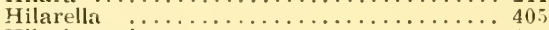

Hilarimorpha .................. 15?

Himantostoma $=$ Imitomyia

Himeroëssa .................. 281

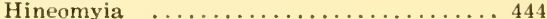

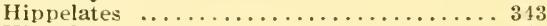

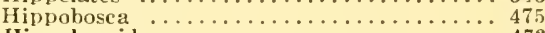

Hippoboscida $\ldots \ldots \ldots \ldots \ldots \ldots \ldots \ldots \ldots .473$

Hirmoneura ................. $20^{3}$

Histiodroma ................... 143

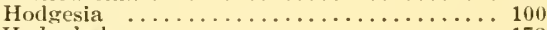

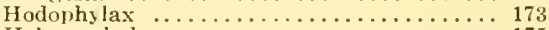

Holcocephala $\ldots \ldots \ldots \ldots \ldots \ldots \ldots \ldots \ldots \ldots 175$

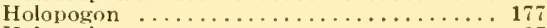

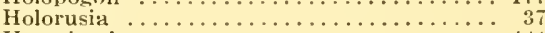

IIomalactia $\ldots \ldots \ldots \ldots \ldots \ldots \ldots \ldots \ldots \ldots \ldots \ldots . . .444$

Homogenia $=$ Trichiopoda

Homoneura . . . . . . . . . . . . . . 321

Hoplocheiloma $\ldots \ldots \ldots \ldots \ldots \ldots \ldots \ldots \ldots \ldots \ldots . \ldots \ldots{ }^{5}$

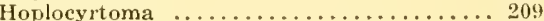

Hoplodictya .................. 369

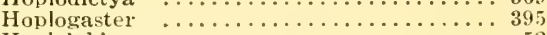

Hoplolabis .................... 52

Horidiplosis .................. 117

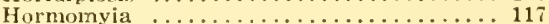

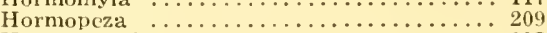

Hormosomyia $\ldots \ldots \ldots \ldots \ldots \ldots \ldots \ldots \ldots \ldots \ldots \ldots . \ldots \ldots$

Houghia ...................... 459

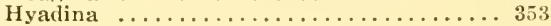

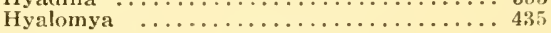

Hyalomyodes $\mathrm{T} .=$ Clistomorpha

Hyalurgus . . . . . . . . . . . . 44.

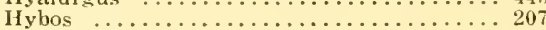

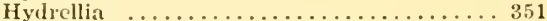

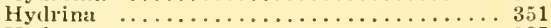

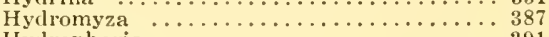

Hylrophoria .................... 391

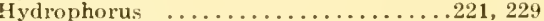

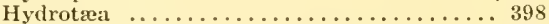

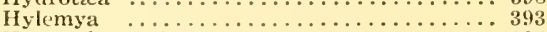

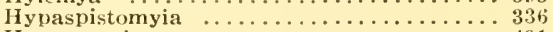

Hypenomyia .................. 431

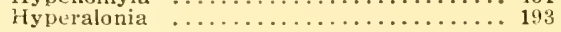




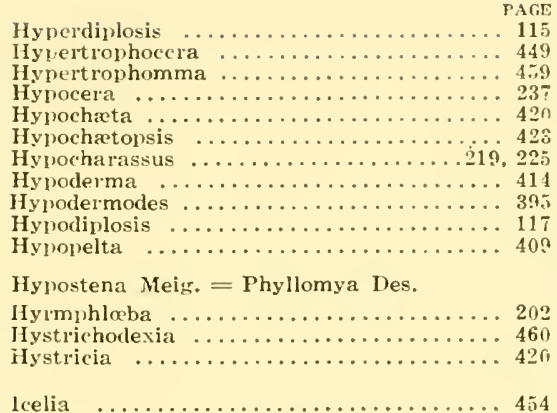

Iconomedina Tns. = Trichopareia B.B.

Icterica ...................... 28

Ietericophyto .................. 442

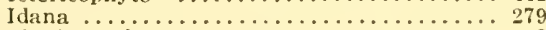

Idiolimnophila $\ldots \ldots \ldots \ldots \ldots \ldots \ldots \ldots \ldots . \ldots \ldots$

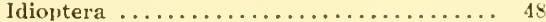

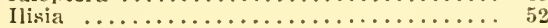

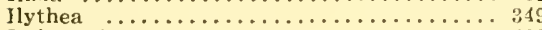

Imitomyia .................... 433

Ischnomyia $\ldots \ldots \ldots \ldots \ldots \ldots \ldots \ldots \ldots \ldots \ldots$

Ischyrophaga Tns. = Ebenia

Ischyrosyrphus $\ldots \ldots \ldots \ldots \ldots \ldots \ldots \ldots \ldots . \ldots \ldots$

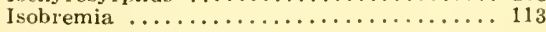

Isoecacta $=$ Dasyhelea

Isoneuromyia = Platyura

Isostomyia

Iteauhila

Jamacaria

Janetiella $\ldots \ldots \ldots \ldots . \ldots \ldots$

Jicaltepecia $\ldots \ldots \ldots \ldots \ldots \ldots \ldots \ldots \ldots \ldots \ldots \ldots \ldots . \ldots \ldots$

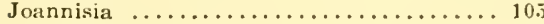

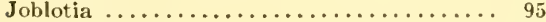

Johannsenomyia ............... 76

Johnsonia .......................... 407

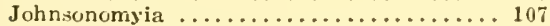

Johnsonomyia Mal = Berkshiria Johnson

Jurinella B.B. = Pseudohystricia

Jurinia ...................... 423

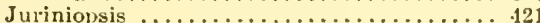

Kalodiplosis .................. 119

Kar'schomyia ................. 115

Keirosoma ...................225, 230

Kelloggina ................... 62

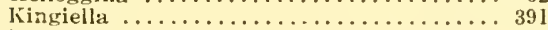

Konisomyia .................... 105

Kophosoma V.D. = Peloropeodes Wheeler

Kröberia ...................... 300

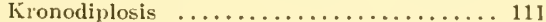

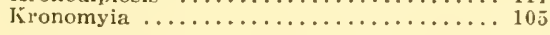

Lachnommolsis $\mathrm{T}$. = Paradidyma

Lactistomyia ................... 207

Lamprempis ....................... 212

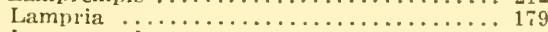

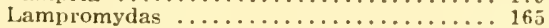

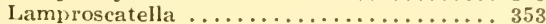

Laphria . . . . . . . . . . . . . . . . 179

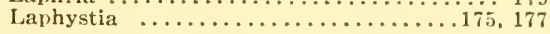

Lapyruta $=$ Platyura

Lasia ........................ 20s

Lasiomastix
PACE

Lasionalia .................4437,467

Lasiopa ........................... 141

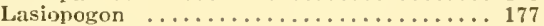

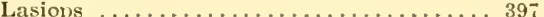

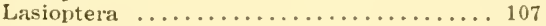

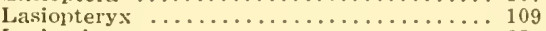

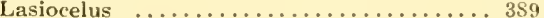

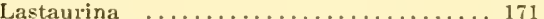

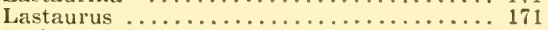

Lathyrophthalmus .................. 264

Latreillia Desv. = Belvosia

Latreillimyia $T_{0}=$ Belvosia

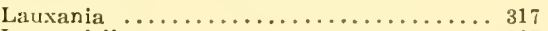

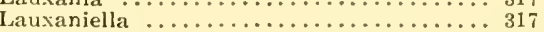

Lauxaniida .................. 315

Laximasicera .................... 459

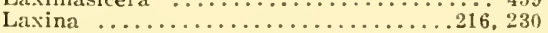

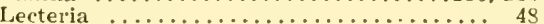

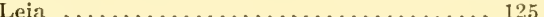

Leicesteria ...................... 99

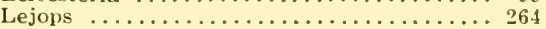

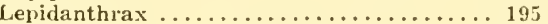

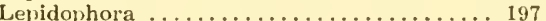

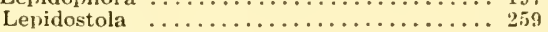

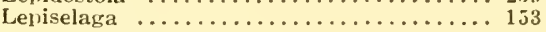

Leptis = Rhagio

Leptocera .................... 361

Leptochata B.B. = Phorocera

Leptocorypha . . . . . . . . . . 217, 225

Leptoda Wulp = Zelia

Leptogaster ...................... 173

Leptomorphus .................... 123

Lentomydas auct. $=$ Nomoneura

Leptopeza . . . . . . . . . . . . . . . . . . . 209

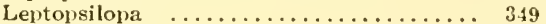

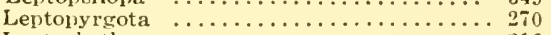

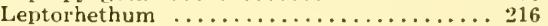

Leptostylum .................... 446

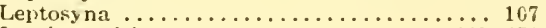

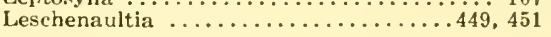

Leskia Desv. = Pyrrhosia

Leskiomima ................. 460

Leskiopalpus $\mathrm{T}$. $=$ Fischeria

Leskiopsis Tns. = Telothyria

Lestodiplosis ................. 115

Lestomyia $\ldots \ldots \ldots \ldots \ldots \ldots \ldots \ldots \ldots \ldots \ldots \ldots \ldots 171$

Lestremia .................... 105

Leucophenga ... . . . . . . . . . . . . . . . . 327

Leucopis . . . . . . . . . . . . . . . . . 365

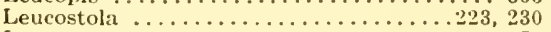

Leucostoma . . . . . . . . . . . . . . 455

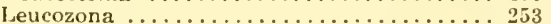

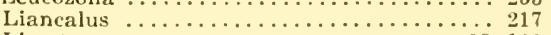

Limatus ..................... . . . 100

Limnia ......................... 370

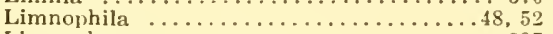

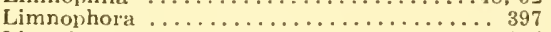

Limosia ......................... 395

Limnospila ................... 396

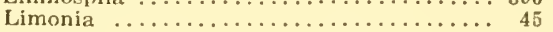

Linacerus $=$ Podonomus

Linnæmya . . . . . . . . . . 429,441,442

Liogma ....................... 41

Lipochrta .................. 347

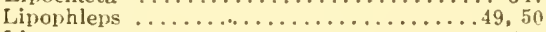

Lipoptena ....................... 475

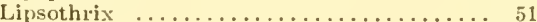

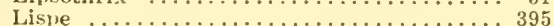

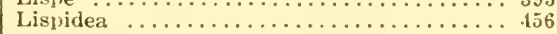




\begin{tabular}{|c|c|}
\hline Lispocephala $\ldots \ldots \ldots \ldots \ldots \ldots \ldots \ldots \ldots \ldots \ldots \ldots .396$ & egapariopsis T. = Megaparia \\
\hline 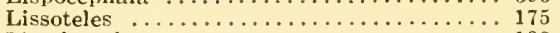 & $\ldots \ldots \ldots \ldots \ldots \ldots \ldots \ldots 78,389$ \\
\hline rhynchus $\ldots \ldots \ldots \ldots \ldots \ldots \ldots \ldots$ & egaprosopus $\ldots \ldots \ldots \ldots \ldots \ldots \ldots \ldots \ldots \ldots \ldots .447$ \\
\hline a $\ldots \ldots \ldots \ldots \ldots \ldots \ldots \ldots \ldots \ldots \ldots \ldots \ldots \ldots \ldots$ & legarhinus $\ldots \ldots \ldots \ldots \ldots \ldots \ldots \ldots \ldots \ldots 9 . \ldots \ldots$ \\
\hline $\begin{array}{l}\text { Lixophaga } \ldots \ldots \ldots \ldots \ldots \ldots \ldots \ldots \ldots \ldots \ldots \ldots \ldots \ldots \ldots \\
\text { Lobodiplosis } \ldots \ldots \ldots \ldots \ldots \ldots \ldots \ldots \ldots \ldots \ldots \ldots \ldots \ldots \ldots \\
\end{array}$ & legaselia...$\ldots \ldots \ldots \ldots \ldots \ldots \ldots$ \\
\hline opteromyia $\ldots \ldots \ldots \ldots \ldots \ldots \ldots \ldots \ldots$ & ida auct. = Megaselia \\
\hline 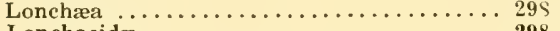 & \\
\hline$\ldots \ldots \ldots \ldots \ldots \ldots \ldots \ldots{ }^{29}$ & ...... \\
\hline 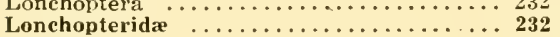 & $\ldots \ldots \ldots$ \\
\hline 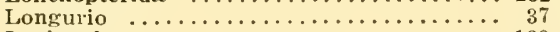 & $\ldots \ldots$ \\
\hline eles $\ldots \ldots \ldots \ldots \ldots \ldots \ldots \ldots \ldots \ldots$ & $\ldots \ldots \ldots$ \\
\hline 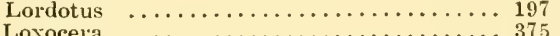 & halmidia $\ldots \ldots$ \\
\hline $\begin{array}{l}\text { cera } \ldots \ldots \ldots \ldots \ldots \ldots \ldots \ldots \ldots \ldots \ldots \ldots \ldots \ldots \\
\text { ia } \ldots \ldots \ldots \ldots \ldots \ldots \ldots \ldots \\
n_{4}\end{array}$ & \\
\hline 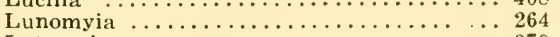 & . \\
\hline ia $\ldots \ldots \ldots \ldots \ldots \ldots \ldots \ldots \ldots \ldots \ldots \ldots \ldots$ & elloides Tns. = Dexo \\
\hline 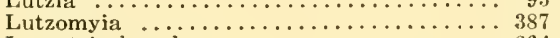 & ulp = Zelia \\
\hline 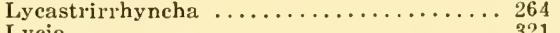 & \\
\hline$\ldots \ldots \ldots \ldots$ & $\ldots \ldots \ldots \ldots \ldots 221$ \\
\hline ct. $=$ & $=\mathrm{P}$ \\
\hline 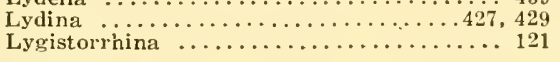 & $\cdots \cdots \cdots$ \\
\hline ia auct. $=$ Psel & ys $\ldots \ldots \ldots$ \\
\hline Lynchia $\ldots \ldots \ldots \ldots \ldots \ldots \ldots \ldots \ldots \ldots$ & $\ldots \ldots \ldots 2$ \\
\hline - & $\ldots \ldots \ldots$ \\
\hline & $\ldots \ldots \ldots \ldots$ \\
\hline 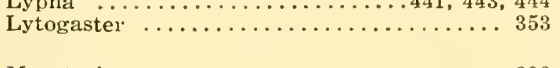 & 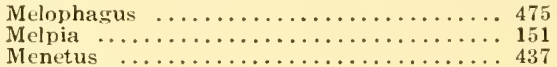 \\
\hline ia $\ldots \ldots \ldots \ldots \ldots \ldots \ldots \ldots \ldots . . \ldots \ldots$ & $a \ldots \ldots \ldots$ \\
\hline is $\ldots .$. & dus $\ldots \ldots \ldots \ldots \ldots$. \\
\hline $\mathrm{tia}=\mathrm{Ly}$ & $\begin{array}{ll}\ldots \ldots \ldots & 44 \\
\ldots \ldots \ldots & 42\end{array}$ \\
\hline$\ldots \ldots \ldots \ldots \ldots \ldots \ldots \ldots 35$ & a $\ldots \ldots \ldots$ \\
\hline$\ldots \ldots \ldots$ & $\ldots \ldots \ldots \ldots$ \\
\hline osia ... & crus $\quad \ldots \ldots \ldots \ldots$ \\
\hline$\ldots \ldots 446$ & $\ldots \ldots \ldots \ldots$ \\
\hline deria. & $\ldots \ldots \ldots \ldots$ \\
\hline$\ldots \ldots \ldots 43$ & us $\ldots \ldots \ldots \ldots \ldots$. \\
\hline$\ldots \ldots \ldots 39$ & ia $\ldots \ldots \ldots \ldots \ldots$. \\
\hline s $\ldots \ldots \ldots \ldots \ldots \ldots \ldots$ & 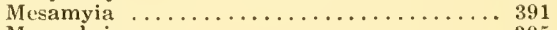 \\
\hline comyia ................. 275 & na $\ldots \ldots \ldots \ldots \ldots \ldots \ldots \ldots \ldots \ldots \ldots \ldots \ldots \ldots \ldots$ \\
\hline 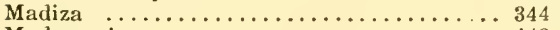 & nbrinella ... \\
\hline yia $\ldots \ldots \ldots \ldots \ldots \ldots \ldots \ldots \ldots \ldots \ldots \ldots \ldots$ & \\
\hline ia $\ldots \ldots \ldots \ldots \ldots \ldots \ldots \ldots \ldots \ldots . \ldots \ldots$ & ( \\
\hline$a \ldots \ldots \ldots \ldots \ldots \ldots \ldots \ldots$ & \\
\hline rina $\ldots \ldots \ldots \ldots \ldots \ldots \ldots \ldots \ldots \ldots \ldots \ldots \ldots \ldots \ldots \ldots \ldots$ & haga $\ldots \ldots \ldots \ldots \ldots \ldots \ldots \ldots \ldots$ \\
\hline$\ldots \ldots \ldots \ldots \ldots \ldots 264$ & \\
\hline ... 19 & $=\mathrm{W}$ \\
\hline iplosis ... & \\
\hline 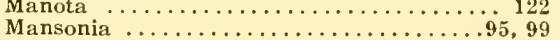 & \\
\hline ia $\ldots \ldots \ldots \ldots \ldots \ldots \ldots$ & HCHO 1. $=w$ \\
\hline Rond. & \\
\hline Maruina $\ldots \ldots \ldots \ldots \ldots \ldots \ldots \ldots \ldots$ & $\because$ \\
\hline$r a=L y d$ & a $\cdots$ \\
\hline 57,45 & $\cdot$ \\
\hline$\ldots \ldots \ldots \ldots .456$ & $\cdots$ \\
\hline$\ldots \ldots \ldots \ldots \ldots \ldots 442$ & $\ldots \ldots \ldots \ldots \ldots \ldots \ldots$ \\
\hline$=$ Ceratox & $\ldots \ldots \ldots \ldots \ldots \ldots$ \\
\hline $.217,229$ & $\cdots$ \\
\hline ... 214 & ......... \\
\hline .. 277 & ... \\
\hline$\ldots \ldots 125$ & pteryx $\ldots \ldots$ \\
\hline$\ldots \ldots 37$ & mus ..... \\
\hline$\ldots 251$ & \\
\hline$\ldots \ldots \ldots \ldots \ldots \ldots \ldots \ldots \ldots \ldots \ldots \ldots \ldots$ & $\ldots \ldots \ldots \ldots \ldots \ldots \ldots \ldots$ \\
\hline
\end{tabular}


Michogaster Macq. $=$ Setellia $\quad$ PAGE

Micrapemon $=$ Platyura

Micrempis .................... 214

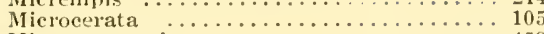

Nicroceromacia .................. 459

Nicrochrtina ................431, 448

Microchira B.B. = Paradidyma

Microchrysa $\ldots \ldots \ldots \ldots \ldots \ldots \ldots \ldots \ldots 11$.

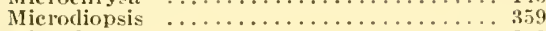

Microdon ....................... 249

Mierolynchia .................

Micromintho Tus. = Wagneria

Micromorphus ............. 221, 227

Mieronyehia B.B. = Eversmannia

Micropeza ................... 307

Micropezida $\ldots \ldots \ldots \ldots \ldots \ldots \ldots \ldots \ldots, 306$

Mierophorella ................... 209

Microphorus ...................... 209

Microphthalma ................ 117

Microprosopa ................... 389

Micropselapha ................ 389

Microptera Desv. = Dexia

Microsania .................... 244

Mierosillus $\ldots \ldots \ldots \ldots \ldots \ldots \ldots \ldots \ldots .459$

Microtipula $\ldots \ldots \ldots \ldots \ldots \ldots \ldots \ldots \ldots, 37$

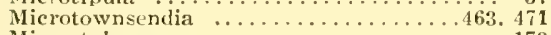

Microstylum ..................... 173

Midas $=$ Mydas

Milesia ..................... 26a

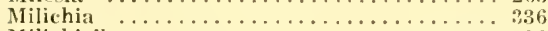

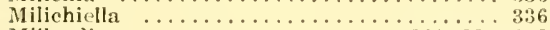

Millardia $. \ldots \ldots \ldots \ldots \ldots \ldots \ldots \ldots \ldots 221,229,231$

Minettia ...................... 321

Minthodexia B.B. = Xanthodexia

Minthoplagia ...............429, 445

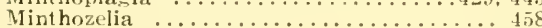

Misgomyia $=$ Bolbomyia

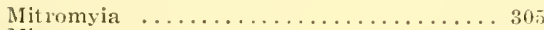

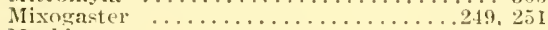

Mochlonyx $\ldots \ldots \ldots \ldots \ldots \ldots \ldots \ldots \ldots, 93 . \ldots \ldots$

Alochlosoma $\ldots \ldots \ldots \ldots \ldots \ldots \ldots \ldots \ldots \ldots \ldots 131$

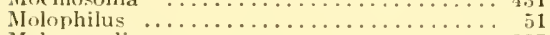

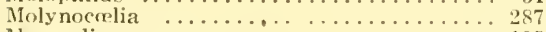

Monardia .........................

Monäthropalpus ................... 115

Monocheta B. B. = Cyzenis

Monoclona ...................... 125

Monohelea ................... 76

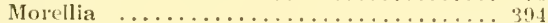

Morpholeria ..................... 381

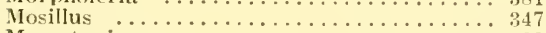

Mumetopia .............................. 329

Murdockiana .................. 44

Mlusea ...................... 394

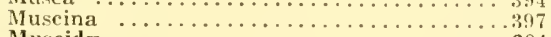

Muscida $\ldots \ldots \ldots \ldots \ldots \ldots \ldots \ldots \ldots \ldots \ldots . . \ldots \ldots$

Muscopteryx ...............427,442

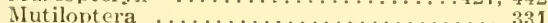

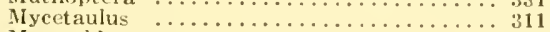

Mycetobia ........................ 60

Mycetophila ..................... 127

Mycetophilidx ................... 120

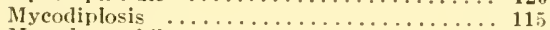

Mycodrosophila $\ldots \ldots \ldots \ldots \ldots \ldots \ldots \ldots \ldots \ldots \ldots . . \ldots \ldots 27$

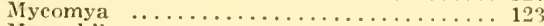

Mycophila ......................... 105

Mycothera $=$ Mycetophila

Mydrea $\ldots \ldots \ldots \ldots \ldots \ldots \ldots \ldots \ldots \ldots \ldots . \ldots \ldots 7$

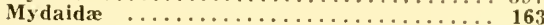

Mydas ...................... 165

Myelaphus ........................... 173

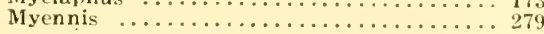

PAGE
Myiolenta

Myiomima . . . . . . . . . . . . 423, 425

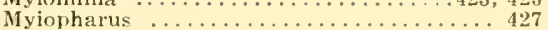

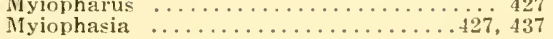

Myocera Ron. = Billaa Desv.

Myocerops $\mathrm{T}$. = Billea Desv.

Myoceropsis ...................4431

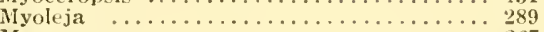

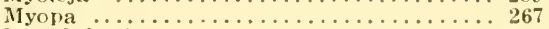

Myouhthyria .................. 175

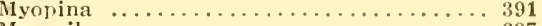

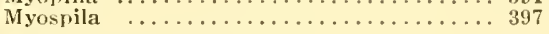

Myothyria $\mathrm{Wulp}=$ Ceracia

Myothyriopsis ................4 459

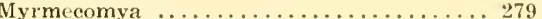

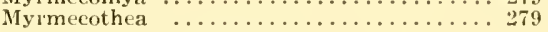

Myrsina Desv. $=$ Bessa Desv.

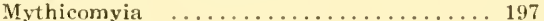

Myxosargus ......................... 14

Napea Desv. = Parydra

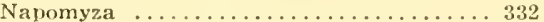

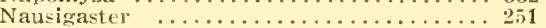

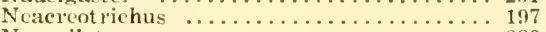

Neaspilota ...................... 289

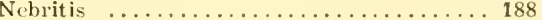

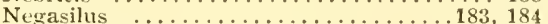

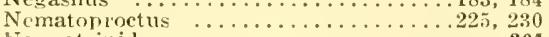

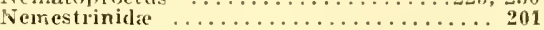

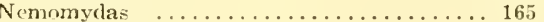

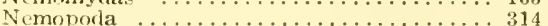

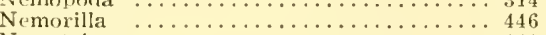

Nemotelus $\ldots \ldots \ldots \ldots \ldots \ldots \ldots \ldots \ldots \ldots \ldots \ldots \ldots . \ldots \ldots$

Neoascia $\ldots \ldots \ldots \ldots \ldots \ldots \ldots \ldots \ldots \ldots \ldots . \ldots \ldots$

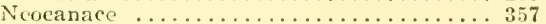

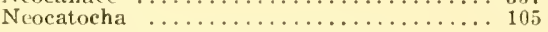

Neocelatoria Walton $=$ Chretophleps

Neoceratopogon $=$ Alluaudomyia

Neochauna ..................... 139

Neochrysops .................. 151

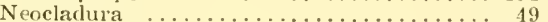

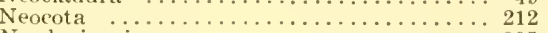

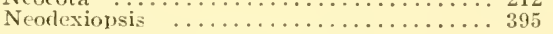

Neodichocera Walton $=$ Dichoeera

Neodionnea T. $=$ Dionrea

Neodiplocampta ..............193, 200

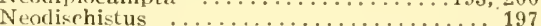

Neodixa $\ldots \ldots \ldots \ldots \ldots \ldots \ldots \ldots \ldots \ldots \ldots \ldots . \ldots \ldots{ }_{81}$

Neodohiniphora $\ldots \ldots \ldots \ldots \ldots \ldots \ldots \ldots \ldots \ldots . . . \ldots . . .239$

Neö̈mpheria .................. 123

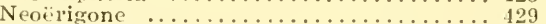

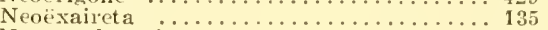

Neognophomyia .................. 51

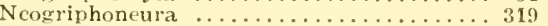

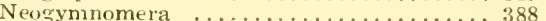

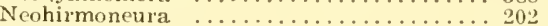

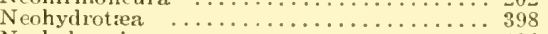

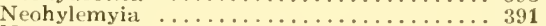

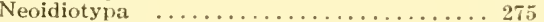

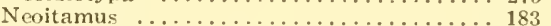

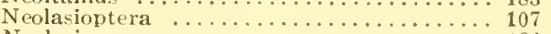

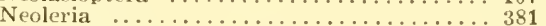

Neolimnobia .................... 45

Neolimnophila ................... 49

Neometachæta $\ldots \ldots \ldots \ldots \ldots \ldots \ldots \ldots \ldots \ldots \ldots .444$

Neominettia ..................... . 319

Neomochtherus O.S. = Heligmoneura Big.

Neomusea Mal. = Philornis

Neomuscina ..................... 399

Neopachygaster ..................... 139

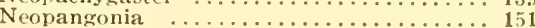

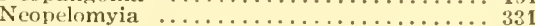


Neophryxe $\ldots \ldots \ldots . \ldots . \ldots . \ldots 456$

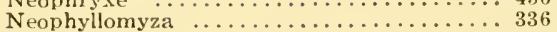

Ncophyto . ...............405,408

Neoplatyura $=$ Platyura

Neopogon ................... 175

Neorhynchocephalus ............... 20

Neorondania $\ldots . . . \ldots . . . . . . . .143$

Neoseiara $=$ Sciara

Neoscutops ................... 323

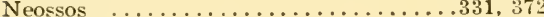

Neosyntormon ..............223, 230

Neothelaira Tns. $=$ Dexodes

Neotrafoia Tns. $=$ Trafoia

Nephopteropsis ................4 461

Nephrocerus .................... 246

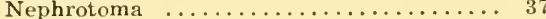

Nesotipula .................... 37

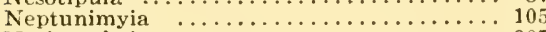

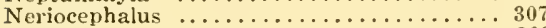

Neriidre ..................... 308

Nerius ...................... 309

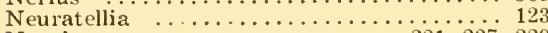

Neurigona $\quad \ldots \ldots \ldots \ldots \ldots \ldots \ldots \ldots .221,227,229$

Neuroctena $\ldots \ldots \ldots \ldots \ldots \ldots \ldots \ldots \ldots \ldots . \ldots \ldots . \ldots \ldots$

Neuromyia ...................... 109

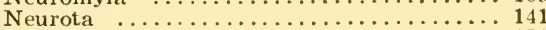

Nicocles ..................... 17

Niphogenia ................... 212

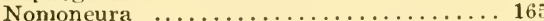

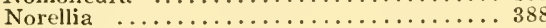

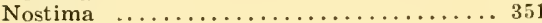

Nothodixa ..................... 8

Nothomyia .................... 143

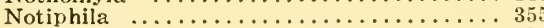

Notochreta $\ldots \ldots \ldots \ldots \ldots \ldots \ldots \ldots \ldots \ldots \ldots . \ldots 40 . \ldots \ldots$

Notogramma .................. 275

Nycteribia .................. 476

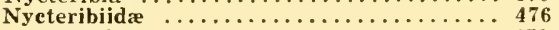

Nycterophilia ................. 479

Obolocera .................... 446

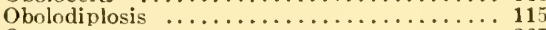

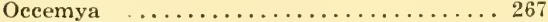

Ochrocera .................... 456

Och1omeigenia .......................... 44

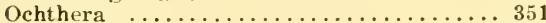

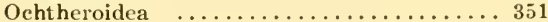

Ochthiphila $=$ Chamamyja

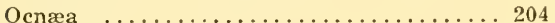

Ocydromia ................... 209

Ocyptera $=$ Cylindromyia

Ocypterosons $\mathbf{T}$. $=$ Phyllomya Desv.

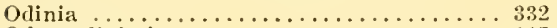

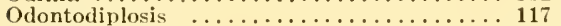

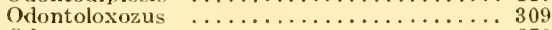

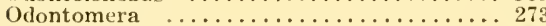

Odontonıyia $\ldots \ldots \ldots \ldots \ldots \ldots \ldots \ldots \ldots \ldots \ldots 113$

Odontopoda $=$ Neuratelia

Ecothea .................... 379

Edalia ............................ 209

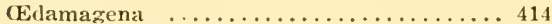

Edemasonia $\mathbf{T}=$ Pesseria

Edematocera .................. 462

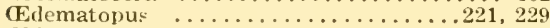

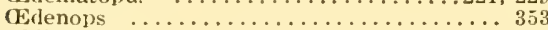

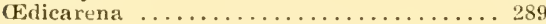

Edopa ......................... 277

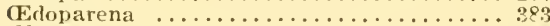

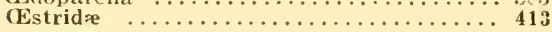

Estrogaster T. $=$ Calodexia
Estrogastrodes $\mathrm{T} .=$ Calodexia

PAGE

Estrogastropsis T. = Calodexia

Estrohilarella $\ldots \ldots \ldots \ldots \ldots \ldots \ldots . .405$

Estrophasia .................... 450

Estrus ....................... 414

Ogcodes ........................ 204

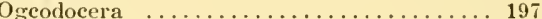

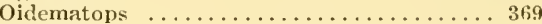

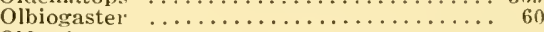

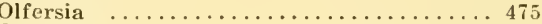

Oligarces ...................... 105

Oligotrophus .......................... 109

Ollachea $\mathrm{T} .=$ Cryptomeigenia

Ommatius .................. 179

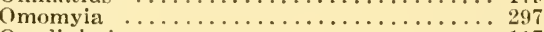

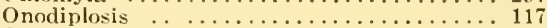

Opeatocerata .................211

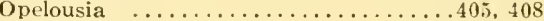

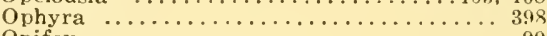

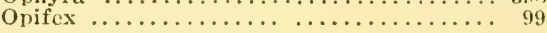

Opistholoba $=$ Mycetophila

Oponydas .................. 16

Opomyza $\ldots \ldots \ldots \ldots \ldots \ldots \ldots \ldots \ldots \ldots \ldots$

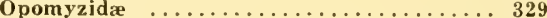

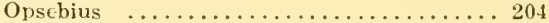

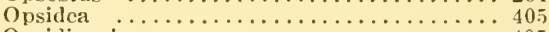

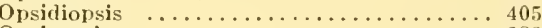

Opsiomyia .................... 389

Opsodexia ................ 408, 423

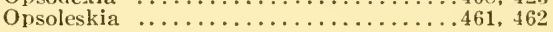

Opsophagus $=$ Cyıtophløba

Opsotheresia ...............421,425

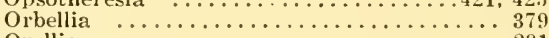

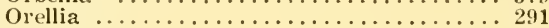

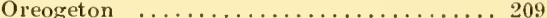

Oreothalia .................. 212

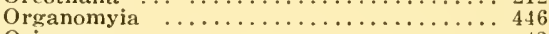

Orimarga $\ldots \ldots \ldots \ldots \ldots \ldots \ldots \ldots \ldots \ldots \ldots .43$

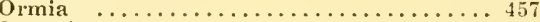

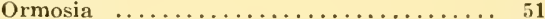

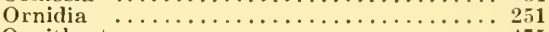

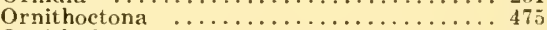

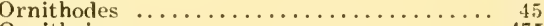

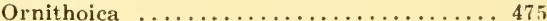

Ornithomyia $\ldots \ldots \ldots \ldots \ldots \ldots \ldots \ldots \ldots \ldots \ldots$

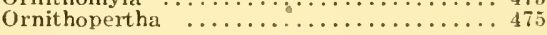

Ornithoponus Ald. = Lynchia

Oropeza $\ldots \ldots \ldots \ldots \ldots \ldots \ldots \ldots \ldots \ldots$

Orphnephila $=$ Thaumalea

Ortalida $=$ Otitidre

Ortalimyia .................281, 284

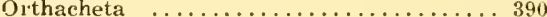

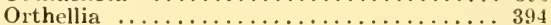

Orthocladius $\ldots \ldots \ldots \ldots \ldots \ldots \ldots \ldots \ldots \ldots \ldots \ldots . \ldots \ldots$

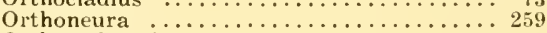

Orthopodomyia $\ldots \ldots \ldots \ldots \ldots \ldots \ldots \ldots . \ldots 9 . \ldots 9$

Osca Walker $=$ Scaptia

Oscinella ..................... 344

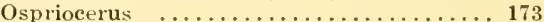

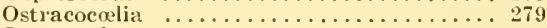

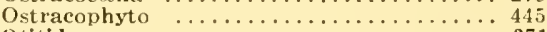

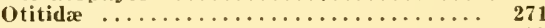

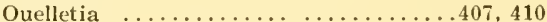

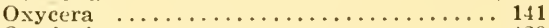

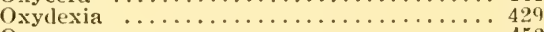

Oxynops $\ldots \ldots \ldots \ldots \ldots \ldots \ldots \ldots \ldots \ldots . \ldots \ldots 2$

Orynopsalia ...............444,467

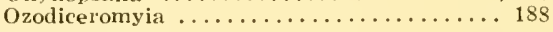

Pachycerina .................. 319

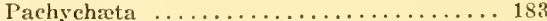

Pachygastel ........................ 139 
Pachyneres $=$ Glabellula

FAGE

Pachynocera $\mathrm{T}$. = Wagneria

Pachyophthalmus ................ 407

Pachypyga Par. = Peloropeodes $\mathrm{Wh}$.

Padarium ................... 437

Palreoplatyura ...................... 121

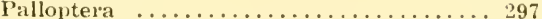

Pallopterida $\ldots \ldots \ldots \ldots \ldots \ldots \ldots \ldots . \ldots \ldots$

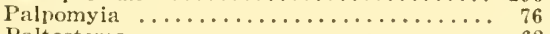

Paltostoma $\ldots \ldots \ldots \ldots \ldots \ldots \ldots \ldots \ldots, 62$

Panacemyia .................. 458,463

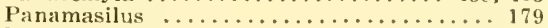

Panamenia .......................... 323

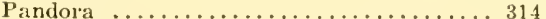

Paneryma .........................275

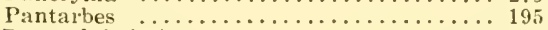

Pantophthalıida .................. 155

Pantophthalmus ................... 156

Parabezzia .................... 77

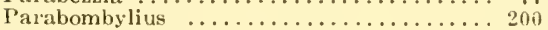

Parabrunettia .................. 79

Paracantha ..................... 291

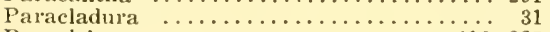

Paracleius $\ldots \ldots \ldots \ldots \ldots \ldots \ldots \ldots \ldots 219,227$

Paraclunio ......................... 73

Paracosmus ...................... 200

Paradejeania ..................... 423

Parademoticus .................. 423

Paradicranota .......................... 46

Paradidyma ................427, 442

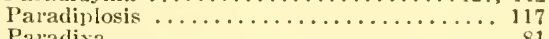

Paradixa $\ldots \ldots \ldots \ldots \ldots \ldots \ldots \ldots \ldots \ldots .61$

Paradmontia .................. 442

Paradrosophila Duda $=$ Clastopteromyia

Paradyschiria ..................... 479

Parafischeria $\mathrm{T}$. = Fischeria

Paragermaria Tns, = Distichona

Paragorgopsis .................... 279

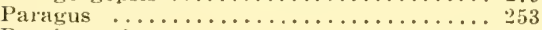

Paraleucopis .................... 365

Paralimna ........................... 347

Paralispe $\ldots \ldots \ldots \ldots \ldots \ldots \ldots 427,443,452,453$

Paralispidea .......................... 449

Parallelodiplosis .................. 117

Parallelomma ........................ 389

Paralueilia $\ldots \ldots \ldots \ldots \ldots \ldots \ldots \ldots \ldots \ldots \ldots, 407$

Paramadiza Mall. = Hypaspistomyia

Paramadiza Mel., not Mal. = Hemeromyia

Parametopina .....................239

Paramilichia ................... 336

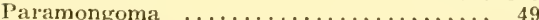

Paramyia ...................... 334

Puramyocera $=$ Rhynchiodexia

Paraphasionsis .................. 454

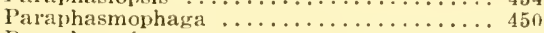
Paraphrosylus $\ldots \ldots \ldots \ldots \ldots \ldots 217,223,229,230$ Pararhinoleucophenga ............. 327

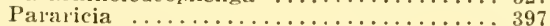

Parasimulium ..................... 66

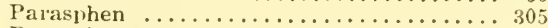

Paraspinophora ................. 237

Parasymmictus ....................... 202

Parasyntormon $\ldots \ldots \ldots \ldots \ldots \ldots \ldots \ldots \ldots .223,230$

Paratactopsis Tns. = Chætoprosopa

Paratanypus $=$ Podonomus

Parataracticus ................... 171

Parathalassius .................... 209

Palathelaira ........................ 459

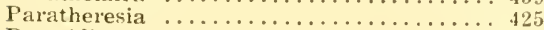

Paratidia ......................... 387
Paratinia

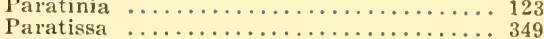

Paratrichobius .................. 479

Paratronesa ............................. 50

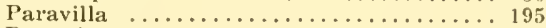

Parawinnertzia ....................... 107

Parazelia ...................... 431

Parectecephala .................. 341

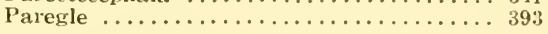

Parephydra Coq. $=$ Atissa

Parhelophilus ................... 264

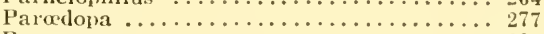

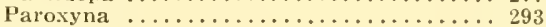

Parydra ....................... 353

Pateloa ......................... 444

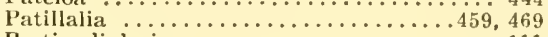

Pectinodiplosis ...................... 111

Pedicella ........................ 145

Pedicia ....................... 45

Pegomya ........................... 393

Pelagomyia ..................... 141

Pelastoneurus .................217, 225

Pelatachina ........................458,462

Pelecocera .............................. 259

Pelecotheca ...................... 143

Peleteria .................... 447

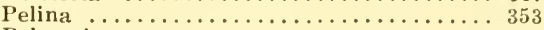

Pelomyia ........................ 331

Pelomyiella ....................... 331

Peloropeodes $\ldots \ldots \ldots \ldots \ldots \ldots \ldots 219,225,230,231$

Peltopsilopa $\ldots \ldots \ldots \ldots \ldots \ldots \ldots \ldots \ldots \ldots \ldots, 347$

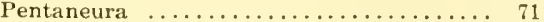

Pentapedilum .................... 73

Penthoptera ...................... 46

Penthosia ...................... 450

Pericoma .......................... 79

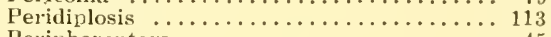

Peripheroptera .................... 45

Periscelida ..................... 323

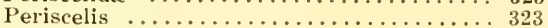

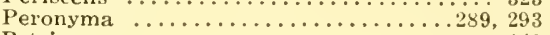

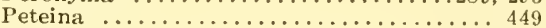

Phanopsis ........................ 443

Phalacrocera $. \ldots \ldots \ldots \ldots \ldots \ldots \ldots \ldots \ldots, 41$

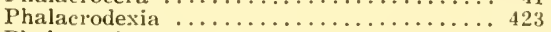

Phalacrophyto .................... 425

Phalacrotophora End. = Megaselia

Phantasiomyia ...............456, 463

Phaonia .......................... 39s

Phasia ........................ 435

Phasioclista Tns. $=$ Myiophasia

Phasiophyto ...................... 449

Phasions ....................... 121

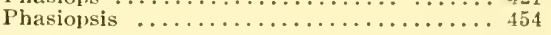

Phasiostoma $\mathbf{T}_{\mathrm{*}}=$ Clausicella

Phasmophaga Tns. = Archiclops

Pheneus $=$ Vermileo

Phenicia .....................4 408

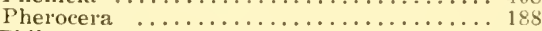

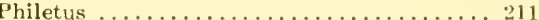

Philonicus ...................... 183

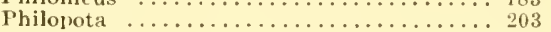

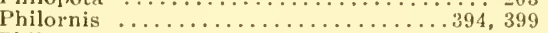

Philorus ..................... 62

Phoniciomyia .................... 452

Pholeomyia ......................... 336

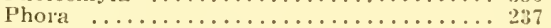

Phorantha $=$ Alophora

Phorellia Ron. = Trypeta

Phorichæta = Wagneria

Phorida ....................... 231 
Phomia $\ldots \ldots \ldots \ldots \ldots \ldots \ldots$ PAGE

408

Phorocera $\ldots \ldots \ldots \ldots \ldots \ldots \ldots \ldots \ldots . . \ldots \ldots 44$

Phoirodonta .................... 119

Phorostoma Desv. = Billaea Desv.

Phosocephala .................. 421

Phrissopodia ...................4 409

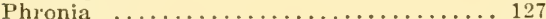

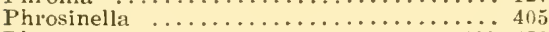

Phrynofrontina ..............439,458

Phthinia ................... 123

Phthiria .................... 197

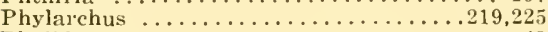

Phylidorea ..................... 4s

Phyllogaster .................. 399

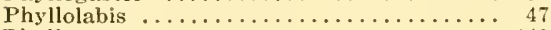

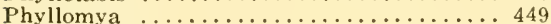

Phyllomydas ................... 165

Phyllomyza .................. 336

Phyllomyzidre $\ldots \ldots \ldots \ldots \ldots \ldots \ldots \ldots \ldots \ldots \ldots$

Phyllophila $\mathrm{T} .=$ Phyllophilopsis

Phyllophilopsis ................. 461

Phylygria Sten. = Hydrina

Physegenua ..................... 319

Physocenhala .................. 26?

Phytoadmontia T. = Paradidyma

Phytodes ....................... 405

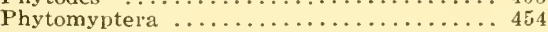

Phytomyza ................... 332

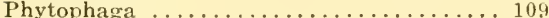

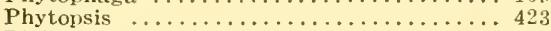

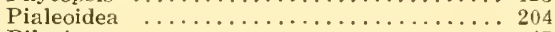

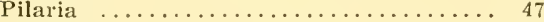

Pilica $\ldots \ldots \ldots \ldots \ldots \ldots \ldots \ldots \ldots \ldots \ldots \ldots \ldots$

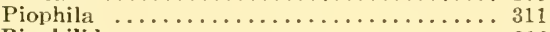

Piophilidae $\ldots \ldots \ldots \ldots \ldots \ldots \ldots \ldots \ldots \ldots \ldots . \ldots . \ldots$

Pipiza .................. 257

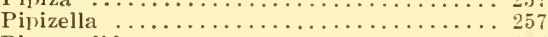

Pipunculidae ................. 245

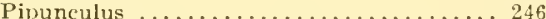

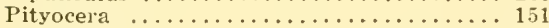

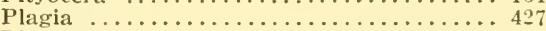

Plagiomima ................... 448

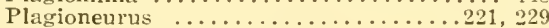

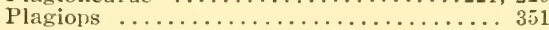

Plagiotoma Lœw = Tomoplagia

Plagiprospherysa Tns. = Stomatomya

Planes ....................... 261

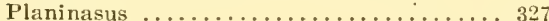

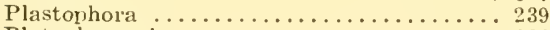

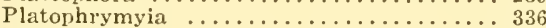

Platycheirus .................... 257

Platycnema ..................... 244

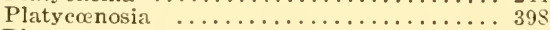

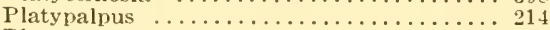

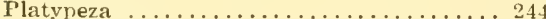

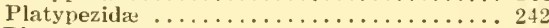

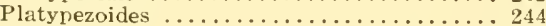

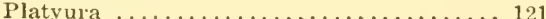

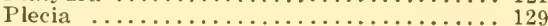

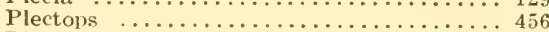

Plectromyia .......................... 46

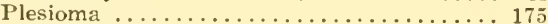

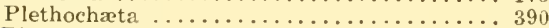

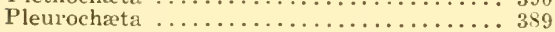

Ploas Latr. $=$ Conophorus

Plocascelus $=$ Cardiacephala

Plunomia ..................... 365

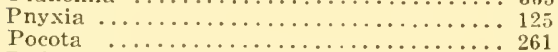

Podonomus $\ldots \ldots \ldots \ldots \ldots \ldots \ldots \ldots \ldots \ldots \ldots \ldots \ldots{ }^{261}$
Podotachina $=$ Thryeolyoga- PACE

Pucilanthrax ................. 193

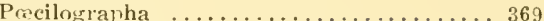

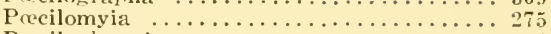

Poecilophaonia ........................ 394

Pogonephydra = Cirrula

Pogonomya .................... 399

Pogonomyioides ................ 399

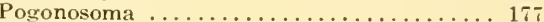

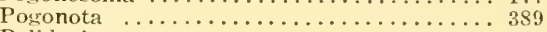

Polidaria ................. $429,444,461$

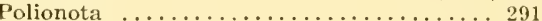

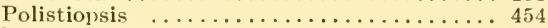

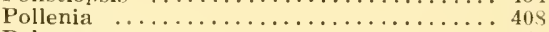

Polyangreus .................. 45

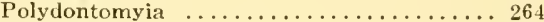

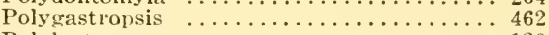

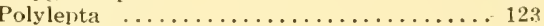

Polymedon .................217, 297

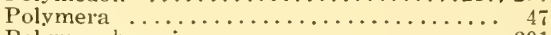

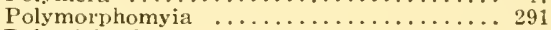

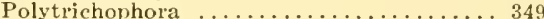

Porphyrochroa ................ 212

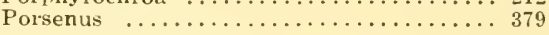

Postleria $=$ Neoleria

Prionellus ................... 105

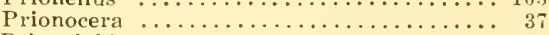

Prionolabis ................... 48

Probezzia $\ldots \ldots \ldots \ldots \ldots \ldots \ldots \ldots \ldots \ldots \ldots \ldots, 77$

Probolæus Will. = Lygistorrhina

Proboscimyia .................. 391

Procanace ...................... 357

Procecidochares $\ldots \ldots \ldots \ldots \ldots \ldots \ldots \ldots \ldots \ldots \ldots . \ldots \ldots 291$

Proceroplatus = Platyura

Prochyliza ................... 311

Procladius $\ldots \ldots \ldots \ldots \ldots \ldots \ldots \ldots \ldots \ldots \ldots \ldots, \ldots_{11}$

Proclinonyga .................. 212

Proctacanthella ................. 183

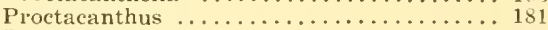

Procystiphora .................. 109

Prodiamesa .................. $† 1$

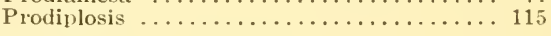

Proëpalpus T. $=$ Jurinia

Progonomyia ................... 51

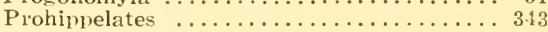

Prolimnophila .................... 47

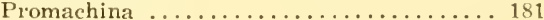

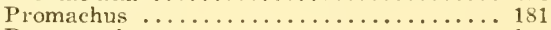

Promeranisa .................. 143

Promochlonyx ................... 97

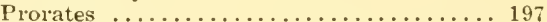

Proroglutea $\ldots \ldots \ldots \ldots \ldots \ldots \ldots \ldots \ldots \ldots \ldots \ldots \ldots . \ldots . \ldots \ldots 41$

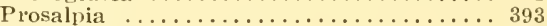

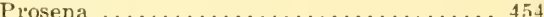

Prosenoides ............................ 425

Prosimulium ................. 66

Prosonza ...................4 451

Protanyderus .................. 29

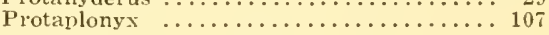

Protenthes Joh. = Tanypus

Protichisma ..................... 179

Protacalliphoia $\ldots \ldots \ldots \ldots \ldots \ldots \ldots \ldots \ldots \ldots \ldots \ldots . \ldots 40 . \ldots \ldots$

Protodejeania ................. 423

Protoplasa ..................... 29

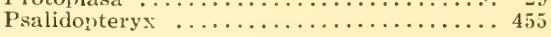

Psammoppia $=$ Muscopteryx

Psaronius .................. 47

Psectrocladius $=$ Orthocladius

Psectrosciara ................. 182

Psegmomma $\ldots \ldots \ldots \ldots \ldots \ldots \ldots \ldots \ldots \ldots \ldots \ldots \ldots 139$ 


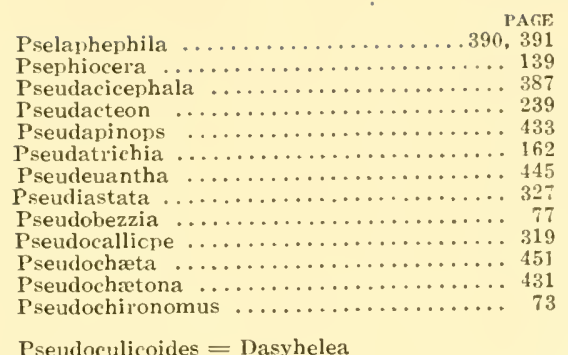

Pseudaculicoides $=$ Dasyhelea

Pseudodexia ................... 461

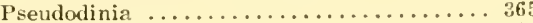

Pseurlogametes ................... 41'

Pseudogaurax ...................... 344

Pseudogermaria B.B. = Distichona

Pseudogriphoneura ................ 319

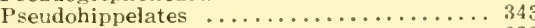

Pseudohymocera ................... 239

Pseudohystricia ................... 420

Pseudoleria $\ldots \ldots \ldots \ldots \ldots \ldots \ldots \ldots \ldots \ldots \ldots$

Pseudolimnophila ................ 4

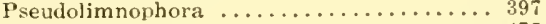

Pseudolynchia ................. 475

Pseudophaonia ................. 395

Pseudophortica $=$ Rhinoleucophenga

Pseudopogonota ................. 389

Pseudopsila .................... 375

Pseudopterocalla .................... 279

Pseudorus ........................ 169

Pseudotephritis ................. 279

Pseudotractocera $\mathrm{T} .=$ Viviania

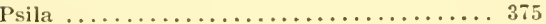

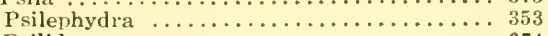

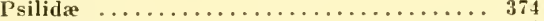

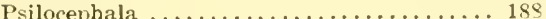

Psiloconopa ....................... 52

Psilocurus $\ldots \ldots \ldots \ldots \ldots \ldots \ldots \ldots \ldots \ldots \ldots$ 175

Psilodiamesa .................. 71

Psiloneura Ald. = Grisdalemyia

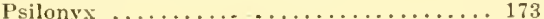

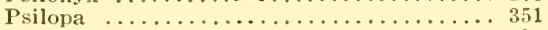

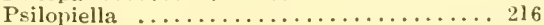

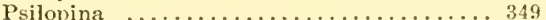

Psilota ..................... 257

Psorophora ..................... . . . . 99

Psychoda $\ldots \ldots \ldots \ldots \ldots \ldots \ldots \ldots \ldots \ldots \ldots \ldots \ldots$

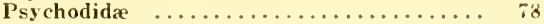

Ptecticus ...................... 145

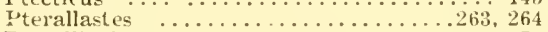

Pterallipsis $\ldots \ldots \ldots \ldots \ldots \ldots \ldots \ldots \ldots \ldots . \ldots \ldots$

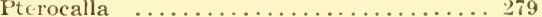

Pterochionea .................... 49

Pterodontia ......................... 201

Pteromicra ............................ 369

Ptilodegeeria $\ldots \ldots \ldots \ldots \ldots \ldots \ldots \ldots \ldots \ldots \ldots$

Ptilomyia

Ptilcmyioides $\ldots \ldots \ldots \ldots \ldots \ldots \ldots \ldots \ldots \ldots \ldots . \ldots 21$

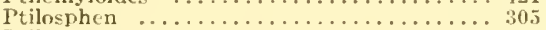

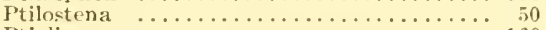

Ptiolina ...................... 160

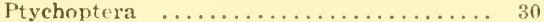

Ptychopterida $\ldots \ldots \ldots \ldots \ldots \ldots \ldots \ldots \ldots, 30$

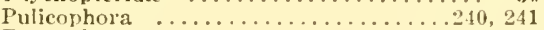

Pycnoglossa . . . . . . . . . . . . 393

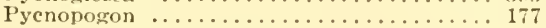

Pyraustomyia $=$ Eriothrix

Pyrellia

394

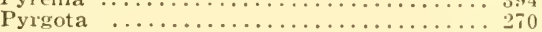

\begin{tabular}{|c|c|}
\hline & \\
\hline $\begin{array}{c} \\
\cdots\end{array}$ & \\
\hline 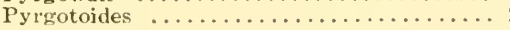 & \\
\hline 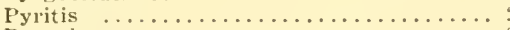 & \\
\hline Pyrophena $\ldots \ldots \ldots \ldots \ldots \ldots \ldots \ldots \ldots$ & \\
\hline$\ldots \ldots \ldots \ldots \ldots \ldots \ldots \ldots \ldots$ & \\
\hline 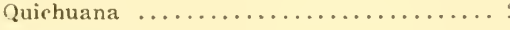 & \\
\hline Rachicerida $\quad \ldots \ldots \ldots \ldots \ldots \ldots \ldots \ldots \ldots$ & \\
\hline 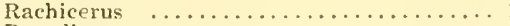 & \\
\hline Racodincura $\ldots \ldots \ldots \ldots \ldots \ldots \ldots \ldots \ldots$ & \\
\hline 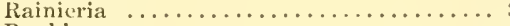 & \\
\hline Raphiocera $\ldots \ldots \ldots \ldots \ldots \ldots \ldots \ldots \ldots$ & \\
\hline$\ldots \ldots \ldots \ldots \ldots \ldots \ldots \ldots \ldots$ & \\
\hline 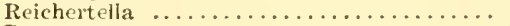 & \\
\hline 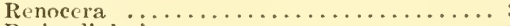 & \\
\hline 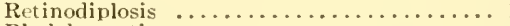 & \\
\hline Rhabdomastix $\ldots \ldots \ldots \ldots \ldots \ldots \ldots$ & \\
\hline Rhabdophaga $\ldots \ldots \ldots \ldots \ldots \ldots \ldots \ldots$ & \\
\hline Rhabdoselaphus $\quad \ldots \ldots \ldots \ldots \ldots \ldots \ldots \ldots$ & \\
\hline Rhacoëpalpus $\ldots \ldots \ldots \ldots \ldots \ldots \ldots \ldots$ & \\
\hline Rhadiurgus $\ldots \ldots \ldots \ldots \ldots \ldots \ldots \ldots \ldots$ & \\
\hline 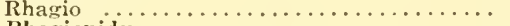 & \\
\hline Rhagionida $\quad \ldots \ldots \ldots \ldots \ldots \ldots \ldots \ldots$ & \\
\hline 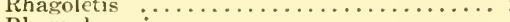 & \\
\hline 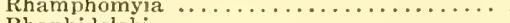 & \\
\hline Rhaphidolabis $\quad \ldots \ldots \ldots \ldots \ldots \ldots \ldots \ldots$ & \\
\hline Rhaphiomidas $\ldots \ldots \ldots \ldots \ldots \ldots \ldots \ldots$ & \\
\hline Rhaphiorhynchus $\quad \ldots \ldots \ldots \ldots \ldots \ldots \ldots$ & \\
\hline 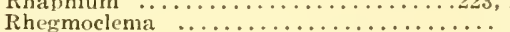 & \\
\hline$\ldots \ldots \ldots \ldots \ldots \ldots \ldots \ldots \ldots \ldots$ & \\
\hline Rhingia .. & 259 \\
\hline 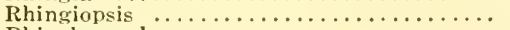 & 14 \\
\hline Rhinoleucophenga $\ldots \ldots \ldots \ldots \ldots \ldots \ldots$ & 327 \\
\hline Rhinophora $\ldots \ldots \ldots \ldots \ldots \ldots \ldots \ldots \ldots$ & \\
\hline & \\
\hline & \\
\hline
\end{tabular}

Rhoecius End. = Cardiacephala

Rhogenhofera ................. 412

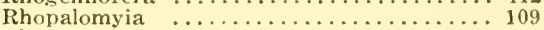

Rhopalosyrphus ............... 249

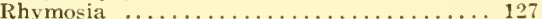

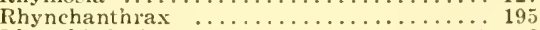

Rhynchiodexia ...................... 431,4

Rhy nchophoromyia ................ 239

Rhynchosciara .................. 119

Rhynencina Johnson $=$ Euribia

Rhyphus Lat. = Anisopus

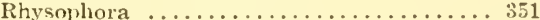

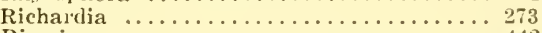

Ricosia .......................... 442

Rivellia ....................... 281

Roederioides $\ldots \ldots \ldots . . . \ldots \ldots$

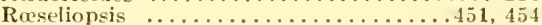

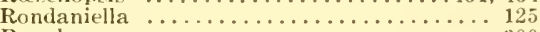

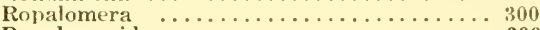

Ropalomerida ................... 299

Sabethes ...................98, 100

Sabethoides $\ldots \ldots \ldots \ldots \ldots \ldots \ldots \ldots \ldots \ldots \ldots \ldots \ldots 9,100$

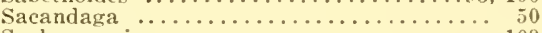

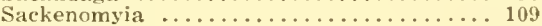

Salningogaster ................. 255

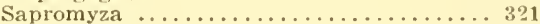

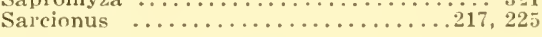

Sarcofahrtia = Sarcophaga?

Sarconesia .................... 408

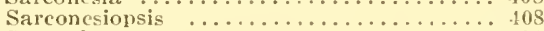

Sarcophaga ................... 409

Sarcophagina Curran $=$ Raviniopsis Tns.

Sarcophagula ................ 409

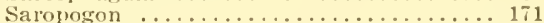

Sarothromyia ........................ 409 
Saskatchewania $=$ Imitomyia

Saundersiops Tns. = Rhachoëpalpus

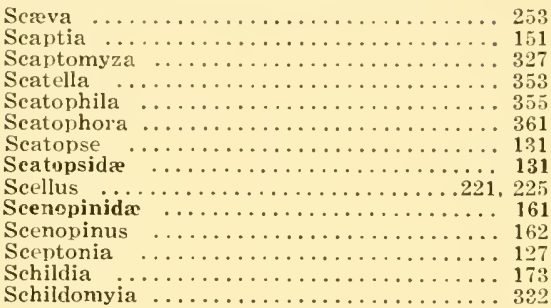

Schizactia T. $=$ Schizotachina

Schizocerophaga ............... 459

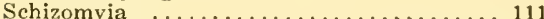

Schizotachina $\ldots \ldots \ldots \ldots \ldots \ldots \ldots \ldots \ldots \ldots \ldots, 45,454$

Schœenomyza $\ldots \ldots \ldots \ldots \ldots \ldots \ldots \ldots \ldots \ldots \ldots . \ldots \ldots . \ldots \ldots$

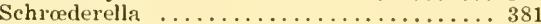

Schwarzalia .................431,466

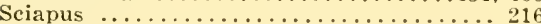

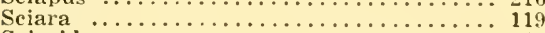

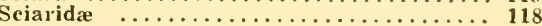

Sciasma $=$ Catharosia

Sciomyza ................... 369

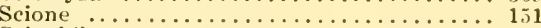

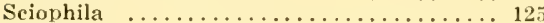

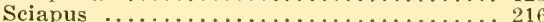

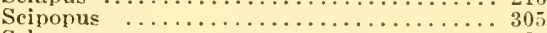

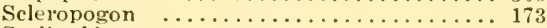

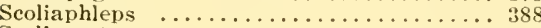

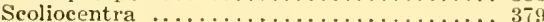

Scoliopelta .......................... 141

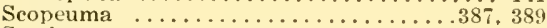

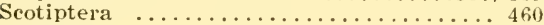

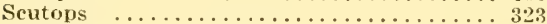

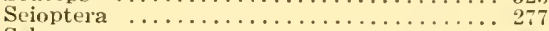

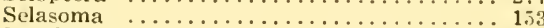

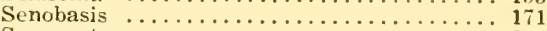

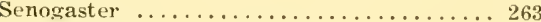

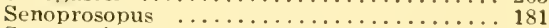

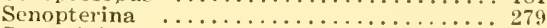

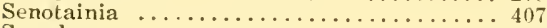

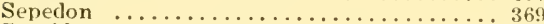

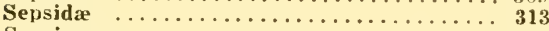

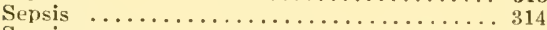

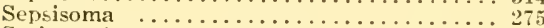

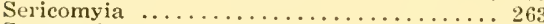

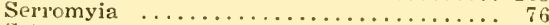

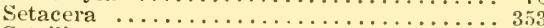

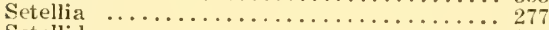

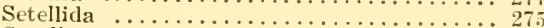

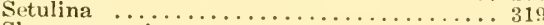

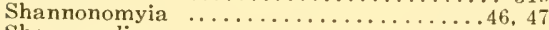

Shermanalia .................. . . . 40,470

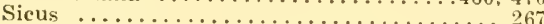

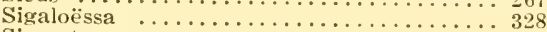

Sigmatomera $\ldots \ldots \ldots \ldots \ldots \ldots \ldots \ldots \ldots \ldots \ldots \ldots .{ }_{5}$

Signosomopsis T. = Rhachoëpalpus

Silvius

Simulium $\quad \ldots \ldots \ldots \ldots \ldots \ldots \ldots \ldots \ldots \ldots \ldots \ldots \ldots \ldots$

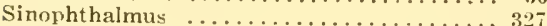

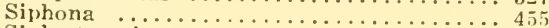

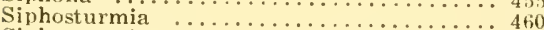

Siphosturmiopsis ..................... 450

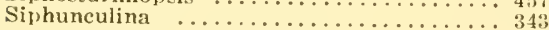

Sisyrosturmia $\mathrm{T}$. = Blondclia

Slossnnamyia $\ldots \ldots \ldots \ldots$
Smithomyia $\ldots \ldots \ldots \ldots \ldots \ldots \ldots \ldots \ldots \ldots$

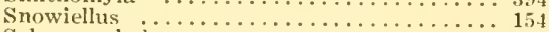

Sobarocephala
PAGE

Solieria .................... 461

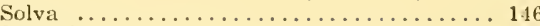

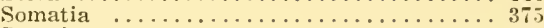

Somula ........................ 261

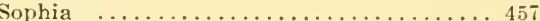

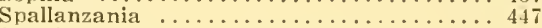

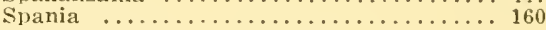

Spaniotoma Edw. = Orthocladius

Sparnopolius ..............197, 200

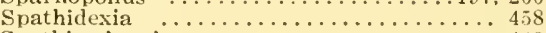

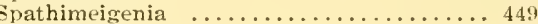

Spathimyia ..................... 427

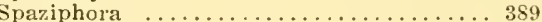

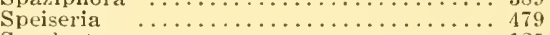

Speolepta ..................... 125

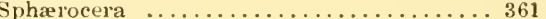

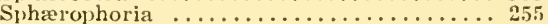

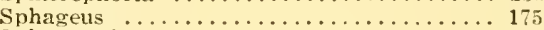

Sphecomyia ................... 262

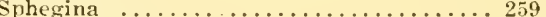

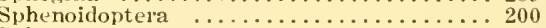

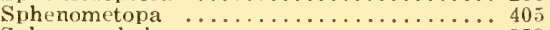

Sphyracephala ..................... 359

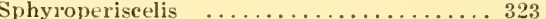

Spilaria $\ldots \ldots \ldots \ldots \ldots \ldots \ldots \ldots \ldots \ldots \ldots . \ldots \ldots$

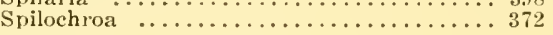

Spilographa Lw. = Trypeta

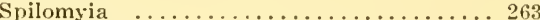

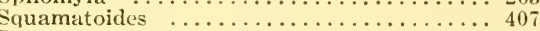

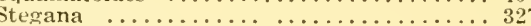

Steganolauxania .............. 317

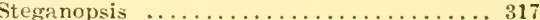

Steinella ............................. 394

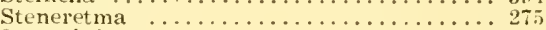

Sterochthera $\ldots \ldots \ldots \ldots \ldots \ldots \ldots \ldots \ldots \ldots . \ldots \ldots$

Stenomacra $=$ Macrostenomyia

Stenomyia . . . . . . . . . . . . 277

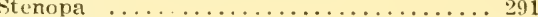

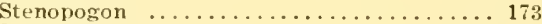

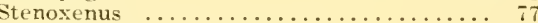

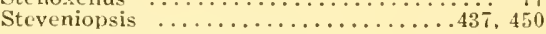

Steringomyia $=$ Calliphora

Sthenopyga ..................... 409

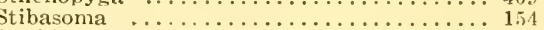

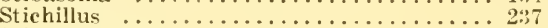

Stictodiplosis ................. 111

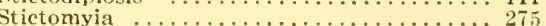

Stilbometopa $\ldots \ldots \ldots \ldots \ldots \ldots \ldots \ldots \ldots \ldots \ldots . \ldots \ldots 45$

Stilobezzia $\ldots \ldots \ldots \ldots \ldots \ldots \ldots \ldots \ldots \ldots \ldots \ldots{ }_{76}$

Stilpon ....................... 214

Stolidosoma ...................219, 227

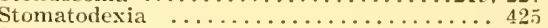

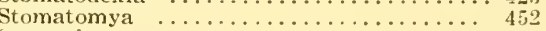

Stomosis .................... 336

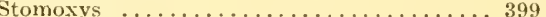

Strationyida $\ldots \ldots \ldots \ldots \ldots \ldots \ldots \ldots \ldots \ldots \ldots . \ldots \ldots$

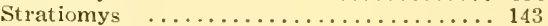

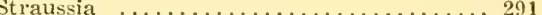

Strebla ..................... 479

Streblida $\ldots \ldots \ldots \ldots \ldots \ldots \ldots \ldots \ldots \ldots \ldots \ldots . \ldots \ldots 47$

Strongylogaster auct. $=$ Strongygaster

Strongylophthalmyia ....................

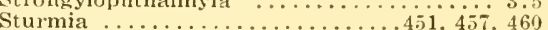

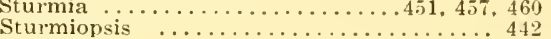

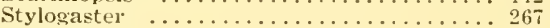

Styringomyia $\ldots \ldots \ldots \ldots \ldots \ldots \ldots \ldots \ldots \ldots$

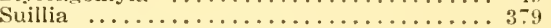

Sumichrastia T. = Eudexia

Swammerdamella ................. 131

Symbiocladius $=$ Trissocladius

Symmerus ..................... 121

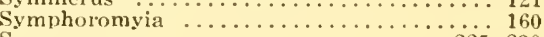

Sympycnus . . . . . . . . . . . . 225. 230

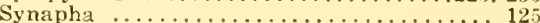




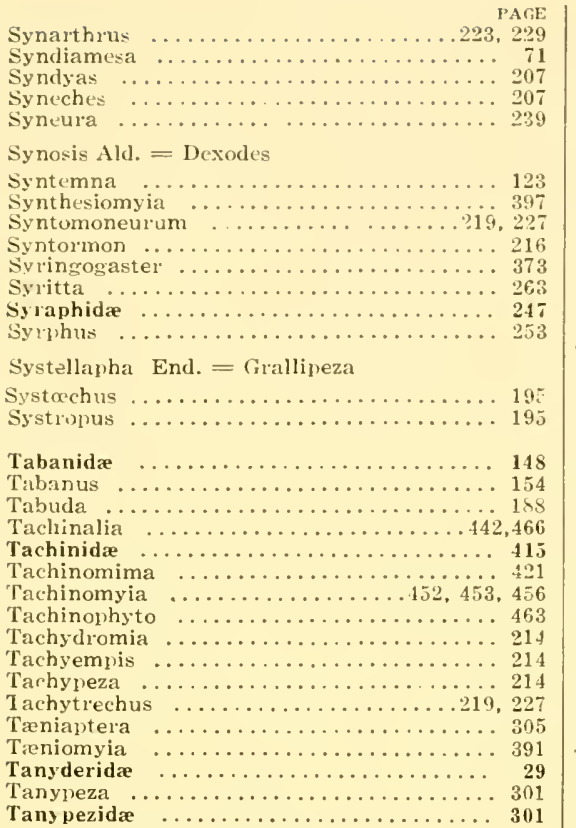

Thelodiscus $=$ Sar'ofahrtia

Themira .................... 314

Theobaldia ................95, 97

Theresia .................... 425

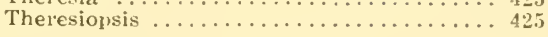

Theruons B.B. = Telothyria

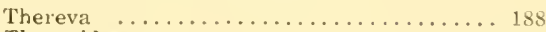

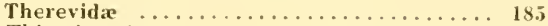

Thinodromia ...................... 211

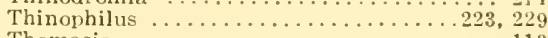

Thomasia .................... 113

Thry colyga .................... 443

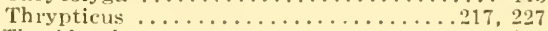

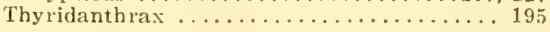

Thysanousis Tns. = Leschenaultia Desv.

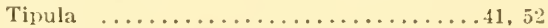

Tipulida $\quad \ldots \ldots \ldots \ldots \ldots \ldots \ldots \ldots \ldots \ldots \ldots \ldots, 32$

Tolmerus Lw. = Machimus Lw.

Tomollapia . . . . . . . . . . . . . . 291

Tomoplagina $=$ Peronyma

Topomeigenia Tns. = Sturmia

Topomyia .................... 100

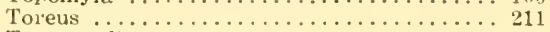

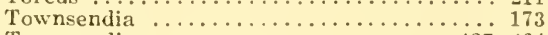

Townsendina ................ 427,461

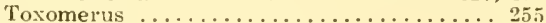

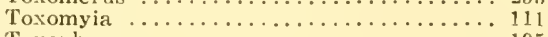

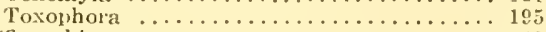

Coxorhina .................... 49

Toxotrypaner .................. 293

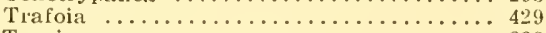

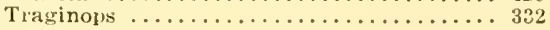

Tanypoda Ron. = Rainieria

'Tanypremna ................. 36

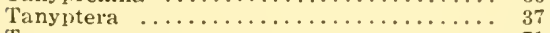

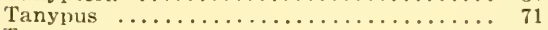

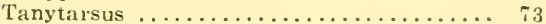

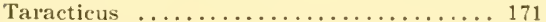

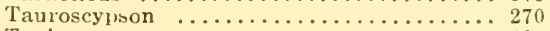

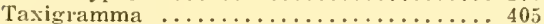

Teleopsis ....................... 359

Telinatogeton Coq. (not Schiner) = Paraclunio

Telothy ria .................... 450

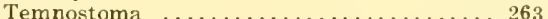

Tephrella ....................... 293

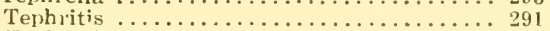

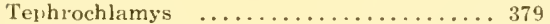

Tephronota ..................... 281

Terellia .......................... 289

Tersesthes $=$ Leptoconols

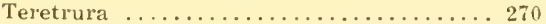

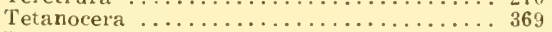

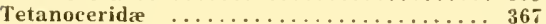

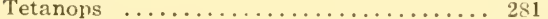

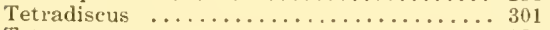

Tetragoneura ................... 125

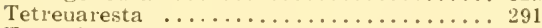

Tetropismenus ................... 2s1

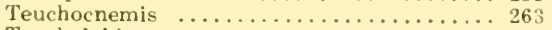

Teucholabis ...................... 49

Teuchophorus ...........225, 230, 231

Thalassomyia Johan. (not Schiner) = Cardiocladius

Thaumalea

Thaumaleide $\ldots \ldots \ldots \ldots \ldots \ldots \ldots \ldots \ldots \ldots \ldots \ldots \ldots \ldots \ldots \ldots \ldots \ldots$

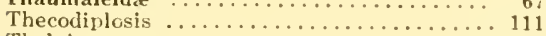

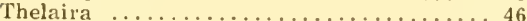

Thelairalia ................462.470

Thelairochatona $\ldots \ldots \ldots \ldots \ldots \ldots \ldots \ldots \ldots . \ldots . \ldots . \ldots . \ldots 41$

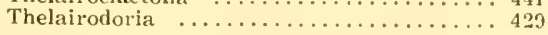

Triachora Tns. $=$ Belvosia

Tribremia ................... 113

Trichephelia ................... 46

Trichina ........................ 209

Trichiopoda $\ldots \ldots \ldots \ldots \ldots \ldots \ldots \ldots \ldots \ldots \ldots \ldots \ldots \ldots \ldots, 433,437$

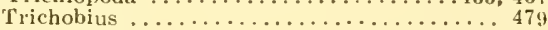

Trichocera $\ldots \ldots \ldots \ldots \ldots \ldots \ldots \ldots \ldots \ldots, 31$

Trichocerida $\ldots \ldots \ldots \ldots \ldots \ldots \ldots \ldots \ldots, 31$

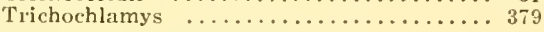

Trichocladius $=$ Orthocladius

Trichoclytia $\ldots \ldots \ldots \ldots \ldots \ldots \ldots \ldots \ldots$. 435

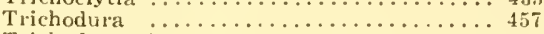

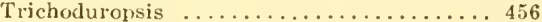

Trichogena ...................446

Trichomyia ........................ 79

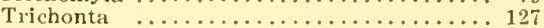

Trichopalus ....................... 383

Trichopareia $\ldots \ldots \ldots \ldots \ldots \ldots \ldots \ldots \ldots \ldots \ldots+453$

Trichoprosopon ................... 100

Trichosaundersia Tns. = Rhachoëyalpus

Trichopteromyia ................. 105

Trichopticus = Lasiops

Trichoscelis $=$ Trixoscelis

Trichosia $\ldots \ldots \ldots \ldots \ldots \ldots \ldots \ldots \ldots \ldots \ldots \ldots$
Trichotanypus

Trichothaumalea ................ 68

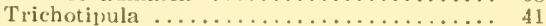

Trichotopteryx ........................

Tricimba ................... $33_{4}^{4} 4$

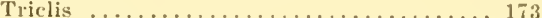

Tricyphona $\ldots \ldots \ldots \ldots \ldots \ldots \ldots \ldots \ldots \ldots \ldots \ldots \ldots \ldots \ldots \ldots \ldots, 52$

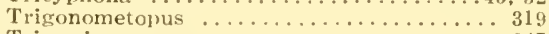

Trimerina .................. 847

Trimerinoides .................... 347

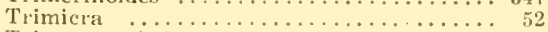

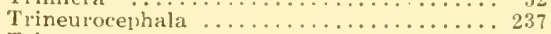

Triogma ...................... 41 
Triphleba $\ldots \ldots \ldots \ldots$

Triplasius ..................... 195

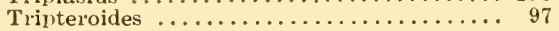

Triptotricha $=$ Dialysis

Trishormomyia ..................... 117

Trissocladius .................. 73

Tritaxys $\ldots \ldots \ldots \ldots \ldots \ldots \ldots \ldots \ldots \ldots \ldots \ldots \ldots 441$

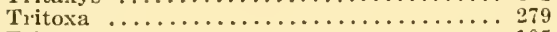

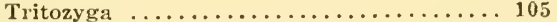

Trixa ....................... 450

Trixodes ......................... 450

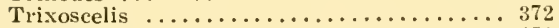

Trochilodes ...................... 450

Trochiloleskia T. $=$ Neaphria T.

Trophithauma .................. 239

Tropidea ....................... 263

Tropidodexia T. $=$ Eudexia

Tropidomyia ................... 265

Tropidopsis ................... 445

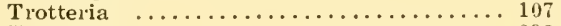

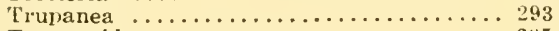

Trupaneida $\ldots \ldots \ldots \ldots \ldots \ldots \ldots \ldots \ldots . \ldots \ldots$

Trupheoneura $=$ Triphleba

Trypanea $=$ Trupanea

Trypeta ...................... 289

Trypetisoma .................... 321

Trypetoptera ................... 370

Tryptochreta ..................... 327

Typopsilopa Cress. $=$ Psilopina

Uclesia $\ldots \ldots \ldots \ldots \ldots \ldots \ldots \ldots \ldots \ldots \ldots \ldots .487$

Ula ........................ 45

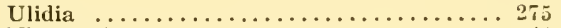

Ulomorpha ....................... 46

Uramya ...................... 445

Uranotænia $\ldots \ldots \ldots \ldots \ldots \ldots \ldots \ldots \ldots \ldots, 99$

Ulellia Lw. = Trupanea

Uromacquartia Tns, = Uramya Desv.

Urophilophilla ................. 462

Urophora Lw. = Tephritis

Ursophyto $\ldots \ldots \ldots \ldots \ldots \ldots \ldots \ldots \ldots \ldots \ldots 423$

Vanderwulpia .................. 455

Vermileo .................... 159

Verrallia .................... 246

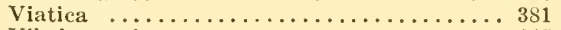

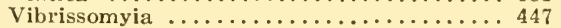

Vibrissovoria .................... 451

Villa .......................193. 195

Viviania ................... $\ldots 499,441$

Volucella ........................ 251

Volucellosia ..................... 251

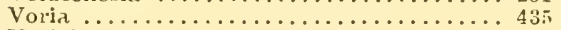

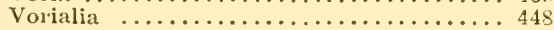

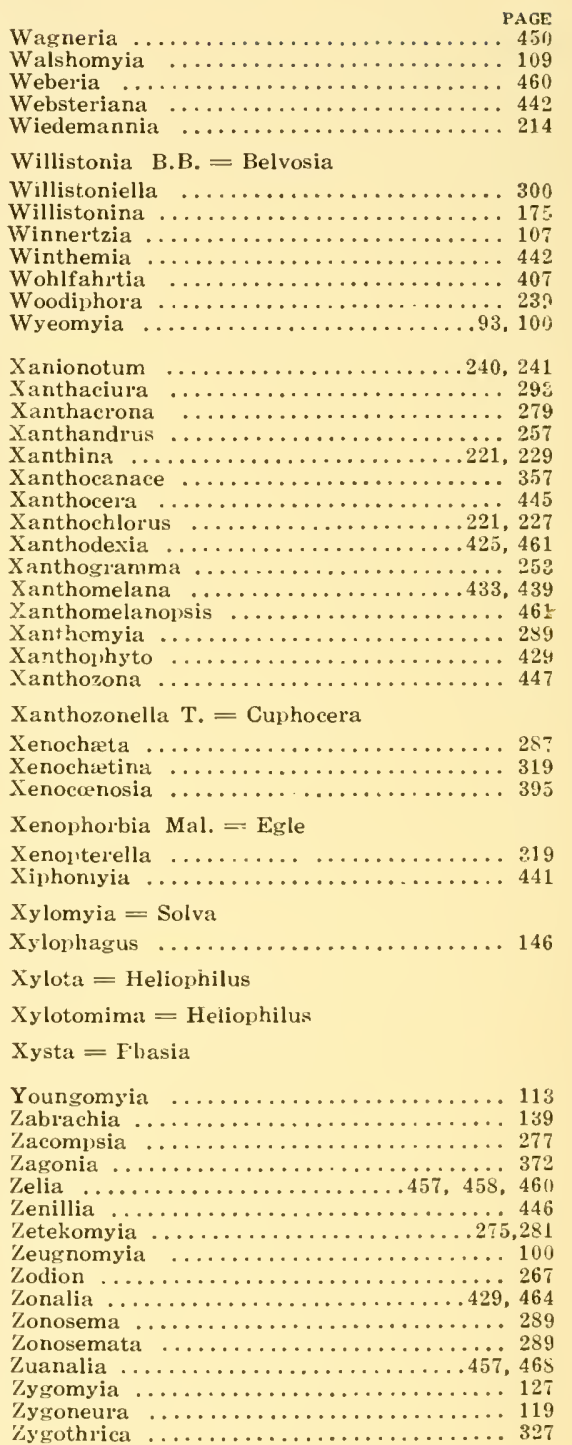

$\ldots \ldots \ldots \ldots$

Weberia .................... 460

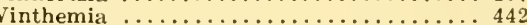

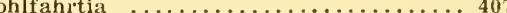

Wyeomyia .................93, 1013

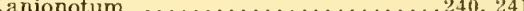

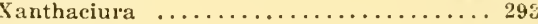

Yanthandru $\cdots . . . . . . . . . .$.

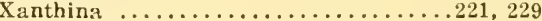

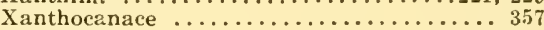

(

Xanthodexia .................425, 461

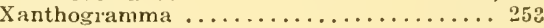

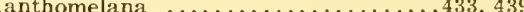

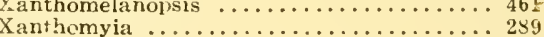

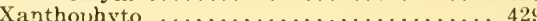

Xanthozona ..................... 447

Xanthozonella $\mathrm{T}$. = Cuphocera

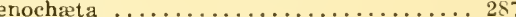

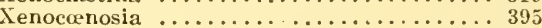

Xenophorbia Mal. = Egle

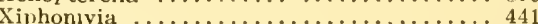

Xylomyia $=$ Solva

Xylophagus ................... 146

Xylota $=$ Heliophilus

Xylotomima $=$ Heliophilus
Willistonia B.B. = Belvosia 



, in:

3.

W.

(4) 5 ing

A

15.

(3)

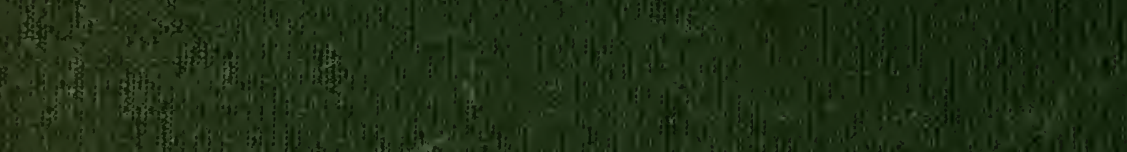

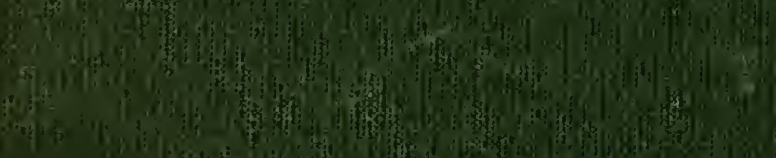

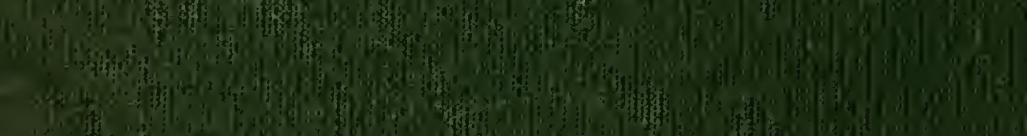
and

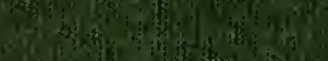

(2) 140

(1)

(1)

:

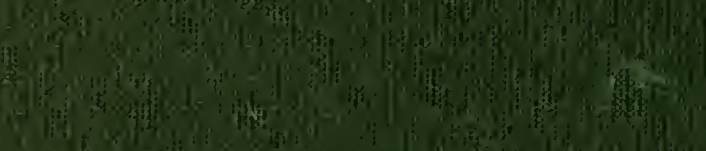

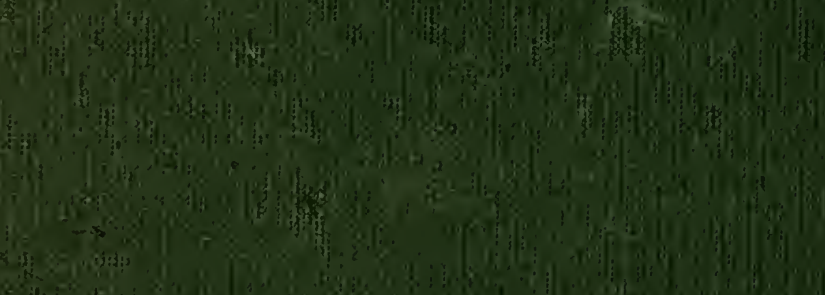

(4)

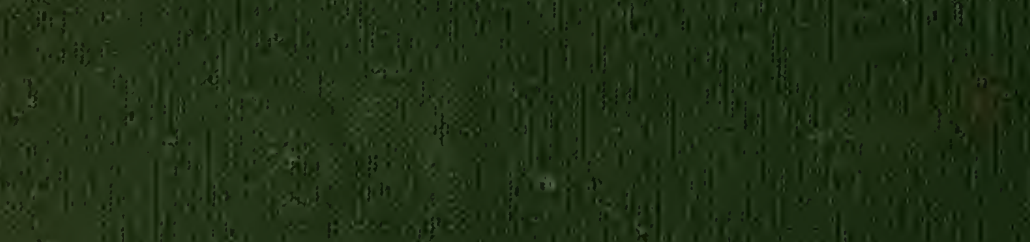

the

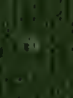

(i)

$\mid$ 